\title{
Refined families of Dothideomycetes: orders and families incertae sedis in Dothideomycetes
}

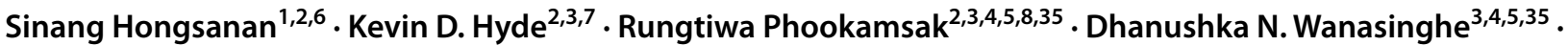 \\ Eric H. C. McKenzie ${ }^{9} \cdot$ V. Venkateswara Sarma ${ }^{10} \cdot$ Robert Lücking $^{12}$ - Saranyaphat Boonmee ${ }^{2,11}$. \\ Jayarama D. Bhat ${ }^{13} \cdot$ Ning-Guo Liu, 2,14,15 . Danushka S. Tennakoon ${ }^{2,11} \cdot$ Dhandevi Pem ${ }^{2,11}$. \\ Anuruddha Karunarathna ${ }^{2,3,4,6,50}$. Shu-Hua Jiang ${ }^{17}$. Gareth E. B. Jones ${ }^{18,19}$. Alan J. L. Phillips ${ }^{20}$. \\ Ishara S. Manawasinghe $e^{2,7,21}$. Saowaluck Tibpromma ${ }^{3,4,5,35}$. Subashini C. Jayasiri ${ }^{2}$. Diana Sandamali2,11,50 . \\ Ruvishika S. Jayawardena ${ }^{2,11} \cdot$ Nalin N. Wijayawardene ${ }^{22}$ - Anusha H. Ekanayaka ${ }^{2} \cdot$ Rajesh Jeewon $^{23}$.

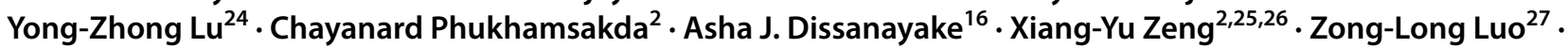 \\ Qing $\operatorname{Tian}^{2} \cdot$ Kasun M. Thambugala ${ }^{28} \cdot$ Dongqin Dai $^{22} \cdot$ Milan C. Samarakoon ${ }^{2,48} \cdot$ K. W. Thilini Chethana ${ }^{2,11}$. \\ Damien Ertz ${ }^{29,30}$. Mingkwan Doilom ${ }^{3,4,5,35}$. Jian-Kui (Jack) Liu ${ }^{16}$. Sergio Pérez-Ortega ${ }^{31}$. Ave Suija ${ }^{32}$. \\ Chanokned Senwanna ${ }^{2,6}$. Subodini N. Wijesinghe ${ }^{2,11,33} \cdot$ Mekala Niranjan $^{10,36}$. Sheng-Nan Zhang ${ }^{2,6}$. \\ Hiran A. Ariyawansa ${ }^{34} \cdot$ Hong-Bo Jiang 2,3,4,11 . Jin-Feng Zhang ${ }^{2,37}$. Chada Norphanphoun ${ }^{2}$. Nimali I. de Silva ${ }^{3,48}$. \\ Vinodhini Thiyagaraja ${ }^{2,3,4,6} \cdot$ Huang Zhang ${ }^{38}$. Jadson D. P. Bezerra ${ }^{39} \cdot$ Ricardo Miranda-González ${ }^{40}$. \\ André Aptroot ${ }^{41}$. Hiroyuki Kashiwadani ${ }^{42}$. Dulanjalee Harishchandra ${ }^{2,11,21} \cdot$ Emmanuël Sérusiaux $^{43}$. \\ Pranami D. Abeywickrama ${ }^{2,11,21} \cdot$ Dan-Feng Bao ${ }^{2,6,27} \cdot$ Bandarupalli Devadatha ${ }^{2,10} \cdot \mathrm{Hai}^{2} \mathrm{Xia} \mathrm{Wu}^{44}$. \\ Kwang Hee Moon ${ }^{45}$. Cecile Gueidan ${ }^{46} \cdot$ Felix Schumm $^{47}$. Digvijayini Bundhun ${ }^{2,6}$. Ausana Mapook ${ }^{2}$. \\ Jutamart Monkai $^{2}$. Chitrabhanu S. Bhunjun ${ }^{2,11} \cdot$ Putarak Chomnunti $^{11}$ - Satinee Suetrong ${ }^{49} \cdot$ Napalai Chaiwan $^{2,3}$. \\ Monika C. Dayarathne ${ }^{33}$. Jing Yang ${ }^{2,15}$. Achala R. Rathnayaka2,11,50 • Jian-Chu Xu 3,4,5,35 • Jiesheng Zheng ${ }^{1}$. \\ Gang Liu ${ }^{1}$ Y Yao Feng ${ }^{51} \cdot$ Ning Xie $^{1}$
}

Received: 9 June 2020 / Accepted: 10 September 2020 / Published online: 24 December 2020

(C) The Author(s) 2020

\begin{abstract}
Numerous new taxa and classifications of Dothideomycetes have been published following the last monograph of families of Dothideomycetes in 2013. A recent publication by Honsanan et al. in 2020 expanded information of families in Dothideomycetidae and Pleosporomycetidae with modern classifications. In this paper, we provide a refined updated document on orders and families incertae sedis of Dothideomycetes. Each family is provided with an updated description, notes, including figures to represent the morphology, a list of accepted genera, and economic and ecological significances. We also provide phylogenetic trees for each order. In this study, 31 orders which consist 50 families are assigned as orders incertae sedis in Dothideomycetes, and 41 families are treated as families incertae sedis due to lack of molecular or morphological evidence. The new order, Catinellales, and four new families, Catinellaceae, Morenoinaceae Neobuelliellaceae and Thyrinulaceae are introduced. Seven genera (Neobuelliella, Pseudomicrothyrium, Flagellostrigula, Swinscowia, Macroconstrictolumina, Pseudobogoriella, and Schummia) are introduced. Seven new species (Acrospermum urticae, Bogoriella complexoluminata, Dothiorella ostryae, Dyfrolomyces distoseptatus, Macroconstrictolumina megalateralis, Patellaria microspora, and Pseudomicrothyrium thailandicum) are introduced base on morphology and phylogeny, together with two new records/reports and five new collections from different families. Ninety new combinations are also provided in this paper.
\end{abstract}

Electronic supplementary material The online version of this article (https://doi.org/10.1007/s13225-020-00462-6) contains supplementary material, which is available to authorized users.

Extended author information available on the last page of the article 
Keywords Abrothallales $\cdot$ Ascrospermales $\cdot$ Asterinales $\cdot$ Botryosphaeriales $\cdot$ Catinellales $\cdot$ Cladoriellales $\cdot$ Collemopsidiales $\cdot$ Dyfrolomycetales $\cdot$ Eremithallales $\cdot$ Eremomycetales $\cdot$ Jahnulales $\cdot$ Kirschsteiniotheliales . Lembosinales $\cdot$ Lichenotheliales $\cdot$ Microthyriales $\cdot$ Minutisphaerales $\cdot$ Monoblastiales $\cdot$ Murramarangomycetales . new family $\cdot$ new genera $\cdot$ new order $\cdot$ new species $\cdot$ Parmulariales $\cdot$ Patellariales $\cdot$ Phaeotrichales $\cdot$ Phylogeny $\cdot$ Stigmatodiscales $\cdot$ Strigulales $\cdot$ Superstratomycetales $\cdot$ Taxonomy $\cdot$ Trypetheliales $\cdot$ Tubeufiales $\cdot$ Valsariales $\cdot$ Venturiales . Zeloasperisporiales

\section{Table of contents and contributors}

\section{Abrothallales \\ Lichenoconiaceae (S Pérez-Ortega, A Suija, S Hong-} sanan, R Jeewon)

\section{Ascospermales}

Ascospermaceae (D Pem, D Bundhun, S Hongsanan, KD Hyde)

\section{Asterinales}

Asterinaceae (XY Zeng, S Hongsanan, KD Hyde, R Jeewon)

Asterotexaceae (S Hongsanan, KD Hyde, EHC McKenzie)

Hemigraphaceae (DQ Dai, S Hongsanan, EHC McKenzie)

Lembosiaceae (D Sandamali, KD Hyde, S Hongsanan, EHC McKenzie)

Melaspileellaceae (S Hongsanan, Q Tian, KD Hyde, R Jeewon)

Morenoinaceae (S Hongsanan, KD Hyde, EHC McKenzie)

Neobuelliellaceae (S Hongsanan, KD Hyde, EHC

McKenzie)

Stictographaceae (DQ Dai, S Hongsanan, R Jeewon)

\section{Botryosphaeriales}

Aplosporellaceae (AH Ekanayaka, AJL Phillips, KD Hyde)

Botryosphaeriaceae (IS Manawasinghe, AJ Dissanaya,

A Phillips)

Melanopsaceae (S Hongsanan, AJL Phillips, KD Hyde)

Phyllostictaceae (AJ Dissanaya, P Abeywickrama, AJL

Phillips, S Hongsanan, KD Hyde)

Planistromellaceae (J Monkai, AJL Phillips, KD Hyde)

Saccharataceae (AJ Dissanaya, AJL Phillips, S Hongsanan KD Hyde)

\section{Catinellales}

Catinellaceae (AH Ekanayaka, HA Ariyawansa, JS Zheng, KD Hyde)

\section{Cladoriellales}

Cladoriellaceae (S Hongsanan, DJ Bhat, EHC McKenzie, KD Hyde)

\section{Collemopsidiales}

Xanthopyreniaceae (S Pérez-Ortega, A Suija, S Hongsanan, EHC McKenzie)

\section{Dyfrolomycetales}

Pleurotremataceae (JF Zhang, VV Sarma, S Hongsanan, EBG Jones, KD Hyde)

\section{Eremithallales}

Melaspileaceae (V Thiyagaraja, D Ertz, S Hongsanan, KD Hyde)

\section{Eremomycetales}

Eremomycetaceae (D Pem, S Boonmee, KD Hyde, S Hongsanan, EHC McKenzie)

\section{Jahnulales}

Aliquandostipitaceae (ZL Luo, DF Bao, EBG Jones, KD Hyde)

Manglicolaceae (S Suetrong, S Preedanon, EBG Jones, KD Hyde)

\section{Kirschsteiniotheliales}

Kirschsteiniotheliaceae (ZL Luo, DF Bao, R Jeewon, KD Hyde)

Lembosinales

Lembosiaceae (S Hongsanan, KD Hyde, EHC McKenzie)

\section{Lichenotheliales}

Lichenotheliaceae (V Thiyagaraja, S Hongsanan, R Jeewon, KD Hyde)

\section{Microthyriales}

Microthyriaceae (XY Zeng, S Hongsanan, DJ Bhat, KD Hyde, EHC McKenzie)

\section{Minutisphaerales}

Agrogenosporaceae (J Yang, DJ Bhat, EHC McKenzie, KD Hyde)

Minutisphaeraceae (KM Thambugala, HA Raja, DJ Bhat, KD Hyde) 


\section{Monoblastiales}

Monoblastiaceae (R Lücking, A Aptroot, H Kashiwadani, KH Moon, C Gueidan, F Schumm, R Phookamsak)

\section{Murramarangomycetales}

Murramarangomycetaceae (S Hongsanan, DJ Bhat, KD Hyde, EHC McKenzie)

\section{Muyocopronales}

Muyocopronaceae (N Chaiwan, S Hongsanan, C Senwanna, KD Hyde)

\section{Natipusillales}

Natipusillaceae (S Hongsanan, ZL Luo, KD Hyde, EHC McKenzie)

\section{Parmulariales}

Parmulariaceae (DQ Dai, S Hongsanan, R Jeewon, KD Hyde)

\section{Patellariales}

Patellariaceae (AH Ekanayaka, S Hongsanan, R Jeewon, KD Hyde)

\section{Phaeotrichales}

Phaeotrichaceae (D Sandaruwan, JS Zheng, KD Hyde, S Hongsanan, EHC McKenzie)

\section{Stigmatodiscales}

Stigmatodiscaceae (S Hongsanan, A Rathnayaka, EHC McKenzie, KD Hyde)

\section{Strigulales}

Strigulaceae (SH Jiang, R Lücking, E Sérusiaux)

Tenuitholiascaceae (SH Jiang, R Lücking)

\section{Superstratomycetales}

Superstratomycetaceae (P Abeywickrama, S Hongsanan)

\section{Trypetheliales}

Polycoccaceae (S Hongsanan, D Ertz, EHC McKenzie)

Trypetheliaceae (R Lücking, SN Zhang, R MirandaGonzález, A Aptroot)

\section{Tubeufiales}

Bezerromycetaceae (YZ Lu, J Bezerra, EHC McKenzie, KD Hyde)

Tubeufiaceae (YZ Lu, J Bezerra, EHC McKenzie, KD Hyde)

Wiesneriomycetaceae (C Senwanna, J Bezerra, EHC McKenzie)

\section{Valsariales}

Valsariaceae (C Senwanna, D Pem, S Hongsanan, EHC McKenzie, KD Hyde)

\section{Venturiales}

Sympoventuriaceae (D Sandamali, KD Hyde, R Jeewon) Venturiaceae (D Sandamali, KD Hyde, S Hongsanan, R Jeewon)

\section{Zeloasperisporiales}

Zeloasperisporiaceae (S Hongsanan, DJ Bhat R Jeewon, KD Hyde)

\section{Dothideomycetes, families incertae sedis} Alinaceae (S Hongsanan, S Boonmee, EHC McKenzie) Argynnaceae (S Boonmee, S Hongsanan, S Konta) Ascoporiaceae (S Boonmee, EHC McKenzie) Aulographaceae (D Sandamali, S Hongsanan) Balladynaceae (S Hongsanan, D Pem, S Boonmee) Cleistosphaeraceae (S Hongsanan, D Pem, S Boonmee) Coccoideaceae (S Boonmee, EHC McKenzie, KD Hyde) Cookellaceae (S Boonmee, EHC McKenzie, KD Hyde) Dimeriaceae (S Boonmee, KD Hyde, EHC McKenzie, S Konta)

Dubujianaceae (D Pem, S Hongsanan, KD Hyde)

Dysrhynchisceae (S Boonmee, KD Hyde, S Konta)

Endosporiaceae (D Pem, KD Hyde)

Englerulaceae (HX Wu, S Hongsanan, EHC McKenzie, KD Hyde)

Homortomycetaceae (KM Thambugala, EHC McKenzie, KD Hyde)

Hyalomeliolinaceae (S Boonmee, S Konta)

Leptopeltidaceae (R Phookamsak, EHC McKenzie, KD Hyde)

Macrovalsariaceae (D Pem, KD Hyde)

Meliolinaceae (XY Zeng, S Hongsanan, EHC McKenzie Mesnieraceae (P Chomnunti, S Hongsanan, S Boonmee) Naetrocymbaceae (S Hongsanan, DQ Dai, KD Hyde) Nematotheciaceae (S Hongsanan, S Boonmee, KD Hyde) Neoparodiaceae (S Hongsanan, S Boonmee, KD Hyde)

Palawaniaceae (A Mapook, S Hongsanan, EHC McKenzie)

Paranectriellaceae (S Boonmee, EHC McKenzie, KD Hyde)

Parodiellaceae (S Hongsanan, P Chomnunti, KD Hyde) Perisporiopsidaceae (S Boonmee, EHC McKenzie, KD Hyde)

Phaeodimeriellaceae (S Hongsanan, S Boonmee, KD Hyde)

Pododimeriaceae (S Hongsanan, S Boonmee KD Hyde) 
Pododimeriellaceae (S Hongsanan, D Sandamali, S Boonmee, KD Hyde)

Polyclypeolinaceae (S Hongsanan, S Boonmee, KD Hyde)

Polystomellaceae (D Pem, S Boonmee, KD Hyde)

Protoscyphaceae (S Boonmee, EHC McKenzie, KD Hyde)

Pseudoperisporiaceae (S Boonmee, EHC McKenzie, KD Hyde)

Pseudorobillardaceae (S Tibpromma, WJ Li, S Hongsanan, EHC McKenzie)

Pyrenidiaceae (S Hongsanan, N Huanraluek, D Ertz, KD Hyde)

Seynesiopeltidaceae (D Pem, S Boonmee, EHC McKenzie, KD Hyde)

Stomatogeneceae (S Hongsanan, S Boonmee, EHC McKenzie, KD Hyde)

Toroaceae (S Hongsanan, S Boonmee, KD Hyde, EHC McKenzie)

Thyrinulaceae (XY Zeng, S Hongsanan, KD Hyde, EHC McKenzie)

Trichopeltinaceae (D Sandamali, S Hongsanan, KD Hyde)

Trichothyriaceae (XY Zeng, HX Wu, KD Hyde)

Vizellaceae (HX Wu, S Hongsanan, S Boonmee, KD Hyde)

\section{Introduction}

Dothideomycetes were previously known as Loculoascomycetes, and is the largest class of ascomycetes (Nannfeldt 1932; Luttrell 1955; Janex-Favre 1971; Barr 1979a, b; Eriksson 1981; Reynolds 1971; Tehler 1990, 1995; LetrouitGalinou et al. 1994; Barr and Huhndorf 2001; Liu and Hall 2004; Hyde et al. 2013; Hongsanan et al. 2020). Members of this class mostly have bitunicate, fissitunicate asci (Nannfeldt 1932; Luttrell 1955; Eriksson 1981; Barr and Huhndorf 2001; Hyde et al. 2013; Hongsanan et al. 2020). Hyde et al. (2013) provided descriptions, notes and discussed taxonomic placement of families in Dothideomycetes. They also confirmed that Dothideomycetes comprises two subclasses viz. Dothideomycetidae and Pleosporomycetidae, while other uncertain orders and families were treated as incertae sedis in Dothideomycetes. Based on morphology and phylogeny, Dothideomycetidae comprised Capnodiales, Dothideales, and Myrangiales, and Pleosporomycetidae comprised Gloniales, Hysteriales, Mytilinidiales, and Pleosporales (Hyde et al. 2013, Hongsanan et al. 2020). Hongsanan et al. (2020) provided a monograph of families in Dothideomycetidae and Pleosporomycetidae based on 'Families of Dothideomycetes' (Hyde et al. 2013) which was the latest update and the most complete monograph of families in Dothideomycetes, included in Wijayawardene et al. (2017a) who provided 'Notes for genera: Ascomycota' and Wijayawardene et al. (2020) who provided 'Outline of Fungi and fungus-like taxa'. Hongsanan et al. (2020) provided an updated description, notes, including figures to represent the morphology, list of accepted genera, and economic and ecological significance of families in Dothideomycetidae and Pleosporomycetidae. They accepted three orders with 25 families in Dothideomycetidae and four orders with 94 families in Pleosporomycetidae (Hongsanan et al. 2020). Liu et al. (2017) established guidelines of using divergence estimates in the classification of Dothideomycetes, and this was followed by Hongsanan et al. (2020) who provided an updated divergence estimation of families in Dothideoycetes using two representative strains from each family. In our paper, we used the divergence time estimation from Hongsanan et al. (2020) to discuss orderal and familial status of incertae sedis groups.

The aim of this paper is to bring together data of orders and families which were not assigned to Dothideomycetidae nor Pleosporomycetidae due to their uncertain phylogenetic placement or lack of sequence data. We included all published data that we could locate in 2019 and have also included some data that we were aware of up to the date of publication. This work refined account of the families of Dothideomycetes and will provide a baseline for research on Dothideomycetes over the next decade. As an online database, dothideomycetes.org (Pem et al. 2019b) and fungalgenera.org (Monkai et al. 2019), the contents will be be continually refined and updated and stay abreast of classification changes as new data and additional evidence are published.

\section{Materials and methods}

\section{Layout of the paper}

Each family which is currently not assigned to Dothideomycetidae and Pleosporomycetidae is introduced with descriptions and important notes. Accepted genera including the type species, and notes are provided with basionyms (other synonyms can be found in Index Fungorum 2020). Faces of Fungi and Index Fungorum numbers are provided as in Jayasiri et al. (2015) and Index Fungorum (2020). Estimated numbers of species for each genus is provided mainly based on data in Species Fungorum (2020), with species transferred to other genera or species not being included. The number of species with sequence data available in GenBank is provided. The morphology of each family is illustrated by representative photographic plates from type herbarium specimens, or new species/new collections with sequence data. We provide drawing for families which we were unable to obtain herbarium specimens or fresh collections. Notes on the ecological and economic significance are also provided. 


\section{Molecular phylogeny}

Phylogenetic trees of each order are provided, except for orders where too little sequence data is available. Trees for each order include representatives from all genera that have sequence data (Supplemental material 1). The methods below were applied for most of the phylogenetic trees shown in this paper. Other additional methods are mentioned in the legend of each analysis.

Gene regions used in each analysis were selected based on the most recent study or the availability of sequence data. Datasets for each partition were aligned using MAFFT (Katoh et al. 2019), and adjusted manually using Bioedit (Hall 2004). All missing genes were coded as missing data. Phylogenetic trees based on individual gene partitions (data not shown) were congruent with the combined data sets. The phylogenetic analyses of the combined dataset were performed using maximum likelihood algorithms in RAxML and Bayesian analyses.

Maximum likelihood analysis (ML) was carried out by using raxmlGUIv.0.9b2 (Silvestro and Michalak 2012). The search strategy was set to bootstrapping and the analysis performed using the GTRGAMMAI model. The number of replicates was inferred using the stopping criterion (Pattengale et al. 2009). The bootstrap values expressed from 1,000 repetitions by RAxML analysis which are equal or greater than $70 \%$ are given on each node. The best fit model of evolution was selected by MrModeltest 2.2 (Nylander et al. 2008). Bayesian phylogenetic analyses, posterior probabilities (PP) were set by MCMC sampling in MrBayes v3.1.2 (Huelsenbeck and Ronquist 2001; Zhaxybayeva and Gogarten 2002), following the details in Cai et al. (2008). The first $20 \%$ were discarded, and the remaining trees were used for calculating posterior probabilities. Posterior probabilities values (PP) from Bayesian analysis which are equal or greater than 0.90 are given on each node. Phylogenetic tree was viewed in FigTree v.1.4.0 (Rambaut 2014).

\section{Order of Dothideomycetes}

For the subclasses Dothideomycetidae and Pleosporomycetidae see Hongsanan et al. (2020) and Dothideomycetes genera incertae sedis see Wijayawardene et al. (2020).

\author{
Abrothallales Pérez-Ort. \& Suija \\ Lichenoconiaceae Diederich \& Lawrey (= Abrothallaceae \\ Pérez-Ort. \& Suija) (57) \\ Abrothallus De Not. \\ Lichenoconium Petr. \& Syd.
}

Acrospermales Minter et al.

Acrospermaceae Fuckel

Acrospermum Tode

Gonatophragmium Deighton

Oomyces Berk. \& Broome

Pseudovirgaria H.D. Shin et al.
Asterinales M.E. Barr ex D. Hawksw. \& O.E. Erikss. (= Asterotexales Firmino et al.)

Asterinaceae Hansf.

Asterina Lév.

Asterinella Theiss.

Asterolibertia G. Arnaud

Asterostomella Speg.

Batistinula Arx

Cirsosia G. Arnaud

Dothidasteromella Höhn.

Echidnodella Theiss. \& Syd.

Halbania Racib.

Meliolaster Höhn.

Parasterinopsis Bat.

Platypeltella Petr.

Prillieuxina G. Arnaud

Pycnocarpon Theiss.

Schenckiella Henn.

Trichasterina G. Arnaud

Trichopeltospora Bat. \& Cif.

Uleothyrium Petr.

Vizellopsis Bat. et al.

Asterotexaceae Firmino et al.

Asterotexis Arx

Hemigraphaceae D.Q. Dai \& K.D. Hyde Hemigrapha (Müll. Arg.) D. Hawksw.

Lembosiaceae Luttrell ex P.M. Kirk et al. Lembosia Lév.

Melaspileellaceae D.Q. Dai \& K.D. Hyde Melaspileella (P. Karst.) Vain.

Morenoinaceae Hongsanan \& K.D. Hyde Morenoina Theiss.

Neobuelliellaceae Hongsanan \& K.D. Hyde Neobuelliella Hongsanan \& K.D. Hyde

Stictographaceae D.Q. Dai \& K.D. Hyde

Buelliella Fink

Karschia Körb.

Labrocarpon Etayo \& Pérez-Ort.

Melaspileopsis (Müll. Arg.) Ertz \& Diederich

Stictographa Mudd

Asterinales genera incertae sedis

Andamanomyces Hosag.

Caribaeomyces Cif.

Caudella Syd. \& P. Syd.

Discopycnothyrium Hongsanan \& K.D. Hyde 
Hazslinszkya Körb.

Inocyclus Theiss. \& Syd.

Melanographa Müll. Arg.

Pirozynskiella S. Hughes

Vishnumyces Hosag.

Botryosphaeriales C.L. Schoch et al. Aplosporellaceae Slippers et al.

Alanomyces Sharma

Aplosporella Speg.

Botryosphaeriaceae Theiss. \& H. Syd. Alanphillipsia Crous \& M.J. Wingf.

Barriopsis A.J.L. Phillips et al.

Botryobambusa Phook. et al.

Botryosphaeria Ces. \& De Not.

Cophinforma Doilom et al.

Diplodia Fr.

Dothiorella Sacc.

Endomelanconiopsis Rojas \& Samuels

Eutiarosporella Crous

Lasiodiplodia Ellis \& Everh.

Macrophomina Petr.

Marasasiomyces Crous

Mucoharknessia Crous et al.

Neodeightonia C. Booth

Neofusicoccum Crous et al.

Neoscytalidium Crous \& Slippers

Oblongocollomyces Tao Yang \& Crous

Phaeobotryon Theiss. \& Syd.

Sakireeta Subram. \& K. Ramakr.

Sardiniella Linaldeddu et al.

Sphaeropsis Sacc.

Tiarosporella Höhn.

Melanopsaceae Phillips et al.

Melanops Nitschke ex Fuckel

Phyllostictaceae Fr.

Phyllosticta Pers.

Pseudofusicoccum Mohali et al.

Planistromellaceae M.E. Barr

Kellermania Ellis \& Everh.

Mycosphaerellopsis Höhn.

Planistroma A.W. Ramaley

Umthunziomyces Crous \& M.J. Wingf.

Saccharataceae Slippers et al.

Pileospora Tanney \& Seifert

Saccharata Denman \& Crous (= Neoseptorioides Crous et al.)
Septorioides Quaedvl. et al.

Botryosphaeriales genera incertae sedis

Auerswaldiella Theiss. \& Syd.

Coccostromella Petr.

Leptoguignardia E. Müll.

Metameris Theiss. \& Syd.

Phyllachorella Syd.

Pilgeriella Henn.

Sivanesania W.H. Hsieh \& C.Y. Chen

Vestergrenia Rehm

Catinellales Ekanayaka et al.

Catinellaceae Ekanayaka et al.

Catinella Boud.

Cladoriellales Crous

Cladoriellaceae Crous

Cladoriella Crous

Collemopsidiales Perez-Ortega et al.

Xanthopyreniaceae Zahlbr.

Collemopsidium Nyl.

Didymellopsis (Sacc.) Clem. \& Shear

Frigidopyrenia Grube

Rhagadodidymellopsis Fdez.-Brime et al.

Xanthopyrenia Bachm.

Zwackhiomyces Grube \& Hafellner

Zwackhiomacromyces Etayo \& van den Boom

Dyfrolomycetales K.L. Pang et al.

Pleurotremataceae Walt. Watson (= Dyfrolomycetaceae

K.D. Hyde et al.)

Dyfrolomyces K.D. Hyde et al.

Melomastia Nitschke ex Sacc.

Pleurotrema Müll. Arg.

Eremithallales Lücking \& Lumbsch

Melaspileaceae W. Watson (= Eremithallaceae Lücking \&

Lumbsch)

Encephalographa A. Massal.

Melaspilea Nyl.

Eremomycetales Crous et al.

Eremomycetaceae Malloch \& Cain

Eremomyces Malloch \& Cain

Rhexothecium Samson \& Mouch.

Eremomycetales genus incertae sedis

Arthrographis G. Cochet ex Sigler \& J.W. Carmich. 
Jahnulales Pang et al.

Aliquandostipitaceae Inderbitzin

Aliquandostipite Inderbitzin

Brachiosphaera Nawawi

Jahnula Kirschst.

Megalohypha A. Ferrer \& Shearer

Neojahnula W. Dong et al.

Pseudojahnula W. Dong et al.

Xylomyces Goos et al.

Manglicolaceae Suetrong \& E.B.G. Jones

Manglicola Kohlm. \& E. Kohlm.

Kirschsteiniotheliales Hern.-Restr. et al.

Kirschsteiniotheliaceae Boonmee \& K.D. Hyde

Kirschsteiniothelia D. Hawksw.

Kirschsteiniotheliales genus incertae sedis

Brachysporiella Bat. (Brachysporiella sensu lato)

Taeniolella S. Hughes sensu lato

\section{Lembosinales Crous}

\section{Lembosinaceae Crous}

Lembosina Theiss.

Lichenotheliales K. Knudsen et al.

Lichenotheliaceae Henssen

Lichenothelia D. Hawksw.

Endococcus Nyl.

Microthyriales G. Arnaud

Microthyriaceae Sacc.

Arnaudiella Petr.

Calothyriopsis Höhn.

Chaetothyriothecium Hongsanan \& K.D. Hyde

Hamatispora L.T.H. Yen et al.

Microthyrium Desm.

Neoanungitea Crous

Paramicrothyrium H.X. Wu \& K.D. Hyde

Pseudomicrothyrium X.Y. Zeng et al.

Pseudopenidiella Crous \& Koukol

Seynesiella G. Arnaud

Tumidispora Hongsanan \& K.D. Hyde

Microthyriales genera incertae sedis

Heliocephala V. Rao et al.

Mitopeltis Speg.

Neoscolecobasidium Crous

Parazalerion Madrid et al.

Thyriodictyella Cif.

Tothia Bat.
Minutisphaerales Raja et al.

Acrogenosporaceae Jayasiri \& K.D. Hyde.

Acrogenospora M.B. Ellis

Minutisphaeraceae Raja et al Minutisphaera Shearer et al.

Monoblastiales Lücking et al.

Monoblastiaceae Walt. Watson (= Eriomycetaceae Huanraluek \& K.D. Hyde)

Acrocordia A. Massal.

Anisomeridium (Müll. Arg.) M. Choisy

Caprettia Bat. \& H. Maia

Eriomyces Huanraluek, Thambugala \& K.D. Hyde

Funbolia Crous \& Seifert

Heleiosa Kohlm. et al.

Megalotremis Aptroot

Monoblastia Riddle

Phellinocrescentia Crous \& Decock

Pseudopassalora Crous

Trypetheliopsis Asahina

Murramarangomycetales Crous

Murramarangomycetaceae Crous

Phaeothyriolum Syd.

Muyocopronales Mapook et al.

Muyocopronaceae K.D. Hyde

Arxiella Papendorf

Leptodiscella Papendorf

Muyocopron Speg.

Mycoleptodiscus Ostaz.

Neocochlearomyces Pinruan et al.

Neomycoleptodiscus Hern.-Restr. et al.

Paramycoleptodiscus Crous \& M.J. Wingf.

Pseudopalawania Mapook \& K.D. Hyde

Setoapiospora Mapook \& K.D. Hyde

Natipusillales Raja et al.

Natipusillaceae Raja et al.

Natipusilla A. Ferrer

Parmulariales D.Q. Dai \& K.D. Hyde

Parmulariaceae E. Müll. \& Arx ex M.E. Barr

Aldona Racib.

Aldonata Sivan. \& A.R.P. Sinha

Antoniomyces Inácio

Aulacostroma Syd. \& P. Syd.

Campoa Speg.

Cirsosiopsis Butin \& Speer 
Cocconia Sacc.

Cycloschizon P. Henn.

Cyclostomella Pat.

Dothidasteroma Höhn.

Ferrarisia Sacc.

Hysterostomella Speg.

Kiehlia Viégas

Mintera Inácio \& P.F. Cannon

Pachypatella Theiss. \& Syd.

Palawaniella Doidge

Parmularia Lév.

Parmulariopsella Sivan.

Parmulariopsis Petr.

Parmulina Theiss. \& Syd.

Placoasterella Sacc. ex Theiss. \& Syd

Placosoma Syd.

Placostromella Petr.

Pleiostomellina Bat. et al.

Polycyclina Theiss. \& Syd.

Polycyclus Höhn.

Protothyrium G. Arnaud

Pseudolembosia Theiss.

Rhagadolobiopsis Guatim. \& R.W. Barreto

Rhagadolobium P. Henn. \& Lindau

Rhipidocarpon (Theiss.) Theiss. \& Syd.

Symphaeophyma Speg.

Syrropeltis Bat. et al.

Thallomyces H.J. Swart

Viegasiella Inácio \& P.F. Cannon

Patellariales D. Hawksw. \& O.E. Erikss.

Patellariaceae Corda

Baggea Auersw.

Banhegyia L. Zeller \& Tóth

Colensoniella Hafellner

Endotryblidium Petr.

Glyphium Nitschke ex F. Lehm.

Haematomyxa Sacc

Holmiella Petrini et al.

Hysteropatella Rehm

Hysteropeltella Petr.

Lahmiomyces Cif. \& Tomas.

Lecanidiella Sherwood

Lirellodisca Aptroot

Murangium Seaver

Patellaria Fr.

Poetschia Körb.

Pseudoparodia Theiss. \& Syd.

Rhizodiscina Hafellner

Rimula Velen.

Schrakia Hafellner

Stratisporella Hafellner

Tryblidaria (Sacc.) Sacc.
Phaeotrichales Ariyaw. et al.

Phaeotrichaceae Cain

Echinoascotheca Matsush.

Phaeotrichum Cain \& M.E. Barr

Trichodelitschia Munk

Stigmatodiscales Voglmayr \& Jaklitsch

Stigmatodiscaceae Voglmayr \& Jaklitsch

Stigmatodiscus Voglmayr \& Jaklitsch

Strigulales Lücking et al.

Strigulaceae Zahlbr. (= Phyllobatheliaceae Bitter \& F.

Schill.)

Dichoporis Clem.

Flagellostrigula Lücking et al.

Flavobathelium Lücking et al.

Phyllobathelium (Müll. Arg.) Müll. Arg

Phyllocharis Fée,

Phyllocraterina Sérus. \& Aptroot

Phylloporis Clem.

Puiggariella Speg.

Raciborskiella Höhnel

Racoplaca Fée

Serusiauxiella S.H. Jiang et al.

Strigula Fr.

Swinscowia S.H. Jiang et al.

Tenuitholiascaceae S.H. Jiang et al.

Tenuitholiascus S.H. Jiang et al.

Superstratomycetales van Nieuwenhuijzen et al.

Superstratomycetaceae van Nieuwenhuijzen et al.

Superstratomyces van Nieuwenhuijzen et al.

Trypetheliales Lücking et al.

Polycoccaceae Ertz et al.

Clypeococcum D. Hawksw.

Polycoccum Saut. ex Körb.

Trypetheliaceae Zenker

Alloarthopyrenia Phukhams. et al.

Aptrootia Lücking \& Sipman

Architrypethelium Aptroot

Astrothelium Eschw.

Bathelium Ach.

Bogoriella Zahlbr.

Constrictolumina Lücking et al.

Dictyomeridium Aptroot et al.

Macroconstrictolumina Lücking et al.

Marcelaria Aptroot

Nigrovothelium Lücking et al.

Polymeridium (Müll. Arg.) R.C. Harris

Polypyrenula D. Hawksw. 
Pseudobogoriella Lücking et al.

Pseudopyrenula Müll. Arg.

Schummia Lücking et al.

Trypethelium Sprengel

Viridothelium Lücking et al.

Tubeufiales Boonmee \& K.D. Hyde

Bezerromycetaceae J.D.P. Bezerra et al.

Bezerromyces J.D.P. Bezerra et al.

Neorhamphoria Boonmee et al.

Xiliomyces J.D.P. Bezerra et al.

\section{Tubeufiaceae M.E. Barr}

Acanthohelicospora Boonmee \& K.D. Hyde

Acanthophiobolus Berl.

Acanthostigma De Not.

Acanthostigmina Höhn.

Acanthotubeufia Y.Z. Lu \& K.D. Hyde

Aquaphila Goh et al.

Artocarpomyces Subram.

Berkleasmium Zobel

Bifrontia Norman

Boerlagiomyces Butzin

Camporesiomyces D.P. Wei \& K.D. Hyde

Chaetosphaerulina I. Hino

Chlamydotubeufia Boonmee \& K.D. Hyde

Dematiohelicoma Y.Z. Lu et al.

Dematiohelicomyces Y.Z. Lu et al.

Dematiohelicosporum Y.Z. Lu et al.

Dematiotubeufia Y.Z. Lu et al.

Dictyospora Brahamanage et al.

Discotubeufia Jayasir et al.

Helicangiospora Boonmee et al.

Helicoarctatus Y.Z. Lu et al.

Helicodochium J.S. Monteiro et al.

Helicohyalinum Y.Z. Lu et al.

Helicoma Corda

Helicomyces Link

Helicosporium Nees

Helicotruncatum Y.Z. Lu et al.

Helicotubeufia Y.Z. Lu \& J.K. Liu

Kamalomyces R.K. Verma et al.

Kevinhydea N.G. Liu et al.

Manoharachariella Bagyan. et al.

Muripulchra Z.L. Luo et al.

Neoacanthostigma Boonmee et al.

Neochlamydotubeufia Y.Z. Lu et al.

Neohelicoma Y.Z. Lu et al.

Neohelicomyces Z.L. Luo et al.

Neohelicosporium Y.Z. Lu et al.

Neotubeufia Chaiwan et al.

Pleurohelicosporium Y.Z. Lu et al.

Podonectria Petch
Pseudohelicomyces Y.Z. Lu et al.

Pseudohelicoon Y.Z. Lu \& K.D. Hyde

Tamhinispora Rajeshkumar \& Rahul Sharma

Thaxteriella Petr.

Thaxteriellopsis Sivan. et al.

Tubeufia Penz. \& Sacc.

Wiesneriomycetaceae Suetrong et al.

Parawiesneriomyces Crous \& M.J. Wingf.

Phalangispora Nawawi \& J. Webster

Pseudogliophragma Phadke \& V.G. Rao

Setosynnema D.E. Shaw \& B. Sutton

Speiropsis Tubaki

Wiesneriomyces Koord.

Valsariales Jaklitsch et al.

Valsariaceae Jaklitsch et al.

Bambusaria Jaklitsch et al.

Myrmaecium Nitschke ex Fuckel

Valsaria Ces. \& De Not.

Venturiales Y. Zhang ter et al.

Sympoventuriaceae Y. Zhang ter et al.

Acroconidiellina M.B. Ellis

Clavatispora Boonmee \& K.D. Hyde

Echinocatena R. Campb. \& B. Sutton

Fusicladium Bonord.

Matsushimaea Subram.

Mycosisymbrium Carris

Ochroconis de Hoog \& Arx

Scolecobasidiella M.B. Ellis

Scolecobasidium E.V. Abbott

Sympoventuria Crous \& Seifert

Veronaeopsis Arzanlou \& Crous

Verruconis Samerp. et al.

Yunnanomyces Tibpromma \& K.D. Hyde

Venturiaceae E. Müll. \& Arx ex M.E. Barr

Apiosporina Höhn.

Atopospora Petr.

Caproventuria U. Braun

Coleroa (Fr.) Rabenh.

Cylindrosympodium W.B. Kendr. \& R.F. Castañeda

Dimeriella Speg.

Dimerosporiopsis Henn.

Magnohelicospora R.F. Castañeda et al.

Metacoleroa Petr.

Neocoleroa Petr.

Protoventuria Berl. \& Sacc.

Pseudoanungitea Crous

Pseudoparodiella F. Stevens

Sympodiella W.B. Kendr.

Tyrannosorus Unter. \& Malloch 
Venturia Sacc.

Venturiales genus incertae sedis

Cylindrosympodioides Crous \& M.J. Wingf.

Lasiobotrys Kunze

Zeloasperisporiales Hongsanan \& K.D. Hyde

Zeloasperisporiaceae Crous

Zeloasperisporium R.F. Castañeda

Dothideomycetes families incertae sedis

Alinaceae Boonmee \& K.D. Hyde

Alina Racib.

Argynnaceae Shearer \& J.L. Crane

Argynna Morgan

Lepidopterella Shearer \& J.L. Crane

Ascoporiaceae Kutorga \& D. Hawksw. Ascoporia Samuels \& A.I. Romero

Aulographaceae Luttr. ex P.M. Kirk et al. Aulographum Lib.

Echidnodes Theiss. \& Syd.

Lembosiella Sacc.

Thyriopsis Theiss. \& Syd.

Balladynaceae Boonmee \& K.D. Hyde Balladyna Racib.

Balladynocallia Bat.

Balladynopsis Theiss. \& Syd.

Cleistosphaeraceae Boonmee \& K.D. Hyde Cleistosphaera Syd. \& P. Syd.

Coccoideaceae P. Henn. ex Sacc. \& D. Sacc. Coccoidea P. Henn.

Coccoidella Höhn.

Englerodothis Theiss. \& Syd.

Cookellaceae Höhn. ex Saccardo \& Trotter Cookella Sacc.

Pycnoderma Syd. \& P. Syd.

Dimeriaceae E. Müll. \& Arx ex Arx \& E. Müll. Dimerium (Sacc. \& P. Syd.) McAlpine

Dubujianaceae D. Pem et al. Dubujiana D.R. Reynolds \& G.S. Gilbert

Dysrhynchisceae Boonmee \& K.D. Hyde Dysrhynchis Clem.
Endosporiaceae D. Pem

Endosporium Tsuneda

Englerulaceae P. Henn.

Allosoma Syd.

Digitosarcinella S. Hughes

Englerula P. Henn.

Goosia B. Song

Parenglerula Höhn.

Rhytidenglerula Höhn.

Schiffnerula Höhn.

Thrauste Theiss.

Homortomycetaceae Thambug. et al.

Homortomyces Crous \& M.J. Wingf.

Hyalomeliolinaceae Boonmee \& K.D. Hyde Hyalomeliolina F. Stevens

Leptopeltidaceae Höhn. ex Trotter

Dothiopeltis E. Müll.

Leptopeltis Höhn.

Ronnigeria Petr.

Staibia Bat. \& Peres

Macrovalsariaceae D. Pem et al. Macrovalsaria Petr.

Meliolinaceae S. Hughes

Briania D.R. Reynolds

Meliolina Syd. \& P. Syd.

Mesnieraceae Arx \& E. Müll.

Bondiella Piroz.

Mesniera Sacc. \& P. Syd.

Stegasphaeria Syd. \& P. Syd.

Naetrocymbaceae Höhn. ex R.C. Harris

Bonaria Bat.

Jarxia D. Hawksw.

Leptorhaphis Körb.

Naetrocymbe Körb.

Tomasellia A. Massal.

Nematotheciaceae Boonmee \& K.D. Hyde Nematothecium Syd. \& P. Syd. Nematostigma Syd. \& P. Syd.

Ophioparodia Petr. \& Cif.

Neoparodiaceae Boonmee \& K.D. Hyde Neoparodia Petr. \& Cif. 
Palawaniaceae Mapook \& K.D. Hyde Palawania (Niessl) Syd. \& P. Syd.

Paranectriellaceae Boonmee \& K.D. Hyde Paranectriella (Henn. ex Sacc. \& D. Sacc.) Magnus. (= Araneomyces Höhn.)

Puttemansia Henn.

Parodiellaceae Theiss. \& H. Syd. ex M.E. Barr Parodiella Speg.

Perisporiopsidaceae E. Müll. \& Arx ex R. Kirschner \& T.A. Hofm. (= Parodiopsidaceae Toro)

Asteronia (Sacc.) Henn.

Byssocallis Syd.

Chevalieropsis G. Arnaud

Parodiellina Henn. ex G. Arnaud

Perisporiopsis Henn.

Phaeodimeriellaceae Boonmee et al.

Phaeodimeriella Speg.

Pododimeriaceae Boonmee \& K.D. Hyde

Chaetoscutula E. Müll.

Pododimeria E. Müll.

Polyclypeolinaceae Boonmee \& K.D. Hyde Polyclypeolina Bat. \& I.H. Lima

Polystomellaceae Theiss. \& H. Syd.

Dermatodothella Viégas

Dothidella Speg.

Munkiella Speg.

Parastigmatea Doidge

Protoscyphaceae Kutorga \& D. Hawksw. Protoscypha Syd.

Pseudoperisporiaceae Toro

Bryomyces Döbbeler

Eudimeriolum Speg.

Lasiostemma Theiss.

Nematostoma Syd. \& P. Syd.

Pseudorobillardaceae Crous

Pseudorobillarda M. Morelet

Pyrenidiaceae Zahlbr.

Pyrenidium Nyl.

Seynesiopeltidaceae K.D. Hyde

Seynesiopeltis F. Stevens \& R.W. Ryan
Stomatogeneceae Boonmee \& K.D. Hyde

Stomatogene Theiss.

Thyrinulaceae X.Y. Zeng et al.

Blastacervulus H.J. Swart

Paraopeba V.P. Abreu et al.

Thyrinula Petr. \& Syd.

Toroaceae Boonmee \& K.D. Hyde

Toroa Syd.

Trichopeltinaceae Bat. et al.

Acrogenotheca Cif. \& Bat.

Brefeldiella Speg.

Saccardinula Speg.

Trichopeltella Höhn.

Trichopeltheca Bat.

Trichopeltina Theiss.

Trichothyrinula Petr.

Trichothyriaceae Theiss.

Lichenopeltella Höhn.

Macrographa Etayo

Pachythyrium G. Arnaud ex Spooner \& P.M. Kirk

Trichothyrium Speg.

Vizellaceae H.J. Swart

Acarella Syd.

Blasdalea Sacc. \& P. Syd.

Vizella Sacc.

Abrothallales Pérez-Ort. \& Suija.

$=$ Lichenoconiales Diederich, Lawrey \& K.D. Hyde.

Index Fungorum number: IF 805297; Facesoffungi number: FoF 08045.

Abrothallales was established by Pérez-Ortega and Suija (in Pérez-Ortega et al. 2014) based on its monophyletic placement and morphological distinctness within the class Dothideomycetes. Diederich et al. (in Hyde et al. 2013) had introduced Lichenoconiales, which Liu et al. (2017) recovered as a sister clade of Abrothallales, raising the question of whether both orders should be maintained. Diederich et al. (2018) synonymized Lichenoconiales with Abrothallales and tentatively Lichenoconiaceae with Abrothallaceae. Pérez-Ortega and Suija agreed with Diederich et al. (2018) to use the name Abrothallales since Abrothallus is the most outstanding, easily recognizable and better-known genus of the group. Lichenoconiaceae is the older name, therefore, we retain Lichenoconiaceae over Abrothallaceae. Abrothallales contains species which are lichenicolous, parasymbiontic or parasitic on macrolichens from a single family Abrothallaceae (Pérez-Ortega et al. 2014; Wijayawardene et al. 
2017a). The divergence time for Abrothallales is estimated as 204 MYA (stem age, Hongsanan et al. 2020) (Fig. 1).

Accepted families: Lichenoconiaceae.

Lichenoconiaceae Diederich \& Lawrey, in Hyde et al., Fungal Diversity 63: 131 (2013).

= Abrothallaceae Pérez-Ort. \& Suija, in Pérez-Ortega, Suija, Crespo \& Ríos, Fungal Diversity 64(1): 303 (2014).

Index Fungorum number: IF 803667; Facesoffungi number: FoF 08046, 58 species.

Parasitic or parasymbiotic on lichen thalli. Vegetative hyphae immersed in lichen thallus, usually hyaline, I+ violet in some species. Sexual morph: Ascomata apothecioid, solitary or in groups, superficial, rounded, convex to almost globose, rarely flattened, black or dark brown, some species with greenish pruina, at least in young stages. Proper exciple thin, usually disappearing when mature, composed of radiating hyphae. Hymenium hyaline or greenish in upper part, covered with light to dark brown or reddish granules dissolving in $\mathrm{KOH}$. Hypothecium light to dark brown, composed of isodiametric cells (textura angularis type). Hamathecium comprising septate, anastomosed and irregularly dichotomously branching interascal filaments. Asci 4-8-spored, thick-walled, bitunicate, functionally fissitunicate, ovate to clavate, apedicellate, with a distinct ocular chamber, I-. Ascospores 2-seriate, irregularly or 2-seriately arranged within the ascus, ellipsoid to broadly ellipsoid, light to dark brown, 1- to 3-septate, asymmetric and soleiform, splitting into part-spores within the ascus in some species, wall finely ornamented to verrucose. Asexual morph: Coelomycetous. Vouauxiomyces-type, pycnidium immersed, semi-immersed or almost superficial, black, with a small ostiole. Pycnidial wall thick-walled, comprises isodiametric cells (textura angularis-type). Conidiophores reduced. Conidiogenous cells percurrently proliferating, ampulliform to lageniform, lining the cavity of the pycnidium, hyaline, smooth-walled. Conidia holoblastic, clavate to obpyriform or almost roundish, hyaline to dark brown, smooth to slightly echinulate, usually embedded in mucilage.

Type: Lichenoconium Petr. \& Syd.
Fig. 1 Phylogram generated from maximum likelihood analysis (RAxML) of Abrothallales based on combined ITS, LSU and tef1 sequence data. Maximum likelihood bootstrap values equal or above $70 \%$, Bayesian posterior probabilities equal or above 0.90 (MLBS/ $\mathrm{PP})$ are given at the nodes. An original isolate number is noted after the species name. The tree is rooted to Patellaria quercus (CPC 27232 and BHI F828a).

The ex-type strains are indicated in bold. Hyphen (-) represents support values below $70 \%$ MLBS and 0.90 PP

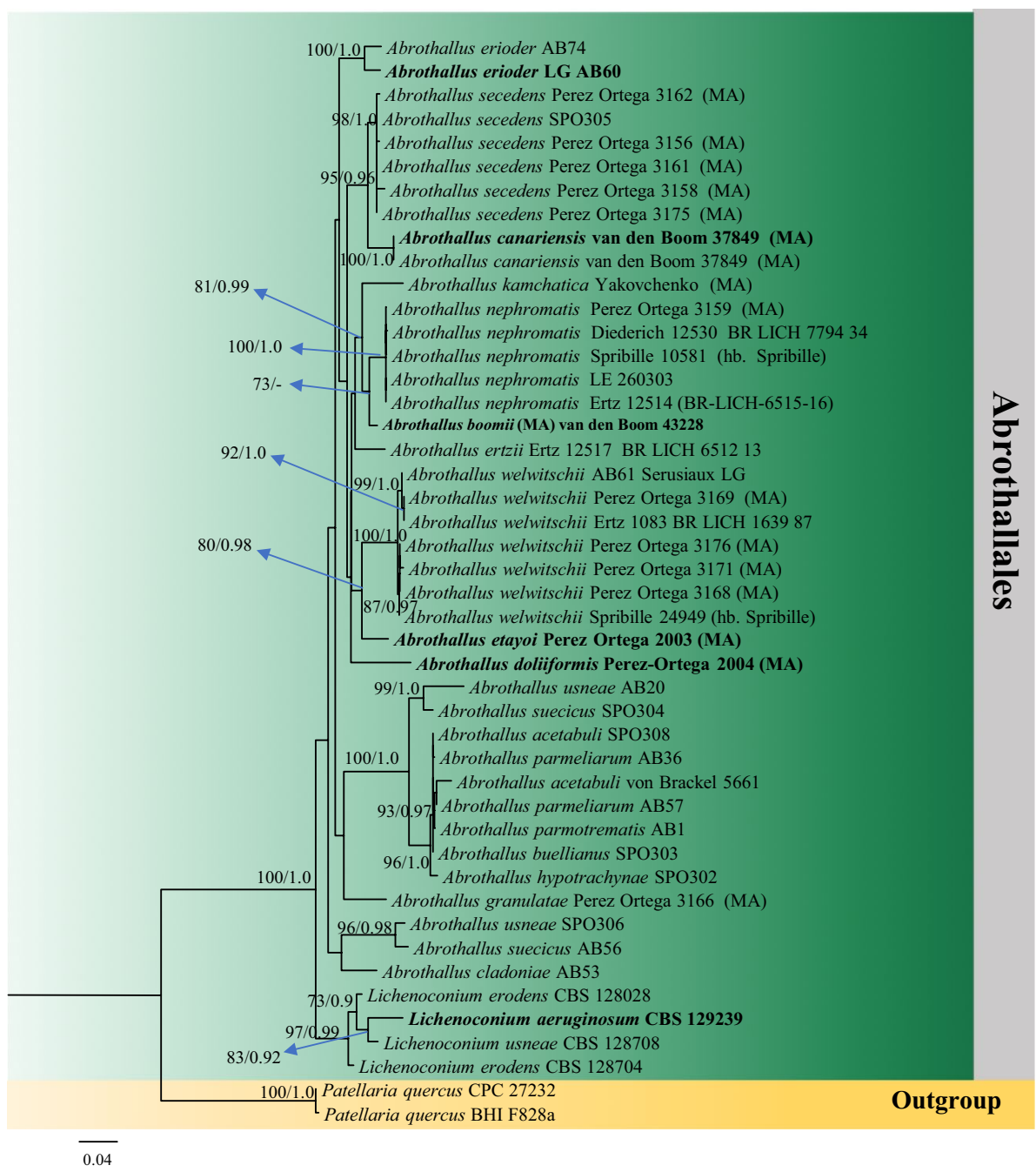


Notes: Lawrey et al. (2011) studied the phylogenetic affinities of Lichenoconium, a genus of lichenicolous fungi known only in its asexual morph. They found that Lichenoconium is also a member of Dothideomycetes, and subsequently Hyde et al. (2013) introduced a new order Lichenoconiales to accommodate it. Pérez-Ortega et al. (2014) introduced Abrothallaceae and the new order Abrothallales for the lichenicolous genus Abrothallus. The classification of this genus had long been debated. This is one of the few Dothideomycetes genera having apothecioid ascomata, but the bitunicate asci and the shape of interascal filaments clearly segregates it from other similar groups (Pérez-Ortega et al. 2014). Pérez-Ortega et al. (2011) established the connection between the sexual morph Abrothallus and the asexual morph Vouauxiomyces. Vouauxiomyces and Lichenoconium share many features, such as the mode of conidiogenesis and shape of conidia (detailed descriptions in Hawksworth 1981b), although the conidia are hyaline in Abrothallus (except in Abrothallus kamchatica) and dark brown in Lichenoconium. Recent phylogenetic analyses recovered Abrothallus and Lichenoconium as sister genera, with a relatively young split (9 MYA) raising the question of the need to keep two separate orders (Liu et al. 2017). Diederich et al. (2018) in their review of lichenicolous fungi treated Lichenoconiales as a synonym of Abrothallales, and Lichenoconiaceae as a possible synonym of Abrothallaceae.

Lichenoconium Petr. \& Syd., Beih. Reprium nov. Spec. Regni veg. 42(1): 432 (1927) [1926].

Index Fungorum number: IF 8772; Facesoffungi number: FoF 08047; 16 morphological species (Species Fungorum 2020), 4 species with molecular data.

Type species: Lichenoconium lichenicola (P. Karst.) Petr. $\&$ Syd. [as 'lichenicolum'], Beih. Reprium nov. Spec. Regni veg. 42(1): 432 (1927) [1926].

$\equiv$ Dactylium dendroides subsp. lichenicola P. Karst., Meddn Soc. Fauna Flora fenn. 14: 107 (1887).

Notes: Lichenoconium species are distributed worldwide as lichenicolous taxa on a variety of lichen hosts (Lawrey et al. 2011; Hyde et al. 2013; Wijayawardene et al. 2017a; Diederich et al. 2018). Many are host-specific, while others occur on disparate genera (Lawrey et al. 2011). The asexual morph is characterized by coelomycetous, immersed to sessile, dark brown pycnidia, an undifferentiated pycnidial ostiole, simple conidia, globose to ellipsoid, basally often truncate, thick-walled, brown and commonly verrucose and conidiogenous cells that are hyaline or poorly pigmented, holoblastic, elongate and annellidic (Lawrey et al. 2011). The sexual morph has not been recorded.

\section{Other genera included}

Abrothallus De Not. Giorn. Bot. Ital. 1: 194 (1846).

= Vouauxiomyces Dyko \& D. Hawksw., Lichenologist 11(1): 57 (1979).
Index Fungorum number: IF 4; Facesoffungi number: FoF 08048; - 42 morphological species (Species Fungorum 2020), 20 species with molecular data.

Type species: Abrothallus bertianus De Not. Giorn. Bot. Ital. 1: 194 (1846).

Notes: De Notaris described Abrothallus as a lichenized taxon (De Notaris 1846, 1849). Tulasne (1852) and Lindsay (1857) unequivocally established its lichenicolous habit. Suija et al. (2018) fixed the nomenclatural problems concerning the exact date of publication, confirming A. bertianus as the type species. They also reviewed the material described by Giuseppe De Notaris, Søren Christian Sommerfelt, and Ignaz Kotte lectotypifying Abrothallus species described by these authors (Suija et al. 2018). These authors also introduced the combination A. santessonii ( $\equiv$ Vouauxiomyces santessonii), providing an updated description for this taxon. Pérez-Ortega et al. (2011) established the connection between the sexual and asexual morphs. The number of species is tentative since there are numerous single collections occurring on unusual hosts that may represent new species and there are only a few collections from certain regions, e.g. from Africa and Asia. Recent studies focused on the taxonomy of species growing on Peltigerales (Suija et al. 2011, 2015). However, species delimitation, especially those on specimens growing on Parmeliaceae, is difficult and in need of a thorough revision (Suija et al. 2018). For morphology of the type species, see Suija et al. (2018) (Fig. 2).

\section{Economic and ecological significance}

Species in Abrothallaceae are not harmful to plants or animals. However, their lichenicolous, parasymbiontic or parasitic lifestyles on macrolichens are interesting for biodiversity and ecological research.

Acrospermales Minter, Peredo \& A.T. Watson.

Index Fungorum number: IF 90786; Facesoffungi number: FoF 06407.

Acrospermales was introduced by Minter (2007) to accommodate Acrospermaceae. The ordinal position of Acrospermaceae was previously unresolved and was referred to various orders by many authors. First, it was placed in Hysteriales or Dothideales in the 1st and 2nd editions of Ainsworth \& Bisby's Dictionary of the Fungi (Kirk et al. 2001). In the 3rd to 5th editions it was transferred to the Dothideales and in the $6^{\text {th }}$ and $7^{\text {th }}$ it was placed in the Ostropales and Clavicipitales, respectively. The family was also placed, rather hesitantly, in Pyrenulales by Eriksson (1982). Barr (1990) argued its ordinal position in more detail, and transferred it to Xylariales. Minter et al. (2007) introduced a new species in Acrospermaceae and discussed the ordinal position of Acrospermaceae with the introduction of Acrospermales. The divergence time for Acrospermales is estimated as 156 MYA (stem age, Hongsanan et al. 2020) (Fig. 3). 

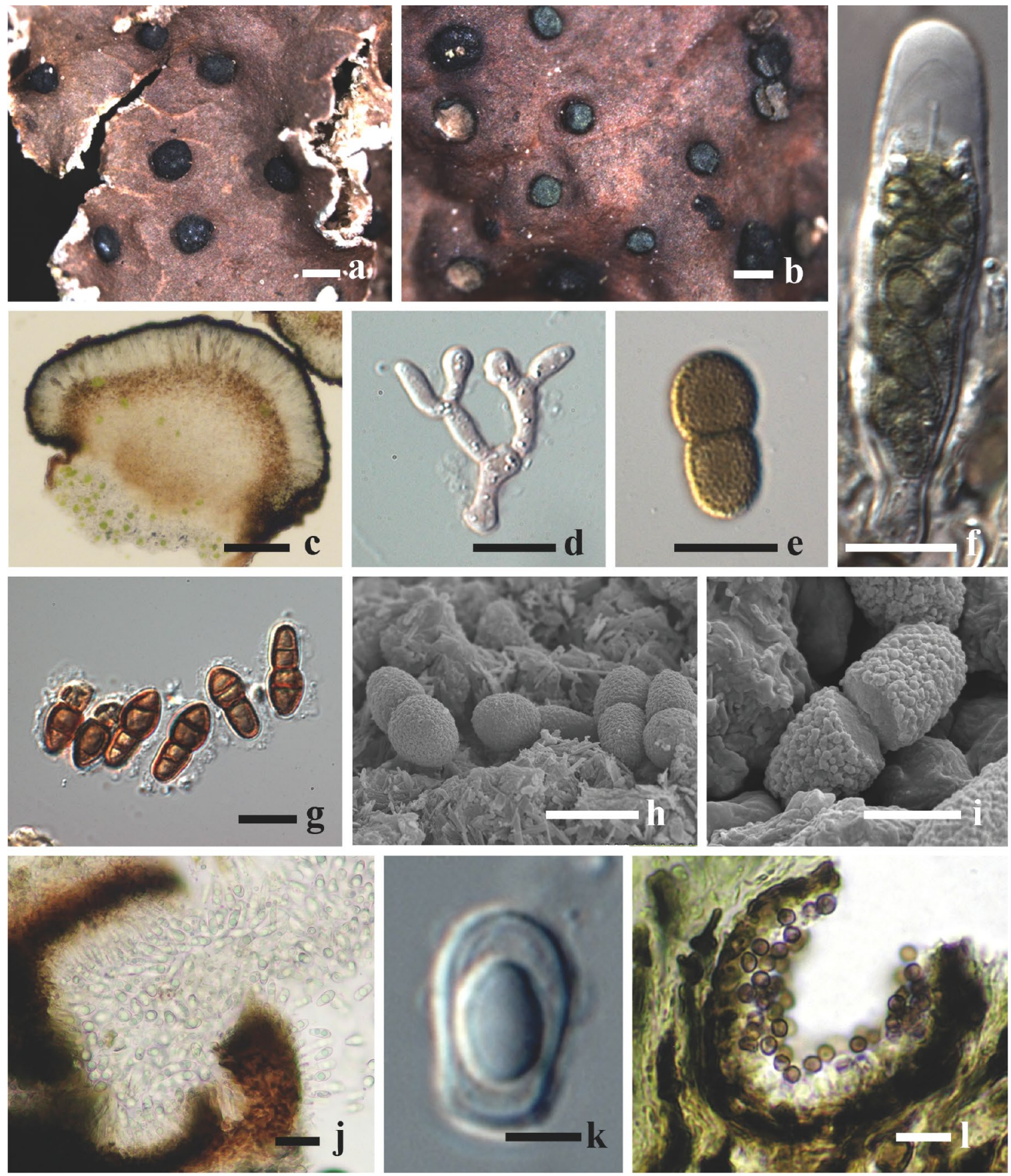

Fig. 2 Morphological and anatomical features of Abrothallaceae. a Habitus Abrothallus welwitschii, mature apothecia. b Habitus A. welwitschii, young apothecia with greenish pruina. c Cross-section of $A$. parmotrematis on Parmotrema sp. d Interascal elements from A. bertianus. e One-septate ascospore of $A$. welwitschii, with surface showing ornamentation. $\mathbf{f}$ Ascus of $A$. boomii. $\mathbf{g}$ Three-septate ascospores

Accepted families: Acrospermaceae.

Acrospermaceae Fuckel, Jb. nassau. Ver. Naturk. 23-24: 92 (1870) [1869-70]. of A. suecicus. h Scanning electron micrograph of A. welwitschii ascospores. i Ascospore of A. buellianus showing occasional splitting at the septum. $\mathbf{j}$ A. caerulescens asexual stage (pycnidium, Vouauxiomyces-type). k Conidia from A. boomii. $\mathbf{l}$ Lichenoconium sp. on A. santessonii ascoma. Scale bars: $\mathbf{a}-\mathbf{b}=0.5 \mathrm{~mm}, \mathbf{c}=50 \mu \mathrm{m}, \mathbf{d}-\mathbf{h}, \mathbf{k}=$ $10 \mu \mathrm{m} ; \mathbf{i}=5 \mu \mathrm{m}, \mathbf{j}=30 \mu \mathrm{m}, \mathbf{l}=20 \mu \mathrm{m}$

Index Fungorum number: IF 80430; Facesoffungi number: FoF 06380, 52 species.

Saprobic, epiphytic or symbiotic on herbaceous plants. Sexual morph: Ascomata solitary or in groups, superficial or immersed in stromata, erect, elongate, with smooth or 
Fig. 3 Phylogram generated from maximum likelihood analysis based on combined LSU and SSU sequence data representing Acrospermaceae. Strigula nemathora (MPN72) (Strigulaceae, Pleosporales) is used as the outgroup taxon. Bootstrap values for maximum likelihood (ML) equal to or greater than $70 \%$ and clade credibility values greater than 0.90 (the rounding of values to 2 decimal proportions) from Bayesian-inference analysis are labeled on the nodes. Ex-type strains are in bold and black, the new isolate is indicated in bold and blue

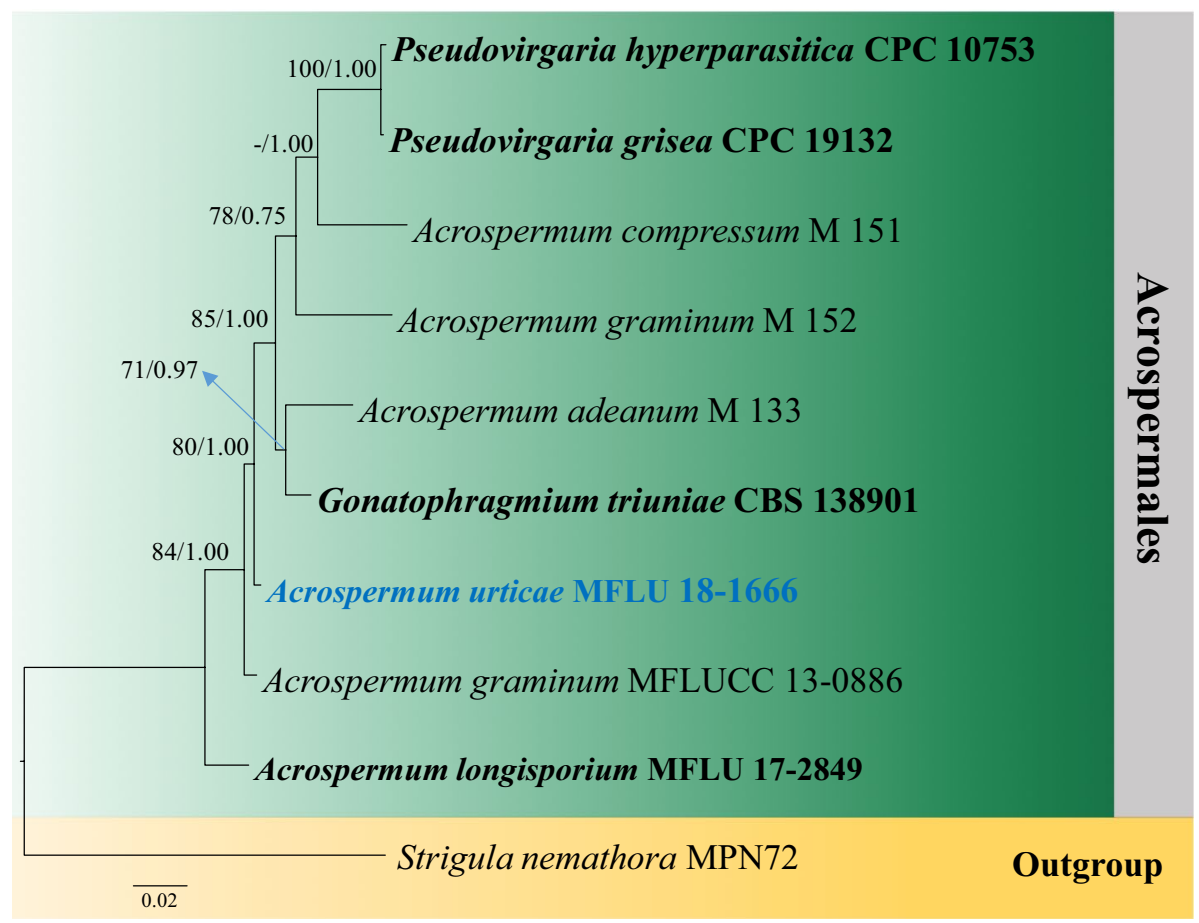

sometimes rough surface, dark brown to black, flattened, club-shaped to conoid, with a short stipe, swelling when moist, ostiolate. Peridium comprising two or three layers, an outer layer composed of dark brown cells of textura angularis, a central layer, composed of hyaline, sometimes pale brown tissue of elongated cells intertwined, and an inner layer composed of dense tissue of small, light brown cells. Hamathecium comprising narrow, long, hyaline, filiform pseudoparaphyses. Asci typically 8-spored, bitunicate, long, narrowly cylindrical, pedicellate, apically rounded with an ocular chamber. Ascospores fasciculate, filiform, hyaline, multi-septate, almost as long as the asci, smooth-walled, not fragmenting, without sheath, typically intertwined in a fascicle within the ascus. Asexual morph: Hyphomycetous. Conidiophores micronematous, pale brown, septate, branched or unbranched. Conidiogenous cells holoblastic, sympodial with denticles, pale brown, smooth-walled. Conidia cylindrical, long ellipsoid, pale yellow, 1-3-septate, smooth-walled.

Type: Acrospermum Tode.

Notes: Acrospermaceae was introduced with a single genus Acrospermum by Fuckel (1870) and since then its higher taxonomic placement has undergone various changes (Saccardo 1883; Rehm 1887; Ellis and Everhart 1892; Ainsworth et al. 1973; Barr 1990). The family was previously placed in the class Dothideomycetes family incertae sedis, due to its uncertain position (Hyde et al. 2013). Two genera, Acrospermum and Oomyces are currently accepted (Lumbsch and Huhndorf 2010; Wijayawardene et al. 2018). Acrospermum is characterised by erect, elongate, usually brown, superficial ascomata that are more or less club-shaped and are solitary or in small groups, with long paraphyses which resemble ascospores. Oomyces is considered to be clavicipitalean (Diehl 1950) as it has conoid, yellowish white, multi-locular stromata, bitunicate asci and lacks pseudoparaphyses (Eriksson 1981). No monograph of the genus is available. Riddle (1920) reviewed Acrospermum and introduced A. maxoni and A. graminum var. foliicolum based on asexual morphs. Presently, the asexual morphs of Acrospermaceae comprise members of Dactylaria and Gonatophragmium (Wijayawardene et al. 2018). Dactylaria was shown to be polyphyletic by Bussaban et al. (2005) and is heterogenous (Seifert et al. (2011). Gonatophragmium was also found to be an asexual morph of Acrospermum by Kirk et al. (2008), but Seifert et al. (2011) did not assign it to any taxonomic rank. A Blast search of an LSU sequence of Gonatophragmium triuniae showed closed hits to Acrospermum adeanum (Crous et al. 2014). We therefore, agree with Wijayawardene et al. (2018) and include Gonatophragmium in Acrospermaceae until further data becomes available. The hyphomycetous genus Pseudovirgaria was introduced by Shin et al. in Arzanlou et al. (2007), with P. hyperparasitica as type species. Pseudovirgaria is assigned to Capnodiales, genera incertae sedis in Index Fungorum (2020), while it was mentioned as Dothideomycetes genera incertae sedis in Wijayawardene et al. (2018). In our phylogenetic analysis, two species of Pseudovirgaria clustered in Acrospermales. Pseudovirgaria is a hyphomycetous genus and morphologically resembles Gonatophragmium in having cylindric-clavate, thin-walled conidia. Therefore, we include Pseudovirgaria in Acrospermaceae based on phylogenetic evidence, and morphological resemblance to asexual genera of Acrospermaceae. 
Descriptions and illustrations of the asexual morphs of Acrospermaceae can be seen in previous studies (i.e. Crous et al. 2014; Berger et al. 2015; Shamsi et al. 2017)

Acrospermum Tode, Fung. mecklenb. sel. (Lüneburg) 1: 8 (1790).

Index Fungorum number: IF 54; Facesoffungi number: FoF 06381; 28 morphological species (Species Fungorum 2020), 8 species with molecular data.

Type species: Acrospermum compressum Tode, Fung. mecklenb. sel. (Lüneburg) 1: 8 (1790).

Notes: Tode (1790) introduced Acrospermum with A. compressum as the type species based on fruiting body and ostiole type. Acrospermum is characterised by superficial, club-like ascomata, bitunicate asci and fasciculate, filiform, hyaline, multi-septate ascospores (Riddle 1920). Species of Acrospermum are mostly saprobic and are distributed worldwide. The specimens of $A$. compressum were found on dry stems of Heracleum sphondylium in Germany. Acrospermum compressum can also be observed on dead stems of Urtica dioica, and A. graminum on grass culms. Acrospermum adeanum is a necrotrophic parasite and has been observed on 32 different moss species from 22 different genera, most of which belong to the pleurocarpous superorder Hypnanae (Döbbeler 1979; Bell and Newton 2004). The asexual morph of Acrospermum is hyphomycetous (Wijayawardene et al. 2018).

Acrospermum urticae D. Pem, Camporesi \& K.D. Hyde, sp. nov.

Index Fungorum number: IF 556687; Facesoffungi number: FoF 06382; Fig. 4

Etymology: Name reflects the host from which the fungus is isolated.

Holotype: MFLU 18-1666.

Saprobic on dead stem of Urtica dioica. Sexual morph: Ascomata 940-1057 high $\times 301-345 \mu \mathrm{m}$ diam. $(\bar{x}=1021$ $\times 318 \mu \mathrm{m}$ ), solitary or in groups, superficial, club-shaped to conoid, erect, uni-locular, brown to blackish when dry, with a short stipe or sessile, flattened when dry, swelling when moist, ostiole large, apex rounded. Peridium 11-12 $\mu \mathrm{m}$ in vertical section comprising three layers, an outer layer comprising dark brown cells of textura angularis, a central thick layer, comprising pale brown to hyaline tissue of gelatinized hyphae with elongated cells, and an inner layer comprising dense tissue of small, hyaline cells. Hamathecium comprising narrow, long, pseudoparaphyses. Asci 195-319 $\times 6.2-6.7 \mu \mathrm{m}(\bar{x}=252.5 \times 6.4 \mu \mathrm{m}), 8$-spored, bitunicate, narrowly cylindrical, pedicellate, with an ocular chamber. Ascospores $122-170 \times 1.1-1.2 \mu \mathrm{m}(\bar{x}=146.2 \times 1.2 \mu \mathrm{m})$, fasciculate, filiform, hyaline, multi-septate, nearly as long as the asci, smooth-walled. Asexual morph: undetermined

Material examined: Italy, Ravenna [RA], San Cassiano di Brisighella, on dead aerial stem of Urtica dioica
(Urticaceae), 13 August 2018, Erio Camporesi (IT 3999, holotype; MFLU 18-1666, isotype).

GenBank numbers: LSU: MN597994, SSU: MN597996.

Notes: Acrospermum urticae differs from Acrospermum longisporium by its smaller ascomata (940-1057 high $\times$ 301-345 $\mu \mathrm{m}$ diam. v.s. $1500-2000$ high $\times 400-500 \mu \mathrm{m}$ diam.) and wider ascospores (122.1-175.3 $\times 1.1-1.2 \mu \mathrm{m}$ v.s. $150-170 \times 0.5-1 \mu \mathrm{m})$. Phylogenetic analyses of a combined LSU, SSU sequence dataset show that $A$. urticae forms a distinct lineage in Acrospermaceae with strong ML and BYPP support (80\% ML, 1.0 BYPP; Fig. 3). Therefore, we introduce Acrospermum urticae as a new species.

\section{Other genera included}

Gonatophragmium Deighton, in Cejp \& Deighton, Mycol. Pap. 117: 13 (1969).

Index Fungorum number: IF 8376; Facesoffungi number: FoF 06486; - 17 morphological species (Species Fungorum 2020), 1 species with molecular data.

Type species: Gonatophragmium mori (Sawada) Deighton 1969, in Cejp \& Deighton, Mycol. Pap. 117: 13 (1969).

三Spondylocladium mori Sawada, Spec. Bull. Agric. Exp. Station Formosa 19: 665 (1919).

Notes: Gonatophragmium was described in Cejp and Deighton (1969) with G. mori as the type species, a combination based on Spondylocladium mori. Gonatophragmium mori is a tropical-subtropical leaf-spotting species and is found on a wide range of hosts. Takahashi and Teramine (1986) considered Acrospermum viticola to be the sexual morph of this species, however this association was not proven by molecular data. Gonatophragmium is distinct in having pigmented, branched conidiophores formed as erect to decumbent threads with terminal and intercalary conidiogenous cells, which are regularly swollen around fertile portions with mostly numerous noticeable conidiogenous loci. The sexual morph of this genus is undetermined.

Oomyces Berk. \& Broome, Ann. Mag. nat. Hist., Ser. 27 : 185 (1851).

Index Fungorum number: IF 8376; Facesoffungi number: FoF 06488; -7 morphological species (Species Fungorum 2020), molecular data unavailable.

Type species: Oomyces carneoalbus (Lib.) Berk. \& Broome, Ann. Mag. Nat. Hist., Ser. 2 7: 185 (1851).

ESphaeria carneoalba Lib., Pl. crypt. Arduenna, fasc. (Liège) 3(nos 201-300): no. 241 (1834).

Notes: Oomyces (= Coscinaria Ellis \& Everh. 1886 fide Species Fungorum 2017) was introduced by Berk and Broome (1851), with $O$. carneoalbus as the type species. The genus is characterized by conoid, yellowish white, multi-locular stromata and lacks pseudoparaphyses (Eriksson 1981). Oomyces was described as similar to the egg of some insects, 


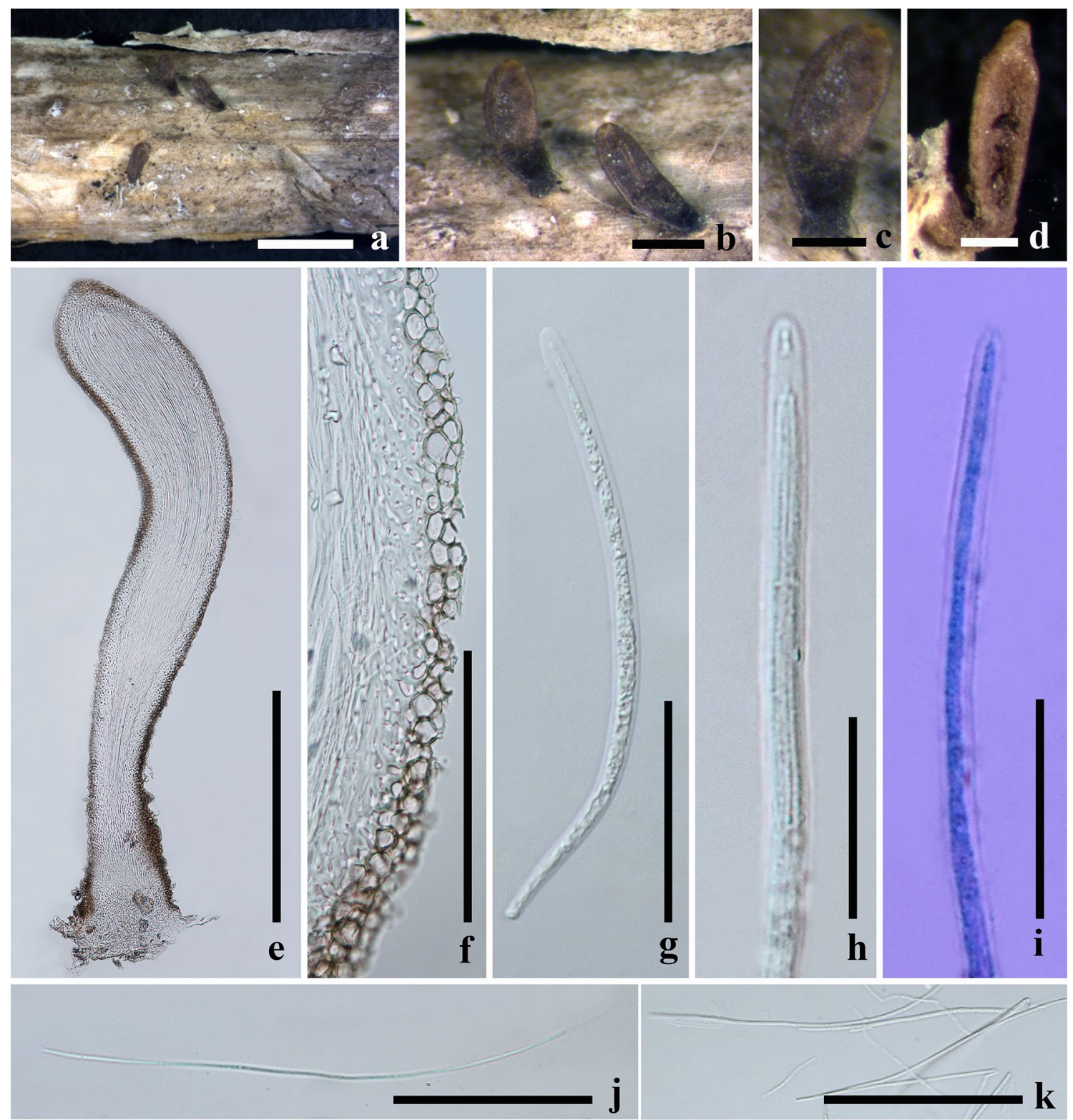

Fig. 4 Acrospermum urticae (IT 3999, holotype). a-d Ascomata on host surface. e Ascoma in vertical section f Peridium. g-i Narrowly cylindrical asci. $\mathbf{j}-\mathbf{k}$ Filiform ascospores Scale bars: $\mathbf{a}=2000 \mu \mathrm{m}, \mathbf{b}$,

such as Crioceris, because its perithecia are visible as little dimples in the truncate apex of the fruiting body.

Pseudovirgaria H.D. Shin, U. Braun, Arzanlou \& Crous, in Arzanlou et al., Shin \& Crous, Stud. Mycol. 58: 87 (2007)

Index Fungorum number: IF504564; Facesoffungi number: FoF 06487; - 2 morphological species (Species Fungorum 2020), 2 species with molecular data.

Type species: Pseudovirgaria hyperparasitica H.D. Shin, U. Braun, Arzanlou \& Crous, in Arzanlou et al., Stud. Mycol. 58: 87 (2007)

Notes: Phylogenetic analyses indicated that two species of Pseudovirgaria clustered within Acrospermaceae (Hudson $\mathbf{e}=500 \mu \mathrm{m}, \mathbf{c}, \mathbf{d}=300 \mu \mathrm{m}, \mathbf{f}, \mathbf{g}=100 \mu \mathrm{m}, \mathbf{h}=25 \mu \mathrm{m}, \mathbf{i}=30 \mu \mathrm{m}, \mathbf{j}=$ $50 \mu \mathrm{m}, \mathbf{k}=40 \mu \mathrm{m}$

et al. 2019, this study). Morphologically, it resembles Gonatophragmium in having cylindric-clavate, thin-walled conidia. Therefore, we agree with Hudson et al. (2019) to accept this genus in Acrospermaceae.

\section{Economic and ecological significance}

Species of Acrospermaceae are parasitic or endophytic and may play a negative role by infecting ferns. In Mexico, several species of Terpsichore (T. subtilis and T. taxifolia) are infected by Acrospermum, typically as black clavate stromata on the hosts.

Asterinales M.E. Barr ex D. Hawksw. \& O.E. Erikss. 
Index Fungorum number: IF 90461; Facesoffungi number: FoF 07605.

Asterinales contains epifoliar fungi which have superficial mycelium forming a network on host plants, 1-celled appressoria, with a star-like opening to the thyriothecium. The order was revised by Hongsanan et al. (2014b), however, its classification is unclear due to insufficient sequence data. Sequence data of Asterinales clustered in two unrelated clades in phylogenetic trees (Ertz et al. 2016; Hyde et al. 2016b; Liu et al. 2017). The clade containing the type species Asterotexis cucurbitacearum was treated as Asterotexales (Ertz et al. 2016). However, Hyde et al. (2016b) synonymized it under Asterinales sensu stricto because most Asterinales strains cluster in this clade. The other clade, including species of Parmulariaceae were treated as Asterinales sensu lato (Liu et al. 2017). Parmulariaceae was transferred to its own order Parmulariales by Dai et al. (2018).

Although the type species Asterina melastomatis and a few other Asterinales-like taxa fell within the clade Asterinales sensu lato (Ertz et al. 2016; Hyde et al. 2016b), we did not include these sequence data in our analysis. This is because Asterinales-like taxa forming in the Asterinales sensu lato need to be rechecked since other hyphomycetous strains were added into this clade, thus, there is possibility that these sequence data are not Asterinales. Thyrinulaceae is introduced to accommodate a clade sister to Parmulariales (= Asterinales sensu lato) with Thyrinula as generic type based on the rules of nomenclatural priority. Hongsanan et al. (2014b) synonymised Lembosiaceae under Asterinaceae, however, adding more sequence data for Lembosia (Fig. 5) indicates that Lembosia should be raised to a family in Asterinales.

By considering phylogenetic trees (Fig. 5), we retain Lembosiaceae in Asterinales and introduce Morenoinaceae and Neobuelliellaceae to accommodate the clades of Morenoina and Neobuelliella, respectively. Based on morphology and phylogeny, the current Asterinales comprises eight families. The classification of Asterinales is questionable and needs more morphological and molecular data to clarify its phylogenetic relationship. The divergence time for Asterinales is estimated as 221 MYA (stem age, Hongsanan et al. 2020).

Accepted families: Asterinaceae, Asterotexaceae, Hemigraphaceae, Lembisiaceae, Melaspileellaceae, Morenoinaceae, Neobuelliellaceae and Stictographaceae.

Asterinaceae Hansf., Mycol. Pap. 15: 188 (1946).

Index Fungorum: IF 80492; Facesoffungi number: FoF 06726, >1000 species.

Colonies epiphyllous or hypophyllous. Hyphae superficial, straight to substraight, dark brown, reticulate, with appressoria. Appressoria 1-celled, mostly lateral, alternate to unilateral. Sextual morph: Thyriothecia superficial, flattened, with stellate or longitudinal dehiscence. Upper walls brown, comprising radial, septate cells of textura prismatica. Asci 8-spored, bitunicate, ellipsoid, usually thickened at the apex. Hamathecium cellular pseudoparaphyses present or absent. Ascospores 2-5-seriate or fasciculate or conglobate, fusoid to ellipsoid, hyaline to dark brown, mostly 1-septate, smooth-walled or toughened. Asexual morph: Coelomycetous states with pycnidia or pycnothyria, and hyphomycetous states without conidiomata or sporodochia then gelatinous, pale. Hyphae brown, superficial, with appressoria. Conidiomata pycnothyria, flattened, dimidiate, radiate, orbicular, stellately dehisced at the centre. Conidiophores branched or unbranched, hyaline or brown. Conidiogenous cells monoblastic or percurrent, hyaline or brown. Conidia ovate, pyriform, angular, or wall straight to sinuate, brown.

Type: Asterina Lév.

Notes: Asterinaceae was established as a member of Microthyriales by Hansford (1946). Members of the family typically have upper walls comprising radiating cells with star-like or longitudinal splits and dark brown hyphae with appressoria. There are 18 genera in this family based on morphology (Hongsanan et al. 2014b; Guatimosim et al. 2015; Wijayawardene et al. 2017a; Dai et al. 2018). Although Wijayawardene et al. (2017a) included Echidnodes in Asterinaceae, we exclude it from Asterinaceae as Hongsanan et al. (2014b) transferred this genus to Aulographaceae. Phylogenetic studies have several different interpretations of this family. In this study, we reappraise the phylogenetic relationship of Asterinaceae and related families based on all available sequence data and previous studies.

Asterina Lév., Annls Sci. Nat., Bot., sér. 3 3: 59 (1845).

Index Fungorum number: IF 409; Facesoffungi number: FoF 06727; > 1000 morphological species (Species Fungorum 2020), 9 species with molecular data.

Type species: Asterina melastomatis Lév., Annls Sci. Nat., Bot., sér. 3 3: 59 (1845).

Notes: Asterina was introduced as a member of Sphaeriaceae with A. azarae, A. compacta, A. pulla and the type A. melastomatis. It is the largest genus in Asterinaceae, but only nine species have sequence data available in GenBank due to its unculturable character. Members of the genus have circular thyriothecia with stellate dehiscence, lateral appressoria, globose asci, and dark brown, 1-septate ascospores.

Asterina magnoliae X.Y. Zeng, T.C. Wen \& K.D. Hyde, in Hyde et al., Mycosphere 9(2): 349 (2018).

Index Fungorum number: IF 554238; Facesoffungi number: FoF 04089; Fig. 6

Description: see Hyde et al. (2018).

Material examined: Thailand, Chiang Mai, Mae Taeng, Pa Pae, Bahn Pa Deng, Mushroom Research Centre, 128 Moo 3, on living leaves of Magnolia odora (Magnoliaceae), 8 July 2015, Xiang-Yu Zeng (MFLU 16-0071).

GenBank number: LSU: MN629745.

Notes: Our new collection of Asterina magnoliae is identified by morphological characters (Fig. 6) and phylogenetic 


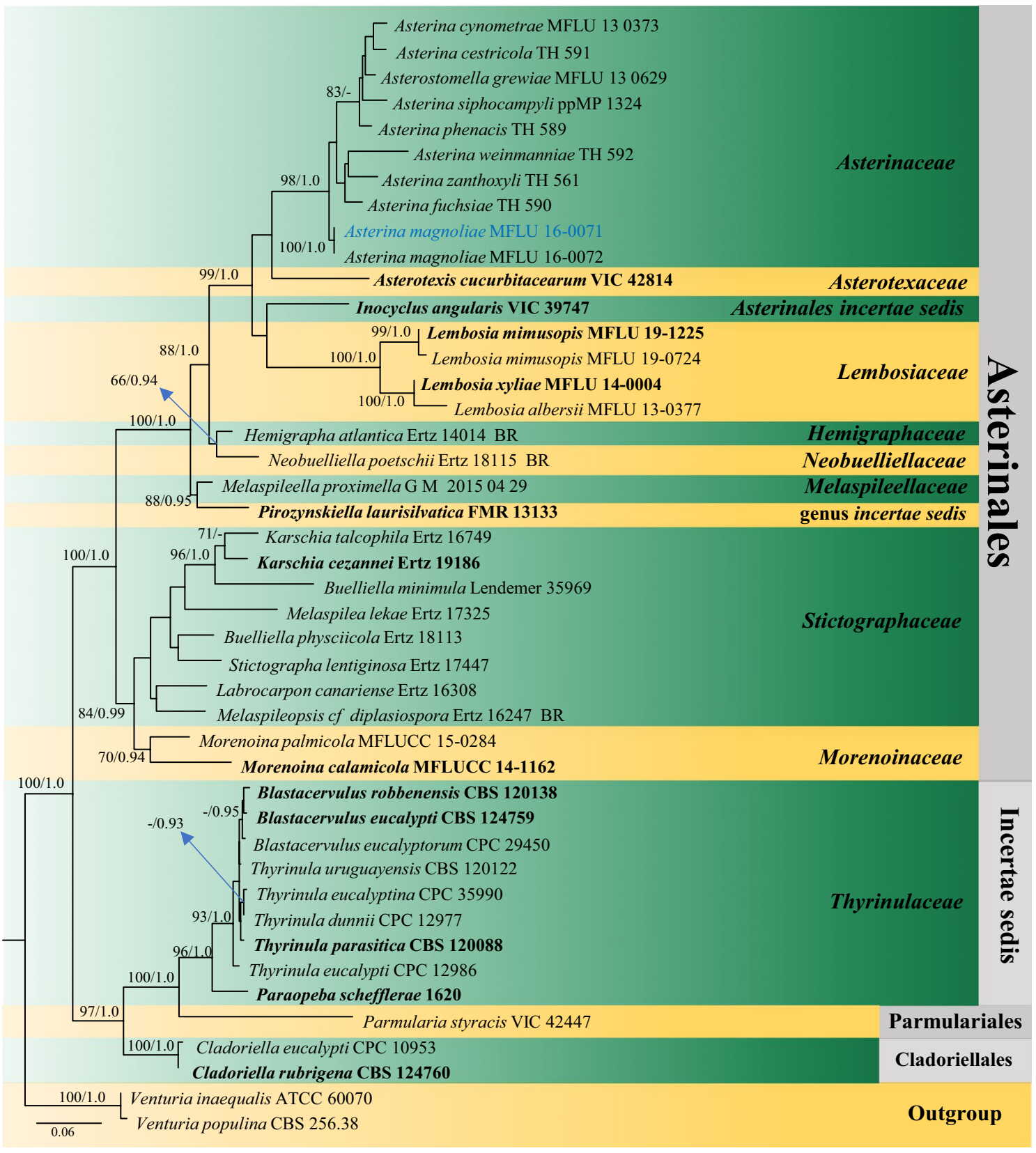

Fig. 5 Phylogram generated from maximum likelihood analysis (RAxML) of Asterinales based on LSU sequence data. Maximum likelihood bootstrap values equal to or greater than $70 \%$, Bayesian posterior probabilities equal to or greater than 0.90 (MLBS/PP) are given at the nodes. Isolate numbers are noted after each species name.

evidence (Fig. 5). Hyde et al. (2018) provided a full description of this species.

\section{Other genera included}

Asterinella Theiss., Annls mycol. 10(2): 160 (1912).

Index Fungorum number: IF 411; Facesoffungi number: FoF 06729; - 35 morphological species (Species Fungorum
The tree is rooted to Venturia inaequalis (ATCC 60070) and Venturia populina (CBS 256.38). Newly sequence data generated in this study are in blue. Ex-types are indicated in bold. Hyphen (-) represents support values less than 70\% MLBS and 0.90 PP

2020), molecular data available for an unnamed species in the genus.

Type species: Asterinella puiggarii (Speg.) Theiss., Brotéria, sér. bot. 10(2): 116 (1912).

$\equiv$ Asterina puiggarii Speg., Anal. Soc. cient. argent. 12(3): 99 (1881).

Notes: Asterinella was introduced as a member of Microthyriaceae. It is characterised by superficial hyphae with 


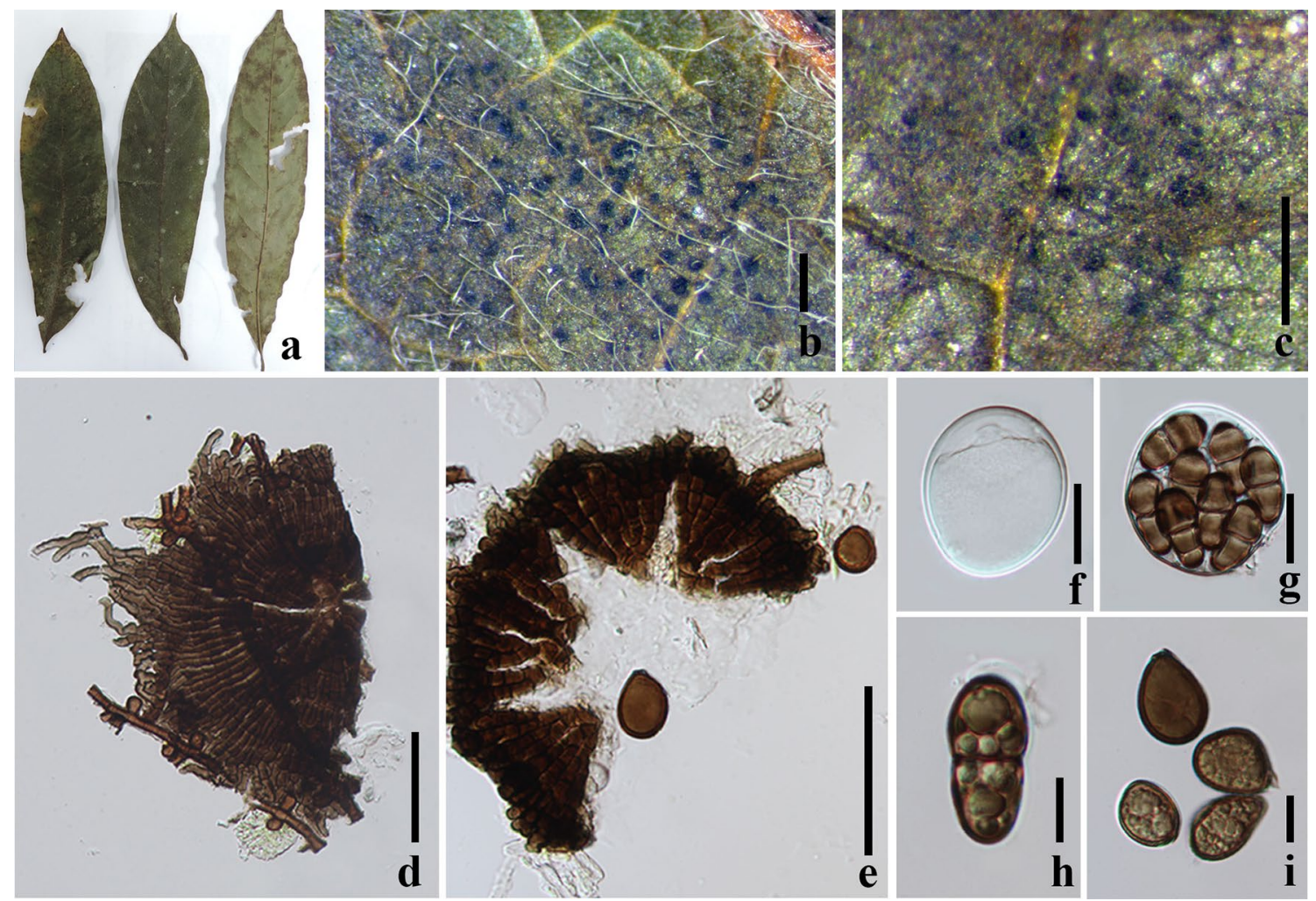

Fig. 6 Asterina magnoliae (MFLU 16-0071). a Host leaves. b, c Colonies on leaf surface. d Thyriothecium. e Pycnidioma. f Young asci. g Mature asci. h Ascospores. i Pycnidia. Scales bars: $\mathbf{b}-\mathbf{c}=500 \mu \mathrm{m}, \mathbf{d}-\mathbf{e}=50 \mu \mathrm{m}, \mathbf{f}-\mathbf{g}=20 \mu \mathrm{m}, \mathbf{h}-\mathbf{i}=10 \mu \mathrm{m}$

intercalary appressoria and thyriothecia with a stellate ostiole. Wu et al. (2014) transferred it to Asterinaceae based on morphology.

Asterolibertia G. Arnaud 1918, Annals d'École National d'Agric. de Montpellier, Série 2 16(1-4): 165 (1918) [1917].

Index Fungorum number: IF 421; Facesoffungi number: FoF 06731; - 35 morphological species (Species Fungorum 2020), molecular data unavailable.

Type species: Asterolibertia couepiae (Henn.) G. Arnaud, Annals d'École National d'Agric. de Montpellier, Série 2 16(1-4): 165 (1918) [1917].

三Asterina couepiae Henn., Hedwigia 34: 104 (1895).

Notes: Asterolibertia is characterised by intercalary appressoria. Hongsanan et al. (2014b) synonymised Asterolibertia under Asterina, while Firmino et al. (2016) questioned the intercalary appressoria in Asterolibertia as not homologous to the lateral appressoria in Asterina. However, both justifications are based on morphology.

Asterostomella Speg., Anal. Soc. cient. argent. 22(4): 198 (1886).

Index Fungorum number: IF 7271; Facesoffungi number: FoF 06730; - 87 morphological species (Species Fungorum 2020), 1 species with molecular data.
Type species: Asterostomella paraguayensis Speg., Anal. Soc. cient. argent. 22(4): 198 (1886).

Notes: Asterostomella is a coelomycetous genus characterised by brown, ovoid, aseptate pycnidia, sometimes with a non-pigmented band in the middle. The genus is considered as a member of Asterinaceae based on its scutellate conidiomata with stellate dehiscence, which is similar to Asterina.

Batistinula Arx, Publicações Inst. Micol. Recife 287: 4 (1960).

Index Fungorum number: IF 523; Facesoffungi number: FoF 06732; - 1 morphological species (Species Fungorum 2020), 1 species with molecular data.

Type species: Batistinula gallesiae Arx, Publicações Inst. Micol. Recife 287: 6 (1960).

Notes: Batistinula typically has 3-septate ascospores. A specimen that shares the same morphological and biometric characteristics of the type was collected and sequenced by Guatimosim et al. (2015). However, that fresh collection was found on a different host family, which may contradict the host-specificity of Asterinaceae.

Cirsosia G. Arnaud, Annals d'École National d'Agric. de Montpellier, Série 2 16(1-4): 127 (1918) [1917]. 
Index Fungorum number: IF 1065; Facesoffungi number: FoF 06734; - 15 morphological species (Species Fungorum 2020), molecular data unavailable.

Type species: Cirsosia manaosensis (Henn.) G. Arnaud [as 'manaoensis'], Annals d'École National d'Agric. de Montpellier, Série 2 16(1-4): 127 (1918) [1917].

$\equiv$ Lembosia manaosensis Henn. [as 'manaoensis'], Hedwigia 43(4): 265 (1904).

Notes: Cirsosia is mostly similar to Lembosia in having a linear fissure, but has intercalary appressoria.

Dothidasteromella Höhn., Sber. Akad. Wiss. Wien, Math.naturw. Kl., Abt. 1 119: 421 (1910).

Index Fungorum number: IF 1692; Facesoffungi number: FoF 06236; - 11 morphological species (Species Fungorum 2020), molecular data unavailable.

Type species: Dothidasteromella sepulta (Berk. \& M.A. Curtis) Höhn., Sber. Akad. Wiss. Wien, Math.-naturw. K1., Abt. 1 119: 421 (1910).

三 Asterina sepulta Berk. \& M.A. Curtis, Proc. Amer. Acad. Arts \& Sci. 4: 129 (1860).

Notes: Dothidasteromella is mostly similar to Echidnodella, Halbania and Uleothyrium in lacking appressoria, but has Y-shaped dehiscence, 1-septate ascospores, and lack pseudoparaphyses.

Echidnodella Theiss. \& Syd., Annls mycol. 15(6): 422 (1918) [1917].

Index Fungorum number: IF 1731; Facesoffungi number: FoF 06761; - 33 morphological species (Species Fungorum 2020), molecular data unavailable.

Type species: Echidnodella linearis (Syd. \& P. Syd.) Syd., Annls mycol. 15(6): 422 (1918) [1917].

$\equiv$ Morenoella linearis Syd. \& P. Syd., Annls mycol. 15(3/4): 250 (1917).

Notes: Echidnodella is similar to Lembosia and Cirsosia in having linear fissures, but lacks appressoria and has cellular pseudoparaphyses.

Halbania Racib., Crypt. Par. Java: no. 89 (1889).

Index Fungorum number: IF 2201; Facesoffungi number: FoF 06735; - 3 morphological species (Species Fungorum 2020), molecular data unavailable.

Type species: Halbania cyathearum Racib., Crypt. Par. Java: no. 89 (1889).

Notes: Halbania is mostly similar to Batistinula in having 3-septate ascospores, but lacks appressoria on the hyphae. Sequence data is needed to confirm its phylogenetic placement.

Meliolaster Höhn., Ber. dt. bot. Ges. 35(10): 701 (1918).
Index Fungorum number: IF 3102; Facesoffungi number: FoF 06738; - 2 morphological species (Species Fungorum 2020), molecular data unavailable.

Type species: Meliolaster clavisporus (Pat.) Höhn., Ber. dt. bot. Ges. 35(10): 701 (1918).

三 Meliola clavispora Pat., J. Bot., Paris 4: 61 (1890).

Notes: Thyriotheica in Meliolaster are composed of radially arranged of cells, which open by star-like fissures when mature. Meliolaster is similar to Batistinula and Halbania in having 3-septate ascospores, but differs in the presence and shape of appressoria on the hyphae.

Parasterinopsis Bat., Atas Inst. Micol. Univ. Recife 1: 327 (1960).

Index Fungorum number: IF 3722; Facesoffungi number: FoF 06739; - 3 morphological species (Species Fungorum 2020), molecular data unavailable.

Type species: Parasterinopsis sersalisiae (Hansf.) Bat., Atas Inst. Micol. Univ. Recife 1: 327 (1960).

$\equiv$ Patouillardina sersalisiae Hansf., Proc. Linn. Soc. London 156: 117 (1944) [1943-44].

Notes: Parasterinopsis is retained in Asterinaceae based on its thyriothecia with irregular fissures and the superficial hyphae with appressoria. However, it typically has cylindrical, 1-4-septate ascospores.

Platypeltella Petr., in Sydow \& Petrak, Annls mycol. 27(1/2): 62 (1929).

Index Fungorum number: IF 4178; Facesoffungi number: FoF 06741; - 3 morphological species (Species Fungorum 2020), molecular data unavailable.

Type species: Platypeltella smilacis Petr., Annls mycol. 27(1/2): 62 (1929).

Notes: Platypeltella was introduced as a member of Microthyriaceae. Wu et al. (2014) included it in Asterinaceae based on the superficial hyphae with intercalary capitate appressoria. Platypeltella is similar to Asterinella, but differs in having paraphyses and a round ostiole.

Prillieuxina G. Arnaud, Annals d'École National d'Agric. de Montpellier, Série 2 16(1-4).

Index Fungorum number: IF 4365; Facesoffungi number: FoF 06742; - 62 morphological species (Species Fungorum 2020), 1 species with molecular data.

Type species: Prillieuxina winteriana (Pazschke) G. Arnaud, Annals d'École National d'Agric. de Montpellier, Série 2 16(1-4): 162 (1918) [1917].

三Asterina winteriana Pazschke, Hedwigia 31(3): 104 (1892).

Notes: Prillieuxina is typical of Asterinaceae in having stellate fissures and brown, 1-septate ascospores. However, appressoria are very rare in Prillieuxina, and the cells of the upper walls are radially arranged as in Microthyrium. 
Guatimosim et al. (2015) provided the only sequence for this genus.

Pycnocarpon Theiss., Abh. K.K. Zool.-Bot. Ges. Wien 7(3): 31 (1913).

Index Fungorum number: IF 4564; Facesoffungi number: FoF 07606; - 4 morphological species (Species Fungorum 2020), 1 species with molecular data.

Type species: Pycnocarpon magnificum (Syd., P. Syd. \& E.J. Butler) Theiss., Abh. K.K. Zool.-Bot. Ges. Wien 7(3): 31 (1913).

三 Asterina magnifica Syd., P. Syd. \& E.J. Butler, Annls mycol. 9(4): 391 (1911).

Notes: Wijayawardene et al. (2018) accepted this genus in Dothideomycetes genera incertae sedis. However, Doilom et al. (2018) included Pycnocarpon in Asterinaceae based on its superficial, web-like hypha, flattened thyriothecia, opening by radiating star-like or longitudinal splits, saccate asci, and conglobose, hyaline to brown, 1-septate ascospores strongly constricted at the septum (Doilom et al. 2018). We accept Pycnocarpon in Asterinaceae but note that the upper wall of ascomata of Pycnocarpon differs from members of Asterinaceae in having radially arranged, subglobose cells instead of cells of textura prismatica. Thus, sequence data is needed to confirm its placement.

Schenckiella Henn., Bot. Jb. 17: 523 (1893).

Index Fungorum number: IF 4885; Facesoffungi number: FoF 06743; - 1 morphological species (Species Fungorum 2020), molecular data unavailable.

Type species: Schenckiella marcgraviae Henn., Bot. Jb. 17: 523 (1893).

Notes: This is a very unusual genus with a unique combination of characters, with surface hyphae lacking appressoria, Asterina-like thyriothecia, elongated clavate asci, brown, cellular pseudoparaphyses, which are rarely observed in the Dothideomycetes, and 4-5-septate brown ascospores.

Trichasterina G. Arnaud, Annals d'École National d'Agric. de Montpellier, Série 2 16(1-4): 172 (1918) [1917].

Index Fungorum number: IF 5544; Facesoffungi number: FoF 06744; - 11 morphological species (Species Fungorum 2020), molecular data unavailable.

Type species: Trichasterina styracis (Theiss.) G. Arnaud, Annals d'École National d'Agric. de Montpellier, Série 2 16(1-4): 172 (1918) [1917].

$\equiv$ Asterina styracis Theiss., Abh. K.K. Zool.-Bot. Ges. Wien 7(3): 41 (1913).

Notes: Thyriothecia shares almost the same morphology as Asterina, but with setae on the hyphae. Whether such a character difference justifies separate genera should be tested using molecular data.
Trichopeltospora Bat. \& Cif., in Batista, Costa \& Ciferri, Publicações Inst. Micol. Recife 90: 17 (1958) [1957].

Index Fungorum number: IF 5569; Facesoffungi number: FoF 06745; - 2 morphological species (Species Fungorum 2020), molecular data unavailable.

Type species: Trichopeltospora pipericola Bat., Cif. \& C.A.A. Costa, in Batista, Costa \& Ciferri, Publicações Inst. Micol. Recife 90: 17 (1958) [1957].

Notes: Trichopeltospora was introduced as a member of Microthyriaceae. Wu et al. (2011b) transferred Trichopeltospora to Asterinaceae based on its irregular ostiole and appressoria on the hyphae. This transfer needs to be confirmed by phylogenetic analyses.

Uleothyrium Petr., Annls mycol. 27(5/6): 388 (1929).

Index Fungorum number: IF 5661; Facesoffungi number: FoF 06762; - 2 morphological species (Species Fungorum 2020), molecular data unavailable.

Type species: Uleothyrium amazonicum Petr., Annls mycol. 27(5/6): 388 (1929).

Notes: Uleothyrium is similar to Platypeltella in having rounded ostioles, which are distinct from any other genera in Asterinaceae. However, Uleothyrium lacks appressoria, while Platypeltella has intercalary appressoria.

Vizellopsis Bat., J.L. Bezerra \& T.T. Barros, Publicações Inst. Micol. Recife 637: 5 (1969).

Index Fungorum number: IF 5748; Facesoffungi number: FoF 06746; - 1 morphological species (Species Fungorum 2020), molecular data unavailable.

Type species: Vizellopsis grevilleae Bat., J.L. Bezerra \& T.T. Barros, Publicações Inst. Micol. Recife 637: 5 (1969).

Notes: Vizellopsis was introduced as a member of Microthyriaceae, and Lumbsch and Huhndorf (2010) included this genus in Dothideomycetes incertae sedis. Dai et al. (2014a) transferred Vizellopsis to Asterinaceae based on the small, black thyriothecia, forming below the dark brown mycelium, comprising radiating cells and a concentrically ridged surface, but strongly thickened and septate hyphae which is different from other genera of Asterinaceae.

\section{Economic and ecological significance}

Asterinaceae species produce haustoria to gain nutrients from host plants without causing pathogenic damage. They may reduce photosynthesis by covering the host surface, and increase the temperature and respiration in those areas as do other black mildews.

Asterotexaceae Firmino, O.L. Pereira \& Crous [as 'Asterotexiaceae'], in Guatimosim et al., Persoonia 35: 238 (2015).

Index Fungorum number: IF 548079; Facesoffungi number: FoF 07607, 2 species. 
Epiphytes, phytopathogens, forming dark colonies irregular to star-shaped, solitary to confluent. External mycelium growing through ascomatal cavity or fusing with the host epidermis cells, septate, hyaline, smooth. Appressoria formed underneath the ascomata, solitary or forming in small clusters, globose, cone-shaped or ovoid to elongate, brown, with a central hyaline penetration peg. Sexual morph: Ascomata superficial to erumpent, scutellate, dimidiate, brown to black. Scutellum of radially arranged rows of cells, poorly developed base, opening by numerous irregular fissures. Hamathecium comprising septate, anastomosing, cellular pseudoparaphyses, embedded in a gelatinous matrix. Asci 8-spored, bitunicate, fissitunicate, oblong to cylindri$\mathrm{cal}$, with short and rounded pedicel or pedicel sometimes absent. Ascospores overlapping 2-3-seriate, ellipsoidal, hyaline to slightly yellowish, 1-septate, slightly constricted at the septum, upper cell broader than lower cell (adapted from Hongsanan et al. 2014b; Guatimosim et al. 2015). Asexual morph: Undetermined.

Type: Asterotexis Arx.

Notes: Asterotexaceae was established by Guatimosim et al. (2015), with the generic type Asterotexis. A phylogenetic tree provided by Guatimosim et al. (2015) showed that species of Asterotexis formed a distinct clade sister to the Inocyclus angularis (Incertae sedis clade). They introduced Asterotexiales to accommodate Asterotexaceae (Guatimosim et al. 2015). Ertz et al. (2016) indicated that the Asterotexiales clade contains Asterotexis species, Inocyclus angularia (Parmulariaceae) and some Asterinales species. However, the Asterotexiales clade in Ertz et al. (2016) was treated as Asterinaceae sensu stricto (Hyde et al. 2016b). Asterotexales was synonymized under Asterinales by Liu et al. (2017). In our phylogenetic analyses (Fig. 5), Asterotexis species cluster with the clade of Asterina species as an unstable clade. In another analysis, which did not include Lembosia mimusopis (data not shown), Asterotexis clustered with Inocyclus angularis (Incertae sedis clade). Thus, we retain Asterotexaceae within Asterinales and note that more sequence data are needed to clarify its phylogenetic placement.

Asterotexis Arx, Fungus, Wageningen 28: 6 (1958).

Index Fungorum number: IF 430; Facesoffungi number: FoF 06766; 2 morphological species (Index Fungorum 2020), 1 species with molecular data.

Type species: Asterotexis cucurbitacearum (Rehm) Arx.

Notes: Asterotexis is a plant-pathogen found on leaves, and was identified as a member of Asterinaceae (Inácio and Cannon 2008; Guerrero et al. 2011; Hongsanan et al. 2014b). Morphologically and phylogenetically, the genus could not be placed in any family of Asterinales (this study). Thus, Asterotexis is placed in its own family, Asterotexaceae.
Asterotexis cucurbitacearum (Rehm) Arx [as 'cucurbitarum'], Fungus, Wageningen 28: 6 (1958).

$\equiv$ Dothidella cucurbitacearum Rehm, Hedwigia 36(6): 376 (1897).

Index Fungorum number: IF 118911; Facesoffungi number: FoF 07608; Fig. 7

Description: see Hongsanan et al. (2014b).

Material examined: Brazil, Brazilia, Rio de Janeiro, on Cucurbitaceae, May 1887, E. Ule 676, Ex Herb. Sydow (SF7565, holotype); COSTA RICA, San José, Finca La Caja, on surface of leaves of Sechium edule (Cucurbitaceae), 25 March 1927, Det. J.A. Stevensen (S-F220847).

\section{Economic and ecological significance}

Species in this family are phytopathogens. The appearance of colonies on leaves can mainly reduce the photosynthesis, respiration, disrupt other plants mechanism and can make host tissues become pale.

Hemigraphaceae D.Q. Dai \& K.D. Hyde, in Dai et al., MycoKeys 369(2): 67 (2018).

Index Fungorum number: IF 554062; Facesoffungi number: FoF 03910, 9 species.

Biotrophic on lichens. Sexual morph: Ascostromata solitary to gregarious, superficial, stellate, irregularly opening from the centre to margin, conical in section, coriaceous, black to dark brown. Peridium comprises two layers, black and thick-walled cells of textura angularis in outer part, thin and light brown cells of textura angularis at inner layers. Hamathecium comprising few, brown, unbranched, filamentous, septate, cellular pseudoparaphyses. Asci 8-spored, bitunicate, clavate to cylindric-clavate, subglobose, with an ocular chamber and a short pedicel. Ascospores 3-seriate to irregularly arranged, ellipsoid, brown, 1-septate, with larger upper cell and narrower lower cell, smooth-walled. Asexual morph: Undetermined.

Type: Hemigrapha (Müll. Arg.) R. Sant. ex D. Hawksw.

Notes: Dai et al. (2018) studied the syntype of Hemigrapha asteriscus ( $\equiv$ Melanographa asteriscus), and concluded that it is different from the family type of Parmulariaceae. Phylogenetically (LSU), H. atlantica forms a distint lineage within Asterinales (Ertz and Diederich 2015; Dai et al. 2018; this study). Thus, Hemigraphaceae was established in Asterinales to accommodate a single genus Hemigrapha (Dai et al. 2018).

Hemigrapha (Müll. Arg.) R. Sant. ex D. Hawksw., Kew Bull. 30(1): 9 (1975).

$\equiv$ Melanographa sect. Hemigrapha Müll. Arg., Flora, Regensburg 65(33): 519 (1882).

Index Fungorum number: IF 2282; Facesoffungi number: FoF 02311; 8 morphological species (Index Fungorum 2020), 1 species with molecular data. 

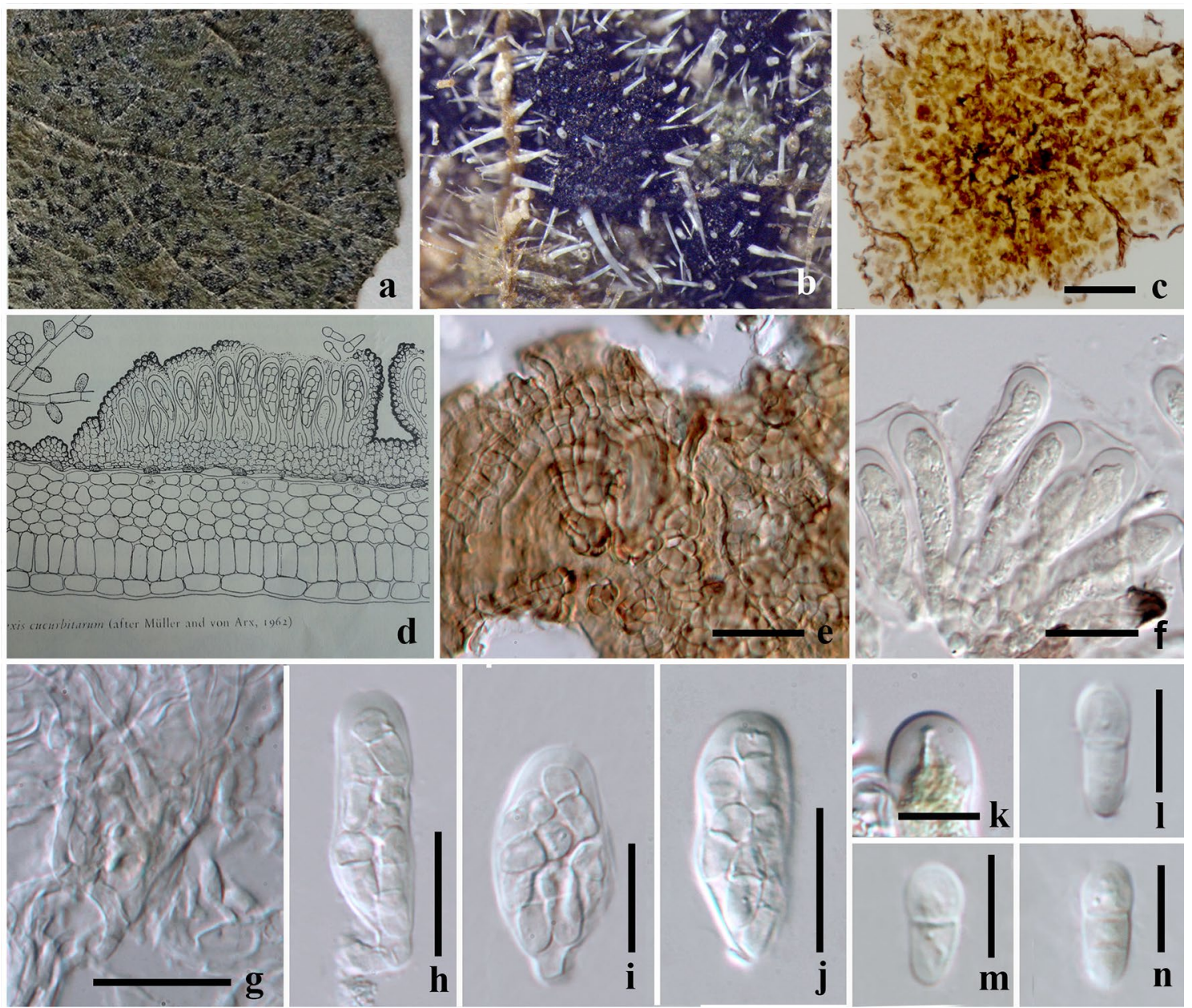

Fig. 7 Asterotexis cucurbitacearum (a, b, d, f from S-F7565, holotype and c, e, g-n from from S-F22084). a Herbarium specimen. b Ascomata on substrate. c Ascoma when viewed in squash mount. d Drawing from von Arx and Müller (1975). e Upper wall of ascoma. f

Type species: Hemigrapha asteriscus (Müll. Arg.) R. Sant. ex D. Hawksw., Kew Bull. 30(1): 191 (1975).

Notes: Hemigrapha was included in Parmulariaceae by Lumbsch and Huhndorf (2010), Hyde et al. (2013) and Wijayawardene et al. (2014a). However, it is dissimilar with the family type of Parmulariaceae having dark, superficial, star-shaped ascomata forming on a thallus of lichens (Diederich and Wedin 2000; Dai et al. 2018). Ertz and Diederich (2015) included H. atlantica in their phylogenetic analysis and indicated that this genus belongs to Asterinales based on LSU sequence data, without assigning the family placement. The same result was shown in Dai et al. (2018) and in this study (Fig. 5).

Hemigrapha asteriscus (Müll. Arg.) R. Sant. ex D. Hawksw., Kew Bull. 30(1): 191 (1975).

$\equiv$ Melanographa asteriscus Müll. Arg., Flora, Regensburg 65(33): 519 (1882).
Asci. g Hamathecium. h-j Asci. k Ocular chamber strained in Melzer's reagent. l, m 1-septate ascospores. $n$ 2-septate ascospore. Scale bars: $\mathbf{c}=100 \mu \mathrm{m}, \mathbf{e}-\mathbf{j}=20 \mu \mathrm{m}, \mathbf{k}-\mathbf{n}=10 \mu \mathrm{m}$

Index Fungorum number: IF 530383; Facesoffungi number: FoF 02312; Fig. 8

Description: see Dai et al. (2018).

Material examined: Australia, New South Wales, Mount Kosciuszko, on thallus of Peltigera dolichorrhiza (Lichen). Müller J. 1882 (G 00292584, syntype).

\section{Economic and ecological significance}

Members of this family are biotrophic on lichens and appear as black colonies on the host surface.

Lembosiaceae Hosag, in Hosagoudar et al., J. Mycopathol. Res. 39(1): 61 (2001).

Index Fungorum number: IF 80503; Facesoffungi numbers: FoF 07609, 160 species.

Epiphytic on living leaves. Superficial hyphae with lateral appressoria. Sexual morph: Thyriothecia solitary, scattered, superficial, oval, ellipsoidal, X- or Y-shaped, easily removed 


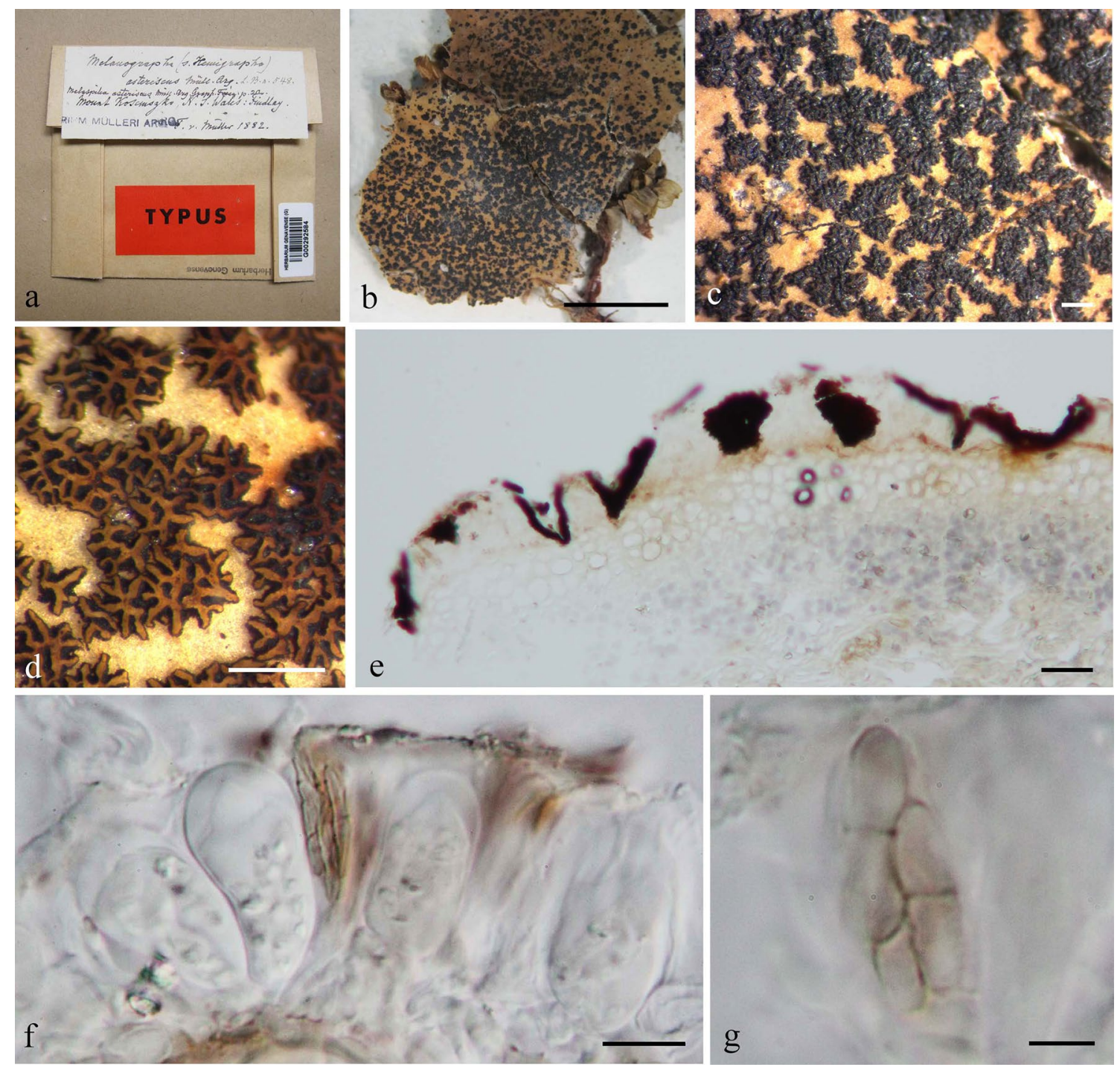

Fig. 8 Hemigrapha asteriscus (G 00292584, syntype). a, b Herbarium material. c, d Appearance of ascostromata on host surface. d Ascostromata in the water. e Section of ascostroma. f Asci with

from the host surface, black, opening by a linear fissure, with basal peridium poorly developed. Upper wall comprising linear, dark cells, which are branched at the margin. Hamathecium comprising vertical asci inclined upwards, pseudoparaphyses not observed. Asci bitunicate, fissitunicate dehiscence not observed, subglobose to ovoid, apedicellate, apical region of asci usually with a thick opaque region, ocular chamber not observed, not staining blue in IKI. Ascospores overlapping, oblong to obvoid, hyaline to brown, 1-septate. Asexual morph: Undetermined.

Type: Lembosia Lév.

Notes: Hosagoudar et al. (2001) introduced Lembosiaceae using the morphological character of elongate thyriothecia with longitudinal or X- or Y-shaped slits (Hongsanan et al. 2014b). However, Hongsanan et al. (2014b) treated hamathecial tissues. $\mathbf{g}$ Ascospores. Scale bars: $\mathbf{b}=10 \mathrm{~mm}, \mathbf{c}, \mathbf{d}=500$ $\mu \mathrm{m}, \mathbf{e}=50 \mu \mathrm{m}, \mathbf{f}, \mathbf{g}=5 \mu \mathrm{m}$

Lembosiaceae as a synonym of Asterinaceae based on the first phylogenetic evidence of LSU sequence data of Lembosia albersii. Here, we re-introduced Lembosiaceae using sequence data currently available in GenBank.

Lembosia Lév., Annls Sci. Nat., Bot., sér. 3 3: 58 (1845). Index Fungorum number: IF 2724; Facesoffungi number: FoF 06736, - 160 morphological species (Species Fungorum 2020), 6 species with molecular data

Type species: Lembosia tenella Lév., Annls Sci. Nat., Bot., sér. 3 3: 58 (1845).

Notes: Species of Lembosia and Asterina are obligately biotrophic, having appressoria and similar thyriothecia (Hosagoudar et al. 2001). However, Lembosia differs from Asterina in having elongate thyriothecia which dehisce to 
open by a longitudinal or X- or Y-shaped slit (Hosagoudar 1991).

Lembosia xyliae X.Y. Zeng, T.C. Wen \& K.D. Hyde, in Ariyawansa et al., Fungal Diversity: 75: 50 (2015).

Index Fungorum number: IF 551345; Facesoffungi number: FoF 00933, Fig. 9

Description: see Ariyawansa et al. (2015a).

Material examined: Thailand, Chiang Rai, Mae Fah Luang University, on leaves of Xylia sp. (Fabaceae), 18 January 2014, XY Zeng (MFLU 14-0004, holotype).

\section{Economic and ecological significance}

Species in Lembosiaceae are considered as obligatory biotrophs, however, there are no records available to show its economic significance.

Melaspileellaceae D.Q. Dai \& K.D. Hyde, in Dai et al., Phytotaxa 369(2): 70 (2018).

Index Fungorum number: IF 554063; Facesoffungi number: FoF 03911, 1 species.

Saprobic on trees and shrubs. Sexual morph: Ascostromata solitary, superficial, dark to black, coriaceous, small rounded. Peridium comprises 2 layers, black and thickwalled cells at outer layers, light brown to hyaline cells of textura angularis of inner layers. Hamathecium comprising dense, hyaline, mainly unbranched, filamentous, septate, cellular pseudoparaphyses around asci, with brownish tips. Asci 8 -spored, bitunicate, broadly clavate to subglobose, with a rounded apex and a short pedicel. Ascospores 2-seriate to irregularly arranged, ellipsoid, hyaline, 1-septate, with slightly larger upper cell, with slightly narrower lower cell, smooth-walled, bearing 2-3 appendages which disappear when dry. Asexual morph: Undetermined (adapted from Dai et al. 2018).

Type: Melaspileella (P. Karst.) Vain.

Notes: This family was established by Dai et al. (2018) to accommodate a single genus Melaspileella based on phylogenetic placement generated from LSU and SSU of M. proximella. The family formed a clade sister to Hemigraphaceae within Asterinales with high bootstrap support in Dai et al. (2018), while sister to Pirozynskiella laurisilvatica (FMR 13133) genus incertae sedis in Asterinales in our analyses (Fig. 5). Thus, we retain Melaspileellaceae in Asterinales.

Melaspileella (P. Karst.) Vain., Ann. Acad. Sci. fenn., Ser. A 15(no. 6): 317 (1921).

$=$ Mycomelaspilea Reinke, in Pringsheim, Jb. wiss. Bot. 28: 136 (1895).

Index Fungorum number: IF 3095; Facesoffungi number: FoF 07733; 1 morphological species (Species Fungorum 2020), 1 species with molecular data.
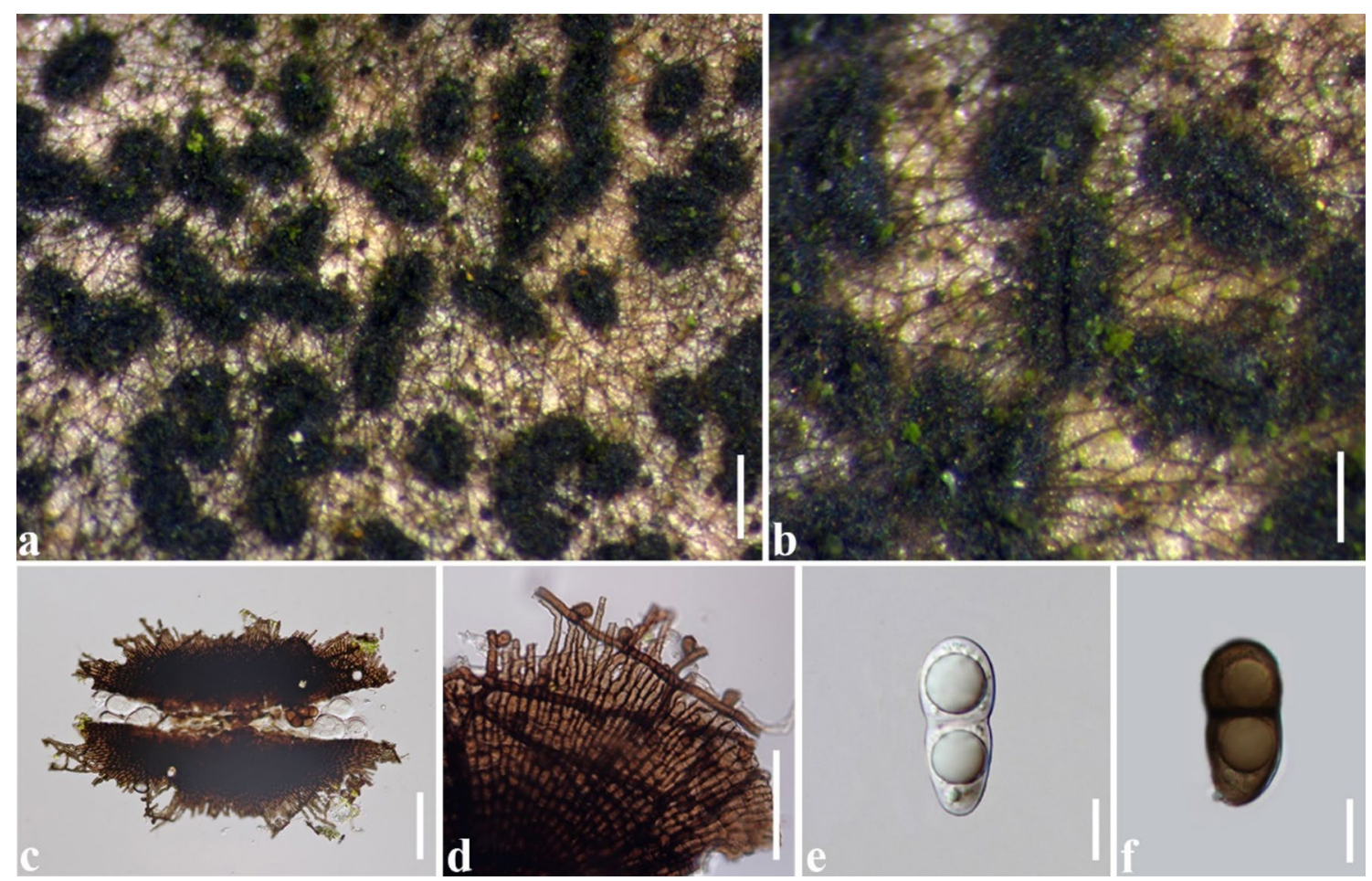

Fig. 9 Lembosia xyliae (MFLU 14-0004, holotype). a, b Colonies on leaf surface. c Squash mount of ascomata with asci. d Upper walls and hyphae with hyphopodia. e Immature ascospores. f Mature ascospores. Scale bars: $\mathbf{a}=400 \mu \mathrm{m}, \mathbf{b}=200 \mu \mathrm{m}, \mathbf{c}=100 \mu \mathrm{m}, \mathbf{d}=50$ $\mu \mathrm{m}, \mathbf{e}-\mathbf{f}=10 \mu \mathrm{m}$ 
Type species: Melaspileella proximella (Nyl.) Ertz \& Diederich.

Notes: Melaspileella was introduced by Vainio (1921b). Ertz and Diederich (2015) lectotypified the genus with $M$. proximella. They also transferred the genus to Asterinales without assigning it to any family. A phylogenetic tree based on LSU and SSU sequence data in Dai et al. (2018) indicated that $M$. proximella should be assigned in a new family, Melaspileellaceae.
Melaspileella proximella (Nyl.) Ertz \& Diederich, Fungal Diversity 71: 161 (2015).

三 Arthonia proximella Nyl., Lich. Scand. (Helsinki): 262 (1861).

Index Fungorum number: IF 811374; Facesoffungi number: FoF 07610; Fig. 10

Description: see Zeller and Tóth (1960).
Fig. 10 Melaspileella proximella. a Fruiting body on host (redrawn from ERD-7986. Photo: Enrique Rubio). b Section through ascoma, in water (redrawn from Finland, H-NYL 4827, lectotype). c Ascus with ascospores, in water (redrawn from Finland, H-NYL 4827, lectotype). d Ascus with ascospores (Hungary, on Juniperus, Zeller \& Tóth 2835, BP - paratype of Banhegyia setispora). e Ascospore with polar setulae, in water (redrawn from Belgium, Ertz 19187). f Ascospore with polar setulae (redrawn from Finland, Nylander, $\mathrm{H}$ - lectotype). Scale bars: $\mathbf{b}=20 \mu \mathrm{m}, \mathbf{c}, \mathbf{d}=10 \mu \mathrm{m}$, e, $\mathbf{f}=5 \mu \mathrm{m}$
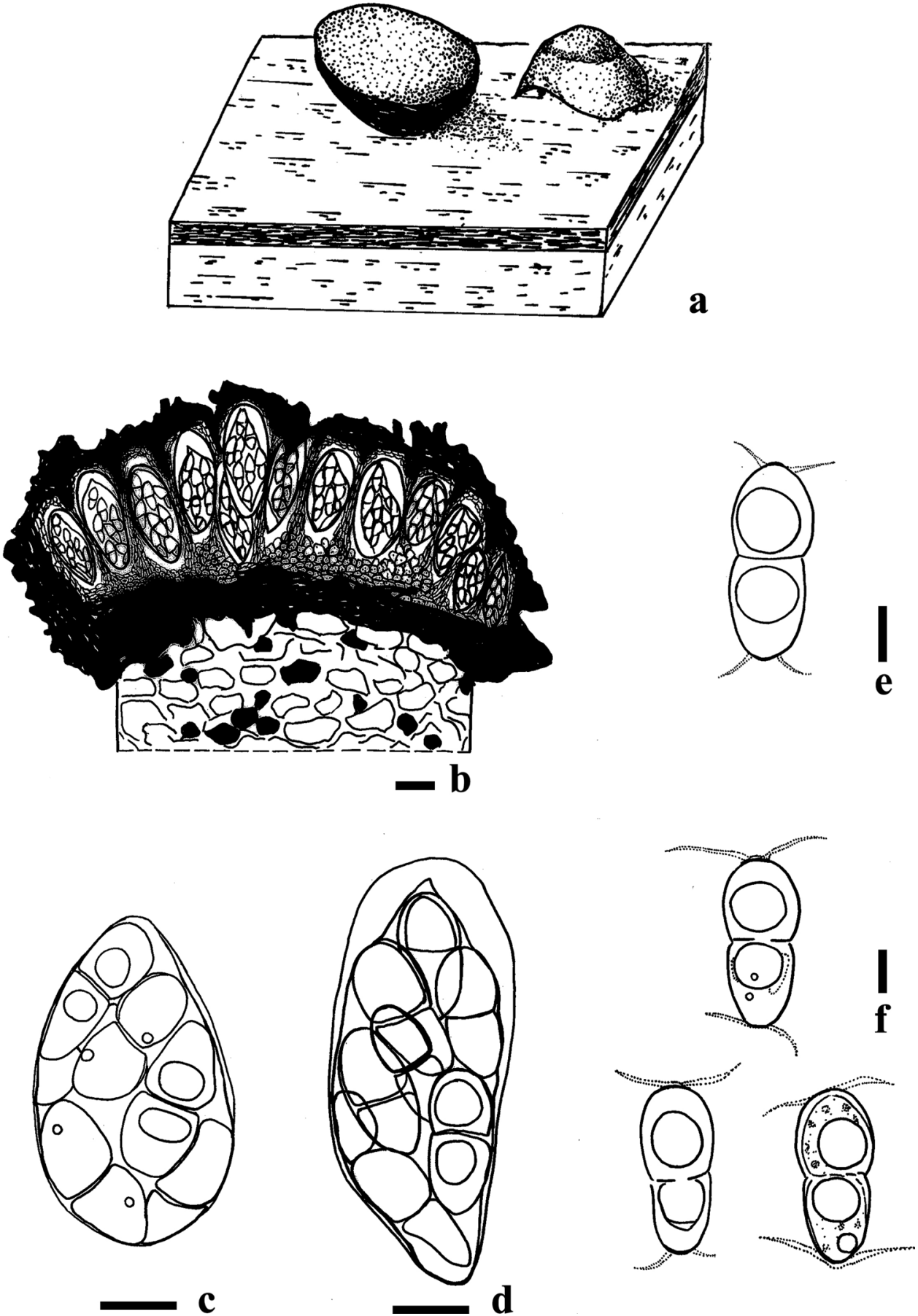


\section{Economic and ecological significance}

Members of this family are saprobic on plants and involved in recycling organic matter. Melaspileella proximella grows on trees and shrubs including trunks of Pinus and Tilia, and twigs of Juniperus (Ertz and Diederich 2015).

\section{Morenoinaceae Hongsanan \& K.D. Hyde, fam. nov.}

Index Fungorum number: IF 557813; Facesoffungi number: FoF 07611, 26 species.

Saprobic on stem or leaves, forming blackened areas. Sexual morph: Thyriothecia solitary, aggregated, or gregarious, superficial, easily removed from the host surface, black, ellipsoid, oblong, curved, opening by X- or Y-shaped or linear fissures, branched at the margin, from the center to the outer rim, lacking free hyphae and appressoria at the margin. Upper wall comprising linear, dark cells, which are branched at the margin, radiating from the center to the outer rim. Hamathecium pseudoparaphyses not observed. Asci 8-spored, bitunicate, fissitunicate dehiscence not observed, subglobose to oblong or saccate to globose, apedicellate, ocular chamber not observed, or with a distinct, thickened apical region. Ascospores overlapping 2-3-seriate, oblong to obvoid, or fusiform, hyaline, 1-septate, constricted at the septum, with or without guttules, smooth-walled (Hongsanan et al. 2014b; Tibpromma et al. 2017). Asexual morph: Coelomycetous. "Sirothyriella", Pycnothyria circular, radially scutellate. Conidiogenous cells holoblastic, simple, hyaline. Conidia cylindrical, hyaline, 1-celled (asexual morph from Sivanesan 1984; drawing of asexual characters can be seen in Ellis 1980).

Type: Morenoina Theiss.

Notes: Morenoinaceae resembles Aulographaceae (Hongsanan et al. 2014b). In our phylogenetic analyses (Fig. 5), Morenoina calamicola is closely related to Morenoina palmicola (MFLUCC 15-0284) with 67\% ML and 0.93 BYPP support as a distinct clade within Asterinales. Therefore, we introduce Morenoinaceae to accommodate the Morenoina clade.

Morenoina Theiss., Annls mycol. 11(5): 434 (1913).

= Aulographella Höhn., Ber. dt. bot. Ges. 35: 359 (1917).

Index Fungorum number: IF 3270; Facesoffungi number: FoF 07612, 26 morphological species (Species Fungorum 2020), 2 species with molecular data.

Type species: Morenoina antarctica (Speg.) Theiss.

Notes: Morenoina was placed in Leptopeltidaceae and Asterinaceae (von Arx and Müller 1975; Lumbsch and Huhndorf 2010). Hongsanan et al. (2014b) designated an epitype and placed this genus in Aulographaceae as Morenoina did not have free hyphae with appressoria as other members of Asterinaeceae and it has different ascus form from members of Leptopeltidaceae. Morenoina resembles Aulographum and differs only in the morphology of the scutellum which comprises inordinately arranged cells and a hypostroma of subcuticular hyphae beneath the thyriothecium, which is lacking in Morenoina (Ellis 1980). Phylogenetic placement of Aulographaceae is uncertain due to lack of sequence data. Sequence data of Aulographum hederae (type species) formed an unstable clade, while two species of Morenoina form a distinct clade within Asterinales (Fig. 5). Therefore, we place Morenoina in the new family Morenoinaceae.

Morenoina antarctica (Speg.) Theiss., Annls mycol. 11(5): 434 (1913).

$\equiv$ Morenoella antarctica Speg., Boln Acad. nac. Cienc. Córdoba 11(2): 240 (1887) [1888].

Index Fungorum number: IF 174884; Facesoffungi number: FoF 07613; Fig. 11

Material examined: Argentina, Tierra del Fuego, Ushuaia, south of Paso e Garibaldi, on the stem of Gramineae, 29 October 1989, collected by P.F. Cannon and D.W. Minter, identified by P.F. Cannon (IMI 349680, epitype).

\section{Economic and ecological significance}

Species of this family are saprobic and play a role in recycling organic matter.

Neobuelliellaceae Hongsanan \& K.D. Hyde, fam. nov.

Index Fungorum number: IF 558103;

Facesoffungi number: FoF 07614, 1 species.

Lichenicolous. Vegetative hyphae intercellular. Sexual morph: Ascomata apothecioid, dispersed over the host thallus as black dots, grouped, rarely single, rounded, globose when young, pressed at the edges, oval when mature, often bleaching the host thallus, occasionally sunken. Excipulum dark brown, $\mathrm{K}+$ greenish-brown. Hymenium hyaline to brownish. Disc olive-brown, I-, KI-. Hamathecium comprising branched, anastomosing, cellular pseudoparaphyses, capitate at apical and intercalary cells with pigment, thick at tips, with dark-brown pigment. Asci 4-6-spored, bitunicate, fissitunicate, cylindrical. Ascospores long, cells rounded, the upper cell sometimes tapered, hyaline, later \pm brown, 1-septate, clearly constricted at the septa, thin-walled (adapted from Hafellner et al. 2008; Etayo 2010; Yazici and Etayo 2013). Asexual morph: Undetermined.

Type: Neobuelliella Hongsanan \& K.D. Hyde

Notes: Neobuelliellaceae is similar to species of Buelliella which are placed in genus incertae sedis in Dothideomycetes. Buelliella minimula (type species) together with B. physciicola cluster within Stictographaceae (Asterinales) in the phylogenetic analyses of Dai et al. (2018) and this study. Two strains of Neobuelliella poetschii (三Buelliella poetschii) form a distinct clade separately from Stictographaceae, and are sister to Hemigraphaceae (Ertz et al. 


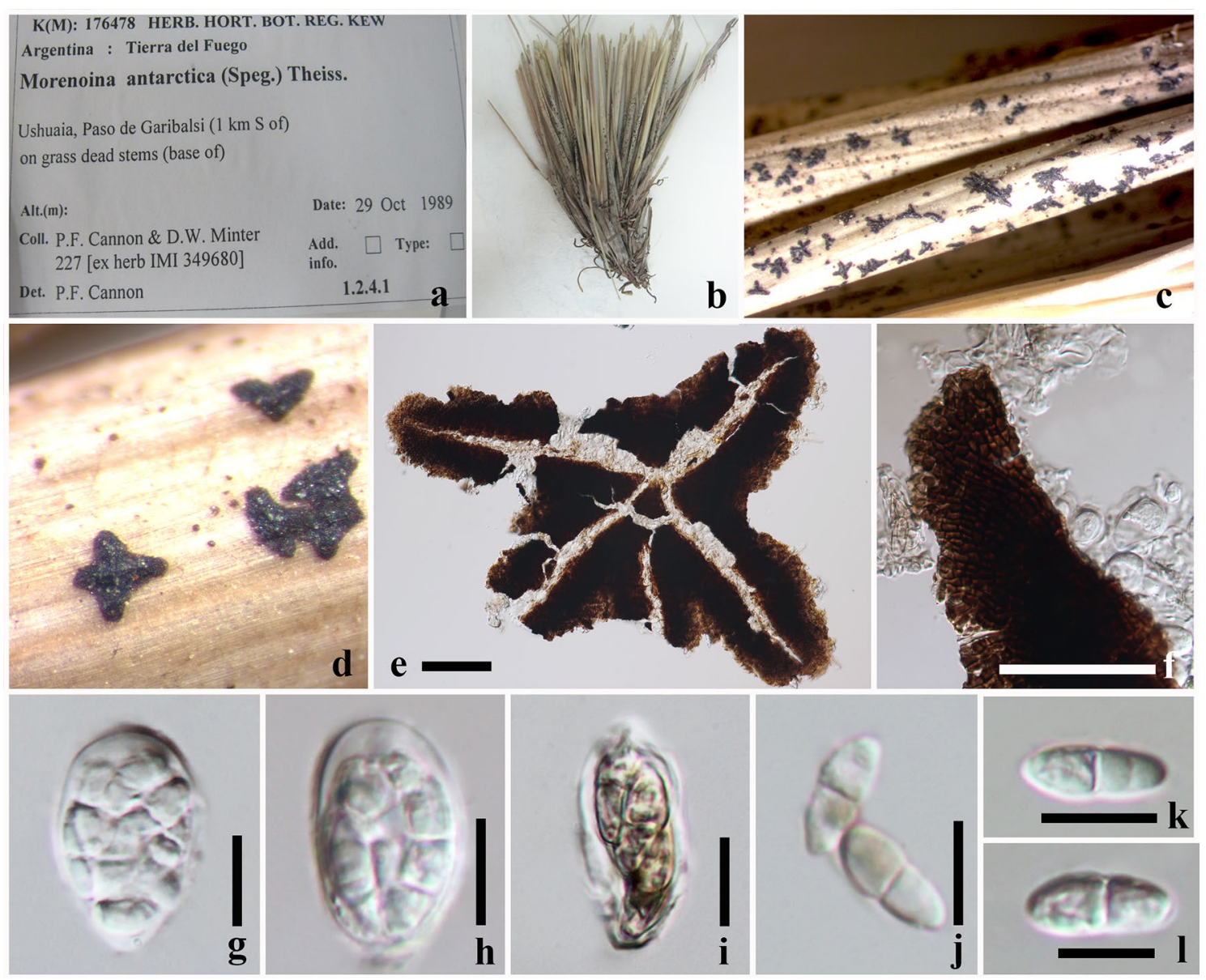

Fig. 11 Morenoina antarctica (IMI 349680, epitype). a, b Herbarium and specimen. c, d Appearance of thyriothecia on surface of plant. e Squash mount of thyriothecium. f Upper wall of thyriothe-

2015; Dai et al. 2018; this study). Therefore, we introduce a new family Neobuelliellaceae to accommodate this clade.

\section{Neobuelliella Hongsanan \& K.D. Hyde, gen. nov.}

Index Fungorum number: IF 557815; Facesoffungi number: FoF 07615; 1 morphological species (this study), 1 species with molecular data.

Lichenicolous. Vegetative hyphae intercellular. Sexual morph: Ascomata apothecioid, dispersed over the host thallus as black dots, grouped, rarely single, rounded, globose when young, pressed at the edges, oval when mature, often bleaching the host thallus, occasionally sunken. Hymenium hyaline to brownish. Disc olive-brown, I-, KI-. Excipulum dark brown, $\mathrm{K}+$ greenish-brown. Hamathecium comprising branched, anastomosing, cellular pseudoparaphyses, capitate at apical and intercalary cells with pigment, thick at tips, with dark-brown pigment. Asci 4-6-spored, bitunicate, fissitunicate cylindrical. Ascospores long, cells rounded, the upper cell sometimes tapered, hyaline, later \pm brown, 1-septate, clearly constricted at the septa, thin-walled (Hafellner cium. $\mathbf{g}-\mathbf{h}$ Asci when immature. $\mathbf{i}$ Asci at maturity. $\mathbf{j}-\mathbf{l}$ Ascospores. Scale bars: $\mathbf{e}=100 \mu \mathrm{m}, \mathbf{f}=50 \mu \mathrm{m}, \mathbf{g}-\mathbf{l}=20 \mu \mathrm{m}$

et al. 2008; Etayo 2010; Yazici and Etayo 2013). Asexual morph: Undetermined.

Type species: Neobuelliella poetschii (Hafellner) Hongsanan \& K.D. Hyde.

Notes: The genus is introduced to accommodate Neobuelliella poetschii which was known as Buelliella poetschii. Phylogenetic analyses from Dai et al. (2018) and this study (Fig. 5) indicate that it does not cluster with the type species of Buelliella. Thus, we introduce the new genus Neobuelliella to accommodate a single species Buelliella poetschii (current name is Neobuelliella poetschii).

Neobuelliella poetschii (Hafellner) Hongsanan \& K.D. Hyde, comb. nov.

$\equiv$ Buelliella poetschii Hafellner, in Hafellner, Herzog \& Mayrhofer, Mitt. naturw. Ver. Steierm. 137: 187 (2008).

Index Fungorum: IF 557814, Facesoffunginumber: FoF 07616; Fig. 12

Description: see Yazici and Etayo (2013). 


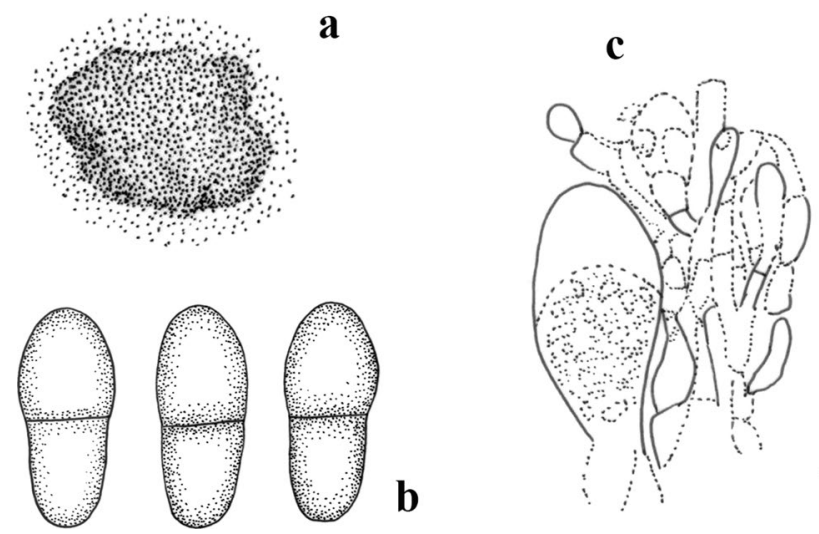

Fig. 12 Neobuelliella poetschi a Apothecioid ascomata (redrawn from Yazici and Etayo 2013). b Ascospores (redrawn from holotype in Hafellner et al. 2008). c Young ascus among hamathecium (redrawn from Ertz and Diederich 2015)

Notes: Phylogenetically, Buelliella poetschii formed a distinct lineage within Asterinales, and did not cluster with B. minimula (type species of Buelliella). Thus, B. poetschii is synonymized in Neobuelliella.

\section{Economic and ecological significance}

Neobuelliellaceae comprises lichenicolous taxa which play insignificant roles in ecosystems. There is only a single species in this family. Fresh collections are needed to understand the ecological significance of Neobuelliellaceae.

Stictographaceae D.Q. Dai \& K.D. Hyde, in Dai et al., MycoKeys 369(2): 70 (2018).

Index Fungorum number: IF 554064; Facesoffungi number: FoF 03912, 39 species.

Lichenicolous. Sexual morph: Ascomata solitary, scattered to clustered, superficial, cymbiform to lirelliform, with slit-like disc, with a slit or star-shaped fissure, black to dark brown. Peridium thick, outer layers of black to dark brown, thick-walled cells of textura angularis, inner layers of light brown to hyaline cells of textura angularis. Hamathecium comprising dense, filamentous, septate, unbranched or occasionally branched at upper part around the asci, cellular pseudoparaphyses. Asci 8-spored, bitunicate, clavate to subglobose, with an ocular chamber, apically rounded, short pedicellate. Ascospores 2-seriate to irregularly arranged, ellipsoid, hyaline, becoming light brown to dark brown, 1-septate, with slightly larger upper cell, and narrower lower cell, smooth-walled. Asexual morph: Undetermined (Dai et al. 2018).

Type: Stictographa Mudd.

Notes: Stictographaceae was introduced to accommodate four lichenicolous or saprobic genera which have cymbiform to lirelliform, or a slit-like discs, black to dark brown ascomata, wide clavate to subglobose asci, and ellipsoid, brown, 1-septate ascospores (viz. Karschia, Labrocarpon, Melaspileopsis and Stictographa; Dai et al. 2018). In the phylogenetic tree, these four genera clustered as a distinct clade within Asterinales (Dai et al. 2018). As the type species of Buelliella clustered within the clade of Stictographaceae, we therefore include Buelliella in Stictographaceae.

Stictographa Mudd, Man. Brit. Lich.: 226 (1861).

Index Fungorum number: IF 5238; Facesoffungi number:

FoF 07617; 1 morphological species (Species Fungorum 2020), 1 species with molecular data.

Type species: Stictographa lentiginosa (Lyell ex Leight.) Mudd.

Notes: Stictographa can be compared with Labrocarpon in having lichenicolous, black, simple to occasionally short, branched, lirelliform ascomata with a slit-like opening (Ertz and Diederich 2015; Diederich et al. 2017). Ertz and Diederich (2015) inferred that Stictographa and Labrocarpon might be synonyms, however, they do not phylogenetically cluster together (Ertz and Diederich 2015; Dai et al. 2018). Thus, Labrocarpon is accepted as a distinct genus. More collections and species of these genera are needed to clarify their relationship.

Stictographa lentiginosa (Lyell ex Leight.) Mudd, Man. Brit. Lich.: 226 (1861).

$\equiv$ Opegrapha lentiginosa Lyell ex Leight., Ann. Mag. nat. Hist., Ser. 2 13: 211 (1854).

Index Fungorum number: IF 406525; Facesoffungi number: FoF 07618; Fig. 13

Description: see Redinger (1938), Sanderson et al. (2009), Ertz and Diederich (2015).

\section{Other genera included}

Buelliella Fink, Lich. Fl. U.S.: 372 (1935).

Index Fungorum number: IF 676; Facesoffungi number: FoF 03625; 12 morphological species (Species Fungorum 2020, this study), 2 species with molecular data.

Type species: Buelliella minimula (Tuck.) Fink, Lich. Fl. U.S.: 372 (1935).

$\equiv$ Buellia minimula Tuck., Syn. N. Amer. Lich. (Boston) 2: 106 (1888).

Notes: The original diagnosis of this genus was provided by Fink (1935), and valided by Hafellner (1979). Buelliella is characterised by a non-lichenized, lichenicolous habit, initially subsphaerical and closed ascomata, with the upper ascomatal breaking gradually away to expose the hymenium when mature, becoming apothecioid, with bitunicate, broadly clavate to subcylindrical asci, and a distinct ocular chamber, and ellipsoid, 1-septate, pale to medium brown ascospores. Ertz and Diederich (2015) noted that the genus is not monophyletic due to $B$. physciicola and B. poetschii being distantly related, and sequence data of the type species 
Fig. 13 Stictographa lentiginos (redrawn Ertz and Diederich 2015). a Ascomata growing on lichen. b Clavate to subglobose asci and pseudoparaphyses. c Ascospores. Scale bars: $\mathbf{a}=200$ $\mu \mathrm{m}, \mathbf{b}, \mathbf{c}=10 \mu \mathrm{m}$
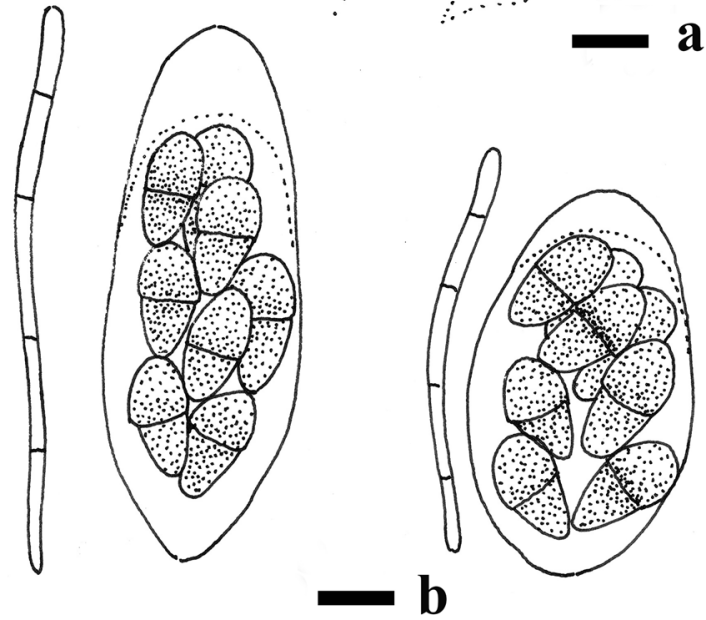

(B. minimula) was unavailable. Thus, it was placed as incertae sedis in Dothideomycetes (Kirk et al. 2008; Ertz and Diederich 2015; Wijayawardene et al. 2017a). We included sequence data of $B$. minimula in our analyses and found that it forms a lineage within Sticgraphaceae. Buelliella poetschii is transferred to a new genus, Neobuelliella in this paper.

Karschia Körb., Parerga lichenol. (Breslau) 5: 459 (1865). Index Fungorum number: IF 2545; Facesoffungi number: FoF 07619; - 24 morphological species (Species Fungorum 2020), 2 species with molecular data.

Type species: Karschia talcophila (Ach.) Körb., Parerga lichenol. (Breslau) 5: 460 (1865).

三Lecidea talcophila Ach., Lich. univ.: 183 (1810).

Notes: More than 100 species of Karschia are listed in Index Fungorum (2020), however, most taxa have been transferred to other genera, such as Buelliella, Cycloschizon, Dothidea and others by Hafellner (1979). Two species were accepted by Hawksworth et al. (1995), and later four species were included (Kirk et al. 2008). Karschia is characterized by a lichenicolous life-style, immersed to erumpent, rounded, black ascomata with a large, irregular opening, producing pseudoparaphyses with a slightly enlarged and brown apex, bitunicate, clavate to subcylindrical asci, ellipsoid, brown, smooth ascospores with one septum (Ertz and Diederich 2015).

Labrocarpon Etayo \& Pérez-Ort., in Pérez-Ortega \& Etayo, Lichenologist 42(3): 271 (2010).

Index Fungorum number: IF 515228; Facesoffungi number: FoF 07620; - 1 morphological species (Species Fungorum 2020), 1 species with molecular data.

Type species: Labrocarpon canariense (D. Hawksw.) Etayo \& Pérez-Ort. [as 'canariensis'], in Pérez-Ortega \& Etayo, Lichenologist 42(3): 272 (2010).

$\equiv$ Melaspilea canariensis D. Hawksw., Lichenologist 14(1): 84 (1982). 


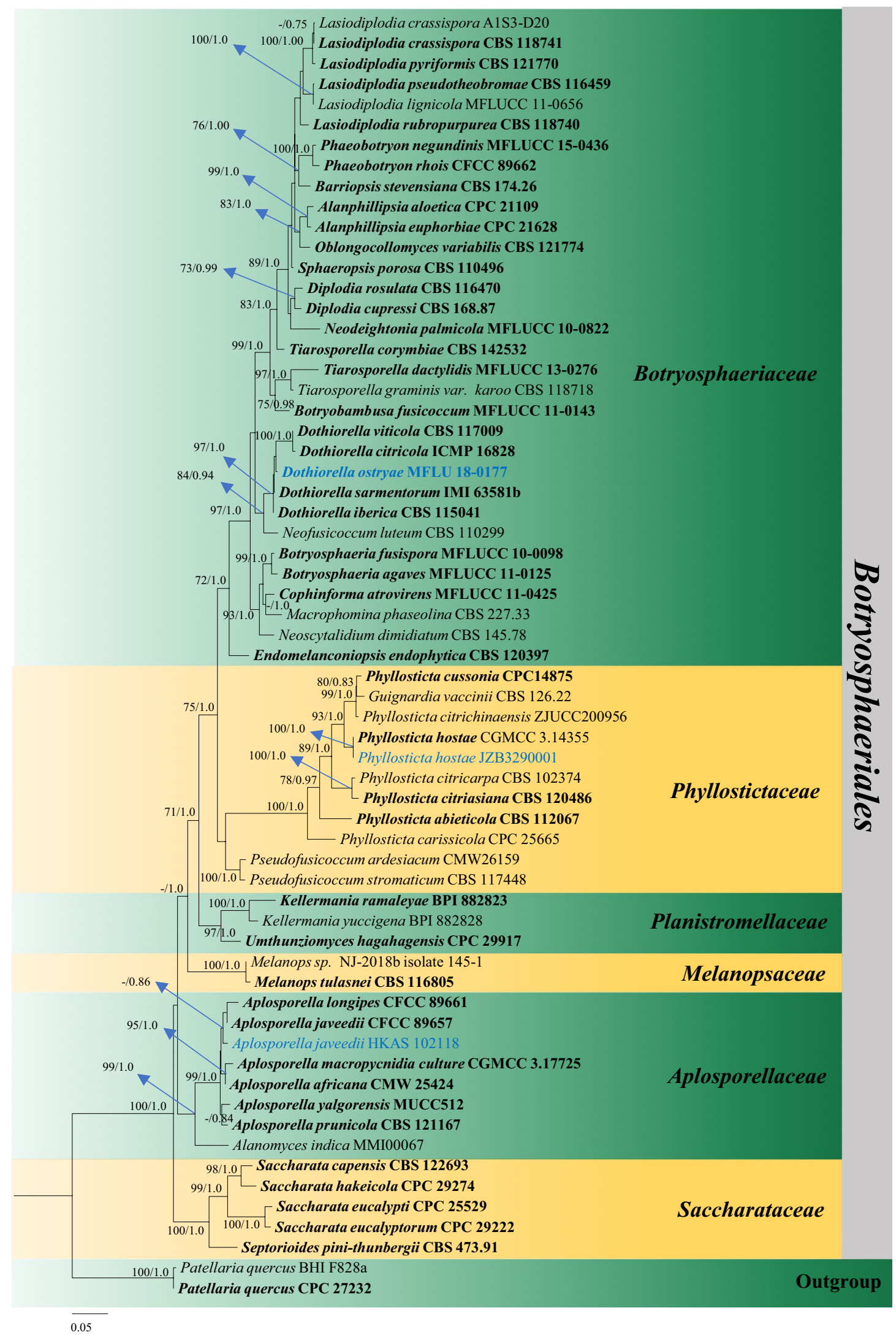


4Fig. 14 Phylogram generated from maximum likelihood analysis (RAxML) of Botryosphaeriales based on ITS and LSU sequence data. Maximum likelihood bootstrap values equal to or greater than $70 \%$, Bayesian posterior probabilities equal to or greater than 0.90 (MLBS/PP) are given at the nodes. Isolate numbers are noted after each species name. The tree is rooted to Patellaria quercus (CPC 27232 and BHI F828a). Newly sequence data generated in this study are in blue. Ex-type and references strains are indicated in bold. Hyphen (-) represents support values less than 70\% MLBS and 0.90 PP

Notes: Labrocarpon is a monotypic genus which was introduced by Pérez-Ortega and Etayo (2010) based on morphology of ascomata with periphyses (Ertz and Diederich 2015). Labrocarpon is more or less similar to Stictographa (Pérez-Ortega and Etayo 2010; Ertz and Diederich 2015). However, it formed a separate clade from Stictographa (Ertz and Diederich 2015; Dai et al. 2018). Labrocarpon is characterized by a lichenicolous life-style, superficial, rounded to slightly elliptic, black, disk-like ascomata with a slit-like opening and a well-developed exciple, producing pseudoparaphyses with a swollen and brown apex, bitunicate, clavate, thick-walled asci with an ocular chamber, and two-celled ascospores (Ertz and Diederich 2015).

Melaspileopsis (Müll. Arg.) Ertz \& Diederich, Fungal Diversity 71: 161 (2015).

Index Fungorum number: IF 811387; Facesoffungi number: FoF 07621; - 1 morphological species (Dai et al. 2018), 1 species with molecular data.

Type species: Melaspileopsis diplasiospora (Nyl.) Ertz \& Diederich, Fungal Diversity 71: 161 (2015).

$\equiv$ Opegrapha diplasiospora Nyl., Acta Soc. Sci. fenn. 7(2): 476 (1863).

Notes: The genus was established by Ertz and Diederich (2015), with the type species M. diplasiospora (三 Melaspilea diplasiospora in Index Fungorum 2020). Phylogenetically, it does not belong to Melaspileaceae but is sister to Stictographa within Stictographaceae (Dai et al. 2018). This genus was placed in Melaspileaceae, order Eremithallales (Wijayawardene et al. 2018). However, we agree with Dai et al. (2018) to retain Melaspileopsis within Stictographaceae.

\section{Economic and ecological significance}

Stictographaceae accommodates several lichenicolous and one saprobic genus. Members of this family usually occur on the thallus of lichens. They are distributed in tropiccal to temperate areas. Stictographa lentiginosa is much rarer than the host (Phaeographis dendritica) and thus can act as a useful indicator of the quality of ancient woodlands in western Europe (Ertz and Diederich 2015).

Botryosphaeriales C.L. Schoch, Crous \& Shoemaker.
Index Fungorum number: IF 501513; Facesoffungi number: FoF 07659.

Botryosphaeriales was introduced to accommodate a single family Botryosphaeriaceae (Schoch et al. 2006). Previously, nine families (Aplosporellaceae, Botryosphaeriaceae, Melanopsaceae, Phyllostictaceae, Planistromellaceae, Saccharataceae, Septorioideaceae, Endomelanconiopsidaceae, Pseudofusicoccaceae) were accepted in Botryosphaeriales in the Outline of Ascomycetes (Wijayawardene et al. 2018). However, currently only six families (Aplosporellaceae, Botryosphaeriaceae, Melanopsaceae, Phyllostictaceae, Planistromellaceae, Saccharataceae) are accepted in this order (Phillips et al. 2019), the remaining three families were synonymized with existing families. Thus, Endomelanconiopsidaceae is considered a synonym of Botryosphaeriaceae, Pseudofusicoccaceae a synonym of Phyllostictaceae and Septorioideaceae a synonym of Saccharataceae (Phillips et al. 2019). Species in the order are characterized by uni- or multilocular ascostromata with multi-layered dark brown walls, occurring individually or in clusters, frequently embedded in stromatic tissue. Asci are bitunicate, with a thick endotunica, pedicellate or sessile, clavate, with a welldeveloped ocular chamber, intermixed with hyaline, septate pseudoparaphyses, branched or not. Ascospores are hyaline or pigmented, septate or not, ellipsoid to ovoid, with or without mucoid appendages or mucilaginous sheath. Conidiomata are pycnidial, uni- to multilocular, frequently embedded in stromatic tissue. Conidiogenous cells are hyaline, phialidic or annelidic. Conidia are hyaline or pigmented, septate or not, thin- or thick-walled, with or without mucoid appendages or sheaths (Phillips et al. 2019). The divergence time for Botryosphaeriales is estimated as 150 MYA (stem age, Hongsanan et al. 2020) (Fig. 14).

Accepted families: Aplosporellaceae, Botryosphaeriaceae, Melanopsaceae, Phyllostictaceae, Planistromellaceae, Saccharataceae.

Aplosporellaceae Slippers, Boissin \& Crous, Stud. Mycol. 76(1): 41 (2013).

Index Fungorum: IF 805795; Facesoffungi number: FoF 00113, 13 species.

Sexual morph: Stromata pseudothecial, multiloculate ascomata with multi-layered, dark brown walls, embedded in stromatic tissue. Hamathecium comprising hyphoid, hyaline pseudoparaphyses. Asci bitunicate, mostly with a thick endotunica, clavate, with a well-developed ocular chamber and intermixed with pseudoparaphyses. Ascospores 1-2-seriate, ellipsoid to ovoid, mostly aseptate, or septate, hyaline to pigmented, lacking mucoid appendages or sheaths (Slippers et al. 2013; Liu et al. 2012; Thambugala et al. 2014a; photoplates of sexual characters can be seen in Ekanayaka et al. 2016). Asexual morph: Coelomycetous. Conidiomata pycnidial, multilocular, embedded in stromatic tissues. 


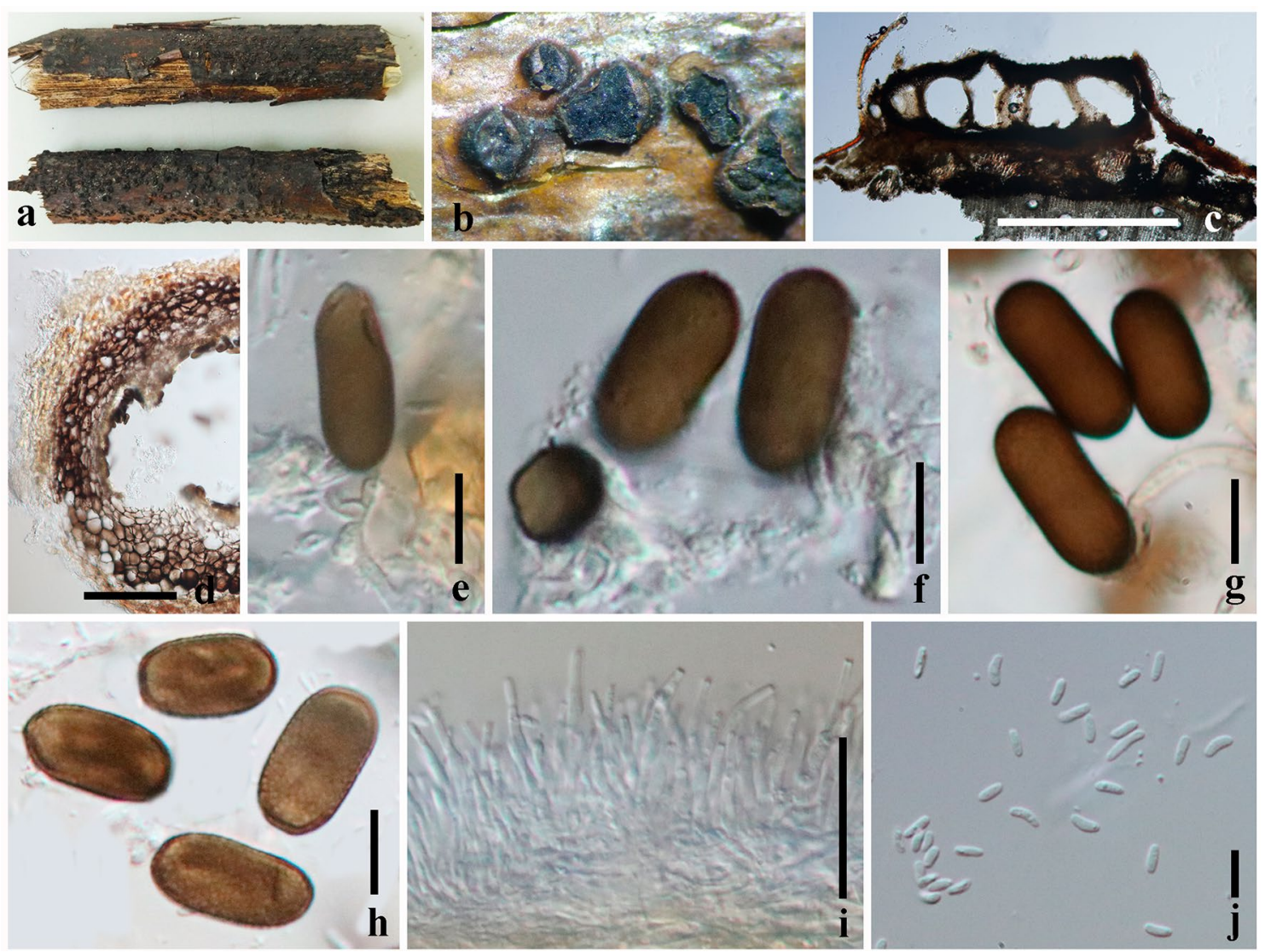

Fig. 15 Asexual morph of Aplosporella javeedii (HKAS 102118). a Substrate. b Conidiomata on substrate. c Cross section of multiloculate conidioma. d Conidioma wall. e, f Different stages of con-

Conidiophores reduced to conidiogenous cells. Conidiogenous cells hyaline, phialidic. Conidia ellipsoid to subcylindrical, initially hyaline, thin-walled and smooth, becoming pigmented, thick-walled and spinulose, aseptate (Sutton 1980).

\section{Type: Aplosporella Speg.}

Notes: Aplosporellaceae was introduced by Slippers et al. (2013) to accommodate Aplosporella and Bagnisiella. Currently two genera (Aplosporella and Alanomyces) are accepted in this family. This family is phylogenetically close to Botryosphaeriaceae. Liu et al. (2017), using evolutionary evidence, questioned whether this family was introduced unnecessarily and should be regarded as a genus. However, based on morphology, phylogeny and evolutionary divergence times, Phillips et al. (2019) regarded Aplosporellaceae as a distinct family.

Aplosporella Speg., Anal. Soc. cient. argent. 10(4): 157 (1880).

= Bagnisiella Speg., Anal. Soc. cient. argent. 10(4): 146 (1880). idiogenesis. g, h Conidia. i Spermatogenous cells. j Spermatia. Scale bars: $\mathbf{c}=1.5 \mathrm{~mm}, \mathbf{d}=100 \mu \mathrm{m}, \mathbf{e}-\mathbf{h}, \mathbf{j}=10 \mu \mathrm{m}, \mathbf{i}=25 \mu \mathrm{m}$

Index Fungorum number: IF 7191; Facesoffungi number: FoF 01427; 12 morphological species (botryosphaeriales.org 2020), 10 species with molecular data.

Type species: Aplosporella chlorostroma Speg.

Notes: Aplosporella was introduced by Spegazzini (1880). This genus has frequently been incorrectly referred to as "Haplosporella" (Tilak and Rao 1964; Petrak and Sydow 1927; Tai 1979; Wei 1979). About 340 epithets for Aplosporella are listed in Index Fungorum (July 2019). This genus is characterised by multiloculate pycnidia, brown, aseptate, spinulose conidia, hyaline, aseptate spermatia and fusiform paraphyses (Du et al. 2017). Its sexual morph is not common (Ekanayaka et al. 2016). Slippers et al. (2013) indicated that Aplosporella should be separate from Botryosphaeriaceae as a distinct family, which they named Aplosporellaceae, and confirmed that Aplosporella is wellresolved with species described from living culture. They also found a close genetic relationship between the genera Aplosporella and Bagnisiella and considered that Bagnisiella represents the sexual morph and should be reduced to synonymy with Aplosporella (Schoch et al. 2009a; Slippers et al. 2013). Ekanayaka et al. (2016) introduced a new 
species Aplosporella thailandica from Thailand with morphology corresponding to Bagnisiella. Phillips et al. (2019) formally placed Bagnisiella as a synonym of Aplosporella. The most recent phylogenetic tree of species in Aplosporella is provided by Hyde et al. (2020a).

Aplosporella javeedii Jami, Gryzenh., Slippers \& M.J. Wingf., Fungal Biology 118(2): 174 (2013).

Index Fungorum number: IF 803637; Facesoffungi number: FoF 07383; Fig. 15

Description: see Phillips and Alves (2009).

Saprobic on dead stems. Sexual morph: Undetermined. Asexual morph: Conidiomata 1-2 mm diam., erumpent from bark surface, separate, discoid, dark-brown to black, multi-locular. Peridium composed cells of textura angularis, 4-10 layers, thick-celled, dark-brown to black cells at outer layers, thin-walled and hyaline cells at inner layers. Conidiophores reduced to conidiogenous cells. Conidiogenous cells hyaline, holoblastic, smooth, cylindrical. Conidia 18-25 $\times$ 9-13 $\mu \mathrm{m}(\bar{x}=20 \times 11 \mu \mathrm{m}, \mathrm{n}=20)$ ellipsoidal to subcylindrical, with rounded ends, initially light brown, slightly granulated walls, becoming dark brown (black in mass), aseptate. Spermatophores reduced to Spermatogenous cells, occurring intermingled among conidiogenous cells in same conidioma, subcylindrical, hyaline, smooth. Spermatia 4-7 $\times 1-3 \mu \mathrm{m}(\bar{x}=6 \times 2 \mu \mathrm{m}, \mathrm{n}=20)$ subcylindrical, straight or slightly curved, hyaline, smooth-walled, granular.

Material examined: China, Yunnan Province, Kunming, Kunming Institute of Botany, Botanical Garden, on dead stems, 24 May 2018, A.H. Ekanayaka (HKAS 102118).

GenBank number: ITS: MW136694, LSU: MW142386, SSU: MW127178

Notes: This collection is morphologically and phylogenetically similar to the type specimen of Aplosporella javeedii from South Africa (Jami et al. 2014). Comparison of ITS and LSU sequence data of this collection with sequence data of A. javeedii (CMW38165) has 99\% similarity. However, spermatia were found in HKAS 102118.

\section{Other genus included}

Alanomyces Roh. Sharma, Phytotaxa 297(2): 170 (2017).

Index Fungorum number: IF 804153; Facesoffungi number: FoF 07623; - 1 morphological species (Species Fungorum 2020), 1 species with molecular data.

Type species: Alanomyces indica Roh. Sharma, Phytotaxa 297(2): 172 (2017).

Notes: Alanomyces, introduced by Sharma et al. (2017), is characterised by rapidly spreading dark greenish black colonies. Pycnidia are multilocular with a long neck and cylindrical, hyaline, guttulate, single celled spermatia (Sharma et al. 2017).

\section{Economic and ecological significance}

Some taxa in Aplosporellaceae are recorded as plant pathogens. Aplosporella prunicola was recorded as a probable tree pathogen on gymnosperms (Aylward et al. 2017). Aplosporella beaumontiana was recorded as a major pathogen associated with a disease of okra (Yan et al. 2018).

Botryosphaeriaceae Theiss. \& Syd. [as 'Botryosphaeriacae'], Annls mycol. 16(1/2): 16 (1918).

Index Fungorum number: IF 80530; Facesoffungi number: FoF 00116, 279 species.

Endophytic, pathogenic and saprobic on a wide range of hosts worldwide. Sexual morph: Ascomata uniloculate, solitary or clustered, becoming fully or partially erumpent with maturity, wall multi-layered, dark brown, infrequently embedded in stromatic tissues. Asci 8-spored, bitunicate, fissitunicate, with well-developed ocular chamber, thick endotunica, short pedicellate, clavate. Pseudoparaphyses cellular, intermixed with asci, hyaline, septate, frequently constricted at septa, hyphae-like, branched or not, deliquescing with maturity. Ascospores 2-3-seriate, fusoid to ellipsoid or ovoid, hyaline or pigmented, smooth to verruculose, septate or not, mucoid sheath mostly absent (photoplates of sexual characters can be seen in Phillips et al. 2013, 2019). Asexual morph: Coelomycetous. Conidiomata uni or rarely multiloculate, pycnidial, infrequently embedded in stromatic tissue. Conidiophores mostly reduced to conidiogenous cells. Conidiogenous cells hyaline, phialidic, proliferating percurrently or internally giving rise to periclinal thickenings, or proliferating percurrently forming annelations, without collarettes. Conidia hyaline or pigmented, aseptate or one or multi-septate, sometimes muriform, smooth or striate, thin- or thick-walled, without mucoid sheaths or appendages. Spermatogonia similar to conidiomata in anatomy. Spermatogenous cells ampulliform to lageniform or subcylindrical, hyaline smooth, phialidic. Spermatia developing in conidiomata or spermatogonia, hyaline, smooth, granular, subcylindrical or dumbbell-shaped, with rounded ends. (Liu et al. 2012; Slippers et al. 2013; Phillips et al. 2013).

Type: Botryosphaeria Ces. \& De Not.

Notes: Botryosphaeriaceae was introduced by Theissen and Sydow (1918) for three genera, Botryosphaeria, Phaeobotryon and Dibotryon. Over decades of taxonomic revisions and updates based on morphology, the family became increasingly complex. However, based on LSU sequence data Crous et al. (2006a) revealed ten lineages within Botryosphaeriaceae, which they considered to represent individual genera. Phillips et al. (2008) defined, introduced and reinstated a further five genera in Botryosphaeriaceae. Aplosporella was shown to reside in Botryosphaeriaceae by Damm et al. (2007). Endomelanconiopsis was assigned to this family by Rojas et al. (2008) while Phillips and Alves (2009) considered that Melanopsis is another genus in Botryosphaeriaceae. Two new genera (Botryobambusa and 
Cophinforma) were introduced by Liu et al. (2012). Phillips et al. (2013) resolved Botryosphaeriaceae into 17 genera and 110 species known from culture. Thereafter six new genera and 85 new species/species combinations have been introduced (Dissanayake et al. 2016). According to a recent study by Phillips et al. (2019) currently 22 genera are accepted in Botryosphaeriaceae. In earlier studies Dothiorella and Spencermartinsia were regarded as two separate genera in the family (Phillips et al. 2008, 2013). However, Yang et al. (2017) synonymized Spencermartinsia under Dothiorella. These two genera are morphologically distinguishable only in sexual morphs by the hyaline apiculi in Spencermartinsia. So far, these characters are reported only in S. viticola but no other species in this genus have been observed with asexual morphs. Furthermore, phylogenetic distance is also small between these two genera. Therefore, in this paper we accept that Spencermartinsia is a synonym of Dothiorella. Phyllostictaceae was re-instated for Phyllosticta (Wikee et al. 2013a). Another three families were introduced in Botryosphaeriales by Slippers et al. (2013), namely Saccharataceae for Saccharata, Aplosporellaceae for Aplosporella and Melanopsaceae for Melanops. Wyka and Broders (2016) introduced Septorioideaceae for Septorioides while Yang et al. (2017) raised Endomelanconiopsis and Pseudofusicoccum to familial status as Endomelanconiopsidaceae and Pseudofusicoccaceae respectively. Taking into account morphology, phylogeny and evolutionary divergence times, Phillips et al. (2019) synonymised Endomelanconiopsidaceae with Botryosphaeriaceae, Pseudofusicoccaceae with Phyllostictaceae, and Septorioideaceae with Saccharataceae. In addition to that, Pilgeriella which fit within Botryosphaeriaceae, but do not have cultures or DNA (Wijayawardene et al. 2017a). Therefore, we place this genus incertae sedis in Botryosphaeriales.

Botryosphaeria Ces. \& De Not., Comm. Soc. crittog. Ital. 1(fasc. 4): 211 (1863).

Index Fungorum number: IF 635; Facesoffungi number: FoF 00141; 283 morphological species (Index Fungorum January, 2020), 13 species with molecular data.

Type species: Botryosphaeria dothidea (Moug.) Ces. \& De Not.

Notes: Botryosphaeria was introduced by Cesati and De Notaris (1863). Species in Botryosphaeria, based on the type species $B$. dothidea, are characterised by ascospores that are hyaline and aseptate, although they can become pale brown and septate with age (Shoemaker 1964; Sivanesan 1984; Denman et al. 2000; Alves et al. 2004; Phillips et al. 2005; Jayawardena et al. 2018).

\section{Other genera included}

Alanphillipsia Crous \& M.J. Wingf., in Crous et al., Persoonia 31: 197 (2013).
Index Fungorum number: IF 805816; Facesoffungi number: FoF 01417; - 5 morphological species (Species Fungorum 2020), 5 species with molecular data.

Type species: Alanphillipsia aloes Crous \& M.J. Wingf., in Crous et al. Persoonia 31: 197 (2013).

Notes: Alanphillipsia was introduced by Crous et al. (2013) to accommodate species that are aplosporella-like in morphology, but have conidia with a hyaline outer layer.

Barriopsis A.J.L. Phillips, A. Alves \& Crous (2008).

Index Fungorum number: IF 511712; Facesoffungi number: FoF 01679; - 6 morphological species (Species Fungorum 2020), 6 species with molecular data.

Type species: Barriopsis stevensiana A.J.L. Phillips \& Pennycook, in Wijayawardene et al., Fungal Diversity 86: 56 (2017).

Based on Barriopsis fusca A.J.L. Phillips, A. Alves \& Crous, in Phillips, Alves, Pennycook, Johnston, Ramaley, Akulov \& Crous, Persoonia 21: 39 (2008).

Notes: Barriopsis is characterised by aseptate, brown ascospores without apiculi (Phillips et al. 2008). Absence of apiculi on the ascospores differentiates this genus from Sphaeropsis.

Botryobambusa Phook., Jian K. Liu \& K.D. Hyde, in Liu et al., Fungal Diversity 57(1): 166 (2012).

Index Fungorum number: IF 801313; Facesoffungi number: FoF 02408; - 2 morphological species (Species Fungorum 2020), 2 species with molecular data.

Type species: Botryobambusa fusicoccum Phook., Jian K. Liu \& K.D. Hyde, in Liu et al., Fungal Diversity 57(1): 166 (2012).

Notes: Botryobambusa was introduced by Liu et al. (2012) with a single species with both sexual and asexual morphs. Phylogenetically this genus is clearly distinguished from Botryosphaeria. However, it is similar to Botryosphaeria except for smaller asci and ascospores that are surrounded by a mucilagenous sheath.

Cophinforma Doilom, Jian K. Liu \& K.D. Hyde, in Liu et al., Fungal Diversity 57(1): 174 (2012).

Index Fungorum number: IF 801315; Facesoffungi number: FoF 07624; - 2 morphological species (Species Fungorum 2020), 2 species with molecular data.

Type species: Cophinforma eucalypti Doilom, Jian K. Liu \& K.D. Hyde, in Liu et al., Fungal Diversity 57(1): 174 (2012).

Notes: Cophinforma was introduced by Liu et al. (2012) as a monotypic genus for C. eucalypti. Phillips et al. (2013), based on a multi-gene analysis, introduced two species to this genus that were previously included in Botryosphaeria. Cophinforma is phylogenetically distinguished from 
Botryosphaeria despite being similar, except for conidia that are longer than any known species in Botryosphaeria.

Diplodia Fr., in Montagne, Annls Sci. Nat., Bot., sér. 21 : 302 (1834).

Index Fungorum number: IF 8047; Facesoffungi number: FoF 00147; - 397 morphological species (Species Fungorum 2020), 30 species with molecular data (Jayawardena et al. 2019b, c).

Type species: Diplodia mutila (Fr. : Fr.) Fr., Summa Veg. Scand. 2: 417. 1849.

$\equiv$ Sphaeria mutila Fr. : Fr., Syst. Mycol. 2: 424. 1823.

$\equiv$ Physalospora mutila (Fr. : Fr.) N.E. Stevens, Mycologia28: 333. 1936.

$\equiv$ Botryosphaeria stevensii Shoemaker, Can. J. Bot. 42: 1299. 1964.

Notes: Diplodia comprises two morphological groups that are supported by two distinct phylogenetic lineages. In one type the conidia are initially hyaline and aseptate, later becoming brown and 1-septate. Pigmentation is often delayed and in some species dark conidia are never seen. In the second type the conidia become pigmented at an early stage, even while they are enclosed within the pycnidia, they only rarely become septate.

Dothiorella Sacc., Michelia 2(no. 6): 5 (1880).

Index Fungorum number: IF 8098; Facesoffungi number: FoF 00148; - 257 morphological species (Species Fungorum 2020), 44 species with molecular data.

Type species: Dothiorella pyrenophora Berk. ex Sacc., Michelia 2(no. 6): 5 (1880)

Notes: Dothiorella has often been confused with Diplodia in morphological characterisations. The type species, Dothiorella pyrenophora differs from Diplodia by conidia that are brown and 1-septate early in their development, while they are still attached to the conidiogenous cells. Sexual morphs of Dothiorella have pigmented, septate ascospores. However, the sexual stage of the species is rarely found in nature and has never been reported in culture.

Dothiorella ostryae Manawasinghe, Camporesi \& K.D. Hyde, sp. nov.

Index Fungorum number IF556874, Facesoffungi number: FoF 06578; Fig. 16

Etymology: Name reflects the host genus of Ostrya carpinifolia.

Holotype: MFLU 18-0177.

Saprobic on dead aerial branch of Ostrya carpinifolia. Sexual morph Undetermined. Asexual morph Conidiomata pycnidial, stromatic, solitary, dark brown, semiimmersed, unilocular, globose papillate with a short neck, wall 5-7 cell layers, outer layers composed of light-brown cells of textura angularis, inner layer hyaline and thin-walled
Conidiophores reduced to conidiogenous cells. Conidiogenous cells holoblastic, hyaline, cylindrical, proliferating percurrently. Conidia $15-21 \times 7-10(\bar{x}=19 \times 9 \mu \mathrm{m}, \mathrm{n}=$ 30) $\mu \mathrm{m}$, ellipsoidal initially hyaline and aseptate, becoming pale brown while attached to the conidiogenous cells, finally dark brown or sepia, 1-septate, with 2 cells of equal length, thick-walled.

Culture characteristics: Colonies on PDA reach $70 \mathrm{~mm}$ after $5 \mathrm{~d}$ in the dark at $25^{\circ} \mathrm{C}$.

Material examined: Italy, Passo delle Forche - Galeata (province of Forlì-Cesena), dead aerial branch of Ostrya carpinifolia L. (Betulaceae), 9 April 2018, Erio IT Camporesi (MFLU 18-0177, holotype), ex-type living culture, JZB3150026.

GenBank number: ITS: MN533805, tef1 MN537429.

Notes: The species identified in this study is similar to other species in Dothiorella (Phillips et al. 2013). In phylogenetic analysis (Fig. 14), Dothiorella ostryae is closely related to the clade that contains Dothiorella citricola (ICMP 16828) and D. viticola (CBS 117009). There are four Dothiorella species associated with the host genus Ostrya, namely D. iberica, D. omnivora, D. parva (Farr and Rossman) and $D$. ostryae (this study).

Endomelanconiopsis Rojas \& Samuels, Mycologia 100: 770. (2008).

Index Fungorum number: IF 555482; Facesoffungi number: FoF 07625; - 3 morphological species (Species Fungorum 2020), 3 species with molecular data.

Type species: Endomelanconiopsis endophytica Rojas \& Samuels, Mycologia 100: 770 (2008).

Notes: This genus was introduced by Rojas et al. (2008) with two species. Tibpromma et al. (2018a) introduced a third species, Endomelanconiopsis freycinetiae, bringing the total to three species. Endomelanconiopsis is characterized by eustromatic conidiomata and holoblastically produced, brown, non-apiculate, unicellular conidia, each with a longitudinal germ slit (Rojas et al. 2008).

Eutiarosporella Crous, in Crous et al., Phytotaxa 202(2): 85 (2015).

Index Fungorum number: 811248; Facesoffungi number: FoF 07365; 7 morphological species (Species Fungorum 2020), 7 species with molecular data.

Type species: Eutiarosporella tritici (B. Sutton \& Marasas) Crous, in Crous et al., Phytotaxa 202(2): 85 (2015).

$\equiv$ Tiarosporella tritici B. Sutton \& Marasas, Trans. Br. mycol. Soc. 67(1): 74 (1976)

Notes: This genus was introduced by Crous et al. (2015a) to accommodate tiarosporella-like taxa with long conidiomatal necks and holoblastic conidiogenesis. Eutiarosporella differs from Marasasiomyces by developing clustered conidiomata. 

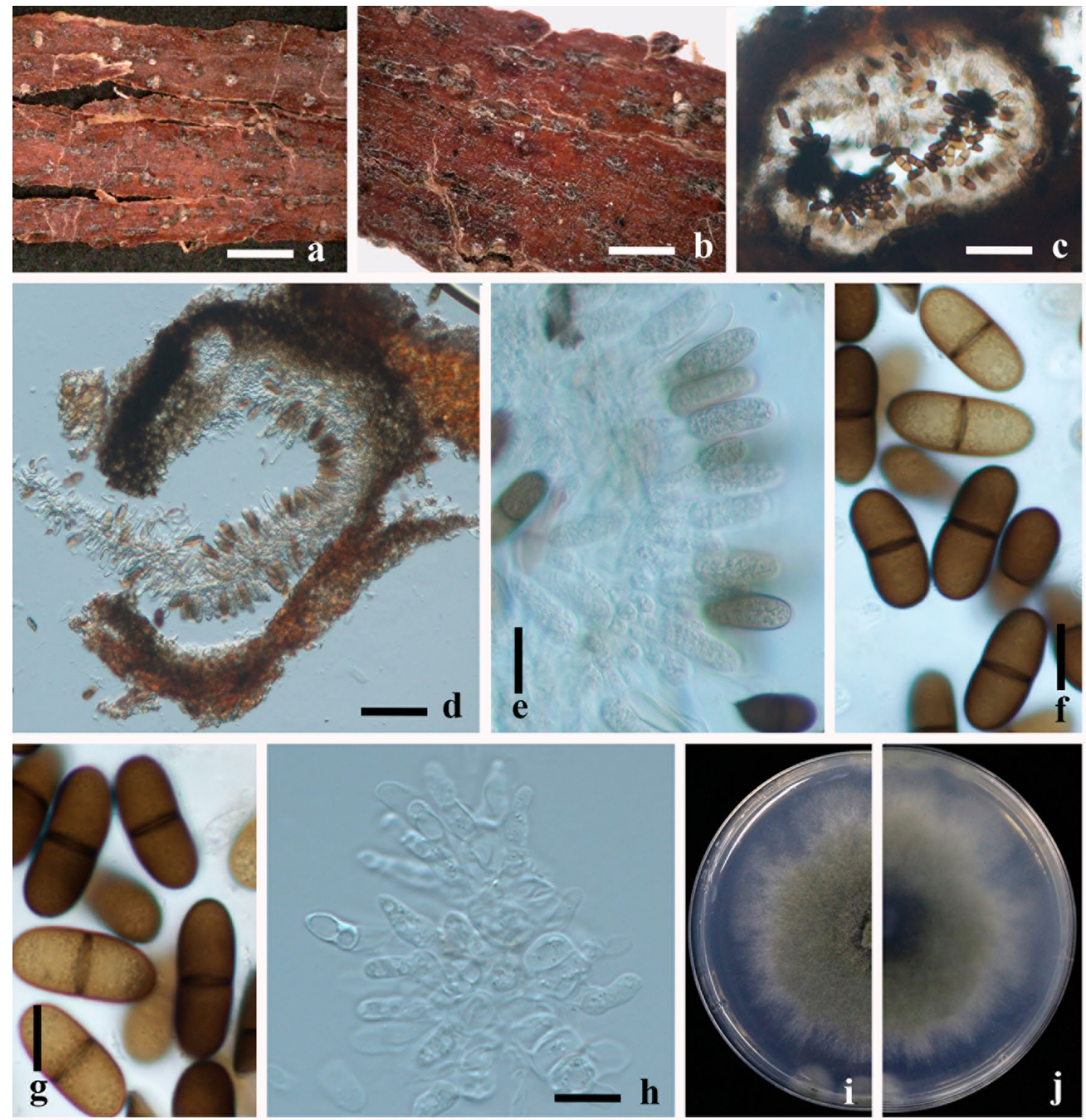

Fig. 16 Dothiorella ostryae (MFLU 18-0177, holotype). a Material examined. b Submerged conidiomata on host. c, d Cross section of conidiomata on host. e Developing conidia while attached to the pyc-

Lasiodiplodia Ellis \& Everh., Bot. Gaz. 21: 92 (1896).

Index Fungorum number: IF 8708; Facesoffungi number: FoF 00151; - 64 morphological species (Species Fungorum 2020), 35 species with molecular data.

Type species: Lasiodiplodia theobromae (Pat.) Griff. \& Maubl. Bull. trimest. Soc.Mycol. Fr. 25: 57 (1909).

$\equiv$ Botryodiplodia theobromae Pat., in Patouillard \& Lagerheim, Bull. Soc. mycol. Fr. 8(3): 136 (1892).

Notes: Lasiodiplodia was introduced by Ellis in 1894 with $L$. tubericola as the type species. Ellis did not provide a description of the genus and species, but this was provided by Clendenin (1896) who attributed both the genus nidial wall on host. $\mathbf{f}, \mathbf{g}$ Conidia on host. $\mathbf{h}$ Conidiogenous cells in culture. 1 Upper view of colony on PDA. $\mathbf{j}$ reverse view of 7 days old culture on PDA. Scale bars: $\mathbf{a}, \mathbf{b}=2 \mathrm{~mm}, \mathbf{c}-\mathbf{h}=10 \mu \mathrm{m}$

and species to Ellis and Everhart. Griffon and Maublanc (1909) considered that Botryodiplodia theobromae was more suitably accommodated in Lasiodiplodia. Since the epithet theobromae (1892) is older than tubericola (1896), L. theobromae should be regarded as the type species of Lasiodiplodia. In earlier works on Lasiodiplodia and Diplodia it was considered that Lasiodiplodia could represent a possible synonym of Diplodia (Denman et al. 2000). However, in phylogenetic analyses these two genera were clearly separated in two distinct clades (Zhou and Stanosz 2001; Slippers et al. 2004a, b; Phillips et al. 2008). Lasiodiplodia is distinguished from Diplodia by striations on the conidia. 
Conidiomatal paraphyses distinguishes Lasiodiplodia from Neodeightonia. Although Barriopsis has striate conidia, they are unique in Botryosphaeriaceae because they are also present on immature, hyaline conidia.

Macrophomina Petr., Annls mycol. 21(3/4): 314 (1923).

Index Fungorum number: IF 8814; Facesoffungi number: FoF 07626; - 4 morphological species (Species Fungorum 2020), 3 species with molecular data.

Type species: Macrophomina philippinensis Petr., Annls mycol. 21(3/4): 314 (1923).

Other synonyms can be seen in Index Fungorum.

Notes: Macrophomina comprises two species with cultures and moleular data. This genus is similar to Tiarosporella in having apical mucoid appendages (Sutton and Marasas 1976). Apart from the phylogeny, these two species can be distinguished, since Macrophomina has percurrently proliferating conidiogenous cells (Nag-Raj 1993; Crous et al. 2006a) and conidia that become dark brown at maturity, and microsclerotia (Phillips et al. 2013).

Marasasiomyces Crous, in Crous et al., Phytotaxa 202(2): 86 (2015).

Index Fungorum number: IF 811252; Facesoffungi number: FoF $07440 ;-1$ morphological species (Species Fungorum 2020), 1 species with molecular data.

Type species: Marasasiomyces karoo (B. Sutton \& Marasas) Crous, Crous et al., Phytotaxa 202(2): 85 (2015).

$\equiv$ Tiarosporella graminis var. karoo B. Sutton \& Marasas, Trans. Br. mycol. Soc. 67(1): 73 (1976).

Notes: This monotypic genus was introduced by Crous et al. (2015a) for M. karooo to accommodate tiarosporellalike taxa. Marasasiomyces is distinguished from Tiarosporella by conidiomata with long necks covered in brown setae, and holoblastic conidiogenesis. These characters are similar to Eutiarosporella, but differ on account of the nonclustered conidiomata.

Mucoharknessia Crous, R.M. Sánchez \& Bianchin., in Crous et al., Phytotaxa 202(2): 86 (2015).

Index Fungorum number: IF 811254; Facesoffungi number: FoF 01651; - 2 morphological species (Species Fungorum 2020), 2 species with with molecular data.

Type species: Mucoharknessia cortaderiae Crous, R.M. Sánchez \& Bianchin Crous, in Crous et al., Phytotaxa 202(2): 85 (2015).

Notes: This genus was introduced by Crous et al. (2015a) for species resembling Harknessia. The genus is characterised by conidia bearing mucoid appendages. Mucoharknessia comprises two species.

Neodeightonia C. Booth, in Punithalingam, Mycol. Pap. 119: 17 (1970) [1969].
Index Fungorum number: IF 3450; Facesoffungi number: FoF 07627; -8 morphological species (Species Fungorum 2020), 8 species with with molecular data.

Type species: Neodeightonia subglobosa C. Booth, Mycol. Pap. (1970).

Notes: Neodeightonia was regarded as a synonym of Botryosphaeria (von Arx and Müller 1975). However, it was reinstated by Phillips et al. (2008) based on morphological characters including the dark, 1-septate ascospores, and its phylogenetic placement. Longitudinal striations on the conidial wall are an additional characteristic feature of this genus (Crous et al. 2006a; Phillips et al. 2008). Neodeightonia can be differentiated from Lasiodiplodia by the absence of conidiomatal paraphyses, and conidial striations distinguish it from Diplodia.

Neofusicoccum Crous, Slippers \& A.J.L. Phillips, in Crous et al., Stud. Mycol. 55: 247 (2006).

Index Fungorum number: IF 500870; Facesoffungi number: FoF 00153; - 45 morphological species (Species Fungorum 2020), 43 species with molecular data (Jayawardena et al. 2019a, c).

Type species: Neofusicoccum parvum (Pennycook \& Samuels) Crous, Slippers \& A.J.L. Phillips., in Crous et al., Stud. Mycol. 55: 247 (2006).

$\equiv$ Fusicoccum parvum Pennycook \& Samuels, Mycotaxon 24: 455 (1985).

Notes: Neofusicoccum was introduced by Crous et al. (2006a) to accommodate species that are similar to Botryosphaeria, but phylogenetically distinct. Dichomera synasexual morph in Neofusicoccum has been used to differentiate it from Botryosphaeria, even though not all Neofusicoccum species form such a synasexual morph (Phillips et al. 2005; Barber et al. 2005). Development of paraphyses can be observed in all accepted Botryosphaeria species, but have not been reported in conidiomata of any Neofusicoccum species. However, this character is difficult to use as developing conidiogenous cells can resemble paraphyses. Accepted species in this genus have been separated on the basis of conidial dimensions and pigmentation, pigment production in culture media and ITS sequence data (Phillips et al. 2013). However, morphological characterisation of these species remains controversial (Abdollahzadeh et al. 2013). To resolve the species, multi-gene sequence data are essential. Species in Neofusicoccum have been reported as endophytes, pathogens and saprobes on a wide range of hosts.

Neoscytalidium Crous \& Slippers, Stud. Mycol. (2006).

Index Fungorum number: IF 500868; Facesoffungi number: FoF 07628; - 3 morphological species (Species Fungorum 2020), 7 species with molecular data.

Type species: Neoscytalidium dimidiatum (Penz.) Crous \& Slippers, in Crous et al., Stud. Mycol. 55: 244 (2006). 
$\equiv$ Torula dimidiata Penz., in Saccardo, Michelia 2(no. 8): 466 (1887).

Notes: In earlier studies, species belonging to this genus was introduced as Hendersonula toruloidea, which have conidia that become septate with a darker central cell and formed a Scytalidium-like synanamorph (Crous et al. 2006a). Since the description, the production of both arthroconidial and pycnidial synasexual morphs has been shown and led to several controversies in the nomenclature. However, the current genus name was introduced by Crous et al. (2006a) and other relevant epitypifications and synonymies by Madrida et al. (2009). Species in this genus have been reported as pathogens on human skin and nails (Campbell and Mulder 1977) and plants. Diseases reported associated with this genus tend to be more common in tropical regions (Polizzi et al. 2009, 2011; Phillips et al. 2013).

Oblongocollomyces Tao Yang \& Crous., in Yang et al., Fungal Biology 121: 339 (2016).

Index Fungorum number: IF 817640; Facesoffungi number: FoF 08049; 1 morphological species (Species Fungorum 2020), 1 species with molecular data.

Type species: Oblongocollomyces variabilis (F.J.J. Van der Walt, Slippers \& G.J. Marais) Tao Yang \& Crous, in Yang et al., Fungal Biology 121: 339 (2016).

三Sphaeropsis variabilis F.J.J. Van der Walt, Slippers \& G.J. Marais, in Slippers et al., Persoonia 33: 164 (2014).

Notes: Oblongocollomyces was introduced by Yang et al. (2017) as a monotypic genus in Botryosphaeriaceae. In earlier studies, this species was identified as Sphaeropsis variabilis and it was different from Sphaeropsis in having long conidiomatal necks on PNA, aggregated in dense clusters of conidiomata on OA (Yang et al. 2017). This species has conidia with up to 3 septa. Phylogenetically Oblongocollomyces close to Alanphillipsia (Fig. 14).

Phaeobotryon Theiss. \& Syd., Annls mycol. 13(5/6): 664 (1915).

Index Fungorum number: IF 3892; Facesoffungi number: FoF 07629; - 8 morphological species (Species Fungorum 2020), 6 species with molecular data.

Type species: Phaeobotryon cercidis (Cooke) Theiss. \& Syd., Annls mycol. (1915).

三Dothidea cercidis Cooke, Grevillea 13(no. 67): 66 (1885).

Notes: Phaeobotryon has 2-septate, brown ascospores with an apiculus at each end.

Sakireeta Subram. \& K. Ramakr., J. Indian bot. Soc. 36: 83 (1957).

Index Fungorum number: IF 9775; Facesoffungi number: FoF 07583; - 1 morphological species (Wijayawardene et al. 2017a), 1 species with molecular data.
Type species: Sakireeta madreeya Subram. \& K. Ramakr., J. Indian bot. Soc. 36: 84 (1957).

Notes: Sakireeta comprises a single species, S. madreeya, which was previously known as Tiarosporella madreeya. This genus is distinguished from the closely related Tiarosporella by conidiomata that are aggregated in a stroma, and being plurilocular whereas, Tiarosporella has solitary unilocular conidiomata. In addition, Sakireeta has holoblastic conidiogenous cells (Crous et al. 2015a).

Sardiniella Linald., A. Alves \& A.J.L. Phillips, Mycosphere (2016).

Index Fungorum number: IF 817511; Facesoffungi number: FoF 02405; - 2 morphological species (Species Fungorum 2020), 2 species with molecular data.

Type species: Sardiniella urbana Linald., A. Alves \& A.J.L. Phillips, Mycosphere (2016).

Notes: Sardiniella was introduced as a monotypic genus for Sardiniella urbana. This genus is characterised by thick-walled, oblong conidia that become pigmented and 1-septate, which distinguishes it from Neofusicoccum. This genus is similar to Diplodia and Dothiorella. However, in Dothiorella, and in some species of Diplodia the conidia become pigmented while still attached to the conidiogenous cell and this character is not seen in Sardiniella. The conidial wall in species of Diplodia is thicker than in Sardiniella. Phylogenetically these two genera are clearly separated.

Sphaeropsis Sacc., Michelia 2(no. 6): 105 (1880).

Index Fungorum number: IF 562041; Facesoffungi number: FoF 01704; - 142 morphological species (Species Fungorum 2020), 5 species with molecular data.

Type species: Sphaeropsis visci (Alb. \& Schwein.) Sacc., Michelia 2(no. 6): 105 (1880).

三Dothidea visci Kalchbr., Hedwigia 8: 117 (1869).

Notes: Sphaeropsis was introduced by Saccardo (1880) to accommodate species of Diplodia with brown, aseptate conidia. Since then species were described based on host association, resulting in more than 600 species names. Pycnidial paraphyses distinguish Sphaeropsis from Diplodia. The striate conidia of Lasiodiplodia differentiate it from Sphaeropsis, which has smooth-walled conidia.

Tiarosporella Höhn., in Weese, Ber. dt. bot. Ges. (1919). Index Fungorum number: IF 10233; Facesoffungi number: FoF 00333; - 8 morphological species (Species Fungorum 2020), 5 species with molecular data.

Type species: Tiarosporella paludosa (Sacc. \& Fiori) Höhn., in Weese, Ber. dt. bot. Ges. 37: 159 (1919).

$\equiv$ Neottiospora paludosa Sacc. \& Fiori, in Sydow, Hedwigia 38(Beibl.): (137) (1899).

Notes: This genus is characterised by conidia formed from smooth, hyaline conidiogenous cells that lack periclinal 
thickenings and percurrent proliferations. The conidia are hyaline, subcylindrical to fusiform with irregular mucoid appendages. There are 22 species names for this genus in Index Fungorum.

\section{Economic and ecological significance}

Botryosphaeriaceae comprises a diverse range of taxa that are pathogens, endophytes or saprobes on a wide range of hosts including dicotyledonous monocotyledonous, and gymnosperms (Schoeneweiss 1981; Manawasinghe et al. 2016). Their distribution is vast, covering all geographic and climatic regions, except Polar Regions (Crous et al. 2007a; Rodas et al. 2009; Wunderlich et al. 2011; Manawasinghe et al. 2016). At present, their ecological role as phytopathogens has gained a great attention (Manawasinghe et al. 2016). The pathogenic taxa in Botryosphaeriaceae cause several important diseases such as leaf spots, cankers, dieback, fruit rot, gummosis and even plant death on many economically important crops (Rodas et al. 2009, Hyde et al. 2014). Some species are pathogenic on many hosts (Diplodia seriata, Lasiodiplodia spp., and Neofusicoccum parvum) in the same geographic area. Pathogenicity of some taxa (e.g. B. dothidea) varies with the country for the same host species (Chen et al. 2014; Netto et al. 2014; Linaldeddu et al. 2015). The pathogenic fungal taxa of this family are recognized as "opportunistic plant fungal pathogens" (Chethana et al. 2016). It is not clear whether changes in the environment triggers pathogenicity or if disease development is due to weakening of the host defenses (Chethana et al. 2016; Manawasinghe et al. 2016). Since phytopathogenic botryosphaeriaceous taxa also have an endophytic lifestyle they may act as latent pathogens. Some species in this family have been reported as human pathogens (Polizzi et al. 2009, 2011; Phillips et al. 2013).

Melanopsaceae A.J.L. Phillips, Slippers, Boissin \& Crous, Stud. Mycol. 76(1): 43 (2013).

Index Fungorum number: IF 805796; Facesoffungi numbers: FoF 07630, 111 species.

On woody hosts. Sexual morph: Ascostromata pseudothecial, multiloculate, locules at various levels in ascoma, immersed, partially erumpent at maturity, black, subglobose, thick-walled. Ascomatal wall thick-walled, comprised of cells of textura angularis. Asci 8-spored, bitunicate, fissitunicate, pedicellate, clavate. Hamathecium comprising hyaline, thin-walled, hypha-like, septate, not constricted at septa, cellular pseudoparaphyses. Ascospores overlapping, ellipsoid to rhomboid, hyaline, aseptate, thin-walled, with a persistent mucus sheath. Asexual morph: Coelomycetous. Conidiomata often formed in the same stroma as ascostromata. Paraphyses septate, branched or not, filiform, hyaline, arising from between the conidiogenous cells. Conidiophores 1-2-septate, branched or not, hyaline, smooth, or reduced to conidiogenous cells. Conidiogenous cells subcylindrical, branched or unbranched, discrete, hyaline, formed from the inner wall of the conidioma, proliferating percurrently at apex, or with periclinal thickening. Conidia fusoid, hyaline, aseptate, with a persistent mucus sheath, rarely with minute marginal frill (adapted from Slippers et al. 2013; Phillips et al. 2019)

Type: Melanops Nitschke ex Fuckel.

Notes: Slippers et al. (2013) established Melanopsaceae in Botryosphaeriales to accommodate Melanops. Melanops has a mucilage sheath around the ascospores and in that respect is identical to Phyllostictaceae. However, Phyllostictaceae has uniloculate ascostromata, while those of $\mathrm{Mel}$ anops are multiloculate (Slippers et al. 2013). Phylogenetic analyses supported the placement of Melanops as a distinct family in Botryosphaeriales (Wikee et al. 2013b; Slippers et al. 2013; Phillips et al. 2019). Divergence time estimates for this family also support its familial status (Slippers et al. 2013; Phillips et al. 2019). However, Jiang et al. (2018b) suggested that the divergence time estimation in the previous studies might not be accurate estimates due to the fact that sequence data from only two taxa were used in the phylogenetic placement, an opinion also voiced by Phillips et al. (2019).

Melanops Nitschke ex Fuckel, Jb. nassau. Ver. Naturk. 23-24: 225 (1870) [1869-70].

Index Fungorum number: IF 3078; Facesoffungi number: FoF 07442; 111 morphological species (Species Fungorum 2020), 3 species with molecualar data.

Type species: Melanops tulasnei Fuckel.

Notes: Over 100 species names are listed under Melanops in Index Fungorum (2020), but, only three species have sequence data (Jiang et al. 2018b). We were unable to obtain fresh collections to represent this genus. Thus, a drawing is provided. A description of the type species can be seen in Phillips and Alves (2009).

Melanops tulasnei Fuckel, Jb. nassau. Ver. Naturk. 23-24: 225 (1870) [1869-70].

Index Fungorum number: IF 150956; Facesoffungi number: FoF 07444; Fig. 17

Description: see Phillips and Alves (2009).

\section{Economic and ecological significance}

The ecology and distribution of Melanops is poorly known. Although its appearance is similar to other Botryosphaeriales, it is not clear whether it is pathogenic or endophytic (Slippers et al. 2013).

Phyllostictaceae Fr. (as "Phyllostictei”), Summa vegetabilium Scandinaviae 2: 420 (1849). 


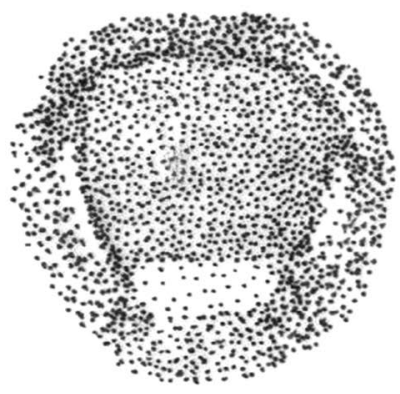

a
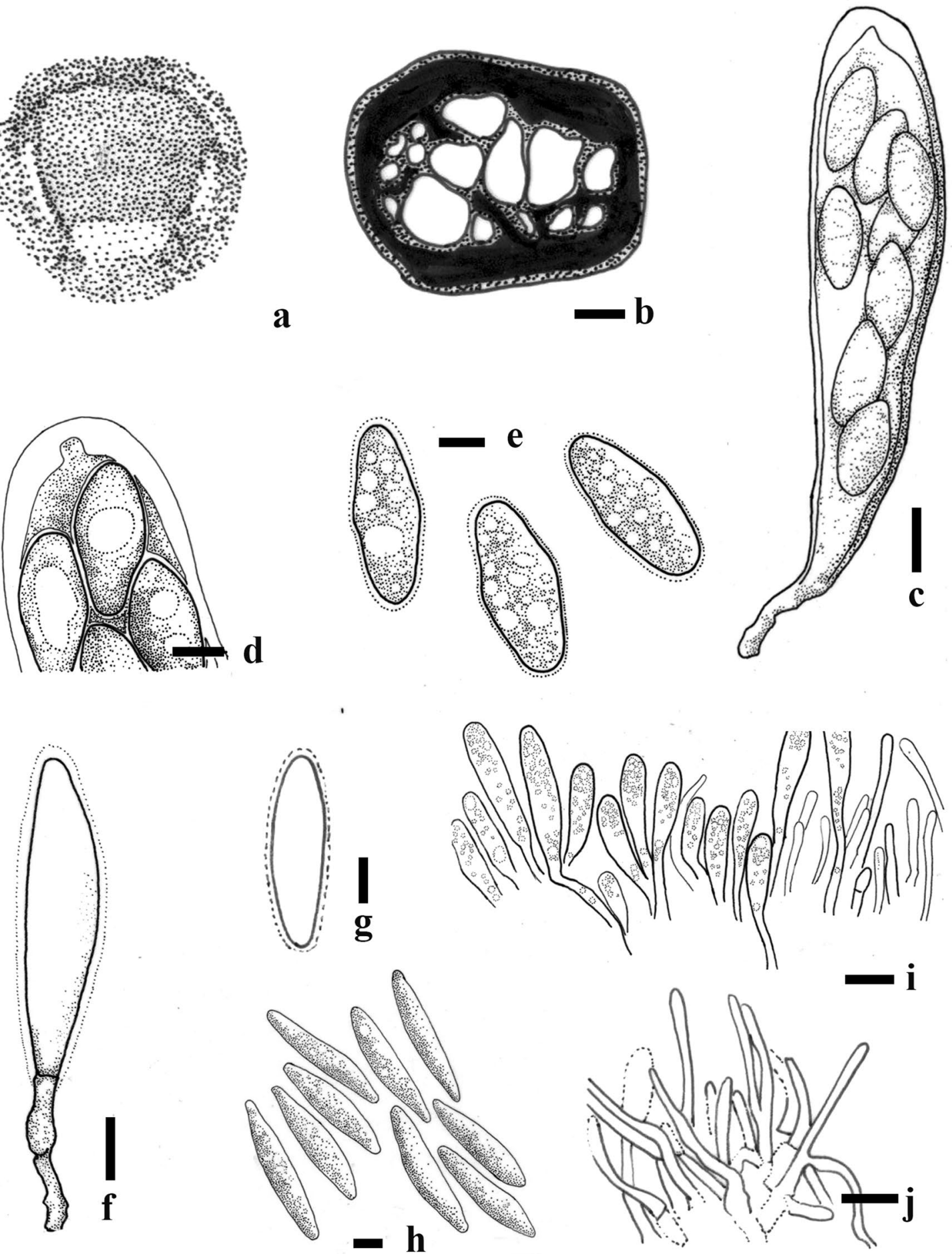

Fig. 17 Melanops tulasnei (redrawn from neotype and epitype specimens in Phillips and Alves 2009). a Stroma erumpent through the bark. b Stroma cut through horizontally revealing ascomata and conidiomata. c Ascus. d Ascus tip. e Ascospores. f Conidium and conid-

Index Fungorum number: IF 81162; Facesoffungi numbers: FoF 02296, >2000 species. iogenous cell with mucus sheath around the conidium. $\mathbf{g}$ Conidium with mucous sheath. h Conidia. i Conidiogenous with conidia developing on conidiogenous cells. j Paraphyses. Scale bars: $\mathbf{b}=250 \mu \mathrm{m}$, $\mathbf{c}=20 \mu \mathrm{m}, \mathbf{d}, \mathbf{e}, \mathbf{g}-\mathbf{j}=10 \mu \mathrm{m}, \mathbf{f}=5 \mu \mathrm{m}$

Foliicolous, pathogenic, endophytic or saprobic on plants. Sexual morph: Ascostromata pseudothecial, uniloculate, separate to gregarious, globose, brown to black, 
with a central ostiole. Asci 8-spored, bitunicate, fissitunicate, clavate to subcylindrical, fasciculate, pedicellate, with an ocular chamber. Pseudoparaphyses mostly absent at maturity, when present broad-cylindric, septate, cellular. Ascospores 2-3-seriate, ellipsoid-fusoid to limoniform, hyaline, aseptate, smooth-walled, usually with mucilaginous caps, or surrounded by a mucilaginous sheath. Asexual morph: Coelomycetous. Conidiomata pycnidial globose, dark brown, separate to aggregated, with a central ostiole; wall of 3-6 layers of brown cells of textura angularis. Conidiogenous cells lining the inner wall, hyaline, smooth, subcylindrical to ampulliform or doliiform, proliferating percurrently near apex, frequently covered in mucilaginous sheath. Conidia ellipsoid-fusoid to obovoid or ovoid, hyaline, aseptate, smooth-walled, guttulate or granular, frequently surrounded by a mucilaginous sheath, often bearing a single mucilaginous apical appendage.

\section{Type: Phyllosticta Pers.}

Notes: Phyllostictaceae (as Phyllostictei) was proposed by Fries (1849). Seaver (1922) used Phyllostictales and Phyllostictaceae for Phyllosticta. Phyllostictaceae was accepted by Hawksworth and David (1989). Schoch et al. (2006) suggested that Phyllosticta belongs to Botryosphaeriaceae and this was accepted by Crous et al. (2006a) and Liu et al. (2012) who noted that Phyllosticta is distinct from other genera in Botryosphaeriaceae. Wikee et al. (2013b) suggested Phyllostictaceae as a distinct family in Botryosphaeriales and Slippers et al. (2013) formally re-instated the family.

Ascospores in Melanopsaceae and Phyllostictaceae have a mucilage sheath. Phyllostictaceae differs from Melanopsaceae by uniloculate ascostromata. Though mucoid apical appendages on the conidia have been regarded as characteristic of Phyllosticta, this feature is not necessarily a characteristic of the family since they are absent in some species such as P. leucothoicola or P. neopyrolae (Wikee et al. 2013b).

Phyllosticta Pers., Traite'sur les Champignons Comestibles (Paris): 147 (1818).

Index Fungorum number: IF 9384; Facesoffungi number: FoF 00155; > 2000 records (Species Fungorum 2020), several species with molecular data.

f.

Type species: Phyllosticta cruenta (Kunze: Fr.) J. Kickx

三Sphaeria cruenta Fr., Syst. mycol. (Lundae) 2(2): 581 (1823).

Notes: Phyllosticta is a geographically widespread genus of plant pathogenic fungi with a diverse host range and a Guignardia sexual morph (Fig. 18). Seaver (1922) used Phyllostictales and Phyllostictaceae for Phyllosticta. Phyllosticta was placed in Botryosphaeriales by Schoch et al. (2006), who proposed that Botryosphaeriaceae contained
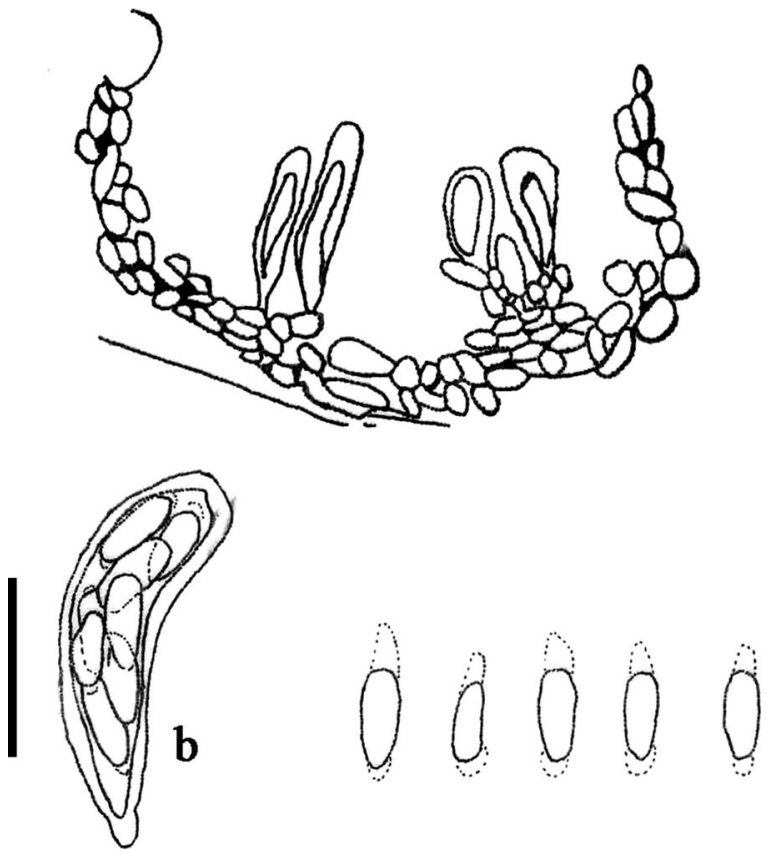

C

Fig. 18 Sexual morph of Phyllosticta ellipsoidea (redrawn from Wulandari et al. 2011, MFLU 10-0475). a Section of ascoma. b Asci. c Ascospores with polar mucilaginous appendage at each end. Scale bars: $25 \mu \mathrm{m}$

both Botryosphaeria and Phyllosticta, although no support was obtained for this relationship. Crous et al. (2006a) and Liu et al. (2012) also classified Phyllosticta in Botryosphaeriaceae. In both studies it was noted that Phyllosticta was distinct from other genera in Botryosphaeriaceae, and that these authors eventually expected it to be placed elsewhere. Wikee et al. (2013b) redefined Phyllosticta, and showed that it clusters sister to Botryosphaeriaceae, for which the older family name Phyllostictaceae was resurrected. In moving away from a dual nomenclature for fungi, the generic name Phyllosticta was chosen over Guignardia in previous studies. There are 3214 Phyllosticta epithets listed in Index Fungorum. In this entry we illustrate Phyllosticta hostae (Fig. 19).

Phyllosticta hostae Y.Y. Su \& L. Cai, Persoonia 28: 79 (2012).

Index Fungorum number: IF 564904; Facesoffungi number: FoF 07380; Fig. 19

Leaf spots circular to somewhat irregularly rotundate, pale brown to brown. Sexual morph: Undetermined. Asexual morph: Colonies on PDA, Pycnidia black, sub epidermal, globose, $40-150 \mu \mathrm{m}$ in diam. dark brown to black, darker around ostiole. Conidiogenous cells holoblastic, phialidic, cylindrical, subcylindrical to ampulliform, hyaline, thin-walled, smooth. Conidia $8-15 \times 5-9 \mu \mathrm{m}(\bar{x}=10$ $\times 7, n=20$ ), unicellular, thin- and smooth-walled, ellipsoid, subglobose to obovoid, with large central guttule, truncate at 

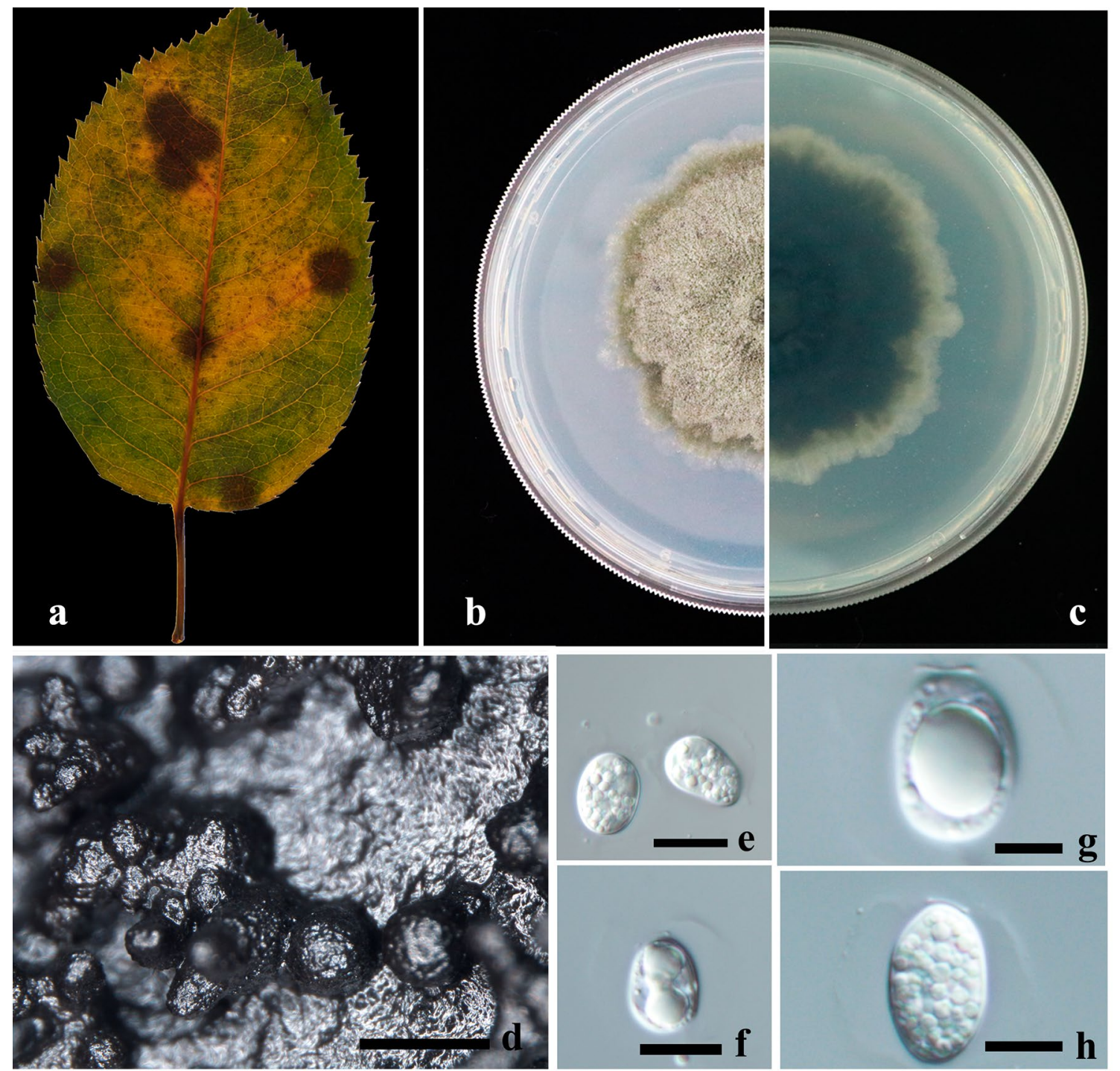

Fig. 19 Phyllosticta hostae (JZB 3290001). a Leaf spot on rose leaf. b Front view of the colony on PDA. c Rear view of the colony on PDA. d Conidiomata in culture. $\mathbf{e}-\mathbf{h}$ Conidia. Scale bars: $\mathbf{d}=100 \mu \mathrm{m}, \mathbf{e}-\mathbf{h}=10 \mu \mathrm{m}$

the base when young, later rounded at both ends, enclosed in a 1-3 $\mu \mathrm{m}$ thick mucilaginous sheath, and bearing a hyaline, mucoid apical appendage, $4-8 \times 1-3 \mu \mathrm{m}$, straight to flexuous, unbranched, tapering towards an acute tip.

Material examined: China, Beijing Tongzhou-Yongle Eco Park, leaf spot on rose (Rosaceae) leaves, 18 August 2018, Jia Jing Yi, 28-10-1, living culture: JZB 3290001.

GenBank number: ITS: MW130255.

Notes: Phyllosticta is an important genus of plant pathogens and contains quarantinable pathogenic species in some countries, especially in Europe (Wulandari et al. 2013). Phyllosticta hostae was introduced by Su and Cai (2012) from Hosta plantaginia (Liliaceae). This is the first record of $P$. hostae causing leaf spots in rose in China.

\section{Other genera included}

Pseudofusicoccum Mohali, Slippers \& M.J. Wingf., Stud. Mycol. 55: 249 (2006).

Index Fungorum number: IF 555584; Facesoffungi number: FoF 05299; - 8 morphological species (Species Fungorum 2020), 7 species with molecular data.

Type species: Pseudofusicoccum stromaticum (Mohali, Slippers \& M.J. Wingf.) Mohali, Slippers \& M.J. Wingf., in Crous et al., Stud. Mycol. 55: 249 (2006).

$\equiv$ Fusicoccum stromaticum Mohali, Slippers \& M.J. Wingf., Mycol. Res. 110(4): 408 (2006).

Notes: The type species of Pseudofusicoccum, P. stromaticum was introduced as Fusicoccum stromaticum and was distinguished from other species by its large conidiomata, the ability to grow at $35^{\circ} \mathrm{C}$, and thick-walled conidia. Crous 


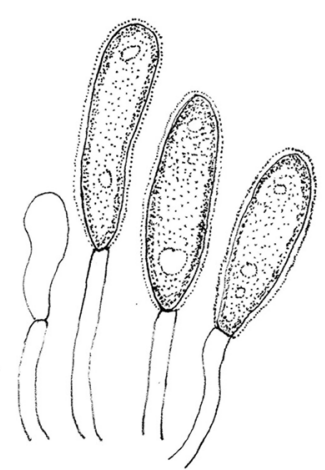

a

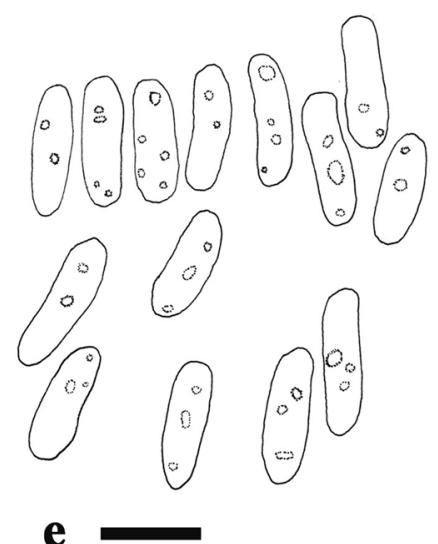

e
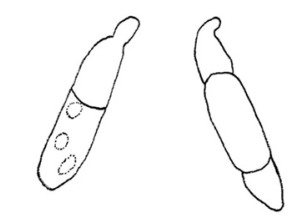

i

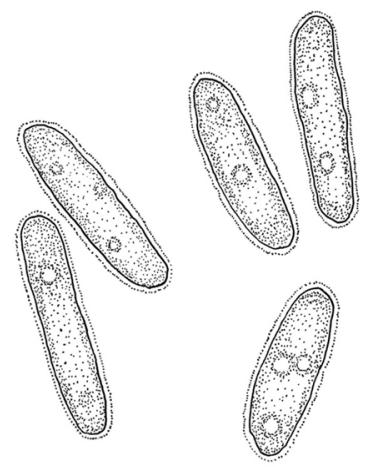

b

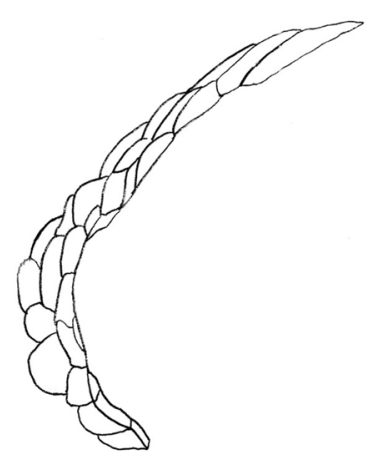

c

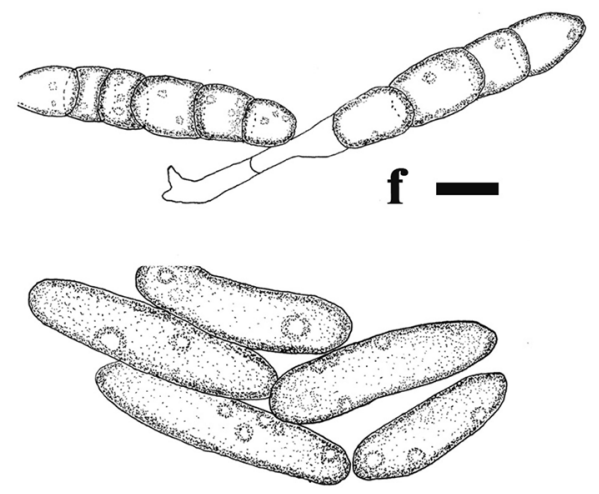

g

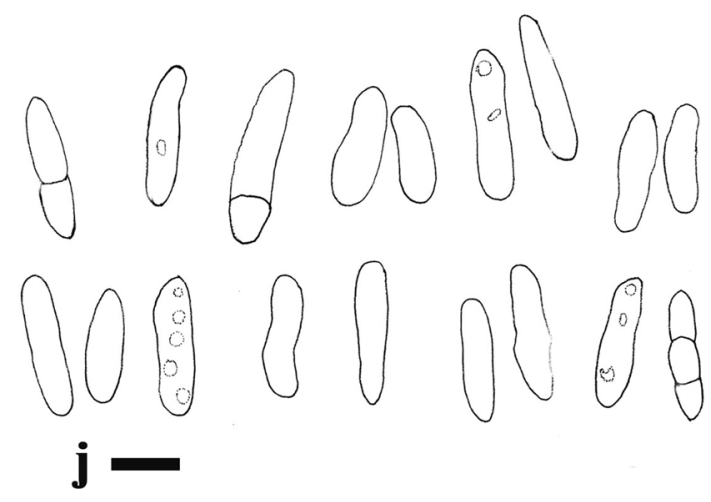

Fig. 20 Morphology of Pseudofusicoccum. a, b Conidiophores and conidia of $P$. stromaticum. c-e Conidiomatal wall, conidiophore and conidia of $P$. africanum. $\mathbf{f}, \mathbf{g}$ Conidia becoming brown and septate

et al. (2006a) recognized that its conidia were covered by a mucous sheath, which is lacking in all species of Fusicoccium. Therefore, they introduced Pseudofusicoccum as a new genus to accommodate this taxon. Pseudofusicoccum adansoniae, $P$. ardesiacum and P. kimberleyense were proposed and distinguished from others by production of a pigment in culture and the size of conidia (Pavlic et al. 2008). Later, P. olivaceum was identified as a new species because of the discrepancy between ITS and tef1 BLAST results when mature and young conidia of $P$. artocarpi. $\mathbf{h}-\mathbf{j}$ Conidiogenous cells, germinating conidia and conidia of $P$. adansoniae Scale bars: a $=5 \mu \mathrm{m}, \mathbf{b}, \mathbf{c}, \mathbf{e}, \mathbf{f}-\mathbf{j}=10 \mu \mathrm{m}, \mathbf{d}=25 \mu \mathrm{m}$

(Mehl et al. 2011). Pseudofusicoccum artocarpi was introduced as its conidia were clearly longer than others (Trakunyingcharoen et al. 2015). Pseudofusicoccum violaceum is distinctive because of the violet/purple pigment formed in culture and this has not been observed in any other Pseudofusicoccum species (Mehl et al. 2011). Pseudofusicoccum africanum was introduced as it is different from its neighbor $P$. violaceum by unique fixed alleles in ITS and tef1 (Jami et al. 2018). Yang et al. (2017) raised the genus to familial 
status as Pseudofusicoccaceae. The phylogenies reported in Phillips et al. (2019), as well as those of Minnis et al. (2012) and Liu et al. (2017), place Pseudofusicoccum in the same clade as Phyllosticta species. In view of this consistent relationship, together with the evolutionary divergence evidence as well as morphological data presented in Phillips et al. (2019), Pseudofusicoccum is considered to be an additional genus within Phyllostictaceae (Fig. 20).

\section{Economic and ecological significance}

Phyllosticta species have globally been recorded as endophytes, plant pathogens and saprobes from economically and ecologically important plant hosts. Some cause important diseases such as Citrus black spot and tan spot, subjected to phyto-sanitary legislation in the European Union and the USA. Further leaf- and fruit-spotting disease of Musa spp. (freckle disease), leaf spots in turmeric, cashew, ginger, orchids and black rot of grapes diseases are also caused by Phyllosticta species.

Planistromellaceae M.E. Barr, Mycotaxon 60: 437 (1996). Index Fungorum: IF 81919; Facesoffungi number: 06689, 33 species.

Biotrophic, hemibiotrophic or saprobic on leaves and stems of various plants in terrestrial habitats. Sexual morph: Ascostromata multi- or uni-loculate, immersed to erumpent through cracking or splitting of the host tissue, solitary to gregarious, with periphysate ostioles, with or without papilla. Cells of ascostromata thick-walled, composed of several layers of dark brown cells, arranged in a textura angularis. Locules ovoid to globose, developing in the same stroma of the conidiogenous and/or spermatogenous locules, collapsed with the empty locule, which previously produced conidia or spermatia or both, ostiole periphysate. Peridium of locules composed of a few layers of hyaline to light brown flattened cells. Hamathecium lacking pseudoparaphyses, interascal cells abundant even at maturity. Asci 8-spored, bitunicate, fissitunicate, oblong, clavate to nearly cylindrical, with a pedicel and with an ocular chamber, forming in a basal layer, often interspersed with and covered by cellular remnants of interthecial tissues. Ascospores overlapping 1-3-seriate, ellipsoid to broadly obovoid, hyaline or lightly pigmented, yellowish to brownish, aseptate or 1-2-trans-septate, thin-walled, with or without gelatinous sheath, guttulate. Asexual morph: Coelomycetous. Conidiomata subepidermal, dark, immersed to erumpent, solitary to gregarious, pycnidia, locules or acervuli in a stroma or bearing conidia over stroma surface prior to locule formation, ostiolate. Conidiomata walls comprising several layers with cells of textura angularis, the outer layers composed of dark thick-walled cells, lighter towards the inner layers of hyaline cells. Conidiogenous cells short cylindric, conidiogenesis holoblastic, hyaline, smooth. Conidia oblong, ellipsoid-cylindric, hyaline to brown, aseptate or 1-multitrans-septate, smooth-walled or verruculose, with or without one or more apical appendages. Spermatial state developing in the same or separate locules. Spermatogenous cells discrete or integrated, phialidic, cylindric to elongate-conical, determinate, hyaline, smooth. Spermatia bacillary, hyaline, aseptate, smooth-walled.

Type: Kellermania Ellis \& Everh.

Notes: Planistromellaceae was introduced by Barr (1996) and belongs to Botryosphaeriales (Minnis et al. 2012; Monkai et al. 2013). Lumbsch and Huhndorf (2010) included the genera Comminutispora, Eruptio, Loratospora., Microcyclus, Mycosphaerellopsis, Planistroma and Planistromella in Planistromellaceae based on morphology. Phylogenetic analysis based on SSU, ITS and LSU sequence data by Minnis et al. (2012) showed that Kellermania, Piptarthron, Planistroma and Planistromella should be treated as a single genus, thus, they synonymized them under Kellermania (oldest name). However, Monkai et al. (2013) indicated that the type species of Kellermania, which is also the type of Planistromella, clustered separately from Planistroma based on LSU and ITS sequence data. Planistroma was accepted as a distinct genus. The family was revised to accommodate Kellermania, Planistroma Mycosphaerellopsis and Umthunziomyces based on morphology and molecular data (Monkai et al. 2013; Phillips et al. 2019).

Kellermania Ellis \& Everh., J. Mycol. 1(12):153 (1885).

Index Fungorum number: IF 8668; Facesoffungi number: FoF 06690; 23 morphological species (Species Fungorum 2020), 18 species with molecular data.

Type species: Kellermania yuccifoliorum A.W. Ramaley.

Notes: Species in this genus are known from the host genera Agave and Nolina (Asparagaceae). Five species have been reported with both sexual and asexual morphs in Ramaley (1993, 1995, 1998) and Barr (1996). Many species of Kellermania were illustrated by Minnis et al. (2012) and conidia range from 0 to several trans-septa, and with or without appendages.

Kellermania yuccifoliorum A.W. Ramaley, Mycotaxon 47: 262 (1993).

Index Fungorum: IF 360150; Facesoffungi number: FoF 06691; Figs. 21 and 22

Description: see Monkai et al. (2013).

Material examined: USA, Califonia, San Bernardino County, Roadside 20 miles east of Baker (Hwy. 91/466), on leaves of Yucca brevifolia Engelmann, 14 April 1960, Isabelle Tavares No. 466 (UC 1202973, holotype of Planistromella yuccifoliorum).

Notes: The type species of Kellermania (K. yuccifoliorum $\equiv$ Planistromella yuccifoliorum) differs from other genera in Planistromellaceae in having 1-2-septate ascospores 


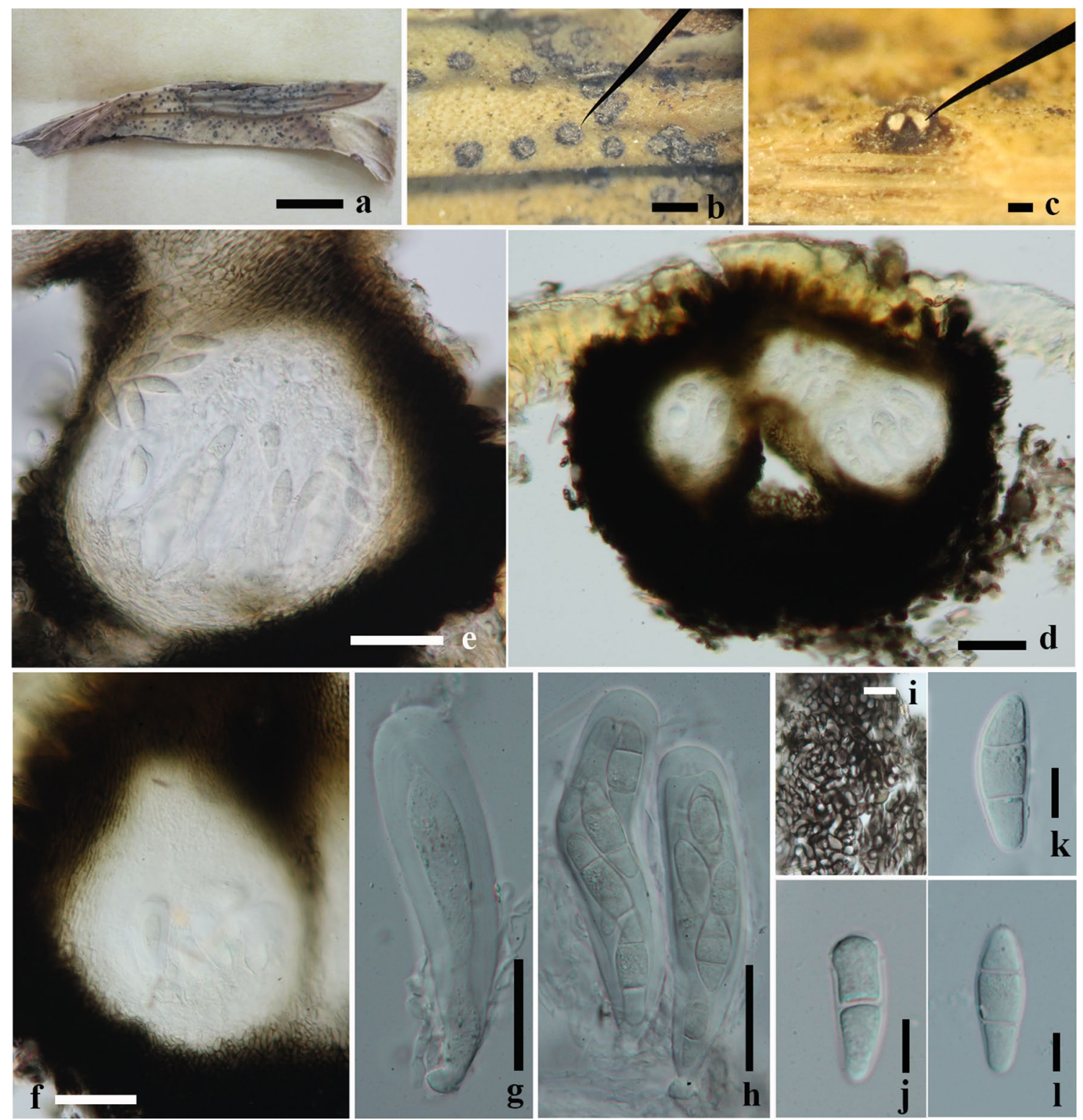

Fig. 21 Kellermania yuccifoliorum (UC 1202973, holotype of $P$. yuccifoliorum). a, b Ascostromata on the host surface. c, $\mathbf{d}$ Section of ascostroma. e, f Ascoma. $\mathbf{g}$ Immature ascus. h Mature asci. i Cells

(Ramaley 1993; Barr 1996). The asexual morph of K. yuccifoliorum is characterized by uniloculate conidiomata, which develops in the same stroma as the ascogenous locules and 2-septate conidia with a unique apical appendage (Ramaley 1993).

\section{Other genera included}

Mycosphaerellopsis Höhn., Annal. Mycol. 16(1/2): 157 (1918).

Index Fungorum number: IF 3345; Facesoffungi number: FoF 06263; - 2 morphological species (Monkai et al. 2013), molecular data unavailable. of ascostroma. j Immature ascospore. $\mathbf{k}$, $\mathbf{l}$ Mature ascospores. Scale bars: $\mathbf{a}=1 \mathrm{~cm}, \mathbf{b}=1000 \mu \mathrm{m}, \mathbf{c}=200 \mu \mathrm{m}, \mathbf{d}=100 \mu \mathrm{m}, \mathbf{e}, \mathbf{f}=50 \mu \mathrm{m}$, $\mathbf{g}, \mathbf{h}=30 \mu \mathrm{m}, \mathbf{i}=20 \mu \mathrm{m}, \mathbf{j}-\mathbf{l}=10 \mu \mathrm{m}$

Type species: Mycosphaerellopsis myricariae (Fuckel) Höhn., Annal. Mycol. 16(1/2):157 (1918).

$\equiv$ Sphaeria myricariae Fuckel, Jb. nassau. Ver. Naturk. 27-28: 22 (1874) [1873-74].

Notes: Mycosphaerellopsis differs from other genera in Planistromellaceae in having uniloculate ascomata and 1-septate, broadly obovoid ascospores. We accept Mycosphaerellopsis in this family based on its morphology (Monkai et al. 2013).

Planistroma A.W. Ramaley, Mycotaxon 42: 69 (1991). 
Fig. 22 Kellermania yuccifoliorum (redrawn from Ramaley 1993). a Conidioma. b Microconidia. c Spermatia and spermatiogenesis. d Conidiogenesis and origin appearance of apical appendage. e Conidia. Scale bars: $\mathbf{a}=80 \mu \mathrm{m}, \mathbf{b}, \mathbf{d}=$ $27 \mu \mathrm{m}, \mathbf{e}=40 \mu \mathrm{m}$
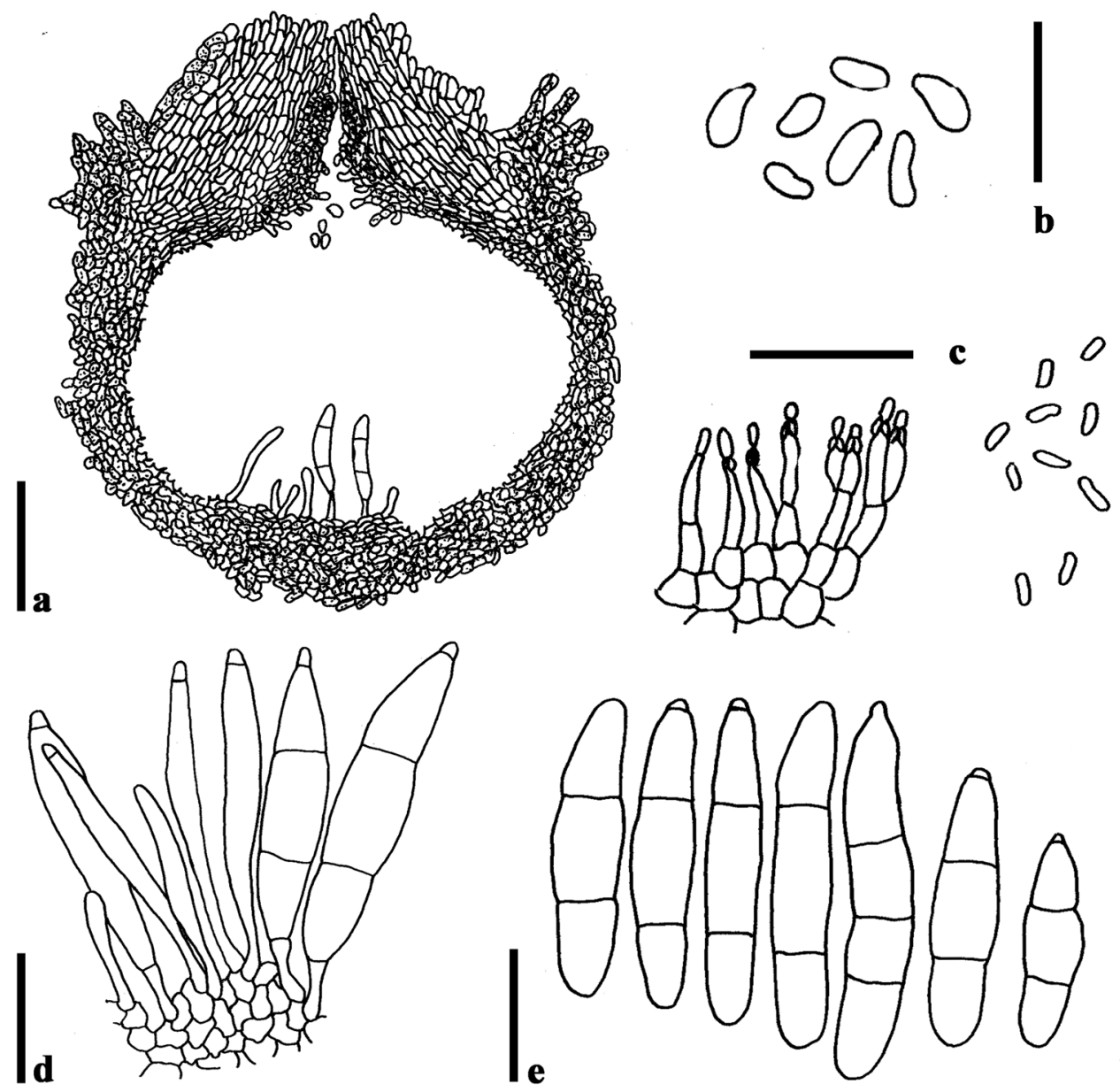

Index Fungorum number: IF 25358; Facesoffungi number: FoF 06264; -7 morphological species (Monkai et al. 2013), 6 species with molecular data.

Type species: Planistroma yuccigenum A.W. Ramaley, Mycotaxon 42: 69 (1991), MycoBank: MB 358836.

Notes: Planistroma was established by Ramaley (1991), and is similar to Kellermania in ascostromata characters, but Planistroma differs on account of its aseptate ascospores (Barr 1996). The asexual morphs of Planistroma resemble Kellermania except in having apically appendaged conidia in the latter genus (Ramaley 1995). Minnis et al. (2012) synonymized Planistroma under Kellermania based on molecular data support. However, we follow Monkai et al. (2013) who assigned Planistroma as a distinct genus based on both morphological and molecular data.

Umthunziomyces Crous \& M.J. Wingf., in Crous et al., Persoonia 37: 315 (2016).

Index Fungorum number: IF 819069; Facesoffungi number: FoF 06718; - 1 morphological species (Species Fungorum 2020), 1 species with molecular data.

Type species: Umthunziomyces hagahagensis Crous \& M.J. Wingf., Persoonia 37: 315 (2016).
Notes: The monotypic genus Umthunziomyces was introduced by Crous et al. (2016a) and is known only from its asexual morphs. Umthunziomyces is similar to Kellermania in having septate conidia, but they are longer and narrower than in the latter genus. Phillips et al. (2019) included Umthunziomyces in Planistromellaceae with evidence from the phylogenetic analyses of ITS and LSU sequence data.

\section{Economic and ecological significance}

Members in this family usually grow on living or dead leaves or on stems of various plants, and are mostly saprobes, but some species are pathogens such as Kellermania agaves, and Mycosphaerellopsis moravica (Barr 1996; Ramaley 1993, 1995, 1998; Minnis et al. 2012; Crous et al. 2013). Most species inhabit Asparagaceae.

Saccharataceae Slippers, Boissin \& Crous, Studies in Mycology 76: 41 (2013).

Index Fungorum number: IF 805794; Facesoffungi numbers: FoF 02296, 22 species.

Saprobic, endophytic, or pathogenic on plants. Sexual morph: Ascostromata pseudothecial, uniloculate, solitary or in clusters, with multi-layered, dark brown walls, 
Fig. 23 Saccharata proteae (redrawn from Slippers et al. 2013, CBS 121406). a Immersed ascomata with clypeus-like structure. b Asci and ascospores. c-e Conidiogenous cells and paraphyses. $\mathbf{f}$ Conidia. Scale bars: $\mathbf{b}-\mathbf{f}=10$ $\mu \mathrm{m}$
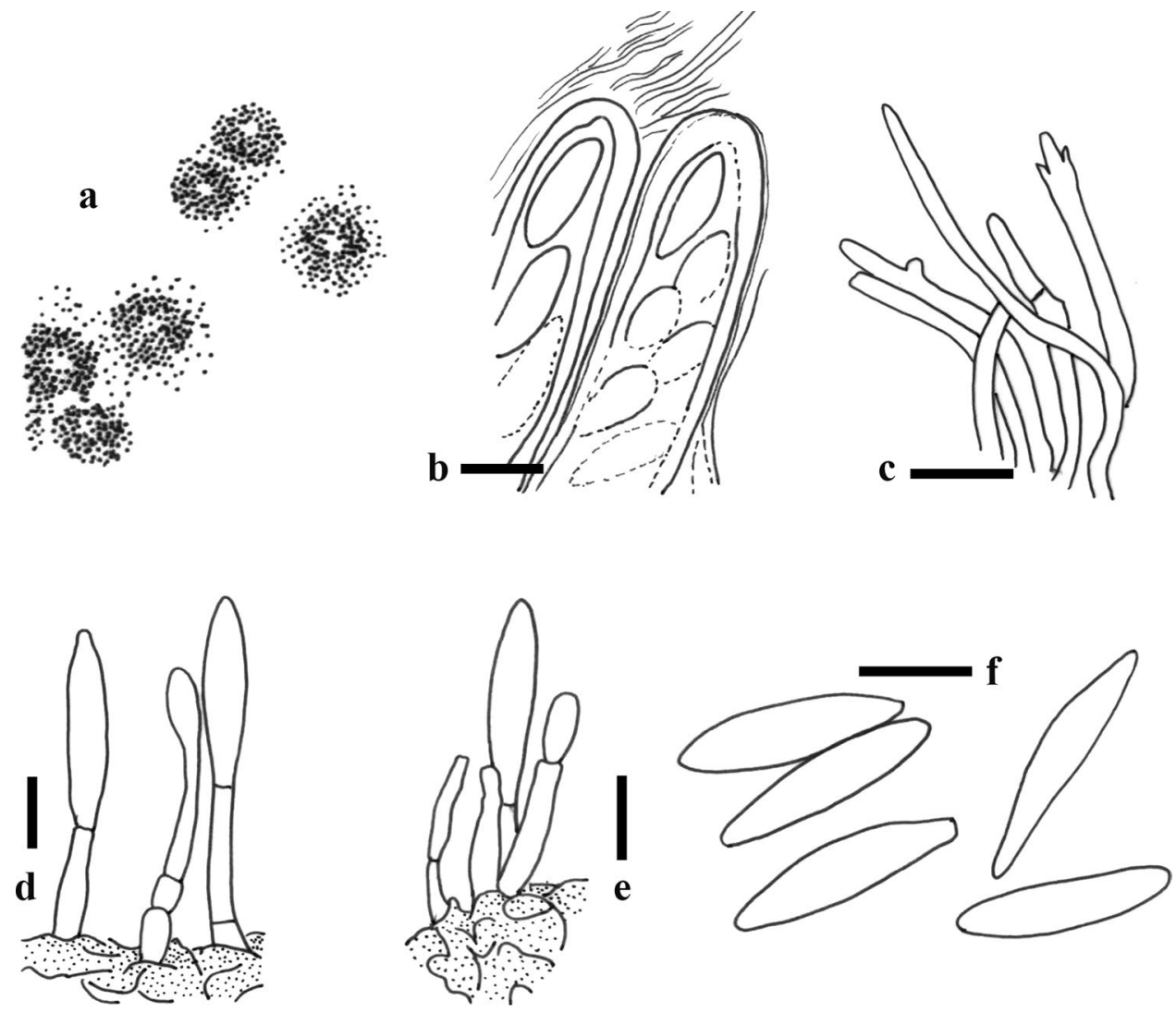

or dumbbell-shaped, with rounded ends, hyaline, smooth, granular.

Type: Saccharata Denman \& Crous.

Notes: The narrow, aseptate, filiform pseudoparaphyses in Saccharataceae are unique in Botryosphaeriales and the pale golden brown ascospores are also distinctive. Slippers et al. (2013) accommodated this family in Botryosphaeriales. Saccharataceae grouped separately from all other families that were basal in the phylogenetic tree, suggesting a long, separate evolutionary history. Saccharataceae has previously been known only from southern Africa, and is most diverse on the Proteaceae. Recent research has shown, however, that it has also been introduced as endophytes in other countries where South African Proteaceae are now being cultivated (Marincowitz et al. 2008).

Saccharata Denman \& Crous, in Crous et al., CBS Diversity Ser. (Utrecht) 2: 104 (2004).

Index Fungorum number: IF 28918; Facesoffungi number: FoF 02297; 19 morphological species (Species Fungorum 2020), 15 species with molecular data.

Type species: Saccharata proteae (Wakef.) Denman \& Crous.

$\equiv$ Phyllachora proteae Wakef., Bull. Misc. Inf., Kew(5): 164 (1922). 
Notes: Crous et al. (2004) described the first species of this genus from Proteaceae in the South Western Cape region of South Africa. Three other species were added to the genus, two from Proteaceae and one from Encephalartos (Marincowitz et al. 2008; Crous et al. 2008, 2009). Apart from its restricted distribution and host range, Saccharata is also unique in its asexual morphology, which includes a hyaline, fusicoccum-like and a pigmented diplodia-like asexual morph. Based on phylogenetic analysis, evolutionary estimates and morphological data, Phillips et al. (2019) considered Septorioideaceae a synonym of Saccharataceae. We were unable to obtain fresh collections of Saccharata or other genera of Saccharataceae, therefore, a drawing of Saccharata proteae is provided (Fig. 23).

Saccharata proteae (Wakef.) Denman \& Crous, in Crous et al., CBS Diversity Ser. (Utrecht) 2: 104 (2004).

$\equiv$ Phyllachora proteae Wakef., Bull. Misc. Inf., Kew(5): 164 (1922).

Index Fungorum number: IF 370531; Facesoffungi number: FoF 07631; Fig. 23

Description: see Slippers et al. (2013).

\section{Other genera included}

Pileospora J.B. Tanney \& K.A. Seifert, Mycol. Prog. 18: 169 (2019).

Index Fungorum number: IF 824738; MycoBank number: MB82473; - 1 species with molecular data.

Type species: Pileospora piceae J.B. Tanney \& K.A. Seifert, Mycol. Prog. 18: 169 (2019).

Notes: Pileospora is distinct from Septorioides by its aseptate, ellipsoidal-fusiform conidia with apical appendages versus subcylindrical to fusiform-ellipsoidal, 1-10-septate conidia lacking appendages. Pileospora is similar to Neofusicoccum, Saccharata, and other genera of Botryosphaeriales having fusicoccum-like asexual states with cooccurring irregularly-shaped conidia. An irregular, mucoid, apical appendage distinguishes conidia of Pileospora from above mentioned similar genera.

Septorioides Quaedvl., Verkley \& Crous, Stud. Mycol. 75: 383 (2013).

Index Fungorum number: IF 804464; Facesoffungi number: FoF 06278; - 2 morphological species (Species Fungorum 2020), 2 species with molecular data.

Type species: Septorioides pini-thunbergii (S. Kaneko) Quaedvlieg et al. Stud. Mycol. 75: 383 (2013).

三Septoria pini-thunbergii S. Kaneko, in Kaneko et al., Trans. Mycol. Soc. Japan 30(4): 463 (1989).

Notes: This genus is characterized by acervular conidiomata that open by means of an irregular rupture and paraphyses that are intermingled among conidiogenous cells (Quaedvlieg et al. 2013). Septorioides pini-thunbergii was associated with needle blight and the cause of sooty mould of Pinus thunbergii in Japan (Suto 2000). Later, this species was isolated as an endophyte from P. densiflora in South Korea (Yoo and Eom 2012). The trend of raising established genera to familial status continued when Wyka and Broders (2016) introduced Septorioideaceae within the Botryosphaeriales to accommodate Septorioides species. They introduced a novel species Septorioides strobi as the second species of this family. However, Phillips et al. (2019) placed Septorioides as a genus in Saccharataceae taking into consideration the results of phylogenetic analyses, evolutionary divergence and morphological data.

\section{Economic and ecological significance}

Saccharataceae has previously been known only from southern Africa, and is most diverse on Proteaceae. Research has shown, however, that it has also been introduced as an endophyte into other countries where South African Proteaceae are now cultivated (Marincowitz et al. 2008). This plant family, which has a high endemic richness in southern Africa, has evolved in the region for more than 100 million years (Barker et al. 2007). This date allows for the estimated 57 (28-100) MYA (based on rDNA SSU) separation of the Saccharataceae as a family and to have evolved with these endemic plant hosts in the region. The species are typically associated with leaf spots and stem cankers and they appear to be pathogens. Separate studies have also shown that they are endophytes (Swart et al. 2000, Taylor et al. 2001), similar to members of the Botryosphaeriaceae.

Catinellales Ekanayaka, K.D. Hyde \& Ariyawansa, ord. nov.

Index Fungorum number: IF 557327; Facesoffungi number: FoF 07646

Saprobic on dead wood in terrestrial habitats. Sexual morph: Ascomata apothecial, discoid. Excipulum composed of angularis to globose cells. Hamathecium comprising cylindric, septate, paraphyses. Asci cylindric, clavate, inoperculate with an ocular chamber, J-. Ascospores ellopsoidal, uni-seriate. Asexual morph: Undetermined.

Type: Catinellaceae Ekanayaka, K.D. Hyde \& Ariyawansa.

Notes: Catinella was established by Boudier (1907). Several authors have misidentified this fungus and placed it within Leotiomycetes (Durand 1922). However phylogenetic study of Greif et al. (2007) strongly supported its placement within Dothideomycetes. Catinella formed a distinct lineage within Dothideomycetes in Hongsanan et al. (2020), thus we introduced this new order to accommodate Catinella and allied species in the class Dothideomycetes. The divergence time for Catinellales is estimated as 163 MYA (Hongsanan et al. 2020). 

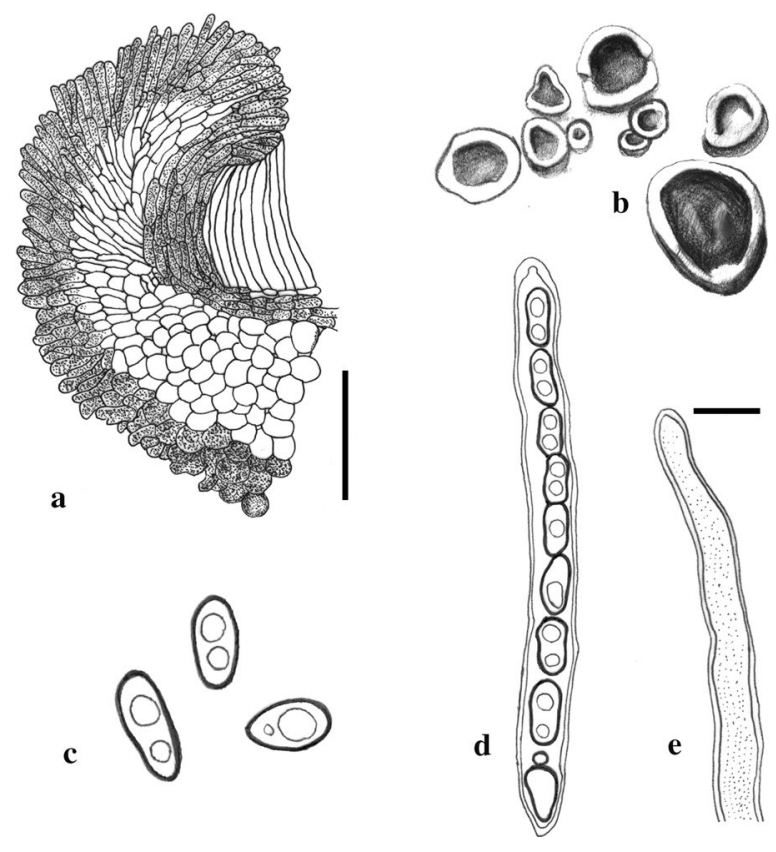

Fig. 24 Catinella olivacea $(\mathbf{a}=$ redrawn from Gamundí 1981; b-e = redrawn from Akata et al. 2016). a Peridium. b Apothecial ascomata. c Ascospores. d Asci. e Anchor hyphae. Scale bars: $\mathbf{a}=10 \mu \mathrm{m}, \mathbf{b}=$ $20 \mu \mathrm{m}$

Accepted families: Catinellaceae.

Catinellaceae Ekanayaka, K.D. Hyde \& Ariyawansa, fam. nov.

Index Fungorum number: IF 557328; Facesoffungi number: FoF 07647, 1 species.

Saprobic on dead wood in terrestrial habitats. Sexual morph: Ascomata apothecial, discoid, cupulate, flattened disc. Excipulum composed of subangularis to globose cells, ectal cells are pigmented. Hamathecium comprising cylindric, septate, swollen apices agglutinate to form a pseudoepithecium, paraphyses. Asci 8-spored, cylindric, clavate, inoperculate, unitunicate, J-, with well-developed ocular chamber. Ascospores ellopsoidal, uni-seriate, darkly pigmented, one-celled. Asexual morph: Undetermined.

Type genus: Catinella Boud.

Notes: The new family Catinellaceae bears some morphological characteristics similar to Leotiomycetes, i.e. cupulate apothecia, unitunicate asci, aseptate ascospores. However, Dothideomycetes also show these characters, although they are not common within the class (Greif et al. 2007).

Catinella Boud., Hist. Class. Discom. Eur. (Paris): 150 (1907).

Index Fungorum number: IF 845; Facesoffungi number: FoF 07648; 3 morphological species (Species Fungorum 2020), 1 species with molecular data.

Type: Catinella olivacea (Batsch) Boud. $\equiv$ Peziza olivacea Batsch, Elench. fung. (Halle): 127 (1783).

Notes: Catinella was established by Boudier (1907), with C. olivacea as the type species. The genus was recognised as a member in Leotiomycetes based on its morphology. However, sequence data of $C$. olivacea indicated that this genus formed a distinct clade within Dothideomycetes (Fig. 24).

\section{Economic and ecological significance}

Catinellaceae is saprobic on dead wood and plays a role in recycling of organic matter.

\section{Cladoriellales Crous.}

Index Fungorum number: IF 823435; Facesoffungi number: FoF 07649.

Cladoriellales was established by Crous et al. (2017), with a single genus Cladoriella. Molecular data (LSU) confirmed its status as a distinct order within Dothideomycetes. This order contains asexual, cladosporium-like species which are found as saprobes or pathogens on leaf surface. In Fig. 25, four species of Cladoriella (Cladoriella eucalypti, $C$. kinglakensis, $C$. rubrigena, and $C$. xanthorrhoeae) grouped with high support. The divergence time for Cladoriellales is estimated as 183 MYA (stem age, Hongsanan et al. 2020, Fig. 2).

Accepted families: Cladoriellaceae.

Cladoriellaceae Crous, in Crous et al., Persoonia 39: 417 (2017).

Index Fungorum number: IF 823436; Facesoffungi numbers: FoF 07650, 5 species.

Saprobes or pathogens on leaf surface. Sexual morph: Undetermined. Asexual morph: Hyphae coiling, branched, septate, with swollen cells giving rise to conidiophores, with hyphopodium-like structures at the base, simple, intercalary, brown to dark brown, thick-walled, smooth to finely verruculose. Conidiophores separate, erect, subcylindrical, straight, septate, thick-walled, brown to dark brown, smooth to finely verruculose. Conidiogenous cells terminal or intercalary, mono- or poly-tretic, sympodial, with 1-2 conspicuous loci, thickened, darkened, refractive, with a minute central pore. Conidia remains in long acropetal chains, narrowly ellipsoidal to cylindrical or fusoid, brown, non or 1-septate, thickwalled, finely verruculose, with apical conidium rounded at the apex; additional conidia with 1-2 truncate, conspicuous hila; thickened, darkened, refractive, with a minute central pore. Chlamydospores absent (Crous et al. 2006b, 2017).

Type: Cladoriella Crous.

Notes: Cladoriellaceae was established by Crous et al. (2017) to accommodate a single genus Cladoriella. Sequence data for this family are available in GenBank and it also supports Cladoriellaceae as a family of Cladoriellales in Dothideomycetes. 
Fig. 25 Phylogram generated from maximum likelihood analysis (RAxML) of Cladoriellales based on LSU sequence data. Maximum likelihood bootstrap values equal or above $70 \%$, Bayesian posterior probabilities equal or above 0.90 (MLBS/ $\mathrm{PP})$ are given at the nodes. An original isolate number is noted after the species name. The tree is rooted to Capnodium coffeae (OSC 100414) and Leptoxyhium fumago (CBS 123.26). The ex-type strains are indicated in bold. Hyphen (-) represents support values below $70 \%$ MLBS and $0.90 \mathrm{PP}$

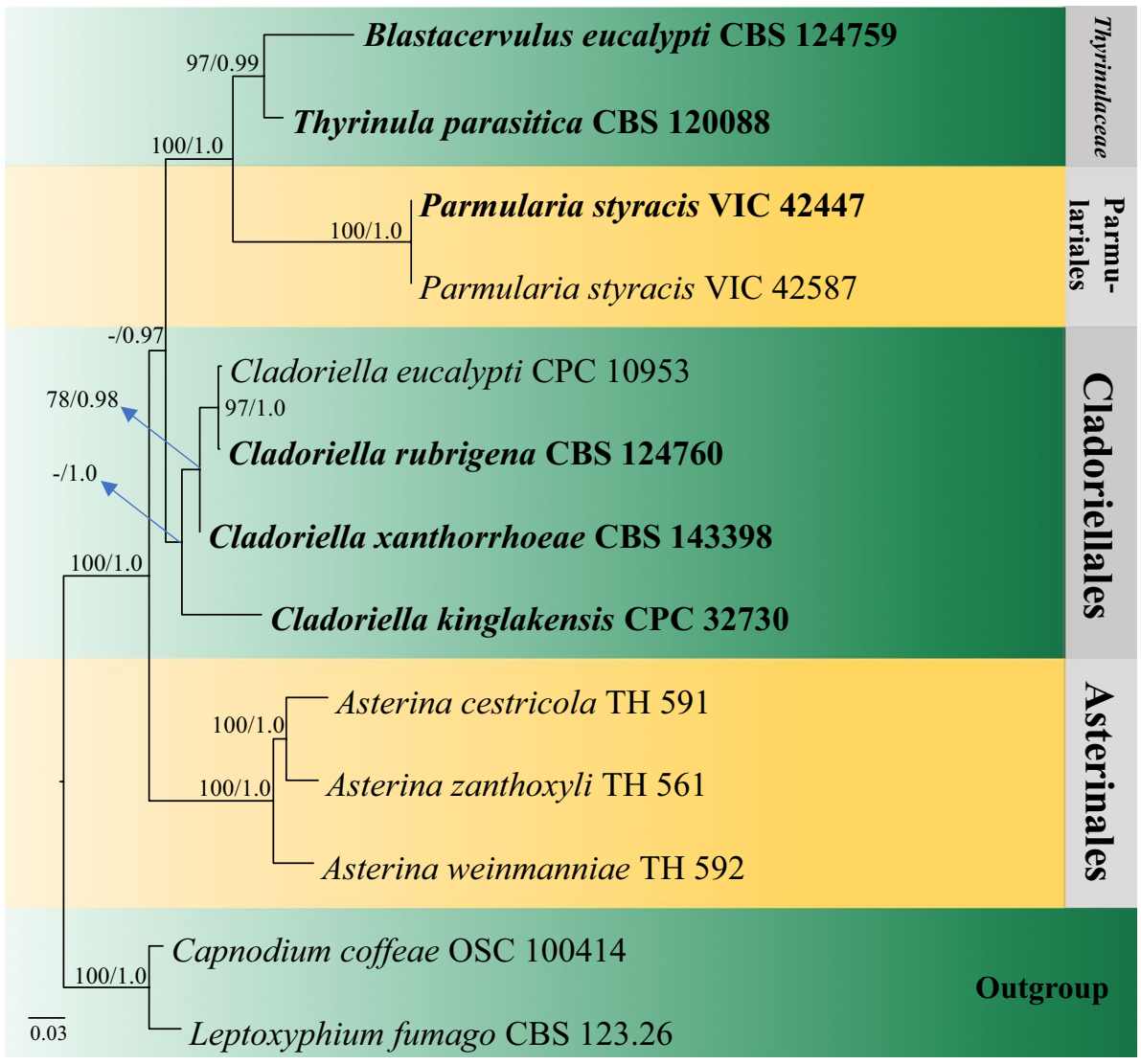

Cladoriella Crous, Stud. Mycol. 55: 54 (2006).

Index Fungorum number: IF 500799; Facesoffungi number: FoF 07651; 5 morphological species (Species Fungorum 2020), 4 species with molecular data.

Type species: Cladoriella eucalypti Crous.

Notes: Crous et al. (2006b) introduced Cladoriella to accommodate cladosporium-like species. This genus is similar to Devriesia, but lacks chlamydospores, and produces a distinct red pigment on media. Phylogenetic analyses also support this distinctness as Cladoriella formed a clade apart from Cladosporium complex (Mycosphaerellaceae), Cladophialophora complex (Herpotrichiellaceae), or Pseudocladosporium complex (Venturiaceae) (Crous et al. 2006b) (Fig. 26).

\section{Economic and ecological significance}

Species in this family are saprobic and probably are plant pathogenic (Wijayawardene et al. 2017a). They are found on leaf surfaces, however, the lifestyle of species in Cladoriellaceae is not well-studied.

\section{Collemopsidiales Pérez-Ort.}

Index Fungorum number: IF 815627; Facesoffungi number: FoF 07652.

This recently erected order includes a single family, Xanthopyreniaceae. It encompasses species of lichen-forming fungi, lichenicolous or forming loose associations with cyanobacteria. The diversity of the order has been largely underestimated and the actual number of species could exceed 200. The divergence time for Collemopsidiales is estimated as 230 MYA (stem age, Hongsanan et al. 2020) (Fig. 27).

Accepted families: Xanthopyreniaceae.

Xanthopyreniaceae Zahlbr., in Engler \& Prantl, Nat. Pflanzenfam., Edn 2 (Leipzig) 8: 91 (1926).

Index Fungorum number: IF 81525; Facesoffungi number: FoF 07653, 53 species.

Lichen-forming fungi, lichenicolous or forming loose associations with cyanobacteria. Vegetative hyphae usually hyaline. Sexual morph: Ascomata perithecioid, solitary or in groups, superficial or immersed in the substrarum, subglobose. Peridium thin to thick, composed by elongated to roundish, more or less compresed cells of textura angularis. Involucrelum present in some species, with textura intricata. Hamathecium comprising thin, septate, highly branched and anastomosed interascal filaments. Asci 4-8-spored, thickwalled, bitunicate, fissitunicate, ovate to clavate, apedicellate, with a distinct ocular chamber. Ascopores irregularly arranged within the ascus, ellipsoid to broadly ellipsoid, hyaline, 1-septate, wall cell smooth, usually with a gelatinous shell. Asexual morph: Coelomycetous. Pycnidium, 


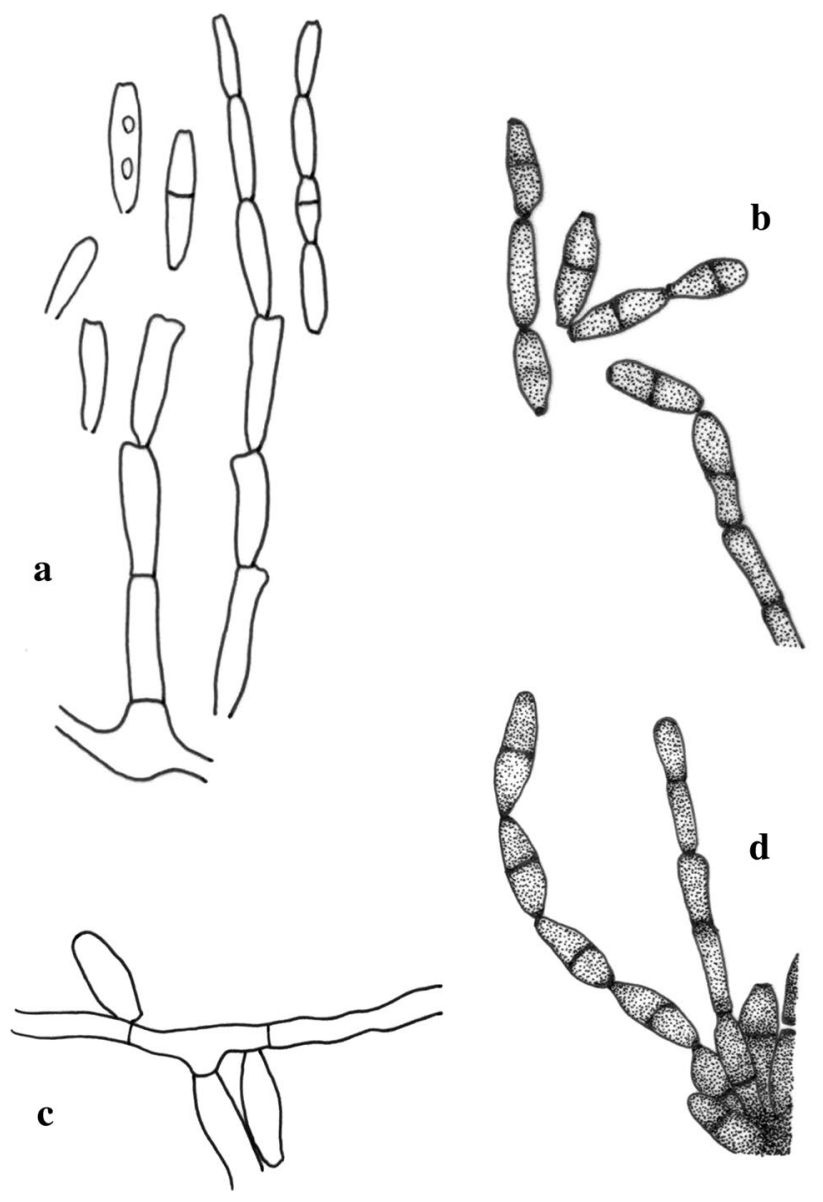

Fig. 26 Conidiophore and conidia of Cladoriella spp. a Cladoriella eucalypti (redrawn from Crous et al. 2006, CBS H-18043). b-d Cladoriella xanthorrhoeae (redrawn from Crous et al. 2017, CBS H-23300)

superficial or immersed in the substratum, black, with a small ostiole. Pycnidial wall thick-walled cells of textura angularis, composed of \pm isodiametric or elongated cells. Conidiogenous cells \pm cylindrical, phialidic. Conidiospores bacilliform to ellipsoid.

Type: Xanthopyrenia Bachm.

Notes: Xanthopyreniaceae was introduced by Zahlbruckner to accommodate the single species Xanthopyrenia tichothecioides (= Arthopyrenia tichothecioides), a species growing on periodically inundated calcareous rocks. The species was later combined into Pyrenocollema (P. tichothecioides) and subsequently many species associated with cyanobacteria, and with perithecioid ascomata, highly branched and anastomosed interascal filaments and hyaline 1-septate ascospores were transferred or described in Pyrenocollema (e.g. Santesson 1992; Coppins et al. 1992; McCarthy and Kantvilas 1999; Nordin 2002). However, Grube and Ryan (2002) stated that the type species of the genus, $P$. tremelloides is in fact a parasite on Nostoc and is not congeneric with $X$. tichothecioides, suggesting that the correct generic name for those species should be Collemopsidium, and many species of Pyrenocollema were subsequently combined into this genus (Grube and Ryan 2002; Mohr et al. 2004). Pérez-Ortega et al. (2016) studied the phylogenetic relationships of Xanthopyreniaceae using six molecular markers. Although they found Xanthopyreniaceae belongs to Dothiodeomycetes, and described the new order Collemopsidiales, their exact position remained elusive despite of using different taxa sampling, very likely due to the use of Arthoniomycetes as outgroup. Subsequent work by Liu et al. (2017) found high support for the sister relationships of Collemopsidiales with Monoblastiales. Based on uncertainties by Pérez-Ortega et al. (2016), Tedersoo et al. (2018) described the new class Collemopsidiomycetes which should be considered as a synonym of Dothiodeomycetes. Lumbsch and Huhndorf (2007) included the genera Collemopsidium, Didymellopsis, Frigidopyrenia, Pyrenocollema, and Zwackhiomyces as members of the Xanthopyreniaceae. Later, Wijayawardene et al. (2018) excluded Frigidopyrenia and Pyrenocollema from the family and placed them in Pezizomycotina genera incertae sedis. Unfortunately, no molecular data is available for Didymellopsis, Frigidopyrenia and Pyrenocollema. Pérez-Ortega et al. (2016) discussed that the number of species in the family may have been highly underestimated.

Xanthopyrenia Bachm., Nova Acta Acad. Caes. Leop.Carol. German. Nat. Cur. 105(1): 65 (1919).

Index Fungorum number: IF 5810; Facesoffungi number: FoF 07654; - 2 morphological species (Pérez-Ortega et al. 2016), molecular data unavailable.

Type species: Xanthopyrenia tichothecioides (Arnold) Bachm.

$\equiv$ Arthopyrenia tichothecioides Arnold, Flora, Regensburg 52: 268 (1869).

Notes: The genus was described to accommodate the single species Arthopyrenia tichothecioides, a species occurring with seawater or spray on calcareous rocks (Thüs and Schultz 2009). This species and $X$. heardensis, the only other species described in the genus, were subsequently transferred to Pyrenocollema. Pérez-Ortega et al. (2016) showed that Collemopsidium as currently circumscribed is paraphyletic, so Xanthopyrenia might be the correct generic name for non-marine Collemopsidium species (Fig. 28).

\section{Other genera included}

Collemopsidium Nyl., Flora, Regensburg 64: 6 (1881).

Index Fungorum number: IF 1182; Facesoffungi number: FoF 07655; - 16 morphological species (Species Fungorum 2020), 3 species with molecular data (Pérez-Ortega et al. 2016). 
Fig. 27 Phylogram generated from maximum likelihood analysis (RAxML) of Collemopsidiales based on LSU and SSU sequence data. Maximum likelihood bootstrap values equal or above $70 \%$, Bayesian posterior probabilities equal or above 0.90 (MLBS/PP) are given at the nodes. An original isolate number is noted after the species name. The tree is rooted to and Abrothallus cladoniae (AB53) and A. parmeliarum (AB36). Hyphen (-) represents support values below $70 \%$ MLBS and 0.90 PP

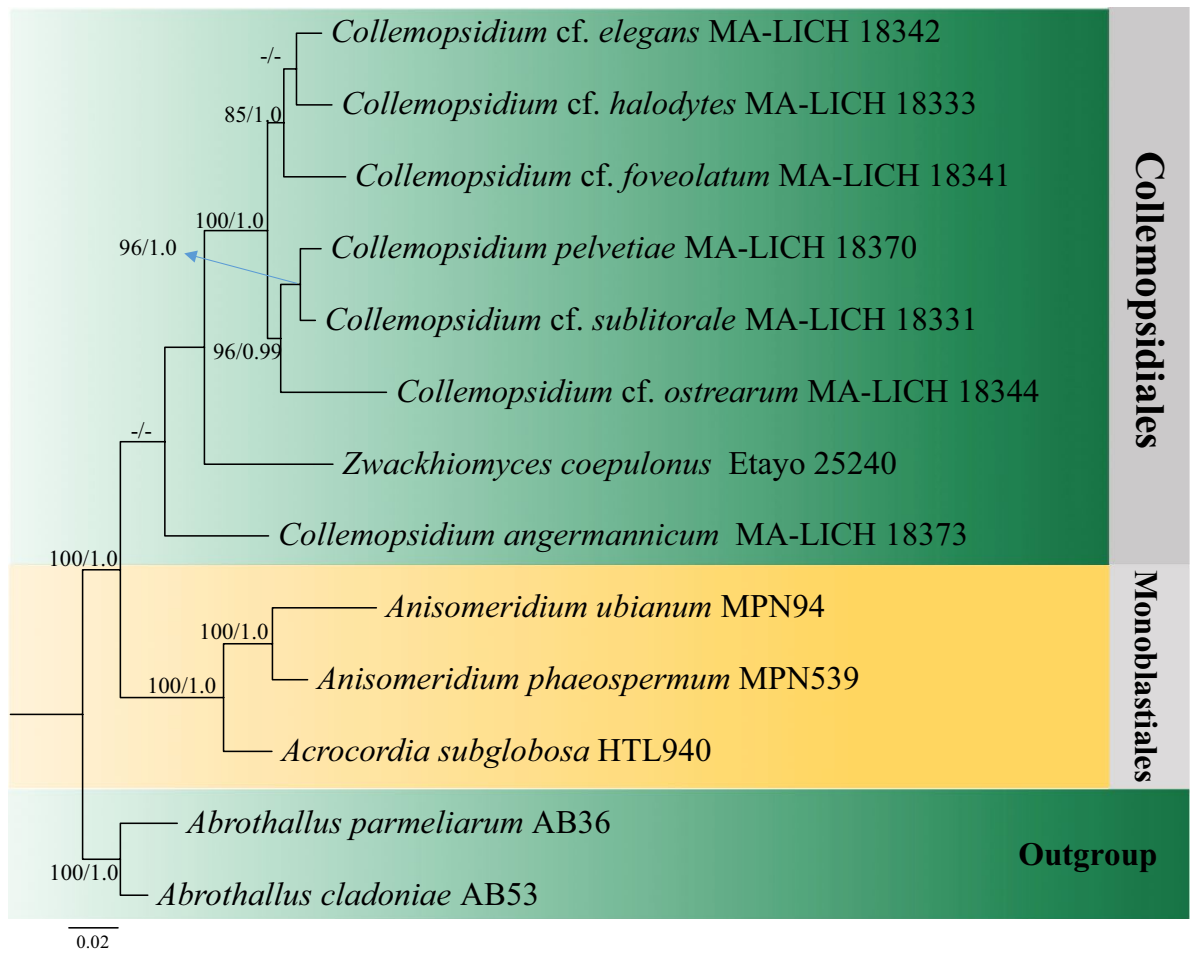

Type species: Collemopsidium iocarpum ( $\mathrm{Nyl}.) \mathrm{Nyl}$, Flora, Regensburg 64: 6 (1881).

$\equiv$ Pyrenopsis iocarpa Nyl., Not. Sällsk. Fauna et Fl. Fenn. Förh., Ny Ser. 5: 26 (1861).

Notes: Grube and Ryan (2002) studied the types of Collemopsidium and Pyrenocollema and stated that the former is the correct generic name for species previously included in Pyrenocollema. Pérez-Ortega et al. (2016) showed that the genus as currently understood is paraphyletic and species occurring in marine and terrestrial and freshwater habitats belong to different lineages. Collemopsidium iocarpum was described growing close to the seashore and it is likely the correct name for the marine clade. Species concepts and taxonomy have to be thoroughly studied. Pérez-Ortega et al. (2016) showed that each of the species commonly accepted in the literature likely encompass dozens of different taxa. Cyanobacteria associated with Collemopsidium are largely undetermined, marine species likely belong to Hyella (Swinscow 1965b). Xanthocapsa may be involved in freshwater symbioses (Grube and Hafellner 1990).

Didymellopsis (Sacc.) Clem. \& Shear, Gen. fung., Edn 2 (Minneapolis): 66 (1931).

= Didymella subgen. Didymellopsis Sacc. \& D. Sacc., Syll. fung. (Abellini) 17: 657 (1905).

Index Fungorum number: IF 1550; Facesoffungi number: FoF 07656; - 8 morphological species (Species Fungorum 2020), molecular data unavailable.
Type species: Didymellopsis latitans (Nyl.) Sacc. ex Clem. \& Shear, Gen. fung., Edn 2 (Minneapolis): 265 (1931).

三 Obryzum latitans Nyl., Flora, Regensburg 68: 298 (1885).

Notes: All species in Didymellopsis are found on lichens with cyanobacterial photobionts, but $D$. perigena which grows on Catapyrenium squamulosum might be associated with cyanobacteria surrounding the host thallus. Differences between Didymyellopsis and Zwackhiomyces are subtle (Zhurbenko et al. 2015) and a thorough revision of the group, including DNA sequence analyses should be carried out.

Frigidopyrenia Grube, Phyton, Horn 45(2): 307 (2005). Index Fungorum number: IF 521258; Facesoffungi number: FoF 07657; - 1 morphological species (Species Fungorum 2020), molecular data unavailable.

Type species: Frigidopyrenia bryospila (Nyl.) Grube, Phyton, Horn 45(2): 308 (2005).

三Verrucaria bryospila Nyl., Flora, Regensburg 47: 357 (1864).

Notes: Grube (2005) described the monotypic genus Frigidopyrenia for Verrucaria bryospila occurring on mosses in arctic-alpine areas, forming distinct squamules and with cyanobacteria as photobiont. Grube (2005) discussed the morphological differences of the genus with similar genera such as Collemopsidium, Magmopsis and 

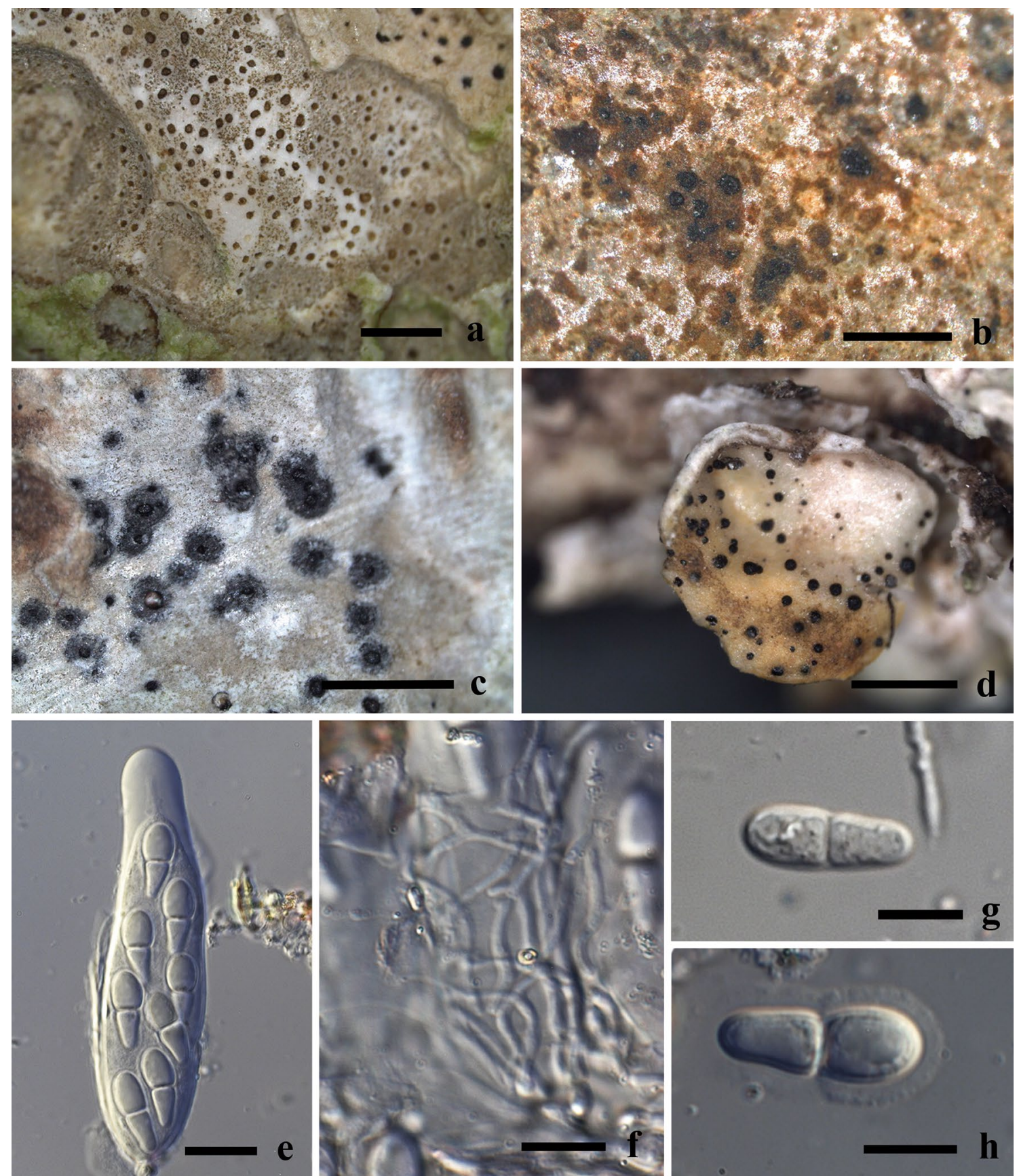

Fig. 28 Morphological and anatomical features of Xanthopyreniaceae. a Habitus Collemopsidium foveolatum-morphotype. b C. halodytes-morphotype. c C. ostrearum-morphotype. d Zwackhiomyces coepulonus. e Ascus from $C$. angermannicum. F Interascal fila-

Pyrenocollema, which have different peridial structure. It is not clear that the genus belongs in Xanthopyreniaceae.

Rhagadodidymellopsis Fdez.-Brime, Gaya, Llimona \& Nav.-Ros., Plant and Fungal Systematics 65(1): 177 (2020). ments from $C$. cf. foveolatum. g Ascospore from $C$. cf. sublitorale. h Ascospore from $C$. angermannicum with gelatinous sheath. Scale bars: $\mathbf{a}-\mathbf{c}=1 \mathrm{~mm} ; \mathbf{d}=0.5 \mathrm{~mm} ; \mathbf{e}-\mathbf{h}=10 \mu \mathrm{m}$

Index Fungorum number: IF 835454; Facesoffungi number: FoF 09130; - 1 morphological species (Species Fungorum 2020), molecular data unavailable.

Type species: Rhagadodidymellopsis endocarpi Fdez.Brime, Gaya, Llimona \& Nav.-Ros., Plant and Fungal Systematics 65(1): 177 (2020). 
Fig. 29 Phylogram generated from maximum likelihood analysis (RAxML) of Dyfrolomycetales based on LSU and SSU sequence data. Maximum likelihood bootstrap values equal or above $70 \%$, Bayesian posterior probabilities equal or above 0.90 (MLBS/PP) are given at the nodes. An original isolate number is noted after the species name. The tree is rooted to Anisomeridium phae ospermum (MPN539) and $A$. ubianum (94). The ex-type and reference strains are indicated in bold. Hyphen (-) represents support values below $70 \%$ MLBS and $0.90 \mathrm{PP}$

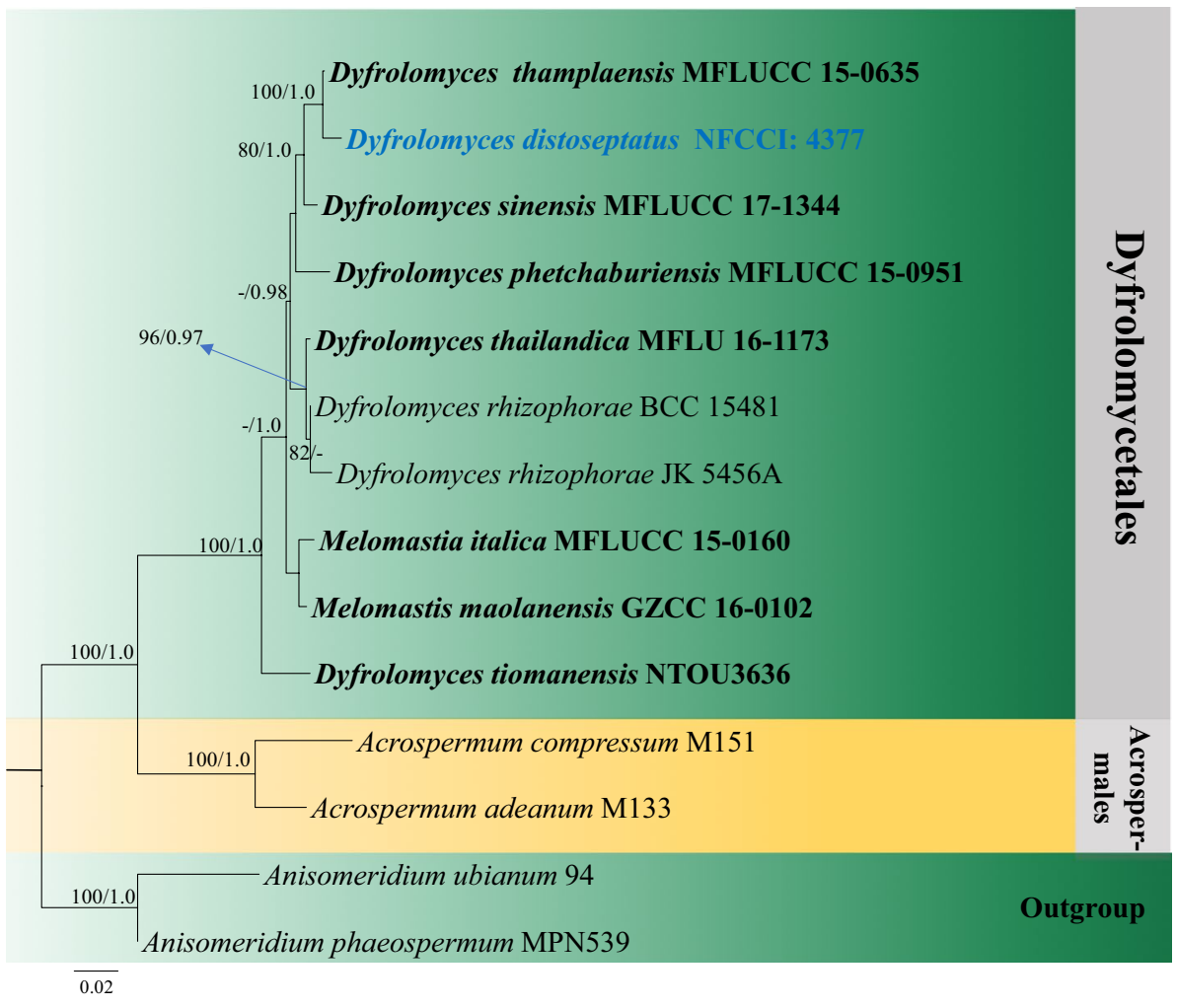

Notes: This recently erected genus, with the only species $R$. endocarpi growing on Endocarpon pusillum, was described based on the presence of ascomata occurring in stromata with uneven wall. It seems to be closely related to Didymellopsis and Zwackhiomyces (Fernández-Brime et al. 2020). It is here tentatively placed in Collemopsidiales and Xanthopyreniaceae until molecular data is available.

Zwackhiomyces Grube \& Hafellner, Nova Hedwigia 51(34): 305 (1990).

Index Fungorum number: IF 25388; Facesoffungi number: FoF 07658; - 26 morphological species (Species Fungorum 2020), 1 species with molecular data.

Type species: Zwackhiomyces coepulonus (Norman) Grube \& R. Sant., in Grube \& Hafellner, Nova Hedwigia 51(3-4): 310 (1990).

三 Arthopyrenia coepulona Norman, Bot. Notiser: 192 (1868) [1867].

Notes: Zwackhiomyces is one of the most diverse genera of lichenicolous fungi with 35 known species (Diederich et al. 2018). Species mostly grow on crustose lichens with green photobionts, although five species grow on hosts with cyanobacteria as photobiont. Pérez-Ortega et al. (2016) sequenced the type species and confirmed the genus is a member of Xanthopyreniaceae.

Zwackhiomacromyces Etayo \& van den Boom, Opuscula Philolichenum 13: 70 (2014).
Index Fungorum number: IF 803963; Facesoffungi number: FoF 08929; - 2 morphological species (Species Fungorum 2020), molecular data unavailable.

Type species: Zwackhiomacromyces constrictocarpus Etayo \& van den Boom, Opuscula Philolichenum 13: 72 (2014).

Notes: van den Boom and Etayo (2014) established the new genus based on material from the Iberian Peninsula growing on Megaspora verrucosa. The new genus differs from Zwackhiomyces in having lageniform ascomata, with large and granulose papillae, larger asci and ascospores, and normally 3-septate smooth-walled ascospores (van den Boom and Etayo 2014). Later, Etayo and Berger (in Berger and Zimmerman 2016) combined Pyrenidium hyalosporum growing in Placopsis gelida into Zwackhiomacromyces based on ascoma and ascospore characters. This genus tentatively placed in the order Collemopsidiales and Xanthopyreniaceae until molecular data is available.

\section{Economic and ecological significance}

Members of the Xanthopyreniaceae are usually inconspicuous and have been often overlooked. Most of the lichenicolous species do not cause harm to the hosts, and many of the interactions may be considered commensalistic. Marine species of Collemopsidium with boring capacity may have relevant ecological significance since they actively produce bioweathering in littoral rocky substrates, boosting the deteriorative action of waves. Furthermore, those species are 
able to colonize and modified mollusk and barnacle shells, mediating mimicry in some species (Espoz et al. 1995).

Dyfrolomycetales K.L. Pang, K.D. Hyde and E.B.G. Jones. Index Fungorum number: IF 805281; Facesoffungi number: FoF 07670.

Dyfrolomycetales with the type genus Dyfrolomyces was introduced to accommodate marine fungi and now includes terrestrial, wood-inhabiting taxa which are characterized by immersed, ostiolate, clypeate, papillate ascomata, bitunicate, cylindrical, short pedicellate asci, with a distinct ocular chamber along with a ring-like subapical ring, and overlapping uni-seriate, broadly fusiform, symmetrical, hyaline, multi-septate ascospores. Only the single family Pleurotremataceae is accepted in this order. The divergence time for Dyfrolomycetales is estimated as 171 MYA (stem age, Hongsanan et al. 2020) (Fig. 29).

Accepted families: Pleurotremataceae.

Pleurotremataceae Walt. Watson, New Phytol. 28: 113 (1929).

Index Fungorum: IF 81192; Facesoffungi number: FoF 01911, 47 species.

= Dyfrolomycetaceae K.D. Hyde, K.L. Pang, Alias, Suetrong \& E.B.G. Jones, in Pang et al., Cryptog. Mycol. 34(3): 227 (2013).

Saprobic on wood in terrestrial and aquatic habitats. Sexual morph: Ascomata perithecial, gregarious or solitary, immersed or erumpent throughout the host, dark-brown to black, ovoid to subglobose, carbonaceous to membranaceous, clypeate, ostiolate, papillate. Peridium comprising of dark pigmented cells of textura angularis or epidermoidea. Hamathecium comprising numerous, filamentous, hyaline, septate, branched or unbranched, narrow cellular pseudoparaphyses. Asci 8-spored, bitunicate, clavate to cylindrical, short pedicellate, apical ring present, J-. Ascospores uniseriate, ellipsoidal to cylindrical or fusiform, hyaline, septate, smooth-walled, mostly with guttules. Asexual morph: Undetermined.

Type: Pleurotrema Müll.

Notes: Pleurotremataceae is typified by Pleurotrema with Pleurotrema polysemum as the type species. Subsequently, the nomenclature and placement of this family has been the subject of discussion until Maharachchikumbura et al. (2015) placed it under Chaetosphaeriales, Sordariomycetes. Maharachchikumbura et al. (2016) examined the isotype of $P$. polysemum and found that Dyfrolomycetaceae (Dyfrolomycetales) is a synonym of Pleurotremataceae, thus removed Pleurotremataceae from Sordariomycetes to be a single family of Dyfrolomycetales. This family comprises three genera, and most members are characterized by perithecial, ostiolate, glabrous, ovoid to subglobose ascomata, clavate to cylindrical, unitunicate, short pedicellate asci with a J- apical ring, and hyaline, ellipsoidal to cylindrical, septate, guttulate ascospores that are uni-seriately arranged in the asci.

Pleurotrema Müll. Arg., Bot. Jb. 6: 388 (1885). Index Fungorum number: IF 4251; Facesoffungi number: FoF 07671; 14 morphological species (Species Fungorum 2020), molecular data unavailable.

Type species: Pleurotrema polysemum (Nyl.) Müll. Arg. 三 Parathelium polysemum Nyl., Bot. Ztg. 20: 279 (1872).

Notes: Pleurotrema was introduced as lichenized by Müller (1885). The placement of this genus has been the subject of controversy as it has been placed in different families viz., Pyrenulaceae, Pleurotremataceae and Ascomycota genera incertae sedis, based on its morphological characters (Barr 1994; Kirk et al. 2001; Lumbsch and Huhndorf 2010). Maharachchikumbura et al. (2016) re-examined the isotype of Pleurotrema polysemum, and synonymized Dyfrolomycetaceae under Pleurotremataceae.

\section{Other genera included}

Dyfrolomyces K.D. Hyde, K.L. Pang, Alias, Suetrong \& E.B.G. Jones, in Pang et al., Cryptog. Mycol. 34(3): 227 (2013).

Index Fungorum number: IF 804660; Facesoffungi number: FoF 07672; - 9 morphological species (Species Fungorum 2020), 6 species with molecular data.

Type species: Dyfrolomyces tiomanensis K.L. Pang, Alias, K.D. Hyde, Suetrong \& E.B.G. Jones, in Pang et al., Cryptog. Mycol. 34(3): 228 (2013).

Notes: Dyfrolomyces was established based on morphological and molecular analyses. Members of this genus are characterized by relatively large, immersed, globose or subglobose, clypeate, ostiolate, papillate ascomata, bitunicate, fissitunicate, cylindrical asci and broadly fusiform, symmetrical, hyaline, septate ascospores, with or without a mucilaginous sheath.

Dyfrolomyces distoseptatus M. Niranjan and V.V Sarma, sp. nov.

Index Fungorum number: IF 556726; Facesoffungi number: FoF 06625; Fig. 30

Etymology: In reference to the distoseptate ascospores.

Saprobic on undetermined decaying twig. Sexual morph: Ascomata 550-630 high $\times 450-600 \mu \mathrm{m}$ wide, perithecial, immersed in periderm, erumpent neck with pseudoparaphyses, clypeate, ostiolate, papillate. Peridium $40 \mu \mathrm{m}$, with two strata, outer thick, carbonaceous and inner brown and hyaline cells of textura angularis to epidermoidea cells. Hamathecium comprising 1.8-2.1 $\mu \mathrm{m}$ wide, filamentous, septate, unbranched, dense, narrow cellular pseudoparaphyses, longer than asci. Asci (123.1)126.7-146.2 (148.6) $\times(4.1) 4.7-6.3(6.5) \mu \mathrm{m}(\bar{x}=136.8 \times 5.6, \mathrm{n}=25), 8$-spored, 


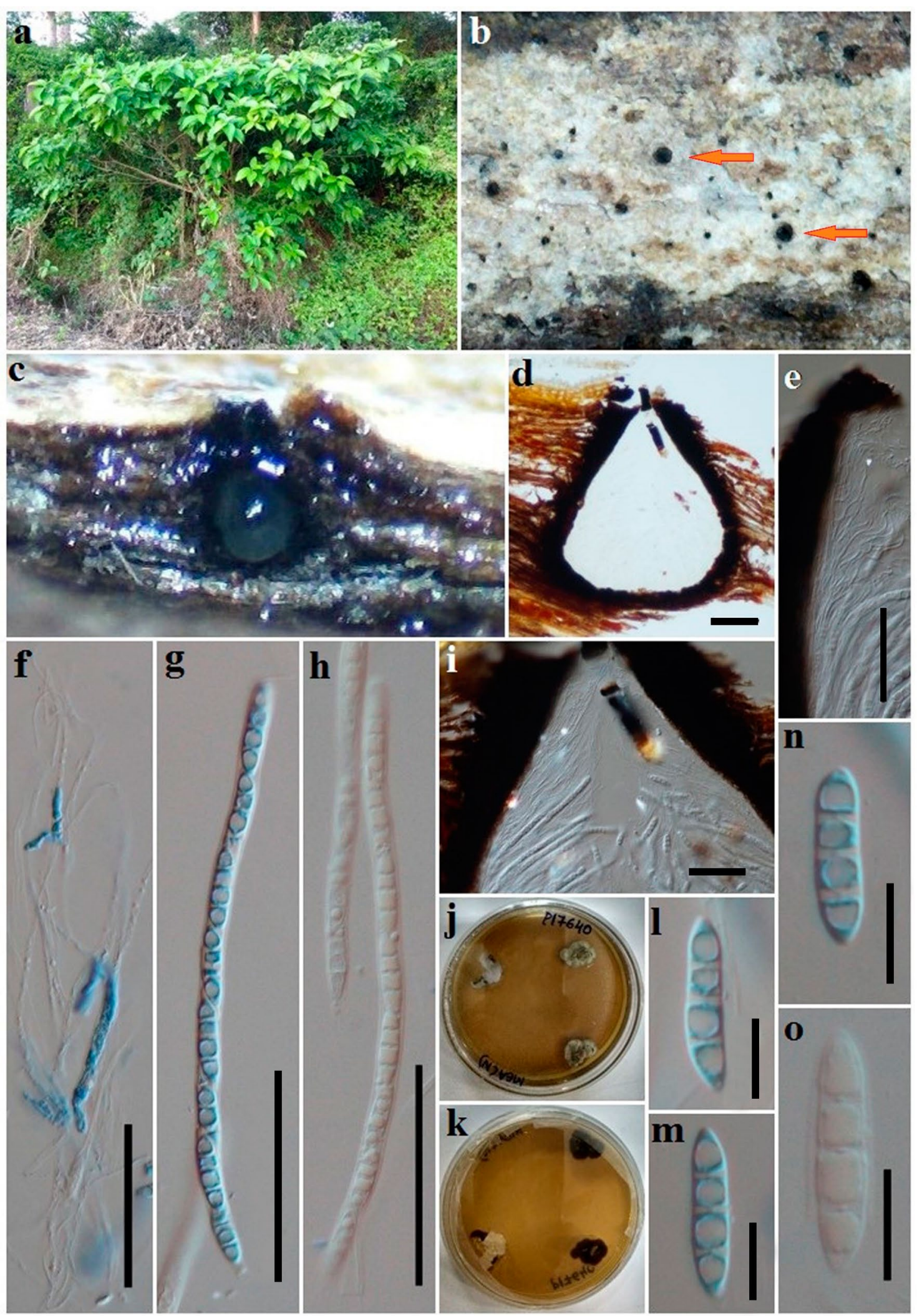

Fig. 30 Dyfrolomyces distoseptatus (AMH 9984, holotype). a Host plant. b Papillate necks. c, d, i Vertical section of ascomata. e Peridium. f Pseudoparaphyses. $\mathbf{g}, \mathbf{h}$ Asci $\mathbf{j}$, $\mathbf{k}$ Cultures in Petri plates from single spore isolations. $\mathbf{l}-\mathbf{o}$ Ascospores. Scale bars: $\mathbf{d}=100 \mu \mathrm{m}, \mathbf{e}-\mathbf{i}$ $=50 \mu \mathrm{m}, \mathbf{l}-\mathbf{0}=10 \mu \mathrm{m}$ 
bitunicate, cylindrical, apical ends obtuse, smooth-walled, short pedicellate, persistent. Ascospores (19.4)19.7-24.9 $\times$ (4.1) $4.3-5 \mu \mathrm{m}(\bar{x}=21.9 \times 4.7, \mathrm{n}=25)$, uni-seriate, fusoid, obtuse ends, hyaline, 3 -distoseptate, apical ends slightly bent. Asexual morph: Undetermined.

Material examined: India, Andaman and Nicobar Islands,

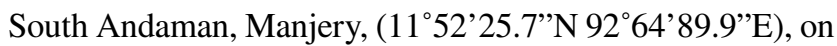
unidentified twig, 10 December 2017, M. Niranjan (AMH 9984, holotype), extype living culture NFCCI: 4377.

GenBank numbers: ITS: MK024391, LSU: MH971236.

Notes: Dyfrolomyces distoseptatus clustered with $D$. thamplaensis with strong bootstrap support (100\%) in ML analysis. It also forms a sister relationship clade with $D$. sinensis (Fig. 29). However, D. distoseptatus has several distinguishable characters. It is closely related to $D$. thamplaensis in having distoseptate ascospores with acute ends, but the ascospores in the latter have prominent guttules. In addition, the asci of $D$. distoseptatus are smaller than $D$. thamplaensis $(123.1-148.6 \times 4.1-6.3 \mu \mathrm{m}$ vs. $114-160 \times$ 6-8.5 $\mu \mathrm{m}$ ) (Zhang et al. 2017a). Furthermore, D. distoseptatus produces ascospores that are 3-septate when compared to 6-7 septate ascospores in D. sinensis (Hyde et al. 2018). Hence, based on the above-mentioned morphological differences (Fig. 30) and molecular sequence analyses (Fig. 29), a new species, Dyfrolomyces distoseptatus, is introduced.

Melomastia Nitschke ex Sacc., Atti Soc. Veneto-Trent. Sci. Nat., Padova, Sér. 4 4: 90 (1875).

Index Fungorum number: IF 3118; Facesoffungi number: FoF 07673; - 24 morphological species (Species Fungorum 2020), 2 species with molecular data.

Type species: Melomastia mastoidea (Fr.) J. Schröt., in Chon, Krypt. -Fl. Schlesien (Breslau) 3.2(3): 320 (1894) [1908].

三Sphaeria mastoidea Fr., K. svenska Vetensk-Akad. Handl., ser. 3 38: 267 (1817).

Notes: Melomastia was introduced by Saccardo (1875) to accommodate the type species M. friesii. Schröter (1894) synonymized $M$. friesii under $M$. mastoidea. Species of Melomastia are characterized by immersed, black, ostiolate ascomata, cylindrical, thick-walled, pedicellate asci with a J- subapical ring, and ovoid, hyaline, 2-septate, guttulate ascospores (Norphanphoun et al. 2017).

\section{Economic significance}

Only three genera are accepted in Pleurotremaceae, and most of the taxa in this family are saprobes in aquatic, mangrove and terrestrial habitats (Pang et al. 2013; Norphanphoun et al. 2017; Zhang et al. 2017a).

Eremithallales Lücking \& Lumbsch.

Index Fungorum number: IF 540500; Facesoffungi number: FoF 07674.
Eremithallales was introduced for a single species Eremithallus costaricensis (Lücking et al. 2008). Previously Eremithallales was reported close to Lichinomycetes. However, both phylogenetic and morpholocal analysis confirmed the placement of this order in Dothideomycetes with strong support and later Melaspileaceae was included (Ertz and Diederich 2015). In Hongsanan et al. (2020), Eremithallales froms a distinct clade within Dothideomycetes. The divergence time for Eremithallales is estimated as 238 MYA (stem age Hongsanan et al. 2020).

Accepted families: Melaspileaceae.

Melaspileaceae Walt. Watson, New Phytol. 28: 94 (1929).

$=$ Eremithallaceae Lücking \& Lumbsch, in Lücking, Lumbsch, Di Stéfano, Lizano, Carranza, Bernecker, Chaves \& Umaña, Symbiosis 46(3): 163 (2008).

Index Fungorum number: IF 80992; Facesoffungi number: FoF 07675, 40 species.

Lichenized. Thallus thin, white, corticolous, with Trentepohlia photobiont. Sexual morph: Ascomata apothecioid, immersed when young, erumpent to superficial when mature, with a flat to slightly convex disk and a slightly elevated margin, often surrounded by marginal lobes from the substrate, roundish. Peridium reddish brown, $\mathrm{K}+$ olivaceous brown at exciple issue, with a I- hymenium, apically not enlarged, cellular pseudoparaphyses that are sometimes branched or anastomosed, anastomosed periphyses arising from the inner excipular layer. Asci 6-8-spored, elongate or clavate to subcylindrical, wall apically thickened, with a distinct ocular chamber, I- and K/I-. Ascospores overlapping, 2-seriate, ellipsoid to oblong, hyaline to brown, 1-septate, constricted near the septum, smooth-walled, sometimes K/ $\mathrm{I}+$ blue gelatinous sheath. Asexual morph: Undetermined.

Type: Melaspilea Nyl.

Notes: The taxonomic placement of this group was uncertain due to the absence of molecular data. However, the first phylogenetic analysis confirmed the placement of Melaspileaceae under Eremithallales. The same result is shown in our phylogenetic tree (Fig. 31). Morphologically, Melaspilea sensu stricto is similar to Eremithallus in ascomata, exciple, hamathecium, ascus and ascospore types, and being lichenized with a trentepohlioid photobiont (Ertz and Diederich 2015). Thus, Eremithallus was reduced as a synonym of Melaspilea and Eremithallaceae was synonymized under Melaspileaceae (Ertz and Diederich 2015). This was followed by Wijayawardene et al. (2017a) and our study.

Melaspilea Nyl., Act. Soc. linn. Bordeaux 21(4): 416 (1857) [1856].

$=$ Eremithallus Lücking, Lumbsch \& L. Umaña, in Lücking et al., Symbiosis 46(3): 163 (2008). 
Fig. 31 Phylogram generated from maximum likelihood analysis (RAxML) of Eremithallales based on LSU and SSU sequence data. Maximum likelihood bootstrap values equal or above $70 \%$, Bayesian posterior probabilities equal or above 0.90 (MLBS/PP) are given at the nodes. An original isolate number is noted after the species name. The tree is rooted to Diploschistes ocellatus (AFTOL 958) and Stictis radiata (AFTOL 398). The ex-type and references strains is indicated in bold. Hyphen (-) represents support values below $70 \%$ MLBS and $0.90 \mathrm{PP}$

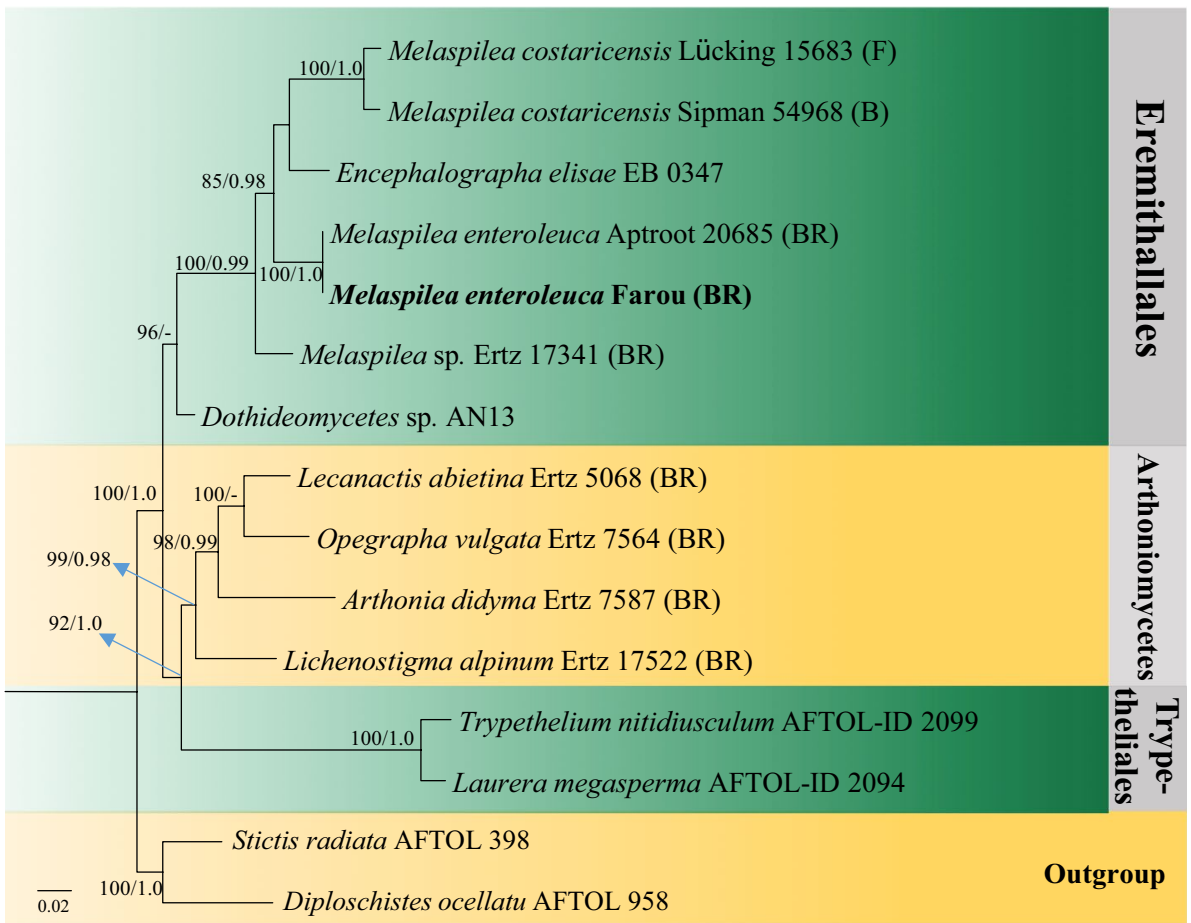

Index Fungorum number: IF 3094; Facesoffungi number: FoF 07676; 37 morphological species (Species Fungorum 2020), 3 species with molecular data.

Type species: Melaspilea arthonioides (A. Massal.) Nyl.

$\equiv$ Catillaria arthonioides A. Massal., Geneac. lich. (Verona): 19 (1854).

Notes: Melaspilea was introduced for two species $M$. deformis and $M$. arthonioides. Taxa in this genus are distributed worldwide and occur primarily as epiphytes on bark or wood, rocks and parasites or commensals with lichens (Ertz and Diederich 2015). Melaspilea is a heterogeneous group and more collections are needed to resolve the genus (Ertz and Diederich 2015).

Melaspilea enteroleuca (Ach.) Ertz \& Diederich, Fungal Diversity 71: 151 (2015).

三Lecidea enteroleuca Ach., Lich. univ.: 177 (1810).

Index Fungorum number: IF 811372; Facesoffungi number: FoF 07677; Fig. 32

Description and discussions: see epitype in Ertz and Diederich (2015).

\section{Other genus included}

Encephalographa A. Massal., Geneac. lich. (Verona): 13 (1854).

Index Fungorum number: IF 1776; Facesoffungi number: FoF 07678; -3 morphological species (Species Fungorum 2020), 1 species with molecular data.

Type species: Encephalographa cerebrina (DC.) A. Massal., Miscell. Lichenol.: 49 (1856).
三 Opegrapha cerebrina DC., in Lamarck \& de Candolle, Fl. franç., Edn 3 (Paris) 2: 312 (1805).

Notes: Encephalographa comprises only a single species (Wijayawardene et al. 2017a). This genus was placed in Hysteriaceae (Renobales and Aguirre 1990). Ertz and Diederich (2015) indicated that the type species Encephalographa elisae, belongs in Eremithallales. Presently, Encephalographa is included in Melaspileaceae (Ertz and Diederich 2015). The species is characterized by saxicolous, lirelliform, superficial and black ascomata, lichenized, dark brown to black exciple, I- hymenium, anastomosed paraphyses, clavate, 8-spored and thick-walled asci, apically thickened with distinct ocular chamber, I- and K/I-, and ellipsoid, 1-septate, smooth to finely ornamented, hyaline to brownish ascospores, constricted at the septum with thin perispore (Renobales and Aguirre 1990; Ertz and Diederich 2015).

\section{Economic and ecological significance}

Melaspileaceae comprises lichenized, lichenicolous and saprobic taxa (Ertz and Diederich 2015). Saprobic fungi play a vital role in decomposing plant and animal debris (Dix and Webster 1995) while lichens are frequently used as air pollution indicators, which is a simple and economically viable approach to detect and monitor air pollution (Lopes et al. 2019).

Eremomycetales Crous, Spatafora, Haridas \& I.V. Grig., in Haridas et al., Stud. Mycol. 96: 151 (2020)

Index Fungorum number: IF 831891; Facesoffungi number: FoF 07679 

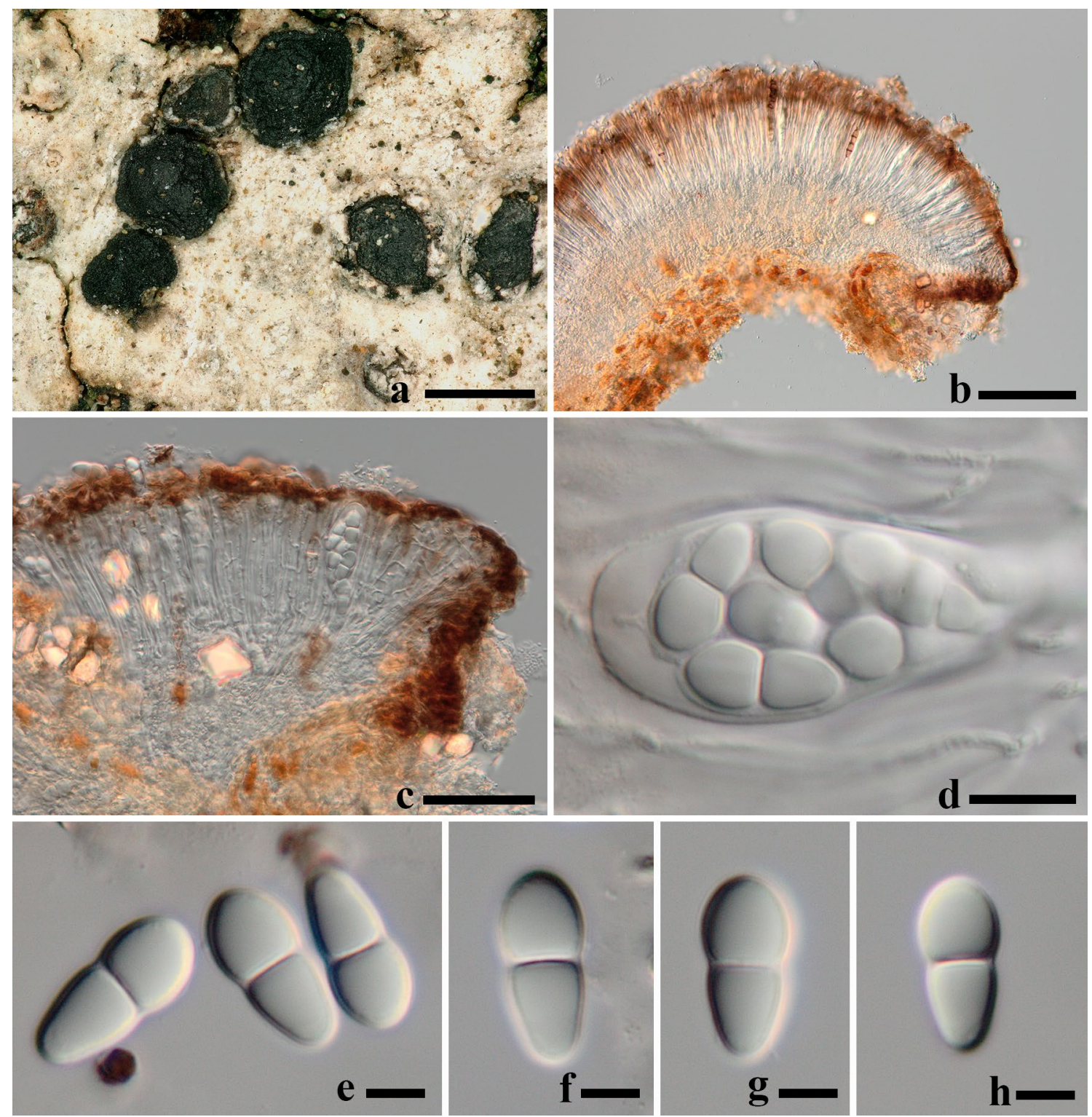

Fig. 32 Melaspilea enteroleuca (France, Ertz 19235 (BR)). a Thallus with apothecia. b Section of a single apothecium in water. c Hymenium and ascomatal margin in water. $\mathbf{d}$ Ascus in water. e Ascospores in water. Scale bars: $\mathbf{a}=0.5 \mathrm{~mm}, \mathbf{b}=100 \mu \mathrm{m}, \mathbf{c}=50 \mu \mathrm{m}, \mathbf{d}=10 \mu \mathrm{m}, \mathbf{e}=5 \mu \mathrm{m}$

Notes: This order was introduced by Haridas et al. (2020). Analyses of combined LSU and SSU sequence data (Fig. 33) reveals that the genera Arthrographis, Eremomyces and Rhexothecium grouped together, forming a distinct clade apart from other orders in Dothideomycetes. The divergence time for Eremomycetales is estimated as 262 MYA (stem age, Hongsanan et al. 2020).

Accepted families: Eremomycetaceae.

Eremomycetaceae Malloch \& Cain, Can. J. Bot. 49: 847 (1971).

Index Fungorum number: IF 80751; Facesoffungi number: FoF 05359, 3 species.
Saprobic, isolated primarily on animal dung or soil. Colonies flocculent, drift white, superficial, dense, and growing slowly on agar media. Hyphae septate, branch, hyaline to brown. Sexual morph: Ascomata sphaerical to ellipsoid, solitary, scattered, superficial on hyphae, or submerged in the agar, dark brown to black, lacking ostioles, but tending to split open before maturity. Peridium thin, pseudoparenchymatous, composed of large brown cells of textura angularis. Hamathecium lacking pseudoparaphyses. Asci irregularly disposed within the ascoma, 8-spored, bitunicate, not fissitunicate, obovoid to clavate, thin-walled, pedicellate, and evanescent. Ascospores multi-seriate, small, often fabiform to broadly oblate, hyaline to pale brown, aseptate, 
Fig. 33 Phylogram generated from maximum likelihood analysis (RAxML) of genera in Eremomycetales based on LSU and SSU sequence data. Maximum likelihood bootstrap values equal or above $70 \%$, Bayesian posterior probabilities equal or above 0.90 (MLBS/ PP) are given at the nodes. An original isolate number is noted after the species name. The tree is rooted to Dyfrolomyces thamplaensis (MFLUCC 15-0635). The ex-type strains are indicated in bold. Hyphen (-) represents support values below $70 \%$ MLBS and 0.90 PP

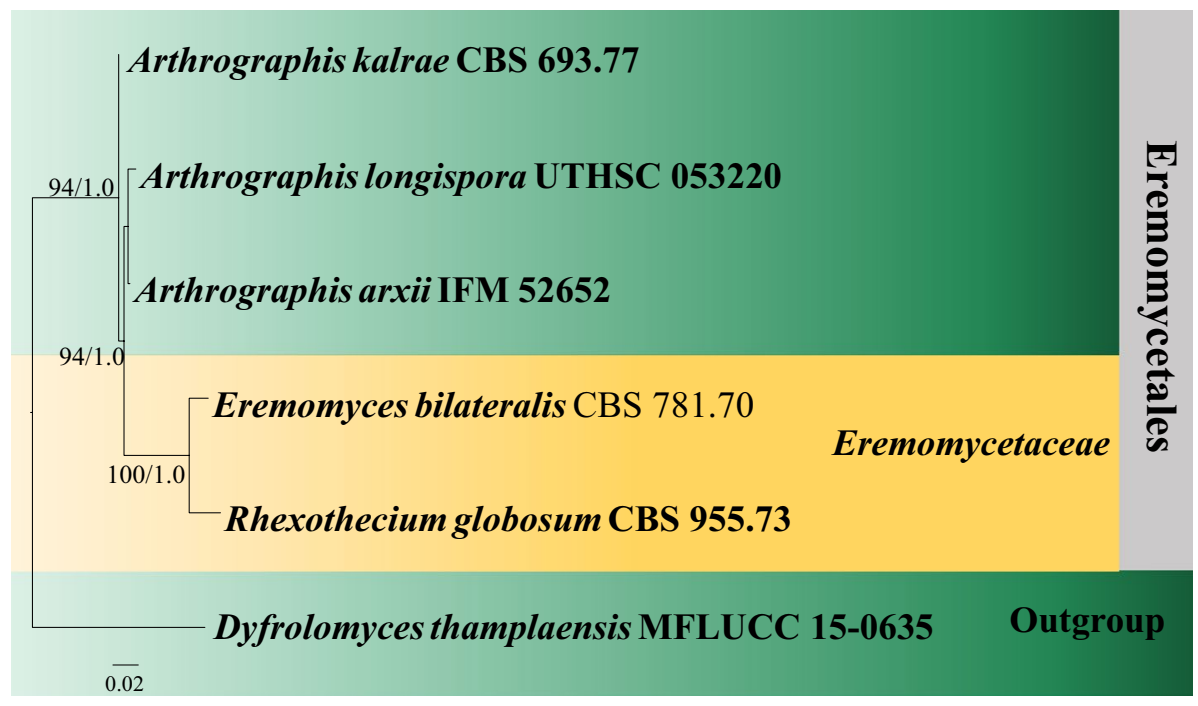

smooth-walled to slightly verrucose. Asexual morph: Coelomycetous or hyphomycetous. Pycnidia globose to subglobose, thin-walled, papillate. Conidiophores filiform, septate, hyaline to brown. Conidia ellipsoidal, hyaline, aseptate, thinwalled, guttulate.

Type: Eremomyces Malloch \& Cain.

Notes: Malloch and Cain (1971) introduced Eremomycetaceae for species having solitary ascomata and hyaline, aseptate ascospores. Eremomycetaceae consists of three species: Eremomyces bilateralis, Rhexothecium globosum, and Pithoascus langeronii, (= Eremomyces langeronii). Eremomycetaceae are most similar to Pseudeurotiaceae (Malloch and Sigler 1988), but differ in ascomatal initials (coiled in Pseudeurotiaceae, pseudoparenchymatous in Eremomycetaceae). Eremomycetaceae comprises two genera Eremomyces, the type genus and Rhexothecium (Lumbsch and Huhndorf 2010). Eremomyces has fabiform and hyaline ascospores, while Rhexothecium has broadly oblate and pale yellow to brown ascospores. Eremomyces is more similar to Trichosporiella (Helotiales) in having subglobose to globose, black conidiomata and scopulariopsis-like hyaline conidia. Rhexothecium resembles Trichosporiella (Helotiales) in having solitary to catenulate, lateral, and hyaline, basic truncate conidia. Species of Eremomycetaceae are distributed worldwide and can be commonly found in Egypt, Kenya, North America and the Netherlands. Wijayawardene et al. (2018) included Arthrographis in Eremomycetaceae, while Liu et al. (2017) included Arthrographis in a new family Arthrographaceae. However, whether Arthrographaceae is valid or not is unclear as there is no mention of this family in the literature or in Index Fungorum. Members of both Arthrographis and Eremomyces produce hyaline to subhyaline conidia, however Arthrographis is distinct in producing unicellular arthroconidia and chlamydospores which are absent in Eremomyces. We include Arthrographis in
Eremomycetales, genera incertae sedis until further studies are carried out.

Eremomyces Malloch \& Cain, Can. J. Bot. 49(6): 847 (1971).

= Pithoascina Valmaseda et al., Can. J. Bot. 65(9): 1905 (1987).

Index Fungorum number: IF 1880; Facesoffungi number: FoF 05360; 2 morphological species (Species Fungorum 2020), 1 species with molecular data.

Type species: Eremomyces bilateralis Malloch \& Cain.

Notes: Eremomyces bilateralis, which was isolated on dung of the North American porcupine. The genus is characterised by pseudoparenchymatous ascomatal initials and cleistothecia, clavate to ovoid, evanescent short asci and one-celled hyaline to pale brown ascospores (Hyde et al. 2013). Superficially, Eremomyces resembles some tropical parasites such as Cleistosphaera and Pilgeriella (Malloch and Cain 1971). However, it differs from these genera in having irregularly disposed asci, a cephalothecoid peridium and in its coprophilous habitat. Eremomyces was compared to members of Sporormiaceae based on cleistothecial characters and members of Venturiaceae as it produces setose ascomata (Malloch and Cain 1971). Presently, it is clear that Eremomyces is distinct from all other genera and it is included in its own monotypic family Eremomycetaceae because of apparent lack of close association with any other group. Cultures and sequence data are available but lacking for the type.

Eremomyces bilateralis Malloch \& Cain, Can. J. Bot. 49(6): 849 (1971).

Index Fungorum number: IF 313945; Facesoffungi number: FoF 05361; Fig. 34 


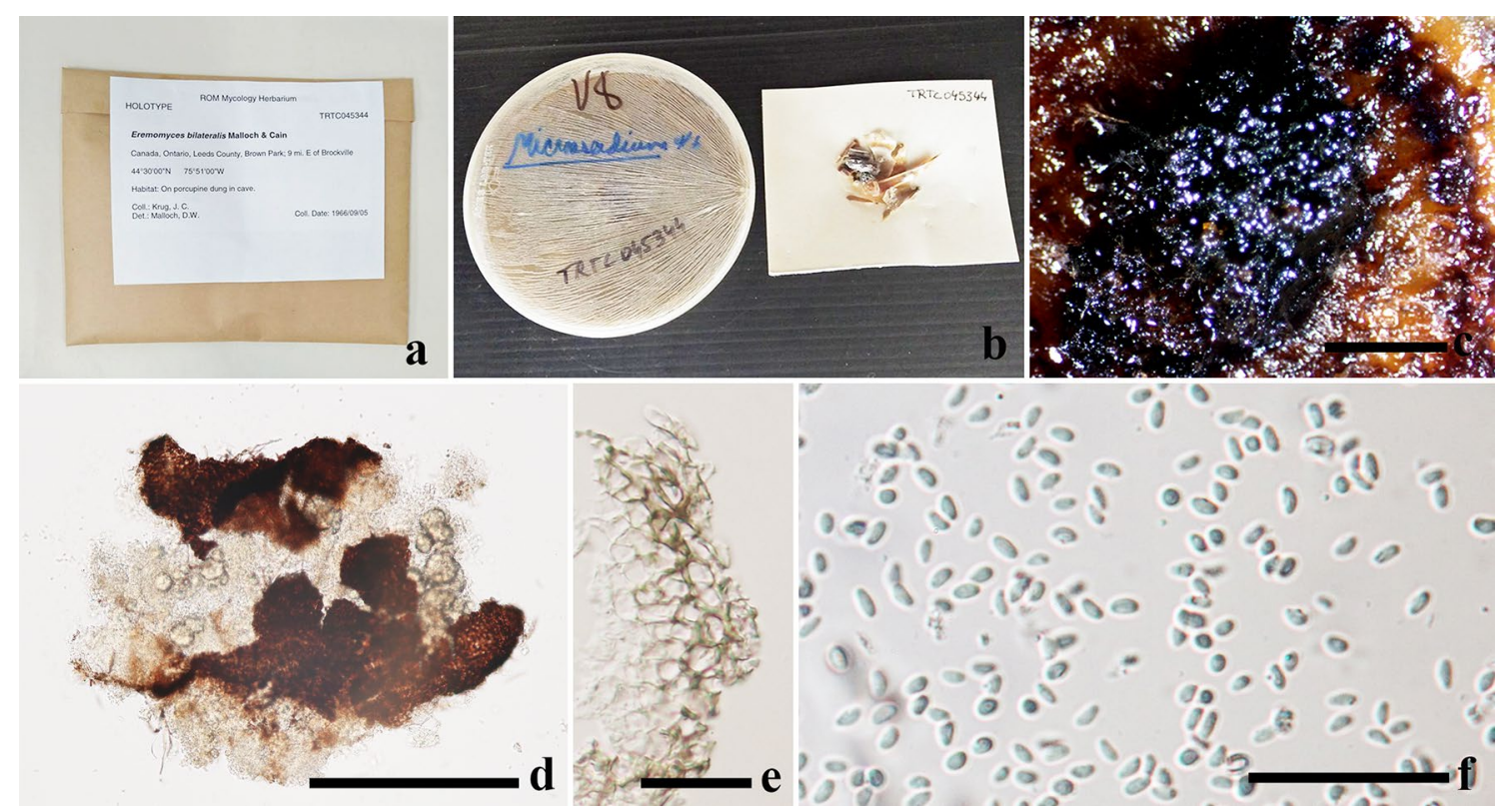

Fig. 34 Eremomyces bilateralis (TRTC 045344, holotype). a Herbarium packet and label. b Hebarium culture c Pycnidium on the upper surface of agar media. $\mathbf{d}$ Squash mount of pycnidium. e Conidia. Scale bars: $\mathbf{c}=2000 \mu \mathrm{m}, \mathbf{d}=300 \mu \mathrm{m}, \mathbf{e}=25 \mu \mathrm{m}, \mathbf{f}=50 \mu \mathrm{m}$

Saprobic on dung of the North American porcupine. Colonies flocculent, drift white to dark brown, superficial, compact, and growing slowly on agar media. Hyphae septate, branched, hyaline to brown. Sexual morph: Ascomata solitary, scattered, superficial on hyphae, globose to ellipsoid, dark brown to black, lacking ostioles. Peridium thin, composed of large brown cells of textura angularis. Hamathecium lacking pseudoparaphyses. Asci 8-spored, bitunicate, obovoid, thin-walled, pedicellate, evanescent. Ascospores multi-seriate, fabiform, hyaline, aseptate, smooth-walled (adapted from Hyde et al. 2013). Asexual morph: Coelomycetous. Pycnidia in culture brown to dark-brown, globose to subglobose, thin-walled, papillate. Conidiophores filiform, septate, hyaline to brown. Conidiogenous cells formed inside the swollen part. Conidia 3.2-4.8 $\times 1.7-2.8 \mu \mathrm{m}(\bar{x}=3.85 \times$ $2.3 \mu \mathrm{m}, \mathrm{n}=20$ ), ellipsoidal, hyaline, aseptate, thin-walled, guttulate.

Material examined: Canada, Ontario, Leeds Co., East of Brockville, on porcupine dung in cave, 5 September 1966, J.C. Krug (TRTC 45344, holotype).

Notes: Eremomyces bilateralis is found on dung of usually sedentary animals, particularly rodents in Canada (Ontario), Kenya, Tanzania and the USA (California). Colonies are relatively slow growing on most media. Ascomata tend to be fragmented when immature and lack characteristic cephalothecoid peridium when mature. On the natural substrate the ascomata are equally conspicuous and produce short setae compared to long hairs seen in culture.

\section{Other genera included}

Rhexothecium Samson \& Mouch., Can. J. Bot. 53(16): 1637 (1975).

Index Fungorum number: IF 4699; Facesoffungi number: FoF 06699; - 1 morphological species (Species Fungorum 2020), 1 species with molecular data.

Type species: Rhexothecium globosum Samson \& Mouch., Can. J. Bot. 53(16): 1637 (1975).

Notes: Rhexothecium globosum was found from desert soil in Egypt. The genus is characterised by sphaerical ascomata with a pseudoparenchymatous peridium, clavate 8 -spored asci and yellow to yellow-brown sphaerical ascospores. The asexual morph of Rhexothecium is hyphomycetous and described as trichosporiella-like. Hyde et al. (2013) accepted Rhexothecium as a genus in Eremomycetaceae. Cultures and sequence data are available but lacking for the type species.

\section{Economic and ecological significance}

Species included in Eremomyces are implicated as opportunistic human pathogens.

Jahnulales K.L. Pang, Abdel-Wahab, El-Shar., E.B.G. Jones \& Sivichai.

Index Fungorum number: IF 90550; Facesoffungi number: FoF 07682.

Jahnulales was introduced in Dothideomycetes based on phylogenetic analysis of SSU nrDNA sequence data from Aliquandostipite, Jahnula and Patescospora (Pang et al. 2002). This order is phylogenetically related to the 


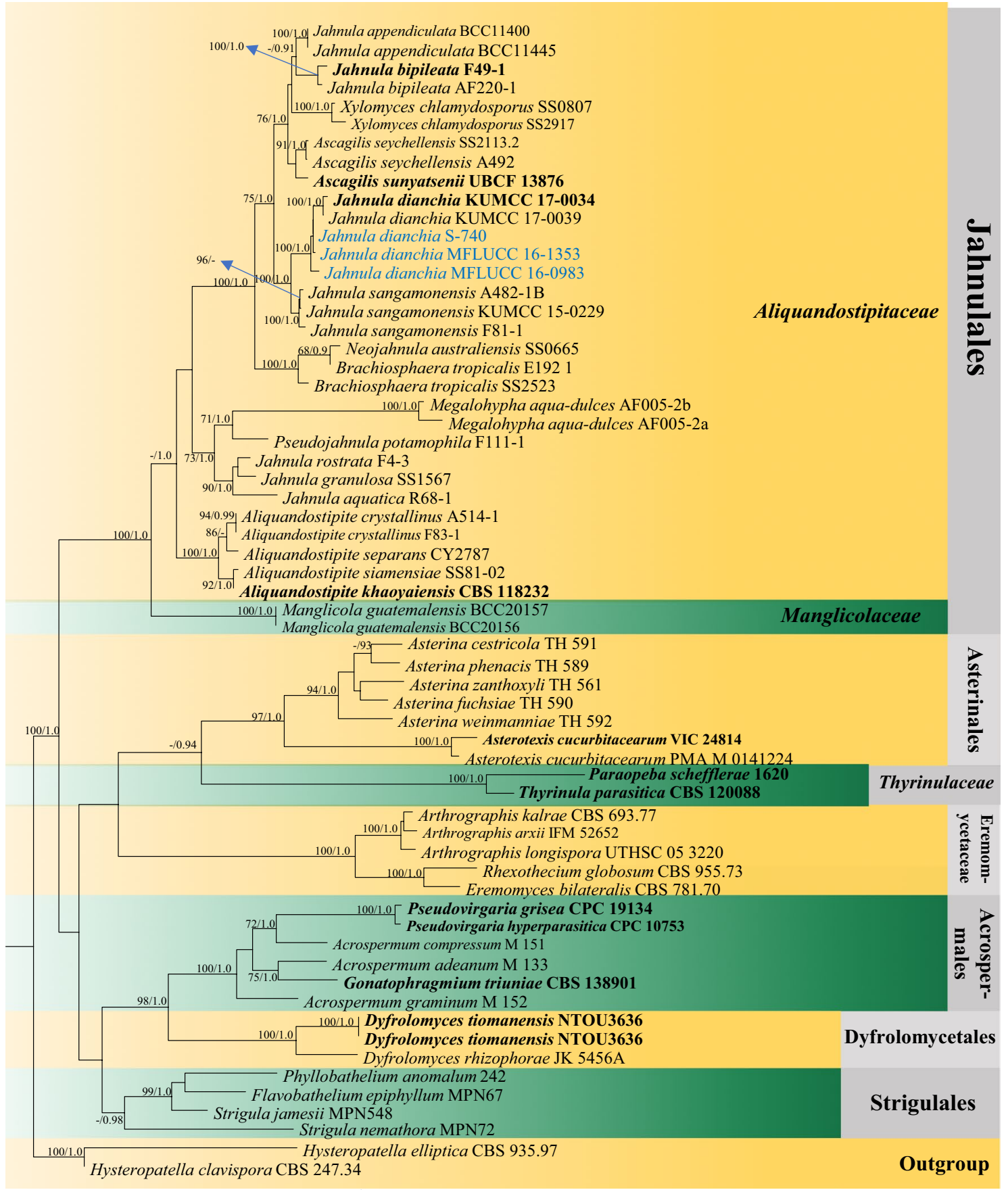

Fig. 35 Phylogram generated from maximum likelihood analysis (RAxML) of Jahnulales based on ITS, LSU and SSU sequence data. Maximum likelihood bootstrap values equal or above $60 \%$, Bayesian posterior probabilities equal or above 0.90 (MLBS/PP) are given at

Dothideales, Patellariales and Pleosporales (Campbell et al. 2007). Most Jahnulales species occur on rotting or soft submerged corticated or decorticated wood (Huang et al. 2018). Phylogenetic analyses (Fig. 35) indicate that Jahnulales comprises two major lineages which are designated as the nodes. Isolate/specimen number is noted after the species name. The tree is rooted to Hysteropatella clavispora (CBS 247.34) and H. elliptica (CBS 935.97). The ex-type strains are indicated in bold. Hyphen (-) represents support values below 70\% MLBS and 0.90 PP

two different families (Aliquandostipitaceae and Manglicolaceae). Jahnula forms as paraphyletic within Aliquandostipitaceae. The divergence time for Jahnulales is estimated as 204 MYA (stem age, Hongsanan et al. 2020).

Accepted families: Aliquandostipitaceae, Manglicolaceae. 
Aliquandostipitaceae Inderb., in Inderbitzin et al., Am. J. Bot. 88(1): 54 (2001).

Index Fungorum IF82130; Facesoffungi number: FoF 07683, 36 species.

Saprobic on submerged or trapped decorticated wood or leaves in freshwater streams, rivers, lakes, peat swamps and marine habitats. Sexual morph: Ascomata scattered or rarely in small groups, immersed to erumpent or superficial, if superficial often attached to substrate by hyphal stalks, with repent or pendant thick brown hyphal strands, globose to subglobose, hyaline, pale brown or black, coriaceous to subcarbonaceous, ostiolate, papillate. Peridium variable, 3-7 cell layers thick, comprising very large, light brown to brown, thin-walled, cells of textura globulosa to angularis. Hamathecium comprising 2-7 $\mu \mathrm{m}$ wide, hyaline, septate, sparsely branched, filamentous, cellular pseudoparaphyses, anastomosing above the asci. Asci 8-spored, bitunicate, fissitunicate, clavate to cylindrical, pedicel absent or very short, with or without an ocular chamber. Ascospores 2- to multiseriate, ellipsoid to fusiform, hyaline to pale brown to dark brown, 1-septate, guttulate, with or without various types of appendages and/or sheaths. Asexual morph: Hyphomycetous. Conidiophores reduced or un-branched or sparingly branched, hyaline. Conidiogenous cells monoblastic, thallic or sympodial or percurrent, monilioid, hyaline or brown. Conidia phragmosporous or staurosporous, with globose central cell, with 4-several, radiating septate arms, hyaline or brown, single or branched or un-branched chains (Seifert et al. 2011) or tetraradiate with 4-8 appendages.

Type: Aliquandostipite Inderb.

Notes: Aliquandostipitaceae was introduced by Inderbitzin et al. (2001) for taxa characterized by mycelium five times wider than those of most ascomycetes. Ascomata, borne either on these thick hyphae or on hyphal stalks are membranous, have a hamathecium of persistent pseudoparaphyses, bitunicate asci and hyaline to pale brown, 1-septate ascospores with or without a sheath or with appendages.

Manglicola has also been referred to the Jahnulales and as the type for Manglicolaceae by Suetrong et al. (2011). Patescospora was synonymised under Aliquandostipite (Suetrong et al. 2011). The phylogenetic analysis based on ITS and LSU sequence data showed that the genera Aliquandostipite, Ascagilis, Brachiosphaera, Jahnula, Megalohypha, Neojahnula Pseudojahnula, and Xylomyces cluster together with high support (100\% ML, 1.00 PP). We follow the previous studies and accept these eight genera in Aliquandostipitaceae (Dong et al. 2020).

Aliquandostipite Inderb., Am. J. Bot. 88(1): 54 (2001).

Index Fungorum number: IF 28650; Facesoffungi number: FoF 07684; 6 morphological species (Index Fungorum 2020), 6 species with molecular data.

Type species: Aliquandostipite khaoyaiensis Inderb.
Notes: The genus was introduced for two freshwater lignicolous ascomycetes collected in Thailand and China and it is characterised by immersed-erumpent or superficial ascomata. Hamathecium consists of pseudoparaphyses. Asci are bitunicate, and fissitunicate. Hyphae are up to $50 \mu \mathrm{m}$ wide (Suetrong et al. 2011; Liu et al. 2015).

\section{Other genera included}

Ascagilis K.D. Hyde, Aust. Syst. Bot. 5(1): 109 (1992).

Index Fungorum number: IF 21262; Facesoffungi number: FoF 09187; -7 morphological species (Dong et al. 2020), 7 species with molecular data.

Type species: Ascagilis bipolaris K.D. Hyde, Aust. Syst. Bot. 5(1): 111 (1992).

Notes: The type species Ascagilis bipolaris was transferred to Jahnula by Hyde and Wong (1999). Dong et al. (2020) resurrected Ascagilis to accommodate 7 species based on its mucilaginous pad of ascospores which is considered as noticeable characteristic of Ascagilis. Phylogenetic analyses supported the placement of Ascagilis in Aliquandostipitaceae (Dong et al. 2020; this study).

Brachiosphaera Nawawi, in Descals et al., Trans. Br. mycol. Soc. 67: 213 (1976).

Index Fungorum number: IF 7438; Facesoffungi number: FoF 07685; -2 morphological species (Species Fungorum 2020), 2 species with molecular data.

Type species: Brachiosphaera tropicalis Nawawi, Transactions of the British Mycological Society 67 (2): 213 (1976).

Notes: The hyphomycetous genus Brachiosphaera is characterised by its effuse colonies, septate hyphae and conidia frequently formed in chains.

Jahnula Kirschst., Ann. mycol. 34(3): 196 (1936). Index Fungorum number: IF 2526; Facesoffungi number: FoF 07686; - 17 morphological species (Huang et al. 2018, Species Fungorum 2020), 6 species with molecular data.

Type species: Jahnula aquatica (Plötner \& Kirschst.) Kirschst., Ann. Mycol. 34: 196 (1936).

$\equiv$ Amphisphaeria aquatica Plöttn. \& Kirschst., in Kirschstner, Verh. bot. Ver. Prov. Brandenb. 48: 52 (1906) [1907].

Notes: The largest genus within Jahnulales, Jahnula, is characterised by perithecial, solitary, superficial to subimmersed ascomata, bitunicate, fissitunicate, cylindrical, pedicellate asci and light brown to dark brown ascospores. All 17 Jahnula species have been reported from wood or decorticated wood in freshwater habitats (Huang et al. 2018). The genus is currently polyphyletic, and Jahnula sensu stricto accommodates J. aquatica, J. granulosa, J. potamophila and J. rostrata (Suetrong et al. 2011; Huang et al. 2018). 

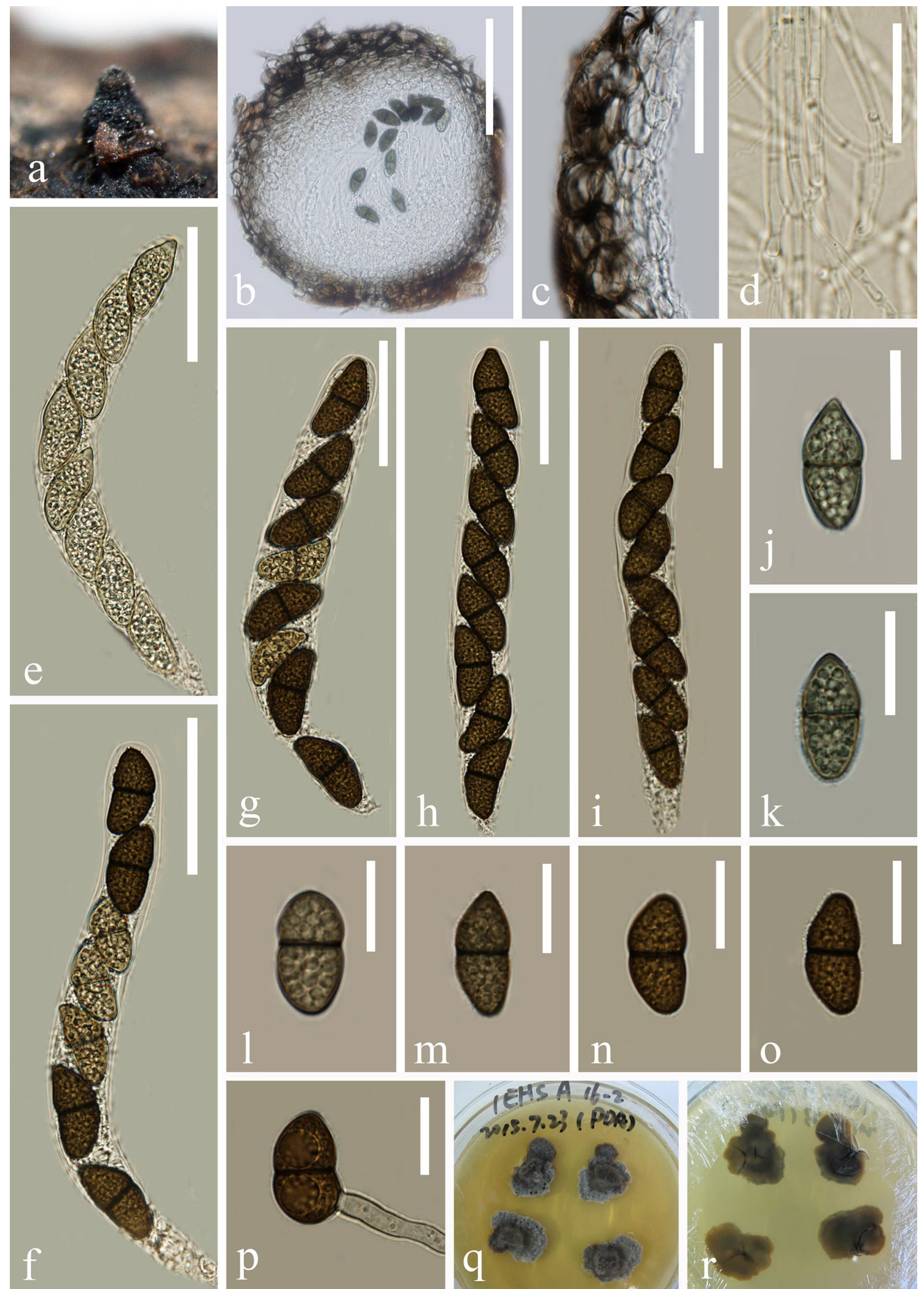

Fig. 36 Jahnula dianchia (HKAS 92632). a Appearance of ascomata on substrate. b Vertical section of ascoma. c Structure of peridium. d Pseudoparaphyses. e-i Asci. j-o Ascospores. p Germinating

ascospore. $\mathbf{q}, \mathbf{r}$ Colony on MEA. Scale bars: $\mathbf{b}=150 \mu \mathrm{m}, \mathbf{c}, \mathbf{e}-\mathbf{i}=50$ $\mu \mathrm{m}, \mathbf{j}-\mathbf{p}=20 \mu \mathrm{m}, \mathbf{d}=15 \mu \mathrm{m}$ 
Jahnula dianchia S.K. Huang \& K.D. Hyde, Mycol. Progr. 17: 549 (2018).

Index Fungorum number: IF 553200; Facesoffungi number: FoF 03149; Fig. 36

Saprobic on decaying wood submerged in freshwater habitats. Sexual morph: Ascomata 285-390 $\mu \mathrm{m}$ high, 250-350 $\mu \mathrm{m}$ diam, perithecial, solitary, superficial to semi-immersed, obpyriform to subglobose, black, papillate, ostiolate. Peridium around $40 \mu \mathrm{m}$ thick, membranous, composed of brown to hyaline cells of textura angularis. Hamathecium comprising 2-3 $\mu \mathrm{m}$ wide, septate, branched, filiform, cellular pseudoparaphyses, embedded in a gelatinous matrix. Asci 150-170 $\mu \mathrm{m}(\bar{x}=160 \mu \mathrm{m}, \mathrm{SD}=10, \mathrm{n}=15)$ long, $15-17$ $\mu \mathrm{m}(\bar{x}=16 \mu \mathrm{m}, \mathrm{SD}=1, \mathrm{n}=15)$ wide, 8 -spored, bitunicate, fissitunicate, cylindrical, pedicellate, rounded at apex, with a distinct ocular chamber. Ascospores $27-29 \mu \mathrm{m}(\bar{x}=28$ $\mu \mathrm{m}, \mathrm{SD}=1, \mathrm{n}=20)$ long, $11-13 \mu \mathrm{m}(\bar{x}=12 \mu \mathrm{m}, \mathrm{SD}=1$, $\mathrm{n}=20$ ) wide, uni-seriate, oval to broadly ellipsoid, slightly curved, initially pale brown, becoming dark brown at maturity, 1-septate, verruculose, multiguttulate. Asexual morph: Undetermined.

Material examined: China, Yunnan Province, saprobic on decaying wood submerged in Erhai Lake, December 2014, Z.L. Luo, S-364 (HKAS 92632), living culture MFLUCC 16-0983; saprobic on decaying wood submerged in Erhai Lake, December 2014, H.Y. Su, S-460, living culture MFLUCC 16-1353; saprobic on decaying wood submerged in a freshwater stream in Cangshan Mountain, June 2016, S.M. Tang, S-740.

GenBank numbers: ITS: MH793537, LSU: MH793543 (MFLUCC 16-0983); ITS: MH793538, LSU: MH793544 (MFLUCC 16-1353), LSU: MT797171 (S-740).

Notes: Jahnula dianchia was collected from a freshwater lake in Yunnan Province, China. During our study of lignicolous freshwater fungi from Northwestern Yunnan Province, three isolates were obtained from different collections. The morphology of those isolates fit well with Jahnula dianchia, and the phylogenetic analysis showed that our isolates cluster with this species wih strong support. We therefore identify our isolates as J. dianchia based on morphology and phylogeny.

Megalohypha A. Ferrer \& Shearer, in Ferrer et al., Mycologia 99: 458 (2007).

Index Fungorum number: IF 505741; Facesoffungi number: FoF 07687; - 1 morphological species (Species Fungorum 2020), 1 species with molecular data.

Type species: Megalohypha aqua-dulces A. Ferrer \& Shearer, in Ferrer et al., Mycologia 99(3): 456 (2007).

Notes: Megalohypha was introduced based on two collections obtained from submerged wood in tropical forest streams in Panama and Thailand. Megalohypha is characterized by hyaline, translucent ascomata, with subtending, wide, brown, septate, stoloniferous hyphae, a peridium of large, thin-walled cells, a hamathecium of septate pseudoparaphyses, clavate, fissitunicate, 8 -spored asci and 1-septate, brown, rough-walled ascospores, with longitudinal sulcate striations (Ferrer et al. 2007).

Neojahnula W. Dong, H. Zhang \& K.D. Hyde, Fungal Divers (revising).

Index Fungorum number: IF 557823; Facesoffungi number: FoF 07688; - 1 morphological species (Dong et al. 2020), 1 species with molecular data.

Type species: Neojahnula australiensis (K.D. Hyde) W. Dong, H. Zhang \& K.D. Hyde, Fungal Divers (revising).

$\equiv$ Jahnula australiensis K.D. Hyde, Aust. Syst. Bot. 6(2): 161 (1993).

Notes: The type species, Neojahnula australiensis was transferred from Jahnula collected from submerged wood in freshwater (Hyde 1993). Phylogenetically, the species clustered basal to Brachiosphaera within Aliquandostipitaceae (Prihatini et al. 2008; Hyde et al. 2017; Huang et al. 2018; Dong et al. 2020). Morphologically, J. australiensis could not be placed in Jahnula because of the few setae surrounding the ascomata, a thin peridium comprising single row of cells, asci with an ocular chamber and a faint apical ring (Dong et al. 2020). Therefore, Dong et al. (2020) introduced Neojahnula to accommodate this species.

Pseudojahnula W. Dong, H. Zhang \& K.D. Hyde, Fungal Divers (revising).

Index Fungorum number: IF 557824; Facesoffungi number: FoF 07689; - 1 morphological species (Dong et al. 2020), 1 species with molecular data.

Type species: Pseudojahnula potamophila (K.D. Hyde \& S.W. Wong) W. Dong, H. Zhang \& K.D. Hyde, Fungal Divers (revising).

三 Jahnula potamophila K.D. Hyde \& S.W. Wong, Nova Hedwigia 68(3-4): 499 (1999).

Notes: Pseudojahnula was introduced by Dong et al. (2020) to accommodate the unstable lineage of Jahnula potamophila. This genus differs from Jahnula by hyaline to metallic grey ascomata, a several-layered peridium, comprising hyaline cells and covered with sparse hyaline hairs, obclavate asci, with an ocular chamber, and ascospores surrounded by a wavy mucilaginous sheath (Hyde and Wong 1999; Dong et al. 2020).

Xylomyces Goos et al., Mycologia 69(2): 282 (1977).

Index Fungorum number: IF 10460; Facesoffungi number: FoF 07690; - 8 morphological species (Species Fungorum 2020), 2 species with molecular data.

Type species: Xylomyces chlamydosporus Goos et al. [as'chlamydosporis’], Mycologia 69(2): 282 (1977). 
Notes: Xylomyces is characterised by large, dematiaceous, thick-walled, multi-septate, more or less fusiform chlamydospores that superficially resemble phragmoconidia, however, it has been shown to be polyphyletic and not all species belong in the Jahnulales.

\section{Ecological significance}

Members of Aliquandostipitaceae are saprobes with the ability to decompose lignocellulose in woody litter, and thus contribute to the recycling of material in aquatic habitats (Yuen et al. 1998; Bucher et al. 2004).

Manglicolaceae Suetrong \& E.B.G. Jones, in Suetrong et al., Fungal Divers 51(1): 183 (2011).

Index Fungorum number: IF 563225; Facesoffungi numbers: FoF 07691, 2 species.

Saprobic on intertidal mangrove wood and the brackish water palm Nypa fruticans. Sexual morph: Ascomata superficial, solitary, or in groups, immersed in the substrate with a hypostroma, obtuse clavate to fusiform, coriaceous, olive-brown, pedicellate, ostiolate, epapillate, periphysate. Peridium thick, 3-5-layered, inner layers hyaline, outer layers pale brown to olive-brown of cells of textura angularis. Hamathecium comprising numerous, simple, septate, trabeculate pseudoparaphyses. Asci 8-spored, bitunicate, cylindrical, thick-walled, with an ocular chamber and a short pedicel, developed at the base of the ascocarp venter between the pseudoparaphyses. Ascospores uni-seriate, fusiform, apiculate, 1-septate, with larger and dark brown upper cell, with smaller and light brown lower cell, gelatinous appendages covering both ends. Asexual morph: Undetermined.

Type: Manglicola Kohlm. \& E. Kohlm.

Notes: The family was introduced to accommodate a marine ascomycete with large, club-shaped, coriaceous ascomata, lacking a papilla, and with trabeculate pseudoparaphyses, cylindrical asci and ascospores, with a large apical cell, and a basal turbinate cell with gelatinous appendages at each end. Phylogenetic analyses using LSU and SSU indicated that Manglicolaceae is related to Aliquandostipitaceae within Jahnulales (100 ML/1.0 PP). This result was confirmed by many studies, such as Suetrong et al. (2011) and Hyde et al. (2013). Manglicolaceae is similar to Aliquandostipitaceae in that it has wide hyphae, ascomata with short stalks, cylindrical asci, and large ascospores with appendages, and all are saprobic species in aquatic habitats (Hyde et al. 2013). However, it differs from Aliquandostipitaceae by its marine mangrove habitat, larger ascomata, with a wide ostiole, surrounded by hyaline, clavate hyphae and periphysate ostioles, large, unequally, 1-septate, pale brown ascospores, with a turbinate basal cell and with few asci per ascoma. Manglicolaceae comprises a monotypic genus, Manglicola.
Manglicola Kohlm. \& E. Kohlm., Mycologia 63(4): 840 (1971).

Index Fungorum number: IF 2995; Facesoffungi number: FoF 07692; 2 morphological species (Species Fungorum 2020), 1 species with molecular data.

Type species: Manglicola guatemalensis Kohlm. \& E. Kohlm.

Notes: Huhndorf (1994) referred Manglicola to the Hypsostromataceae order incertae sedis based on its superficial, large, elongate ascomata (stalked) with a soft texture, trabeculate pseudoparaphyses, long pedicellate asci attached in a basal arrangement in the centrum and fusiform, septate ascospores. However, phylogenetic analyses indicated that Manglicola formed a clade as a family in Jahnulales (Suetrong et al. 2010, 2011; Hyde et al. 2013), while Hypsostroma saxicola and $H$. caimitalense (Hypsostromataceae) are placed in Pleosporales with high bootstrap support (Hyde et al. 2013). Manglicola contains two species, M. guatemalensis (type species) and M. samuelsii Huhndorf. Manglicola guatemalensis differs from $M$. samuelsii by its marine habitat, few asci per ascomata, 1-septate ascospores which are constricted at the septum, deliquescing appendages covering both ascospore apices, with an apical cylindrical appendage and subglobose basal appendage, while $M$. samuelsii is terrestrial, found on bamboo in lowland rainforest, has numerous asci per ascomata and 3-septate ascospores without a sheath or appendages (Jones et al. 2019). Further studies are required to determine if $M$. samuelsii is correctly placed in Manglicolaceae.

Manglicola guatemalensis Kohlm. \& E. Kohlm., Mycologia 63(4): 841 (1971).

Index Fungorum number: IF 317136, Facesoffungi number: FoF 06123; Fig. 37

Saprobic on frond bases of Nypa fruticans. Sexual morph: Ascomata 425-866 $\mu \mathrm{m}$ height, 115-310 $\mu \mathrm{m}$ in diam around the center, obtusely clavate to fusiform, pedicellate, solitary or aggregated, superficial, ostiolate, coriaceous, olive-brown. Ascoma attached by a hypostroma immersed in the host tissue of $N$. fruticans. Hamathecium comprising 1.25-2.5 $\mu \mathrm{m}$ in diam., simple, numerous, septate trabeculate, hyaline, pseudoparaphyses. Asci 300-605 × 30-42.5 $\mu \mathrm{m}$, 8-spored, cylindrical, bitunicate, thick-walled, with an apical apparatus. Ascospores 95-112.5 × 20-30 $\mu \mathrm{m}$, uni-seriate, fusiform, apiculate, light brown to dark brown, unequally 1-septate, constricted at the septum, apical cell larger, basal cell, turbinate, light brown, with a gelatinous appendage at the spore apex. Asexual morph: Undetermined.

Material examined: Thailand, Suratthani Province, Ban Hui Sap Mangrove Forest, superficial on frond bases of Nypa fruticans, 8 Jan 2019, S. Preedanon \& S. Suetrong (BBH 45364). 

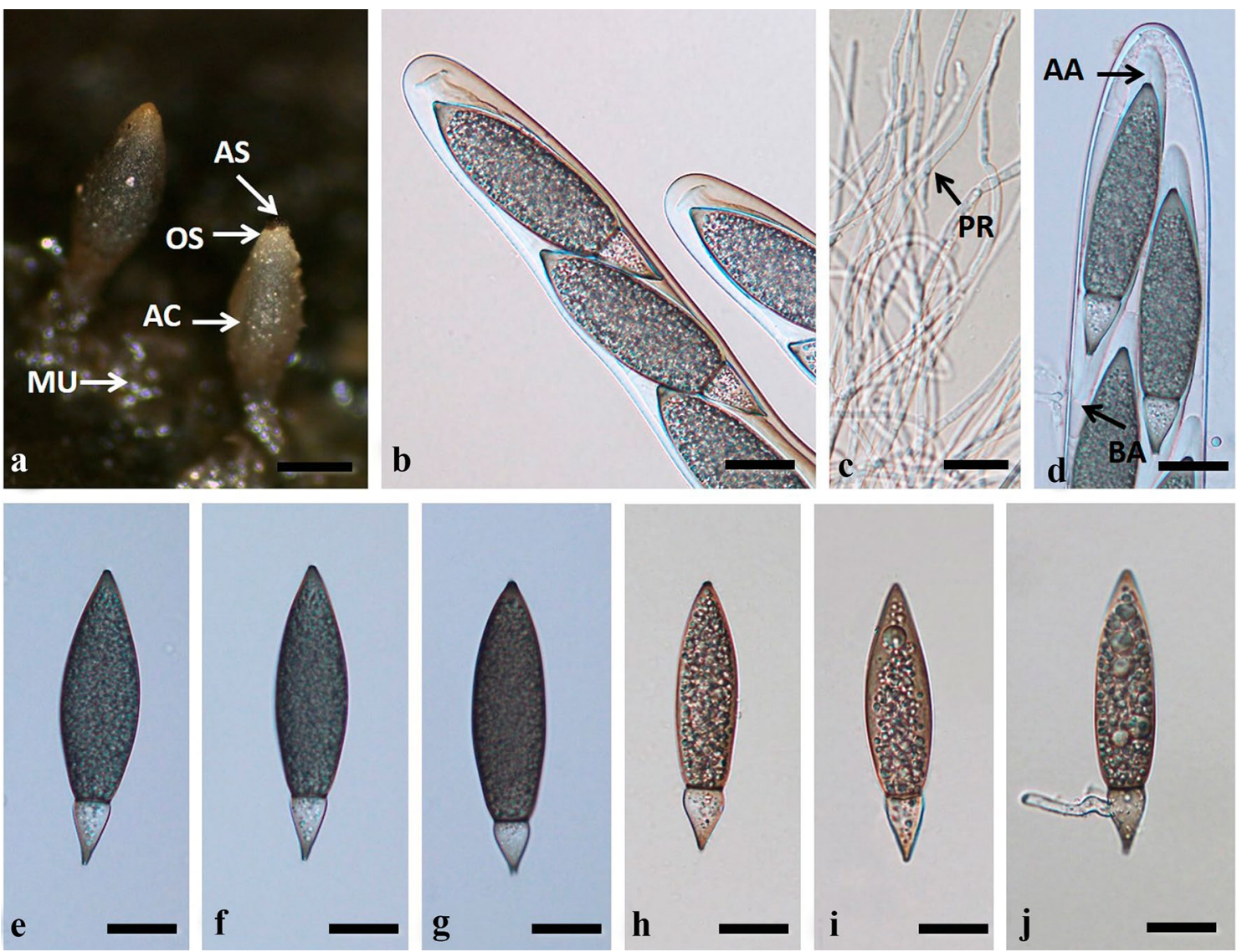

Fig. 37 Manglicola guatemalensis (BBH 45364). a Superficial ascomata on $N$. fruticans, partially immersed in mud (MU), composed of dark ascospores (AS) in mature asci (AC), visible through the thin wall peridium, spores exuded at the ostiole (OS). b Ascus apex with an apical apparatus. c Trabeculate pseudoparaphyses (PR) numerous, septate,

Notes: The genus has been reported as a saprobe from bark of dead roots, and from a seedling of Rhizophora mangle in Guatemala (see morphology Suetrong et al. 2010).

\section{Economic and ecological significance}

Manglicolaceae contains two species saprobic on woody material involved in decay of dead woody structures and likely to be involved in nutrient recycling.

Kirschsteiniotheliales Hernandez-Restrepo, R.F. Castañeda, Gen. \& Crous.

Index Fungorum number: IF 821220; Facesoffungi number: FoF 07693.

Kirschsteiniotheliales was introduced based on phylogenetic analysis. Only a single family Kirschsteiniotheliaceae is accepted in this order. Phylogenetic analyses indicate that Kirschsteiniotheliales formed a distinct clade within Dothideomycetes with high support (Fig. 38). The divergence time for Kirschteiniotheliales is estimated as 221 MYA (stem age, Hongsanan et al. 2020).

simple. d Ascospore in ascus with apical (AA) and basal (BA) appendages. e-i Ascospores. j Germinating ascospore, with germ tube developing laterally from the basal cell. Scale bars: $a=250 \mu \mathrm{m}, \mathbf{b}, \mathbf{e}-\mathbf{j}=25$ $\mu \mathrm{m}, \mathbf{c}=15 \mu \mathrm{m}, \mathbf{d}=20 \mu \mathrm{m}$

\section{Accepted families: Kirschsteiniotheliaceae.}

Kirschsteiniotheliaceae Boonmee \& K.D. Hyde, Mycologia 104(3): 705 (2012).

Index Fungorum number: IF 561021; Facesoffungi number: FoF 01737, 24 species.

Saprobic on decaying wood. Sexual morph: Ascomata superficial, subglobose to globose, dark brown to black, membranaceous, solitary, with a central papilla. Peridium composed of cells of textura angularis. Hamathecium comprising numerous, filiform, hyaline, mostly cellular pseudoparaphyses. Asci 8-spored, bitunicate, cylindrical to clavate, with a long pedicel, apical rounded, with an ocular chamber. Ascospores 2-seriate, ellipsoidal, septate, slightly curved, dull green, brown to dark brown at maturity, with median septum or in lower part, some ascospores with secondary septa, thick-walled, lacking a mucilaginous sheath. Asexual morph: Hyphomycetous. Conidiophores macronematous, mononematous, erect, apically branched, arising straight or slightly curved, solitary, elongate and thick-walled, septate, brown to 


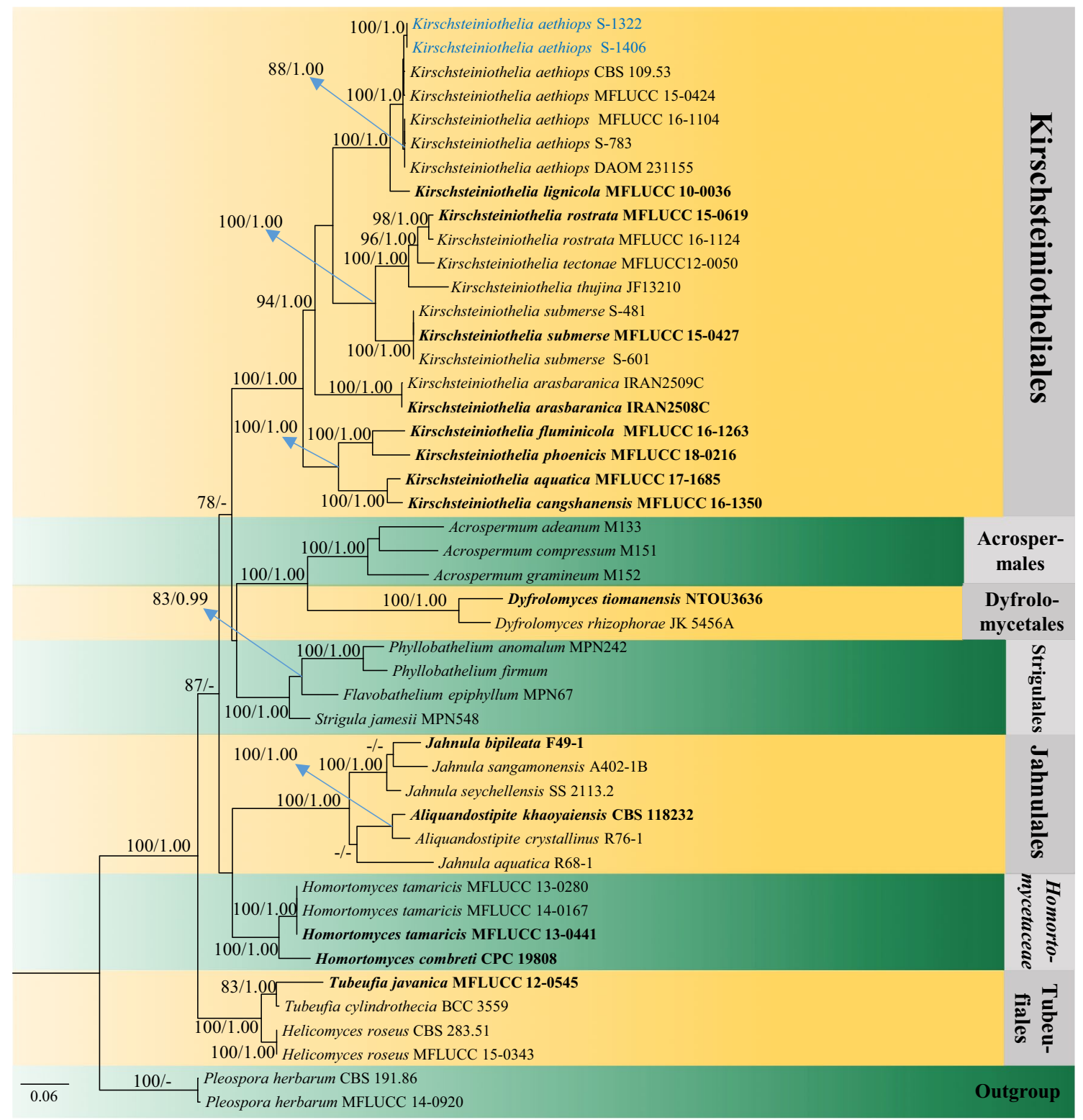

Fig. 38 Phylogram generated from maximum likelihood analysis (RAxML) of Kirschsteiniotheliales based on ITS, LSU and SSU sequence data. Maximum likelihood bootstrap values equal or above $70 \%$, Bayesian posterior probabilities equal or above 0.90 (MLBS/

dark brown, smooth-walled. Conidiogenous cell tretic, terminal, constricted at delimiting septa. Conidia broadly ellipsoid-obovoid, brown to dark brown, constricted and darkly pigmented at the septa, rounded at both ends, smooth-walled.

Type: Kirschsteiniothelia D. Hawksw., J. Linn. Soc., Bot. 91: 182 (1985).

Notes: Kirschsteiniotheliaceae species are mostly saprobes on dead wood from terrestrial and aquatic habitats (Boonmee et al. 2012; Hyde et al. 2013; Su et al. 2016).
PP) are given at the nodes. Isolate/specimen number is noted after the species name. The tree is rooted to Pleospora herbarum (CBS 191.86, MFLUCC 14-0920). The ex-type strains are indicated in bold. Hyphen (-) represents support values below 70\% MLBS and 0.90 PP

Taeniolella is an asexual genus with saprobic, endophytic and lichenicolous life styles. It was found to be a polyphyletic genus distributed between the Dothideomycetes and the Sordariomycetes (Ertz et al. 2016). The type species Taeniolella exilis formed a lineage within Kirschsteiniotheliaceae (Ertz et al. 2016), therefore, the genus was placed in Kirschsteiniotheliaceae by Ertz et al. (2016) and Wijayawardene et al. (2017a). However, Heuchert et al. (2018) and Dong et al. (2020) suggested that four freshwater species of Taeniolella are undoubtedly not congeneric with Taeniolella 

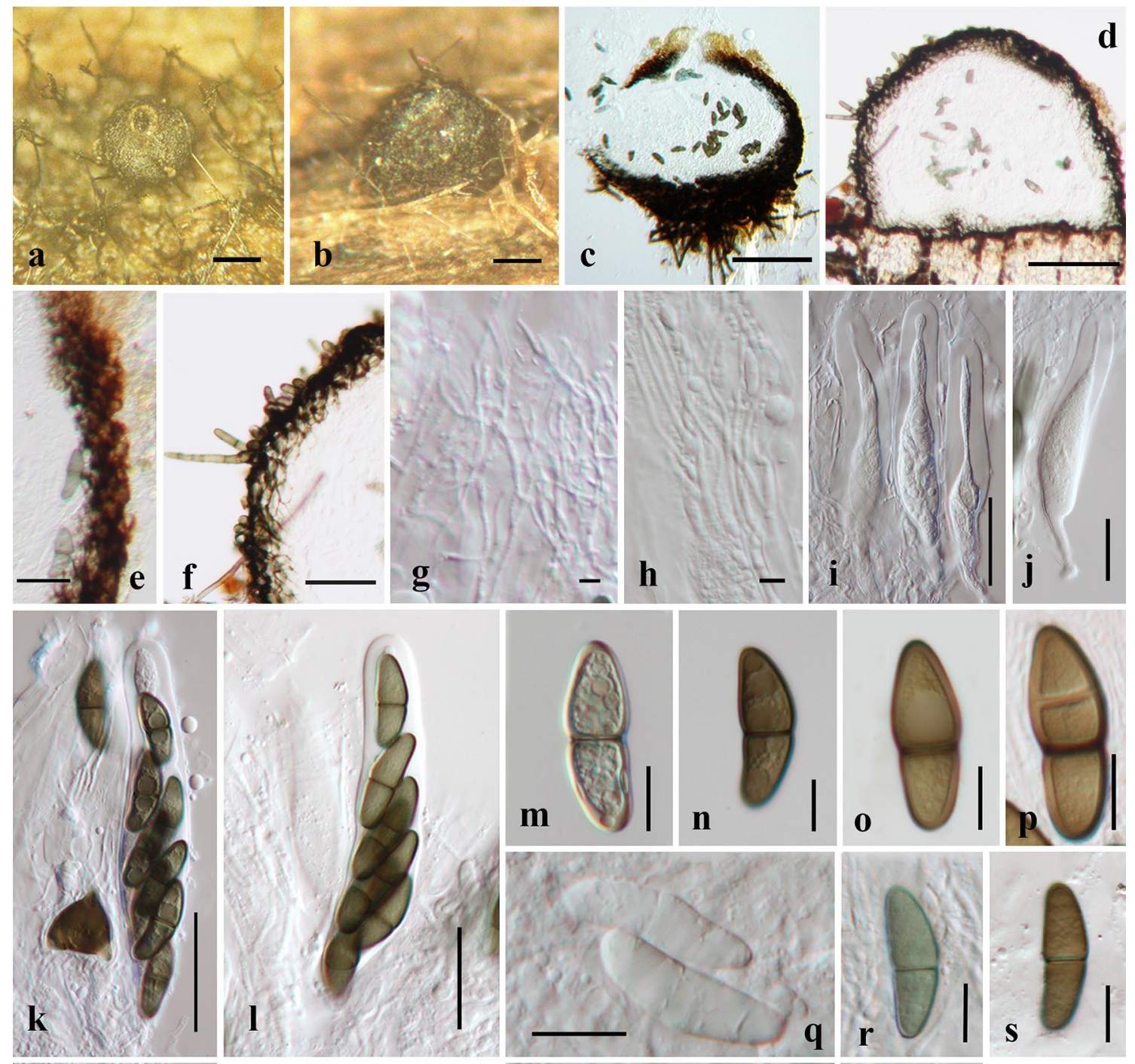

Fig. 39 The sexual morph characters of Kirschsteiniothelia spp. a, b Appearance of ascomata on host surface. c, d Section through ascoma. e, f Peridium. i, j Immature asci. k, l Asci. m-s Ascospores.

sensu lato. Thus, we suggest to exclude this genus from Kirschsteiniotheliaceae and further studies are needed to resolve placement of this group.

Kirschsteiniothelia D. Hawksw., J. Linn. Soc., Bot. 91: 182 (1985).

Index Fungorum number: IF 25723; Facesoffungi number: FoF 08040; 24 morphological species (Bao et al. 2018; Species Fungorum 2020), 11 species with molecular data.

Type species: Kirschsteiniothelia aethiops (Sacc.) D. Hawksw., Bot. J. Linn. Soc. 91(1-2): 185 (1985).

Notes: Kirschsteiniothelia has little DNA sequence data for Kirschsteiniothelia species available in GenBank, thus, more collections and sequence data are needed (Fig. 39).
Note: a, c, e, g, i, k, m-p = Kirschsteiniothelia lignicola (holotype); $\mathbf{b}, \mathbf{d}, \mathbf{f}, \mathbf{h}, \mathbf{j}, \mathbf{l}, \mathbf{q}-\mathbf{s}=$ Kirschsteiniothelia emarceis (holotype)

Kirschsteiniothelia aethiops (Sacc.) D. Hawksw., J. Linn. Soc., Bot. 91(1-2): 185 (1985).

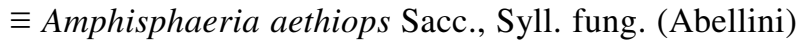
1: 722 (1882).

Index Fungorum number: IF 104401; Facesoffungi number: FoF 01738; Fig. 40

Saprobic on decaying wood submerged in freshwater habitats. Sexual morph: Undetermined. Asexual morph: Colonies on the natural substrate superficial, effuse, gregarious, hairy, dark brown to black. Mycelium immersed, composed of septate, branched, thin-walled, smooth, pale brown hyphae. Coinidiophores $148-228 \mu \mathrm{m}(\bar{x}=188 \mu \mathrm{m}$, $\mathrm{SD}=40, \mathrm{n}=20)$ long, $6-8 \mu \mathrm{m}(\bar{x}=7 \mu \mathrm{m}, \mathrm{SD}=1, \mathrm{n}=20)$ wide, mononematous, macronematous, septate, usually with one or a number of short branches near apex, erect, straight 

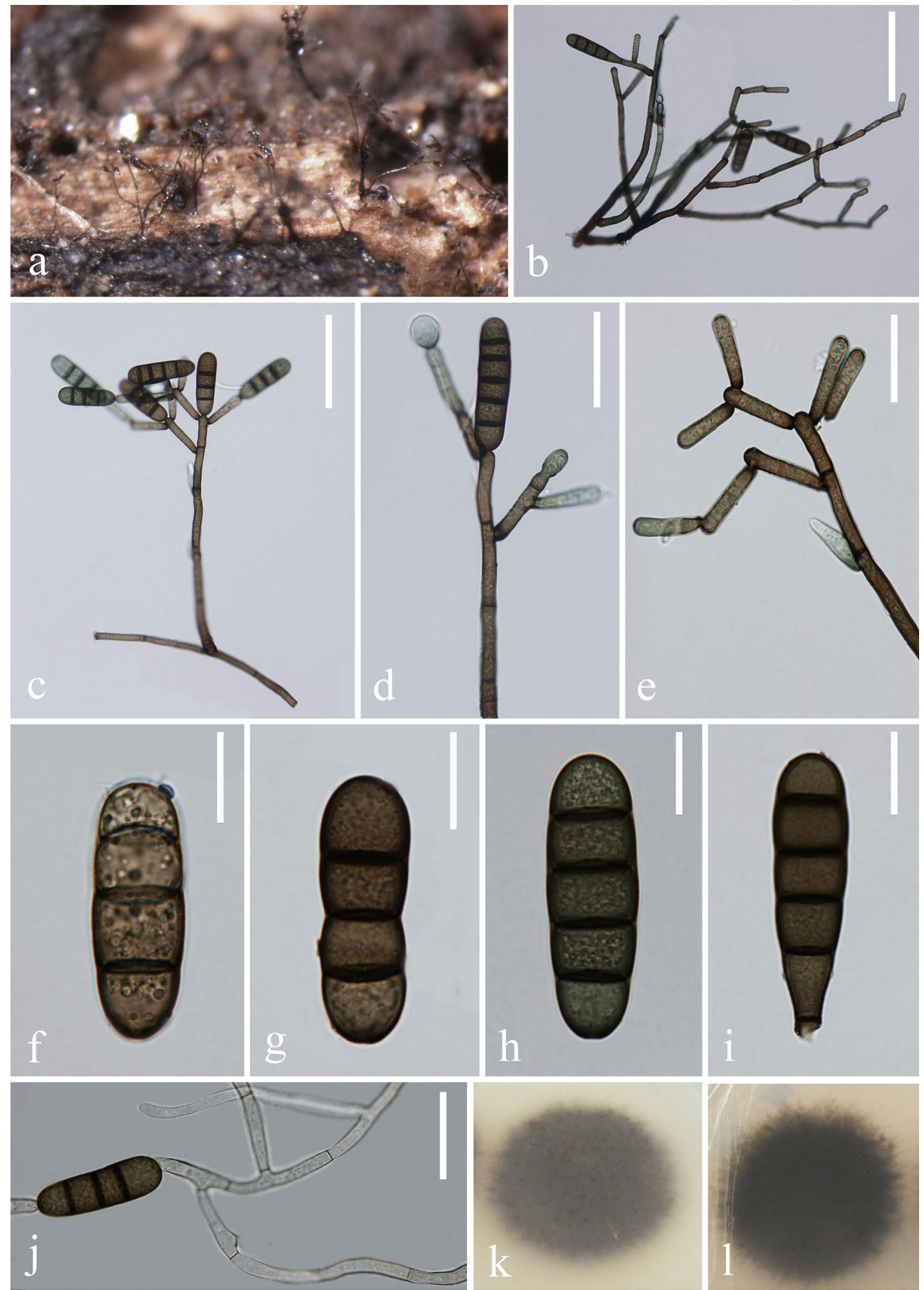

Fig. 40 Kirschsteiniothelia aethiops (S-1322) a Colonies on natural substrate. b, c Conidiophores with conidia. d, e Conidiogenous cells. $\mathbf{f}-\mathbf{i}$ Conidia. $\mathbf{j}$ Germinating conidium. $\mathbf{k}$, $\mathbf{l}$ Culture on PDA from sur-

face and reverse. Scale bars: $\mathbf{b}=90 \mu \mathrm{m}, \mathbf{c}=70 \mu \mathrm{m}, \mathbf{d}, \mathbf{e}=40 \mu \mathrm{m}, \mathbf{f}-\mathbf{i}$ $=15 \mu \mathrm{m}, \mathbf{j}=30 \mu \mathrm{m}$ 
Fig. 41 Lembosina aulographoides (redrawn from Crous et al. 2019b, CPC 33049, holotype). a Hysterothecioid ascomata on host surface. b, c Young asci. d Asci viewed from above. e Asci when mature. $f$ Ascospores. Scale bars: $\mathbf{a}=250 \mu \mathrm{m}, \mathbf{b}-\mathbf{f}=$ $10 \mu \mathrm{m}$

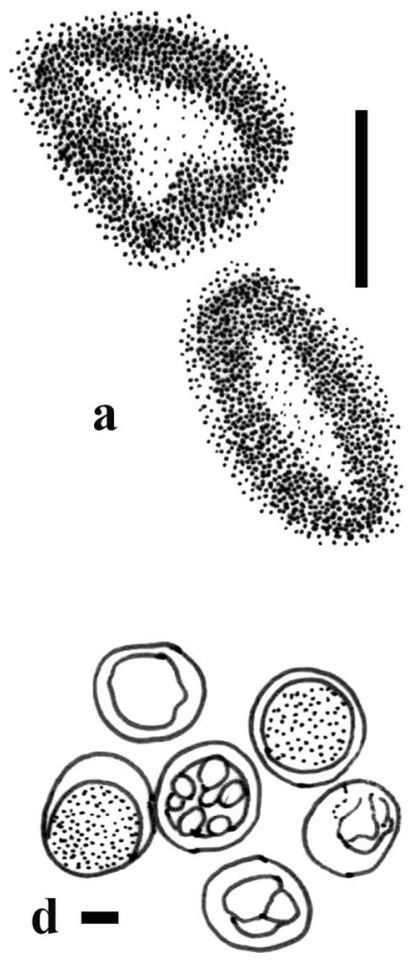

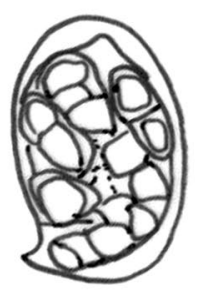

c

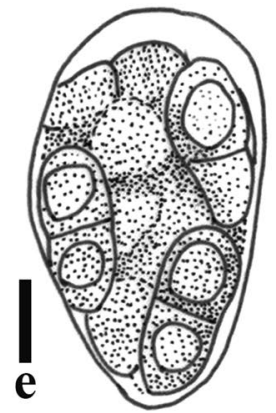

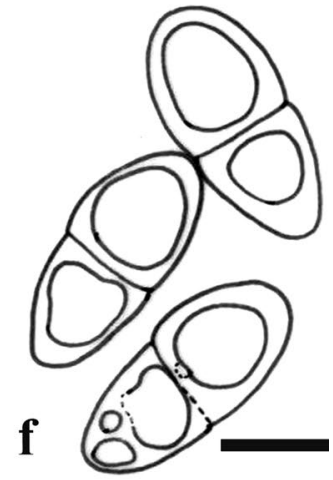

or flexuous, smooth, brown to dark brown, gradually paler towards the apex, cylindrical, septate. Conidiogenous cells 25-33 $\mu \mathrm{m}(\bar{x}=29 \mu \mathrm{m}, \mathrm{SD}=4, \mathrm{n}=20)$ long, 5-7 $\mu \mathrm{m}(\bar{x}=$ $6 \mu \mathrm{m}, \mathrm{SD}=1, \mathrm{n}=20$ ) wide, tretic, integrated, sometimes percurrent, terminal, subhyaline to pale brown, doliiform or lageniform, new cell developing from apical or subapical part of subtending cell. Conidia $41-53 \mu \mathrm{m}(\bar{x}=47 \mu \mathrm{m}$, $\mathrm{SD}=6, \mathrm{n}=40)$ long, $12-16 \mu \mathrm{m}(\bar{x}=14 \mu \mathrm{m}, \mathrm{SD}=2, \mathrm{n}=$ 40) wide, acrogenous, solitary, dry, cylindrical, sometimes clavate, rounded at the apex, 3-4-septate, constricted and darkly pigmented at the septa, smooth, brown.

Material examined: China, Yunnan Province, saprobic on submerged decaying wood in a freshwater stream in Laojunshan Mountain, H.W. Shen, June 2017, S-1322.

Sequence data: ITS MH793539, LSU MH793545, SSU MH793556.

Notes: Kirschsteiniothelia aethiops is the generic type of Kirschsteiniothelia. Phylogenetic analysis based on ITS, LSU and SSU sequence data showed that our strains (S-1322 and S-1406) are identical to the strains of $K$. aethiops (Fig. 38). The morphology of our isolates also fit well with $K$. aethiops ( $\mathrm{Su}$ et al. 2016).

\section{Economic and ecological significance}

Poch et al. (1992) reported the first chemical examination of a Kirschsteiniothelia species and extracted five major compounds from cultures of this species. Species of Kirschsteiniotheliales have the potential as important sources of novel biologically active secondary metabolites. Most Kirschsteiniothelia species are saprobes involved in nutrient cycling.

\section{Lembosinales Crous.}

Index Fungorum number: IF 832086; Facesoffungi number: FoF 07694.

Crous et al. (2019b) provided the first molecular data for Lembosina and found that it formed a distinct lineage next to Lichenoconiales. Therefore, they introduced Lembosinales to accommodate this lineage. The divergence time for Lembosinales is estimated as 253 MYA (Hongsanan et al. 2020).

Accepted families: Lembosinaceae.

Lembosinaceae Crous, in Crous et al., Fungal Systematics and Evolution 5: 91 (2019) [2020].

Index Fungorum number: IF 832087; Facesoffungi number: FoF 07695, 26 species.

Sexual morph: Ascomata thyriothecial or hysterothecial, linear, rarely y-shaped, solitary, gregarious, superficial, loose on host surface, black, opening with linear fissures. Upper wall comprises thin layer of mostly neatly arranged dark cells, branched at the outer rim, poorly developed at the base. Hamathecium comprising sparse, filiform, cellular pseudoparaphyses. Asci 8-spored, bitunicate, subglobose to oblong. Ascospores 2-4-seriate, hyaline to brown, 1-septate, upper cell slightly wider and shorter than the lower cell, 


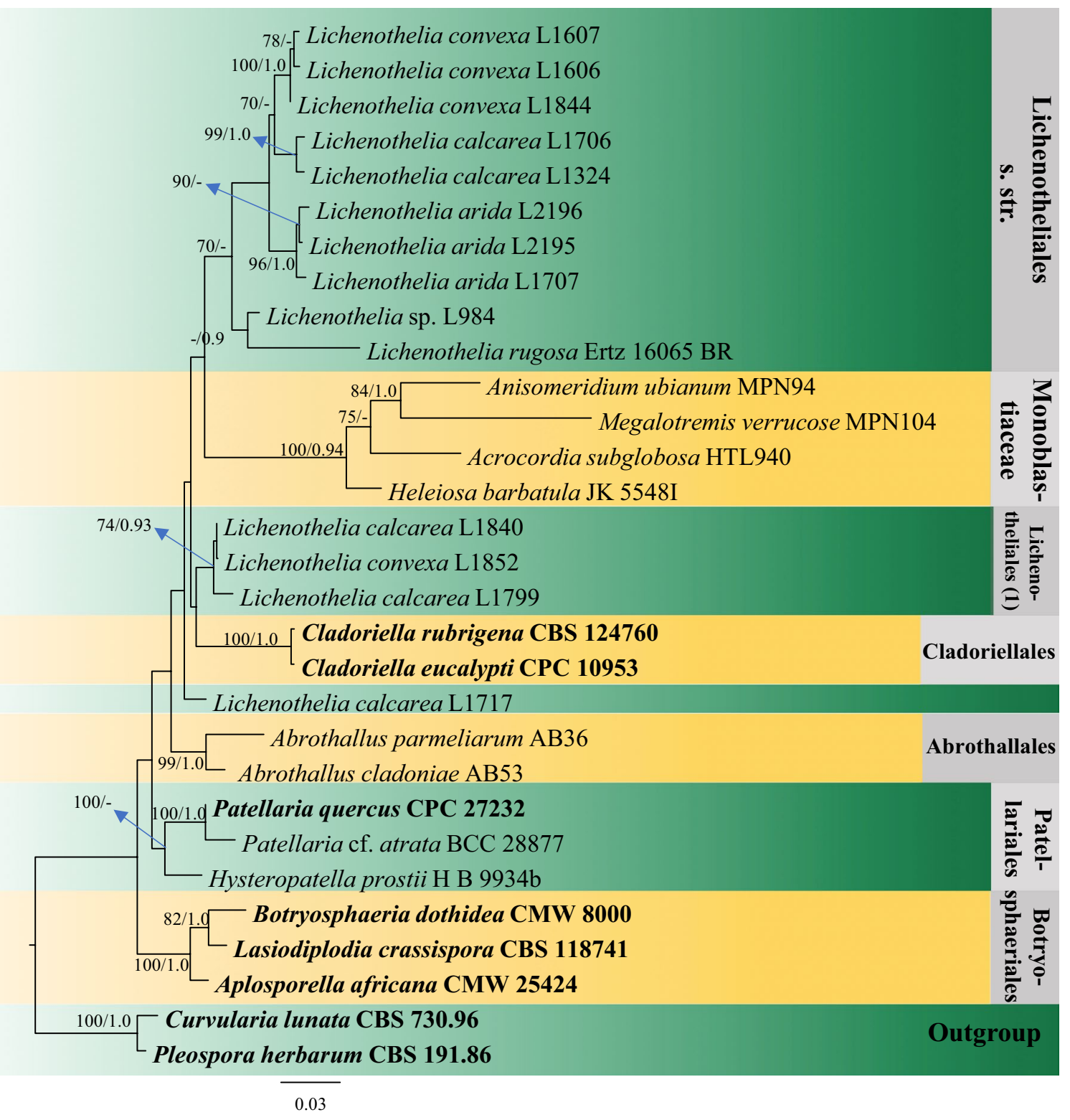

Fig. 42 Phylogram generated from maximum likelihood analysis (RAxML) of Lichenotheliales based on LSU, SSU and mtSSU sequence data. Maximum likelihood bootstrap values equal or above $70 \%$, Bayesian posterior probabilities equal or above 0.90 (MLBS/ $\mathrm{PP})$ are given at the nodes. An original isolate number is noted after

with basal protrusion (Crous et al. 2019b). Asexual morph: Undetermined.

Type: Lembosina Theiss.

Notes: This family was established based on phylogenetic placement of Lembosina aulographoides. More fresh collections and sequence data are needed to confirm its placement.

Lembosina Theiss., Annls mycol. 11(5): 437 (1913). the species name. The tree is rooted to Curvularia lunata (CBS 730.96) and Stemphylium versicarium (CBS 191.86). The ex-type strains are indicated in bold. Hyphen (-) represents support values below $70 \%$ MLBS and 0.90 PP

Index Fungorum number: IF 2728; Facesoffungi number: FoF 07696; 26 morphological species (Species Fungorum 2020), 1 species with molecular data.

Type species: Lembosina aulographoides (E. Bommer et al.) Theiss.

Notes: Lembosina was placed in Leptopeltidaceae and Asterinaceae by von Arx and Müller (1975) and Hawksworth et al. (1995), respectively. Hyde et al. (2013) placed this genus in Aulographaceae. However, Crous et al. (2019b) indicated that Lembosina based on L. aulographoides, does 
not belong to any of these families and should be placed in its own family and order.

Lembosina aulographoides (E. Bommer, M. Rousseau \& Sacc.) Theiss., Annls mycol. 11(5): 437 (1913).

$\equiv$ Lembosia aulographoides E. Bommer et al., Bull. Soc. R. Bot. Belg. 29(1): 238 (1890).

Index Fungorum number: IF 148168; Facesoffungi number: FoF 07697; Fig. 41

Description: see Crous et al. (2019b).

\section{Economic and ecological significance}

The life style of Lembosiaceae is unclear, however, they tend to be saprobes and involved in nutrient recycling.

Lichenotheliales K. Knudsen, Muggia \& K.D. Hyde.

Index Fungorum number: IF 805298; Facesoffungi number: FoF 07698.

The order Lichenotheliales comprises non-lichenized taxa, including saprobic, lichenicolous, epiphytic or endolithic species growing on or within rocks where they are associated with algae (Hyde et al. 2013). These fungi are found in hot and cold arid regions worldwide (Muggia et al. 2015). Lichenotheliales comprises only Lichenotheliaceae which comprises one genus Lichenothelia and Endococcus. Ametrano et al. (2019) indicated that Lichenotheliales formed two clades within Dothideomycetes named Lichenotheliales sensu stricto and Lichenotheliales (1). The same result is shown in our analyses (Fig. 42). Lichenotheliales sensu stricto is monophyletic (Ametrano et al. 2019). The divergence time for Lichenotheliales is estimated as 265 MYA (stem age, Hongsanan et al. 2020).

Accepted families: Lichenotheliaceae.

Lichenotheliaceae Henssen, Syst. Ascom. 5: 137 (1986).

Index Fungorum number: IF 81652; Facesoffungi numbers: FoF 07699, 51 species.

Saprobic or lichenicolous. Endolithic or epilithic thallus in saxicolous lifestyle. Lichenicolous shows episubstratic or endokapylic thallus black, dispersed or continuous, areolate or not, frequently producing black superficial or rarely effigurate, hyphae, branching or not, sometimes connecting scattered stromata; meristematic growth frequent. Sexual morph: Ascomata perithecioid and with interascal filaments or fertile stromata without an ostiole and with asci forming in pseudoparenchymatous locules. Asci 8-spored, globose to broadly clavate, bitunicate, sometimes K/I+bluish around the outer layers or apex of the ascus. Interascal gel amyloid or not. Ascospores uni- to 2-seriate, partially overlapping, hyaline or brown, 1-septate to muriform (sometimes variable). Asexual morph: Undetermined.

Type: Lichenothelia D. Hawksw.
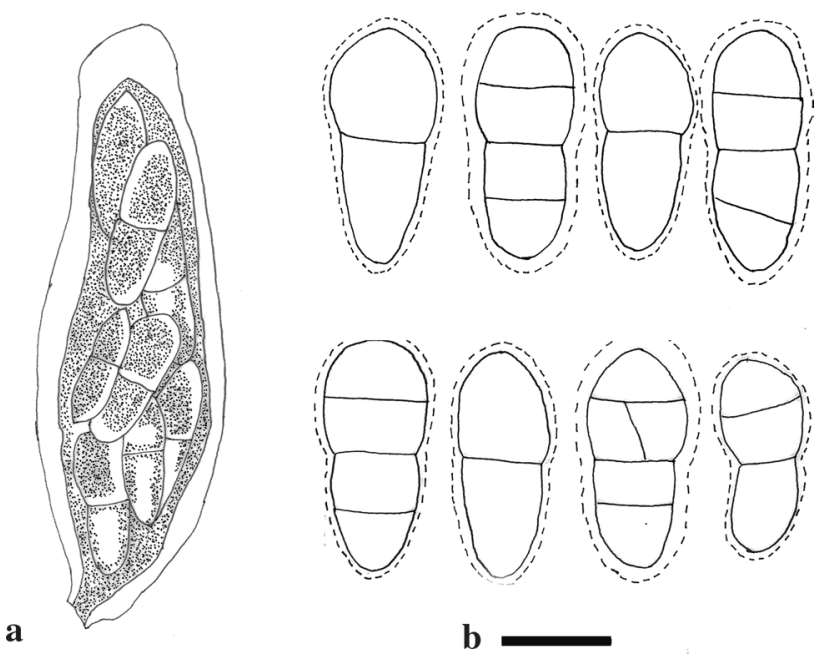

Fig. 43 Morphology of Lichenothelia spp. (redrawn from Hawksworth 1981a). a Asci of Lichenothelia scopularia. b Ascospores of Lichenothelia metzleri

Notes: The family Lichenotheliaceae was introduced to encompass Lichenothelia and Lichenostigma in Dothideales (Henssen and Jahns 1973; Hyde et al. 2013; Valadbeigi et al. 2016). Lichenostigma was placed with Lichenothelia in Lichenotheliaceae based on morphology (Henssen 1987; Muggia et al. 2015). However, based on phylogenetic analysis Lichenostigma was excluded from Lichenotheliaceae and placed to Lichenostigmatales in Arthoniomycetes (Ertz et al. 2014; Hyde et al. 2013; Muggia et al. 2013, 2015). Presently, Lichenotheliaceae comprises two genera namely Lichenothelia and Endococcus. Endococcus was formally referred to Dothideales (Hawksworth 1979). Lumbsch and Huhndorf (2010) and Hyde et al. (2013) placed Endococcus in Dothideomycetes genera incertae sedis. However, Jayasiri et al. (2016) included this genus in Lichenotheliaceae based on morphological similarities to the type species of Lichenothelia. Lichenotheliaceae is placed in Lichenotheliales based on morphological, habitat and molecular evidence (Hyde et al. 2013). Both sexual and asexual morphs have been recorded as saprobic, lichenicolous or lichenized taxa (Hyde et al. 2013; Valadbeigi et al. 2016; Wijayawardene et al. 2017a).

Lichenothelia D. Hawksw., Lichenologist 13(2): 142 (1981). Index Fungorum number: IF 2855; Facesoffungi number FoF07700; 11 morphological species (Species Fungorum 2020), 9 species with molecular data.

Type species: Lichenothelia scopularia (Nyl.) D. Hawksw.

$\equiv$ Verrucaria scopularia Nyl., Not. Sällsk. Fauna et Fl. Fenn. Förh., Ny Ser. 3: 85 (1861).

Notes: The cosmopolitan genus Lichenothelia is characterized by fertile ascomata and many species are described 
based on morphological identification (Ametrano et al. 2019). Both sexual and asexual morphs have been recorded (Valadbeigi et al. 2016; Wijayawardene et al. 2017a) and the taxa show a wide range of life strategies including rock inhabiting, lichenized, lichenicolous and saprobic taxa (Ametrano et al. 2019). Based on modern phylogeny, this genus is incorporated in the order Lichenotheliales (Hyde et al. 2013). Broader sampling with informative loci at the species level is required for species delimitation within this genus (Ametrano et al. 2019) (Fig. 43).

Endococcus Nyl., Mém. Soc. Sci. Nat. Cherbourg 3: 193 (1855).

Index Fungorum number: IF 1791; Facesoffungi number FoF 00560; 40 morphological species (Species Fungorum 2020), 1 species with molecular data.

Type species: Endococcus rugulosus Nyl., Mém. Soc. Imp. Sci. Nat. Cherbourg 3: 193 (1855).

$=$ Verrucaria rugulosa Borrer ex Leight., Brit. Sp. Ang. Lich.: 47 (1851).

Notes: Endococcus species occur on crustose, foliose, and fruticose lichens and some are lichenicolous, while others colonize diverse rock types (Halıc1 et al. 2007; Knudsen 2008; Jayasiri et al. Hong). Species are commonly hostspecific, while some species have wide host ranges (Halıc1 et al. 2007; Jayasiri et al. 2016). Endococcus was affiliated in Dothideales (Hawksworth 1979). However, the taxonomic placement of this genus has changed over time (Hafellner 2019). Jayasiri et al (2016a) transferred this genus to Lichenotheliaceae based on the morphological characteristics, such as perithecioid ascomata with widely porate ostioles, globose to broadly clavate asci and hyaline or brown with 1-septate ascospores. However, Diederich et al (2018) accepted this genus under Verrucariaceae while Wijayawardene et al (2018) accepted in uncertain placement in Dothideomycetes. Molecular data are lacking for this genus and needs critical revision (Hafellner 2019).

\section{Economic and ecological significance}

Species such as Lichenothelia scopularia, Lichenothelia arida, L. calcarea and $L$. convexa are lichenicolous (Hawksworth 1981a), while other species are reported as lichenized and non-lichenized (Hyde et al. 2013). Ametrano et al. (2019) stated that Lichenothelia consists of rock-inhibiting taxa which colonize natural and anthropogenic lithic substrates.

Microthyriales G. Arnaud.

Index Fungorum number: IF 90485; Facesoffungi number: FoF 07701.

Arnaud (1918) introduced this order, with type family Microthyriaceae. Microthyriales contained two families viz. Microthyriaceae and Micropeltidaceae based on their flattened ascomata with poorly developed base. However, members of Microthyriaceae have brown to black thyriothecia, comprising cuboid or angular cells arranged in parallel rows, with prominent central ostioles, and usually uniseptate ascospores (Doidge 1942; Müller and von Arx 1962; Luttrell 1973; Barr 1987b; Hofmann and Piepenbring 2006; Wu et al. 2011b; Hyde et al. 2013; Hongsanan et al. 2015b; Hongsanan and Hyde 2017), while Micropeltidaceae has black-blue or greenish thyriothecia, comprising interwoven hyphae, with a central ostiole, and multiple trans-septate ascospores (Clements and Shear 1931; Batista 1959; von Arx and Müller 1975; Barr 1987b; Wu et al. 2011b; Hyde et al. 2013; Hongsanan and Hyde 2017; Hongsanan et al. 2015a; Zeng et al. 2019). Hongsanan and Hyde (2017) excluded Micropeltidaceae from Microthyriales based on their phylogenetic analyses. This was supported by new collections of Micropeltidaceae in Zeng et al. (2019). Therefore, Microthyriales contains a single family, Microthyriaceae based on morphology and phylogeny. Species of Microthyriales cluster together as a distinct clade within Dothideomycetes with high support (Fig. 44). The divergence time for Microthyriales is estimated as 184 MYA (stem age, Hongsanan et al. 2020).

Accepted families: Microthyriaceae.

Microthyriaceae Sacc., Syll. fung. (Abellini) 2: 658 (1883).

Index Fungorum number: IF 81008; Facesoffungi number: FoF 06747, 120 species.

Saprobic on leaves. Hyphae mostly absent, superficial, brown, septate, branched, reticulate. Sexual morph: Thyriothecia superficial, circular, flattened, dark brown, solitary or gregarious, with a round, central ostiole, with poorly developed basal plate. Upper wall brown, comprising radially arranged cells of textura prismatica, often darkened at the ostiole and tapering at the margin. Hamathecium comprising asci inclined from the base and rim towards the central ostiole. Pseudoparaphyses present or absent. Asci 8-spored, bitunicate, fissitunicate, cylindrical to obpyriform, with or without a pedicel, with or without an ocular chamber at the tip. Ascospores overlapping uni- to 3-seriate, fusiform to ellipsoidal, hyaline or brown, usually 1 -septate, with cilia or appendages, smooth-walled. Asexual morph: Mycelium consisting of hyaline to pale brown, smooth to verruculose, branched, septate hyphae. Conidiophores micronematous or macronematous, mononematous, arising from a brown stroma or from superficial hyphae, erect, solitary, unbranched or branched, straight or flexuous, smooth or roughened, septate, subcylindrical, pale brown to brown; microconidiophores when present, reduced to conidiogenous cells on hyphae, visible as slight thickenings on hyphal cells, somewhat erumpent, pale brown, truncate apex. Conidiogenous cells mono- to polyblastic, integrated, terminal, smooth or verruculose, determinate or sympodial, clavate, 


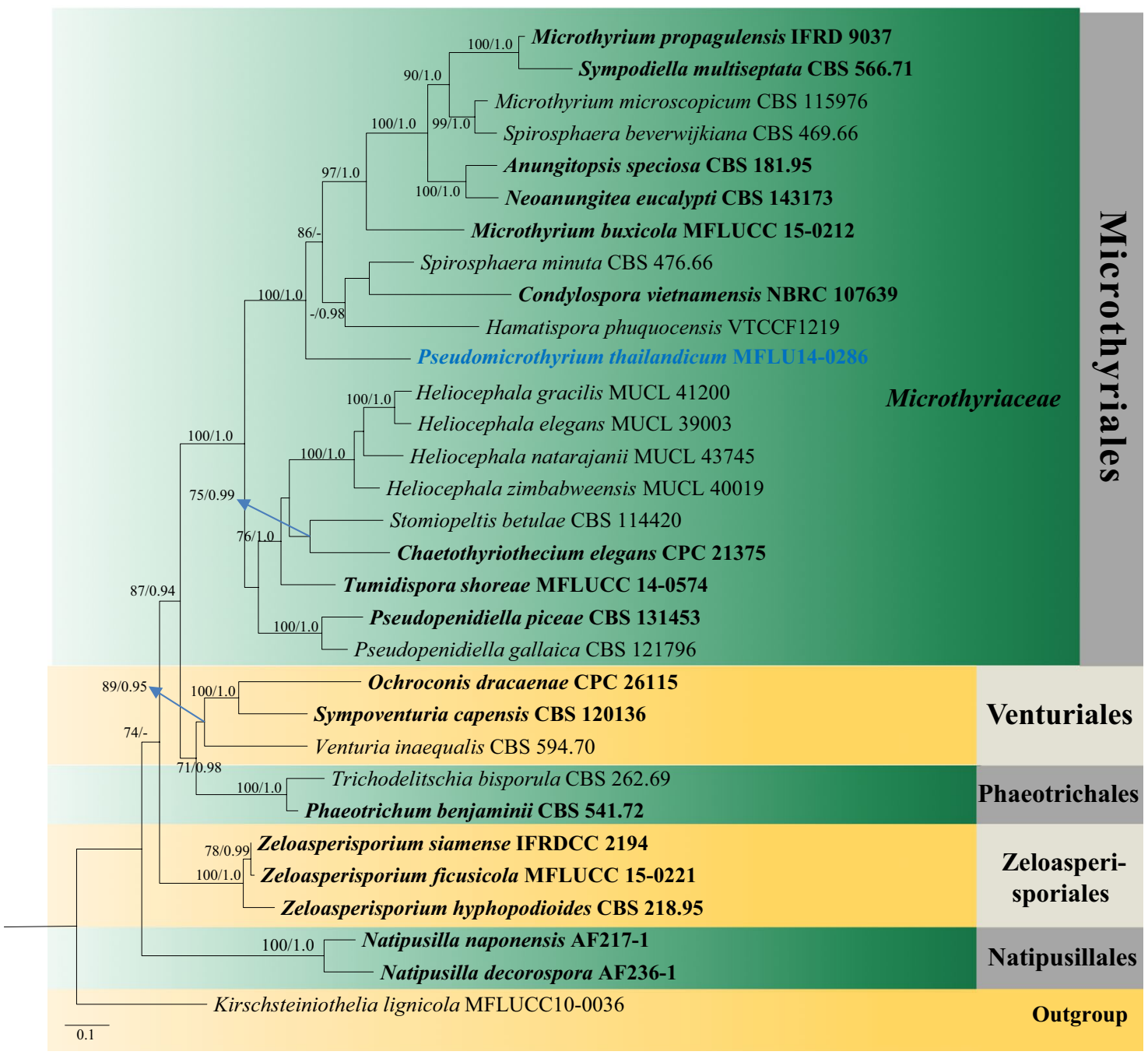

Fig. 44 Phylogram generated from maximum likelihood analysis (RAxML) of Microthyriales and related orders based on ITS and LSU sequence data. Maximum likelihood bootstrap values equal or above $70 \%$, Bayesian posterior probabilities equal or above 0.90 (MLBS/PP) are given at the nodes. An original isolate number is

subcylindrical, ampulliform or ovoid. Ramoconidia when present, pale brown, verruculose, subcylindrical to fusoidellipsoid, aseptate, giving rise to branched chains of conidia. Conidia solitary or in branched chains, sometimes radial on compact heads, acrogenous or acropleurogenous, verruculose, subcylindrical to ellipsoid, obclavate, pale brown, aseptate to multi-septate, sometimes rostrate; hilum inconspicuous, truncate, sometimes unthickened, sometimes thickened; conidia in Hamatispora consisting of a main axis and lateral branches; main axis hook-shaped with a long tail bearing lateral branches; lateral branches straight,developing from different cells of the helicoid part of the main axis.

Type: Microthyrium Desm.

Notes: The phylogenetic placement of this family was first provided by Wu et al. (2011b), represented by Microthyrium noted after the species name. The tree is rooted to Kirschsteiniothelia lignicola (MFLUCC10-0036). The ex-type strains are indicated in bold. Hyphen (-) represents support values below 70\% MLBS and $0.90 \mathrm{PP}$

microscopicum. New genera and new species in Microthyriaceae with molecular data were provided to support the placement of Microthyriaceae. Eleven genera are accepted in this family based on morphology and phylogeny.

The genera Condylospora, Spirosphaera and Stomiopeltis are not included in the family due to their polyphyletic characters or lack of evidence. Caribaeomyces is excluded from the family as it is typical of Asterinales by its hyphopodia and structure of upper walls. Hansfordiella and Isthmospora are also excluded from the family, as they are asexual morphs of Trichothyrium (Trichothyriaceae) (Wijayawardene et al. 2017a). Monorhizina was referred as a member of Microthyriaceae in some studies. This genus was synonymised under Lauterbachiella and Rhagadolobium by Dingley (1972) and Müller and von Arx (1962), respectively. 
Hofmann (2009) accepted Monorhizina in Microthyriaceae, while Hyde et al. (2013) did not accept this genus. Kirk et al. (2013) retained Monorhizina as a distinct genus but did not assign it to any family. Wijayawardene et al. (2017a) listed Monorhizina as a genus in Microthyriaceae. We do not accept Monorhizina in Microthyriaceae and note that the placement of this genus in Microthyriaceae needs future study.

Microthyrium Desm., Annls Sci. Nat., Bot., sér. 2 15: 137 (1841).

Index Fungorum number: IF 3206; Facesoffungi number: FoF 06748; 91 morphological species (Species Fungorum 2020), 3 species with molecular data.

Type species: Microthyrium microscopicum Desm., Annls Sci. Nat., Bot., sér. 2 15: 138 (1841).

Notes: Microthyrium is characterized by flattened thyriothecia with cells of radial arrangement and hyaline ascospores with cilia.

\section{Other genera included}

Arnaudiella Petr., Annls mycol. 25(3/4): 339 (1927).

Index Fungorum number: IF 311; Facesoffungi number: FoF 06749; - 10 morphological species (Species Fungorum 2020), molecular data unavailable.

Type species: Arnaudiella caronae (Pass.) Petr., Annls mycol. 25(3/4): 339 (1927).

E Seynesia caronae Pass., Atti Reale Accad. Lincei, Rendic., Sér. 4 4(2): 63 (1888).

Notes: Arnaudiella is similar to Microthyrium in having flattened thyriothecia and the radial arrangement of upper wall with a darkened ostiole, but is distinct in brown ascospores.

Calothyriopsis Höhn., Sber. Akad. Wiss. Wien, Math.naturw. Kl., Abt. 1 128(7-8): 552 (1919).

Index Fungorum number: IF 761; Facesoffungi number: FoF 06750; - 4 morphological species (Species Fungorum 2020), molecular data unavailable.

Type species: Calothyriopsis conferta (Theiss.) Höhn., Sber. Akad. Wiss. Wien, Math.-naturw. Kl., Abt. 1 128(7-8): 552 (1919).

三 Microthyrium confertum Theiss., Annls mycol. 7(4): 352 (1909).

Notes: Calothyriopsis is typical of Microthyriaceae in having flattened thyriothecia and 1-septate ascospores. However, the arrangement of upper wall is different from the type genus. Therefore, its placement needs to be confirmed by phylogeny.

Chaetothyriothecium Hongsanan \& K.D. Hyde, Phytotaxa 161(2): 161 (2014).
Index Fungorum number: IF 804964; Facesoffungi number: FoF 06751; - 1 morphological species (Species Fungorum 2020), 1 species with molecular data.

Type species: Chaetothyriothecium elegans Hongsanan \& K.D. Hyde, Phytotaxa 161(2): 161 (2014).

Notes: Chaetothyriothecium was introduced with a single species C. elegans, which typically has radial setae growing around a central ostiole. Based on the flattened thyriothecia with cells in a radial arrangement and phylogenetic analyses, Chaetothyriothecium is accommodated in Microthyriaceae. Sequence data of LSU is available for the genus

Hamatispora L.T.H. Yen, K. Yamag. \& K. Ando, in Yen et al., Mycoscience 59(6): 468 (2018).

Index Fungorum number: IF 822829; Facesoffungi number: FoF 06752; - 1 morphological species (Species Fungorum 2020), 1 species with molecular data.

Type species: Hamatispora phuquocensis L.T.H. Yen, K. Yamag. \& K. Ando, in Yen et al., Mycoscience 59(6): 468 (2018).

Notes: Hamatispora is a hyphomycetous genus with staurospores that are question mark-shaped or hook-shaped with 3 arms developing from each cell on the helicoid part (Yamaguchi et al. 2018). It is considered as a member of Microthyriaceae based on the phylogeny.

Neoanungitea Crous, in Crous et al., Persoonia 39: 359 (2017).

Index Fungorum number: IF 823489; Facesoffungi number: FoF 07702; - 2 morphological species (Species Fungorum 2020), 1 species with molecular data.

Type species: Neoanungitea eucalypti Crous, in Crous et al., Persoonia 39: 359 (2017)

Notes: Neoanungitea was introduced with a single species that shares features of both Anungitea and Anungitopsis. It is characterized by conidiogenous cells forming a terminal rachis with flat-tipped sympodial loci. Crous et al. (2017) classified Neoanungitea as a member of Microthyriaceae based on phylogenetic analysis. Sequence data of ITS and LSU is available for the genus.

Paramicrothyrium H.X. Wu \& K.D. Hyde, in Wu, Schoch, Boonmee, Bahkali, Chomnunti \& Hyde, Fungal Diversity 51(1): 204 (2011).

Index Fungorum number: IF 563363; Facesoffungi number: FoF 06754; - 1 morphological species (Species Fungorum 2020), 1 species with molecular data.

Type species: Paramicrothyrium chinensis H.X. Wu \& K.D. Hyde [as 'chinensis'], in Wu et al., Fungal Diversity 51(1): 204 (2011).

Notes: Paramicrothyrium was introduced with a single species Paramicrothyrium chinensis, which is characterized by irregular ostioles without a darkened ring. However, the 

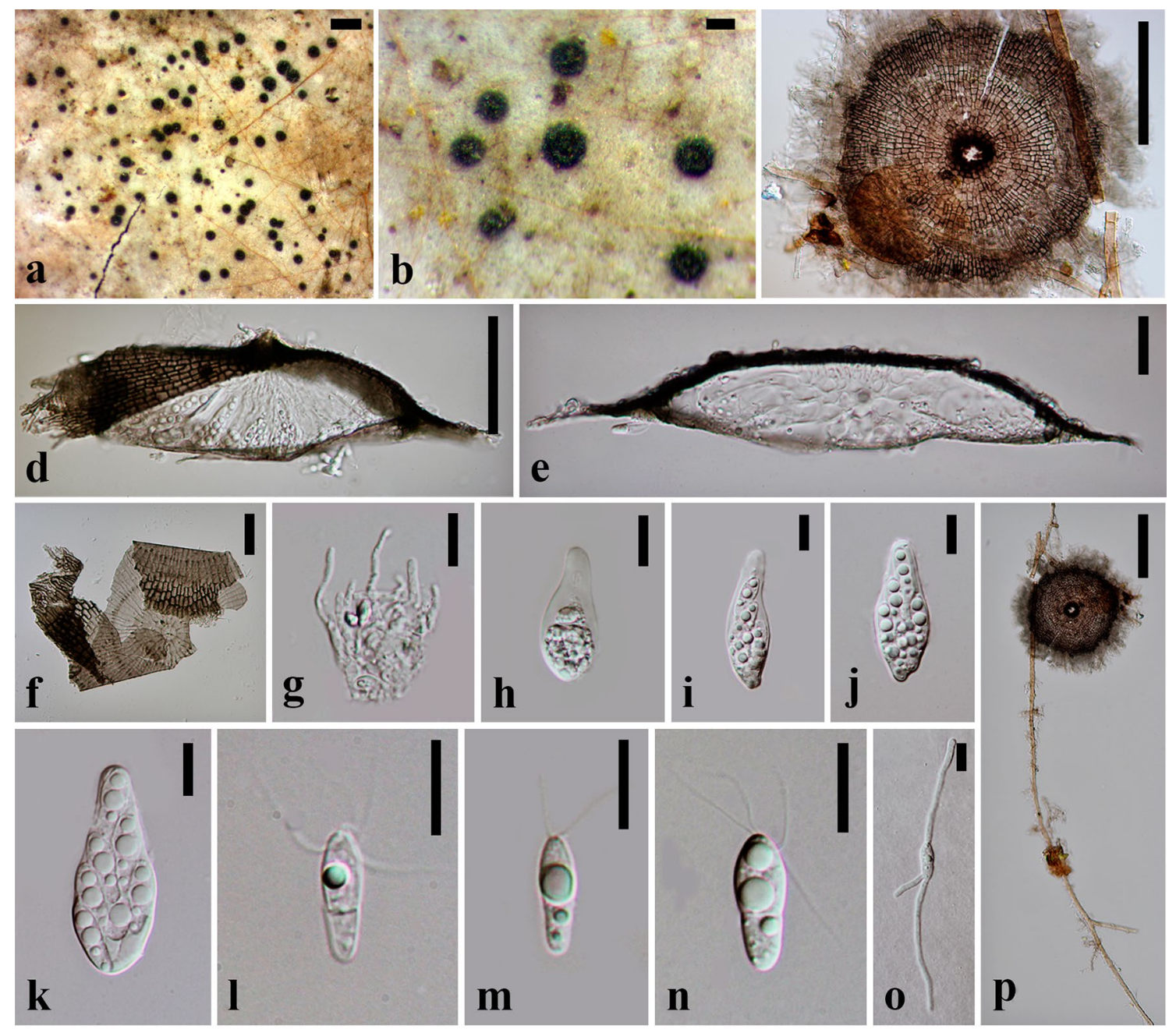

Fig. 45 Pseudomicrothyrium thailandicum (MFLU 14-0286, holotype). a, b Colony on the surface of host leaf. c Ascoma. d, e Ascoma in cross section. f Basal layer. g Pseudoparaphyses. $\mathbf{h}-\mathbf{k}$ Asci from young state to mature state. $\mathbf{l}-\mathbf{n}$ Ascospores from young state to

sequence data of the type species is questionable, as it does not cluster with the main clade of Microthyriales.

\section{Pseudomicrothyrium X.Y. Zeng, S. Hongsanan \& K.D.} Hyde, gen. nov.

Index Fungorum number: IF 556881; Facesoffungi number: FoF 06755; - 1 morphological species (this study), 1 species with molecular data.

Saprobic on dead leaves. Hyphae superficial, pale brown, septate, branched, loosely reticulate. Sexual morph: Thyriothecia superficial, circular, light brown, solitary or gregarious, slightly carbonaceous, with a colorless basal layer, connected with hyphae, easily separated from the host surface. Upper wall light brown, comprising cells of radial arrangement of textura prismatica, darken at the central ostiole, tapering at margin. Hamathecium comprising asci inclined from the base and rim towards the central ostiole, with thin, mature state. o Germinating ascospore. p Ascoma with hyphae. Scale bars: $\mathbf{a}=400 \mu \mathrm{m}, \mathbf{b}, \mathbf{p}=100 \mu \mathrm{m}, \mathbf{c}, \mathbf{d}=50 \mu \mathrm{m}, \mathbf{e}, \mathbf{f}=20 \mu \mathrm{m}, \mathbf{g}-\mathbf{o}=$ $10 \mu \mathrm{m}$

filiform, narrow cellular pseudoparaphyses. Asci 8-spored, bitunicate, fissitunicate, ovoid to obpyriform. Ascospores 2-3-seriate, fusiform to ellipsoidal, hyaline, 1-septate, upper cell slightly wider than lower cell, not constricted at the septum, with 2-4 apical appendages, usually with 2 large guttules in the upper cell, 2 small guttules in the lower cell, smooth-walled. Asexual morph: Undetermined.

Type species: Pseudomicrothyrium thailandicum X.Y. Zeng, S. Hongsanan \& K.D. Hyde.

Notes: Pseudomicrothyrium is similar to Microthyrium in having hyaline ascospores with cilia around the ostiole, but differs in superficial, brown, reticulate hyphae. Phylogenetically, the new species described below forms a distinct clade within Microthyriaceae.

Pseudomicrothyrium thailandicum X.Y. Zeng, S. Hongsanan \& K.D. Hyde, sp. nov. 
Etymology: Referring to its occurrence in Thailand.

Index Fungorum: IF 556882; Facesoffungi number: FoF 06756; Fig. 45

Saprobic on dead leaves. Hyphae superficial, pale brown, septate, branched, loosely reticulate. Sexual morph: Thyriothecia $32-42$ high $\times 140-160 \mu \mathrm{m}$ diam. $(\bar{x}=37 \times 148$ $\mu \mathrm{m}, \mathrm{n}=10$ ), superficial, circular, light brown, solitary or gregarious, slightly carbonaceous, with a colorless basal layer, connected with hyphae, easily separated from the host surface. Upper wall light brown, comprising cells of radial arrangement of textura prismatica, darken at the central ostiole, tapering at margin. Hamathecium comprising asci inclined from the base and rim towards the central ostiole, with thin, filiform, narrow cellular pseudoparaphyses. Asci $35-40 \times 10-15 \mu \mathrm{m}(\bar{x}=37 \times 13 \mu \mathrm{m}, \mathrm{n}=10), 8$-spored, bitunicate, fissitunicate, ovoid to obpyriform. Ascospores $13-15 \times 4-5 \mu \mathrm{m}(\bar{x}=14 \times 5 \mu \mathrm{m}, \mathrm{n}=20), 2-3$-seriate, fusiform to ellipsoidal, 1 -septate, upper cell slightly wider than lower cell, not constricted at the septum, hyaline, with 2-4 apical appendages, usually with 2 large guttules in the upper cell and 2 small guttules in the lower cell, smooth-walled. Asexual morph: Undetermined.

Material examined: Thailand, Chaing Rai, Mae Fah Luang University, on dead leaves of unidentified host, 3 March 2014, Xiang-Yu Zeng (MFLU 14-0286, holotype).

GenBank numbers: LSU: MT741680, SSU: MT741682.

Notes: Pseudomicrothyrium is introduced in this paper. Sequence data of $P$. thailandicum indicate that it forms a distinct lineage within Microthyriaceae with high support (100\% ML, 1.0 PP).

Pseudopenidiella Crous \& Koukol, in Crous et al., Persoonia 28: 167 (2012).

Index Fungorum number: IF 800382; Facesoffungi number: FoF 06757; - 3 morphological species (Species Fungorum 2020), 2 species with molecular data.

Type species: Pseudopenidiella pini (P.M. Kirk \& Minter) P.M. Kirk, Index Fungorum 120: 1 (2014).

$\equiv$ Polyscytalum pini P.M. Kirk \& Minter, in Kirk, Trans. Br. mycol. Soc. 80(3): 462 (1983).

Notes: Pseudopenidiella was introduced as a hyphomycetous genus characterised by the formation of dimorphic conidiophores with terminal, aseptate ramoconidia producing branched conidial chains and lack of coronate-type scars on conidia or conidiogenous cells (Crous et al. 2012b). It is similar to Cladosporium (Capnodiaceae), Digitopodium and Penidiella (Teratosphaeriaceae), but phylogenetically related to Microthyriaceae.

Seynesiella G. Arnaud, Annals d'École National d'Agric. de Montpellier, Série 2 16(1-4): 202 (1918) [1917].
Index Fungorum number: IF 5018; Facesoffungi number: FoF 06758; - 5 morphological species (Species Fungorum 2020), molecular data unavailable.

Type species: Seynesiella juniperi (Desm.) G. Arnaud, Annals d'École National d'Agric. de Montpellier, Série 2 16(1-4): 203 (1918) [1917].

$\equiv$ Dothidea juniperi Desm., Annls Sci. Nat., Bot., sér. 2 15: 141 (1841)

Notes: Seynesiella was transferred from Venturiaceae to Microthyriaceae by Barr (1987b) based on the upper walls with cells of radial arrangement. However, the light brown ascospores are different from the type genus. Sequence data are needed to confirm its taxonomic placement.

Tumidispora Hongsanan \& K.D. Hyde, in Ariyawansa et al., Fungal Diversity 75: 95 (2015)

Index Fungorum number: IF 551375; Facesoffungi number: FoF 00944; - 1 morphological species (Species Fungorum 2020), 1 species with molecular data.

Type species: Tumidispora shoreae Hongsanan \& K.D. Hyde, in Ariyawansa et al., Fungal Diversity 75: 95 (2015).

Notes: Tumidispora is similar to Microthyrium in having flattened thyriothecia with radial arrangement of upper wall and hyaline, 1-septate ascospores, but differs in the shape of ostiole, lack superficial hyphae, and lacking appendages around the ascospores.

\section{Economic and ecological significance}

Species of this group are saprobes and poorly studied but play a role in recycling organic matter.

Minutisphaerales Raja, Oberlies, Shearer \& A.N. Mill. Index Fungorum number: IF 811951; Facesoffungi number: FoF 08064.

Minutisphaerales was established by Raja et al. (2015) to accommodate Minutisphaeraceae, members of which are found on submerged wood in freshwater streams. Jayasiri et al. (2018) included Acrogenosporaceae in this order based on the morphological similarities and phylogenetic analyses. The same result is shown in Fig. 46. The divergence time for Minutisphaerales is estimated as 224 MYA (stem age, Hongsanan et al. 2020).

Accepted families: Acrogenosporaceae, Minutisphaeraceae.

Acrogenosporaceae Jayasiri \& K.D. Hyde, Mycosphere 9(4): 809 (2018).

Index Fungorum number: IF 554451; Facesoffungi number: FoF 04575; 13 species.

Saprobic on bark and wood. Sexual morph: Hysterothecia superficial, laterally compressed, thick-walled, with a prominent sunken slit, solitary to gregarious, erect and elevated, presenting an almost pedicellate appearance. 
Fig. 46 Phylogram generated from maximum likelihood analysis (RAxML) of Minutisphaerales based on ITS, LSU, SSU and tef1 sequence data. Maximum likelihood bootstrap values equal or above $70 \%$, Bayesian posterior probabilities equal or above 0.90 (MLBS/ PP) are given at the nodes. An original isolate number is noted after the species name. The tree is rooted to Capnodium coartatum (MFLUCC 10-0069) and Leptoxyphium kurandae (CBS 129530). The ex-type strains are indicated in bold. Hyphen (-) represents support values below $70 \%$ MLBS and $0.90 \mathrm{PP}$

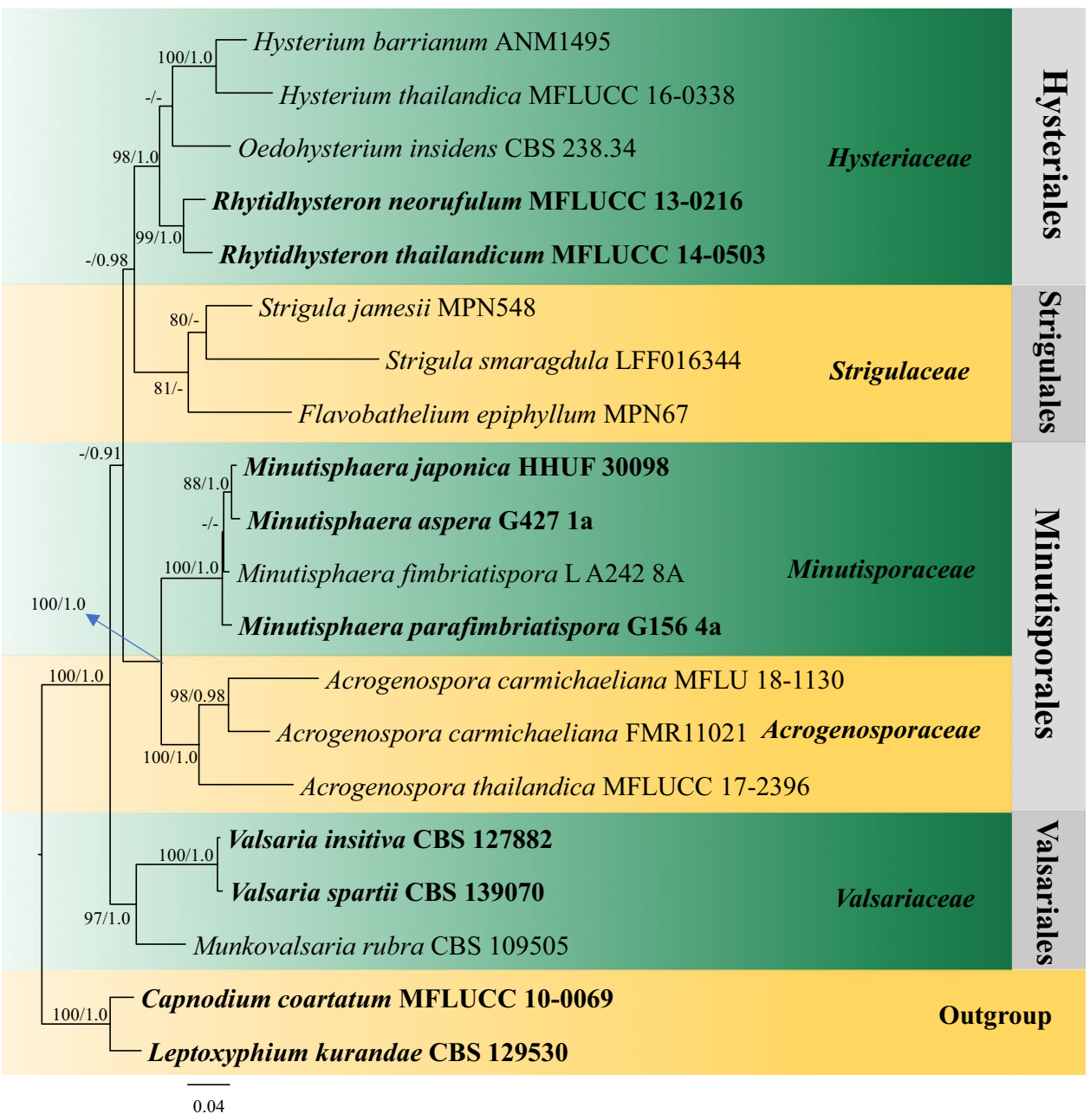

Hamathecium comprising persistent cellular, hypha-like, hyaline, septate, paraphyses. Asci 8-spored, cylindrical to clavate. Ascospores 1-2-seriate, ellipsoidal to fusiform, hyaline or moderately pigmented, 1- or 2-celled, with the septum near the lower end, hyaline or moderately pigmented. Asexual morph: Hyphomycetous. Colonies effuse, scattered, black, glistening, hairy. Mycelium mostly immersed, consisting of septate, subhyaline to pale brown hyphae. Conidiophores macronematous, mononematous, pale to mid brown, often slightly paler at the apex, smooth, septate, unbranched, long cylindrical or slightly tapering towards the apex, straight or slightly flexuous, erect, solitary or in small groups. Conidiogenous cells monoblastic, integrated, terminal or intercalary, light brown or hyaline, cylindrical, often elongated percurrently. Conidia holoblastic, solitary, globose, obovoid to ellipsoidal, asaptate, dark brown to black, smooth or verrucose, truncate at base.

Type genus: Acrogenospora M.B. Ellis.

Notes: Acrogenosporaceae was introduced by Jayasiri et al. (2018) for a single genus Acrogenospora. Based on morphological characters and phylogenetic analyses,
Acrogenosporaceae was placed within Minutisphaerales as a sister clade to the type family Minutisphaeraceae (Jayasiri et al. 2018). This study further supports the earlier result (Fig. 46). Descriptions and illustrations of the sexual morphs of Acrogenosporaceae can be seen in previous studies (i.e. Greville 1825; Duby 1862; von Arx and Müller 1975).

Acrogenospora M.B. Ellis, Dematiaceous Hyphomycetes (Kew): 114 (1971).

Index Fungorum number: IF 7036; Facesoffungi number: FoF 08065; 13 morhological species (Species Fungorum 2020), 3 species with molecular data.

Type species: Acrogenospora sphaerocephala (Berk. \& Broome) M.B. Ellis.

Notes: Acrogenospora altissima was presumed to be the asexual morph of Farlowiella australis Dennis on host surfaces (Ellis 1972) while A. megalospora and F. carmichaeliana were linked by cultural studies (Mason 1941). Molecular data support the synonymy of Acrogenospora and Farlowiella (Jayasiri et al. 2018; Hyde et al. 2019). Nomenclaturally, Acrogenospora was protected over Farlowiella 


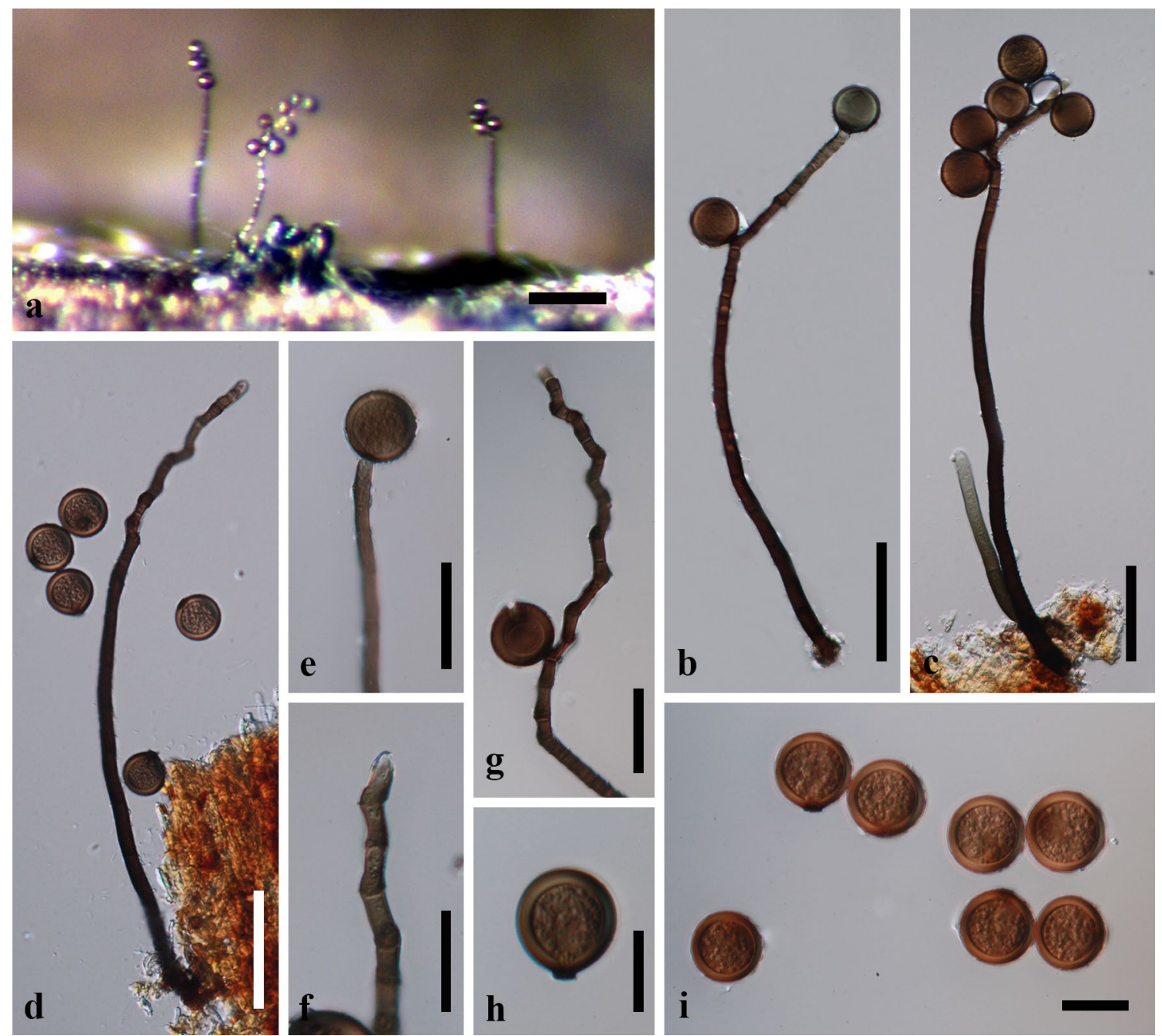

Fig. 47 Acrogenospora sphaerocephala (MFLU 18-1130). a Colony on substrate. b, c Conidiophores with conidia. d Conidiophore. e Conidiogenous cell with conidium. f, $\mathbf{g}$ Conidiogenous cells. h, i

(Rossman et al. 2015). Acrogenospora was monographed by Goh et al. (1998b). The genus is similar to Monotosporella in having macronematous, mononematous conidiophores, monoblastic conidiogenous cells and brown, sphaerical, obovoid to ellipsoidal conidia. However, Acrogenospora has unicellular conidia, while Monotosporella has septate conidia. With little available sequence data, two strains of Monotosporella clustered in Melanommataceae (Dothideomycetes) and Pleurotheciales (Sordariomycetes), respectively (Schoch et al. 2009a; Yang et al. 2019), which are phylogenetically distinct from Acrogenospora.

Acrogenospora cf. sphaerocephala (Berk. \& Broome) M.B. Ellis, Dematiaceous Hyphomycetes (Kew): 114 (1971).

Index Fungorum number: IF 308236; Facesoffungi number: FoF 04687; Fig. 47

Description: see Hyde et al. (2019).
Conidia. Scale bars: $\mathbf{a}=100 \mu \mathrm{m}, \mathbf{b}-\mathbf{d}=50 \mu \mathrm{m}, \mathbf{e}, \mathbf{g}=30 \mu \mathrm{m}, \mathbf{f}, \mathbf{i}=$ $20 \mu \mathrm{m}, \mathbf{h}=15 \mu \mathrm{m}$

Material examined: Thailand, Prachuap Khiri Khan Province, near $1230.1950 \mathrm{~N}, 9931.3500 \mathrm{E}$, on decaying wood submerged in a freshwater stream, 25 December 2014, Jaap van Strien, Site 5-14-2 (MFLU 18-1130).

\section{Ecological and economic significance}

Acrogenosporaceae contains saprobic, lignicolous taxa found in terrestrial, but mostly in freshwater habitats. They play an important role in wood decay by the decomposition of lignocelluloses (Wong et al. 1998; Krauss et al. 2011; Hyde et al. 2016b). Generally, it is assumed that aquatic fungi transfer organic matter directly to the higher trophic levels of aquatic food webs (Christian et al. 2011).

Minutisphaeraceae Raja, Oberlies, Shearer \& A.N. Mill., Mycologia 107 (4): 854 (2015). 
Fig. 48 Minutisphaera parafimbriatispora (ILLS 72341, holotype). a, e Squash mount of ascoma. b Asci. d Ascomata on host surface. $\mathbf{f}$ Ascospores. Scale bars: $\mathbf{a}, \mathbf{b}=20 \mu \mathrm{m}, \mathbf{c}=$ $10 \mu \mathrm{m}, \mathbf{d}, \mathbf{e}=100 \mu \mathrm{m} . \mathbf{f}=50$ $\mu \mathrm{m}$

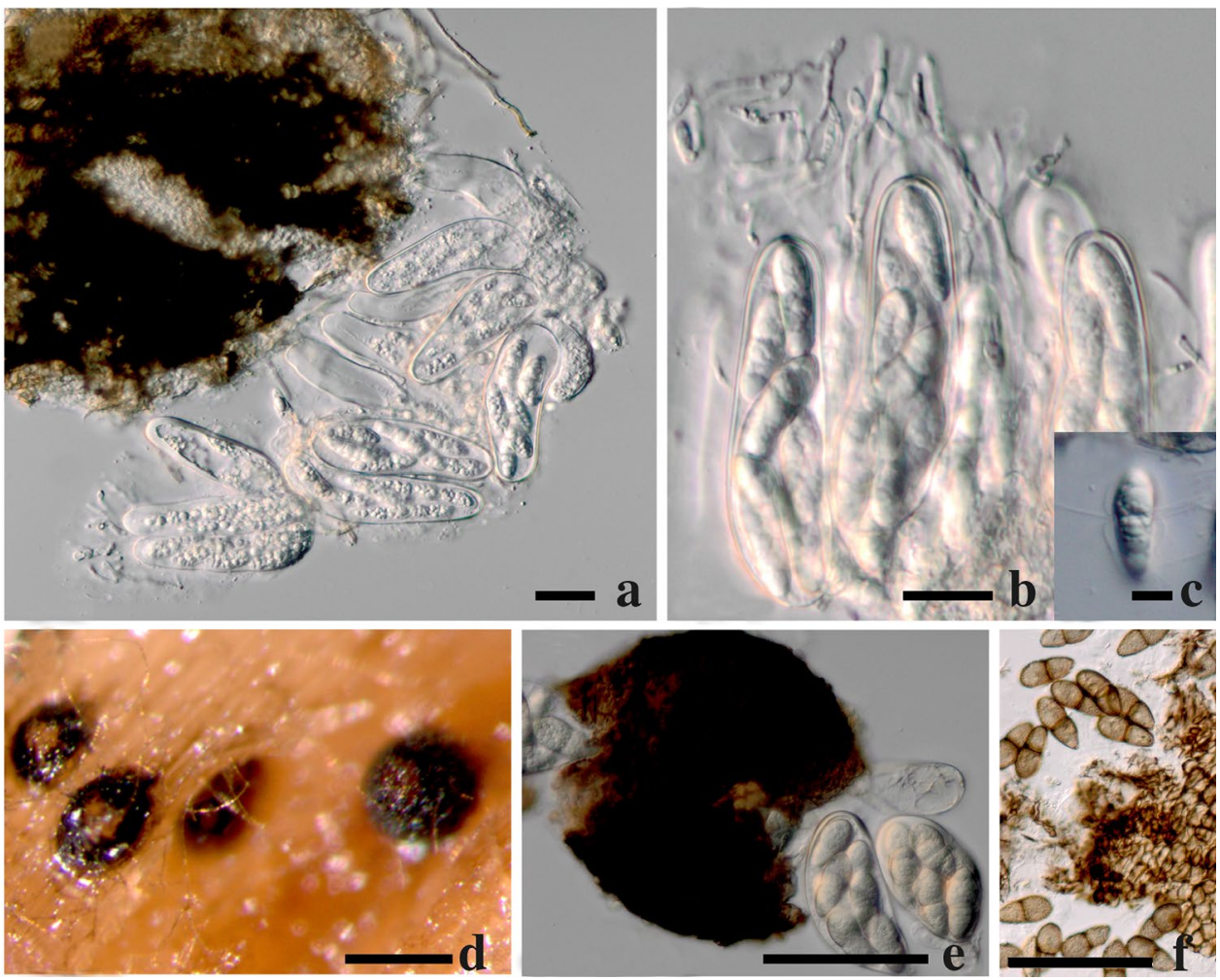

Index Fungorum number: IF 811062; Facesoffungi numbers: FoF 08066, 4 species.

Saprobic on submerged wood in freshwater habitats. Sexual morph: Ascomata pseudothecioid or apothecioid, erumpent to superficial, brown, with an ostiole and irregularly curved, dark brown to black hypha-like structures around the ostiole. Peridium thin-walled, composed of cells of textura angularis to textura globosum. Hamathecium comprising septate, cellular pseudoparaphyses with or without enlarged pigmented tips. Asci 8-spored, fissitunicate, ovoid to obclavate, sessile to short-pedicellate, apically rounded with or without an ocular chamber. Ascospores 2-4-seriate, clavate, fusiform to ellipsoidal, hyaline or pale brown septate, multiguttulate, smooth or rough-walled, with gelatinous sheath, with or without filamentous appendages radiating around the mid-septum. Asexual morph: Undetermined.

Type: Minutisphaera Shearer, A.N. Mill. \& A. Ferrer, Ferrer et al.

Notes: This monotypic family was established by Raja et al. (2015) to accommodate Minutisphaera. Raja et al. (2015) placed Minutisphaeraceae in a newly introduced order Minutisphaerales, Dothideomycetes based on its distinct morphological characters and multi-gene phylogenies. The morphological characters such as small, globose to subglobose, ostiolate ascomata, septate, cellular pseudoparaphyses, fissitunicate, ovoid to obclavate asci and hyaline to brown, 1-septate, ascospores with or without a gelatinous sheath, suggest that Minutisphaeraceae could be placed in Pleosporales (Zhang et al. 2012). Nevertheless, the molecular phylogenetic analysis shows that the family has no relationship with the members of Pleosporales (Raja et al. 2015; Liu et al. 2017). Bao et al. (2019) provided a new species of Minutisphaera. All the taxa of Minutisphaeraceae are freshwater fungi occurring on submerged woody substrates.

Minutisphaera Shearer, A.N. Mill. \& A. Ferrer, Mycologia 103(2): 415 (2011).

Index Fungorum number: IF 518355; Facesoffungi number: FoF 08067; 5 morphological species (Species Fungorum 2020), 5 species with molecular data.

Type species: Minutisphaera fimbriatispora Shearer, A.N. Mill. \& A. Ferrer.

Notes: Minutisphaera, typified by M. fimbriatispora was described from submerged wood in freshwater habitats in the USA (Ferrer et al. 2011). Subsequently, M. japonica was described in Japan (Raja et al. 2013), and M. aspera and $M$. parafimbriatispora in the USA (Raja et al. 2015). The members of this genus are only known by their sexual morphs and no asexual morph has been reported.

Minutisphaera parafimbriatispora Raja, Oberlies, Shearer \& A.N. Mill., in Raja et al., Mycologia 107(4): 855 (2015).

Index Fungorum number: IF 5811064; Facesoffungi number: FoF 08068; Fig. 48

Description: see Raja et al. (2015). 
Material examined: USA, North Carolina, Guilford County, Piedmont Plateau, Bur-Mil Park, Greensboro, swampy area behind Lake Brandt, on submerged decorticated wood, 20 October 2011, H.A. Raja G156-1 (ILLS 72341, holotype).

\section{Economic and ecological significance}

Members of this family usually inhabit woody substrates in freshwater habitats as saprobes (Ferrer et al. 2011; Raja et al. 2013, 2015). Some species produce dipeptides and aromatic polyketides secondary metabolites belonging to two structural classes (Raja et al. 2015).

Monoblastiales Lücking, M.P. Nelsen \& K.D. Hyde.

MycoBank number: MB 805299; Index Fungorum number: IF 805299; Facesoffungi number: FoF 08069.

This order comprises lichenized and non-lichenized fungi. It was introduced by Hyde et al. (2013) to accommodate the single family, Monoblastiaceae. Among the mostly lichenized orders in Dothideomycetes, Monoblastiales differs from Strigulales in the net-like physes and from most Trypetheliales in having euseptate ascospores with few septa and the poor secondary chemistry; from both orders it also deviates in the macroconidia often arranged in a gelatinous matrix (Hyde et al. 2013). The divergence time for Monoblastiales is estimated as 230 MYA (stem age, Hongsanan et al. 2020).

Accepted families: Monoblastiaceae.

Monoblastiaceae Walt. Watson, New Phytologist 28: 106 (1929).

= Eriomycetaceae Huanraluek \& Hyde, in Hyde et al., Fungal Diversity 100: 146 (2020).

MycoBank number: MB 81020; Index Fungorum number: IF 81020; Facesoffungi number: FoF 08851; approximately 120 species (this paper).

Lichenized on bark, more rarely on rocks or leaves (supraor rarely subcuticular), more rarely non-lichenized and saprobic on leaves or bark (Eriomyces, Funbolia, Heleiosa, Pseudopassalora) or hyperparasitic on bracket fungi (Phellinocrescentia); usually in terrestrial, chiefly lowland to montane tropical to subtropical habitats, with few species extending into temperate regions and in one case (Heleiosa) growing on leaves of Juncus in salt marshes. Thallus in lichenized species mostly reduced and ecorticate, white, to distinctly corticate, grey-green to olive brown, sometimes shiny (Megalotremis, Trypetheliopsis), in nonlichenized species absent. Photobiont in lichenized species trentepohlioid. Ascomata when present scattered, clustered, or aggregated, immersed to sessile, mostly black but sometimes covered by thallus, rarely non-carbonaceous, globose to pear-shaped or conical, ostiolate, ostiole apical or eccentric, with periphyses. Involucrellum present, sometimes only apically, or reduced, usually dark brown to carbonized, paraplectenchymatous in thin sections. Excipulum dense, consisting of compressed hyphae, appearing prosoplectenchymatous in thin sections but structure sometimes difficult to observe when carbonaceous, hyaline to brown or brownblack. Hamathecium usually comprising 0.5-0.7 $\mu \mathrm{m}$ wide paraphyses (trabeculate pseudoparaphyses according to Harris (1990, 1995), hyaline, straight, branched and anastomosing, rarely (Eriomyces) formed by $1-3 \mu \mathrm{m}$ wide, branched cellular pseudoparaphyses. Asci (1-)2-8-spored, rarely polyspored (Eriomyces), bitunicate, fissitunicate, mostly cylindrical to sometimes cylindrical-clavate, shortly pedicellate, with narrow to broad, non-amyloid ocular chamber and in part fluorescent ring- or cap-structures. Ascospores uni- to biseriate or irregularly arranged, ellipsoid-oval to oblong or sometimes fusiform, hyaline to rarely brown, aseptate or 1-3-septate, with thin to rather thick (Megalotremis, Trypetheliopsis) eusepta and more or less rectangular lumina, smooth-walled or ornamented or rarely with appendages (Heleiosa), sometimes slightly constricted at the septa, in 1 -septate ascospores the upper cell often distinctly larger than the lower cell (particularly in Anisomeridium). Conidiomata common, usually pycnidia, very rarely hyphomycetous (Funbolia, Pseudopassalora); pycnidia immersed to sessile and usually visible as black dots, but sometimes conspicuous and flask-shaped with a short to long a beak or hair-like (Anisomeridium, Caprettia) or asymmetrically cup- or earshaped (campylidiiform: Trypetheliopsis). Conidia acrogenous or rarely pleurogenous (Funbolia), either macro- or microconidia; macroconidia usually aseptate (septate in Funbolia, Pseudopassalora), (globose to) broadly ellipsoid to oblong-bacillar or guttuliform, $(2.5-) 5-15(-45) \times$ (2-)3-7(-16) $\mu \mathrm{m}$ large, hyaline (brown in Funbolia, Pseudopassalora), often forming clusters embedded in a gelatinous matrix, these clusters in some species in the form of sacci or cirri (Anisomeridium, Caprettia); microconidia aseptate, globose to broadly ellipsoid or fusiform, small, 2-4(-5) $\times$ 1-2(-4) $\mu \mathrm{m}$ large, hyaline. Chemistry: Most species do not contain secondary substances; lichexanthone and anthraquinone pigments are known from a few taxa.

Type: Monoblastia Riddle.

Notes: For a detailed discussion of the lichenized core group of the family (Acrocordia, Anisomeridium, Caprettia, Megalotremis, Monoblastia, Trypetheliopsis), including a critical review of the currently applied genus concept, see Lücking et al. in Hyde et al. (2013). The scarce molecular data available support monophyly of Megalotremis and a close relationship of the latter with Trypetheliopsis, while Anisomeridium is likely polyphyletic (Fig. 49), a notion anticipated by Harris (1995). Representatives of all genera except Caprettia and the type genus, Monoblastia, have been sequenced, so the position of Caprettia within the family, based on hamathecium and ascus structure, ascospore type, 
Fig. 49 Best-scoring maximum likelihood tree of currently available data in Monoblastiales and its only family, Monoblastiaceae (including Eriomycetaceae), based on a combined alignment of five markers (nuSSU, nuLSU, ITS, $\mathrm{mtSSU}, \mathrm{TEF} 1 \alpha$ ), with a length of 3612 bases (single autapomorphic base calls in gappy sites removed). The tree was reconstructed using the universal GTR-Gamma model without site partitioning, and the final likelihood was - 10218.109712

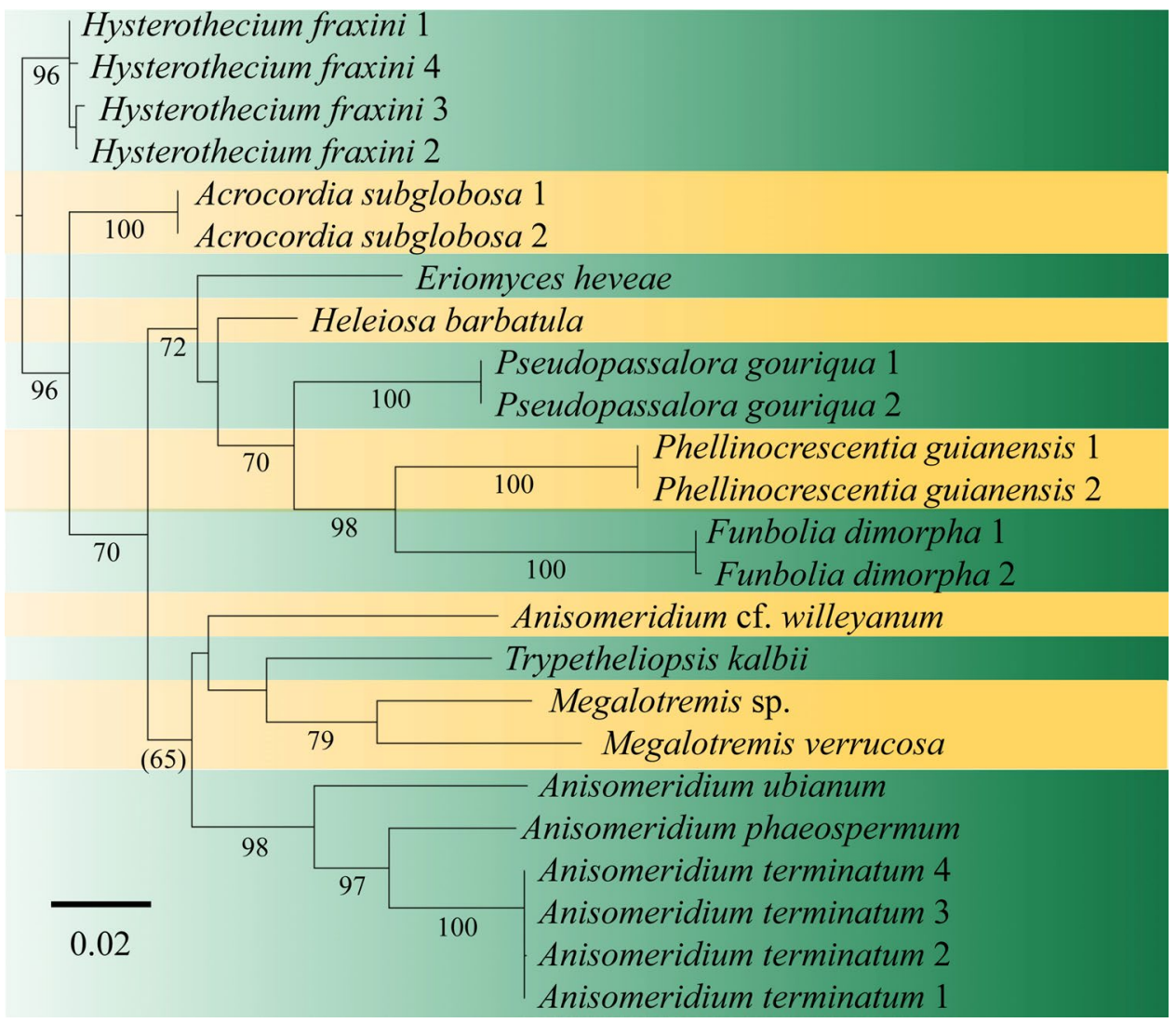

and the peculiar conidiomata and conidia, remains tentative. The accurcate circumscription of the family hinges on the presumed close relationship of Monoblastia with e.g. Acrocordia, and so far only a single species of the latter has been sequenced. The taxonomic delimitation between Anisomeridium, Megalotremis, and Trypetheliopsis is discussed in detail below.

In this updated treatment, we also include several nonlichenized, monospecific genera in the family. None of them were originally established with a connection to Monoblastiaceae (Kohlmeyer et al. 1996; Crous et al. 2011a, b, 2014; Hyde et al. 2020b), but two genera (Funbolia, Heleiosa) were associated with the latter in a subsequent study (Nelsen et al. 2011a). Recently, Hyde et al. (2020b) established the new family Eriomycetaceae for the five non-lichenized lineages; however, these authors did not include lichenized representatives of Monoblastiaceae in their analysis and therefore overlooked the close relationship that had previously been established by Nelsen et al. (2011a). The expanded phylogeny presented here does not resolve Monoblastiaceae and Eriomycetaceae as reciprocally monophyletic, but renders the non-lichenized lineages as a moderately supported clade nested within a paraphyletic backbone comprising the lichenized lineages (Fig. 49).

Given this topology, one could theoretically retain Eriomycetaceae by splitting a Acrocordiaceae from
Monoblastiaceae, the latter then corresponding to the clade containin Anisomeridium sensu lato, Megalotremis, and Trypetheliopsis (Fig. 49). However, this solution is not appropriate, for various reasons. First, the type of Monoblastiaceae, Monoblastia, has not yet been sequenced. While its relationship with the other lichenized genera is supported by morphological and anatomical characters (Lücking et al. in Hyde et al. 2013), it is unclear whether it is more closely related to Acrocordia or to the Anisomeridium-Megalotremis-Trypetheliopsis clade, thus creating potentially unstable nomenclature regarding the application of the name Monoblastiaceae. Second, while the non-lichenized lineages partly deviate from the lichenized taxa anatomically, the genus Heleiosa is very similar to the latter: its ascoma anatomy, including the thin, anastomosing paraphyses and the cylindrical asci with broad ocular chamber (Kohlmeyer et al. 1996), is in line with that of Acrocordia and Monoblastia. Also the pycnidial genus Phellinocrescentia agrees with lichenized taxa, in particular species of Anisomeridium, in the guttuliform conidia (Crous et al. 2014). Thus, even if Eriomyces differs in its peculiar asci and the rather thick pseudoparaphyses (Hyde et al. 2020b), and Funbolia and Pseudopassalora deviate from the other genera by their hyphomycetous asexual morphs (Crous et al. 2011a, b), there are at least two genera in the former Eriomycetaceae that agree phenotypically with lichenized Monoblastiaceae. 
The inclusion of lichenized and non-lichenized lineages in a single family, even with such disparate morphological and anatomical features, is not entirely surprising. The situation is analogous to Graphidaceae and Trypetheliaceae, which feature some non-lichenized or borderline lichenized lineages as early diverging clades (Nelsen et al. 2009, 2011a, 2014; Lücking et al. 2016; Cáceres et al. 2020; MirandaGonzález et al. 2020). Several lineages of lichenized fungi produce hyphomycetous asexual morphs, particularly in the order Arthoniales (Arthoniomycetes), e.g. in the genera Reichlingia and Tylophoron (Frisch et al. 2014; Van den Broeck et al. 2018), so the relationship of Funbolia and Pseudopassalora with the other lineages in Monoblastiaceae is also not entirely unexpected, although without molecular evidence such relationships would not have been predicted.

\section{Monoblastia Riddle, Mycologia 15: 70 (1923).}

MycoBank number: MB 3251; Index Fungorum number: IF 3251; Facesoffungi number: FoF 08070; 12 morphologically defined species (Lücking et al. 2017; Harada 2018), molecular data thus far unavailable.

Lichenized on bark or rarely on limestone, in terrestrial, chiefly lowland to montane tropical to subtropical habitats, with few species extending into temperate regions. Thallus usually ecorticate, white. Photobiont Trentepohlia. Ascomata scattered or rarely clustered, erumpent to sessile, mostly black, carbonaceous, ostiolate, ostiole round. Involucrellum present or reduced, carbonized. Excipulum dense, consisting of compressed hyphae, appearing prosoplectenchymatous in thin, bleached sections, hyaline to brown or brown-black. Hamathecium comprising 0.5-0.7 $\mu \mathrm{m}$ wide paraphyses, hyaline, straight, branched and anastomosing. Asci (2-)8-spored, bitunicate, fissitunicate, cylindrical, short pedicellate, with broad, non-amyloid ocular chamber and fluorescent cap-structures. Ascospores mostly uni-seriate, ellipsoid-oval, hyaline, aseptate, ornamented with warts, short ridges or spines. Pycnidia rare. Conidia acrogenous, microconidia, aseptate, oblong to ellipsoid to fusiform, small, hyaline. Chemistry: Secondary substances absent.

Type species: Monoblastia palmicola Riddle, Mycologia 15: 70 (1923).

Notes: See Lücking et al. in Hyde et al. (2013) for discussion and illustrations.

\section{Other genera:}

Acrocordia A. Massal., Geneac. Lich. (Verona): 17 (1854).

MycoBank number: MB 46; Index Fungorum number: IF 46; Facesoffungi number: FoF 08071; ten morphologically defined species (Lücking et al. 2017), molecular data available for one species.

Lichenized on bark or rarely on bryophytes or on limestone, in temperate to tropical montane regions. Thallus ecorticate, white. Photobiont Trentepohlia. Ascomata scattered or rarely clustered, erumpent to sessile, black, carbonaceous, ostiolate, ostiole apical or lateral. Involucrellum present or reduced, carbonized. Excipulum dense, consisting of compressed hyphae, appearing prosoplectenchymatous in thin, bleached sections, hyaline to brown or brown-black. Hamathecium comprising 0.5-0.7 $\mu \mathrm{m}$ wide paraphyses, hyaline, straight, branched and anastomosing. Asci (2-)8-spored, bitunicate, fissitunicate, cylindrical, short pedicellate, with broad, non-amyloid ocular chamber and fluorescent cap-structures. Ascospores mostly uni-seriate, rarely biseriate, ellipsoid-oval to rarely oblong, hyaline, 1 -septate, usually granular ornamented. Pycnidia rare. Conidia acrogenous, microconidia, aseptate, oblong to ellipsoid to fusiform, small, hyaline. Chemistry: Secondary substances absent.

Type species: Acrocordia garovaglii A. Massal., Geneac Lich (Verona): 17 (1854) [= A. conoidea (Fr.) Körb. var. conoidea, Syst Lich Germ: 358 (1855)].

Notes: This genus was not treated in detail by Lücking et al. in Hyde et al. (2013). Acrocordia resembles both Anisomeridium and Monoblastia in general habit. It differs from the first in the broad ocular chamber of the asci and from the second in the 1-septate vs. aseptate ascospores (Fig. 50). The septum usually has characteristing endospore thickenings that make it appear laterally somewhat bulging (Fig. 50).

Arthopyrenia endobrya ( $\equiv$ Anisomeridium endobryum; Megalotremis endobrya) is an unusual lichen that grows intracellularly within dead bryophytes, known from tropical montane forest in Brazil (type; Döbbeler and Poelt 1981) and Costa Rica (Aptroot et al. 2008). It is characterized by sessile, basally constricted, black perithecia and 1-septate ascospores 35-50 × 10-15 $\mu \mathrm{m}$ in size. Harris (1995) recognized its position within Monoblastiaceae and placed it in Anisomeridium. Because of its slight septal endospore thickenings, it was later recombined into Megalotremis (Aptroot et al. 2008), although the ascospore size range (see below Megalotremis for further discussion) fits Anisomeridium better, Given the ecorticate thallus, the fully exposed perithecia, the asci with broad ocular chamber, and the thin-walled ascospores lacking crystals and with the septa slightly bulging (Fig. 51), the species is actually best referred to Acrocordia, where several other species have sessile, subglobose perithecia, such as A. subglobosa. The biseriately arranged ascospores apparently lacking granular ornamentation deviate from most of the other species in that genus, but such variation is also accepted in Anisomeridium (see below). The necessary combination is introduced below.

Acrocordia endobrya (Döbbeler \& Poelt) Lücking \& Aptroot, comb. nov.

MycoBank number: MB 836365; Index Fungorum number: IF 836365; Facesoffungi number: FoF 08072. 

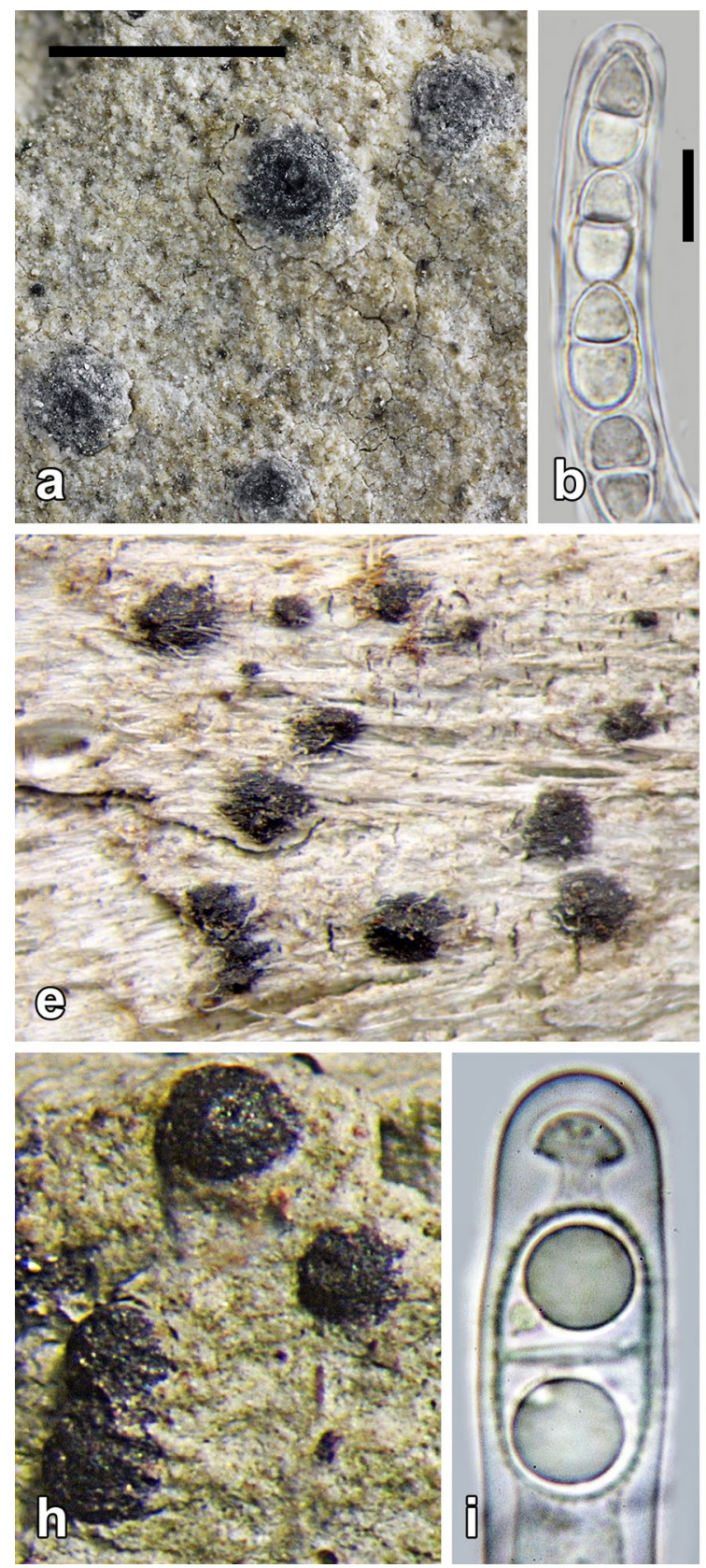

Fig. 50 Morphology, asci and ascospores in Acrocordia species. a-d A. conoidea (a, b Germany, Schumm 70; c, d Germany, Schumm 12542). e-h A. gemmata (e-f Portugal, Schumm 11491; g Portugal, Schumm 11547; h, i Germany, Schumm 11586). j, k A. salweyi (Por-

Bas.: Arthopyrenia endobrya Döbbeler \& Poelt, Pl Syst Evol 138: 276 (1981); Anisomeridium endobryum (Döbbeler \& Poelt) R.C. Harris, More Florida Lichens: 146 (1995); Megalotremis endobrya (Döbbeler \& Poelt) Aptroot in Aptroot et al., Biblioth Lichenol 97: 68 (2008).

Anisomeridium (Müll. Arg.) M. Choisy, Icon Lich Univ 1: 24 (1928).
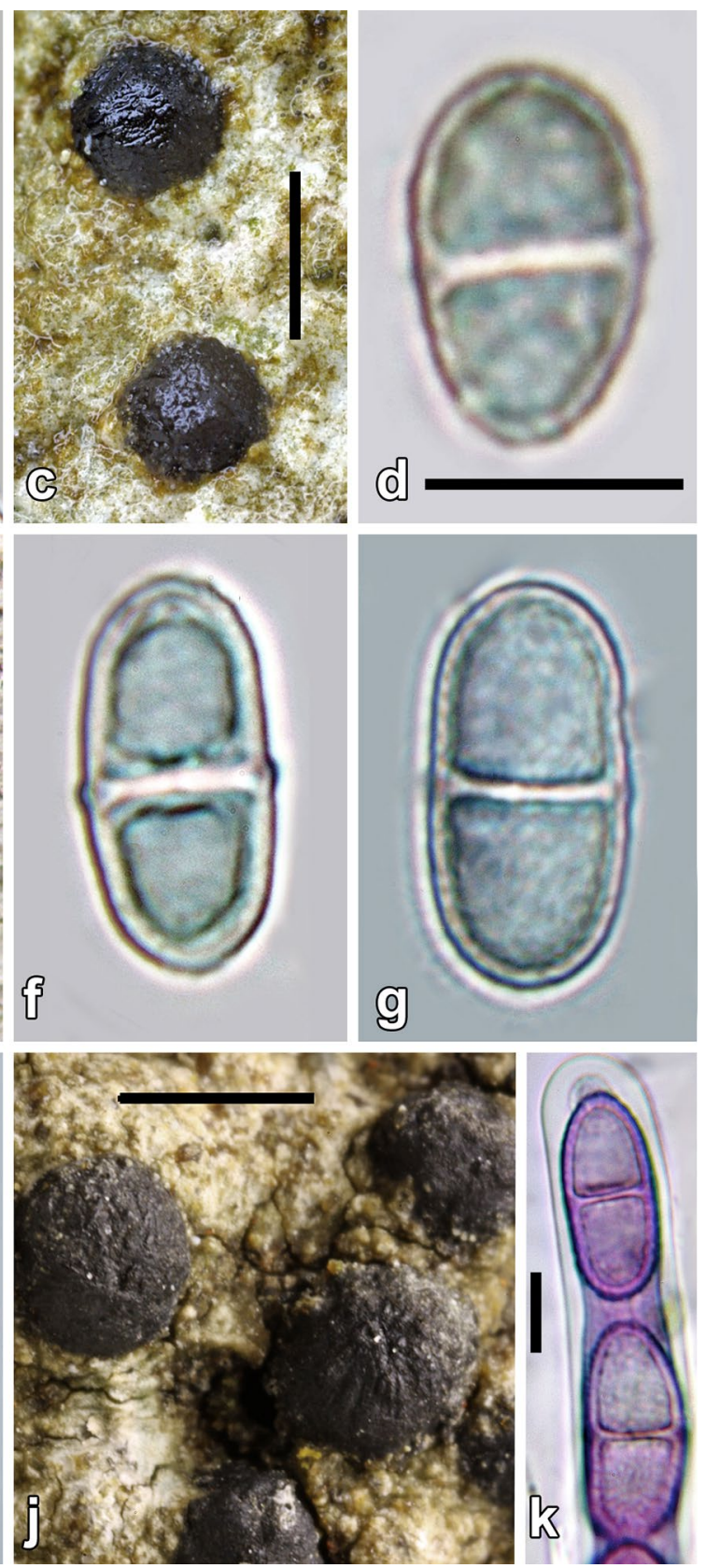

tugal, Aptroot \& Schumm 14215). Scale bars: a, c, j = $1 \mathrm{~mm}, \mathrm{~b}, \mathrm{~d}, \mathrm{k}$ $=10 \mu \mathrm{m}$. For further illustrations of species of this genus, see also Schumm $(2008,2011)$ and Schumm and Aptroot (2013)

MycoBank number: MB 201; Index Fungorum number: IF 201; Facesoffungi number: FoF 08073; approximately 60 morphologically defined species (this paper; Harada 2019), molecular data thus far available for four species.

$\equiv$ Arthopyrenia sect. Anisomeridium Müll. Arg., Flora 66: 290 (1883)

MycoBank number: MB 700075; Index Fungorum number: IF 700075; Facesoffungi number: FoF 08852. 



Fig. 51 Morphology, asci and ascospores of Acrocordia endobrya (Costa Rica, Sipman 51790). a, b Thallus on dead bryophytes with perithecia and perithecia enlarged. c-e Mature and immature asci

showing broad ocular chamber. $\mathbf{f}-\mathbf{h}$ Ascospores. Scale bars: $\mathbf{a}, \mathbf{b}=1$ $\mathrm{mm}, \mathbf{c}, \mathbf{d}=50 \mu \mathrm{m} ; \mathbf{e}, \mathbf{f}, \mathbf{g}=10 \mu \mathrm{m}$

Lichenized on bark or more rarely on leaves or rocks, possibly lichenicolous; in lowland to montane tropical to subtropical habitats, with few species extending into temperate regions. Thallus usually ecorticate or sometimes with thin cortex, white or shades of grey-green to green. Photobiont Trentepohlia. Ascomata scattered or rarely clustered, erumpent to sessile, mostly black, carbonaceous, ostiolate, ostiole apical or lateral. Involucrellum present or reduced, carbonized. Excipulum dense, consisting of compressed

hyphae, appearing prosoplectenchymatous in thin, bleached sections, hyaline to brown or brown-black. Hamathecium comprising $0.5-0.7 \mu \mathrm{m}$ wide paraphyses, hyaline, straight, branched and anastomosing. Asci (2-)8-spored, bitunicate, fissitunicate, cylindrical, short pedicellate, with narrow, nonamyloid ocular chamber and fluorescent cap- or ring-structures. Ascospores uni- or biseriate to irregularly arranged, ellipsoid-oval to broadly fusiform, small to medium-sized $[(10-) 15-45(-55) \times 4.5-15(-20) \mu \mathrm{m}]$, hyaline to very rarely 
brown, 1(-3)-septate, with thin eusepta and rectangular lumina, smooth-walled or granular ornamented, sometimes slightly constricted at the septa, in 1-septate ascospores the upper cell often distinctly larger than the lower cell (very rarely the opposite). Pycnidia common, immersed to sessile, visible as black dots but sometimes conspicuous and flaskshaped. Conidia acrogenous, either macro- or microconidia; macroconidia usually aseptate, (globose to) broadly ellipsoid to bacillar, $(2.5-) 5-15(-45) \times(2-) 3-7(-16) \mu \mathrm{m}$ large, hyaline, often forming clusters embedded in a gelatinous matrix, these clusters in some species in the form of sacci or cirri; microconidia aseptate, globose to broadly ellipsoid or fusiform, small, 2-4(-5) $\times 1-2(-4) \mu \mathrm{m}$ large, hyaline. Chemistry: Most species do not contain secondary substances; lichexanthone present in some taxa.

Type species: Arthopyrenia xylogena Müll.Arg., Flora 66: 290 (1883) [= Anisomeridium subnectendum (Nyl.) R.C.Harris, More Florida Lichens: 150 (1995)].

Notes: Lücking et al. (in Hyde et al. 2013) did not treat this genus in detail. Citing Riedl (1963), Harris (1995) considered Arthopyrenia xylogena Müll. Arg. the 'lectotype' of the genus. However, Müller (1883) only included a single species in Arthopyrenia sect. Anisomeridium, viz. Arthopyrenia xylogena, which is then by default the (holo-) type (although the terms 'holo-' and 'lectotype' technically do not apply to names above species [ICN Art. 10.1, Note 1]. Riedl's (1963: 270) statement that “... xylogena muss als Typusart der Sektion Anisomeridium Müll. Arg. betrachtet werden." [“... xylogena is to be considered the type species of section Anisomeridium Müll. Arg."] refers to the differences between Müller's protologue of the species description and the features observed by Riedl himself, casting doubt as to Müller properly described the taxon at hand. However, this only affects typification of the species itself, not typification of the genus, which is fixed by the single species name listed in the protologue.

The taxonomic delimitation between Anisomeridium and Megalotremis is elaborated in detail below under the latter genus (see below). Lücking et al. (2017) gave the number of species in Anisomeridium as 200, but revision of published literature revealed that only 57 species are currently to be accepted in the genus, after transferral of several taxa to Megalotremis (see below).

Caprettia Bat. \& H. Maia, Atas Inst Micol Univ Pernambuco 2: 377 (1965).

MycoBank number: MB 813; Index Fungorum number: IF 813; Facesoffungi number: FoF 08074; 8 morphologically defined species (this paper), molecular data thus far unavailable.

Lichenized on leaves, in tropical regions. Thallus ecorticate, greenish, subcuticular (subgenus Caprettia) or supracuticular (subgenus Porinula). Photobiont trentepohloid.
Ascomata scattered (absent in subgenus Caprettia), sessile, subglobose, yellowish to red-brown or brown-black, carbonaceous or not, glabrous or with short to conspicuous, horizontal setae, ostiolate, ostiole apical. Involucrellum reduced, carbonized or not. Excipulum dense, consisting of compressed hyphae, appearing prosoplectenchymatous in thin sections, hyaline to brown. Hamathecium comprising 0.5-0.7 $\mu \mathrm{m}$ wide paraphyses, hyaline, straight, branched and anastomosing. Asci (2-)4-8-spored, bitunicate, fissitunicate, cylindrical, short pedicellate, with broad, non-amyloid ocular chamber and fluorescent cap-structures. Ascospores uniseriate, ellipsoid-oval to sometimes curved, hyaline, 1-septate, smooth. Pycnidia frequent, typically hair-like (subgenus Caprettia) or long-beaked with often slightly inflated base (subgenus Porinula). Conidia acrogenous, microconidia, aseptate, ellipsoid, small, hyaline, within pycnidial tube aggregated into gelatinous, rectangular sacci extruded from pycnidial beak as single diaspores. Chemistry: Secondary substances absent.

Type species: Caprettia amazonensis Bat. \& H. Maia, Atas Inst Micol Univ Pernambuco 2: 378 (1965).

Notes: For illustrations of selected species, see Lücking et al. in Hyde et al. (2013). This genus includes several phenotytically disparate elements. The type species, $C$. amazonensis, grows subcuticularly and produces black, hair-like, straight pycnidia (no ascomata). Subgenus Porinula Lücking \& Sérus. presents supracuticular growth and includes two distinct groups. The type species, $C$. tanzanica, as well as $C$. ornata, $C$. setifera, $C$. goderei, $C$. neotropica, and $C$. nyssogenoides, all frequently produce long-beaked pycnidia and intergrade from very pale and glabrous to black and distinctly setose ascomata. A further species, $C$. confusa, differs in the absence of pycnidia and the large ascospores, resembling those of Trypetheliopsis (Sérusiaux and Lücking 2003; Lücking 2008; Yeshitela et al. 2009). In lieu of molecular data, these taxa are here kept in a single genus, although it is unclear whether they form a monophyletic group and to what extend they are related to Anisomeridium sensu lato and Trypetheliopsis (see also Harris 1995).

Sérusiaux and Lücking (2003) introduced Caprettia subgenus Porinula as a combination based on Porinula [non Porinula (Nyl.) Flagey], overlooking that an illegitimate later homonym cannot serve as base for a legitimate combination. The name must therefore be considered a replacement name, Caprettia subgenus Porinula [ICN Art. 58.1]. At the genus level, however, the replacement name Porinella R. Sant. has priority.

Eriomyces Huanraluek, Thambugala \& K.D. Hyde in Hyde et al., Fungal Diversity 100: 146 (2020).

MycoBank number: MB 556538; Index Fungorum number: IF 556538; Facesoffungi number: FoF 06151; one 
phylogenetically and morphologically defined species (Hyde et al. 2020b).

Saprobic on dead twigs of Hevea brasiliensis in terrestrial, lowland to montane tropical to habitats. Ascomata scattered to somewhat aggregate, immersed to erumpent, brown-black to greyish black, applanately wart-shaped to drop-shaped or angular, ostiolate, ostiole more or less eccentric, with periphyses. Involucrellum present apically, dark brown to carbonized, paraplectenchymatous in thin sections. Excipulum prosoplectenchymatous, hyaline to pale brown. Hamathecium comprising 1-3 $\mu \mathrm{m}$ wide, branched cellular pseudoparaphyses. Asci polyspored, bitunicate, fissitunicate, clavate, long-pedicellate, with indistinct tholus and ocular chamber. Ascospores densely arranged, oblong, sometimes slightly curved, hyaline, aseptate, smooth-walled. Conidiomata not observed.

Type species: Eriomyces heveae Huanraluek, Thambugala \& K.D. Hyde in Hyde et al., Fungal Diversity 100: 147 (2020).

Notes: This monospecific genus is characterized by the unusual, polyspored, clavate asci with long stipe, deviating from the other genera in this family in which ascomata are known. In the original description, the ostioles were given as central but based on the published photographic plate (Hyde et al. 2020b: Fig. 92) they appear to be irregularly excentric, also shown by the irregular shape of the ascomata.

Funbolia Crous \& Seifert in Crous et al., Persoonia 26: 115 (2011).

MycoBank number: MB 560161; Index Fungorum number: IF 560161; Facesoffungi number: FoF 08075; 1 phylogenetically and morphologically defined species (Crous et al. 2011a).

Type species: Funbolia dimorpha Crous \& Seifert in Crous et al., Persoonia 26: 115 (2011).

Notes: For description and illustrations see Crous et al. (2011a).

Heleiosa Kohlm., Volkm.-Kohlm. \& O.E. Erikss., Can J Bot 74: 1830 (1996).

MycoBank number: MB 27767; Index Fungorum number: IF 27767; Facesoffungi number: FoF 08076; 1 phylogenetically and morphologically defined species (Kohlmeyer et al. 1996).

Type species: Heleiosa barbatula Kohlm., Volkm.Kohlm. \& O.E. Erikss., Can J Bot 74: 1830 (1996).

Notes: For description and illustrations see Kohlmeyer et al. (1996).

Megalotremis Aptroot, Biblioth Lichenol 44: 124 (1991).

MycoBank number: MB 26295; Index Fungorum number: IF 26295; Facesoffungi number: FoF 08077; 16

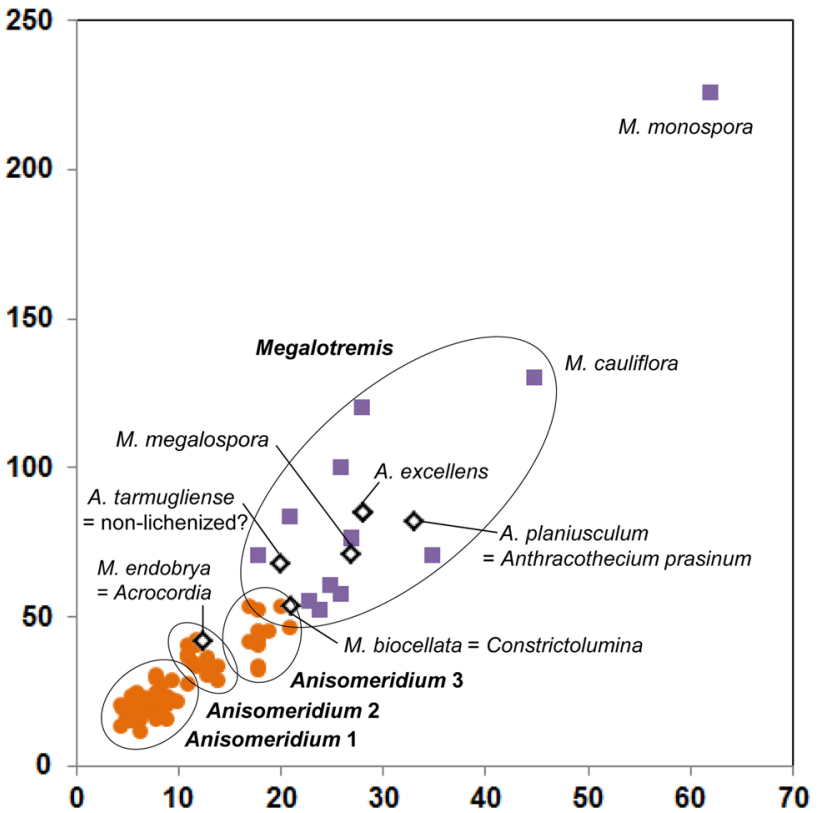

Fig. 52 Ascospore size variation in Anisomeridium and Megalotremis, highlighting taxa of uncertain affinity to either genus and their current status. Axes denote maximum length and width reported for each species (in $\mu \mathrm{m}$ ). Note the formation of three smaller groups in Anisomeridium

morphologically defined species (this paper); molecular data available for one species.

Lichenized on bark, in tropical regions. Thallus usually with thin, cartilaginous cortex, rarely ecorticate, greenish grey to white. Photobiont Trentepohlia. Ascomata scattered, usually erumpent, black but at least partly covered by thalline layer, typically carbonaceous, ostiolate, ostiole apical or lateral. Involucrellum present, carbonized. Excipulum dense, consisting of compressed hyphae, appearing prosoplectenchymatous in thin, bleached sections, brown to brown-black. Hamathecium comprising 0.5-0.7 $\mu \mathrm{m}$ wide paraphyses, hyaline, straight, branched and anastomosing. Asci (1-)2-8-spored, bitunicate, fissitunicate, cylindrical, short pedicellate, with broad, non-amyloid ocular chamber and fluorescent cap-structures. Ascospores uni-seriate to irregularly arranged, ellipsoid-fusiform, rather large [50-130(-225) $\times(18-) 20-45(-60) \mu \mathrm{m}]$, sometimes with the upper cell enlarged, hyaline, 1-septate, with internal, needleshaped crystals. Pycnidia rare. Conidia acrogenous, either macro- or microconidia; macroconidia usually aseptate, (globose to) ellipsoid, (4-)5-9(-15) × 2-5(-15) $\mu \mathrm{m}$ large, hyaline; microconidia aseptate, globose to broadly ellipsoid or fusiform, small, $2-7(-7) \times 1.5-2(-4) \mu \mathrm{m}$ large, hyaline; macro- and/or microconidia in some species aggregated into conglutinate masses sometimes deposited outside the pycnidia. Chemistry: Secondary substances absent. 
Type species: Megalotremis verrucosa (Makhija \& Patw.) Aptroot, Biblioth. Lichenol. 44: 126 (1991).

Notes: In the protologue, Aptroot (1991) did not compare Megalotremis with Anisomeridium but placed the new genus in Trypetheliaceae because of the endospore thickenings; he also pointed out the 'internal folds' of the ascospores which were subsequently interpreted as crystals (Aptroot et al. 2008). Harris (1995) synonymized Megalotremis under Anisomeridium, stating that corticate thalli, one of the perceived differences, also occur in the latter genus. Harris (1995) further suspected that the second species of Megalotremis included in the protologue, $M$. biocellata, was related to Arthopyrenia sensu lato. Aptroot et al. (2008) differentiated Megalotremis from Anisomeridium by the corticate thallus and large ascospores with endospore thickenings, and from Trypetheliopsis (as Musaespora) by the absence of campylidioid asexual morphs.

Given that the currently available molecular data support this separation (Fig. 49), we analysed the species included under Anisomeridium sensu lato by Harris (1995) in terms of thallus morphology and ascospore size (and endospore thickenings). Of the 72 species included in the world-wide key, plus an additional eight species of Megalotremis not included or established subsequently, 55 have endoperidermal, ecorticate thalli with erumpent to prominent, usually exposed, black perithecia, and ascospores with rather thin walls and septa up to $55 \times 20 \mu \mathrm{m}$, but in most cases smaller than $30 \times 10 \mu \mathrm{m}$ (Fig. 52), with smooth or granular ornamented walls. Notably, these species cluster in three ascospore size groups (Fig. 52). Fifteen species have epiperidermal, corticate thalli with immersed-erumpent perithecia partly covered by thallus, and ascospores with thickened walls and septa larger than $55 \times 20 \mu \mathrm{m}$ and up to $130(-225)$ $\times 45(-60) \mu \mathrm{m}$, typically with internal, needle-shaped crystals (or in two cases lack ascomata but have peculiar, tubeshaped pycnidia). These correspond to the current concept of Megalotremis, and of the eight species treated by Harris (1995), the following four are currently included in that genus: $M$. infernale, $M$. megalospora, $M$. nemorosa, and $M$. verrucosa (type of Megalotremis). Another four species are recombined into Megalotremis below.

Several species do not fit into the above scheme and deserve attention. A group of at least four species has corticate thalli but fully exposed, prominent, black perithecia and ascospores typical of Anisomeridium, including A, glaucescens, A. indicum, A. stromaticum, and A. truncatum. These taxa superficially resemble certain species of Lithothelium, although they differ fundamentally in anatomy, and require further study. Their thalli, although corticate, are opaque and differ from the usually shiny thalli of Megalotremis. The transference of Anisomeridium endobryum ( $\equiv$ Megalotremis endobrya) to Acrocordia is discussed above under that genus.
Anisomeridium excellens produces large ascospores (55-85 $\times 20-28 \mu \mathrm{m})$ fitting the range of Megalotremis and far above typical Anisomeridium, but the thallus is clearly endoperidermal and ecorticate, thus fitting Anisomeridium morphologically. Specimens identifiable with this species are not uncommon in the Caribbean, and usually also have at least partly clustered ascomata, and never any superficial thallus. The unusually large ascospores are granular ornamented, a rare feature in bitunicate lichenized Ascomycota and largely known from the genera Anisomeridium and Bogoriella (Trypetheliaceae); they also lack internal crystals, another feature pointing to Anisomeridium rather than Megalotremis. Thus, A. excellens is currently retained in Anisomeridium (see also further discussion under M. biocellata below), but represents an oddball due to its ascospore size and requires molecular study.

Anisomeridium megalosporum ( $\equiv$ Megalotremis megalospora) was described by Vainio (1923) almost as an afterthought in his work on Thaxter's lichen collections from Trinidad, as he considered it non-lichenized. Aptroot (1995) found it to be lichenized, with the ascospores containing needle-shaped crystals, and therefore proposed its inclusing in Megalotremis. The only obstacle to this classification is the thallus morphology, keyed out as endoperidermal and ecorticate by Harris (1995), who also saw the type. Notably, Harris (1995) describes the ascospores as granular ornamented, not mentioning any crystals. In that respect, great similarities exist with A. excellens, which in Harris's key strongly overlaps with his concept of A. megalosporum except for 2-4-spored vs. 2-spored asci. It is possible that part of Harris's A. megalosporum represents a 2-spored form of A. excellens, whereas A. megalosporum sensu stricto is a different taxon. For the time being, we retain the latter in Megalotremis as an exception analogous to the case of $A$. excellens in Anisomeridium.

The presumably large-spored Anisomeridium planiusculum revealed a complex situation. Nylander (1858) described the ascospores as 1-septate, hyaline, and 58-78 $\times 20-30 \mu \mathrm{m}$. Harris (1995) reported the ascospores as 1-septate, hyaline, and 62-82 $\times(22-) 27-33 \mu \mathrm{m}$, i.e. congruent with Nylander's protologue, giving the diminutive specimen in $\mathrm{H}$ (H-NYL 732; H9505212) as holotype. Said holotype features a portion of an apparently endoperidermal, whitish thallus with erumpent ascomata not sharply delimited from the surrounding thallus. Harris's drawings along with that material agree with his published measurements and depict the ascospore walls as uniform. However, the same type has an annotation and drawing by P. G. Patwardhan \& U. Makhija date 1977, which shows secondary endospore constrictions (as in Constrictolumina) and give the size of the ascospores as considerably smaller, namely $35-65 \times 13-20 \mu \mathrm{m}$. All this would point to similarities of the presumed 'holotype' with $M$. biocellata (see below). Two more collections from 
Fée's herbarium with the name Verrucaria planiuscula are in G, one with three large pieces and (G00290329) one with a small portion of the same species abundantly present on the large pieces (G00290330), both featuring a lichen with well-developed, corticate thallus and sharply delimited, black perithecia. The large pieces feature a drawing of two ascospores with the size annotation " $58-78 \times 20-30 \mu \mathrm{m}$ ", in Nylander's handwriting and with an additional annotation by Müller "= jun!". The small piece has two ascospore drawings by Müller, one depicting a 1-septate and the other a muriform ascospore, with the size annotation " $65-75 \times$ 23-37 $\mu \mathrm{m}$ ", and the name annotation "Anthracothecium planiusculum Müll. Arg.' Müller (1888) indeed published the combination A. planiusculum (Nyl.) Müll.Arg., stating that the 1-septate, hyaline ascospores are young and the mature ascospores become muriform and brown. While this sounds unlikely, precisely such ascospore ontogeny has been demonstrated e.g. for Aptrootia terricola in the Trypetheliaceae (Sweetwood et al. 2012; Aptroot and Lücking 2016). Given the agreement of the ascospore size annotation on the specimen with the three large pieces in G (G00290329) with Nylander's (1858) protologue, that specimen must be selected as lectotype: Verrucaria planiuscula Nyl., Expos. Synopt. Pyrenocarp.: 58 (1858); Pyrenula planiuscula (Nyl.) Tuck., Proc. Amer. Acad. Arts \& Sci. 7: 233 (1868); Anthracothecium planiusculum (Nyl.) Müll. Arg., Flora 71: 208 (1888); Arthopyrenia planiuscula (Nyl.) Zahlbr., Cat. Lich. Univers. 1: 310 (1921); Anisomeridium planiusculum (Nyl.) R.C. Harris, More Florida Lichens: 149 (1995). Type. Jamaica, on Quassia excelsa (= Q. amara), s.dat., s.col. (G G00290329, lectotype, here selected, MycoBank MBT393283). The initially 1-septate ascospores and the morphology and substrate make a relationship of this taxon with Aptrootia unlikely and suggest correct placement in the genus Anthracothecium. Based on ascospore size, it would then largely agree with $A$. prasinum, although that species has 8-spored asci (Aptroot 2012), whereas Harris (1995) gives the asci of Anisomeridium planiusculum as 2-4-spored. The only other species of Anthracothecium with solitary ascomata and apical ostioles, A. macrosporum, agrees with the presumably 2-4-spored asci of $V$. planiuscula but has much larger ascospores. However, Nylander (1858) described the asci of $V$. planiuscula as “... $4^{\text {nae }}$ (8nae ?) ..." and Müller (1888) as “... 8-nae ...”. Notably, on the isolectotype material of Verrucaria prasina in G (G00290128), which Müller (1884) renamed Anthracothecium eschweileri, because he considered the thallus not to be green (Latin: prasinus), Müller depicted a similar ascospore development as for Verrucaria planiuscula, with 1-septate ascospores next to muriform ones. We can therefore rather safely assume that Verrucaria planiuscula Nyl. is another synonym of Anthracothecium prasinum and not a species of Anisomeridium or Megalotremis.
Anisomeridium tarmugliense (三 Ditremis tarmugliensis) was described as having "vertically elongated" ascomata with wide open ostioles that are white inside (Makhija and Patwardhan 1990). The illustration shows an irregularly lobed ascoma circumference. These characters contradict placement in Anisomeridium or Monoblastiaceae. Except for the ascospores (the hamathecial filaments were not described), the morphology points to Stictidaceae, e.g. Ostropa or Robergea. We regard the position of this taxon as unresolved, but it is unlikely to be a lichenized bitunicate ascomycete.

Megalotremis biocellata Aptroot is characterized by an endoperidermal, ecorticate thallus and rather large ascospores with secondary endospore invaginations in each cell. Both the thallus and the ascospore type are characteristic for tropical, lichenized species of Arthopyrenia sensu lato currently placed in the genus Constrictolumina in Trypetheliaceae (Aptroot and Lücking 2016). Harris (1995) also related M. biocellata to Arthopyrenia sensu lato and suspected that it could be the same as Tomasellia dispora. The latter was described as having 12-locular ascospores (Müller 1887, p. 427), but this is surely a lapsus for 2-locular, as Müller drew the ascospores on the holotype material (G-G00294870) as 1-septate. Harris (1995) annotated the holotype of $T$. dispora as synonymous with A. malaccitula (三 Constrictolumina malaccitula), although he did not list that name as synonym of the latter. Instead, he gave A. bifera and Didymella gigantea as synonyms. Examination of the type of M. biocellata supports its placement in Constrictolumina, but it was initially unclear whether it is actually conspecific with $C$. malaccitula or represents a closely related taxon with larger ascospores. Aptroot (1991) described the ascospores of M. biocellata as 47-53 × 17-21 $\mu \mathrm{m}$ in size. Harris (1995) studied the holotype of Verrucaria malaccitula (H-H9505214, H-NYL 1706) and, contrary to Nylander's (in Nylander and Crombie 1884) measurements $(26-36 \times 12-16 \mu \mathrm{m})$, gave the ascospores as $37-48 \times$ 15-16 $\mu \mathrm{m}$, a range adopted by Aptroot and Lücking (2016). A specimen from Papua New Guinea (Aptroot 19093) included under $C$. malaccitula in the latter work had mature ascospores measuring up to $49 \times 17 \mu \mathrm{m}$. The type material of $T$. dispora reportedly has ascospores 38-48 $\times 14-16$ $\mu \mathrm{m}$ (Müller 1887), and that of A. bifera $42-45 \times 15-16 \mu \mathrm{m}$ (Zahlbruckner 1935), whereas Didymella gigantea, with smaller ascospores, does not seem to belong in this complex also on account of its morphology. Specimens identified as M. biocellata from Costa Rica (Aptroot et al. 2008) have ascospores $40-45 \times 16-20 \mu \mathrm{m}$ in size [due to a lapsus, the ascospores of Costa Rican material of that species (FH, Brenes 188; see Aptroot et al. 2008: 71, Fig. 11A-B) were due to a mixup of images erroneously also illustrated as those of C. cinchonae in Aptroot and Lücking 2016: 919, fig. $45 \mathrm{~L}]$. All this would point to a continuous range of about 
$40-50 \times 15-20 \mu \mathrm{m}$ large ascospores for a single species, with malaccitula as the oldest available epithet. We also discovered a lapsus in the protologue of M. biocellata (Aptroot 1991: 125): whereas in the description the ascospores were given as $47-53 \times 17-21 \mu \mathrm{m}$ in size, in the corresponding illustration (Aptroot 1991: fig. 48) they were depicted as $67-68 \times 20-21 \mu \mathrm{m}$. Re-examination of the type material showed an ascospore size of 45-50 $\times 15-20 \mu \mathrm{m}$. Thus, we consider M. biocellata, another synonym of $C$. malaccitula, besides T. dispora and A. bifera (see Lücking et al. in Hongsanan et al. 2020, this volume: Trypetheliaceae).

Megalotremis elegans (R.C. Harris) Lücking \& Aptroot, comb. nov.

MycoBank number: MB 836366; Index Fungorum number: IF 836366; Facesoffungi number: FoF 08078.

Bas.: Anisomeridium elegans R.C. Harris, More Florida Lichens: 145 (1995).

Megalotremis holopolia (Nyl.) Lücking \& Aptroot, comb. nov.

MycoBank number: MB 836367; Index Fungorum number: IF 836367; Facesoffungi number: FoF 08079.

Bas.: Verrucaria holopolia Nyl., Bull. Soc. Linn. Normandie, Sér. 2(2): 131 (1868); Anisomeridium holopolium (Nyl.) R.C. Harris, More Florida Lichens: 147 (1995).

Megalotremis immersa (Makhija \& Patw.) Lücking \& Aptroot, comb. nov.

MycoBank number: MB 836368; Index Fungorum number: IF 836368; Facesoffungi number: FoF 08080.

Bas.: Ditremis immersa Makhija \& Patw., Biovigyanam 16: 17 (1990); Anisomeridium immersum (Makhija \& Patw.) R.C. Harris, More Florida Lichens: 147 (1995).

Megalotremis monospora (Makhija \& Patw.) Lücking \& Aptroot, comb. nov.

MycoBank number: MB 836369; Index Fungorum number: IF 836369; Facesoffungi number: FoF 08081.

Bas.: Ditremis monospora Makhija \& Patw., Biovigyanam 16: 20 (1990); Anisomeridium monosporum (Makhija \& Patw.) R.C. Harris, More Florida Lichens: 148 (1995).

Phellinocrescentia Crous \& Decock in Crous et al., Persoonia 33: 235 (2014)

MycoBank number: MB 810600; Index Fungorum number: IF 810600; Facesoffungi number: FoF 08082; one phylogenetically and morphologically defined species (Crous et al. 2014).

Type species: Phellinocrescentia guianensis Crous \& Decock in Crous et al., Persoonia 33: 235 (2014).

Notes: For description and illustrations see Crous et al. (2014).
Pseudopassalora Crous in Crous et al., Persoonia 27: 41 (2011).

MycoBank number: MB 560570; Index Fungorum number: IF 560570; Facesoffungi number: FoF 08083; one phylogenetically and morphologically defined species (Crous et al. 2014).

Type species: Pseudopassalora gouriqua Crous in Crous et al., Persoonia 27: 41 (2011).

Notes: For description and illustrations see Crous et al. (2011b).

Trypetheliopsis Asahina, J. Jap. Bot. 13: 319 (1937).

MycoBank number: MB 5627; Index Fungorum number: IF 5627; Facesoffungi number: FoF 08084; 8 morphologically defined species (Harada 2017; Lücking et al. 2017), molecular data available for one species.

= Musaespora Aptroot \& Sipman, Lichenologist 25(2): 123 (1993).

MycoBank number: MB 22430; Index Fungorum number: IF 22430; Facesoffungi number: FoF 08085.

Lichenized on bark or leaves, in tropical regions. Thallus corticate, olive-green to brownish. Photobiont Trentepohlia. Ascomata scattered or rarely pseudostromatic, erumpent to prominent, brown-black and carbonaceous or rarely with orange-red pigment, ostiolate, ostiole apical. Involucrellum present, carbonized. Excipulum dense, consisting of compressed hyphae, appearing prosoplectenchymatous in thin, bleached sections, brown to brown-black. Hamathecium comprising 0.5-0.7 $\mu \mathrm{m}$ wide paraphyses, hyaline, straight, branched and anastomosing, usually inspersed. Asci 8-spored, bitunicate, fissitunicate, cylindrical, short pedicellate, with broad, non-amyloid ocular chamber and fluorescent cap-structures. Ascospores irregularly arranged, ovaloblong, typically slightly curved, hyaline, 1 -septate, large (70-120 × 12-25 $\mu \mathrm{m})$, with internal, needle-shaped crystals. Conidiomata campylidiiform, brown black or rarely with orange-red pigment. Conidia acrogenous, microconidia, aseptate, drop-shaped, small, hyaline, aggregated in gelatinous mass. Chemistry: Secondary substances absent except for unidentified red pigment in the type and in $T$. coccinea.

Type species: Trypetheliopsis boninensis Asahina, J. Jap. Bot. 13: 319 (1937).

Notes: Trypetheliopsis was described as a monospecific genus for a corticolous lichen with pseudostromatic ascomata producing a bright, orange-red pigment and with large, 1-septate, fusiform ascospores with markedly submedian septum (Asahina 1937; Santesson 1970). The genus was largely forgotten, until Kashiwadani et al. (2009) resurrected it, considering it an earlier name for Musaespora, based on similarities (in particular the orange-red pigment) with Musaespora coccinea. 

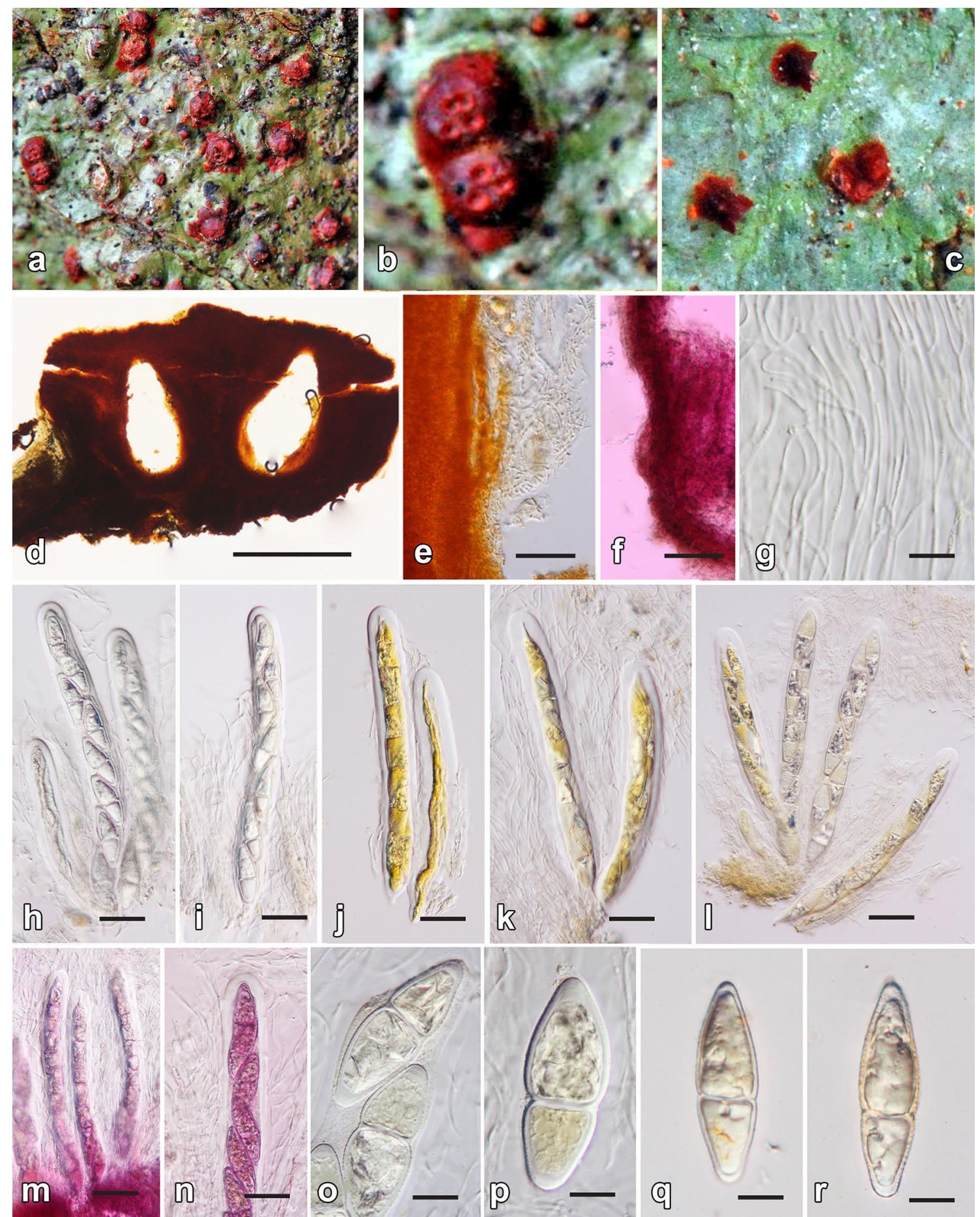

Fig. 53 Morphology, asci and ascospores in Trypetheliopsis boninensis. a-c Thallus with ascomata, pycnidia, and campylidia (Japan, Kashiwadani 52239 \& Moon). d-r Hamathecium, asci, and ascospores (holotype). Scale bars: $\mathbf{d}=0.5 \mu \mathrm{m}, \mathbf{e}, \mathbf{f}, \mathbf{h}-\mathbf{n}=40 \mu \mathrm{m}, \mathbf{g}, \mathbf{o}-\mathbf{r}=10 \mu \mathrm{m}$

Trypetheliopsis boninensis Asahina, J. Jap. Bot. 13(5): 319 (1937).

MycoBank number: MB 411966; Index Fungorum number: IF 411966; Facesoffungi number: FoF 08086; Fig. 53.
Lichenized on bark in tropical regions. Thallus corticate, olive-green. Photobiont Trentepohlia. Ascomata pseudostromatic, prominent, with orange-red pigment, ostiolate, ostiole apical. Involucrellum present, carbonized. Excipulum dense, consisting of compressed hyphae, appearing 
prosoplectenchymatous in thin, bleached sections, brown. Hamathecium comprising $0.5-0.7 \mu \mathrm{m}$ wide paraphyses, hyaline, straight, branched and anastomosing, usually inspersed. Asci 8-spored. Ascospores irregularly arranged, oval-oblong, fusifurm, 1-septate, with constrictions at septum, 40-50 $\times$ 15-20 $\mu \mathrm{m}$, with internal, needle-shaped crystals. Conidiomata of two type, pycnidia and campylidiiform, with orangered pigment. Conidia acrogenous, aseptate, drop-shaped, small, hyaline, aggregated in gelatinous mass. Chemistry: Several orange-red pigments, identified as skyrin, oxyskyrin and skyrinol (Santesson 1970).

Material examined: JAPAN, Ryukyu, Pref. Okinawa, Iriomote-jima, around Kanpirei Fall, Taketomi-cho, Yaeyamagun, $24^{\circ} 21^{\prime} 17^{\prime \prime} \mathrm{N}, 123^{\circ} 48^{\prime} 29^{\prime \prime}$ E, alt. c. $70 \mathrm{~m}$, on bark, 9 March 2018, Kashiwadani 52239 \& Moon, TNS).

Notes: We were able to restudy the type and other material in detail (Fig. 53). The ascomata are pseudostromatic, with 5-10 perithecia per pseudostroma, rather closely resembling the pseudostromata of Trypethelium sensu stricto (Aptroot and Lücking 2016). The ascospores are distinctly fusiform with a marked submedian septum, resembling those of certain Megalotremis species. Recently collected material (Kashiwadani 52239 \& Moon, TNS) shows two types of conidiomata: red pycnidia and dark red campylidia (Fig. 53). Trypetheliopsis boninensis is thus clearly congeneric with Musaespora and differs from the type of the latter, $M$. corticola $(=T$. gigas) largely in the sessile vs. prominent, strongly pigmented ascomata. The close relationship between these taxa is also illustrated by $T$. coccinea, which features a similar pigment as $T$. boninensis and differs from the latter in the foliicolous growth habit, distinctly verrucose thallus and erumpent to prominent, solitary ascomata.

\section{Key to genera of Monoblastiaceae:}

1. Ascomata absent; conidiomata present................2

1. Ascomata present................................6

2. Conidiomata hyphomycetous; conidia brown.........3

2. Conidiomata coelomycetous (pycnidia, frequently beaked or campylidiiform)........................... 4

3. Conidia pleurogenous, dimorphic, broadly ellipsoid and 1-septate to oblong-bacillar and tapering and (2-)3(-7)-septate, walls smooth; on bark......Funbolia

3. Conidia acrogenous, uniform, oblong-fusiform, aseptate to 1-septate, walls finely verruculose; on leaves..............................Pseudopassalora

4. Non-lichenized; growing on bracket fungi (Phellinus) Phellinocrescentia

4. Lichenized; growing on bark or leaves................5

5. Conidiomata campylidiiform............Trypetheliopsis

5. Conidiomata beaked pycnidia or entirely hair-like
6. Pycnidia with distinctly inflated base and short beak; on bark........................Anisomeridium p.p.

6. Pycnidia with slightly inflated base or entirely hairlike; on leaves....................................7

7. Thallus subcuticular, with Cephaleuros-like photobiont or appearing non-lichenized; ascomata unknown; pycnidia hair-like, very thin, straight, rather dense.

Caprettia subgenus Caprettia

7. Thallus supracuticular, with Phycopeltis photobiont; ascomata frequent; pycnidia setiform, thicker, often bent, usually scattered

Caprettia subgenus Porinula

8. Non-lichenized; growing on leaves; either asci clavate with long stipe or ascospores with appendages........9

8. Lichenized; growing on bark or rarely on rock; asci cylindrical, with short stipe, ascospores lacking appendages..........................................10

9. Asci distinctly clavate, with long stipe, polyspored; ascospores aseptate, oblong, without appendages; growing on dead twigs and leaves...........Eriomyces

9. Asci cylindrical, with short stype, 8-spored; ascospores 1 -septate, ellipsoid, with appendages; growing on senescent leaves of Juncus in salt marshes...Heleiosa

10. Ascospores aseptate, with granular or peg-like ornamentation Monoblastia

10. Ascospores 1-3-septate, smooth or with granular ornamentation. .11

11. Ascospores small to medium-sized (less than $50 \times 20$ $\mu \mathrm{m})$ and with thin walls and septa or septa slightly buldging laterally; thallus mostly thin and ecorticate or with thin cortex and opaque.........................12

11. Ascospores large (more than $50 \times 20 \mu \mathrm{m}$ ) and with thickened walls and/or septa and often with internal, needle-shaped crystals; thallus usually well-developed, usually with cartilaginous cortex and often with metallic glance, very rarely endoperidermal and ecorticate.........................................14

12. Asci with broad ocular chamber; ascospores oblong, usually granular ornamented; perithecia often sessile; in temperate or tropical montane regions...Acrocordia

12. Asci with narrow ocular chamber; ascospores ellipsoid to fusiform, smooth to more rarely granular ornamented; perithecia usually immersed to prominent, rarely in sessile pseudostromata; mostly tropical...........................................13

13. Pycnidia hair-like or setiform; ascomata often non-carbonaceous; on leaves.......................Caprettia

13. Pycnidia wart-shaped or at best flask-shaped with short beak; ascomata carbonaceous; usually on bark, rarely on leaves................................Anisomeridium

14. Pycnidia campylidiiform; ascospores usually slightly curved. Trypetheliopsis 
Fig. 54 Phylogram generated from maximum likelihood analysis (RAxML) of Murramarangomycetales based on ITS, LSU, and SSU sequence data. Maximum likelihood bootstrap values equal or above $70 \%$, Bayesian posterior probabilities equal or above 0.90 (MLBS/ PP) are given at the nodes. An original isolate number is noted after the species name. The tree is rooted to Patellaria quercus (CPC 27232). The ex-type strains are indicated in bold. Hyphen (-) represents support values below $70 \%$ MLBS and $0.90 \mathrm{PP}$

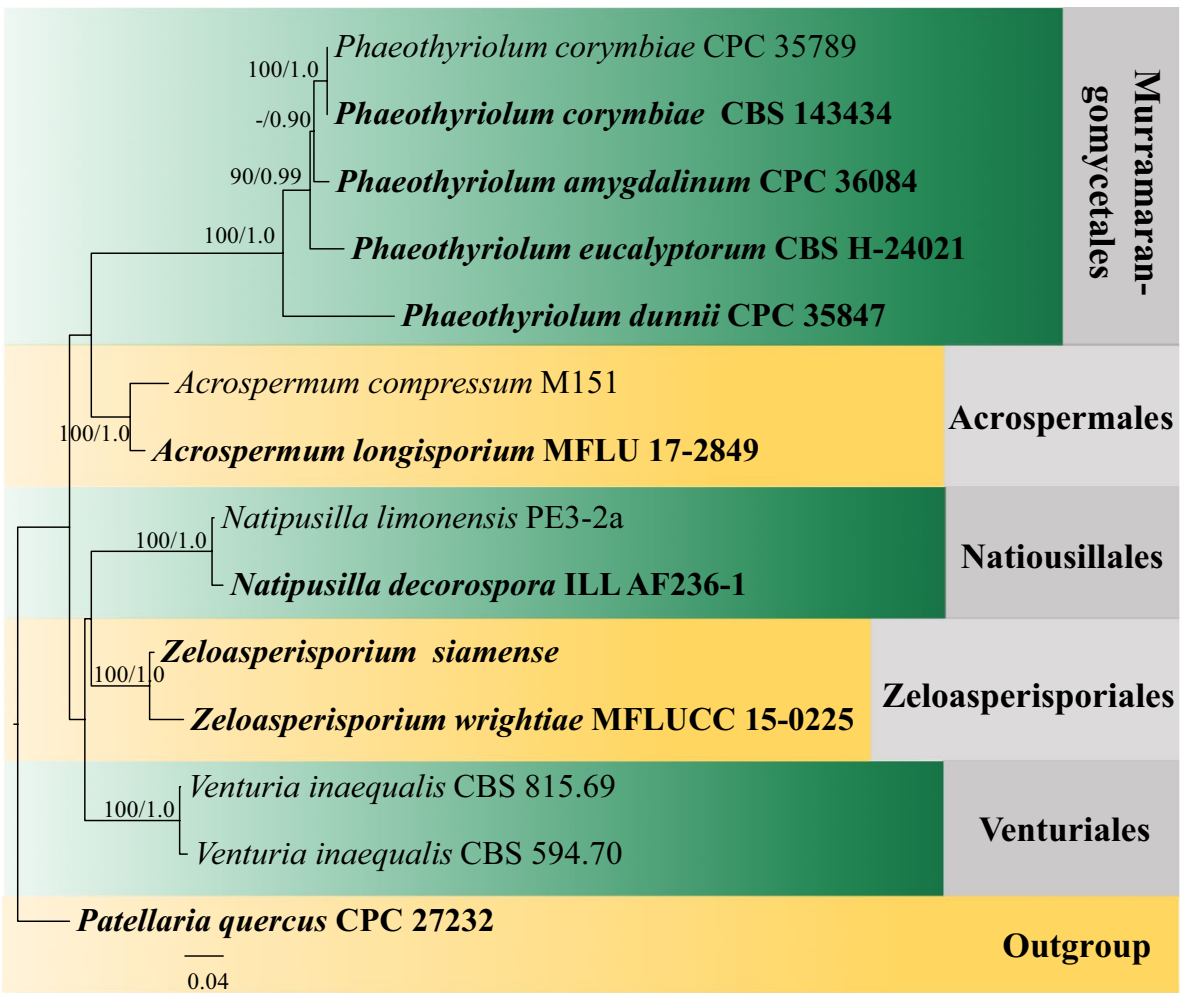

14. Pycnidia variously shaped but not campylidiiform (or pycnidia absent); ascospores straight or slightly curved..... ...15

15. On leaves; ascospores slightly curved. Caprettia (confusa)

15. On bark; ascospores straight.....................16

16. Thallus epiperidermal, corticate and usually shiny; ascospores with internal, needle-shaped crystals...... Megalotremis

16. Thallus endoperidermal, ecorticate................17

17. Ascospores with internal, needle-shaped crystals Megalotremis (megalospora)

17. Ascospores granular ornamented Anisomeridium (excellens)

\section{Economic and ecological significance}

Monoblastiaceae (including Eriomycetaceae) comprises both lichenized and non-lichenized ascomycetes. No economic significance has been reported for lichenized members of the family, but foliicolous representatives have been classified according to their potential to monitor environmental health of tropical forest ecosystems. Thus, Anisomeridium foliicola, Trypetheliopsis epiphylla and T. kalbii were listed as characteristic of mostly closed forest (Lücking 1997). Corticolous Monoblastiaceae also appear to be largely confined to closed forest (Rivas Plata et al. 2008), although Lucheta et al. (2019) characterized Anisomeridium leptospermum as urban lichen. The anthraquinone pigments in Trypetheliopsis have been chemically studied (Santesson 1970) but their potential applications are unknown. In studies in the semi-arid vegetation of northeastern Brazil, species of Anisomeridium were shown to form part of the diet of termites (Barbosa-Silva and Vasconcellos 2019; BarbosaSilva et al. 2019).

The non-lichenized lineages formerly separated in Eriomycetace are apparently mostly saprobic and hence function as decomposers of plant and fungal organic matter, but their exact ecology has not yet been assessed (Kohlmeyer et al. 1996; Crous et al. 2011a, b, 2014; Hyde et al. 2020b).

Murramarangomycetales Crous.

Index Fungorum number: IF 823433; Facesoffungi number: FoF 08087.

Murramarangomycetales was introduced by Crous et al. (2017) to accommodate Murramarangomycetaceae. The family formed a distinct lineage which could not be assigned to any orders in Dothideomycetes (Crous et al. 2017; Hongsanan et al. 2020; this study, Fig. 54).

Accepted families: Murramarangomycetaceae.

Murramarangomycetaceae Crous, in Crous et al., Persoonia 39: 385 (2017).

Index Fungorum number: IF 823434; Facesoffungi numbers: FoF 08088, 7 species. 

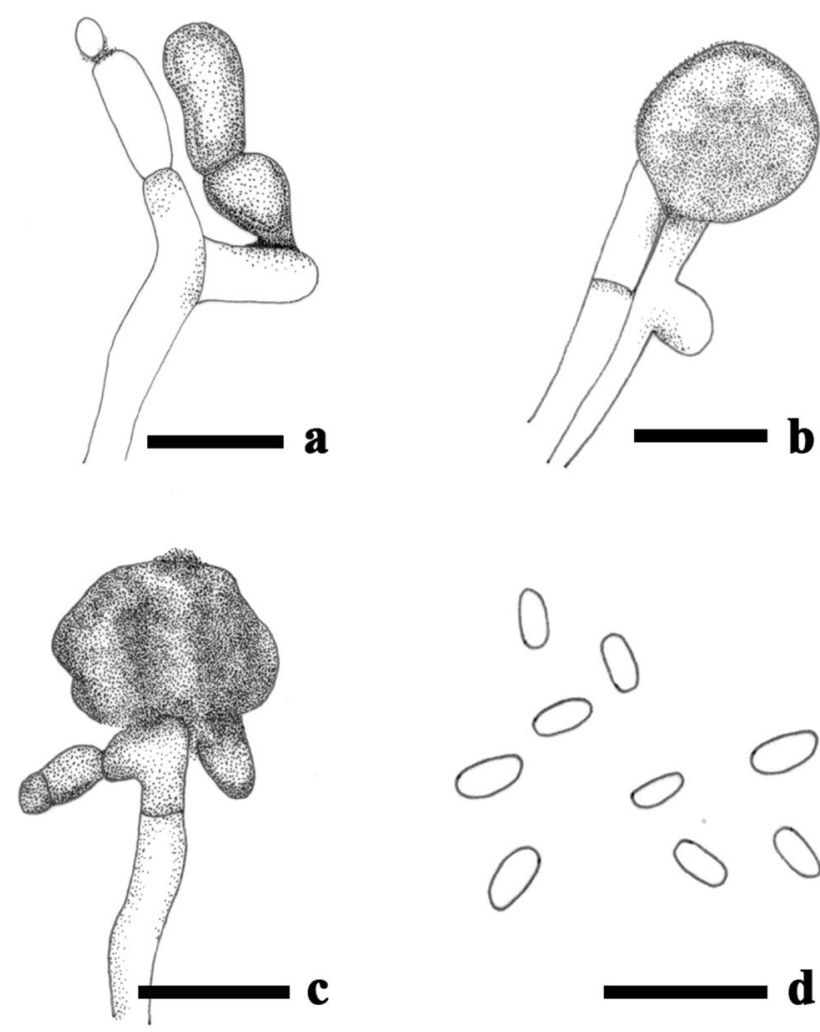

Fig. 55 Phaeothyriolum corymbiae (redrawn from Crous et al. 2017, CBS H-23281, holotype). a Mycelium becoming fertile conidiogenous cells. b, c Conidigenous cell aggregated in cauliflower-like form. d Conidia

Leaf spots, associated with several fungi in a leaf spot colony, confined to one side of the leaf. Mycelium interepidermal, brown, septate, branched, giving leaf spots a redpurple appearance without any superficial mycelium being present, mycelium aggregating in substomatal cavity. Sexual morph: Thyrothecium superficial, radial orientation or clusters, circular, flattened, with lobed, brown, smooth to irregular margin of cells of textura epidermoidea or angularis. Hamathecium comprising hypha-like, dissolving at maturity, or persistent, hyaline, septate, anastomosing or not, pseudoparaphyses. Asci 8-spored, ellipsoid-obclavate, pedicellate, with small ocular chamber. Ascospores 3- to multi-seriate, fusoid-ellipsoid to obovoid, 1-septate, guttulate, granular, slightly constricted at median septum or not, encased in prominent mucoid sheath which is absent at maturity, hyaline, becoming brown once discharged onto agar. Asexual morph: Hyphomycetous. Hypophyllous, circular, dark brown. Mycelium in vitro consisting of hyaline, smooth hyphae, irregular, constricted at septa. Conidiogenous cells thick-walled cells that become fertile conidiogenous cells, aggregated in cauliflower-like clusters of brown, doliiform to globose, brown conidiogenous cells, phialidic, giving rise to solitary conidia. Conidia in slimy mass, aseptate, hyaline, smooth, bacilliform (adapted from Crous et al. 2017, 2019c).

Type: Phaeothyriolum Syd.

Notes: This family was introduced by Crous et al. (2017) to accommodate the monotypic genus, Murramarangomyces which contains a single species, M. corymbiae. Phylogenetic analyses indicated that Murramarangomycetaceae is different from other families and orders within Dothideomycetes, therefore, Crous et al. (2017) established a new order to accommodate this family. However, Murramarangomyces was synonymised under Phaeothyriolum by Crous et al. (2019c). Murramarangomycetaceae and Murramarangomycetales accommodates Phaeothyriolum base on the Phaeothyriolum clade not clustering with any other families and orders in Dothideomycetes. Seqeuence data of the type species of Phaeothyriolum is needed.

Phaeothyriolum Syd., Annls mycol. 36(4): 305 (1938).

= Murramarangomyces Crous, in Crous et al., Persoonia 39: 385 (2017).

Index Fungorum number: IF 3962; Facesoffungi number: FoF 08089; 7 morphological species (Species Fungorum 2020), 4 species with molecular data.

Type species: Phaeothyriolum eucalyptinum Syd.

Notes: Phaeothyriolum was placed in genera incertae sedis in Dothideomycetes in Wijayawardene et al. (2017a). Sequence data of the type species is unavailable. Murramarangomyces based on a single species $M$. corymbiae was found to be aexual morph of Phaeothyriolum corymbiae. Thus, Murramarangomyces was synonymized under Phaeothyriolum (Crous et al. 2019c). Crous et al. (2019c) indicated that four species of Phaeothyriolum clustered together within Dothideomycetes, but its placement was not assigned. We were unable to obtain a fresh collection of species in this family, so a drawing is provided (Fig. 55)

\section{Economic and ecological significance}

Species in this family cause leaf spots either on living leaves, or on leaf litter (Crous et al. 2019c), confined to one side of the leaf.

Muyocopronales Mapook, Boonmee \& K.D. Hyde.

Index Fungorum number: IF 551615; Facesoffungi number: FoF 01886.

This order was established by Mapook et al. (2016b) to accommodate a single family, Muyocopronaceae. The order formed a distinct clade within Dothideomycetes and was related to Acrospermales and Dyfrolomycetales (Mapook et al. 2016b; this study). Muyocopronales differs from Acrospermales and Dyfrolomycetales by superficial, flattened, carbonaceous, brittle ascomata, cellular pseudoparaphyses that are longer than the asci and ellipsoidal to ovate, unicellular ascospores (Hyde et al. 2013; Mapook 


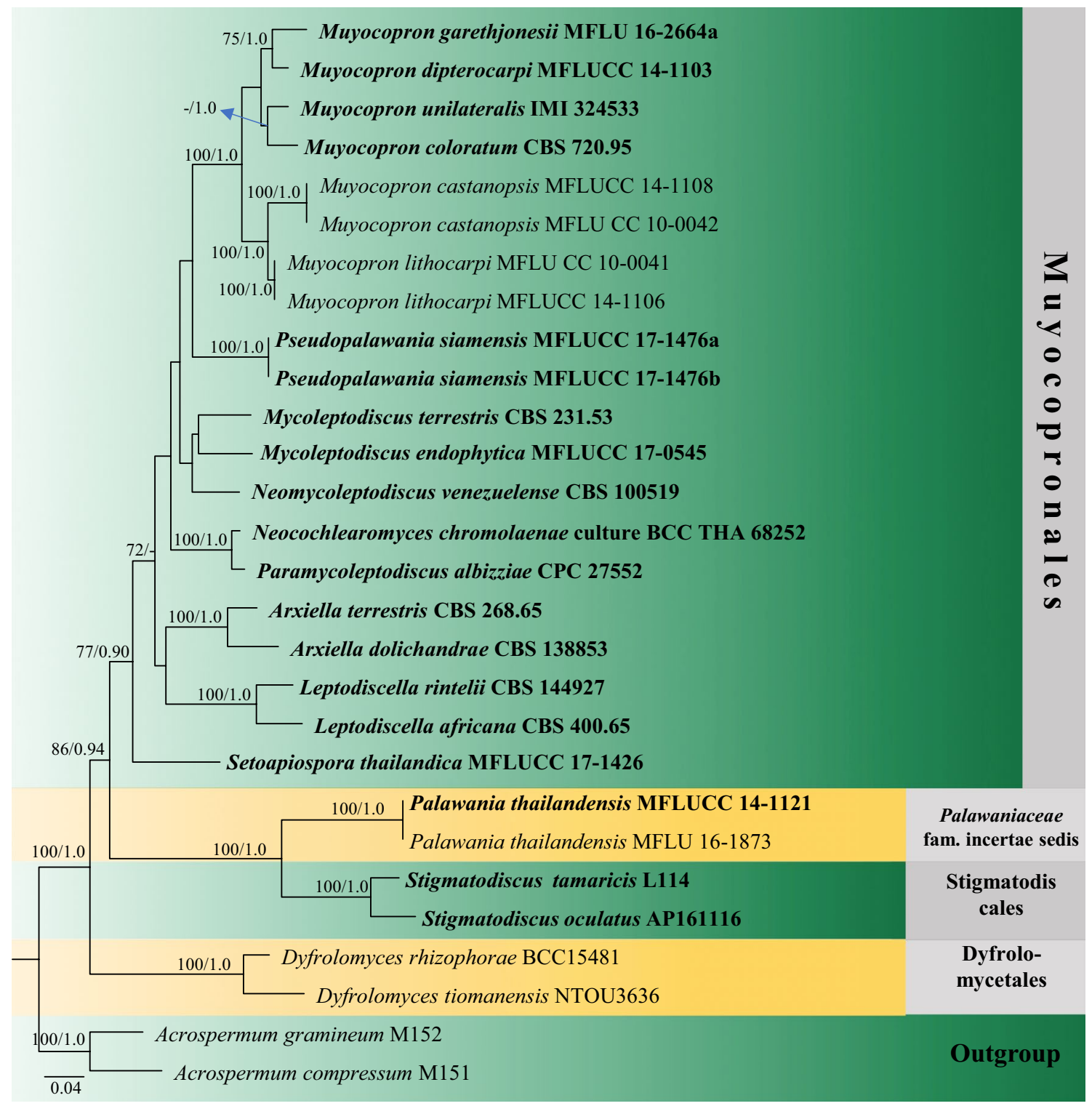

Fig. 56 Phylogram generated from maximum likelihood analysis (RAxML) of Muyocopronales based on ITS, LSU, rpb-2, SSU and tef1 sequence data. Maximum likelihood bootstrap values equal or above $70 \%$, Bayesian posterior probabilities equal or above 0.90 (MLBS/PP) are given at the nodes. An original isolate number is

et al. 2016b). Our phylogenetic analyses indicate that the order comprises a single family, Muyocopronaceae. Palawaniaceae is sister to the clade of Muyocopronaceae $(81 \%$ ML, Fig. 56). Thus, we do not include this family within Muyocopronales. Currently there is one family with seven accepted genera in this order (this paper). The divergence time for Muyocopronales is estimated as 171 MYA (stem age, Hongsanan et al. 2020).

Accepted families: Muyocopronaceae. noted after the species name. The tree is rooted to Acrospermum compressum (M151) and A. gramineum (M152). The ex-type strains are indicated in bold. Hyphen (-) represents support values below $70 \%$ MLBS and $0.90 \mathrm{PP}$

Muyocopronaceae K.D. Hyde, in Hyde et al., Fungal Diversity 63: 164 (2013).

Index Fungorum number: IF 804506; Facesoffungi numbers: FoF 08090, 68 species.

Saprobic, common on the surface of dried twigs, stems and less common on leaves, appearing as black spots, mycelium absent. Sexual morph: Ascomata superficial on host surface, circular, scattered, flattened, rarely coalescing, carbonaceous and coriaceous, black, with a poorly developed basal layer, with a central irregular ostiole, lenticular when section. Upper wall irregularly arranged radiating cells, 

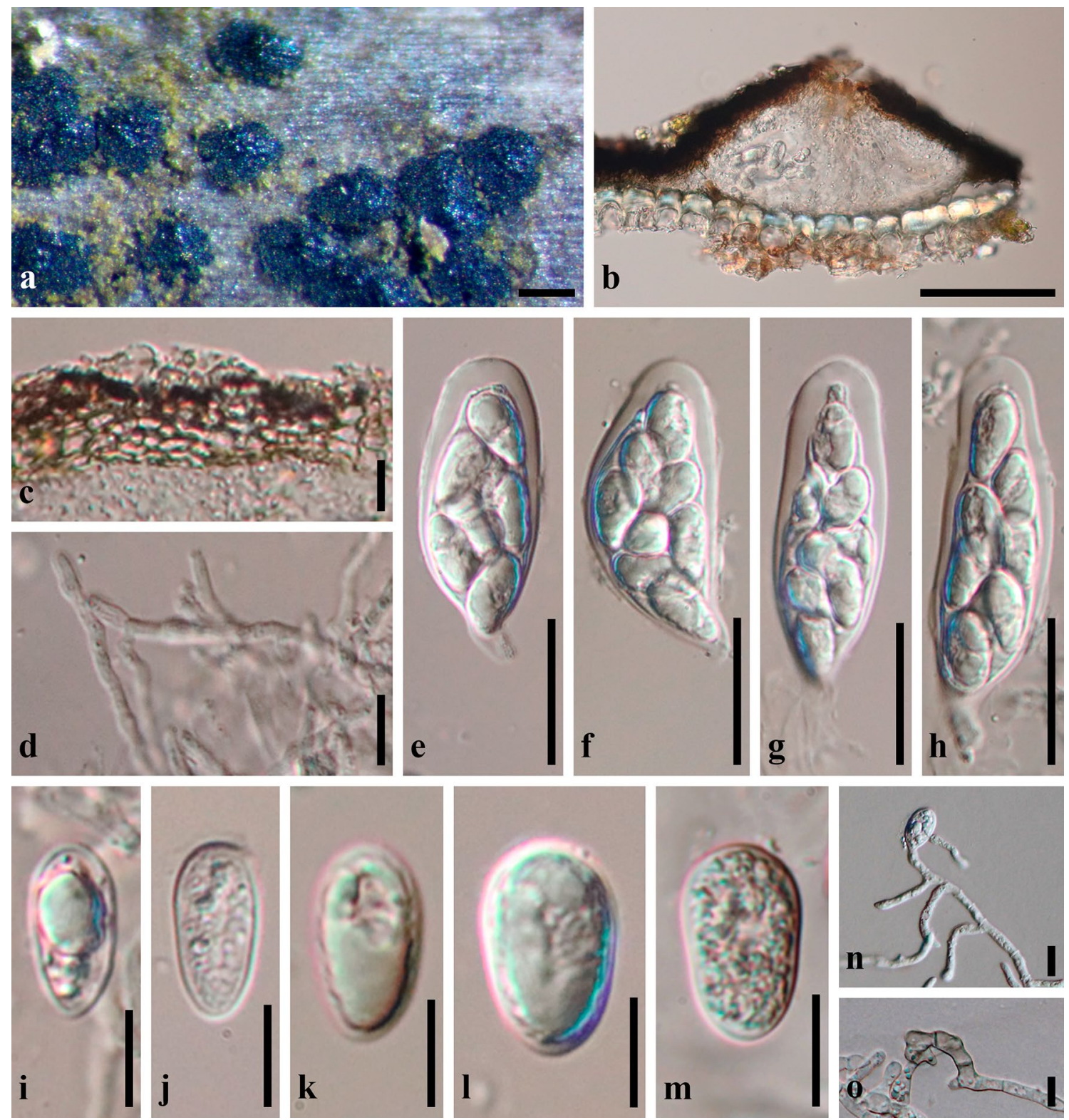

Fig. 57 Muyocopron dipterocarpi (MFLU 18-1385). a Ascomata on host substrate. b Section through ascostroma. c Peridium d Pseudoparaphyses. e-h Asci. i-m Ascospores. $\mathbf{n}$ Germinated spores. o Appressoria. Scale bars $\mathbf{a}=200 \mu \mathrm{m}, \mathbf{b}=100 \mu \mathrm{m}, \mathbf{c}, \mathbf{d}, \mathbf{i}-\mathbf{0}=10 \mu \mathrm{m}, \mathbf{e}-\mathbf{h}=30 \mu \mathrm{m}$

branched at margin cells. Peridium 2-layered, an outer layer comprises brown to black pseudoparenchymatous of compact thick-walled textura epidermoidea cells, light brown of textura angularis cells at inner layer. Hamathecium comprising dense, septate, cellular pseudoparaphyses which are longer than the asci and immersed in mucilage and inclined towards the centre. Asci 8-spored, bitunicate, fissitunicate, pedicellate, with small ocular chamber. Ascospores 2-3-seriate, ellipsoidal to ovate with obtuse ends, hyaline, aseptate, with or without granular appearance. Asexual morph: See Papendorf (1967), Crous et al. (2016b, 2018a), HernándezRestrepo et al. (2019).
Type: Muyocopron Speg.

Notes: Muyocopronaceae was invalidly introduced by Luttrell (1951), and was synonymized under Microthyriaceae (Wu et al. 2011a, b). Hyde et al. (2013) accepted and formally introduced Muyocopronaceae as a distinct family, as well as provided an English diagnosis (Latin diagnosis no longer required). Phylogenetic analyses indicated that the family, Muyocopronaceae comprises nine genera Arxiella, Leptodiscella, Mycoleptodiscus, Muyocopron, Neocochlearomyces, Neomycoleptodiscus, Paramycoleptodiscus, Setoapiospora, and Pseudopalawania (Mapook et al 2020; this study, Fig. 56) 
Muyocopron Speg., Anal. Soc. cient. argent. 12(3): 113 (1881).

Index Fungorum number: IF 3294; Facesoffungi number: FoF 01887; 48 morphological species (Species Fungorum 2020), 5 species with molecular data.

Type species: Muyocopron corrientinum Speg.

Notes: Muyocopron was introduced by Spegazzini (1881), with the type species M. corrientinum. Saccardo (1883) re-described this genus and placed it in Microthyriaceae. Muyocopron was synonymized under Ellisiodothis by von Arx and Müller (1954). Later, it was transferred to Botryosphaeriaceae and Microthyriaceae (von Arx and Müller 1975; Lumbsch and Huhndorf 2007, 2010). However, Muyocopron differs from members of Microthyriaceae by pseudothyriothecia with the peridial wall comprising two layers, pseudoparaphyses longer than the asci, and aseptate ascospores (Hyde et al. 2013; Mapook et al. 2016b). Molecular studies indicated that Muyocopron is distantly related to the Microthyriaceae (Wu et al. 2011a, b; Mapook et al. 2016b, and Fig. 56). The genus clustered with Dyfrolomycetaceae (Dyfrolomycetales), but as a distinct order (Hyde et al. 2013; Mapook et al. 2016b).

Muyocopron dipterocarpi Mapook, Doilom, Boonmee \& K.D. Hyde, Phytotaxa 265 (3): 223 (2016).

Index Fungorum number: IF 551617; Facesoffungi number: FoF 01889, Fig. 57

Description: see Senwanna et al. (2019).

Material examined: Thailand, Phayao Province, Mueang District, Wiang Subdistrict, on dried twig (attached on tree) of Hevea brasiliensis, 2 October 2016, C. Senwanna, RBPY036 (MFLU 18-1385).

\section{Other genera included}

Arxiella Papendorf, Trans. Br. mycol. Soc. 50(1): 73 (1967). Index Fungorum number: IF 7233; Facesoffungi number: FoF 08091; - 3 morphological species (Species Fungorum 2020), 3 species with molecular data.

Type species: Arxiella terrestris Papendorf, Trans. $\mathrm{Br}$. mycol. Soc. 50(1): 73 (1967).

Notes: Species of Arxiella have been reported with asexual morphs (Papendorf 1967; Crous et al. 2014). Arxiella terrestris and A. lunata have hyphomycetous characters, while A. dolichandrae has coelomycetous characters. Coelomycetous Arxiella is characterized by sporodochial, brown conidiomata on agar surface, with globose to somewhat elongated, phialidic, brown conidiogenous cells, and reniform, medianly 1-septate conidia, with guttulate, hornlike appendages at the ends (Crous et al. 2014). Hyphomycetous Arxiella is characterized by septate, branched, hyaline to slightly olivaceous hyphae, with 1- to multi-celled, all cells conidiiferous conidiophores, and reniform, ends obliquely cornute, 1-septate, hyaline to slightly coloured conidia, on short or elongate sterigma-like projections, single or in short chains or in small irregular groups (Papendorf 1967). Arxiella was treated as incertae sedis by Crous et al. (2014). Crous et al. (2018a) showed the placement of Arxiella within Muyocopronaceae. Subsequently, this was supported by Hernández-Restrepo et al. (2019) who provided a phylogenetic tree from four loci (ITS, LSU, rpb-2, and tef1) and concluded that this genus should be placed in Muyocopronaceae.

Leptodiscella Papendorf, Trans. Br. mycol. Soc. 53(1): 146 (1969).

Index Fungorum number: IF 8743; Facesoffungi number: FoF 08092; - 5 morphological species (Species Fungorum 2020), 5 species with molecular data.

Type species: Leptodiscella africana (Papendorf) Papendorf, Trans. Br. mycol. Soc. 53(1): 146 (1969).

三Leptodiscus africanus Papendorf, Trans. Br. mycol. Soc. 50(4): 687 (1967).

Notes: Leptodiscella was described based on hyphomycetous characters, producing conidia, long appendages, chlamydospores forming long or short chains or without chlamydospores present, ellipsoid to oblong-oval or obovoid appressoria or absent. Conidiogenous cells are solitary or aggregated, mono- or polyblastic, sympodial (Papendorf 1969; Udagawa and Toyazaki 1985; Madrid et al. 2012). Papendorf (1967) reported that Leptodiscella was isolated from leaf litter and soil of an Acacia karroo Heyne community in South Africa, but molecular data is unavailable. Madrid et al. (2012) provided sequence data of Leptodiscella based on phenotypic comparisons and presented taxonomic position. Crous et al. (2018a) used ITS region in their phylogenetic analysis and showed the placement of Leptodiscella within Muyocopronaceae.

Mycoleptodiscus Ostaz., Mycologia 59(6): 970 (1968) [1967].

Index Fungorum number: IF 9029; Facesoffungi number: FoF 08094; - 7 morphological species (Hernández-Restrepo et al. 2019), 3 species with molecular data.

Type species: Mycoleptodiscus terrestris (Gerd.) Ostaz., Mycologia 59(6): 970 (1968) [1967].

三Leptodiscus terrestris Gerd., Mycologia 45(4): 552 (1953).

Notes: The type species was included in the invalid genus Leptodiscus (Gerdemann 1953) which was placed in Microthyriaceae (von Arx and Müller 1975; Lumbsch and Huhndorf 2007). Thongkantha et al. (2009) provided the first phylogenetic analysis of a Mycoleptodiscus species (M. coloratus) based on LSU sequence data, and placed it in Magnaporthales (Sordariomycetes). However, Crous et al. (2018a) indicated that Mycoleptodiscus, based on phylogenetic placement of the type species, $M$. terrestris, is a 
member of Muyocopronales. More discussion can be seen in Hernández-Restrepo et al. (2019). The sexual morph of this genus has not been described, except for M. affinis, it however was introduced as Omnidemptus affinis by Cannon and Alcorn (1994). The major characters are restricted to species characterized by cylindrical conidia with appendages at one or both ends. Conidiogenous cells lack a collarette, are solitary or aggregated, mono- or polyblastic, sympodial, often denticulate or phialidic, globose or ampulliform. Conidia are cylindrical, the appressoria have a visible pore surrounded by dark radial lines, and sclerotia (HernándezRestrepo et al. 2019)

Neocochlearomyces Pinruan, Sommai, Suetrong, J.Z. Groenew. \& Crous, in Crous et al., Persoonia 41: 381 (2018).

Index Fungorum number: IF 828085; Facesoffungi number: FoF 08095; - 1 morphological species (Species Fungorum 2020), 1 species with molecular data.

Type species: Neocochlearomyces chromolaenae Pinruan, Sommai, Suetrong, J.Z. Groenew. \& Crous, in Crous et al., Persoonia 41: 381 (2018).

Notes: The phylogenetic analyses from ITS, LSU, rpb2, and tef1 (Hernández-Restrepo et al. 2019) showed that Neocochlearomyces formed a distinct lineage within Muyocopronaceae. The type species was sister to Neomycoleptodiscus venezuelense (CBS 100519) and Mycoleptodiscus endophyticus (MFLUCC 17-0545) in the analysis of Hernández-Restrepo et al. (2019). While, it is related to Paramycoleptodiscus albizziae in our analyses but as a distinct genus (Fig. 56). The genus is characterized by macronematous and mononematous, subcylindrical, septate, thick-walled conidiophores, with terminal and intercalary conidiogenous cells on one side of the swollen fan-like structure, and falcate, aseptate conidia that are equilateral, convex, obtuse to subobtusely rounded, forming a slimy spore mass (Crous et al. 2018a).

Neomycoleptodiscus Hern.-Restr., J.D.P. Bezerra \& Crous, in Hernández-Restrepo et al., Persoonia 42: 221 (2019).

Index Fungorum number: IF 829829; Facesoffungi number: FoF 08096; - 1 morphological species (Species Fungorum 2020), 1 species with molecular data.

Type species: Neomycoleptodiscus venezuelense Hern.Restr., J.D.P. Bezerra \& Crous, in Hernández-Restrepo et al., Persoonia 42: 221 (2019).

Notes: Neomycoleptodiscus was established by Hernández-Restrepo et al. (2019) to accommodate a single species Neocochlearomyces venezuelense. The genus has broadly lunate conidia and variable production of conidial appendages, smooth, hyaline to pale brown hyphae, sporodochiumlike, brown conidiomata, with ampulliform to doliiform, angular, smooth, with a circular aperture situated conidiogenous cells, and one septate, cylindrical, guttulate conidia, with a filamentous appendage at each end, produced in a mucous pale yellow to brown mass (Hernández-Restrepo et al. 2019). The only species in this genus was found on leaf litter of Gyranthera caribensis in Venezuela. In the phylogenetic analyses of Hernández-Restrepo et al. (2019), this genus formed a lineage within Muyocopronaceae and sister to the strain of Mycoleptodiscus endophyticus (MFLUCC 17-0545) with good support (71\% ML, 0.98 BYPP). In our analysis (Fig. 56), the genus is related to the clade containing Mycoleptodiscus endophyticus and Mycoleptodiscus terrestris with moderate support. However, both analyses showed that Neomycoleptodiscus is a distinct genus in Muyocopronaceae.

Paramycoleptodiscus Crous \& M.J. Wingf., in Crous et al., Persoonia 36: 371 (2016).

Index Fungorum number: IF 817042; Facesoffungi number: FoF 08093; - 1 morphological species (Species Fungorum 2020), 1 species with molecular data.

Type species: Paramycoleptodiscus albiziae Crous \& M.J. Wingf. [as 'albizziae'], in Crous et al., Persoonia 36: 371 (2016).

Notes: The genus is characterised by mycelium consisting of hyaline to brown, branched, septate hyphae, chlamydospore-like cells that form a stroma, sporodochium of densely aggregated stroma, solitary or aggregated, subglobose to slightly ampulliform conidiogenous cells, and mono- or polyblastic, sympodial, aseptate conidia that are hyaline, smooth, granular, and base with well defined fusarium-like foot cell (Crous et al. 2016b). The phylogenetic analyses of Crous et al. (2018a) indicated that the type species of this genus is closely related to Mycoleptodiscus terrestris, but morphological characters are different. Paramycoleptodiscus differs from Mycoleptodiscus by aseptate conidia and basal appendage in the form of a foot cell, while Mycoleptodiscus has septate conidia with apical appendages.

Pseudopalawania Mapook. \& K.D. Hyde, Biomolecules, 10: 569 (2020).

Mycobank number: MB834934; Facesoffungi number: FoF 08097; - 1 morphological species (Species Fungorum 2020), 1 species with molecular data.

Type species: Pseudopalawania siamensis Mapook \& K.D. Hyde, Biomolecules, 10: 569 (2020).

Notes: The genus has sub-carbonaceous to superficial, flattened, carbonaceous ascomata, poorly developed basal layer and an irregular margin, with an ostioles, branching pseudoparaphyses, cylindric-clavate asci, with an ocular chamber observed clearly when immature, and broadly fusiform to inequilateral, 1-septate, hyaline ascospores, guttulate when immature, with thin gelatinous sheath (Mapook et al. 2020). Although, morphology of Pseudopalawania is typical of Palawania, molecular analyses confirmed its 
Fig. 58 Phylogram generated from maximum likelihood analysis (RAxML) of Natipusillales based on LSU and SSU sequence data. Maximum likelihood bootstrap values equal or above $70 \%$, Bayesian posterior probabilities equal or above 0.90 (MLBS/PP) are given at the nodes. Isolate/specimen number is noted after the species name. The tree is rooted to Astrothelium variolosum (MPN43), Trypthelium eluteriae (111). The ex-type strains are indicated in bold. Hyphen (-) represents support values below 70\% MLBS and 0.90 PP

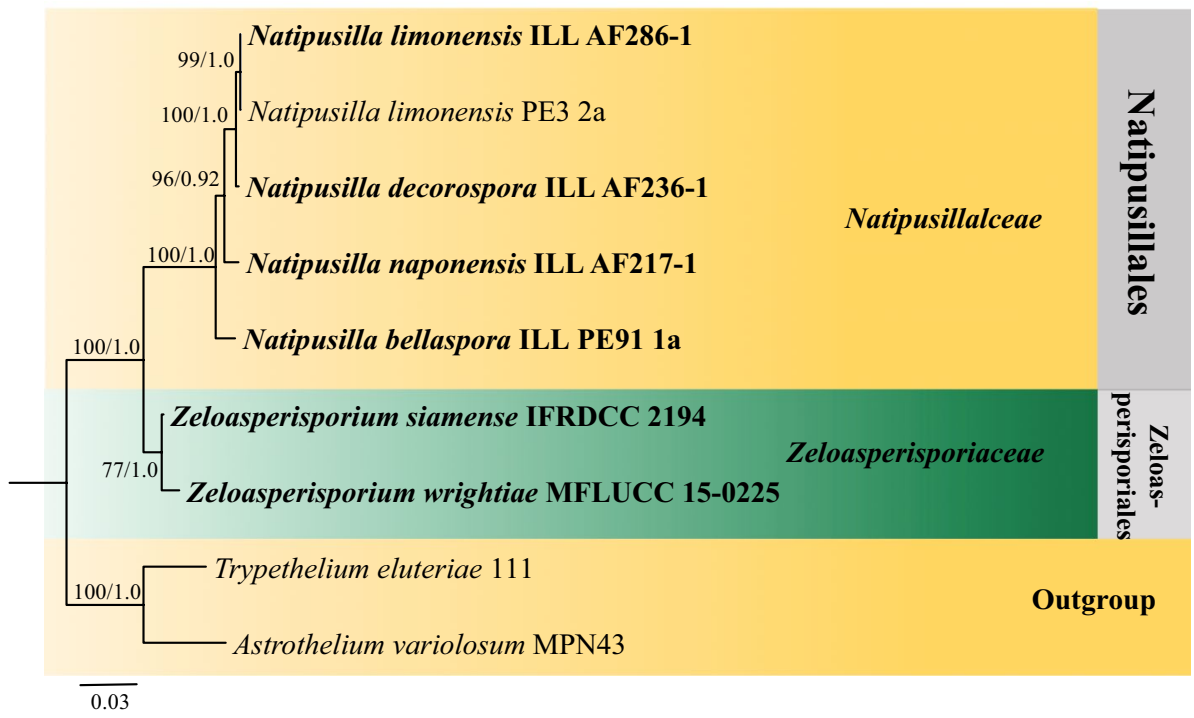

placement within Muyocopronaceae (Mapook et al. 2020; this study Fig. 56).

Setoapiospora Mapook \& K.D. Hyde, Fungal Diversity 100: 5-277 (2020).

Index Fungorum number: IF 556905; Facesoffungi number: FoF 06793; - 1 morphological species (Species Fungorum 2020), 1 species with molecular data.

Type species: Setoapiospora thailandica Mapook \& K.D. Hyde, in Fungal Diversity 100: 5-277 (2020).

Notes: The genus is characterised by appearing as dark brown to black spots on branches of wood, carbonaceous ascomata, with dark brown setae, peridium composed of cells of textura epidermoidea, pseudoparaphyses, 8-spored asci, with an ocular chamber, and 1-septate ascospores, constricted at the septum, with a small lower cell and a large upper cell, tapering towards ends, with granular appearance. (Hyde et al. 2020b). In the phylogenetic analyses indicated that this genus formed a distinct lineage within Muyocopronaceae (Hyde et al. 2020b, this study Fig. 56).

\section{Economic and ecological significance}

Species of Muyocopronaceae are commonly found as saprobes on dead twigs and stems, thus playing roles in decomposition.

Natipusillales Raja, Shearer, A.N. Mill. \& K.D. Hyde.

Index Fungorum number: IF 805300; Facesoffungi number: FoF 08110.

Natipusillales was established to accommodate members of the freshwater ascomycetes belonging to Natipusillaceae based on LSU and SSU sequence data (Hyde et al. 2013). Phylogenetic analyses placed this order in Dothideomycetes (Hyde et al. 2013; Liu et al. 2017). Natipusillales was related to Zeloasperisporiales which is not freshwater fungi and has very different morphological characters (Hongsanan et al. 2015b). There is a single family with one genus accepted in this order (Fig. 58). The divergence time for Natipusillales is estimated as 180 MYA (stem age, Hongsanan et al. 2020).

Accepted families: Natipusillaceae.

Natipusillaceae Raja, Shearer \& A.N. Mill., Mycologia 104(2): 570 (2012).

Index Fungorum number: IF 561948; Facesoffungi number: FoF 08111, 4 species.

Saprobic on decaying wood. Sexual morph: Ascomata globose to subglobose, erumpent to superficial, hyaline to light brown. Peridium membranous, composed of pseudoparenchyma cells of textura angularis in surface view. Hamathecium comprising septate, sparse, cellular pseudoparaphyses. Asci 8-spored, bitunicate, fissitunicate, globose, subglobose or obclavate. Ascospores multi-seriate, fusiform to cylindrical, hyaline becoming brown with age, one to several septate, multiguttulate or not. Asexual morph: Undetermined.

Type: Natipusilla A. Ferrer, A.N. Mill. \& Shearer.

Notes: Natipusillaceae comprises the freshwater genus Natipusilla with four species (Ferrer et al. 2011; Raja et al. 2012). Natipusillales was established to accommodate members of Natipusillaceae based on LSU and SSU sequence data (Hyde et al. 2013).

Natipusilla A. Ferrer, A.N. Mill. \& Shearer, Mycologia 103(2): 417 (2011).

Index Fungorum number: IF 518365; Facesoffungi number: FoF 08112; 4 morphological species (Species Fungorum 2020), 4 species with molecular data. 

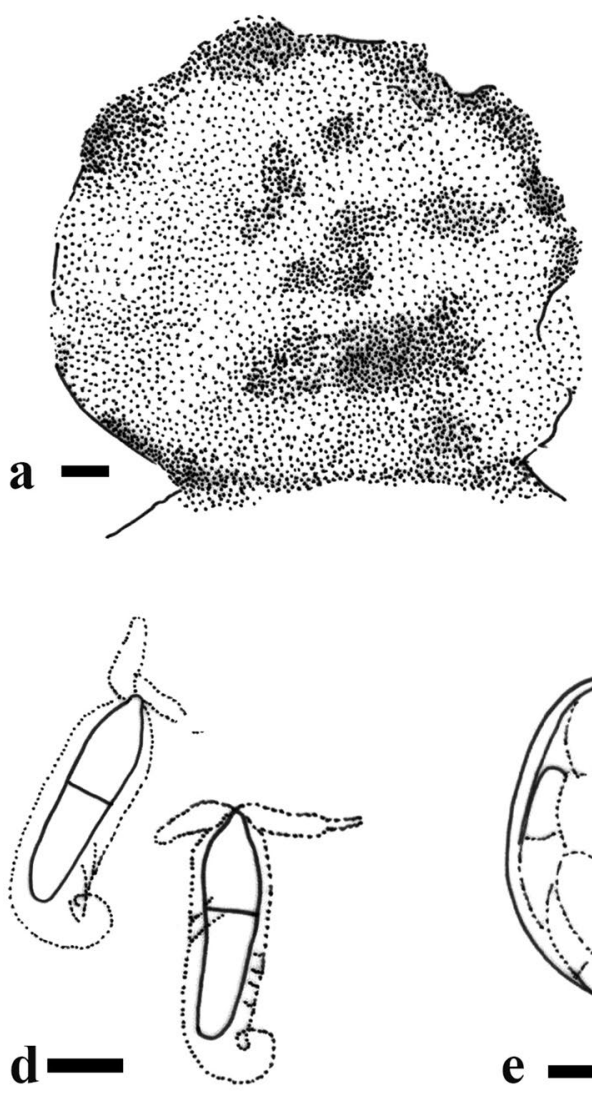
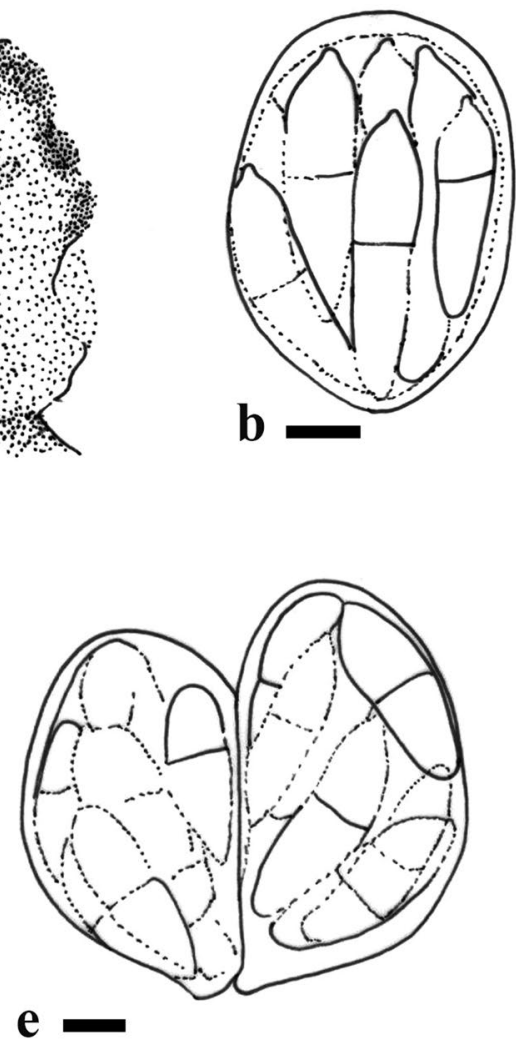

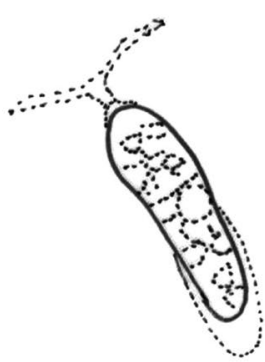

c

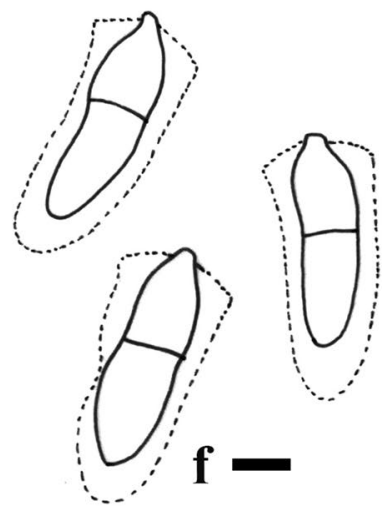

Fig. 59 Morphology of Natipusilla $\mathbf{s p p}$. (a-d = redrawn of Natipusilla decorospora from holotype AF236-1; e, $\mathbf{f}=$ redrawn of N. limonensis from holotype AF286-1). a Ascomata. b, e Asci. c, d, f Ascospores. Scale bars: $\mathbf{a}-\mathbf{f}=10 \mu \mathrm{m}$

Type species: Natipusilla decorospora A. Ferrer, A.N. Mill. \& Shearer.

Notes: Species of Natipusilla have small ascomata, none to few pseudoparaphyses, globose asci and mostly one-septate ascospores (Ferrer et al. 2011; Raja et al. 2012). There are four species accepted in this genus. We were unable to obtain a fresh collection of species in this family, so a drawing is provided (Fig. 59).

\section{Economic and ecological significance}

As typical lignicolous freshwater taxa, species of Natipusillales play an important role in nutrient and carbon cycling, biological diversity and ecosystem functioning of freshwater ecosystems with their ability to decompose lignocellulose in woody litter, softening the wood and releasing nutrients (Palmer et al. 1997; Wong et al. 1998; Yuen et al. 1998; Bucher et al. 2004; Hyde et al. 2016a).

Parmulariales D.Q. Dai \& K.D. Hyde.

Index Fungorum number: IF 554065; Facesoffungi number: FoF 03913.

The order was established by Dai et al. (2018) based on its phylogeny and morphological characters which are different from Asterinales. Taxonomic details can be seen in Dai et al. (2018). Only a single from Parmulariales has sequence data. The clade of Parmulariales is sister to the new family Thyrinulaceae with high boostrap support (Figs. 5, 60), and this result is similar to that found by Dai et al. (2018). The divergence time for Parmulariales is estimated as 115 MYA (stem age, Hongsanan et al. 2020).

Accepted families: Parmulariaceae.

Parmulariaceae E. Müll. \& Arx ex M.E. Barr, Mycologia 71(5): 944 (1979).

Index Fungorum number: IF 81109; Facesoffungi numbers: FoF 02296, 149 species.

Epiphytic or parasitic on living leaves of plants and ferns or thallus of lichens. Colonies foliicolous, superficial, dark brown to black. Hyphae spreading out from ascomata border, brown, septate, branching, sinuous, with or lacking appressoria. Sexual morph: Ascostromata solitary to gregarious, or in groups, superficial to immersed, shield-like to star-shaped, elliptical to boat-shaped, dark brown to black, carbonaceous to membranaceous, strongly flated, or longitudinal slits slightly protuberant, and contain numerous asci. Locules immersed in ascostromata or in longitudinal ridges 
Fig. 60 Phylogram generated from maximum likelihood analysis (RAxML) of Parmulariales based on LSU sequence data. Maximum likelihood bootstrap values equal or above $70 \%$, Bayesian posterior probabilities equal or above 0.90 (MLBS/PP) are given at the nodes. Isolate/specimen number is noted after the species name. The tree is rooted to Venturia inaequalis (ATCC 60070) and $V$. populina (CBS 256.38). The ex-type strains are indicated in bold. Hyphen (-) represents support values below $70 \%$ MLBS and $0.90 \mathrm{PP}$

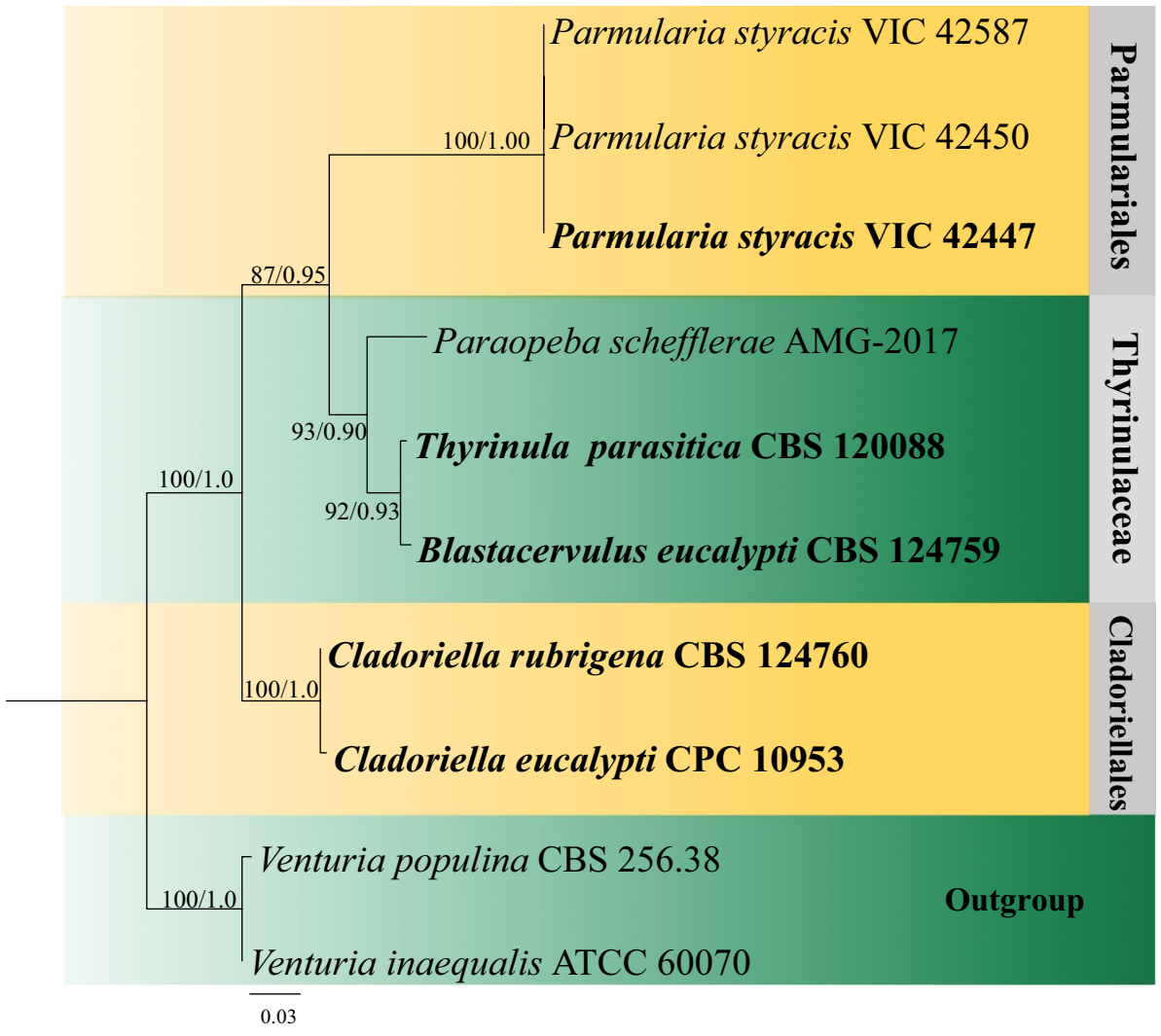

radiating from the centre. Stromata wall thin to thick, composed of black, large cells of textura prismatica. Peridium of locules thin to thick, composed of dark brown to hyaline smaller cells of textura angularis. Hamathecium comprising dark brown to hyaline, septate, pseudoparaphyses present or absent. Asci 8-spored, thick-walled, bitunicate, long ovate, broad cylindrical, broad-clavate, or obclavate, globose to subglobose, short pedicellate, with a distinct ocular chamber. Ascospores 2-multi-seriate, oblong to ellipsoid, ellipsoid to ovate, hyaline to dark brown, 1-septate, wall smooth to verrucose. Asexual morph: Undetermined.

\section{Type: Parmularia Lév.}

Notes: Parmulariaceae was invalidly introduced by Müller and von Arx (1962) for taxa with colonies growing on the surface of living plant tissues, mostly leaves, and later was validated by Barr (1979a). The family contains a range of ascomata types, asci and ascospores forms (Inácio and Cannon 2008). von Arx and Müller (1975) accepted 27 genera in this family and Lumbsch and Huhndorf (2007) included 34 genera. Inácio and Cannon (2008) excluded Chaetaspis and Kentigia, with 34 genera accepted. Hyde et al. (2013) accepted 30 genera including a new genus Antoniomyces, which was erected by Inácio et al. (2012). Placostromella was re-described by Thambugala et al. (2014b) and transferred to this family. Placoasterella and Placosoma were transfered to Parmulariaceae, as they were similar to taxa in this family (Hongsanan et al. 2014b). Pleiostomellina was referred by Ariyawansa et al. (2014). Dictyocyclus was moved to Myriangiaceae based on morphological similarity (Dissanayake et al. 2014). Wijayawardene et al. (2014a) accepted 34 genera in Parmulariaceae. Wu et al. (2014) re-examined the holotype specimen of the type species of Cirsosiopsis and transferred the genus to Parmulariaceae based on its morphology. A new genus Rhagadolobiopsis was introduced by Guatimosim et al. (2014) and Jayasiri et al. (2016) re-examined herbarium of type species of Cocconia Sacc. and confirmed its placement within Parmulariaceae. Dai et al. (2018) excluded Hemigrapha, introducing Hemigraphaceae to accommodate it and re-examined Inocyclus, moving it to Asterinales genera incertae sedis based on the morphology and phylogenetic analysis. Doilom et al. (2018) transferred Syrropeltis to Parmulariaceae based on morphology. Thus, 34 genera are accepted in Parmulariaceae. Parmulariaceae is close to Asterinaceae, but differs in having ascostromata formed by several layers of pigmented cells, pseudoparaphyses, broadly ellipsoidal to obclavate asci, and lacks appressoria (Inácio and Cannon 2008; Inácio et al. 2012). Species of Asterinaceae have superficial hyphae mostly with appressoria, thyriothecia with a thin upper wall layer and poorly developed base and subglobose asci (Pirozynski and Shoemaker 1970; Inácio et al. 2012; Hongsanan et al. 2014b).

Parmularia Lév., Annls Sci. Nat., Bot., sér. 3 5: 286 (1846). 
Index Fungorum number: IF 3744; Facesoffungi number: FoF 02297; 12 morphological species (Species Fungorum 2020), 1 species with molecular data, 34 predicted number species.

Type species: Parmularia styracis Lév.

Notes: Parmularia typified by Parmularia styracis, was introduced by Léveillé (1846). Parmularia is similar to Mintera in having elongate locules radiating from a central point. However, Mintera has mycelium with appresoria, and black ascostroma with a single locule which aggregate into a star shape. In Parmularia single ascostroma contain many locules. Guatimosim et al. (2015) re-collected the type species and provided ITS, LSU and tef1- $\alpha$ sequence data. For further morphological details of type species, see Dai et al. (2018). Parmularia is characterized by large, black, shieldlike, flattened ascostromata with ridges radiating from the centre to the outer rim, and the ridges comprising elongated, radiating locules, filamentous pseudoparaphyses with brown and verrucose apices and ellipsoid, 1-septate ascospores (Inácio and Cannon 2008; Hyde et al. 2013; Dai et al. 2018)

\section{Other genera included}

Aldona Racib., Parasit. Alg. Pilze Java's (Jakarta) 1: 19 (1900).

Index Fungorum number: IF 115; Facesoffungi number: FoF 00309; - 4 morphological species (Species Fungorum 2020), molecular data unavailable.

Type species: Aldona stella-nigra Racib., Parasit. Alg. Pilze Java's (Jakarta) 1: 19 (1900).

Notes: Aldona, typifided by Aldona stella-nigra was introduced by Raciborski (1900). The type was originally collected on living leaves of Pterocarpus indicus in Sumatra, western Indonesia. Aldona was initially placed in Hysteriaceae, then transferred to Phacidiaceae, and finally to Parmulariaceae (Saccardo 1904; von Höhnel 1917; Müller and Patil 1973; von Arx and Müller 1975). The genus was reported as pathogenic occurring on terrestrial habitats and bearing an asexual ceolomycetous morph (for morphology see Tian et al. 2015; Wijayawardene et al. 2018, 2020). Aldona is characterized by semi-immersed to erumpent, black, linear, radial or star-shaped, branching, coriaceous, shiny ascomata opening by longitudinal slits, black, shiny, globose or irregular spermatogonia growing on the spot, surrounded by ascomata and elongate-clavate, hyaline, transseptate ascospores with upper cells larger and wider, basal cells short and narrow (Tian et al. 2015).

Aldonata Sivan. \& A.R.P. Sinha, Mycol. Res. 92(2): 248 (1989)

Index Fungorum number: IF 25242; Facesoffungi number: FoF 00311; - 1 morphological species (Species Fungorum 2020), molecular data unavailable.
Type species: Aldonata pterocarpi Sivan. \& A.R.P. Sinha, Mycol. Res. 92(2): 249 (1989)

Notes: Aldonata was reported as a pathogen on living leaves of Pterocarpus draco in the Andaman Islands (Sivanesan and Sinha 1989). The asexual morph of this genus has not yet been reported (Tian et al. 2015). Aldonata is characterized by semi-immersed, globose to subglobose, black, shiny, ascomata appearing as flexuous lines on the leaf spot surface with a clearly defined margin, solitary to gregarious, sub-immersed, black and shiny, carbonaceous, globose to irregular, spermatogonia mostly growing around the central of greyish white spot and ellipsoid to fusiform, muriform, hyaline ascospores with up to 8 transverse and longitudinal septa (Tian et al. 2015).

Antoniomyces Inácio, Mycol Progress 11: -6 (2012).

Index Fungorum number: IF 563246; Facesoffungi number: FoF 02299; - 1 morphological species (Species Fungorum 2020), molecular data unavailable.

Type species: Antoniomyces loranthicola Inácio, Mycol Progress 11: -6 (2012).

Notes: This genus was introduced by Inácio et al. (2012) according to its similarity of morphology with Parmulariaceae. This was followed in Wijayawardene et al. (2017a). Antoniomyces is characterized by solitary to gregarious, superficial, black, circular, ascostromata opening by longitudinal slits and forming in the central area of mycelium, clavate to subglobose asci and cylindric-ellipsoidal or ellipsoidal to narrowly ovoid, 1-septate ascospores (Inácio et al. 2012).

Aulacostroma Syd. \& P. Syd., Philipp. J. Sci., C, Bot. 9: 176 (1914).

Index Fungorum number: IF 456; Facesoffungi number: FoF 02301; - 4 morphological species (Species Fungorum 2020), molecular data unavailable.

Type species: Aulacostroma palawanense Syd. \& P. Syd., Philipp. J. Sci., C, Bot. 9(2): 176 (1914).

Notes: Aulacostroma was reported as pathogenic on Pandanus merrillii in Philippines (see morphology in Inácio and Cannon 2008; Wijayawardene et al. 2018, 2020). Aulacostroma is characterized by stromatic, solitary to gregarious, superficial, black ascomata, broadly clavate, globose to subglobose, obovoid asci and brown ellipsoid, 1-septate ascospores (Inácio and Cannon 2008).

Campoa Speg., Boln Acad. nac. Cienc. Córdoba 25: 90 (1921).

Index Fungorum number: IF 778; Facesoffungi number: FoF 02303; - 4 morphological species (Species Fungorum 2020), molecular data unavailable. 
Type species: Campoa pulcherrima Speg., Boln Acad. nac. Cienc. Córdoba 25: 90 [no. 173, reprint pages 92] (1921).

Notes: Campoa comprises five species, which were collected from Phillipines, Chile, Japan and the Dominican Republic (Inácio and Cannon 2008). The genus was reported as pathogenic on living leaves of Temu divaricatum (Inácio and Cannon 2008; Wijayawardene et al. 2018, 2020). Campoa is characterized by superficial, flat, black ascostromata with filamentous pseudoparaphyses, cylindrical to cylindricclavate asci and ellipsoidal ascospores (Inácio and Cannon 2008).

Cirsosiopsis Butin \& Speer, Sydowia 31(1-6): 10 (1979) [1978].

Index Fungorum number: IF 1068; Facesoffungi number: FoF 08113; - 1 morphological species (Species Fungorum 2020), molecular data unavailable.

Type species: Cirsosiopsis violacescens Butin \& Speer, Sydowia 31(1-6): 10 (1979) [1978].

Notes: The monotypic genus was introduced by Butin and Speer (1978) with its family placement in Microthyriaceae. Wu et al. (2014) re-examined the holotype of type species $C$. violacescens and transferred it to Parmulariaceae based on its morphological similarity with Parmularia. This genus is characterized by black and discoid ascostromata opening by irregular disintegration at the centre, globose to subglobose asci and 1-septate, ellipsoid to ovate ascospores (Wu et al. 2014).

Cocconia Sacc., Syll. fung. (Abellini) 8: 738 (1889).

Index Fungorum number: IF 1149; Facesoffungi number: FoF 00558; - 14 morphological species (Species Fungorum 2020), molecular data unavailable.

Type species: Cocconia placenta (Berk. \& Broome) Sacc., Syll. fung. (Abellini) 8: 738 (1889).

$\equiv$ Rhytisma placenta Berk. \& Broome, J. Linn. Soc., Bot. 14(no. 74): 131 (1873) [1875].

Notes: Jayasiri et al. (2016) re-examined the holotype and confirmed its family level placement within Parmulariaceae. The genus was reported as pathogenic on living leaves of Symplocos spicata (see morphology in Inácio and Cannon 2008; Jayasiri et al. 2016; Wijayawardene et al. 2018, 2020). Cocconia is characterized by superficial, shield-like, dark brown to black, carbonaceous, flated ascostromata producing thick-walled, cylindrical asci and ellipsoidal,1-septate, brown ascospores (Jayasiri et al. 2016).

Cycloschizon Henn., Bot. Jb. 33: 39 (1902).

Index Fungorum number: IF 1376; Facesoffungi number: FoF 02305; - 13 morphological species (Species Fungorum 2020), molecular data unavailable.
Type species: Cycloschizon brachylaenae (Rehm) Henn., Bot. Jb. 33: 39 (1902).

三Schneepia brachylaenae Rehm, Hedwigia 40(Beibl.): (173) (1901).

Notes: The type species Cycloschizon brachylaenae was collected on living leaves of Brachylaena neriifolia from South Africa. Index Fungorum (2019) lists 14 species, whereas Inácio and Cannon (2008) compared 12 taxa by their hosts, distributions and main morphological characters. Cycloschizon is characterized by clustered, superficial, black, circular, flat ascomata opening by one circumferential, producing broadly clavate to subglobose, thick-walled asci and ellipsoidal ascospores with one septum (Inácio and Cannon 2008). For a drawing and other details, see Inácio and Cannon (2008), Wijayawardene et al. (2018, 2020).

Cyclostomella Pat., Bull. Herb. Boissier 4: 656 (1896).

Index Fungorum number: IF 1378; Facesoffungi number: FoF 02307; - 3 morphological species (Species Fungorum 2020), molecular data unavailable.

Type species: Cyclostomella disciformis Pat., Bull. Herb. Boissier 4: 656 (1896).

Notes: Cyclostomella comprises four species (Inácio and Cannon 2008). The genus was reported as pathogenic on living leaves, usually in tropical regions such as Costa Rica, Cuba and Brazil. A comparison of morphological features of four taxa of Cyclostomella was provided by Inácio and Cannon (2008). Cyclostomella is characterized by superficial, circular to elliptical, disc-like, black, rather flat ascostromata producing cylindric to clavate to subglobose asci and ellipsoid, dark brown, 1-septate ascospores (Inácio and Cannon 2008).

Dothidasteroma Höhn., Sber. Akad. Wiss. Wien, Math.naturw. Kl., Abt. 1 118: 1509 (1909).

Index Fungorum number: IF 1691; Facesoffungi number: FoF 08114; - 4 morphological species (Species Fungorum 2020), molecular data unavailable.

Type species: Dothidasteroma pterygotae (Berk. \& Broome) Höhn., Sber. Akad. Wiss. Wien, Math.-naturw. Kl., Abt. 1 118: 1510 (1909).

$\equiv$ Rhytisma pterygotae Berk. \& Broome, J. Linn. Soc., Bot. 14(no. 74): 131 (1873) [1875].

Notes: Dothidasteroma was erected by von Höhnel (1909a) with D. pterygotae as type species. This genus is characterized by fruiting bodies forming a 1-cell layer, superficial, flat ascostromata with irregular locules. Inácio and Cannon (2008) accepted three species in Dothidasteroma. Inácio et al. (2011) introduced a new species. Thus, four species are accepted in Dothidasteroma.

Ferrarisia Sacc., Atti Inst. Veneto Sci. lett., ed Arti 10: 61 (1919). 
Index Fungorum number: IF 1986; Facesoffungi number: FoF 02309; - 8 morphological species (Species Fungorum 2020), molecular data unavailable.

Type species: Ferrarisia philippina Sacc., Atti Soc. Veneto-Trent. Sci. Nat., Padova 23: 61 (1917).

Notes: Ferrarisia philippina was synonymized under $F$. ipomoeae. Thus, the current name for the generic type is $F$. ipomoeae (Inácio and Cannon 2008). Ferrarisia jasmini was transfered to Palawaniella by von Arx and Müller (1975). Eight species are accepted in Ferrarisia by Inácio and Cannon (2008). Ferrarisia was reported as pathogenic on living leaves and usually occurrs in tropics (Inácio and Cannon 2008; Wijayawardene et al. 2018, 2020). Ferrarisia is characterized by small, superficial, circular to elliptical, black ascostromata with subglobose asci and ellipsoid, brown ascospores with one septum (Inácio and Cannon 2008).

Hysterostomella Speg., Anal. Soc. cient. argent. 19(6): 260 (1885).

Index Fungorum number: IF 2476; Facesoffungi number: FoF 02313; - 25 morphological species (Species Fungorum 2020), molecular data unavailable.

Type species: Hysterostomella guaranitica Speg., Anal. Soc. cient. argent. 19(6): 260 [no. 305] (1885).

Notes: This genus is widely distributed throughout the tropics and is pathogenic on living leaves of palms (Inácio and Cannon 2008; Wijayawardene et al. 2018, 2020). Hysterostomella is characterized by circular or elliptical, flat, black ascostromata opening by irregular slits, with filamentous pseudoparaphyses above the asci, which are subglobose, obovoid, and clavate (Inácio and Cannon 2008).

Kiehlia Viégas, Bragantia 4(1-6): 156 (1944).

Index Fungorum number: IF 2567; Facesoffungi number: FoF 08115; - 1 morphological species (Species Fungorum 2020), molecular data unavailable.

Type species: Kiehlia obscura Viégas, Bragantia 4(1-6): 156 (1944).

Notes: Kiehlia obscurawas originally collected on living leaves of bamboo from Brazil. Inácio and Cannon (2008) reexamined two varieties of the second species $K$. bambusina, and provided illustrations of sexual and asexual morphs. Index Fungorum (2020) listed K. bambusina as Phyllachora bambusina, hence only the type species is accepted in this genus. Kiehlia is characterized by elongate, immersed stromata and conidiomata growing in a same locule, clavate asci and ovoid, hyaline ascospores with one septum (Viégas 1944).

Mintera Inácio \& P.F. Cannon, Mycol. Res. 107(1): 86 (2003).
Index Fungorum number: IF 28710; Facesoffungi number: FoF 02317; - 1 morphological species (Species Fungorum 2020), molecular data unavailable.

Type species: Mintera reticulata (Starbäck) Inácio \& P.F. Cannon, Mycol. Res. 107(1): 86 (2003).

三 Parmularia reticulata Starbäck, Ark. Bot. 5(no. 7): 6 (1905).

Notes: This genus was reported as pathogenic on living leaves with only sexual morph found. Mintera is characterized by stromatic, gregarious, black ascomata grouping into a pyrethrum-like shape on mycelium, cylindric-clavate, subglobose asci and ellipsoid, brown, 1-septate ascospores (Inácio and Cannon 2008).

Pachypatella Theiss. \& Syd., Annls mycol. 13(3/4): 228 (1915).

Index Fungorum number: IF 3670; Facesoffungi number: FoF 02319; - 2 morphological species (Species Fungorum 2020), molecular data unavailable.

Type species: Pachypatella alsophilae (Racib.) Theiss. \& Syd., Annls mycol. 13(3/4): 228 (1915).

$\equiv$ Hysterostomella alsophilae Racib., Parasit. Alg. Pilze Java's (Jakarta) 2: 22 (1900).

Notes: Pachypatella was reported as pathogenic on living leaves of ferns. Two species including the type are described (morphology see Inácio and Cannon 2008; Wijayawardene et al. 2018, 2020). Pachypatella is characterized by superficial, circular or elliptical, flat ascostromata, becoming irregular in shape, with clavate, or cylindrical to cylindric-clavate asci and cylindric-ellipsoidal to ellipsoidal or occasionally oblong ascospores (Inácio and Cannon 2008).

Palawaniella Doidge, Bothalia 1(1): 16 (1921).

Index Fungorum number: IF 3683; Facesoffungi number: FoF 02321; - 6 morphological species (Species Fungorum 2020), molecular data unavailable.

Type species: Palawaniella eucleae Doidge, Bothalia 1(1): 16 (1921).

Notes: Doidge (1942) synonymized $P$. eucleae under $P$. orbiculata. Currently, seven taxa are placed in this genus. It was reported as pathogenic occurring on living leaves from South Africa and Brazil (morphology see Inácio and Cannon 2008; Wijayawardene et al. 2018, 2020). Palawaniella is characterized by stromatic ascomata that are gregarious in the centre of black spots, becoming flattened and with a single locule (Inácio and Cannon 2008).

Parmulariopsella Sivan., Trans. Br. mycol. Soc. 55(3): 509 (1970).

Index Fungorum number: IF 3746; Facesoffungi number: FoF 02323; - 1 morphological species (Species Fungorum 2020), molecular data unavailable. 

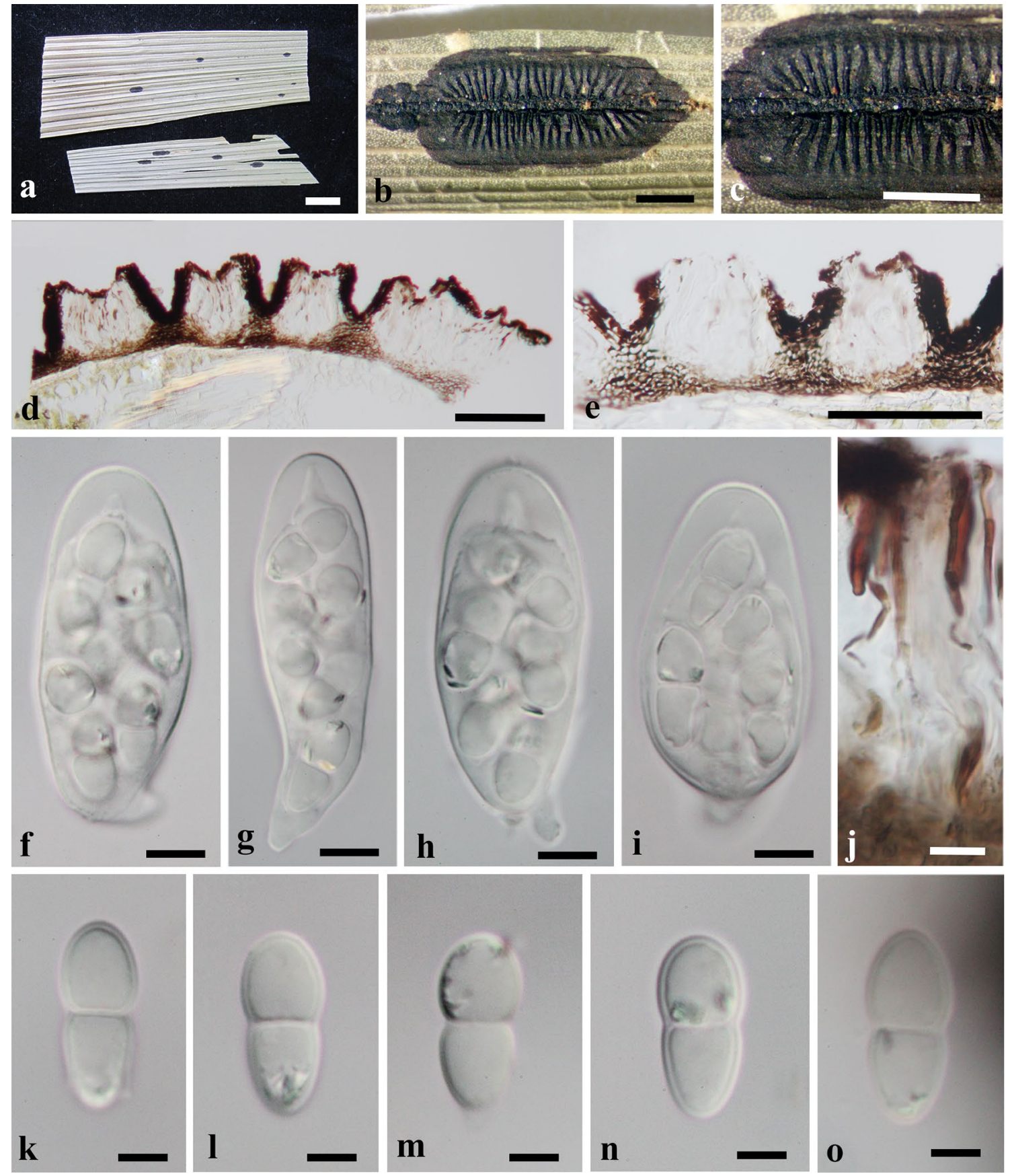

Fig. 61 Parmulariopsis pulchella (W No: 10820, holotype). a Type material. b, c Appearance of black ascostromata on the host. d Section of ascostroma. e Peridium. $\mathbf{f}-\mathbf{i}$ Asci with ascospores. $\mathbf{j}$ Interthe-

Type species: Parmulariopsella burseracearum Sivan., Trans. Br. mycol. Soc. 55(3): 509 (1970).

Notes: This monotypic genus was collected on Santiria trimera from Africa. This genus is similar to Parmularia, but differs as the ascomata are covered by dark hyphae (Inácio and Cannon 2008). Parmulariopsella was reported as pathogenic on living leaves (morphology see Inácio and cial, dark brown filamentous pseudoparaphyses. k-o Ascospores. Scale bars: $\mathbf{a}=10 \mathrm{~mm}, \mathbf{b}, \mathbf{c}=1 \mathrm{~mm}, \mathbf{d}, \mathbf{e}=100 \mu \mathrm{m}, \mathbf{f}-\mathbf{j}=10 \mu \mathrm{m}$, $\mathbf{k}-\mathbf{0}=5 \mu \mathrm{m}$

Cannon 2008; Wijayawardene et al. 2018, 2020). This genus is characterized by solitary ascomata growing in the centre of the black mycelium, globose to subglobose, obovoid asci and ellipsoid, brown, 1-septate ascospores (Inácio and Cannon 2008).

Parmulariopsis Petr., Sydowia 8(1-6): 186 (1954). 
Index Fungorum number: IF 3747; Facesoffungi number: FoF 02325; - 1 morphological species (Species Fungorum 2020), molecular data unavailable.

Type species: Parmulariopsis pulchella Petr., Sydowia 8(1-6): 186 (1954).

Notes: This genus forms large, black ascostromata on living leaves and is only known from the type collection from Malaysia (Inácio and Cannon 2008). Parmulariopsis is characterized by its shield-like ascostromata with locules radiating from the centre. It looks similar to Parmularia, but Parmulariopsis has elliptical to oblong, or long fusiform stromata, whereas Parmularia has rounded stromata.

Parmulariopsis pulchella Petr., Sydowia 8(1-6): 186 (1954).

Index Fungorum number: IF 302295; Facesoffungi number: FoF 02326, Fig. 61

Parasitic on lower surface of leaves. Sexual morph: Ascostromata 2-20 long $\times 1-4 \mathrm{~mm}$ wide, solitary to gregarious, superficial, elliptical to oblong, or long fusiform, or irregular, shield-like, black, carbonaceous, flated, with ridges radiating from the centre to the outer rim; ridges containing elongated locules, which open by a longitudinal slit and contain numerous asci, cells of ascostromata thick-walled and elongate and composed of black, amorphous tissues in the stromatic crust. Locules in vertical section 70-150 diam. $\times 65-85 \mu \mathrm{m}$ high, subglobose, immersed in ascostromata. Peridium of ascostromata 30-40 $\mu \mathrm{m}$ thick, comprises of several black layers, composed of dark brown cells of textura prismatica. Cells between locules 30-55 $\mu \mathrm{m}$ thick, composed of brown to hyaline cells of texture angularis. Hamathecium comprising interthecial, hyaline to brown, septate, filamentous pseudoparaphyses, 50-65 × 1.5-2.5 $\mu \mathrm{m}$, with swollen and brown tips. Asci 40-70 $\times 20-30 \mu \mathrm{m}(\bar{x}=$ $52.4 \times 23.3 \mu \mathrm{m}, \mathrm{n}=20$ ), 8 -spored, thick-walled, bitunicate, clavate to subglobose, short-pedicellate, with a distinct ocular chamber. Ascospores $19-25 \times 8.5-9 \mu \mathrm{m}(\bar{x}=19.7 \times 8.7$ $\mu \mathrm{m}, \mathrm{n}=20$ ), irregularly arranged, ellipsoidal, with larger and rounder upper cells, with narrow and longer lower cells, hyaline, 1-septate, constricted at the septum, smooth-walled. Asexual morph: Undetermined.

Material examined: Malaysia, Sabah, Mt. Kinabalu, Tenmopok, $5000 \mathrm{ft}$., on leaves of Joinvillea sp., 9 March 1932, J. \& M. S. Clemens (W No: 10820, holotype).

Notes: Parmulariopsis was typified by $P$. pulchella, without designating any type specimens. Inácio and Cannon (2008) re-examined the isotypes from $\mathrm{S}$ and $\mathrm{K}$. In the present study, a specimen deposited in $\mathrm{W}$ labeled with the same collecting information as in the original article is thought to be the holotype.

Parmulina Theiss. \& Syd., Annls mycol. 12(2): 194 (1914).
Index Fungorum number: IF 3748; Facesoffungi number: FoF 08116; - 5 morphological species (Species Fungorum 2020), molecular data unavailable.

Type species: Parmulina exsculpta (Berk.) Theiss. \& Syd. [as 'exculpta'], Annls mycol. 12(1): 45 (1914).

$\equiv$ Dothidea exsculpta Berk., Hooker's J. Bot. Kew Gard. Misc. 6: 233 (1854).

Notes: Inácio and Cannon (2008) re-examined a specimen from $\mathrm{K}$, and designated it as neotype, as the authors considered the holotype was missing. This genus was reported as pathogenic on living leaves (morphology see Inácio and Cannon 2008; Wijayawardene et al. 2018, 2020). Parmulina is characterized by superficial, circular to irregular, rather flat, black ascostromata (Inácio and Cannon 2008).

Placoasterella Sacc. ex Theiss. \& Syd., Annls mycol. 13(3/4): 236 (1915).

Index Fungorum number: IF 4121; Facesoffungi number: FoF 08117; - 4 morphological species (Species Fungorum 2020), molecular data unavailable.

Type species: Placoasterella schweinfurthii (Henn.) Theiss. \& Syd., Annls mycol. 13(3/4): 236 (1915).

三Asterella schweinfurthii Henn., Bull. Herb. Boissier 1: 118 (1893).

Notes: Placoasterella was erected with two species. Another two species were introduced with their family placement in Asterinaceae (Müller and von Arx 1962). Hongsanan et al. (2014b) re-examined holotype of $P$. schweinfurthii and transferred the genus to Parmulariaceae based on morphology. Placoasterella is characterized by superficial, circular, flat, black, carbonaceous ascostromata with small, solitary, subglobose locules, lacking pseudoparaphyses, ovoid asci and ellipsoid to fusoid ascospores with one septum (Hongsanan et al. 2014b).

Placosoma Syd., Annls mycol. 22(3/6): 302 (1924).

Index Fungorum number: IF 4139; Facesoffungi number: FoF 08118; - 2 morphological species (Species Fungorum 2020), molecular data unavailable.

Type species: Placosoma nothopanacis Syd., Annls mycol. 22(3/6): 303 (1924).

Notes: Placosoma was introduced by Sydow (1924) with a single species. Prasad et al. (1961) described a second species $P$. salvadorae. Thus, two species are accepted in this genus. Placosoma was placed in Asterinaceae by Lumbsch and Huhndorf (2010). However, Hongsanan et al. (2014b) re-examined the type species $P$. nothopanacis and suggested that Placosoma is typical of Parmulariaceae. Placosoma is characterized by superficial, circular, flattened, blackened, carbonaceous ascostromata, subglobose to oblong asci and broadly ellipsoidal ascospores with one septum (Hongsanan et al. 2014b). 
Placostromella Petr., Sydowia 1(1-3): 9 (1947).

Index Fungorum number: IF 4141; Facesoffungi number: FoF 08119; - 3 morphological species (Species Fungorum 2020), molecular data unavailable.

Type species: Placostromella macrospora Petr., Sydowia 1(1-3): 9 (1947).

Notes: Placostromella was intoduced by Petrak (1947d) with Placostromella macrospora as type species. Later $P$. amazonensis and P. castanopsis were transferred to Placostromella (Inácio et al. 2005). Three taxa including the type are accepted in Placostromella (morphology see Thambugala et al. 2014b; Wijayawardene et al. 2018, 2020). This genus is characterized by subcuticular, carbonaceous, black, rounded or broadly ellipsoid ascostromata with a single locule, cylindrical to clavate asci and cylindric-ellipsoidal or oblong to obovate ascospores (Thambugala et al. 2014b).

Pleiostomellina Bat., J.L. Bezerra \& H. Maia, in Batista \& Bezerra, Portug. acta biol., Sér. B 7(4): 373 (1964).

Index Fungorum number: IF 4204; Facesoffungi number: FoF 08120; - 1 morphological species (Species Fungorum 2020), molecular data unavailable.

Type species: Pleiostomellina pernambucensis Bat., J.L. Bezerra \& Cavalc., in Batista \& Bezerra, Portug. acta biol., Sér. B 7(4): 374 (1964).

Notes: The monotypic genus was introduced by Batista and Bezerra (1964). Ariyawansa et al. (2014) referred Pleiostomellina to Parmulariaceae based on its similarities with Parmularia. Pleiostomellina is characterized by superficial, flattened carbonaceous ascostromata with numerous locules in a circle, subglobose asci without a pedicel and 2-3-seriate, ellipsoidal, brown, 1-septate ascospores (Ariyawansa et al. 2014).

Polycyclina Theiss. \& Syd., Annls mycol. 13(3/4): 212 (1915).

Index Fungorum number: IF 4310; Facesoffungi number: FoF 02327; - 1 morphological species (Species Fungorum 2020), molecular data unavailable.

Type species: Polycyclina rhytismoides (Speg.) Theiss. \& Syd., Annls mycol. 13(3/4): 212 (1915).

$\equiv$ Hysterostomella rhytismoides Speg., Boln Acad. nac. Cienc. Córdoba 11(4): 580 (1889).

Notes: The monotypic genus Polycyclina is parasitic on living leaves of Lomaria imperalis (drawing see Thambugala et al. 2014b; Wijayawardene et al. 2018, 2020). Polycyclina is characterized by solitary, superficial, circular to elliptical to irregular, disc-like, black, rather flat ascostromata, clavate to cylindric-clavate asci and ellipsoid to cylindric-ellipsoid, dark brown, aseptate ascospores (Thambugala et al. 2014b).

Polycyclus Höhn., Sber. Akad. Wiss. Wien, Math.-naturw. Kl., Abt. 1 118: 1542 [82 repr.] (1909).
Index Fungorum number: IF 4312; Facesoffungi number: FoF 02329; -2 morphological species (Species Fungorum 2020), molecular data unavailable.

Type species: Polycyclus andinus (Pat.) Theiss. \& Syd., Annls mycol. 13(3/4): 210 (1915).

$\equiv$ Hysterostomella andina Pat., in Patouillard \& Lagerheim, Bull. Herb. Boissier 3(1): 73 (1895).

Notes: Polycyclus was introduced by von Höhnel (1909a), however, the type species was selected by Theissen and Sydow (1915). Inácio and Cannon (2008) compared P. andinus and P. marginalis, and considered they were possibly conspecific. This genus was reported as pathogenic on living leaves of ferns (morphology see Inácio and Cannon 2008; Wijayawardene et al. 2018, 2020). Polycyclus is characterized by superficial, circular to elliptical, disc-like, black, flat ascostromata with the fissured centre raised up to the wart shape, and with 1-5 locules disposed as a ring around a central column, opening by longitudinal to irregular fissures (Inácio and Cannon).

Protothyrium G. Arnaud, C. r. hebd. Séanc. Acad. Sci., Paris 164: 574 (1917).

Index Fungorum number: IF 4395; Facesoffungi number: FoF 02331; - 3 morphological species (Species Fungorum 2020), molecular data unavailable.

Type species: Protothyrium salvadorae (Cooke) G. Arnaud, Annals d'École National d'Agric. de Montpellier, Série 2 16(1-4): 101 (1918) [1917].

E Phyllachora salvadorae Cooke, Grevillea 13(no. 67): 65 (1885).

Notes: Four species are accepted in Protothyrium (Inácio and Cannon 2008). Species were reported as pathogenic on living leaves (morphology see Inácio and Cannon 2008; Wijayawardene et al. 2018, 2020). Protothyrium is characterized by superficial, circular or elliptical, flat, black ascostromata, becoming irregular in shape, opening by irregular slits (Inácio and Cannon 2008).

Pseudolembosia Theiss., Annls mycol. 11(5): 432 (1913). Index Fungorum number: IF 4448; Facesoffungi number: FoF 02333; - 4 morphological species (Species Fungorum 2020), molecular data unavailable.

Type species: Pseudolembosia geographica (Massee) Theiss., Annls mycol. 11(5): 432 (1913).

三Lembosia geographica Massee, Bull. Misc. Inf., Kew: 181 (1899).

Notes: Pseudolembosia was introduced by Theissen (1913) with P. geographica as the type species. Index Fungorum (2020) listed five epithets, but only four taxa are accepted by Inácio and Cannon (2008). This genus was reported as pathogens on living leaves (morphology see Inácio and Cannon 2008; Wijayawardene et al. 2018, 2020). Pseudolembosia is characterized by superficial, circular to 
elliptical, disc-like, black, rather flat ascostromata raised up to Y-shaped to irregular near the center (Inácio and Cannon 2008).

Rhagadolobiopsis Guatim. \& R.W. Barreto, Mycologia 106(2): 277 (2014).

Index Fungorum number: IF 802297; Facesoffungi number: FoF 08121; - 1 morphological species (Species Fungorum 2020), molecular data unavailable.

Type species: Rhagadolobiopsis thelypteridis Guatim. \& R.W. Barreto, Mycologia 106(2): 277 (2014).

Notes: Rhagadolobiopsis was erected by Guatimosim et al. (2014), with a single species, $R$. thelypteridis. This species is reported as a pathogen on living leaves of Thelypteris serrata from Brazil (morphology and key of genera of Parmulariaceae on fern see Guatimosim et al. 2014; Wijayawardene et al. 2018, 2020). Rhagadolobiopsis is characterized by numerous, scattered, black, stromata forming superficial, ellipsoid tar spot-like colonies on the abaxial surfaces of leaves, multiloculate ascomata, opening by radiating fissures, cylindrical-clavate to clavate asci and fusiform, aseptate, hyaline ascospores (Guatimosim et al. 2014).

Rhagadolobium Henn. \& Lindau, Bot. Jb. 23: 287 (1897).

Index Fungorum number: IF 4688; Facesoffungi number: FoF 02335; - 11 morphological species (Species Fungorum 2020), molecular data unavailable.

Type species: Rhagadolobium hemiteliae Henn. \& Lindau [as 'Rhagadolobium hemitheliae'], (1897).

Notes: Rhagadolobium is characterized by superficial, circular or elliptical, flattened, black ascostromata with upper wall of stromata comprising a thin dark brown tissue (Guatimosim et al. 2014).

Rhipidocarpon (Theiss.) Theiss. \& Syd., Annls mycol. 13(3/4): 197 (1915).

$\equiv$ Parmularia subgen. Rhipidocarpon Theiss., Annls mycol. 11(5): 456 (1913).

Index Fungorum number: IF 4703; Facesoffungi number: FoF 02337; - 1 morphological species (Species Fungorum 2020), molecular data unavailable.

Type species: Rhipidocarpon javanicum (Pat.) Theiss. \& Syd., Annls mycol. 13(3/4): 197 (1915).

इ Schneepia javanica Pat., Ann. Jard. Bot. Buitenzorg, suppl. 1: 122 (1897).

Notes: This genus is only known from type location Indonesia. It was reported as pathogenic on living leaves of palm (morphology see Inácio and Cannon 2008; Wijayawardene et al. 2018, 2020). Rhipidocarpon is characterized by solitary to gregarious, superficial, black, irregular, carbonaceous, flat ascostromata with ridges irregularly radiating from the centre to the outer rim (Inácio and Cannon 2008).
Symphaeophyma Speg., Anal. Mus. nac. Hist. nat. B. Aires 23: 97 (1912).

Index Fungorum number: IF 5316; Facesoffungi number: FoF 02339; - 1 morphological species (Species Fungorum 2020), molecular data unavailable.

Type species: Symphaeophyma subtropicale Speg., Anal. Mus. nac. Hist. nat. B. Aires 23: 97 (1912).

Notes: This monotypic genus was introduced by Spegazzini (1912) to accommodate S. subtropicale, collected from a tropical region. This species was reported as pathogenic on living leaves of Pouteria salicifolia (morphology see Inácio and Cannon 2008; Wijayawardene et al. 2018, 2020). Symphaeophyma is characterized by superficial, circular or elliptical, pulvinate, sinuate, black ascostromata with thick internal part (Inácio and Cannon 2008).

Syrropeltis Bat., J.L. Bezerra \& Matta, in Batista \& Bezerra, Portug. acta biol., Sér. B 7(4): 376 (1964).

Index Fungorum number: IF 5344; Facesoffungi number: FoF 08122; 2 morphological species (Species Fungorum 2020), molecular data unavailable.

Type species: Syrropeltis xylopia Bat., J.L. Bezerra \& Matta, in Batista \& Bezerra, Portug. acta biol., Sér. B 7(4):377 (1964).

Notes: The monotypic genus was introduced by Batista and Bezerra (1964), and was treated as Dothideomycetes genera incertae sedis by Wijayawardene et al. (2014a, 2018). Doilom et al. (2018) re-examined the holotype of S. xylopia and transferred Syrropeltis to Parmulariaceae based on its morphologic similarity to this family. Syrropeltis is characterized by large and black ascostromata on host substrate and 1-septate ascospores that are ovoid with upper cell broader and longer, slightly constricted and pale brown to brown at the septum (Doilom et al. 2018).

Thallomyces H.J. Swart, Trans. Br. mycol. Soc. 65(1): 84 (1975).

Index Fungorum number: IF 5395; Facesoffungi number: FoF 02341; - 1 morphological species (Species Fungorum 2020), molecular data unavailable.

Type species: Thallomyces oritis (Hansf.) H.J. Swart, Trans. Br. mycol. Soc. 65(1): 85 (1975).

इStigmatea oritis Hansf. [as 'oritidis'], Proc. Linn. Soc. N.S.W. 79(3-4): 102 (1954).

Notes: This genus is only known from the type collection, which was pathogenic on living leaves of Orites lancifolius (morphology see Inácio and Cannon 2008; Wijayawardene et al. 2018, 2020). Thallomyces is characterized by superficial, dark brown to black, coriaceous, flat ascomata forming on branching, brown hyphae, which produce round to irregular, brown to dark brown appressoria (Inácio and Cannon 2008). 
Fig. 62 Phylogram generated from maximum likelihood analysis (RAxML) of Patellariales based on ITS, LSU and SSU sequence data. Maximum likelihood bootstrap values equal or above $70 \%$, Bayesian posterior probabilities equal or above 0.90 (MLBS/PP) are given at the nodes. Isolate/ specimen number is noted after the species name. The tree is rooted to Lichenothelia calcarea $(\mathrm{L} 1324)$ and L. convexa (L1609). The ex-type strains are indicated in bold. Hyphen (-) represents support values below $70 \%$ MLBS and $0.90 \mathrm{PP}$

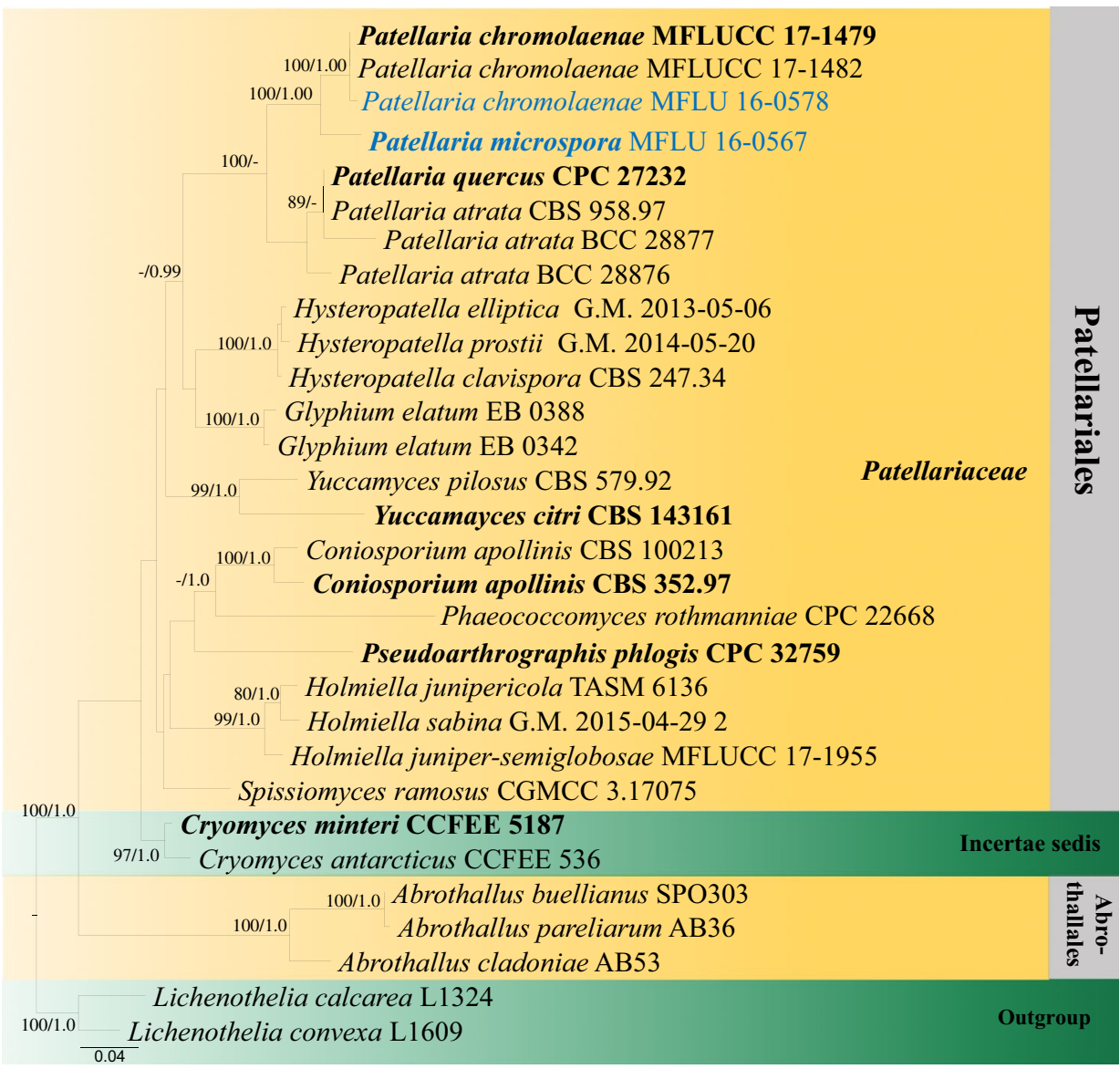

Viegasella Inácio \& P.F. Cannon, Mycol. Res. 107(1): 82 (2003).

Index Fungorum number: IF 28709; Facesoffungi number: FoF 02343; - 1 morphological species (Species Fungorum 2020), molecular data unavailable.

Type species: Viegasella pulchella (Speg.) Inácio \& P.F. Cannon, Mycol. Res. 107(1): 83 (2003).

三Schneepia pulchella Speg., Anal. Soc. cient. argent. 26(1): 55 (1888).

Notes: Viegasella was revised by Inácio and Cannon (2003) with description and illustration. It was reported as pathogen on living leaves in Brazil (morphology see Inácio and Cannon 2003,2008; Tian et al. 2015; Wijayawardene et al. 2018,2020). Viegasella is characterized by gregarious to solitary, black ascostromata with multi-ascomata gregarious and star-shaped, olive-cream, clavate to cylindrical asci and brown, ellipsoid, 1-septate ascospores (Inácio and Cannon 2003,2008; Tian et al. 2015).

\section{Economic and ecological significance}

Parmulariaceae is a large family, usually distributed in tropical regions. Taxa in this family are usually epiphytic or pathogenic on fern fronds or plant leaves, occasionally on thallus of lichens (Inácio and Cannon 2008; Guatimosim et al. 2015). Some genera, such as Aulacostroma are reported as plant pathogens which can cause leaf spots.

Patellariales D. Hawksw. \& O.E. Erikss.

Index Fungorum number: IF 90491; Facesoffungi number: FoF 08123.

Species of the Patellariales are saprobes on bark or wood, although some are lichenized (Jones et al. 2015). Ascomata are apothecial. Pseudoparaphyses are initially attached to both the base and apex, but later become free at the apex. Asci are cylindric-clavate and ascospores are mostly fusoid (Kutorga and Hawksworth 1997). Some species have aposphaeria-like and diplodia-like asexual morphs (Yacharoen et al. 2015), but these are rarely observed. Species are frequently found in terrestrial habitats and occasionally in aquatic habitats (Kirk et al. 2008; Jones et al. 2015). Multigene phylogenetic study on this group was provided by Pem et al. (2018). Phylogenetic placement of genera in this order are shown in Fig. 62. The divergence time for Patellariales is estimated as 276 MYA (stem age, Hongsanan et al. 2020).

Accepted families: Patellariaceae.

Patellariaceae Corda, Icon. fung. (Prague) 2: 37 (1838). 
Fig. 63 Patellaria atrata (MFLU 18-1818). a Substrate. b Apothecia on wood. c Cross section of an apothecium, $\mathbf{d}$ Filiform paraphyses. $\mathbf{e}-\mathbf{g}, \mathbf{h}$ Cylindrical asci. i Clavate ascospores. Scale bars: $\mathbf{c}=100$ $\mu \mathrm{m}, \mathbf{d}=50 \mu \mathrm{m}, \mathrm{e}-\mathrm{h}=75 \mu \mathrm{m}, \mathrm{i}$ $=10 \mu \mathrm{m}$
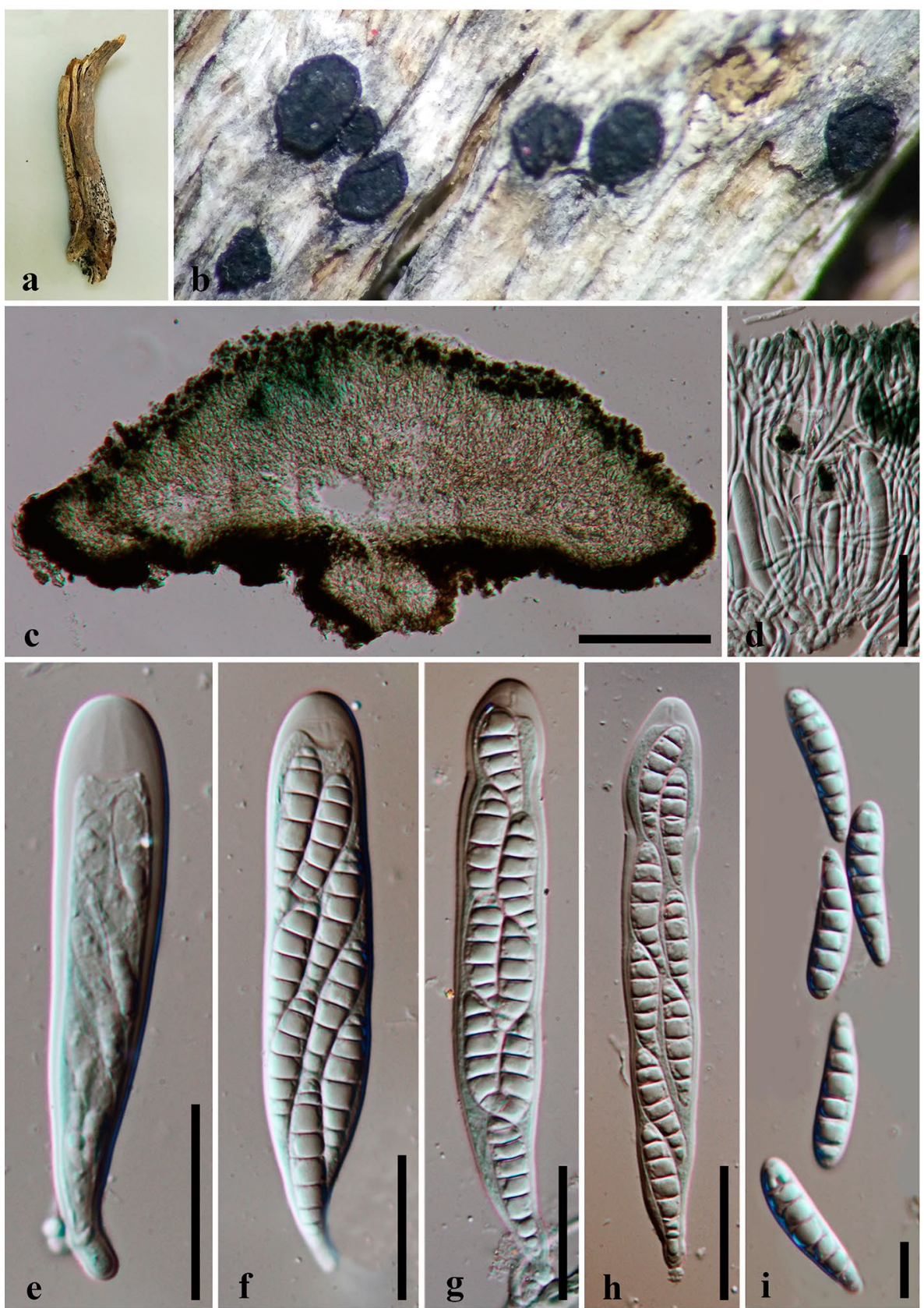

Index Fungorum number: IF 81111; Facesoffungi number: FoF 00342, 143 species.

Sexual morph: Apothecia sessile, black, circular, humidity sensitive and turn into hysterothecia when dry. Ectal excipulum composed of carbonized pseudoparenchymatous tissue. Hamathecium comprising paraphysoids or paraphyses, their apices are branched, pigmented and covered by dark exudates. Asci cylindrical, fissitunicate and arising from croziers. Ascospores overlapping 2-3-seriate, cylindrical, ellipsoid, fusiform, or clavate, hyaline or brown, with septa (Kutorga and Hawksworth 1997; Yacharoen et al. 2015). Asexual morph: Coelomycetous (Yacharoen et al. 2015).
Type: Patellaria Fr.

Notes: Patellariaceae was introduced by Corda (1838). The family includes 21 genera and around 52 species (Jaklitsch et al 2016; Wijayawardene et al. 2017a). This is a widely distributed family mostly found on bark or wood as saprobes (Kutorga and Hawksworth 1997; Yacharoen et al. 2015; Jaklitsch et al 2016).

Patellaria Fr., Syst. mycol. (Lundae) 2(1): 158 (1822).

Index Fungorum number: IF 3765; Facesoffungi number: FoF 00343; 48 morphological species (Species Fungorum 2020; this study), 4 species with molecular data 

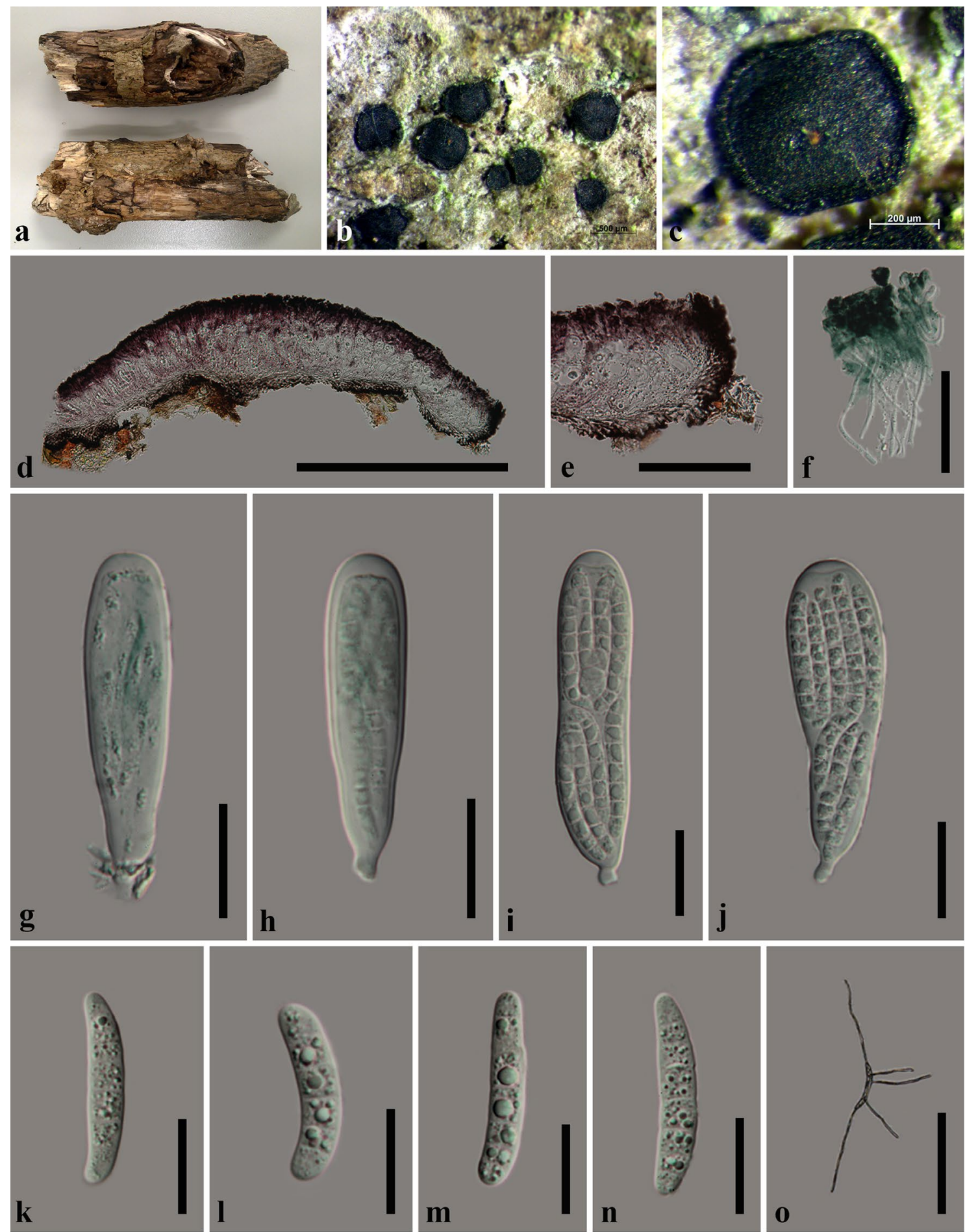

Fig. 64 Patellaria chromolaenae (MFLU 16-0578). a Substrate. b Cylindrical asci, $\mathbf{k}-\mathbf{n}$ allantoid ascospores. o germinating spore. Scale Apothecia on wood. $\mathbf{c}$ Apothecium on wood, d: Cross section of an apothecium (in lacto glycerine). e Vertical section of the apothecium at margin (in lacto glycerine). f Apically enlarged paraphyses. g-j bars: $\mathbf{b}=500 \mu \mathrm{m}, \mathbf{c}=200 \mu \mathrm{m}, \mathbf{d}=300 \mu \mathrm{m}, \mathbf{e}=70 \mu \mathrm{m}, \mathbf{f}=40 \mu \mathrm{m}$ $\mathbf{g}-\mathbf{j}=20 \mu \mathrm{m}, \mathbf{k}-\mathbf{n}=15 \mu \mathrm{m}, \mathbf{o}=100 \mu \mathrm{m}$

Type species: Patellaria atrata (Hedw.) Fr.

Notes: This genus was introduced by Fries (1822) and is characterized by black or dark coloured, sessile or

sub-pedicellate apothecia which appear to be hysterothecia when dry, filiform paraphyses with branched, pigmented apices, cylindrical, fissitunicate asci which arise from croziers, 
and hyaline, brown or greenish ascospores (Kutorga and Hawksworth 1997; Yacharoen et al. 2015).

Patellaria atrata (Hedw.) Fr., Syst. mycol. (Lundae) 2(1): 158 (1822).

$\equiv$ Lichen atratus Hedw., Descr. micr.-anal. musc. frond. (Lipsiae) 2: 61 (1789).

Index Fungorum number: IF 398671; Facesoffungi number: FoF 00344; Fig. 63

Saprobic on dead stems. Sexual morph: Apothecia $600-1000 \times 250-350 \mu \mathrm{m}(\bar{x}=700 \times 270 \mu \mathrm{m}, \mathrm{n}=10)$ arising singly or in small groups, sessile, erumpent from the substrate, black when fresh. Receptacle pulvinate, disc convex, disc and the margins are black in when fresh. Ectal excipulum $20-25 \mu \mathrm{m}(\bar{x}=22.7 \mu \mathrm{m}, \mathrm{n}=10)$ a narrow layer, 3-4 cells deep, thick, black cells of subglobose to subangularis. Medullary excipulum $10-15 \mu \mathrm{m}(\bar{x}=13.5 \mu \mathrm{m}, \mathrm{n}=10)$ composed of narrow, long, thin-walled, hyaline to brownish cells of textura porrecta. Hymenium brownish to greenish. Hamathecium comprising $2-3 \mu \mathrm{m}$ wide $(\bar{x}=2.7 \mu \mathrm{m}, \mathrm{n}=$ $20)$ at the apex, numerous, filiform, septate, branched and swollen at the apex, apices glued together to form epithecium, paraphyses. Epithecium dark green. Asci $75-120 \times$ 12-20 $\mu \mathrm{m}(\bar{x}=101.5 \times 17.3 \mu \mathrm{m}, \mathrm{n}=30) 8$-spored, short to medium pedicellate, cylindric to clavate, rounded at the apex, J-, croziers abscent at the asci base. Ascospore 25-30 $\times 6-10 \mu \mathrm{m}(\bar{x}=28.1 \times 6.8 \mu \mathrm{m}, \mathrm{n}=40)$, partially bi-seriate, upper and lower spores are uni-seriate, sometimes multiseriate, hyaline, smooth-walled, ellipsoid, 6-7-septate, distinctly more tapered towards the distal end. Asexual morph: Undetermined.

Material examined: UK, New Forest, on Ulex wood, 9 June 2015, E. B. G. Jones, GJ183 (MFLU 18-1818).

Notes: Our collection failed in ascospore germination and DNA extraction. However, characteristics of our collection are similar to the description of Patellaria atrata provided by Yacharoen et al. (2015).

Patellaria chromolaenae Mapook \& K.D. Hyde, in Mapook et al., Fungal Diversity 101: 127 (2020).

Index Fungorum number: IF 557350; Facesoffungi number: 07836; Fig. 64

Saprobic on dead stems. Sexual morph: Apothecia $622-693 \times 108-182 \mu \mathrm{m}(\bar{x}=652.2 \times 150.4 \mu \mathrm{m}, \mathrm{n}=10)$ arising singly or in small groups, sessile, erumpent from the substrate, black when fresh. Receptacle pulvinate, disc convex, disc and the margins are greenish black when fresh, in lacto glycerin colour change in to magenta. Excipulum $18-32 \mu \mathrm{m}(\bar{x}=25.1 \mu \mathrm{m}, \mathrm{n}=10)$ ectal excipulum and medullary excipulum are not clearly separable, ectal excipulum a narrow layer, 3-4 cells deep, thick, greenish black colour cells of subglobose to subangularis, medullary excipulum composed of narrow, long, thin-walled, hyaline to greenish cells of textura porrecta. Hymenium hyaline or greenish. Hamathecium comprising $1.2-1.8 \mu \mathrm{m}$ wide $(\bar{x}=1.5 \mu \mathrm{m}$, $\mathrm{n}=20$ ), numerous, obtuse, exceed asci in length, apically enlarged and pigmented, apices glued together to form pseudo epithecium, paraphyses. Asci $60-80 \times 15-20 \mu \mathrm{m}(\bar{x}$ $=69.3 \times 17.1 \mu \mathrm{m}, \mathrm{n}=30$ ) 8 -spored, short pedicellate, cylindric-globose, rounded at the apex, $\mathrm{J}$-at the ascus apex, croziers abscent at the base of asci. Ascospore 27-34 $\times 5.2-6.0$ $\mu \mathrm{m}(\bar{x}=31.5 \times 5.8 \mu \mathrm{m}, \mathrm{n}=40)$, multi-seriate, hyaline to greenish, smooth-walled, amerosporae, allantoid, regularly seven septate. Asexual morph: Undetermined

Material examined: Thailand, Chiang Rai Province, Mae Fah Luang University, 21 March 2015, A. H. Ekanayaka, HD 016, (MFLU 16-0578).

GenBank number: ITS: MW136695, LSU: MW142387, SSU: MW127179

Notes: Patellaria chromolaenae is originally identified from dead stems of Chromolaenae odorata. The dead stem of the present collection was not identified. In the phylogenetic analysis (Fig. 62), our collection grouped with the holotype of Patellaria chromolaenae with strong bootstrap support. In our collection of $P$. chromolaenae (MFLU 16-0578), we observed slightly larger apothecia and the ascospores with 7 septa which was not observed in the holotype collection (Mapook et al. 2020).

Patellaria microspora Ekanayaka \& K.D. Hyde, sp. nov. Index Fungorum number: IF 557819; Facesoffungi number: FoF 08125; Fig. 65

Etymology: The specific epithet microspora refers small ascospores.

Holotype: MFLU 16-0567.

Saprobic on dead stems. Sexual morph: Apothecia $396-402 \times 165-170 \mu \mathrm{m}(\bar{x}=395.4 \times 167.9 \mu \mathrm{m}, \mathrm{n}=10)$ arising singly or in small groups, sessile, erumpent from the substrate, black when fresh. Receptacle turbinate, disc slightly convex, disc and the margins are black when fresh. Ectal excipulum $15-21 \mu \mathrm{m}(\bar{x}=16.7 \mu \mathrm{m}, \mathrm{n}=10)$ a narrow layer, 3-4 cells deep, thick, black colour cells of subglobose to subangularis. Medullary excipulum $22-30 \mu \mathrm{m}(\bar{x}=$ $27.1 \mu \mathrm{m}, \mathrm{n}=10$ ) composed of narrow, long, thin-walled, hyaline to brownish cells of textura porrecta. Hymenium brownish. Hamathecium $1.3-1.8 \mu \mathrm{m}$ wide $(\bar{x}=1.5 \mu \mathrm{m}, \mathrm{n}=$ 20), numerous, filiform towards the apex, branched, septate, paraphyses. Asci $27-38 \times 6.2-7.0 \mu \mathrm{m}(\bar{x}=30.6 \times 6.8 \mu \mathrm{m}$, $\mathrm{n}=30$ ), 8 -spored, short to medium pedicellate, cylindric to clavate, rounded at the apex, asci become orange to brown with the presence of Meltzer's reagent, croziers absent at the base of asci. Ascospores 19.2-20.3 $\times 8.7-9.5 \mu \mathrm{m}(\bar{x}=$ $19.88 \times 9.21 \mu \mathrm{m}, \mathrm{n}=40$ ), partially bi-seriate, lower spores are uni-seriate, hyaline, smooth-walled, ellipsoid, regularly eight septate, distinctly more tapered towards the distal end. Asexual morph: Undetermined 

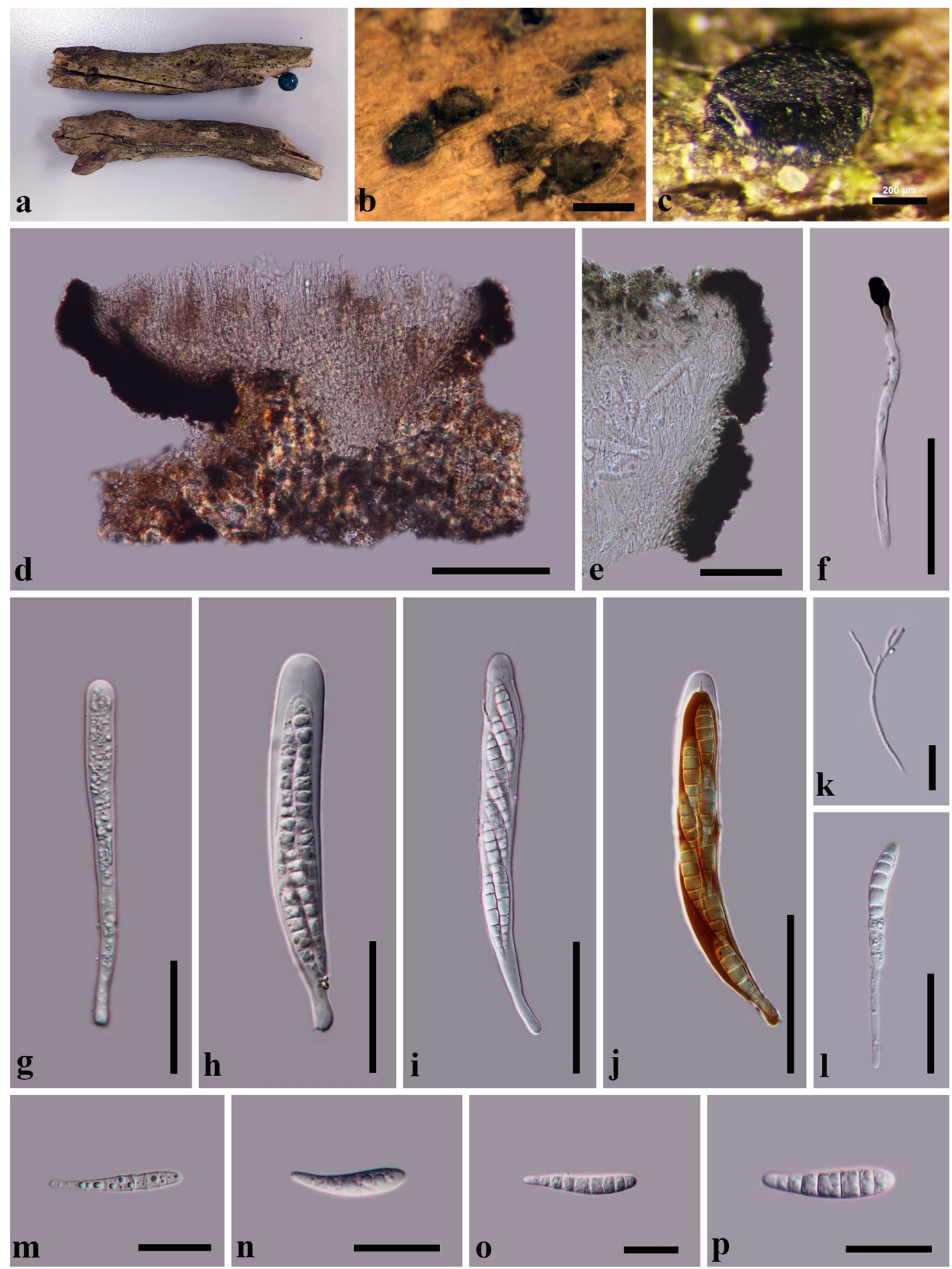

Fig. 65 Patellaria microspora (MFLU 16-0567, holotype). a Substrate. b Apothecia on wood. c Apothecium on wood. d Cross section of an apothecium. e Vertical section of the apothecium at margin. $\mathbf{f}$ Ectal excipular hypha. g-i Cylindrical asci. j Reaction of the ascus in the Meltzer's reagent. $\mathbf{k}$ Septate and branched paraphyses. 1 Germinated spore. $\mathbf{m}-\mathbf{p}$ clavate ascospores. Scale bars: $\mathbf{b}=500 \mu \mathrm{m}, \mathbf{c}=$ $200 \mu \mathrm{m}, \mathbf{d}=100 \mu \mathrm{m}, \mathbf{e}, \mathbf{i}, \mathbf{j}=50 \mu \mathrm{m}, \mathbf{f}=40 \mu \mathrm{m}, \mathbf{g}, \mathbf{h}, \mathbf{l}=30 \mu \mathrm{m}, \mathbf{k}$, $\mathbf{m}-\mathbf{p}=20 \mu \mathrm{m}$ 
Material examined: UK, Lulworth Cove, Dorset, 5 February 2015, E. B. G. Jones, GJ95082 (MFLU 16-0567, holotype).

GenBank number: ITS: MW136696, LSU: MW142388.

Note: Patellaria microspora is phylogenetically related to P. atrata. However, P. atrata has larger ascospores (Yacharoen et al. 2015).

\section{Other genera included}

Baggea Auersw., Hedwigia 5: 1 (1866).

Index Fungorum number: IF 491; Facesoffungi number: FoF 00345; - 1 morphological species (Species Fungorum 2020), molecular data unavailable.

Type species: Baggea pachyascus Auersw., Hedwigia 5: 1 (1866).

Note: Baggea is characterized by apothecial or hysterothecia-like ascomata, polysporous asci and allantoid ascospores (Yacharoen et al. 2015).

Banhegyia L. Zeller \& Tóth, Sydowia 14: 326 (1960).

Index Fungorum number: IF 509; Facesoffungi number: FoF 00601; - 2 morphological species (Species Fungorum 2020), molecular data unavailable.

Type species: Banhegyia setispora L. Zeller \& Tóth, Sydowia 14: 327 (1960).

Note: Banhegyia is characterized by apothecia-like ascomata, bitunicate asci and epithecium formed from pseudoparaphyses, and 8-spored, bitunicate, subglobose to obovoid asci (Yacharoen et al. 2015).

Colensoniella Hafellner, Beihefte zur Nova Hedwigia 62: 160 (1979).

Index Fungorum number: IF 1172; Facesoffungi number: FoF 08126; - 1 morphological species (Species Fungorum 2020), molecular data unavailable.

Type species: Colensoniella torulispora (W. Phillips) Hafellner, Beihefte zur Nova Hedwigia 62: 160 (1979).

$\equiv$ Patellaria torulispora W. Phillips, Grevillea 15(no. 73): 16 (1886).

Note: Colensoniella is characterized by superficial apothecia with raised margins, 8-spored asci, and oblong ascospores which break into two part-spores at maturity (Tian et al. 2014).

Endotryblidium Petr., Sydowia 13 (1-6): 244 (1959). Index Fungorum number: IF 1812; Facesoffungi number: FoF 00347; - 1 morphological species (Species Fungorum 2020), molecular data unavailable.

Type species: Endotryblidium insculptum (Cooke) Petr., Sydowia 13 (1-6): 245 (1959).

$\equiv$ Triblidium insculptum Cooke [as 'Tryblidium'], Grevillea 4(no. 32): 182 (1876)
Note: Endotryblidium is characterized by apothecia aggregated on the host, a pseudoparenchymatous peridium, 4-6-, rarely 8-spored, short pedicellate, clavate asci, numerous filamentous paraphyses and oblong to ellipsoidal ascospores (Yacharoen et al. 2015).

Glyphium Nitschke ex F. Lehm., Nova Acta Acad. Caes. Leop.-Carol. German. Nat. Cur.: 139 (1886).

Index Fungorum number: IF 2095 Facesoffungi number: FoF 08127; -6 morphological species (Species Fungorum 2020), 2 species with molecular data.

Type species: Glyphium dolabriforme (Wallr.) F. Lehm.: 139 (1886).

$\equiv$ Lophium dolabriforme Wallr., Fl. crypt. Germ. (Norimbergae) 2: 433 (1833).

Note: Glyphium is characterized by erect, carbonaceous ligulate to dolabrate ascomata that are strongly laterally compressed and dehisce along a longitudinal slit (Boehm et al. 2015).

Haematomyxa Sacc., Botanisches Centralblatt 18: 250 (1884).

Index Fungorum number: IF 2198; Facesoffungi number: FoF 08128; - 4 morphological species (Species Fungorum 2020), molecular data unavailable.

Type species: Haematomyxa vinosa (Cooke \& Ellis) Sacc., Sylloge Fungorum 8: 646 (1889).

इ Haematomyces vinosus Cooke \& Ellis, Grevillea 4(no. 32): 179 (1876).

Note: Haematomyxa is characterized by subglobose, gelatinous apothecia, broadly clavate, 8 -spored asci, and muriform, brown ascospores (Seaver 1951).

Holmiella Petrini, Samuels \& E. Müll., Berichte der Schweizerischen Botanischen Gesellschaft 89: 83 (1979).

Index Fungorum number: IF 2344; Facesoffungi number: FoF 00349; - 4 morphological species (Species Fungorum 2020), 3 species with molecular data.

Type species: Holmiella sabina (De Not.) Petrini, Samuels \& E. Müll., Berichte der Schweizerischen Botanischen Gesellschaft 89: 84 (1979).

三Triblidium sabinum De Not. [as 'Tryblidium'], Comm. Soc. crittog. Ital. 2(fasc. 3): 491 (1867).

Note: Holmiella is characterized by globose, black apothecia, filamentous, septate pseudoparaphyses, bitunicate, clavate asci and clavate to ellipsoidal, 1-septate ascospores (Yacharoen et al. 2015).

Hysteropatella Rehm, Rabenhorst's Kryptogamen-Flora, Pilze - Ascomyceten 1(3): 367 (1890).

Index Fungorum number: IF 2469; Facesoffungi number: FoF 00351; -7 morphological species (Species Fungorum 2020), 3 species with molecular data. 
Type species: Hysteropatella prostii (Duby) Rehm, Rabenhorst's Kryptogamen-Flora, Pilze - Ascomyceten 1(3): 367 (1890).

三 Hysterium prostii Duby, Mém. Soc. Phys. Hist. nat. Genève 16(1): 38 (1861) [1862].

Note: Hysteropatella is characterized by hysterothecial ascomata, carbonaceous excipulum, bitunicate asci and reniform to ellipsoid or fusoid, 3-septate ascospores (Yacharoen et al. 2015).

Hysteropeltella Petr., Annales Mycologici 21 (1-2): 9 (1923).

Index Fungorum number: IF 2470; Facesoffungi number: FoF 00352; - 1 morphological species (Species Fungorum 2020), molecular data unavailable.

Type species: Hysteropeltella moravica Petr., Annales Mycologici 21 (1-2): 10 (1923).

Note: Hysteropeltella is characterized by apothecial ascomata, bitunicate asci and hyaline ascospores with a sheath (Yacharoen et al. 2015).

Lahmiomyces Cif. \& Tomas., Atti Ist. bot. Univ. Lab. crittog. Pavia, sér. 5 10: 39, 66 (1953).

Index Fungorum number: IF 2632; Facesoffungi number: FoF 08129; - 1 morphological species (Species Fungorum 2020), molecular data unavailable.

Type species: Lahmiomyces piceae Cif. \& Tomas., Atti Ist. bot. Univ. Lab. crittog. Pavia, sér. 5 10(2-3): 270 (1953).

Note: Jaklitsch et al. (2016) treated Lahmiomyces as a genus in Patellariaceae.

Lecanidiella Sherwood, Sydowia 38: 272 (1986).

Index Fungorum number: IF 25053; Facesoffungi number: FoF 00353; - 1 morphological species (Species Fungorum 2020), molecular data unavailable.

Type species: Lecanidiella contortae Sherwood, Sydowia 38: 274 (1986).

Note: Lecanidiella is characterized by apothecia, erumpent, black, serrated at the rim, a brown and powdery epithecium, bitunicate asci, and 3-septate ascospores (Yacharoen et al. 2015).

Lirellodisca Aptroot, Nova Hedwigia 67: 485 (1998).

Index Fungorum number: IF 27901; Facesoffungi number: FoF 00355; - 1 morphological species (Species Fungorum 2020), molecular data unavailable.

Type species: Lirellodisca pyrenulispora Aptroot, Nova Hedwigia 67: 485 (1998).

Note: Lirellodisca is characterized by subglobose, deeply cup-shaped apothecia, filamentous, individual, apically branched, hyaline pseudoparaphyses and thick-walled distoseptate ascospores (Yacharoen et al. 2015).
Murangium Seaver, The North American Cup-fungi (Inoperculates) (3): 367 (1951).

Index Fungorum number: IF 3289; Facesoffungi number: FoF 00357; - 1 morphological species (Species Fungorum 2020), molecular data unavailable.

Type species: Murangium sequoiae (Plowr.) Seaver, The North American Cup-fungi (Inoperculates) (3): 368 (1951).

$\equiv$ Cenangium sequoiae Plowr., Grevillea 7(no. 41): 23 (1878).

Note: Murangium is characterized by cup-shaped apothecia, bitunicate asci and muriform ascospores (Yacharoen et al. 2015).

Poetschia Körb., Parerga lichenologica. Ergänzungen zum Systema lichenum Germaniae: 280 (1861).

Index Fungorum number: IF 4289; Facesoffungi number: FoF 00359; - 4 morphological species (Species Fungorum 2020), molecular data unavailable.

Type species: Poetschia buellioides Körb., Parerga lichenologica. Ergänzungen zum Systema lichenum Germaniae: 280 (1861).

Note: Poetschia is characterized by globose, black apothecial ascomata, pseudoparenchymatous excipulum, obovoid, clavate asci and ellipsoidal to obovoid, 1-septate ascospores (Yacharoen et al. 2015).

Pseudoparodia Theiss. \& Syd., Annls mycol. 15 (1-2): 138 (1917).

Index Fungorum number: IF 4466; Facesoffungi number: FoF 00377; - 1 morphological species (Species Fungorum 2020), molecular data unavailable.

Type species: Pseudoparodia pseudopeziza (Pat.) Theiss. \& Syd., Sydowia 1 (4-6): 169 (1947).

三 Parodiella pseudopeziza Pat., in Patouillard \& Lagerheim, Bull. Herb. Boissier 3(1): 67 (1895).

Note: Pseudoparodia is characterized by apothecia which are superficial and swollen, with dense pseudoparaphyses forming epithecium above the asci (Yacharoen et al. 2015).

Rhizodiscina Hafellner, Beihefte zur Nova Hedwigia 62: 195 (1979).

Index Fungorum number: IF 4709; Facesoffungi number: FoF 00361; - 2 morphological species (Species Fungorum 2020), 1 species with molecular data.

Type species: Rhizodiscina lignyota (Fr.) Hafellner, Beihefte zur Nova Hedwigia 62: 195 (1979).

E Peziza lignyota Fr., Syst. mycol. (Lundae) 2(1): 150 (1822).

Note: Rhizodiscina is characterized by apothecial ascomata, massive exciple and bitunicate asci (Yacharoen et al. 2015). 
Fig. 66 Phylogram generated from maximum likelihood analysis (RAxML) of Phaeotrichales based on LSU and SSU sequence data. Maximum likelihood bootstrap values equal or above $70 \%$, Bayesian posterior probabilities equal or above 0.90 (MLBS/PP) are given at the nodes. Isolate/specimen number is noted after the species name. The tree is rooted to Venturia inaequalis (CBS 815.69 and CBS 594.70). The ex-type strains are indicated in bold. Hyphen (-) represents support values below $70 \%$ MLBS and $0.90 \mathrm{PP}$

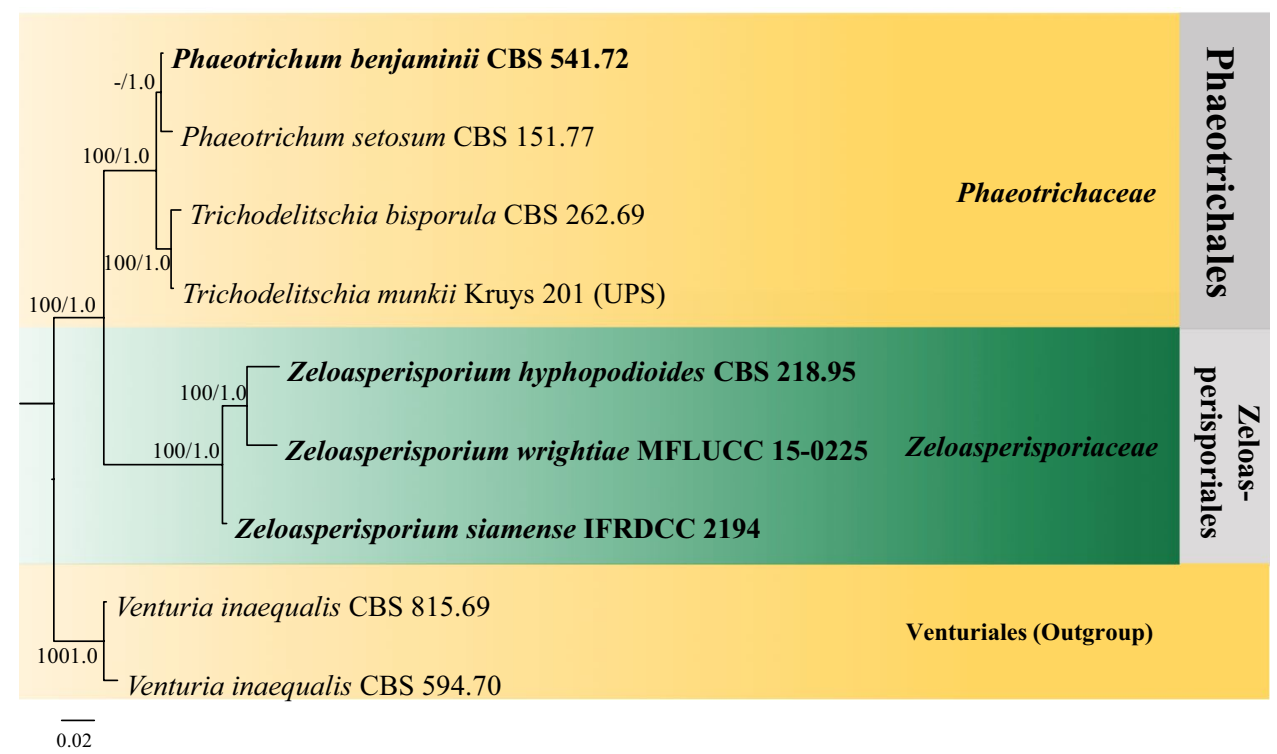

Rimula Velen., Monographia Discomycetum Bohemiae: 38 (1934).

Index Fungorum number: IF 4756; Facesoffungi number: FoF 08130; - 28 morphological species (Species Fungorum 2020), molecular data unavailable.

Type species: Rimula faginea Velen., Monogr. Discom. Bohem. (Prague): 38 (1934).

Note: Jaklitsch et al. (2016) treated Rimula as a genus in Patellariaceae.

Schrakia Hafellner, Nova Hedwigia, Beihefte zur 62: 204(1979).

Index Fungorum number: IF 4917; Facesoffungi number: FoF 00363; - 1 morphological species (Species Fungorum 2020), molecular data unavailable.

Type species: Schrakia crassula (Starbäck) Hafellner, Nova Hedwigia, Beihefte zur. 62: 204 (1979).

$\equiv$ Karschia crassula Starbäck, Bih. K. svenska VetenskAkad. Handl., Afd. 3 25(no. 1): 10 (1899).

Note: The characters of this genus are typical of Patellariaceae and characterised by carbonaceous apothecia and exciple with thick-walled and pseudoparenchymatous cells and bitunicate asci (Yacharoen et al. 2015).

Stratisporella Hafellner, Beihefte zur Nova Hedwigia 62: 207 (1979).

Index Fungorum number: IF 20613; Facesoffungi number: FoF 00365; - 1 morphological species (Species Fungorum 2020), molecular data unavailable.

Type species: Stratisporella episemoides (Nyl.) Hafellner, Beih. Nova Hedwigia 62: 207 (1979).

$\equiv$ Lecidea episemoides Nyl., Bull. Soc. linn. Normandie, sér. 2 2: 515 (1868).
Note: Taxa form apothecioid ascomata and are characterized by carbonaceous excipulum, unitunicate asci and 1-septate ascospores with thick exospores (Yacharoen et al. 2015).

Tryblidaria (Sacc.) Rehm, Hedwigia 42(Beibl.): (172) (1903).

$\equiv$ Blitridium subgen. Tryblidaria Sacc., Syll. fung. (Abellini) 8: 805 (1889).

Index Fungorum number: IF 5620; Facesoffungi number: FoF 00367; - 27 morphological species (Species Fungorum 2020), molecular data unavailable.

Type species: Tryblidaria fenestrata (Cooke \& Peck) M.E. Barr, Bulletin of the New York State Museum 459: 22 (1986).

$\equiv$ Patellaria fenestrata Cooke \& Peck, Ann. Rep. N.Y. St. Mus. nat. Hist. 28: 68 (1876) [1875].

Note: Tryblidaria taxa are saprobic and mostly found in terrestrial, subtropical environments. Sexual morphs are apothecial cupulate and carbonaceous (Yacharoen et al. 2015). Asexual morphs are undetermined (Yacharoen et al. 2015).

\section{Economic and ecological significance}

Patellariaceae is a widely distributed family. Most Patellariaceae taxa are saprobes and weak parasites on a wide variety of plants. Few members are recorded on lichen thalli. Rarely reported endophytic and fungicolous life styles are also known. For example, Rhizodiscina lignyota was recorded from Basidiomycetes and Holmiella sabina was recorded from living needles and wood of Juniperus spp. (Kutorga and Hawksworth 1997).

Phaeotrichales Ariyaw., Jian K. Liu \& K.D. Hyde, in Hyde et al. 


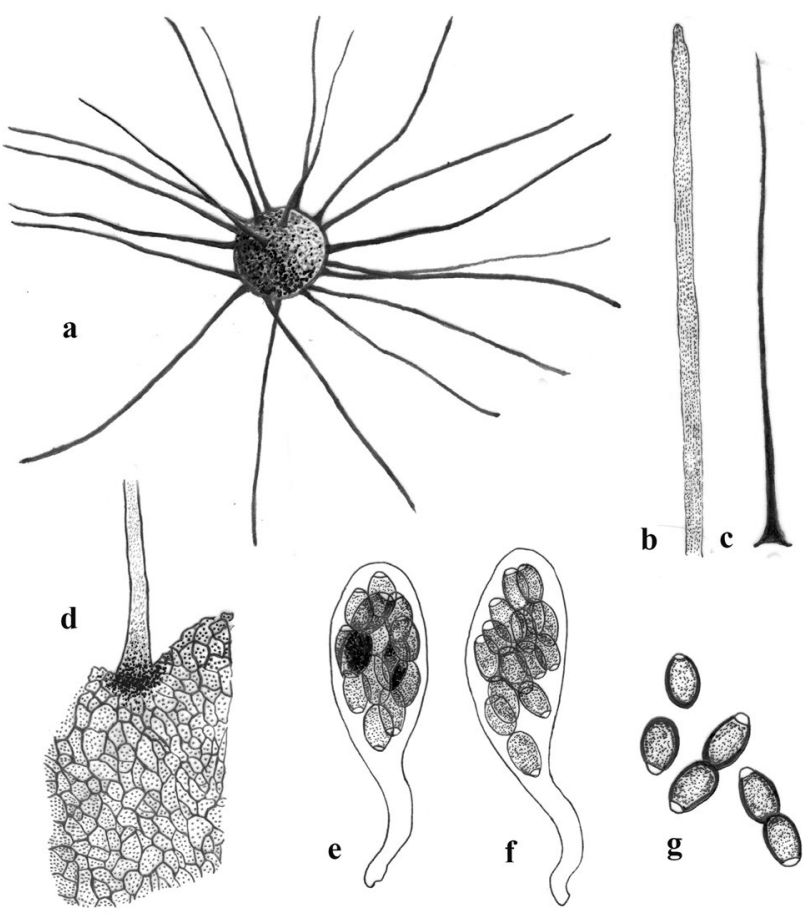

Fig. 67 Phaeotrichum hystricinum (redrawn from Cain 1956). a Ascomata with black appendages. b, c Appendages. d Black and opaque basal appendages. e, f Asci. g Ascospores

Index Fungorum number: IF 805301; Facesoffungi number: FoF 08131.

Phaeotrichales was introduced by Hyde et al. (2013) to accommodate Phaeotrichum as the type genus. Phaeotrichales is considered an order of coprophilous fungi within the class Dothideomycetes. Species in this order are characterized by unilocular, stromatic, globose ascomata with a thin, carbonaceous peridium and dark brown to reddish brown ascospores with terminal germ pores (Hyde et al. 2013). According to the recent outline of Wijayawardene et al. (2018), only a single family (Phaeotrichaceae) is placed in Phaeotrichales. Phylogenetic placement of genera in this order are shown in Fig. 66. The divergence time for Phaeotrichales is estimated as 229 MYA (stem age, Hongsanan et al. 2020).

Accepted families: Phaeotrichaceae.

Phaeotrichaceae Cain, Can. J. Bot. 34: 676 (1956).

Index Fungorum number: IF 81144; Facesoffungi numbers: FoF 08131, 11 species.

Saprobic (coprophilous) in terrestrial habitats. Sexual morph: Ascomata superficial, solitary, or in small groups, dark brown to black, globose, stromatic, perithecial or cleistothecial setose. Peridium thin-walled, carbonaceous, membraneous. Hamathecium comprising tissue absent or of evanescent cellular pseudoparaphyses. Asci 8-spored, bitunicate, fissitunicate, clavate, pedicellate, in irregular or arranged in little groups or bundles and evanescent at maturity. Ascospores overlapping, dark brown to reddish brown, sometimes fragmenting, composed of terminal germ pores, with or without a sheath. Asexual morph: Unknown (adapted from Hyde et al. 2013).

Type: Phaeotrichum Cain \& M.E. Barr.

Notes: Phaeotrichaceae was introduced by Cain (1956) to accommodate a single genus Phaeotrichum, characterized by dark brown, septate ascospores with terminal germ pores. Two coprophilous species were described, $P$. hystricinum (type species) and $P$. circinatum from porcupine dung and lemming dung, respectively. Cain (1956) pointed out some morphological similarities of Phaeotrichum with Trichodelitschia species based on features of the ascospores and setose ascomata. Lundqvist (1964) assigned Trichodelitschia to Phaeotrichaceae. The family comprises three genera, Echinoascotheca, Phaeotrichum and Trichodelitschia (Zhang et al. 2012; Hyde et al. 2013).

Phaeotrichum Cain \& M.E. Barr, Can. J. Bot. 34: 676 (1956).

Index Fungorum number: IF 3967; Facesoffungi number: FoF 08132; 5 morphological species (Species Fungorum 2020), 4 species with molecular data.

Type species: Phaeotrichum hystricinum Cain \& M.E. Barr.

Notes: Phaeotrichum was introduced by Cain (1956) to accommodate two coprophilous species, $P$. hystricinum and $P$. circinatum. Phaeotrichum species are characterized by dark brown, septate ascospores with terminal germ pores, superficial cleistothecial ascomata covered by long hairy appendages and a coprophilous habitat (Cain 1956). Phaeotrichum contains only five species (Index Fungorum 2020). Four species occur in dung and one from soil: P. benjaminii (on dung of Rodentia), P. circinatum (on dung of Lemmini), P. cylindrosporum (on dung of Erythizon dorsatus), $P$. hystricinum (on dung of porcupine) and P. setosum (from soil) (Fig. 67).

\section{Other genera included:}

Echinoascotheca Matsush., Matsush. Mycol. Mem. 8: 19 (1995).

Index Fungorum number: IF 27584; Facesoffungi number: FoF 08133; - 1 morphological species (Species Fungorum 2020), molecular data unavailable.

Type species: Echinoascotheca duplooformis Matsush., Matsush. Mycol. Mem. 8: 19 (1995).

Notes: Echinoascotheca is a monotypic genus (Species Fungorum 2020). Trichodelitschia species differ from Echinoascotheca in having an apical ring in asci (Hyde et al. 2013). For more details on morphology of Echinoascotheca species see Matsushima (1995). 
Fig. 68 Phylogram generated from maximum likelihood analysis (RAxML) of Stigmatodiscales based on ITS, LSU, SSU and tef1 sequence data. Maximum likelihood bootstrap values equal or above $70 \%$, Bayesian posterior probabilities equal or above 0.90 (MLBS/PP) are given at the nodes. Isolate/ specimen number is noted after the species name. The tree is rooted to Jahnula aquatica (R68-1) and J. sangamonensis (F81-1). The ex-type strains are indicated in bold. Hyphen (-) represents support values below $70 \%$ MLBS and $0.90 \mathrm{PP}$

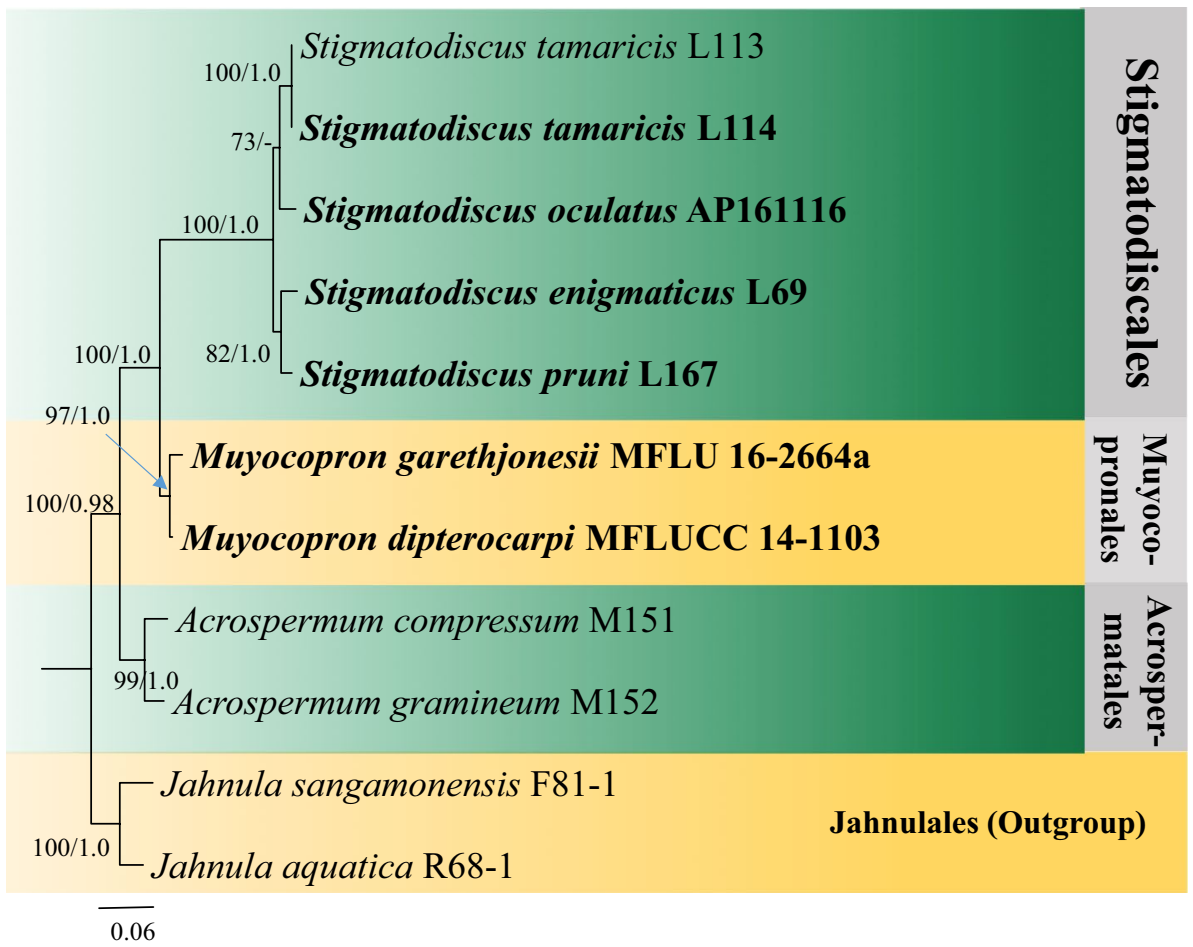

Trichodelitschia Munk, Dansk bot. Ark. 15(no. 2): 109 (1953).

Index Fungorum number: IF 5552; Facesoffungi number: FoF 08134; - 5 morphological species (Species Fungorum 2020), 2 species molecular data.

Type species: Trichodelitschia bisporula (P. Crouan \& H. Crouan) Munk, Dansk bot. Ark. 15(no. 2): 109 (1953).

$\equiv$ Hormospora bisporula P. Crouan \& H. Crouan, Florule Finistère (Paris): 21 (1867).

Notes: Trichodelitschia was erected by Munk (1953) to accommodate Trichodelitschia bisporula, which was previously known as Hormospora bisporula. Initially, Trichodelitschia was placed in Sporormiaceae by Munk (1957), but later Lundqvist (1964) suggested it be transferred to Phaeotrichaceae. Trichodelitschia species are characterized by having dark thick-walled spiny appendages, dark two-celled ascospores with hyaline to subhyaline tenninal apophyses and circular germ pores at the spore apices (Ebersohn and Eicker 1992). Five Trichodelitschia species are accepted in Species Fungorum (2020), i.e. T. adelphica, T. bisporula, T. lundqvistii, T. microspora, and T. munkii.

\section{Economic and ecological significance}

Most Phaeotrichaceae species have been recorded on dung of various animals as saprobes.

Stigmatodiscales Voglmayr \& Jaklitsch, in Voglmayr, Gardiennet \& Jaklitsch.
Index Fungorum number: IF 815325; Facesoffungi number: FoF 08771.

This order was established by Voglmayr et al. (2016) to accommodate a single family, Stigmatodiscaceae. Two genera (Asterodiscus and Stigmatodiscus) were included in the family based on differences in ascomatal shape and hyaline versus brown ascospores. However, Voglmayr and Amengual (2018) synonymized Asterodiscus under Stigmatodiscus. Our phylogenetic tree (Fig. 68) indicates the same result as in Voglmayr and Amengual (2018) which supports Stigmatodiscales as a distinct order in Dothideomycetes. The divergence time for Stigmatodiscales is estimated as 114 MYA (stem age, Hongsanan et al. 2020).

\section{Accepted families: Stigmatodiscaceae.}

Stigmatodiscaceae Voglmayr \& Jaklitsch, in Voglmayr et al., Fungal Diversity 80: 275 (2016): 77 (1903).

Index Fungorum number: IF 815326; Facesoffungi numbers: FoF 08772, 6 species species.

On dead twigs. Sexual morph: Ascomata apothecioid, embedded in cortex of dead twigs, dark brown to black, without distinct margin. Hamathecium comprising septate, unbranched or rarely branched and anastomosing above, with swollen free apical ends, paraphyses, embedded in a rubber-like gel matrix and covered by an epithecium. Hymenial gel I-. Asci 8-spored, bitunicate, fissitunicate, J-, variable in shape from fusoid to saccate or clavate to broadly fusiform broadly, with thin ecto- and thick endotunica, with wide ocular chamber, without a ring. Ascospores 2-3-seriate, 


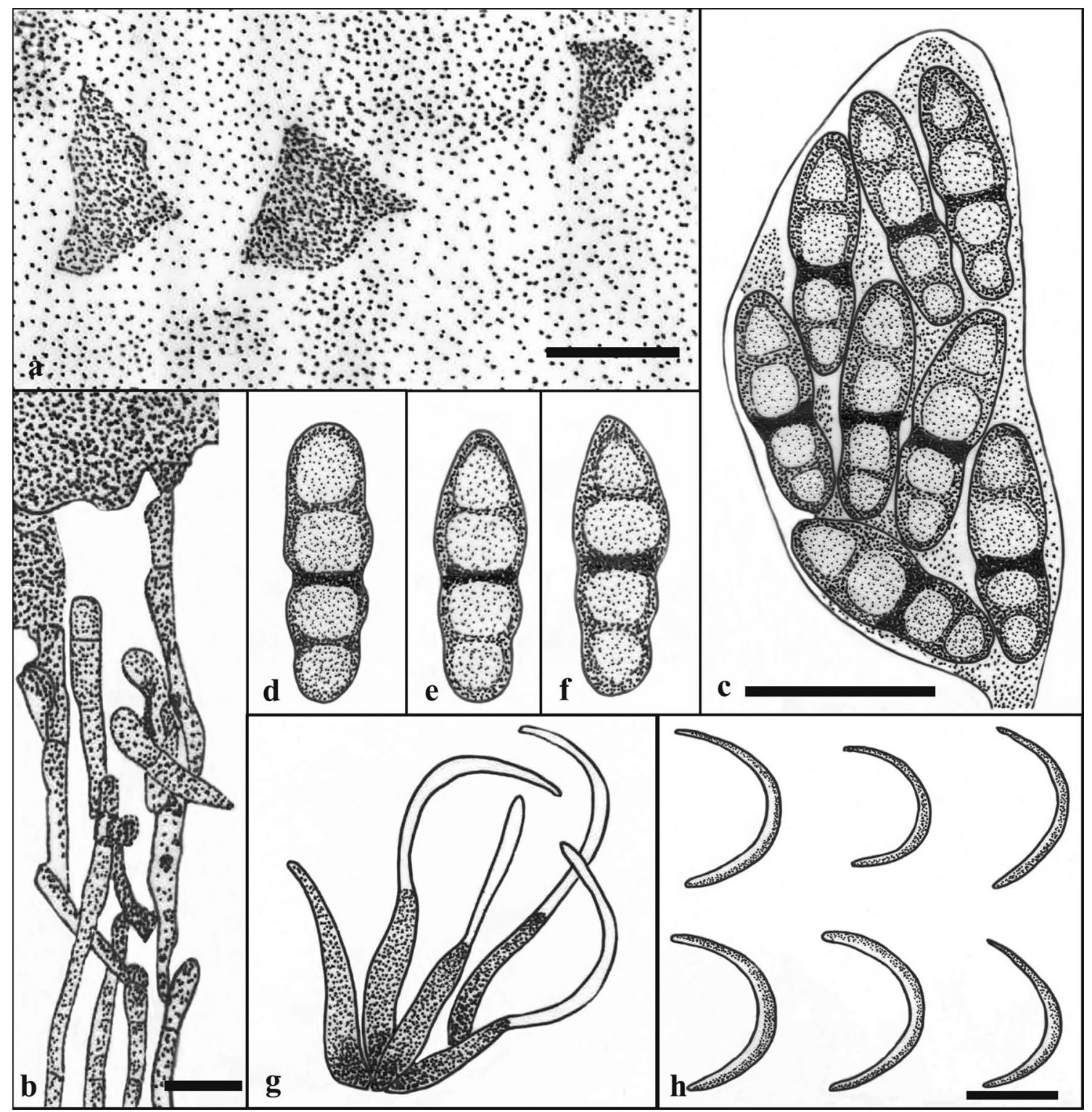

Fig.69 Stigmatodiscus enigmaticus (redrawn from Voglmayr et al. 2016). a Ascomata erumpent from bark in face view. b Paraphyses. c Asci, d-f Ascospores. g Phialides producing conidia. h Falcate conidia. Notes: a, b, d-f from WU 35914 (holotype), c from WU 35925, $\mathbf{g}$ from WU 35925, h fromWU 35922 slightly to strongly asymmetric, broadly fusiform, upper cell broader, with broadly rounded, hyaline to brown, 1-euseptate when immature, with 2 distosepta at maturity, slightly to strongly constricted at the septum, particularly the middle septum, surrounded by a separate gelatinous sheath. Asexual morph: Coelomycetous. Conidiomata in nature immersed, peridermal, pycnidial (adapted from Voglmayr et al. 2016).

Type: Stigmatodiscus Voglmayr \& Jaklitsch.

Notes: Voglmayr et al. (2016) established Stigmatodiscaceae to accommodate two genera, Asterodiscus and Stigmatodiscus, with two new species, Asterodiscus tamaricis and Stigmatodiscus enigmaticus based on phylogenetic placement and morphological characters. However further phylogenetic analyses in Voglmayr and Amengual (2018) with additional strains indicated that Asterodiscus should be synonymized under Stigmatodiscus. Thus, Stigmatodiscaceae currently comprises only Stigmatodiscus.

Stigmatodiscus Voglmayr \& Jaklitsch, in Voglmayr et al., Fungal Diversity 80: 278 (2016).

Index Fungorum number: IF 815327; Facesoffungi number: FoF 01654; 6 morphological species (Species Fungorum 2020), 6 species with molecular data. 
= Asterodiscus Voglmayr, Gardiennet \& Jaklitsch, Fungal Diversity 80: 275 (2016)

Type species: Stigmatodiscus enigmaticus Voglmayr \& Jaklitsch.

Notes: Stigmatodiscus was placed in Stigmatodiscaceae based on morphology and phylogeny. Four new species were added to this genus by Voglmayr et al. (2017) and Voglmayr and Amengual (2018). Asterodiscus was also synonymized under Stigmatodiscus based on sequence data of A. tamaricis that formed among other Sigmatodiscus species (Voglmayr and Amengual 2018). Six species are accepted in this genus based on both morphology and phylogeny. Sequence data are available for all Sigmatodiscus species.

Stigmatodiscus enigmaticus Voglmayr \& Jaklitsch, in Voglmayr et al., Fungal Diversity 80: 278 (2016).

Index Fungorum number: IF 815328; Facesoffungi number: FoF08773; Fig. 69

Description: see Voglmayr et al. (2016).

\section{Economic and ecological significance}

Species in this genus were found on dead twigs and we assume that they are saprobic.

Strigulales Lücking, M.P. Nelsen \& K.D. Hyde.

Index Fungorum number: IF 805302; Facesoffungi number: FoF 08774.

The order was established by Hyde et al. (2013) to accommodate lichenized fungi in Dothideomycetes. Members of Strigulales differ from most Trypetheliales in having euseptate ascospores with few septa and the lack of secondary chemistry (Hyde et al. 2013). It also differs from Monoblastiales in having unbranched physes and the macroconidia producing gelatinous appendages (Hyde et al. 2013). Two families are accepted in this order. The divergence time for Strigulales is estimated as 201 MYA (stem age, Hongsanan et al. 2020).

Accepted families: Strigulaceae, Tenuitholiascaceae.

Strigulaceae Zahlbr. in Engler, Syllabus, Edn 2 (Berlin): 46 (1898).

MycoBank number: MB 81870; Index Fungorum number: IF 81870; Facesoffungi number: FoF 08853; approximately 80 species (Lücking et al. 2017).

= Phyllobatheliaceae Bitter \& F. Schill., Hedwigia, Beibl. 67: 272 (1927). Type: Phyllobathelium (Müll. Arg.) Müll. Arg., Flora, Regensburg 73: 195 (1890).

Lichenized on leaves, bark or rocks in terrestrial, chiefly lowland to montane tropical to subtropical habitats, with few species extending into temperate regions. Thallus reduced and ecorticate, often white, to (pseudo-)corticate, grey-green to bright green, sometimes with metallic appearance. Photobiont Trentepohlia sensu lato (including
Cephaleuros and Phycopeltis). Sexual morph: Ascomata perithecia, scattered, clustered, or aggregated in pseudostromata, immersed to prominent (to rarely sessile), mostly brown or black, rarely pale, often at least partly covered by thallus, globose to pear-shaped or conical, coriaceous to carbonaceous, ostiolate, ostiole round. Involucrellum present in some genera, usually carbonized. Excipulum dense, consisting of compressed hyphae, appearing prosoplectenchymatous in thin sections, but structure may be difficult to observe due to carbonization, hyaline to brown or brown-black. Hamathecium comprising 0.5-0.7(-1.5) $\mu \mathrm{m}$ wide paraphyses, hyaline, flexuous, unbranched or branched to sparsely anastomosing. Asci (1-)8-spored, bitunicate, fissitunicate, obclavate to mostly cylindrical, shortly pedicellate, with narrow to somewhat broader, ocular chamber, non-amyloid. Ascospores irregularly arranged to uni- or biseriate, fusiform to ellipsoid, hyaline, septate to muriform, with eusepta and rectangular lumina, smooth-walled, often constricted at the septa. Asexual morph: Pycnidia common, immersed to erumpent, often visible as black dots, rarely pale and inconspicuous, sometimes in specific, pseudostromatic areas, or whole thalli only producing pycnidia. Conidia acrogenous, either macro- or microconidia; macroconidia 1-septate to rarely muriform, ellipsoid to bacillar, sometimes becoming rather large, with variously shaped gelatinous appendages, hyaline; microconidia usually aseptate, fusiform-ellipsoid to bacillar, small, hyaline.

Chemistry: Most species do not contain secondary substances. Crystalline anthraquinone pigments are found in Flavobathelium.

Type: Strigula Fr., Syst. Mycol. 2(2): 535 (1823).

Notes: For a general discussion of the family see Lücking \& Nelsen in Hyde et al. (2013; Strigulaceae). Recently, a new family, Tenuitholiascaceae, with the single genus, Тепиitholiascus, was established to accomodate a novel lineage sister to Strigulaceae, but with a different ascus type (Jiang et al. 2020a). Simultaneously, molecular phylogenetic analysis focusing on a broad set of foliicolous species hitherto assigned to the genus Strigula demonstrated that the latter is heterogeneous and can be divided into six genera, all characterized by a combination of morphological and anatomical features (Jiang et al. 2020b). Given that $S$. jamesii, the only non-foliicolous representative of Strigula sensu lato sequenced so far, is unrelated to the six foliicolous clades and positioned far from Strigula sensu stricto (Fig. 70), here we consequently also reassess the generic classification of non-foliicolous representatives so far placed in this genus. Based on characters of the ascospores and macroand microconidia, three further genera are recognized: Phyllocharis Fée, for the anatomically unique foliicolous taxon, Strigula orbicularis Fr.; Dichoporis Clem., for nonfoliicolous species with 1-septate ascospores, 1-septate macroconidia and chiefly fusiform microconidia; and the newly 


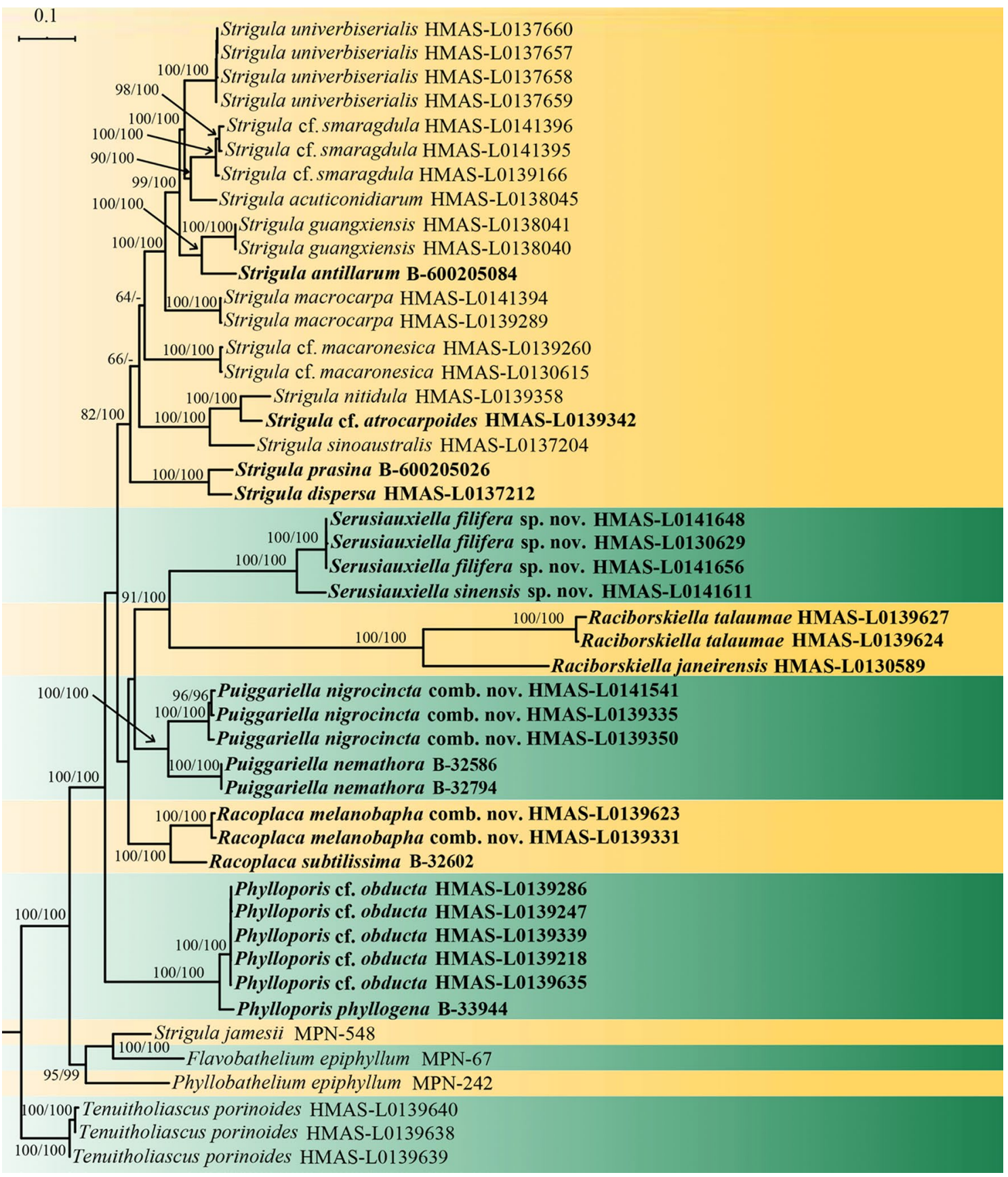

Fig. 70 Best scoring maximum-likelihood tree (also including Bayesian posterior probabilities) of Strigulaceae showing the currently recognized and sequenced genera (adapted from Jiang et al. 2020b; see that reference for further details)

established genus Swinscowia S.H. Jiang, Lücking \& Sérus., for non-foliicolous species with multi-septate to muriform ascospores, multi-septate to muriform macroconidia and chiefly bacillar microconidia. Dichoporis is closely related to Phylloporis Clem., but we keep the two groups separate largely based on the different substrate and photobiont, as molecular data for foliicolous lineages indicate photobiont preference, to be interpreted as a mycological character of mycobiont-photobiont compatibility, be consistent within a lineage. The same applies to Swinscowia in relation to the foliicolous genus Phyllocratera Sérus. \& Aptroot.

Both Index Fungorum and MycoBank list Strigulaceae A.B. Frank (Frank in Leunis 1877) as valid name for the family, antedating Strigulaceae Zahlbr. However, this is not correct. Frank did not publish a new name but cited Strigulini Fr., which was originally established as the name of a suborder (Fries 1825). Names cannot be used unchanged at different ranks unless they are descriptive and not 
automatically typified (ICN Art. 6, Note 3, and Art. 16.1), and the name Strigulini is derived from the genus name Strigula and hence automatically typified. Also, the use of names at different ranks, yet unchanged, does not apply to the level of family. Therefore, Frank's use of the name Strigulini Fr. as "Familie" (Frank in Leunis 1877: 1699) does not constitute valid publication of a name at family level that is to be corrected with unchanged authorship (ICN 18.4); instead it is to be considered a misapplication of an existing name at a different rank.

Strigula Fr., Syst. Mycol. 2(2): 535 (1823) [nom. sanct.]; Fries, Kongl. Vet.-Akad. Handl. 1821: 323 (1821) [nom. nud.].

MycoBank number: MB 5285; Index Fungorum number: IF 5285; Facesoffungi number: FoF 07706; 30 morphologically delimited species (Jiang et al. 2020b); molecular data available for approximately 15 species (Jiang et al. 2016, 2017a, b, 2020b, Ford et al. 2019; Oh et al. 2019; Woo et al. 2020).

= Nemathora Fée, Essai Crypt Écorc. 1: LVIII, XCIV, XCIX (1825); Santesson, Symb. Bot. Upsal. 12(1): 138 (1952). Type species: Nemathora viridissima Fée [= Strigula smaragdula $\mathrm{Fr}$.].

= Craspedon Fée, Essai Crypt Écorc. 1: LIX, XCIV, C (1825); Santesson, Symb. Bot. Upsal. 12(1): 138 (1952). Type species: Craspedon concretum Fée [三 Strigula concreta (Fée) R. Sant.].

= Melanophthalmum Fée, Essai Crypt. Écorc. 1: LX, XCIV, C (1825); Santesson, Symb. Bot. Upsal. 12(1): 138 (1952). Type species: Melanopthalmum antillarum Fée [三 Strigula antillarum (Fée) Müll. Arg.].

= Haploblastia Trevis., Conspectus Verrucarinarum: 16 (1860); Santesson, Symb. Bot. Upsal. 12(1): 138 (1952). Type species: Haploblastia nitidula (Mont.) Trevis. [三 Strigula nitidula Mont.].

$=$ Discosiella Syd. in Sydow \& Sydow, Leafl. Philipp. Bot. 5: 1546 (1912); Eriksson \& Hawksworth, Syst. Ascomycetum 11: 56 (1992). Type species: Discosiella cylindrospora Syd. [= Strigula sp.].

= Strigulomyces [as Strigulomyces] Cif. \& Tomas., Atti Ist. Bot. Univ. Lab. Crittogam. Pavia, Ser. 5, 10: 61 (1953) [nom. illeg.]; Harris, More Florida Lichens: 152 (1995); Lücking \& Hawksworth, Taxon 56: 1274 (2007). Type species: Strigula elegans (Fée) Müll. Arg. [= Strigula smaragdula $\mathrm{Fr}$.].

$=$ Catenata Bat. in Batista \& Bezerra, Publ. Inst. Micol. Univ. Recife 321: 15 (1961) [nom. inval.]; Lücking et al., Lichenologist 30: 161. (1998). Original species: Catenata antillarum (Fée) Bat. [三 Strigula antillarum (Fée) Müll. Arg.].

$=$ Kilikiostroma Bat. \& J. L. Bezerra, Publ. Inst. Micol. Univ. Recife 321: 13 (1961); Lücking et al., Lichenologist
30: 144 (1998). Type species: Kilikiostroma peresii Bat. \& J. L. Bezerra [= Strigula prasina Müll. Arg.].

$=$ Pycnociliospora Bat. in Batista et al., Publ. Inst. Micol. Univ. Recife 251: 6 (1962); Lücking et al., Lichenologist 30: 154 (1998). Type species: Pycnociliospora belluciae Bat. \& J. A. Lima [= Strigula antillarum (Fée) Müll. Arg.].

= Porina sect. Sagediastrella Vain., Ann. Acad. Sci. Fenn., Ser. A, 19: 10 (1923); Santesson, Symb. Bot. Upsal. 12(1): 138. 1952. Type species: Porina nitens Vain. [= Strigula nitidula Mont.].

= Shanoria Anahosur in Harris, More Florida Lichens: 144 (1995) [nom. inval., non Shanoria Subram. \& K. Ramakr., non Shanoria sensu Anahosur (1967)]. Original species: Shanoria indica Anahosur [= Strigula $\mathrm{cf}$. nitidula Mont.].

Lichenized on leaves in terrestrial, lowland to montane, tropical to subtropical, and extending into temperate, habitats. Thallus (pseudo-)corticate, grey-green to bright green, subcuticular and sometimes damaging the supporting leaf. Photobiont Cephaleuros. Sexual morph: Ascomata perithecia, erumpent to prominent, black or covered by thallus layer, lens-shaped to wart-shaped or conical, carbonaceous, ostiolate. Involucrellum present, carbonized. Excipulum prosoplectenchymatous, dark brown to brownblack. Hamathecium comprising $0.5-0.7 \mu \mathrm{m}$ wide paraphyses, hyaline, flexuose, unbranched or very rarely branched and anastomosing. Asci usually 8 -spored but sometimes appearing 9-16-spored due to ascospores breaking in halves within the asci, bitunicate, fissitunicate, cylindrical to narrowly obclavate, shortly pedicellate, with narrow ocular chamber, non-amyloid. Ascospores irregularly arranged to uni- or biseriate, fusiform to ellipsoid or bacillar, hyaline, 1 -septate, rarely 3 -septate, with thin eusepta and rectangular lumina, smooth-walled, often constricted (and sometimes breaking apart) at the septa. Asexual morph: Pycnidia common, immersed to erumpent, visible as black dots, rarely in pseudostromatic clusters, often whole thalli only producing pycnidia. Conidia acrogenous, either macro- or microconidia; macroconidia mostly 1-septate, ellipsoid to bacillar, with gelatinous appendages, hyaline; microconidia usually aseptate, ellipsoid to fusiform, small, hyaline.

Chemistry: No secondary substances known.

Type species: Strigula smaragdula Fr., Linnaea 5: 550 (1830).

Notes: Strigula as here defined includes the bulk of foliicolous species centered around S. smaragdula, after separation of the genera Dichoporis, Phyllocharis, Phylloporis, Puiggariella, Raciborskiella, and Racoplaca, and introduction of the new genera Serusiauxiella and Swinscowia (see below). As shown by Jiang et al. (2020b), a much more narrowly defined Strigula is still heterogeneous: whereas the species with a morphology similar to $S$. smaragdula form a supported clade, three basal lineages differ in morphology 
and/or anatomy, including the $S$. nitidula and S. prasina groups and $S$. macaronesica. While Strigula sensu stricto forms thickened, usually bright green thalli, those of the $S$. nitidula group are very thin and more similar to those of Racoplaca, and S. prasina and relatives have hypophyllous thalli with bluish tinge and branched and anastomosing paraphyses. Should these be confirmed as separate clades in a broader sampling of taxa, the names Haploblastia ( $S$. nitidula group) and Kilikiostroma (S. prasina group) would be available. Currently, about 30 exclusively foliicolous species are to be assigned to the genus Strigula sensu stricto as here defined.

Harris (1995) listed the name Shanoria Anahosur as a synonym of Strigula, given that the only species described by that author, $S$. indica Anahosur, represents the pycnidial stage of Strigula cf. nitidula. While the latter is correct (see also Raj 1981), Harris (1995) misinterpreted its protologue, since Anahosur (1967) did not establish a new genus but placed his new species in the already existing genus, Shanoria Subram. \& K. Ramakr., typified by S. bambusarum Subram. \& K. Ramakr. (Subramanian and Ramakrishnan 1956). The latter has been established as a synonym of Placonema (Sacc. \& D. Sacc.) Petr. (asexual morph; Sutton 1977) and Kiehlia Viégas (sexual morph; Farr 1968), with Placonema having priority. The name Shanoria Anahosur does therefore not exist with that place and date of publication (Anahosur 1967), but was inadvertently, yet effectively created by Harris (1995), who ascribed the name to Anahosur. Unfortunately, this is a rather common lapsus, frequently seen in early mycological literature, which has perpetuated many presumed homonyms that were in fact never established as such by their ascribed authors. The Code (Shenzen Code; Turland et al. 2018) does not include a specific provision for names created through erroneous citation, and so various rules must be consulted to ascertain whether such a name is actually valid (and consequently illegitimate). In the case of Shanoria Anahosur in Harris (1995), Harris (1995) provided a full and direct reference to the Latin description of $S$. indica and cited the latter as type of the genus, so the provisions of ICN Art. 38.1, 38.13, 39.1 and 40.1 are theoretically fulfilled. Since Harris (1995) did not use an explicit rank designation, such as 'gen. nov.', because he did not intend to describe a new genus, one could cite ICN Art. 37.1 to render the name invalid; however, that article does not include a specific provision how it should be applied to genus names, and the genus rank of the name is clear from context. Further, ICN Art. 36.1(b) may suggest the name as not validly published, since it is merely cited in synonymy. However, that article specifically refers to the intention of the author of the name, not the author of the publication. As Harris (1995) ascribed the name to Anahosur and not to himself [ICN Art. 46.2], his placement of Shanoria as synonym of Strigula appears irrelevant with respect to ICN Art. 36.1(b). ICN Art. 38.5 provides another potential avenue, as for a simultaneously established new genus and species, validation through reference to an earlier description is not possible. That article does not apply, though, as Harris (1995) only established a new genus name, whereas the name Shanoria indica Anahosur had already been validly described earlier (Anahosur 1967). Fortunately, this case finds its solution in ICN Art. 38.11(b), which specifies that "...for a name of a genus or subdivision of a genus, the earlier description or diagnosis must be that of a genus or subdivision of a genus". Hence, the name Shanoria Anahosur in Harris (1995) is not validated by reference to the Latin description of Shanoria indica Anahosur (1967), and it its therefore invalid. It appears ineffective that one has to fully explore the Code to eventuelly render a name invalid that was inadvertently created through erroneous citation. ICN Art. 48.1 may seemingly reflect such cases, but in reality it does not apply, as it specifically refers to names intentionally adopted by an author but in a sense different from the protologue, i.e. deliberately excluding the type of the name. Harris (1995) did not intentionally adopt the name Shanoria in a different sense, he simply cited it incorrectly, due to a misinterpretation of Anahosur's (1967) paper. He also did not explicitly exclude its original type but did so by implication, through citing another species erroneously as type of a name that did not actually exist, and through indicating Shanoria Anahosur as illegitimate, which means Harris (1995) was aware of the existence of Shanoria Subram. \& K. Ramakr. but did not realize that Anahosur (1967) was using precisely that name.

Molecular data show that the type species, Strigula smaragdula, in its current definition is a collective species (Jiang et al. 2016, 2017a, b; Oh et al. 2019; Woo et al. 2020). Given that the type is from Nepal, the name is possibly to be applied to a taxon restricted to eastern Asia, whereas the bulk of tropical species will have to be redispositioned using in part available names currently in synonymy of $S$. smaragdula. This may include reinstatement of the epithet elegans for a common and possibly widespread tropical taxon, with the type being from the Caribbean region.

\section{Other genera:}

Dichoporis Clem., Genera of Fungi: 40, 173 (1909). MycoBank number: MB 1517; Index Fungorum number: IF 1517; Facesoffungi number: FoF 08854; 18 morphologically delimited species (this paper); molecular data not available.

= Diporina Clem., Genera of Fungi: 40, 173 (1909). Type species: Diporina subsimplicans (Nyl.) Clem. [= Dichoporis subsimplicans (Nyl.) S.H. Jiang, Lücking \& Sérus.].

Lichenized on bark and rocks in terrestrial, (sub-)tropical to rarely temperate habitats. Thallus usually ecorticate, whitish to brownish. Photobiont Trentepohlia. Sexual morph: 
Ascomata perithecia, usually dispersed but often dense, very rarely fused, immersed-erumpent to prominent, usually black or covered by thallus layer, lens-shaped to wart-shaped, usually carbonaceous, ostiolate. Involucrellum usually present and carbonized, very rarely reduced or absent. Excipulum prosoplectenchymatous, pale to brown. Hamathecium comprising $0.5-0.7 \mu \mathrm{m}$ wide paraphyses, hyaline, flexuose, typically branched and sometimes somewhat anastomosing. Asci usually 8-spored, bitunicate, fissitunicate, cylindrical to narrowly obclavate, shortly pedicellate, with narrow ocular chamber, non-amyloid. Ascospores irregularly arranged to uni- or biseriate, fusiform to ellipsoid or bacillar, hyaline, 1 -septate, very rarely with two obscure, additional septa, with thin eusepta and rectangular lumina, smooth-walled, often constricted (and sometimes breaking apart) at the septa. Asexual morph: Pycnidia common, immersed to erumpent, usually visible as black dots. Conidia typically acrogenous, either macro- or microconidia; macroconidia 1-septate, oblong-bacillar, typically with narrow gelatinous appendages $1-2 \mu \mathrm{m}$ broad, about $3-6$ times as long as broad, and about one fifth to half as long as the conidia, hyaline; microconidia aseptate, typically fusiform, small, hyaline.

Chemistry: No secondary substances known.

Type species: Dichoporis schizospora (Vain.) Clem., [as 'schizopora'], Gen. Fung.: 173 (1909) [= Dichoporis ziziphi (A. Massal.) S.H. Jiang, Lücking \& Sérus. (see below)].

Notes: Dichoporis is here adopted for a group of nonfoliicolous species that was already recognized as separate group (Strigula taylorii group) by Roux and Sérusiaux (2004), though not exactly in the same sense. Two names are available for this group, besides Dichoporis also Diporina Clem., established in the same work (Clements 1909) and based on D. subsimplicans (Nyl.) Clem. We prefer to use Dichoporis, as it better expresses the potential relationships with the genus Phylloporis and is less confusing than Diporina, since these lichen fungi are entirely unrelated to Porina and its allies. The implied differences between the two genera as given by Clements (1909), namely ascospores remaining intact (Diporina) vs. breaking into two part spores (Dichoporis) are not considered taxonomically relevant at the genus level, as molecular data show foliicolous species with ascospores remaining intact or breaking into part spores to be closely related (Jiang et al. 2020b).

Dichoporis is one of two genera here recognized for the bulk of non-foliicolous species thus far placed in Strigula sensu lato, the other one being Swinscowia, established below. The difference between these two groups was also recognized by Roux and Sérusiaux (2004) and can be emended as follows, including their Strigula affinis, $S$. calcarea, and S. tagananae groups within Swinscowia: ascospores and macroconidia 1-septate in Dichoporis vs. 3-septate to muriform in Swinscowia; macroconidial appendages relatively long and narrow, $1-2 \mu \mathrm{m}$ broad, $3-6$ times as long as wide, about $20-50 \%$ of conidial length in Dichoporis vs. relatively short and broad, (1-)2-4 $\mu \mathrm{m}, 1-2(-5)$ times as long as narrow, 15-30\% of conidial length in Swinscowia; and microconidia typically fusiform(-oblong) in Dichoporis vs. (oblong-)bacillar in Swinscowia. Thus far, only the type of Swinscowia, S. jamesii, has been sequenced and shown to be outside the clade containing the foliicolous species of Strigula sensu stricto and sensu lato, being more closely related to Flavobathelium and Phyllobathelium (Fig. 70). The latter two genera, although predominantly foliicolous, share the multi-septate to muriform ascospores and macroconidia with Swinscowia. We therefore predict Dichoporis to form part of the clade containing Strigula sensu stricto and relatives, as it shares ascospore and conidial features with the latter (see also Roux and Sérusiaux 2004).

Whereas the separation of Dichoporis from Swinscowia is straightforward, it is currently unclear how both genera relate to the foliicolous Phylloporis and Phyllocratera, respectively. Apart from the substrate, the principal difference lies in the photobiont, which in the chiefly foliicolous taxa represents the Phycopeltis morphodeme, with cells forming specific, plate-like arrangements (Aptroot et al. 1997; Lücking 2008). This is even the case in occasional corticolous occurrences of e.g. Phylloporis (see below). The nature of the photobiont is generally considered a nonmycological character of no taxonomic value (e.g. Harris 1995), but this is an oversimplification. Photobiont choice is clearly a mycological character, as it is determined by genetically fixed preferences of the mycobiont for specific photobiont types, amply documented in numerous cases. This does not mean that closely related mycobionts cannot associate with disparate photobiont lineages, but it implies that each case has to be evaluated in a phylogenetic context. Whereas such comparative data are currently unavailable for the target taxa, i.e. Dichoporis vs. Phylloporis (only the latter sequenced) and Swinscowia vs. Phyllocratera (only the former sequenced), data from foliicolous lineages show that each genus-level mycobiont lineage consistently associates with a specific photobiont lineage representing either Cephaleuros, Phycopeltis or Trentepohlia (Jiang et al. 2020b), although the generic delimitation within Trentepohlia sensu lato is not settled (Lopez-Bautista et al. 2006; Rindi et al. 2009; Nelsen et al. 2011b; Hametner et al. 2014; Zhu et al. 2017). We therefore maintain this concept to keep Dichoporis and Swinscowia separate from Phylloporis and Phyllocratera, respectively. This appears also supported by the unbranched paraphyses in the latter two genera vs. the generally branched and sometimes anastomosing paraphyses in Dichoporis and Swinscowia.

While the bulk of the 18 species here included in Dichoporis appears rather homogeneous, one taxon is placed in this genus with great hesitation, namely $D$. dichosporidii. The latter was described in Strigula due to its 1-septate 
macroconidia with gelatinous appendages, but differs from all other species by its lichenicolous habit [on thalli of Dichosporidium nigrocinctum (Ehrenb.) G. Thor], the urnshaped perithecia, and the lack of an involucrellum (Etayo 2002). It is unclear whether this species actually belongs in Strigulaceae, but in lieu of a more convincing alternative placement, it is here provisionally assigned to Dichoporis.

Among Strigulaceae, Dichoporis is the genus most similar and most easily confused with Anisomeridium, as the latter typically features a similar thallus morphology and photobiont, black perithecia, and mostly 1-septate ascospores (Harris 1995). In the presence of pycnidia producing macroconidia, the distinction is straightforward, as Anisomeridium produces aseptate macroconidia lacking gelatinous appendages but typically embedded in a gelatinous mass extruded as drops from the pycnidia, very different from Strigulaceae. In the absence of macroconidia, the distinction may pose difficulties, as the differences in ascus structure are rather subtle, although the asci of Anisomeridium are usually cylindrical and those of Strigula obclavate-fusiform. The paraphyses, usually stated to be unbranched in Strigula sensu lato vs. anastomosing in Anisomeridium, can be branched and slightly anastomosing in the former as well. Still, the paraphyses in Anisomeridium typically appear net-like with numerous anastomoses, whereas those of Strigula are usually lax and not net-like. Also, many species of Anisomeridium have lateral ostioles and/or larger ascospores, often with granular ornamentation. In addition, the ascospores in Anisomeridium are usually relatively broader, with a length/width ratio in the range of 2-3(-3.5), whereas those of Dichoporis are in the range of (2.5-)3-5.5. This somewhat narrows down the number of species that could potentially confused, to about seven taxa in Dichoporis with relatively broader ascospores (2.5-3.5 times as long as broad) and those species of Anisomeridium with apical ostiole and smooth ascospores shorter than $30 \mu \mathrm{m}$ and relatively narrow (about 2.5-3.5 times as long as broad). Unfortunately, that still involves about 20 taxa in Anisomeridium, many of them frequent and widespread. These taxa are largely summarized in the world key to Anisomeridium by Harris (1995: 126), between couplets 12 and 19 (for species growing on bark or wood) and couplets 67 and 72 (for species growing on rock). Thus, when in doubt whether a specimen at hand is indeed a Dichoporis, species of Anisomeridium with similar ascospore dimensions should be checked.

\section{New combinations in Dichoporis:}

Dichoporis bermudana (Tuck.) S.H. Jiang, Lücking \& Sérus. comb. nov.

MycoBank number: MB 836370; Index Fungorum number: IF 836370; Facesoffungi number: FoF 08855.

Bas.: Verrucaria bermudana Tuck. in Nylander, Sert. Lich. Trop. Labuan Singapore: 43 (1891); Porina bermudana (Tuck.) Zahlbr., Cat. Lich. Univers. 1: 367 (1922); Strigula bermudana (Tuck.) R.C. Harris, More Florida Lichens: 155 (1995).

Notes: The species is usually cited as "Tuck ex Nyl." but Nylander (1891) ascribed the name to Tuckerman (ICN Art. 46.2), so the 'ex' citation format does not apply.

Dichoporis brevis (Bricaud \& Cl. Roux) S.H. Jiang, Lücking \& Sérus. comb. nov.

MycoBank number: MB 836371; Index Fungorum number: IF 836371; Facesoffungi number: FoF 08856.

Bas.: Strigula brevis Bricaud \& Cl. Roux in Roux \& Sérusiaux, Biblioth. Lichenol. 90: 53 (2004); Strigula brevis Bricaud \& Cl. Roux in Roux \& Bricaud, Bull. Soc. Linn. Provence 44: 107 (1993) [nom. inval., ICN Art. 36.1(a)].

Dichoporis connivens (R.C. Harris) S.H. Jiang, Lücking \& Sérus. comb. nov.

MycoBank number: MB 836372; Index Fungorum number: IF 836372; Facesoffungi number: FoF 08857.

Bas.: Strigula connivens R.C. Harris, More Florida Lichens: 155 (1995).

Dichoporis dichosporidii (Etayo) S.H. Jiang, Lücking \& Sérus. comb. nov.

MycoBank number: MB 836373; Index Fungorum number: IF 836373; Facesoffungi number: FoF 08858.

Bas.: Strigula dichosporidii Etayo, Biblioth. Lichenol. 84: 127 (2002).

Dichoporis elixii (P.M. McCarthy) S.H. Jiang, Lücking \& Sérus. comb. nov.

MycoBank number: MB 836374; Index Fungorum number: IF 836374; Facesoffungi number: FoF 08859.

Bas.: Strigula elixii P.M. McCarthy, Biblioth. Lichenol. 78: 279 (2001).

Dichoporis fractans (P.M. McCarthy) S.H. Jiang, Lücking \& Sérus. comb. nov.

MycoBank number: MB 836375; Index Fungorum number: IF 836375; Facesoffungi number: FoF 08860.

Bas.: Strigula fractans P.M. McCarthy, Lichenologist 29: 516 (1997).

Dichoporis maritima (H. Harada) S.H. Jiang, Lücking \& Sérus. comb. nov.

MycoBank number: MB 836376; Index Fungorum number: IF 836376; Facesoffungi number: FoF 08861.

Bas.: Strigula maritima H. Harada, Bryologist 101: 605 (1998).

Dichoporis minutula (P.M. McCarthy) S.H. Jiang, Lücking \& Sérus. comb. nov. 
MycoBank number: MB 836377; Index Fungorum number: IF 836377; Facesoffungi number: FoF 08862.

Bas.: Strigula minutula P.M. McCarthy, Muelleria 8: 327 (1995).

Dichoporis natalis (P.M. McCarthy) S.H. Jiang, Lücking \& Sérus. comb. nov.

MycoBank number: MB 836378; Index Fungorum number: IF 836378; Facesoffungi number: FoF 08863.

Bas.: Strigula natalis P.M. McCarthy, Biblioth. Lichenol. 78: 281 (2001).

Dichoporis nipponica (H. Harada) S.H. Jiang, Lücking \& Sérus. comb. nov.

MycoBank number: MB 836379; Index Fungorum number: IF 836379; Facesoffungi number: FoF 08864.

Bas.: Strigula nipponica H. Harada, Nova Hedwigia 60: 488 (1995).

Dichoporis occulta (P.M. McCarthy \& Malcolm) S.H. Jiang, Lücking \& Sérus. comb. nov.

MycoBank number: MB 836380; Index Fungorum number: IF 836380; Facesoffungi number: FoF 08865.

Bas.: Strigula occulta P.M. McCarthy \& Malcolm, Mycotaxon 60: 323 (1996).

Dichoporis phaea (Ach.) S.H. Jiang, Lücking \& Sérus. comb. nov.

MycoBank number: MB 836381; Index Fungorum number: IF 836381; Facesoffungi number: FoF 08866.

Bas.: Verrucaria phaea Ach., Syn. Meth. Lich.: 88 (1814); Porina phaea (Ach.) Müll. Arg., Flora 68: 261 (1885); Strigula phaea (Ach.) R.C. Harris in Tucker \& Harris, Bryologist 83: 18 (1980).

= Porina mundula Müll. Arg., Bot. Jahrb. 6: 402 (1885).

= Strigula diederichiana Etayo, $\mathrm{Cl}$. Roux \& Sérus. in

Roux \& Bricaud, Bull. Soc. Linn. Provence 44: 129 (1993) [nom. inval., ICN Art. 36.1].

Dichoporis subprospersella (Vain.) S.H. Jiang, Lücking \& Sérus. comb. nov.

MycoBank number: MB 836382; Index Fungorum number: IF 836382; Facesoffungi number: FoF 08867.

Bas.: Porina subprospersella Vain., Mycologia 21: 39 (1929); Strigula subprospersella (Vain.) P.M. McCarthy, Biblioth. Lichenol. 78: 281 (2001).

Dichoporis subsimplicans (Nyl.) S.H. Jiang, Lücking \& Sérus. comb. nov.

MycoBank number: MB 836383; Index Fungorum number: IF 836383; Facesoffungi number: FoF 08868.

Bas.: Verrucaria subsimplicans Nyl., Lich. Nov. Zeland.: 130 (1888); Diporina subsimplicans (Nyl.) Clem., Gen.
Fung.: 40, 173 (1909); Porina subsimplicans (Nyl.) Müll. Arg., Bull. Herb. Boissier 2(1): 91 (1894); Segestria subsimplicans (Nyl.) Hellb., Bih. K. Svenska Vetensk. Akad. Handl., Afd. 3, 21(13): 132 (1896); Strigula subsimplicans (Nyl.) R.C. Harris, Biblioth. Lichenol. 57: 175 (1995).

Dichoporis taylorii (Carroll) S.H. Jiang, Lücking \& Sérus. comb. nov.

MycoBank number: MB 836384; Index Fungorum number: IF 836384; Facesoffungi number: FoF 08869.

Bas.: Verrucaria taylorii Carroll [as 'taylori'] in Nylander, Expos. Synopt. Pyrenocarp.: 82 (1858); Arthopyrenia taylorii (Carroll) Mudd, Man. Brit. Lich.: 302 (1861); Porina taylorii (Carroll) Swinscow, Lichenologist 2: 169 (1962); Spermatodium taylorii (Carroll) Trevis. Conspect. Verruc.: 11 (1860); Strigula taylorii (Carroll) R.C. Harris in Hawksworth et al., Lichenologist 12: 107 (1980).

Notes: The species is usually cited as "Carroll ex Nyl." but Nylander (1858) ascribed the name to Carroll (ICN Art. 46.2), so the 'ex' citation format does not apply.

Dichoporis tenuis (R.C. Harris) S.H. Jiang, Lücking \& Sérus. comb. nov.

MycoBank number: MB 836385; Index Fungorum number: IF 836385; Facesoffungi number: FoF 08870.

Bas.: Arthopyrenia tenuis R.C. Harris, Michigan Bot. 12: 16 (1973); Strigula americana R.C. Harris in Tucker \& Harris, Bryologist 83: 18 (1980).

Notes: Unfortunately, in the new generic disposition, the original epithet tenuis has priority over the rather well-established replacement name Strigula americana.

Dichoporis viridiseda (Nyl.) S.H. Jiang, Lücking \& Sérus. comb. nov.

MycoBank number: MB 836386; Index Fungorum number: IF 836386; Facesoffungi number: FoF 08871.

Bas.: Verrucaria viridiseda Nyl., Expos. Synopt. Pyrenocarp.: 55 (1858); Strigula viridiseda (Nyl.) R.C. Harris in Tucker \& Harris, Bryologist 83: 18 (1980).

Dichoporis wilsonii (Riddle) S.H. Jiang, Lücking \& Sérus. comb. nov.

MycoBank number: MB 836387; Index Fungorum number: IF 836387; Facesoffungi number: FoF 08872.

Bas.: Porina wilsonii Riddle in Britton \& Millspaugh, The Bahama Flora: 523 (1920); Porina wilsonii Riddle, Mycologia 15: 73 (1923) [nom. inval., ICN Art. 6.23, Note 2]; Strigula wilsonii (Riddle) R.C. Harris in Egan, Bryologist 90: 164 (1987).

Notes: The publication of Porina wilsonii by Riddle (1923) is an exact copy of the earlier publication by the same author in the chapter "Lichenes" in Britton \& Millspaugh's (1920) Bahama Flora. The later publication is 
usually considered a superfluous validation, but likely there was some confusion about publishing the same content twice in different outlets. Riddle had possibly overlooked that he had already published the species, because in the treatment on the Bahamas he included several species that he simultaneously described from other areas, such as in this case the Isle of Pines (Cuba), and in 1923 he focused on taxa from the latter area, without referring back to the Bahama Flora.

Dichoporis ziziphi (A. Massal.) S.H. Jiang, Lücking \& Sérus. comb. nov.

MycoBank number: MB 836388; Index Fungorum number: IF 836388; Facesoffungi number: FoF 08873.

Bas.: Sagedia ziziphi A. Massal., Miscell. Lichenol.: 30 (1856); Porina ziziphi (A. Massal.) Zahlbr., Cat. Lich. Univers. 1: 410 (1922); Spermatodium ziziphi (A. Massal.) Trevis., Conspect. Verruc.: 12 (1860); Strigula ziziphi (A. Massal.) Cl. Roux \& Sérus. in Roux \& Sérusiaux, Biblioth. Lichenol. 90: 55 (2004).

= Strigula mediterranea Etayo, Lichenologist 25: 258 (1993); Porina schizospora Vain., Term. Füz. 22: 340 (1899) [non Strigula schizospora R. Sant., Symb. Bot. Upsal. 12(1): 175 (1952)].

Notes: The epithet schizospora, based on Porina schizospora Vain. (Vainio 1899), was blocked for use in Strigula by S. schizospora R. Sant. (Santesson 1952), which required the replacement name $S$. mediterranea (Etayo 1993). The epithet schizospora is theoretically available in Dichoporis but is predated by Sagedia ziziphi (Massalongo 1856). The identity of both taxa was established by Roux and Sérusiaux (2004). The species was recently reported also from Brazil (Cavalcante and Cáceres 2014).

\section{Key to species of Dichoporis:}

1. Lichenicolous (on Dichosporidium); involucrellum absent......................Dichoporis dichosporidii

1. Lichenized (on bark, wood or rock); involucrellum present ............................................... 2

2. On bark .......................................... 3

2. On rock......................................... 10

3. Ascomata aggregate-fused; ascospores 7-12 $\mu \mathrm{m}$ long; southeastern North America......Dichoporis connivens

3. Ascomata solitary (but sometimes dense); ascospores (9-)12-28 $\mu \mathrm{m}$ long................................ 4

3. Thallus rather dark olive-brown to olive-green, with the black perithecia barely contrasting in colour; perithecia $0.1-0.3(-0.35) \mathrm{mm}$ diam...........................5

4. Thallus white-grey, with the black perithecia strongly contrasting; perithecia (0.3-)0.4-0.6 mm diam.
5. Ascospores 9-14 $\mu \mathrm{m}$ long; macroconidia 6-10 $\times 1.5-$ $2.5 \mu \mathrm{m}$; macroconidiogenous cells rather long (mostly $15-25 \mu \mathrm{m})$; pantropical

Dichoporis phaea

5. Ascospores $13-27 \mu \mathrm{m}$ long; macroconidia $8-20 \times$ (2-)2.5-3.5 $\mu \mathrm{m}$; macroconidiogenous cells rather short

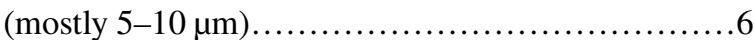

6. Ascospores $13-20 \mu \mathrm{m}$ long, partly obscurely 3 -septate, remaining intact; perithecia $0.1-0.15 \mathrm{~mm}$ diam.; New Zealand.

Dichoporis subsimplicans

6. Ascospores 17-27 $\mu \mathrm{m}$ long, consistently 1-septate, partly breaking into part spores outside the asci; perithecia 0.2-0.3 mm diam.; Europe...................... 7

7. Macroconidia 8-14 $\mu \mathrm{m}$ long.........Dichoporis brevis

7. Macroconidia 13-20 $\mu \mathrm{m}$ long.......Dichoporis taylorii

8. Ascospores 12-17 $\mu \mathrm{m}$ long; macroconidia 7-10 $\times$ 2-2.5 $\mu \mathrm{m}$; North America......Dichoporis viridiseda

8. Ascospores 15-28 $\mu \mathrm{m}$ long; macroconidia 8-19 $\times 3-4.5$

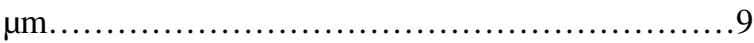

9. Macroconidia 8-12 $\mu \mathrm{m}$ long; mediterranean Europe... Dichoporis ziziphi

9. Macroconidia 14-19 $\mu \mathrm{m}$ long; eastern North America......... Dichoporis tenuis (= Strigula americana)

10. On calcareous rock (limestone) ...................11

10. On siliceous rock (granite) .......................15

11. Ascospores $8-12 \times 2.5-3.5 \mu \mathrm{m}$; perithecia $0.15-0.2$ $\mathrm{mm}$ diam.; strongly prominent to sessile; Australasia (Christmas Island).................Dichoporis natalis

11. Ascospores $11-22 \times(3-) 3.5-6(-7.5) \mu \mathrm{m}$; perithecia $0.2-0.5(-0.9) \mathrm{mm}$ diam.; immersed-erumpent to prominent (if smaller than $0.2 \mathrm{~mm}$ then immersed-eru mpent)........................................ 12

12. Perithecia 0.4-0.9 mm diam.; ascospores 5-7.5 $\mu \mathrm{m}$ broad; chiefly Caribbean including southeasternmost North America, also reported from Papua New Guinea..........................Dichoporis wilsonii

12. Perithecia (0.15-)0.2-0.5 mm diam.; ascospores 3.5$5(-6) \mu \mathrm{m}$ broad...................................13

13. Ascospores 11-15 $\mu \mathrm{m}$ long; macroconidia 10-15 $\mu \mathrm{m}$ long, about the same length as the ascospores; Caribbean and Australasia (Christmas Island).

Dichoporis bermudana

13. Ascospores 13-21 $\mu \mathrm{m}$ long; macroconidia (known from D. elixii) $8-12 \mu \mathrm{m}$ long, much shorter than the asc ospores........................................ 14

14. Perithecia 0.15-0.2 mm diam., immersed-erumpent; ascospores 16-25 $\mu \mathrm{m}$ long; Caribbean....

Dichoporis subprospersella

14. Perithecia $0.25-0.5 \mathrm{~mm}$ diam., erumpent to prominent; ascospores 13-20 $\mu \mathrm{m}$ long; Australasia (Christmas Island). Dichoporis elixii

15. Ascospores 6-10 $\times 2-3 \mu \mathrm{m}$; Australasia. Dichoporis minutula

15. Ascospores $11-32 \times 3.5-6.5 \mu \mathrm{m} . \ldots \ldots \ldots \ldots \ldots \ldots . . . \ldots 16$ 
16. Ascospores breaking into part spores outside the asci; perithecia $0.2-0.4 \mathrm{~mm}$ diam.; macroconidia (known from $D$. fractans) $6-8 \times 2.5-3 \mu \mathrm{m}$; Australasia............................................... 17

16. Ascospores remaining intact; perithecia $0.3-0.8 \mathrm{~mm}$ diam.; macroconidia 12-19 × 2-4 $\mu \mathrm{m}$; Japan.........18

17. Ascospores $22-32 \times 4-6.5 \mu \mathrm{m}$; New Zealand........... Dichoporis occulta

17. Ascospores $11-15 \times 3.5-5 \mu \mathrm{m}$; Australia (Lord Howe Island). Dichoporis fractans

18. Ascospores $15-26 \mu \mathrm{m}$ long; perithecia partly covered by thallus; montane...............Dichoporis nipponica

18. Ascospores 13-17 $\mu \mathrm{m}$ long; perithecia more or less exposed; maritime rocks......... Dichoporis maritima

Flagellostrigula Lücking, S.H. Jiang \& Sérus. gen. nov.

MycoBank number: MB 836389; Index Fungorum number: IF 836389; Facesoffungi number: FoF 08874; one morphologically delimited species (this paper); molecular data not available.

Lichenized on bark in terrestrial, (sub-)tropical habitats. Thallus corticate, greenish. Photobiont Trentepohlia. Sexual morph: Ascomata unknown. Asexual morph: Pycnidia common, prominent, hemisphaerical to wart-shaped, rather large (up to $0.8 \mathrm{~mm}$ diam.), covered by rather thick thalline layer. Conidia typically acrogenous, only macroconidia known; macroconidia 1-septate, broadly bacillar, with long and thin $(15-35 \times 1 \mu \mathrm{m})$ gelatinous appendage at one end only, hyaline.

Chemistry: No secondary substances known.

Type species: Flagellostrigula laureriformis (Aptroot \& Lücking) Lücking, S.H. Jiang \& Sérus. (see below).

Notes: This new genus is established for an oddball that agrees with Dichoporis in its 1-septate macroconidia. Flagellostrigula laureriformis is only known through pycnidia producing macroconidia, which differ from Dichoporis and other genera in having only a single, very long, name-giving flagelliform appendage at the proximal end, about 3-4 times as long as the conidia (Aptroot et al. 2008; Jiang et al. 2016; Cáceres et al. 2017). In addition, the pycnidia are unusually large and covered by a rather thick thalline layer. The single species is with certainty known from the Neotropics only (Costa Rica, Brazil; Aptroot et al. 2008; Cáceres et al. 2017). The report from China (Jiang et al. 2016) may represent an additional species, given the slightly deviating morphology of the pycnidia.

Flagellostrigula laureriformis (Aptroot \& Lücking) Lücking, S.H. Jiang \& Sérus. comb. nov.

MycoBank number: MB 836390; Index Fungorum number: IF 836390; Facesoffungi number: FoF 08875.
Bas.: Strigula laureriformis Aptroot \& Lücking in Aptroot et al., Biblioth Lichenol. 97: 131 (2008).

Flavobathelium Lücking, Aptroot \& Thor, Lichenologist 29: 221 (1997).

MycoBank number: MB 27825; Index Fungorum number: IF 27825; Facesoffungi number: FoF 08876; one morphologically and phylogenetically delimited species (Nelsen et al. 2011a).

Lichenized on leaves in terrestrial, lowland to lower montane tropical forests. Thallus thinly corticate, grey-green with characteristic metallic appearance. Photobiont Trentepohlia. Sexual morph: Ascomata perithecia, immersed in groups in slightly prominent pseudostromata covered by thallus layer and with a medulla containing ochraceous-yellow, $\mathrm{K}+$ dark red, powdery crystals; individual perithecia ostiolate. Involucrellum absent. Excipulum prosoplectenchymatous, brown. Hamathecium comprising 1.5-2 $\mu \mathrm{m}$ wide paraphyses, hyaline, flexuose, unbranched to sparsely branched at the base. Asci 8-spored, bitunicate, fissitunicate, narrowly clavate to oblong-fusiform, shortly pedicellate, with narrow ocular chamber, non-amyloid. Ascospores irregularly arranged to biseriate, fusiform, hyaline, 3(-5)-septate, with thin eusepta and rectangular lumina, smooth-walled, not or slightly constricted at the septa. Asexual morph: Pycnidia common, immersed in groups in slightly prominent pseudostromata covered by thallus layer and with a medulla containing ochraceous-yellow, K+ dark red, powdery crystals; often whole thalli producing pycnidia only. Conidia acrogenous, only macroconidia known; macroconidia 3(-5)-septate, narrowly bacillar to acicular, distal end with a very narrow, ciliate appendage about one third as long as the conidia, proximal end with a short, gelatinous cap, hyaline.

Chemistry: Unidentified ochraceous-yellow anthraquinone crystals in ascomatal and pycnidial pseudostromata.

Type species: Flavobathelium epiphyllum Lücking et al., Lichenologist 29: 221 (1997).

Notes: Flavobathelium is thus far a monospecific, tropical genus growing on living leaves (Lücking et al. 1997; Lücking 2008). Given the inclusion of non-foliicolous species with multi-septate to muriform ascospores and macroconidia in a single genus, Swinscowia (see below), one could theoretically consider Flavobathelium and Phyllobathelium conspecific. However, the two genera are not directly related phylogenetically, with Flavobathelium sister to Swinscowia and Phyllobathelium sister to the clade including the two other genera, with strong support (Fig. 70). This also supports the separation of Swinscowia from Phyllocratera and may indicate that Swinscowia as here circumscribed is still heterogeneous, requiring assessment of some of the genuinely muriform-spored species currently included in the latter genus. 
Phyllobathelium (Müll. Arg.) Müll. Arg., Flora 73: 195 (1890).

MycoBank number: MB 4057; Index Fungorum number: IF 4057; Facesoffungi number: FoF 08877; five morphologically delimited species (Lücking et al. 2017); molecular data available for one species (Nelsen et al. 2011a).

Lichenized on leaves or rarely on bark in terrestrial, lowland to lower montane tropical to subtropical forests. Thallus corticate, grey-green with characteristic metallic appearance, often minutely verrucose. Photobiont Trentepohlia. Sexual morph: Ascomata perithecia, scattered, prominent to sessile, wart-shaped but often irregularly bumpy, immersed in pseudostromata covered by thallus layer and usually filled with a mass of black, powdery crystals, ostiolate. Involucrellum reduced. Excipulum prosoplectenchymatous, colourless. Hamathecium comprising 1.5-2 $\mu \mathrm{m}$ wide paraphyses, hyaline, flexuose, unbranched to sparsely branched. Asci 8-spored, bitunicate, fissitunicate, broadly cylindrical, shortly pedicellate, with broad ocular chamber, non-amyloid. Ascospores irregularly arranged to uni- or 2-seriate, fusiform to ellipsoid, hyaline, muriform, with thin eusepta and rectangular lumina, smooth-walled, often constricted at the septa. Asexual morph: Pycnidia common, immersed in slightly raised, applanate to conical pseudostromata filled with black, powdery crystals, visible as brown to black dots, often whole thalli only producing pycnidia. Conidia acrogenous, only macroconidia known; macroconidia septate to muriform, ellipsoid to bacillar, with more or less ciliate but rather thick gelatinous appendages, hyaline.

Chemistry: Unidentified black, powdery crystals in ascomata warts and pycnidial pseudostromata.

Type species: Phyllobathelium epiphyllum (Müll. Arg.) Müll. Arg. [= Phyllobathelium firmum (Stirt.) Vězda in Lücking \& Kalb, Bot. Jb. 122: 44 (2000)].

Notes: For a detailed discussion of this genus, see Lücking (2008) and Lücking \& Nelsen (in Hyde et al. 2013; Strigulaceae). Over time, 13 taxa, including 11 at species level, have been assigned to Phyllobathelium. Of these, two were subsequently transferred to Strigula (Harris 1995) and are currently treated in Swinscowia (see below), namely $P$. albolinitum (Nyl.) H. Mayrhofer and P. obtectum (Vain.) H. Mayrhofer. Phyllobathelium nudum Zahlbr. was recognized as a second species of Phyllocratera (Lücking \& Sérusiaux 2013). Of the remaining ten names, P. epiphyllum (Müll. Arg.) Müll. Arg. and P. epiphyllum var. majus F. Schill. are synonyms of $P$. firmum (Stirt.) Vězda, and $P$. thaxteri (Vain.) Zahlbr., P. thaxteri var. heterogena (Vain.) Zahlbr., and $P$. megapotamicum (Malme) R. Sant. are synonymous with P. chlorogastricum (Müll. Arg.) Aptroot \& Lücking (Lücking 2008; Aptroot and Lücking 2016). This leaves five species currently accepted in the genus, including also $P$. anomalum Lücking, P. leguminosae (Cavalc. \& A.A. Silva) Lücking \& Sérus., and P. nigrum R. Sant. \& Tibell. The pseudostromatic perithecia with black, crystalline medulla are particularly well-developed in P. firmum and P. chlorogastricum, whereas in the other three species, the perithecia appear naked, with only remnants of a black medullary mass as irregular outer cover on the perithecia.

The macroconidia of Phyllobathelium chlorogastricum are perhaps the largest known among all fungi, reaching 200 $\times 35 \mu \mathrm{m}$ in size (Lücking 2008, as $P$. thaxteri).

Phyllocharis Fée, Essai Crypt Écorc. 1: LIX, XCIV, XCIX (1825).

MycoBank number: MB 4062; Index Fungorum number: IF 4062; Facesoffungi number: FoF 08878; one morphologically delimited species (this paper); molecular data not available.

Lichenized on leaves in terrestrial, lowland to montane, tropical to subtropical habitats. Thallus (pseudo-)corticate, pale grey-green, usually subcuticular and sometimes damaging the supporting leaf. Photobiont Cephaleuros. Sexual morph: Ascomata perithecia, prominent, black but largely covered by thallus layer, wart-shaped, carbonaceous, ostiolate. Involucrellum present, weakly carbonized. Excipulum prosoplectenchymatous, brownish. Hamathecium comprising 0.5-0.7 $\mu \mathrm{m}$ wide paraphyses, hyaline, flexuose, unbranched. Asci 8-spored, bitunicate, fissitunicate, obclavate to fusiform, shortly pedicellate, with narrow ocular chamber, non-amyloid. Ascospores irregularly arranged to biseriate, oblong, hyaline, 3-septate, with thin eusepta and rectangular lumina, smooth-walled. Asexual morph: Pycnidia common, immersed to erumpent, visible as black dots. Conidia acrogenous, either macro- or microconidia; macroconidia 3-9-septate, long-filiform, with gelatinous appendages, hyaline; microconidia aseptate, fusiform, small, hyaline.

Chemistry: No secondary substances known.

Type species: Phyllocharis complanata Fée [= Phyllocharis orbicularis (Fr.) S.H. Jiang, Lücking \& Sérus. (see below)].

Notes: Although no genuine molecular data are available for Strigula orbicularis, the 3-septate ascospores set it apart from all other foliicolous, subcuticularly growing genera (Jiang et al. 2020b), and the peculiar, filiform macroconidia are unique among the entire family. The genus Phyllocharis is therefore resurrected here to reflect this. The name Phyllocharis Fée has a later homonym, Phyllocharis Diels, a plant genus in the family Lobeliaceae. The latter had been proposed for conservation (van den Brink et al. 1961), but the proposal was not accepted (Rickett 1963). Fée's name is therefore available.

Based on ascospore and macroconidial features, we predict $S$. orbicularis to cluster in the clade with Flavobathelium, Phyllobathelium, and Swinscowia. Incidentally, an ITS sequence for S. orbicularis (GenBank accession KU509981) 
was published by Krishnamurthy and Subramanya (2016), based on material from India, but unfortunately that sequence represents a contaminant in the genus Aspergillus.

New combination in Phyllocharis:

Phyllocharis orbicularis (Fr.) S.H. Jiang, Lücking \& Sérus. comb. nov.

MycoBank number: MB 836391; Index Fungorum number: IF 836391; Facesoffungi number: FoF 08879.

Bas.: Strigula orbicularis Fr., Linnaea 5: 549 (1830).

\section{Phyllocraterina Sérus. \& Aptroot nom. nov.}

MycoBank number: MB 836392; Index Fungorum number: IF 836392; Facesoffungi number: FoF 08880; two morphologically delimited species (Lücking and Sérusiaux 2013); molecular data not available.

Replaced syn.: Phyllocratera Sérus. \& Aptroot in Aptroot et al., Biblioth. Lichenol. 64: 132 (1997) [nom. illeg., ICN Art. 53.2; non Phyllocrater Wernham].

Lichenized on leaves in terrestrial, lowland to montane, tropical habitats. Thallus thinly corticate, grey-green, supracuticular. Photobiont Phycopeltis. Sexual morph: Ascomata perithecia, prominent, black, wart-shaped with spreading base, carbonaceous, ostiolate. Involucrellum present, carbonized. Excipulum prosoplectenchymatous, brownish to blackish. Hamathecium comprising 1.5-2 $\mu \mathrm{m}$ wide paraphyses, hyaline, unbranched. Asci 8-spored, bitunicate, fissitunicate, clavate, shortly pedicellate, with rather broad ocular chamber, non-amyloid. Ascospores irregularly arranged, fusiformellipsoid, hyaline, muriform, with thin eusepta and rectangular lumina, smooth-walled, slightly constricted at the median septum. Asexual morph: unknown.

Chemistry: No secondary substances known.

Type species: Phyllocraterina papuana (Sérus. \& Aptroot.) Sérus. \& Aptroot (see below).

Notes: As response to an anonymous request, the Nomenclatural Committee for Fungi considered the name Phyllocratera and Phyllocrater, a monospecific plant genus in the family Rubiaceae known from Indonesia (Wernham in Gibbs 1914), sufficiently alike to be confused and recommended to consider them as homonyms (so-called parahomonyms; Norvell 2011). We therefore introduce here a slightly altered replacement name ascribed to the original authors, in order to limit nomenclatural disruption and to honor original authorship of this enigmatic taxon.

This small, exclusively foliicolous genus, currently containing two species (Lücking and Sérusiaux 2013), largely corresponds to non-foliicolous species of Swinscowia with muriform ascospores. Phyllocraterina is here maintained as a separate genus because of the different substrate and photobiont and because of the unbranched paraphyses (see below Dichoporis for further discussion). However, its relationships to some of the muriform-spored species placed in Swinscowia need to be investigated further.

New combinations in Phyllocraterina:

Phyllocraterina papuana (Sérus. \& Aptroot.) Sérus. \& Aptroot. comb. nov.

MycoBank number: MB 836393; Index Fungorum number: IF 836393; Facesoffungi number: FoF 08881.

Bas.: Phyllocratera papuana Sérus. \& Aptroot in Aptroot et al., Biblioth. Lichenol. 64: 132 (1997).

Phyllocraterina nuda (Zahlbr.) Lücking \& Sérus. comb. nov.

MycoBank number: MB 836394; Index Fungorum number: IF 836394; Facesoffungi number: FoF 09210.

Bas.: Phyllobathelium nudum Zahlbr., Annals Cryptog. Exot. 1: 115 (1928); Phyllocratera nuda (Zahlbr.) Lücking \& Sérus., Lichenologist 45: 691 (2013).

Phylloporis Clem., Gen. Fungi: 41, 173 (1909); Vězda, Folia Geobot. Phytotax. 19: 185 (1984); Jiang et al., Fung. Div. 102: 287.

MycoBank number: MB 4070; Index Fungorum number: IF 4070; Facesoffungi number: FoF 08882; nine morphologically delimited species (Jiang et al. 2020b; this paper); molecular data available for two species (Jiang et al. 2020b).

$=$ Porinomyces Bat. in Bezerra et al., Atas Inst. Micol. Univ. Pernambuco 5: 410 (1967) [nom. inval.]; Lücking et al., Lichenologist 30: 168 (1998). Original species: Porinomyces phyllogenus (Müll. Arg.) Bat. [三 Strigula phyllogena (Müll. Arg.) R. C. Harris].

= Didymaster Bat. \& H. Maia, Atas Inst. Micol. Univ. Pernambuco 5: 58 (1967); Lücking et al., Lichenologist 30: 140 (1998). Type species: Didymaster myrtaciicola Bat., H. Maia \& Castro [= Strigula platypoda (Müll. Arg.) R. C. Harris].

= Manaustrum Cavalc. \& A. A. Silva in Cavalcante et al., Publ. Inst. Micol. Univ. Fed. Pernambuco 647: 13 (1972); Lücking et al., Lichenologist 30: 146 (1998). Type species: Manaustrum palmae Cavalc. \& A. A. Silva [= Strigula multipunctata (R. Sant.) R. C. Harris].

= Porina sect. Sagediastrum Müll. Arg., Flora 66: 335 (1883); Vainio, Ann. Acad. Sci. Fenn., Ser. A, 15 (1921); Santesson, Symb. Bot. Upsal. 12(1): 202 (1952). Sectional type. Porina phyllogena Müll. Arg. [三 Strigula phyllogena (Müll. Arg.) R. C. Harris].

Lichenized on leaves or more rarely on bark and rock in terrestrial, lowland to montane, tropical (to subtropical) habitats. Thallus ecorticate, grey-green to grey, supracuticular. Photobiont Phycopeltis. Sexual morph: Ascomata perithecia, erumpent to prominent, black or covered by thallus layer, wart-shaped to conical, carbonaceous, ostiolate. Involucrellum present, carbonized. Excipulum 
prosoplectenchymatous, dark brown to brown-black. Hamathecium comprising 0.5-0.7 $\mu \mathrm{m}$ wide paraphyses, hyaline, flexuose, unbranched. Asci 8-spored, bitunicate, fissitunicate, cylindrical, shortly pedicellate, with narrow ocular chamber, non-amyloid. Ascospores irregularly arranged to biseriate, fusiform to ellipsoid, hyaline, 1-septate, with thin eusepta and rectangular lumina, smooth-walled, slightly constricted at the septa. Asexual morph: Pycnidia common, erumpent, visible as black dots, often whole thalli only producing pycnidia. Conidia acrogenous, either macro- or microconidia; macroconidia 1-septate, ellipsoid to bacillar, with gelatinous appendages, hyaline; microconidia aseptate, ellipsoid to fusiform, small, hyaline.

Chemistry: No secondary substances known.

Type. Phylloporis phyllogena (Müll. Arg.) Clem., Gen. Fung.: 173 (1909).

Notes: This genus has long been recognized as a separate group within Strigula sensu lato (Clements 1909; Vězda 1984) and has even been treated under Porina instead of Strigula (Santesson 1952). Its inclusion in Strigula based on internal anatomy and ascus type (e.g. Harris 1995; Lücking 2008) expresses close phylogenetic relationship, but a schematic broad genus concept, based on shared anatomical features, is not warranted, as shown in numerous other fungal families where genera agree in ascoma anatomy but differ in thallus morphology (e.g. Parmeliaceae). Phylloporis is a basally diverging clade among the foliicolous clades of Strigula sensu lato (Jiang et al. 2020b), indicating that its supracuticular growth may be a plesiomorphy shared with Flavobathelium and Phyllobathelium and the subcuticular growth of all other clades evolved as a single synapomorphy.

Phylloporis currently includes seven foliicolous species (Jiang et al. 2020b). Here, we also accept two at least partly non-foliicolous species in this genus (see new combinations proposed below). One of these, $P$. cinefaciens, is chiefly foliicolous but also rarely found on smooth bark, whereas the other, $P$. hypothallina, is thus far only known from the corticolous type material. Both may be distinguished from Dichoporis by the very thin thallus featuring a Phycopeltislike photobiont (see also above).

\section{New combinations in Phylloporis:}

Phylloporis cinefaciens (Nyl.) S.H. Jiang, Lücking \& Sérus. comb. nov.

MycoBank number: MB 836708; Index Fungorum number: IF 836708; Facesoffungi number: FoF 08883.

Bas.: Verrucaria cinefaciens Nyl., Ann. Sci. Nat., Bot., Sér. 5(7): 180 (1873); Arthopyrenia cinefaciens (Nyl.) Zahlbr., Cat. Lich. Univers. 1: 320 (1921); Strigula cinefaciens (Nyl.) R.C. Harris, More Florida Lichens: 155 (1995).

$=$ Porina multipunctata G. Merr. ex R. Sant., Symb. Bot. Upsal. 12(1): 216 (1952); Phylloporina multipunctata (G. Merr. ex R. Sant.) Szatala, Ann. Mus. Natn. Hung., N.S. 7:
21 (1956); Phylloporis multipunctata (G. Merr. ex R. Sant.) Vězda, Folia Geobot. Phytotax. 19: 183 (1984); Strigula multipunctata (G. Merr. ex R. Sant.) R.C. Harris, More Florida Lichens: 158 (1995).

Notes: This species agrees with the foliicolous Phylloporis austropunctata (P.M. McCarthy) S.H. Jiang, Lücking \& J.C. Wei and P. multipunctata (G. Merr. ex R. Sant.) Vězda in the thallus featuring numerous black dots. Apart from the corticolous growth, it is in fact identical to the latter, with ascospores $14-15 \times 4-5 \mu \mathrm{m}$ large and breaking into part spores outside the asci; the ascospore size range for $P$. multipunctata was given as $12-16 \times 3.5-4.5 \mu \mathrm{m}$ (Lücking 2008; McCarthy 2009). We therefore synonymize the latter with $P$. cinefaciens.

Phylloporis hypothallina (R.C. Harris) S.H. Jiang, Lücking \& Sérus. comb. nov.

MycoBank number: MB 836709; Index Fungorum number: IF 836709; Facesoffungi number: FoF 08884.

Bas.: Strigula hypothallina R.C. Harris, More Florida Lichens: 149 (1995).

Notes: This corticolous species is also placed in Phylloporis, rather than Dichoporis, based on its thallus anatomy.

Puiggariella Speg., Anal. Soc. Cient. Argentina 12: 99 (1881); Jiang et al., Fung. Div. 102: 280.

MycoBank number: MB 4546; Index Fungorum number: IF 4546; Facesoffungi number: FoF 08885; four morphologically delimited species (Jiang et al. 2020b); molecular data available for two species (Jiang et al. 2020b).

= Amoebomyces Bat. \& H. Maia, Atas Inst. Micol. Univ. Pernambuco 2: 353 (1965); Lücking et al., Lichenologist 30: 135 (1998). Type species: Amoebomyces pseudolmediae Bat. $\&$ H. Maia [= Strigula nemathora Mont.].

Lichenized on leaves in terrestrial, lowland to montane, tropical habitats. Thallus (pseudo-)corticate, light greygreen to whitish green, subcuticular, typically rugoseplicate and with numerous small, white papillae. Photobiont Cephaleuros. Sexual morph: Ascomata perithecia, erumpent to prominent, pale, usually covered by thallus layer, wart-shaped, non-carbonaceous, ostiolate. Involucrellum present, pale to brownish. Excipulum prosoplectenchymatous, pale to brownish. Hamathecium comprising 0.5-0.7 $\mu \mathrm{m}$ wide paraphyses, hyaline, flexuose, unbranched or very rarely branched and anastomosing. Asci 8 -spored, bitunicate, fissitunicate, narrowly obclavate, shortly pedicellate, with narrow ocular chamber, non-amyloid. Ascospores irregularly arranged to biseriate, fusiform, hyaline, 1-septate, with thin eusepta and rectangular lumina, smooth-walled, constricted at the septa. Asexual morph: Pycnidia infrequent, immersed, visible as dark dots. Conidia acrogenous, either macro- or microconidia; macroconidia 1-septate, 
bacillar, with gelatinous appendages, hyaline; microconidia usually aseptate, ellipsoid to fusiform, small, hyaline.

Chemistry: No secondary substances known.

Type species: Puiggariella apiahyna Speg. [= Puiggariella nemathora (Mont.) S.H. Jiang, Lücking \& J.C.Wei in; Jiang et al., Fungal Div. 102: 282.

Notes: The only species previously recognized in this group by Santesson (1952) and subsequent workers, Strigula nemathora, was long considered unique due to its pale, non-carbonized perithecia, in combination with its thallus appearing folded and featuring numerous small, white papillae. Phylogenetically, this taxon not only forms a separate clade, but the available data also indicate that Puiggariella nemathora is a collective species, including several related lineages differing largely in their morphology (Jiang et al. 2020b). Currently, three species are accepted in the genus (Jiang et al. 2020b).

\section{New combinations in Puiggariella:}

Puiggariella hypothelia (P.M. McCarthy) S.H. Jiang, Lücking \& Sérus. comb. nov.

MycoBank number: MB 836710; Index Fungorum number: IF 836710; Facesoffungi number: FoF 08886.

Bas.: Strigula hypothelia Nyl., Bull. Soc. Linn. Normandie, Sér. 2(2): 520 (1868); S. nemathora var. hypothelia (Nyl.) R. Sant., Symb. Bot. Upsal. 12(1): 156 (1952); S. nemathora f. hypothelia (Nyl.) Lücking, Fl. Neotrop., Monogr. 103: 248 (2008).

Raciborskiella Höhnel, Sitz.ber. Math.-Nat. Kl. Akad. Wiss. Wien, Ser. 1, 118: 1176 (1909); Santesson, Symb. Bot. Upsal. 12(1): 194 (1952); Jiang et al., Fungal Div. 102: 278.

MycoBank number: MB 4636; Index Fungorum number: IF 4636; Facesoffungi number: FoF 08887; two morphologically and phylogenetically delimited species (Jiang et al. 2020b).

Lichenized on the underside of leaves in terrestrial, lowland to montane, tropical habitats. Thallus (pseudo-) corticate, greenish to bluish grey, subcuticular. Photobiont Cephaleuros. Sexual morph: Ascomata perithecia, prominent, black, conical, carbonaceous, ostiolate. Involucrellum present, carbonized. Excipulum prosoplectenchymatous, dark brown to brown-black. Hamathecium comprising 0.5-0.7 $\mu \mathrm{m}$ wide paraphyses, hyaline, flexuose, unbranched or very rarely branched and anastomosing. Asci 8 -spored but appearing 9-16-spored due to ascospores breaking in halves within the asci, bitunicate, fissitunicate, cylindrical to narrowly obclavate, shortly pedicellate, with narrow ocular chamber, non-amyloid. Ascospores irregularly arranged to biseriate, fusiform, hyaline, 1-septate, with thin eusepta and rectangular lumina, smooth-walled, strongly constricted and breaking apart at the septa, comparatively large (over $30 \mu \mathrm{m}$ and up to $70 \mu \mathrm{m}$ long). Asexual morph: Pycnidia common, erumpent, visible as black dots. Conidia acrogenous, either macro- or microconidia; macroconidia 1-septate, bacillar, with gelatinous appendages, hyaline; microconidia usually aseptate, ellipsoid to fusiform, small, hyaline.

Chemistry: No secondary substances known.

Type species: Raciborskiella talaumae (Racib.) Höhn., Sber. Akad. Wiss. Wien, Math.-naturw. Kl., Abt. 1 118: 1176 (1909).

Notes: This genus was kept separate by Santesson (1952), on account of the hypophyllous growth and the branched and anastomosing paraphyses particularly in Raciborskiella janeirensis. However, molecular data demonstrate that $R$. prasina, which differs considerably from $R$. janeirensis in morphology and anatomy, is unrelated to the latter and belongs in the genus currently recognized as Strigula sensu stricto above. As a result, the most distinctive character of Raciborskiella are the unusually large ascospores, up to three to four times longer that in species of Strigula sensu stricto.

Santesson (1952) included Clypeolum talaumae Racib. and Melanopsamma areolatum Rehm in the synonymy of Raciborskiella janeirensis, in spite of the reportedly smaller ascospores of the former. Revision of type material and specimens with molecular data showed that indeed two species with differently sized ascospores are involved, the one with smaller ascospores represented by the eastern paleotropical C. talaumae, which was therefore reinstated (Jiang et al. 2020b). However, the Brazilian type of M. areolatum has mostly immature and in part larger ascospores, indicating its conspecificity with $R$. janeirensis, which appears to be a neotropical species. Thus, currently two species are recognized in this genus.

The name 'Raciborskiella Speg.' (MycoBank: MB 4637), a presumed illegitimate later homonym of Raciborskiella Höhn., does not exist. When Spegazzini (1919) made the combination $R$. montana (Racib.) Speg., he did not describe a new genus, so his use of the name must refer to von Höhnel's (1909c) genus. This non-lichenized fungus is currently treated as Trichopeltella montana (Racib.) Höhn. (Hyde et al. in Hyde et al. 2013; Brefeldiellaceae; Wu et al. 2014). von Höhnel (1909a) also recombined Micropeltis orbicularis Cooke into Raciborskiella, as $R$. orbicularis (Cooke) Höhn.; this name is a synonym of Strigula nitidula (Santesson 1952). Raciborskiella parva L. Xavier is a synonym of Racoplaca subtilissima (see below), R. zollerniae Bat. \& J.A. Lima [nom. inval.] is the same as $S$. microspora Lücking (Lücking et al. 1998), and $R$. minor Vězda is currently treated in the genus Strigula (Roux and Sérusiaux 2004).

Racoplaca Fée, Essai Crypt Écorc. 1: LVIII, XCIV, XCIX (1825); Jiang et al., Fung. Div. 102: 285.

MycoBank number: MB 4640; Index Fungorum number: IF 4640; Facesoffungi number: FoF 08888; five 
morphologically delimited species (Jiang et al. 2020b); molecular data available for two species (Jiang et al. 2020b).

$=$ Heterodothis Syd. in Sydow \& Sydow, Philip. J. Sci. Bot. 9: 170 (1914). Type species: Heterodothis leptotheca Syd. [= Strigula maculata (Cooke \& Massee) R. Sant.].

Lichenized on leaves in terrestrial, lowland to montane, tropical habitats. Thallus (pseudo-)corticate, olive-brown to dark (olive-)green, usually with metallic glance, subcuticular and sometimes damaging the supporting leaf, laciniate, with a thin black, continuous or interrupted line along the margins of the laciniae. Photobiont Cephaleuros. Sexual morph: Ascomata perithecia, prominent, black or covered by thin thallus layer, wart-shaped or mostly conical, carbonaceous, ostiolate. Involucrellum present, carbonized. Excipulum prosoplectenchymatous, dark brown to brown-black. Hamathecium comprising $0.5-0.7 \mu \mathrm{m}$ wide paraphyses, hyaline, flexuose, unbranched or very rarely branched and anastomosing. Asci 8-spored, bitunicate, fissitunicate, cylindrical to narrowly obclavate, shortly pedicellate, with narrow ocular chamber, non-amyloid. Ascospores irregularly arranged to biseriate, ellipsoid to fusiform, hyaline, 1-septate, with thin eusepta and rectangular lumina, smooth-walled, at least slightly constricted at the septa. Asexual morph: Pycnidia common, erumpent, visible as black dots. Conidia acrogenous, either macro- or microconidia; macroconidia aseptate or 1-septate, bacillar, with gelatinous appendages, hyaline; microconidia aseptate, ellipsoid to fusiform, small, hyaline.

Chemistry: No secondary substances known.

Type species: Racoplaca subtilissima Fée, Essai Crypt. Exot. (Paris): xciv, xcix (1825).

Notes: This newly recognized genus includes some of the prettiest foliicolous lichens, characterized by narrowly laciniate thalli bordered by a thin black line. It appears to be an early diverging clade within Strigula sensu lato but has no supported relationship with any of the other newly recognized genera (Jiang et al. 2020b). Five species are currently assigned to this genus (Jiang et al. 2020b).

\section{New combinations in Racoplaca:}

Racoplaca melanobapha (Kremp.) S.H. Jiang, Lücking \& J.C. Wei comb. nov.

MycoBank number: MB 836395; Index Fungorum number: IF 836395; Facesoffungi number: FoF 09211.

Bas.: Verrucaria melanobapha Kremp., Lich. Foliic. Leg. Beccari: 18 (1874); Strigula melanobapha (Kremp.) R. Sant., Symb. Bot. Upsal. 12(1): 188 (1952).

Notes: This combination was published invalidly in Jiang et al. (2020b) as the basionym was not indicated.

Serusiauxiella S.H. Jiang, Lücking \& J.C.Wei in Jiang et al., Fung. Div. 102: 274.
MycoBank number: MB 833565; Index Fungorum number: IF 833565; Facesoffungi number: FoF 08889; three morphologically and phylogenetically delimited species (Jiang et al. 2020b).

Lichenized on leaves in terrestrial, lowland to montane, tropical to subtropical habitats. Thallus (pseudo-)corticate, light grey-green, subcuticular. Photobiont Trentepohlia. Sexual morph: Ascomata perithecia, immersed-erumpent, black but mostly covered by thallus layer, lens-shaped to wart-shaped, carbonaceous, ostiolate. Involucrellum present, carbonized. Excipulum prosoplectenchymatous, pale. Hamathecium comprising 0.5-0.7 $\mu \mathrm{m}$ wide paraphyses, hyaline, flexuose, unbranched or very rarely branched and anastomosing. Asci 8-spored, bitunicate, fissitunicate, cylindrical to narrowly obclavate, shortly pedicellate, with narrow ocular chamber, non-amyloid. Ascospores irregularly arranged to biseriate, fusiform, hyaline, 1-septate, with thin eusepta and rectangular lumina, smooth-walled, constricted at the septa. Asexual morph: Pycnidia common, immersederumpent, visible as black dots. Conidia acrogenous, either macro- or microconidia; macroconidia 1-septate, bacillar, with gelatinous appendages becoming extremely long in squash mounts (as if suspended on gelatinous threads), hyaline; microconidia aseptate, ellipsoid to fusiform, small, hyaline.

Chemistry: No secondary substances known.

Type species: Serusiauxiella filifera S.H. Jiang, Lücking \& J.C. Wei in Jiang et al., Fung. Div. 102: 275.

Notes: This entirely novel genus was descovered in eastern Asia, with three species known thus far from China (Jiang et al. 2020b). It most closely resembles Strigula sensu stricto and differs mainly in the highly unusual macroconidial appendages. The known species otherwise have a morphology akin towards $S$. microspora.

Swinscowia S.H. Jiang, Lücking \& Sérus. gen. nov.

MycoBank number: MB 836396; Index Fungorum number: IF 836396; Facesoffungi number: FoF 08890; 34 morphologically delimited species (this paper); molecular data available for one species (Nelsen et al. 2011a).

Lichenized on bark and rocks in terrestrial, temperatesubalpine to tropical habitats. Thallus usually ecorticate, whitish to brownish. Photobiont Trentepohlia. Sexual morph: Ascomata perithecia, usually dispersed but often dense, immersed-erumpent to prominent, usually black or covered by thallus layer, rarely pale, lens-shaped to wartshaped, usually carbonaceous, rarely with pale to brownish walls, ostiolate. Involucrellum usually present and carbonized, rarely reduced or pale. Excipulum prosoplectenchymatous, pale to brown or blackish. Hamathecium comprising $0.5-0.7 \mu \mathrm{m}$ wide paraphyses, hyaline, flexuose, typically 
branched and sometimes somewhat anastomosing. Asci usually 8 -spored, rarely as little as 2 -spored, bitunicate, fissitunicate, cylindrical to narrowly obclavate, shortly pedicellate, with narrow, non-amyloid ocular chamber. Ascospores irregularly arranged to uni- or biseriate, fusiform to ellipsoid or bacillar, hyaline, 1-septate to mostly 3-7-septate to (sub-)muriform, with thin eusepta and rectangular lumina, smooth-walled, often constricted (and sometimes breaking apart) at the septa. Asexual morph: Pycnidia common, immersed to erumpent, usually visible as black dots. Conidia typically acrogenous, either macro- or microconidia; macroconidia (1-)3-7(-11)-septate to more rarely submuriform, oblong-ellipsoid to bacillar, with variably shaped gelatinous appendages, hyaline; microconidia aseptate, ellipsoid to fusiform, small, hyaline.

Chemistry: No secondary substances known.

Type species: Swinscowia jamesii (Swinscow) S.H. Jiang, Lücking \& Sérus. (see below).

Notes: This new genus, named after the British lichenologist Thomas Douglas Victor Swinscow, who first described the type species, Geissleria jamesii (Swinscow 1967), is here introduced for non-foliicolous species centered around Strigula jamesii. Since the latter is the only species sequenced so far, it is unclear whether the taxa included here all form a monophyletic group. Given the phylogenetic and morpho-anatomical differentiation in the foliicolous lineages, likely more than one genus may be recognized for the non-foliicolous species here placed in Swinscowia. In their treatment of European taxa, Roux and Sérusiaux (2004) already arranged the non-foliicolous species into two major groups, their Strigula affinis-tagananae-calcarea group ("ensemble 2") corresponding to Swinscowia.

\section{New combinations in Swinscowia:}

Swinscowia affinis (A. Massal.) S.H. Jiang, Lücking \& Sérus. comb. nov.

MycoBank number: MB 836397; Index Fungorum number: IF 836397; Facesoffungi number: FoF 08891.

Bas.: Sagedia affinis A. Massal., Memor. Lich.: 138 (1853); Spermatodium affine (A. Massal.) Trevis., Conspect. Verruc.: 10 (1860); Segestria affinis (A. Massal.) Zwackh, Flora 45: 550 (1862); Verrucaria affinis (A. Massal.) Cromb., J. Bot., Lond. 14: 360 (1876); Porina affinis (A. Massal.) Zahlbr., Öst. Bot. Z. 51: 277 (1901); Arthopyrenia affinis (A. Massal.) R.C. Harris, Michigan Bot. 12: 10 (1973); Strigula affinis (A. Massal.) R.C. Harris in Hawksworth et al., Lichenologist 12: 107 (1980).

= Pyrenula minuta Nägeli, in Hepp, Flecht. Europ.: no. 458 (1857); Sagedia affinis var. sporophorum Wartm. \& B. Schenk, Schweiz. Kryptogam.: no. 673.

Notes: The name Sagedia affinis var. sporophorum was published in Wartmann \& Schenk's Exsiccate Schweizerische Kryptogamen, listing Pyrenula minuta based on
Hepp's Flechten Europas no. 458 as synonym. The variety name is thus validly published, as it formally constitutes a replacement name at species level, based on the same type.

Swinscowia albicascens (Nyl.) S.H. Jiang, Lücking \& Sérus. comb. nov.

MycoBank number: MB 836398; Index Fungorum number: IF 836398; Facesoffungi number: FoF 08892.

Bas.: Verrucaria albicascens Nyl., Lich. Nov. Zeland. (Paris): 129 (1888); Porina albicascens (Nyl.) Müll. Arg., Bull. Soc. R. Bot. Belg. 31(2): 38 (1892); Segestria albicascens (Nyl.) Hellb., Bih. K. Svenska Vetensk Akad. Handl., Afd. 3, 21(13): 132 (1896); Strigula albicascens (Nyl.) R.C. Harris, More Florida Lichens: 154 (1995).

= Verrucaria indutula Nyl., Lich. Nov. Zeland.: 129 (1888); Porina indutula (Nyl.) Müll. Arg., Bull. Herb. Boissier 2(1): 92 (1894); Segestria indutula (Nyl.) Hellb., Bih. K. Svenska Vetensk. Akad. Handl., Afd. 3, 21(13): 133 (1896); Strigula indutula (Nyl.) R.C. Harris, More Florida Lichens: 157 (1995).

Notes: See discussion under Swincsowia glabra.

Swinscowia albolinita (Nyl.) S.H. Jiang, Lücking \& Sérus. comb. nov.

MycoBank number: MB 836399; Index Fungorum number: IF 836399; Facesoffungi number: FoF 08893.

Bas.: Verrucaria albolinita Nyl., Lich. Ins. Guin.: 38 (1889); Microglaena albolinita (Nyl.) Zahlbr., Cat. Lich. Univers. 1: 188 (1921); Phyllobathelium albolinitum (Nyl.) H. Mayrhofer, Biblioth. Lichenol. 26: 79 (1987); Strigula albolinita (Nyl.) R.C. Harris [as 'albolinitum'], More Florida Lichens: 155 (1995).

Swinscowia alpestris (Vězda) S.H. Jiang, Lücking \& Sérus. comb. nov.

MycoBank number: MB 836400; Index Fungorum number: IF 836400; Facesoffungi number: FoF 08894.

Bas.: Porina faginea var. alpestris Vězda, Acta Mus. Silesiae, Ser. A, 10: 5 (1961); Arthopyrenia faginea var. alpestris (Vězda) Swinscow, Lichenologist 3: 73 (1965); Strigula stigmatella var. alpestris (Vězda) Coppins in Hawksworth et al., Lichenologist 12: 107 (1980); Strigula alpestris (Vězda) Hafellner, Mitt. Naturw. Ver. Steierm. 132: 131 (2002).

Notes: We follow here Hafellner (2002) in separating this taxon from Swinscowia stigmatella (see also discussion under S. glabra), on account of the different habitat and substrate ecology and the longer asci. McCarthy \& Malcolm (1996) reported Strigula stigmatella var. alpestris as silicicolous from Australia, but later this was apparently reidentified as Strigula decipiens. 
Swinscowia amphora (Aptroot \& Lücking) S.H. Jiang, Lücking \& Sérus. comb. nov.

MycoBank number: MB 836401; Index Fungorum number: IF 836401; Facesoffungi number: FoF 08895.

Bas.: Strigula amphora Aptroot \& Lücking in Aptroot et al., Biblioth. Lichenol. 97: 130 (2008).

Swinscowia aquatica (H. Harada) S.H. Jiang, Lücking \& Sérus. comb. nov.

MycoBank number: MB 836402; Index Fungorum number: IF 836402; Facesoffungi number: FoF 08896.

Bas.: Strigula aquatica H. Harada, Nova Hedwigia 66: 420 (1998).

Swinscowia australiensis (P.M. McCarthy) S.H. Jiang, Lücking \& Sérus. comb. nov.

MycoBank number: MB 836403; Index Fungorum number: IF 836403; Facesoffungi number: FoF 08897.

Bas.: Strigula australiensis P.M. McCarthy, Muelleria 8: 323 (1995).

Swinscowia bahamensis (Riddle) S.H. Jiang, Lücking \& Sérus. comb. nov.

MycoBank number: MB 836404; Index Fungorum number: IF 836404; Facesoffungi number: FoF 08898.

Bas.: Lithothelium bahamense Riddle in Britton \& Millspaugh, The Bahama Flora: 532 (1920); Strigula bahamensis (Riddle) R.C. Harris, More Florida Lichens: 155 (1995)

Swinscowia bispora (Aptroot \& K.H. Moon) S.H. Jiang, Lücking \& Sérus. comb. nov.

MycoBank number: MB 836405; Index Fungorum number: IF 836405; Facesoffungi number: FoF 08899.

Bas.: Strigula bispora Aptroot \& K.H. Moon, Herzogia 27: 354 (2014).

Swinscowia calcarea (Bricaud \& Cl. Roux) S.H. Jiang, Lücking \& Sérus. comb. nov.

MycoBank number: MB 836406; Index Fungorum number: IF 836406; Facesoffungi number: FoF 08900.

Bas.: Strigula calcarea Bricaud \& Cl. Roux, Bull. Soc. Linn. Provence 42: 131 (1991).

Swinscowia cavicola (Cl. Roux \& Bricaud) S.H. Jiang, Lücking \& Sérus. comb. nov.

MycoBank number: MB 836407; Index Fungorum number: IF 836407; Facesoffungi number: FoF 08901.

Bas.: Strigula cavicola Cl. Roux \& Bricaud in Roux \& Sérusiaux, Biblioth. Lichenol. 90: 87 (2004).

Swinscowia confusa (A. Massal.) S.H. Jiang, Lücking \& Sérus. comb. nov.
MycoBank number: MB 836408; Index Fungorum number: IF 836408; Facesoffungi number: FoF 08902.

Bas.: Strigula confusa Fryday, Coppins \& Common in Fryday \& Coppins, Lichenologist 36: 92 (2004).

Swinscowia decipiens (Malme) S.H. Jiang, Lücking \& Sérus. comb. nov.

MycoBank number: MB 836409; Index Fungorum number: IF 836409; Facesoffungi number: FoF 08903.

Bas.: Porina decipiens Malme, Ark. Bot. 23A(1): 26 (1929); Strigula decipiens (Malme) P.M. McCarthy, Lichenologist 29: 513 (1997).

Swinscowia divisa (P.M. McCarthy) S.H. Jiang, Lücking \& Sérus. comb. et stat. nov.

MycoBank number: MB 836410; Index Fungorum number: IF 836410; Facesoffungi number: FoF 08904.

Bas.: Strigula decipiens var. divisa P.M. McCarthy, Lichenologist 32: 34 (2000).

Notes: McCarthy (2000) considered this taxon a subspecies of $S$. decipiens, stating that the only difference were occasional longitudinal septa in otherwise similarly sized ascospores. However, not only is ascospore septation an important taxonomic criterion in this genus, but the ascospores of $S$. decipiens are also distinctly longer and narrower (see key below). As the few other known species with submuriform ascospores are different in ascospore size, morphology and/or substrate ecology, the recognition of $S$. divisa as a separate species is justified.

Swinscowia endolithea (Cl. Roux \& Bricaud) S.H. Jiang, Lücking \& Sérus. comb. nov.

MycoBank number: MB 836411; Index Fungorum number: IF 836411; Facesoffungi number: FoF 08905.

Bas.: Strigula endolithea $\mathrm{Cl}$. Roux \& Bricaud in Roux \& Sérusiaux, Biblioth. Lichenol. 90: 88 (2004); S. endolithea $\mathrm{Cl}$. Roux \& Bricaud, Bull. Soc. Linn. Provence 44: 129 (1993) [nom. inval.; ICN Art. 36.1].

Notes: Tretiach (2006) provided a detailed description of the perithecia, asci, and ascospores of this species, which originally was described based on pycnidia and macroconidia only (Roux and Sérusiaux 2004).

Swinscowia fracticonidia (R.C. Harris) S.H. Jiang, Lücking \& Sérus. comb. nov.

MycoBank number: MB 836412; Index Fungorum number: IF 836412; Facesoffungi number: FoF 08906.

Bas.: Strigula fracticonidia R.C. Harris, More Florida Lichens: 156 (1995).

Swinscowia glabra (A. Massal.) S.H. Jiang, Lücking \& Sérus. comb. nov. 
MycoBank number: MB 836413; Index Fungorum number: IF 836413; Facesoffungi number: FoF 08907.

Bas.: Sagedia glabra A. Massal., Ric. Auton. Lich. Crost.: 161 (1852); Spermatodium glabrum (A. Massal.) Trevis., Conspect. Verruc.: 11 (1860); Porina glabra (A. Massal.) Zahlbr., Cat. Lich. Univers. 1: 382 (1922); Arthopyrenia glabra (A. Massal.) J. Nowak \& Tobol., Flora Polska: 1117 (1975); Strigula glabra (A. Massal.) V. Wirth, Flechtenflora: 531 (1980).

= Pyrenula netrospora Nägeli, Flecht. Europ.: no. 461 (1857); Spermatodium netrosporum (Nägeli) Trevis., Conspect. Verruc.: 11 (1860); Sagedia netrospora (Nägeli) Anzi, Comm. Soc. Crittog. Ital. 1(3): 162 (1862); Arthopyrenia netrospora (Nägeli) Müll. Arg., Mém. Soc. Phys. Hist. Nat. Genève 16(2): 429 (1862); Verrucaria netrospora (Nägeli) Nyl., Jahresber. St. Gall. Naturw. Ges.: 504 (1882); Porina netrospora (Nägeli) Lettau, Hedwigia 52: 104 (1912).

= Sagedia candida Anzi, Comm. Soc. Crittog. Ital. 1(3): 162 (1862).

Notes: Swinscowia glabra forms a species complex with S. albicascens and S. stigmatella, all three growing on bark and producing chiefly 7 -septate ascospores with overlapping size ranges. There seem to be no discernable differences between the Australasian S. albicascens and the European $S$. glabra. Roux and Sérusiaux (2004) do not discuss S. albicascens in the context of S. glabra, and McCarthy (2009) does not mention $S$. glabra in the discussion of S. albicascens, although he did synonymize Verrucaria indutula with the latter. We keep S. glabra and S. albicascens separate for the time being, as macroconidia have not yet been reported for the latter and might turn out to provide a diagnostic difference, although we consider this unlikely. Roux \& Sérusiaux (2004) discuss the similarity between $S$. glabra and S. stigmatella and keep both separate on account of slightly different ascospore length (22-26 $\mu \mathrm{m}$ in S. glabra vs. 26-36 $\mu \mathrm{m}$ in S. stigmatella) and differences in substrate (smooth bark in S. glabra and rough bark in S. stigmatella). Harris (1995) gives ascospore length for North American material of S. stigmatella as 24-42 $\mu \mathrm{m}$, whereas McCarthy (2009) cites 16-32 $\mu \mathrm{m}$ for Australasian S. albicascens. McCarthy (1993) reported $S$. stigmatella as saxicolous from Australia but later corrected these records to $S$. decipiens (McCarthy 2009). Thus, the taxonomic treatments for corticolous taxa with 7-septate ascospores are inconsistent between North America, Europe, and Australasia, using one name in North America (stigmatella), two in Europe (glabra, stigmatella), and one but a different name in Australasia (albicascens). This problem is aggravated by the notion that the type of Lichen stigmatellus Ach. grows on smooth bark and apparently fits the concept of S. glabra by Roux \& Sérusiaux (2004). This requires a critical revision of the available material and a reassessment of the types to properly name the taxa distinguished in this complex.
Swinscowia griseonitens (R.C. Harris) S.H. Jiang, Lücking \& Sérus. comb. nov.

MycoBank number: MB 836414; Index Fungorum number: IF 836414; Facesoffungi number: FoF 08908.

Bas.: Strigula griseonitens R.C. Harris, More Florida Lichens: 156 (1995).

Swinscowia jamesii (Swinscow) S.H. Jiang, Lücking \& Sérus. comb. nov.

MycoBank number: MB 836415; Index Fungorum number: IF 836415; Facesoffungi number: FoF 08909.

Bas.: Geisleria jamesii Swinscow, Lichenologist 3: 420 (1967); Strigula jamesii (Swinscow) R.C. Harris in Hawksworth et al., Lichenologist 12(1): 107 (1980).

Swinscowia johnsonii (P.M. McCarthy) S.H. Jiang, Lücking \& Sérus. comb. nov.

MycoBank number: MB 836416; Index Fungorum number: IF 836416; Facesoffungi number: FoF 08910.

Bas.: Strigula johnsonii P.M. McCarthy, Muelleria 8: 324 (1995).

Swinscowia laceribracae (R.C. Harris) S.H. Jiang, Lücking \& Sérus. comb. nov.

MycoBank number: MB 836417; Index Fungorum number: IF 836417; Facesoffungi number: FoF 08911.

Bas.: Strigula laceribracae R.C. Harris, More Florida Lichens: 158 (1995).

Swinscowia muriconidiata (Aptroot, L.I. Ferraro \& M. Cáceres) S.H. Jiang, Lücking \& Sérus. comb. nov.

MycoBank number: MB 836418; Index Fungorum number: IF 836418; Facesoffungi number: FoF 08912.

Bas.: Strigula muriconidiata Aptroot, L.I. Ferraro \& M. Cáceres, Lichenologist 46: 99 (2014).

Notes: This taxon may be the macroconidial stage of $S$. obtecta.

Swinscowia muriformis (Aptroot \& Diederich) S.H. Jiang, Lücking \& Sérus. comb. nov.

MycoBank number: MB 836419; Index Fungorum number: IF 836419; Facesoffungi number: FoF 08913.

Bas.: Strigula muriformis Aptroot \& Diederich in Aptroot et al., Biblioth. Lichenol. 64: 188 (1997).

Swinscowia muscicola (F. Berger, Coppins, Cl. Roux \& Sérus.) S.H. Jiang, Lücking \& Sérus. comb. nov.

MycoBank number: MB 836420; Index Fungorum number: IF 836420; Facesoffungi number: FoF 08914.

Bas.: Strigula muscicola F. Berger, Coppins, Cl. Roux \& Sérus. in Sérusiaux et al., Lichenologist 37: 481 (2005). 
Swinscowia obtecta (Vain.) S.H. Jiang, Lücking \& Sérus. comb. nov.

MycoBank number: MB 836421; Index Fungorum number: IF 836421; Facesoffungi number: FoF 08915.

Bas.: Thelenella obtecta Vain., Acta Soc. Fauna Flora Fenn. 7(2): 218 (1890); Polyblastiopsis obtecta (Vain.) Zahlbr., Cat. Lich. Univers. 1: 351 (1922); Phyllobathelium obtectum (Vain.) H. Mayrhofer, Biblioth. Lichenol. 26: 82 (1987); Strigula obtecta (Vain.) R.C. Harris, More Florida Lichens: 158 (1995).

Swinscowia pallida (Aptroot \& K.H. Moon) S.H. Jiang, Lücking \& Sérus. comb. nov.

MycoBank number: MB 836422; Index Fungorum number: IF 836422; Facesoffungi number: FoF 08916.

Bas.: Strigula pallida Aptroot \& K.H. Moon in Moon \& Aptroot, Biblioth. Lichenol. 99: 308 (2009); Strigula pallidocarpa Aptroot \& K.H. Moon, Herzogia 27: 354 (2014) [nom. illeg., ICN Art. 52.1] [non Strigula pallida Kalchbr. in Stizenberger, Ber. Tät. St Gall. Naturw. Ges.: 218 (1891); nom. inval., ICN Art. 38.1-3].

Notes: Aptroot and Moon (2014) provided a replacement name for their Strigula pallida, described five years prior (Moon and Aptroot 2009), under the impression that the name $S$. pallida had already been used for another species, namely S. pallida Kalchbr. in Stizenberger (1891). However, as already pointed out by Santesson (1952), that name is invalid, as it does not have a validating description [ICN Art. 38.3] and hence has no standing under the Code [ICN Art. 12.1]. Thus, the name $S$. pallida Aptroot \& K.H. Moon is legitimate, although it does not follow the recommendation of the Code to avoid giving a previously invalidly published name to a different taxon [ICN Rec. 38C.1].

Swinscowia porinoides (Canals, Boqueras \& Gómez-Bolea) S.H. Jiang, Lücking \& Sérus. comb. nov.

MycoBank number: MB 836423; Index Fungorum number: IF 836423; Facesoffungi number: FoF 08917.

Bas.: Strigula porinoides Canals, Boqueras \& GómezBolea, Mycotaxon 55: 391 (1995).

Swinscowia rhodinula (Zahlbr.) S.H. Jiang, Lücking \& Sérus. comb. nov.

MycoBank number: MB 836424; Index Fungorum number: IF 836424; Facesoffungi number: FoF 08918.

Bas.: Porina rhodinula Zahlbr., Denkschr. Akad. Wiss. Wien Math.-Naturwiss. Kl. 104: 254 (1941).; Strigula rhodinula (Zahlbr.) P.M. McCarthy, Australas. Lichenol. 78: 3 (2016).

Swinscowia rostrata (R.C. Harris \& Aptroot) S.H. Jiang, Lücking \& Sérus. comb. nov.
MycoBank number: MB 836425; Index Fungorum number: IF 836425; Facesoffungi number: FoF 08919.

Bas.: Strigula rostrata R.C. Harris \& Aptroot in Harris, More Florida Lichens: 159 (1995).

Swinscowia rupestris (P.M. McCarthy) S.H. Jiang, Lücking \& Sérus. comb. nov.

MycoBank number: MB 836426; Index Fungorum number: IF 836426; Facesoffungi number: FoF 08920.

Bas.: Strigula rupestris P.M. McCarthy, Lichenologist 29: 518 (1997).

Swinscowia stigmatella (Ach.) S.H. Jiang, Lücking \& Sérus. comb. nov.

MycoBank number: MB 836427; Index Fungorum number: IF 836427; Facesoffungi number: FoF 08921.

Bas.: Lichen stigmatellus Ach., Lich. Suec. Prodr.: 15 (1799); Verrucaria stigmatella (Ach.) Ach., Methodus, Sectio Prior: 117 (1803): Verrucaria punctiformis var. stigmatella (Ach.) Ficinus \& C. Schub., Fl. Dresden 2: 147 (1823); Arthopyrenia stigmatella (Ach.) A. Massal., Symmict. Lich.: 119 (1855); Leiophloea punctiformis var. stigmatella (Ach.) Trevis., Conspect. Verruc.: 9 (1860); Verrucaria epidermidis var. stigmatella (Ach.) Garov., Tentam. Dispos. Lich. Langob.: 85 (1865); Verrucaria epidermidis f. stigmatella (Ach.) Malbr., Bull. Soc. Amis Sci. Nat. Rouen, Sér. II, 5: 315 (1869); Arthopyrenia cinereopruinosa var. stigmatella (Ach.) Jatta, Syll. Lich. Ital.: 530 (1900); Didymella stigmatella (Ach.) Szatala in Degen, Flora Velebitica 3: 309 (1938); Strigula stigmatella (Ach.) R.C. Harris in Hawksworth et al., Lichenologist 12: 107 (1980).

= Porina faginea var. alpestris Vězda, Acta Mus. Silesiae, Ser. A 10: 5 (1961); Arthopyrenia faginea var. alpestris (Vězda) Swinscow, Lichenologist 3: 73 (1965); Strigula stigmatella var. alpestris (Vězda) Coppins in Hawksworth et al., Lichenologist 12: 107 (1980); Strigula alpestris (Vězda) Hafellner, Mitt. Naturw. Ver. Steierm. 132: 131 (2002).

MycoBank: MB 351488

Notes: See discussion under Swincsowia glabra.

Swinscowia submuriformis (R.C. Harris) S.H. Jiang, Lücking \& Sérus. comb. nov.

MycoBank number: MB 836428; Index Fungorum number: IF 836428; Facesoffungi number: FoF 08922.

Bas.: Arthopyrenia submuriformis R.C. Harris, Michigan Bot. 12: 15 (1973); Strigula submuriformis (R.C. Harris) R.C. Harris in Egan, Bryologist 90: 164 (1987).

Swinscowia tagananae (Harm.) S.H. Jiang, Lücking \& Sérus. comb. nov.

MycoBank number: MB 836429; Index Fungorum number: IF 836429; Facesoffungi number: FoF 08923. 
Bas.: Verrucaria tagananae Harm. in Pitard \& Harmand, Bull. Soc. Bot. Fr. 58(22): 68 (1911); Polyblastiopsis tagananae (Harm.) Zahlbr., Cat. Lich. Univers. 1: 352 (1922); Strigula tagananae (Harm.) R.C. Harris, More Florida Lichens: 160 (1995).

$=$ Strigula lateralis Aptroot \& van den Boom, Mycotaxon 56: 3 (1995).

MycoBank: MB 414225

Swinscowia thelopsidoides (Coppins, Cl. Roux \& Sérus.) S.H. Jiang, Lücking \& Sérus. comb. nov.

MycoBank number: MB 836430; Index Fungorum number: IF 836430; Facesoffungi number: FoF 08924.

Bas.: Strigula thelopsidoides Coppins, $\mathrm{Cl}$. Roux \& Sérus. in Roux \& Sérusiaux, Biblioth. Lichenol. 90: 90 (2004).

\section{Key to species of Swinscowia:}

1. Ascospores transversely 3-7(-9)-septate, very rarely few ascospores with some longitudinal septa, mostly less than $7 \mu \mathrm{m}$ broad; macroconidia transversely septate................................................. 2

1. Ascospores regularly submuriform to muriform (i.e. most or all ascospores with at least a few longitudinal septa); macroconidia transversely septate to muriform.............................................17

2. On bark.............................................. 3

2. On rock (or rarely mosses over rock).................9

3. Ascospores regularly 3-septate; macroconidia (where known) 13-18 $\mu \mathrm{m}$ long.............................. 4

3. Ascospores irregularly 3-7(-9)-septate to regularly 7 -septate, very rarely few ascospores with some longitudinal septa; macroconidia (where known) 18-30 $\mu \mathrm{m}$ long...................................... 7

4. Perithecial with carbonized involucrellum, black; pycnidia with macroconidia frequent; macroconidia 13-18 $\times 2.5-4 \mu \mathrm{m}$; chiefly Europe.........................5

4. Perithecial lacking or with non-carbonized involucrellum, pale to orange-brown; pycnidia with macroconidia unknown.....................................6

5. Ascospores $15-24 \times 4.5-6 \mu \mathrm{m} . . .$. .Swinscowia affinis

5. Ascospores $13-17 \times 3.5-5.5 \mu \mathrm{m}$...Swinscowia jamesii

6. Ascospores 17-22 $\times 6-8 \mu \mathrm{m}$; perithecia pale; Korea .................................Swinscowia pallida

6. Ascospores 10-14 $\times 2.5-3.5 \mu \mathrm{m}$; perithecia orangebrown; Europe........... Swinscowia thelopsidioides

7. Ascospores $25-42 \mu \mathrm{m}$ long, largely over $30 \mu \mathrm{m}$; typically on rough bark; subcosmopolitan.

Swinscowia stigmatella

7. Ascospores $16-30 \mu \mathrm{m}$ long; typically on smooth bark................................................ 8

8. Collected in Europe; macroconidia 18-28 $\times 3.5-4$ $\mu \mathrm{m}$ Swinscowia glabra
8. Collected in Australasia, including New Zealand; macroconidia unknown. Swinscowia albicascens

Notes: See discussion for the three species keyed out under couplets 7 and 8 under Swincsowia glabra

9. On calcareous rock (limestone) ....................10

9. On siliceous rock (granite) or over mosses...........14

10. Perithecial with carbonized involucrellum, black; extraEuropean...........................................11

10. Perithecial lacking involucrellum, pale; Europe

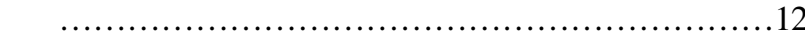

11. Perithecia with lateral ostioles, fused; ascospores irregularly 3-7-septate; Caribbean...Swinscowia bahamensis

11. Perithecia with apical ostioles, solitary; ascospores regularly 3-septate; New Zealand...Swinscowia rhodinula

12. Ascospores (5-)7-septate; macroconidia (3)4-7-septate, 20-30 $\mu \mathrm{m}$ long......... Swinscowia endolithea

12. Ascospores (where known) 3-septate; macroconidia 3(-4)-septate, 10-20 $\mu \mathrm{m}$ long.......................13

13. Macroconidia $15-20 \mu \mathrm{m}$ long...Swinscowia calcarea

13. Macroconidia 10-15 $\mu \mathrm{m}$ long...Swinscowia cavicola

Notes: Strigula cavicola is here keyed out together with S. calcarea following Roux and Sérusiaux (2004), who hypothesized a close relationship between these taxa. However, perithecia and ascospores are thus far unknown from $S$. cavicola

14. Ascospores 3-septate, 18-21 $\mu \mathrm{m}$ long; over mosses; Europe........................Swinscowia muscicola

14. Ascospores 7(-9)-septate, 25-42 $\mu \mathrm{m}$ long; on rock, rarely over mosses on rock..........................15

15. Over mosses on rock; involucrellum carbonized but developed only around ostiole...Swinscowia alpestris

15. Directly on rock; involucrellum carbonized and reaching down to substrate, or involucrellum pale to brownish.......................................... 16

16. Involucrellum carbonized, reaching down to substrate; pantropical....................Swinscowia decipiens

16. Involucrellum pale to brownish, developed only around ostiole; Japan....................Swinscowia aquatica

Notes: Swinscowia aquatica was considered by McCarthy (2001) to possibly represent a pale form of S. decipiens, but the structure of the involucrellum suggests a closer relationship with $S$. alpestris

17. On bark............................................ 18

17. On rock (or rarely mosses over rock) ...............27

18. Ascospores 20-33 × 6-10 $\mu \mathrm{m}$ long, submuriform with few longitudinal septa; macroconidia transversely septate to submuriform................................19

18. Ascospores $35-135 \times 8-48 \mu \mathrm{m}$ long, regularly muriform; macroconidia submuriform to muriform................................................23

19. Perithecial wall pale; North America................. Swinscowia griseonitens

20. Perithecial wall carbonized.........................20 
20. Pycnidia producing macroconidia rostrate; macroconidia submuriform; Madagascar.

.Swinscowia rostrata

21. Pycnidia producing macroconidia not rostrate; macroconidia transversely septate.........................21

21. Ostiole lateral; macroconidia 7-11-septate, 35-45 × 4-5 $\mu \mathrm{m}$; Europe, Australia........ Swinscowia tagananae

22. Ostiole apical; macroconidia 3-7-septate, 20-25 × 3-10 um............................................22

22. Macroconidia 3-septate, $15-20 \times 3-4 \mu \mathrm{m}$, about 5-6 times as long as broad, fragmenting into part spores; New Zealand.................Swinscowia fracticonidia

23. Macroconidia 7-septate, $20-25 \times 8-10 \mu \mathrm{m}$, about 2-3 times as long as broad, remaining intact; North America.......................Swinscowia submuriformis

23. Ascomata unknown; macroconidia regularly muriform, 90-105 × 30-35 $\mu \mathrm{m}$; South America.

Swinscowia muriconidiata

24. Ascomata present; macroconidia unknown........24

24. Ostiole lateral; ascospores 42-50 × 14-17 $\mu \mathrm{m}$, about 2.5-3.5 times as long as broad; Neotropics (Costa Rica).

Swinscowia amphora

25. Ostiole apical; ascospores variously sized but relatively narrower, about 3.5-4.5 times as long as broad...........................................25

25. Ascospores 115-135 × 38-48 $\mu \mathrm{m}, 2$ /ascus; Korea............................Swinscowia bispora

26. Ascospores 35-90 $\times 8-26 \mu \mathrm{m}, 8$ /ascus.................26

26. Ascospores $35-45 \times 8-10 \mu \mathrm{m}$; perithecial wall pale; North America............. Swinscowia laceribracae

27. Ascospores 60-90 × 18-26 $\mu \mathrm{m}$; perithecial wall carbonized but covered by thallus; Neotropics (Brazil)... ..Swinscowia obtecta

27. On calcareous rock (limestone) or mosses over limestone; Europe....................................28

28. On siliceous rock (granite); Africa, Australasia..............................................29

28. Directly on rock; ascospores submuriform, 20-33 $\times$ 5-10 $\mu \mathrm{m}$; macroconidia submuriform, 14-27 $\times 4-9$

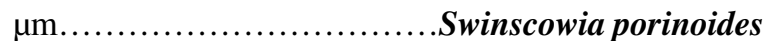

29. On mosses over rock; ascospores muriform, 35-60 $\times$ 7-12 $\mu \mathrm{m}$; macroconidia unknown.

Swinscowia confusa

29. Ascospores $16-36 \times 5.5-11.5 \mu \mathrm{m} \ldots \ldots \ldots \ldots \ldots \ldots . . \ldots 30$

30. Ascospores $37-63 \times 10-27 \mu \mathrm{m} \ldots \ldots \ldots \ldots \ldots \ldots . \ldots . \ldots . \ldots 2$

30. Macroconidia muriform, $19-30 \times 6-9 \mu \mathrm{m}$; ascospores muriform, 23-36 ×7-11.5 $\mu \mathrm{m}$; continental Australia...

Swinscowia australiensis

30. Macroconidia 3-septate, $11-20 \times 3-4.5 \mu \mathrm{m}$, or macroconidia unknown; ascospores submuriform, 16-30 $\times$ $5.5-9 \mu \mathrm{m}$. 31
31. Perithecia 0.2-0.3 mm diam.; involucrellum 30-60 $\mu \mathrm{m}$ thick; thallus thin; Cook Islands.

Swinscowia divisa

31. Perithecia 0.3-0.6 mm diam.; involucrellum 50-120 $\mu \mathrm{m}$ thick; thallus thick; Lord Howe Island

Swinscowia rupestris

32. Perithecial wall pale; ascospores $2-2.5$ times as long as broad; African Paleotropics (São Tomé and Príncipe)

Swinscowia albolinita

32. Perithecial wall carbonized; ascospores $2.5-4$ times as long as broad.......................................33

33. Perithecia 0.2-0.3 mm diam.; Papua New Guinea...... Swinscowia muriformis

33. Perithecia $0.4-0.8 \mathrm{~mm}$ diam.; New Zealand. Swinscowia johnsonii

\section{Excluded genera:}

Oletheriostrigula Huhndorf \& R.C. Harris, Brittonia 48: 551 (1996).

MycoBank number: MB 27751; Index Fungorum number: IF 27751; Facesoffungi number: FoF 08925.

Type species: Oletheriostrigula papulosa (Durieu \& Mont.) Huhndorf \& R.C. Harris, Brittonia 48: 551 (1996); Sphaeria papulosa Durieu \& Mont., Expl. Sci. Alg., Fl. Algér. 1(14): 536 (1848) [1846-49]; Leptosphaeria papulosa (Durieu \& Mont.) Sacc., Nuovo G. Bot. Ital. 7: 313 (1875); Metasphaeria papulosa (Durieu \& Mont.) Sacc., Syll. Fung. 2: 168 (1883); Massarina papulosa (Durieu \& Mont.) S.K. Bose, Phytopath. Z. 41: 176 (1961).

Notes: Huhndorf and Harris (1996) suggested placement of this unique, non-lichenized, apparently saprotrophic fungus in Strigulaceae, based on hamathecium and ascus structure. Close relationship of non-lichenized and lichenized fungi has been demonstrated for other lineages, such as Heleiosa in the Monoblastiaceae (Nelsen et al. 2011a; Lücking et al. in Hongsanan et al. 2020, this volume; Monoblastiaceae). The paraphyses, asci and ascospores of Oletheriostrigula indeed closely resemble those of e.g. Flavobathelium. However, based on Bose (1961), Huhndorf and Harris (1996) gave the asexual morph of Oletheriostrigula as Diplodia stage, which is described as forming rather large (around 20-40 × 10-15 $\mu \mathrm{m}$ ), aseptate, oval-ellipsoid, rather thick-walled conidia that remain mostly hyaline but partially become brown and septate with age and never produce gelatinous appendages (Burgess et al. 2003; Alves et al. 2004; Damm et al. 2007; Phillips et al. 2007). Bose (1961) described the conidia of Massarina populosa as 7-16 $\times 2.5-5 \mu \mathrm{m}$ in size, gradually (not abruptly in age) turning brown, and irregularly pyriform-clavate to elliptical, thus different from Diplodia sensu stricto. Even so, while the conidia of Oletheriostrigula do not seem to represent a 
genuine Diplodia asexual morph, they are also very different from macroconidia in Strigulaceae, which are septate to muriform, persistently hyaline, and with gelatinous appendages; hence Oletheriostrigula must be excluded from that family.

On a side note, the genus Diplodia was established in Montagne (1834: 302), ascribed to Fries, based on Sphaeria mutila Fr., with the description "Asci elliptico-oblongi, didymi, sporidiis binis referti". Also, Fries (1823) had originally described the species in Sphaeria, which he explicitly characterized as producing asci. In spite of this, the name Diplodia has become firmly established for a frequently encountered, economically important asexual morph of various ascomycetous fungi (Kirk et al. 2008). This interpretation, which is in conflict with the protologue, goes back to Stevens (1933), who reportedly saw only pycnidia with conidia in the material identified in Montagne (1834; cited as no. 498) and therefore established the name Diplodia mutila (Fr.) Mont. [sic] as having priority over the previously used name Sphaeropsis malorum (Berk.) Berk. for said asexual morph. The ascospores and conidia of Botryosphaeria stevensii, the current name covering Sphaeria mutila and Diplodia mutila (Shoemaker 1964; Alves et al. 2004), are remarkably similar in size, shape, and development, remaining aseptate and hyaline for a long time and eventually becoming brown and septate in part. Thus, in superficial observation, it is conceivable that pycnidia with conidia might be mistaken for perithecia with asci, and viceversa. However, if that was the case and the original material seen by Fries and Montagne only contained pycnidia, one would still have to proof that neither author actually saw at least one perithecium with asci, in order to superseed the explicit description of asci in the protologue of Diplodia (Montagne 1834). That seems impossible, given that both stages may occur together, both perithecia and pycnidia are formed in black stromata, and perithecia possibly present in the original material might have been used up by previous examinations. Fries (1849) himself later elaborated on the formation of ascospores and conidia in otherwise identical fruiting bodies of Sphaeria sensu lato species, including Diplodia. According to Sutton (1980) and Alves et al. (2004), original material of Sphaeria mutila seen by Fries (Scleromycetes Suecici 164, 385) contains only empty fruiting bodies, which at least in one case (164) were interpreted by Sutton (1980) as ascomata, who therefore suggested to adopt the name for a sexual morph. Alves et al. (2004) also argued that Montagne (1834) did not ascribe to Fries a new combination for Sphaeria mutila Fr., as Diplodia mutila (Fr.) Fr., but instead ascribed to that author a new species, Diplodia mutila Fr. This is incorrect, as Montagne (1834, p. 302) clearly states that "... this species ...", namely Sphaeria mutila Fr., will be the type of Diplodia Fr., providing a valid description for the latter, ascribed to Fries. Hence, the genus
Diplodia is to be based on Sphaeria mutila, with its type to be cited as D. mutila (Fr.) Fr., and cannot be interpreted otherwise. This also means that the relevant elements to assess the status of Diplodia as representing a sexual or asexual morph genus are the material used by Fries (Scleromycetes Suecici 164, 385), with only empty fruiting bodies at least partly interpreted as perithecia, plus Fries's description in Montagne (1834) explicitly describing asci. The assessment of Stevens (1933) and Alves et al. (2004) of Montagne's no. 498 is insofar irrelevant as it does not proof that Fries's original material contained only pycnidia and that therefore Fries's placement of the species in a genus characterized by the formation of asci was in error; neither does it proof that Fries did not see asci in Montagne's material either. Consequently, if Sphaeria mutila is accepted as name of a sexual morph and placed in the genus Botryosphaeria Ces. \& De Not., Diplodia Fr. has priority over the latter name.

On top of this, there is also confusion with the correct name applying to the species originally described as Sphaeria mutila and currently known as Botryosphaeria stevensii Shoemaker (Shoemaker 1964; Alves et al. 2004). Stevens (1936) claimed to have discovered the sexual morph of Sphaeria mutila (Fr.) for the first time and proposed the combination into Physalospora, as P. mutila (Fr.) N.E. Stevens. At the time when Shoemaker (1964) treated this taxon, the Montreal Code (Lanjouw et al. 1961) was in effect, which included Art. 59 on dual nomenclature and the phrase: "The author who first describes a perfect state may adopt the specific epithet applied to the corresponding imperfect state, but his binomial for the perfect state is to be attributed to him alone, and is not to be regarded as a new combination." Thus, assuming that Stevens's (1936) description was the first discovery of the sexual morph and applying the Montreal Code, Shoemaker (1964) changed Steven's name to Physalospora mutila N.E. Stevens, i.e. a new taxon with a type different from Sphaeria mutila Fr. This is problematic for two reasons: (1) the Cambridge Rules (Briquet 1935), which were in effect in 1936, did not include such a provision, and hence Stevens's combination was legitimate, and (2) said provision hinges on the correct assessment of what constitutes the first description of a sexual morph. For the reasons outlined above, the name Sphaeria mutila Fr. must be associated with the sexual morph, even if Fries (1823) did not explicitly describe asci and ascospores for that species, because by placing the species in Sphaeria, Fries (1823) implicitly adopted the name for a taxon producing asci. Therefore, Stevens (1936) cannot be claimed as the first description of the sexual morph, even if he provided essential details beyond Fries's (1823) morphological diagnosis. Shoemaker (1964) also erroneously thought that the combination of Physalospora mutila N.E. Stevens, when interpreted according to the Montreal Code, into Botryosphaeria was blocked by the name Botryosphaeria 
mutila Cooke [sic]. As so often in mycological literature, that name does not exist. Cooke (1885) explicitly referred to Sphaeria mutila as treated in Schweinitz's (1832) work on North American fungi, who in turn explicitly used the name Sphaeria mutila Fr. for his North American material. Therefore, Cooke's name is a combination of Sphaeria mutila Fr. into Botryosphaeria, as B. mutila (Fr.) Cooke, accepting that the fungus in question was a widespread species conspecific with Fries's original material. Incidentally, Cooke (1885) gave a description of the asci and ascospores of the taxon five decades prior to Stevens (1936), a fact overlooked by Shoemaker (1964), hence also clearly associating the name Sphaeria mutila Fr. with a sexual morph. This further underlines the complications from the provisions in Art. 59 of the Montreal Code, since the description of the asexual morph for S. mutila by Stevens (1936) was arguably not the first, and hence that rule did not apply. In subsequent version of the Code (starting with the Edinburgh Code and ending with the Vienna Code; Lanjouw et al. 1966; McNeill et al. 2006), this provision was amended in a way that only combinations accompanied by elements required for valid publication of a new taxon, e.g. a Latin description or diagnosis, were to be corrected to names of new taxa and else were to be treated as new combinations. Thus, under the rules applicable at the time, under the amendment in the Edinburgh Code and thereafter, and particularly starting with the Melbourne Code (Barrie et al. 2012), not only is the name Physalospora mutila (Fr.) N.E. Stevens legitimate, but the correct name for the species to be adopted in the genus Botryosphaeria is B. mutila (Fr.) Cooke. The name B. stevensii Shoemaker is thus a superfluous, illegitimate replacement name and all names considered here, namely Sphaeria mutila Fr., Diplodia mutila (Fr.) Fr., Botryosphaeria mutila (Fr.) Cooke, Physalospora mutila (Fr.) N.E. Stevens, and Botryosphaeria stevensii Shoemaker, are based on the same type and are to be attributed to a sexual morph or holomorph. Given that Fries's original material is sterile, it is an entirely different matter what species Botryosphaeria mutila exactly represents, and this can only be settled by epitypification.

\section{Key to genera of Strigulaceae:}

1. Growing on living leaves (foliicolous) ................2

1. Growing on bark or rock or sometimes over bryophytes or rarely lichenicolous on other lichens (corticolous, saxicolous, muscicolous, hepaticolous, lichenicolous)...........................................11

2. Ascospores 1-septate, very rarely with two obscure additional septa.................................... 3

2. Ascospores 3-septate to muriform ....................

3. Growing supracuticularly, easily removable from the leaf surface; photobiont representing the Phycopeltis morphodeme, with more or less rectangular cells forming net-like plates (Fig. 71a, b).............Phylloporis

3. Growing subcuticularly, difficult to remove from the leaf surface; photobiont representing the Cephaleuros or Trentepohlia morphodeme, with rounded to oblong cells forming irregular groups or plates often in more than one layer......................................... 4

4. Perithecial wall not carbonized; thallus often conspicuously folded or laciniate, with numerous white papillae (Fig. 71c). Puiggariella

4. Perithecial wall carbonized; thallus smooth to uneven, rarely with white papillae............................5

5. Ascospores rather large, over $30 \mu \mathrm{m}$ long; thallus thin, typically dark bluish grey, always hypophyllous (Fig. 71d)

Raciborskiella

5. Ascospores small to medium-sized, up to $25 \mu \mathrm{m}$; thallus thin to thickened, usually bright to dark green to greygreen or olive-brown, usually epiphyllous, very rarely bluish grey or hypophyllous........................6

6. Thallus olive-brown to dark green with often metallic glance, composed of dichotomously branched but sometimes confluent lacinia bordered by a continuous or interrupted black line; perithecia covered by thin thallus layer up to ostiole, therefore not pure black (Fig. 71e, f) Racoplaca

6. Thallus bright green to grey-green or rarely with bluish tinge, with entire to crenulate or lobed margin but rarely laciniate, not bordered by a thin black line except in the S. nitidula aggregate and then thallus green and perithecia exposed, black............................... 7

7. Macroconidia with appendages becoming very long after release from pycnidia (up to 70-100 $\mu \mathrm{m}$ ), appearing as if suspended along gelatinous strands; photobiont representing the Trentepohlia morphodeme, forming a single layer (Fig. 71g, h)..........Serusiauxiella

7. Macroconidia with appendages remaining rather short after release from pycnidia (below $35 \mu \mathrm{m}$ or typically much shorter); photobiont representing the Cephaleuros morphodeme, forming more than one layer (Fig. 71i-o).................Strigula sensu stricto

8. Ascospores 3(-5)-septate; macroconidia acicular to filiform, multi-septate.............................9

8. Ascospores muriform; macroconidia bacillar to oblong-ellipsoid, multi-septate to muriform.........10

9. Thallus supracuticular; perithecia aggregate in slightly raised pseudostromata filled with ochraceousyellow, $\mathrm{K}+$ dark red crystals; macroconidia acicular, 3(-5)-septate (Fig. 72a, b)..............Flavobathelium

9. Thallus subcuticular; perithecia solitary, strongly prominent and laterally covered by a thin thallus layer; macroconidia filiform, 3-9-septate (Fig. 72c).

Phyllocharis 

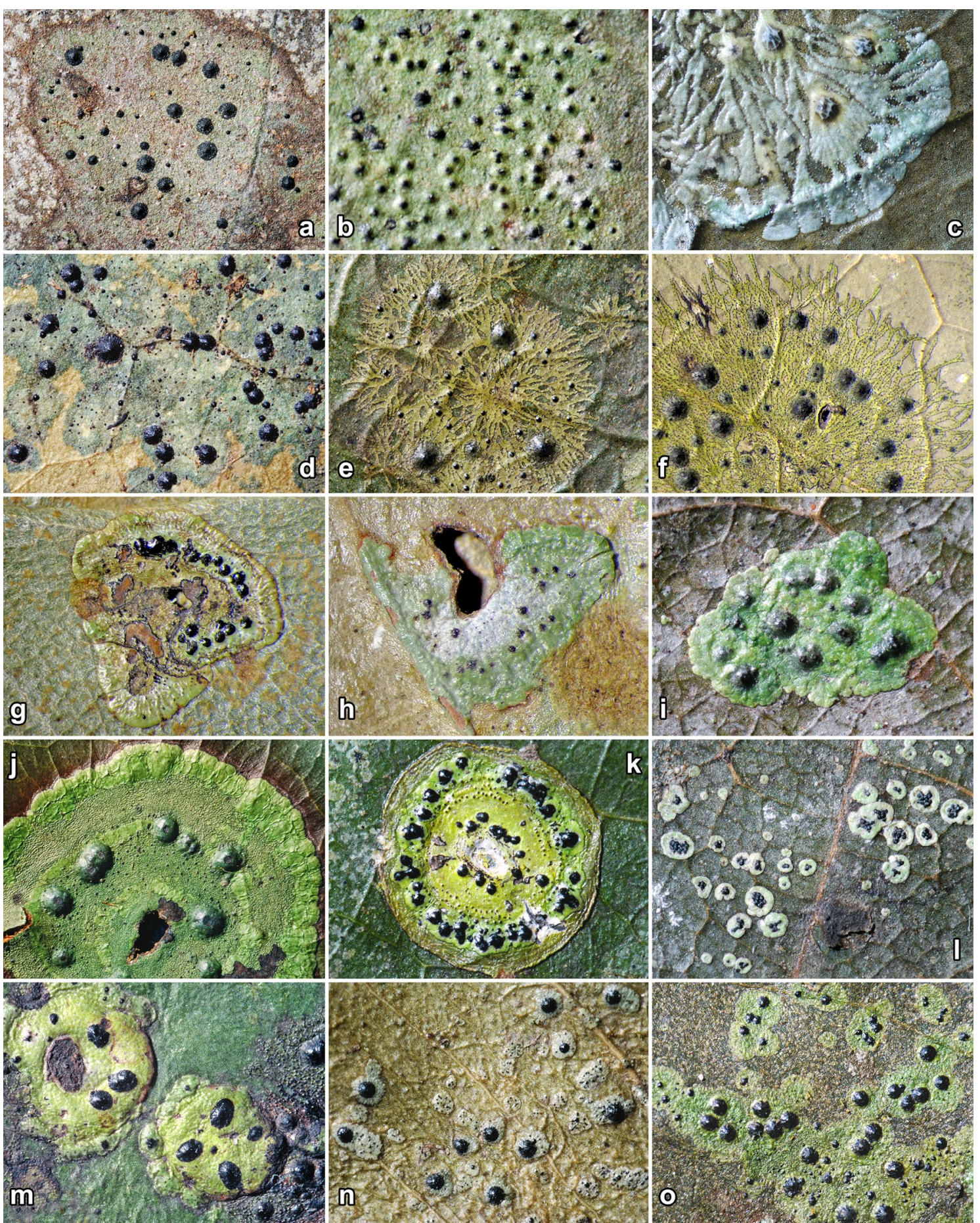

Fig. 71 Habit of genera and species in Strigulaceae. a Phylloporis phyllogena. b P. obducta. c Puiggariella nemathora. d Raciborskiella janeirensis. e Racoplaca subtilissima. f R. melanobapha. g Seru- siauxiella sinensis. h $S$. filifera. i Strigula smaragdula. j S. macrocarpa. $\mathbf{k}$ S. schizospora. $\mathbf{l}$ S. antillarum. $\mathbf{m}$ S. bella. $\mathbf{n}$ S. prasina. o $S$. nitidula
10. Perithecia immersed in thalline verrucae filled with black, pulveraceous crystals or exposed and then with somewhat roughened surface and wart-shaped to subglobose; pycnidia usually aggregate in pseudostromata, rarely solitary in thalline verrucae (Fig. $72 \mathrm{~d}-\mathrm{h}) \ldots \ldots \ldots$. Phyllobathelium

10. Perithecia exposed or covered by very thin thallus layer, not immersed in thalline verrucae, with smooth 


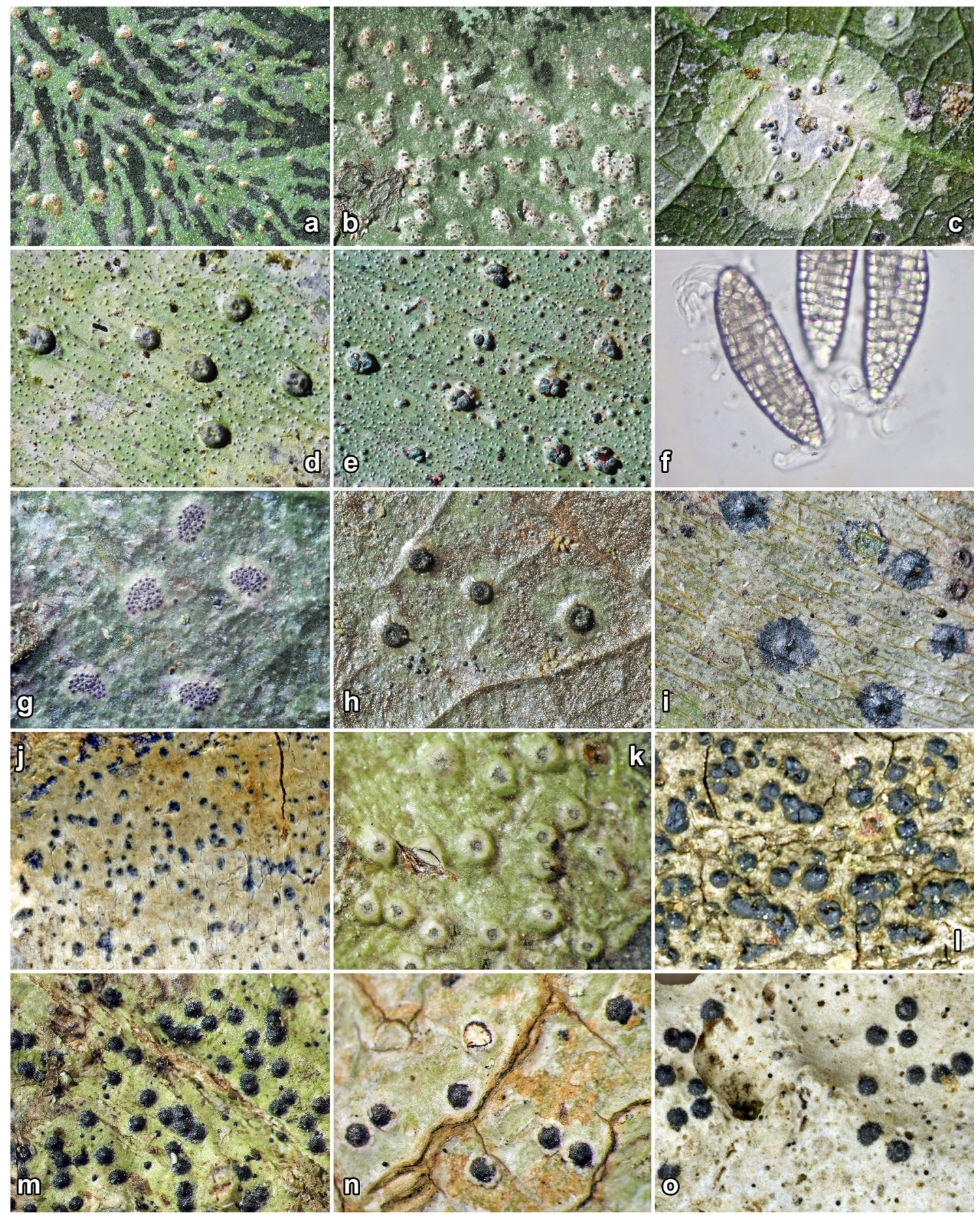

Fig. 72 Habit of genera and species in Strigulaceae. a, b Flavobathelium epiphyllum. c Phyllocharis orbicularis. d Phyllobathelium firmum. e, f P. thaxteri (in f macroconidia). g P. leguminosae. h $P$. anomalum. i Phyllocraterina papuana. j Swinscowia glabra. k Flagellostrigula laureriformis. I Dichoporis ziziphii. m D. phaea. n D. viridiseda. o D. wilsonii surface, lens-shaped to hemisphaerical; pycnidia not known (Fig. 72i).

Phyllocraterina

11. Ascospores and macroconidia 3-septate to muriform; macroconidial appendages relatively short and broad, (1-)2-4 $\mu \mathrm{m}, 1-2(-5)$ times as long as narrow, 15-30\% of conidial length in Swinscowia; microconidia typically (oblong-)bacillar (Fig. 72j)...........Swinscowia

11. Ascospores and macroconidia 1-septate; macroconidial appendages relatively long and narrow, $1-2 \mu \mathrm{m}$ broad, $3-6$ times as long as wide, about $20-50 \%$ of conidial 
length (or rarely much longer); microconidia typically fusiform(-oblong)............................ 12

12. Perithecia and ascospores unknown; macroconidia with a single, flagelliform, very long appendage at the proximal end, about 3-4 times as long as the conidia; pycnidia producing macroconidia very large $(0.4-$ $0.8 \mathrm{~mm}$ diam.), covered by rather thick thallus layer (Fig. 72k) Flagellostrigula

12. Perithecia and ascospores frequently present; macroconidia with similar appendages at each end, up to half of the length of the conidia; pycnidia small (usually less than $0.2 \mathrm{~mm}$ diam.), visible as dark dots

13. Photobiont representing the Phycopeltis morphodeme, with more or less rectangular cells forming net-like plates; paraphyses unbranched

Phylloporis (rare instances on bark)

13. Photobiont representing the Trentepohlia morphodeme, with rounded to oblong cells forming irregular groups or plates; paraphyses generally branched and sometimes slightly anastomosing (Fig. 721-o)

Dichoporis

Checklist of names published in the genus Strigula:

Strigula abietina Fr. [nom. inval.] = Lophodermium abietis

Rostr. (Rhytismataceae)

Strigula actinoplaca Nyl. = Actinoplaca strigulacea Müll.

Arg. (Gomphillaceae)

Strigula actinoplacoides Vain. = Puiggariella nemathora

(Mont.) S.H. Jiang, Lücking \& J.C. Wei

Strigula acuticonidiarum S.H. Jiang, X.L. Wei \& J.C. Wei

Strigula affinis (A. Massal.) R.C. Harris $\equiv$ Swinscowia

affinis (A. Massal.) S.H. Jiang, Lücking \& Sérus.

Strigula africana Vain. = Strigula smaragdula Fr.

Strigula africana var. africana Vain. = Strigula smaragdula Fr.

Strigula africana var. crenulata Vain. = Strigula smaragdula Fr.

Strigula africana var. natalensis Vain. ex Van der Byl = Strigula smaragdula Fr.

Strigula africana var. vegetior Vain. = Strigula subelegans Vain.

Strigula albicascens (Nyl.) R.C. Harris $\equiv$ Swinscowia albicascens (Nyl.) S.H. Jiang, Lücking \& Sérus.

Strigula albolinita (Nyl.) R.C. Harris $\equiv$ Swinscowia albolinita (Nyl.) S.H. Jiang, Lücking \& Sérus.

Strigula albomaculata Sérus.

Strigula alpestris (Vezda) Hafellner $\equiv$ Swinscowia alpestris

(Vězda) S.H. Jiang, Lücking \& Sérus.

Strigula amblyoloba Müll. Arg. = Racoplaca subtilissima

(Fée) S.H. Jiang, Lücking \& J.C. Wei

Strigula americana R.C. Harris $\equiv$ Dichoporis tenuis (R.C.

Harris) S.H. Jiang, Lücking \& Sérus.
Strigula amphora Aptroot \& Lücking $\equiv$ Swinscowia amphora (Aptroot \& Lücking) S.H. Jiang, Lücking \& Sérus.

Strigula angustata $\mathrm{Cl}$. Roux \& Sérus.

Strigula angustata Sérus. \& Cl. Roux [nom. inval.] $\equiv$ Strigula angustata $\mathrm{Cl}$. Roux \& Sérus.

Strigula angustissima Vain. = Phyllocharis orbicularis (Fr.) S.H. Jiang, Lücking \& Sérus.

Strigula antillarum (Fée) Müll. Arg.

Strigula aquatica $\mathrm{H}$. Harada $\equiv$ Swinscowia aquatica $(\mathrm{H}$. Harada) S.H. Jiang, Lücking \& Sérus.

Strigula argentea $($ Fée) Trevis. $=$ Strigula sp.

Strigula argyronema Müll. Arg. = Puiggariella nemathora (Mont.) S.H. Jiang, Lücking \& J.C. Wei

Strigula argyronema var. argyronema Müll. Arg. = Puiggariella nemathora (Mont.) S.H. Jiang, Lücking \& J.C. Wei

Strigula argyronema var. confluens Müll. Arg. $\equiv$ Puiggariella confluens (Müll. Arg.) S.H. Jiang, Lücking \& J.C. Wei

Strigula astroidea Vain. = Strigula smaragdula Fr.

Strigula astroidiza Vain. = Puiggariella nemathora (Mont.) S.H. Jiang, Lücking \& J.C. Wei

Strigula atrocarpa Vain. = Strigula concreta $($ Fée) R. Sant.

Strigula atrocarpa var. atrocarpa Vain. = Strigula concreta (Fée) R. Sant.

Strigula atrocarpa var. fumigata Vain. [in Zahlbruckner (1931)] $\equiv$ Strigula atrocarpoides var. fumingata Vain. = Strigula nitidula Mont.

Strigula atrocarpoides Vain. = Strigula nitidula Mont.

Strigula atrocarpoides var. atrocarpoides Vain. $=$ Strigula nitidula Mont.

Strigula atrocarpoides var. fumigata Vain. [in Zahlbruckner (1931)] $\equiv$ Strigula atrocarpoides var. fumingata Vain. = Strigula nitidula Mont.

Strigula atrocarpoides var. fumingata Vain. = Strigula nitidula Mont.

Strigula australiensis P.M. McCarthy $\equiv$ Swinscowia australiensis (P.M. McCarthy) S.H. Jiang, Lücking \& Sérus.

Strigula austropunctata P.M. McCarthy $\equiv$ Phylloporis austropunctata (P.M. McCarthy) S.H. Jiang, Lücking \& J.C.Wei

Strigula babingtonii Berk. $\equiv$ Dennisiella babingtonii (Berk.) Bat. \& Cif. (Coccodiniaceae)

Strigula bahamensis (Riddle) R.C. Harris $\equiv$ Swinscowia bahamensis (Riddle) S.H. Jiang, Lücking \& Sérus.

Strigula banksii Schwein. [nom. inval.] $=$ [unidentified fungus]

Strigula bella G. Thor, Lücking \& Tat. Matsumoto Strigula bermudana (Tuck. ex Nyl.) R.C. Harris $\equiv$ Dichoporis bermudana (Tuck.) S.H. Jiang, Lücking \& Sérus.

Strigula bispora Aptroot \& K.H. Moon $\equiv$ Swinscowia bispora (Aptroot \& K.H. Moon) S.H. Jiang, Lücking \& Sérus. 
Strigula brevis Bricaud \& Cl. Roux $\equiv$ Dichoporis brevis (Bricaud \& Cl. Roux) S.H. Jiang, Lücking \& Sérus.

Strigula brevis Bricaud \& Cl. Roux [nom. inval.] EDichoporis brevis (Bricaud \& Cl. Roux) S.H. Jiang, Lücking \& Sérus.

Strigula buxi Chodat

Strigula caerulensis P.M. McCarthy

Strigula calcarea Bricaud \& Cl. Roux $\equiv$ Swinscowia calcarea (Bricaud \& Cl. Roux) S.H. Jiang, Lücking \& Sérus.

Strigula cavicola $\mathrm{Cl}$. Roux \& Bricaud $\equiv$ Swinscowia cavicola (Cl. Roux \& Bricaud) S.H. Jiang, Lücking \& Sérus.

Strigula ciliata Mont. $=$ Cephaleuros $\mathrm{sp}$. (Trentepohliaceae) Strigula cinefaciens (Nyl.) R.C. Harris $\equiv$ Phylloporis cinefaciens (Nyl.) S.H. Jiang, Lücking \& J.C.Wei

Strigula complanata (Fée) Nyl. [IF 370567] $\equiv$ Strigula complanata $($ Fée) Mont. $=$ Phyllocharis orbicularis $(\mathrm{Fr}$.) S.H. Jiang, Lücking \& Sérus.

Strigula complanata Mont. [IF 547404] $\equiv$ Strigula complanata (Fée) Mont. = Phyllocharis orbicularis (Fr.) S.H. Jiang, Lücking \& Sérus.

Strigula complanata f. complanata Mont. = Phyllocharis orbicularis (Fr.) S.H. Jiang, Lücking \& Sérus.

Strigula complanata f. major Nyl. = Puiggariella nemathora f. hypothelia (Nyl.) S.H. Jiang, Lücking \& Sérus.

Strigula complanata var. ciliata (Mont.) Müll. Arg. = Cephaleuros sp. (Trentepohliaceae)

Strigula complanata var. complanata Mont. = Phyllocharis orbicularis (Fr.) S.H. Jiang, Lücking \& Sérus.

Strigula complanata var. diplomorpha Müll. Arg. = Phyllocharis orbicularis (Fr.) S.H. Jiang, Lücking \& Sérus.

Strigula complanata var. genuina Müll. Arg. [nom. inval.] EStrigula complanata var. complanata (Fée) Mont. = Phyl-

locharis orbicularis (Fr.) S.H. Jiang, Lücking \& Sérus.

Strigula complanata var. major Nyl. = Puiggariella nemathora f. hypothelia (Nyl.) S.H. Jiang, Lücking \& Sérus.

Strigula complanata var. mesotropa Müll. Arg. = Cephaleuros sp. (Trentepohliaceae)

Strigula complanata var. stellata Nyl. \& Cromb. ex H.M. Ward $\equiv$ Strigula smaragdula var. stellata $(\mathrm{Nyl}$. \& Cromb. ex H.M. Ward) Farkas

Strigula complanata var. subtilis Müll. Arg. = Phycopeltis sp. (Trentepohliaceae)

Strigula complanata var. virescens Nyl. [IF 604058] $\equiv$ Strigula complanata var. virescens (Kunze ex Fr.) Nyl. $\equiv$ Cephaleuros virescens Kunze ex Fr. (Trentepohliaceae) Strigula concentrica Müll. Arg. = Strigula smaragdula Fr. Strigula concreta (Fée) R. Sant.
Strigula confusa Fryday, Coppins \& Common $\equiv$ Swinscowia confusa (A. Massal.) S.H. Jiang, Lücking \& Sérus.

Strigula connivens R.C. Harris $\equiv$ Dichoporis connivens (R.C. Harris) S.H. Jiang, Lücking \& Sérus.

Strigula contristans Zahlbr. = Racoplaca maculata $($ Cooke \& Massee) S.H. Jiang, Lücking \& J.C. Wei

Strigula dacrydiospora Zahlbr. = Strigula subelegans Vain. Strigula decipiens (Malme) P.M. McCarthy $\equiv$ Swinscowia decipiens (Malme) S.H. Jiang, Lücking \& Sérus.

Strigula decipiens var. decipiens (Malme) P.M. McCarthy 三Swinscowia decipiens (Malme) S.H. Jiang, Lücking \& Sérus.

Strigula decipiens var. divisa P.M. McCarthy $\equiv$ Swinscowia divisa (P.M. McCarthy) S.H. Jiang, Lücking \& Sérus.

Strigula delicata Sérus. $\equiv$ Strigula delicata Sérus.

Strigula deplanata Müll. Arg. = Puiggariella nemathora f. hypothelia (Nyl.) (Nyl.) S.H. Jiang, Lücking \& Sérus.

Strigula dichosporidii Etayo $\equiv$ Dichoporis dichosporidii (Etayo) S.H. Jiang, Lücking \& Sérus.

Strigula diederichiana Etayo, Cl. Roux \& Sérus. = Dichoporis phaea (Ach.) S.H. Jiang, Lücking \& Sérus.

Strigula difformis Vain. = Puiggariella nemathora (Mont.) S.H. Jiang, Lücking \& J.C. Wei

Strigula difformis var. arimensis Vain. = Puiggariella nemathora (Mont.) S.H. Jiang, Lücking \& J.C. Wei

Strigula difformis var. difformis Vain. = Puiggariella nemathora (Mont.) S.H. Jiang, Lücking \& J.C. Wei

Strigula dilatata Vain. [IF 454751] $\equiv$ Porina dilatata Vain. $=$ Strigula nitidula Mont.

Strigula dispersa Vain. = Strigula prasina Müll. Arg.

Strigula donacis Vain. = Puiggariella nemathora $\mathbf{f}$. hypothelia (Nyl.) (Nyl.) S.H. Jiang, Lücking \& Sérus.

Strigula effusa Fr. = Echinoplaca sp. (Gomphillaceae)

Strigula elatior Stirt. = Strigula smaragdula Fr.

Strigula elegans (Fée) Müll. Arg. = Strigula smaragdula Fr.

Strigula elegans f. elegans (Fée) Müll. Arg. = Strigula smaragdula Fr.

Strigula elegans f. feei (Mont.) Müll. Arg. = Strigula smaragdula Fr.

Strigula elegans f. fuscata Müll. Arg. [as var. genuina f. fuscata; nom. inval.] $\equiv$ Strigula elegans var. elegans $\mathrm{f}$. fuscata Müll. Arg. = Strigula smaragdula Fr.

Strigula elegans $\mathrm{f}$. hirtella (Fée) Nyl. [IF 477956] $\equiv$ Strigula elegans var. elegans f. hirtella Müll. Arg. = Cephaleuros sp. (Trentepohliaceae)

Strigula elegans f. hirtella Müll. Arg. [as var. genuina f. hirtella; nom. inval.] $\equiv$ Strigula elegans var. elegans $\mathrm{f}$. hirtella Müll. Arg. = Cephaleuros sp. (Trentepohliaceae) 
Strigula elegans subsp. elegans (Fée) Müll. Arg. = Strigula smaragdula Fr.

Strigula elegans subsp. intermedia Müll. Arg. [IF 451609] 三Strigula elegans var. intermedia Müll. Arg. = Strigula concreta (Fée) R. Sant.

Strigula elegans var. antillarum (Fée) R. Sant. $\equiv$ Strigula antillarum (Fée) Müll. Arg.

Strigula elegans var. concreta (Fée) Zahlbr. $\equiv$ Strigula concreta (Fée) R. Sant.

Strigula elegans var. elatior (Stirt.) Zahlbr. = Strigula smar agdula Fr.

Strigula elegans var. elegans (Fée) Müll. Arg. = Strigula smaragdula Fr.

Strigula elegans var. eumorpha Müll. Arg. = Strigula microspora Lücking

Strigula elegans var. feei (Mont.) Müll. Arg. = Strigula smaragdula Fr.

Strigula elegans var. genuina Müll. Arg. [nom. inval.] $\equiv$ Strigula elegans var. elegans (Fée) Müll. Arg. = Strigula smaragdula Fr.

Strigula elegans var. hirtella Fée [IF 451584] $\equiv$ Strigula elegans var. elegans f. hirtella Müll. Arg. = Cephaleuros sp. (Trentepohliaceae)

Strigula elegans var. intermedia Müll. Arg. = Strigula concreta (Fée) R. Sant.

Strigula elegans var. nematora (Nyl.) Müll. Arg. [IF 588134] 三Strigula elegans var. nematora (Mont.) Müll. Arg. = Puiggariella nemathora (Mont.) S.H. Jiang, Lücking \& J.C. Wei

Strigula elegans var. oxyloba Müll. Arg. = Strigula smaragdula Fr.

Strigula elegans var. pertenuis Müll. Arg. = Cephaleuros sp. (Trentepohliaceae)

Strigula elegans var. stellata (Nyl. \& Cromb. ex H.M. Ward) R. Sant. $\equiv$ Strigula smaragdula var. stellata $(\mathrm{Nyl}$. \& Cromb. ex H.M. Ward) Farkas

Strigula elegans var. subciliata Müll. Arg. = Strigula smaragdula Fr.

Strigula elegans var. tremula Müll. Arg. = Strigula smaragdula Fr.

Strigula elegans var. viridissima Müll. Arg. = Strigula smaragdula Fr.

Strigula elegantior Vain. = Strigula subelegans Vain.

Strigula elixii P.M. McCarthy $\equiv$ Dichoporis elixii (P.M. McCarthy) S.H. Jiang, Lücking \& Sérus.

Strigula endolithea $\mathrm{Cl}$. Roux \& Bricaud $\equiv$ Swinscowia endolithea ( $\mathrm{Cl}$. Roux \& Bricaud) S.H. Jiang, Lücking \& Sérus.
Strigula endolithea $\mathrm{Cl}$. Roux \& Bricaud [nom. inval.] $\equiv$ Swinscowia endolithea (Cl. Roux \& Bricaud) S.H. Jiang, Lücking \& Sérus.

Strigula epiphylla Eschw. [IF 454754] $\equiv$ Verrucaria epiphylla Eschw. [nom. illeg.] = Strigula smaragdula Fr.

Strigula feei Mont. = Strigula smaragdula Fr.

Strigula fibrillosa Zahlbr. = Racoplaca melanobapha (Kremp.) S.H. Jiang, Lücking \& J.C. Wei

Strigula fossulicola P.M. McCarthy, Streimann \& Elix Strigula fossulicoloides Sérus.

Strigula fractans P.M. McCarthy $\equiv$ Dichoporis fractans (P.M. McCarthy) S.H. Jiang, Lücking \& Sérus.

Strigula fracticonidia R.C. Harris $\equiv$ Swinscowia fracticonidia (R.C. Harris) S.H. Jiang, Lücking \& Sérus.

Strigula gibberosa Müll. Arg. = Strigula schizospora $\mathrm{R}$. Sant. [nom. cons.]

Strigula gibbosa Vain. = Strigula smaragdula $\mathrm{Fr}$.

Strigula glabra (A. Massal.) V. Wirth $\equiv$ Swinscowia glabra (A. Massal.) S.H. Jiang, Lücking \& Sérus.

Strigula glaziovii Müll. Arg. = Cephaleuros sp. (Trentepohliaceae)

Strigula graminicola $\mathrm{R}$. Sant.

Strigula griseonitens R.C. Harris $\equiv$ Swinscowia griseonitens (R.C. Harris) S.H. Jiang, Lücking \& Sérus.

Strigula guangxiensis S.H. Jiang, X.L. Wei \& J.C. Wei

Strigula hymenaeicola Bat. \& J.L. Bezerra [nom. inval.] = Strigula sp.

Strigula hypothallina R.C. Harris $\equiv$ Phylloporis hypothallina (R.C. Harris) S.H. Jiang, Lücking \& Sérus.

Strigula hypothelia Nyl. EPuiggariella nemathora f. hypothelia (Nyl.) S.H. Jiang, Lücking \& Sérus.

Strigula indutula (Nyl.) R.C. Harris = Swinscowia albicascens (Nyl.) S.H. Jiang, Lücking \& Sérus.

Strigula insignis Jatta $=$ Racoplaca melanobapha $($ Kremp. $)$ S.H. Jiang, Lücking \& J.C. Wei

Strigula jamesii (Swinscow) R.C. Harris $\equiv$ Swinscowia jamesii (Swinscow) S.H. Jiang, Lücking \& Sérus.

Strigula janeirensis (Müll. Arg.) Lücking $\equiv$ Raciborskiella janeirensis (Müll. Arg.) R. Sant.

Strigula johnsonii P.M. McCarthy $\equiv$ Swinscowia johnsonii (P.M. McCarthy) S.H. Jiang, Lücking \& Sérus.

Strigula kaitokensis Sérus. \& Polly

Strigula laceribracae R.C. Harris $\equiv$ Swinscowia laceribracae (R.C. Harris) S.H. Jiang, Lücking \& Sérus.

Strigula lacericola P.M. McCarthy

Strigula lacinulata Vain. = Phyllocharis orbicularis (Fr.) S.H. Jiang, Lücking \& Sérus. 
Strigula lacinulata var. compactior Zahlbr. = Phyllocharis orbicularis (Fr.) S.H. Jiang, Lücking \& Sérus.

Strigula lacinulata var. lacinulata Vain. = Phyllocharis orbicularis (Fr.) S.H. Jiang, Lücking \& Sérus.

Strigula lamellosa Zahlbr. = Strigula subelegans Vain.

Strigula lamprocarpa Müll. Arg. [IF 454755] 三 Porina lamprocarpa Müll. Arg. = Strigula nitidula Mont.

Strigula lateralis Aptroot \& van den Boom $=$ Swinscowia tagananae (Harm.) S.H. Jiang, Lücking \& Sérus.

Strigula laureriformis Aptroot \& Lücking $\equiv$ Flagellostrigula laureriformis (Aptroot \& Lücking) Lücking, S.H. Jiang \& J.C. Wei

Strigula linearis Vain. = Racoplaca melanobapha (Kremp.)

S.H. Jiang, Lücking \& J.C. Wei

Strigula lobulosa Kunze ex Fr. = Strigula sp.

Strigula mabae Zahlbr. = Strigula smaragdula Fr.

Strigula macaronesica Sérus.

Strigula macrocarpa Vain.

Strigula maculata (Cooke \& Massee) R. Sant. $\equiv$ Racoplaca maculata (Cooke \& Massee) S.H. Jiang, Lücking \& J.C. Wei

Strigula maritima $\mathrm{H}$. Harada $\equiv$ Dichoporis maritima $(\mathrm{H}$. Harada) S.H. Jiang, Lücking \& Sérus.

Strigula mediterranea Etayo = Dichoporis ziziphi (A. Massal.) S.H. Jiang, Lücking \& Sérus.

Strigula melanobapha (Kremp.) R. Sant. $\equiv$ Racoplaca melanobapha (Kremp.) S.H. Jiang, Lücking \& J.C. Wei

Strigula melanophthalma Mont. = Strigula antillarum (Fée) Müll. Arg.

Strigula microspora Lücking

Strigula microthyrium Mont. $=$ [unidentified fungus]

Strigula minor (Vezda) Cl. Roux \& Sérus.

Strigula minuta Lücking

Strigula minutula P.M. McCarthy $\equiv$ Dichoporis minutula

(P.M. McCarthy) S.H. Jiang, Lücking \& Sérus.

Strigula mori Schulzer ex Keissl. $=$ [unidentified fungus]

Strigula multipunctata (G. Merr. ex R. Sant.) R.C. Harris $=$ Phylloporis cinefaciens (Nyl.) S.H. Jiang, Lücking \& J.C.Wei

Strigula muriconidiata Aptroot, L.I. Ferraro \& M. Cáceres 三Swinscowia muriconidiata (Aptroot, L.I. Ferraro \& M. Cáceres) S.H. Jiang, Lücking \& Sérus.

Strigula muriformis Aptroot \& Diederich $\equiv$ Swinscowia muriformis (Aptroot \& Diederich) S.H. Jiang, Lücking \& Sérus.

Strigula muscicola F. Berger, Coppins, Cl. Roux \& Sérus. 三 Swinscowia muscicola (F. Berger, Coppins, Cl. Roux \& Sérus.) S.H. Jiang, Lücking \& Sérus.

Strigula natalis P.M. McCarthy $\equiv$ Dichoporis natalis (P.M. McCarthy) S.H. Jiang, Lücking \& Sérus.

Strigula nemathora Mont. $\equiv$ Puiggariella nemathora (Mont.) S.H. Jiang, Lücking \& J.C. Wei
Strigula nemathora $\mathrm{f}$. hypothelia $(\mathrm{Nyl}$.) Lücking $\equiv$ Puiggariella nemathora f. hypothelia (Nyl.) S.H. Jiang, Lücking \& Sérus.

Strigula nemathora f. nemathora Mont. $\equiv$ Puiggariella nemathora (Mont.) S.H. Jiang, Lücking \& J.C. Wei

Strigula nemathora var. hypothelia (Nyl.) R. Sant. $\equiv$ Puiggariella nemathora f. hypothelia (Nyl.) S.H. Jiang, Lücking \& Sérus.

Strigula nemathora var. nemathora Mont. $\equiv$ Puiggariella nemathora (Mont.) S.H. Jiang, Lücking \& J.C. Wei

Strigula nemathora var. pulchella (Müll. Arg.) R. Sant. = Puiggariella nemathora (Mont.) S.H. Jiang, Lücking \& J.C. Wei

Strigula nemathora var. pulchella Mont. [IF 451376] $\equiv$ Strigula nemathora var. pulchella (Müll. Arg.) R. Sant. = Puiggariella nemathora (Mont.) S.H. Jiang, Lücking \& J.C. Wei

Strigula nematora Nyl. [in Zahlbruckner 1922)] $\equiv$ Puiggariella nemathora (Mont.) S.H. Jiang, Lücking \& J.C. Wei

Strigula nigrocarpa Lücking

Strigula nigrocincta Müll. Arg. $\equiv$ Puiggariella nigrocincta (Müll. Arg.) S.H. Jiang, Lücking \& J.C. Wei

Strigula nigrocincta var. nigrocincta Müll. Arg. $\equiv$ Puiggariella nigrocincta (Müll. Arg.) S.H. Jiang, Lücking \& J.C. Wei

Strigula nigrocincta var. soluta Müll. Arg. = Puiggariella nigrocincta (Müll. Arg.) S.H. Jiang, Lücking \& J.C. Wei

Strigula nipponica $\mathrm{H}$. Harada $\equiv$ Dichoporis nipponica $(\mathrm{H}$. Harada) S.H. Jiang, Lücking \& Sérus.

Strigula nitidula Mont.

Strigula novae-zelandiae (Nag Raj) Sérus.

Strigula nylanderi Vain. = Strigula smaragdula Fr.

Strigula nylanderiana F. Schill. = Puiggariella nemathora

f. hypothelia (Nyl.) S.H. Jiang, Lücking \& Sérus.

Strigula obducta (Müll. Arg.) R.C. Harris $\equiv$ Phylloporis obducta (Müll. Arg.) R. Sant. \& Tibell

Strigula obtecta (Vain.) R.C. Harris $\equiv$ Swinscowia obtecta (Vain.) S.H. Jiang, Lücking \& Sérus.

Strigula obvelata Vain. = Strigula macrocarpa Vain.

Strigula occulta P.M. McCarthy \& Malcolm $\equiv$ Dichoporis occulta (P.M. McCarthy \& Malcolm) S.H. Jiang, Lücking \& Sérus.

Strigula oceanica P.M. McCarthy, Streimann \& Elix

Strigula orbicularis Fr. $\equiv$ Phyllocharis orbicularis (Fr.) S.H. Jiang, Lücking \& Sérus.

Strigula pachyneura Müll. Arg. = Phyllocharis orbicularis (Fr.) S.H. Jiang, Lücking \& Sérus.

Strigula pallida Aptroot \& K.H. Moon $\equiv$ Swinscowia pallida (Aptroot \& K.H. Moon) S.H. Jiang, Lücking \& Sérus. Strigula pallida Kalchbr. \& Stizenb.[IF 479700; nom. inval.] $\equiv$ Strigula pallida Kalchbr. = Strigula sp. 
Strigula pallidocarpa Aptroot \& K.H. Moon $\equiv$ Swinscowia pallida (Aptroot \& K.H. Moon) S.H. Jiang, Lücking \& Sérus.

Strigula parksii Räsänen = Strigula subelegans Vain.

Strigula phaea (Ach.) R.C. Harris E Dichoporis phaea

(Ach.) S.H. Jiang, Lücking \& Sérus.

Strigula philippina Vain. = Strigula smaragdula Fr.

Strigula phyllogena (Müll. Arg.) R.C. Harris $\equiv$ Phylloporis phyllogena (Müll. Arg.) Clem.

Strigula plana Müll. Arg. = Strigula smaragdula Fr.

Strigula platypoda (Müll. Arg.) R.C. Harris $\equiv$ Phylloporis platypoda (Müll. Arg.) Vězda

Strigula porinoides Canals, Boqueras \& Gómez-Bolea $\equiv$ Swinscowia porinoides (Canals, Boqueras \& GómezBolea) S.H. Jiang, Lücking \& Sérus.

Strigula prasina Müll. Arg.

Strigula pulchella Müll. Arg. = Puiggariella nemathora

(Mont.) S.H. Jiang, Lücking \& J.C. Wei

Strigula puncticulata Müll. Arg. = Puiggariella nemathora

f. hypothelia (Nyl.) S.H. Jiang, Lücking \& Sérus.

Strigula racoplaca Mont. = Racoplaca subtilissima (Fée)

S.H. Jiang, Lücking \& J.C. Wei

Strigula radiata Lücking $\equiv$ Phylloporis radiata (Lücking)

S.H. Jiang, Lücking \& J.C. Wei

Strigula rhodinula (Zahlbr.) P.M. McCarthy $\equiv$ Swinscowia rhodinula (Zahlbr.) S.H. Jiang, Lücking \& Sérus.

Strigula rostrata R.C. Harris \& Aptroot $\equiv$ Swinscowia rostrata (R.C. Harris \& Aptroot) S.H. Jiang, Lücking \& Sérus.

Strigula rotula Mont. 三 Mazosia rotula (Mont.) A. Massal. (Roccellaceae)

Strigula rugulosa Müll. Arg. = Strigula concreta (Fée) R. Sant.

Strigula rugulosa var. irregularis Müll. Arg. = Strigula microspora Lücking

Strigula rugulosa var. rugulosa Müll. Arg. = Strigula concreta (Fée) R. Sant.

Strigula rupestris P.M. McCarthy $\equiv$ Swinscowia rupestris

(P.M. McCarthy) S.H. Jiang, Lücking \& Sérus.

Strigula schizospora R. Sant. [nom. cons.]

Strigula setacea Müll. Arg. = Cephaleuros $\mathrm{sp}$. (Trentepohliaceae)

Strigula sinoaustralis S.H. Jiang, X.L. Wei \& J.C. Wei

Strigula smaragdula Fr.

Strigula smaragdula var. smaragdula Fr. $\equiv$ Strigula smaragdula Fr.

Strigula smaragdula var. stellata (Nyl. \& Cromb. ex H.M. Ward) Farkas $\equiv$ Strigula smaragdula var. stellata (Nyl. \& Cromb. ex H.M. Ward) Farkas

Strigula stigmatella (Ach.) R.C. Harris $\equiv$ Swinscowia stigmatella (Ach.) S.H. Jiang, Lücking \& Sérus.
Strigula stigmatella var. alpestris (Vĕzda) Coppins = Swinscowia stigmatella (Ach.) S.H. Jiang, Lücking \& Sérus.

Strigula stigmatella var. stigmatella (Ach.) R.C. Harris $\equiv$ Swinscowia stigmatella (Ach.) S.H. Jiang, Lücking \& Sérus.

Strigula stilboideum Bat. = Strigula $\mathrm{sp}$.

Strigula subelegans Vain.

Strigula submuriformis (R.C. Harris) R.C. Harris $\equiv$ Swinscowia submuriformis (R.C. Harris) S.H. Jiang, Lücking $\&$ Sérus.

Strigula subprospersella (Vain.) P.M. McCarthy $\equiv$ Dichoporis subprospersella (Vain.) S.H. Jiang, Lücking \& Sérus.

Strigula subsimplicans (Nyl.) R.C. Harris $\equiv$ Dichoporis subsimplicans (Nyl.) S.H. Jiang, Lücking \& Sérus.

Strigula subtilissima (Fée) Müll. Arg. 三 Racoplaca subtilissima (Fée) S.H. Jiang, Lücking \& J.C. Wei

Strigula sulcata Vain. = Strigula concreta (Fée) R. Sant.

Strigula sychnogonoides (Nitschke) R.C. Harris $\equiv$ Geisleria sychnogonoides Nitschke (Stictidaceae)

Strigula tagananae (Harm.) R.C. Harris $\equiv$ Swinscowia tagananae (Harm.) S.H. Jiang, Lücking \& Sérus.

Strigula taylorii (Carroll ex Nyl.) R.C. Harris $\equiv$ Dichoporis taylorii (Carroll) S.H. Jiang, Lücking \& Sérus.

Strigula tenuis Müll. Arg. = Strigula smaragdula Fr.

Strigula thelopsidoides Coppins, Cl. Roux \& Sérus. $\equiv$ Swinscowia thelopsidoides (Coppins, Cl. Roux \& Sérus.) S.H. Jiang, Lücking \& Sérus.

Strigula transversoundulata Sipman $\equiv$ Racoplaca transversoundulata (Sipman) S.H. Jiang, Lücking \& J.C. Wei

Strigula tremens Müll. Arg. 三 Racoplaca tremens (Müll. Arg.) S.H. Jiang, Lücking \& J.C. Wei

Strigula umbilicata Müll. Arg. $\equiv$ Asterothyrium umbilicatum (Müll. Arg.) Müll. Arg. (Gomphillaceae)

Strigula undulata Müll. Arg. = Strigula smaragdula Fr.

Strigula urticae Bonord. = [unidentified fungus]

Strigula vincentina Vain. [IF 454756] 三 Porina vincentina Vain. = Racoplaca subtilissima (Fée) S.H. Jiang, Lücking \& J.C. Wei

Strigula virescens (Kunze ex Fr.) Trevis. $\equiv$ Cephaleuros virescens Kunze ex Fr. (Trentepohliaceae)

Strigula viridis (Lücking) R.C. Harris $\equiv$ Phylloporis viridis Lücking

Strigula viridiseda (Nyl.) R.C. Harris 三 Dichoporis viridiseda (Nyl.) S.H. Jiang, Lücking \& Sérus.

Strigula viridissima (Fée) Trevis. = Strigula smaragdula Fr. Strigula vulgaris (Müll. Arg.) Lücking $\equiv$ Phylloporis vulgaris (Müll. Arg.) S.H. Jiang, Lücking \& J.C. Wei

Strigula wandae M. Cáceres \& Lücking

Strigula wilsonii (Riddle) R.C. Harris 三 Dichoporis wilsonii (Riddle) S.H. Jiang, Lücking \& Sérus.

Strigula xylopiae Bat. \& Cavalc. = Strigula schizospora $\mathrm{R}$. Sant. [nom. cons.] 
Strigula ziziphi (A. Massal.) Cl. Roux \& Sérus. $\equiv$ Dichoporis ziziphi (A. Massal.) S.H. Jiang, Lücking \& Sérus.

\section{Economic and ecological significance}

For foliicolous species of Strigulaceae, indicator values have been published that allow applications in monitoring the conservation status of forest ecosystems (Lücking 1997). Particularly species of Strigula sensu lato now dispositioned in the genera Phylloporis, Puiggariella, Raciborskiella, Racoplaca, and Strigula sensu stricto allow for a rather precise monitoring, as their scores are highly specific to individual genera and species (Lücking 1997). In a recent study, the population genetics of a new species segregated from Strigula smaragdula, S. multiformis, and its correlation with modeled habitat preferences was studied (Oh et al. 2019).

Tenuitholiascaceae S.H. Jiang, Lücking \& J.C. Wei, in Jiang et al., IMA Fungus 11: 1 (2020).

Fungal Names: FN570578; Facesoffungi number: FoF 08775, 1 species.

Lichenized on leaves chiefly in lowland to montane tropical to subtropical habitats. Thallus supracuticular, easily separated from the leaf surface, smooth, pale green. Photobiont Phycopeltis, cells rectangular, composed of anastomosing filaments in one layer forming regular, radiating plates. Ascomata perithecia, wart-shaped, scattered or somewhat clustered, ostiolate, exposed but covered by thin thallus layer up to the ostiole, with the basal part spreading to form a horizontal plate. Involucrellum carbonized, black. Exciple dense, prosoplectenchymatous, colourless to brown. Hamathecium comprising unbranched paraphyses. Asci bitunicate in structure but lacking a distinct tholus, apex rounded, I-, appearing nearly unitunicate in some stages, clavate to almost cylindrical, I-, KI-, 8-spored. Ascospores irregularly arranged to 2-seriate, fusiform, 3-septate, hyaline. Asexual state: Pycnidia common, wart-shaped, immersed to erumpent, visible as black dots. Conidia acrogenous, only microconidia known; microconidia fusiform, hyaline, aseptate. Chemistry: No secondary substances detected in TLC.

Type: Tenuitholiascus S.H. Jiang, Lücking \& J.C. Wei.

Notes: The family was introduced by Jiang et al. (2020a) to accomodate a novel lineage sister to Strigulaceae, but with a different ascus type. To assess placement of the new lineage within Dothideomycetes, a dataset consisting of three loci (SSU, LSU, and tef1- $\alpha$ ) was constructed and analysed. Even if superficially similar to Porina in Lecanoromycetes, it was evident that the new lineage was a member of class Dothideomycetes, forming a clade supported sister to Strigulaceae. Since the asci of the novel lineage differed from those of Strigulaceae in lacking a thickened tholus and ocular chamber, it was considered prudent to introduce the monospecific family Tenuitholiascaceae and genus Tenuitholiascus for this taxon. The specific epithet, T. porinoides, thereby refers to the remarkable similarity with Porina both in morphological and anatomical features.

Tenuitholiascus S.H. Jiang, Lücking \& J.C. Wei, IMA Fungus 11: 1 (2020).

Fungal Names: FN570581; Facesoffungi number: FoF 08776, 1 morphological species (Jiang et al. 2020a), 1 species with molecular data.

Type species: Tenuitholiascus porinoides S.H. Jiang, Lücking \& J.C. Wei.

Notes: Besides ascus type, the only genus in the family is distinguished from genera in the sister family Strigulaceae as follows: from Phylloporis in the 3-septate, oblong ascospores, from Phyllocratera in the small, 3-septate ascospores, and from Flavobathelium in the external habit with exposed perithecia. Tenuitholiascus closely resembles Porina in external morphology and ascospore type, as well as the thin-walled asci and unbranched paraphyses. Yet, it is entirely unrelated to the latter, which belongs in Gyalectales in class Lecanoromycetes (Kraichak et al. 2018; Lücking 2019).

Tenuitholiascus porinoides S.H. Jiang, Lücking \& J.C. Wei, IMA Fungus 11: 1 (2020).

Fungal Names: FN570580; Fig. 73

Thallus supracuticular, easily separated from the leaf surface, continuous, smooth, pale green, 3-12 mm diam, 30-52.5 $\mu \mathrm{m}$ thick. Algal partner: Phycopeltis, cells rectangular, 8-14 $\times 3-5 \mu \mathrm{m}$, composed of anastomosing filaments lying in one layer and forming regular radial plates or irregular nets. Ascomata perithecia, globose, scattered or clustered, exposed but covered by thin thallus layer up to the ostiole, central part wart-shaped, sometimes basal part broadly spreading to form horizontal plate, $0.25-0.5 \mathrm{~mm}$ diam and 80-150 $\mu \mathrm{m}$ high, greyish black. Involucrellum carbonized, black, 55-125 $\mu \mathrm{m}$ thick. Exciple dense, prosoplectenchymatous, $10-12.5 \mu \mathrm{m}$ thick, colourless to brown. Interascal filaments: unbranched or simply branched, thin. Asci bitunicate in structure, apex with a I- rounded, sometimes appearing almost unitunicate in some developmental stages, due to the gradually thinner inner walls (Fig. 73f), clavate to cylindrical, 75-90 × 10-12.5 $\mu \mathrm{m}, \mathrm{I}-$, KI-, 8-spored. Ascospores fusiform, 3-septate, colourless, 25-30 $\times 6-8 \mu \mathrm{m}$. Pycnidia common, wart-shaped, immersed to erumpent, $0.05-0.1 \mathrm{~mm}$ diam, black. Conidia (microconidia) fusiform, hyaline, aseptate, $4-5 \times 1.5-2 \mu \mathrm{m}$.

\section{Economic and ecological significance}

Since this family is poorly known, it is difficult at the moment to elaborate on this topic. As foliicolous lichen apparently found in shady conditions, Tenuitholiascaceae is a potential indicator of well-reserved forest ecosystems, 

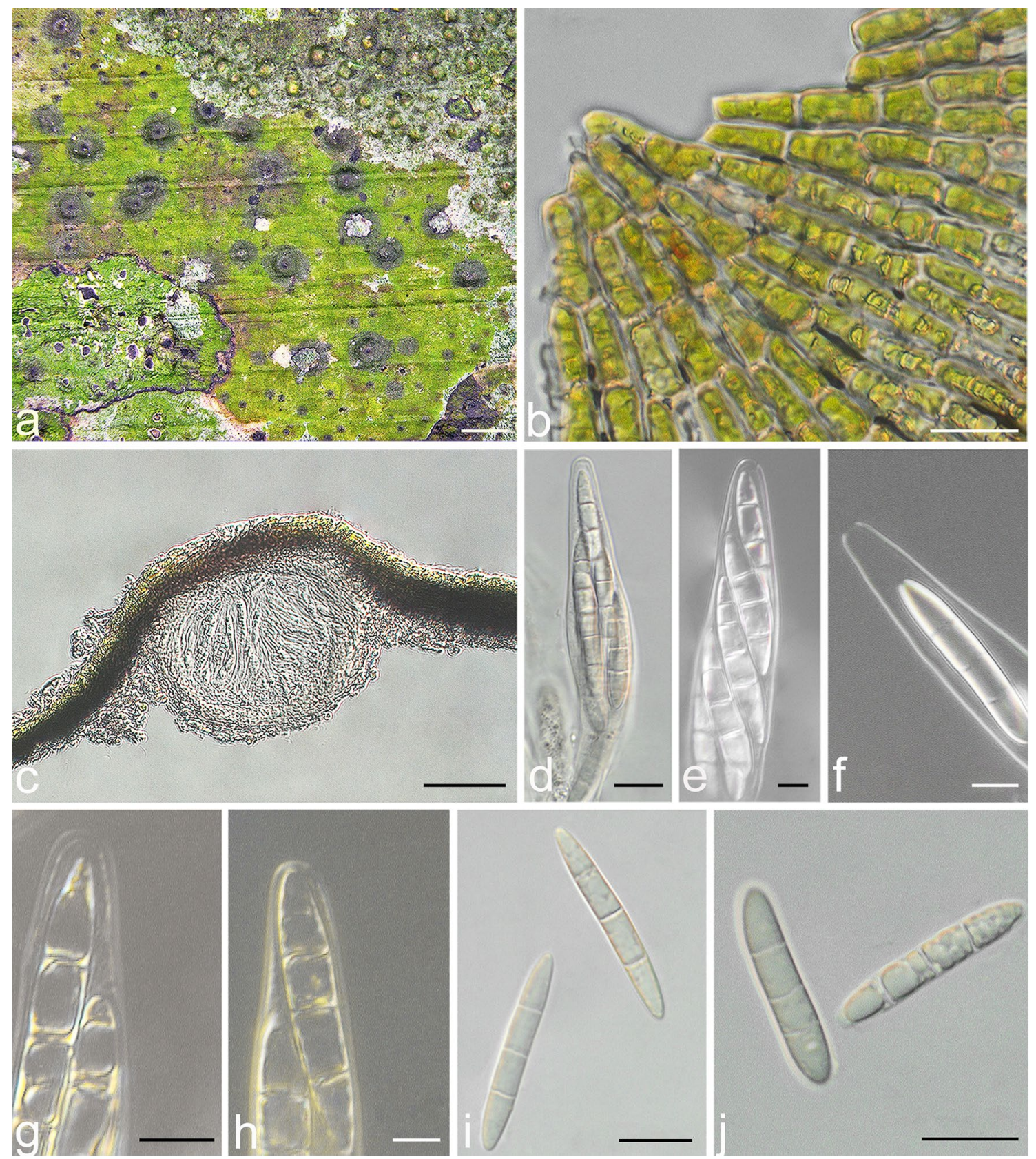

Fig. 73 Tenuitholiascus porinoides (HMAS-L0139638). a Thallus. b The Phycopeltis algal partner. c Perithecia in vertical section. d Ascus (HMAS-L0139639). e Ascus (HMAS-L0139640). f Ascus apex (HMAS-L0141346). g Ascus with iodine reaction (HMAS-
L0139638). h Ascus with iodine reaction (HMAS-L0141348). i Ascospores (HMAS-L0139639). j Ascospores (HMAS-L0139638). Scale bars: $\mathbf{a}=300 \mu \mathrm{m}, \mathbf{c}=20 \mu \mathrm{m}, \mathbf{b}, \mathbf{d}, \mathbf{i}, \mathbf{j}=10 \mu \mathrm{m}, \mathbf{e}-\mathbf{h}=5 \mu \mathrm{m}$

Superstratomycetales was introduced to accommodate previously unknown taxa in Pezizomycotina which were recovered from oil-treated timber after outdoor exposure in Australia and the Netherlands (Nieuwenhuijzen et al. 2016). The phylogenetic tree (Fig. 74) indicates that species of Superstratomyces form a clade with high support (100\% ML, 1.0 PP, Fig. 74) within Dothideomycetes. The
Superstratomycetales van Nieuwenh., Miądl., Houbraken, Adan, Lutzoni \& Samson.

Index Fungorum number: IF 819160; Facesoffungi number: FoF 08926. 
Fig. 74 Phylogram generated from maximum likelihood analysis (RML) of genera in Superstratomycetales based on ITS, LSU, rpb-2, SSU and tef1 sequence data. Maximum likelihood bootstrap values equal or above $70 \%$, Bayesian posterior probabilities equal or above 0.90 (MLBS/PP) are given at the nodes. An original isolate number is noted after the species name. The tree is rooted to Venturia inaequalis (CBS 815.69). The ex-type strains are indicated in bold. Hyphen (-) represents support values below $70 \%$ MLBS and $0.90 \mathrm{PP}$

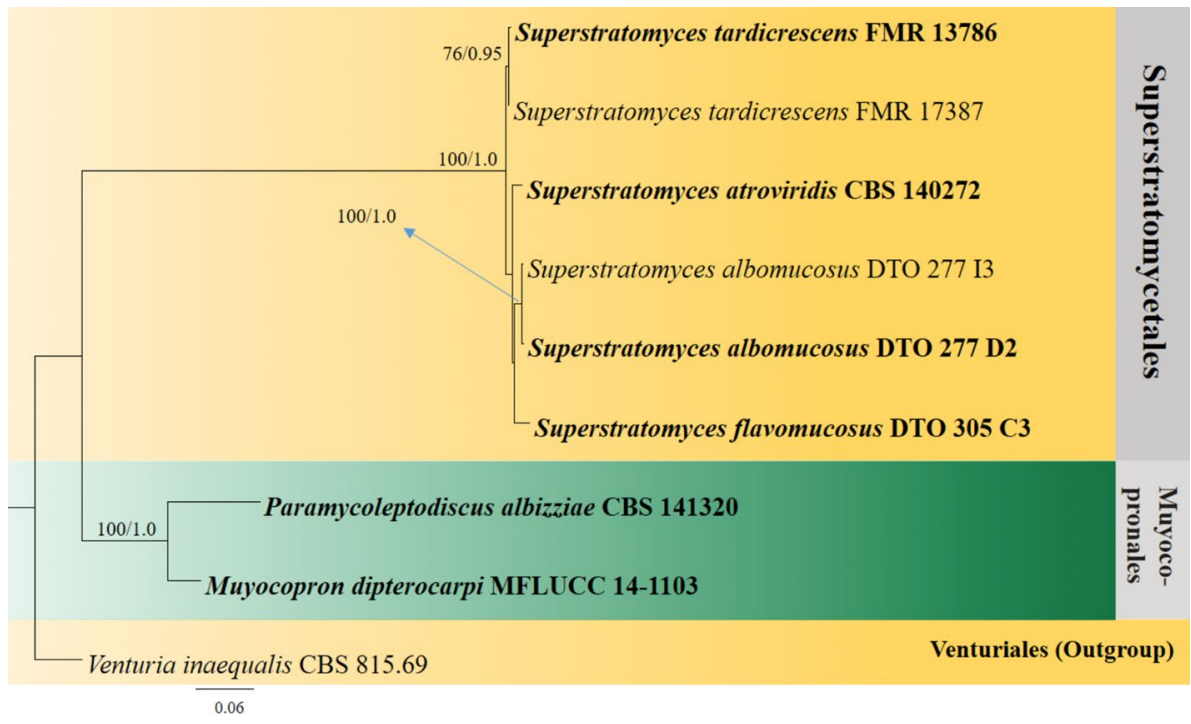

to black, glabrous, globose, filled by a white mass of slimy conidia; pycnidial wall pseudoparenchymatous, of textura angularis cells, composed of several layers of pale brown to brown, flattened. Setae erect to recurved, hyaline to subhyaline at apex and turning brown towards the base, 1-2-septate, strongly verrucose to tuberculate. Conidiophores branched, hyaline, smooth-walled, bearing lateral conidiogenous cells. Conidiogenous cells phialidic, hyaline, cylindrical to barrelshaped or ampulliform, smooth-walled, solitary or laterally disposed on the conidiophores. Conidia cylindrical to navicular, hyaline, aseptate, smooth- and thin-walled, guttulate.

Type: Superstratomyces van Nieuwenh., Miądl. \& Samson.

Notes: Superstratomycetaceae comprises one genus named Superstratomyces, and it was typified by Superstratomyces albomucosus. Multi-locus phylogenies are necessary for the identification of species in Superstratomyces. Superstratomycetaceae lacks unique characteristics and, therefore, cannot be identified based only on morphology. With the recent introduction of Superstratomyces tardicrescens, the number of species in Superstratomyces, family Superstratomycetaceae has been increased up to four (Crous et al. 2018a).

Superstratomyces van Nieuwenh., Miądl. \& Samson, in van Nieuwenhuijzen et al., Stud. Mycol. 85: 115 (2016).

Index Fungorum number: IF 819162; Facesoffungi number: FoF 08778; 4 morphological species (Species Fungorum 2020), 4 species with molecular data.

Type species: Superstratomyces albomucosus van Nieuwenh. \& Samson.

Notes: Superstratomyces was introduced by van Nieuwenhuijzen et al. (2016) to accommodate the species that was recovered from outdoor wood in the Netherlands. Currently there are four Superstratomyces species including 
S. albomucosus, S. flavomucosus, S. atroviridis and $S$. tardicrescens.

Superstratomyces albomucosus van Nieuwenh., Miądl. \& Samson, in van Nieuwenhuijzen et al., Stud. Mycol. 85: 115 (2016).

Index Fungorum: IF 819163; Facesoffungi number: FoF 08779, Fig. 234

Description: see van Nieuwenhuijzen et al. (2016) (Fig. 75).

\section{Economic and ecological significance}

Superstratomyces albomucosus and S. atroviridis were isolated from exposed, oil-treated wood and may decay wood. Superstratomyces flavomucosus and S. tardicrescens were recovered from leaves of Hakea multilinearis in Australia and a human eye specimen in the USA (Crous et al. 2018a).

Trypetheliales Lücking, Aptroot \& Sipman.

Index Fungorum number: IF 90793; Facesoffungi number: FoF 08780.

Aptroot et al. (2008) established Trypetheliales to accommodate a lichen-forming family Trypetheliaceae, which is phylogenetically distinct from other orders and families in Dothideomycetes (Del Prado et al. 2006). Based on molecular phylogeny and morphology, a second family Polycoccaceae, with lichenicolous fungi, was introduced by Ertz et al. (2015). The order Trypetheliales accommodates primarily lichenized and less commonly non-lichenized taxa, characterized by perithecioid ascomata appearing solitary or aggregated in pseudostromata, branched and anastomosing paraphysoids forming a distinct network, and hyaline or rarely brown ascospores, transversely septate to muriform ascospores often with diamond-shaped lumina and angular wall thickenings (Aptroot et al. 2008; Hyde et al. 2013; Nelsen et al. 2014; Ertz et al. 2015). In a case study of divergence time estimates in Dothideomycetes (Liu et al. 2017), the order was diversified approximately 215 (140-298) MYA (crown age) and 309 (231-388) MYA (stem age).

Polycoccaceae Ertz, Hafellner \& Diederich, in Ertz et al., Fungal Diversity 74: 82 (2015).

Index Fungorum number: IF 814032; Facesoffungi numbers: FoF 08781, 50 species.

Lichenicolous. Sexual morph: Ascomata arising singly, often becoming grouped, sometimes united by a clypeus or enclosed in galls, immersed with only the ostiole visible to erumpent and the upper half exposed when mature, perithecioid, subglobose to obpyriform, dark brown to black, ostiolate, neck not extended and scarcely distinguishable from the ascomatal wall. Peridium thick or somewhat broader near the ostiole, comprises 3-6 layers of polyhedral pseudoparenchymatous cells, radially compressed in vertical section and roughly isodiametric in surface view, forming a textura angularis, thick, brown to dark brown and continuing below the centrum in outer layers, less intensely pigmented to hyaline with thin-walled cells at inner layers. Hamathecium comprising branched, anastomosing net of thin, septate to remotely septate narrow hyphal filaments, probably trabeculate pseudoparaphyses (paraphysoids), periphyses absent, hymenial gel I+ blue to violet or unchanged. Asci 2-8-spored, bitunicate, fissitunicate, broadly cylindrical to subclavate, shortly stalked, wall thicker in the upper part of mature asci, with a small internal apical beak. Ascospores irregularly distichously arranged in the asci, ellipsoid, brown to dark brown when mature, 1-septate (euseptate), somewhat constricted at the septum, normally equal in size or the upper cell larger and broader, generally rounded or rarely attenuated at apex, smooth or delicately verruculose, sometimes with a gelatinous sheath (adapted from Ertz et al. 2015).

Type: Polycoccum Saut. ex Körb.

Notes: Ertz et al. (2015) included species of Clypeococcum and Polycoccum in phylogenetic analyses and found that members of the two genera formed a new lineage within Trypetheliales. Therefore, the sister family of Trypetheliaceae was introduced and named as Polycoccaceae to accommodate Clypeococcum and Polycoccum based on molecular and morphological data.

Polycoccum Saut. ex Körb., Parerga lichenol. (Breslau) 5: 470 (1865).

Index Fungorum number: IF 4309; Facesoffungi number: FoF 08782; 41 morphological species (Species Fungorum 2020), 4 species with molecular data.

Type species: Polycoccum sauteri Körb.

Notes: Polycoccum is considered as polyphyletic, with species being presented in two distantly related clades in Trypetheliales and Pleosporales (Ertz et al. 2015). Polycoccum sensu stricto and species of Clypeococcum form a lineage in Trypetheliales, thus Ertz et al. (2015) established Polycoccaceae to accommodate these genera. Polycoccum sensu stricto (in Polycoccaceae) is characterized by ascomata formed on the host thallus, induce the formation of galls, thick-walled with cells \pm isodiametric in longitudinal section, relatively thick paraphysoids, broadly cylindrical to subclavate asci, generally with irregularly distichously or irregularly uni-seriate arranged ascospores, often distinctly ornamented ascospores (Ertz et al. 2015). The genus has 57 species accepted by Lawrey and Diederich (2015) and new species are described almost every year (Ertz et al. 2015). It has become one of the most species-rich genera of lichenicolous fungi. The most complete key to species of Polycoccum so far was provided by Hawksworth and Diederich (1988). Other regional keys were established such as key for 13 species from Spain (Atienza et al. 2003), and key for 14 

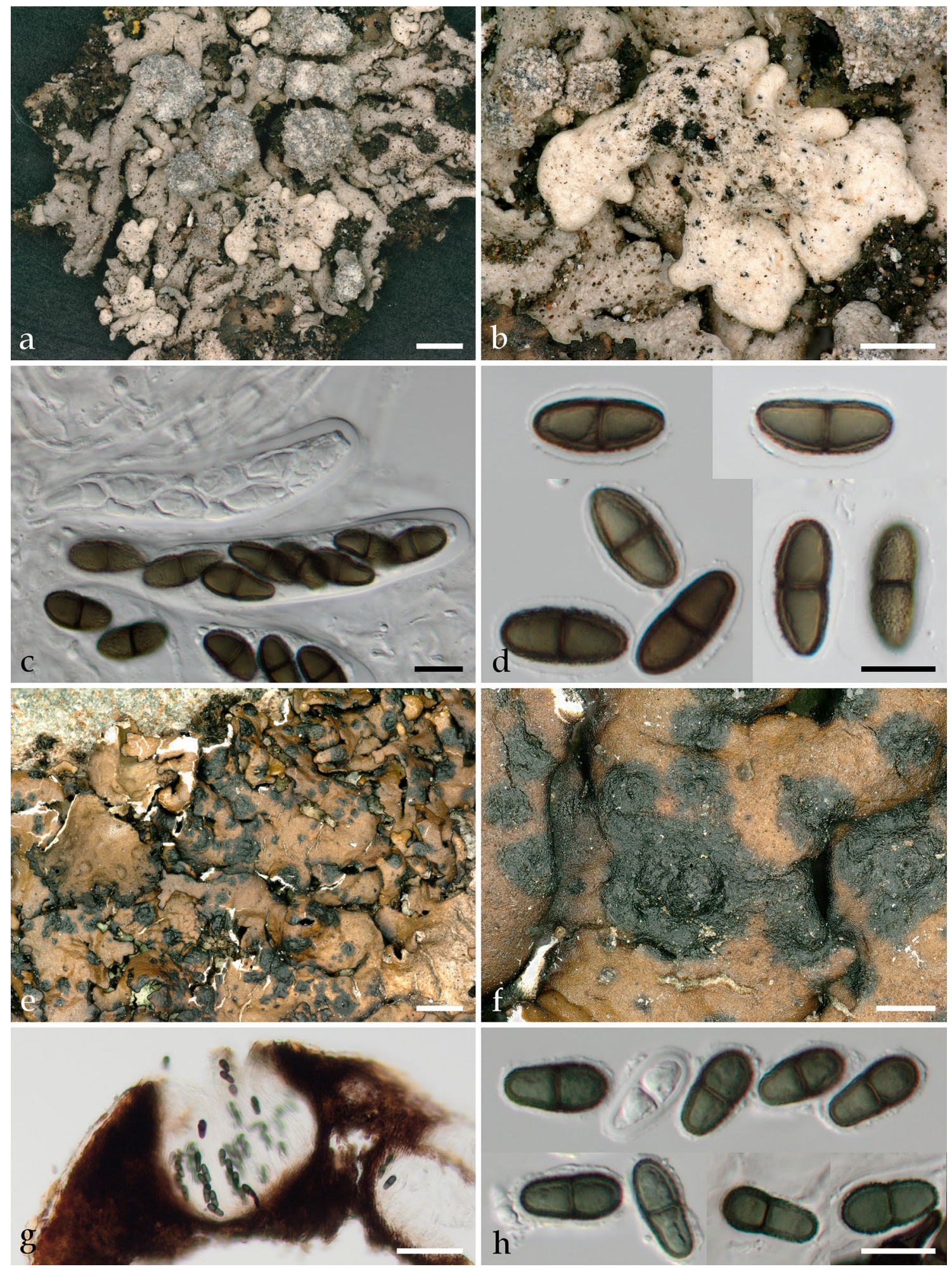

Fig. 76 Morphology of genera in Polycoccaceae (a-d = Polycoccum pulvinatum, Belgium, Ertz 18114 (BR); e-h = Clypeococcum cladonema, Belgium, Ertz 15260 (BR)). a, b Galls with immersed ascomata on Physcia caesia. c Asci with ascospores in water. d Ascospores in water, the one in the lower right corner showing the

verruculose surface. e, f ascomata (= black areas) on Xanthoparmelia (= brownish host thallus). $\mathbf{g}$ Section of ascomata in water. $\mathbf{h}$, ascospores in water. Scale bars: $\mathbf{a}, \mathbf{e}=1 \mathrm{~mm}, \mathbf{b}=500 \mu \mathrm{m}, \mathbf{f}=250$ $\mu \mathrm{m}, \mathbf{g}=50 \mu \mathrm{m}, \mathbf{c}, \mathbf{d}, \mathbf{h}=10 \mu \mathrm{m}$ 
species from Sweden (Ihlen and Wedin 2008), and a key for 13 species from France (Gardiennet 2012) (Fig. 76).

\section{Other genera included:}

Clypeococcum D. Hawksw., J. Linn. Soc., Bot. 75: 196 (1977).

Index Fungorum number: IF 1114; Facesoffungi number: FoF 08783; - 9 morphological species (Species Fungorum 2020), 2 species with molecular data.

Type species: Clypeococcum cladonema (Wedd.) D. Hawksw., Bot. J. Linn. Soc. 75(2): 197 (1977).

三Lecidea cladonema Wedd., Bull. Soc. bot. Fr. 21: 345 (1874).

Notes: According to Hawksworth and Diederich (1988), this genus shares some characters with Polycoccum, but differs by hyphal rather than pseudoparenchymatous ascomatal walls, thickened around the ostiole, and by the ascomata occurring in groups united by a common clypeus. In phylogenetic tree of Ertz et al. (2015), Clypeococcum represented by $C$. placopsiiphilum and C. psoromatis is paraphyletic among Polycoccum. Ertz et al. (2015) noted that the long branches within Polycoccaceae clade showed the fast-evolving contrasting with low morphological variability, which results in few phenotypic characters useful for the recognition of different genera (Ertz et al. 2015). Clypeococcum is however included in Polycoccaceae but its placement will need to be confirmed by molecular data of type species. Fourteen epithets and 9 epithets of Clypeococcum are listed in Index Fungorum (2020) and Species Fungorum (2020), respectively, while sequence data are available for two species.

\section{Economic and ecological significance}

Species in this family are lichenicolous living on lichens as parasites.

Trypetheliaceae Zenker in Goebel \& Kunze, Pharmaceutische Waarenkunde: 123 (1827); Fée, Essai Crypt. Écorc. 1: xxxvi (1824), nom. inval.; Eschweiler, Syst. Lich.: 17 (1824), nom. inval.

MycoBank number: MB 81884; Index Fungorum number: IF 81884; Facesoffungi number: FoF 08784; approximately 440 species (Aptroot and Lücking 2016; Aptroot et al. 2016, 2019; Lücking et al. 2017; this paper).

Lichenized or more rarely saprobic on bark or rarely on bryophytes over soil; in terrestrial, chiefly lowland to lower montane tropical habitats, with few species extending into temperate regions. Thallus reduced and ecorticate, white, to distinctly corticate, yellow-brown to olive-green, sometimes partly or completely bright yellow, orange or red due to superficial anthraquinone pigments. Photobiont Trentepohlia. Ascomata scattered, clustered, aggregated in pseudostromata, or fused with common ostiole, immersed to sessile, brown-black but usually covered by thallus, globose to pear-shaped or conical, coriaceous to carbonaceous, ostiolate, ostiole round. Excipulum dense, consisting of compressed hyphae, appearing prosoplectenchymatous in thin, bleached sections but structure usually difficult to observe due to heavy carbonization, generally dark brown to brown-black. Hamathecium comprising 0.5-0.7(-1.5) $\mu \mathrm{m}$ wide paraphysoids, hyaline, straight or rarely flexuose, branched and usually anastomosing, usually embedded in a thick, gelatinous matrix, occasionally with hyaline or yellow oil inspersion. Asci 1-8-spored, bitunicate, fissitunicate, obclavate to cylindrical, short pedicellate, with refractive ring and very wide, non-amyloid ocular chamber comprising more than half of the width of the ascus. Ascospores irregularly arranged to biseriate, fusiform-ellipsoid to oblong, hyaline to dark brown, septate to muriform, with distosepta and sometimes additional eusepta and rectangular to diamond-shaped (generally six-angled) lumina, smooth-walled or rarely ornamented, not or slightly constricted at the septa, with evanescent mucilaginous material on the outside, either as polar pads or irregular median pads or a complete sheath enveloping the whole ascospore. Pycnidia known from a few species, immersed, visible as black dots in specific, often pseudostromatic areas on fertile thalli, or whole thalli only producing pycnidia; rarely old ascospores within asci transforming into pycnidia. Conidia acrogenous, hyaline, aseptate, bacillar. Chemistry: lichexanthone sometimes produced on thallus surface; yellow to orange or red anthraquinones and perylenequinones often produced in the medulla of the thalline layer covering the perithecia and sometimes in the thallus medulla or superficial on various parts of the thallus.

Type: Trypethelium Spreng.

Notes: Trypetheliaceae (Zenker in Goebel and Kunze 1827 ) is one of the oldest described families of lichenized Ascomycota. Its delimitation was obscure throughout the past nearly 200 years, but in general the family included pyrenocarpous, epiphytic lichens with crustose thalli containing a Trentepohlia photobiont, anastomosing paraphysoids forming a network embedded in a gelatinous matrix, bitunicate asci, and hyaline, distoseptate ascospores with diamondshaped lumina (Aptroot 1991; Harris 1995; Aptroot et al. 2008; Sweetwood et al. 2012). Several genera that had been included at some point have subsequently been placed in other families, such as Megalotremis, Ornatopyrenis, and Trypetheliopsis (Aptroot 1991; Harris 1995; Lumbsch and Huhndorf 2010). Traditionally, the family included seven core genera: Pseudopyrenula (ecorticate; ascospores astrothelioid), Polymeridium (ecorticate; ascospores euseptate), Trypethelium (corticate; ascomata with apical ostiole; ascospores astrothelioid, transversely septate), Laurera (corticate; ascomata with apical ostiole; ascospores astrothelioid, 
Fig. 77 Best-scoring maximumlikelihood tree of Trypetheliaceae, showing all currently sequenced and recognized genera, based on the mtSSU marker, with a length of 962 bases. The tree was reconstructed in RAxML 8, using the universal GTR-Gamma model without site partitioning, and the final likelihood was - 7368.672686. The currently accepted genera are highlighted

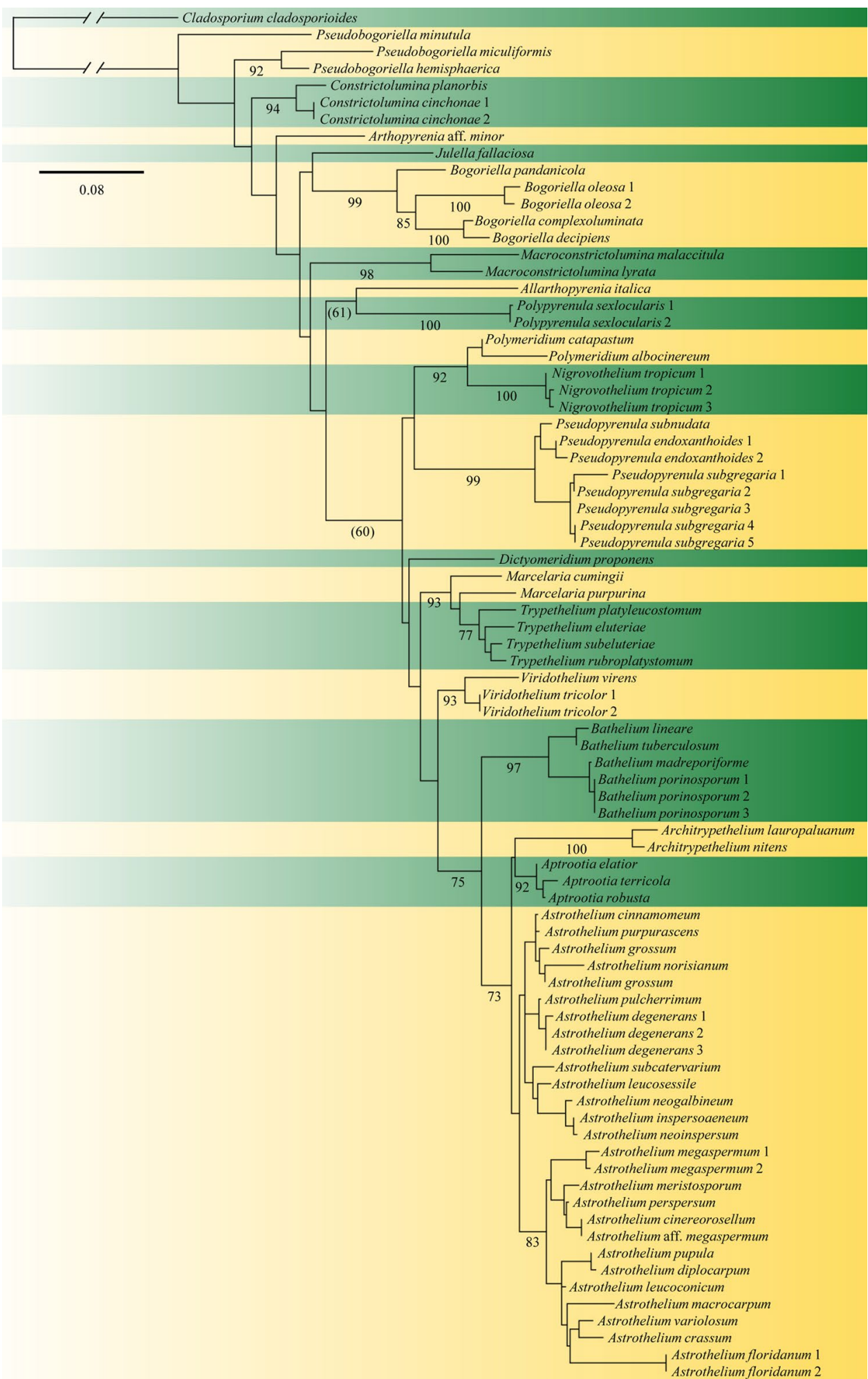

muriform), Astrothelium (corticate; ascomata with lateral or shared ostiole; ascospores astrothelioid, transversely septate), Campylothelium (corticate; ascomata with lateral ostiole; ascospores astrothelioid, muriform), and Cryptothelium (corticate; ascomata with shared ostiole; ascospores astrothelioid, muriform). Four additional genera were included or recognized in more recent treatments (Aptroot 1991; Tucker and Harris 1980; Harris 1986, 1995; Lücking et al. 2007): Exiliseptum (corticate; ascomata with shared ostiole; ascospores euseptate), Bathelium (corticate; ascomata pseudostromatic, 
with walls composed of brown, jigsaw-puzzle-shaped hyphal cells), Architrypethelium (corticate; ascomata with apical or lateral ostiole; ascospores transversely septate, very large, hyaline or brown), and Aptrootia (corticate; ascomata with apical ostiole; ascospores muriform, dark brown).

Molecular phylogenetic data (Fig. 77) have profoundly changed both the family circumscription of Trypetheliaceae and the delimitation of its genera (Del Prado et al. 2006; Nelsen et al. 2009, 2011a, 2014; Aptroot and Lücking 2016; Lücking et al. 2016; Miranda-González et al. 2020). Apart from the core Trypetheliaceae, the family now also contains a large number of species previously placed in the genera Arthopyrenia and Mycomicrothelia, for which the genera Bogoriella, Constrictolumina and Novomicrothelia have been established or reinstated (Aptroot and Lücking 2016; Lücking et al. 2016). In addition, Polypyrenula has been shown to be another member of Trypetheliaceae (MirandaGonzález et al. 2020). Other newly added elements are Alloarthopyrenia (Hyde et al. 2016b) and Julella fallaciosa (Nelsen et al. 2011a; Lücking et al. 2016). Based on molecular data, also the core Trypetheliaceae were reorganized, with most species now in a single genus, Astrothelium, and additional lineages with special characters allocated in the genera Architrypethelium, Aptrootia, Bathelium, Dictyomeridium (segregated from Polymeridium), Marcelaria (Laurera purpurina group), Nigrovothelium (Trypethelium tropicum group), Polymeridium sensu stricto, Pseudopyrenula, and Trypethelium sensu stricto (T. eluteriae group). The previously recognized genera Campylothelium, Cryptothelium, and Laurera are now considered synonyms of Astrothelium (Aptroot and Lücking 2016). As a whole, Trypetheliaceae forms a strongly supported, somewhat isolated clade within Dothideomycetes, and has therefore been assigned its own order, Trypetheliales (Aptroot et al. 2008). Recently, the mostly lichenicolous family Polycoccaceae was also assigned to this order (Ertz et al. 2015).

The hamathecial hyphae (physes) have variously been labeled paraphysoids or (trabeculate or trabecular) pseudoparaphyses (Henssen and Jahns 1973; Barr 1979a; Eriksson 1981; Liew et al. 2000). These terms were originally coined for hamathecium physes of presumably ascolocular fungi, to distinguish from true paraphyses. As per formal definition, the various types are clearly distinguished (Barr 1979a; Henssen and Jahns 1973; Eriksson 1981): true paraphyses develop from below and remain mostly unbranched; paraphysoids develop from stretching interascal plectenchyma; and pseudoparaphyses grow from top to bottom during ontogeny, attaching below and eventually becoming free above. However, the ontogeny of most Ascomycota regarding these features has not been studied and there are intermediate types. Furthermore, the terminology is confounded, e.g. by paraphysoids being named with 'trabecular pseudoparaphyses' (Eriksson 1981), thus combining two supposedly different types into one. Also, according to Henssen and Jahns (1973), paraphysoids can either be precursors of true paraphyses or the only physes, which by extension means that paraphysoids can occur both in ascohymenial and in ascolocular fungi. In addition, ascohymenial and ascolocular fungi do not form phylogenetic entities and taxa thought to be closely related are now known to be unrelated and viceversa (Liew et al. 2000; Schoch et al. 2009a, b). For instance, Henssen and Jahns (1973) included Trypethelium in Pyrenulaceae, a family forming paraphyses (e.g. Pyrenula) or paraphysoids (e.g. Trypethelium), but whose elements actually belong to two different classes (Eurotiomycetes and Dothideomycetes). Eriksson (1981) also hypothesized a close relationship between these two lineages, using the term paraphyses for Pyrenulaceae and paraphysoids for Trypetheliaceae. We consider this terminology largely misleading and suggest to use only paraphysoids.

Trypetheliaceae now includes 18 genera plus some currently orphaned lineages (see key below) and well over 400 species, with about 800 predicted globally (Aptroot et al. 2016, 2019), mostly found in tropical lowland to lower montane, rain forest, dry forest, and savanna habitats.

Trypethelium Spreng., Anleit. Kennt. Gew. 3: 350 (1804).

MycoBank number: MB 5628; Index Fungorum number: IF 5628; Facesoffungi number: FoF 08785; 16 morphologically defined species (Aptroot and Lücking 2016; Lücking et al. 2017); molecular data available for six species (Lücking et al. 2016).

Lichenized on bark in terrestrial, lowland to lower montane tropical habitats. Thallus corticate, yellow-brown to olive-green. Photobiont Trentepohlia. Ascomata aggregated in pseudostromata, sessile, brown-black or covered by algal-free, sterile tissue filled with crystalline, yellow to orange, $\mathrm{KOH}+$ red to purple pigment, globose, coriaceous to carbonaceous, ostiolate, ostiole round. Excipulum prosoplectenchymatous, dark brown to brown-black. Hamathecium comprising $0.5-0.7 \mu \mathrm{m}$ wide paraphysoids, hyaline, straight, branched and anastomosing, embedded in a thick, gelatinous matrix. Asci 8-spored, bitunicate, fissitunicate, obclavate, short pedicellate, with refractive ring and nonamyloid ocular chamber. Ascospores irregularly arranged to biseriate, fusiform, hyaline, multi-septate, with thin distosepta and more or less rectangular lumina, smooth-walled, not constricted at the septa, surrounded by an evanescent mucilaginous sheath. No asexual state known. Chemistry: Yellow to orange or red anthraquinones and perylenequinones produced in the pseudostromata.

Type species: Trypethelium eluteriae Spreng., Anleit. Kennt. Gew. 3: 350 (1804).

Notes: A tropical, lichenized genus found on bark of branches and trunks of trees, usually in (semi-)exposed situations. Traditionally, Trypethelium included all 
Trypetheliaceae with thallus-dominated perithecia with separate, apical ostioles and transversely septate, astrothelioid ascospores. In its current circumscription, the genus is limited to species with pseudostromatic perithecia, the pseudostromata typically containing yellow to orange, crystalline pigments, and multi-septate ascospores with more or less thin septa and walls and rectangular lumina (Aptroot and Lücking 2016).

\section{Other genera included}

Alloarthopyrenia Phukhams., Lücking \& K.D. Hyde in Hyde et al., Fungal Diversity 80: 122, 131 (2016).

MycoBank number: MB 552236; Index Fungorum number: IF 552236; Facesoffungi number: FoF 02379; one phylogenetically and morphologically defined species (Hyde et al. 2016b).

Saprobic on tree branches in terrestrial, temperate forest habitats. Thallus and photobiont absent. Ascomata solitary, erumpent, carbonaceous, ostiolate, ostiole apical, periphysate. Involucrellum distinct, dark brown. Excipulum prosoplectenchymatous, brownish above, colorless below. Hamathecium comprising 0.5-1 $\mu \mathrm{m}$ wide paraphysoids, hyaline, straight, branched and anastomosing, embedded in a gelatinous matrix. Asci 8-spored, bitunicate, fissitunicate, clavate, short pedicellate, with a non-amyloid ocular chamber. Ascospores irregularly arranged to biseriate, fusiformellipsoid to oblong, hyaline, 1-septate, euseptate, with secondary constrictions in each cell, rough-walled, constricted at the septum, with a gelatinous halo. Pycnidia unknown. Chemistry: no substances detected by TLC.

Type species: Alloarthopyrenia italica Phukhams., Camporesi, Ariyaw. \& K.D. Hyde in Hyde et al., Fungal Diversity 80: 122, 135 (2016).

Notes: This monospecific genus was recently introduced for a previously undescribed species growing saprobically on tree branches in Italy. It represents one of now four separate clades in Trypetheliaceae that include members of the collective genus Arthopyrenia, besides Constrictolumina, Macroconstrictolumina (see below) and "Arthopyrenia" aff. minor. Three of these lineages feature ascospores with characteristic secondary constrictions in each of the cells. The discovery of this novel lineage further challenges the systematics of the families Arthopyreniaceae and Naetrocymbaceae the genera Arthopyrenia sensu stricto and Naetrocymbe. Lücking and Nelsen (in Hyde et al. 2013) argued that the type of Arthopyrenia, A. cerasi (Schrad.) A. Massal. differs from the lineages now included in Trypetheliaceae in various anatomical characters, thus likely representing an unrelated lineage; the same argument was made for Naetrocymbe, with the type species $N$. fuliginea Körb. (Dai et al. in Hyde et al. 2013). However, almost every sequenced member of the collective genera Arthopyrenia and Julella has so far been found to represent a lineage of Trypetheliaceae, and so the fate of Arthopyrenia sensu stricto and Naetrocymbe, whose type species have not yet been sequenced, remains uncertain.

Aptrootia Lücking \& Sipman in Lücking et al., Lichenologist 39: 188 (2007).

MycoBank number: MB 29134; Index Fungorum number: IF 29134; Facesoffungi number: FoF 08786; three morphologically and phylogenetically defined species (Aptroot and Lücking 2016; Lücking et al. 2016, 2017).

Lichenized on bark or bryophytes or soil in terrestrial, chiefly montane tropical forest habitats. Thallus distinctly corticate, yellow-brown to mostly green, or ecorticate and greyish. Photobiont Trentepohlia. Ascomata solitary, immersed to erumpent, brown-black but usually covered by thick thallus layer except for ostiolar area, globose to pear-shaped or ovoid, coriaceous to carbonaceous, ostiolate, ostiole apical. Involucrellum reduced. Excipulum prosoplectenchymatous, colorless to brownish. Hamathecium comprising 0.5-1 $\mu \mathrm{m}$ wide paraphysoids, hyaline, straight, branched and anastomosing, embedded in a gelatinous matrix. Asci 1(-2)-spored, bitunicate, fissitunicate, oblongellipsoid, short pedicellate, with a non-amyloid ocular chamber. Ascospores oblong-ellipsoid, initially hyaline and I+ amyloid, but soon becoming dark brown, richly muriform, weakly distoseptate, wall smooth to granular ornamented, outer wall easily breaking under pressure, with gelatinous sheath. Pycnidia unknown. Chemistry: no substances detected by TLC.

Type species: Aptrootia terricola (Aptroot) Lücking, Umaña \& Chaves in Lücking et al., Lichenologist 39: 188 (2007).

Notes: For key and discussion see Aptroot and Lücking (2016). The genus currently includes three species (Fig. 78).

Architrypethelium Aptroot, Biblioth. Lichenol. 44: 120 (1991).

MycoBank number: MB 26294; Index Fungorum number: IF 26294; Facesoffungi number: FoF 08787; eight morphologically defined species (Aptroot and Lücking 2016; Lücking et al. 2017; Luangsuphabool et al. 2018); molecular data available for four species (Lücking et al. 2016; Luangsuphabool et al. 2018).

Lichenized on bark in terrestrial, chiefly lowland to lower montane tropical habitats. Thallus distinctly corticate, yellow-brown to olive-green. Photobiont Trentepohlia. Ascomata solitary to aggregated, erumpent to prominent, brown-black but usually covered by thallus layer except for ostiolar area, coriaceous to carbonaceous, ostiolate, ostiole apical or lateral. Involucrellum reduced, brown-black. Excipulum prosoplectenchymatous, brownish to colorless. Hamathecium comprising 0.5-1 $\mu \mathrm{m}$ wide paraphysoids, hyaline, straight, branched and anastomosing, embedded in 

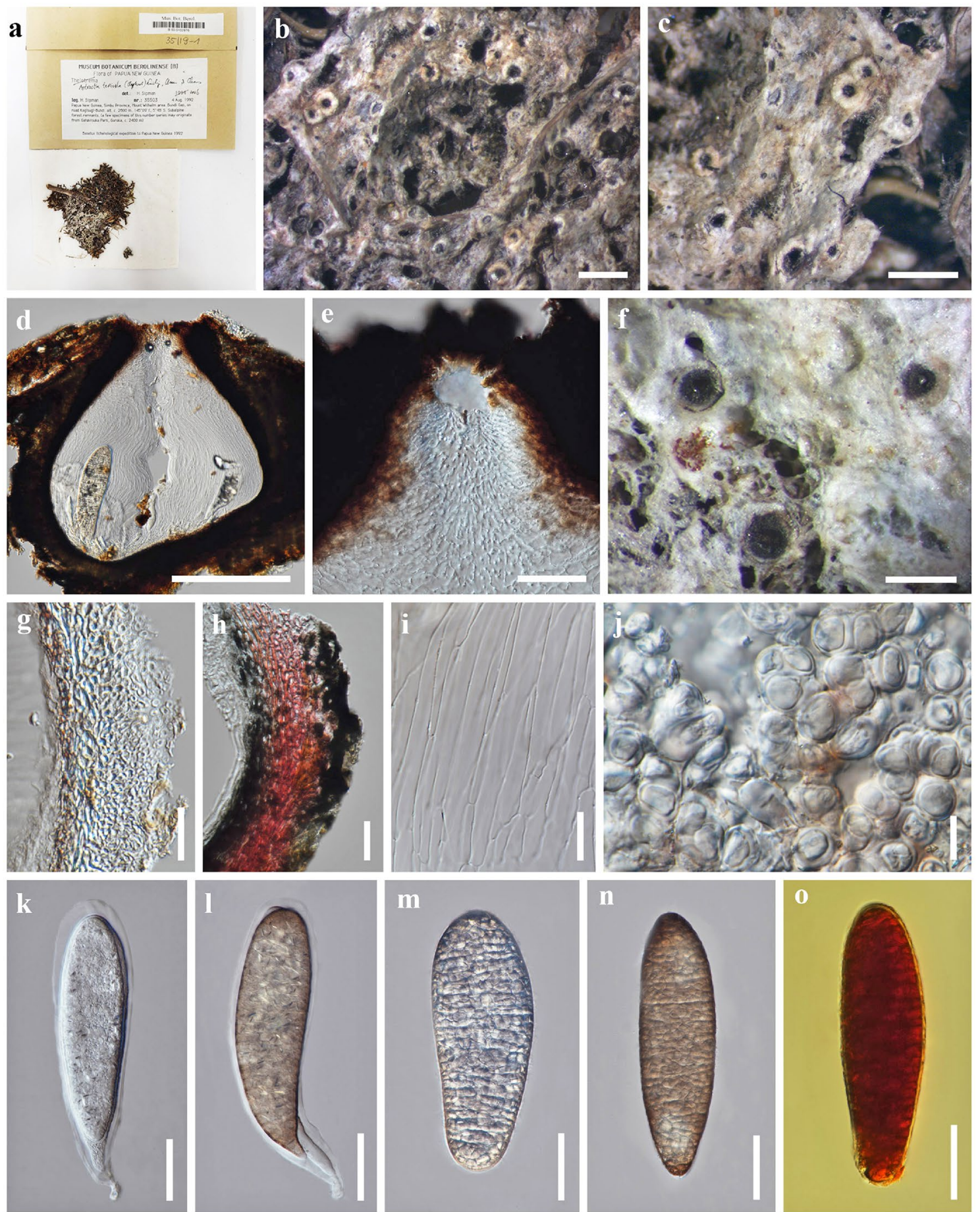

Fig. 78 Aptrootia terricola (Sipman 35503; f, j: Sipman 51849). a Herbarium package and specimen. b, c, f Thallus with ascomata. d Vertical section through an ascoma. e Ostiolar region with periphyses. $\mathbf{g}-\mathbf{h}$ Perithecial wall in thin section, and the outer layer become

a gelatinous matrix, in some species inspersed with oil droplets. Asci 2-8-spored, bitunicate, fissitunicate, oblong-ellipsoid, short pedicellate, with a non-amyloid ocular chamber. Ascospores irregularly arranged, oblong-ellipsoid, hyaline to reddish in $10 \% \mathrm{KOH}$. i Paraphysoids. j Trentepohlioid photobiont. k, l Asci. m, $\mathbf{n}$ Ascospores. o Ascospore in Lugol's iodine. Scale bars: $\mathbf{b}, \mathbf{c}=1 \mathrm{~mm}, \mathbf{d}=200 \mu \mathrm{m}, \mathbf{e}, \mathbf{k}-\mathbf{n}=50 \mu \mathrm{m}, \mathbf{f}=500 \mu \mathrm{m}, \mathbf{g}-\mathbf{i}=20 \mu \mathrm{m}$, $\mathbf{j}=10 \mu \mathrm{m}$

mostly dark brown, 3-5-septate and very large (usually over $100 \mu \mathrm{m}$ ) or rarely muriform and small, somewhat distoseptate but not astrothelioid, smooth-walled or with longitudinal wall folds or crystals, not or slightly constricted at the septa, 
surrounded by a mucilaginous sheath. Pycnidia unknown. Chemistry: lichexanthone sometimes produced on thallus surface.

Type species: Architrypethelium seminudum (Mont.) Aptroot. [= Architrypethelium nitens (Fée) Aptroot in Aptroot et al., Biblioth. Lichenol. 97: 38 (2008)].

Notes: For discussion see Aptroot and Lücking (2016). The genus currently includes eight species. With the recent, surprising discovery of a species with rather small, muriform ascospores falling into this clade (Luangsuphabool et al. 2018), the generic boundaries towards Astrothelium have become more diffuse.

Astrothelium Eschw., Syst. Lich.: 18, 26 (1824).

MycoBank number: MB 443; Index Fungorum number: IF 443; Facesoffungi number: FoF 08788; Over 250 morphologically defined species (Aptroot and Lücking 2016; Lücking et al. 2017); molecular data available for over 50 species (Lücking et al. 2016).

Lichenized on bark in terrestrial, chiefly lowland to lower montane tropical habitats. Thallus distinctly corticate, yellow-brown to mostly green. Photobiont Trentepohlia. Ascomata scattered, clustered, aggregated in pseudostromata, or fused with common ostiole, immersed to sessile, brown-black but usually covered by thick thallus layer except for ostiolar area, globose to pear-shaped or conical, coriaceous to carbonaceous, ostiolate, ostiole round. Excipulum prosoplectenchymatous, dark brown to brown-black. Hamathecium comprising 0.5-0.7 $\mu \mathrm{m}$ wide paraphysoids, hyaline, straight, branched and anastomosing, embedded in a thick, gelatinous matrix. Asci 1-8-spored, bitunicate, fissitunicate, obclavate, short pedicellate, with a non-amyloid ocular chamber. Ascospores irregularly arranged to uni- or biseriate, fusiform-ellipsoid to oblong-cylindrical, hyaline, septate to muriform, with distinct distosepta and sometimes eusepta and diamond-shaped lumina (best visible in septate ascospores), smooth-walled, not or slightly constricted at the septa, often surrounded by an evanescent mucilaginous material on the outside, either as polar pads, or irregular median pads or a complete sheath enveloping the whole ascospore. Pycnidia known from a few species, immersed to erumpent, visible as black dots. Conidia acrogenous, rodshaped, hyaline. Chemistry: lichexanthone sometimes produced on thallus surface; yellow to orange or red anthraquinones and perylenequinones often produced in the medulla of the thalline layer covering the perithecia and sometimes in the thallus medulla or superficial on various parts of the thallus.

Type species: Astrothelium conicum Eschw., Syst. Lich.: 26 (1824) [= Astrothelium cinnamomeum (Eschw.) Müll. Arg., Flora 67: 670 (1884)].

Notes: Astrothelium traditionally included species with thallus-dominated perithecia featuring lateral, fused ostioles and transversely septate, astrothelioid ascospores. In its modern circumscription (Aptroot and Lücking 2016), practically all species with thickly corticate thalli, thallus-dominated perithecia, and astrothelioid ascospores are now included in this genus, regardless of the disposition of the perithecia and their ostioles or ascospore septation, with a total of over 250 taxa (Aptroot and Lücking 2016; Cáceres and Aptroot 2017; Aptroot and Weerakoon 2018; Aptroot et al. 2019). Astrothelium is essentially a fusion of the previously separated genera Astrothelium, Bathelium p.p., Campylothelium, Cryptothelium, Laurera, and Trypethelium p.p. Harris (1995) had already predicted the existence of this clade, suggesting the use of the name Laurera. However, Laurera postdates Astrothelium, a name Harris (1995) intended to reserve for a small group of species that have been shown to form part of a single, large clade including most species of the family (Lücking et al. 2016).

\section{Bathelium Ach., Method. Lich.: 111 (1803).}

MycoBank number: MB 517; Index Fungorum number: IF 517; Facesoffungi number: FoF 08789; 16 morphologically defined species (Aptroot and Lücking 2016; Lücking et al. 2017); molecular data available for four species (Lücking et al. 2016).

Lichenized on bark in terrestrial, chiefly lowland to lower montane tropical habitats, often in drier situations. Thallus corticate, yellow-brown to olive-green. Photobiont Trentepohlia. Ascomata solitary to aggregated in distinct pseudostromata, prominent to sessile, brown-black and remaining fully exposed, rarely pruinose, coriaceous to carbonaceous, ostiolate, ostiole apical. Involucrellum reduced. Excipulum brown-black. Hamathecium comprising 0.5-0.7 $\mu \mathrm{m}$ wide paraphysoids, hyaline, straight, branched and anastomosing, embedded in a gelatinous matrix. Asci 1-8-spored, bitunicate, fissitunicate, clavate to oblong, short pedicellate, with a non-amyloid ocular chamber. Ascospores irregularly arranged to biseriate, fusiform-ellipsoid, hyaline, septate to mostly muriform, more or less euseptate, smooth-walled, not or slightly constricted at the septa (often at the middle septum only), surrounded by a gelatinous sheath. Pycnidia unknown. Chemistry: lichexanthone sometimes produced on thallus surface; yellow to orange anthraquinones often produced in the medulla of the pseudostromata.

Type species: Bathelium mastoideum Afz. ex Ach., Method. Lich.: 111 (1803).

Notes: For key and discussion see Aptroot and Lücking (2016).

Bogoriella Zahlbr., Annals Cryptog. Exot. 1(2): 111 (1928). MycoBank number: MB 608; Index Fungorum number: IF 608; Facesoffungi number: FoF 08790; 18 morphologically defined species (this paper); molecular data available 


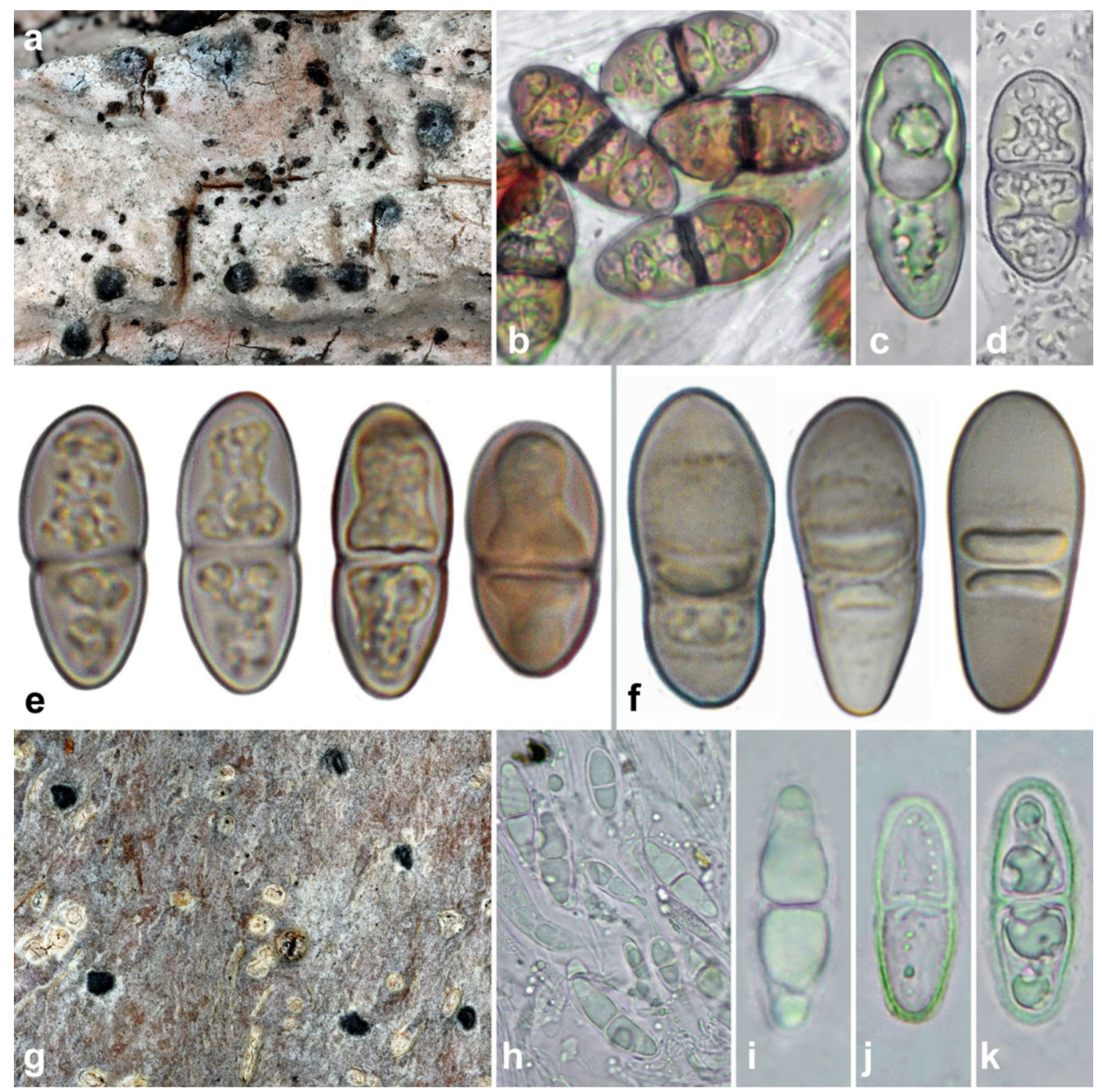

Fig. 79 a-d Bogoriella complexoluminata (holotype). a Thallus with ascomata. b-d Ascospores in various stages of development. e $B$. isthmospora (Aptroot s.n.), ascospores in various stages of development. f Schummia angulata (Aptroot 14061), ascospores in various stages of development. $\mathbf{g - k}$ Macroconstrictolumina megalateralis

for four species (Lücking et al. 2016; Zhang et al. 2017b; this paper).

= Ornatopyrenis Aptroot, Biblioth. Lichenol. 44: 127 (1991). Type species: Ornatopyrenis queenslandica (Müll. Arg.) Aptroot [三 Bogoriella queenslandica (Müll. Arg.) Aptroot \& Lücking].

$=$ Distothelia Aptroot in Seaward \& Aptroot, Bryologist 108: 284 (2005). Type species: Distothelia isthmospora Aptroot in Seaward \& Aptroot, Bryologist 108: 284 (2005).

$=$ Novomicrothelia Aptroot, M.P. Nelsen \& Lücking in Lücking et al., Lichenologist 48: 757 (2016). Type species: (holotype). $\mathbf{g}$ Thallus with ascomata. $\mathbf{h}$ Hamathecium and ascospores. $\mathbf{i}-\mathbf{k}$ Ascospores in various stages of development. Scale bars: $\mathbf{a}, \mathbf{g}=1$ $\mathrm{mm}, \mathbf{b}-\mathbf{f}, \mathbf{h}-\mathbf{k}=10 \mu \mathrm{m}$. Photographs by André Aptroot except $\mathbf{e}$ and f, by Felix Schumm

Novomicrothelia oleosa (Aptroot) Aptroot, M.P. Nelsen \& Lücking in Lücking et al., Lichenologist 48: 758 (2016).

Lichenized (sometimes barely so or apparently nonlichenized) on bark in terrestrial, chiefly lowland to lower montane tropical habitats. Thallus ecorticate, mostly whitish to pale brownish. Photobiont Trentepohlia. Ascomata solitary, erumpent to prominent, brown-black to carbonaceous, hemisphaerical to wart-shaped or conical, coriaceous to carbonaceous, ostiolate, ostiole apical to rarely lateral. Involucrellum usually well-developed, carbonaceous. Excipulum prosoplectenchymatous, usually brownish, in lateral and apical parts typically fused with the involucrellum. 


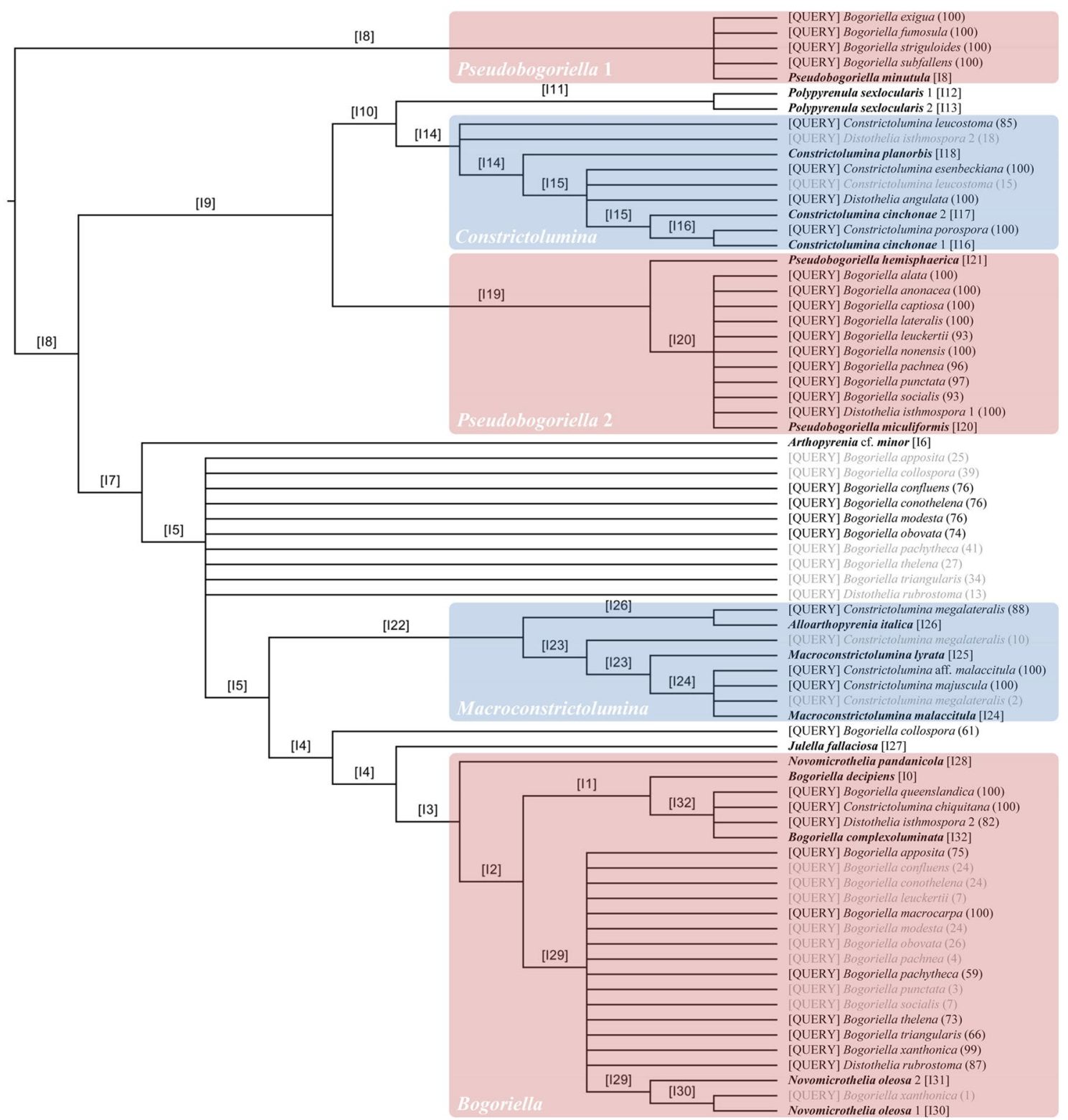

Fig. 80 Classification tree for non-sequenced species of Bogoriella sensu lato and Constrictolumina sensu lato [QUERY] based on phenotype-based phylogenetic binning into a molecular reference tree of sequenced species (in boldface). Numbers in parentheses behind each

Hamathecium comprising 1(-2) $\mu \mathrm{m}$ wide para-physoids, hyaline, straight to somewhat wavy, branched and anastomosing, embedded in a thin, gelatinous matrix. Asci 8 -spored, bitunicate, fissitunicate, (ob-)clavate to fusiform, short pedicellate, with a non-amyloid ocular chamber. Ascospores irregularly arranged to uni- or biseriate, fusiform-ellipsoid to oblong, grey-brown, 1-5-septate to small muriform, with eusepta and rectangular lumina or with thickened distosepta making the lumina appear halter-shaped, wall smooth to finely granular ornamented, not constricted at the septa or rarely with constrictions. Pycnidia known from query taxon represent bootstrap support for the corresponding placement. Queries with alternative placements supported with less than $70 \%$ are greyed out

a few species, immersed to erumpent, visible as black dots. Conidia fusiform, aseptate, bacillar, hyaline, $4-5 \times 0.8 \mu \mathrm{m}$. Chemistry: no substances detected by TLC.

Type species: Bogoriella subpersicina Zahlbr., Annals Cryptog. Exot. 1: 111 (1928) [= Bogoriella decipiens (Müll. Arg.) Aptroot \& Lücking].

Sequence data for Bogoriella decipiens: mtSSU: MT968881.

Notes: Aptroot and Lücking (2016) adopted the name Bogoriella for more or less lichenized, tropical species previously classified in the genus Mycomicrothelia (Hawksworth 
1985). The expanded molecular phylogeny now available shows that these taxa form several lineages (Fig. 77): two in a paraphyletic grade formed by the most basally diverging lineages, and three in a distant clade, forming several lineages on long branches. One of these had been named Novomicrothelia (Aptroot and Lücking 2016; Lücking et al. 2016), whereas a second clade of previously unpublished sequences includes the type species of Bogoriella, together with a new taxon, both with small muriform ascospores, one with eusepta and the other with peculiar distosepta (Fig. 79a-d). The third clade is formed by the recently described species Novomicrothelia pandanicola S.N. Zhang \& K.D. Hyde (Zhang et al. 2017b). In the original analysis, nuLSU sequence data suggested a phylogenetic position of the latter close to $N$. oleosa, prompting inclusion in that genus. Our expanded phylogeny based on new mtSSU data showed that the genus Bogoriella, for which no data were originally available (Zhang et al. 2017b), is nested within Novomicrothelia sensu lato. Novomicrothelia pandanicola forms small, rather narrow $(20-35 \times 7-10 \mu \mathrm{m}$, about 3-3.5 times as long as broad), muriform ascospores with thin walls and septa and constrictions at the septa, whereas in the Bogoriella sensu stricto clade the ascospores are broadly ellipsoid (20-30 × 12-16 $\mu \mathrm{m}$, about 1.5-2 times as long as broad) and muriform with either thin or conspicuously thickened walls and septa. Novomicrothelia sensu stricto has thin-walled, 1-septate ascospores without constrictions.

The species hitherto classified in Bogoriella sensu lato (including Novomicrothelia) thus represent a polyphyletic assembly. Given that most species of this morphodeme have not been sequenced yet, we employed morphology-based phylogenetic binning (Berger et al. 2011; Parnmen et al. 2012; Lücking and Kalb 2018) to assess the likely placement of the remaining species. As a result, 13 species clustered with support with the basal paraphyletic grade formed by B. minutula, B. miculiformis, and B. hemisphaerica, seven clustered with Novomicrothelia sensu stricto, none with $N$. pandanicola, four outside but close to Novomicrothelia in an unresolved position, and three with Bogoriella sensu stricto (Fig. 80). Given this result, the underlying topology, and the observation that taxa with different ascospore types ( $B$. complexoluminata and $B$. decipiens) are closely related, we saw no alternative to merging Bogoriella and Novomicrothelia into a single genus, under the name Bogoriella. The basal grade is here recognized conservatively as a separate, single genus, under the name Pseudobogoriella (see below).

Based on the phylogenetic analysis and the binning exercise, Bogoriella in its revised sense includes three generic synonyms, since the type species of Distothelia $(D$. isthmospora) and Ornatopyrenis (O. queenslandica) are also assigned to this genus by the binning approach. Indeed, the ascospores of the type species of the latter two genera are similar to those of B. complexoluminata (Fig. 79b-e) in development and endospore formation (Aptroot 1991; Harris 1995; Seaward and Aptroot 2005). One species previously placed in Distothelia, D. angulata, is here transferred to the new genus Schummia, as its ascospores are quite different (Fig. 79f; see below).

New species and new combinations in Bogoriella Bogoriella chiquitana (Flakus, Kukwa \& Aptroot) Lücking, R. Miranda \& Aptroot comb. nov.

MycoBank number: MB 836785; Index Fungorum number: IF 836785; Facesoffungi number: FoF 08791

Bas.: Constrictolumina chiquitana Flakus, Kukwa \& Aptroot, Lichenologist 48: 681 (2016).

Bogoriella complexoluminata Aptroot \& Lücking sp. nov. (Fig. 79a-d)

MycoBank number: MB 836786; Index Fungorum number: IF 836786; Facesoffungi number: FoF 08792

Etymology: Named for the complex lumina of the ascospores.

Diagnosis: Corticolous Bogoriella with thallus UV-negative; ostioles apical, ascospores $27-37 \times 10-15 \mu \mathrm{m}$, initially hyaline and 1-septate with an euseptum, constricted at the septum, wall thickened in two open distosepta two places in each cell, so as to from three pseudoloculi per cell; mature ascospores brown with 1 dark brown median euseptum and a distoseptate wall that leaves six rows of 2-6 oval loculi of c. $5 \mu \mathrm{m}$ diam.

Holotype: A. Aptroot 78050 (CGMS; isotype: ABL).

GenBank accessions for type-based sequences: mtSSU: MT968880.

Thallus inapparent, immersed in the soft, corky bark, covering up to $10 \mathrm{~cm}$ diam., apparently not lichenized; no algae observed. Ascomata erumpent to sessile, hemisphaerical with flattened top, black, $0.3-0.5 \mathrm{~mm}$ diam. and up to 0.4 $\mathrm{mm}$ high; ostiole black, minute, usually in a c. $0.1 \mathrm{~mm}$ wide and $0.05 \mathrm{~mm}$ deep depression; clypeus covering the top and the sides; wall c. $100 \mu \mathrm{m}$ thick at the sides, only c. $20 \mu \mathrm{m}$ thick below the hamathecium. Hamathecium clear, hyaline, of c. $1 \mu \mathrm{m}$ wide filaments that are anastomosing above the asci. Asci broadly cylindrical, c. $100 \times 25 \mu \mathrm{m}$, wall c. 2 $\mu \mathrm{m}$ thick all around; without ocular chamber. Ascospores 8/ascus, $27-37 \times 10-15 \mu \mathrm{m}$, initially hyaline and 1-septate with an euseptum, constricted at the septum, wall thickened in two open distosepta two places in each cell, so as to form three pseudoloculi per cell; mature ascospores brown with 1 dark brown median euseptum and a distoseptate wall that leaves six rows of 2-6 oval loculi of c. $5 \mu \mathrm{m}$ diam. Pycnidia not observed.

Chemistry: Thallus UV-, C-, P-, K-. TLC: nil. 
Ecology and distribution: On tree bark in rural and urban areas; thus far only known from Brazil.

Material examined: Brazil. Mato Grosso do Sul, Campo Grande, UFMS campus; 20³0’ S, 54³7' W, 550 m; on soft, corky bark of Aspidosperma tomentosa (Apocynaceae) tree (identified by Dr Angela Sartori); 22 November 2018, A. Aptroot 78050 (holotype: CGMS; isotype: ABL); Bonito, outskirts, near tower; $21^{\circ} 07^{\prime} 44^{\prime \prime} \mathrm{S}, 56^{\circ} 30^{\prime} 41^{\prime \prime} \mathrm{W}, 475 \mathrm{~m}$; on bark of tree; 9 November 2018, A. Aptroot 78013 (paratype: CGMS).

Notes: This new species is phylogenetically closely related to the type species, Bogoriella decipiens, but the latter differs in having regularly muriform ascospores. The endospore development of $B$. complexoluminata appears to be unique, producing a peculiar shape of the lumina.

Bogoriella isthmospora (Aptroot) Lücking, R. Miranda \& Aptroot comb. nov. (Fig. 79e)

MycoBank number: MB 836787; Index Fungorum number: IF 836787; Facesoffungi number: FoF 08793

Bas.: Distothelia isthmospora Aptroot in Seaward \& Aptroot, Bryologist 108: 284 (2005).

Bogoriella pandanicola (S.N. Zhang \& K.D. Hyde) S.N. Zhang, Lücking \& Aptroot comb. nov.

MycoBank number: MB 836822; Index Fungorum number: IF 836822; Facesoffungi number: FoF 09232.

Bas.: Novomicrothelia pandanicola S.N. Zhang \& K.D. Hyde in Zhang et al., Phytotaxa 321: 258 (2017).

Sequence data: mtSSU: MT967501.

Bogoriella rubrostoma (Aptroot) Lücking, R. Miranda \& Aptroot comb. nov.

MycoBank number: MB 836788; Index Fungorum number: IF 836788; Facesoffungi number: FoF 08794

Bas.: Mycomicrothelia rubrostoma Aptroot, Biblioth. Lichenol. 44: 135 (1991); Distothelia rubrostoma (Aptroot) Aptroot \& Lücking, Lichenologist 48(6): 927 (2016).

\section{Key to species of Bogoriella:}

1. Ascospores becoming distinctly muriform, with thin eusepta and rectangular lumina.................... 2

1. Ascospores 1-septate to rarely 3-septate or submuriform, with thin eusepta or with irregularly thickened endospore and distosepta........................4

2. Ascospores becoming thick-walled and with thickened median septum, 28-45 $\mu \mathrm{m}$ long

Bogoriella chiquitana

2. Ascospores remaining thin-walled, 20-35 $\mu \mathrm{m}$ long..........................................
3. Ascospores $20-30 \times 12-16 \mu \mathrm{m}$, about $1.5-2$ times as long as broad.

Bogoriella decipiens

3. Ascospores 20-35 × 7-10 $\mu \mathrm{m}$, about 3-3.5 times as long as broad. ...

Bogoriella pandanicola

4. Ascospores with irregularly thickened endospore and distosepta, 1-septate or rarely 3-septate to submuriform; lumina irregular to halter-shaped...............5

4. Ascospores with thin eusepta, 1-septate or rarely 3-septate; lumina rectangular...........................8

5. Ascospores (1-)3-septate to appearing submuriform,

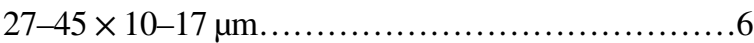

5. Ascospores 1-septate but cells with irregular endospore invaginations, $15-29 \times 6-14 \mu \mathrm{m} . . . \ldots \ldots . . \ldots \ldots . . .7$

6. Ascospores mostly distinctly 3 -septate, occasionally 1-septate or with additional longitudinal septa.........

Bogoriella queenslandica

6. Ascospores with one distinct, rather dark central septum and the two cells with irregular endospore invaginations giving them the appearance of a (sub-)muriform division. Bogoriella complexluminata

7. Ostiole with red pigment; ascospores 23-29 × 10-14 $\mu \mathrm{m}$, secondary endospore invaginations developing late.

Bogoriella isthmospora

7. Ostiole lacking pigment; ascospores $15-18 \times 6-8 \mu \mathrm{m}$, secondary endospore invaginations developing soon...

...........................Bogoriella rubrostoma

8. Ostiole lateral.................Bogoriella triangularis

8. Ostiole apical................................... 9

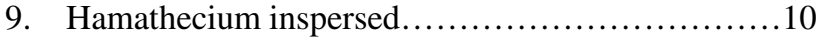

10. Hamathecium clear............................12

10. Ascospores $24-27 \times 8-11 \mu \mathrm{m}$.

Bogoriella oleosa

10. Ascospores $30-45 \times 10-15 \mu \mathrm{m} \ldots \ldots \ldots \ldots \ldots \ldots . \ldots 11$

11. Ascomata $0.5-0.7 \mathrm{~mm}$ diam.......................

1. Ascomata $0.7-1.1 \mathrm{~mm}$ diam.

Bogoriella xanthonica

Bogoriella macrocarpa

12. Ascospores becoming 3-septate.

Bogoriella obovata

12. Ascospores remaining 1-septate.................13

13. Ascospores $28-40 \mu \mathrm{m}$ long......Bogoriella megaspora

13. Ascospores 17-27 $\mu \mathrm{m}$ long..................... 14

14. Black prothallus line present.....................15

14. Black prothallus line absent......................16

15. Asci 10-20 $\mu \mathrm{m}$ broad.........Bogoriella conothelena

15. Asci 20-30 $\mu \mathrm{m}$ broad.........Bogoriella thelena

16. Ascomata $0.8-1 \mathrm{~mm}$ diam., basally broadly expanded.......................Bogoriella confluens

16. Ascomata $0.2-0.4 \mathrm{~mm}$ diam., basally barely or not expanded.......................................17

17. Ascomata conical..............Bogoriella pachytheca

17. Ascomata flattened.................Bogoriella modesta 
Constrictolumina Aptroot, M.P. Nelsen \& Lücking in Lücking et al., Lichenologist 48: 756 (2016).

MycoBank number: MB 816872; Index Fungorum number: IF 816872; Facesoffungi number: FoF 08795; five morphologically defined species (this paper); molecular data available for two species (Lücking et al. 2016).

Lichenized on bark in terrestrial, chiefly lowland to lower montane tropical habitats. Thallus ecorticate, usually whitish. Photobiont Trentepohlia. Ascomata solitary to rarely aggregate, erumpent to prominent, carbonaceous, ostiolate, ostiole apical to rarely lateral. Involucrellum carbonized. Excipulum prosoplectenchymatous, brownish to colorless below. Hamathecium comprising ca. $1 \mu \mathrm{m}$ wide, hyaline, straight, branched and anastomosing, pseudoparaphyses, embedded in a gelatinous matrix. Asci 4-8-spored, bitunicate, fissitunicate, clavate, short pedicellate, with a nonamyloid ocular chamber. Ascospores irregularly arranged to biseriate, fusiform-ellipsoid, hyaline, 1-3-septate, euseptate, with secondary constrictions in each cell and often with slightly thickened walls, smooth-walled, slightly constricted at the septum, with a gelatinous halo, rather small (15-30 $\times$ 5-11 $\mu \mathrm{m})$. Pycnidia unknown. Chemistry: no substances detected by TLC.

Type species: Constrictolumina cinchonae (Ach.) Lücking, M.P. Nelsen \& Aptroot in Lücking et al., Lichenologist 48(6): 756 (2016).

Notes: This genus was recently introduced for lichenized species of Arthopyrenia sensu lato with secondary cell wall constrictions clustering within Trypetheliaceae (Aptroot and Lücking 2016; Lücking et al. 2016). At the time, it was already noted that the species formed two lineages, $C$. malaccitula coming out separate. A phenotype-based phylogenetic binning approach of 11 species included in the genus demonstrated that about half of them each cluster with either with notable differences in the ascospores, those of the $C$. malaccitula group being mostly larger [(20-)30-50 $\times$ (7-)10-16 $\mu \mathrm{m})$ ], with more distinct secondary constrictions, and granular ornamented. We therefore introduce the genus Macroconstrictolumina for this group below. Constrictolumina in a strict sense then retains five species, which are keyed out below.

\section{Key to species of Constrictolumina sensu stricto}

1. Ascospores $17-23 \times 5-8 \mu \mathrm{m}, 1-3$-septate............2

1. Ascospores (20-)22-46 × 7-24 $\mu \mathrm{m}, 1$-septate.......... 3

2. Perithecia aggregate...Constrictolumina esenbeckiana

2. Perithecia solitary.........Constrictolumina cinchonae

3. Ascospores 40-46 × 16-24 $\mu \mathrm{m}$. Constrictolumina porospora

3. Ascospores $20-30 \times 7-16 \mu \mathrm{m}$......................4

4. Perithecia aggregate; ascospores 3-septate.

Constrictolumina leucostoma
4. Perithecia solitary; ascospores 1(-3)-septate..

Constrictolumina planorbis

Dictyomeridium Aptroot, M.P. Nelsen \& Lücking in Lücking et al., Lichenologist 48: 756 (2016).

MycoBank number: MB 816873; Index Fungorum number: IF 816873; Facesoffungi number: FoF 08796; seven morphologically defined species (Aptroot and Lücking 2016); molecular data available for one species (Lücking et al. 2016).

Lichenized on bark in terrestrial, chiefly lowland to lower montane tropical habitats, typically in drier situations. Thallus ecorticate, usually whitish. Photobiont Trentepohlia. Ascomata solitary to sometimes aggregated, erumpent to prominent, somewhat pyriform when seen from above, brown-black to grey-black, carbonaceous, ostiolate, ostiole lateral. Involucrellum carbonized. Excipulum prosoplectenchymatous, brownish. Hamathecium comprising 0.5-0.7 $\mu \mathrm{m}$ wide paraphysoids, hyaline, straight, branched and anastomosing, embedded in a gelatinous matrix. Asci 2-8-spored, bitunicate, fissitunicate, clavate, short pedicellate, with a non-amyloid ocular chamber. Ascospores irregularly arranged to biseriate, oblong-ellipsoid, hyaline, often I+ amyloid, muriform, euseptate, smooth-walled, not constricted at the septa, with a gelatinous sheath. Pycnidia known from a few species, immersed to erumpent, visible as black dots. Conidia aseptate, bacillar, hyaline. Chemistry: lichexanthone sometimes produced on thallus surface.

Type species: Dictyomeridium proponens (Nyl.) Aptroot, M.P. Nelsen \& Lücking in Lücking et al., Lichenologist 48): 757 (2016)

Notes: For key and discussion see Aptroot and Lücking (2016).

"Julella" fallaciosa (Stizenb. ex Arnold) R.C. Harris, in Egan, Bryologist 90(2): 163 (1987)

MycoBank number: MB 132219; Index Fungorum number: IF 132219; Facesoffungi number: FoF 08797.

Notes: The genus Julella has usually been considered a muriform-spored counterpart of Arthopyrenia sensu lato (Barr 1985, 1987b; Harris 1995). Species assigned to this genus are typically non-lichenized and possibly saprobic, about some doubtful lichenization has been discussed (Aptroot 2002a). The few studies available about this genus seem to disagree widely about species taxonomy. Thus, while Harris (1995) distinguished at least 13 species, Aptroot and van den Boom (1995) only accepted three. The latter authors included all forms with 2-4(-6) ascospores in a single species, J. lactea (A. Massal.) M.E. Barr, whereas Harris (1995) keyed out six species in this group, separated by ascospore size and numbers of ascospores per ascus. Among taxa with 8-spored asci, Aptroot and van den Boom (1995) 
distinguished two species: J. vitrispora (Cooke \& Harkn.) M.E. Barr with longer ascospores and larger ascomata and J. sericea (A. Massal.) Coppins with shorter ascospores and smaller ascomata. In contrast, Harris (1995) accepted at least seven species in this group, distinguished by ascus shape and ascospore arrangement, size, and color, among other features. These differences are less the result of a disparate species concept (the theoretical approach of both treatments not being that much different) and more due to the fact that these authors studied a very different set of names and material and hence came to such different conclusions. Given the findings in other, similarly defined genera such as Arthopyrenia sensu lato, it is conceivable that Julella is also a highly heterogeneous assemblage not only including many species but also representing several, partly unrelated genera.

Only two species of Julella have been sequenced so far, viz. J. avicenniae (Borse) K.D. Hyde and J. fallaciosa (Nelsen et al. 2011a, 2014; Ariyawansa et al. 2013a; Lücking et al. 2016), thus not including the type species, J. buxi. Julella avicenniae was shown to be different from the type species in ascus type, the brownish ascospores, and the habitat on bark of mangrove trees in the genus Avicennia, a notion anticipated by Harris (1995), and consequently was placed in a separate, monospecific genus and family, Halojulella and Halojulellaceae (Ariyawansa et al. 2013a). The sequenced material of $J$. fallaciosa, which agrees well with the key provided by Harris (1995) and Wirth et al. (2013) clustered within Trypetheliaceae (Nelsen et al. 2011a, 2014; Lücking et al. 2016; Fig. 77), which is in line with the ascus featuring a broad ocular chamber and the hamathecial physes being thin and anastomosing. Notably, most species currently placed in Julella agree with J. fallaciosa in ascus and hamathecium type and are likely congeneric with $J$. fallaciosa, whereas the type, J. buxi, differs by the asci lacking a distinct tholus and ocular chamber and by the physes being flexuose and only sparsely branched (Barr 1987b; Ariyawansa et al. 2013a). This situation is thus comparable to that of Arthopyrenia (Lücking and Nelsen in Hyde et al. 2013).

Barr (1987b) was the first to propose synonymy of the genera Polyblastiopsis, based on P. naegelii (= Julella lacteal), and Peltosphaeria, based on P. vitrispora (三 Julella vitrispora), with Julella. Various workers pointed out the asci with broad ocular chamber and the thin, anastomosing physes of the type species of both genera (Riedl 1971; Barr 1987b; Mayrhofer 1987), which suggests that these taxa are not actually congeneric with $J$. buxi but would likely cover the clade falling in Trypetheliaceae. We have refrained from taking up either name for this clade, given that most species of this complex have not been sequenced and also considering the complex situation emerging with the taxa previously placed on Arthopyrenia sensu lato and Mycomicrothelia sensu lato, which now form several clades each within Trypetheliaceae. Indeed, the two types of Polyblastiopsis and Peltosphaeria differ in ascospore shape, being (ob-)clavate in Polyblastiopsis naegelii (J. lactea group) and cylindrical in Peltosphaeria vitrispora (J. vitrispora group). Thus, if the two generic names indeed correspond to two separate phylogenetic units, then Polyblastiopsis would be the name applicable to the $J$. fallaciosa clade, as the latter belongs in the J. lactea group (Harris 1995; Aptroot and van den Boom 1995). However, if both groups are congeneric, then the older name Peltosphaeria has priority.

Index Fungorum currently lists Polyblastiopsis sericea (三Julella sericea) as type of Polyblastiopsis. However, Clements and Shear (1931) had listed P. naegelii as lectotype, a selection adopted by Riedl (1971) and Barr (1987b). Polyblastiopsis was established as replacement name for Polyblastia (Müller 1882), an illegitimate later homonym of Polyblastia [nom. cons.]. Since Zahlbruckner (1907) did not cite a type, Polyblastiopsis is to be typified by the type of Polyblastia, which means the lectotypification by Clements and Shear (1931) must be in accordance with Müller's (1882) protologue. This fortunately is the case, as P. naegelii is explicitly listed in the protologue. While Aptroot and van den Boom (1995) synonymized P. naegelii under J. lactea, both Riedl (1971) and Barr (1987b) recognized the taxon as variety of the latter, according to Riedl (1971) differing in the complete (var. lactea) vs. cap-shaped (var. naegelii) gelatinous sheath of the ascospores and in substrate preferences (Fraxinus vs. conifers). Given that the two taxa have overlapping ranges, it seems appropriate to recognize them as separate species, in which case the type of Polyblastiopsis is to be cited as $P$. naegelii and not as P. lactea or P. sericea.

\section{Macroconstrictolumina Lücking, R. Miranda \& Aptroot gen. nov.}

MycoBank number: MB 836789; Index Fungorum number: IF 836789; Facesoffungi number: FoF 08798; Four morphologically defined species (this paper); molecular data available for two species (Lücking et al. 2016; this paper).

Diagnosis: Differing from Constrictolumina chiefly in the larger ascospores with granular ornamentation.

Etymology: The name refers to the relatively large ascospores.

Lichenized on bark in terrestrial, chiefly lowland to lower montane tropical habitats. Thallus ecorticate, usually whitish. Photobiont Trentepohlia. Ascomata solitary to rarely aggregate, erumpent to prominent, carbonaceous, ostiolate, ostiole apical to rarely lateral. Involucrellum carbonized. Excipulum prosoplectenchymatous, brownish to colourless below. Hamathecium comprising ca. $1 \mu \mathrm{m}$ wide pseudoparaphyses, hyaline, straight, branched and anastomosing, embedded in a gelatinous matrix. Asci 2-8-spored, bitunicate, fissitunicate, clavate, short pedicellate, with a nonamyloid ocular chamber. Ascospores irregularly arranged 
to biseriate, fusiform-ellipsoid, hyaline, 1(-3)-septate, euseptate, with secondary constrictions in each cell and often with slightly thickened walls, typically granular ornamented, slightly constricted at the septum, with a gelatinous halo, medium-sized [30-50 × 10-16(-24) $\mu \mathrm{m}]$, only in one species (M. lyrata) somewhat smaller. Pycnidia unknown. Chemistry: no substances detected by TLC.

Type species: Macroconstrictolumina malaccitula ( $\mathrm{Nyl}$. Lücking, R. Miranda \& Aptroot (see below).

Notes: This new genus accommodates the lineage phylogenetically separate from the Constrictolumina cinchonae group (Fig. 77), but which had so far been included in that genus (Aptroot and Lücking 2016; Lücking et al. 2016). The difference in ascospore size, in combination with the granular ornamented ascospore wall, appears to be consistent, but further species of both genera need to be sequenced to test this taxonomic hypothesis developed from the binning exercise (Fig. 80).

\section{New species and new combinations in Macroconstrictolu} mina:

Macroconstrictolumina lyrata (R.C. Harris) Lücking, R. Miranda \& Aptroot comb. nov.

MycoBank number: MB 836790; Index Fungorum number: IF 836790; Facesoffungi number: FoF 08799.

Bas.: Arthopyrenia lyrata R.C. Harris in Tucker \& Harris, Bryologist 83: 6 (1980); Constrictolumina lyrata (R.C. Harris) Lücking, M.P. Nelsen \& Aptroot in Aptroot \& Lücking, Lichenologist 48: 921 (2016).

Sequence data: mtSSU: MT948052.

Macroconstrictolumina majuscula (Nyl.) Lücking, R. Miranda \& Aptroot comb. nov.

MycoBank number: MB 836791; Index Fungorum number: IF 836791; Facesoffungi number: FoF 08800.

Bas.: Verrucaria majuscula Nyl., Ann. Sci. Nat., Bot., Sér. 4 20: 253 (1863); Arthopyrenia majuscula (Nyl.) Zahlbr., Cat. Lich. Univers. 1: 332 (1922); Ciferriolichen majusculus (Nyl.) R.C. Harris, Moscosoa 6: 215 (1990); Constrictolumina majuscula (Nyl.) Lücking, M.P. Nelsen \& Aptroot in Aptroot \& Lücking, Lichenologist 48: 921 (2016).

Macroconstrictolumina malaccitula (Nyl.) Lücking, R. Miranda \& Aptroot comb. nov.

MycoBank number: MB 836792; Index Fungorum number: IF 836792; Facesoffungi number: FoF 08801.

Bas.: Verrucaria malaccitula Nyl. in Nylander \& Crombie, J. Linn. Soc., Bot. 20: 61 (1883); Arthopyrenia malaccitula (Nyl.) Zahlbr., Cat. Lich. Univers. 1: 284 (1921); Constrictolumina malaccitula (Nyl.) Lücking, M.P. Nelsen \& Aptroot in Aptroot \& Lücking, Lichenologist 48: 921 (2016).
$=$ Tomasellia dispora Müll. Arg., Flora, Regensburg 70: 427 (1887).

= Arthopyrenia bifera Zahlbr., Annls mycol. 33(1/2): 34 (1935).

= Megalotremis biocellata Aptroot, Biblthca Lichenol. 44: 125 (1991).

Notes: This species is being discussed in detail in the Monoblastiaceae treatment of this issue (Lücking et al. in this paper), based on the finding that Megalotremis biocellata, previously classified in a genus belonging to Monoblastiaceae, was found to be conspecific with M. malaccitula.

Macroconstrictolumina megalateralis Aptroot sp. nov. (Fig. 79 g-k)

MycoBank number: MB 836793; Index Fungorum number: IF 836793; Facesoffungi number: FoF 08802.

Diagnosis: Corticolous Macroconstrictolumina with thallus UV-negative; ostioles lateral, ascospores granular ornamented, 34-37 × 11-14 $\mu \mathrm{m}$, with gelatinous sheath of c. $4 \mu \mathrm{m}$.

Etymology: The epithet refers to the large ascomata and ascospores and the lateral ostioles.

Holotype: A. Aptroot 77751 (CGMS).

Thallus crustose, endoperidermal, whitish to pinkish, opaque, not surrounded by a prothallus. Ascomata solitary, pyriform, 0.6-0.8 mm diam., black. Ostioles lateral, black. Hamathecium clear. Ascospores 8/ascus, hyaline, 1-septate, septum median, 34-37 × 11-14 $\mu \mathrm{m}$, sole-shaped with upper cell wider than lower cell, with conspicuous granular wall ornamentation, more or less distinctly constricted but not thickened at the median septum, with secondary constriction or invagination in each cell, surrounded by a c. $4 \mu \mathrm{m}$ thick gelatinous sheath. Pycnidia not observed.

Chemistry: Thallus UV-, $\mathrm{C}-, \mathrm{P}-, \mathrm{K}-$; no substances detected by TLC.

Ecology and distribution: On tree bark in Atlantic Forest; thus far only known from Brazil.

Material examined: Brazil. Mato Grosso do Sul: Serra da Bodoquena, Bonito, Fazenda Marambaia; 2058' S, $56^{\circ} 42^{\prime}$ W, $650 \mathrm{~m}$; Atlantic Forest, on tree bark in pasture close to forest; 30 October 2018, A. Aptroot 77751 (holotype: CGMS; isotype: ABL); Serra da Bodoquena, Fazenda Monte Negro; 20 54'25" S, 56 48'04" W, 530 m; Atlantic Forest, on tree bark in forest; 8 November 2018, A. Aptroot 77888, 77930, 77933, 77940, 77941, 77948, 77966 (paratypes: CGMS). Acre: Núcleo Cazumbá; 0907' S, 6857’ W, $150 \mathrm{~m}$; disturbed tropical rain forest; 2019, M. Cáceres \& A. Aptroot (ABL, ISE 50171).

Notes: Four species of Macroconstrictolumina are so far recognized. The new species is unmistakable by the lateral ostioles.

Key to species of Macroconstrictolumina: 
1. Ascospores $18-30 \times 7-10(-12) \mu \mathrm{m}$ Macroconstrictolumina lyrata

1. Ascospores 30-48 × 10-16(-24) $\mu \mathrm{m} . . . \ldots \ldots \ldots \ldots \ldots . . .2$

2. Ostiole lateral; ascospores 1-septate.

Macroconstrictolumina megalateralis

2. Ostiole apical; ascospores $1(-3)$-septate................ 3

3. Ascospores $27-37 \times 10-12 \mu \mathrm{m}$, often 3-septate......... Macroconstrictolumina majuscula

3. Ascospores $40-50 \times 15-20 \mu \mathrm{m}$, mostly 1-septate Macroconstrictolumina malaccitula

Marcelaria Aptroot, M.P. Nelsen \& Parnmen, Glalia 5(2): 3 (2013), nom. cons. prop.

MycoBank number: MB 805450; Index Fungorum number: IF 805450; Facesoffungi number: FoF 08803; three morphologically defined species (Aptroot and Lücking 2016); molecular data available for two species (Lücking et al. 2016).

= Buscalionia Sambo nom. cons. prop., Ann. Bot., Roma 22: 27 (1940). Type species: Buscalionia rubra Sambo, Ann. Bot., Roma 22: 27 (1940) [= Marcelaria purpurina (Nyl.) Aptroot, Nelsen \& Parnmen].

Lichenized on bark in terrestrial, chiefly lowland tropical wet forest habitats. Thallus distinctly corticate, yellow-brown to olive-green. Photobiont Trentepohlia. Ascomata solitary to often crowded or loosely aggregate, prominent to sessile, brown-black but covered by thick thallus and a thick layer of yellow-orange to red pigment crystals, hemispherical to wart-shaped, coriaceous, ostiolate, ostiole apical. Excipulum prosoplecten-chymatous, dark brown to carbonized. Hamathecium comprising 0.5-0.7 $\mu \mathrm{m}$ wide para-physoids, hyaline, straight, branched and anastomosing, embedded in a gelatinous matrix. Asci 2-8-spored, bitunicate, fissitunicate, oblong-clavate, short pedicellate, with a non-amyloid ocular chamber. Ascospores irregularly arranged to biseriate, fusiform-ellipsoid, hyaline, richly muriform, with somewhat thickened distosepta and rounded lumina, smooth-walled, not or slightly constricted at the septa, often with a gelatinous sheath. Pycnidia unknown. Chemistry: lichexanthone sometimes produced on thallus surface; yellow to orange or red anthraquinones present on the ascomata.

Type species: Marcelaria purpurina (Nyl.) Aptroot, Nelsen \& Parnmen, Glalia 5(2): 9 (2013) [= Buscalionia rubra Sambo, Ann. Bot., Roma 22: 27 (1940)].

Notes: For key and discussion see Aptroot and Lücking (2016). The older name Buscalionia has recently been discovered to be congeneric with Marcelaria and has been proposed for conservation (Aptroot and Nepi 2017), with the decision pending.

Nigrovothelium Lücking, M.P. Nelsen \& Aptroot in Lücking et al., Lichenologist 48: 757 (2016).
MycoBank number: MB 816875; Index Fungorum number: IF 816875; Facesoffungi number: FoF 08804; three morphologically and partly phylogenetically defined species (Aptroot and Lücking 2016); molecular data available for two species (Lücking et al. 2016).

Lichenized on bark in terrestrial, chiefly lowland to lower montane tropical habitats, often in drier situations. Thallus distinctly corticate, olive-green to yellowish brown. Photobiont Trentepohlia. Ascomata solitary, prominent to sessile, black, subglobose to egg-shaped, carbonaceous, ostiolate, ostiole apical. Involucrellum carbonized. Excipulum prosoplectenchymatous, brownish to carbonized. Hamathecium comprising $0.5-0.7 \mu \mathrm{m}$ wide paraphysoids, hyaline, straight, branched and anastomosing, embedded in a gelatinous matrix. Asci 8-spored, bitunicate, fissitunicate, clavate, short pedicellate, with a non-amyloid ocular chamber. Ascospores irregularly arranged to biseriate, fusiform-ellipsoid, hyaline, 3-septate, astrothelioid with distinct distosepta and diamondshaped lumina, smooth-walled, not constricted at the septa, often with a gelatinous sheath. Pycnidia rare, immersed to erumpent, visible as black dots. Conidia aseptate, bacillar, hyaline. Chemistry: no substances detected by TLC.

Type species: Nigrovothelium tropicum (Ach.) Lücking, M.P. Nelsen \& Aptroot in Lücking et al., Lichenologist 48: 757 (2016).

Notes: For key and discussion see Aptroot and Lücking (2016).

Polymeridium (Müll. Arg.) R.C. Harris in Tucker \& Harris, Bryologist 83: 12 (1980).

MycoBank number: MB 4316; Index Fungorum number: IF 4316; Facesoffungi number: FoF 08805; Approximately 50 morphologically defined species (Aptroot and Lücking 2016; Aptroot and Weerakoon 2018); molecular data available for three species (Lücking et al. 2016).

Lichenized on bark in terrestrial, chiefly lowland to lower montane tropical habitats, often in drier situations. Thallus usually ecorticate, rarely indistinctly corticate, whitish. Photobiont Trentepohlia. Ascomata solitary to aggregate, erumpent to prominent, black, hemisphaerical to wartshaped or conical, carbonaceous, ostiolate, ostiole apical, rarely lateral or fused. Involucrellum carbonized. Excipulum prosoplectenchymatous, brownish to carbonized. Hamathecium comprising $0.5-0.7 \mu \mathrm{m}$ wide paraphysoids, hyaline, straight, branched and anastomosing, embedded in a gelatinous matrix. Asci 4-8-spored, bitunicate, fissitunicate, clavate, short pedicellate, with a non-amyloid ocular chamber. Ascospores irregularly arranged to biseriate, fusiformellipsoid, hyaline, multi-septate to rarely (sub-)muriform, with thin eusepta and rectangular lumina, smooth-walled, not or slightly constricted at the septa, often with a gelatinous sheath. Pycnidia rare, immersed to erumpent, visible as black dots. Conidia aseptate, bacillar, hyaline. Chemistry: 
lichexanthone sometimes produced on thallus surface; ostiolar area or hamathecium rarely with anthraquinones.

Type species: Polymeridium contendens (Nyl.) R.C. Harris in Tucker \& Harris, Bryologist 83: 12 (1980).

Notes: For key and discussion see Aptroot and Lücking (2016).

Polypyrenula D. Hawksw., Bull. Br. Mus. Nat. Hist., Bot. 14: 165 (1985).

MycoBank number: MB 25730; Index Fungorum number: IF 25730; Facesoffungi number: FoF 08806; one morphologically and phylogenetically defined species (MirandaGonzález et al. 2020).

Lichenized (sometimes indistinctly or photobiont apparently absent) on bark in terrestrial, lowland tropical, seasonally dry forest habitats. Thallus ecorticate, whitish to pale greyish or brownish. Photobiont (when present) Trentepohlia. Ascomata dispersed, solitary, erumpent to prominent, black but basally covered by thin thallus layer, hemisphaerical to wart-shaped, carbonaceous, ostiolate, ostiole apical. Involucrellum well-developed, carbonaceous. Excipulum prosoplectenchymatous, basally reddish brown, laterally and apically thin and fused with involucrellum. Hamathecium comprising $0.5-1 \mu \mathrm{m}$ wide paraphysoids, hyaline, straight, branched and anastomosing, embedded in a gelatinous matrix. Asci (6-)8-spored, bitunicate, clavate, shortly pedicellate, with a non-amyloid ocular chamber. Ascospores biseriate, fusiform-ellipsoid and tapering towards the distal end, reddish brown but with basal cell paler, 5(-6)-septate, with distinct distosepta and rounded lumina except for the lowermost cell which is separated by a thin euseptum and has a triangular lumen, smooth-walled, not constricted at the septa, lacking a gelatinous sheath. Pycnidia unknown. Chemistry: no substances detected by TLC.

Type species: Polypyrenula sexlocularis (Müll. Arg.) D. Hawksw., Bull. Br. Mus. Nat. Hist., Bot. 14: 165 (1985) [= Polypyrenula albissima Aptroot, Biblioth. Lichenol. 44: 102 (1991); nom. illeg., ICN Art. 52.1].

Notes: This monospecific genus is characterized by highly unique ascospores, which coincides with its position on a very long branch but with unresolved affinities among the basally diverging clades of the family (Fig. 77). For a long time, Polypyrenula was classified in the families Pyrenulaceae and Requienellaceae (Aptroot 1991; Lumbsch and Huhndorf 2007, 2010; Jaklitsch et al. 2016). However, the paraphysoids are more in line with those of Trypetheliaceae and molecular data recently demonstrated placement of the genus in that family (Miranda-González et al. 2020), a result anticipated in two recent classification papers (Lücking et al. 2017; Wijayawardene et al. 2017a). Miranda-González et al. (2020) also showed that $P$. sexlocularis is the correct name for the only species, $P$. albissima Aptroot being an illegitimate, homotypic synonym. The species appears to be found mostly in dry forests across the Neotropics (known from the Caribbean, Mexico and Bolivia) and has likely been overlooked due to the nondescript thallus and ascomata.

Pseudobogoriella Lücking, R. Miranda \& Aptroot gen. nov. MycoBank number: MB 836794; Index Fungorum number: IF 836794; Facesoffungi number: FoF 08807; 15 morphologically defined species (this paper); molecular data available for three species (Lücking et al. 2016; this paper).

Diagnosis: Differing from Bogoriella chiefly in the smaller ascospores always lacking endospore thickenings.

Etymology: The name refers to the notion as a "false" Bogoriella, i.e. similar but not closely related to the latter.

Lichenized (sometimes barely so or apparently nonlichenized) on bark in terrestrial, chiefly lowland to lower montane tropical habitats. Thallus ecorticate, mostly whitish to pale brownish or pinkish. Photobiont Trentepohlia. Ascomata solitary, erumpent to prominent, brown-black to carbonaceous, hemisphaerical to wart-shaped, coriaceous to carbonaceous, ostiolate, ostiole apical to rarely lateral. Involucrellum usually well-developed, carbonaceous. Excipulum prosoplectenchymatous, usually brownish, in lateral and apical parts typically fused with the involucrellum. Hamathecium comprising $1 \mu \mathrm{m}$ wide para-physoids, hyaline, straight to somewhat wavy, branched and anastomosing, embedded in a thin, gelatinous matrix. Asci 8-spored, bitunicate, fissitunicate, clavate to fusiform, short pedicellate, with a nonamyloid ocular chamber. Ascospores irregularly arranged to uni- or biseriate, fusiform-ellipsoid, grey-brown, 1-septate, with eusepta and rectangular lumina, wall finely granular ornamented, not or slightly constricted at the septa, typically rather small (mostly around 15-20 $\times 6-8 \mu \mathrm{m}$ ), only in the type species somewhat larger. Pycnidia known from a few species, immersed to erumpent, visible as black dots. Conidia aseptate, bacillar, hyaline. Chemistry: no substances detected by TLC.

Type species: Pseudobogoriella hemisphaerica (Müll. Arg.) Lücking, R. Miranda \& Aptroot (see below).

Notes: The establishment of this new genus follows the topology of the phylogenetic tree, in which former members of Mycomicrothelia sensu lato emerge on three separate clades (Fig. 77). The systematics of these taxa is not settled, given that only few species have been sequenced. Pseudobogoriella currently represents a paraphyletic grade of two clades, but we have adopted the conservative solution of merging the two clades into a single genus for the time being. This reflects the fact that these species cannot be classified in Bogoriella sensu stricto for topological reasons, but at the same time too few data are available to further resolve this basally emerging grade. The main difference when compared to Bogoriella are the small, 1-septate ascospores lacking endospore thickenings. 
New combinations in Pseudobogoriella:

Pseudobogoriella alata (Groenh. ex Aptroot) Lücking, R. Miranda \& Aptroot comb. nov.

MycoBank number: MB 836795; Index Fungorum number: IF 836795; Facesoffungi number: FoF 08808.

Bas.: Mycomicrothelia alata Groenh. ex Aptroot, Biblioth. Lichenol. 44: 130 (1991); Bogoriella alata (Groenh. ex Aptroot) Aptroot \& Lücking, Lichenologist 48: 905 (2016).

Pseudobogoriella annonacea (Müll. Arg.) Lücking, R. Miranda \& Aptroot comb. nov.

MycoBank number: MB 836796; Index Fungorum number: IF 836796; Facesoffungi number: FoF 08809.

Bas.: Microthelia annonacea Müll. Arg., [as 'anonacea'], Hedwigia 34: 145 (1895); Mycomicrothelia annonacea (Müll. Arg.) D. Hawksw., [as 'anonacea'] Bull. Br. Mus. Nat. Hist., Bot. 14(2): 67 (1985); Bogoriella annonacea (Müll. Arg.) Aptroot \& Lücking, Lichenologist 48: 907 (2016).

Pseudobogoriella captiosa (Kremp.) Lücking, R. Miranda \& Aptroot comb. nov.

MycoBank number: MB 836797; Index Fungorum number: IF 836797; Facesoffungi number: FoF 08810.

Bas.: Verrucaria captiosa Kremp., Flora 59: 524 (1876); Microthelia captiosa (Kremp.) Müll. Arg., Flora 66: 272 (1883); Mycomicrothelia captiosa (Kremp.) D. Hawksw., Bull. Br. Mus. Nat. Hist., Bot. 14: 73 (1985); Bogoriella captiosa (Kremp.) Aptroot \& Lücking, Lichenologist 48: 908 (2016).

Pseudobogoriella exigua (Müll. Arg.) Lücking, R. Miranda $\&$ Aptroot comb. nov.

MycoBank number: MB 836798; Index Fungorum number: IF 836798; Facesoffungi number: FoF 08811.

Bas.: Microthelia exigua Müll. Arg., Bot. Jahrb. 6: 416 (1885); Mycomicrothelia exigua (Müll. Arg.) D. Hawksw., Bull. Br. Mus. Nat. Hist., Bot. 14: 84 (1985); Bogoriella exigua (Müll. Arg.) Aptroot \& Lücking, Lichenologist 48: 910 (2016).

Pseudobogoriella fumosula (Zahlbr.) Lücking, R. Miranda \& Aptroot comb. nov.

MycoBank number: MB 836799; Index Fungorum number: IF 836799; Facesoffungi number: FoF 08812.

Bas.: Microthelia fumosula Zahlbr. in Handel-Mazzetti, Symb. Sinic. 3: 18 (1930); Mycomicrothelia fumosula (Zahlbr.) D. Hawksw., Bull. Br. Mus. Nat. Hist., Bot. 14: 86 (1985); Bogoriella fumosula (Zahlbr.) Aptroot \& Lücking, Lichenologist 48: 910 (2016).

Pseudobogoriella hemisphaerica (Müll. Arg.) Lücking, R. Miranda \& Aptroot comb. nov.
MycoBank number: MB 836800; Index Fungorum number: IF 836800; Facesoffungi number: FoF 08813.

Bas.: Microthelia hemisphaerica Müll. Arg., Bot. Jahrb. 6: 417 (1885); Mycomicrothelia hemisphaerica (Müll. Arg.) D. Hawksw., Bull. Br. Mus. Nat. Hist., Bot. 14: 86 (1985); Bogoriella hemisphaerica (Müll. Arg.) Aptroot \& Lücking, Lichenologist 48: 910 (2016).

Pseudobogoriella lateralis (Sipman) Lücking, R. Miranda \& Aptroot comb. nov.

MycoBank number: MB 836801; Index Fungorum number: IF 836801; Facesoffungi number: FoF 08814.

Bas.: Mycomicrothelia lateralis Sipman, Lichenologist 37: 309 (2005); Bogoriella lateralis (Sipman) Aptroot \& Lücking, Lichenologist 48: 911 (2016).

Pseudobogoriella leuckertii (D. Hawksw. \& J.C. David) Lücking, R. Miranda \& Aptroot comb. nov.

MycoBank number: MB 836802; Index Fungorum number: IF 836802; Facesoffungi number: FoF 08815.

Bas.: Mycomicrothelia leuckertii D. Hawksw. \& J.C. David in David \& Hawksworth, Biblioth. Lichenol. 57: 98 (1995); Bogoriella leuckertii (D. Hawksw. \& J.C. David) Aptroot \& Lücking, Lichenologist 48: 911 (2016).

Pseudobogoriella minutula (Zahlbr.) Lücking, R. Miranda \& Aptroot comb. nov.

MycoBank number: MB 836803; Index Fungorum number: IF 836803; Facesoffungi number: FoF 08816.

Bas.: Microthelia minutula Zahlbr. in Handel-Mazzetti, Symb. Sinic. 3: 18 (1930); Mycomicrothelia minutula (Zahlbr.) D. Hawksw., Bull. Br. Mus. Nat. Hist., Bot. 14(2): 102 (1985); Bogoriella minutula (Zahlbr.) Aptroot \& Lücking, Lichenologist 48: 912 (2016).

Pseudobogoriella nonensis (Stirt.) Lücking, R. Miranda \& Aptroot comb. nov.

MycoBank number: MB 836804; Index Fungorum number: IF 836804; Facesoffungi number: FoF 08817.

Bas.: Verrucaria nonensis Stirt., Proc. Roy. Phil. Soc. Glasgow 11: 320 (1879); Microthelia nonensis (Stirt.) Zahlbr., Cat. Lich. Univers. 1: 264 (1921); Mycomicrothelia nonensis (Stirt.) D. Hawksw., Bull. Br. Mus. Nat. Hist., Bot. 14: 105 (1985); Bogoriella nonensis (Stirt.) Aptroot \& Lücking, Lichenologist 48: 913 (2016).

Pseudobogoriella pachnea (Körb.) Lücking, R. Miranda \& Aptroot comb. nov.

MycoBank number: MB 836805; Index Fungorum number: IF 836805; Facesoffungi number: FoF 08818.

Bas.: Microthelia pachnea Körb., Parerga Lichenol. 5: 398 (1865); Amphisphaeria pachnea (Körb.) Rehm, Ann. 
Mycol. 4: 264 (1906); Mycomicrothelia pachnea (Körb.) D. Hawksw., Bull. Br. Mus. Nat. Hist., Bot. 14: 108 (1985).

Pseudobogoriella punctata (Aptroot) Lücking, R. Miranda \& Aptroot comb. nov.

MycoBank number: MB 836806; Index Fungorum number: IF 836806; Facesoffungi number: FoF 08819

Bas.: Mycomicrothelia punctata Aptroot, Biblioth. Lichenol. 44: 134 (1991); Bogoriella punctata (Aptroot) Aptroot \& Lücking, Lichenologist 48: 914 (2016).

Pseudobogoriella socialis (Zahlbr.) Lücking, R. Miranda \& Aptroot comb. nov.

MycoBank number: MB 836807; Index Fungorum number: IF 836807; Facesoffungi number: FoF 08820.

Bas.: Microthelia socialis Zahlbr., Mycologia 22: 69 (1930); Mycomicrothelia socialis (Zahlbr.) D. Hawksw., Bull. Br. Mus. Nat. Hist., Bot. 14: 110 (1985); Bogoriella socialis (Zahlbr.) Aptroot \& Lücking, Lichenologist 48: 915 (2016).

Pseudobogoriella striguloides (Sérus. \& Aptroot) Lücking, R. Miranda \& Aptroot comb. nov.

MycoBank number: MB 836808; Index Fungorum number: IF 836808; Facesoffungi number: FoF 08821.

Bas.: Mycomicrothelia striguloides Sérus. \& Aptroot, Bryologist 101: 145 (1998); Bogoriella striguloides (Sérus. \& Aptroot) Aptroot \& Lücking, Lichenologist 48: 915 (2016).

Notes: This species is highly unusual among the genus due to its foliicolous, Strigula-like, subcuticular thallus. Sérusiaux and Aptroot (1998) already discussed the possibility of this being a lichenicolous fungus on a Strigula thallus, but found no support for this hypothesis. The anatomical characters of the ascomata and asci are reminiscent of the lichenicolous genus Polycoccum Saut. ex Körb. (Matzer 1996; Diederich et al. 2018), which has recently been identified as a close relative of Trypetheliaceae (Ertz et al. 2015). We refrain from proposing any taxonomic changes at this point but we predict that this taxon is not a genuine Trypetheliaceae.

Pseudobogoriella subfallens (Müll. Arg.) Lücking, R. Miranda \& Aptroot comb. nov.

MycoBank number: MB 836809; Index Fungorum number: IF 836809; Facesoffungi number: FoF 08822

Bas.: Microthelia subfallens Müll. Arg., Bot. Jahrb. 6: 416 (1885); Mycomicrothelia subfallens (Müll. Arg.) D. Hawksw., Bull. Br. Mus. Nat. Hist., Bot. 14: 111 (1985); Bogoriella subfallens (Müll. Arg.) Aptroot \& Lücking, Lichenologist 48: 915 (2016).

Key to species of Pseudobogoriella:
1. Ostiole lateral..............Pseudobogoriella lateralis

1. Ostiole apical...................................... 2

2. Ascospores $24-28 \mu \mathrm{m}$ long. .Pseudobogoriella hemisphaerica

2. Ascospores 12-22 um long.............................. 3

3. Thallus foliicolous, subcuticular, distinctly lobed...... Pseudobogoriella striguloides

3. Thallus corticicolous, not lobed.........................4

4. Excipulum with $\mathrm{K}+\mathrm{red}$, dissolving pigment........... Pseudobogoriella leuckertii

4. Excipulum lacking pigment........................5

5. Black prothallus line with numerous pycnidia........... Pseudobogoriella punctata

5. Black prothallus line lacking pycnidia or absent..............................................6

6. Thallus besides ascomata with numerous black dots representing pycnidia..................................... 7

6. Thallus lacking pycnidia............................ 8

7. Ascomata aggregate; ascospores $15-20 \times 6-9 \mu \mathrm{m} \ldots \ldots$. ..Pseudobogoriella socialis

7. Ascomata solitary; ascospores 11-17 $\times 5-7 \mu \mathrm{m} . . . .$. Pseudobogoriella fumosula

8. Involucrellum broadly expanding basally to over 0.5 $\mathrm{mm}$ diam......................Pseudobogoriella alata

8. Ascomata including basally slightly expanding involucrellum $0.2-0.5 \mathrm{~mm}$ diam............................9

9. Ascospores $12-16 \mu \mathrm{m}$ long..........................10

9. Ascospores 16-22 $\mu \mathrm{m}$ long........................... 12

10. Ascomata $0.3-0.5 \mathrm{~mm}$ diam......................... Pseudobogoriella subfallens

10. Ascomata $0.2-0.3 \mathrm{~mm}$ diam......................11

11. Ascospores $4-5.5 \mu \mathrm{m}$ broad, $2.5-3$ times as long as broad; involucrellum basally not expanding........... .Pseudobogoriella exigua

11. Ascospores 5.5-7 $\mu \mathrm{m}$ broad, 2-2.5 times as long as broad; involucrellum basally expanding.

Pseudobogoriella minutula

12. Black prothallus line present.....................13

12. Black prothallus line absent.........................14

13. Ascomata conical, basally not expanded.............. Pseudobogoriella captiosa

13. Ascomata flattened, basally expanded. Pseudobogoriella miculiformis

14. Ascomata basally broadly expanded, fringe $50-100 \mu \mathrm{m}$ broad...................Pseudobogoriella annonacea

14. Ascomata basally narrowly expanded, fringe $20-50 \mu \mathrm{m}$ broad. Pseudobogoriella nonensis

Pseudopyrenula Müll. Arg., Flora 66: 247 (1883).

MycoBank number: MB 4481; Index Fungorum number: IF 4481; Facesoffungi number: FoF 08823; Approximately 20 morphologically defined species (Aptroot and Lücking 
2016: Aptroot et al. 2019); molecular data available for four species (Lücking et al. 2016).

Lichenized on bark in terrestrial, chiefly lowland to lower montane tropical habitats, often in drier situations. Thallus ecorticate, whitish. Photobiont Trentepohlia. Ascomata solitary, erumpent to prominent, black, hemisphaerical to wart-shaped or conical, carbonaceous, ostiolate, ostiole apical, rarely lateral. Involucrellum carbonized. Excipulum prosoplectenchymatous, brownish to carbonized. Hamathecium comprising 0.5-0.7 $\mu \mathrm{m}$ wide paraphysoids, hyaline, straight, branched and anastomosing, embedded in a gelatinous matrix. Asci 8 -spored, bitunicate, fissitunicate, clavate, short pedicellate, with a non-amyloid ocular chamber. Ascospores irregularly arranged to biseriate, fusiformellipsoid, hyaline, 3(-5)-septate, astrothelioid with distinct distosepta and diamond-shaped lumina, smooth-walled, not constricted at the septa, often with a gelatinous sheath. Pycnidia rare, immersed to erumpent, visible as black dots. Conidia aseptate, bacillar, hyaline. Chemistry: lichexanthone sometimes produced on thallus surface; hamathecium and/or ascospores sometimes with yellow anthraquinones.

Type species: Pseudopyrenula diluta (Fée) Müll. Arg., Flora 66: 249 (1883)

Notes: For key and discussion see Aptroot and Lücking (2016).

Schummia Lücking, R. Miranda \& Aptroot gen. nov.

MycoBank number: MB 836810; Index Fungorum number: IF 836810; Facesoffungi number: FoF 08824; one morphologically defined species (this paper); molecular data thus far unavailable.

Diagnosis: Differing from Bogoriella in the ascospores with lens-shaped lumina and very thick terminal walls.

Etymology: Named after our colleague and friend, Felix Schumm, for his excellent contributions to our knowledge of the morphology and anatomy of lichen fungi.

Lichenized (weakly so) on bark in terrestrial, lowland to lower montane subtropical habitats (Azores). Thallus ecorticate, pale brownish (to pinkish). Photobiont Trentepohlia. Ascomata solitary, erumpent, brown-black to carbonaceous, applanately wart-shaped to irregular in outline, ostiolate, ostiole apical. Involucrellum weakly developed, with periderm layers, carbonaceous. Excipulum prosoplectenchymatous, brown-black, in apical parts fused with involucrellum. Hamathecium comprising $1.5 \mu \mathrm{m}$ wide paraphysoids, hyaline, straight to somewhat wavy, slightly branched. Asci 8-spored, bitunicate, fissitunicate, clavate, short pedicellate, with a non-amyloid, rather long ocular chamber. Ascospores irregularly arranged to biseriate, ellipsoid to drop-shaped, grey-brown, 1-septate, with a central euseptum and rectangular lumina, the terminal walls much thickened and inflated, not or slightly constricted at the septa. Pycnidia unknown. Chemistry: no substances detected by TLC.
Type species: Schummia angulata (Aptroot \& Schumm) Lücking, R. Miranda \& Aptroot (see below).

Notes: This new genus is introduced for a single species with highly unusual ascospores that in their mature stage are reminiscent of Arthoniaceae and Graphidaceae rather than Trypetheliaceae. The species was originally described in the genus Distothelia (Schumm and Aptroot 2013), but the ascospores differ clearly in shape and endospore development, resulting in two strongly thickened terminal walls. Immature ascospores appear 3-septate with three eusepta, somewhat similar to ascospores in Novomicrothelia and Pseudobogoriella except for the more numerous septa. However, the two terminal lumina eventually become filled entirely with endospore material and simultaneously inflated, so that the two-remaining central lumina appear much smaller than the thickened terminal walls (Fig. 79f). Given the current distribution of ascospore types among basally diverging lineages in the family, we predict that this taxon represents its own lineage, and placement in Bogoriella, together with the other two species previously placed in Distothelia, would be misleading.

Schummia angulata (Aptroot \& Schumm) Lücking, R. Miranda \& Aptroot comb. nov.

MycoBank number: MB 836811; Index Fungorum number: IF 836811; Facesoffungi number: FoF 08825.

Bas.: Distothelia angulata Aptroot \& Schumm in Schumm \& Aptroot, Flechten Madeiras, der Kanaren und Azoren 2: 200 (2013).

Viridothelium Lücking, M.P. Nelsen \& Aptroot in Lücking et al., Lichenologist 48: 758 (2016).

MycoBank number: MB 816877; Index Fungorum number: IF 816877; Facesoffungi number: FoF 08826; 11 morphologically defined species (Aptroot and Lücking 2016; Cáceres and Aptroot 2017); molecular data available for three species (Lücking et al. 2016).

$=$ ?Exiliseptum R.C. Harris, Acta Amazonica 14(1-2, Suppl.): 65 (1986) [1984]. Type species: Exiliseptum ocellatum (Müll. Arg.) R.C. Harris, Acta Amazonica 14(1-2, Suppl.): 66 (1986) [1984].

Lichenized on bark in terrestrial, chiefly lowland to lower montane tropical to temperate forest habitats. Thallus distinctly corticate, yellow-brown to olive-green. Photobiont Trentepohlia. Ascomata solitary to aggregated or diffusely pseudostromatic, immersed to erumpent, brown-black but usually covered by thallus layer except for ostiolar area, coriaceous to carbonaceous, ostiolate, ostiole apical to lateral, sometimes fused. Excipulum prosoplectenchymatous, brownish. Hamathecium comprising $0.5-0.7 \mu \mathrm{m}$ wide paraphysoids, hyaline, straight, branched and anastomosing, embedded in a thick, gelatinous matrix. Asci 4-8-spored, bitunicate, fissitunicate, clavate to oblong, short pedicellate, 

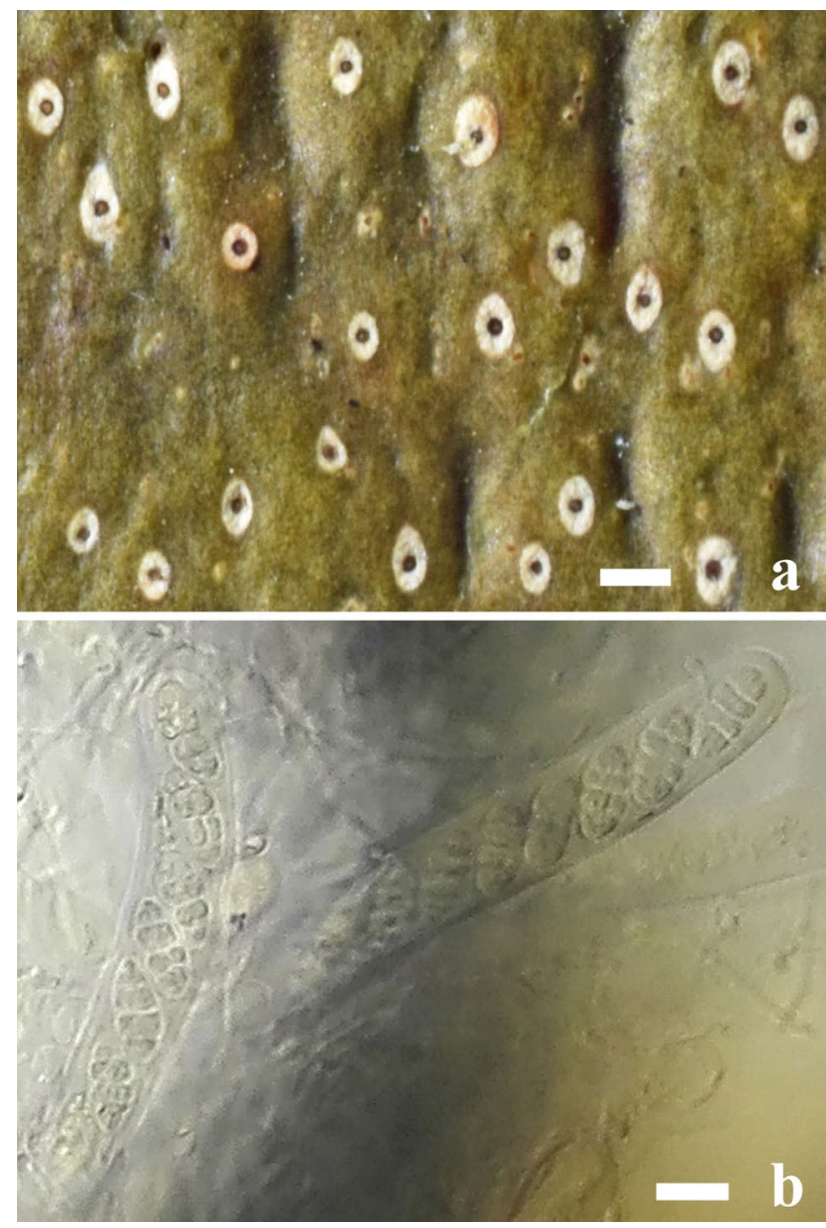

Fig. 81 Exiliseptum ocellatum (holotype). a, b habitus and asci with ascospores. Scale bars: $\mathbf{a}=1 \mathrm{~mm}, \mathbf{b}=10 \mu \mathrm{m}$

with a non-amyloid ocular chamber. Ascospores irregularly arranged to biseriate, oblong-fusiform, hyaline, septate to rarely muriform, with slightly thickened distosepta and more or less rectangular lumina, smooth-walled, not constricted at the septa, often with a gelatinous sheath. Pycnidia rare, immersed to erumpent, visible as black dots. Conidia aseptate, bacillar, hyaline. Chemistry: orange anthraquinone known from one species

Type species: Viridothelium virens (Tuck. ex Michener) Lücking, M.P. Nelsen \& Aptroot in Lücking et al., Lichenologist 48: 759 (2016).

Notes: For key and discussion see Aptroot and Lücking (2016). The genus currently includes 11 species (Cáceres and Aptroot 2017). The genus Exiliseptum, described by Harris (1986), was later considered a member of Polymeridium with a corticate thallus (Aptroot and Cáceres 2014), and this view was followed in the recent synopsis on Trypetheliaceae (Aptroot and Lücking 2016). However, upon re-examination of the type material (Fig. 81), we believe that this taxon may be congeneric with Viridothelium, in which case it would provide an earlier name for that genus. We have refrained from formal implementation of this finding, as the phylogenetic placement of odd lineages in Trypetheliaceae is somewhat unpredictable and we anticipate collecting authentic material for sequencing.

\section{Key to genera of Trypetheliaceae:}

1. Ascospores remaining hyaline......................2

1. Ascospores becoming brown.......................23

2. Ascospores 1-septate............................... 3

2. Ascospores 3-septate to muriform....................6

3. Ascospores up to $15 \times 5 \mu \mathrm{m}$, lacking secondary constrictions...................."Arthopyrenia" (aff. minor)

3. Ascospores larger than $15 \times 5 \mu \mathrm{m}$, usually with secondary constrictions...................................... 4

4. Non-lichenized; saprobic on branches in southern Europe. Alloarthopyrenia (italica)

4. Lichenized (often barely so); (sub-)tropical...........5

5. Ascospores smooth-walled, up to $30 \times 11 \mu \mathrm{m}$ (in one species up to $46 \times 24 \mu \mathrm{m}) \ldots .$. . Constrictolumina p.p.

5. Ascospores granular ornamented, mostly larger than 30 $\times 11 \mu \mathrm{m}$ (in one species $20-30 \times 7-12 \mu \mathrm{m}$ ).

Macroconstrictolumina p.p.

6. Thallus ecorticate or indistinctly corticate, usually whitish or greyish, contrasting with the black ascomata................................................ 7

6. Thallus distinctly corticate, olive-green to yellowish brown............................................13

7. Hamathecium physes basally somewhat thickened, somewhat flexuose, branched but usually not anastomosing; ascospores (1-)3-septate.......................8

7. Hamathecium physes thin, straight, branched and anastomosing to form a net-like structure.................9

8. Ascospores up to $23 \times 8 \mu \mathrm{m}$, smooth-walled........... .Constrictolumina p.p.

8. Ascospores mostly larger than $30 \times 11 \mu \mathrm{m}$ (in one species $20-30 \times 7-12 \mu \mathrm{m})$, granular ornamented.

.Macroconstrictolumina p.p.

9. Ascospores astrothelioid, with diamond-shaped lumina.............................Pseudopyrenula

9. Ascospores euseptate, with thin septa and rectangular lumina.............................................10

10. Ascospores transversely septate...Polymeridium p.p.

10. Ascospores muriform............................11

11. Ostioles lateral.......................Dictyomeridium

11. Ostioles apical.....................................12

12. Non-lichenized; temperate........."Julella" (fallaciosa)

12. Lichenized; (sub-)tropical...........Polymeridium p.p.

13. Ascospores transversely septate......................14

13. Ascospores muriform...............................19

14. Ascospores very large with few (3-5) septa, typically over $100 \times 30 \mu \mathrm{m}$ and up to $190 \times 60 \mu \mathrm{m}$; septa and 
walls somewhat thickened but lumina not astrothelioid. Architrypethelium p.p.

14. Ascospores when 3-5-septate very rarely exceeding $100 \times 30 \mu \mathrm{m}$ and if so, ascospores distinctly astrothelioid, with diamond-shaped lumina.

..15

15. Ascospores astrothelioid, with diamond-shaped lumina ..16

15. Ascospores euseptate, with rather thin septa and more or less rectangular lumina. 17

16. Perithecia strongly prominent to sessile, completely exposed, pure black, somewhat egg-shaped .Nigrovothelium

16. Perithecia immersed to erumpent or aggregate in erumpent to sessile pseudostromata.

Astrothelium p.p.

17. Perithecia aggregate in prominent to sessile, brownblack pseudostromata; ascospores with thin septa and walls

Bathelium p.p.

17. Perithecia solitary to pseudostromatic but pseudostromata not as above; ascospores with slightly thickened septa. .18

18. Perithecia immersed to erumpent or rarely indistinctly pseudostromatic; pigments mostly absent. Viridothelium p.p.

18. Perithecia aggregate in distinct, prominent to sessile pseudostromata; internal and/or external pigments usually present. Trypethelium

19. Ascospores with thin (eu-)septa and thin walls.....20

19. Ascospores with thickened (disto-)septa, in young stages often astrothelioid. .

20. Perithecia aggregate in prominent to sessile, brownblack pseudostromata.................Bathelium p.p.

20. Perithecia dispersed and with whitish rim or in erumpent, whitish pseudostromata strongly contrasting with the blackish perithecia and the olive-brown thallus..............Viridothelium (incl. Exsiliseptum)

21. Perithecia in prominent to sessile warts covered by a thick layer of yellow-orange or red pigment

Marcelaria

21. Perithecia immersed to erumpent, rarely prominent, usually covered by thallus, rarely with a thin layer of pigment pruina.

22. Perithecia aggregate in irregular, blackish pseudostromata; ascospores about $50 \times 15 \mu \mathrm{m}$.

Architrypethelium (murisporum)

22. Perithecia and ascospores not in the above combination..............................Astrothelium p.p.

23. Ascospores transversely septate..................24

23. Ascospores (sub-)muriform....................... 30

24. Ascospores with a basal euseptum and the basal cell pale, otherwise distoseptate and brown

Polypyrenula (sexlocularis)

24. Ascospores with either eu- or distosepta..........25
25. Ascospores large, usually over $100 \mu \mathrm{m}$ long........26

25. Ascospores small, under $50 \mu \mathrm{m}$ long..............27

26. Ascospores 3-septate, 25-50 $\mu \mathrm{m}$ broad, about 3-4 times as long as broad........Architrypethelium p.p.

26. Ascospores 11-15-septate, 25-30 $\mu \mathrm{m}$ broad, about 4-5 times as long as broad...Astrothelium (fuscosporum)

27. Ascospores with strongly thickened distosepta.......................................28

27. Ascospores with thin eusepta....................29

28. Ascospores drop-shaped, macrocephalic, with strongly thickened terminal walls and two narrow, rectangular lumina near the center...........Schummia (angulata)

28. Ascospores ellipsoid, with irregular wall thickenings and halter-shaped to irregular lumina

Bogoriella p.p.

29. Ascospores up to $20 \times 8 \mu \mathrm{m}$, only in one species larger (up to $30 \times 10 \mu \mathrm{m}) \ldots \ldots \ldots \ldots \ldots \ldots$................

29. Ascospores $20-50 \times 8-15 \mu \mathrm{m}$........Bogoriella p.p.

30. Ascospores small, under $50 \times 20 \mu \mathrm{m}$, often with irregularly thickened endospore and halter-shaped lumina...

Bogoriella p.p.

30. Ascospores very large, 150-400 × 50-140 $\mu \mathrm{m}$, with outer wall often breaking under pressure.

Aptrootia

\section{Corrections for errors detected in previous synopsis of Trypetheliaceae}

Given the large size of the previous synopsis of the Trypetheliaceae (Aptroot and Lücking 2016), unfortunate errors and omissions were almost inevitable. Corrections to most of these were already listed in Aptroot et al. (2019). A few more are reported and corrected below. When using the key, it should also be noted that additional species have been described in the meanwhile, particularly in Astrothelium but also in other genera.

Page 783, Table 1: for (Astrothelium) subinterjectum, replace +/+ with -/+ (lichexanthone on ascomata only).

Page 802 , key couplet 24, first alternative, add: ascospores 48-65 × 17-20 $\mu \mathrm{m}$.

Page 802 , key couplet 24, second alternative, add: ascospores 62-80 × 20-25 $\mu \mathrm{m}$.

Page 806, key couplet 21, first alternative: replace "Hamathecium inspersed" with "Lichexanthone on thallus only".

Page 806, key couplet 21, second alternative: replace "Hamathecium clear" with "Lichexanthone on thallus and ascomata or on ascomata only".

Page 808, key couplet 39, first alternative: replace "Thallus cracked" with "Thallus covered with yellow to orange pigment".

Page 808, key couplet 39, second alternative: replace "Thallus not cracked" with "Thallus olive-green to brownish 
yellow, lacking pigment, only pseudostromata covered with yellow to orange pigment".

Page 857, left column, description of Astrothelium defossum: replace "8 per ascus" with "4 per ascus".

Page 911, left column, description of Bogoriella lateralis (Sipman) Aptroot \& Lücking comb. nov.: replace "Ascomata with apical ostioles" with "Ascomata with lateral ostioles".

Page 916, right column, description of Bogoriella triangularis (Aptroot) Aptroot \& Lücking comb. nov.: replace "Ascomata with apical ostioles" with "Ascomata with lateral ostioles".

Page 961, right column, description of Pseudopyrenula superans: replace "Hamathecium inspersed" with "Hamathecium clear.", "UV-" by "UV+ yellow", and "no substances found" by "lichexanthone".

\section{Economic and ecological significance}

Trypetheliaceae is the second most diverse family of tropical crustose lichens, with over 400 species known and about 800 predicted (Aptroot et al. 2016). It is an important component of lichen communities particularly in wet and dry tropical forest and savanna ecosystems (Komposch and Hafellner 2000, 2003; Rivas Plata et al. 2008; Aptroot 2013; Menezes et al. 2018). There are no currently known uses of economic importance of Trypetheliaceae; the family is chemically comparatively simple, but with diverse anthraquinone and other pigments (Mathey 1979; Mathey et al. 1980; Aptroot and Lücking 2016). Some of these pigments appear to have potential pharmaceutical properties (Manojlovic et al. 2010; Sun et al. 2010; Takenaka et al. 2013; Elsebai et al. 2014; Basnet et al. 2019; Srinivasan et al. 2019). The copious red pigment of the ascomata of Marcelaria purpurina, collected during the 1899 expedition of Luigi Buscalioni (Sambo 1940; Daly and Millozza 2007), has apparently been used as dye by Amazonian indigenous tribes. Harris (1986) reported the use of the same species by the Bolivian Chácobo people as a treatment against headaches. Prance (1972) described the use of a pyrenocarpous lichen by the Denís tribe in Amazonian Brazil as 'Badhu', sniffed through the nose; this lichen may well represent a Trypetheliaceae but its exact affinity is unknown. Trypetheliaceae is one of four families that has been studied in detail regarding the latitudinal diversity gradient in lichens and the potential impact of climate change on lichen distribution ranges (Menezes et al. 2018).

Tubeufiales Boonmee \& K.D. Hyde.

Index Fungorum number: IF 550704; Facesoffungi number: FoF 00203.

Tubeufiales was established by Boonmee et al. (2014b) based on phylogenetic analyses and morphology. Liu et al.
(2017) treated Bezerromycetaceae and Wiesneriomycetaceae as families of Tubeufiales on the basis of divergence time estimates. The latest comprehensive revision on Tubeufiales was carried out by Lu et al. (2018b), who expanded the circumscription of the type family Tubeufiaceae, accepted 42 genera in this family, and revised the taxonomy of tubeufiaceous species. This revision, in particular, helped to highlight fungi which were misidentified and resolved which morphs are important in classifying species. Tubeufiaceous fungi have the potential to produce bioactive compounds (Ohtsu et al. 2003; Lu et al. 2018b; Fan et al. 2019). Fan et al. (2019) tested the antifungal and anticancer effects of 19 tubeufiaceous strains, and found that most of them showed obvious bioactivities. We introduce a new morphological record of Tubeufia longiseta. The divergence time for Tubeufiales is estimated as 234 MYA (stem age, Hongsanan et al. 2020).

Accepted families: Bezerromycetaceae, Tubeufiaceae, and Wiesneriomycetaceae (Fig. 82).

Bezerromycetaceae J.D.P. Bezerra, Souza-Motta \& Crous, Mycol. Progr. 16: 301 (2017).

Index Fungorum: IF 817521; Facesoffungi number: FoF 06809, 4 species.

Saprobic on dead wood in terrestrial habitats, or as endophytic fungi associated with cactus species in tropical dry forests. Sexual morph: Ascomata superficial or immersed in culture media, pseudothecial, unilocular, globose to subglobose, gregarious or solitary, pale brown to brown at maturity, minutely papillate with ostiole, collapsing cupulate or laterally, smooth or hairy. Peridium comprising pale brown cells of textura angularis, and small cells of textura prismatica. Hamathecium comprising numerous, filiform, septate, branched, hyaline pseudoparaphyses. Asci 8-spored, bitunicate, fissitunicate, cylindrical to cylindric-clavate, short pedicellate, with or without a minute ocular chamber. Ascospores 1-2-seriate, ellipsoidal, hyaline when young, becoming pale brown to brown at maturity, muriformly septate, smooth or minutely verrucose. Chlamydospores sometimes linked to ascomata by hyphae, multi-septate, brown, dictyochlamydospore-like, globose to subglobose or ellipsoid to cylindrical. Asexual morph: Undetermined.

Type: Bezerromyces J.D.P. Bezerra, Souza-Motta \& Crous

Notes: Bezerromycetaceae was introduced based on multi-gene phylogenetic analyses and morphological characteristics to accommodate the genera Bezerromyces and Xiliomyces. Liu et al. (2017) treated Bezerromycetaceae as a family of Tubeufiales by divergence time estimates. Lu et al. 


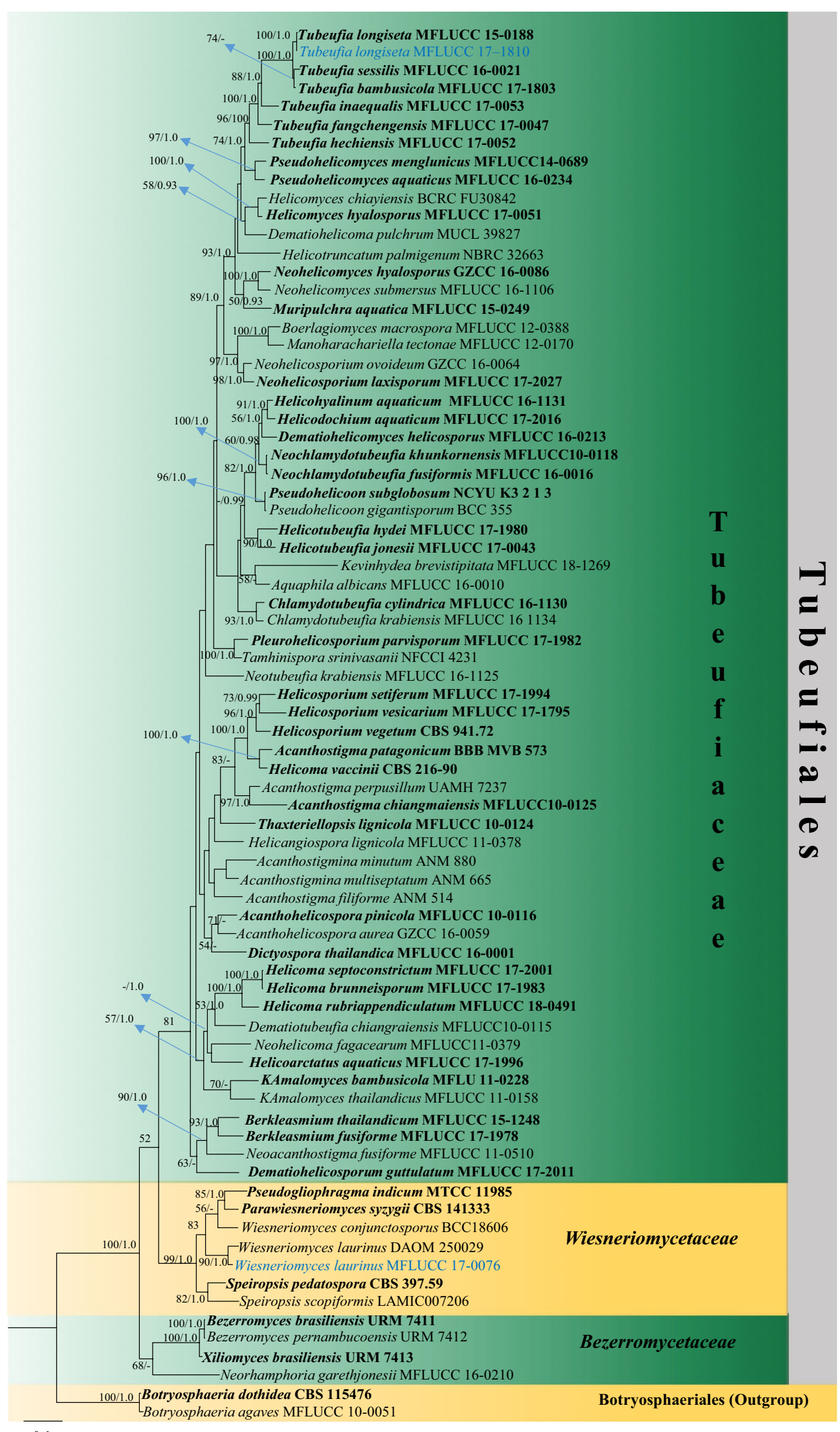

0.1 
4Fig. 82 Phylogram generated from maximum likelihood analysis (RAxML) of genera in Tubeufiales based on ITS, LSU, rpb-2 and tef1 sequence data. Maximum likelihood bootstrap values equal or above $70 \%$, Bayesian posterior probabilities equal or above 0.90 (MLBS/ PP) are given at the nodes. An original isolate number is noted after the species name. The tree is rooted to Botryosphaeria agaves (MFLUCC 10-0051) and B. dothidea (CBS 115476). The ex-type strains are indicated in bold. Hyphen (-) represents support values below 70\% MLBS and 0.90 PP

(2018b) transferred Neorhamphoria to Bezerromycetaceae based on phylogenetic and morphological evidence. Four species of Bezerromycetaceae are reported, Bezerromyces brasiliensis, B. pernambucoensis, Neorhamphoria garethjonesii, and Xiliomyces rasiliensis, and all have both morphology and DNA molecular data (Boonmee et al. 2016; Bezerra et al. 2017).

Bezerromyces J.D.P. Bezerra, Souza-Motta \& Crous, Mycol. Progr. 16: 301 (2017).

Index Fungorum number: IF 817522; Facesoffungi number: FoF 06810; 2 morphological species (Species Fungorum 2020), 2 species with molecular data.

Type species: Bezerromyces brasiliensis J.D.P. Bezerra, Souza-Motta \& Crous, Mycol. Progr. 16: 302 (2017).

Notes: Bezerromyces was established based on the type species B. brasiliensis and a second species $B$. pernambucoensis. They are known only as endophytes associated with cactus species in tropical dry forests (Bezerra et al. 2017). Their ascomata are superficial or immersed in culture media, and sometimes there have multi-septate, brown chlamydospores linked to ascomata by hyphae (Bezerra et al. 2017).

Bezerromyces brasiliensis J.D.P. Bezerra, Souza-Motta \& Crous, in Bezerra et al., Mycol. Progr. 16(4): 302 (2016) [2017].

Index Fungorum number: IF 817523; Facesoffungi number: FoF 06810; Fig. 83

Description: see Bezerra et al. (2017).

Material examined: Brazil, Pernambuco, Catimbau National Park ( $\left.8^{\circ} 36^{\prime} 35^{\prime \prime} \mathrm{S}, 37^{\circ} 14^{\prime} 40^{\prime \prime} \mathrm{W}\right)$, as endophyte from cactus Tacinga inamoena, September 2013, J.D.P. Bezerra (URM 89943, holotype).

\section{Other genera included}

Neorhamphoria Boonmee, Hüseyın \& Selçuk, Mycosphere 7(9): 1450 (2016).

Index Fungorum number: IF 552704; Facesoffungi number: FoF 02823; - 1 morphological species (Species Fungorum 2020), 1 species with molecular data.

Type species: Neorhamphoria garethjonesii Boonmee, Hüseyın \& Selçuk, Mycosphere 7(9): 1451 (2016).

Notes: Neorhamphoria was introduced as a genus incertae sedis in Tubeufiales. Lu et al. (2018b) accepted it as a member of Bezerromycetaceae based on phylogenetic and morphological evidence. Neorhamphoria is characterized by dark apothecial ascomata, broad cellular pseudoparaphyses, with bitunicate, broad-clavate asci, and hyaline, muriform ascospores.

Xiliomyces J.D.P. Bezerra, Souza-Motta \& Crous, Mycol. Progr. 16: 304 (2017).

Index Fungorum number: IF 817525; Facesoffungi number: FoF 06811; - 1 morphological species (Species Fungorum 2020), 1 species with molecular data.

Type species: Xiliomyces brasiliensis J.D.P. Bezerra, Souza-Motta \& Crous, Mycol. Progr. 16: 304 (2017).

Notes: Xiliomyces was established mainly based on phylogenetic analyses. Xiliomyces brasiliensis was reported as an endophyte from cactus Tacinga inamoena, and its morphology is incomplete because it lacks well-defined sexual or asexual structures (Bezerra et al. 2017).

\section{Economic and ecological significance}

There is no report on their economic significance but they play roles in recycling organic matter.

Tubeufiaceae M.E. Barr, Mycologia 71(5): 948 (1979).

Index Fungorum: IF 81599; Facesoffungi number: FoF 00204, 377 species.

Saprobic on decaying wood and leaves in terrestrial and/ or aquatic habitats. Sexual morph: Ascomata superficial, seated on a subiculum, unilocular, globose-subglobose to obovate, solitary to gregarious, cream-white, yellow, pale brown, brown to black, ostiolate, with or without setae. Peridium composed of cells of textura angularis, thickwalled cells, yellow, pale brown, dark brown to black externally, with thin layers of textura prismatica inwardly, hyaline, yellow, pale brown to brown. Hamathecium comprising numerous filiform, septate, branched, sometimes anastomosing, hyaline pseudoparaphyses, embedded in a gelatinous matrix. Asci 8-spored, bitunicate, fissitunicate, saccate, cylincrical to clavate, sometimes broadly oblong-subclavate, with or without an apically rounded, distinct ocular chamber, with or without pedicel, smooth-walled. Ascospores 2-3-seriate to fasciculate, elongate, cylindric, fusiform to filiform, tapering towards narrow ends, hyaline to pale brown, sometimes yellow, multi-septate, smooth-walled. Asexual morph: Hyphomycetous, 1) helicosporous. Colonies on the substratum superficial, effuse, gregarious, white to pink, pale yellow to yellow green, pale brown to brown. Mycelium mostly immersed, partly superficial, composed of branched, septate hyphae, hyaline, pale brown to brown, with masses of crowded conidia. Conidiophores macronematous, mononematous, erect, cylindrical, branched or unbranched, hyaline, pale brown to dark brown, smooth-walled. Conidiogenous cells holoblastic, mono- to polyblastic, discrete 

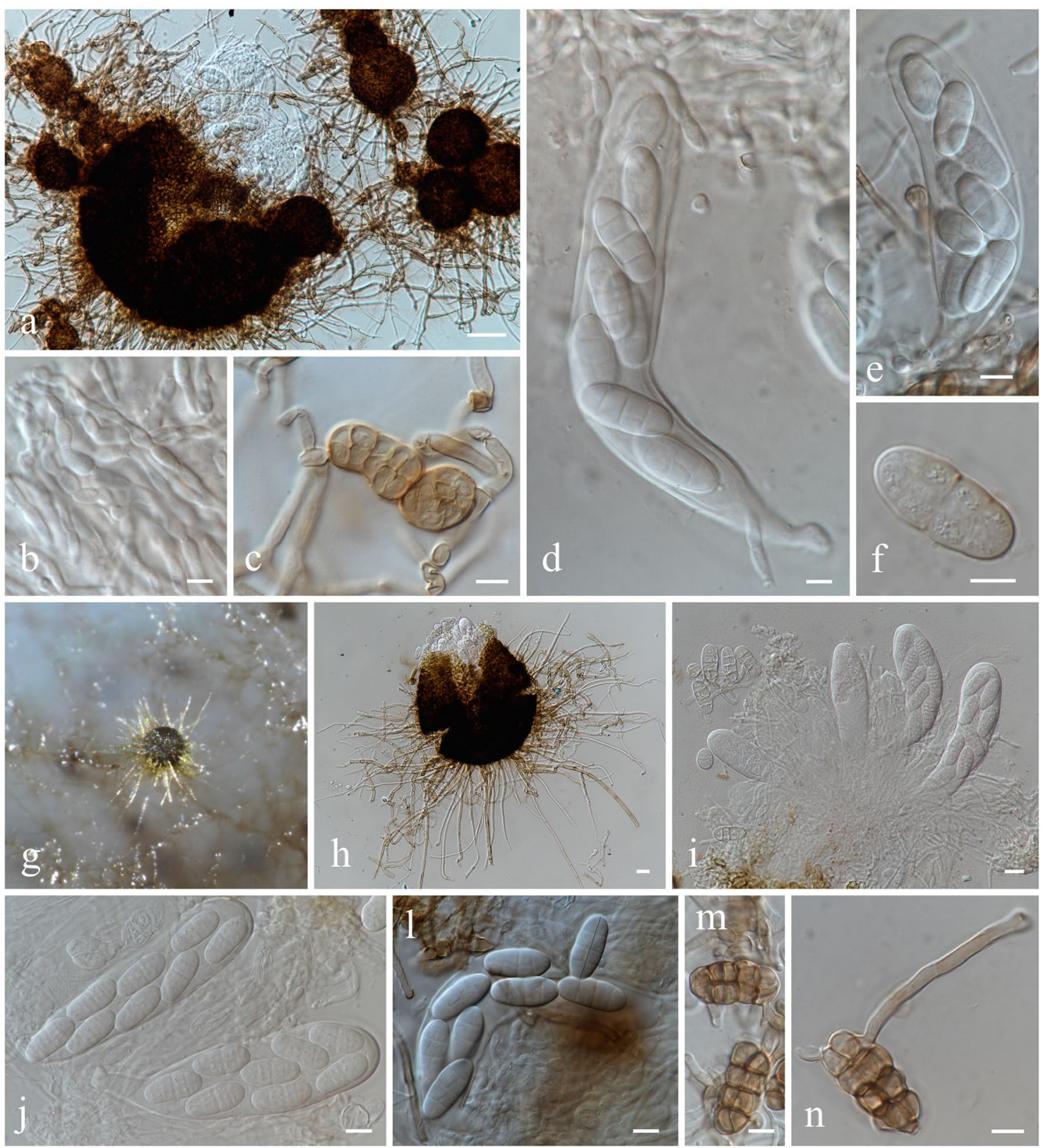

Fig. 83 Bezerromyces brasiliensis (URM 89943, holotype). a Ascomata. b Pseudoparaphyses. c Chlamydospores. d, e Asci and ascospores. f Ascospore. Bezerromyces pernambucoensis. g Asco-

or integrated, determinate or sympodial, terminal or intercalary, denticulate, arising laterally from the lower parts of conidiophores as tiny tooth-like protrusions or bladderlike protrusions, sometimes truncate at apex after conidial secession, hyaline to pale brown, smooth-walled. Conidia solitary, acrogenous, or pleurogenous, or acropleurogenous, helicoid, rounded at tip, hyaline to yellow green, yellow, pale brown to brown, multi-septate, guttulate, smooth-walled; 2 ) chlamydosporous. Conidiophores lacking. Chlamydospores holoblastic, broadly oval to ellipsoid, dictyoseptate, pale mata on culture medium. h Ascoma and ascospores. i-l Asci and ascospores. $\mathbf{m}, \mathbf{n}$ Germinating ascospores. Scale bars: $\mathbf{a}, \mathbf{h}=25 \mu \mathrm{m}$, $\mathbf{b}-\mathbf{f}, \mathbf{i}-\mathbf{n}=10 \mu \mathrm{m}$

brown when immature, darkened to black when matured, with terminal cells round and subhyaline; 3) phragmosporous. Conidiophores macronematous, mononematous, erect, arising as lateral branches from creeping hyphae, branched or unbranched, thin-walled and smooth, indistinctly septate, flexuous, hyaline. Conidiogenous cells holoblastic, mono- to polyblastic, sympodial, terminal or intercalary, cylindrical, with denticles, hyaline. Conidia solitary, acrogenous, fusiform to obclavate, slightly curved and acute at both ends, 
hyaline, multi-septate, slightly constricted at the septa, guttulate, smooth-walled.

Type: Tubeufia Penz. \& Sacc., Malpighia 11(11-12): 517 (1898) [1897].

Notes: Tubeufiaceae was introduced based on the generic type Tubeufia to accommodate bitunicate ascomycetes occurring as saprobes on decaying wood. Barr (1979a) accepted six genera in the family, while Rossman (1987) accepted 12 genera, Kirk et al. (2001) accepted 21 genera, Lumbsch and Huhndorf (2010) accepted 23 genera, and Boonmee et al. (2014b) accepted 19 genera. Brahamanage et al. (2017) introduced Dictyospora, Chaiwan et al. (2017) introduced Neotubeufia, Luo et al. (2017) introduced Muripulchra and Neohelicomyces, Liu et al. (2018) introduced Helicotubeufia and Neohelicosporium to this family based on morphology and phylogeny (Lu et al. (2018b) reappraised Tubeufiaceae and introduced 13 genera, and accepted 43 genera in this family based on phylogenetic analyses and morphological evidence. Liu et al. (2019) introduced Kevinhydea and Jayasiri et al. (2019) introduced Discotubeufia and Hyde et al. (2020b) introduced Camporesiomyces. Currently, Tubeufiaceae contains 46 genera (Lu et al. 2018b; Jayasiri et al. 2019; Liu et al. 2019).

Tubeufiaceous fungi are widespread distributed in tropical and temperate regions (Rossman 1987; Kirk et al. 2001; Lumbsch and Huhndorf 2010; Boonmee et al. 2014b; Luo et al. 2017; Lu et al. 2018a, b). Most species in this family are saprobic on terrestrial woody substrates and some are found on aquatic habitats (Barr 1979a, 1980; Rossman 1987; Kirk et al. 2001; Zhao et al. 2007; Lumbsch and Huhndorf 2010; Boonmee et al. 2011, 2014b; Hyde et al. 2016b; Doilom et al. 2017; Luo et al. 2017; Phookamsak et al. 2018). Interestingly, most asexual morphs of Tubeufiaceae were collected from freshwater habitats (Hyde et al. 2016b, 2017; Brahamanage et al. 2017; Chaiwan et al. 2017; Lu et al. 2017a, b, c, 2018a, b; Luo et al. 2017; Liu et al. 2018).

Tubeufia Penz. \& Sacc., Malpighia 11(11-12): 517 (1898) [1897].

Index Fungorum number: IF 5635; Facesoffungi number: FoF 00063; 57 morphological species (Species Fungorum 2020), 38 species with molecular data.

Notes: Tubeufia is the type genus of Tubeufiaceae, established by Penzig and Saccardo (1897) based on the type species T. javanica. Boonmee et al. (2014b) designated the epitype of T. javanica with phylogenetic analyses. Lu et al. (2018b) reappraised the taxonomy of Tubeufia and introduced 18 species and six combinations in this genus based on phylogeny and morphology.

Tubeufia longiseta D.Q. Dai \& K.D. Hyde, Fungal Diversity 82: 42 (2016).
Index Fungorum: IF 552029; Facesoffungi number: FoF 01985; Fig. 84

Saprobic on dead culms of bamboo in a forest. Sexual morph: Ascomata 230 $-350 \mu \mathrm{m}$ high $\times 170-220 \mu \mathrm{m}$ diam. superficial, gregarious, ellipsoidal, subglobose, setose, coriaceous, with a central ostiole, dark brown to black. Ostiole single, central. Setae 320-410 × 3.5-4.5 $\mu \mathrm{m}$, dense, flexuous, covering the whole ascoma, unbranched, rounded at apical end, septate, dark brown. Peridium 25-45 $\mu \mathrm{m}$ wide, composed cells of textura angularis, dark, with innermost part comprising thin layers of hyaline to pale brown cells of textura subprismatica. Hamathecium comprising numerous filiform, septate, branched, cellular pseudoparaphyses. Asci $130-160 \times 13-18 \mu \mathrm{m}(\bar{x}=150 \times 15 \mu \mathrm{m}, \mathrm{n}=20)$, 8 -spored, bitunicate, cylindrical, rounded at apex, with an ocular chamber, thick-walled, short-pedicellate. Ascospores 55-75 × 4.5-6 $\mu \mathrm{m}(\bar{x}=65 \times 5.3 \mu \mathrm{m}, \mathrm{n}=50), 2-3$-seriate, broad fusiform, cylindrical to long subfusiform, elongate, slightly curved, tapering towards rounded ends, hyaline, 13-17-septate, guttulate. Asexual morph: undetermined.

Culture characteristics: Ascospores germinating on water agar and germ tubes produced from ascospores within 12 hours. Colonies growing on PDA, circular, with flat surface, edge undulate, reaching $11 \mathrm{~mm}$ in two weeks at 28 ${ }^{\circ} \mathrm{C}$, brown to dark brown. Mycelium superficial and partially immersed, branched, septate, hyaline to pale brown, smooth.

Material examined: Thailand, Chiang Rai, Mae Fah Luang University, on dead culms of bamboo, 19 February 2017, Yong-Zhong Lu, MFU01 (MFLU 17-1119, HKAS 100789); living culture, MFLUCC 17-1810.

GenBank numbers: ITS: MW136949, TEF1: MW147764, RPB2:MW147765.

Notes: Morphologically, our new collection resembles Tubeufia longiseta in ascomata, asci, and ascospores (Dai et al. 2017). Although the ascospores of our new collection are longer than the holotype of $T$. longiseta (55-75 vs. $38.5-55.5 \mu \mathrm{m}$ ), we identify them as the same species as there is only a single base pair difference in the ITS sequence data. We provide LSU, rpb-2 and tef $1-\alpha$ sequence data in this study, but we could not compare them to the holotype of T. longiseta as it has only ITS sequence data available (Dai et al. 2017).

\section{Other genera included}

Acanthohelicospora Boonmee \& K.D. Hyde, Fungal Diversity 68(1): 251 (2014).

Index Fungorum number: IF 550572; Facesoffungi number: FoF 00206; - 4 morphological species (Species Fungorum 2020), 4 species with molecular data.

Type species: Acanthohelicospora pinicola Boonmee \& K.D. Hyde, Fungal Diversity 68(1): 251 (2014).

Notes: Acanthohelicospora was introduced based on morphological and phylogenetic evidence. Its sexual morph 

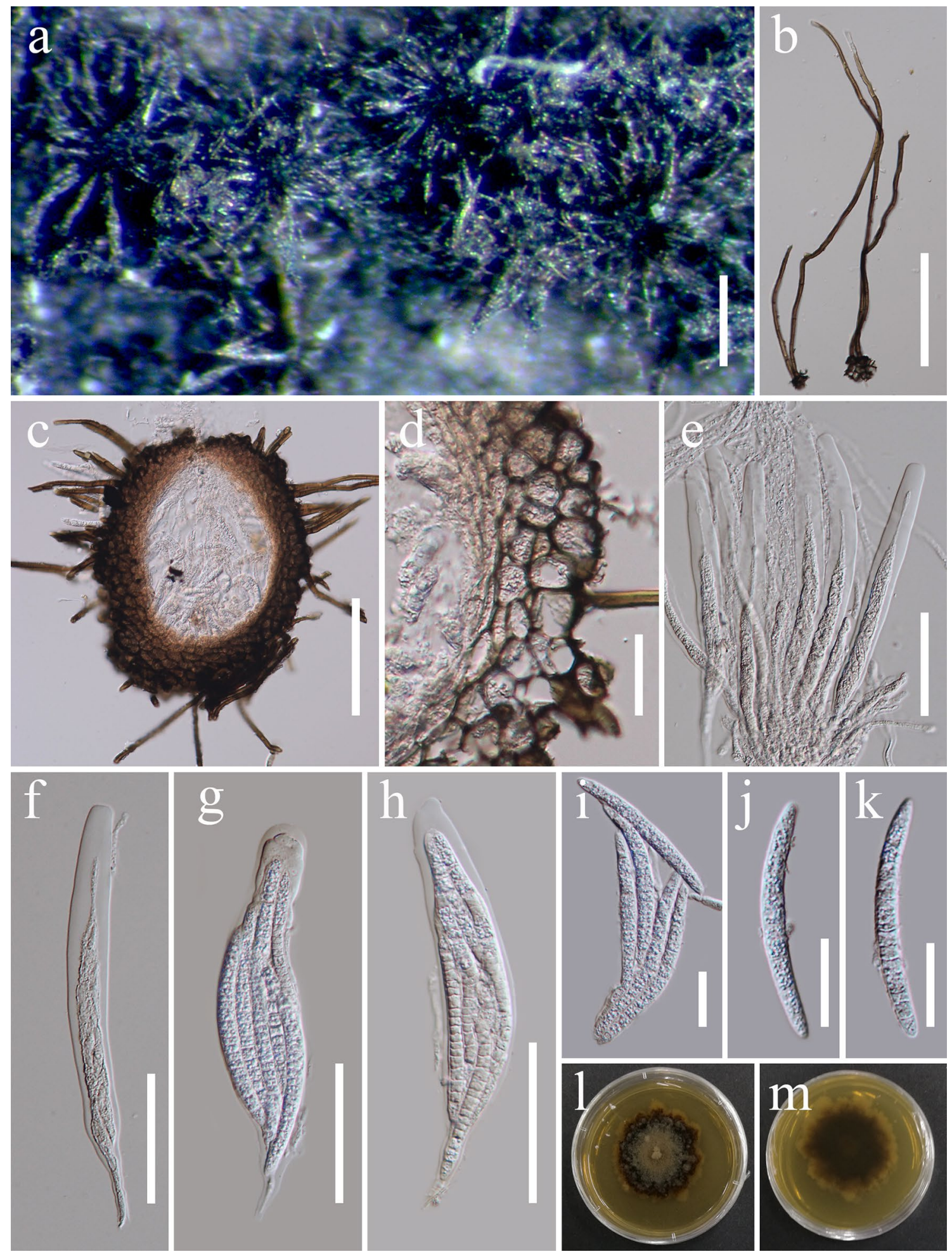

Fig. 84 Tubeufia longiseta (MFLU 17-1119). a Superficial ascomata on substrate. Note ascomata surrounded by black setae. b Setae. c Ascoma. d Peridium. e-h Asci. i-k Ascospores. l, m Colonies on
PDA from above and below. Scale bars: $\mathbf{a}, \mathbf{d}, \mathbf{i}-\mathbf{k}=200 \mu \mathrm{m}, \mathbf{b}, \mathbf{c}=$ $100 \mu \mathrm{m}, \mathbf{e}-\mathbf{h}=50 \mu \mathrm{m}$ 
is characterized by superficial ascomata covered by setae which taper to an acute apex, 8-spored, bitunicate asci and slightly curved, fusiform ascospores, which taper towards rounded ends (Boonmee et al. 2014b; Lu et al. 2018b). Its asexual morph is characterized by helicosporous hyphomycetous, which are similar to Helicosporium in conidiophores, conidiogenous cells and conidial morphology ( $\mathrm{Lu}$ et al. 2017a, 2018b). Four species are accommodated in this genus, A. aurea, A. guianensis, A. pinicola, and A. scopula (Lu et al. 2018b).

Acanthophiobolus Berl., Atti Congr. Bot. Intern. di Genova, 1892: 571 (1893).

Index Fungorum number: IF 13; Facesoffungi number: FoF 06812; - 3 morphological species (Species Fungorum 2020), molecular data unavailable.

Type species: Acanthophiobolus helicosporus (Berk. \& Broome) J. Walker, Trans. Br. mycol. Soc. 58(3): 445 (1972).

ESphaeria helicospora Berk. \& Broome, Ann. Mag. nat. Hist., Ser. 2 9: 383 (1852).

Notes: Acanthophiobolus was introduced with A. helicosporus as the type species (Berlese 1893, as A. helminthosporus). Boonmee et al. (2011) reexamined the holotype of A. helicosporus and accepted Acanthophiobolus as a member of Tubeufiaceae. The ascomata of Acanthophiobolus are globose to subglobose, reddish brown to dark brown, with much longer red brown to dark brown setae, and asci are elongate-cylindrical with long filiform ascospores (Boonmee et al. 2011, 2014). Lu et al. (2018b) listed three species, A anogeissi, A. helicosporus, and A. indicus.

Acanthostigma De Not., Hedwigia 4: 28 [1865].

Index Fungorum number: IF 16; Facesoffungi number: FoF 06813; - 41 morphological species (Species Fungorum 2020), 2 species with molecular data.

Type species: Acanthostigma perpusillum De Not., Hedwigia 4: 28 [1865].

Notes: Réblová and Barr (2000) reviewed Acanthostigma and six species were accepted. Boonmee et al. (2011) introduced A. chiangmaiensis based on phylogenetic analyses and morphology. Boonmee et al. (2014b) accepted only A. perpusillum, A. chiangmaiensis, and A. minutum within Acanthostigma, but did not change the status of other Acanthostigma species. The ascomata of Acanthostigma are globose to subglobose, dark brown to black and covered by dark setae, asci are clavate with a short pedicel, and ascospores are broadly fusiform to clavate, with one of the middle cells often broader than others (Boonmee et al. 2011, 2014). Lu et al. (2018b) accepted seven species, A. chiangmaiensis, A. ellisii, A. longisporum, A. minutum, A. patagonicum, $A$. perpusillum, and $A$. revocatum.
Acanthostigmina Höhn., Sber. Akad. Wiss. Wien, Math.naturw. Kl., Abt. 1 118: 1499 (1909).

Index Fungorum number: IF 19; Facesoffungi number: FoF 06814; -2 morphological species (Species Fungorum 2020), 2 species with molecular data.

Type species: Acanthostigmina minuta (Fuckel) Clem. \& Shear, Gen. fung., Edn 2 (Minneapolis): 270 (1931).

$\equiv$ Lasiosphaeria minuta Fuckel, Jb. nassau. Ver. Naturk. 23-24: 148 (1870) [1869-70].

Notes: Boonmee et al. (2014b) reported that A. minuta (ANM810, ANM818 and ANM238) is related to two strains of A. multiseptatum (ANM475 and ANM665) which represented Acanthostigmina. The ascomata of Acanthostigmina are globose to subglobose, dark brown, and covered by sparse dark brown to black setae, and asci are broadly cylindric-subclavate with curved fusiform ascospores (Boonmee et al. 2014b). Lu et al. (2018b) accepted two species, A. minuta and A. multiseptatum.

Acanthotubeufia Y.Z. Lu \& K.D. Hyde, Fungal Diversity 92: 146 (2018).

Index Fungorum number: IF 554812; Facesoffungi number: FoF 04696; - 1 morphological species (Species Fungorum 2020), 1 species with molecular data.

Type species: Acanthotubeufia filiforme (Promp. \& A.N. Mill.) Y.Z. Lu \& K.D. Hyde, Fungal Diversity 92: 146 (2018).

E Acanthostigma filiforme Promp. \& A.N. Mill., Mycologia 102(3): 575 (2010).

Notes: Acanthotubeufia was introduced based on morphological and phylogenetic analyses. Its morphology is similar to Neoacanthostigma and Acanthostigma with one-celled or rarely one-septate setae covering the globose to subglobose ascomata, but differs by its longer, narrower and symmetrical filiform ascospores (Promputtha and Miller 2010, as Acanthostigma filiforme; Lu et al. 2018b).

Aquaphila Goh, K.D. Hyde \& W.H. Ho, Mycol. Res. 102(5): 588 (1998).

Index Fungorum number: IF 27791; Facesoffungi number: FoF 02356; - 2 morphological species (Species Fungorum 2020), 1 species with molecular data.

Type species: Aquaphila albicans Goh, K.D. Hyde \& W.H. Ho, Mycol. Res. 102(5): 588 (1998).

Notes: Castañeda-Ruíz et al. (2000) introduced A. edentata based on morphology. Tsui et al. (2007) accepted Aquaphila as a member of Tubeufiaceae based on phylogenetic analyses. Boonmee et al. (2014b) linked its sexual-asexual morphs based on phylogenetic evidence. The sexual morph of Aquaphila is characterized by dark globose to subglobose ascomata covered by brown setae, and cylindrical-clavate asci with fusiform ascospores (Boonmee et al. 2014b). Its asexual morphs are hyaline flexuous to geniculate 
conidiophores with hyaline fusoid to falcate or sigmoid conidia (Goh et al. 1998a; Boonmee et al. 2014b; Hyde et al. 2016b). Hyde et al. (2016b) reported a new record of A. albicans associated with submerged wood in southern Thailand.

Artocarpomyces Subram., Kavaka 22/23: 52 (1996) [1994]. Index Fungorum number: IF 28736; Facesoffungi number: FoF 06815; - 1 morphological species (Species Fungorum 2020), 1 species with molecular data.

Type species: Artocarpomyces paradoxus Subram. [as 'paradoxa'], Kavaka 22/23: 52 (1996) [1994].

Notes: Artocarpomyces is characterized by macronematous conidiophores arising from a brown pseudoparenchymatous stroma, and conidia are muriform, irregular and resembling the fruit of Artocarpus (Subramanian 1994). Lu et al. (2018b) accepted Artocarpomyces as a genus of Tubeufiaceae based on morphological evidence.

Berkleasmium Zobel, Icon. fung. (Prague) 6: 4 (1854).

Index Fungorum number: IF 7362; Facesoffungi number: FoF 01879; - 44 morphological species (Species Fungorum 2020), 7 species with molecular data.

Type species: Berkleasmium concinnum (Berk.) S. Hughes, Canad. J. Bot. 36: 740 (1958).

三Sporidesmium concinnum Berk., London J. Bot. 4: 309 (1845).

Notes: Tanney and Miller (2017) accepted Berkleasmium within Tubeufiaceae, and reported that the type species $B$. concinnum, is the asexual morph of Neoacanthostigma septoconstrictum based on phylogenetic analyses. Lu et al. (2018b) accepted seven Berkleasmium species within Tubeufiaceae based on phylogenetic and morphological evidence. Berkleasmium is characterized by superficial ascomata with dark brown to black multi-celled setae, and cylindrical asci with slightly curved fusiform ascospores (Tanney and Miller 2017; Lu et al. 2018b). Its asexual morphs comprise dictyosporous and helicosporous hyphomycetes (Tanney and Miller 2017; Lu et al. 2018b).

Bifrontia Norman, Bot. Notiser: 18 (1872).

Index Fungorum number: IF 569; Facesoffungi number: FoF 00175; - 2 morphological species (Species Fungorum 2020), molecular data unavailable.

Type species: Bifrontia compactior Norman, Bot. Notiser: 19 (1872).

Notes: Boonmee et al. (2014b) reexamined the holotype of B. compactior and accepted Bifrontia as a genus of Tubeufiaceae. The ascomata of Bifrontia are globose to subglobose, collapsing when mature or dried, and asci are fusiform with straight to slightly curved fusiform ascospores (Boonmee et al. 2014b).
Index Fungorum number: IF 607; Facesoffungi number: FoF 00176; - 8 morphological species (Species Fungorum 2020), molecular data unavailable.

Type species: Boerlagiomyces velutinus (Penz. \& Sacc.) Butzin, Willdenowia 8(1): 39 (1977).

$\equiv$ Boerlagella velutina Penz. \& Sacc., Malpighia 11(9-10): 404 (1897).

Notes: Crane et al. (1998) reviewed and accepted six Boerlagiomyces species in Tubeufiaceae. The ascomata of Boerlagiomyces are globose and covered with flexuous and hairy black velvety setae, and asci are cylindric-clavate with hyaline muriform ascospores (Boonmee et al. 2014b). Lu et al. (2018b) listed eight species in this genus.

Camporesiomyces D.P. Wanas. \& K.D. Hyde, Fungal Diversity 100: 139 (2020).

Index Fungorum number: IF 557070; Facesoffungi number: FoF 07074; -3 morphological species (Species Fungorum 2020), 3 species with molecular data.

Type species: Camporesiomyces mali D.P. Wei \& K.D. Hyde, Fungal Diversity 100: 139 (2020).

Notes: Camporesiomyces was introduced based on morphological and phylogenetic analyses. The type species of Camporesiomyces is distinguished from other members in Tubeufiaceae by multi-loculate ascomata (Hyde et al. 2020b). Acanthostigma patagonicum and Helicoma vaccinii were transferred to Camporesiomyces patagonicus and $C$. vaccinii based on phylogenetic evidence, respectively (Hyde et al. 2020b).

Chaetosphaerulina I. Hino, Bull. Miyazaki Coll. Agric. Forest. 10: 62 (1938).

Index Fungorum number: IF 971; Facesoffungi number: FoF 06816; - 6 morphological species (Species Fungorum 2020), molecular data unavailable.

Type species: Chaetosphaerulina yasudae I. Hino, Canad. J. Plant Sci. 10: 62 (1938).

Notes: Pirozynski (1972) transferred C. yasudae and $C$. vermicularispora to Herpotrichia. Sivanesan (1984) transferred these two species to Tubeufia. Crane (1998) transferred Thaxteriellopsis bambusicola and T. lignicola to Chaetosphaerulina. Boonmee et al. (2011) accepted Crane's evaluation for Thaxteriellopsis bambusicola but reinstated $T$. lignicola as the type species of Thaxteriellopsis. Boonmee et al. (2014b) excluded Chaetosphaerulina from Tubeufiaceae. Lu et al. (2018b) accepted Chaetosphaerulina as a member of Tubeufiaceae based on morphological evidence. The ascomata of Chaetosphaerulina are ovoid to ellipsoid and covered with hairy setae, asci are cylindrical and slightly truncate at apex, with curved hyaline fusiform ascospores which are constricted at the median (Boonmee et al. 2011).

Boerlagiomyces Butzin, Willdenowia 8(1): 39 (1977). 
Chlamydotubeufia Boonmee \& K.D. Hyde, Fungal Diversity 51(1): 78 (2011).

Index Fungorum number: IF 563500; Facesoffungi number: FoF 02357; - 5 morphological species (Species Fungorum 2020), 4 species with molecular data.

Type species: Chlamydotubeufia huaikangplaensis Boonmee \& K.D. Hyde, Fungal Diversity 51(1): 78 (2020).

Notes: Lu et al. (2018b) accepted five species in Chlamydotubeufia and excluded three species from this genus based on phylogenetic inference. The sexual morph of Chlamydotubeufia is characterized by globose to subglobose ascomata covered with dark brown to black setae, and cylindrical to clavate asci with straight to slightly curved fusiform ascospores (Boonmee et al. 2011; Lu et al. 2018b). Its asexual morphs are mostly chlamydosporous and rarely helicosporous hyphomycetous (Lu et al. 2018b).

Dematiohelicoma Y.Z. Lu, J.C. Kang \& K.D. Hyde, Fungal Diversity 92: 157 (2018).

Index Fungorum number: IF 554821; Facesoffungi number: FoF 04700; - 2 morphological species (Species Fungorum 2020), 2 species with molecular data.

Type species: Dematiohelicoma pulchrum (R.F. Castañeda \& Guarro) Y.Z. Lu \& K.D. Hyde, Fungal Diversity 92: 158 (2018).

$\equiv$ Helicoma pulchrum R.F. Castañeda \& Guarro [as 'pulchra'], in Castañeda Ruíz, Kendrick, Guarro \& Mayayo, Mycol. Res. 102(1): 58 (1998).

Notes: Dematiohelicoma was introduced based on morphological and phylogenetic analyses. The conidia of Dematiohelicoma are characterized by hyaline or subhyaline basal cells, tapering gradually towards a truncated base, while the remaining cells are reddish brown, and their conidial septa are dark brown and obviously darker than the adjacent parts (Lu et al. 2018b).

Dematiohelicomyces Y.Z. Lu, Boonmee \& K.D. Hyde, Fungal Diversity 92: 159 (2018).

Index Fungorum number: IF 554824; Facesoffungi number: FoF 04701; - 1 morphological species (Species Fungorum 2020), 1 species with molecular data.

Type species: Dematiohelicomyces helicosporus (Boonmee, Y.Z. Lu \& K.D. Hyde) Y.Z. Lu, Fungal Diversity 92: 159 (2018).

$\equiv$ Chlamydotubeufia helicospora Boonmee, Y.Z. Lu \& K.D. Hyde, in Hyde et al., Fungal Diversity 80:123 (2016).

Notes: Dematiohelicomyces was introduced based on morphological and phylogenetic analyses. Dematiohelicomyces resembles Helicomyces in having short conidiophores that are $0-3$-septate, and helicoid conidia, having a spathulate basal end cell, but can be distinguished by its brown conidiophores (Lu et al. 2018b).
Dematiohelicosporum Y.Z. Lu, J.K. Liu \& K.D. Hyde, Fungal Diversity 92: 159 (2018).

Index Fungorum number: IF 554826; Facesoffungi number: FoF 04703; - 1 morphological species (Species Fungorum 2020), 1 species with molecular data.

Type species: Dematiohelicosporum guttulatum Y.Z. Lu, J.K. Liu \& K.D. Hyde, Fungal Diversity 92: 160 (2018).

Notes: Dematiohelicosporum was introduced based on morphological and phylogenetic analyses. Conidia of Dematiohelicosporum are slightly circinate in three dimensions, clearly verrucose and guttulate, olivaceous to brown ( $\mathrm{Lu}$ et al. 2018b).

Dematiotubeufia Y.Z. Lu, Boonmee \& K.D. Hyde, Fungal Diversity 92: 160 (2018).

Index Fungorum number: IF 554828; Facesoffungi number: FoF 04705; - 1 morphological species (Species Fungorum 2020), 1 species with molecular data.

Type species: Dematiotubeufia chiangraiensis (Boonmee \& K.D. Hyde) Y.Z. Lu, Fungal Diversity 92: 162 (2018).

$\equiv$ Helicoma chiangraiense Boonmee \& K.D. Hyde, in Boonmee, Rossman, Liu, Crous, Bhat, Chukeatirote, Jones \& Hyde, Fungal Diversity 68: 271 (2014).

Notes: Dematiotubeufia was introduced based on morphology and phylogenetic analysis. It is characterized by dark brown to black, shiny ascomata with distinct ostioles, and cylindrical asci with straight to slightly curved fusiform ascospores (Boonmee et al. 2014b, as Helicoma chiangraiense; Lu et al. 2018b).

Dictyospora Brahaman., Y.Z. Lu, Boonmee \& K.D. Hyde, Mycosphere 8(7): 924 (2017).

Index Fungorum number: IF 553178; Facesoffungi number: FoF 03262; - 1 morphological species (Species Fungorum 2020), 1 species with molecular data.

Type species: Dictyospora thailandica Brahaman., Y.Z. Lu, Boonmee \& K.D. Hyde, Mycosphere 8(7): 924 (2017).

Notes: Lu et al. (2018b) described a new record of $D$. thailandica bearing some peculiar morphological characteristics, and pointed out that Dictyospora resembles Chlamydotubeufia in both asexual and sexual morphs, but phylogenetic analyses indicated that they are distinct genera.

Discotubeufia Jayasiri, E.B.G. Jones \& K.D. Hyde, Mycosphere 10(1): 156 (2019).

Index Fungorum number: IF 555585; Facesoffungi number: FoF 05300; - 1 morphological species (Species Fungorum 2020), 1 species with molecular data.

Type species: Discotubeufia browneae Jayasiri, E.B.G. Jones \& K.D. Hyde, Mycosphere 10(1): 158 (2019).

Notes: Discotubeufia is characterized by cup-shaped, erumpent to superficial, light brown to dark, setiferous 
ascomata and cylindrical to sub cylindrical asci (Jayasiri et al. 2019).

Helicangiospora Boonmee, Bhat \& K.D. Hyde, Fungal Diversity 68(1): 259 (2014).

Index Fungorum number: IF 550574; Facesoffungi number: FoF 00210; - 1 morphological species (Species Fungorum 2020), 1 species with molecular data.

Type species: Helicangiospora lignicola Boonmee, Bhat \& K.D. Hyde, Fungal Diversity 68(1): 262 (2014).

Notes: Helicangiospora helicoma-like asexual morph was found from the culture of sexual morph specimen (Boonmee et al. 2014b).

Helicoarctatus Y.Z. Lu, J.C. Kang \& K.D. Hyde, Fungal Diversity 92: 165 (2018).

Index Fungorum number: IF 554830; Facesoffungi number: FoF 04707; - 1 morphological species (Species Fungorum 2020), 1 species with molecular data.

Type species: Helicoarctatus aquaticus Y.Z. Lu, J.C. Kang \& K.D. Hyde, Fungal Diversity 92: 166 (2018).

Notes: Helicoarctatus shares similar morphology with Helicosporium by setiform conidiophores, and discrete, tooth-like protrusions conidiogenous cells arising laterally from lower portion of the conidiophores, with each bearing 1-2 tiny sporogenous conidiogenous loci ( $\mathrm{Lu}$ et al. 2018b).

Helicodochium J.S. Monteiro, R.F. Castañeda, A.C. Cruz \& Gusmão, Mycotaxon 127: 6 (2014).

Index Fungorum number: IF 804995; Facesoffungi number: FoF 04709; -2 morphological species (Species Fungorum 2020), 1 species with molecular data.

Type species: Helicodochium amazonicum J.S. Monteiro, R.F. Castañeda, A.C. Cruz \& Gusmão, Mycotaxon 127: 6 (2014).

Notes: Lu et al. (2018b) accepted Helicodochium as a genus of Tubeufiaceae based on morphological and phylogenetic evidence. Helicodochium is characterized by sporodochial conidiomata, macronematous branched conidiophores, and conidiogenous cells that produce helicoids, multi-septate, smooth and hyaline conidia (Monteiro et al. 2014; Lu et al. 2018b).

Helicohyalinum Y.Z. Lu, J.K. Liu \& K.D. Hyde, Fungal Diversity 92: 168 (2018).

Index Fungorum number: IF 554833; Facesoffungi number: FoF 04710; - 2 morphological species (Species Fungorum 2020), 2 species with molecular data.

Type species: Helicohyalinum infundibulum Y.Z. Lu, J.K. Liu \& K.D. Hyde, Fungal Diversity 92: 170 (2018).

Notes: Helicohyalinum is characterized by flexuous, cylindrical, 0-3-septate, hyaline conidiophores with the terminal conidiogenous cells tapering towards apex, having an inverted funnel shape at apex (Lu et al. 2018b).

Helicoma Corda, Icon. fung. (Prague) 1: 15 (1837).

Index Fungorum number: IF 8473; Facesoffungi number: FoF 00211; - 64 morphological species (Species Fungorum 2020), 22 species with molecular data.

Type species: Helicoma muelleri Corda, Icon. fung. (Prague) 1: 15 (1837).

Notes: Goos (1986) reviewed the status of Helicoma species. Lu et al. (2018b) introduced ten new Helicoma species, and redefined the morphological concept of Helicoma to include two additional asexual morphs, one is the typicalhelicoma morphology with conidia that are acrogenous or acropleurogenous, helicoid, circinate, dry, tapering towards apex, truncate at the base, coiled 11/4-13/4 times, not becoming loose in water. Another one is characterized by conidiogenous cells that are intercalary, cylindrical, with denticles, arising laterally from the lower portion of conidiophores as tooth-like protrusions, and conidia are pleurogenous, helicoid, hygroscopic, tapering towards apex and rounded at tip, coiled $1 \frac{1}{2}-5$ times, becoming loosely coiled in water $(\mathrm{Lu}$ et al. 2018b). Lu et al. (2018b) accepted 57 species within Helicoma, and excluded twelve species from this genus. Liu et al. (2019) reported a new species, $H$. hydei, from decaying wood in Thailand.

Helicomyces Link, Mag. Gesell. naturf. Freunde, Berlin 3(1-2): 21 (1809).

Index Fungorum number: IF 8476; Facesoffungi number: FoF 00212; - 17 morphological species (Species Fungorum 2020), 4 species with molecular data.

Type species: Helicomyces roseus Link, Mag. Gesell. naturf. Freunde, Berlin. 3: 21 (1809).

Notes: Linder (1929) redefined this genus, and many of the species originally assigned to Helicomyces were reassigned to Helicosporium or Helicoma. Moore (1955) provided a key for all known Helicomyces species. Goos (1985) reviewed the taxonomic status of Helicomyces, provided updated descriptions and a key to accepted species. Lu et al. (2018b) pointed out the confusion of Helicomyces and reappraised its taxonomy and phylogeny. Twelve species were accepted in Helicomyces and four species were excluded ( $\mathrm{Lu}$ et al. 2018b). Helicomyces is characterized by conidiophores that are 0-3-septate, arising as lateral branches from creeping hyphae, conidiogenous cells are integrated, sympodial and truncate at apex after conidial secession, and conidia are acrogenous or acropleurogenous, helicoid and rounded at tip (Link 1809; Linder 1929; Moore 1955; Goos 1985; Lu et al. 2018b).

Helicosporium Nees, Syst. Pilze (Würzburg): 68 (1817) 13 species (Lu et al. 2018b). 
Index Fungorum number: IF 8484; Facesoffungi number: FoF 00213; - 20 morphological species (Species Fungorum 2020), 8 species with molecular data.

Type species: Helicosporium vegetum Nees, Syst. Pilze (Würzburg): 68 (1817).

Notes: Linder (1929) redefined the generic concept of Helicosporium. Goos (1989) reviewed the status of Helicosporium species and redefined the generic concept including species with hyaline conidia whose filaments do not exceed $3 \mu \mathrm{m}$ diam. Lu et al. (2018b) reviewed all Helicosporium species, redefined the generic concept, and accepted 13 species and excluded 25 species from this genus.

Helicotruncatum Y.Z. Lu, J.C. Kang \& K.D. Hyde, Fungal Diversity 92: 220 (2018).

Index Fungorum number: IF 554859; Facesoffungi number: FoF 04730; - 1 morphological species (Species Fungorum 2020), 1 species with molecular data.

Type species: Helicotruncatum palmigenum (Penz. \& Sacc.) Y.Z. Lu \& K.D. Hyde, Fungal Diversity 92: 220 (2018).

三 Helicosporium intermedium var. palmigenum Penz. \& Sacc., Malpighia 15(7-9): 249 (1902) [1901].

Notes: Helicotruncatum was established based on morphological and phylogenetic evidence. Helicotruncatum is characterized by the lateral cell wall of the conidiophore and by the basal cells of conidia distinctively thickened ( $\mathrm{Lu}$ et al. 2018b).

Helicotubeufia Y.Z. Lu \& J.K. Liu, Mycosphere 9(3): 500 (2018).

Index Fungorum number: IF 554759; Facesoffungi number: FoF 04385; - 3 morphological species (Species Fungorum 2020), 3 species with molecular data.

Type species: Helicotubeufia guangxiensis Y.Z. Lu \& J.K. Liu, Mycosphere 9(3): 500 (2018).

Notes: Helicotubeufia was introduced based on phylogenetic and morphological evidence to accommodate three species, the type species $H$. guangxiensis, $H$. hydei, and $H$. jonesii. Helicotubeufia is characterized by subglobose to ellipsoidal-ovate, dark brown to black ascomata, and cylindrical asci with hyaline fusiform, slightly curved ascospores, and hyphomycetous helicosporous asexual morphs (Liu et al. 2018).

Kamalomyces R.K. Verma, N. Sharma \& Soni, Forest Fungi of Central India: 196 (2008).

Index Fungorum number: IF 512509; Facesoffungi number: FoF 06817; - 6 morphological species (Species Fungorum 2020), 3 species with molecular data.

Type species: Kamalomyces indicus R.K. Verma, N. Sharma \& Soni, Forest Fungi of Central India: 196 (2008).
Notes: Phookamsak et al. (2018) reported the phylogenetic relationship of Kamalomyces and first described its asexual morph. Kamalomyces is characterized by subglobose to lemoniform ascomata with short stalks on a subiculum of black hyphae, and broadly cylindrical to clavate asci with crowded, hyaline vermiform and septate ascospores (Verma et al. 2008; Phookamsak et al. 2018). Six Kamalomyces species are accepted, $K$. bambusicola, $K$. indicus, $K$. mahabaleshwarensis, K. mangrovei, $K$. polyseptatus and $K$. thailandicus (Lu et al. 2018b, Hyde et al. 2019).

Kevinhydea N.G. Liu, Y.Z. Lu \& J.K. Liu, Mycol. Prog. 18: 675 (2019).

Index Fungorum number: IF 555352; Facesoffungi number: FoF 04875; - 1 morphological species (Liu et al. 2019), 1 species with molecular data.

Type species: Kevinhydea brevistipitata N.G. Liu, Y.Z. Lu \& J.K. Liu, Mycol. Prog. 18: 677 (2019).

Notes: Kevinhydea was introduced based on phylogenetic and morphological evidence. Kevinhydea is characterized by dictyosporous asexual morph and has short conidiophores which differentiate it from Chlamydotubeufia, Dictyospora, Tamhinispora, and Tubeufia, genera that lack conidiophores (Liu et al. 2019).

Manoharachariella Bagyan., N.K. Rao \& Kunwar, Mycotaxon 109: 301 (2009).

Index Fungorum number: IF 512919; Facesoffungi number: FoF 07530; - 4 morphological species (Species Fungorum 2020), 1 species with molecular data.

Type species: Manoharachariella lignicola Bagyan., N.K. Rao \& Kunwar, Mycotaxon 109: 302 (2009).

Notes: Rajeshkumar and Singh (2012) introduced Manoharachariella indica and Selcuk and Ekici (2014) introduced M. elsadii based on morphological evidence. Doilom et al. (2017) introduced the fourth species, M. tectonae, and accepted this genus as a member of Tubeufiaceae based on phylogenetic analysis and morphological evidence. Manoharachariella is characterized by macronematous, mononematous conidiophores with integrated monoblastic conidiogenous cells producing solitary, doliiform, obpyriform dictyoseptate and apiculate conidia (Bagyanarayana et al. 2009; Rajeshkumar and Singh 2012; Selcuk and Ekici 2014; Doilom et al. 2017).

Muripulchra Z.L. Luo, Hong Y. Su \& K.D. Hyde, Cryptog. Mycol. 38(1): 36 (2017).

Index Fungorum number: IF 818825; Facesoffungi number: FoF 02647; - 1 morphological species (Species Fungorum 2020), 1 species with molecular data.

Type species: Muripulchra aquatica Z.L. Luo, Hong Y. Su \& K.D. Hyde, Cryptog. Mycol. 38(1): 39 (2017). 
Notes: Muripulchra was introduced based on phylogenetic and morphological analyses. Muripulchra is characterized by its obpyriform conidia often carrying part of conidiogenous cells at the base as a broken frill (Luo et al. 2017).

Neoacanthostigma Boonmee, Bhat \& K.D. Hyde, Fungal Diversity 68(1): 278 (2014).

Index Fungorum number: IF 550576; Facesoffungi number: FoF 00214; - 3 morphological species (Species Fungorum 2020), 1 species with molecular data.

Type species: Neoacanthostigma fusiforme Boonmee, Bhat \& K.D. Hyde, Fungal Diversity 68(1): 279 (2014).

Notes: Neoacanthostigma was introduced based on phylogenetic and morphological evidence. Lu et al. (2017c) introduced four new Neoacanthostigma species. Lu et al. (2018b) accepted only the type species $N$. fusiforme based on phylogenetic and morphological analyses. The ascomata of Neoacanthostigma are globose to subglobose, reddish brown to dark brown, to black, and are covered by black setae. Asci are cylindric-clavate with a short rounded pedicel, ascospores are narrowly fusiform and tapering towards the rounded ends. The asexual morph of Neoacanthostigma is characterized by helicosporous hyphomycetous, which lack conidiophores, and conidia are acrogenous with loosely coiled conidial filaments (Boonmee et al. 2014b; Lu et al. 2018b).

Neochlamydotubeufia Y.Z. Lu, Boonmee \& K.D. Hyde, Fungal Diversity 92: 221 (2018).

Index Fungorum number: IF 554861; Facesoffungi number: FoF 04731; 2 morphological species (Species Fungorum 2020), 2 species with molecular data.

Type species: Neochlamydotubeufia fusiformis Y.Z. Lu, Boonmee \& K.D. Hyde, Fungal Diversity 92: 221 (2018).

Notes: Neochlamydotubeufia was introduced based on phylogenetic evidence. Neochlamydotubeufia shares similar sexual and asexual morphs with Chlamydotubeufia and Dictyospora, but phylogenetic analyses support Neochlamydotubeufia as a distinct genus (Lu et al. 2018b).

Neohelicoma Y.Z. Lu, Boonmee \& K.D. Hyde, Fungal Diversity 92: 224 (2018).

Index Fungorum number: IF 554864; Facesoffungi number: FoF 04734; - 1 morphological species (Species Fungorum 2020), 1 species with molecular data.

Type species: Neohelicoma fagacearum (Boonmee \& K.D. Hyde) Y.Z. Lu, Fungal Diversity 92: 224 (2018).

$\equiv$ Helicoma fagacearum Boonmee \& K.D. Hyde, in Boonmee et al., Fungal Diversity 68: 271 (2014).

Notes: Neohelicoma was introduced based on phylogenetic evidence. Neohelicoma shares similar sexual morph with Helicoma in ascomata, asci and ascospores, but phylogenetic analyses supported it as a distinct genus (Lu et al. 2018b). The type species Neohelicoma fagacearum is the only accepted species within this genus.

Neohelicomyces Z.L. Luo, Bhat \& K.D. Hyde, Cryptog. Mycol. 38(1): 39 (2017).

Index Fungorum number: IF 818820; Facesoffungi number: FoF 02643; - 8 morphological species (Species Fungorum 2020), 8 species with molecular data.

Type species: Neohelicomyces aquaticus Z.L. Luo, Bhat \& K.D. Hyde, Cryptog. Mycol. 38(1): 40 (2017).

Notes: Neohelicomyces was introduced to accommodate $N$. aquaticus, $N$. grandisporus, and $N$. submersus. Lu et al. (2018b) introduced Neohelicomyces hyalosporus, and synonymized Helicosporium pallidum under Neohelicomyces based on phylogenetic and morphological evidence. Tibpromma et al. (2018b) reported Neohelicomyces pandanicola from dead roots of Pandanus. Crous et al. (2019a) introduced $N$. deschampsiae from the culm base of dead leaf sheath of Deschampsia cespitosa. Neohelicomyces can be recognized from other helicosporous hyphomycetous by its hyaline conidiophores and conidia (Luo et al. 2017; Lu et al. 2018b; Crous et al. 2019a).

Neohelicosporium Y.Z. Lu, J.C. Kang \& K.D. Hyde, Mycol. Progr. 17 (5): 637 (2017).

Index Fungorum number: IF 822045; Facesoffungi number: FoF 03570; - 22 morphological species (Species Fungorum 2020), 18 species with molecular data.

Type species: Neohelicosporium parvisporum Y.Z. Lu, J.C. Kang \& K.D. Hyde, Mycol. Progr. 17 (5): 637 (2017).

Notes: Neohelicosporium was established based on phylogenetic and morphological evidence. Lu et al. (2018b) accepted 22 species in this genus. Neohelicosporium differs from Helicosporium in having acrogenous and/or acropleurogenous conidia developing from an integrated, sympodial conidiogenous cells while Helicosporium species have pleurogenous conidia and discrete, determinate conidiogenous cells (Lu et al. 2018a, b).

Neotubeufia Chaiwan, Boonmee, Y.Z. Lu \& K.D. Hyde, Mycosphere 8(9): 1149 (2017).

Index Fungorum number: IF 553871; Facesoffungi number: FoF 03777; - 1 morphological species (Species Fungorum 2020), 1 species with molecular data.

Type species: Neotubeufia krabiensis Chaiwan, Boonmee, Y.Z. Lu \& K.D. Hyde, Mycosphere 8(9): 1149 (2017).

Notes: Neotubeufia was introduced based on phylogenetic and morphological evidence. The type species $N$. krabiensis is the only accepted species in this genus. The ascomata of Neotubeufia are dark brown to black subglobose without setae, and asci are broadly cylindrical with slightly curved cylindric-fusiform ascospores (Chaiwan et al. 2017). 
Pleurohelicosporium Y.Z. Lu, J.C. Kang \& K.D. Hyde, Fungal Diversity 92: 247 (2018).

Index Fungorum number: IF 554884; Facesoffungi number: FoF 04743; - 1 morphological species (Species Fungorum 2020), 1 species with molecular data.

Type species: Pleurohelicosporium parvisporum Y.Z. Lu, J.C. Kang \& K.D. Hyde, Fungal Diversity 92: 248 (2018).

Notes: Pleurohelicosporium was introduced based on phylogenetic and morphological evidence. Pleurohelicosporium shares similar asexual morphs with Neohelicosporium but can be distinguished by its pleurogenous conidia, while the conidia of Neohelicosporium are acrogenous or acropleurogenous (Lu et al. 2018b). The type species P. parvisporum is the only accepted species in this genus.

Podonectria Petch, Trans. Br. mycol. Soc. 7(3): 146 (1921). Index Fungorum number: IF 4280; Facesoffungi number: FoF 06818; - 9 morphological species (Species Fungorum 2020), molecular data unavailable.

Type species: Podonectria coccicola (Ellis \& Everh.) Petch, Trans. Br. mycol. Soc. 7(3): 146 (1921).

三 Nectria coccicola Ellis \& Everh., J. Mycol. 2(4): 39 (1886).

Notes: Rossman (1978) reviewed this genus and accepted eight species. The ascomata of Podonectria are subgloboseglobose, light yellow reddish and covered with light brown mycelium, asci are cylindric-clavate with short pedicele, and ascospores are clavate to fusiform. Its asexual morph is characterized by phragmosporous hyphomycetous, and conidia are produced on sympodial conidiophores (Petch 1921; Rossman 1978; Boonmee et al. 2011). Boonmee et al. (2014b) accepted Podonectria in Tubeufiaceae and pointed out that its sexual morphs were compatible with Tubeufiaceae.

Pseudohelicomyces Y.Z. Lu, J.K. Liu \& K.D. Hyde, Fungal Diversity 92: 248 (2018), nom. illegit., non Garnica \& E. Valenz. (2000).

Index Fungorum number: IF 554886; Facesoffungi number: FoF 04745; - 8 morphological species (Species Fungorum 2020), 7 species with molecular data.

Type species: Pseudohelicomyces talbotii (Goos) Y.Z. Lu \& K.D. Hyde, Fungal Diversity 92: 252 (2018).

三 Helicosporium talbotii Goos, Mycologia 81(3): 368 (1989).

Notes: Pseudohelicomyces was introduced to accommodate five species, $P$. aquaticus, $P$. hyalosporus, $P$. indicus, $P$. paludosus, and $P$. talbotii based on phylogenetic and morphological evidence (Lu et al. 2018b). Phookamsak et al. (2019) reported Pseudohelicomyces menglunicus from an unidentified seed in China. Jayasiri et al. (2019) introduced a new Pseudohelicomyces species and two new records. Hyde et al. (2019) described a new member, Pseudohelicomyces menglunicus, from an unidentified seed coat. Recently, Lu et al. (2020) submitted a proposal to conserve Pseudohelicomyces (Tubeufiaceae) against Pseudohelicomyces (Hymenogastraceae). Pseudohelicomyces shares similar conidial characters with Helicomyces but can be distinguished by its erect and branched cylindrical conidiophores ( $\mathrm{Lu}$ et al. 2018b; Jayasiri et al. 2019).

Pseudohelicoon Y.Z. Lu \& K.D. Hyde, Fungal Diversity 92: 254 (2018).

Index Fungorum number: IF 554919; Facesoffungi number: FoF 04748; - 2 morphological species (Species Fungorum 2020), 2 species with molecular data.

Type species: Pseudohelicoon subglobosum (Goh \& C.H. Kuo) Y.Z Lu \& Hyde, Fungal Diversity 92: 255 (2018).

$\equiv$ Helicoon subglobosum Goh \& C.H. Kuo [as 'Helicoön'], Phytotaxa 346(2): 145 (2018).

Notes: Pseudohelicoon shares similar asexual morph with Helicoön in non-proliferating and ellipsoidal to doliiform conidia but phylogenetic analyses indicated that they are different genera (Lu et al. 2018b).

Tamhinispora Rajeshk. \& Rah. Sharma, Mycosphere 4(2): 166 (2013).

Index Fungorum number: IF 803105; Facesoffungi number: FoF 00215; - 3 morphological species (Species Fungorum 2020), 3 species with molecular data.

Type species: Tamhinispora indica Rajeshk. \& Rah. Sharma, Mycosphere 4(2): 167 (2013).

Notes: Tamhinispora was established based on phylogenetic and morphological evidence. Rajeshkumar et al. (2018) introduced Tamhinispora srinivasanii and Sommai et al. (2019) introduced $T$. saraburiensis. The conidia of Tamhinispora are irregular, dictyoseptate, dark brown and adorned with brown to blackish apical appendages, which are unique in Tubeufiaceae (Rajeshkumar and Sharma 2013; Rajeshkumar et al. 2018; Sommai et al. 2019).

Thaxteriella Petr., Annls mycol. 22(1/2): 63 (1924).

Index Fungorum number: IF 5408; Facesoffungi number: FoF 00189; - 10 morphological species (Species Fungorum 2020), molecular data unavailable.

Type species: Thaxteriella corticola Petr., Annls mycol. 22(1/2): 63 (1924).

Notes: Boonmee et al. (2011) reexamined the type material of T. corticola and accepted Thaxteriella as a genus of Tubeufiaceae. The ascomata of Thaxteriella are globose or subglobose, shiny, and collapsing in the middle when dried, asci are broadly clavate or subclavate with a short pedicel, and ascospores are cylindrical to long fusiform (Boonmee et al. 2011, 2014). 
Thaxteriellopsis Sivan., Panwar \& S.J. Kaur, Kavaka 4: 39 (1977) [1976].

Index Fungorum number: IF 5409; Facesoffungi number: FoF 01866; - 1 morphological species (Lu et al. 2018b), 1 species with molecular data.

Type species: Thaxteriellopsis lignicola Sivan., Panwar \& S.J. Kaur, Kavaka 4: 39 (1977) [1976].

Notes: Crane et al. (1998) transferred T. lignicola to Chaetosphaerulina. Boonmee et al. (2011) reexamined the holotype of T. lignicola (IMI 197065), designated an epitype (MFLU 10-0057), and retained Thaxteriellopsis as a distinct genus within Tubeufiaceae. Doilom et al. (2017) introduced an asexual record of T. lignicola based on phylogenetic evidence. Lu et al. (2018b) reported new records of T. lignicola with new morphological characteristics. Thaxteriellopsis is characterized by globose to subglobose ascomata are reddish brown to dark brown, collapsed when dry, and covered with brown to black setae, cylindrical asci with a long pedicel, and straight or slightly curved ascospores are fusiform to clavate with 5 septa. The conidia of Thaxteriellopsis are typical helicoma-like but conidiophores are distinct from Helicoma species (Boonmee et al. 2011; Doilom et al. 2017; Lu et al. 2018b).

\section{Economic and ecological significance}

Tubeufiaceae fungi have the potential to produce a number of bioactive compounds. Hanada et al. (1996) reported a novel protein produced by a species of Helicosporium, which had effects on neurite outgrowth via cultured cortical neurons and NGF-treated PC12 cells. Ohtsu et al. (2003) obtained five compounds from Helicomyces sp. No. 19353, and found that one compound had a significant anti-diabetic activity (Ohtsu et al. 2003; Yoshimura et al. 2003; Zenkoh et al. 2003). Dong et al. (2004) reported that mobility of nematodes was inhibited by $98.95 \%$ by the mycelial extracts from Helicomyces roseus. Jiao et al. (2006) reported that seven compounds were isolated from Tubeufiaceae sp. A-00471 and exhibited antibiotic activity against Gram-positive bacteria (Jiao et al. 2006). Hu et al. (2006) obtained one Diepoxin and five Decaspirones compounds from Helicoma viridis. Jung et al. (2012) reported that 2-methylresorcinol from Helicosporium sp. KCTC 0635BP exhibited antimicrobial activity against various types of bacteria and fungi, and also exhibited considerable cytotoxicity activity against human cancer cells. Lee et al. (2013) found that Helicosporium sp. 0635BP was effective against Fusarium oxysporum, Phytophthora drechsleri, and Rhizoctonia solani.

Wiesneriomycetaceae Suetrong, Rungjindamai, Somrithipol. \& E.B.G. Jones, Phytotaxa 176: 288 (2014).

Index Fungorum: IF 550306; Facesoffungi number: FoF 06311, 20 species.
Saprobic on different substrates, colonies effuse, consisting of scattered conidiomata. Mycelium immersed. Asexual morph: Conidiomata sporodochial or synnematal, solitary to gregarious, with or without setae. Setae subulate, septate, pigmented, thick-walled, erect, flexuous, arising from basal pseudoparenchymatous stalk or mycelium immersed in the substrate. Conidiophores macronematous, mononematous, penicillate, septate, branched, straight or flexuous, solitary or gregarious. Conidiogenous cells holoblastic, monoblastic, polyblastic, discrete, determinate, terminate, clavate, cylindrical, slightly ampulliform. Conidia solitary to gregarious, catenate, connected by narrow isthmi, fusiform to falcate, cylindrical, subcylindrical, cuneiform, branched, hyaline to slightly pigmented, aseptate. Sexual morph: undetermined.

Type: Wiesneriomyces Koord.

Notes: Suetrong et al. (2014) introduced Wiesneriomycetaceae as order incertae sedis, based on morphology and molecular phylogenetic inference. Pratibha et al. (2015) placed Wiesneriomycetaceae in Tubeufiales, and included Pseudogliophragma in this family. Santos (2015) included Speiropsis in this family and suggested Pseudogliophragma as a synonym of Wiesneriomyces. Parawiesneriomyces was included in this family by Crous et al. (2016b). Bezerra et al. (2017) introduced Wiesneriomycetales to accommodate Wiesneriomycetaceae based on morphological characteristics and phylogenetic analyses. Liu et al. (2017) assigned Wiesneriomycetales as a synonym of Tubeufiales based on phylogenetic inference and divergence times estimates which estimated as 40 MYA (crown age).

Wiesneriomyces Koord., Verh. K. Akad. Wet., tweede sect. 13(4): 246 (1907).

Index Fungorum number: IF 10438; Facesoffungi number: FoF 06312; 3 morphological species (Species Fungorum 2020), 2 species with molecular data.

Type species: Wiesneriomyces laurinus (Tassi) P.M. Kirk, Trans. Br. mycol. Soc. 82(4): 748 (1984).

$\equiv$ Volutellaria laurina Tassi, Atti R. Accad. Fisiocrit. Siena, Sér. 4 8: 5 (1897).

Notes: Kirk (1984) proposed the new combination, Wiesneriomyces laurinus, based on the holotype of Volutellaria laurina and showed that it was an earlier name for Wiesneriomyces javanicus. No sexual morph has been reported for this genus (Suetrong et al. 2014; Bezerra et al. 2017; Lu et al. 2018b).

Wiesneriomyces laurinus (Tassi) P.M. Kirk, Trans. Br. mycol. Soc. 82(4): 748 (1984).

Index Fungorum number: IF 107371; Facesoffungi number: FoF 06313; Fig. 85

Saprobe, on bark of Hevea brasiliensis; Sexual morph: Undetermined. Asexual morph: Colonies 385-440 $\mu \mathrm{m}$ diam., on the substrate inconspicuous. Conidiomata 

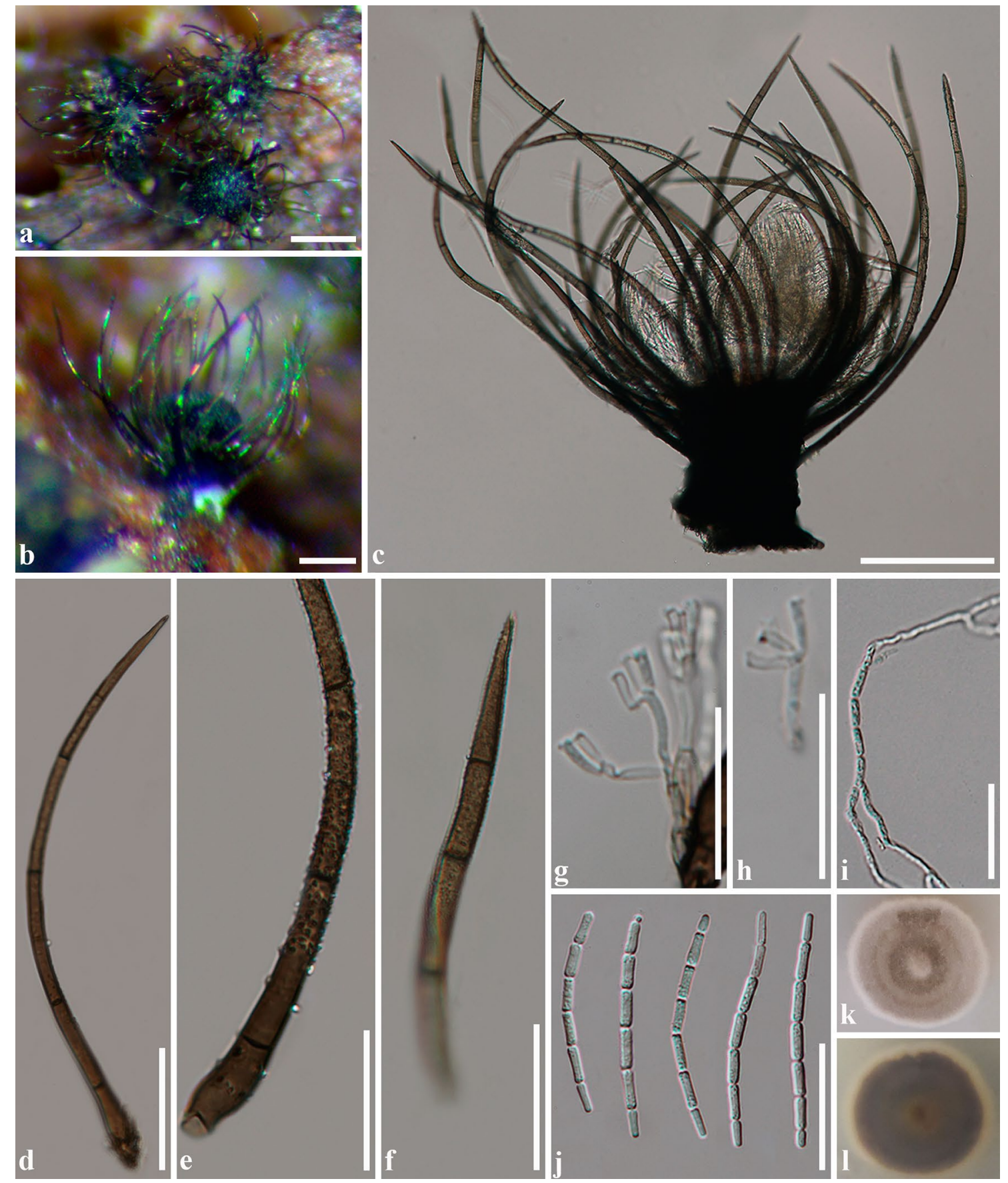

Fig. 85 Wiesneriomyces laurinus (MFLU 18-1384, new host record). a, b Habit on substrate. c Conidioma. d Seta. e Base of seta. $\mathbf{f}$ Tip of seta. $\mathbf{g}, \mathbf{h}$ Conidiophores. $\mathbf{i}$ Germinated spores. $\mathbf{j}$ Conidia. $\mathbf{k}$

sporodochial, superficial, solitary to gregarious, scattered. Setae $130-430 \times 3-12 \mu \mathrm{m}$, arising from basal pseudostromatal stalk, straight or \pm bent, abundant, dark brown to black, verruculose, 5-10-septate, tapering to subulate apex. Conidiophores $18-38 \times 2-3 \mu \mathrm{m}$, macronematous, hyaline to subhyaline, smooth-walled, branched. Conidiogenous cells terminal, clavate to slightly inflated, hyaline, smooth-walled,
Culture characteristic on PDA after 21 days $(\mathbf{k}=$ colony from above, $\mathbf{l}$ = colony from below). Scale bars: $\mathbf{a}-\mathbf{c}=100 \mu \mathrm{m}, \mathbf{d}-\mathbf{j}=30 \mu \mathrm{m}$

5.5-8.5 × 1.5-2.5 $\mu \mathrm{m}$. Conidia [(4)5-7 cells], 46-67 $\times 2-4$ $\mu \mathrm{m}$, in chains, straight, long cylindrical, hyaline to subhyaline, aseptate, smooth-walled.

Culture characteristics: Conidia germinated on MEA within 12 hours and germ tube produced from one or both end or several cell of the conidia. Colonies on PDA reaching $4.5-5 \mathrm{~cm}$ diam. after 21 days at room temperature (20-25 


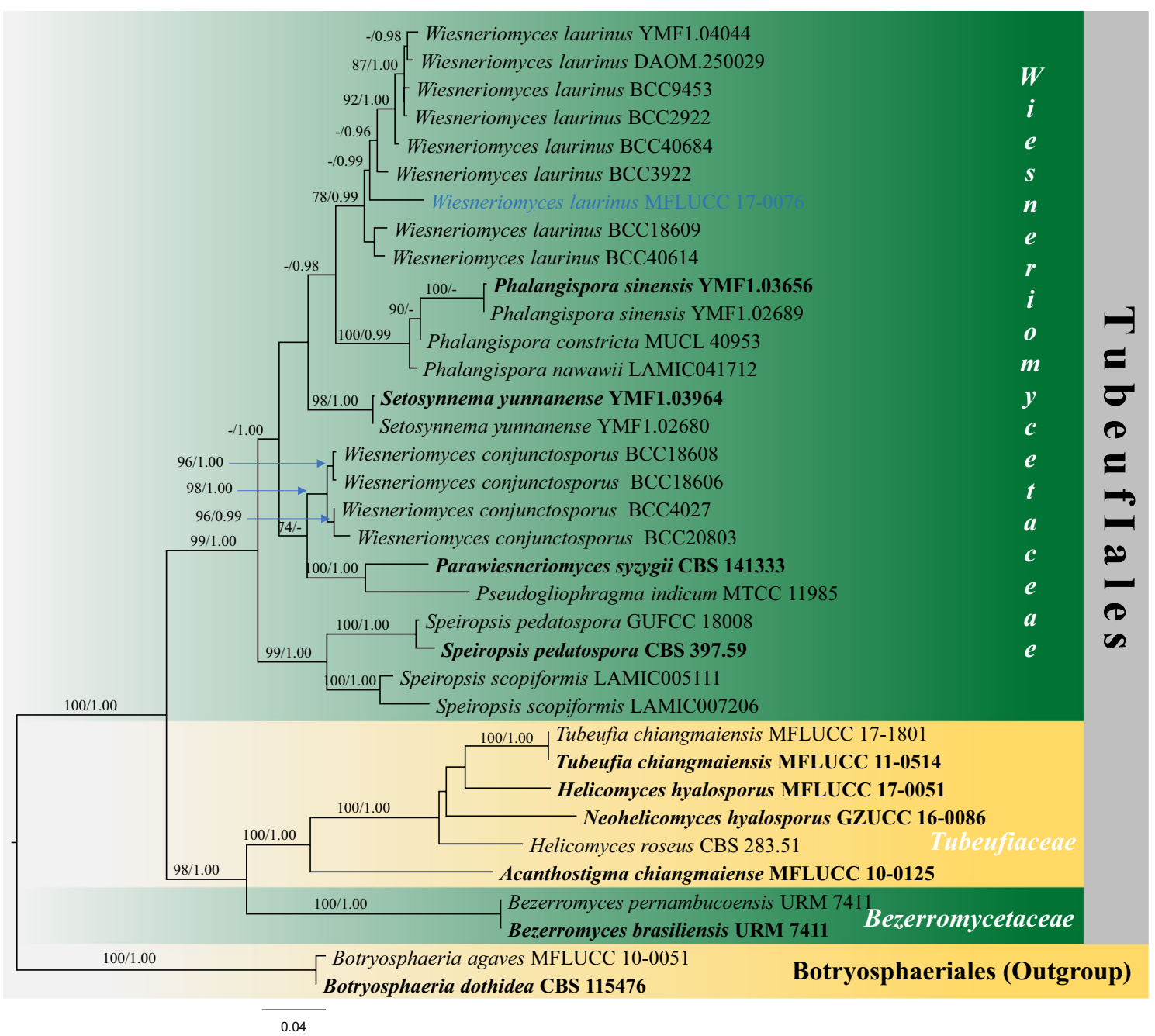

Fig. 86 Phylogram generated from maximum likelihood analysis (RAxML) of genera in Wiesneriomycetaceae based on ITS, LSU, rpb-2, SSU and tef1 sequence data. Maximum likelihood bootstrap values equal or above $70 \%$, Bayesian posterior probabilities equal or above 0.90 (MLBS/PP) are given at the nodes. An original iso-

$\left.{ }^{\circ} \mathrm{C}\right)$, circular, effuse, velvety to hairy, initially white, becoming slightly radiating with greyish-brown concentric ring, white at the margin from above, dark grey to blackish at the center from below, with white circular edge.

Material examined: Thailand, Phayao Province, Muang, inner bark of Hevea brasiliensis (Euphorbiaceae), 5 December 2016, Senwanna C., RBPY019 (MFLU 18-1384; living culture MFLUCC 17-0076)

Sequence data: ITS: MN168764, LSU: MN168761, rpb2: MN174863, SSU: MN168759, tef1: MT050455.

Notes: During our study of microfungi on Para rubber in Thailand, a fresh specimen was obtained from inner bark of Hevea brasiliensis. The morphological characters of our fresh collection fit well with the description of W. laurinus (Suetrong et al. 2014, Chen and Tzean 2015). Based on our late number is noted after the species name. The tree is rooted to Botryosphaeria agaves (MFLUCC 10-0051) and B. dothidea (CBS 115476). The ex-type strains are indicated in bold. The new sequence is in blue. Hyphen (-) represents support values below 70\% MLBS and $0.90 \mathrm{PP}$

phylogenetic analysis of combined LSU and SSU sequence data, our strain groups with other $W$. laurinus strains with moderate bootstrap support (Fig. 86). Thus, this fresh collection is identified as $W$. laurinus.

\section{Other genera included}

Parawiesneriomyces Crous \& M.J. Wingf., in Crous et al., Persoonia 36: 389 (2016).

Index Fungorum number: IF 817060; Facesoffungi number: FoF 06556; - 1 morphological species (Species Fungorum 2020), 1 species with molecular data.

Type species: Parawiesneriomyces syzygii Crous \& M.J. Wingf., in Crous et al., Persoonia 36: 389 (2016).

Notes: Parawiesneriomyces was introduced based on phylogeny and morphology (Crous et al. 2016b). 
Fig. 87 Phylogram generated from maximum likelihood analysis (RAxML) of genera in Valsariales based on ITS, LSU, SSU and tef1 sequence data. Maximum likelihood bootstrap values equal or above $70 \%$, Bayesian posterior probabilities equal or above 0.90 (MLBS/ PP) are given at the nodes. An original isolate number is noted after the species name. The tree is rooted to Capnodium coffeae (OSC 100414) and Leptoxyphium fumago (CBS 123.26). The ex-type strains are indicated in bold. Hyphen (-) represents support values below 70\% MLBS and $0.90 \mathrm{PP}$

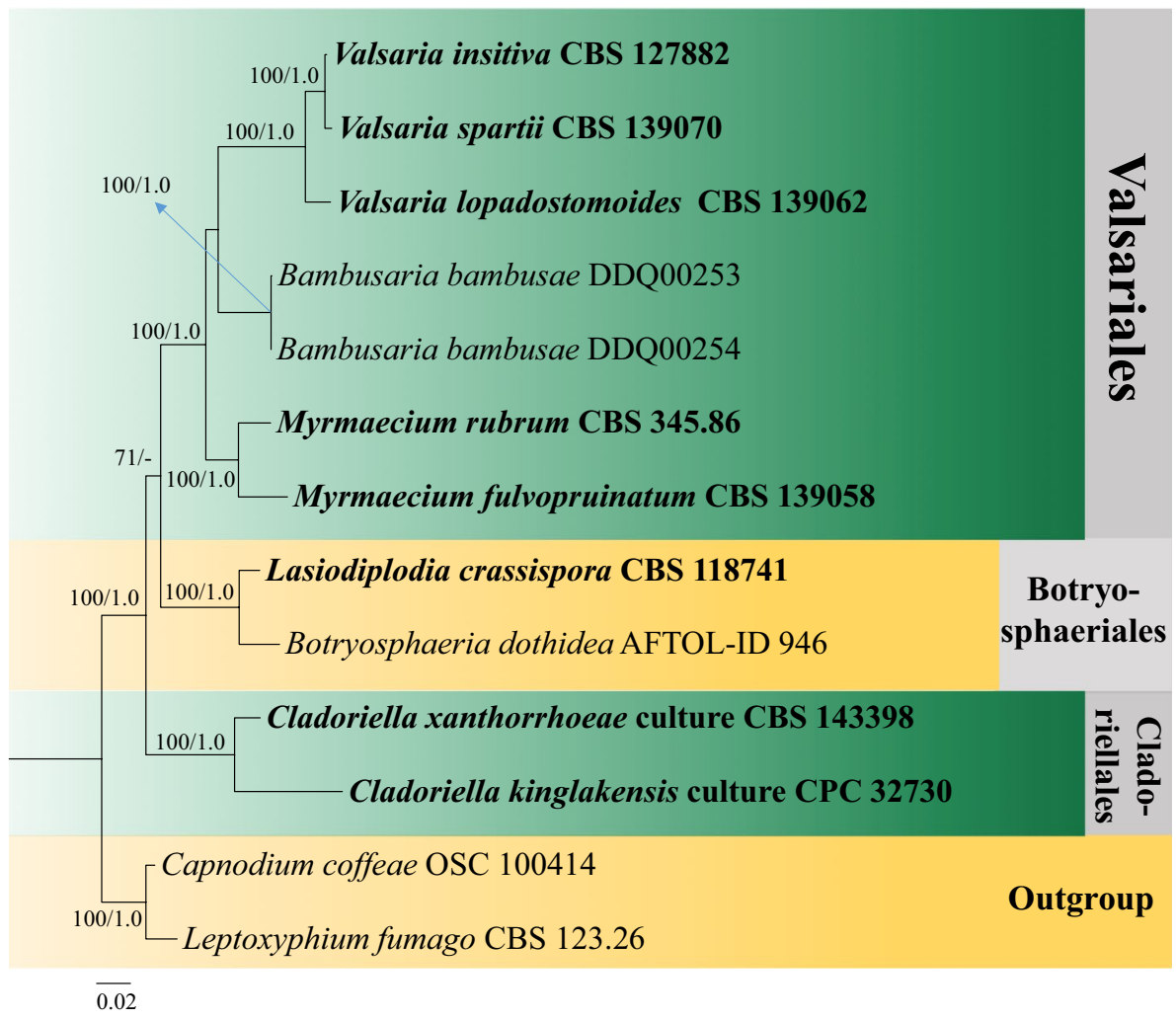

Parawiesneriomyces is similar to Wiesneriomyces in its conidial characters, however they differ in conidiomata and setae characters (Crous et al. 2016b). Thus, further collections and sequence data are necessary to resolve and to confirm the validity of the new genus.

Phalangispora Nawawi \& J. Webster, Trans. Br. mycol. Soc. 79(1): 65 (1982).

Index Fungorum number: IF 9328; Facesoffungi number: FoF 07568; - 4 morphological species (Species Fungorum 2020), 3 species with molecular data.

Type species: Phalangispora constricta Nawawi \& J. Webster, Trans. Br. mycol. Soc. 79(1): 65 (1982).

Notes: Phalangispora is characterized by setose, sporodochial conidiomata and branched, tetraradiate conidia (Nawawi and Webster 1982). A combined dataset of ITS, LSU, tub1 and tub2 sequence data placeed Phalangispora within Wiesneriomyces (Santos 2015). Recent molecular phylogenetic data showed that Phalangispora is a distinct group within Wiesneriomycetaceae (Guo et al. 2019).

Pseudogliophragma Phadke \& V.G. Rao, Norw. J Bot. 27: 127 (1980).

Index Fungorum number: IF 9579; Facesoffungi number: FoF 06557; - 1 morphological species (Species Fungorum 2020), 1 species with molecular data.
Type species: Pseudogliophragma indica Phadke \& V.G. Rao, Norw. J1 Bot. 27(2): 127 (1980).

Notes: Pseudogliophragma was introduced to accommodate a single species characterized by synnematous conidiomata, 4-8-celled, fusiform to falcate conidia. Recent molecular phylogenetic data showed that Pseudogliophragma is a distinct genus within Wiesneriomycetaceae (Pratibha et al. 2015).

Setosynnema D.E. Shaw \& B. Sutton, J. Linn. Soc., Bot. 91: 33 (1985).

Index Fungorum number: IF 9328; Facesoffungi number: FoF 07569; - 3 morphological species (Species Fungorum 2020), 1 species with molecular data.

Type species: Setosynnema isthmosporum D.E. Shaw \& B. Sutton, Bot. J. Linn. Soc. 91(1-2): 34 (1985).

Notes: Setosynnema is charactered by synnematous conidiomata, filiform conidia with an isthmus at the central septum (Shaw and Sutton 1985). The genus was introduced as a genus incertae sedis and reported as aquatic fungi (Bai et al. 2013; Rajeshkumar 2014; Guo et al. 2019). Guo et al. (2019) accepted Setosynnema as a member of Wiesneriomycetaceae based on phylogenetic and morphological evidence.

Speiropsis Tubaki, J. Hattoribot. Lab. 20: 171 (1958). 


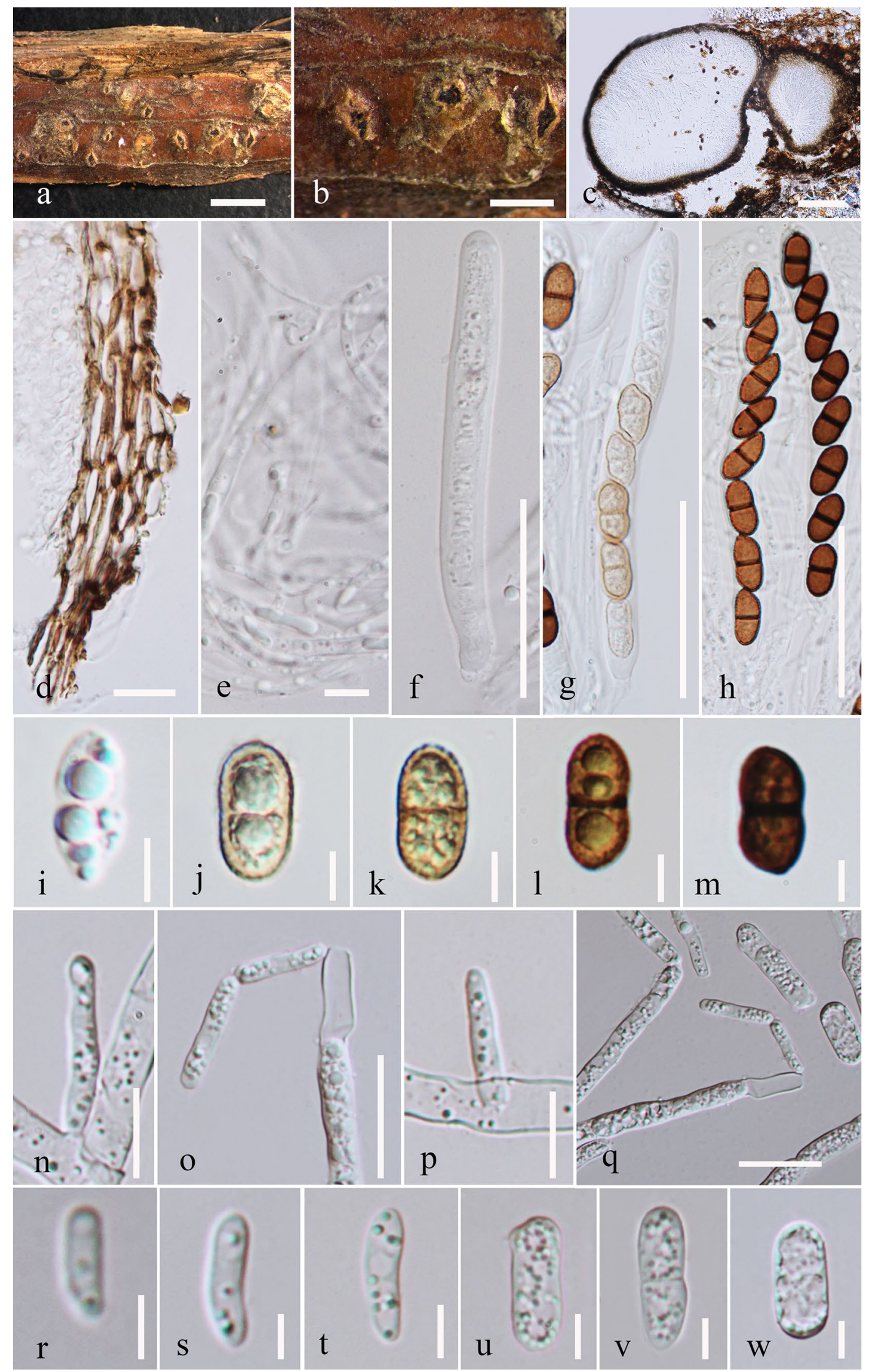


4Fig. 88 Valsaria ostryae (MFLU 17-0837, holotype). a, b Habit and appearance of ectostromata on host surface. c Vertical section of stroma. d Peridium wall. e Apically free pseudoparaphyses. f, $\mathbf{g}$ Immature asci $\mathbf{h}$ Mature asci. i-k Immature ascospores $\mathbf{l}, \mathbf{m}$ Mature ascospore. q Hyphae with denticles and conidia (partly budding). $\mathbf{n}-\mathbf{p}$ Phialides. r-w Conidia. Scale bars: $\mathbf{a}=500 \mu \mathrm{m}, \mathbf{b}, \mathbf{c}=200 \mu \mathrm{m}, \mathbf{f}-\mathbf{h}$ $=50 \mu \mathrm{m}, \mathbf{d}, \mathbf{n}-\mathbf{q}=10 \mu \mathrm{m}, \mathbf{e}, \mathbf{i}-\mathbf{m}, \mathbf{r}-\mathbf{w}=5 \mu \mathrm{m}$

Index Fungorum number: IF 9965; Facesoffungi number: FoF 06558; - 8 morphological species (Species Fungorum 2020), 2 species with molecular data.

Type species: Speiropsis pedatospora Tubaki, J. Hattori bot. Lab 20: 171 (1958).

Notes: Speiropsis is characterized by erect, simple, straight, mostly mononematous conidiophores, polyblastic conidiogenous cells and catenate conidia in branched or unbranched chains connected by narrow isthmi (Barbosa and Gusmao 2005; Pratibha et al. 2016). Based on morphology and molecular analyses, Pratibha et al. (2016) referred Speiropsis to Wiesneriomycetaceae. There are 28 DNA sequence data available in GenBank, comprising $S$. pedatospora and S. scopiformis.

\section{Economic and ecological significance}

Genera included in Wiesneriomycetaceae play a role as saprobes, occurring on different substrates with a worldwide distribution (Suetrong et al. 2014; Pratibha et al. 2015; 2016; Crous et al. 2016b). In addition, Speiropsis has been reported as an aquatic hyphomycete (Barbosa and Gusmao 2005; Santos 2015).

Valsariales Jaklitsch, K.D. Hyde \& Voglmayr.

Index Fungorum number: IF 811900; Facesoffungi number: FoF 08827.

Valsariales was introduced by Jaklitsch et al. (2015) based on multi-gene phylogeny analyses to accommodate the single family Valsariaceae. Valsariales species have perithecioid ascomata, immersed in eu- or pseudostromata, bitunicate asci, without obvious fissitunicate dehiscence and dark brown, bicelled ascospores. Member of Valsariales have a worldwide distribution on various substrates as saprobes, plant pathogens or necrotrophs (Ju et al. 1996; Jaklitsch et al. 2015). There are only three genera with molecular data. Our phylogenetic analyses generated from ITS, LSU, SSU and tef1 sequence data (Fig. 87) indicate that the three genera cluster with high bootstrap support (100\% ML, 1.0 PP), and each genus is well-resolved. The divergence time for Valsariales is estimated as 224 MYA (stem age, Hongsanan et al. 2020).

Accepted families: Valsariaceae.

Valsariaceae Jaklitsch, K.D. Hyde \& Voglmayr, in Jaklitsch et al., Fungal Diversity 73: 167 (2015).
Index Fungorum number: IF 811901; Facesoffungi number: FoF 06561, 41 species.

Saprobic and pathogens in bark of dicotyledons in terrestrial habitats or on culms of bamboo. Sexual morph: Stromata eu- or pseudostromatic, immersed, erumpent to superficial on bark, enclosed on top and/or at the sides by a black pseudoparenchymatous. Ascomata perithecial, immersed in the stromata, usually monostichous in valsoid or diatrypoid configuration, upright or oblique, with several ostiolar necks fusing into one. Ostiole periphysate. Peridium composed of several cell layers of brown to black cells. Hamathecium comprising numerous paraphyses. Asci 4-8-spored, bitunicate, with or without obvious fissitunicate, cylindrical, with short pedicel, an ocular chamber apex, and a pulvinate ring staining in Congo Red. Ascospores (often obliquely) uni-seriate, ellipsoid to subfusiform, dark brown, 1 -septate, with a dark, usually not or slightly constricted at the septum, budding in artificial culture, with surface ornamentation. Asexual morph: in nature coelomycetous, in culture hyphomycetous or coelomycetous. Conidia produced on phialides, minute pegs or by budding of ascospores and conidia, oblong or bullet-shaped, hyaline, 1-celled, smoothwalled, with inconspicuous guttules.

Type: Valsaria Ces. \& De Not.

Notes: Based on bitunicate asci without obvious fissitunicate dehiscence, Ju et al. (1996) placed Valsaria in Dothideomycetes (as Loculoascomycetes). However, Kirk et al. (2008) referred Valsaria to Diaporthales (Sordariomycetes), based on the hamathecium consisting of true, apically free paraphyses, a true ascomatal wall distinct from the surrounding pseudostroma and unitunicate asci (Barr 1978, 1990; Glawe 1985; Huhndorf 1992). Recent phylogenetic analyses have shown Valsariaceae to be a distinct family within Dothideomycetes (Jaklitsch et al. 2015; Pem et al. 2019b). Valsariaceae was introduced by Jaklitsch et al. (2015) to accommodate Bambusaria, Myrmaecium and Valsaria, based on multi-gene phylogeny analyses of ITS, LSU, SSU, rpb- 2 and tef 1 sequence data.

Valsaria Ces. \& De Not., Comm. Soc. crittog. Ital. 1(fasc. 4): 205 (1863).

Index Fungorum number: IF 5704; Facesoffungi number: 33 morphological species (Species Fungorum 2020), 6 species with molecular data.

Type species: Valsaria insitiva (Tode) Ces. \& De Not.

三 Sphaeria insitiva Tode, Fung. mecklenb. sel. (Lüneburg) 2: 36 (1791).

Notes: Valsaria contains plant pathogens and saprobes on various hosts (Phillips 2000; Jaklitsch et al. 2015; Žežlina et al. 2016). Morphological characteristic of Valsaria are ovelapping and hence DNA sequence analyses are needed to classify and delineate them. There are six epithets accommodated in Valsaria based on molecular data coupled with 
morphological characteristics (Jaklitsch et al. 2015; Wijayawardene et al. 2017a; Index Fungorum 2020).

Valsaria ostryae D. Pem, R. Jeewon, Camporesi \& K.D. Hyde, in Pem et al., PLoS ONE 14(6): e0217982, 5 (2019).

Index Fungorum number: IF 554758; Facesoffungi number: FoF 04614, Fig. 88

Description: see Pem et al. (2019b).

Material examined: Italy, Province of Forlì-Cesena [FC], Santa Sofia, Camposonaldo, on dead branches of Ostrya carpinifolia (Betulaceae), 18 March 2017, E. Camporesi, IT 3290 (MFLU 17-0837, holotype).

\section{Other genera included}

Bambusaria Jaklitsch, D.Q. Dai, K.D. Hyde \& Voglmayr, in Jaklitsch et al., Fungal Diversity 73: 196 (2015).

Index Fungorum number: IF 811906; Facesoffungi number: FoF 06559; - 1 morphological species (Species Fungorum 2020), 1 species with molecular data.

Type species: Bambusaria bambusae (J.N. Kapoor \& H.S. Gill) Jaklitsch, D.Q. Dai, K.D. Hyde \& Voglmayr, in Jaklitsch et al., Fungal Diversity 73: 196 (2015).

$\equiv$ Valsaria bambusae J.N. Kapoor \& H.S. Gill, Indian Phytopath. 14(2): 152 (1962) [1961].

Notes: Based on a multi-locus phylogeny and morphological features, Jaklitsch et al. (2015) established a new genus Bambusaria with a single species B. bambusae (synonym: Valsaria bambusae) as the type species, which is hostspecific for Bambusoideae. The genus is characterized by eustromatic stromata, ascomata immersed in a stromata in valsoid configuration, bitunicate asci without obvious fissitunicate dehiscence, ellipsoid to broadly fusiform or biconoid, brown, 1-septate ascospores with longitudinally ribbed and produces asexual morph in culture.

Myrmaecium Nitschke ex Fuckel, Jb. nassau. Ver. Naturk. 23-24: 227 (1870) [1869-70].

Index Fungorum number: IF 3385; Facesoffungi number: FoF 06560; 7 morphological species (Species Fungorum 2020), 3 species with molecular data.

Type species: Myrmaecium rubricosum (Fr.) Fuckel, Jb. nassau. Ver. Naturk. 23-24: 227 (1870) [1869-70].

इSphaeria rubricosa Fr., Elench. fung. (Greifswald) 2: 63 (1828).

Notes: Previously Myrmaecium was treated as a synonym of Valsaria (Ju et al. 1996, Jaklitsch et al. 2015). However, a multi-gene molecular study established the monophyly of Myrmaecium species, and their inclusion in Valsariaceae (Jaklitsch et al. 2015). Myrmaecium can be distinguished from other genera in Valsariaceae by the eu- or pseudostro-

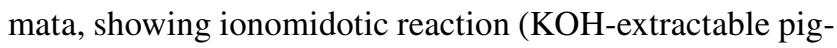
ments). Myrmaecium has a worldwide distribution occurring on sun-exposed, corticated logs and branches of coniferous and broadleaf trees. In addition, Myrmaecium fulvopruinatum and M. rubrum are sources of secondary metabolites (Aptroot 1995; Jaklitsch et al. 2015).

\section{Economic and ecological significance}

Species of Valsariaceae occur on a wide range of hosts as saprobes, only Myrmaecium fulvopruinatum and Valsaria insitiva were reported as pathogenic and play a negative role in causing canker disease of Chinese chestnut (Castanea mollissima) and stone fruit (Žežlina et al. 2016, Jiang et al. 2018a).

Venturiales Y. Zhang ter, C.L. Schoch \& K.D. Hyde. Index Fungorum number: IF 513386; Facesoffungi number: FoF 06345.

Venturiales was introduced by Zhang et al. (2011) using morphological and ecological characteristics, as well as strong support in multi-gene phylogenetic analyses. This order presently contains Sympoventuriaceae and Venturiaceae (Zhang et al. 2011; Hyde et al. 2013). Some species of this order are plant pathogens or saprobes, mostly on leaves or stems of dicotyledons. Important characters of this order are small to medium-sized ascomata, with or without setae, a mostly evanescent hamathecium, 8-spored, broadly or usually obclavate asci, usually lacking a pedicel, hyaline, light greenish olivaceous to brown, 1-septate, symmetrical, asymmetrical or apiosporous ascospores and hyphomycetous asexual morphs (Zhang et al. 2011). The divergence time for Venturiales is estimated as 184 MYA (stem age, Hongsanan et al. 2020).

Accepted families: Sympoventuriaceae, Venturiaceae.

Sympoventuriaceae Y. Zhang ter, C.L. Schoch \& K.D. Hyde, Fungal Diversity 51: 255 (2011).

Index Fungorum number: IF 563117; Facesoffungi number: FoF 06346, 130 species.

Pathogenic or saprobic on plants. Sexual morph: Ascomata pseudothecia, solitary or aggregated, immersed in host tissue, erumpent when mature, subglobose to globose, substomatal, subepidermal, inconspicuous; walls pigmented; papillate, ostiolate. Peridium thick-walled, comprising of 2-3 layers of brown to dark brown cells of textura angularis. Hamathecium comprising $2 \mu \mathrm{m}$ wide, septate, hyaline, cellular pseudoparaphyses, anastomosing between and above the asci, constricted at the septa. Asci 8-spored, bitunicate, fissitunicate, subcylindrical, pedicellate. Ascospores crowded or partially overlapping in asci, symmetrical, fusoid-ellipsoidal, hyaline, medianly 1-septate, constricted at the septum, widest in the middle of each cell, guttulate, smooth-walled with slightly rough ends. Asexual morph: Hyphomycetous. "sympodiella"-like, "fusicladium"-like, Veronaeopsis. Mycelium forming a superficial network with pigmented, thin- to thick-walled, smooth, septate, anastomosing hyphae. 
Fig. 89 Sympoventuria capensis (redrawn from Crous et al. 2007b) a Pseudoparaphyses. b Asci. c Ascospores. Scale bars: $\mathbf{a}-\mathbf{c}=10 \mu \mathrm{m}$

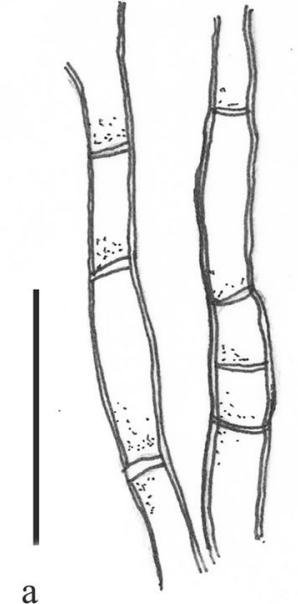

Conidiogenous cells integrated, mono-blastic, holoblastic or polyblastic, sympodial, with inconspicuous scars. Conidiophores septate, solitary, slightly thickened and darkened, producing conidial chains with up to 20 conidia. Conidia thin-walled, cylindrical, sometimes globose to broadly oval at maturity, with truncate ends, hyaline to yellow brown, 1-5 septate to muriform, in unbranched chains on terminal portion of the conidiophores, smooth-walled, guttulate or not.

Type: Sympoventuria Crous \& Seifert.

Notes: Species of Sympoventuriaceae have parasitic or saprobic lifestyles and can be found on leaves or stems of dicotyledons (Zhang et al. 2011). Species of Sympoventuriaceae are hyphomycetous and sexual morphs for most of the species are not determined (Huanraluek et al. 2019b). According to the outline of Ascomycota 2017, Acroconidiellina and Sympoventuria are included in this family (Wijayawardene et al. 2018).

Sympoventuria Crous \& Seifert, Fungal Divers 25: 31 (2007).

Index Fungorum number: IF 501002; Facesoffungi number: FoF 06347; 3 morphological species (Species Fungorum 2020), 3 species with molecular data.

Type species: Sympoventuria capensis Crous \& Seifert.

Notes: Sympoventuria is the type genus in the Sympoventuriaceae, distinguished from Venturiaceae by its saprobic habitat, pseudoparaphyses, and hyaline, symmetrical ascospores (Fig. 89). The asexual morph of Sympoventuria was described as "sympodiella"-like by Crous et al. (2007b).

\section{Other genera included}

Acroconidiellina M.B. Ellis, Mycol. Pap. 125: 22 (1971).

Index Fungorum number: IF 7031; Facesoffungi number: FoF 08828; - 4 morphological species (Species Fungorum 2020), 1 species with molecular data.

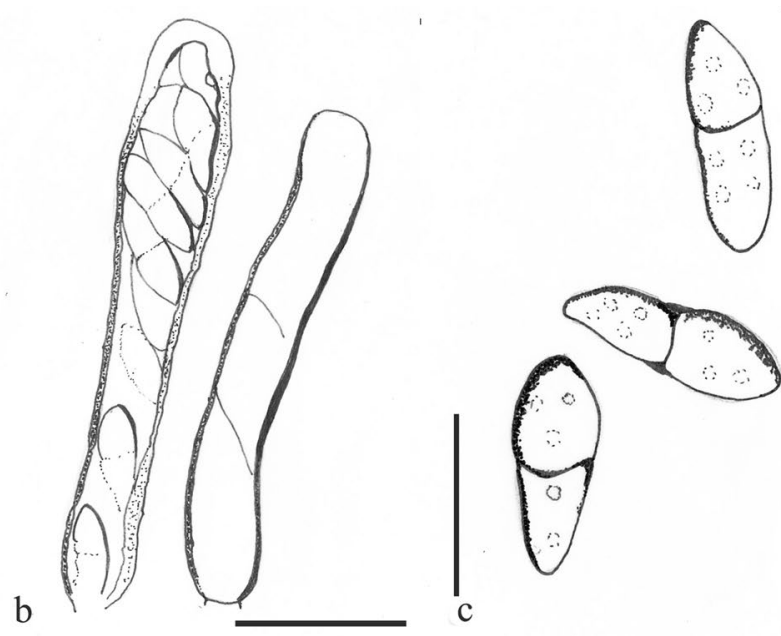

Type species: Acroconidiellina loudetiae M.B. Ellis, Mycol. Pap. 125: 23 (1971).

Notes: Species of Acroconidiellina can be distinguished by having dark brown to blackish brown hairy colonies, superficial hyphae arising setae, sclerotia, macronematous conidiophores, polytretic conidiogenous cells, and broadly ellipsoidal, brown, echinulate, 1- septate conidia (Ellis 1960).

Clavatispora Boonmee \& K.D. Hyde, Phytotaxa 176(1): 95 (2014).

Index Fungorum number: IF 805923; Facesoffungi number: FoF 08829; -1 morphological species (Species Fungorum 2020), 1 species with molecular data.

Type species: Clavatispora thailandica Boonmee \& K.D. Hyde, Phytotaxa 176(1): 96 (2014).

Notes: The genus is characterized by solitary, superficial ascomata, covered by dark setae, with an ostiole, clavate, multi-septate, yellowish to reddish brown ascospores (Boonmee et al. 2014a). It does not resemble other genera in Sympoventuriaceae. However, the LSU sequence data showed that Clavatispora clusters with the hyphomycete genus Scolecobasidiella in Sympoventuriaceae along with Ochroconis, Scolecobasidium, Fusicladium and Veronaeopsis (Boonmee et al. 2014a). The asexual morph of Clavatispora are unique in having 1-3-phragmoseptate, smooth-walled, guttulate conidia, deeply constricted at septa, while other genera have conidia and conidiogenous apparatus which are mostly verrucose to denticulate (Boonmee et al. 2014a).

Echinocatena R. Campb. \& B. Sutton, Trans. Br. mycol. Soc. 69(1): 126 (1977).

Index Fungorum number: IF 8121; Facesoffungi number: FoF 09212; -1 morphological species (Species Fungorum 2020), 1 species with molecular data. 


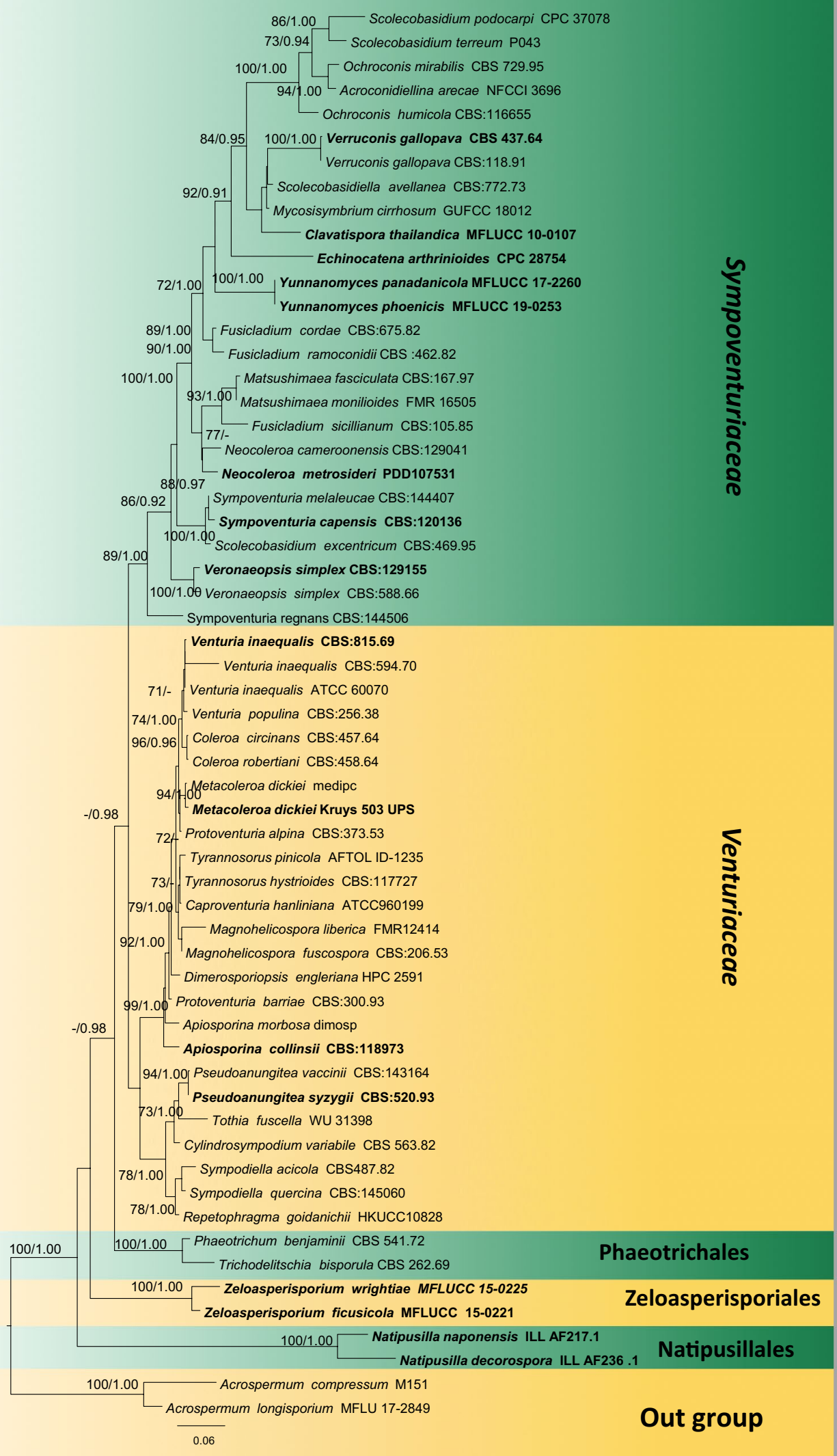


4Fig. 90 Phylogram generated from maximum likelihood analysis (RAxML) of genera in Venturiales based on LSU, SSU and RPB2 sequence data. Maximum likelihood bootstrap values equal or above $70 \%$, Bayesian posterior probabilities equal or above 0.90 (MLBS/ PP) are given at the nodes. An original isolate number is noted after the species name. The tree is rooted to Acrospermum compressum (M151) and Acrospermum longisporium (MFLU 17-2849). The extype strains are indicated in bold. Hyphen (-) represents support values below 70\% MLBS and 0.90 PP

Type species: Echinocatena arthrinioides R. Campb. \& B. Sutton, Trans. Br. mycol. Soc. 69(1): 130 (1977).

Notes: The genus is characterized by micronematous and mononematous conidiophores, consisting of branched, acropetal chains of polyblastic conidiogenous cells, with solitary, sphaerical, brown, aseptate, echinulate conidia (Campbell and Sutton 1977). Crous et al. (2018b) included this genus in Sympoventuriaceae based on the sequence data of type species (Echinocatena arthrinioides). Its polyblastic conidiogenous cells and straight and flexuous conidiophores are reminiscent of the Venturiales (Shen et al. 2020). Therefore, we accept this genus in Sympoventuriaceae and note that more sequence data is needed to resolve its taxonomic placement.

Fusicladium Bonord., Handb. Allgem. mykol. (Stuttgart): 80 (1851).

Index Fungorum number: IF 8292; Facesoffungi number: FoF 08830; - 81 morphological species (Species Fungorum 2020), 31 species with molecular data.

Type species: Fusicladium virescens Bonord., Handb. Allgem. mykol. (Stuttgart): 80 (1851).

Note: Species of Fusicladium are characterised by having immersed, subcuticular to intra-epidermal mycelia, often forming radiating strands or loose to dense stromatic aggregations, which give rise to conidiogenous cells or conidiophores penetrating the cuticle (Schubert et al. 2003).

Matsushimaea Subram., Kavaka 5: 96 (1978) [1977].

Index Fungorum number: IF 8865; Facesoffungi number: FoF 08831; - 4 morphological species (Species Fungorum 2020), 3 species with molecular data.

Type species: Matsushimaea fasciculata Subram., Kavaka 5: 96 (1978) [1977].

Note: Species of Matsushimaea are characterised by having branched, septate, olive mycelium with hyphal coils, by the production of sessile branched conidia arising directly from vegetative hyphae and integrated, mono- or polyblastic, intercalary or terminal, elongated conidiogenous cells, with irregular-shaped, septate, often branched filaments and brown conidia. The production of sessile branched conidia arising directly from vegetative hyphae is an important character of this genus (Crous et al. 2018b).
Mycosisymbrium Carris, Mycologia 86(1): 132 (1994).

Index Fungorum number: IF 27274; Facesoffungi number: FoF 06348; - 1 morphological species (Species Fungorum 2020), 1 species with molecular data.

Type species: Mycosisymbrium cirrhosum Carris, Mycologia 86(1): 132 (1994).

Note: According to Prathiba and Prabhugaonkar (2016), Mycosisymbrium is well-supported as a genus in Sympoventuriaceae and is sister to Ochroconis and Verruconis (Samerpitak et al. 2014; Machouart et al. 2014; Hyde et al. 2013; Zhang et al. 2011). This genus is similar to Ochroconis in having 2-celled conidia, slightly constricted at the septa and polyblastic conidiogenous cells (Prathiba and Prabhugaonkar 2016).

Ochroconis de Hoog \& Arx, Kavaka 1: 57 (1974).

Index Fungorum number: IF 9136; Facesoffungi number: FoF 06349; - 24 morphological species (Species Fungorum 2020), 14 species with molecular data.

Type species: Ochroconis constricta (E.V. Abbott) de Hoog \& Arx, Kavaka 1: 57 (1974) [1973].

EScolecobasidium constrictum E.V. Abbott, Mycologia 19(1): 30 (1927).

Notes: Ochroconis species can be distinguished in their slow to moderate growth, colonies of brown to olivaceous, brownish, septate conidiophores and dark pigmented, and rough-walled conidia produced by sympodial conidiogenesis and liberated rhexolytically (Giraldo et al. 2014). Machouart et al. (2014) included Ochroconis in Sympoventuriaceae based on phylogeny. Pseudoparaphyses and hyaline, symmetrical ascospores and a saprobic nutritional mode are considered to confirm its placement in Sympoventuriaceae.

Scolecobasidiella M.B. Ellis, Mycol. Pap. 125: 12 (1971).

Index Fungorum number: IF9839; Facesoffungi number: FoF 09213; - 2 morphological species (Species Fungorum 2020), 1 species with molecular data.

Type species: Scolecobasidiella avellanea (Sappa \& Mosca) M.B. Ellis, Mycol. Pap. 125: 10 (1971).

Notes: Species of Scolecobasidiella are characterized by superficial straw coloured to pale brown hyphae, septate, pale brown, smooth conidiophores, 1-3 septate ramo-conidia and broadly ellipsoidal or clavate, 1-septate, pale brown, smooth conidia (Ellis 1971). This genus is closely related to Clavatispora based on phylogenetic analyses (Boonmee et al. 2014a). However, the type species of Scolecobasidiella is related to Verruconis gallopava in our phylogenetic analyses (Fig. 90). The pale brown colonies with conidiophores and conidia show a close affinity with Venturiales. Therefore, we accept this genus in Sympoventuriaceae.

Scolecobasidium E.V. Abbott, Mycologia 19(1): 30 (1927). 

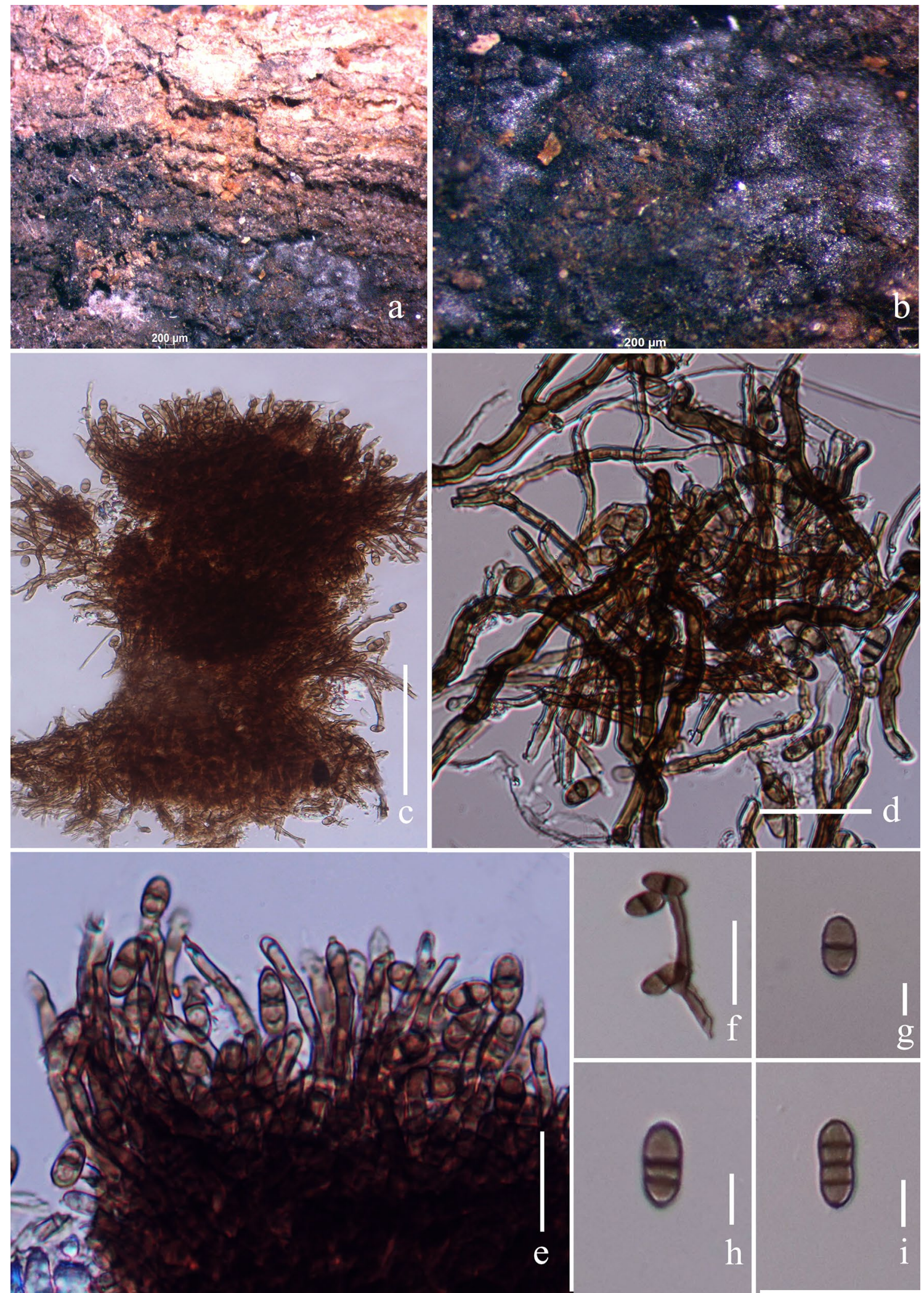

Fig. 91 Verruconis hevea (MFLU 17-1578, holotype). a Host specimen. b Colonies on the latex. c Arrangement of hyphal mass. d Hyphal mass e Conidiogenesis cells. f Attachment of conidia to hypha. $\mathbf{g}-\mathbf{i}$ Conidia. Scale bars: $\mathbf{c}=100 \mu \mathrm{m}, \mathbf{d}-\mathbf{e}=50 \mu \mathrm{m}, \mathbf{f}=20 \mu \mathrm{m}, \mathbf{g}-\mathbf{i}=5 \mu \mathrm{m}$ 
Index Fungorum number: IF9840; Facesoffungi number: FoF 09214; - 34 morphological species (Species Fungorum 2020), 4 species with molecular data.

Type species: Scolecobasidium terreum E.V. Abbott, Mycologia 19(1): 30 (1927).

Notes: Scolecobasidium are characterized by having T- or Y-shaped or bilobed, 2- to many-celled conidia and ampulliform conidiogenous cells, possessing one to three conidiumbearing denticles at the apex of the conidiophores (Hao et al. 2013). Shen et al. (2020) included this genus in Sympoventuriaceae based on morphology of slow growing olivaceous colonies. The type species of this genus also clusters inside the family. Therefore, we accept this genus in this family.

Veronaeopsis Arzanlou \& Crous, Stud. Mycol. 58: 91 (2007).

Index Fungorum number: IF 504571; Facesoffungi number: FoF 06350 - 1 morphological species (Species Fungorum 2020), 1 species with molecular data.

Type species: Veronaeopsis simplex (Papendorf) Arzanlou \& Crous, in Arzanlou et al., Stud. Mycol. 58: 91 (2007).

$\equiv$ Veronaea simplex Papendorf, Trans. Br. mycol. Soc. 52(3): 486 (1969).

Notes: Veronaeopsis is similar to Veronaea in its 1-septate conidia. Veronaeopsis differs from Veronaea based on its much shorter, macronematous conidiophores and conidiogenous cells. Furthermore, Veronaeopsis has a geniculate rachis and Veronaea has a more or less straight rachis (Arzanlou et al. 2007).

Verruconis Samerp., H.J. Choi, van den Ende, Horré \& de Hoog, Fungal Diversity 65: 117 (2014).

Index Fungorum number: IF 519169; Facesoffungi number: FoF 06351; - 9 morphological species (Species Fungorum 2020), 9 species with molecular data.

Type species: Verruconis gallopava (W.B. Cooke) Samerp. \& de Hoog, in Samerpitak, Van der Linde, Choi, Gerrits van den Ende, Machouart, Gueidan \& de Hoog, Fungal Diversity 65: 117 (2013) [2014].

三Diplorhinotrichum gallopavum W.B. Cooke, in Georg, Bierer \& Cooke, Sabouraudia 3: 242 (1964).

Notes: Verruconis are dematiaceous hyphomycetes characterized by clavate to cylindrical, two-celled conidia (Samerpitak et al. 2014). Verruconis hevea is illustrated below.

Verruconis heveae Huanraluek., Senwanna., Jayaward. \& K.D. Hyde, in Huanraluek et al., Phytotaxa 403(1): 50 (2019).

Index Fungorum number: IF 555289; Facesoffungi number: FoF 04838, Fig. 91

Description: see Huanraluek et al. (2019b).
Material examined: Thailand, Phayao Province, on dried latex of rubber, Hevea brasiliensis (Euphorbiaceae), 1 November 2016, C. Senwanna M2 (MFLU 17-1578, holotype).

Yunnanomyces Tibpromma \& K.D. Hyde, Fungal Diversity: 92: 75 (2018).

Index Fungorum number: IF 555334; Facesoffungi number: FoF 04518; - 2 morphological species (Species Fungorum 2020), 2 species with molecular data.

Type species: Yunnanomyces pandanicola Tibpromma \& K.D. Hyde, in Tibpromma et al., Fungal Diversity 93:75 (2018).

Notes: Yunnanomyces is characterized by globose to broadly oval and yellow-brown, muriform conidia (Zang et al. 2019). It is similar to Pseudocoleodictyospora reported from teak (Doilom et al. 2017), but phylogenetic analysis of Yunnanomyces does not support its placement in Pseudocoleodictyosporaceae. Yunnanomyces differs from Fusicladium and Verruconis based on characters of conidiophores and conidia (Tibpromma et al. 2018b).

\section{Economic and ecological significance}

Ochroconis species are opportunistic pathogens which cause diseases of vertebrate animals and humans. Ochroconis humicola is the causal agent of muscular black spot disease of Atlantic salmon (Schaumann and Priebe 1994). Verruconis gallopava was considered to be the source of several zoonoses in broiler house chickens and trumpeters. Horré et al. (1999) have listed 13 brain infections in young birds and one in a cat brain (Samerpitak et. al 2014).

Venturiaceae E. Müll. \& Arx ex M.E. Barr, Mycologia 71(5):947 (1979).

Index Fungorum number: IF 81516; Facesoffungi numbers: FoF 06352, 217 species.

Saprobic or parasitic on leaves or stems usually on dicotyledons, sometimes on monocotyledons. Sexual morph: Ascomata superficial or immersed or slightly erumpent at maturity, scattered or gregarious, single locules in a stroma or below a blackened clypeus, globose to subglobose, membraneous or carbonaceous, usually with seta or without seta, ostiolate, sometimes occurring on a well-developed subiculum with ascomata. Peridium comprising a pigmented single cell layer of textura angularis. Hamathecium comprising branched, cellular pseudoparaphyses. Asci 8-spored, bitunicate, fissitunicate, evanescent, broadly or usually obclavate or cylindrical, with or without short pedicel, ocular chamber distinct. Ascospores uni-seriate or overlapping 2-seriate, cylindrical to ellipsoidal, with broadly rounded apex, hyaline or light greenish, or pale yellow to brown, 1-septate upper cell shorter and broader than lower one. Asexual morph: Hyphomycetous. Conidiophores pigmented, singly or in 
clusters, simple or branched. Conidiogenous cells integrated, terminal or sometimes intercalary, proliferating sympodially or percurrently, with conspicuous annellations Conidia solitary or arranged as chains, pigmented, aseptate or septate.

Type: Venturia Sacc.

Notes: Venturiaceae comprises 12 genera (Wijayawardene et al. 2018). The members of this family are characterized by having sphaerical superficial or erumpent ascomata comprising elongated or oblong or nearly cylindrical, bitunicate, 8-spored asci and 2-celled, symmetric or asymmetric ascospores, which are hyaline or pale green when immature and olive-brown or greyish green, or rarely dark brown at maturity ( $\mathrm{Li}$ et al. 2014). Crous et al. (2018b) included Cylindrosympodium, Pseudoanungitea, Sympodiella, Tothia, and Repetophragma in Venturiaceae based on their phylogenetic analyses without including all genera of the family in their analyses. In our analyses (Fig. 90), we included all genera that have sequence data and found that the main clade of Venturiaceae comprises species of Apiosporina, Caproventuria, Coleroa, Dimerosporiopsis, Metacoleroa, Protoventuria, Tyrannosorus, and Venturia with high support (99\% ML, 1.0 BYPP). Cylindrosympodium, Pseudoanungitea, Sympodiella, Tothia, and Repetophragma cluster together as a sister clade with the main clade of Venturiaceae with low support, but sometimes in other analyses, these genera did not cluster with members of the family (data not shown). We presume that this separate clade can be a new family in Venturiales, and tentatively accept Cylindrosympodium, Pseudoanungitea, and Sympodiella in Venturiaceae as their type species cluster within this clade. More sequence data are needed to confirm this clade as a new family. The placement of Repetophragma is not clear as the sequence data of type species is unavailable, thus we follow Wijayawardene et al. (2020) and place it in Pleosporales genera incertae sedis. We exclude Tothia from Venturiaceae base on its morphology (thyriothecial ascomata), and place the genus in Microthyriales genera incertae sedis.

Venturia Sacc., Syll. fung. (Abellini) 1: 586 (1882).

Index Fungorum number: IF 5717; Facesoffungi number: FoF 06353; 123 morphological species (Species Fungorum 2020), 58 species with molecular data.

Type species: Venturia inaequalis (Cooke) G. Winter.

इSphaerella inaequalis Cooke, J. Bot., Lond. 4: 248 (1866).

Notes: Venturia species can be distinguished by separate or aggregated ascomata with or without stroma, or forming below a blackened clypeus, symmetrical or asymmetrical, olive green, pale brown or dark brown ascospores and being parasitic on leaves or stems of dicotyledons (Zhang et al. 2011).

\section{Other genera included}

Apiosporina Höhn., Sber. Akad. Wiss. Wien, Math.- naturw. Kl., Abt. 1 119: 439 (1910).

Index Fungorum number: IF 266; Facesoffungi number: FoF 06354; -3 morphological species (Species Fungorum 2020), 2 species with molecular data.

Type species: Apiosporina collinsii (Schwein.) Höhn.

Notes: Apiosporina species are characterized by erumpent, subglobose, black ascomata, 8-spored bitunicate, subcylindrical or broadly clavate asci and hyaline to pale brown, clavate apiospores (Zhang et al. 2011). The asexual morph of A. collinsii was reported as Cladosporium sp. (Sivanesan 1984) and it was assigned as Fusicladium sensu lato by Braun et al. (2003). Dibotryon had been treated as a synonym of Apiosporina (von Arx and Müller 1975; Crous et al. 2007b). Although the black knots on branches of Prunis cultis formed by Dibotryon morbosum can readily be distinguished from the black spots on leaves formed by Apiosporina, their congeneric relationship was confirmed by molecular data (Winton et al. 2007). Sequence data are available for Apiosporina collinsii and Apiosporina morbosa.

Apiosporina collinsii (Schwein.) Höhn., Sber. Akad. Wiss. Wien, Math.-naturw. Kl., Abt. 1 119: 439 (1910).

$\equiv$ Sphaeria collinsii Schwein., Trans. Am. phil. Soc., New Series 4(2): 211 (1832) [1834].

Index Fungorum number: IF 122234; Facesoffungi number: FoF 06355; Fig. 92

Parasitic on leaves, stems petioles, buds and flowers appearing as black dots like areas. Sexual morph: Ascomata 150-200 high $\times 150-200$ diam. $\mu \mathrm{m}(\bar{x}=194 \times 195 \mu \mathrm{m}, \mathrm{n}$ $=10$ ) small, gregarious, superficial, globose to subglobose, developing on a dark hyphal mass, easily removed from the substrate, small papillate and ostiolate. Hypha $4 \mu \mathrm{m}$ wide, pale brown to dark brown, branched, septate. Peridium thinwalled, composed of three layers, dark brown to hyaline cells of textura angularis. Hamathecium comprising $4 \mu \mathrm{m}$ wide, rare, septate, cellular pseudoparaphyses. Asci 7-9 $\times 55-65$ $\mu \mathrm{m}(\bar{x}=7.8 \times 62.2 \mu \mathrm{m}, \mathrm{n}=10), 8$-spored, bitunicate to narrowly obclavate, cylindrical, with a short, thick, furcate or knob-like pedicel or pedicel lacking. Ascospores 4-6 $\times$ $12-15 \mu \mathrm{m}(\bar{x}=5.1 \times 13.4 \mu \mathrm{m}, \mathrm{n}=10)$, uni-seriate and partially overlapping, ovoid to narrowly ovoid, hyaline to pale brown, apiosporous, 1-septate near the lower end, barely constricted at the septum, verrucose. Asexual morph: Cladosporium sp. (Sivanesan 1984).

Material examined: Canada, Saskatchwan, on leaves of Cotoneaster sp. (K(M):158702, ex herb. Broome).

Atopospora Petr., Annls mycol. 23(1/2): 100 (1925).

Index Fungorum number: IF 450; Facesoffungi number: FoF 06356; - 4 morphological species (Species Fungorum 2020), molecular data unavailable. 


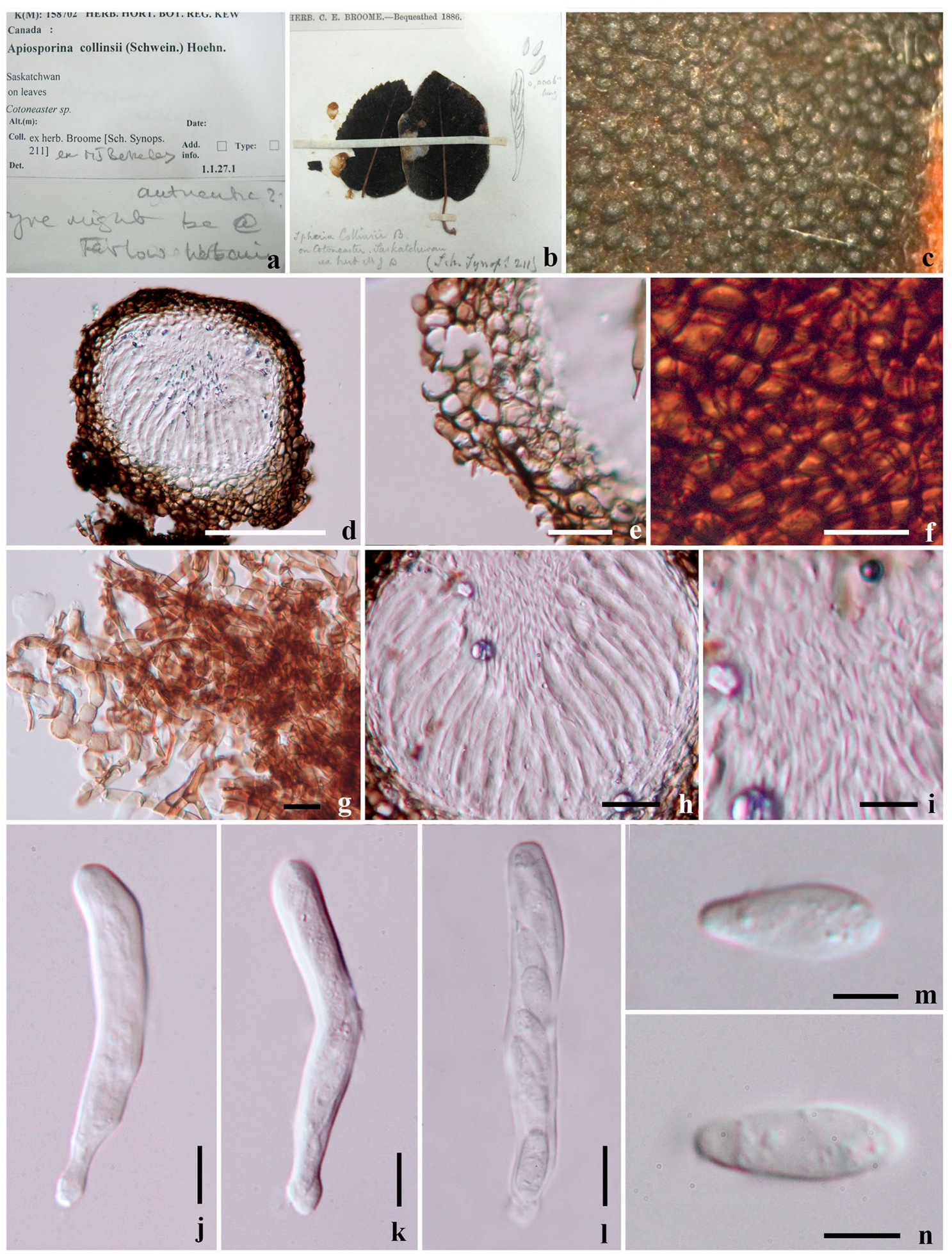

Fig. 92 Apiosporina collinsii (K(M):158702). a, b Herbarium specimens. c Ascomata on host substrate. d Cross section of ascoma. e Peridium. f Wall of ascoma composed darkly pigmented cells. g

Type species: Atopospora betulina (Fr.) Petr., Annls mycol. 23(1/2): 101 (1925).
Hyphal mass. h Arrangement of hamathecium. i Pseudoparaphyses. j-l Asci. m, $\mathbf{n}$ Ascospores. Scale bars: $\mathbf{d}=100 \mu \mathrm{m}, \mathbf{e}, \mathbf{g}, \mathbf{h}=20 \mu \mathrm{m}$, $\mathbf{f}, \mathbf{i}-\mathbf{l}=10 \mu \mathrm{m}, \mathbf{m}, \mathbf{n}=5 \mu \mathrm{m}$

三Xyloma betulinum Fr., Observ. mycol. (Havniae) 1: 198 (1815). 
Notes: The multiloculate ascostromata, fusoid asci and lightly pigmented, bi-seriate, apiospores are the main characteristics that allows its placement in the family Venturiaceae (Müller and von Arx 1962).

Caproventuria U. Braun, Monogr. Cercosporella, Ramularia Allied Genera (Phytopath. Hyphom.) 2: 396 (1998).

Index Fungorum number: IF 27882; Facesoffungi number: FoF 06357; - 1 morphological species (Species Fungorum 2020), 1 species with molecular data.

Type species: Caproventuria hanliniana (U. Braun \& Feiler) U. Braun, Annls mycol. 23(1/2): 101 (1925).

$\equiv$ Capronia hanliniana U. Braun \& Feiler, Microbiol. Res. 150(1): 90 (1995).

Notes: Species of Caproventuria are characterized by astromatic, papillate, ostiolate ascomata with aseptate dark brown setae and 8 -spored bitunicate asci with yellowish olivaceous monostichous or distichous and ellipsoidovoid ascospores (Zhang et al. 2011). Crous et al. (2007b) and Seifert et al. (2011) suggested Pseudocladosporium as a synonym of Fusicladium. However, Zhang et al. (2011) concluded Pseudocladosporium to be asexual morph of Caproventuria. We accept Pseudocladosporium as asexual morph of Caproventuria, but this needs confirmation by phylogenetic analyses. In our phylogenetic analysis, Caproventuria hanliniana (CBS 588.93, type material) was observed to be phylogenetically distant from Venturiaceae (data not shown), while the strain ATCC 96019 is related to Tyrannosorus in Venturiaceae. We tentatively place this genus in Venturiaceae until more collections and sequence data are available to resolve its taxonomic placement.

Coleroa Rabenh., Klotzschii Herb. Viv. Mycol., Edn 1: no. 1456 (in sched.) (1850).

Index Fungorum number: IF 1174; Facesoffungi number: FoF 06358; - 30 morphological species (Species Fungorum 2020), 1 species with molecular data.

Type species: Coleroa chaetomium (Kunze) Rabenh., Rabenh. Krypt.-Fl., Edn 2 (Leipzig) 1: 198 (1850).

$\equiv$ Dothidea chaetomium Kunze, Syst. mycol. (Lundae) 2(2): 563 (1823).

Notes: The scattered, setose ascomata, deliquescing pseudoparaphyses, fusoid to obclavate asci and 1-septate, constricted ascospores are similar characters to other genera of Venturiaceae. However, the 1-septate ascospores with a pale brown to greenish tint, separates this genus (Zhang et al. 2011).

Cylindrosympodium W.B. Kendr. \& R.F. Castañeda, in Castañeda Ruiz \& Kendrick, Univ. Waterloo Biol. Ser. 32: 9 (1990).
Index Fungorum number: IF11257; Facesoffungi number: FoF 09215; - 12 morphological species (Species Fungorum 2020), 2 species with molecular data.

Type species: Cylindrosympodium variabile (de Hoog) W.B. Kendr. \& R.F. Castañeda, in Castañeda Ruiz \& Kendrick, Univ. Waterloo Biol. Ser. 32: 10 (1990).

इSubulispora variabilis de Hoog, Stud. Mycol. 26: 56 (1985).

Notes: Species of Cylindrosympodium are characterized by cylindrical, hyaline or sub hyaline, erect conidiophores with cylindrical, septate hyaline conidia. Conidiogenous cells are conspicuous, flat-topped denticles and extended sympodially reduced from conidiophores (Paulus et al. 2003). In our analyses (Fig. 90), we tentatively accept this genus in Venturiaceae based on the sequence data of type species. However, the clade contains Cylindrosympodium is unstable within Venturiales, thus more sequence data are needed to clarify its placement within Venturiales.

Dimeriella Speg., Revta Mus. La Plata 15(2): 12 (1908).

Index Fungorum number: IF 1575; Facesoffungi number: FoF 06359; - 25 morphological species (Species Fungorum 2020), molecular data unavailable.

Type species: Dimeriella hirtula Speg., Revta Mus. La Plata 15(2): 12 (1908).

Notes: Dimeriella is a plant pathogenic genus characterized by brown ascospores and brown, superficial mycelium. This mycelium forms pale-coloured hyphal clumps and penetrate via hyaline hyphae through sub-stomatal chamber to the mesophyll (Farr 1965).

Dimerosporiopsis Henn., Hedwigia 40(Beibl.): (173) (1901).

Index Fungorum number: IF 1588; Facesoffungi number: FoF 08832; -2 morphological species (Species Fungorum 2020; Crous et al. 2019b), 1 species with molecular data.

Type species: Dimerosporiopsis engleriana (Henn.) Henn., Hedwigia 40(Beibl.): (173) (1901).

三 Dimerosporium englerianum Henn., Bot. Jb. 17: 31 (1893).

Notes: Dimerosporiopsis is similar to other genera such as Proventuria in having superficial pseudothecia with pseudoparaphyses, cylindrical asci and pale olivaceous 1-septate ascospores. However, this genus differs from other genera in having pluri-guttulate ascospores (Crous et al. 2019b).

Magnohelicospora R.F. Castañeda, Hern.-Restr., Gené \& Guarro, Mycotaxon 121: 172 (2013).

Index Fungorum number: IF 563847; Facesoffungi number: FoF 06360; - 2 morphological species (Species Fungorum 2020), 2 species with molecular data. 
Type species: Magnohelicospora iberica R.F. Castañeda, Hern.-Restr., Gené \& Guarro, in Castañeda-Ruiz et al., Mycotaxon 121: 172 (2013) [2012].

Notes: Members of Magnohelicospora can be distinguished by polyblastic, integrated, sympodial conidiogenous cells and solitary, doliiform or conical, multi-euseptate, brown conidia, tightly coiled in three planes (CastañedaRuíz et al. 2013).

Metacoleroa Petr., Annls mycol. 25(3/4): 332 (1927).

Index Fungorum number: IF 3139; Facesoffungi number: FoF 06361; - 1 morphological species (Species Fungorum 2020), 1 species with molecular data.

Type species: Metacoleroa dickiei (Berk. \& Broome) Petr. [as 'dieckiei'], Annls mycol. 25(3/4): 332 (1927) [as 'dieckiei'], Annls mycol. 25(3/4): 332 (1927).

三Sphaeria dickiei Berk. \& Broome, Ann. Mag. nat. Hist., Ser. 2 9: 317 (1852).

Notes: Metacoleroa is a monotypic genus characterized by ascomata produced on well-defined subiculum, not cupulate when dry and olivaceous brown ascospores at maturity (Zhang et al. 2011). No mature ascomata were found on the specimen examined by Crous et al. (2007b).

\section{Neocoleroa Petr., Hedwigia 74: 38 (1934).}

Index Fungorum number: IF 3446; Facesoffungi number: FoF 06362; - 3 morphological species (Species Fungorum 2020), 1 species with molecular data.

Type species: Neocoleroa sibirica Petr., Hedwigia 74: 38 (1934).

Notes: Neocoleroa is characterized by lobed to dichotomously branched, blunt-tipped setae and persistent pseudoparaphyses. Recent authors have used morphology to accomodate Neocoleroa in Pseudoperisporiaceae (e.g. Barr 1997, Kirk et al. 2008), although it was noted that these taxa are similar to Venturiaceae (Johnston and Park 2016).

Protoventuria Berl. \& Sacc., Atti Soc. Veneto-Trent. Sci. Nat. 10(1): 174 (1887).

Index Fungorum number: IF 4399; Facesoffungi number: FoF 06363; - 19 morphological species (Species Fungorum 2020), 3 species with molecular data.

Type species: Proventuria rosae De Not., G. bot. ital. 1(1): 332 (1844).

Notes: Proventuria is characterized by superficial ascomata developing on dead leaf tissues, sparse aerial mycelium, a subcuticular hypostroma and penetrating, intramaterical hyphae (Carris and Poole 1993).

Pseudoanungitea Crous, in Crous et al., Fungal Systematics and Evolution 1: 199 (2018).
Index Fungorum number: IF 824789; Facesoffungi number: FoF 08833; - 2 morphological species (Species Fungorum 2020), 2 species with molecular data.

Type species: Pseudoanungitea syzygii (Crous, W.B. Kendr. \& M.J. Wingf.) Crous, in Crous, et al., Fungal Systematics and Evolution 1: 199 (2018).

三Anungitea syzygii Crous, W.B. Kendr. \& M.J. Wingf., Can. J. Bot. 73(2): 225 (1995).

Notes: Species of Pseudoanungitea are similar in characters to Anungitea in having dark, solitary conidiophores with flattened denticle heads and 1-septate, subhyaline conidia forming as a cylindrical chain with apical and basal scars (Crous et al. 2018b).

Pseudoparodiella F. Stevens, Illinois Biol. Monogr. (Urbana) 11(2): 166 (1927).

Index Fungorum number: IF 4467; Facesoffungi number: FoF 06364; - 1 morphological species (Species Fungorum 2020), molecular data unavailable.

Type species: Pseudoparodiella vernoniae F. Stevens, Illinois Biol. Monogr. (Urbana) 11(no. 2): 166 (1927).

Notes: Pseudoparodiella is similar with other genera in having smaller ascomata with or without pseudoparaphyses, obclavate asci and 1-septate, olivaceous brown ascospores (Zhang et al. 2011). However, this genus differs from the similar genus Acantharia in having mature pale brown ascospores (Zhang et al. 2011). Ascomata consisting of rare pseudoparaphyses and obclavate asci 1-septate, olivaceous brown ascospores showing a close affinity with Venturiaceae (Zhang et al. 2011).

Sympodiella W.B. Kendr., Trans. Br. mycol. Soc. 41(4): 519 (1958).

Index Fungorum number: IF10151; Facesoffungi number: FoF 09216; - 7 morphological species (Species Fungorum 2020), 4 species with molecular data.

Type species: Sympodiella acicola W.B. Kendr., Trans. Br. mycol. Soc. 41(4): 519 (1958).

Notes: Sympodiella is characterized by superficial networks of darkly pigmented, septate, anastomosing hyphae. Conidiophores are simple, septate, and darkly pigmented except at the extreme apex and conidia are cylindrical, smooth-walled and hyaline (Kendrick 1958).

Tyrannosorus Unter. \& Malloch, Mycol. Res. 99(8): 910 (1995).

Index Fungorum number: IF 11631; Facesoffungi number: FoF 06365; - 1 morphological species (Species Fungorum 2020), 1 species with molecular data.

Type species: Tyrannosorus pinicola (Petrini \& P.J. Fisher) Unter. \& Malloch, Mycol. Res. 99(8): 910 (1995). 
Fig. 93 Phylogram generated from maximum likelihood analysis (RAxML) of genera in Zeloasperisporiales based on LSU and SSU sequence data. Maximum likelihood bootstrap values equal or above $70 \%$, Bayesian posterior probabilities equal or above 0.90 (MLBS/ $\mathrm{PP})$ are given at the nodes. An original isolate number is noted after the species name. The tree is rooted to Venturia inaequalis (CBS 594.70, CBS 815.69). The ex-type strains are indicated in bold. Hyphen (-) represents support values below $70 \%$ MLBS and $0.90 \mathrm{PP}$

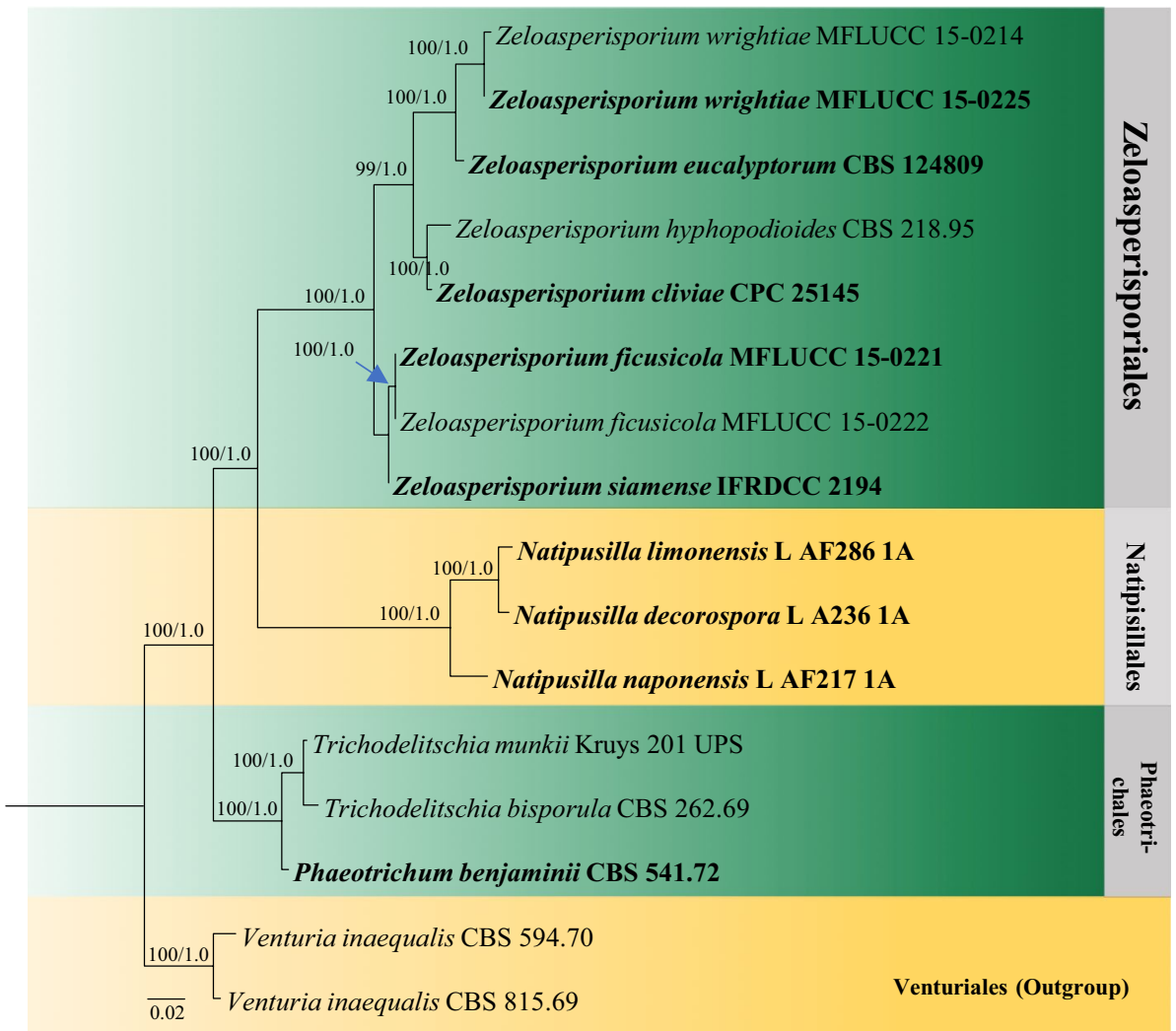

三 Capronia pinicola Petrini \& P.J. Fisher, in Müller et al., Trans. Br. mycol. Soc. 88(1): 68 (1987).

Notes: Tyrannosorus was introduced as a monotypic genus. Helicodendron is considered as the asexual morph (Untereiner et al. 1995). This genus differs from other genera in having a helicosporous asexual morph and longitudinally ridged ascospores with multiple germ slits (Zhang et al. 2011).

\section{Economic and ecological significance}

Most species in Venturiaceae are saprobic or parasitic. They are capable of growing in living or dead leaves, stalks, or twigs of various higher plants, rarely on Sphagnum or dung. Some are important plant pathogens which have a cosmopolitan distribution causing diseases of perennial plants, such as apple scab (Venturia inaequalis), pear scab (V. pyrina), poplar shoot blight ( $V$. populina), soybean black leaf blight (Arkoola nigra), and the widespread black knot disease of cherry (Dibotryon morbosum) (von Arx and Müller 1975; Talbot 1971). Apiospora mabosa is another important pathogenic species causing black knot disease of Prunus, mainly affecting cultivated plum, prune and cherry and to a lesser extent wild plum and cherry (Snover and Arneson 2002).

Zeloasperisporiales Hongsanan \& K.D. Hyde.

Index Fungorum number: IF 551336; Facesoffungi number: FoF 551336.
The order was established by Hongsanan et al. (2015b) to accommodate Zeloasperisporiaceae. Previous phylogenetic analyses using LSU and SSU sequence data indicated that this order is a distinct lineage from Microthyriales within Dothideomycetes, and formed as a sister clade to freshwater order Natipusillales. Morphologically, this order is very different from Natipusillales. Therefore, the order status of Zeloasperisporiales is strongly supported by both phylogeny and morphology (Figs. 93 and 94). The divergence time for Zeloasperisporiales is estimated as 180 MYA (stem age, Hongsanan et al. 2020).

\section{Accepted families: Zeloasperisporiaceae.}

\section{Zeloasperisporiaceae Crous, Persoonia 34: 215 (2015).}

Index Fungorum number: IF 812487; Facesoffungi numbers: FoF 08834, 8 species.

Epiphytic on the surface of living and dead fallen leaves, appearing as small black dots, or in air. Superficial hyphae absent. Sexual morph: Thyriothecia superficial, solitary, circular, flattened, brown to dark brown, poorly developed at the base, ostiole lacking. Upper wall comprises ellipsoid angular cells, radiating from the center to the outer rim. Hamathecium pseudoparaphyses not observed. Asci 8-spored, bitunicate, fissitunicate, globose to ovoid or clavate, apedicellate, with an apical ocular chamber. Ascospores 2-3-seriate, obovoid to clavate, hyaline, 1-septate, slightly constricted at the septum, wider in upper cell, 


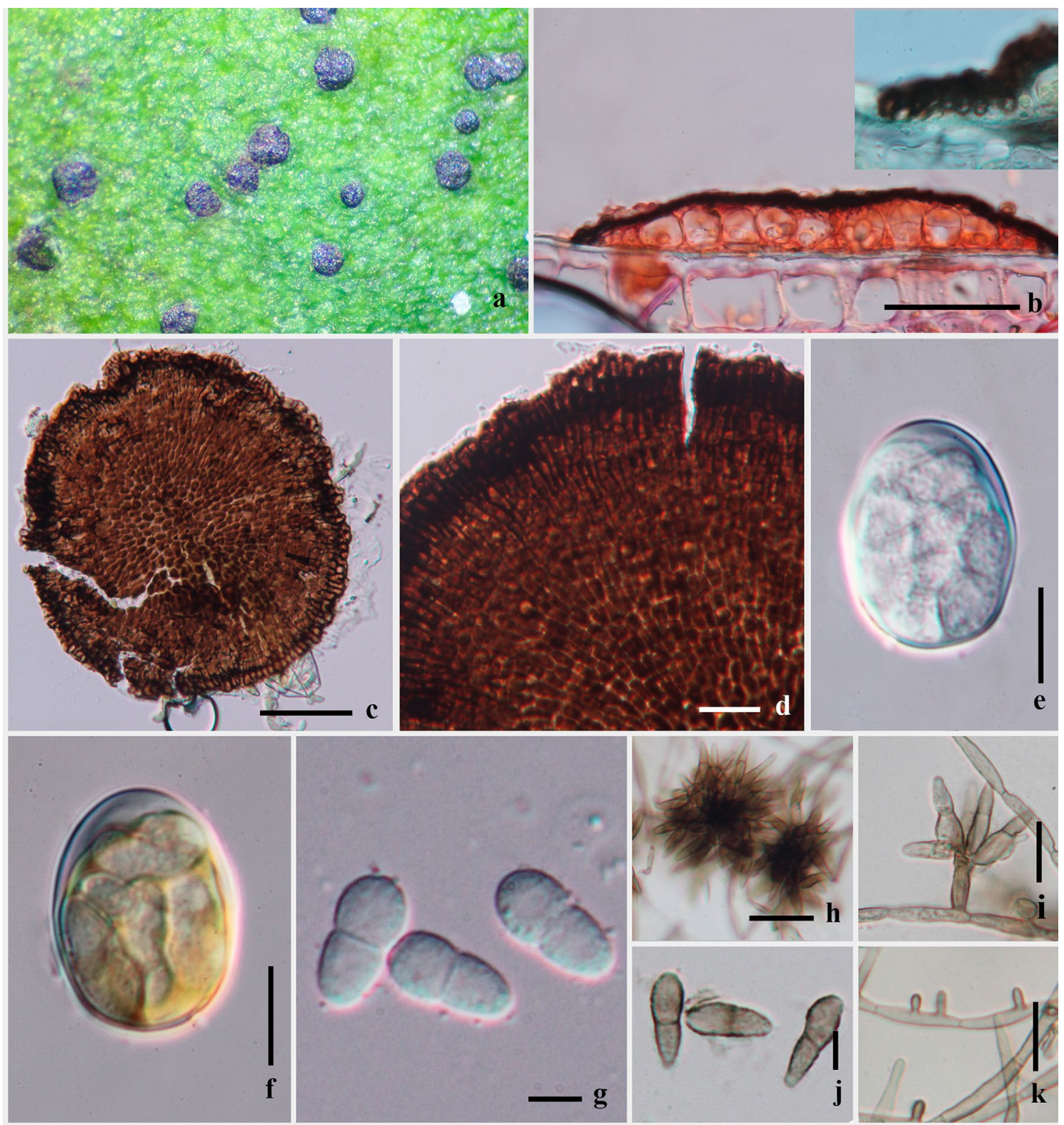

Fig. 94 Zeloasperisporium wrightiae (MFLU 15-1308, holotype). a Thyriothecia on host surface. b Section through thyriothecium and close-up of margin. c Thyriothecium in squash mount. d Upper wall of thyriothecium in squash mount. e Ascus. f Ascus in Melzer's reagent. g Ascospores. h Crowded conidia on conidiogenous cells. i Conidia on conidiogenous cell with sympodial proliferation. $\mathbf{j}$ Conidia. $\mathbf{k}$ Micronematous conidiogenous cells. Scale bars: $\mathbf{b}, \mathbf{c}=50$ $\mu \mathrm{m}, \mathbf{d}-\mathbf{f}, \mathbf{h}, \mathbf{i}, \mathbf{k}=10 \mu \mathrm{m}, \mathbf{g}, \mathbf{j}=5 \mu \mathrm{m}$

conidiogenous loci, mostly crowded at the apex, protuberant of thickened, refractive, conidial scars. Conidia fusiform to obclavate or cylindrical, straight to curved, pale brown to brown, 1-3-septate, distinctly or slightly constricted at the septum, tapered towards the apex, towards a protruding scar, somewhat thickened and darkened, refractive, smoothwalled or verrucose (Hongsanan et al. 2015b).

Type: Zeloasperisporium R.F. Castañeda.

Notes: Zeloasperisporiaceae was established by Crous et al. (2015b) to accommodate Neomicrothyrium (sexual 
genus Microthyrium-like) and Zeloasperisporium (asexual genus). This family was poorly resolved in molecular analysis as it is related to freshwater taxa in Natipusillales, and morphology of Zeloasperisporiaceae is very different from Natipusillales (Ferrer et al. 2011; Wu et al. 2011b). Hongsanan et al. (2015b) linked morphs and synonymized Neomicrothyrium under Zeloasperisporium. Moreover, they introduced the new order, Zeloasperisporiales to accommodate Zeloasperisporiaceae based on its distinct clade within Dothideomycetes.

Zeloasperisporium R.F. Castañeda, Mycotaxon 60: 284 (1996).

Index Fungorum number: IF 27808; Facesoffungi number: FoF 08835; 8 mophological species (Species Fungorum 2020), 8 species with molecular data

Type species: Zeloasperisporium hyphopodioides R.F. Castañeda.

Notes: Zeloasperisporium was introduced as genus incertae sedis by Castañeda-Ruíz et al. (1996), with the type species $Z$. hyphopodioides isolated from air in Cuba. Crous et al. (2007b) placed this genus in Venturiaceae based on phylogenetic placement basal to Venturiaceae. Two species from leaves of Eucalyptus and Clivia were introduced based on asexual characters and molecular data (Cheewangkoon et al. 2009; Crous et al. 2015b). Hongsanan et al. (2015b) linked the sexual morph genus (Neomicrothyrium) with Zeloasperisporium and added two new species to this genus. Phylogenetic analyses strongly support species of Zeloasperisporium as a distinct family and order (Hongsanan et al. 2015b).

Zeloasperisporium wrightiae Hongsanan \& K.D. Hyde, in Hongsanan et al., Cryptog. Mycol. 36(3): 310 (2015).

Index Fungorum number: IF 551313; Facesoffungi number: FoF 551313, Fig. 94

Description: see Hongsanan et al. (2015b).

Material examined: Thailand, Chiang Rai, Tasud, Mae Fah Luang University, on leaves of Wrightiar eligiosa Benth. (Apocynaceae), 15 January 2015, S. Hongsanan MOK01 (MFLU 15-1308, holotype).

\section{Economic and ecological significance}

Species of Zeloasperisporiaceae are usually found on living and dead fallen leaves, and rarely sampled in air. Species found on leaves sometimes produce organs to attach the surface of host plants at the ascomatal margin. However, it does not reveal any penetration of the host (Hongsanan et al. 2015b). The appearance of Zeloasperisporiaceae on leaves as a few small black dots is not a serious problem.

\section{Dothideomycetes, families incertae sedis}

In this section we include families that cannot be accommodated in orders of Dothideomycetes, mainly because they lack molecular data. However, since they have a suite of characters that exclude them from other families, they are accepted as distinct families.

Alinaceae Boonmee \& K.D. Hyde, in Boonmee et al., Mycosphere 8(10): 1699 (2017).

Index Fungorum number: IF 553826; Facesoffungi numbers: FoF 03661, 1 species.

Parasitic or epiphytic on living leaves. Sexual morph: Ascomata superficial, developed on hyphae, globose to subglobose, brown, covered by brown hyphae. Peridium comprises brown cells of textura angularis, lacking pseudoparaphyses. Asci 8-spored, bitunicate, subglobose to clavate, sessile, thick-walled. Ascospores overlapping, ovoid to obovoid, apex wider, narrower towards the lower and rounded end, brown, 1-septate. Asexual morph: Hyphomycetous, Septoidium sp., Shivomyces sp. (adapted from Boonmee et al. 2017).

Type: Alina Racib.

Notes: Boonmee et al. (2017) re-examined the ex-isotype of Alina jasmini, and concluded that the morphology of Alina has a set of characters that can differentiate it from other families in Dothideomycetes. Therefore, they introduced Alinaceae to accommodate the monotypic genus, Alina (Boonmee et al. 2017). Molecular data is unavailable to confirm its taxonomic placement.

Alina Racib., Bull. int. Acad. Sci. Lett. Cracovie, Cl. sci. math. nat. Sér. B, sci. nat. 3: 374 (1909).

Index Fungorum number: IF 125; Facesoffungi number: FoF 07866; 1 morphological species (Species Fungorum 2020), molecular data unavailable.

Type species: Alina jasmini Racib.

Notes: Alina was introduced from living leaves of Jasminum sp. Alina is similar to Tretospora (the asexual morph of Balladynopsis) based on some hyphomycetous conidial structures found on the ex-isotype of Alina jasmini (Sivanesan 1981). By re-examining the same specimen, Boonmee et al. (2017) reported that they were unable to find some structures e.g. setae, hyphopodia-like structures or even conidia as previously shown in Raciborski (1909) and Sivanesan (1981). They concluded that Alina has unique characters and could not be placed in any families in Dothideomycetes (Boonmee et al. 2017). Thus, they established Alinaceae to accommodate this genus.

Alina jasmini Racib., Bull. int. Acad. Sci. Lett. Cracovie, Cl. sci. math. nat. Sér. B, sci. nat. 3: 375 (1909).

Index Fungorum number: IF 205013; Facesoffungi number: FoF 03662; Fig. 95

Description: see Boonmee et al. (2017). 


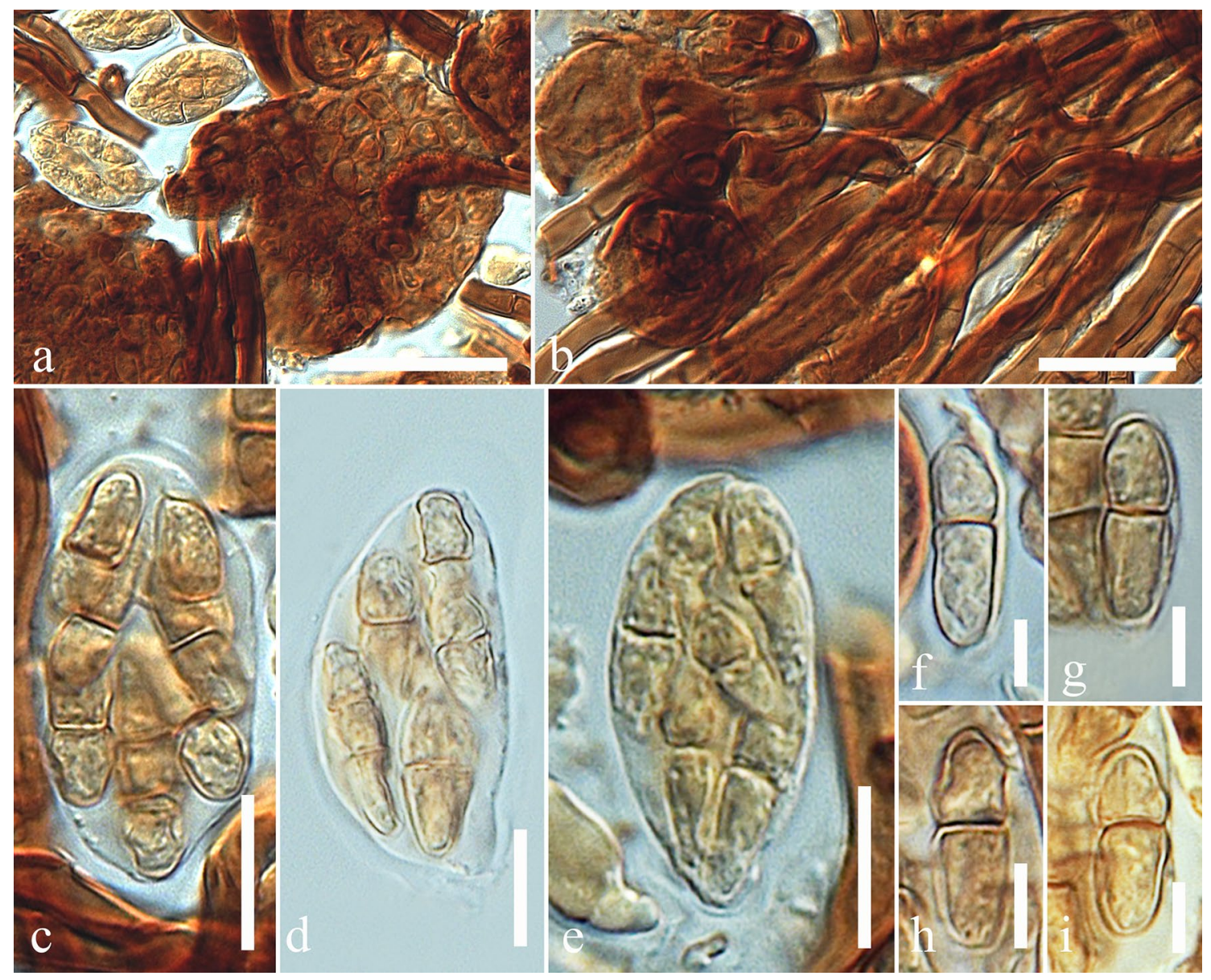

Fig. 95 Alina jasmini (IMI 214481, ex-isotype). a Squash mount of ascomata. b Mycelia. c-e Asci. e-i Ascospores. Scale bars: $\mathbf{a}=20 \mu \mathrm{m}, \mathbf{b}=$ $50 \mu \mathrm{m}, \mathbf{c}-\mathbf{e}=10 \mu \mathrm{m}$

Material examined: Indonesia, Java, Djasinga, on living leaves of Jasminum sp. (Oleaceae), 1900, Raciborski M. (K(M) 177969 = IMI 214481, ex-isotype).

\section{Economic and ecological significance}

Species in Alinaceae are parasitic or epiphytic on living leaves, however they do not cause serious problem on plants.

Argynnaceae Shearer \& J.L. Crane, Trans. Br. mycol. Soc. 75(2): 193 (1980).

Index Fungorum: IF 80470; Facesoffungi numbers: FoF 06386, 3 species.

Saprobic on plant stems or wood and in freshwater and terrestrial habitats. Sexual morph: Ascomata apothecial or perithecial, solitary, superficial to slightly immersed, discoid, dark brown to black, coriaceous, lacking ostioles, lacking a stipe. Excipulum thick, ectal excipulum composed of brown to dark brown tissues mixed with host cells, medullary excipulum composed of hyaline cells of textura porrecta. Hymenium composed of wide, septate, branching, hyaline, cellular pseudoparaphyses. Epithecium lacking. Asci 8-spored, bitunicate, fissitunicate, clavate, globose to subglobose, pedicellate, thick-walled, lacking an ocular chamber, exposed or not. Ascospores 2-3-seriate, or multi-seriate, papilionaceous to broadly reniform, light brown, orange to light orange-brown, 1-septate, smooth-walled, 2- to multiguttulate, with a dark band at the septum. Asexual morph: Undetermined.

\section{Type: Argynna Morgan.}

Notes: Argynnaceae was introduced to accommodate two genera of Argynna and Lepidopterella (Hyde et al. 2013; Kirk et al. 2013; Wijayawardene et al. 2018). The species in Argynnaceae are saprobes and occurring on stems, twigs and woody debris from dicotyledonous and monocotyledonous plants. Additional collections and molecular study are required to clarify the phylogeny of this family.

Argynna Morgan, J. Cincinnati Soc. Nat. Hist. 18: 41 (1895).

Index Fungorum number: IF 306; Facesoffungi numbers: FoF 06387; 1 morphological species (Species Fungorum 2020), molecular data unavailable. 

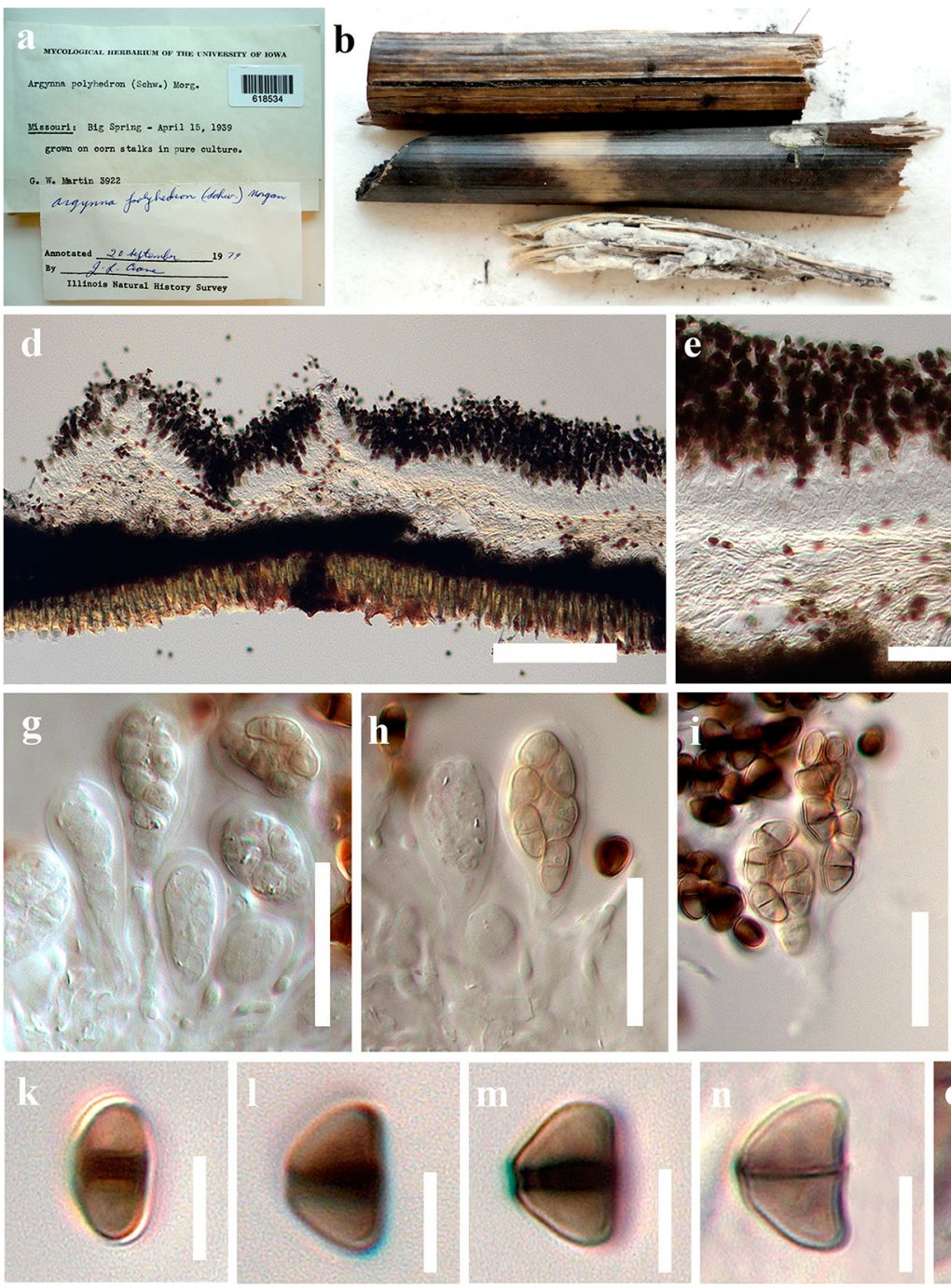

Fig. 96 Argynna polyhedron (BPI 618534). a Material label. b Ascoma on the host substrate. c Ascoma. d Section of ascoma and peridium. e Hymenium. f Pseudoparaphyses. g-j Immature and

Type species: Argynna polyhedron (Schwein.) Morgan. Notes: Argynna comprises a single species, Argynna polyhedron (Morgan 1895). The genus is characterized by solitary, superficial apothecia and 1-septate papilionaceous, light brown, smooth-walled ascospores with a dark band at the septum. Argynna polyhedron is a rare species and lacks molecular data to allow its taxonomic placement.

Argynna polyhedron (Schwein.) Morgan [as 'polyedron'], J. Cincinnati Soc. Nat. Hist. 18: 41 (1895).

$\equiv$ Physarum polyhedron Schwein. [as 'polyaedron'], Trans. Am. phil. Soc., New Series 4(2): 257 (1832) [1834].

Index Fungorum: IF 140004; Facesoffungi number: FoF 06388; Fig. 96

Description: see Hyde et al. (2013).
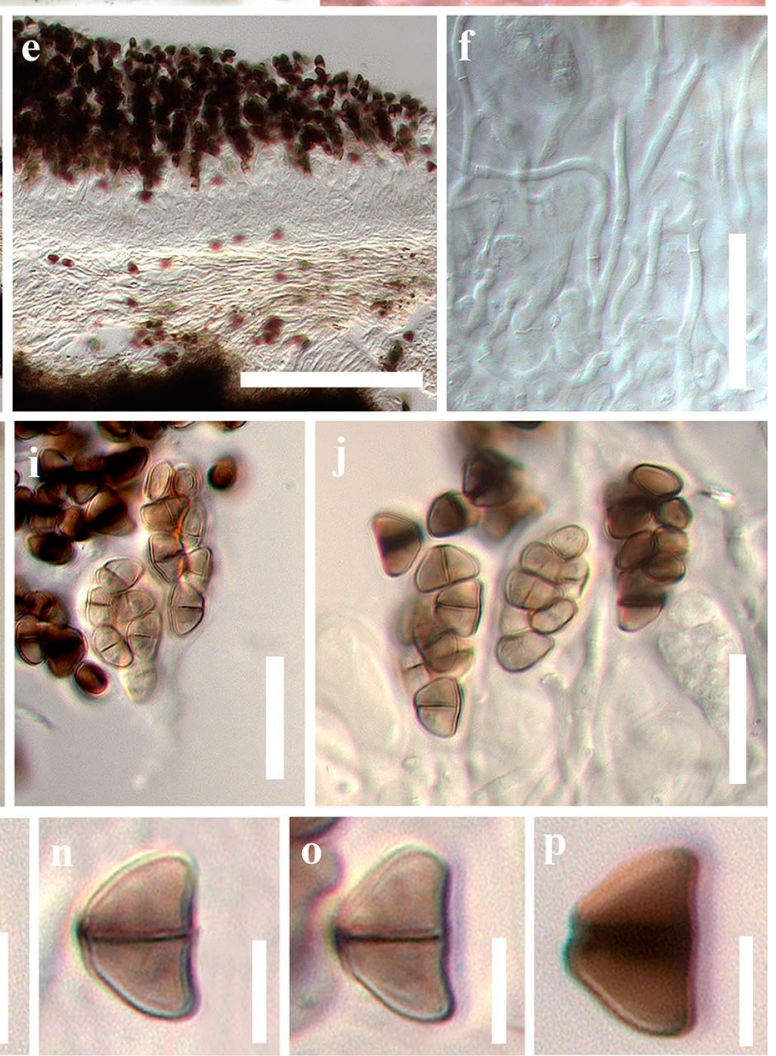

mature asci. k-p Papilionaceous ascospores. Scale bars: $\mathbf{c}=1000$ $\mu \mathrm{m}, \mathbf{d}=200 \mu \mathrm{m}, \mathbf{e}=100 \mu \mathrm{m}, \mathbf{f}-\mathbf{j}=20 \mu \mathrm{m}, \mathbf{k}-\mathbf{p}=5 \mu \mathrm{m}$

Material examined: USA, Missouri, Big Spring, on stalks of Zea mays, 15 April 1939, G.W. Martin (3922), BPI618534.

\section{Other genera included}

Lepidopterella Shearer \& J.L. Crane, Trans. Br. mycol. Soc. 75(2): 194 (1980).

Index Fungorum number: IF 2746; Facesoffungi numbers: FoF 06389; -2 morphological species (Species Fungorum 2020), 2 species with molecular data.

Type species: Lepidopterella palustris Shearer \& J.L. Crane, Trans. Br. mycol. Soc. 75(2): 194 (1980).

Notes: Lepidopterella was introduced by Shearer and Crane (1980) and placed in Argynnaceae. The asexual morph has not been reported. Species are saprobic fungi in aquatic habitats (Raja and Shearer 2008; Shearer et al. 2009; 

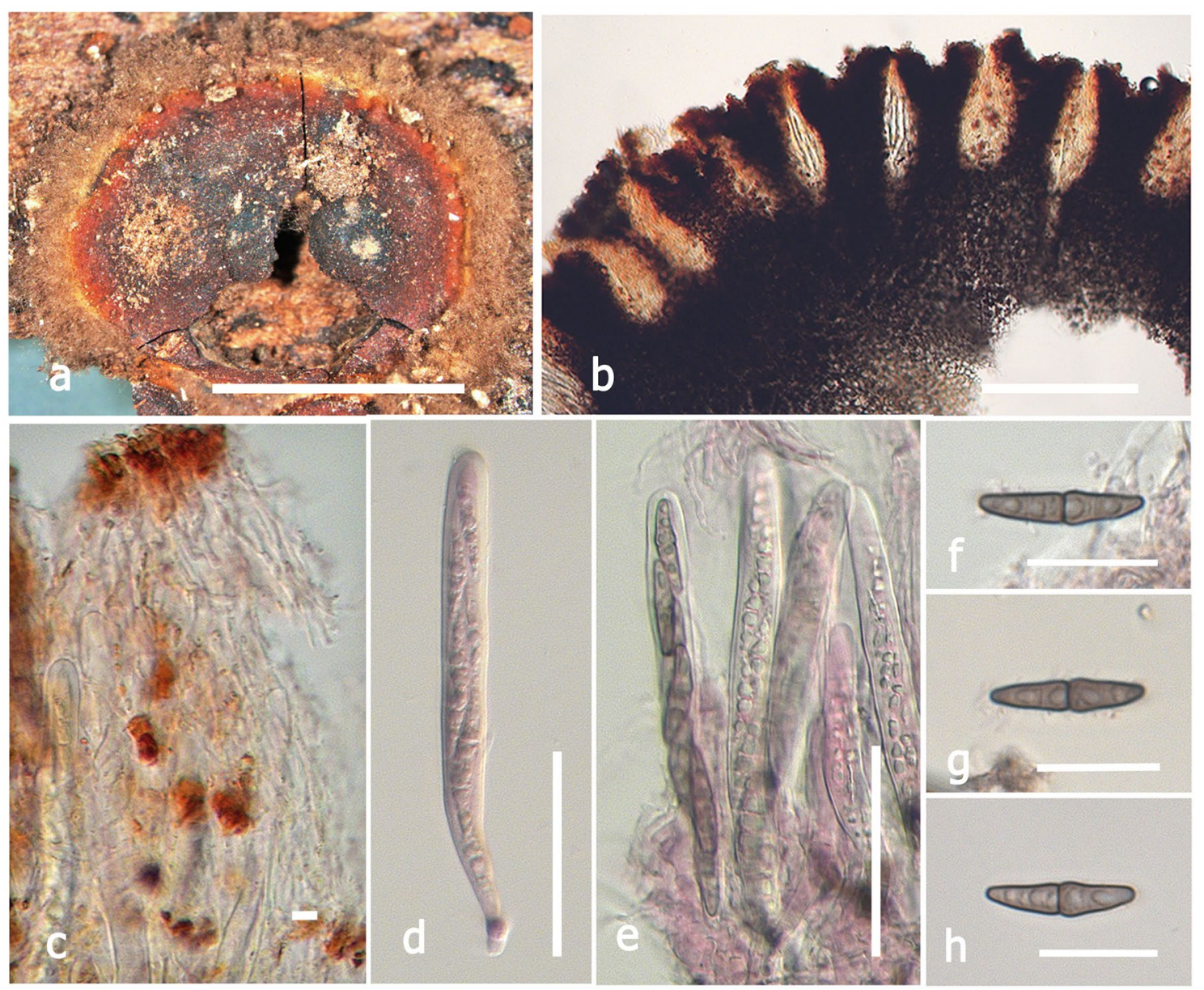

Fig. 97 Ascoporia lateritia (BPI 1109903). a Material, habit on decorticated wood and appearance of ascostroma on wood substrate. b Section of ascostroma showing arrangement of locules. c Hamathe-

cium pseudoparaphyses. d, e Asci changed to pinkish in $3 \% \mathrm{KOH}$. f-h Ascospores. Scale bars: $\mathbf{a}=5 \mathrm{~mm}, \mathbf{b}=200 \mu \mathrm{m}, \mathbf{c}=5 \mu \mathrm{m}, \mathbf{d}, \mathbf{e}=$ $50 \mu \mathrm{m}, \mathbf{f}-\mathbf{h}=20 \mu \mathrm{m}$

Hyde et al. 2013). Sequence data are available for the type species, Lepidopterella palustris, and L. tangerina. Phylogenetic analysis indicated that the type species represents a basal taxon to Mytilinidiales in Dothideomycetes with moderate support (Shearer et al. 2009). Lepidopterella shares butterfly-shaped ascospores with Argynna, but differs in having globose to subglobose ascomata, and papilionaceous to broadly reniform, brown to orange-brown ascospores (Hyde et al. 2013).

\section{Economic and ecological significance}

Members of Argynnaceae are saprobic on plant stems or wood and in freshwater and terrestrial habitats and play a role in recycling organic matter.

Ascoporiaceae Kutorga \& D. Hawksw., Syst. Ascom. 15(12): 25 (1997).

Index Fungorum number: IF 81923, Facesoffungi number: FoF 07867, 1 species.

Saprobic on decorticated wood in terrestrial habitats. Sexual morph: Ascostromata relatively large, superficial, circular or cupulate, slightly raised, pedicellate, solitary, exterior surrounded by brown mycelium, orange to red-brown at the margin or edge, dark brown to black in the centre, cells of ascostromata comprising a maze-like arrangement of mixed, brown-walled cells of textura angularis to subglobosa or epidermoidea, multi-loculate. Locules in a single layer at the periphery of the ascostromata, subcylindric-elongate, obpyriform to ovoid, crowded, opening by small, narrow, vertical ostiole. Hamathecium comprising numerous filiform, branched, septate, cellular pseudoparaphyses, embedded in a gelatinous matrix. Asci 8-spored, bitunicate, fissitunicate, narrowly cylindric-clavate, pedicellate, apically rounded with a small ocular chamber. Ascospores 2-seriate, fusiform, hyaline to yellowish when immature, olive-brown to dark brown when mature, 1-septate, constricted at the septum. Asexual morph: Coelomycetous.

Type: Ascoporia Samuels \& A.I. Romero. 
Notes: Ascoporiaceae is presently treated in Dothideomycetes as family incertae sedis (Wijayawardene et al. 2018). The family is monotypic with a single species Ascoporia lateritia (Hyde et al. 2013). Ascoporiaceae lacks molecular data to establish phylogenetic placement.

Ascoporia Samuels \& A.I. Romero, Bolm Mus. paraense 'Emílio Goeldi', sér. bot. 7(2): 264 (1993) [1991].

Index Fungorum number: IF 26458, Facesoffungi number: FoF 07945; - 1 morphological species (Species Fungorum 2020), molecular data unavailable.

Type species: Ascoporia lateritia Samuels \& A.I. Romero.

Notes: Ascoporia was introduced to accommodate a single species A. lateritia that occurs on terrestrial decorticated wood (Samuels and Romero 1991).

Ascoporia lateritia Samuels \& A.I. Romero, Bolm Mus. paraense ‘Emílio Goeldi', sér. bot. 7(2): 264 (1993) [1991].

Index Fungorum number: IF 360813, Facesoffungi number: FoF 07946; Fig. 97

Description: see Hyde et al. (2013).

Material examined: Brazil, Belem, Iha do Combu, Estacao Experimental Combu, Para. 01d30's, 48d27'w, on decorticated wood, January 1989, G.J. Samuels; K.F. Rodrigues, 6207 (BPI1 109903, isotype of Ascoporia lateritia).

\section{Economic and ecological significance}

Ascoporiaceae is a small family only known from Brazil. Species in this family are saprobes on decorticated wood (Samuels and Romero 1991).

Aulographaceae Luttrell ex P.M. Kirk et al., in Kirk et al., Ainsworth \& Bisby's Dictionary of the Fungi, Edn 9 (Wallingford): ix (2001).

Index Fungorum number: IF 80503; Facesoffungi numbers: FoF 06201, 50 species.

Saprobic on fallen leaves. Mycelium sparse, not radially arranged. Sexual morph: Ascomata forming as small black dots on host surfaces, solitary or clustered, nearly superficial, easily removed or breaking from the substrate, globose when immature, becoming sub-linear or v-shaped at maturity, rounded, carbonaceous, dark brown to black, absence of ostiole at the maturity, with slit-like opening. Hamathecium comprising septate, anastomosing and branched, trabeculate pseudoparaphyses, embedded in a gelatinous matrix with asci. Asci 8 -spored, bitunicate, fissitunicate, oval to ellipsoid, apex thickened, short pedicellate or lacking, and with a wide indistinct ocular chamber. Ascospores overlapping 2-3-seriate, oblong to ovate, narrow at both ends, hyaline, 1 -septate at the center, the upper cell often broader than lower cell. Asexual morph: Undertermined.

Type: Aulographum Lib.
Notes: Aulographaceae was established by Libert (1834) with the type genus Aulographum. They are characterized by superficial elongate thyriothecia, opening by longitudinal or slit-like, X- or Y-shaped dehiscence, with walls composed of dark cells that are pale at the margin of the scutellum, and lack of appressoria (Hyde et al. 2013; Hongsanan et al. 2014b). Hongsanan et al. (2014b) provided notes on this family and excluded the family from Asterinales based on morphology and phylogeny. Only a single species of Aulographum has sequence data and its placement is uncertain. Thus, more collections and sequence data are needed to clarify the taxanomic placement of this family within Dothideomycetes. Crous et al. (2019b) provided sequence data of Lembosina species and excluded this genus from Aulographaceae. Aulographaceae comprises three genera Aulographum, Echidnodes, and Lembosiella (Wijayawardana et al. 2018; Crous et al. 2019b).

Aulographum Lib., Pl. crypt. Arduenna, fasc. (Liège) 3 (nos 201-300): no. 272 (1834)

Index Fungorum number: IF 461; Facesoffungi number: FoF 06202; 18 morphological species (Species Fungorum 2020), 1 species with molecular data

Type species: Aulographum hederae Lib.

Notes: Aulographum is similar to Aulographina (incertae sedis genus in Capnodiales) and Lembosia (Asterinaceae) and these genera may be synonyms. However, only a single sequence is available for this genus, and its phylogenetic placement is uncertain. Molecular data of fresh specimens are needed to resolve its placement (Hyde et al. 2013). Several of the species however, were transferred to other families, such as Asterinaceae, Elsinoaceae, Leptopeltidaceae, or Lophiostomataceae (Hongsanan et al. 2014b).

Aulographum hederae Lib., Pl. crypt. Arduenna, fasc. (Liège) 3: no. 272 (1834).

Index Fungorum number: IF 161393; Facesoffungi number: FoF 07947; Fig. 98

Saprobic on fallen leaves of Hedera helix. Mycelium sparse, not radially arranged. Sexual morph: Ascomata 52-76 $\mu \mathrm{m}$ diam, 35-42 $\mu \mathrm{m}$ high $(\bar{x}=72 \times 40 \mu \mathrm{m}, \mathrm{n}=5)$, forming as small black dots on host surfaces, solitary or clustered, nearly superficial, easily removed or breaking from the substrate, globose when immature, becoming sublinear or v-shaped at maturity, rounded, carbonaceous, dark brown to black, with slit-like opening, ostiolar canal filled with hyaline cells, with cells comprising parallel, radiating lines from center of the ostiole to outer cells, becoming pale brown at the margin. Hamathecium comprising $1 \mu \mathrm{m}$ wide, septate, anastomosing, branched, trabeculate pseudoparaphyses, embedded in a gelatinous matrix with asci. Asci $24-30 \times 10-15 \mu \mathrm{m}(\bar{x}=28-12 \mu \mathrm{m}, \mathrm{n}=10)$ 8 -spored, bitunicate, fissitunicate, oval to ellipsoid, apex 

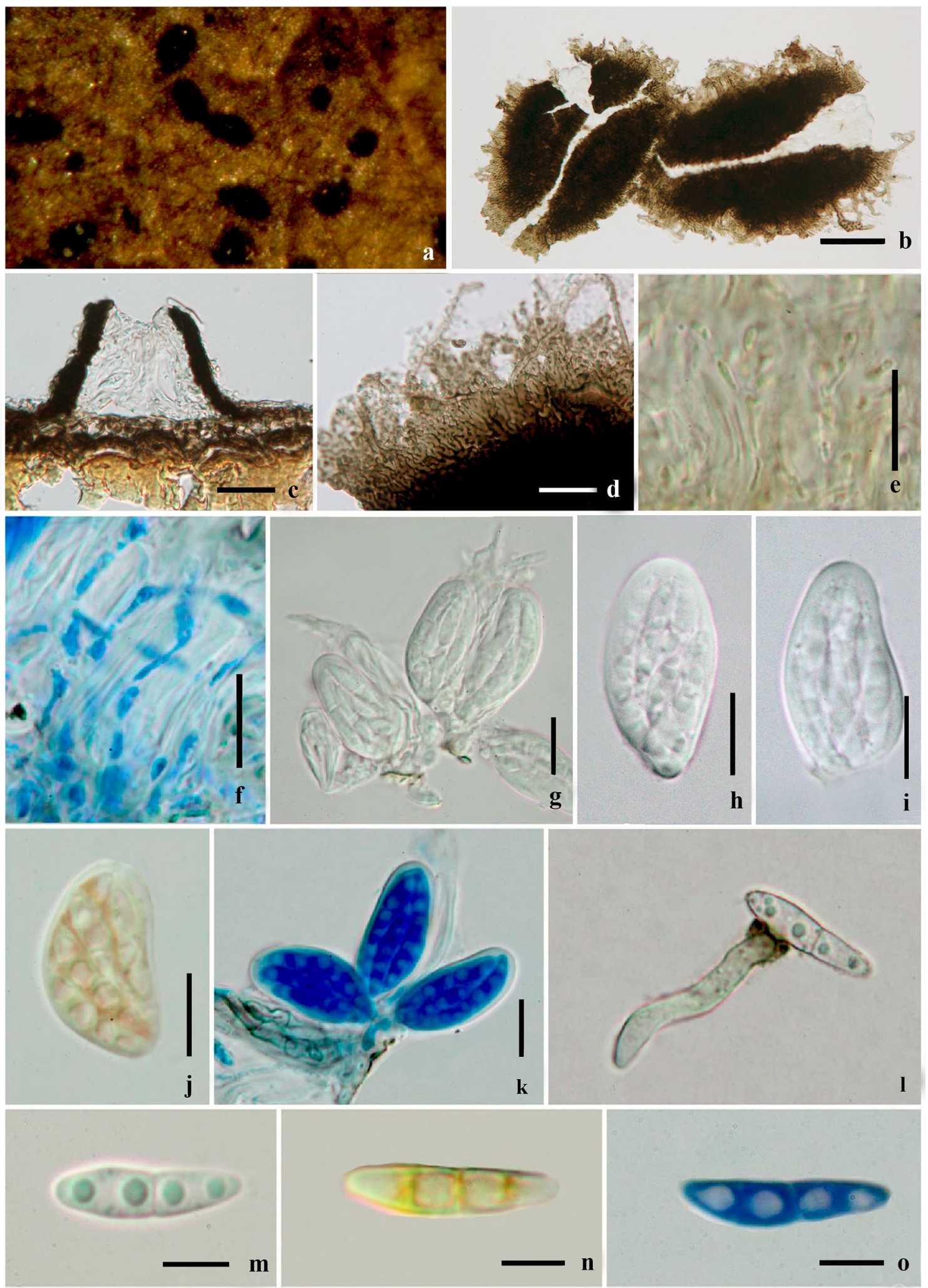

Fig. 98 Aulographum hederae (MFLUCC 12-0397). a Habit, ascomata on host substrate. b Ascomata with slit-like opening. c Section through ascoma. d Walled cells of ascoma. e, $\mathbf{f}$ Hamathecium in Melzer's reagent and Cotton blue reagent respectively. g-i Asci. j
Asci in Melzer's reagent. k Asci in Cotton blue reagent. 1 Ascospore germinated. $\mathbf{m}-\mathbf{o}$ Ascospore in water, Melzer's reagent and Cotton blue reagent respectively. Scale Bars: $\mathbf{b}=50 \mu \mathrm{m}, \mathbf{c}, \mathbf{g}-\mathbf{k}=20 \mu \mathrm{m}, \mathbf{d}-\mathbf{f}$ $=10 \mu \mathrm{m}, \mathbf{l}-\mathbf{0}=5 \mu \mathrm{m}$ 
thickened, short pedicellate or lacking, and with a wide, indistinct ocular chamber. Ascospores $11-14 \times 3-5 \mu \mathrm{m}$ ( $\bar{x}=12-3 \mu \mathrm{m}, \mathrm{n}=10$ ) overlapping $2-3$-seriate, oblong to ovate, narrow at both ends, hyaline, 1-septate at the center, constricted at the septum, the upper cell often broader than lower cell, smooth-walled. Asexual morph: Undertermined.

Material examined: Germany, Frankfurt, on fallen leaves of Hedera helix, in 2012, Meike Piepenbring MFLU, culture MFLUCC 12-0397 (MFU) = CPC21373 (CBS).

Notes: Aulographum hederae is the type species of Aulographaceae. It is characterized by longitudinally splitting ascomata and a perithecial wall appressed by mycelium with bright coloured margin (Hongsanan et al. 2014b). Sequence data of this specimen was provided by Hongsanan et al. (2014b), but without a plate and description. Therefore, we provide a photoplate of the same specimen with descriptions.

\section{Other Genera included}

Echidnodes Theiss. \& Syd., Annls mycol. 15(6): 422 (1918). Index Fungorum number: 1732; Facesoffungi number: FoF 07949; - 29 morphological species (Species Fungorum 2020), molecular data unavailable.

Type species: Echidnodes liturae (Cooke) Theiss. \& Syd. [as 'litsurae'], Annls mycol. 15(6): 422 (1918).

$\equiv$ Aulographum liturae Cooke [as 'Ailographium'], Grevillea 12(no. 61): 38 (1883).

Notes: Hongsanan et al. (2014b) placed Echidnodes in Aulographaceae based on its superficial hyphae, lack of appressoria and similar morphological characters of its asci and ascospores. However, molecular data is needed to confirm the placement of Echidnodes in Asterinales.

Lembosiella Sacc., Syll. fung. (Abellini) 9: 1101 (1891). Index Fungorum number: IF 2726; Facesoffungi number: FoF 07948; - 1 morphological species (Species Fungorum 2020), molecular data unavailable.

Type species: Lembosiella polyspora (Pat.) Sacc., Syll. fung. (Abellini) 9: 1101 (1891)

$\equiv$ Lembosia polyspora Pat., Bull. Soc. mycol. Fr. 3(2): 125 (1887).

Notes: Wu et al. (2011b) transferred Lembosiella to Aulographaceae based on the elongate thyriothecia with a slit-like opening and lack of appressoria on the superficial hyphae of Lembosiella polyspora (Hongsanan et al. 2014b).

Thyriopsis Theiss. \& Syd., Annls mycol. 13(3/4): 369 (1915).

Index Fungorum number: IF 5468; Facesoffungi number: FoF 07950; - 2 morphological species (Species Fungorum 2020), molecular data unavailable.
Type species: Thyriopsis halepensis (Cooke) Theiss. \& Syd., Annls mycol. 13(3/4): 369 (1915).

$\equiv$ Dothidea halepensis Cooke, Grevillea 7(no. 41): 35 (1878).

Notes: Lumbsch and Huhndorf (2010) placed Thyriopsis in Asterinaceae. However, the thyriothecia of Thyriopsis differs from Asterinaceae in having elongate thyriothecia, globose asci, hyaline ascospores without surface mycelia bearing appressoria. While Asterinaceae has circular thyriothecia, surface mycelia with appressoria and brown ascospores at maturity (Hongsanan et al. 2014b). Therefore, Thyriopsis is replaced in Aulugraphaceae (Hongsanan et al. 2014b). However, Thyriopsis is somewhat different from other genera in this family as its thyrothecia lack a fibrous dark brown margin and has dark brown elongate peridium cells. Molecular data of fresh collection is needed to confirm its placement in this family.

\section{Economic and ecological significance}

The members of this family differ from other species in Asterinales as these species can grow in artificial media indicating that the growth of the species is not reliant on the host (Hongsanan et.al 2014b). They are saprobic and play a role in recycling organic matter.

Balladynaceae Boonmee \& K.D. Hyde, in Boonmee et al., Mycosphere 8(10): 1701 (2017).

Index Fungorum number: IF 553827; Facesoffungi numbers: FoF 03663, 47 species.

Parasitic on living leaves. Sexual morph: Mycelium network-like, branched, septate, with hyphopodia, with or without setae. Hyphopodia numerous, knob-like, dark brown. Ascomata superficial, formed on hyphae, with a subiculum, solitary, scattered, globose to subglobose, with apical pore, minutely pedicellate at the base, olivaceous brown to dark brown, with transparent wall, surrounded by mycelium network. Peridium comprises 1-2 layers of olivaceous-brown cells of textura angularis, lacking pseudoparaphyses. Asci 8-spored, bitunicate, globose to subglobose, sessile. Ascospores multi-seriate, ellipsoid, upper cell wider, hyaline to light brown when immature, fawn to olivaceous-brown or brown at maturity, 1-septate. Asexual morph: Hyphomycetous. Clasterosporium sp., Tretospora sp. (adapted from Boonmee et al. 2017).

Type: Balladyna Racib.

Notes: Balladynaceae was established by Boonmee et al. (2017) to accommodate Balladyna (type), Balladynocallia and Balladynopsis. Balladynaceae can be distinguished from other families of Dothideomycetes based on its parasitic lifestyle, hyphae with hyphopodia, ascomata formed on hyphae, with or without setae, subglobose asci and 1-septate, hyaline to brown ascospores. No molecular data is available to confirm its phylogenetic placement within Dothideomycetes. 


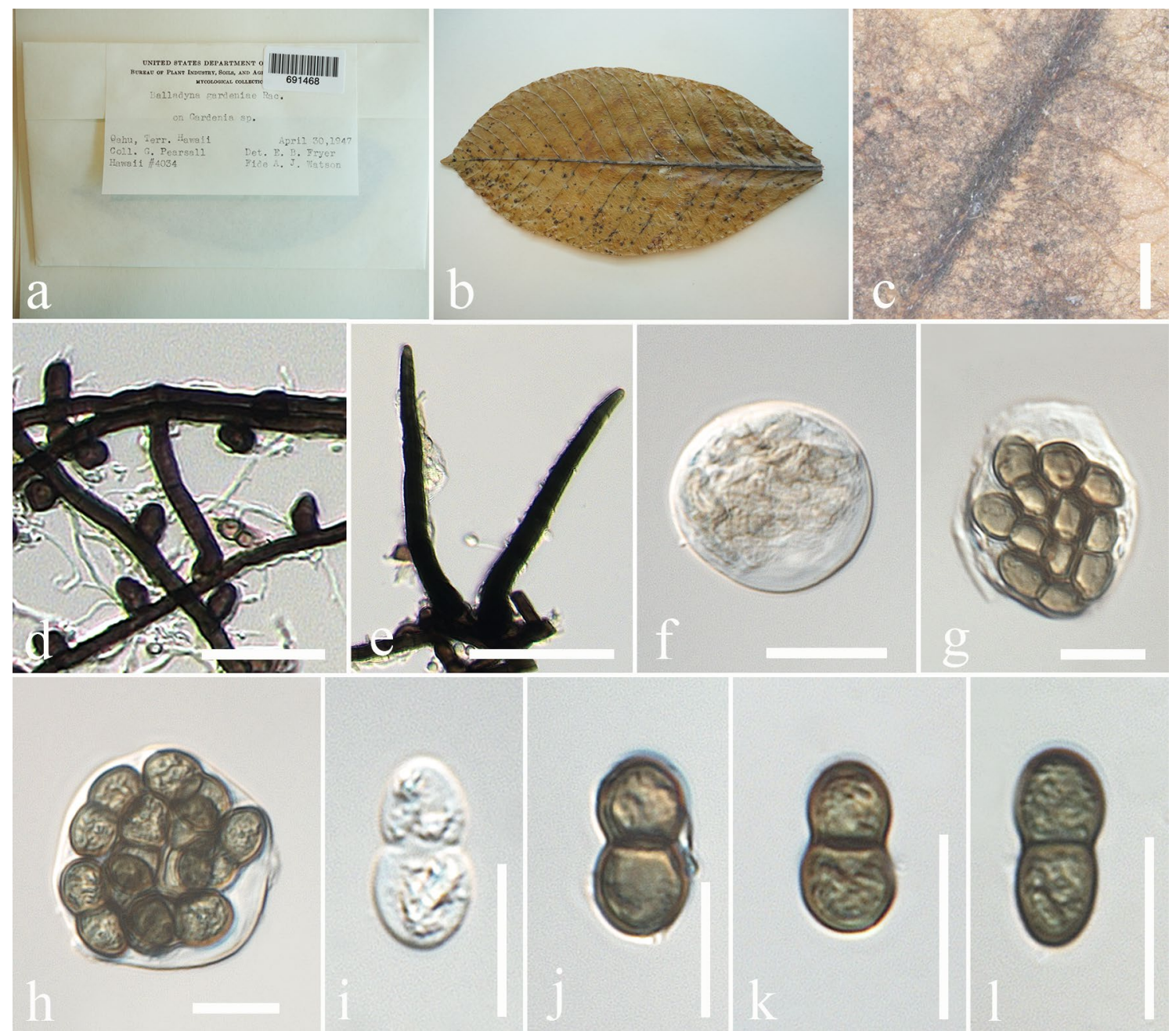

Fig. 99 Balladyna gardenia (BPI 691469, isotype). a, b Herbarium specimen. c Colonies on leaf surface. d Hyphae with hyphopodia. e Setae. $\mathbf{f}-\mathbf{h}$ Asci when immature and mature. i-l Ascospores. Scale bars: $\mathbf{c}=200 \mu \mathrm{m}, \mathbf{d}=30 \mu \mathrm{m}, \mathbf{e}=100 \mu \mathrm{m}, \mathbf{f}-\mathbf{l}=20 \mu \mathrm{m}$

Balladyna Racib., Parasit. Alg. Pilze Java's (Jakarta) 2: 6 (1900).

Index Fungorum number: IF 502; Facesoffungi number: FoF 07868; 35 morphological species (Species Fungorum 2020), molecular data unavailable.

Type species: Balladyna gardeniae Racib.

Notes: Seifert et al. (2011) reported the asexual morphs as Clasterosporium sp. found in Balladyna vanderystii var. ferulae-foetidae and Tretospora sp. found in Balladyna negrii. Boonmee et al. (2017) re-examined the isotype specimen (BPI 691469), but were unable to find asexual characters. They also established Balladynaceae to accommodate Balladyna, Balladynocallia and Balladynopsis based on morphology.

Balladyna gardeniae Racib., Parasit. Alg. Pilze Java's (Jakarta) 2: 6 (1900).
Index Fungorum number: IF 218036; Facesoffungi number: FoF 03664; Fig. 99

Description: see Boonmee et al. (2017).

Material examined: Indonesia, Java, Bogor, on living leaves of Gardenia lucida Roxb. (Rubiaceae), M. Raciborski Nr. 88 (BPI 691469, isotype).

\section{Other genera included}

Balladynocallia Bat., in Batista, Silva \& Bezerra, Atas Inst. Micol. Univ. Pernambuco 2: 216 (1965).

Index Fungorum number: IF 505; Facesoffungi number: FoF 07951; - 3 morphological species (Species Fungorum 2020), molecular data unavailable.

Type species: Balladynocallia glabra (Hansf.) Bat., in Batista, Silva \& Bezerra, Atas Inst. Micol. Univ. Recife 2: 216 (1965).

$\equiv$ Balladynastrum glabrum Hansf., Proc. Linn. Soc. London 157(3): 157 (1946) [1944-45]. 


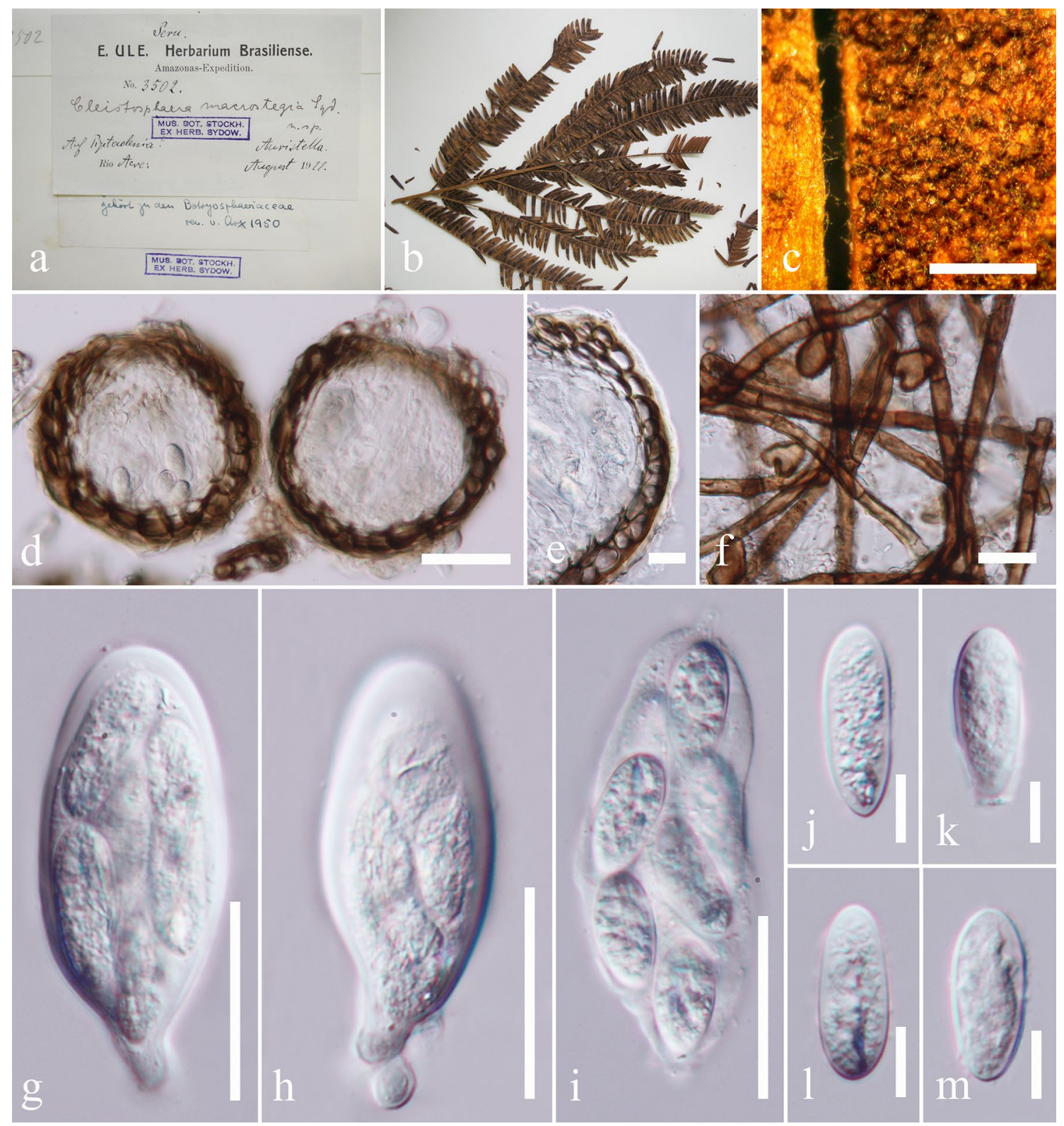

Fig. 100 Cleistosphaera macrostegia (S-F10853, holotype). a, b Herbarium specimen. c Habit on leaf surface. d Sections of ascomata. e Peridium. f Hyphae with hyphopodia. $\mathbf{g}-\mathbf{i}$ Asci. $\mathbf{j}-\mathbf{m}$ Ascospores. Scale bars: $\mathbf{c}=1000 \mu \mathrm{m}, \mathbf{d}, \mathbf{g}-\mathbf{i}=100 \mu \mathrm{m}, \mathbf{e}=30 \mu \mathrm{m}, \mathbf{f}=50 \mu \mathrm{m}, \mathbf{j}-\mathbf{m}=20 \mu \mathrm{m}$

Notes: The genus was introduced to accommodate $B$. amazonensis and the type species B. glabra. Boonmee et al. (2017) re-examined the type specimen of $B$. glabra, but it was not in good condition. However, they used descriptions and illustrations from Sivanesan (1981) to place this Balladynocallia in Balladynaceae.

Balladynopsis Theiss. \& Syd., Annls mycol. 15(6): 475 (1918) [1917].

Index Fungorum number: IF 506; Facesoffungi number: FoF 07952; - 9 morphological species (Species Fungorum 2020), molecular data unavailable.
Type species: Balladynopsis philippinensis Syd. \& P. Syd., Annls mycol. 15(6): 476 (1918) [1917].

$\equiv$ Henningsomyces philippinensis Syd. \& P. Syd., Philipp. J. Sci., C, Bot. 9(2): 161 (1914)

Notes: Descriptions and illustrations can be seen in Boonmee et al. (2017).

\section{Economic and ecological significance}

Species in Balladynaceae are parasitic on living leaves. Currently there is no report concerning species economic significance. By considering their appearance on leaves which is somewhat similar to Asterinaceae, they probably reduce 
respiration and photosynthesis of plants and probably cause leaf stunt disease or host tissues to become pale.

Cleistosphaeraceae Boonmee \& K.D. Hyde, in Boonmee et al., Mycosphere 8(10): 1708 (2017).

Index Fungorum number: IF 553828; Facesoffungi numbers: FoF 03669, 1 species.

Parasitic or saprobic on leaves. Mycelium superficial, branched, septate, with hyphopodia. Hyphopodia formed on mycelium, subglobose, dark brown Sexual morph: Ascomata superficial, grouped to solitary, globose to subglobose, dark brown, covered with mycelium. Hamathecium comprising sparse, septate, cellular pseudoparaphyses. Peridium comprises dark brown cells of textura angularis. Asci 8 -spored, bitunicate, ovoid to broadly clavate, sessile or with knob-like pedicel. Ascospores 2-3-seriate, ellipsoid-oblong, hyaline to pale grey, aseptate, smooth-walled, with granular contents, gelatinous sheath. Asexual morph: Coelomycetous (adapted from Boonmee et al. 2017).

Type: Cleistosphaera Syd. \& P. Syd.

Notes: Cleistosphaeraceae was established to accommodate the monotypic genus Cleistosphaera. The morphology of this family is quite similar to Botryosphaeriaceae, however, the generic type of Cleistosphaeraceae, Cleistosphaera differs from Botryosphaeriaceae by its ascomata features, mycelium with hyphopodia and sparse pseudoparaphyses.

Cleistosphaera Syd. \& P. Syd., Annls mycol. 14(1/2): 74 (1916).

Index Fungorum number: IF 1100; Facesoffungi number: FoF 07869; 1 morphological species (Species Fungorum 2020), molecular data unavailable.

Type species: Cleistosphaera macrostegia Syd. \& P. Syd.

Notes: Cleistosphaera is similar to taxa in Botryosphaeriaceae based on its asci and ascospore features, however, it differs from Botryosphaeriaceae by mycelium with hyphopodia. The asexual morph of $C$. macrostegia are phoma-like (coelomycetous) which differentiates it from all genera in Perisporiopsidaceae (hyphomycetous).

Cleistosphaera macrostegia Syd. \& P. Syd. [as 'macrostegiae'], Annls mycol. 14(1/2): 75 (1916).

Index Fungorum number: IF 161307; Facesoffungi number: FoF 03670; Fig. 100

Description: see Boonmee et al. (2017).

Material examined: Peru, Amazonas, Rio Acre, Seringal Auristela, on leaves of Piptadenia sp. (Leguminosae), August 1911, E.H.G Ule No. 3502 (S-F10853, holotype).

\section{Economic and ecological significance}

Species of Cleistosphaeraceae can be plant parasitic or play a role in recycling organic matter.
Coccoideaceae P. Henn. ex Sacc. \& D. Sacc., Henn. ex Sacc. \& D. Sacc., Syll. fung. (Abellini) 17: 860 (1905).

Index Fungorum number: IF 80616, Facesoffungi number: FoF 07953, 14 species.

Parasitic on living leaves. Sexual morph: Ascostromata large, up to $2 \mathrm{~mm}$ diam., single to solitary, or scattered, mostly superficial, slightly immersed in host tissue, circular to subcircular, discoid, cushion-like, semicircular in section, edge entire, slightly convex at the top, raised from the base, black, thickened at the base, soft, multi-loculate, in a layer in the upper part the ascostromata. Cells of ascostromata comprising heavily, pigmented cells of textura angularis. Locules completely immersed in ascostromata, globose, subglobose or obpyriform, with apical ostiole. Hamathecium comprising filiform, anastomosing, branched, septate, hyaline, relatively wide, cellular pseudoparaphyses. Asci 8-spored, bitunicate, fissitunicate, cylindrical to subclavate, pedicellate, apically rounded, with a distinct, wide, ocular chamber. Ascospores 2-seriate, apiosporous, ellipsoidal-obovoid, slightly oval, subglobose, tapering towards the narrow, lower end, yellowish to light brown, 1-septate at the lower end, not constricted at the septum, darkened at the septa, smooth-walled. Asexual morph: Undetermined.

Type: Coccoidea Henn.

Notes: Coccoideaceae includes Coccoidea, Coccoidella and Englerodothis, and is treated in Dothideomycetes as family incertae sedis (Hyde et al. 2013; Boonmee et al. 2017; Wijayawardene et al. 2018; Pem et al. 2019c). The characteristic feature of the family is ascostromata which are formed as circular to discoid or cushion-like with dark pigment, which is rather unique of its members. Boonmee et al. (2017) revisited Coccoidella and provided a description and illustration of type species $C$. scutula and accepted this genus in Coccoideaceae. Pem et al. (2019c) included Englerodothis in Coccoideaceae. The family lacks molecular data to establish phylogenetic placement, especially as the type species is yet to be sequenced and no additional new taxa in this family.

Coccoidea Henn., Bot. Jb. 28(3): 275 (1900).

Index Fungorum number: IF 1144, Facesoffungi number: FoF 07954; 2 morphological species (Species Fungorum 2020), molecular data unavailable.

Type species: Coccoidea quercicola Henn. \& Shirai.

Notes: Coccoidea was introduced by Hennings (1900) and typified by $C$. quercicola, which is parasitic on living leaves. The genus lacks molecular data to indicate its generic placement.

Coccoidea quercicola Henn. \& Shirai, in Hennings, Bot. Jb. 28(3): 275 (1900).

Index Fungorum number: IF 167300, Facesoffungi number: FoF 07955; Fig. 101 


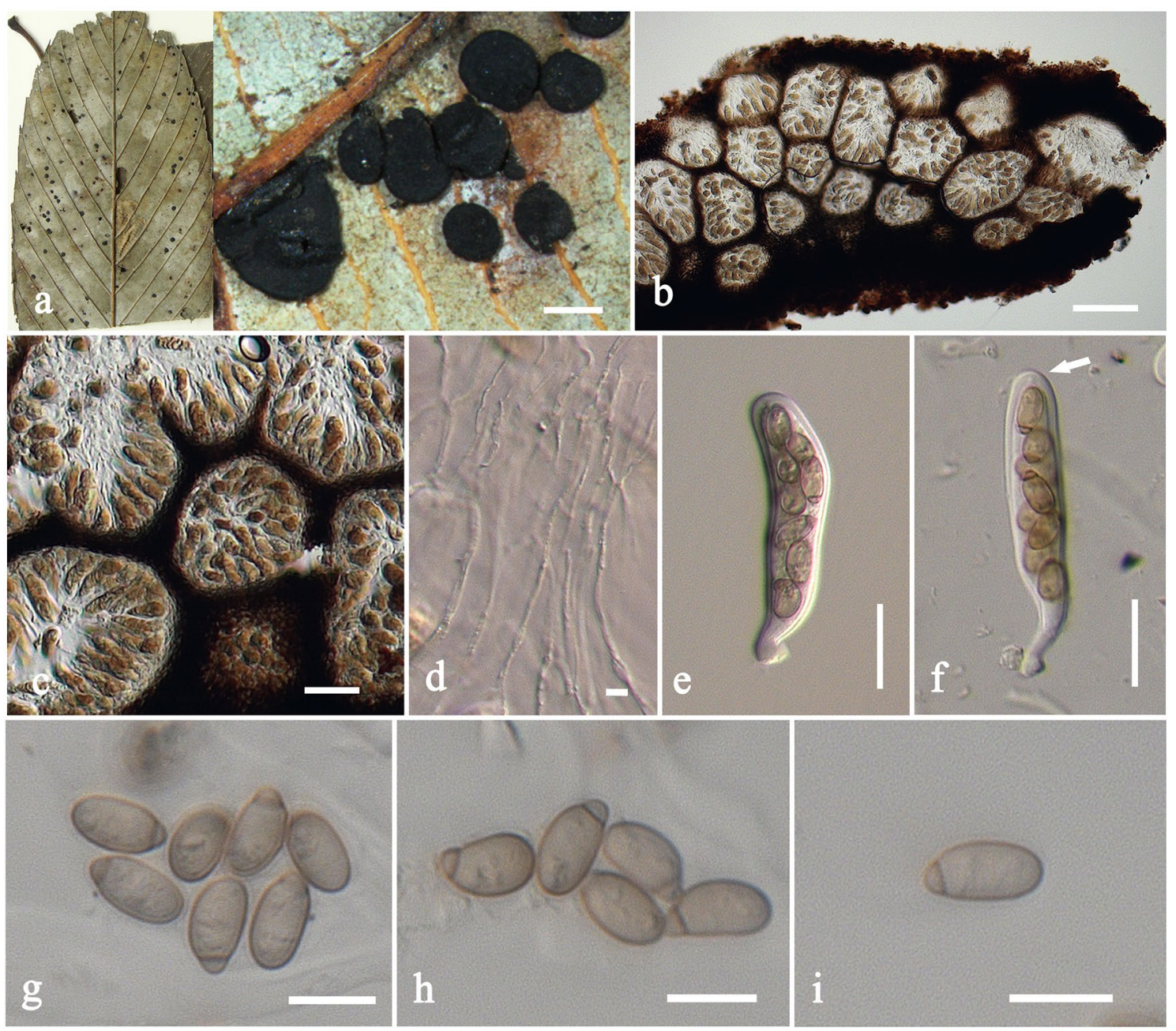

Fig. 101 Coccoidea quercicola (BPI 643971). a Material, habit on leaf and appearance of ascostromata on lower leaf surface. b Section of ascostroma showing arrangement of multilocule ascomata. $\mathbf{c}$ Close

Description: see Hyde et al. (2013).

Material examined: India, Sukliapokhari, Alt. 7,000 ft., on living leaves of Quercus lamellosa Sm., 11 May 1967, M.K. Maity PCC 1252, (BPI 643971).

\section{Other genera included}

Coccoidella Höhn., Sber. Akad. Wiss. Wien, Math.-naturw. Kl., Abt. 1 118: 847 (1909).

Index Fungorum number: IF 1145; Facesoffungi number: FoF 07956; - 9 morphological species (Species Fungorum 2020), molecular data unavailable.

Type species: Coccoidella scutula (Berk. \& M.A. Curtis) Höhn., Sber. Akad. Wiss. Wien, Math.-naturw. Kl., Abt. 1 118: 847 (1909).

$\equiv$ Dothidea scutula Berk. \& M.A. Curtis, Grevillea 4(no. 31): 105 (1876). up of peridial wall. d Hamathecium of trabeculate pseudoparaphyses. e, f Asci. g-i Ascospores. Scale bars: $\mathbf{a}=1 \mathrm{~mm}, \mathbf{b}=100 \mu \mathrm{m}, \mathbf{c}=40$ $\mu \mathrm{m}, \mathbf{d}=5 \mu \mathrm{m}, \mathbf{e}, \mathbf{f}=20 \mu \mathrm{m}, \mathbf{g}-\mathbf{i}=10 \mu \mathrm{m}$

Notes: Coccoidella was revisited by Boonmee et al. (2017) with description and illustration under a specimen named Coccoidella scutula (BPI642219) to represent the genus. This species was reported as parasitic on living leaves of Persea palustris (Lauraceae) from the USA. Coccoidella is placed in Coccoideaceae based on ascomata features (Boonmee et al. 2017). However, collections and sequence data are required to confirm the placement of this genus.

Englerodothis Theiss. \& Syd., Annls mycol. 13(3/4): 285 (1915).

Index Fungorum number: IF1818; Facesoffungi number: FoF 06240; -3 morphological species (Species Fungorum 2020), molecular data unavailable.

Type species: Englerodothis kilimandscharica (Henn.) Theiss. \& Syd., Annls mycol. 13(3/4): 285 (1915). 
Fig. 102 Cookella microscopica (PAD: no. 2509) a Material and habit on leaves. b Ascostroma with multilocule asci. c, $\mathbf{d}$ Young and mature asci. e Ascospores
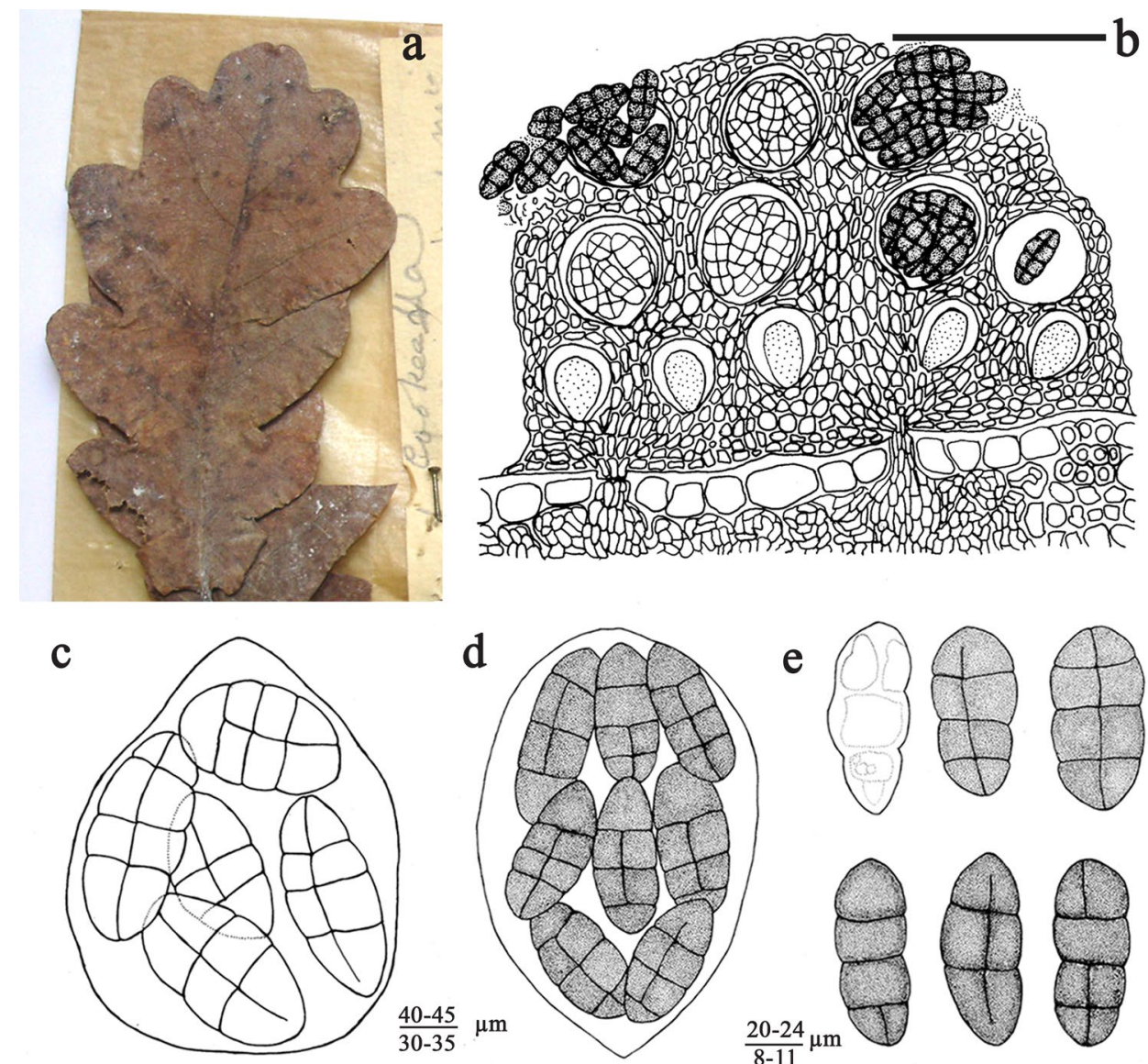

$\frac{40-45}{30-35}$
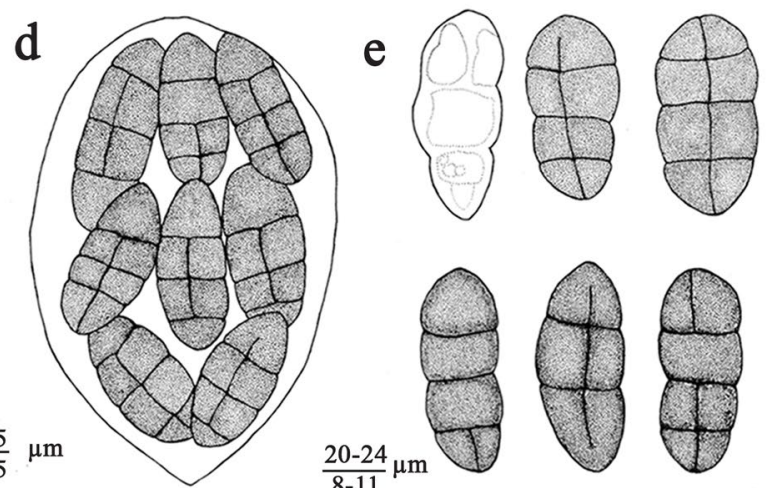

$\equiv$ Cocconia kilimandscharica Henn., in Engler, Pflanzenw. Ost-Afrikas Nachbarg., Teil C: 31 (1895).

Notes: Pem et al. (2019c) re-examined the type species Englerodothis kilimandscharica (S-F203689). They included Englerodothis in Coccideaceae based on its superficial, circular or discoid, multi-loculate ascomata, saccate-oblong to cylindric-cavate asci, and ellipsoidal-oblong to clavulate, 1-septate, light pigmented ascospores. Species of Englerodothis are reported as parasitic or saprobic on living and dead leaves. Fresh collections and sequence data are required to indicate phylogenetic placement.

\section{Economic and ecological significance}

Coccoideaceae includes three genera with 14 species and is distributed in temperate and tropical regions. Its members are parasitic or saprobic on living leaves of dicotyledons and angiosperms (Hyde et al. 2013; Boonmee et al. 2017; Pem et al. 2019c).

Cookellaceae Höhn.ex Saccardo \& Trotter, in Saccardo, Syll. Fung. (Abellini) 22: 585 (1913).

Index Fungorum number: IF 80637; Facesoffungi numbers: FoF 07870, 6 species.
Parasitic (or epiphytic) on leaves in terrestrial habitats, some possibly fungicolous. Sexual morph: Ascostromata superficial, subglobose or irregular, pulvinate to effuse, cushion-shaped, surface rough, flat or applanate at the base, scattered, pigmented, containing locules with individual asci, apapillate, opening by breaks in the upper surface; soft textured, cells of ascostromata comprising textura angularis to subglobulosa, with a basal hypostroma, developing in the host tissue, appearing as stromal blocks and swollen cells, of compressed packages of textura angularis to prismatica. Locules scattered throughout ascostromata, small, globose to subglobose, containing single asci, wall not obvious. Hamathecium lacking pseudoparaphyses. Asci 8-spored, bitunicate, fissitunicate, globose to subglobose or saccate, apedicellate, lacking an ocular chamber. Ascospores scattered in 3-5-seriate overlapping rows, muriform, ellipsoid to oblong, hyaline when immature, becoming brown at maturity, straight to slightly curved, ends rounded, with 3-transverse septa and 1-longitudinal septum in each cell, constricted at the septa, smooth-walled. Asexual morph: Coelomycetous, in genus Stigmella.

Type: Cookella Sacc.

Notes: The family includes only two genera Cookella and Pycnoderma (Wijayawardene et al. 2018), while Uleomyces 
was transferred to Myriangiaceae by Boonmee et al. (2017). Cookellaceae is treated in Dothideomycetes as family incertae sedis (Wijayawardene et al. 2018). The family is parasitic or epiphytic on leaves of dicotyledons and monocotyledons, with cushion-shaped to irregular thyriothecial single to multiloculate, ascostromata or ascomata, absent of pseudoparaphyses, 8-spored, bitunicate asci and muriform, light to dark pigmented ascospores (Hyde et al. 2013). The family lacks molecular data to establish its phylogenetic placement, especially as the type species is yet to be sequenced and there are no additional new taxa in this family.

Cookella Sacc., Michelia 1(no. 4): 407 (1878).

Index Fungorum number: IF 1225, Facesoffungi number: FoF 07957; 4 morphological species (Species Fungorum 2020), molecular data unavailable.

Type: Cookella microscopica Sacc.

Notes: Cookella was introduced to accommodate $C$. microscopica found on lower surface of leaves of Quercus pedunculatum (oak) in Italy (Saccardo 1878). The genus needs sequence data to resolve its generic placement.

Cookella microscopica Sacc., Michelia 1(no. 4): 407 (1878). Index Fungorum number: IF 218808, Facesoffungi number: FoF 07958; Fig. 102

Description and Material examined: see Hyde et al. (2013).

\section{Other genera included}

Pycnoderma Syd. \& P. Syd., Annls mycol. 12(6): 563 (1914).

Index Fungorum number: IF 4565, Facesoffungi number: FoF 07959; - 2 morphological species, (Species Fungorum 2020), molecular data unavailable.

Type species: Pycnoderma bambusinum Syd. \& P. Syd., Annls mycol. 12(6): 563 (1914).

Notes: Pycnoderma was introduced to accommodate $P$. bambusinum found on bamboo leaves (Sydow and Sydow 1914a). Only two species are accepted in the genus (Hongsanan et al. 2014a; Wijayawardene et al. 2017a). Fresh collections of its members are needed to clarify the generic placement.

\section{Economic and ecological significance}

Cookellaceae includes two genera with six species. Its genera are parasitic or epiphytic on leaves of dicotyledons and monocotyledons (Hyde et al. 2013; Hongsanan et al. 2014a).

Dimeriaceae E. Müll. \& Arx ex Arx \& E. Müll., Stud. Mycol. 9: 104 (1975).

Index Fungorum: IF 80704; Facesoffungi number: FoF 06390, 73 species.
Parasitic on living leaves, colonies dark brown, mycelium superficial, dark brown, amphigenous. Sexual morph: Ascomata superficial, subglobose, with hyphal appendages, flexuous, cylindrical, septate, dark brown, roughened. Asci 8-spored, bitunicate, fissitunicate, saccate-oblong to ellipsoidal, apically thickened. Ascospores conglobate, ellipsoidfusiform to subclavate, ends rounded, olivaceous-brown to brown, 1-septate, darkly pigmented at the septum, upper cell wider than lower cell, septum supramedian. Asexual morph: Hyphomycetous.

Type: Dimerium (Sacc. \& P. Syd.) McAlpine.

Notes: Dimeriaceae accommodates taxa occurring on the surface of living leaves (Hawksworth and Eriksson 1986; von Arx and Müller 1975; Barr 1987b, 1997). Its members are characterized by solitary, superficial ascomata with hyphal appendages and 1-septate ellipsoidal, dark brown ascospores darkly pigmented at the septum (Boonmee et al. 2017). Dimerium olivaceum was assigned as the type species (Boonmee et al. 2017). However, the family lacks molecular data to confirm the taxonomic placement.

Dimerium (Sacc. \& P. Syd.) McAlpine, Proc. Linn. Soc. N.S.W. 28: 98 (1903).

三 Dimerosporium subgen. Dimerium Sacc. \& P. Syd., Syll. fung. (Abellini) 16: 410 (1902).

Index Fungorum number: IF 25887; Facesoffungi number: FoF 06391; 73 morphological species (Species Fungorum 2020), molecular data unavailable.

Type species: Dimerium olivaceum Syd. \& P. Syd.

Notes: Dimerium is a single genus in Dimeriaceae (Wijayawardene et al. 2018). Many species were transferred to other genera based on shared characters (Boonmee et al. 2017). More collections of the members in this genus and sequence data are needed to clarify their taxonomic placement.

Dimerium olivaceum Syd. \& P. Syd., Annls mycol. 2(2): 169 (1904).

Index Fungorum number: IF 234107; Facesoffungi number: FoF 06392, Fig. 103

Description: see Boonmee et al. (2017).

Material examined: Chile, Anden bei Villarica, on living leaves of Cynoctonum nummulariaefolium (Asclepiadaceae), February 1897, F.W. Neger (SF11956, holotype).

\section{Economic and ecological significance}

The members in Dimeriaceae are reported as parasitic on living leaves of various hosts.

Dubujianaceae D. Pem, Doilom \& K.D. Hyde, Mycosphere 10(1): 1115-1246 (2019).

Index Fungorum number: IF 557065; Facesoffungi number: FoF 06679, 1 species. 

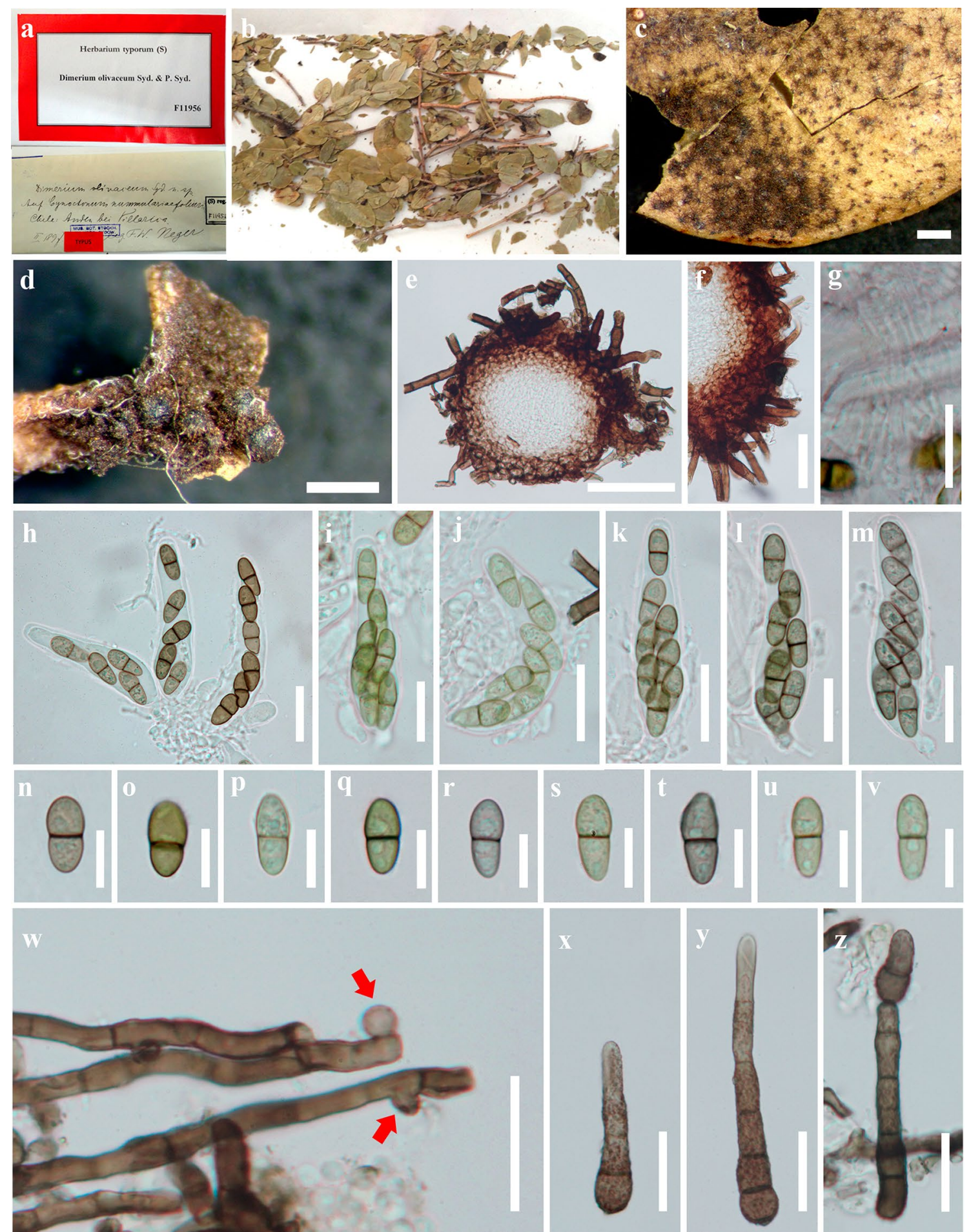

Fig. 103 Dimerium olivaceum (SF11956, holotype). a Material label. b Herbarium specimen and habit on leaves. c Appearance of colonies on the leaves surface. d Ascomata, marked by arrows e Section of ascoma. f Peridium. g Hamathecium comprising pseudopara-

Endophytic, saprobic or pathogenic on leaves. Sexual morph: Undetermined. Asexual morph: Mycelium at first subcuticular, developing onto leaf surface from leaf physes. h-m Asci. $\mathbf{n}-\mathbf{v}$ Ascospores. w Mycelium with septate and hyphopodia-like structures (red arrows). $\mathbf{x}-\mathbf{z}$ Conidiophores in different stages of developing conidia. Scale bars: $\mathbf{c}, \mathbf{d}=500 \mu \mathrm{m}, \mathbf{e}=50$ $\mu \mathrm{m}, \mathbf{f}-\mathbf{m}=20 \mu \mathrm{m}, \mathbf{n}-\mathbf{z}=10 \mu \mathrm{m}$

glands forming scattered to sporadically confluent superficial thalli, circular in outline, composed of a basal layer of flattened, parallel, branching, brown hyphae with setae. 

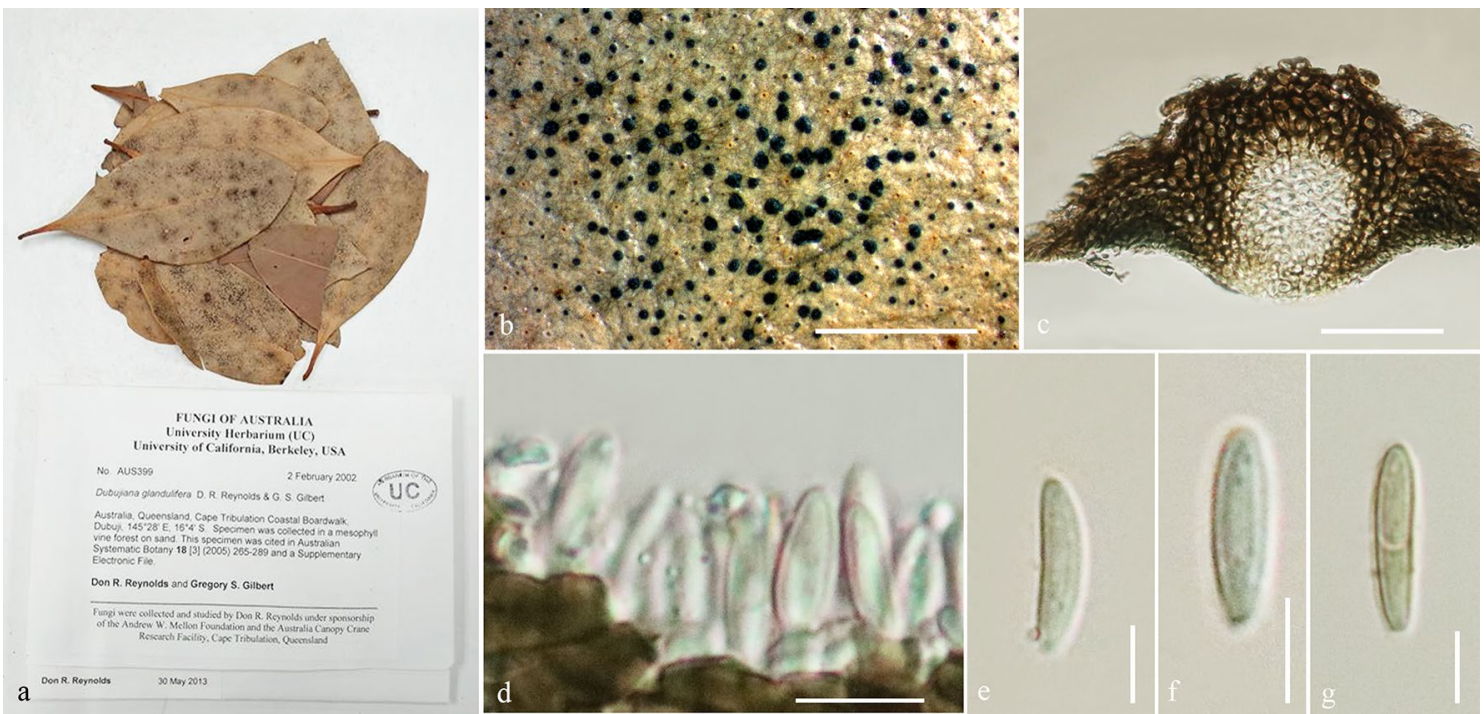

Fig. 104 Dubujiana glandulifera (UC AUS399, holotype). a Details of herbarium material. b Habit and appearance of conidiomata on host surface. $\mathbf{c}$ Section of conidioma. $\mathbf{d}$ Conidiogenesis. e-g Conidia. Scale bars: $\mathbf{b}=2 \mathrm{~mm}, \mathbf{c}=40 \mu \mathrm{m}, \mathbf{d}=100 \mu \mathrm{m}, \mathbf{e}, \mathbf{f}=5 \mu \mathrm{m}, \mathbf{g}=10 \mu \mathrm{m}$

Lacking hyphopodia, Hyphal strands radiate from base of central, raised pycnidium over the basal layer and onto the substrate. Conidiomata wall composed of thick dark-brown walled cells of textura globulosa. Conidiophores densely aggregated, slender, subulate, simple, frequently branched above, reduced to conidiogenous cells, or with 1-2 supporting cells. Conidiogenous cells annellidic, simple, tapering, hyaline, smooth, rarely with percurrent proliferations. Conidia ellipsoidal, fusiform to lunate, hyaline becoming pale brown at maturity, 1-septate, punctate, smooth-walled.

Type: Dubujiana D.R. Reynolds \& G.S. Gilbert.

Notes: Pem et al. (2019c) introduced Dubujianaceae with Dubujiana as the type genus. Species of Dubujianaceae have an epifoliar lifestyle with pycnidia arising from leaf glands in the outer portions of the hyphal system with individual hyphal strands extending from the large central pycnidium.

Dubujiana D.R. Reynolds \& G.S. Gilbert, Aust. Syst. Bot. 18(3): 282 (2005).

Index Fungorum number: IF 28993; Facesoffungi number: FoF 06238; 1 morphological species (Species Fungorum 2020), molecular data unavailable.

Type species: Dubujiana glandulifera D.R. Reynolds \& G.S. Gilbert.

Notes: The monotypic genus Dubujiana is characterized by raised pycnidia over the basal layer of the substrate, densely aggregated, slender conidiophores, and tapering, hyaline conidiogenous cells giving rise to pale brown, 1 -septate, punctate conidia. No cultures or sequence data are available for this genus.
Dubujiana glandulifera D.R. Reynolds \& G.S. Gilbert, Aust. Syst. Bot. 18(3): 282 (2005).

Index Fungorum number: IF 344434; Facesoffungi number: FoF 08038; Fig. 104

Description: see Pem et al. (2019c).

Material examined: Australia, Queensland, Cape Tribulation Coastal Boardwalk Dubuji, $145^{\circ} 28^{\prime}$ E, $16^{\circ} 4^{\prime}$ S., on leaves, 2 February 2002, D.R. Reynolds (UC AUS399, holotype).

\section{Economic and ecological significance}

Species of Dubujiana are epifoliar and maintain a commensal relationship with the host (Reynolds and Gilbert 2005).

Dysrhynchaceae Boonmee \& K.D. Hyde [as 'Dysrhynchisceae'], in Boonmee et al., Mycosphere 8(10): 1714 (2017).

Index Fungorum: IF 628246; Facesoffungi number: FoF 06393, 4 species.

Saprobic on dead leaves. Sexual morph: Ascomata superficial, globose to subglobose, dark brown, solitary, aggregated, with central pore, with a protruding synnematous neck, comprised of tightly compacted hyphae, sparse superficial mycelium with hyphopodia, brown to dark brown, with partially immersed mycelia, lacking setae, lacking pseudoparaphyses. Peridium membranous, comprising brown cells of textura angularis. Asci 8-spored, bitunicate, broadly obclavate to ovoid, sessile, apically thickened. Ascospores multi-seriate, conglobate, ellipsoidal, clavate to obpyriform, hyaline to light brown. Asexual morph: Hyphomycetous.

Type: Dysrhynchis Clem. 
Notes: Boonmee et al. (2017) introduced Dysrhynchisceae as a new family to accommodate Dysrhynchis. The morphological features of sexual and asexual morphs were described in Boonmee et al. (2017). Additional collections and molecular study are required to further clarify the phylogeny of this family.

Dysrhynchis Clem., Gen. fung. (Minneapolis): 32 (1909).

Index Fungorum number: IF 1728; Facesoffungi number: FoF 06394; 4 morphological species (Species Fungorum 2020), molecular data unavailable.

Type species: Dysrhynchis pulchella (Sacc.) Clem.

Notes: Dysrhynchis is the type genus of Dysrhynchaceae and both morphs of the life cycle have been reported. The genus lacks molecular data to establish phylogenetic placement and no additional new taxa have been introduced.

Dysrhynchis pulchella (Sacc.) Clem., in Clements \& Shear, Gen. fung., Edn 2 (Minneapolis): 253 (1931).

$\equiv$ Henningsomyces pulchellus Sacc. \& D. Sacc., Syll. fung. (Abellini) 17: 689 (1905).

Index Fungorum: IF 254191; Facesoffungi number: FoF 06395; Fig. 105

Description: see Boonmee et al. (2017).

Material examined: Brazil, Rio de Janeiro, Mauá, on dead leaves of Byrsonima sericae A. Juss. (Malpighiaceae), 21 July 1899, E.H.G. Ule, Mycotheca brasiliensis no. 71 (PAD No. 71, holotype).

\section{Economic and ecological significance}

Dysrhynchisceae are saprobes, occurring on plants from terrestrial habitats (Wijayawardene et al. 2017a). This family has no report as causing plant diseases.

Endosporiaceae D. Pem, Doilom \& K.D. Hyde, Mycosphere 10(1): 1115-1246 (2019).

Index Fungorum number: IF 557066; Facesoffungi number: FoF 06681, 2 species.

Pathogenic on bud of Populus tremuloides. Sexual morph: Undetermined. Asexual morph: Colonies (conidiomata) on PDA, OA and CA black, raised, cerebriform, comprising numerous cellular clumps in a thin covering, subcircular to irregular in outline, reverse black. Margin irregular with scarce, occasionally aggregated hyphae on PDA, even with adpressed or submerged hyphae on MEA. On PDA, cells more broad, swollen, subhyaline and dumbbell-shaped when two-celled, becoming multicellular by splitting in all directions, becoming darkly pigmented, irregular in shape, frequently separating into smaller clumps. Hyphae cylindrical or toruloid, light to dark brown, branched or unbranched, aerially determinate in growth, mostly elongated, hyaline at apex, forming muriform and darkly pigmented bodies.
Endoconidia developing from the separation of adjacent daughter cells in cellular clumps through septum schizolysis, ellipsoidal to subglobose becoming broadly ellipsoidal to globose, hyaline, aseptate. Blastic conidia abundant in mature colonies, arising from cells of cellular clumps or seldom from sides of hyphae, cylindrical to ellipsoidal, regularly truncate at the base, sometimes globose, obovoid, fusiform, hyaline or light brown, aseptate.

Type: Endosporium Tsuneda.

Notes: Pem et al. (2019c) introduced Endosporiaceae to accommodate Endosporium. The family is characterized by cylindric hyphae, ellipsoidal, subglobose to globose endoconida and cellular clumps, globose, obovoid, fusiform blastic conidia. Endosporiaceae is unique in producing endoconidia from cellular clumps.

Endosporium Tsuneda, in Tsuneda et al., Botany 86(9): 1022 (2008).

Index Fungorum number: IF 536893; Facesoffungi number: FoF 06239; 2 morphological species (Species Fungorum 2020), 2 species with molecular data.

Type species: Endosporium populi-tremuloides Tsuneda.

Notes: Endosporium is characterized by cylindrical hyphae, ellipsoidal, subglobose to globose endoconida and cellular clumps, globose, obovoid, fusiform blastic conidia. The sexual morph is unknown. Two species are known, $E$. aviarium and E. populi-tremuloides.

Endosporium populi-tremuloides Tsuneda, in Tsuneda et al., Botany 86(9): 1023 (2008).

Index Fungorum number: IF 536901; Facesoffungi number: FoF 08836; Fig. 106

Description: see Pem et al. (2019c).

Material examined: Canada, Whitemud Creek, Edmonton, Lansdowne, ca. $1 \mathrm{~km}$ west of the Northern Forestry Centre, Alberta, on bud of Populus tremuloides (Salicaceae), 3 November 2002, A. Tsuneda (UAMH 10529, holotype).

\section{Economic and ecological significance}

Two species in Endosporiaceae were found as pathogens which can uptake nutrients from plants.

Englerulaceae Henn., Hedwigia 43: 353 (1904).

= Schiffnerulaceae Hosag., Pl. Pathol. Quarant. 1(2): 132 (2011).

Index Fungorum number: IF 80736; Facesoffungi number: FoF 07960, 125 species.

Parasitic or epiphytic on living leaves, primarily tropical. Colonies superficial, thin to dense, brown to dark brown, confluent, velvety, with unicellular appressoria. Hyphae straight to flexuous, septate, irregularly to reticulate branched, brown. Hyphopodia globose, brown, thick-walled, irregular or absent. Sexual morph: Ascomata relatively 

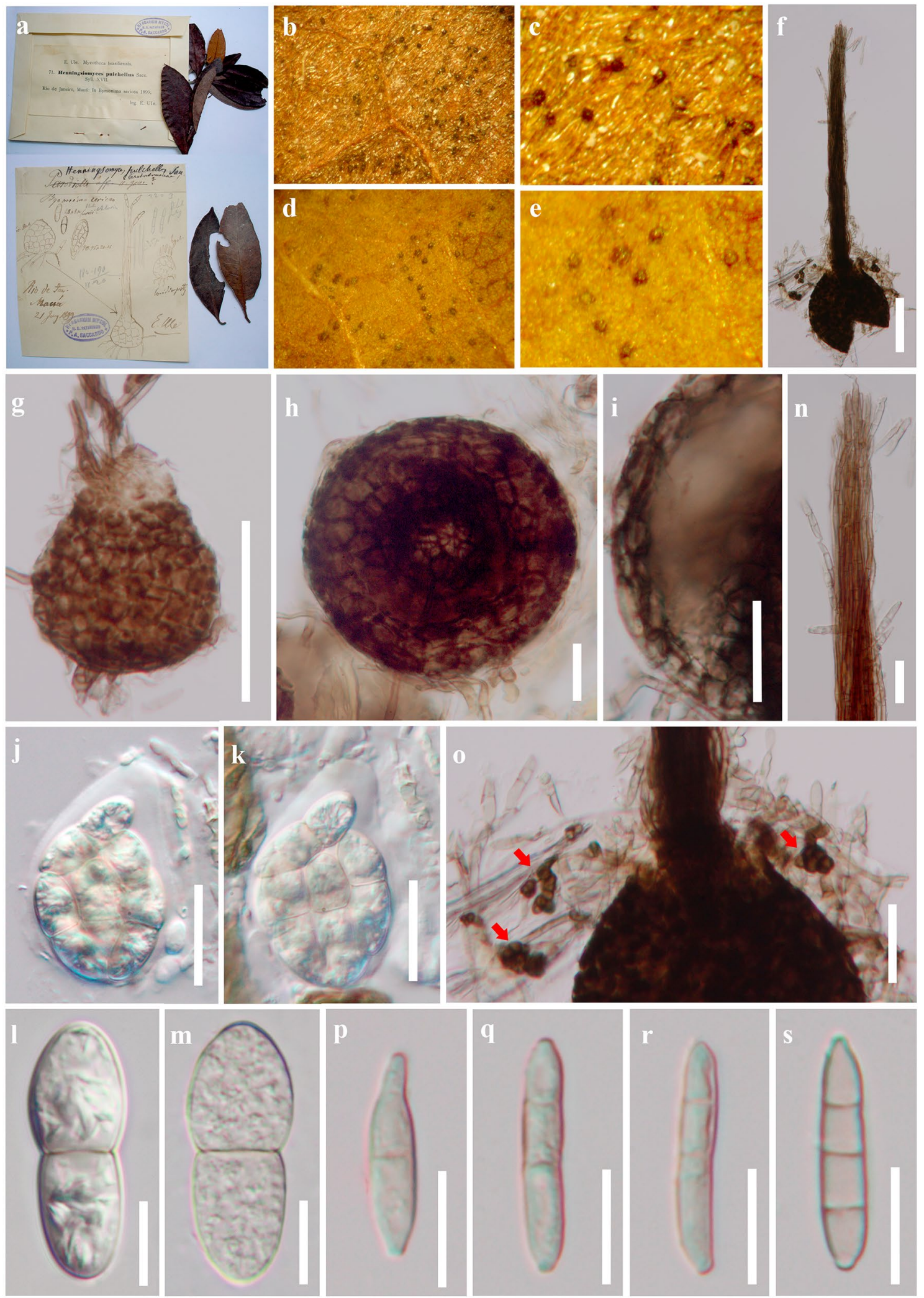

small, superficial on the hyphae or on a short stalk-cell, scattered, ellipsoid to globose, cupulate, brown to black, membranous, containing few asci, lacking ostioles, dissolving at center to release asci. Hamathecium comprising brown, septate, cellular pseudoparaphyses or pseudoparaphyses lacking. Asci 2 to 8 spored, bitunicate, thick-walled, ovate, 
४Fig. 105 Dysrhynchis pulchella (PAD No. 71, holotype). a, b Material label and herbarium specimen. b Appearance of ascomata on the upper leaf surface. c Close up the appearance of ascomata on the upper leaf surface. d Appearance of ascomata on the lower leaf surface. e Close up the appearance of ascomata on the lower leaf surface. $\mathbf{f}$ Squash mount of ascoma with protruding synnematous necks. g Appearance of ascoma at from the side. $\mathbf{h}$ Appearance of ascomamfrom at below. i Peridium. j, k Asci. l, m Ascospores. $\mathbf{n}$ Synnema with apical conidia. o Hyphopodia and appressoria (red arrows). p-s Conidia. Scale bars: $\mathbf{f}, \mathbf{g}=50 \mu \mathrm{m}, \mathbf{h}-\mathbf{k}, \mathbf{n}, \mathbf{o}=20 \mu \mathrm{m}, \mathbf{l}, \mathbf{m}, \mathbf{p}-\mathbf{s}=10$ $\mu \mathrm{m}$

globose to subglobose, pedicellate, with an ocular chamber. Ascospores uni- to multi-seriate, oblong to ellipsoid, ellipsoid to ovate, or fusiform, hyaline to dark brown, 1-septate, smooth-walled, constricted at the septum. Asexual morph: Conidiomata pycnidial, similar to ascomata, superficial, globose, thin-walled. Conidiogenous cells holoblastic, phialidic, discrete, hyaline, smooth, 1-celled, nearly ampulliform, alternate or absent. Conidia oblong to ovate, globose or nearly globose, hyaline to brown, aseptate.

\section{Type: Englerula Henn.}

Notes: Englerulaceae was introduced by Hennings $(1904 a, b)$ for taxa with brown to dark brown colonies on host leaves, with superficial hyphae, scattered, ascomata lacking ostioles. Lumbsch and Huhndorf (2007, 2010) included seven genera (Englerula, Goosia, Parenglerula, Rhizotexis, Rhytidenglerula, Schiffnerulaand and Thrauste) in the family, while Hyde et al. (2011) considered Schiffnerulaceae (Hosagoudar 2011) to be a synonym. Schiffnerula was introduced by von Höhnel (1909b) and placed in Englerulaceae based on its globose ascomata and globose to ovate asci. Hosagoudar (2011) included four asexual genera in the family with more than 100 species. Schiffnerula has dark colonies on the leaf surface, with brown, superficial, septate mycelium, 8-spored, bitunicate, cylindrical to globose asci, and brown, 1-septate, ascospores which are constricted at the septa. With such characters Schiffnerula can be accommodated in Englerulaceae (Hyde et al. 2013). Dai et al. (2014b) redescribed and illustrated type species of all genera in this family. They suggested that Rhizotexis should be excluded from this family and placed into Dothideomycetes genera incertae sedis based on having stromatic ascomata and lack of hyphae.

There is no molecular data for any species of Englerulaceae in GenBank. Fresh collections and molecular data are required to clarify the relationships in Englerulaceae. Englerulaceae are closely related to the Asterinaceae, but differ in having sphaerical ascomata without radiate wall and growing on brown mycelium (von Arx and Müller 1975; Eriksson 1981; Hyde et al. 2013).

Englerula Henn., Bot. Jb. 34: 49 (1904). = Anatexis Syd., Annls mycol. 26(1/2): 90 (1928).
Index Fungorum number: IF 1820; Facesoffungi number: FoF 07961; 10 morphological species (Species Fungorum 2020), molecular data unavailable.

Type species: Englerula macarangae Henn.

Notes: This genus is characterized by brown to black colonies with angled hyphae, globose to subglobose ascomata with a thin peridium and obovoid to globose asci (von Arx and Müller 1975; Eriksson 1981; Hosagoudar et al. 2011; Hyde et al. 2013; Dai et al. 2014b). The species of this genus needs to be recollected.

Englerula macarangae Henn., Bot. Jb. 34: 49 (1904). Index Fungorum number: IF 140464; Facesoffungi number: FoF 07962; Fig. 107

Description: see Dai et al. (2014b).

\section{Other genera included}

Allosoma Syd., Annls mycol. 24(5/6): 353 (1926).

Index Fungorum number: IF 143; Facesoffungi number: FoF 08927; - 4 morphological species (Species Fungorum 2020), molecular data unavailable.

Type species: Allosoma cestri Syd., Annls mycol. 24(5/6): 353 (1926).

Notes: The genus is characterized by superficial, globose to subglobose ascomata, subglobose asci, and oblongellipsoid to ellipsoid, 1-septate ascospores. This genus was placed this genus in Englerulaceae by Thambugala et al. (2014b) and Wijayawardene et al. (2017a, 2020). Sequence data is needed to confirm its placement.

Digitosarcinella S. Hughes, Can. J. Bot. 62(11): 2208 (1984).

Index Fungorum number: IF 11070; Facesoffungi number: FoF 08928; - 1 morphological species (Species Fungorum 2020), molecular data unavailable.

Type species: Digitosarcinella caseariae S. Hughes, Can. J. Bot. 62(11): 2208 (1984).

Notes: The genus is characterized by cheiroid conidia, hyphae with sessile hyphopodia and as asexual state of Schiffnerula (Hughes 1984). Wijayawardene et al. (2017a, 2020) placed this genus in Englerulaceae.

Goosia B. Song, Mycotaxon 87: 413 (2003).

Index Fungorum number: IF 28768; Facesoffungi number: FoF 07963; - 1 morphological species (Species Fungorum 2020), molecular data unavailable.

Type species: Goosia melastomatis B. Song, Mycotaxon 87: 413 (2003).

Notes: The monotypic genus is characterized by dark brown phialides developing directly on the hyphae, and obovoid asci containing two ascospores (Bin 2003). This genus is similar to Thrauste in its superficial, ellipsoid ascomata and globose hyphopodia formed on dark brown hyphae. Bin 


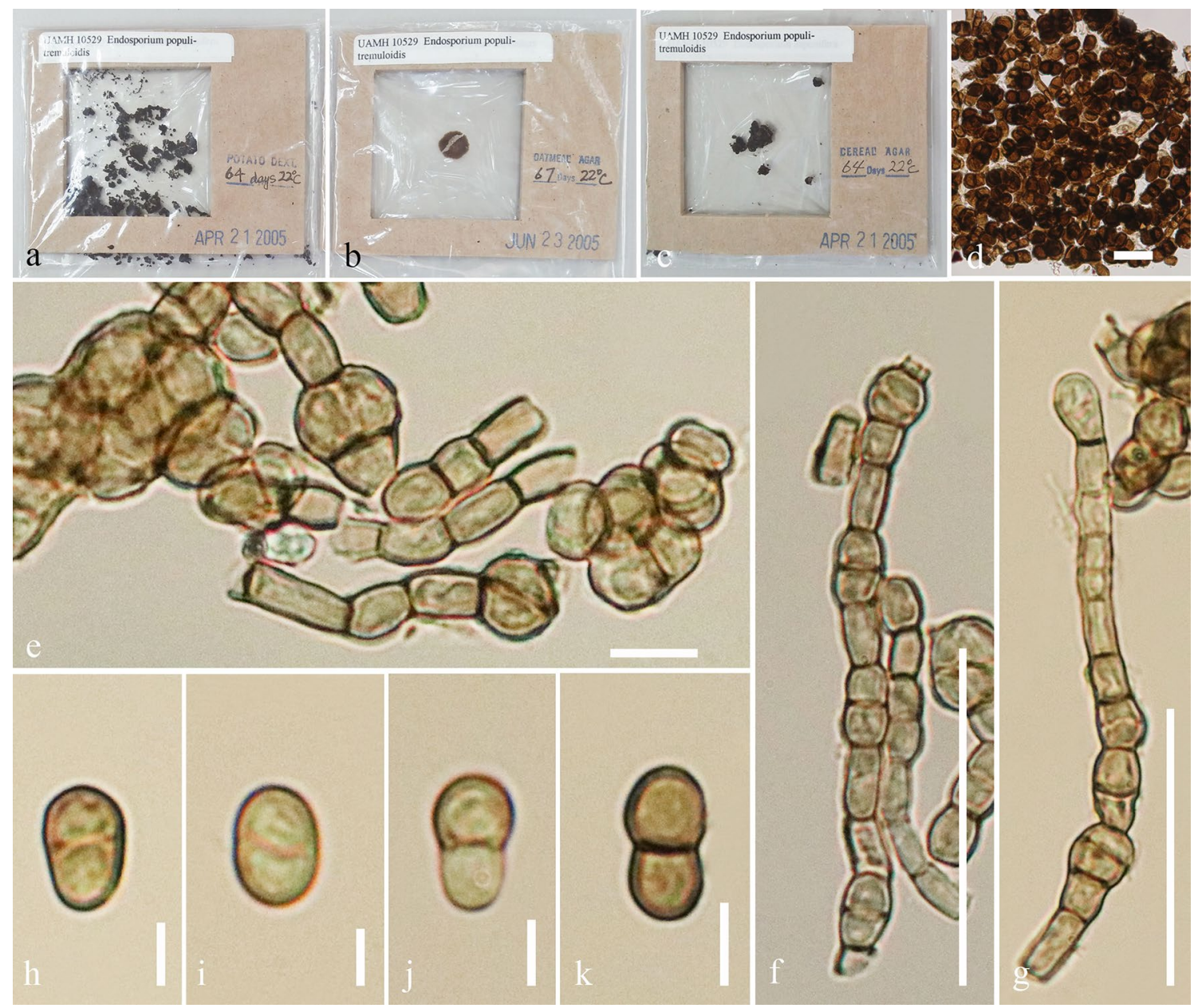

Fig. 106 Endosporium populi-tremuloides (UAMH 10529, holotype). a-c Details of herbarium material. d Squash mount of mycelium. e-g Hyphae giving rise to cellular clumps. h-k Blastic conidia. Scale bars: $\mathbf{d}, \mathbf{e}=20 \mu \mathrm{m}, \mathbf{f}, \mathbf{g}=30 \mu \mathrm{m}, \mathbf{h}-\mathbf{k}=5 \mu \mathrm{m}$

(2003) did not observe mature ascomata and considered that Goosia differs from Thrauste with the former having phialides and smaller ascospores. Fresh collections are needed to confirm if they are different and also show its natural taxonomic relationships. Dai et al (2014b) redrew the main characters from Bin (2003).

Parenglerula Höhn., Sber. Akad. Wiss. Wien, Math.-naturw. Kl., Abt. 1 119: 465 [73 repr.] (1910).

Index Fungorum number: IF 3727; Facesoffungi number: FoF 07964; - 6 morphological species (Species Fungorum 2020), molecular data unavailable.

Type species: Parenglerula macowaniana (Thüm.) Höhn., Sber. Akad. Wiss. Wien, Math.-naturw. Kl., Abt. 1 119: 465 [73 repr.] (1910).

$\equiv$ Meliola macowaniana Thüm., Mycoth. Univ., cent. 6: no. 568 (1876).

Notes: Parenglerula was erected by von Höhnel (1910) with seven species. Parenglerula is similar to Englerula in having superficial, globose to subglobose, dark ascomata containing obovoid asci and broadly ellipsoid to subobovoid ascospores with a single septum, but differs by darker ascomata and ascospores (von Höhnel 1910; Dai et al. 2014b). The genus has not been studied recently and thus needs fresh collections.

Rhytidenglerula Höhn., Sber. Akad. Wiss. Wien, Math.naturw. Kl., Abt. 1 127: 386 [58 repr.] (1918).

Index Fungorum number: IF 4738; Facesoffungi number: FoF 07965; - 9 morphological species (Species Fungorum 2020), molecular data unavailable.

Type species: Rhytidenglerula carnea (Ellis \& G. Martin) Höhn., Sber. Akad. Wiss. Wien, Math.-naturw. Kl., Abt. 1 127(4): 386 [58 repr.] (1918).

三 Asterina carnea Ellis \& G. Martin, Am. Nat. 17(2): 1285 (1883).

Notes: Rhytidenglerula has small ascomata forming on dark hyphae, a character that distinguishes it from other 

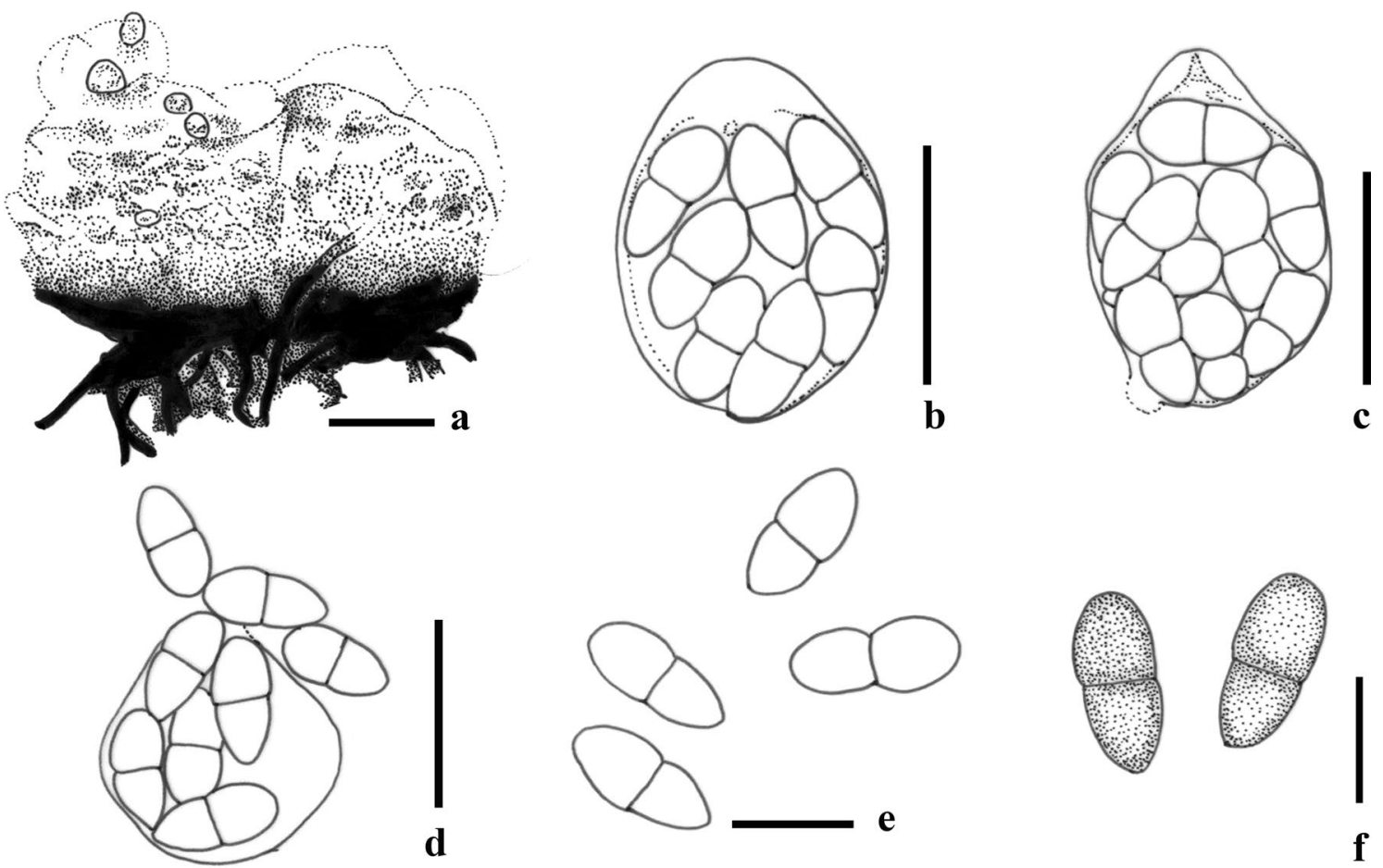

Fig. 107 Englerula macarangae (redrawn from Dai et al. 2014b). a Squash mount of ascoma. b-d Asci with ascospores. e-f Ascospores with one septum. Scale bars: $\mathbf{a - d}=50 \mu \mathrm{m}, \mathbf{e}, \mathbf{f}=20 \mu \mathrm{m}$

genera with large and dark ascomata in the family. Rhytidenglerula is similar to Schiffnerula in having hyphopodia and globose ascomata, obovoid asci and hyaline ascospores with a single septum. Rhytidenglerula is linked to a coelomycetous asexual morph, Capnodiastrum (Kirk et al. 2008; Wijayawardene et al. 2012) which is characterized by holoblastic, doliiform, conidiogenous cells and ellipsoid, pale brown, 1-celled conidia with a conic apex (Sutton 1980). Schiffnerula has been linked to four different hyphomycetous asexual morphs, Digitosarcinella, Mitteriella, Questieriella and Sarcinella (Hosagoudar 2011; Hosagoudar et al. 2011; Seifert et al. 2011). These four genera are characterized by monoblastic to polyblastic conidiogenous cells and sigmoid to ellipsoid, dark brown to reddish brown, or black, 0-4-celled conidia (Hosagoudar 2011).

Schiffnerula Höhn., Sber. Akad. Wiss. Wien, Math.-naturw. Kl., Abt. 1 118: 867 [55 repr.] (1909).

Index Fungorum number: IF 4886; Facesoffungi number: FoF 07966; - 96 morphological species (Species Fungorum 2020), molecular data unavailable.

Type species: Schiffnerula mirabilis Höhn., Sber. Akad. Wiss. Wien, Math.-naturw. Kl., Abt. 1 118: 868 [56 repr.] (1909).

Notes: Hosagoudar (2011) considered Schiffnerula as a new family, because Schiffnerula has young ascomata which look like a shield-plate on hyphae. According to von Höhnel (1909b, 1910), both Rhytidenglerula and Schiffnerula have thin, shield-like immature ascomata and should belong to Englerulaceae. In addition, Schiffnerula has globose, ascomata, developing on brown hyphae and contain a few globose to ovate asci with multi-seriate, ellipsoid, 1-septate ascospores, with Digitosarcinella, Mitteriella, Sarcinella, Questieriella as its asexual morph. Therefore, we retain Schiffnerula as a genus in Englerulaceae.

Thrauste Theiss., Verh. zool.-bot. Ges. Wien 66: 337 (1916). Index Fungorum number: IF 5455; Facesoffungi number: FoF 07967; -3 morphological species (Species Fungorum 2020), molecular data unavailable.

Type species: Thrauste medinillae (Racib.) Theiss., Verh. zool.-bot. Ges. Wien 66: 338 (1916).

三Balladyna medinillae Racib., Bull. int. Acad. Sci. Lett. Cracovie, Cl. sci. math. nat. Sér. B, sci. nat. 3: 373 (1909).

Notes: This genus is similar to Goosia in its dark hyphopodia and ellipsoid immature ascomata growing directly on hyphae (Theissen 1916; Bin 2003). However, Thrauste differs in its 8-spored, pyriform to clavate asci with an ocular chamber, while Goosia has 2-spored, obovoid asci and the ocular chamber is not well-developed. Dai et al. (2014b) examined a collection (F: 111745), labelled T. medinillae, obtained from $\mathrm{S}$. There are marked differences in the shape and size of asci and ascospores between the original description of the species (Saccardo 1913) under the genus. Based 

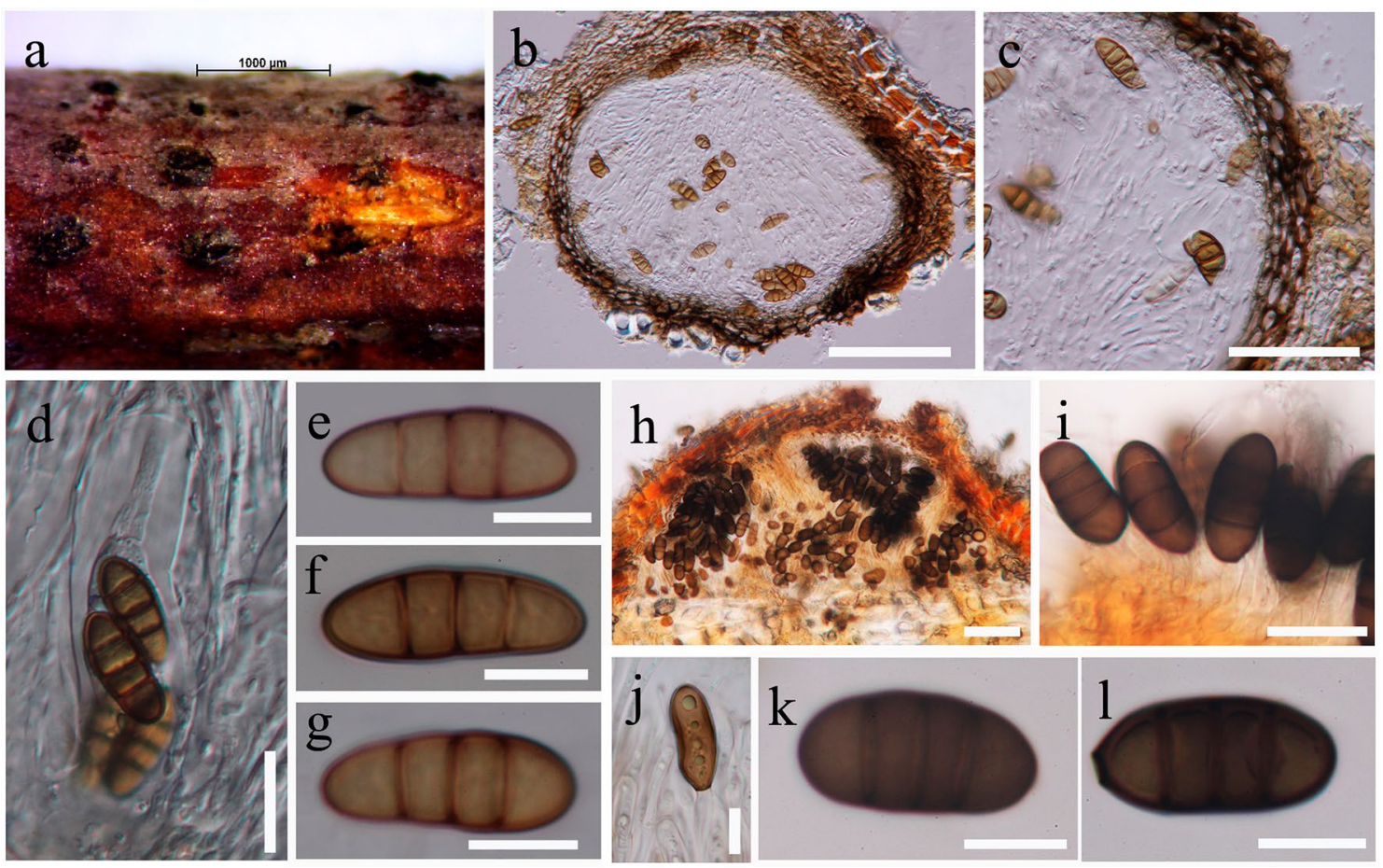

Fig. 108 Homortomyces tamaricis (a-g = MFLU 14-0595; $\mathrm{h}-1=$ MFLU 14-0167). a Appearance of ascomata on host surface b Vertical section through ascoma c Peridium d Pseudoparaphyses and

on these differences, they proposed a new species for this specimen (Thrauste parvii).

\section{Economic and ecological significance}

Englerulaceae is a poorly known family, most species are parasitic on leaves. There is no sequence data for any members of this family in GenBank and more fresh collections are required to clarify the relationships in Englerulaceae.

Homortomycetaceae Thambug., A.J.L. Phillips \& K.D. Hyde, in Thambugala et al., Fungal Diversity 82: 45 (2016).

Index Fungorum number: IF 552086; Facesoffungi number: FoF 02150, 2 species.

Foliicolous, associated with leaf spots or saprobic on dead twigs or branches. Sexual morph: Ascomata scattered, immersed to erumpent, black, globose to subglobose, ostiolate. Peridium composed of a few layers of brown to dark brown, thick-walled cells of textura angularis. Hamathecium comprising septate, cellular pseudoparaphyses. Asci 2-6-spored, bitunicate, fissitunicate, cylindrical, apically rounded. Ascospores 1-2-seriate, fusiform with broadly to narrowly rounded ends, yellowish brown to brown, 3-septate, smooth-walled. Asexual morph: Coelomycetous. Conidiomata pycnidial, solitary or gregarious, immersed or slightly erumpent, uniloculate or multi-loculate, globose to subglobose, ostiolate. Conidiomatal wall comprising a few mature ascus $\mathbf{e}-\mathbf{g}$ Ascospores $\mathbf{h}$ Vertical sections through conidioma. $\mathbf{i}, \mathbf{j}$ Developing conidia and paraphyses $\mathbf{k}-\mathbf{l}$ Conidia. Scale bars: $\mathbf{b}=$ $100 \mu \mathrm{m}, \mathbf{c}, \mathbf{h}=50 \mu \mathrm{m}, \mathbf{d}, \mathbf{i}=20 \mu \mathrm{m}, \mathbf{e}-\mathbf{g}, \mathbf{j}=10 \mu \mathrm{m}$

layers, of lightly pigmented to hyaline cells of textura angularis. Hamathecium comprising cylindrical, smooth, flexuous, apex obtuse, hyaline, sparingly septate, paraphyses, intermingled among conidiogenous cells. Conidiophores reduced to conidiogenous cells or one supporting cell. Conidiogenous cell with supporting cell, hyaline, percurrently proliferating at the tip of the supporting cells. Conidia ellipsoid to subcylindrical, straight to slightly curved, golden brown to dark brown, 3(-4)-euseptate, apex obtuse, base truncate with a visible scar.

Type: Homortomyces Crous \& M.J. Wingf.

Notes: Thambugala et al. (2017) introduced the monotypic family Homortomycetaceae to accommodate its type Homortomyces, as its phylogenetic placement is uncertain. Thambugala et al. (2017) placed Homortomycetaceae in Dothideomycetes, families incertae sedis.

Homortomyces Crous \& M.J. Wingf., in Crous et al., IMA Fungus 3(2): 110 (2012).

Index Fungorum number: IF 801349; Facesoffungi number: FoF 07968; 2 morphological species (Species Fungorum 2020), 2 species with molecular data.

Type species: Homortomyces combreti Crous \& M.J. Wingf.

Notes: Crous et al. (2012a) established Homortomyces in Dothideomycetes genera incertae sedis to accommodate 
H. combreti, which was associated with leaf spots on Combretum erythrophyllum. The second species, $H$. tamaricis was introduced by Wijayawardene et al. (2014b) from dead branches of Tamarix gallica. Thambugala et al. (2017) described the sexual morph of $H$. tamaricis associated with the same host. Homortomyces is similar to Stilbospora, which is classified in Stilbosporaceae, Diaporthales, Sordariomycetes (Wijayawardene et al. 2014b; Senanayake et al. 2017), while the genera Endocoryneum, Hendersoniopsis, Angiopomopsis and Ceratopycnis show similar conidial characteristics of Homortomyces. However, all these genera have been classified in incertae sedis due to lack sequence data (Crous et al. 2012a; Thambugala et al. 2017).

Homortomyces tamaricis Wijayaw., Camporesi \& K.D. Hyde, in Wijayawardene et al., Phytotaxa 176(1): 160 (2014).

Index Fungorum: IF 550192; Facesoffungi number: FoF 02151; Fig. 108

Saprobic on Tamarix gallica L. Sexual morph: Ascomata 190-280 $\mu \mathrm{m}$ high $\times 280-350 \mu \mathrm{m}$ diam. $(\bar{x}=234 \times 310$ $\mu \mathrm{m}, \mathrm{n}=6$ ), scattered, sometimes aggregated, immersed to partially erumpent through the host tissues, black, globose to subglobose, unilocular, ostiolate. Peridium 20-40 $\mu \mathrm{m}$ wide, comprising several layers of brown to dark brown, thick-walled cells of textura angularis. Hamathecium comprising $2-4 \mu \mathrm{m}$ wide, septate, cellular pseudoparaphyses. Asci $80-100 \times 18-23 \mu \mathrm{m}(\bar{x}=87 \times 21 \mu \mathrm{m}, \mathrm{n}=6)$, mostly 2-6-spored, bitunicate, fissitunicate, cylindrical, short pedicellate, apically rounded, with a distinct ocular chamber. Ascospores $23-30 \times 8-12 \mu \mathrm{m}(\bar{x}=25 \times 10 \mu \mathrm{m}, \mathrm{n}=25)$, 1-2-seriate, fusiform with broadly to narrowly rounded ends, yellowish brown to brown, 3-septate, smooth-walled, without a mucilaginous sheath. Asexual morph: Coelomycetous. Conidiomata $150-250 \mu \mathrm{m}$ high $\times 300-350 \mu \mathrm{m}$ diam. $(\bar{x}=$ $200 \times 330 \mu \mathrm{m}, \mathrm{n}=5$ ), solitary or gregarious, immersed to slightly erumpent, pycnidial to irregular, uniloculate to multi-loculate, subglobose, ostiolate. Conidiomatal wall 10-22 $\mu \mathrm{m}$ ), comprising a few layers of lightly pigmented to hyaline cells of textura angularis. Hamathecium comprising numerous, aseptate, cylindrical, guttulate, paraphyses. Conidiophores reduced to conidiogenous cells. Conidiogenous cell $6-25 \times 2.5-5.5 \mu \mathrm{m}(\bar{x}=15 \times 3.6 \mu \mathrm{m}, \mathrm{n}=20)$, with supporting cell, hyaline, percurrently proliferating at the tip of the supporting cells. Conidia ellipsoid to subcylindrical, straight to slightly curved, $20-30 \times 9-12.5 \mu \mathrm{m}(\bar{x}=25 \times$ $11 \mu \mathrm{m}, \mathrm{n}=30$ ), golden brown to dark brown, becoming coloured before release from conidiogenous cells, smoothwalled, initially asptate to 1 -septate, becoming at maturity 3-septate, apex obtuse, base truncate, smooth-walled.

Material examined: Italy, Province of Forlì-Cesena [FC]), Ravaldino in Monte Forlì, on dead branches of Tamarix gallica L. (Tamaricaceae), 22 November 2012, Erio Camporesi IT 922 (MFLU 14-0595 \& MFLU 14-0167).

Notes: Wijayawardene et al. (2014b) introduced Homortomyces tamaricis from Tamarix gallica based on its asexual morph, while Thambugala et al. (2017) described the sexual morph of this species from the same host based both morphological traits and molecular sequence data.

\section{Economic and ecological significance}

As the species of Homortomyces are associated with ornamental plants such as Combretum erythrophyllum and Tamarix gallica, they reduce the value of those plants.

Hyalomeliolinaceae Boonmee \& K.D. Hyde, in Boonmee et al., Mycosphere 8(10): 1718 (2017).

Index Fungorum: IF 553830; Facesoffungi number: FoF 06396, 2 species.

Parasitic on living leaves. Sexual morph: Colonies form on a lower surface of leaves, black, subcircular, with outwardly radiating mycelium, with hyphae that are long hairy, flexible, dark brown to black, densely, fluffy, partially erect, unbranched, and septate. Ascomata superficial, globose to subglobose, black, seated on dark hyphae, covered by dense hyphae, superficial mycelium, unbranched, septate, dark to black. Peridium comprising dark brown to black cells of textura angularis. Hamathecium comprising elongate-filiform, septate, unbranched, filamentous, cellular pseudoparaphyses, extending over asci, constricted at the septa. Asci 8-spored, bitunicate, fissitunicate, saccate-oblong to ellipsoidal, sessile, lower median widest, with the small ocular chamber. Ascospores 2-3-seriate, ellipsoid-fusiform, end narrow, pigmented, multi-septate. Asexual morph: Undetermined.

Type: Hyalomeliolina F. Stevens.

Notes: Boonmee et al. (2017) re-examined the type species Hyalomeliolina guianensis and concluded the unique suite of characters and could not place it in any families in Dothideomycetes. Therefore, Hyalomeliolinaceae was established to accommodate Hyalomeliolina (Boonmee et al. 2017). No molecular data is available to confirm its phylogenetic placement within Dothideomycetes.

Hyalomeliolina F. Stevens, Illinois Biol. Monogr. (Urbana) 8(no. 3): 27 (1924).

Index Fungorum: IF 553830; Facesoffungi number: FoF 06397; 2 morphological species (Species Fungorum 2020), molecular data unavailable.

Type species: Hyalomeliolina guianensis F. Stevens.

Notes: Hyalomeliolina is a single genus in Hyalomeliolinaceae, and it was established by Stevens (1923) based on morphology. The genus is characterized by a life mode as parasites on living leaves, forming black colonies on leaf surfaces, ascomata covered by dense hyphae and 


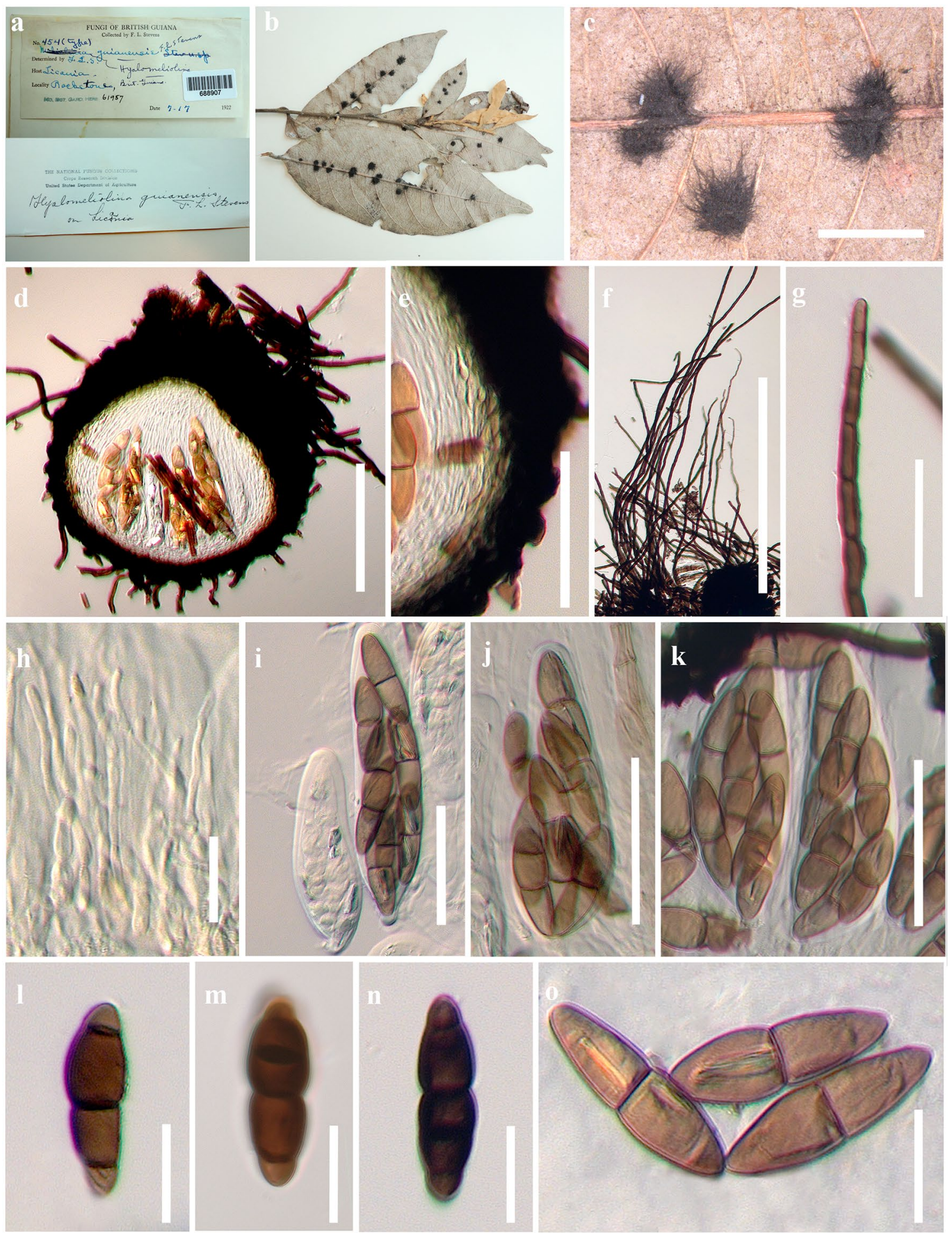

Fig. 109 Hyalomeliolina guianensis (BPI688907, holotype), a Material label. b Herbarium specimen. c Ascomata covered by hyphae on the leaf surface. d Section of ascoma. e Peridium. $\mathbf{f}, \mathbf{g}$

ellipsoid-fusiform, 1-3-septate, light to dark pigmented ascospores. The genus comprises Hyalomeliolina guianensis
Hairy hyphae. h Pseudoparaphyses. i-k Asci. l-o Ascospores. Scale bars: $\mathbf{c}=5 \mathrm{~mm}, \mathbf{d}, \mathbf{f}=500 \mu \mathrm{m}, \mathbf{e}, \mathbf{g}, \mathbf{i}-\mathbf{k}=50 \mu \mathrm{m}, \mathbf{h}, \mathbf{l}-\mathbf{o}=20 \mu \mathrm{m}$

and $H$. linderi, while $H$. costaricensis were transferred to Nematostoma by Hansford (1946). 
Hyalomeliolina guianensis F. Stevens, Illinois Biol. Monogr. (Urbana) 8(no. 3): 28 (1924) [1923].

Index Fungorum number: IF 266643; Facesoffungi number: FoF 06398, Fig. 109

Description: see Boonmee et al. (2017).

Material examined: Guyana (= British Guiana), Rockstone, on living leaves of Licania Aubl. (Chrysobalanaceae), 17 July 1922, F.L. Stevens No. 454 (BPI688907, holotype).

\section{Economic and ecological significance}

Members in Hyalomeliolinaceae play roles in host plant penetration by being parasitic.

Leptopeltidaceae Höhn. ex Trotter [as 'Leptopeltineae'], Syll. fung. (Abellini) 24(2): 1255 (1928).

Index Fungorum: IF 81594; Facesoffungi number: FoF 07969, 15 species.

Epiphytic on ferns (Aspidium), Aruncus, Potentilla and other flowering herbaceous plants as well as Connarus suberosus Planch. Sexual morph: Ascomata thyriothecial, superficial, visible as black dots or irregular on host surface, producing vegetative mycelium penetrating the host, solitary to gregarious, flattened, circular, round, elongate or irregular, or Y-shaped, easily removed from the host, brown to dark brown, waxy, in section lenticular, scutate, conical, or quadrilateral trapezoid, dehiscence by slit-like opening, or splitting of the upper wall. Peridium thin-walled, composed of reddish-brown to dark brown, isodiametric or polygonal upper-walled cells with a parallel or irregular arrangement, radiating from the centre, basal layer poorly developed, occasionally forming basal cell layers, arranged in a textura angularis in verical section. Hamathecium comprising broadly filamentous, septate, unbranch, tapering towards the apex, paraphyses, embedded in gelatinous matrix. Asci 8-spored, bitunicate, broadly cylindrical to cylindric-clavate, or subglobose to ampulliform, with obtuse to truncate or acutate apex, sesille to subsessile, with truncate base, ocular chamber indistinct, clearly visible when young. Ascospores overlapping 1-3-seriate, twisted or fasciculate, varied in shape, ellipsoidal, broadly fusiform, cylindrical, lunate, or muriform, with rounded to acute ends, hyaline, aseptate or septate, smooth-walled, with or without small guttules. Asexual morph: Hyphomycetous idriella-like (asexual morph of Dothiopeltis) and coelomycetous leptothyriumlike (asexual morph of Leptopeltis) (Wijayawardene et al. 2017b).

\section{Type: Leptopeltis Höhn.}

Notes: von Höhnel (1917) invalidly introduced Leptopeltidaceae as 'Leptopeltineen' and treated the family in Phacidiales. However, the family was validly introduced by Saccardo (1928). The familial concept contained highly heterogenous taxa which were described as epiphytic fungi having excipular or subcuticular, uni-loculate ascomata with longitudinal irregular scratch-like openings and hyaline, fusoid, two-celled ascospores with paraphyses (von Höhnel 1917; Holm and Holm 1977; Hyde et al. 2013). von Höhnel (1917) included 12 genera in this family, Bifusella, Coccomyces, Duplicaria, Entopeltis, Haplophyse, Leptopeltella, Leptopeltis, Lophodermina, Phacidina, Schizothyrioma, Thyriopsis and Vizella. The family has a long historical discussion by various authors and many genera were included and excluded from this family (Petrak 1947a, b; von Arx and Müller 1975; Holm and Holm 1977; Eriksson 1981; Lumbsch and Huhndorf 2010; Hyde et al. 2013). Holm and Holm (1977) mentioned that taxa in Leptopeltidaceae have unitunicate asci as they could not find the "Jack in the box" dehiscence exhibited by Leptopeltis asci based on their observation under the transmission electron microscope (TEM). Eriksson (1981) disagreed with Holm and Holm (1977) and demonstrated bitunicate asci with "Jack in the box" dehiscence in Leptopeltidaceae as he had found the endotunica and ectotunica layers of the asci. However, there was no sharp delimitation between endotunica and ectotunica in ascomycetes. Hence, it is difficult to name the bitunicate or unitunicate asci in many cases of which Leptopeltis is one of these cases (Eriksson 1981; Hyde et al. 2013).

Hyde et al. (2013) re-circumscribed genera in Leptopeltidaceae following the lists of Lumbsch and Huhndorf (2010). Based on the generic type studies, Hyde et al. (2013) accepted five genera in Leptopeltidaceae viz. Leptopeltis, Dothiopeltis, Nannfeldtia Ronnigeria and Staibia and classified the family in Dothideomycetes, family incertae sedis. Hyde et al. (2013) excluded Phacidina from Leptopeltidaceae as the type genus, $P$. gracilis has unitunicate asci, with $\mathrm{J}+$, subapical ring. However, Wijayawardene et al. (2018) listed the genus in Leptopeltidaceae. We re-examine the type of genera in Leptopeltidaceae and exclude Nannfeldtia from Leptopeltidaceae. The generic type of Nannfeldtia, N. atra has morphological similarity with taxa in Leotiomycetes in having apothecial ascomata, apically swollen paraphyses and unitunicate asci, with $\mathrm{J}+$ apex (Phookamsak, pers. comm.). Therefore, we accept four genera: Leptopeltis, Dothiopeltis, Ronnigeria and Staibia in Leptopeltidaceae. However, these genera lack molecular data to clarify their phylogenetic affinities, and their morphological characteristics are heterogeneous. A taxonomic revision of genera in this family based on molecular data awaits study and will resolve whether these taxa are Dothideomycetes or belong in another class.

Leptopeltis Höhn., Ber. dt. bot. Ges. 35: 418 (1917).

Index Fungorum number: IF 2786; Facesoffungi number: FoF 07970; 9 morphological species (Species Fungorum 2020), molecular data unavailable.

Type species: Leptopeltis filicina (Lib.) Höhn., Ber. dt. bot. Ges. 35: 422 (1917). 

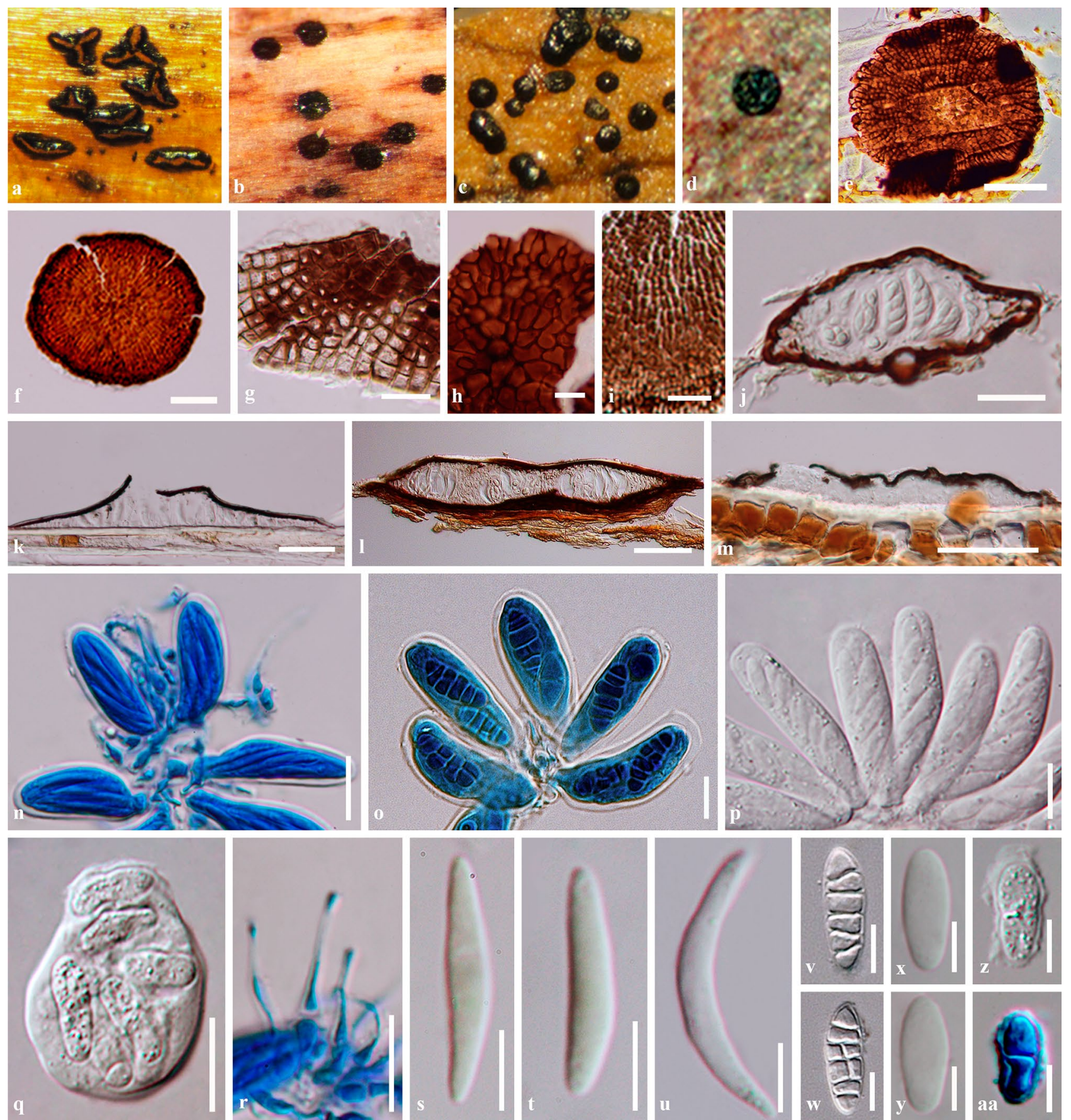

Fig. 110 Morphological characteristics of genera in Leptopeltidaceae based on the type studies (a, g, k, n, r-u = Leptopeltis filicina (三 Aulographum filicinum); b, e, h, 1, o, v, w = Dothiopeltis arunci; c, j, $\mathrm{p}, \mathrm{x}, \mathrm{y}=$ Ronnigeria arctica (三 Microthyrium arcticum Oudem.); $\mathrm{d}$, $\mathrm{f}, \mathrm{i}, \mathrm{m}, \mathrm{q}, \mathrm{z}, \mathrm{aa}=$ Staibia connari). a-d Appearance of ascomata on host surface. e, $\mathbf{f}$ Upper view of ascomata. $\mathbf{g}-\mathbf{i}$ Upper view of perid-

$\equiv$ Aulographum filicinum Lib., Pl. crypt. Arduenna, fasc. (Liège) 3(nos 201-300): no. 275 (1834).

Notes Leptopeltis was introduced by von Höhnel (1917) and is typified by L. filicina (三Aulographum filicinum 1834).

ium showing cell arrangement. $\mathbf{j}-\mathbf{m}$ Section through ascomata. $\mathbf{n}-\mathbf{q}$ Asci ( $\mathrm{n}, \mathrm{o}=$ stained by cotton blue). $\mathbf{r}$ Paraphyses stained by cotton blue. $\mathbf{s}-\mathbf{a a}$ Ascospores (s, t, $\mathrm{x}, \mathrm{y}=$ stained by Melzer's reagent, $\mathrm{aa}=$ stained by cotton blue). Scale bars: $\mathbf{e , ~} \mathbf{l}, \mathbf{m}=50 \mu \mathrm{m}, \mathbf{f}, \mathbf{h}, \mathbf{i}-\mathbf{k}=20$ $\mu \mathrm{m}, \mathbf{g}, \mathbf{n}-\mathbf{r}=10 \mu \mathrm{m}, \mathbf{s}-\mathbf{a a}=5 \mu \mathrm{m}$

The genus is characterized by subcuticular or superficial, elongate or Y-shaped thyriothecia, opening with slit-like ostiole. The peridium is composed of a single layer of dark brown to black, isodiametric cells, which are paler at the 
base. Asci are 8-spored, bitunicate, cylindrical to cylindricclavate, ellipsoidal to oblong, sessile, apically rounded, with an indistinct ocular chamber, raising in between broad, aseptate paraphyses and ascospores are fusiform, oblong to cylindrical, or sometimes falcate to reniform, hyaline, 0-3-septate (Hyde et al. 2013). The genus lacks a modern taxonomic treatment and molecular data to investigate its phylogenetic placement. The type species, L. filicina was collected from Asplenium felix-mas in Belgium and is currently treated as a synonym of Fouragea filicina (三 Opegrapha filicina 1845) in Opegraphaceae (Index Fungorum 2020, accessed 8 June 2020). However, the basionym of Leptopeltis filicina was introduced earlier than the basionym of Fouragea filicina. We therefore, reinstate Leptopeltis based on its generic type being introduced earlier. The asexual morph of Leptopeltis was reported as coelomycetous, leptothyrium-like, forming in dimidiate or scutate pycnidial cavities, with small, onecelled conidia (von Arx and Müller 1975; Hyde et al. 2013; Wijayawardene et al. 2017b). However, the connection of the sexual and asexual morhs has not been proven (Fig. 110).

\section{Other genera included}

Dothiopeltis E. Müll., Sydowia 10(1-6): 197 (1957) [1956]. Index Fungorum number: IF 1700; Facesoffungi number: FoF 07971; -2 morphological species (Species Fungorum 2020), molecular data unavailable.

Type species: Dothiopeltis arunci E. Müll., Sydowia 10(1-6): 198 (1957) [1956].

Notes: Dothiopeltis arunci was collected from Aruncus silvester in Switzerland. The genus is epiphytic on dry stems. Ascomata are superficial, rounded, lenticular, scattered to clustered, shiny, lacking ostioles, forming brown, septate, vegetative hyphal webs at the margin, immersed in host tissue and lack paraphyses. The upper wall of the peridium is composed of thickened, dark, radially globose or angular cells, with well-developed basal walls. Asci are 8-spored, bitunicate, ellipsoidal to clavate, sessile to subsessile and ascospores are hyaline, muriform, ellipsoidal to cylindrical and occasionally clavate to obclavate (Müller 1956). Holm and Holm (1977) found that $D$. arunci has longitudinal slitlike openings and they did not see the basal layers of the peridium. The second species, D. cicerbitae Granmo \& Math. was found on stalks of Cicerbita alpina in Norway and is distinct from D. arunci in several aspects (Granmo and Mathiassen 2013). The asexual morph of Dothiopeltis was reported as hyphomycetous, idriella-like which is characterized by hyaline or brown hyphae, brown, simple, aseptate geniculate conidiophores, tapering towards the tip and lunate or falcate conidia with acuminate tips, produced in dry heads (Nelson and Wilhelm 1956; Hyde et al. 2013; Wijayawardene et al. 2017b).

Ronnigeria Petr., Sydowia 1(4-6): 310 (1947).
Index Fungorum number: IF 4782; Facesoffungi number: FoF 07972; - 1 morphological species (Species Fungorum 2020), molecular data unavailable

Type species: Ronnigeria arctica (Oudem.) Petr., Sydowia 1(4-6): 310 (1947).

$\equiv$ Microthyrium arcticum Oudem., Ned. kruidk. Archf, 2 sér. 3: 160 (1886).

Notes: Petrak (1947b) introduced a monotypic genus Ronnigeria to accommodate Ronnigeria arctica ( $\equiv$ Microthyrium arcticum), epiphytic on Potentilla fragiformis in Novaya Zemlya, Russia (Holm and Holm 1977). The genus is characterized by perithecial, subcuticular, gregarious, amphigenous, orbicular to elliptical ascomata, lacking ostioles, opening by peridial cracks, with a thin-walled peridium, composed of a single layer of dark brown, membranous, pseudoparenchymatous cells and with paraphyses. Asci are 8-spored, clavate, with rounded to truncate bases and ascospores are hyaline, oblong to clavate, or subfusoid (Petrak 1947b; Holm and Holm 1977). The asexual morph of this genus is undetermined. Petrak (1947b) accommodated the genus in Leptopeltidaceae and this was followed by various subsequent authors (von Arx and Müller 1975; Holm and Holm 1977; Lumbsch and Huhndorf 2010; Hyde et al. 2013; Wijayawardene et al. 2014a, 2018). The genus has an arctic-alpine distribution and is commonly found on Potentilla spp. in northern Scandinavia and central Europe (Holm and Holm 1977; Farr and Rossman 2020). However, the genus lacks modern taxonomic treatment and molecular data to confirm its phylogenetic affinity. Recollection based on type material is required for a better understanding of this genus.

Staibia Bat. \& Peres, in Batista et al., Atas Inst. Micol. Univ. Pernambuco 3: 142 (1966).

Index Fungorum number: IF 5181; Facesoffungi number: FoF 07973; - 1 morphological species (Species Fungorum 2020), molecular data unavailable.

Type species: Staibia connari Bat. \& Peres, in Batista et al., Atas Inst. Micol. Univ. Recife 3: 142 (1966).

Notes: Staibia was introduced as a monotypic genus to accommodate an epiphytic fungus occurring on leaves of Connarus suberosus in Brazil and is characterized by subcuticular, dark brown, orbicular, dimidiate, membranous ascomata, lacking ostioles and paraphyses. The upper wall of the peridium is radiate, with longitudinally isodiametric cells, endowed with multiple hymenium, black at the margin and with a poorly-developed base. Asci are 8-spored, bitunicate and globose and ascospores are hyaline, oblong to subovoid and 1-septate (Batista et al. 1966). The asexual morph of this genus is undetermined. Batista et al. (1966) treated the genus in Leptopeltidaceae and this was followed by subsequent authors (von Arx and Müller 1975; Lumbsch and Huhndorf 2010; Hyde et al. 2013; Wijayawardene et al. 


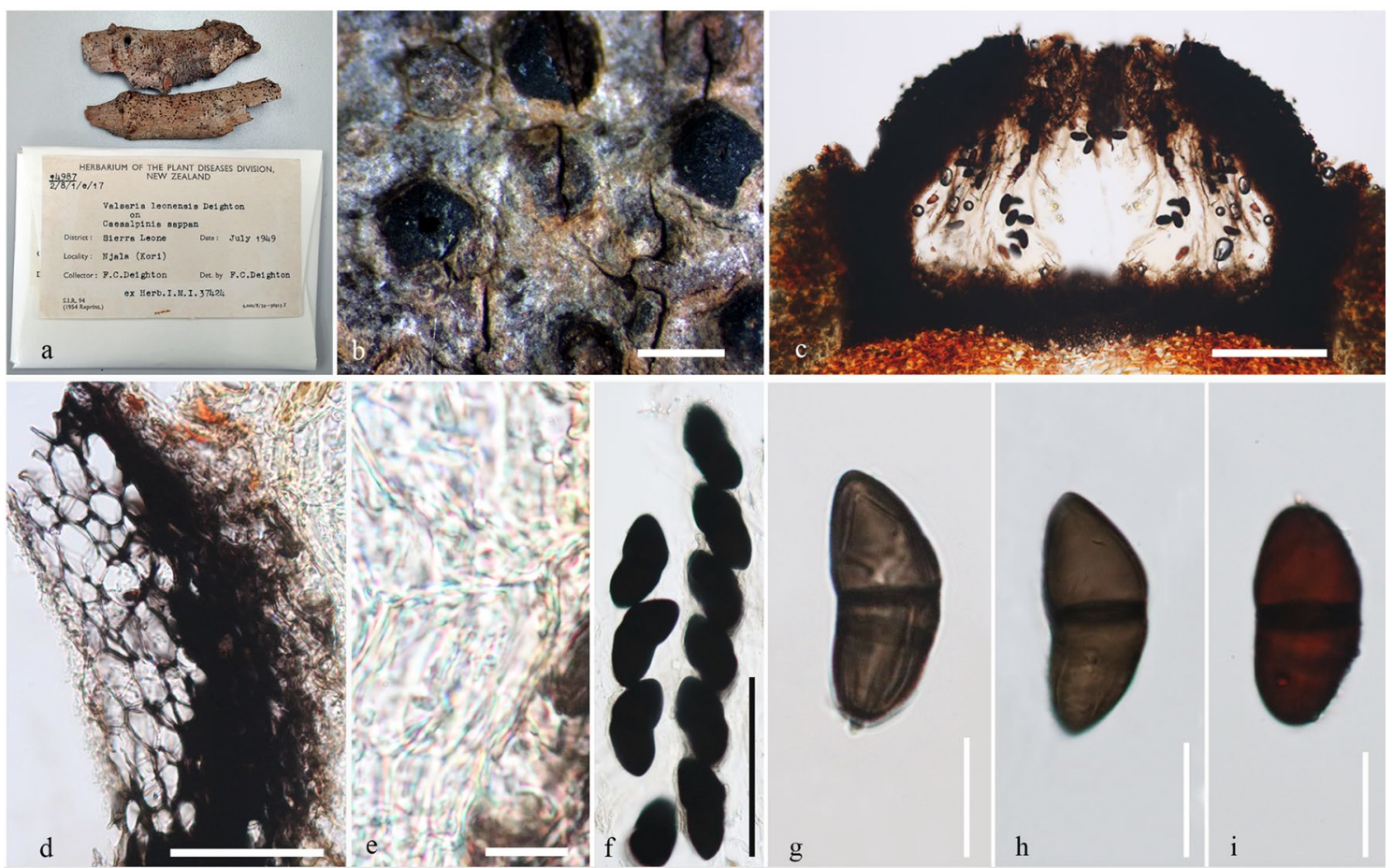

Fig. 111 Macrovalsaria megalospora (= M. leonensis PDD 14987, co-extype). a Details of herbarium material. b Habit and appearance of ascomata on host surface. $\mathbf{c}$ Section of ascoma. d Peridium. e

2014a, 2018). The genus is poorly known and lacks molecular data to reveal its taxonomic status, hence, it was tentative placed in this family pending further studies.

\section{Economic and ecological significance}

Taxa in Leptopeltidaceae are commonly as epiphytic occurring on stems or leaves of ferns and some dicotyledonous plants. Species in this family are mainly distributed in Europe, except Staibia connari which was found on leaves of Connarus suberosus in Brazil (Batista et al. 1966; von Arx and Müller 1975; Holm and Holm 1977; Farr and Ross$\operatorname{man} 2020)$.

Macrovalsariaceae D. Pem, Doilom \& K.D Hyde, in Pem et al., Mycosphere 10(1): 1149 (2019).

Index Fungorum number: IF 557067; Facesoffungi number: FoF 06682, 2 species.

Saprobic on dead twigs, wood, bamboo and culms of a wide range of hosts. Sexual morph: Ascostromata dark brown to black, immersed to erumpent, solitary to a few in a group, carbonaceous, oblate, sphaeroid to subsphaerical, with a central ostiole. Peridium comprising brown and small-celled textura angularis. Asci 8-spored, bitunicate, fissitunicate, cylindro-clavate, with a short fine pedicel,
Hamathecium. f Asci. g-i Ascospores. Scale bars: $\mathbf{b}=1 \mathrm{~mm}, \mathbf{c}, \mathbf{d}=$ $200 \mu \mathrm{m}, \mathbf{e}=10 \mu \mathrm{m}, \mathbf{g}-\mathbf{i}=20 \mu \mathrm{m}$

apically rounded with a small ocular chamber. Hamathecium comprising unbranched, tapering upwards, apically free, paraphyses. Ascospores uni-seriate to irregularly uni-seriate, elliptical-fusoid, brown, 1-septate, slightly constricted at septum, with skull cap-like germ apparatus at the lower end, transverse striation near the center of lower cell with longitudinal striations from transverse striation to the end cell surface smooth, granular to verrucose. Asexual morph: Undetermined.

Type: Macrovalsaria leonensis (Deighton) Petr.

Notes: Pem et al. (2019c) introduced Macrovalsariaceae to accommodate Macrovalsaria. The family is characterized by dark brown to black ascostromata, cylindro-clavate asci, with a short fine pedicel and elliptical to fusoid ascospores with skull cap-like germ apparatus.

Macrovalsaria Petr., Sydowia 15(1-6): 298 (1962) [1961]. Index Fungorum number: IF 2971; Facesoffungi number: FoF 06251; 2 morphological species (Species Fungorum 2020), 2 species with molecular data.

Type species: Macrovalsaria megalospora (Mont.) Sivan.

Notes: Macrovalsaria is unique in producing brown, uniseptate ascospores that are constricted at the septum and the 


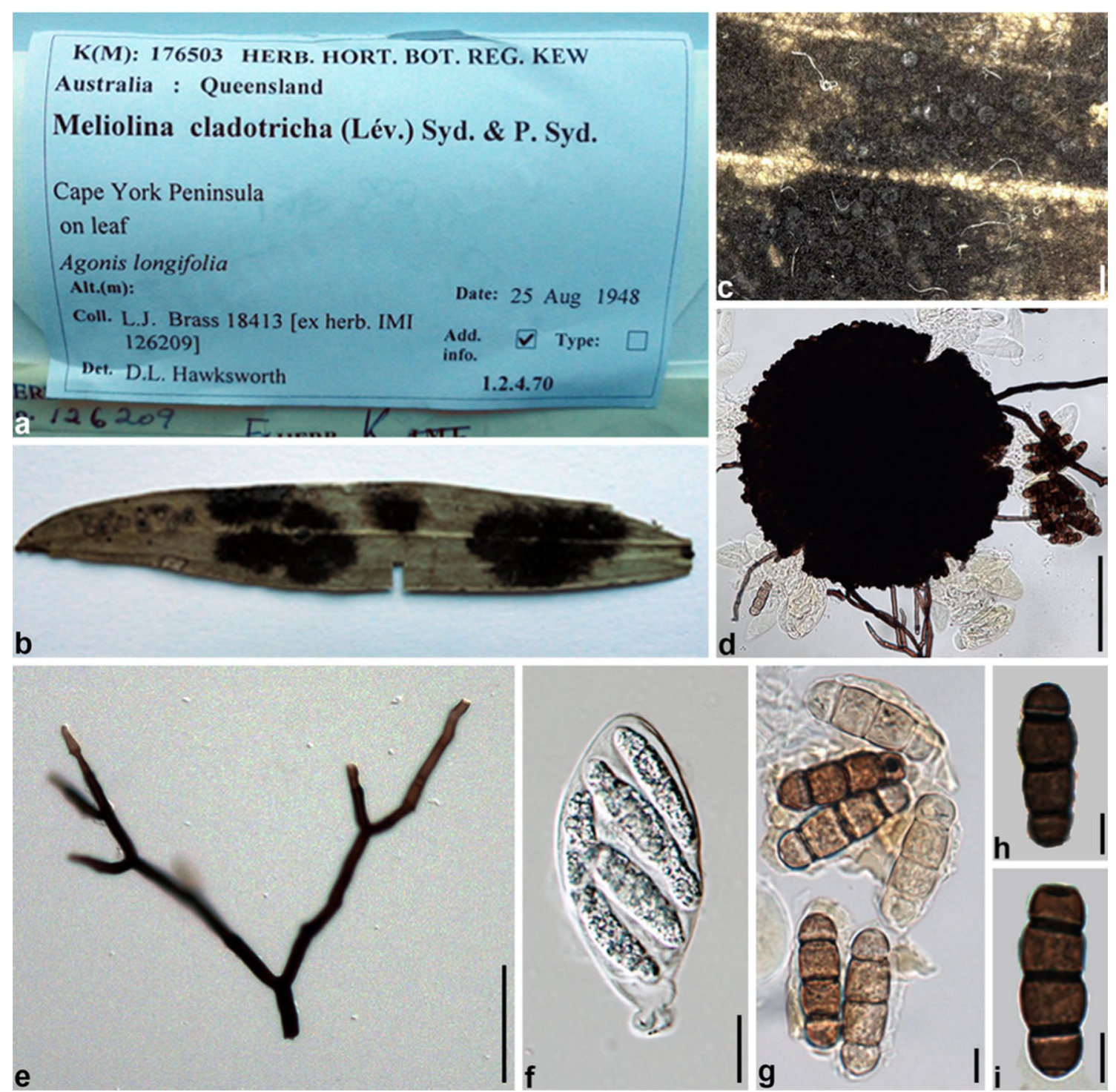

Fig. 112 Meliolina cladotricha (K 176503). a Herbarium packet. b The host leaf. c Ascomata on the leaf surface. d Squash mount of ascoma. e Hyphae with dichotomously branched phialophores. f Ascus. $\mathbf{g}-\mathbf{i}$ Ascospores. Scale bars: $\mathbf{c}=400 \mu \mathrm{m}, \mathbf{d}=100 \mu \mathrm{m}, \mathbf{f}=20 \mu \mathrm{m}, \mathbf{e}, \mathbf{g}-\mathbf{i}=10 \mu \mathrm{m}$

skull cap-like germ apparatus at the base (Sivanesan 1975). The asexual morph is unknown.

Macrovalsaria megalospora (Mont.) Sivan. Trans. Br. Mycol. Soc. 65: 400 (1975).

三Sphaeria megalospora Mont., Annls Sci. Nat., Bot., sér. 2 14: 324 (1840).

Index Fungorum number: IF 317110; Facesoffungi number: FoF 01868; Fig. 111

Description: see Pem et al. (2019c).

Material examined: Africa, Sierra Leone, Njala (Kori), on dead branches of Caesalpinia sappan (Fabaceae), 12 July 1949, F.C Deighton (PDD 14987, co-extype).

\section{Economic and ecological significance}

This family is saprobic and thus involved in nutrient recycling.

Meliolinaceae S. Hughes, Mycol. Pap. 166: 176 (1993).

Index Fungorum number: IF 81959; Facesoffungi numbers: FoF 06889; 50 species.

Parasitic on living leaves. Colonies superficial, dense to subdense, black. Hyphae superficial, brown, straight to substraight, branched, septate, darker at septa, reticulate, with setiform phialides. Sexual morph: Ascomata globose to subglobose, dense, gregarious, with a central ostiole, verrucose. Hamathecium lacking paraphyses. Asci 4-8-spored, fissitunicate, ellipsoid to broadly clavate, evanescent. Ascospores overlapping 2-4-seriate, cylindrical, hyaline when young, becoming brown at maturity, 3-septate, end 
cells shorter and smaller, with hyaline subterminal bands. Asexual morph: Undetermined.

Type: Meliolina Syd. \& P. Syd.

Notes: Meliolinaceae comprises a single genus Meliolina and 38 species, all but one of which are confined to members of Myrtaceae. Reynolds (1989) described Briania fruticetum as the mitosporic state of Meliolina, and this was accepted by Kirk et al. (2008). The only phylogenetic study of Meliolinaceae was carried out by Saenz and Taylor (1999), illustrating that it is a separate family from Meliolaceae. Lumbsch and Huhndorf (2010) and Wijayawardene et al. (2018) placed the family as Dothideomycetes incertae sedis.

Meliolina Syd. \& P. Syd., Annls mycol. 12(6): 553 (1914). Index Fungorum number: IF 3105; Facesoffungi number FoF06890; 49 morphological species (Species Fungorum 2020), 1 species with molecular data.

Type species: Meliolina cladotricha (Lév.) Syd. \& P. Syd.

Notes: Meliolina species produce thick, spongy, hypophyllous colonies that predominantly infect Myrtaceae plants. Stevens $(1927,1928)$ included the genus in Meliolaceae. Eriksson (1981) postulated that Meliolaceae and Meliolina may share a common ancestry, but the result from Saenz and Taylor (1999) demonstrated that Meliolina is phylogenetically distant from Meliolaceae. However, Hyde et al. (2013) treated this genus as a member of Meliolales based on morphology. There are several morphological differences between Meliola and Meliolina. Meliola species produce haustoria from capitate hyphopodia, while Meliolina species penetrate the host by stomatopodia (Hansford 1946; Hughes 1993) and develop internal hyphae. The superficial mycelium of Meliola develops directly from an ascospore, while the superficial mycelium of Meliolina is the result of egress cells which grow out of leaf stomata and produce mini-colonies of superficial hyphae (Hughes 1993). Meliola produce phialospores by possessing sessile phialides (mucronate hyphopodia) which are produced directly from the superficial hyphae, while Meliolina produces setiform phialides which are produced from arborescent branches of the superficial hyphae (Hughes 1981; Reynolds 1989; Mueller et al. 1991). Meliolina usually forms eight ascospores per ascus (Hughes 1993), whereas Meliola never produces eight mature ascospores within an ascus (Stevens 1925; Hansford 1961; Hongsanan et al. 2015d). The ascospores of Meliolina usually display hyaline subterminal bands, which are never found in Meliola.

Meliolina cladotricha (Lév.) Syd. \& P. Syd., Annls mycol. 12(6): 553 (1914).

三 Meliola cladotricha Lév., Annls Sci. Nat., Bot., sér. 3 5: 266 (1846).

Index Fungorum number: IF 120177; Facesoffungi numbers: FoF 06891; Fig. 112
Parasitic on living leaves. Colonies hypophyllous, superficial, dense to subdense, black. Hyphae superficial, brown, straight to substraight, branched, septate, darker at septa, closely reticulate. Sexual morph: Ascomata globose to subglobose, dense, gregarious, with a central ostiole, verrucose. Hamathecium lacking paraphyses. Asci 6-8-spored, fissitunicate, ellipsoid to broadly clavate, with short pedicel, evanescent. Ascospores overlapping 2-4-seriate, cylindrical with somewhat flattened ends, hyaline when young, becoming brown at maturity, 3 -septate, constricted and darken at septa, end cells shorter and smaller than central cells, with hyaline bands near the septum, with roughened walls. Asexual morph: Undetermined.

Material examined: Australia, Queensland, Cape York Peninsula, on leaves of Agonis longifolia, L.J. Brass, 25 August 1948 (K 176503).

\section{Other genus included}

Briania D.R. Reynolds, Pacific Sci. 43(2): 161 (1989).

Index Fungorum number: IF 11017; Facesoffungi numbers: FoF 06892; 1 morphological species (Species Fungorum 2020), molecular data unavailable.

Type species: Briania fruticetum D.R. Reynolds, Pacific Sci. 43(2): 161 (1989).

Notes: Briania is a monotypic genus introduced as the asexual morph of Meliolina sydowiana found on leaves of Metrosideros polymorpha. The link between the sexual and asexual morph are questionable.

\section{Economic and ecological significance}

Meliolinaceae is a poorly understood family with limited taxa. Similar to black mildews and sooty moulds, their colonies cover the leaf surface and may reduce photosynthesis and increase the temperature and respiration in those areas (Hongsanan et al. 2015c).

Mesnieraceae Arx \& Müller, Stud. Mycol. 9: 94 (1975).

Index Fungorum number: IF 80998, Facesoffungi numbers: FoF 07871, 6 species.

Synonym: Stegasphaeriaceae Syd. \& P. Syd., Annls mycol. 14(5): 364 (1916).

Parasitic on leaves, causing necrotic symptoms on leaves, or saprobic. Sexual morph: Mycelium hyaline, developing within host tissue. Ascomata densely gregarious, immersed, sphaerical, flattened or globose to subglobose, yellowishgreen, fleshy, light with peridium composed of many cells, uni-loculate, with numerous asci and pseudoparaphyses. Ostiole present or lacking, usually opening apically with a pore, or with wide and large hole in mature ascomata, erumpent through the upper epidermis, comprising elongated columnar cells. Peridium thin-walled, hyaline, composed of many layers of flattened cells of textura angularis, or comprising a few layers of elongate cells. Hamathecium 
comprising numerous, hypha-like, filamentous, septate pseudoparaphyses, embedded in a gelatinous matrix. Asci 4-24-spored, bitunicate, cylindrical to clavate, or elongateellipsoidal, short-pedicellate, inner membrane thickened in the upper part, apex rounded, with or without a welldeveloped ocular chamber. Ascospores 2- to multi-seriate, ellipsoidal, dark brown to brown, or dark reddish-brown, 0-1-septate, thick-walled, constricted at the septum, with or without a mucilaginous sheath. Asexual morph: Undetermined.

Type: Mesniera Sacc. \& P. Syd.

Notes: Mesnieraceae was introduced by von Arx and Müller (1975) and type species is Mesniera rottlerae. Mesnieraceae includes the genera Bondiella, Mesniera and Stegasphaeria (Kirk et al. 2008). Hyde (1996) considered Bondiella as a good member in Mesnieraceae (Pirozynski 1972; Eriksson 1981) and observed, redescribed and illustrated Bondiella palmicola from leaf blades of dried fallen palm fronds, while Lumbsch and Huhndorf (2010) included four genera with the addition of Helochora. Helochora was isolated from Puya sp. in Chile, and described as a new genus by Sherwood (1979) and was accommodated in Polystigmataceae. It has ornamented spores which are uni-seriate in the asci. Hyde et al (2013) observed the type specimen of Helochora hypertropha and considered that Helochora does not belong to Mesnieraceae therefore Helochola was transferred to Sordariomycetes genera incertae sedis.

Mesniera Sacc. \& Syd., Syll. Fung. 16: 440 (1902).

Index Fungorum number: IF 3134; Facesoffungi number: FoF 07872; 3 morphological species (Species Fungorum 2020), molecular data unavailable.

Type species: Mesniera rottlerae (Racib.) Sacc. \& P. Syd. [as 'rotlerae'], Syll. fung. (Abellini) 16: 441 (1902).

$\equiv$ Anthostomella rottlerae Racib., Parasit. Alg. Pilze Java's (Jakarta) 2: 11 (1900).

Notes: Eriksson (1981) examined several collections of Mesniera and all had concentric rings of ascomata in necrotic patches, wide pores usually containing mature asci with ascospores, and mature ascomata present on both of the upper and lower side of the leaves. Unfortunately, the type species of Mesniera rottlerae ( $\equiv$ Anthostomella rottlerae) may be lost (Hyde et al. 2013) and need recollecting and neotypifying.

\section{Other genera included}

Bondiella Piroz., Mycol. Pap. 129: 6 (1972).

Index Fungorum number: IF 625; Facesoffungi number: FoF 07873; - 1 morphological species (Species Fungorum 2020), molecular data unavailable.

Type species: Bondiella palmicola Piroz., Mycol. Pap. 129: 6 (1972).
Notes: Barr (1987b) placed Bondiella in Pleosporales, but did not mention about Bondiella or Mesnieraceae. Hyde (1996) observed type species Bondiella palmicola and considered Bondiella is a member of Mesnieraceae which supports the findings of Pirozynski (1972) and Eriksson (1981).

Bondiella palmicola Piroz., Mycol. Pap. 129: 6 (1972).

Index Fungorum number: IF 309834; Facesoffungi number: FoF 07874; Fig. 113

Description: see Hyde et al (2013).

Material examined: Tanzania, Kigoma, Kakombe, on fallen fronds of Elaeis guineensis, 19 December 1963, K.A. Pirozynski M26c, IMI 105789c, holotype).

Stegasphaeria Syd. \& P. Syd., Annls mycol. 14(5): 362 (1916).

Index Fungorum number: IF 5190; Facesoffungi number: FoF 07875; - 2 morphological species (Species Fungorum 2020), molecular data unavailable.

Type species: Stegasphaeria pavonina Syd. \& P. Syd., Annls mycol. 14(5): 362 (1916).

Notes: Stegasphaeria is pathogenic forming very rough round spots on leaves, consisting of many individual ascomata arranged in narrow rings. The mature ascospore are released through breakdown of the upper part of ascomata as in Mesniera; this is the main character that places them in Mesnieraceae.

Stegasphaeria pavonina Syd. \& P. Syd., Annls mycol. 14(5): 362 (1916).

= Mesniera pavonina (Syd. \& P. Syd.) Petr., Annls mycol. 39(4/6): 345 (1941).

Index Fungorum number: IF 139864; Facesoffungi number: FoF 07876; Fig. 114

Description: see Hyde et al (2013).

Material examined: Philippines, Laguna, Mount Maquiling, near Los Baños, on living leaf of Macaranga sp., 7 March 1914 (C.F. Baker no.4032, holotype)

\section{Economic and ecological significance}

Parasitic on leaves causing necrotic patches, this is important as it can cause serious problems to economic plants. Fungi can be saprobic over the winter on dead wood or leaves, forming the sexual morph and waiting to infect the plant in the next crop.

Naetrocymbaceae Höhn. [as 'Naetrocymbeen'], Sber. Akad. Wiss. Wien, Math.-naturw. Kl., Abt. 1 118: 1200 (1909).

Index Fungorum number: IF 81056; Facesoffungi number: FoF 07877, 41 species.

Epiphytic or Lichenicolous on twigs, wood, or on upper and lower surface of living leaves, rarely on stone. Mycelium on host surface, branched, septate, brown to grayish. Sexual 

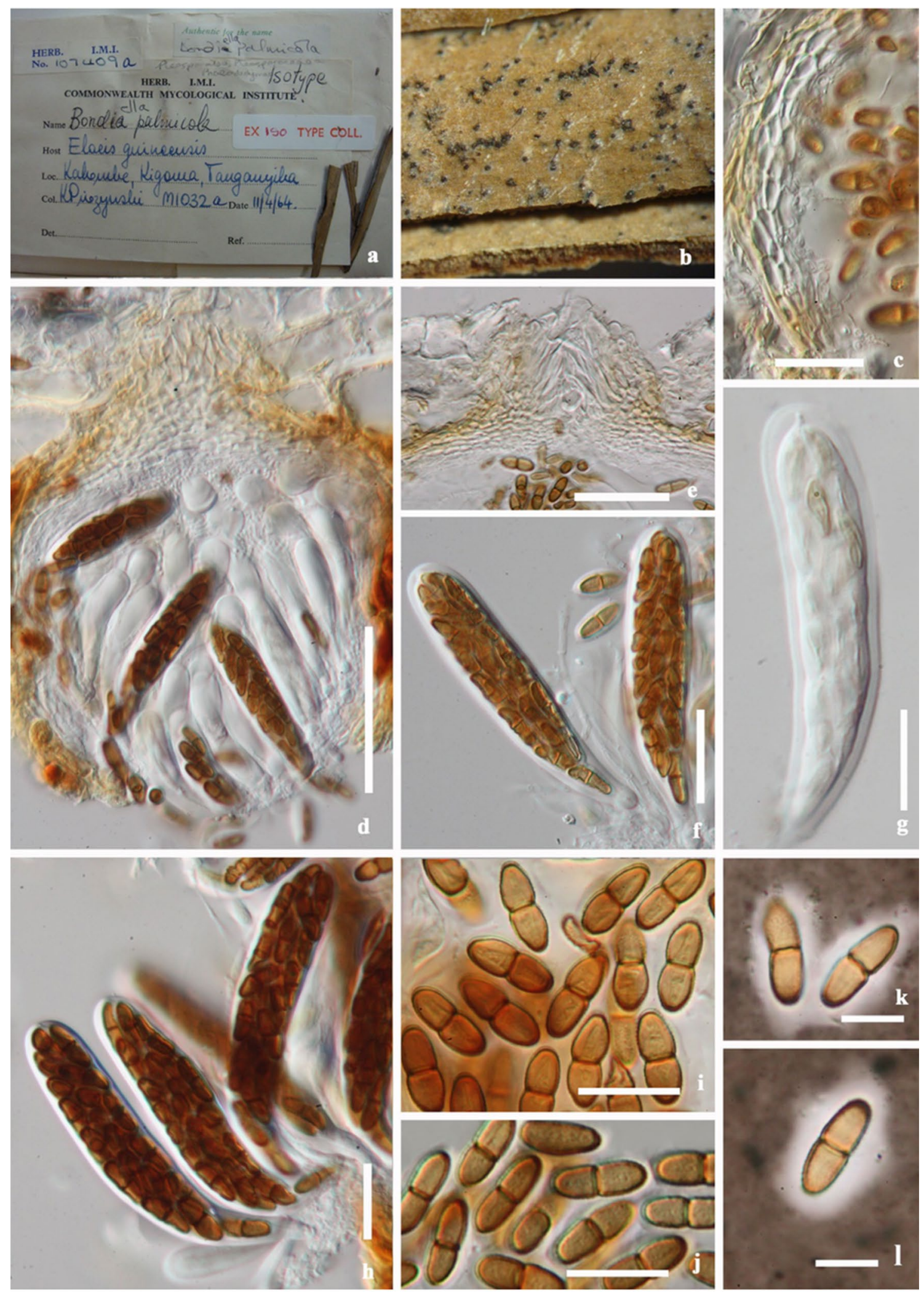

Fig. 113 Bondiella palmicola (IMI 105789c, holotype). a Herbarium specimens. b Ascomata semi-immerged on host. c Peridium. d Vertical section of ascoma. e Ostiolar canal with hyaline periphyses. f, h Asci. $\mathbf{g}$ Immature bitunicate asci. $\mathbf{i}, \mathbf{j}$ Ascospores with 2 cells. $\mathbf{k}, \mathbf{l}$ Ascospores strained in India ink. Scale bars: $\mathbf{d}=100 \mu \mathrm{m}, \mathbf{e}=50 \mu \mathrm{m}$, $\mathbf{c}, \mathbf{f}-\mathbf{h}=20 \mu \mathrm{m}, \mathbf{i}, \mathbf{j}=10 \mu \mathrm{m}, \mathbf{k}, \mathbf{l}=5 \mu \mathrm{m}$ 

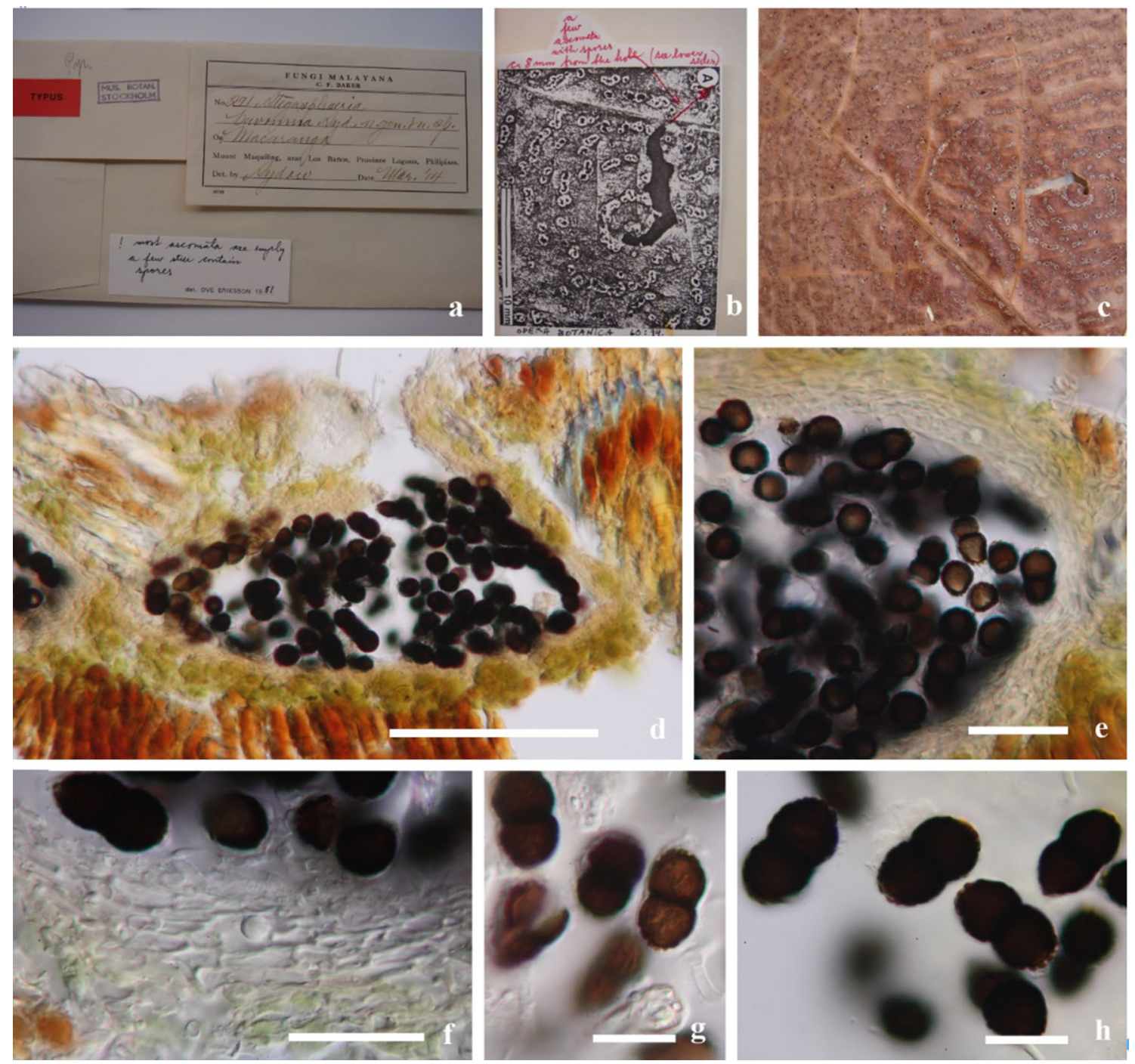

Fig. 114 Stegasphaeria pavonina (C.F. Baker no.4032, holotype). a, b Herbarium specimen labels. c Ostiolate ascomata on leaf of Macaranga sp. d Vertical section through ascoma. e, f Peridium. $\mathbf{g}, \mathbf{h}$ Ascospores. Scale bars: $\mathbf{d}=100 \mu \mathrm{m}, \mathbf{e}, \mathbf{f}=20 \mu \mathrm{m}, \mathbf{g}, \mathbf{h}=10 \mu \mathrm{m}$

morph: Ascomata perithecial or thyriothecial, superficial to immersed, globose to subglobose, comprises a single to multiple chambers, dark brown to black, ostiolate. Peridium thin, comprises hyaline to dark brown cells of textura angularis to epidermoidea. Hamathecium comprising coarse, branching pseudoparaphyses, hyaline, often with re- fractive or differentially-staining, cellular pseudoparaphyses tips. Asci 6-8-spored, bitunicate, fissitunicate, obpyriform, globose-subglobose or oblong, thick-walled near apex, with a short pedicellate, apically rounded and endotunica, lacking an ocular chamber. Ascospores 2-3 to multi- seriate, oblong to broad ellipsoid, elongate to ellipsoid, or fusiform, hyaline, olivaceous-brown when mature, 1- to multi-septate, slightly constricted at septa, wall slightly ornamented. Asexual morph: Microconidia short and rod-shaped, macroconidia known from some Leptorhaphis species (Hyde et al. 2013).

\section{Type: Naetrocymbe Körb.}

Notes: The family (as Naetrocymbeen) was originally described by von Höhnel (1909b), but without Latin or in accordance with ICBN rules. Harris (1995) validated the family name and included four genera in this family, Jarxia, Leptorhaphis, Naetrocymbe, and Tomasellia. This was followed by Lumbsch and Huhndorf (2010), Hyde et al. (2013), Doilom et al. (2018) and Wijayawardene et al. (2018). Pem et al. (2019c) included Bonaria in this family based on morphological characters. Sequence data is not available for this family.

Naetrocymbe Körb., Parerga lichenol. (Breslau) 5: 441 (1865). 



Fig. 115 Tomasellia arthonioides (F217044). a Herbarium materials. b Black stromata on the host. c, d Section of astroma. e Psuedoparaphyses. f, $\mathbf{g}$ Asci with ascospores. Scale bars: $\mathbf{b}=500 \mu \mathrm{m}, \mathbf{c}, \mathbf{d}=50 \mu \mathrm{m}, \mathbf{e}-\mathbf{g}=10 \mu \mathrm{m}$

Index Fungorum number: IF 3410; Facesoffungi number: FoF 07878; 25 morphological species (Species Fungorum 2020), molecular data unavailable.

Type species: Naetrocymbe fuliginea Körb.

Notes: Most species in Naetrocymbe were transferred to Limacinula (Reynolds 1971), however, Luttrell (1973) noted that Naetrocymbe has questionable status. Naetrocymbe species are characterized by immersed, globose, black ascomata, surrounded by dark brown fungal tissue, thickwalled, clavate to obovoid asci, and 1-septate, oblong to long ellipsoid, hyaline ascospores. Naetrocymbe was accepted as a distinct genus by Barr (1979a) and Eriksson (1981). Species in this genus were found as non-lichen-forming fungi (Harris 1995) and found associated with Trentepohlia algae (Roux 2009; Coppins 2002). Hyde et al. (2013) noted that the concept of this genus is debatable.

\section{Other genera included}

Bonaria Bat., Publicações Inst. Micol. Recife 56: 438 (1959).
Index Fungorum number: IF 624; Facesoffungi number: FoF 05164; 3 morphological species (Species Fungorum 2020), molecular data unavailable.

Type species: Bonaria lithocarpi (V.A.M. Mill. \& Bonar) Bat., Publicações Inst. Micol. Recife 56: 439 (1959).

$\equiv$ Protopeltis lithocarpi V.A.M. Mill. \& Bonar, University of Calif. Publ. Bot. 19: 412 (1941).

Notes: Bonaria was treated as a genus incertae sedis in Dothideomycetes by (Wijayawardene et al. 2018). Pem et al. (2019c) re-examined the isotype specimen of $B$. lithocarpi (S-F 3573) anf concluded that Bonaria should be placed in Naetrocymbaceae based on its immersed, subglobose, black ascomata, 8-spored, thick-walled, obpyriform asci, and multi-seriate, oblong to long ellipsoid, hyaline, 1-septate ascospores (Pem et al. 2019c).

Jarxia D. Hawksw., Stud. Mycol. 31: 93 (1989).

Index Fungorum number: IF 25310; Facesoffungi number: FoF 07879; - 2 morphological species (Species Fungorum 2020), molecular data unavailable. 
Type species: Jarxia thelenula (Müll. Arg.) D. Hawksw., Stud. Mycol. 31: 95 (1989).

三 Microthelia thelenula Müll. Arg., Bot. Jb. 6: 416 (1885).

Notes: Jarxia contains two non lichen-forming species (Doilom et al. 2018; Index Fungorum 2020). Doilom et al. (2018) re-examined the syntype of J. thelenula which has the same morphology as the holotype (Hawksworth 1989), thus they agree to place this genus in Naetrocymbaceae.

Leptorhaphis Körb., Syst. lich. germ. (Breslau): 371 (1855). Index Fungorum number: IF 2795; Facesoffungi number: FoF 07880; 8 morphological species (Species Fungorum 2020), molecular data unavailable.

Type species: Leptorhaphis oxyspora (Nyl.) Körb., Syst. lich. germ. (Breslau): 371 (1855).

$\equiv$ Verrucaria oxyspora Nyl., Bot. Notiser: 179 (1852).

Notes: Leptorhaphis occurs on bark, with a high level of host-specificity (Aguirre-Hudson 1991, 2009; AguirreHudson et al. 2002). This genus has been considered as saprotrophic and non lichen-forming (Vainio 1921a; Swinscow 1965a; Harris 1973, 1995; Aguirre-Hudson and Hawksworth 1987). One species is lichenicolous (Kalb et al. 1995), while some species are associated with algae (Swinscow 1965a; Aguirre-Hudson 1991, 2009; Aguirre-Hudson and Fiol 1993; Aguirre-Hudson et al. 2002). This genus has been placed in Naetrocymbaceae by Harris (1995), AguirreHudson et al. (2002), and Doilom et al. (2018). However, Harris (1995) mentioned that Leptorhaphis differs from other genera in Naetrocymbaceae based on the characters of hamathecium, asci, and macroconidia.

Tomasellia A. Massal., Flora, Regensburg 39: 283 (1856).

Index Fungorum number: IF 5489; Facesoffungi number: FoF 07881; - 6 morphological species (Species Fungorum 2020), molecular data unavailable.

Type species: Tomasellia arthonioides (A. Massal.) A. Massal., Flora, Regensburg 39: 284 (1856).

Notes: The morphology of Tomasellia has often been discussed with reference to Mycoporum based on compound ascomata containing several locules, each producing their own ostiole (Harris 1995). These two genera can be distinguished based on ascus, ascospore, conidial and hamathecial characters (Harris 1995). Harris (1995) transferred most species of this genus to Mycoporum (Mycoporaceae), and accepted only five non lichen-forming species in Tomasellia. The generic delimitations in Harris (1995) have been accepted by Sanderson and Coppins (2009a, b), while others accept a different circumscription (Aptroot 2002b, c). Although, sequence data is not available for Tomasellia, it is accepted as a genus in Naetrocymbaceae in many studies (Hyde et al. 2013; Wijayawardene et al. 2017a; Doilom et al. 2018).
Tomasellia arthonioides (A. Massal.) A. Massal., Flora, Regensburg 39: 284 (1856).

$\equiv$ Arthopyrenia arthonioides A. Massal., Ric. auton. lich. crost. (Verona): 169 (1852).

Index Fungorum number: IF 124738; Facesoffungi number: FoF 04652; Fig. 115

Description: see Doilom et al. (2018).

Material examined: Italy, Trentino-Alto Adige Province, on the bark of Fraxinus ornus L., J. Milde. (S, F217044).

\section{Economic and ecological significance}

Species in Naetrocymbaceae are not harmful to plants or animals. However, they have lichenicolous lifestyle which is a parasitic fungus living on lichens as the host.

Nematotheciaceae Boonmee \& K.D. Hyde, in Boonmee et al., Mycosphere 8(10): 1728 (2017).

Index Fungorum number: IF 553836; Facesoffungi numbers: FoF 03700, 12 species.

Parasitic on lower surface of living leaves. Mycelium covered ascomata, with or without hyphopodia-like structures. Sexual morph: Ascomata superficial, with a subiculum, gregarious or solitary, globose to subglobose, dark brown, with apical ostiole, covered by dark brown mycelium. Peridium comprises multilayers of dark brown cells of textura angularis. Hamathecium comprising numerous, cylindrical, filiform, branched, septate, cellular pseudoparaphyses. Asci 8-spored, bitunicate, cylindrical-subclavate, sessile. Ascospores fasciculate, multi-seriate, elongate fusiform, curved or flexuous, tapering towards the acute ends, brown, multi-septate. Asexual morph: Undetermined (adapted from Boonmee et al. 2017).

Type: Nematothecium Syd. \& P. Syd.

Notes: Nematotheciaceae was established based on morphology by Boonmee et al. (2017) to accommodate three parasitic genera Nematothecium (type genus), Nematostigma and Ophioparodia. Boonmee et al. (2017) mentioned that Nematotheciaceae is similar to Tubeufiaceae in the features of ascomata, asci and ascospores, however, it differs from Tubeufiaceae by being parasitic and occurring on living leaves. Sequence data is not available for this family.

Nematothecium Syd. \& P. Syd., Leafl. of Philipp. Bot. 5(no. 76): 1534 (1912).

Index Fungorum number: IF 3444; Facesoffungi number: FoF 07882; 5 morphological species (Species Fungorum 2020), molecular data unavailable.

Type species: Nematothecium vinosum Syd. \& P. Syd.

Notes: The genus was introduced from the Island of Palawan in the Philippines. Nematothecium is characterized by large mycelium colonies, irregular, superficial ascomata with dark red ascomata, bitunicate asci and elongate fusiform, curved or flexuous, multi-septate, hyaline to red brown 

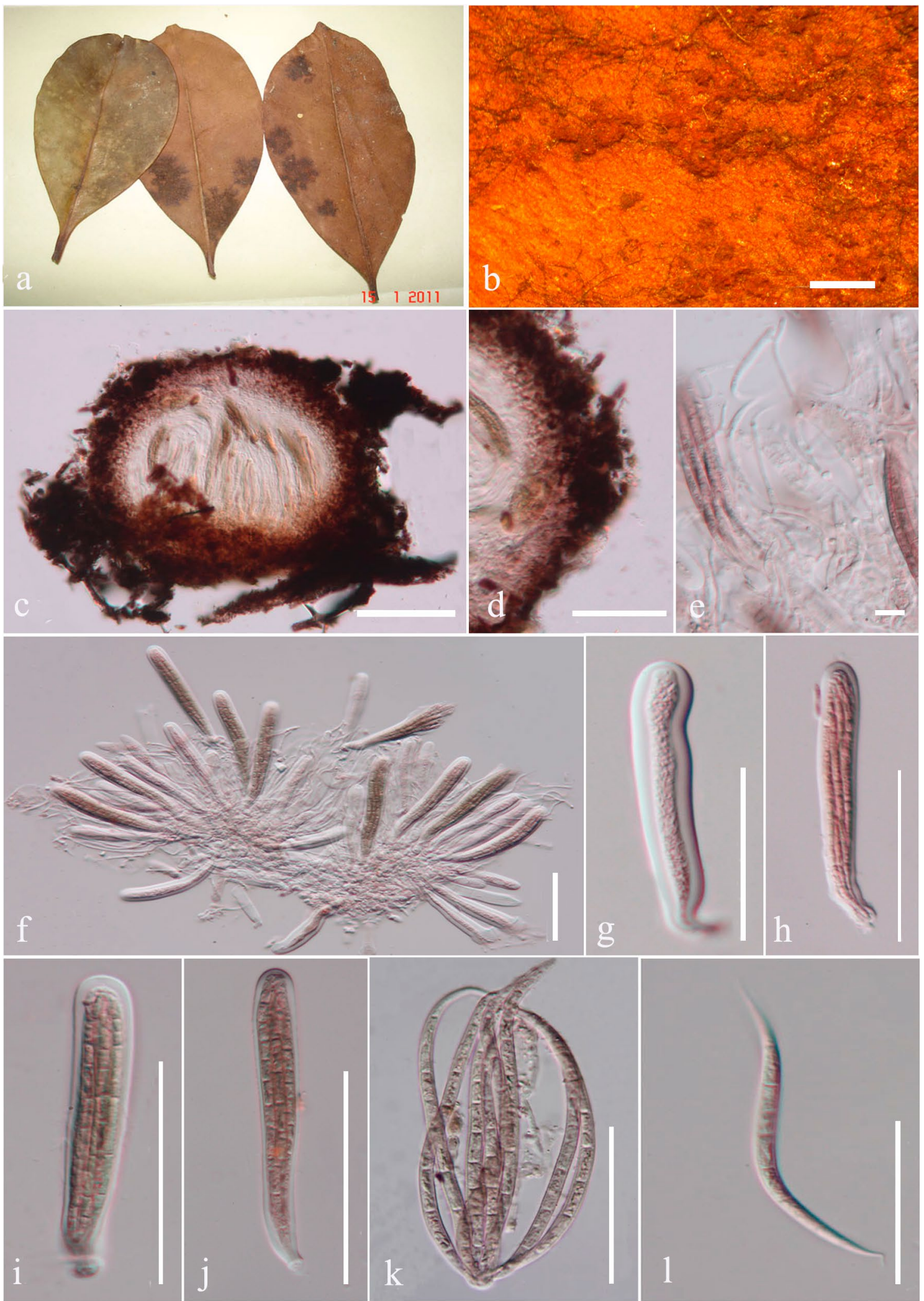

Fig. 116 Nematothecium vinosum (S-F10269, holotype). a Herbarium specimen and habit on leaves. b Appearance of ascomata on leaf surface. c Section of ascoma. d Peridium. e Pseudoparaphyses. $\mathbf{f}$
Arrangement of asci. g-j Asci. k, l Ascospores. Scale bars: $\mathbf{b}=500$ $\mu \mathrm{m}, \mathbf{c}=200 \mu \mathrm{m}, \mathbf{f}-\mathbf{l}=50 \mu \mathrm{m}, \mathbf{d}=40 \mu \mathrm{m}, \mathbf{e}=5 \mu \mathrm{m}$ 
ascospores. Nematothecium was placed in Pseudoperisporiaceae by Kirk et al. (2008), Lumbsch and Huhndorf (2010), and Hyde et al. (2013). Boonmee et al. (2017) re-examined the holotype and lectotype of $N$. vinosum and concluded that the shape and septation of ascospores are typical of Tubeufiaceae, however, its habitat can differentiate them from Tubeufiaceae. Therefore, Nematothecium is placed in the new family Nematotheciaceae (Boonmee et al. 207).

Nematothecium vinosum Syd. \& P. Syd., Leafl. of Philipp. Bot. 5(no. 76): 1534 (1912).

Index Fungorum number: IF 249022; Facesoffungi number: FoF 03243, Fig. 116

Description: see Boonmee et al. (2017).

Material examined: Philippines, Palawan, Island of Palawan: Puerto Princesa, Mt Pulgar, on living leaves of Eugenia incarnata Elmer. (Myrtaceae), May 1911, A.D.E. Elmer (no. 13232), (S-F10269, holotype, BPI 699632, lectotype).

\section{Other genera included}

Nematostigma Syd. \& P. Syd., Annls mycol. 11(3): 262 (1913).

Index Fungorum number: IF 3442; Facesoffungi number: FoF 07883; - 6 morphological species (Species Fungorum 2020), molecular data unavailable.

Type species: Nematostigma obducens Syd. \& P. Syd., Annls mycol. 11(3): 262 (1913).

Notes: The genus is characterized by dark brown, sparse setae, sphaerical ascomata, and hyaline, multi-septate ascospores. Nematostigma was transferred to Dimeriaceae, Parodiopsidaceae (= Parodiellinaceae), and Pseudoperisporiaceae (Hansford 1946; von Arx and Müller 1975; Eriksson and Hawksworth 1993; Hawksworth et al. 1995; Barr 1997; Hyde et al. 2013). However, Boonmee et al. (2017) included this genus in Nematotheciaceae based on morphology.

Ophioparodia Petr. \& Cif., Annls mycol. 30(3/4): 223 (1932).

Index Fungorum number: IF 3610; Facesoffungi number: FoF 07884; - 1 morphological species (Species Fungorum 2020), molecular data unavailable.

Type species: Ophioparodia pulchra Petr. \& Cif., Annls mycol. 30(3/4): 223 (1932).

Notes: The genus was introduced to accommodate a single species Ophioparodia pulchra, with septoidium as its asexual morph. Ophioparodia was placed in Parodiopsidaceae by Sivanesan (1984) based on its septoidium-like conidia. However, Boonmee et al. (2017) re-examinded the type specimens and could not find pseudoparaphyses or the asexual morph. They included Ophioparodia in a new family Nematotheciaceae as it has superficial, globose to subglobose, uniloculate ascomata, cylindrical asci and long, multi-septate ascospores and a hyphomycetous asexual morph (Boonmee et al. 2017).

\section{Economic and ecological significance}

Species in Nematotheciaceae are found as parasitic on leaves which can uptake nutrients from plants.

Neoparodiaceae Boonmee \& K.D. Hyde, in Boonmee et al., Mycosphere 8(10): 1734 (2017).

Index Fungorum number: IF 553832; Facesoffungi numbers: FoF 03683, 1 species.

Epiphytic or parasitic on living leaves. Sexual morph Colonies up to $2 \mathrm{~mm}$ diam. appear as black spots, superficial, subcircular, outwardly radiating, dense, branched, septate, with dark brown mycelia. Ascostromata epiphyllous or hypophyllous, superficial, crustose, on a subiculum, solitary, scattered, dark brown, multi-loculate, comprises subglobose locules, thickened at the base. Peridium comprises hyaline to brown cells of textura angularis. Hamathecium lacking pseudoparaphyses. Asci 8 -spored, bitunicate, broadly clavate, oblong to obovoid, sessile or with short pedicel, apically thickened, with an acute to subacute ocular chamber. Ascospores overlapping 2-seriate, conglobate, broadly ellipsoid, ends rounded, each cell subglobose, reddish-brown to dark brown, separated by light brown regions, 1-septate. Asexual morph: Undetermined (adapted from Boonmee et al. 2017).

Type: Neoparodia Petr. \& Cif.

Notes: Neoparodiaceae was established to accommodate a single genus Neoparodia based on morphology by Boonmee et al. (2017). This family shares some characters with Cookellaceae and Myriangiaceae (Hyde et al. 2013; Dissanayake et al. 2014; Boonmee et al. 2017). However, Neoparodiaceae differs from Cookellaceae and Myriangiaceae in having ascostromata, broadly clavate asci and broadly ellipsoid, 1-septate, dark brown ascospores (Boonmee et al. 2017).

Neoparodia Petr. \& Cif., Annls mycol. 30(3/4): 219 (1932). Index Fungorum number: IF 3471; Facesoffungi number: FoF 07885; 1 morphological species (Species Fungorum 2020), molecular data unavailable.

Type species: Neoparodia ekmanii Petr. \& Cif.

Notes: Neoparodia was placed in Perisporiopsidaceae by Müller and von Arx (1962), but later it was transferred to Parodiopsidaceae (Kirk et al. 2008; Lumbsch and Huhndorf 2010; Hyde et al. 2013; Wijayawardene et al. 2014a). Boonmee et al. (2017) examined the holotype of N. ekmanii and its asexual morph, and introduced a new family Neoparodiaceae to accommodate this genus based on its distinct morphological characters. 


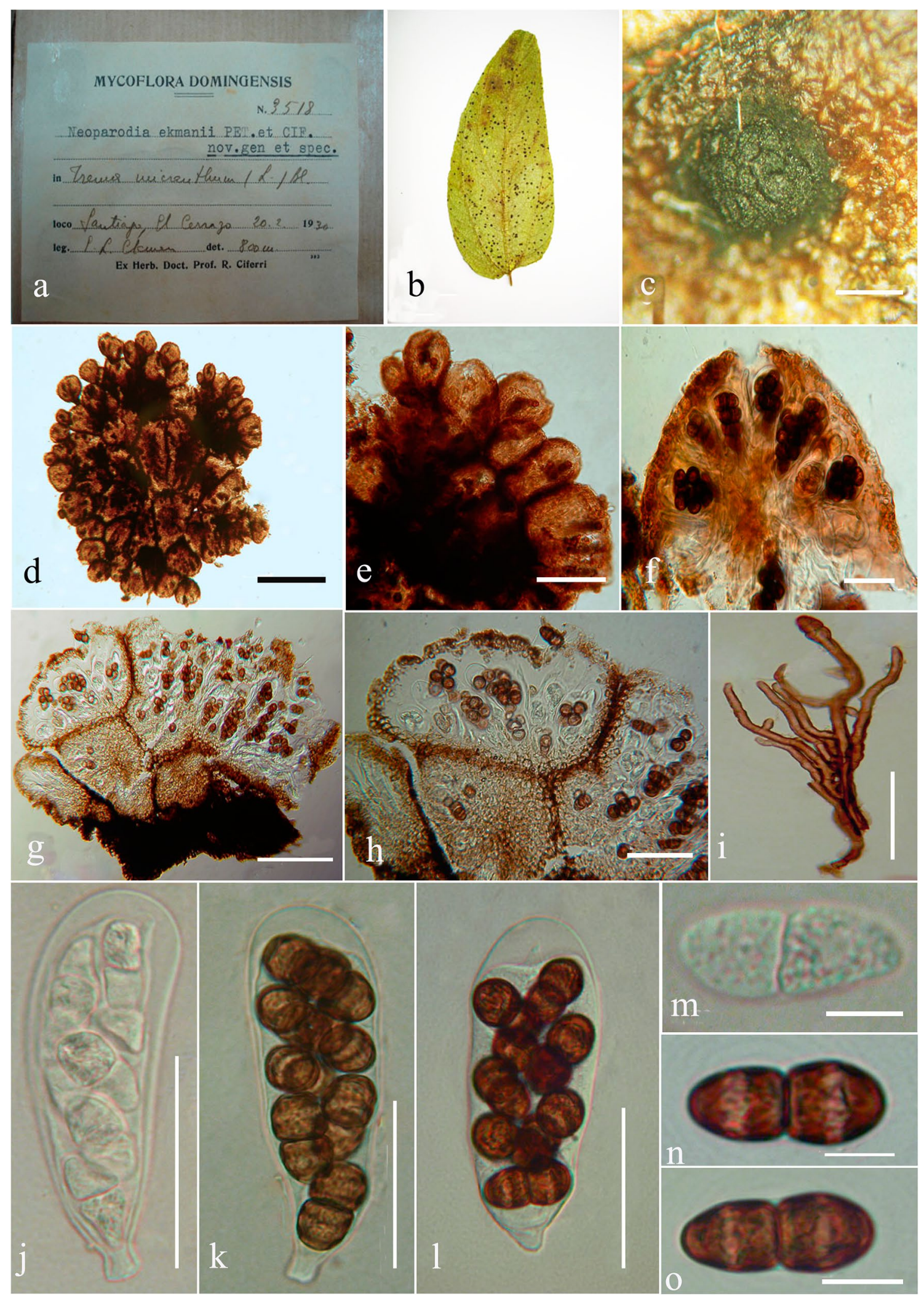

Fig. 117 Neoparodia ekmanii (W Krypto 1977-0019515, holotype). a Herbarium specimen and habit on leaves. b Appearance of colony and ascostromata seated on mycelium. c Close up of ascostroma. d, e Squash mount of ascostroma. f Section of ascomal locules. $\mathbf{g}, \mathbf{h}$
Close up of ascomal locules. i Anastomosing and branched mycelium and apical conidium-like spores. $\mathbf{j}-\mathbf{l}$ Immature and mature asci. m-o Immature and mature ascospores. Scale bars: $\mathbf{b}=1 \mathrm{~mm}, \mathbf{c}-\mathbf{h}=100$ $\mu \mathrm{m}, \mathbf{i}-\mathbf{l}=50 \mu \mathrm{m}, \mathbf{m}-\mathbf{0}=10 \mu \mathrm{m}$ 
Neoparodia ekmanii Petr. \& Cif. Annls mycol. 30(3/4): 219 (1932).

Index Fungorum number: IF 263814; Facesoffungi number: FoF 03684, Fig. 117

Description: see Boonmee et al. (2017).

Material examined: Dominican Republic, Santiago, El Cerrazo, on living leaves of Trema micrantha (Ulmaceae), $19.53^{\circ} \mathrm{N}, 70.62^{\circ} \mathrm{W}$ elev. $800 \mathrm{msl}, 20$ February 1930, P.L. Clemen No. 3518 (W Krypto 1977-0019515, holotype).

\section{Economic and ecological significance}

The family is poorly studied which comprises a single species and it is epiphytic or parasitic on living leaves. Its habitats and distributions have not been reported.

Palawaniaceae Mapook \& K.D. Hyde, in Mapook et al., Mycosphere 7(11): 1737 (2016).

Index Fungorum: IF 552528; Facesoffungi number: FoF 02653, 3 species.

Saprobic on surface of dead rachides and spines of Arecaceae. Sexual morph: Ascomata superficial, solitary or scattered, coriaceous, appearing as circular, scattered, flattened, dark brown to black spots, covering the host, without a subiculum, with a poorly developed basal layer and an irregular margin. Ostiole central. Peridium comprising of dark brown or black to light brown cell of textura epidermoidea at top with light brown cells of textura angularis at side. Hamathecium comprising cylindrical to filiform, septate, cellular pseudoparaphyses. Asci 8 -spored, bitunicate, inequilateral to ovoid, pedicellate, straight or slightly curved, without small ocular chamber. Ascospores overlapping, irregularly arranged, broadly fusiform, hyaline, 1-septate, constricted at the septum, guttulate, surrounded by hyaline gelatinous sheath, observed clearly when mounted in Indian ink. Asexual morph: Undetermined.

Type: Palawania Syd. \& P. Syd.

Notes: The family was placed in Muyocopronales, based on phylogeny and morphology, together with the use of divergence times as additional evidence for the introduction of this family (Mapook et al. 2016c). Palawania species share some morphological characters with Muyocopron species, but differ in its peridium, shape of asci and ascospores which are surrounded by a hyaline gelatinous sheath, while the character was not found in Muyocopron. In the analyses of Hongsanan et al. (2020, Fig. 1), Palawaniaceae has uncertain phylogenetic placement. Thus, we place this family in Dothideomycetes families incertae sedis, until sequence of type species is available.

Palawania (Niessl) Syd. \& P. Syd., Philipp. J. Sci., C, Bot. 9(2): 171 (1914).
Index Fungorum number: IF 3682; Facesoffungi number: FoF 06426; 3 morphological species (Species Fungorum 2020), 1 species with molecular data.

Type species: Palawania grandis (Niessl) Syd. \& P. Syd., Philipp. J. Sci., C, Bot. 9(2): 171 (1914).

三 Microthyrium grande Niessl, in Rabenhorst, Fungi europ. exsicc.: no. 2467 (1876).

Notes: Species in this genus are known from the genera Calamus, Cocos and Dypsis (Arecaceae). There are eight species epithets listed in Index Fungorum (2020), while five species were transferred to Parmulariaceae. The type material was re-examined by Wu et al. (2011b). Recently, a fresh collection was described and illustrated by Mapook et al. (2016c) from Thailand.

Palawania thailandensis Mapook \& K.D. Hyde, in Mapook et al., Mycosphere 7(11): 1740 (2016).

Index Fungorum number: IF 552527; Facesoffungi number: FoF 02654; Fig. 118

Description: see Mapook (2016c).

Material examined: Thailand, Chiang Rai, Chiang Rai Horticultural Research Center, on dried petiole and rachis of Phoenix roebelenii (Arecaceae), 09 September 2014, A. Mapook, (MFLU 16-1873, paratype).

Notes: Palawania thailandensis was introduced as a new species in Mapook et al. (2016c) with molecular data to confirm the phylogenetic placement of the genus. The species clusters with the Muyocopronaceae clade and diverged at 172 MYA in the Jurassic period (Mapook et al. 2016c).

\section{Economic and ecological significance}

Members in this family are usually common on dried petioles and rachiches of palms (Arecaceae), and are mostly saprobes (Batista and Vital 1960; Mapook et al. 2016c; Sydow and Sydow 1914b; Wu et al. 2011b).

Paranectriellaceae Boonmee \& K.D. Hyde, in Hyde et al., Fungal Diversity 63: 186 (2013).

Index Fungorum number: IF 804521, Facesoffungi number: FoF 07886, 24 species.

Parasitic (or biotrophic, hyperparasitic) on leaves causing slight discoloration around fruiting bodies. Sexual morph: Ascostromata superficial, crustose, solitary, scattered, white to light orange, fleshy, soft in texture, surrounded by colourless, sparse hairs, multi-loculate, with ascomata arranged in a peripheral outer layer. Locules globose to subglobose, with individual ostioles. Peridium relatively thin, composed of light yellow, thick-walled cells of textura angularis. Hamathecium comprising filiform, septate, branched, pseudoparaphyses, extending over asci and embedded in a gelatinous layer. Asci 8-spored, bitunicate, fissitunicate, cylindrical, oblong-clavate, apedicellate, rounded at the apex. Ascospores 2-seriate, broadly fusiform, 

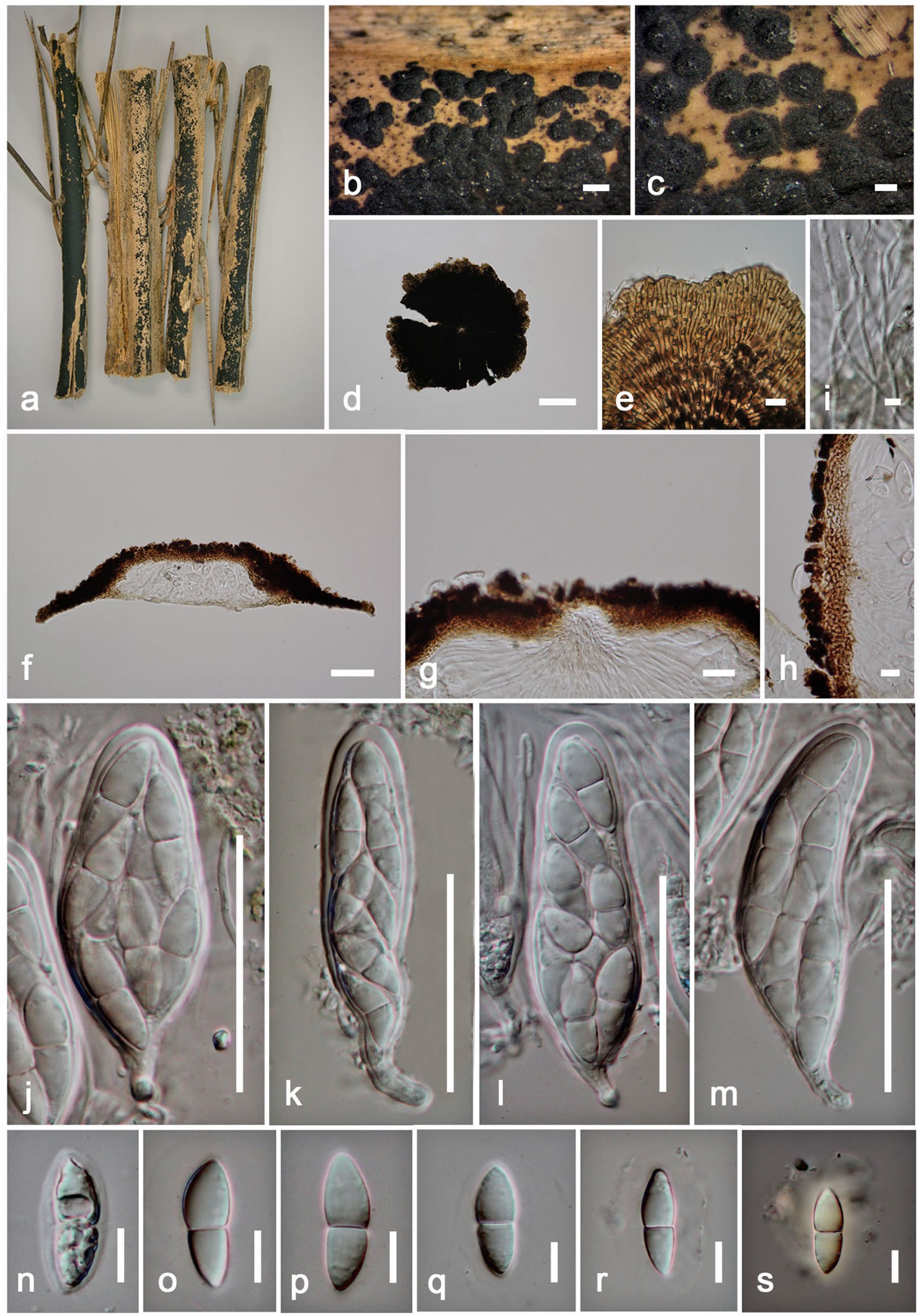

Fig. 118 Palawania thailandensis (MFLU 16-1873, paratype). a-c Superficial ascomata on substrate. d, e Squash mounts showing ascomata walls. f Section of ascoma. $\mathbf{g}$ Ostiole $\mathbf{h}$ Peridium. i Pseudoparaphyses. j-m Asci. $\mathbf{n}-\mathbf{r}$ Ascospores. $\mathbf{s}$ Ascospores surrounded by hya- line gelatinous sheath in Indian ink. Scale bars: $\mathbf{b}=500 \mu \mathrm{m}, \mathbf{c}=200$ $\mu \mathrm{m}, \mathbf{d}=100 \mu \mathrm{m}, \mathbf{f}, \mathbf{j}-\mathbf{m}=50 \mu \mathrm{m}, \mathbf{g}=20 \mu \mathrm{m}, \mathbf{e}, \mathbf{h}, \mathbf{n}-\mathbf{s}=10 \mu \mathrm{m}, \mathbf{i}=$ $5 \mu \mathrm{m}$ 

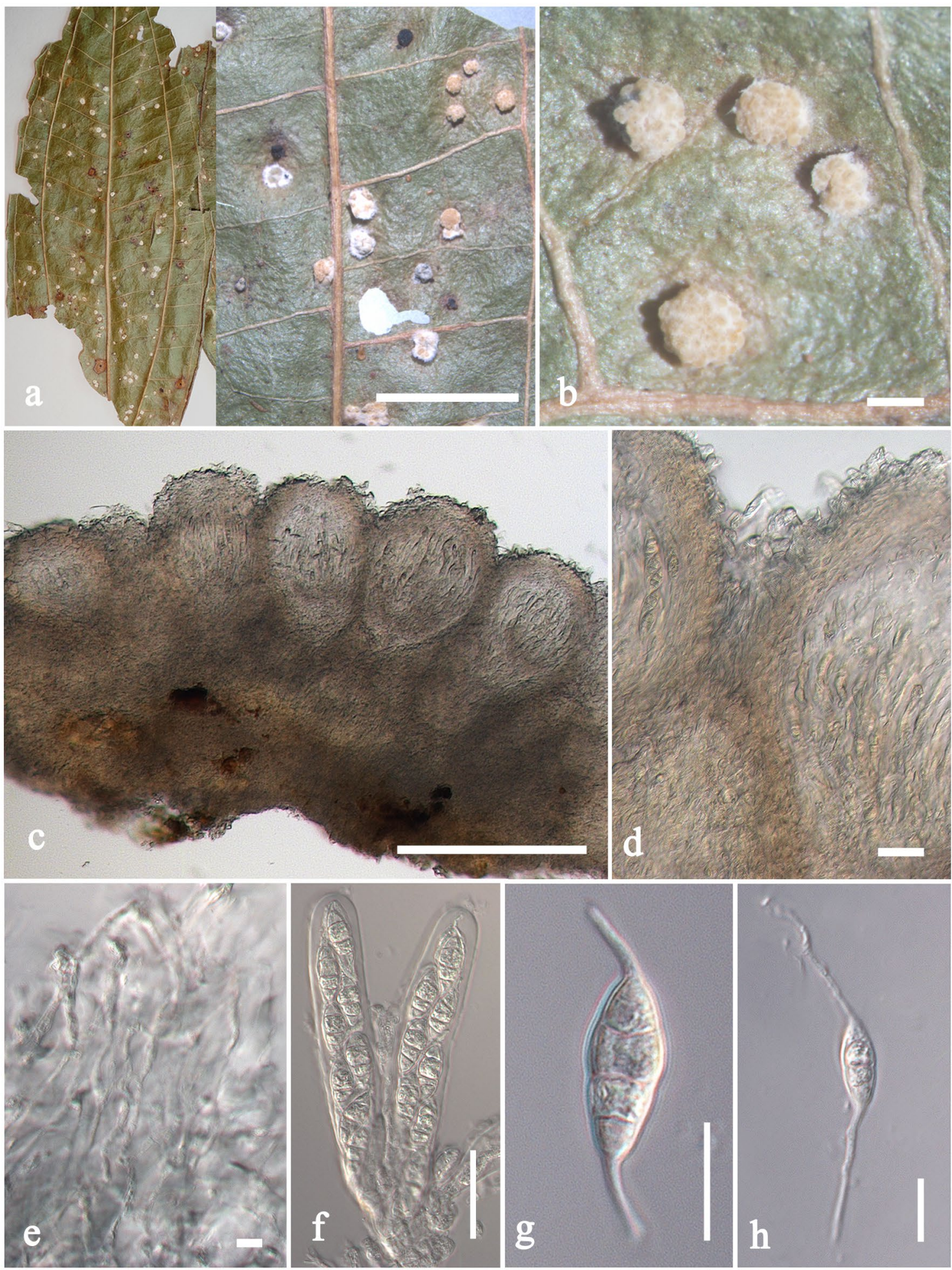

Fig. 119 Paranectriella juruana (BPI 632134). a Material and habit on leaf. b Appearance of ascostromata on lower leaf surface. c Section of ascostroma. d Close up of peridium. e Pseudoparaphyses. $\mathbf{f}$

Asci. $\mathbf{g}, \mathbf{h}$ Ascospores. Scale bars: $\mathbf{a}, \mathbf{e}=5 \mathrm{~mm}, \mathbf{b}=500 \mu \mathrm{m}, \mathbf{c}=200$ $\mu \mathrm{m}, \mathbf{d}, \mathbf{f}=20 \mu \mathrm{m}, \mathbf{g}, \mathbf{i}=10 \mu \mathrm{m}$ 
hyaline, narrowed at the ends, multi-septate, slightly constricted at the septa, with apical spine-like appendages. Asexual morph: Hyphomycetous, staurosporous.

Type: Paranectriella (Henn. ex Sacc. \& D. Sacc.) Magnus.

Notes: Paranectriellaceae was introduced to accommodate two hyperparasitic genera Paranectriella and Puttemansia (Hyde et al. 2013; Boonmee et al. 2014b). Rossman et al. (2015) proposed to protect Paranectriella over Araneomyces because Paranectriella was more widely reported and most species were not linked with Araneomyces. Currently, Paranectriellaceae is placed in Dothideomycetes families incertae sedis (Wijayawardene et al. 2017a, 2020). Sequence data are needed to confirm the placement of taxa in this family.

Paranectriella (Henn. ex Sacc. \& D. Sacc.) Magnus., Botan. Zbl. 98: 587 (1905).

= Araneomyces Höhn., Sber. Akad. Wiss. Wien, Math.naturw. Kl., Abt. 1 118: 894 (1909).

= Paranectria subgen. Paranectriella Henn. ex Sacc. \&

D. Sacc., Syll. fung. (Abellini) 17: 812 (1905).

Index Fungorum number: IF 3708, Facesoffungi number: FoF 07887, 8 morphological species (Species Fungorum 2020), molecular data unavailable.

Type species: Paranectriella juruana (Henn.) Höhn., Sber. Akad. Wiss. Wien, Math.-naturw. Kl., Abt. 1 119: 899 (1910).

Notes: Paranectriella was introduced to accommodate Paranectriella juruana a tropical hyperparasitic. Araneomyces was accepted as the asexual state of Paranectriella (Sutton 1984; Wu et al. 1997). Wijayawardene et al. (2014a) synonymized Araneomyces under Paranectriella.

Paranectriella juruana (Henn.) Höhn., Sber. Akad. Wiss. Wien, Math.-naturw. Kl., Abt. 1 119: 899 (1910).

三 Paranectria juruana Henn., Hedwigia 43(4): 245 (1904).

Index Fungorum number: IF 319198, Facesoffungi number: FoF 07888, Fig. 119

Description: see Hyde et al. (2013).

Material examined: Haiti, Dept. de la Grand' anse, Massif de la Hotte, "Geffrard" $44 \mathrm{~km}$ south of Roseaux Road to Camp Perrin, alt. $780 \mathrm{~m}, 18^{\circ} 25^{\prime} \mathrm{N} 73^{\circ} 53^{\prime} \mathrm{W}$, on leaves of Miconia sp., William R. Buck (9169), 14 November 1982 , determined by A.Y. Rossman, (BPI 632134).

\section{Other genera included}

Puttemansia Henn., Hedwigia 41: 112 (1902).

Index Fungorum number: IF 4562, Facesoffungi number: FoF 00217; - 16 morphological species, (Species Fungorum 2020), molecular data unavailable.

Type species: Puttemansia lanosa Henn., Hedwigia 41: 112 (1902).
Notes: Puttemansia was introduced to accommodate parasitic or hyperparasitic taxa occurring on leaves (Hennings 1902). Its asexual morphs are hyphomycetous in the genera Guelichia and Tetranacrium and may need synonymizing (Hyde et al. 2011, 2013). Puttemansia is presently placed in Paranectriellaceae (see morphological description in Boonmee et al. 2014b). The genus needs sequence data to indicate the generic placement.

\section{Economic and ecological significance}

Paranectriellaceae comprises two genera and their type species occurring on living leaves of dicotyledonous and monocotyledonous plants and are distributed widely in tropical regions, mostly in Africa and South America (Hyde et al. 2013; Boonmee et al. 2014b).

Parodiellaceae Theiss. \& Syd. ex M.E. Barr, Mycotaxon 29: 503 (1987).

Index Fungorum number: IF 81844; Facesoffungi numbers: FoF 07889, 23 species.

Biotrophic on upperside of leaves. Sexual morph: Ascomata superficial, scattered, gregarious between veins, uniloculate, subglobose to globose, with short stalk when mature, smooth or verrucose, black, with blackened fungal tissue in the leaf below stalk. Central ostiole with periphyses. Peridium thick-walled, comprising brown to dark brown cells of textura angularis at outer layer, and pale brown, flattened cells towards the inner layer. Hamathecium comprising irregular pseudoparaphyses. Asci 8-spored, bitunicate, cylindrical to clavate, with broad, with lobed pedicel, apically rounded with ocular chamber. Ascospores overlapping 1-2-seriate, fusoid to ellipsoidal, brown to dark brown, 1-septate, constricted at septum, inequilateral, upper cell broader and longer than lower cell, slightly narrowed at the ends, smooth-walled or striate, lacking a mucilaginous sheath. Asexual morph: Coelomycetous, assumed as Ascochytopsis. Conidiomata thick-walled, black. Conidiogenous cell cylindrical, proliferating percurrently. Conidia straight to falcate, hyaline, aseptate (Sivanesan 1984; Cannon and Kirk 2007; Hyde et al. 2013).

Type: Parodiella Speg.

Notes: Parodiellaceae was invalidly introduced by Theissen and Sydow (1918) and was validated by Barr (1987b). Hyde et al. (2013) provided an updated description based on the syntype of Parodiella hedysari (K(M) 176017) from Kew collection to represent Parodiellaceae. Parodiellaceae comprises a single genus, Parodiella and is treated as Dothideomycetes families incertae sedis (Wijayawardene et al. 2018). Sequence data is not available for this family.

Parodiella Speg., Anal. Soc. cient. argent. 9(4): 178 (1880). 


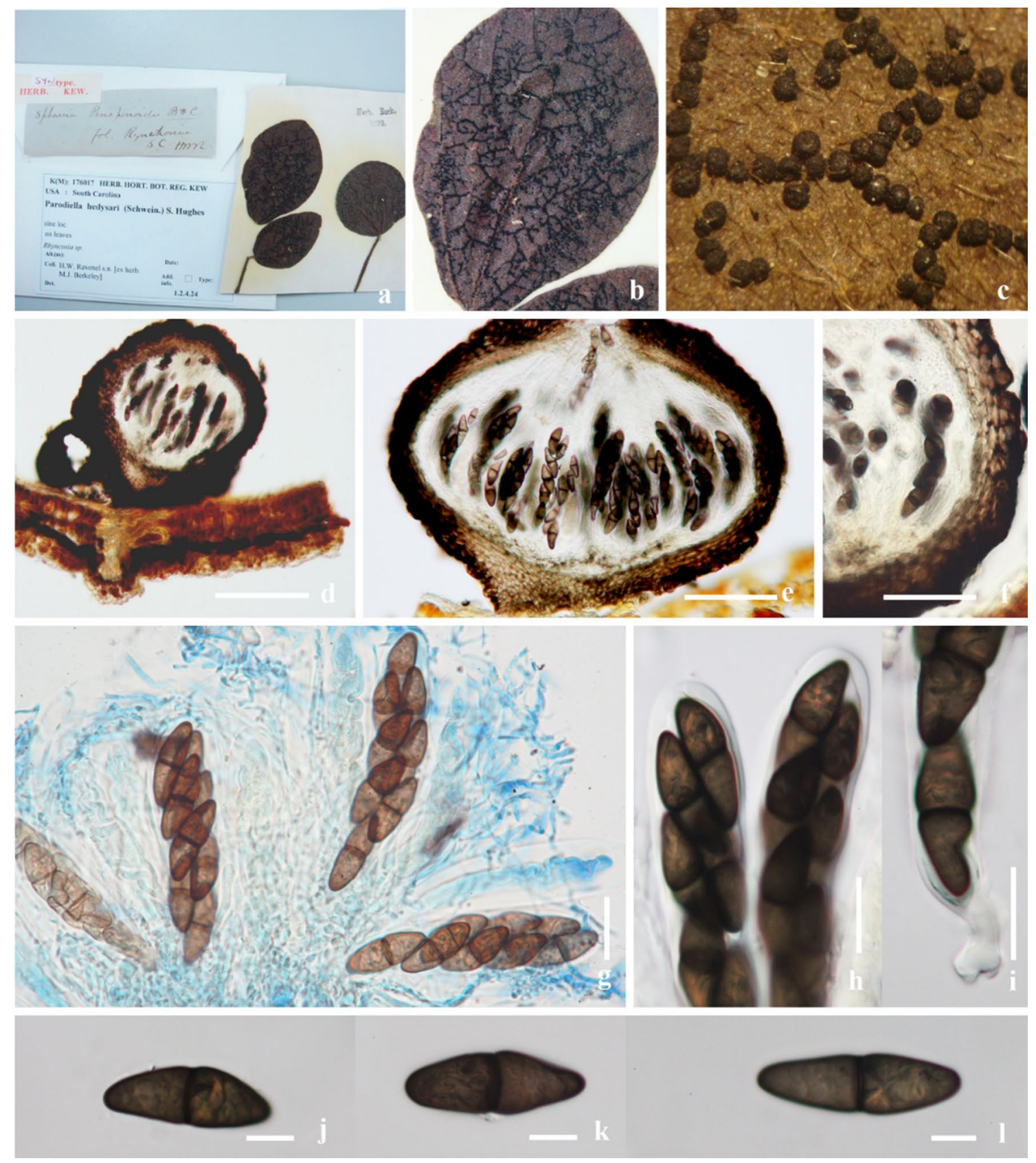

Fig. 120 Parodiella hedysari (K(M) 176017, syntype). a Herbarium specimens. b, c Ascomata on host. d-f Vertical section through the ascoma and peridium. g, h Bitunicate asci. i Pedicel of ascus. j-l

Index Fungorum number: IF 3749 Facesoffungi numbers: FoF 07890; 23 morphological species (Species Fungorum 2020), molecular data unavailable.

Type speices: Parodiella perisporioides (Berk. \& M.A. Curtis) Speg.

Notes: Parodiella is monotypic genus in Parodiellaceae (Lumbsch and Huhndorf 2010), typified by P. perisporioides. Barr (1987b) and Kirk et al. (2008) included Pododimeria and Neopeckia in Parodiellaceae, respectively.
Ascospores. Scale bars: $\mathbf{d}=200 \mu \mathrm{m}, \mathbf{c}=100 \mu \mathrm{m}, \mathbf{e}, \mathbf{f}=50 \mu \mathrm{m}, \mathbf{g}-\mathbf{i}=$ $20 \mu \mathrm{m}, \mathbf{j}-\mathbf{l}=10 \mu \mathrm{m}$

However, Wijayawardene et al. (2018) accepted only a single genus in this family. The type specimen was not located, therefore, Hyde et al. (2013) illustrated Parodiella hedysari.

Parodiella hedysari (Schwein.) S. Hughes, Can. J. Bot.: 75 (1958).

三 Coryneum hedysari Schwein., Trans. Am. phil. Soc., New Series 4(2): 306 (1832) [1834]. 


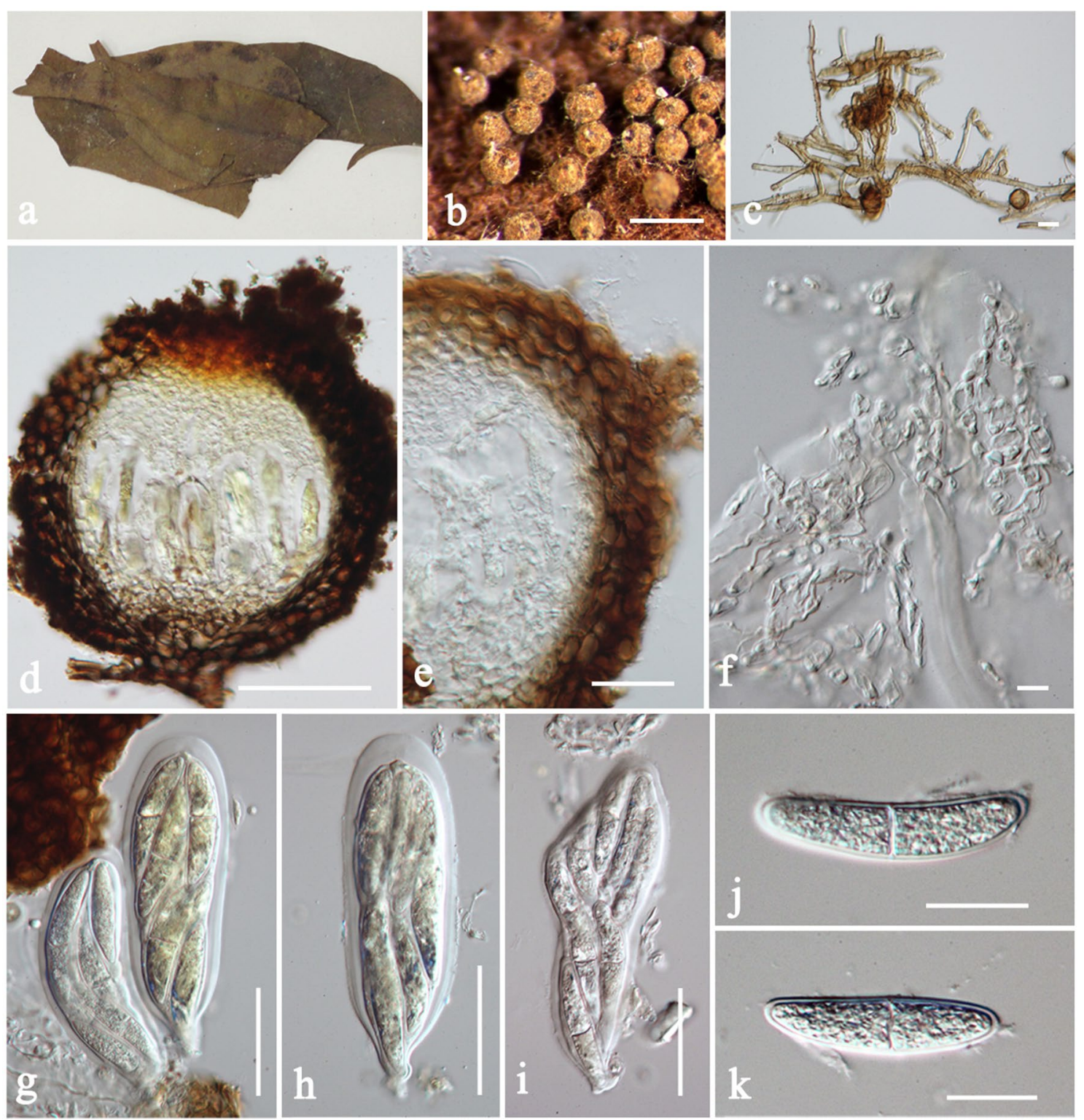

Fig. 121 Perisporiopsis struthanthi (S-F9814, holotype). a Material and habit on leaves. b Appearance of ascomata. c Superficial mycelium. d Sections of ascoma. e Peridium. f Hamathecium pseudopara-

Index Fungorum number: IF 302296; Facesoffungi numbers: FoF 07891; Fig. 120

Description: see Hyde et al. (2013).

Material examined: USA, South Carolina, on leaves of Rhynchosia sp., 1879, H.W Ravenel s.n. [ex herb M.J. Berkeley] (K(M) 176017, syntype).

\section{Economic and ecological significance}

Parodiella is a biotrophic fungus found in several hosts especially Leguminosae, and in different areas such as Australia, Brazil, Columbia, India, Japan, Kenya and Philippines. Based on the type specimen of Parodiella hedysari, it can physes. g-i Asci. j, $\mathbf{k}$ Ascospores. Scale bars: $\mathbf{b}=200 \mu \mathrm{m}, \mathbf{c}, \mathbf{j}, \mathbf{k}=$ $20 \mu \mathrm{m}, \mathbf{d}=100 \mu \mathrm{m}, \mathbf{e}=40 \mu \mathrm{m}, \mathbf{f}=10 \mu \mathrm{m}, \mathbf{g}-\mathbf{i}=50 \mu \mathrm{m}$

colonize leaf surfaces and this may produce some compound against other fungus/microbe.

Perisporiopsidaceae E. Müll. \& Arx ex R. Kirschner \& T.A. Hofm., in Kirschner et al., Sydowia 62(2): 238 (2012).

$=$ Perisporiopsidaceae E. Müll. \& Arx, Beitr. Kryptfl. Schweiz 11(no. 2): 167 (1962).

Index Fungorum number: IF 567164, Facesoffungi humber: FoF 07892, 23 species.

Parasitic, hyperparasitic or pathogenic on living leaves of various plants. Sexual morph: Ascomata or ascostromata, superficial, gregarious, solitary, uni to multi-locules, 
seated on a subiculum, sometimes surrounded by aerial mycelium, globose to subglobose, obovoid, bright to dark pigmented, with or without apical ostiole. Peridium relatively thick-walled, comprising hyaline and bright to dark brown cells of textura angularis. Hamathecium comprising branched, septate, anastomosed, hyaline, cellular pseudoparaphyses. Asci 8-spored, bitunicate, fissitunicate, broadly ellipsoid, apically thickened, with or without ocular chamber, short pedicellate. Ascospores 2-3-seriate, ellipsoidaloblong or fusiform widest in the middle to upper part of the apical cell, with broadly rounded apex and tapering towards the ends, slightly curved, 0-4-septate, hyaline to light pigmented, sometimes pale-yellow brown, smooth- to roughwalled. Asexual morph: Hyphomycetous.

Type: Perisporiopsis Henn.

Notes: Perisporiopsidaceae includes only five genera Asteronia, Byssocallis, Chevalieropsis, Parodiellina and Perisporiopsis and is treated in Dothideomycetes as family incertae sedis (Boonmee et al. 2017; Wijayawardene et al. 2018; Index Fungorum 2020). Taxa in this family are parasitic on the surface of living leaves. Phylogenetic analyses are known from putative Perisporiopsis strains (endophytic taxa) and place the strains close to some genera in Pleosporales, but with no detail of morphology (Chaverri and Gazis 2010; Hyde et al. 2013). Furthermore, other sequence strains in GenBank are unpublished. Therefore, Perisporiopsidaceae is of uncertain taxonomic placement.

Perisporiopsis Henn., Hedwigia 43(2): 83 (1904).

Index Fungorum number: IF 3827, Facesoffungi number: FoF 07893; 17 morphological species, (Species Fungorum 2020), molecular data unavailable.

Type species: Perisporiopsis struthanthi Henn.

Notes: Perisporiopsis was revisited by Boonmee et al. (2017) and provided with a description and illustration of the type species P. struthanthi from the holotype (S-F9814).

Perisporiopsis struthanthi Henn., Hedwigia 43(2): 83 (1904).

Index Fungorum number: IF 216818, Facesoffungi number: FoF 03687; Fig. 121

Description: see Boonmee et al. (2017).

Material examined: Brazil, Rio de Janeiro, Estado de Rio de Janeiro, Serra dos Orgaos, on leaves of Struthanthus sp. (Apocynaceae), August 1899, E.H.G. Ule No. 2631 (S-F9814, holotype).

\section{Other genera included}

Asteronia (Sacc.) Henn., Hedwigia 34: 104 (1895).

Index Fungorum number: IF425, Facesoffungi number: FoF 06215; - 2 morphological species (Species Fungorum 2020), molecular data unavailable.
Type species: Asteronia sweetiae Henn., Hedwigia 34: 104 (1895).

= Parodiopsis sweetiae (Henn.) G. Arnaud, Annls Épiphyt. 7: 53 (1921).

Notes: Wu et al. (2010) revisited Asteronia and provided a description and illustration of the holotype of $A$. sweetiae (K (M) 159800) and suggested to place this genus in families Asterinaceae or Meliolaceae more suitable than place in Microthyriaceae. Later, Wu et al. (2011b) transferred Asteronia to Venturiales incertae cedis. Pem et al. (2019c) provided description and illustration of this genus based on the isotype of A. sweetiae (S-F46114). Its morphology and substrate are consistent with genera in Perisporiopsidaceae. Therefore, Asteronia was transferred to Perisporiopsidaceae by Pem et al. (2019c). Furthermore, species in Asteronia need sequence data to indicate the generic placement.

Byssocallis Syd., Annls mycol. 25(1/2): 14 (1927).

Index Fungorum number: IF 700, Facesoffungi number: FoF 06224; -2 morphological species (Species Fungorum 2020), molecular data unavailable.

Type species: Byssocallis phoebes Syd., Annls mycol. 25(1/2): 14 (1927).

Notes: Boonmee et al. (2011) excluded this genus from Perisporiopsidaceae based on morphology of isolectotype specimen (F10891). Pem et al. (2019c) re-examined the syntype specimen of Byssocallis phoebes (E00455471) and found that it shares common characters with genera in Perisporiopsidaceae such as occur on leaf surface, superficial ascomata with surrounding mycelium and ellipsoidal oblong, multi-septate, hyaline ascospores. Thus, they transferred Byssocallis to Perisporiopsidaceae.

Chevalieropsis G. Arnaud, Annls Épiphyt. 9: 2 (1923).

Index Fungorum number: IF 992, Facesoffungi number: FoF 07894; - 1 morphological species (Speices Fungorum 2020), molecular data unavailable.

Type species: Chevalieropsis ctenotricha (Pat. \& Har.) G. Arnaud, Annls Épiphyt. 9: 2 (1923).

三 Dimerosporium ctenotrichum Pat. \& Har., J. Bot., Paris 14: 242 (1900).

Notes: Chevalieropsis is placed in Perisporiopsidaceae based on its parasitic habit on leaves and shares some characteristics that unite the genus into this family, such as ascomata (or ascostromata) features, thick-walled bitunicate asci and lightly pigmented ascospores.

Parodiellina Henn. ex G. Arnaud, Annals d'École National d'Agric. de Montpellier, Série 2 16(1-4): 21 (1918) [1917].

Index Fungorum number: IF 3750, Facesoffungi number: FoF 07895; - 1 morphological species (Species Fungorum 2020), molecular data unavailable. 
Type species: Parodiellina manaosensis (Henn.) G. Arnaud, Annals d'École National d'Agric. de Montpellier, Série 2 16(1-4): 21 (1918) [1917].

三 Parodiella manaosensis Henn., Hedwigia 43(6): 358 (1904).

Notes: Boonmee et al. (2017) revisited Parodiellina and provided a description and illustration of the holotype of P. manaosensis (PC0084492). Parodiellina is placed in Perisporiopsidaceae based on its parasitic habit on leaves and shares some characteristics that unite the genus into Perisporiopsidaceae.

\section{Economic and ecological significance}

Taxa in this family are parasitic or hyperparasitic on living leaves and occur on upper and lower leaf surfaces. They are widespread in temperate to subtropical and tropical regions such as in Central America and South America (Boonmee et al. 2011, 2017; Hyde et al. 2013; Pem et al. 2019c).

Phaeodimeriellaceae Boonmee, Mapook \& K.D. Hyde, in Boonmee et al., Mycosphere 8(10): 1748 (2017).

Index Fungorum number: IF 553833; Facesoffungi numbers: FoF 03689, 27 species.

Epiphytic on living leaves, or associated with other fungi on leaves. Sexual morph: Ascomata superficial, solitary or scattered, coriaceous, globose to subglobose, dark brown, surrounded by brown to dark brown mycelium at the base, apical ostiole, with hook-like and dark brown setae. Peridium brown to dark brown cells of textura angularis. Hamathecium comprising cylindrical to filiform, branched, septate, cellular pseudoparaphyses. Asci 8-spored, bitunicate, oval to ellipsoidal, apex rounded, short pedicellate, with a small ocular chamber. Ascospores 2-3-seriate, oblong to broadly fusiform, hyaline when immature and pale brown to brown at maturity, 1-septate, with a mucilaginous sheath. Asexual morph: Coelomycetous. Conidiomata pycnidial, superficial, globose to subglobose. Conidiomatal setae long, hook-like, aseptate, dark brown, with blunt apex. Peridium comprises brown cells of textura angularis. Conidiophores reduced to conidiogenous cells. Conidiogenous cells enteroblastic, monophialidic. Conidia fusiform, hyaline, aseptate, guttulate (adapted from Boonmee et al. 2017).

Type: Phaeodimeriella Speg.

Notes: Mapook et al. (2016a) provided sequence data for Phaeodimeriella cissampeli and P. dilleniae, and indicated that both species clustered in a distinct clade within Dothideomycetes. Although, Mapook et al. (2016a) treated Phaeodimeriella as a genus in Pseudoperisporiaceae, Boonmee et al. (2017) excluded this genus and placed it in Phaeodimeriellaceae.

Phaeodimeriella Speg., Revta Mus. La Plata 15(2): 13 (1908).
Index Fungorum number: IF 3908; Facesoffungi number: FoF 01927; 27 morphological species (Species Fungorum 2020), molecular data unavailable.

Type species: Phaeodimeriella parvula (Cooke) Hansf.

Notes: Phaeodimeriella was lectotypified by P. occulta (Theissen 1912). However, P. occulta was synonymized under $P$. parvula by Hansford (1946), therefore the current name of the type species is $P$. parvula. Mapook et al. (2016a) provided molecular data of $P$. cissampeli and $P$. dilleniae. In their analyses, the clade of Phaeodimeriella is related to the clade of Lentitheciaceae with moderate support. However, Phaeodimeriella differs from genera in Lentitheciaceae (see Mapook et al. 2016a). Boonmee et al. (2017) included this genus in the new family Phaeodimeriellaceae based on its morphology and phylogeny. Phaeodimeriella comprises three species, $P$. parvula, $P$. dilleniae and $P$. cissampeli.

Phaeodimeriella parvula (Cooke) Hansf., Mycol. Pap. 15: 64 (1946).

三 Dimerosporium parvulum Cooke, Grevillea 20(no. 93): 5 (1891).

Index Fungorum number: IF 289280; Facesoffungi number: FoF 07896; Fig. 122

Desctiption: see Boonmee et al. (2017).

Material examined: Australia, Queensland, on leaves of Trema tomentosa var. viridis (Cannabaceae). Coll. Bailey 902, Det. A. Sivanesan, (K(M) 181461, holotype).

\section{Economic and ecological significance}

Species in Phaeodimeriellaceae are epiphytic on living leaves, however, they do not cause serious problem on plants. Their life style is unclear.

Pododimeriaceae Boonmee \& K.D. Hyde, in Boonmee et al., Mycosphere 8(10): 1750 (2017).

Index Fungorum number: IF 553834; Facesoffungi numbers: FoF 03692, 5 species.

Parasitic on living coniferous leaves. Sexual morph: Ascomata superficial, with or without hypostroma, solitary, scattered, easily removed, black, with apical ostiole. Peridium comprises multi-layers of brown to dark brown cells of textura angularis. Hamathecium comprising dense, branched, septate, cellular pseudoparaphyses. Asci 8-spored, bitunicate, cylindrical to broadly clavate or ellipsoid, sessile or with knob-like pedicel, rounded at apex, with an ocular chamber. Ascospores 2-3-seriate, irregularly arranged, ellipsoid-fusiform to subclavate, rounded at both ends, olivaceous-brown, 1-supramedian-septate, constricted at the septum, upper cell wider than lower cell. Asexual morph: Undetermined.

Type: Pododimeria E. Müll.

Notes: Pododimeriaceae was introduced by Boonmee et al. (2017) based on morphology to accommodate two 

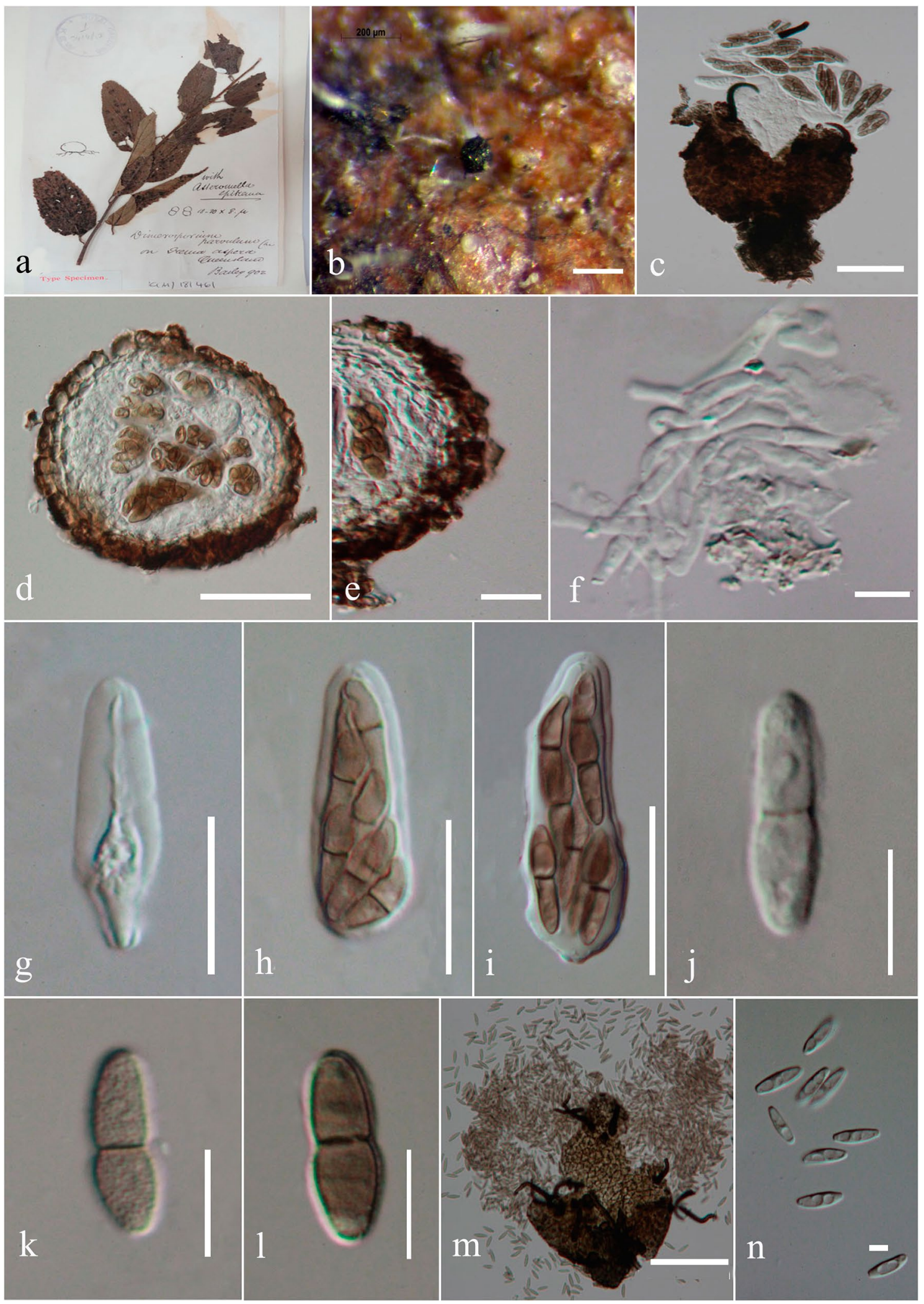

Fig. 122 Phaeodimeriella parvula (K(M) 181461, holotype). a Herbarium specimen and habit on leaves. b Appearance of ascoma on leaf surface. c Setae. d Section of ascoma. e Peridium. f Hamathe- cium of pseudoparaphyses. g, h Asci. i-k Ascospores. $\mathbf{l}$ Section of conidioma. $\mathbf{m}$ Setae. $\mathbf{n}$ Conidia. Scale bars: $\mathbf{b}, \mathbf{d}=40 \mu \mathrm{m}, \mathbf{c}, \mathbf{e}, \mathbf{j}-\mathbf{l}=$ $10 \mu \mathrm{m}, \mathbf{f}, \mathbf{n}=5 \mu \mathrm{m}, \mathbf{g}, \mathbf{i}=20 \mu \mathrm{m}, \mathbf{m}=50 \mu \mathrm{m}$ 

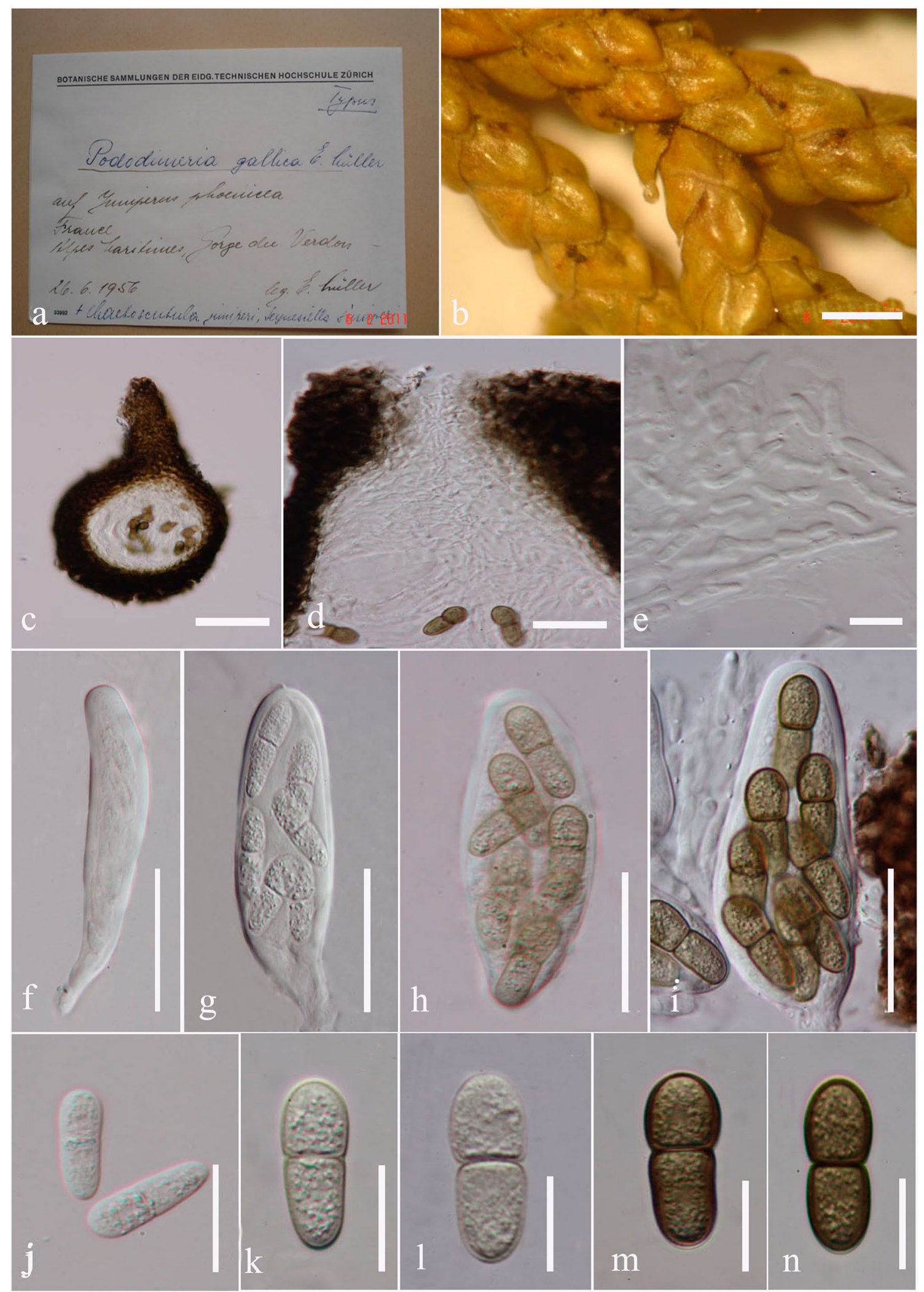

Fig. 123 Pododimeria gallica (Z 33992, holotype). a Herbarium specimen and habit on coniferous leaves. b Appearance of ascomata on leaf surface. $\mathbf{c}$ Section of ascoma. d Close up of apical ostiole. e
Pseudoparaphyses. $\mathbf{f}-\mathbf{i}$ immature to mature asci. $\mathbf{j}-\mathbf{n}$ Immature and mature ascospores. Scale bars: $\mathbf{b}=500 \mu \mathrm{m}, \mathbf{e}=5 \mu \mathrm{m}, \mathbf{c}, \mathbf{d}, \mathbf{f}-\mathbf{i}=40$ $\mu \mathrm{m}, \mathbf{k}-\mathbf{n}=10 \mu \mathrm{m}$ 
genera Chaetoscutula and Pododimeria. No sequence data is available for this family.

Pododimeria E. Müll., Sydowia 12(1-6): 193 (1959) [1958]. Index Fungorum number: IF 4279; Facesoffungi number: FoF 07897; 4 morphological species (Species Fungorum 2020), molecular data unavailable.

Type species: Pododimeria gallica E. Müll.

Notes: Pododimeria was placed in different families, Capnodiaceae, Dimeriaceae, Parodiellaceae, and Pseudoperisporiaceae based on its ascomata and ascospores features and its epiphytic habitat (Gäumann 1964; von Arx and Müller 1975; Barr 1987b; Jaklitsch et al. 2002; Kirk et al. 2008; Lumbsch and Huhndorf 2010; Hyde et al 2013; Wijayawardene et al. 2014a). However, Boonmee et al. (2017) studied the holotype specimen of $P$. gallica and concluded that Pododimeria differs from the species in these families mentioned above. Thus, they introduced a new family Pododimeriaceae to accommodate two genera, Chaetoscutula and Pododimeria.

Pododimeria gallica E. Müll., Sydowia 12(1-6): 195 (1959) [1958].

Index Fungorum number: IF 304077; Facesoffungi number: FoF 03693; Fig. 123

Description: see Boonmee et al. (2017).

Material examined: France, Province Gorges du Verdon, above the bridge over the Artuby River, on living leaves of Juniperus phoenicea (Cupressaceae), 24 June 1956, E. Müller 22813/11 (Z 33992, holotype).

\section{Other genera included}

Chaetoscutula E. Müll., Sydowia 12(1-6): 190 (1959) [1958].

Index Fungorum number: IF 967; Facesoffungi number: FoF 07898; - 1 morphological species (Species Fungorum 2020), molecular data unavailable.

Type species: Chaetoscutula juniperi E. Müll., Sydowia 12(1-6): 191 (1959) [1958].

Notes: Chaetoscutula was placed in Pseudoperisporiaceae by Tian et al. (2014) based on morphology of the herbarium specimen, C. juniper (F225899). Boonmee et al. (2017) included this genus with Pododimeria in the new family Pododimeriaceae, and suggested that molecular data can clarify the relationship between Chaetoscutula and Pododimeria.

\section{Economic and ecological significance}

Pododimeriaceae are parasitic on living leaves of coniferous plants (Butin 1973; Luttrell and Barr 1978; Boonmee et al. 2017).
Polyclypeolinaceae Boonmee \& K.D. Hyde, in Boonmee et al., Mycosphere 8(10): 1754 (2017).

Index Fungorum number: IF 553835; Facesoffungi numbers: FoF 03695, 1 species.

Saprobic, epiphyllous on dried leaves. Sexual morph: Thyriothecium superficial, irregular, scattered to loosely clustered, dark brown to black, slightly shield-like or shallow-convex, epithecium membranaceous cells, edge entire, with apical ostiole. Peridium comprises multi-layers of dark brown cells of textura angularis. Hamathecium comprising branched, septate, cellular pseudoparaphyses. Asci 8-spored, bitunicate, fissitunicate, saccate, cylindric-clavate, with pedicellate. Ascospores irregularly arranged, ellipsoid to fusiform, narrowly obovoid, hyaline, 1-septate, upper cell wider, tapering towards narrow end (adpated from Boonmee et al. 2017). Asexual morph: Undetermined.

Type: Polyclypeolina Bat. \& I.H. Lima.

Notes: Boonmee et al. (2017) established Polyclypeolinaceae to accommodate a single genus Polyclypeolina based on its distinct morphology from other families in Dothideomycetes. No sequence data is available for this family.

Polyclypeolina Bat. \& I.H. Lima, in Batista, Publicações Inst. Micol. Recife 56: 457 (1959).

Index Fungorum number: IF 4307; Facesoffungi number: FoF 07899; 1 morphological species (Species Fungorum 2020), molecular data unavailable.

Type species: Polyclypeolina brideliae (Hansf.) Bat.

Notes: The genus was placed in Aulographaceae based on its branched colonies, superficial, irregular, multi-loculate ascomata, with slit-like opening, and 1-septate, hyaline ascospores (Luttrell 1973). However, Boonmee et al. (2017) introduced Polyclypeolinaceae to accommodate this genus based on its thyriothecium and ascospore features.

Polyclypeolina brideliae (Hansf.) Bat., Publicações Inst. Micol. Recife 56: 457 (1959).

$\equiv$ Polyclypeolum brideliae Hansf., Proc. Linn. Soc. London 157: 37 (1945) [1944-45].

Index Fungorum number: IF 304116; Facesoffungi number: FoF 03696; Fig. 124

Description: see Boonmee et al. (2017).

Materials examined: Uganda, Entebbe, on dried leaves of Brideliae micranthae (Euphorbiaceae), 1945, G.C. Hansford 3309 (K (M) 177972, holotype).

\section{Economic and ecological significance}

Polyclypeolinaceae comprises a single species found on dried leaves. There is no report concerning its economic and ecological significance. More collections and sequence data will help to understand its roles in the environment. 


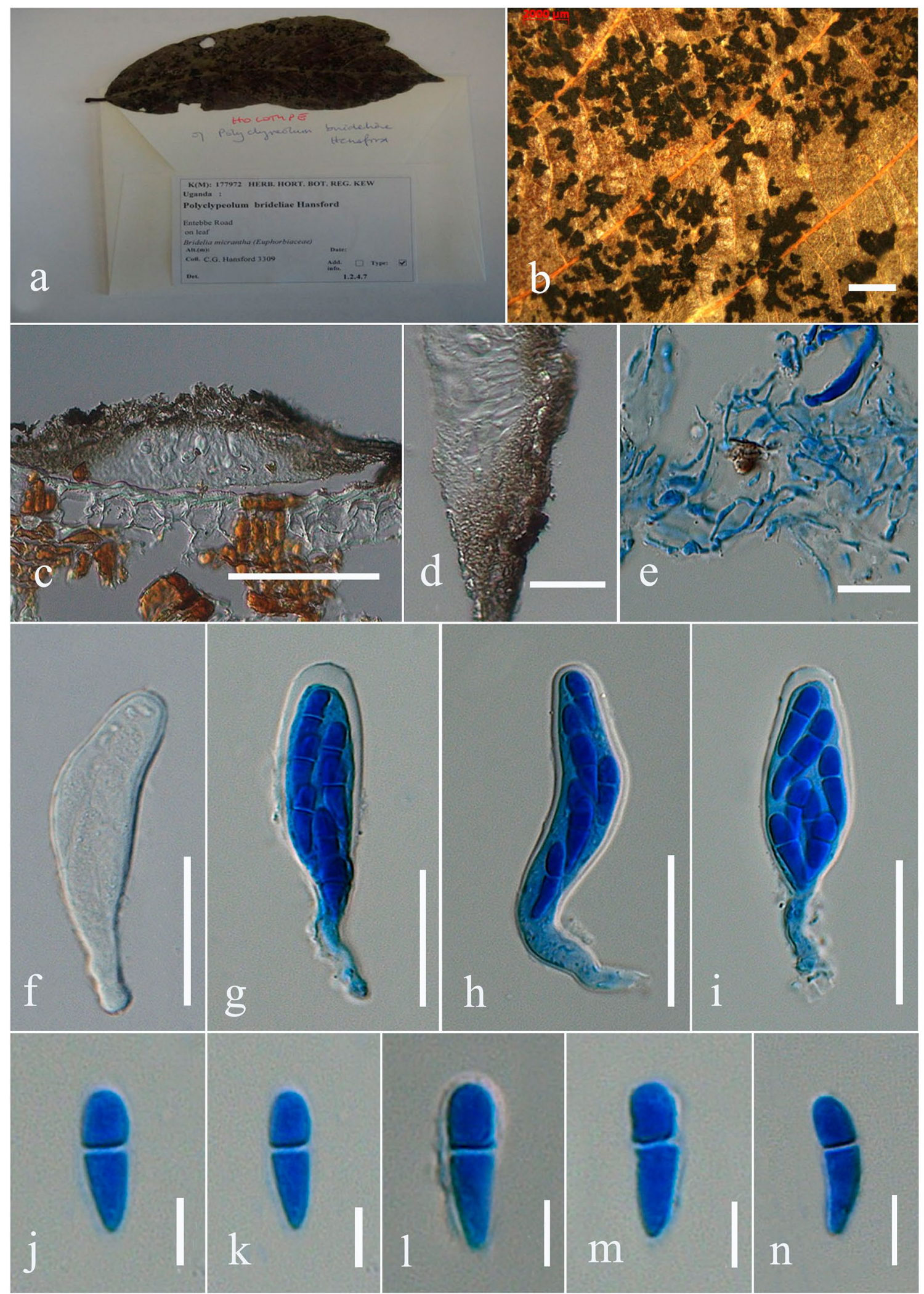

Fig. 124 Polyclypeolina brideliae (K (M) 177972, holotype). a, b Herbarium specimen and habit on leaf. c Section of ascoma. d Peridium e Pseudoparaphyses. f-i Immature and mature asci. j-n
Ascospores. Scale bars: $\mathbf{b}=2 \mathrm{~mm}, \mathbf{c}=100 \mu \mathrm{m}, \mathbf{d}=50 \mu \mathrm{m}, \mathbf{e}=10$ $\mu \mathrm{m}, \mathbf{f}-\mathbf{i}=20 \mu \mathrm{m}, \mathbf{j}-\mathbf{n}=5 \mu \mathrm{m}$ 


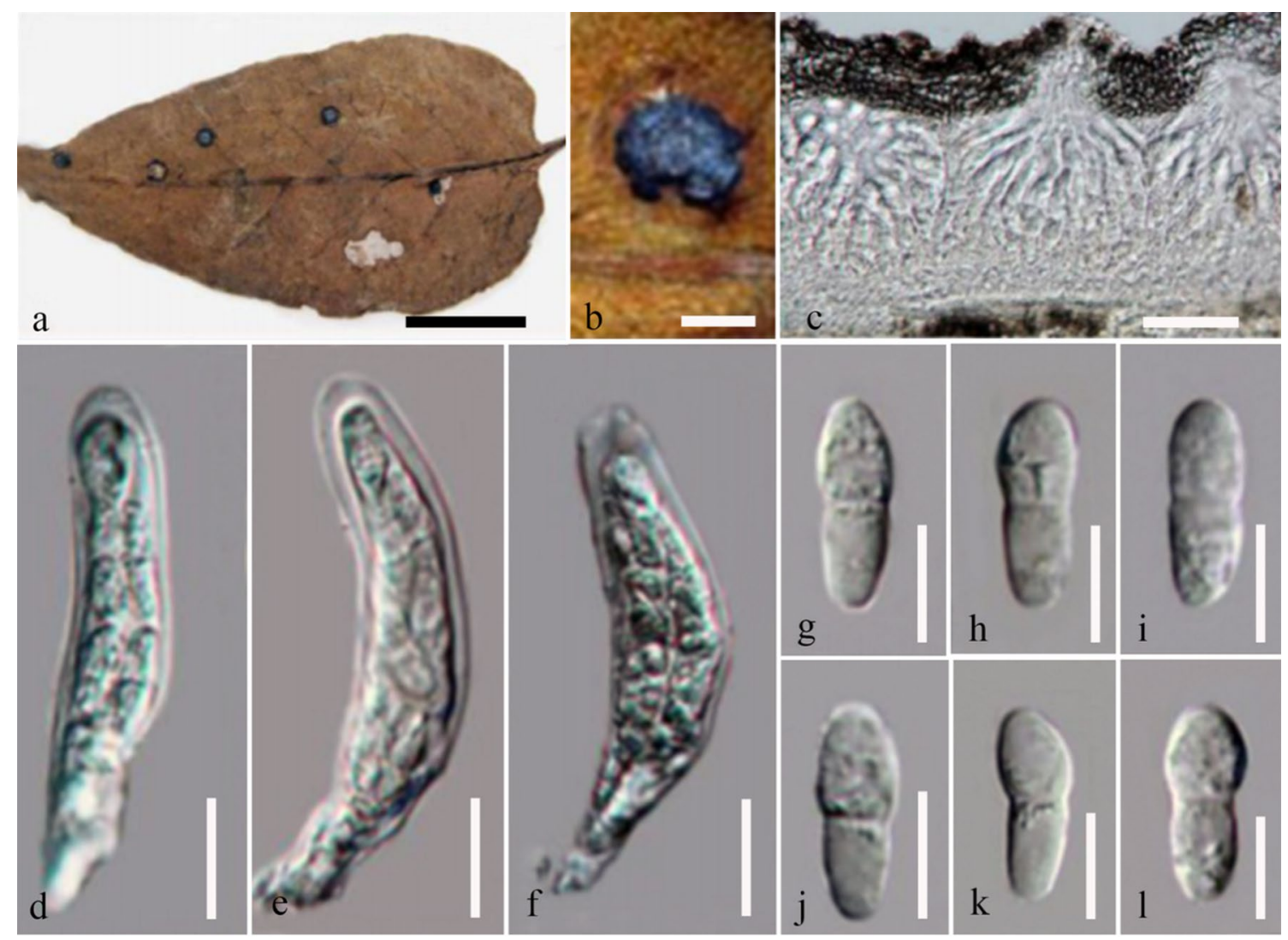

Fig. 125 Dothidella australis (LPS 318, holotype). a Type material. b Appearance of black ascomata on the host. c Section of ascomata. d-f Asci g-l Ascospores. Scale bars: $\mathbf{a}=1 \mathrm{~cm}, \mathbf{b}=1 \mathrm{~mm}, \mathbf{c}=50 \mu \mathrm{m}, \mathbf{d}, \mathbf{e}=15 \mu \mathrm{m}, \mathbf{g}-\mathbf{l}=10 \mu \mathrm{m}$

Polystomellaceae Theiss. \& P. Syd., Annls mycol. 13(3/4): 158 (1915).

Index Fungorum: IF 81205; Facesoffungi number: FoF 06489, 43 species.

= Munkiellaceae (Theiss. \& Syd.) Luttr., in Ainsworth et al., The fungi (London) 4a: 154 (1973).

Biotrophic or parasitic on leaves, typical tropical and subtropical distribution. Sexual morph: Stromata superficial or subcuticular, black, erumpent, pulvinate, and circular to suborbicular, elliptical or elongate, rugulose, containing mostly fungal tissue, globose to subglobose, uniloculate or multiloculate (with 5 to numerous locules), hyphae flattened and ribbon-like with discrete central ostiole. Cells of ascostromata murky brown-walled textura angularis. Peridium of locules soft, often lightly pigmented thick-walled cells of textura angularis and in side view pseudoparenchymatous, darken above locules. Hamathecium comprising numerous, hyaline, septate or aseptate cellular pseudoparaphyses without branching, often deliquescent at maturity. Asci 8-spored, bitunicate, fissitunicate, relatively short, oblong to cylindro-clavate or occasionally obclavate, often ventricose, with a short pedicel, apically rounded, with a small ocular chamber. Ascospores 1-2-seriate, fusiform to ellipsoidal or obpyriform, hyaline, yellowish to olive brown, 0-1-septate, upper cell wider and shorter than the lower cell, euseptate, septate near the lower end or middle, with or without constrictions at the septum, asymmetric, lacking a sheath, wall smooth or verruculose with guttulate contents, sometimes crowded in ascus. Asexual morph: Coelomycetous, acervular, linked to Lasmenia and Stictochorella (Wakefield 1940; Swart 1987; Kirk et al. 2008); conidiogenesis often holoblastic.

\section{Type: Dothidella Speg.}

Notes: Polystomellaceae was introduced by Theissen and Sydow (1915) for Munkiella, Parmularia and Polystomella (the type genus) based upon a foot or hypostroma which anchors the thyrothecium within the host (von Arx and Müller 1975). Other names used for this family are Stigmateaceae (Theissen 1916) and Munkiellaceae (Luttrell 1973). Polystomellaceae consists of species with superficial ascomata, while in Munkiellaceae ascomata are subcuticular, yet the two families were combined by Eriksson (1981). Barr (1987a) included Polystomellaceae as a family in Pleosporales with the genera Atopospora, Hormotheca (currently referred to Venturiaceae) and Ellisiodothis (currently referred to Microthyriaceae). Lumbsch and Huhndorf 
(2010) included three genera Dothidella (= Polystomella) with ascospores having a median septum, Munkiella with apiospores and Parastigmatea in Polystomellaceae under Dothideomycetes, family incertae sedis, and this was followed by Index Fungorum (2020). All share similar characteristics such as a stromatic ascomata resulting from ascolocular ontogeny, with uni- to multi-locular ascostromata, and hyaline ascospores, with one or two cells. Several other genera with amerospores and two with phragmospores have been included in Munkiellaceae (Luttrell 1973). von Arx and Müller (1954) placed Parastigmatea under Botryosphaeriaceae, while in a recent review of the family, Liu et al. (2012) did not include the genus in this family. The three genera placed in Polystomellaceae were described before 1965 (Index Fungorum 2020) and no molecular sequence data is available. Thus, fresh collections are needed to establish the phylogenetic relationships of the genera and Polystomellaceae. Munkiella and Parastigmatea are presently listed in Polystomellaceae, but their inclusion is uncertain for the purpose of keying out the genera.

Dothidella Speg., Anal. Soc. Cient. Argent. 9: 9 (1880).

Index Fungorum number: IF 4327; Facesoffungi number: FoF 06490, 34 morphological species (Species Fungorum 2020), molecular data unavailable.

= Polystomella Speg., Anal. Soc. cient. argent. 26(1): 53 (1888).

Type species: Dothidella australis Speg.

Notes: Dothidella is the type genus of Polystomellaceae and was introduced by Spegazzini (1880). Many species of Dothidella were transferred to Endodothella, Microcyclus, Phyllachora, Rehmiodothis and Stigmochora which belong to Mycosphaerellaceae and Phyllachoraceae (Index Fungorum 2017). They share similar characters such as being biotrophic or parasitic on leaves and have 1-2-celled, hyaline ascospores. Dothidella differs from other genera by its multiloculate ascostromata and ellipsoidal hyaline two celled ascospores, while Phyllachora (Phyllachoraceae) has unilocular ascostromata, unitunicate asci and one celled, hyaline ascospores, and Microcyclus (Mycosphaerellaceae) has multi-loculate ascostromata with two celled hyaline obovoid ascospores (Monkai et al. 2013).

Dothidella australis Speg., Anal. Soc. Cient. Argent. 10: 21 (1880).

$\equiv$ Polystomella pulcherrima Speg., Anal. Soc. cient. argent. 26(1): 53 (1888).

Index Fungorum number: IF 233978; Facesoffungi number: FoF 06491; Fig. 125

Biotrophic or parasitic on leaves. Sexual morph: Ascostromata black, superficial to erumpent, pulvinate, and circular to suborbicular, elliptical or elongate, globose to subglobose, with five to numerous locules, with individual central ostioles, cells of ascostromata compsed of dark brown-walled cells of textura angularis. Peridium of locules composed of small heavily pigmented thick-walled cells of textura angularis. Hamathecium comprising numerous, hyaline, septate or aseptate pseudoparaphyses. Asci 8-spored, bitunicate, fissitunicate, oblong, cylindro-clavate or obclavate with a short pedicel, apically rounded, with a small ocular chamber. Ascospores 2-seriate, ellipsoidal or obpyriform, hyaline, septate, 1-septate, upper cell wider and shorter than the lower cell, euseptate, constricted at the septum, lacking a sheath. Asexual morph: linked to Stictochorella (Wakefield 1940; Swart 1987).

Material examined: Argentina, Buenos Aires, Tigre; on the leaves of Solanum boerhaviaefolium (Solanaceae), O. Schnyder, April1880 (LPS 318, holotype).

\section{Other genera included}

Dermatodothella Viégas, Bragantia 4(1-6): 150 (1944).

Index Fungorum number: IF 1472; Facesoffungi number: FoF 06492; - 1 species (Species Fungorum 2020), molecular data unavailable.

Type species: Dermatodothella multiseptata Viegas, Bragantia 4(1-6): 150 (1944).

Notes: Dermatodothella shares similar characteristics to Dothidella in having multi-loculate, globose to subglobose ascostromata, with widely porate ostioles. Dermatodothella differs from Dothidella in having filiform pseudoparaphyses and multi-septate ascospores, while Dothidella has bi-celled ascospores and lacks pseudoparaphyses (Hyde et al. 2013). Dermatodothella was placed in Polystomellaceae by Ariyawansa et al. (2013b) because of its similarities to other genera in the family.

Munkiella Speg., Anal. Soc. Cient. Argent. 19(6): 248 (1885).

Index Fungorum number: IF 3288; Facesoffungi number: FoF 06493; - 1 morphological species (Species Fungorum 2020), molecular data unavailable.

Type species: Munkiella caa-guazu Speg., Anal. Soc. cient. argent. 19: 248 (1885).

Notes: The asexual morph of this genus is undetermined. The type species of the genera Munkiella, Coscinopeltis and Apiotrabutia were found to be the same fungus, which was named Munkiella caa-guazu. Munkiella was accepted in Polystomellaceae, Dothideomycetes families incertae sedis (Lumbsch and Huhndorf 2010; Hyde et al. 2013; Wijayawardene et al. 2014a).

Parastigmatea Doidge, Bothalia 1(1): 22 (1921).

Index Fungorum number: IF 3723; Facesoffungi number: FoF 06494; 7 morphological species (Species Fungorum 2020), molecular data unavailable. 


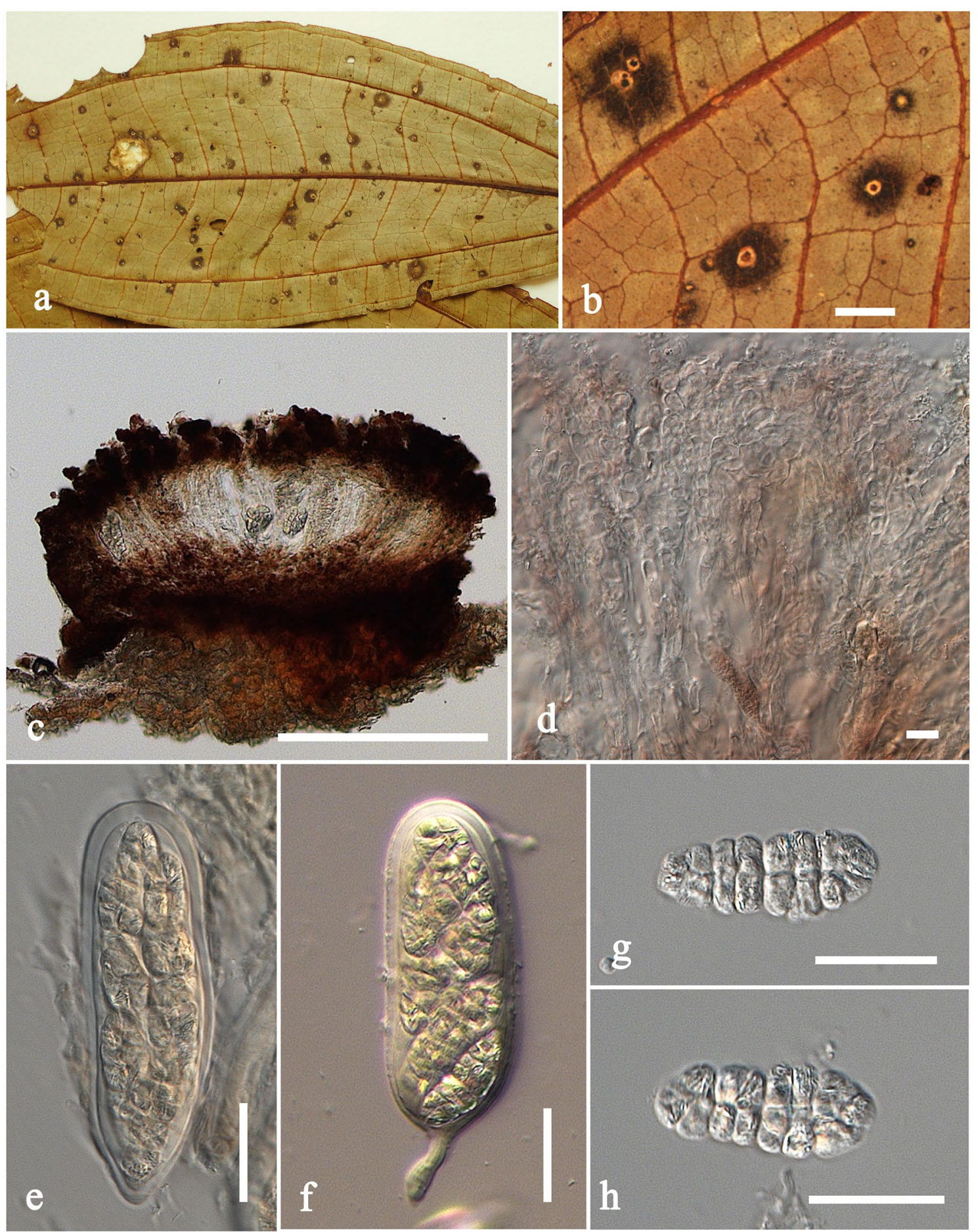

Fig. 126 Protoscypha pulla (BPI663043, type). a Material and habit on leaves. b Appearance of ascostromata. c Sections of ascostroma. d Hamathecium pseudoparaphyses. e, $\mathbf{f}$ Asci. $\mathbf{g}, \mathbf{h}$ Ascospores. Scale bars: $\mathbf{b}=2 \mathrm{~mm}, \mathbf{c}=200 \mu \mathrm{m}, \mathbf{d}=5 \mu \mathrm{m}, \mathbf{e}-\mathbf{h}=20 \mu \mathrm{m}$

Type species: Parastigmatea nervisita Doidge, Bothalia 1(1): 22 (1921).

Notes: Parastigmatea nervisita was isolated from leaves of Stephania hernandifolia in South Africa. Parastigmatea is characterised by epiphyllous ascomata, ovate or broadly ellipsoid, 8-spored asci and conglobate, hyaline ascospores. Parastigmatea was accepted in Polystomellaceae, Dothideomycetes families incertae sedis (Lumbsch and Huhndorf 2010; Hyde et al. 2013; Wijayawardene et al. 2018). The sexual morph is undetermined. 


\section{Economic and ecological significance}

Dothidella include many species which are of economic importance. They play a negative role by causing crop diseases. The Amazon's loss of the rubber market was caused by species from Dothidella making the more efficient plantation cropping impossible in the Amazon (Bunker 1985)

Protoscyphaceae Kutorga \& D. Hawksw., Syst. Ascom. 15(1-2): 70 (1997).

Index Fungorum number: IF 81924, Facesoffungi number: FoF 07900, 2 species.

Parasitic on living leaves of Miconia thomasiana. Sexual morph: Ascostromata superficial, solitary, scattered, occurring on the lower leaf surface, discoid or cup-shaped, slightly convex or raised pulvinate, semi-immersed, flattened and thickened at the base, occurring in lesions of light brown regions and surrounded by external black mycelial, multi-locular, opening by rupturing or cracking of the apical ascostromata. Peridium thick, composed of dark cells arranged in a textura angularis. Hamathecium comprising hyaline, relatively wide, anastomosing, septate, cellular pseudoparaphyses, often with swollen cells, intermixed with reddish brown colouration, and surrounded by a gelatinous matrix. Asci 8 -spored, bitunicate, fissitunicate, subglobose oblong, broadly cylindrical to subclavate, somewhat thickened at the apex, short pedicellate, with a wide, but short ocular chamber. Ascospores 2-3-seriate, muriform, oblong to oval-sub ellipsoid, hyaline, pale brown or light brown, multi-septate, constricted at the septum, surrounded by a thin gelatinous sheath. Asexual morph: Undetermined.

Type: Protoscypha Syd.

Notes: The family currently comprises a monotypic genus Protoscypha with two species and is treated in Dothideomycetes as family incertae sedis (Hyde et al. 2013; Wijayawardene et al. 2018). The family lacks molecular data to establish phylogenetic placement, especially as the type species is yet to be sequenced and no additional new taxa in this family.

Protoscypha Syd., Annls mycol. 23(3/6): 402 (1925).

Index Fungorum number: IF 4394; Facesoffungi number: FoF 07901; - 2 species (Species Fungorum 2020), molecular data unavailable.

Type species: Protoscypha pulla Syd.

Notes: Protoscypha is a tropical genus and comprises only two parasitic species on living leaves (Index Fungorum 2020). The genus is characterized by discoid to cup-like ascostromata, asci in a single locule and muriform, hyaline to lightly pigmented ascospores (Hyde et al. 2013).

Protoscypha pulla Syd., Annls mycol. 23(3/6): 403 (1925). Index Fungorum number: IF 275651; Facesoffungi number: FoF 07902; Fig. 126

Description: see Hyde et al. (2013).
Material examined: Costa Rica, Los Angeles de San Ramon, on leaves of Miconia thomasiana, 30 January 1925, H. Sydow, BPI663043 (type).

\section{Economic significance}

Protoscyphaceae is a parasitic family occurring on living leaves and distributed in tropical countries such as Costa Rica and Brazil.

Pseudoperisporiaceae Toro, in Seaver \& Palacios Chardon, Scient. Surv. P. Rico 8(1): 40 (1926).

Index Fungorum number: IF 81227, Facesoffungi number: FoF 00122, 48 species.

Parasitic, biotrophic or saprobic on leaves, or other fungi, primarily in tropical regions. Sexual morph: Ascomata superficial, solitary to gregarious, scattered, globose to subglobose, collapsed when dry, surrounded by brown mycelium at the base, ostiole central and surrounded by brown, septate setae, tapering to subacute apex. Peridium composed of cells of textura angularis, brown to red brown, thin-walled, sometimes collapsed when dry. Hamathecium comprising cylindrical, filiform, hyaline, branched, septate, cellular pseudoparaphyses, in a gelatinous matrix. Asci 8-spored, bitunicate, fissitunicate, oblong-clavate, slightly curved, thickened at the apex, sessile, or with knob-like pedicel, with small ocular chamber. Ascospores 2-seriate, fusoid-ellipsoid, rounded and subacute ends, hyaline, becoming brownish at maturity, 1-septate, slightly constricted at the septum, wall minutely verrucose. Asexual morph: Coelomycetous.

Type: Lasiostemma Theiss., Syd. \& P. Syd.

Notes: Pseudoperisporiaceae comprises only four genera Bryomyces, Eudimeriolum, Lasiostemma and Nematostoma and is treated in Dothideomycetes as family incertae sedis (Boonmee et al. 2017; Wijayawardene et al. 2018). Taxa in this family are reported as parasitic or saprobic on leaves (Hyde et al. 2013, 2017; Boonmee et al. 2017). The family lacks molecular data to establish phylogenetic placement, especially as the type species is yet to be sequenced.

Lasiostemma Theiss., Syd. \& P. Syd., in Sydow \& Sydow, Annls mycol. 15(3/4): 218 (1917).

Index Fungorum number: IF 2660, Facesoffungi number: FoF 07903, 6 morphological species (Species Fungorum 2020), molecular data unavailable.

Type species: Lasiostemma melioloides (Berk. \& Ravenel) Theiss., Syd. \& P. Syd.

Notes: The genus is characterized by superficial, redbrown to dark brown ascomata, with long hyphae, oblongclavate asci, fusoid-ellipsoid, 1-septate, light brown ascospores. Lasiostemma comprises eight species on living leaves and is distributed in tropical regions e.g., Brazil, Cuba, Malaysia, Uganda (Hyde et al. 2013; Boonmee et al. 


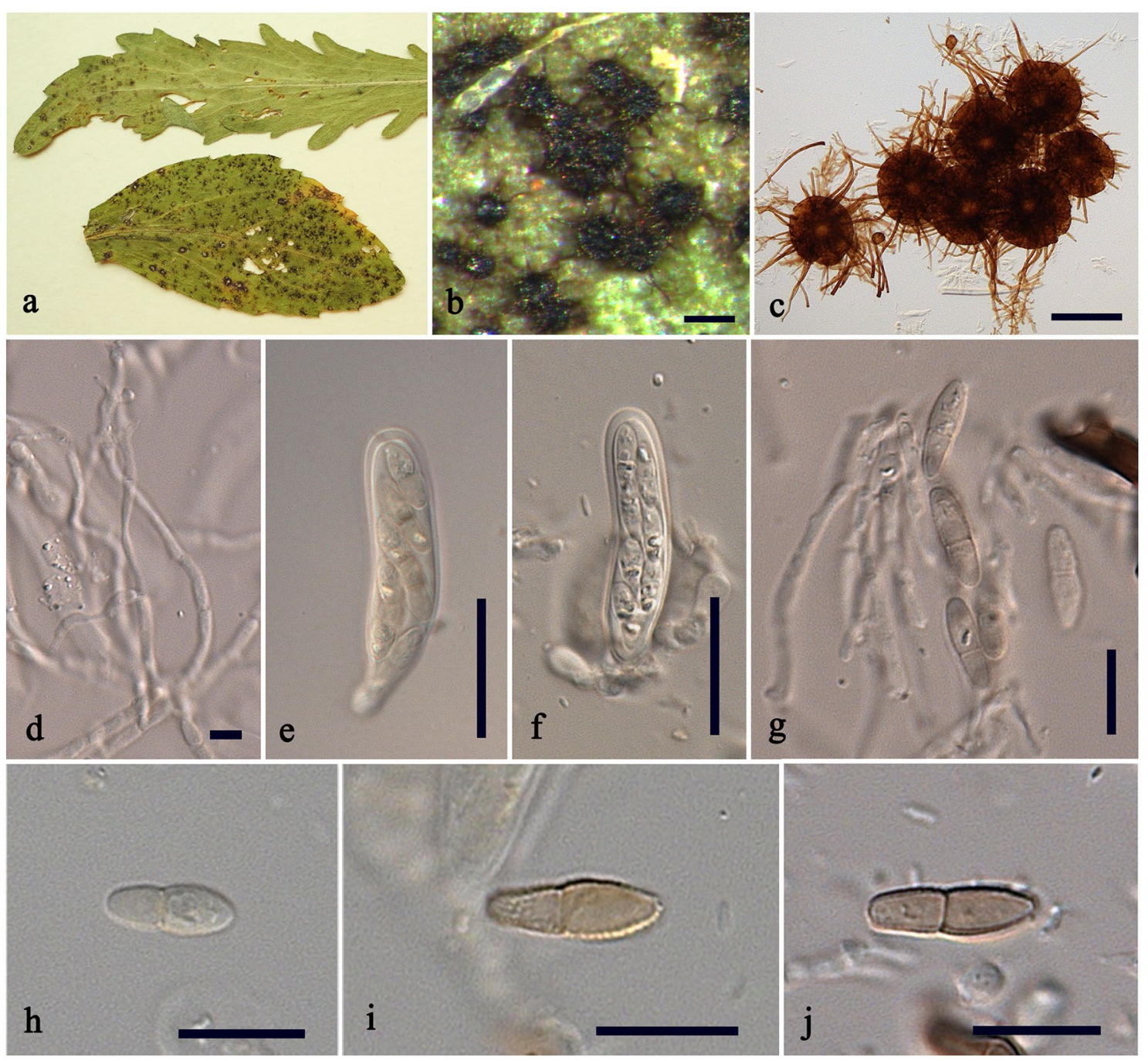

Fig. 127 Lasiostemma melioloides (BPI699548). a Material and habit on leaves. b Appearance of ascomata. c Squash mount of ascoma showing ostiole. d Hamathecium pseudoparaphyses. e, f Asci. $\mathbf{g}-\mathbf{j}$ Ascospores. Scale bars: $\mathbf{b}, \mathbf{c}=100 \mu \mathrm{m}, \mathbf{d}=5 \mu \mathrm{m}, \mathbf{e}, \mathbf{f}=20 \mu \mathrm{m}, \mathbf{g}-\mathbf{j}=10 \mu \mathrm{m}$

2017). Hyde et al. (2013) examined a specimen of Lasiostemma melioloides (BPI699548). The type species Lasiostemma melioloides and its members need sequence data to establish taxonomic placement of this genus.

Lasiostemma melioloides (Berk. \& Ravenel) Theiss., Syd. \& P. Syd., in Sydow \& Sydow, Annls mycol. 15(3/4): 218 (1917).

三Sphaeria melioloides Berk. \& M.A. Curtis, in Berkeley, J. Linn. Soc., Bot. 10(no. 46): 387 (1868) [1869].

Index Fungorum number: IF 102249, Facesoffungi number: FoF 03698; Fig. 127

Description: see Hyde et al. (2013) and Boonmee et al. (2017).

Material examined: Venezuela, Federal district, Puerto La Cruz Valley, El Limón, on leaves of Erigeron bonariensis,
16 January 1928, H. Sydow, Fungi venezuelani No. 249 (BPI699548).

\section{Other genera included}

Bryomyces Döbbeler, Mitt. bot. StSamml., Münch. 14: 233 (1978).

Index Fungorum number: IF 664, Facesoffungi number: FoF 07904; - 9 morphological species (Species Fungorum 2020), molecular data unavailable.

Type species: Bryomyces scapaniae Döbbeler, Mitt. bot. StSamml., Münch. 14: 254 (1978).

Notes: Hyde et al. (2017) revisited Bryomyces and accepted this genus in Pseudoperisporiaceae based on its parasitic or biotrophic habit on living hairy leaves of mosslike plants (liverworts or hornworts). Taxa in this genus are widely distributed and have been found in Austria, Bolivia, 
Japan and Sweden. Hyde et al. (2017) provided description and illustration of the holotype specimen Bryomyces scapaniae, habit on living hairy leaves of Scapania undulata from Austria.

Eudimeriolum Speg., Anal. Mus. nac. Hist. nat. B. Aires 23: 36 (1912).

Index Fungorum number: IF 1922, Facesoffungi number: FoF 07905; - 16 morphological species (Species Fungorum 2020), molecular data unavailable.

Type species: Eudimeriolum elegans Speg., Anal. Mus. nac. Hist. nat. B. Aires 23: 36 (1912).

Notes: Boonmee et al. (2017) revisited Eudimeriolum and accepted this genus in Pseudoperisporiaceae based on its parasitic and saprobic habit on leaves. Taxa in this genus are widely distributed such as in Brazil, Germany, Philippines, Puerto Rico, Tanzania and other tropical countries. Boonmee et al. (2017) provided a description and illustration of the type species Eudimeriolum elegans based on the protologue of Spegazzini (1912).

Nematostoma Syd. \& P. Syd., Annls mycol. 12(2): 161 (1914).

Index Fungorum number: IF 3443, Facesoffungi number: FoF 07906; - 17 morphological species (Species Fungorum 2020), molecular data unavailable.

Type species: Nematostoma artemisiae Syd. \& P. Syd., Annls mycol. 12(2): 161 (1914).

Notes: Boonmee et al. (2017) revisited Nematostoma and accepted this genus in Pseudoperisporiaceae based on parasitic and saprobic habit on leaves. Taxa in this genus are widely distributed such as in Argentina, Japan, Mexico, the USA and other tropical countries. Boonmee et al. (2017) provided a description and illustration of the holotype specimen Nematostoma artemisiae, habit on living leaves of Artemisia vulgaris var. indica from Japan.

\section{Economic and ecological significance}

Pseudoperisporiaceae is rather a large family and comprises 48 taxa which are parasitic, biotrophic or saprobic habit on leaves. All taxa in this family are widespread in distribution and usually associated on living leaves, but some taxa are found on dead leaves. Bryomyces is commonly associated with moss-like plants such as liverwort and hornworts (Döbbeler 1978; Hyde et al. 2017).

Pseudorobillardaceae Crous, Fungal Systematics and Evolution 3: 108 (2019).

Index Fungorum number: IF 829342; Facesoffungi numbers: FoF 07907, 18 species.

Saprobic, pathogenic or endophytic on soil or decaying living and dead leaves, stems. Sexual morph: Undetermined. Asexual morph: Conidiomata immersed, globose, unilocular, with central ostiole. Conidiogenous cells thinwalled with of 3-6 layers, composed of flattened cells of textura angularis. Hamathecium numerous, hyphae-like, aseptate, flexuous, paraphyses, intermingled among conidiophores. Conidiogenous cells sub-cylindrical to ampulliform, hyaline, smooth. Conidia contain micro- or macroconidia, subcylindrical, hyaline, aseptate, smooth-walled, guttulate, apex obtuse, base truncate; apical appendages hair-like, flexuous, unbranched, fragile, flexuous, unbranched.

Type: Pseudorobillarda M. Morelet.

Notes: Pseudorobillardaceae (Dothideomycetes) was informally introduced by Crous et al. (2018a) based on morphology and phylogeny. Later Pseudorobillardaceae was formally introduced by Crous et al. (2019a) to accommodate Pseudorobillarda. In previous studies this genus was placed in Dothideomycetes genera incertae sedis (Tangthirasunun et al. 2014; Wijayawardene et al. 2018).

Pseudorobillarda M. Morelet, Bull. Soc. Sci. nat. Arch. Toulon et du Var 175: 5 (1968).

Index Fungorum number: IF 9607; Facesoffungi number: FoF 07559; 18 morphological species (Species Fungorum 2020), 7 species with molecular data.

Type species: Pseudorobillarda phragmitis (Cunnell) M. Morelet.

Notes: The members of this genus can be saprobic, pathogenic and endophytic and are known from temperate and tropical countries such as Argentina, Canada, Cuba, Germany, India, Nigeria, South Africa, Thailand, UK, Ukraine, and the USA (Petrini 1986; Nag-Raj 1993; Bianchinotti 1997; Vujanovic and St-Arnaud 2003; Plaingam et al. 2005; Tangthirasunun et al. 2014; Crous et al. 2018a). This genus occurs on both living and dead leaves, stems or bark and is also commonly found in soil (Petrini 1986; Vujanovic and St-Arnaud 2003; Kadowaki et al. 2014). Keys to species in Pseudorobillarda were provided in Sutton (1980), Nag-Raj (1993) and Vujanovic and St-Arnaud (2003). The revised descriptions and illustrations of Pseudorobillarda, based on morphological characteristics are available in Plaingam et al. (2005). No sexual morph is linked to Pseudorobillarda (Hyde et al. 2011; Wijayawardene et al. 2012, 2017a; Tangthirasunun et al. 2014).

Pseudorobillarda phragmitis (Cunnell) M. Morelet, Bull. Soc. Sci. nat. Arch. Toulon et du Var 175: 6 (1968).

$\equiv$ Robillarda phragmitis Cunnell, Trans. Br. mycol. Soc. 41(4): 405 (1958).

Index Fungorum number: IF 321865; Facesoffungi number: FoF 07565, Fig. 128

Description: see Li et al. (2020).

Materials examined: UK, England, Middlesex, near Staines, on dead stems of Phragmites communis (Poaceae), July 1955, G. J. Cunnell (IMI 70768, holotype). 


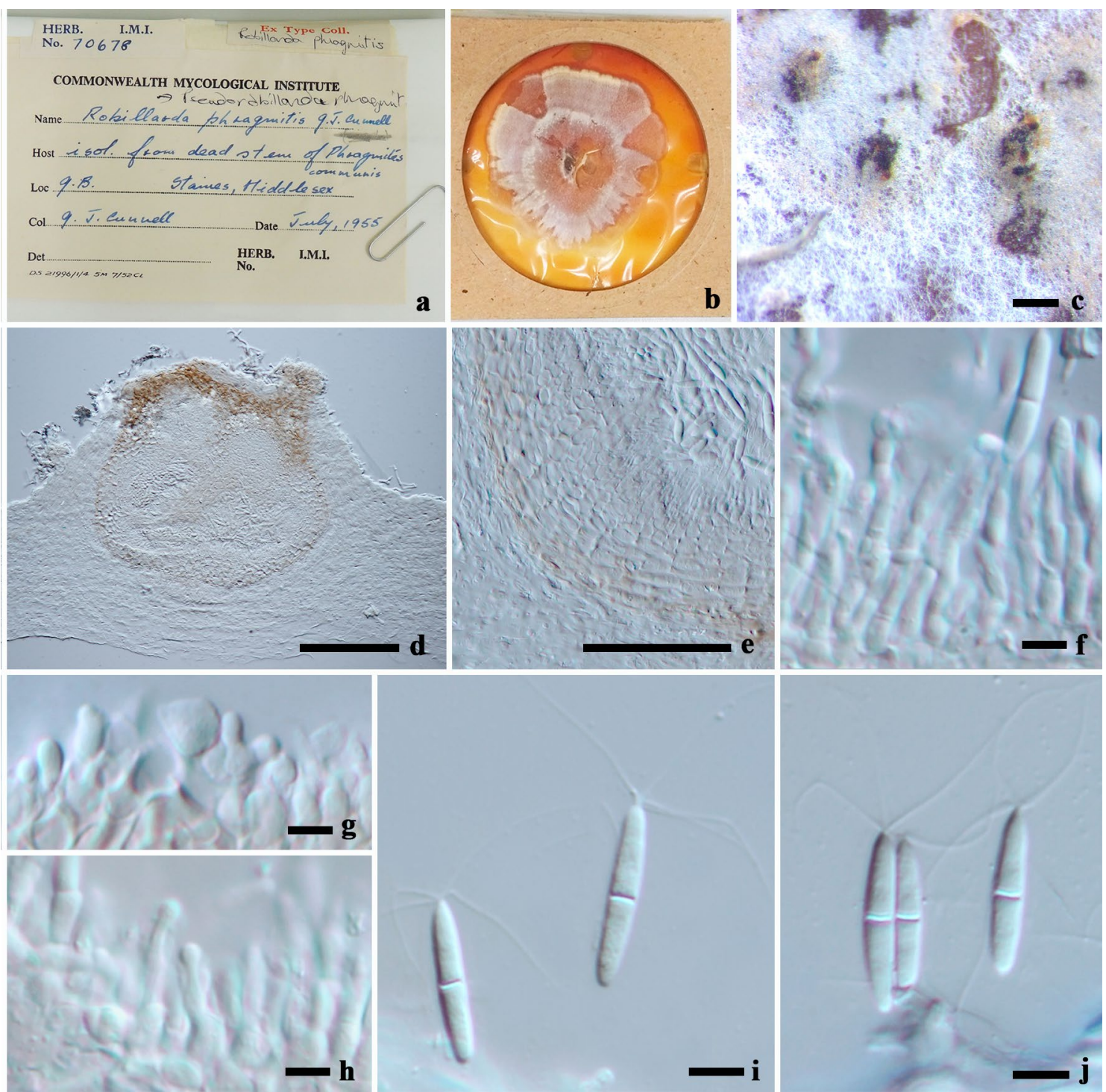

Fig. 128 Pseudorobillarda phragmitis (IMI 70768, holotype). a Herbarium packet. b Dried culture. c Colony characteristics in culture. d Section of conidioma. e Conidiogenous cells with developing conidia.

\section{Economic and ecological significance}

Pseudorobillardaceae is a small family containing only a single genus and they are important for nutrient cycling as they are saprobic on a wide variety of plant substrates. On the other hand, some species of Pseudorobillarda are known as one of the top ten most abundant soil fungi (Kadowaki et al. 2014).

Pyrenidiaceae Zahlbr. in Engler, syllabus der Pflanzenfamilien, Edn 2 (Berlin): 46 (1898).

Index Fungorum number: IF 81790; Facesoffungi numbers: FoF 07908, 13 species. $\mathbf{f}-\mathbf{h}$ Conidiogenous cells. i, j Conidia. Scale bars: $\mathbf{c}=200 \mu \mathrm{m}, \mathbf{d}=$ $100 \mu \mathrm{m}, \mathbf{e}=50 \mu \mathrm{m}, \mathbf{f}-\mathbf{j}=5 \mu \mathrm{m}$,

Lichenicolous on various substrates such as bark, rock, soil, bryophytes or living leaves. Sexual morph: Ascomata perithecioid, densely grouped or dispersed over large areas of the thallus, sessile or immersed in the host thallus, black, in longitudinal section, subglobose to broadly ovoid or pyriform, often with light greenish-blue tint in the ostiolar canal. Peridium with isodiametric to elongated cells, brown to dark brown. Hymenium hyaline, I-, KI-. Hamathecium of numerous, persistent, branched, anastomosing pseudoparaphyses; apical cells not enlarged; non-branching periphyses. Asci 4-8-spored, bitunicate, short pedicellate, I-, KI-, ocular chamber not distinct. Ascospores 1-2-seriate, oblong to ellipsoidal, or fusiform, dark brown, often paler brown at 
Fig. 129 Pyrenidium actinellum (Ertz. 16557 (BR)). a Appearance of ascomata on host surface. b Vertical section of host with perithecioid ascoma visible. $\mathbf{c}, \mathbf{d}$ Asci. $\mathbf{e}-\mathbf{g}$ Ascospores. Scale bars: $\mathbf{b}=50$ $\mu \mathrm{m}, \mathbf{c}, \mathbf{d}=10 \mu \mathrm{m}, \mathbf{e}-\mathbf{g}=5 \mu \mathrm{m}$
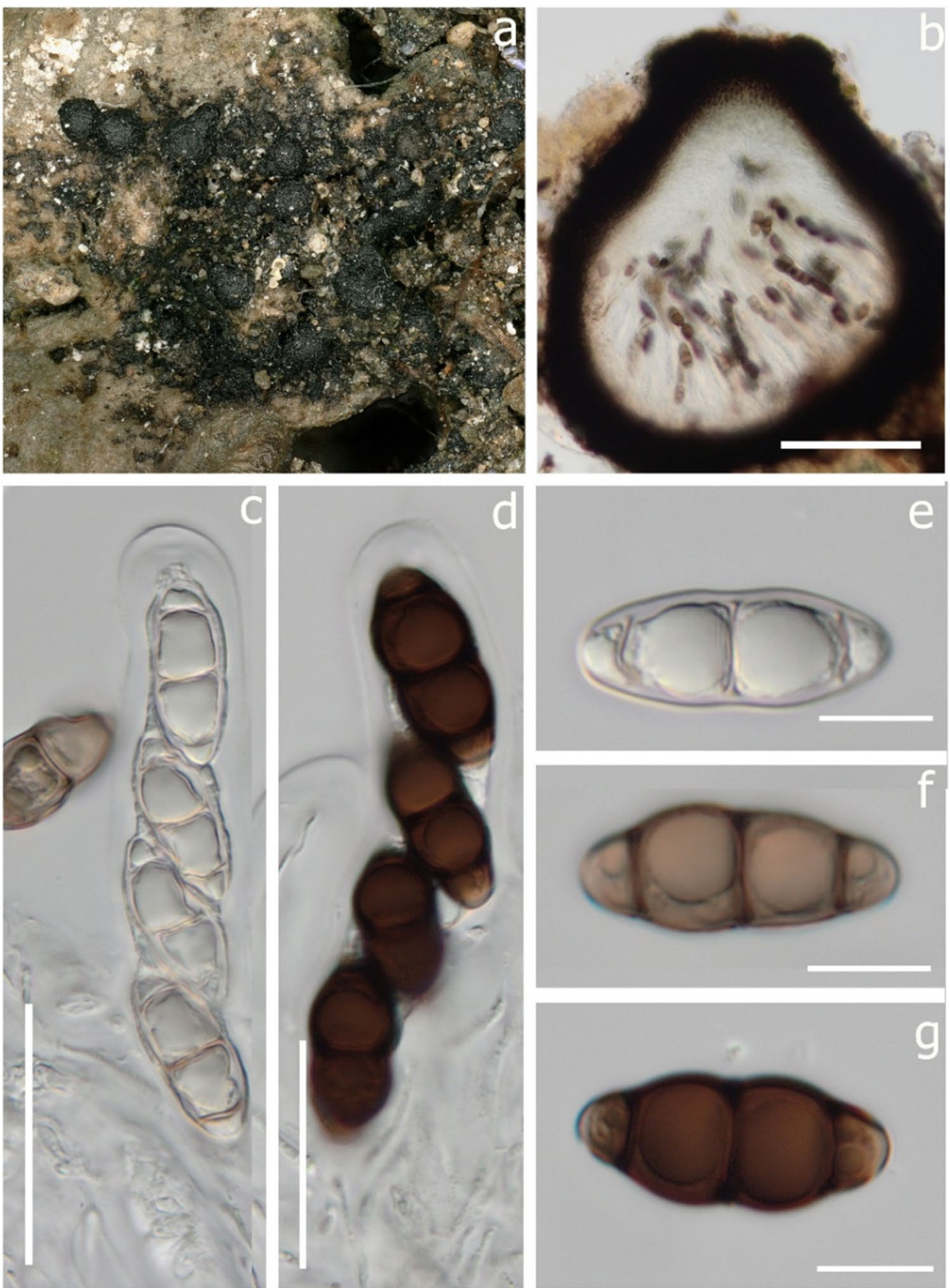

the spore tips, 3-septate, smooth-walled. Asexual morph: Undetermined (adapted from Huanraluek et al. 2019a).

Type: Pyrenidium Nyl.

Notes: Huanraluek et al. (2019a) provided sequence data for Pyrenidium species and indicated that Pyrenidium formed a distinct clade outside Dacampiaceae. However, Huanraluek et al. (2019a) did not assign Pyrenidiaceae to any order. Pyrenidiaceae formed a distinct clade outside Pleosporales in personal analyses of Hongsanan et al. (2020, data not showed), and formed within Pleosporales as a distinct family (data not showed) in the dataset which includes all representative families in Dothideomycetes (data not showed). Therefore, we agree with Huanraluek et al. (2019a) to treat this family as incertae sedis in Dothideomycetes until more collections with multi-loci are available to clarify its phylogenetic placement.

Pyrenidium Nyl., Flora, Regensburg 48: 210 (1865).

Index Fungorum number: IF 4578; Facesoffungi numbers: FoF 07909; 13 morphological species (Species Fungorum 2020), 3 species with molecular data.

Type: Pyrenidium actinellum $\mathrm{Nyl}$.

Notes: Pyrenidium was placed in Dacampiaceae based on morphology and the environmental habitats (Hyde et al. 
2013; Wijayawardene et al. 2014a, 2018; Jaklitsch et al. 2016). Crivelli (1983) suggested that Pyrenidium has close relationship with Dacampia in Dacampiaceae in its similar ascomatal structures and wall tissues (Crivelli 1983). However, sequence data of three species, Pyrenidium actinellum, $P$. aff. aggregatum and $P$. borbonicum, were provided by Huanraluek et al. (2019a). These sequence data formed a distint clade far from Dacampiacceae. Thus, Pyrenidiaceae was resurrected to accommodate species of Pyrenidium.

Pyrenidium actinellum Nyl., Flora, Regensburg 48: 210 (1865).

Index Fungorum number: IF 403001; Facesoffungi numbers: FoF 04634; Fig. 129

Description: see Huanraluek et al. (2019a).

Materail examined: Belgium, Aywaille, versant droit de l'Amblève, Heid des Gattes, $200 \mathrm{~m}$ elev. Paroi de grès à Anema, on the lichen Scytinium plicatile, 2011, (Ertz. 16557 $(\mathrm{BR})$ ).

\section{Economic and ecological significance}

Species of Pyrenidium are lichenicolous developing on lichen thalli, with parasymbionts living in symbiosis (Hawksworth 1982; Diederich et al. 2018). The ascomata of Pyrenidium are immersed to erumpent in host thalli with the upper part exposed and sometimes causing gall-like malformations of the host (Eriksson and Hawksworth 1993; Matzer 1996; Pirogov 2014; Lendemer 2017; Muscavitch et al. 2017).

Seynesiopeltidaceae K.D. Hyde, in Hyde et al., Fungal Diversity 63: 232 (2013).

Index Fungorum number: IF 804042; Facesoffungi number: FoF 06522, 1 species.

Foliar epiphytes on leaves, causing black spots, usually confluent in groups, forming black colonies. Sexual morph: Mycelium superficial, sparse, light, septate, olive-green. Thyriothecia solitary or gregarious, superficial, circular, shield-like, shallow, conical, dome-like, flattened, upper region, carbonaceous, unilocular, brown to black, basal layer poorly developed, lacking a distinct central ostiole. Upper wall comprising radiating arranged parallel cells, cells at margin branching. Hamathecium comprising 1-3 $\mu \mathrm{m}$ wide, comprising numerous, cellular, branched pseudoparaphyses. Asci 8-spored, bitunicate, fissitunicate, saccate, with a knoblike pedicel, and conspicuous ocular chamber (in Congo red). Ascospores irregularly 2-3-seriate, dark brown when mature, 1-septate, strongly constricted at septum, upper cells longer and wider, basal cell shorter and narrower with an acute base, with a thick, structured, hyaline, cell wall. Asexual morph: Undetermined.

Type: Seynesiopeltis F. Stevens \& R.W. Ryan.
Notes: Seynesiopeltidaceae was introduced by Hyde et al. (2013) based on the unique brown ascospores with thick structured walls and thick ascus wall when stained in Congo red. The cells of the peridium consist of two strata of textura angularis cells. Ascomata are described as thyriothecia-like and they resemble some genera in Parmulariaceae (e.g. Polycyclus andinus, Inácio and Cannon 2008). Genera such as Dothidasteroma and Cocconia (also Parmulariaceae) may also be related as they have brown ascospores, but the asci are significantly different (Inácio and Cannon 2008). Notably, Seynesiopeltis differs from Parmularia, the type genus of Parmulariaceae. In Parmularia styracis, the thyriothecia have a similar appearance to shells on the host surface, the asci are obclavate and ascospores are hyaline.

Seynesiopeltis F. Stevens \& R.W. Ryan, in Stevens, Bulletin of the Bernice P. Bishop Museum, Honolulu, Hawaii 19: 69 (1925).

Index Fungorum number: IF 5020; Facesoffungi number: FoF 07910, 1 morphological species (Species Fungorum 2020), molecular data unavailable.

Type species: Seynesiopeltis tetraplasandrae F. Stevens \& R.W. Ryan.

Notes: Seynesiopeltis is the type genus of Seynesiopeltidaceae and it was established by Stevens (1925) as a monotypic genus with $S$. tetraplasandrae as the type and has remained monotypic. This genus was earlier assigned to Microthyriaceae by Stevens (1925) which was followed by Muller and von Arx (1962) and Lumbsch and Huhndorf (2010). This genus was moved to Dothideomycetes genera incertae sedis by $\mathrm{Wu}$ et al. (2011b) since it was unlike any other member of the class Dothideomycetes. It is characterised by unfree mycelium, round and radiate ascomata with thallus being setose. Stevens (1925) mentioned that species in this genus resembles Seynesia but are different in that they possess one to several ascomata in one fungus body and that this bears setae which intensify the uniqueness of the genus and family. However, no setae in the type specimen was observed by Hyde et al. (2013). A plausible reason might be loss of setae during storage as the latter is described as being fragile. The genus is monotypic and warrants further investigation.

Seynesiopeltis tetraplasandrae F. Stevens \& R.W. Ryan, Bulletin of the Bernice P. Bishop Museum, Honolulu, Hawaii 19: 70 (1925).

Index Fungorum number: IF 158371; Facesoffungi number: FoF 06523; Fig. 130

Foliar epiphyte on leaves, causing black spots, typically confluent, forming black colonies. Sexual morph: Mycelium superficial, sparse, septate, olive-green. Thyriothecia 347-483 $\mu \mathrm{m}$ diam. 438-565 $\mu \mathrm{m}$ high, solitary or gregarious, superficial, with a circular, shield-like, shallow, conical, 


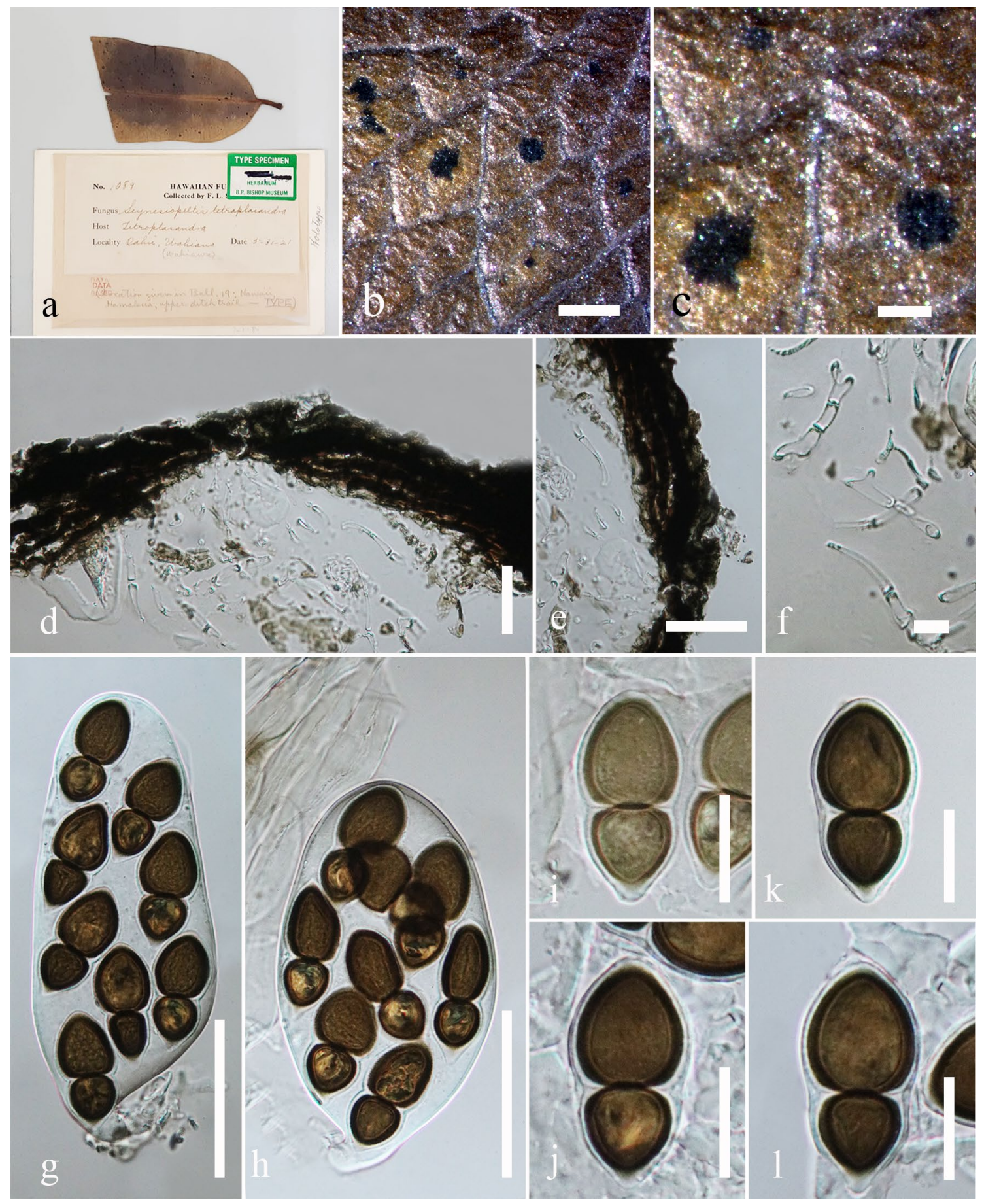

Fig. 130 Seynesiopeltis tetraplasandrae (BISH 1089, holotype). a Details of herbarium material. b, $\mathbf{c}$ Habit and appearance of thyriothecia on the host surface. d Section of ascoma. e Peridium. $\mathbf{f}$

dome-like, flattened, upper region, carbonaceous, unilocular, brown to black, basal layer poorly developed, lacking a distinct central ostiole. Upper wall comprising radiating parallel cells, cells at margin branching. Hamathecium comprising 1-3 $\mu \mathrm{m}$ wide, numerous, cellular, branched
Hamathecium. g, h Asci. i-l Ascospores. Scale bars: $\mathbf{b}=2000 \mu \mathrm{m}$, $\mathbf{c}=500 \mu \mathrm{m}, \mathbf{d}=25 \mu \mathrm{m}, \mathbf{e}=35 \mu \mathrm{m}, \mathbf{f}=10 \mu \mathrm{m}, \mathbf{g}, \mathbf{h}=50 \mu \mathrm{m}, \mathrm{i}-\mathrm{l}=$ $20 \mu \mathrm{m}$

pseudoparaphyses. Asci $117-142 \times 59-68 \mu \mathrm{m}(\bar{x}=127 \times$ $65 \mu \mathrm{m}, \mathrm{n}=20), 8$-spored, bitunicate, fissitunicate, saccate, with a knob-like pedicel and conspicuous ocular chamber. Ascospores $36-41 \times 13-15 \mu \mathrm{m}(\bar{x}=39 \times 14 \mu \mathrm{m}, \mathrm{n}=20)$ irregularly $2-3$-seriate, dark brown when mature, 1 -septate, 

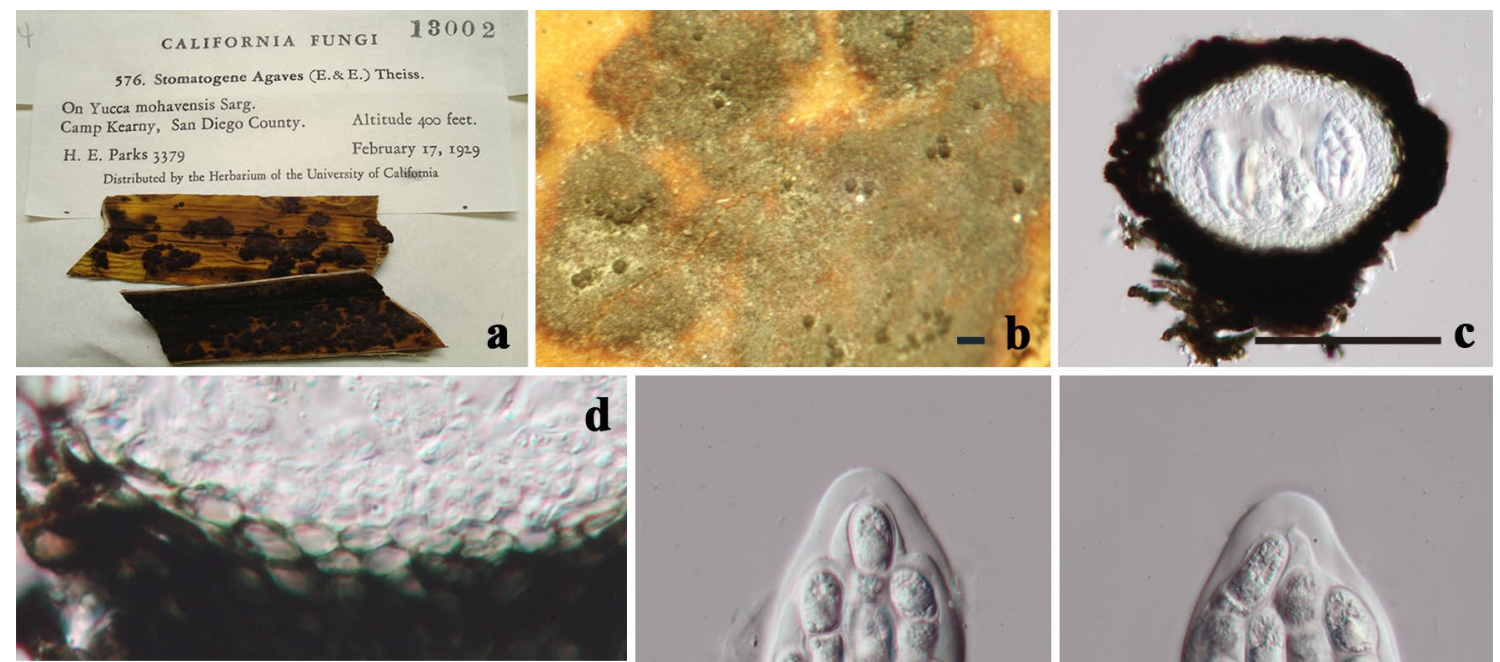

\section{d}
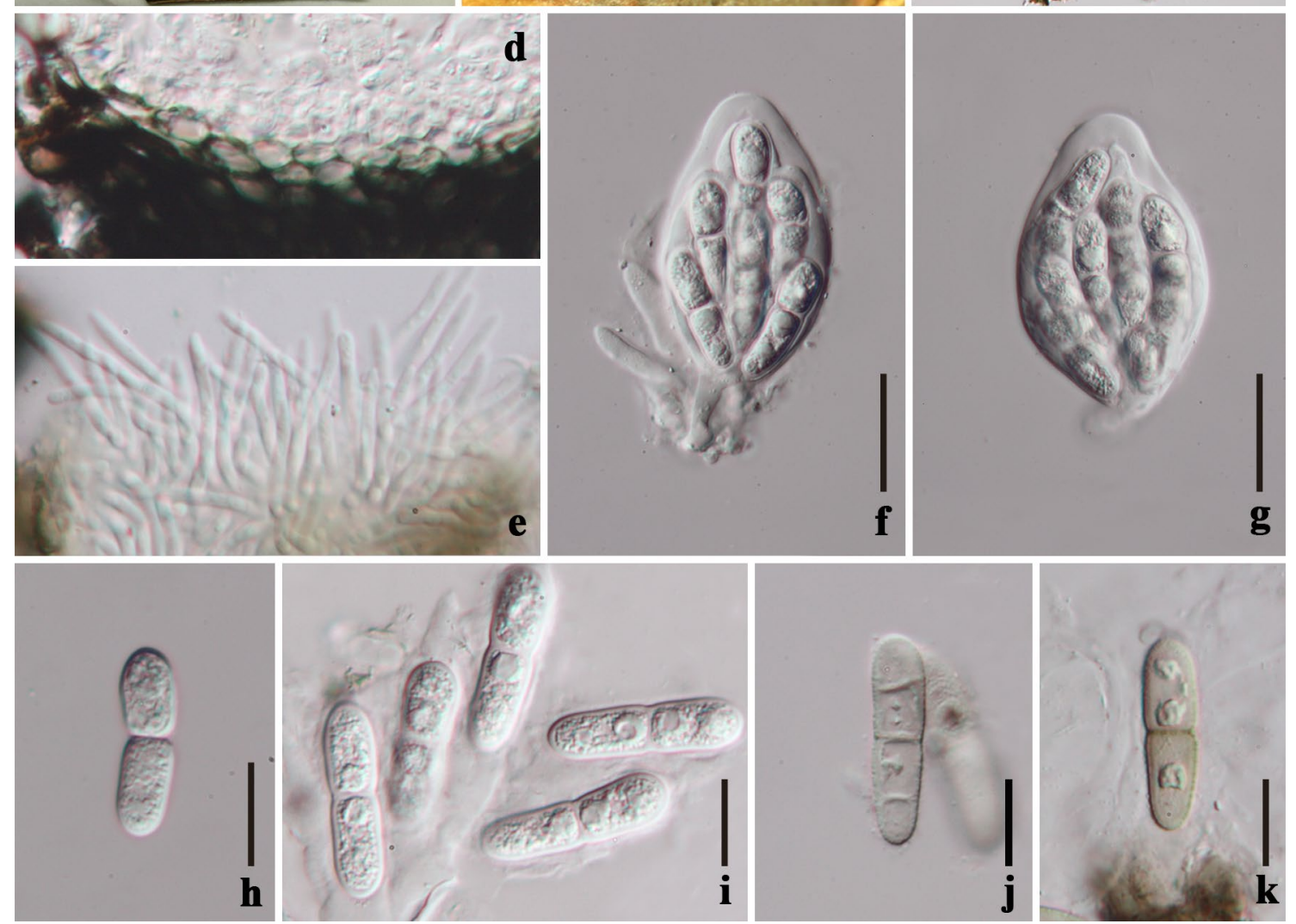

Fig. 131 Stomatogene agaves (NY 02977047). a Herbarium specimen and habit on leaves. b Appearance of ascomata on leaf surface. c Section of ascoma. d Peridium. e Hamathecium. f, $\mathbf{g}$ Asci. $\mathbf{h}-\mathbf{k}$ Ascospores. Scale bars: $\mathbf{b}=200 \mu \mathrm{m}, \mathbf{c}=50 \mu \mathrm{m}, \mathbf{f}, \mathbf{g}=20 \mu \mathrm{m}, \mathbf{h}-\mathbf{k}=10 \mu \mathrm{m}$

strongly constricted at septum, upper cells longer and wider, basal cell shorter and narrower with an acute base, with a thick, structured, hyaline, cell wall. Asexual morph: Undetermined.

Material examined: USA, Hawaii, Oahu, Hamakua, upper ditch trail, on leaves of Tetraplasandra (Araliaceae), 31 May 1921, Stevens F.L. (BISH 1089, holotype).

Notes: Seynesiopeltis tetraplasandrae was introduced by Stevens and Ryan (1925). It was found on leaves of Tetraplasandra in Hawaii and was described as having unfree mycelium, round ascomata consisting several locules and lacking paraphyses. Further collections are required to resolve this genus.

\section{Economic and ecological significance}

Seynesiopeltis is a monotypic genus and foliar epiphytes on leaves. Its life style is unclear as to whether it is saprobic or parasitic.

Stomatogeneceae Boonmee \& K.D. Hyde, in Boonmee et al., Mycosphere 8(10): 1762 (2017).

Index Fungorum number: IF 553837; Facesoffungi numbers: FoF 03703, 4 species.

Parasitic on living leaves of Agave sp. (Asparagaceae) and mosses. Colonies large, superficial, subcircular, irregular, with numerous, dark brown mycelium, radiating outwards, flexuous, septate. Sexual morph: Ascomata superficial, semi-immersed at the base, with a basal hypostroma developing in the host tissue, gregarious, or solitary, black, with apical pore, surrounded by dark brown mycelium. 
Fig. 132 Morphology of Thyrinula $\mathrm{spp} .(\mathrm{a}-\mathrm{d}=$ Thyrinula eucalypti redrawn from Crous et al. 2019c; e-g = Thyrinula parasitica redrawn from Summerell et al. 2006). a Ascomata on lesion surface. b Vertical section through ascomata. c Asci. d Ascospores. e-g Conidiophores and conidia. Scale bars $=10 \mu \mathrm{m}$ a

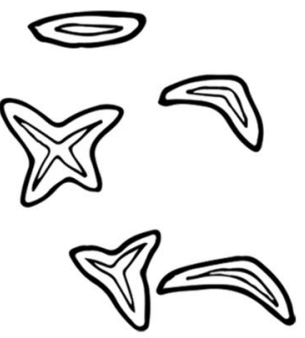

C

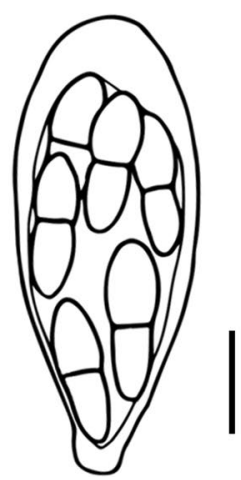

Peridium 3-4 layers, dark pigmented cells of textura angularis, lacking pseudoparaphyses. Asci 8-spored, bitunicate, fissitunicate, subglobose, broadly ovoid to subclavate, apically thickened, with an ocular chamber at apex, knob-like pedicellate. Ascospores multi-seriate, ellipsoidal oblong, hyaline when immature, brown at maturity, 1-septate, upper cell slightly broader and shorter than lower cell, verrucose or smooth-walled. Asexual morph: Undetermined (adapted from Boonmee et al. 2017).

Type: Stomatogene Theiss.

Notes: This family was introduced by Boonmee et al. (2017) to accommodate the single genus, Stomatogene. Stomatogeneceae can be differentiated from other families in Dothideomycetes by its colonies, ascomata, asci and ascospore features. However, no sequence data is available in GenBank.

Stomatogene Theiss., Annls mycol. 14(6): 406 (1917) [1916].

Index Fungorum number: IF 5270; Facesoffungi number: FoF 03704; 4 morphological species (Species Fungorum 2020), molecular data unavailable.

Type species: Stomatogene agaves (Ellis \& Everh.) Theiss.

Notes: The genus was placed in Parodiopsidaceae by Eriksson et al. (2001), Kirk et al. (2008), Lumbsch and Huhndorf (2010) and Hyde et al. (2013). Boonmee et al.

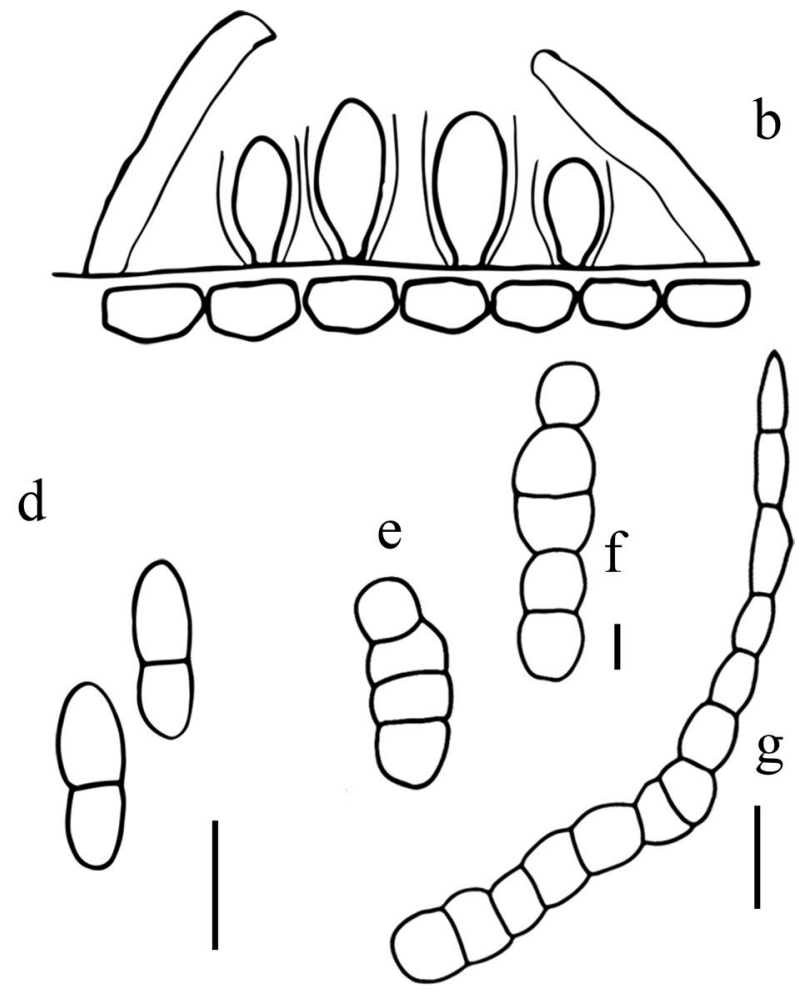

(2017) concluded that Stomatogene should be placed in its own family based on its unique morphological characters.

Stomatogene agaves (Ellis \& Everh.) Theiss., Annls mycol. 14(6): 406 (1918) [1917].

三Asterina agaves Ellis \& Everh., Bull. Torrey bot. Club 27: 571 (1900).

Index Fungorum number: IF 121867; Facesoffungi number: FoF 03705; Fig. 131

Description: see Boonmee et al. (2017).

Material examined: Mexico, Sonora, in the vicinity of Álamos, on living leaves of Agave sp. L (Asparagaceae), March 1910, J.N. Rose No.13063 (NY 02977047).

\section{Economic and ecological significance}

Species in Stomatogeneceae are parasitic on living leaves of Agave sp. (Asparagaceae) and mosses.

Thyrinulaceae X.Y. Zeng, S. Hongsanan \& K.D. Hyde, fam. nov.

Index Fungorum number: IF 557945; Facesoffungi number: FoF 06898, 10 species.

Pathogens on surface of leaves or petioles. Leaf spots epiphyllous or hypophyllous, circular to irregular, single to confluent, brown. Sexual morph: Ascomata superficial, dark brown, hysterothecial, opening by elongated, longitudinal 

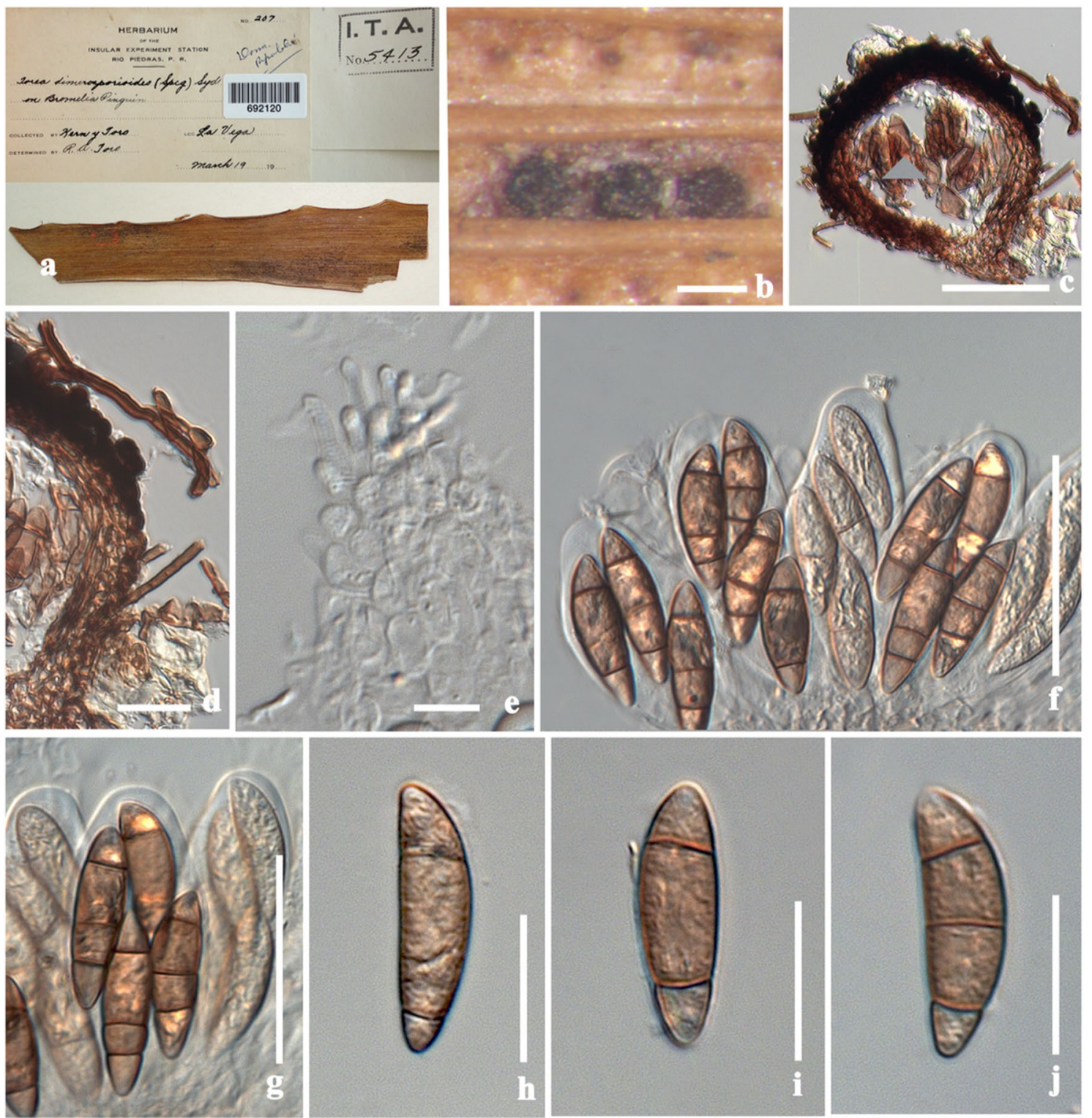

Fig. 133 Toroa dimerosporioides (BPI 692120). a Herbarium specimen. b Ascomata on leaf surface. c Section of ascoma. d Peridium. e Hamathecium. f, $\mathbf{g}$ Asci. $\mathbf{h}-\mathbf{j}$ Ascospores. Scale bars: $\mathbf{b}=100 \mu \mathrm{m}, \mathbf{c}, \mathbf{f}, \mathbf{g}=50 \mu \mathrm{m}, \mathbf{d}, \mathbf{h}-\mathbf{j}=20 \mu \mathrm{m}, \mathbf{e}=10 \mu \mathrm{m}$

or Y-shaped slits, margin without restricted brown, superficial hyphae. Asci 8 -spored, bitunicate, broadly ellipsoid to somewhat obovoid, intermixed among hyphae-like, septate, branched pseudoparaphyses, with ocular chamber. Ascospores cylindrical to ellipsoid, hyaline, 1-septate, constricted at septum, ends obtusely rounded, guttulate, smooth-walled. Asexual morph: Coelomycetous or hyphomycetous. Coelomycetous: Mycelium brown, septate, branched, verrucous. Conidiomata brown, acervular, solitary to gregarious or confluent, immersed to erumpent, depressed globose, unilocular. Ostiole absent, dehiscence by irregular splits of apical wall in the middle part. Conidiomatal wall composed of a single layer of brown cells in the basal part. Conidiophores arising from inner wall layer of basal stroma, brown, branched at the base, septate. Conidiogenous cells brown, holothallic, cylindrical, integrated or discrete, determinate, verrucous. Conidia brown, arthric, formed by disarticulation of the conidial chain, produced in simple unbranched chains with the youngest conidium at the base, surrounding by mucoid sheath, ellipsoidal to globose or subcylindrical, truncate at the base, aseptate, verrucose, guttulate (adapted from Giraldo et al. 2017). Hyphomycetous asexual morph: Conidiophores single or sporodochial, if conidiophores single, micronematous, mononematous, straight to slightly flexuous, brown, septate, smooth; if conidiophores sporodochial, brown, verrucose, thick-walled, 

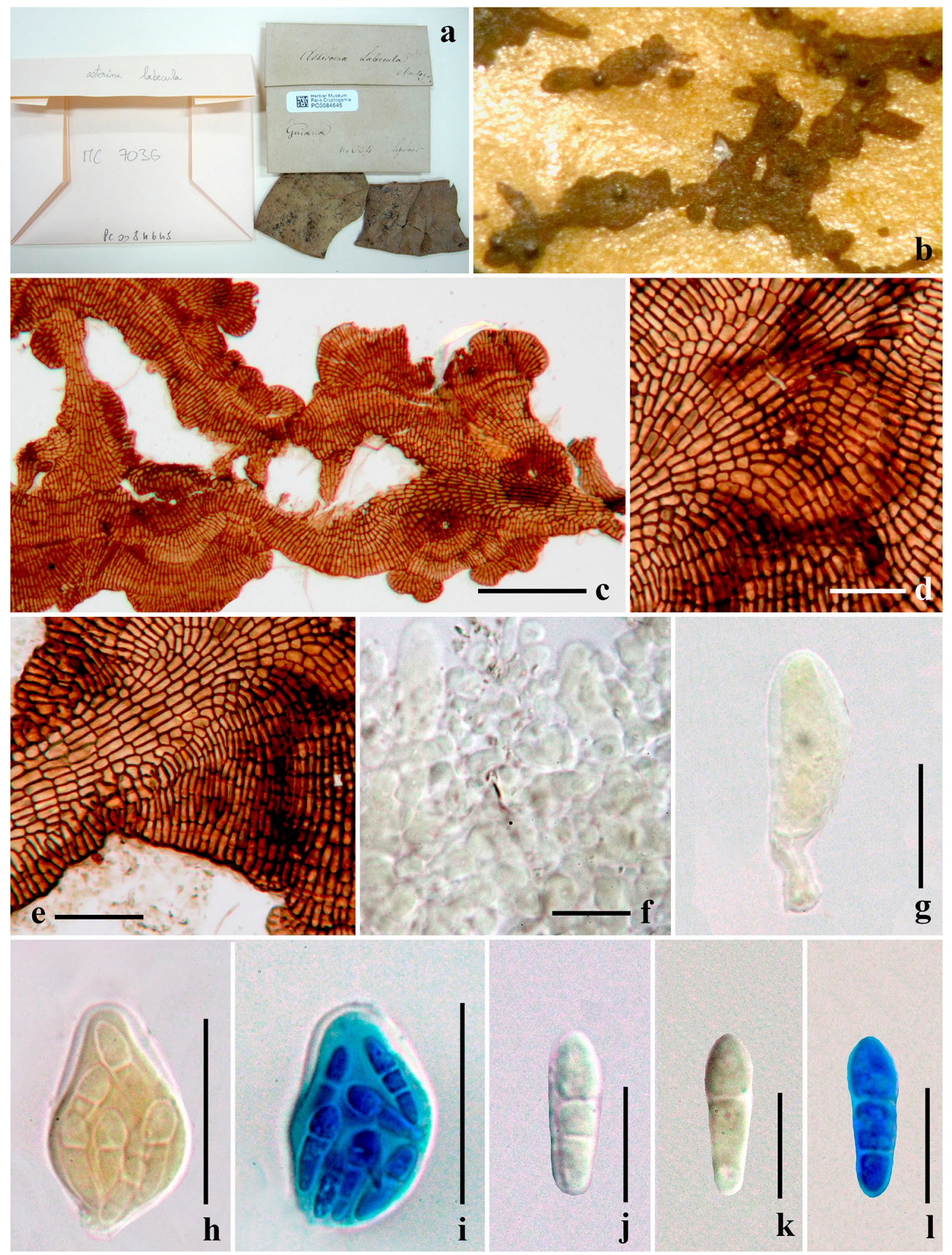

Fig. 134 Asterina labecula (PC 0084645, syntype). a Specimens. b Ascomata on host substrate. c Ascomata with thin and superficial thallus in $70 \%$ lactic acid. d Walled cells of ascoma and ostiole. e Walled cells of thallus composed darkly pigmented cells. f Hamathecium in Melzer's reagent. g Asci when immature in Melzer's reagent. h Asci in Melzer's reagent. i Asci in cotton blue reagent. $\mathbf{j}$ Ascospore 2-septate in 70\% lactic acid. k Ascospore uniseptate in Melzer's reagent. $\mathbf{l}$ Ascospore 2-septate in cotton blue reagent. Scale bars: $\mathbf{c}=100$ $\mu \mathrm{m}, \mathrm{e}-\mathrm{i}=20 \mu \mathrm{m} . \mathrm{j}-\mathrm{l}=10 \mu \mathrm{m}$ 

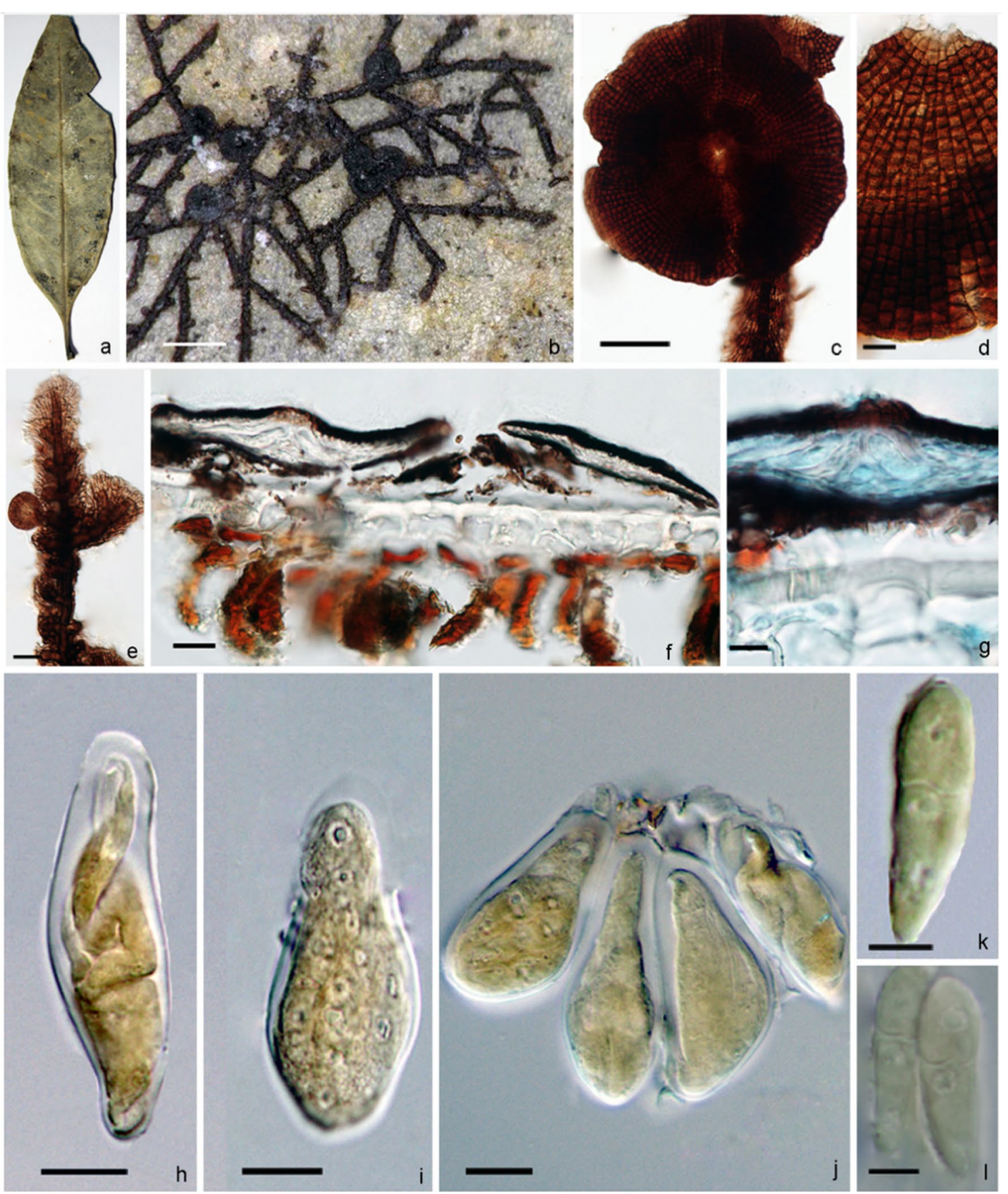

Fig. 135 Trichothyrium sarciniferum (LPS1441, holotype). a The leaf substrate. b Colonies on the leaf surface. $\mathbf{c}$ Squash mount of the ascoma. d The upper wall of ascomata. e Superficial mycelium forming thalli on hyphae of Meliolaceae species. $\mathbf{f}, \mathbf{g}$ Cross section of the ascoma. $\mathbf{h}-\mathbf{j}$ Asci mounted in Melzer's reagent. $\mathbf{k}, \mathbf{l}$ Ascospores mounted in Melzer's reagent. Scale bars: $\mathbf{b}=200 \mu \mathrm{m}, \mathbf{c}=50 \mu \mathrm{m}, \mathbf{e}-\mathbf{f}$ $=20 \mu \mathrm{m}, \mathbf{d}, \mathbf{g}-\mathbf{j}=10 \mu \mathrm{m}, \mathbf{k}-\mathbf{l}=5 \mu \mathrm{m}$ 

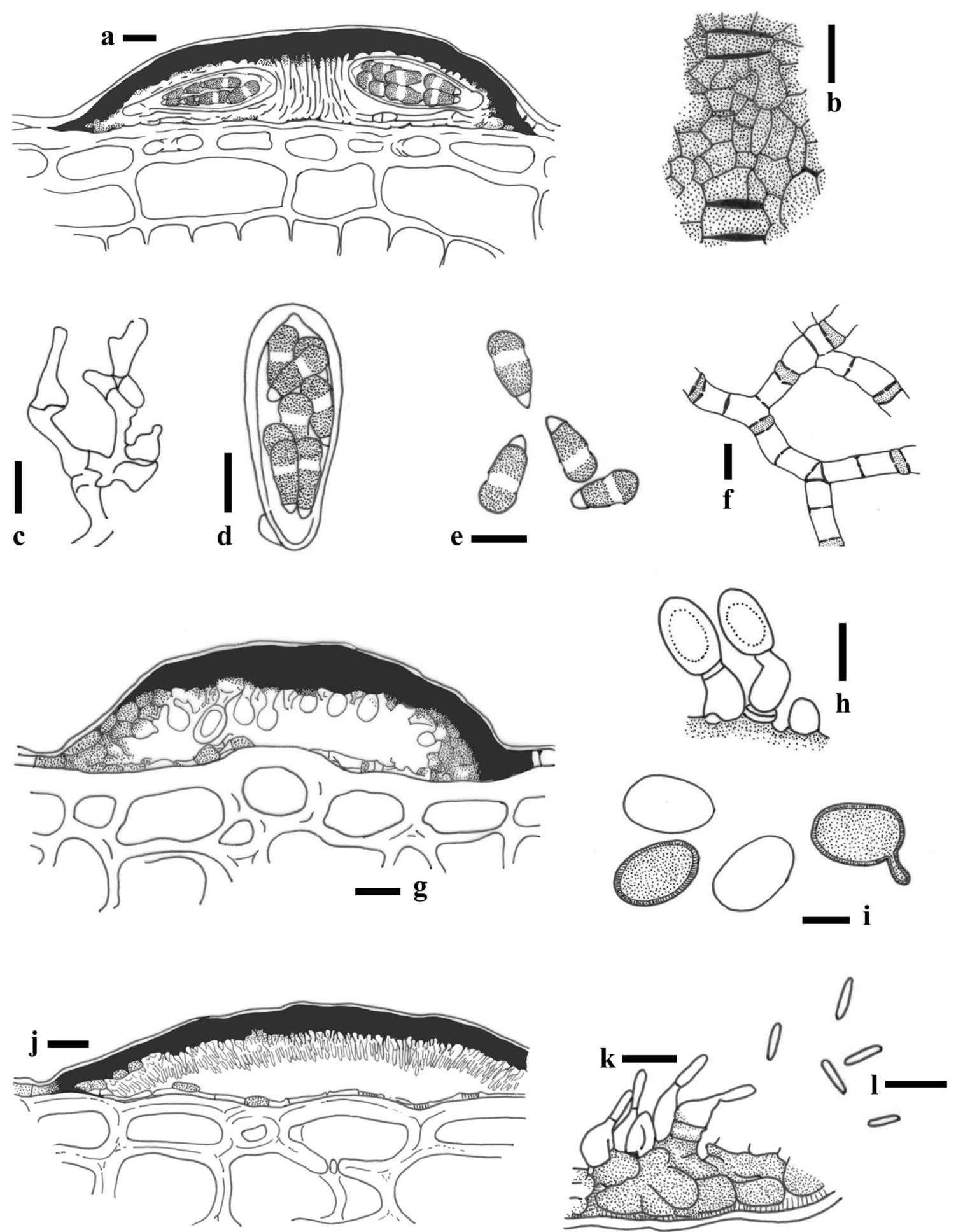

Fig. 136 Vizella oleariae (Redrawn from Swart 1971). a Section through ascoma. b Surface of ascoma. c Proliferating crosiers. d Asci. e Ascospores. f Surface view of hypha. $\mathbf{g}-\mathbf{l}$ Conidia and spermatia. Scale bars: $\mathbf{a}-\mathbf{g}, \mathbf{j}=10 \mu \mathrm{m}, \mathbf{h}, \mathbf{i}, \mathbf{k}, \mathbf{l}=5 \mu \mathrm{m}$ 
branched, septate. Appressoria when present, numerous, entire, globose to cylindrical, alternate to unilateral, aseptate, brown, penetration peg central on the appressorial cell. Conidiogenous cells holoblastic, monoblastic, integrated, intercalary, cylindrical to elliptical, light brown to brown, smooth, sometimes with indistinct scars. Conidial secession schizolytic. Conidia solitary or in branched or simple acropetal chains, ellipsoidal to cylindrical, aseptate to multiseptate, medium brown to brown, smooth or verruculose, sometimes with rounded ends.

Type: Thyrinula Petr. \& Syd.

Notes: This family is introduced to accommodate species that are phylogenetically related to Asterinales sensu lato, a clade that is typified by the type sequence data of Asterina and Lembosia obtained by Guatimosim et al. (2015). However, the genetic distance between the two genera is less than the two Asterina species in their phylogeny, indicating that these two sequences are questionable. There are three genera included in this family based on phylogeny, and they are sister to Parmulariaceae (Parmulariales).

Thyrinula Petr. \& Syd., Annls mycol. 22(3/6): 373 (1924).

$=$ Alysidiella Crous, in Summerell et al., Fungal Diversity 23: 325 (2006).

Index Fungorum number: IF 10218; Facesoffungi number: FoF 06728; 5 morphological species (Crous et al. 2019c), 5 species with molecular data.

Type species: Thyrinula eucalyptina Petr. \& Syd., Annls mycol. 22(3/6): 373 (1924)

Notes: Thyrinula is characterized by hysterothecia opening by elongated, longitudinal or Y-shaped slits, and 1-septate ascospores. Its asexual morph Alysidiella was introduced to accommodate a single species with both aseptate and multi-septate conidia. Crous et al. (2019c) provided sequence data of all members of the genus from fresh collections, and synonymized Alysidiella under Thyrinula based on morphology (Fig. 132).

\section{Other genera included}

Blastacervulus H.J. Swart, Trans. Br. mycol. Soc. 90(2): 289 (1988).

Index Fungorum number: IF 11029; Facesoffungi number: FoF 06733; - 4 morphological species (Species Fungorum 2020), 3 species with molecular data.

Type species: Blastacervulus eucalypti H.J. Swart, Trans. Br. mycol. Soc. 90(2): 289 (1988).

Notes: Blastacervulus is a coelomycetous genus characterised by acervular conidiomata and thallic, 1-septate conidia with truncate, flat hila. Wijayawardene et al. (2016) showed that B. eucalypti clustered in Planistromellaceae, however, it forms within the Thyrinulaceae in our analyses (Fig. 5).
Paraopeba V.P. Abreu, A.A.M. Gomes, Firmino \& O.L. Pereira, in Crous et al., Persoonia 39: 349 (2017).

Index Fungorum number: IF 821209; Facesoffungi number: FoF 06740; - 1 morphological species (Species Fungorum 2020), with molecular data.

Type species: Paraopeba schefflerae V.P. Abreu, A.A.M. Gomes, Firmino \& O.L. Pereira, in Crous et al., Persoonia 39: 349 (2017).

Notes: Paraopeba is hyphomycetous characterized by schizolytic conidiogenous cells, 2-13-septate conidia and the present of appressoria. Crous et al. (2017) introduced it as a monotypic genus in Asterinales based on the phylogenetic analysis.

\section{Economic and ecological significance}

Members of this family are important plant pathogens that can cause leaf and petiole lesions.

Toroaceae Boonmee \& K.D. Hyde, in Boonmee et al., Mycosphere 8(10): 1769 (2017).

Index Fungorum number: IF 553838; Facesoffungi numbers: FoF 03708, 1 species.

Saprobic on dried leaves. Sexual morph: Ascomata superficial, globose to subglobose, solitary to gregarious, scattered, black, with a subiculum, collapsing when dry, with apical ostiole. Peridium comprising red brown to dark brown cells of textura angularis. Asci 4-spored, bitunicate, oblong-ellipsoid to ovoid, sessile, apically thickened. Ascospores 2-seriate, ellipsoid-fusiform, narrow towards the ends, pale brown to orange brown, light at both ends, smooth-walled. Asexual morph: Undetermined (adapted from Boonmee et al. 2017).

Type: Toroa Syd.

Notes: Boonmee et al. (2017) established this family to accommodate the genus Toroa. Toroaceae differs from other families in the Dothideomycetes in having only four ascospores in the ascus and a combination of other characters (Boonmee et al. 2017). No sequence data is available for this family.

Toroa Syd., in Toro, J. Dept. Agric. Porto Rico 10(2): 19 (1926).

Index Fungorum number: IF 5500; Facesoffungi number: FoF 07911; 1 morphological species (Species Fungorum 2020), molecular data unavailable.

Type species: Toroa dimerosporioides (Speg.) Syd.

Notes: Toroa was established to accommodate the type species T. dimerosporioides which is the current name of Asteridium dimerosporioides, Zukalia dimerosporioides, Gibberella dimerosporoides, Perisporium bromeliae and Chaetosphaeria bromeliae (Spegazzini 1888; Saccardo 1891; von Höhnel 1907; Stevens 1917; González-Fragoso and Ciferri 1925; Toro 1926; Boonmee et al. 2017). Barr 
(1997) transferred Toroa to Pseudoperisporiaceae, however, Toroa can be distinguished from Pseudoperisporiaceae and other families in Dothideomycetes in having 4-spored asci, and 2-3-septate, pale brown to orange brown ascospores which are light at both ends (Boonmee et al. 2017).

Toroa dimerosporioides (Speg.) Syd. [as 'dimerosporoides'], J. Dept. Agric. Porto Rico 2: 20 (1926).

$\equiv$ Asteridium dimerosporioides Speg., Anal. Soc. cient. argent. 26(1): 19 [no. 50] (1888).

Index Fungorum number: IF 263219; Facesoffungi number: FoF 03245; Fig. 133

Description: see Boonmee et al. (2017).

Material examined: Puerto Rico, La Vega, on dried leaves Bromelia pinguin L. (Bromeliaceae), 19 March 1919, Kern and R.A. Toro (No. 207 / No. I.T.A 5413, BPI 692120).

\section{Economic and ecological significance}

Toroaceae comprises a single genus which was found as saprobic on dead leaves (Boonmee et al. 2017). It plays a role in recycling organic matter.

Trichopeltinaceae Bat., C.A.A. Costa \& Cif., Atti dell' Istituto Botanico della Università e Laboratorio Crittogamico di Pavia 15: 37 (1958).

Index Fungorum number: IF 81489; Facesoffungi numbers: FoF 06203, 29 species.

Epiphytic on living leaves, appearing as rounded or linear, or "root-like" darkened areas. Thallus very thin on the surface of the host plant, superficial, comprising neatly or irregularly arranged, angular or cylindrical to cuboid cells, with brown to dark brown walls. Sexual morph: Thyriothecia developing under thallus tissue, globose to subglobose, flattened, with a porate, central ostiole. Hamathecium usually lacking pseudoparaphyses, sometimes comprising hyaline pseudoparaphyses. Asci 6-8-spored, bitunicate, fissitunicate, subglobose to clavate, short pedicellate or apedicellate, long pedicellate when immature in some species, apically rounded, sometimes with small ocular chamber or apical ring. Ascospores 2-4-seriate, oblong to ellipsoidal, or clavate, hyaline to pale brown, 1-3-septate or muriform, slightly constricted at the septa in some species, smoothwalled. Asexual morph: Undetermined.

Type: Trichopeltina Theiss.

Notes: Trichopeltinaceae are epiphytes on leaves of various plants with a worldwide distribution. The name Trichopeltinaceae was predated by Trichopeltaceae (Theissen 1914b). Batista et al. (1958) renamed the family to Trichopeltinaceae based on Trichopeltina, and accommodated genera that have flattened thyriothecia developing under a thallus viz. Brefeldiella, Petrakiopeltis, Phragmoscutella, Trichopeltella, Trichopeltheca, Trichopeltina, Trichopeltospora and Trichopeltum. Genera of
Trichopeltinaceae with thyriothecia were transferred to Stephanothecaceae (Petrak 1947c; Luttrell 1951). However, Stephanothecaceae (type genus Stephanotheca) has a hypostroma, and was considered to be distinct from Trichopeltinaceae (Bessey 1952; Batista et al. 1958). This was supported by Jayawardena et al. (2014) who illustrated the thyriothecia of Stephanotheca as individual and not covered by a thallus. Hyde et al. (2013) referred the name Brefeldiellaceae to this group, and divided Brefeldiellaceae into Brefeldiineae and Trichopeltineae. However, the older name Trichopeltinaceae should be used to accommodate this group (Hongsanan et al. 2014a). In the following account, Acrogenotheca, Brefeldiella, Saccardinula, Trichopeltella, Trichopeltheca and Trichopeltina (Trichopeltum) are included in Trichopeltinaceae based on their thyriothecia being covered by a "skin-like" thallus.

Trichopeltina Theiss., Beih. bot. Zbl., Abt. 2 32: 3 (1914). Index Fungorum number: IF 5566; Facesoffungi number: FoF 06204; 5 morphological species (Species Fungorum 2020), molecular data unavailable.

Type species: Trichopeltina labecula (Mont.) Theiss.

Notes: Trichopeltina was established by Theiss (1914a) based on Trichopeltina labecula ( $\equiv$ Asteroma labecula). Clements and Shear (1931) placed fossil material with a thin thallus and 1-septate ascospores in Trichopeltina. Species of Trichopeltina are characterized by a superficial, irregularly arranged thin thallus, globose to subglobose flattened ostioles, thyriothecia, 8-spored, clavate, fissitunicate asci with hyaline, long clavate, 1-3-septate ascospores (Hongsanan et al. 2014a). However, Dilcher (1965) disagreed that the fossil material cited by Clements and Shear (1931) is Trichopeltina.

Trichopeltina labecula (Mont.) Theiss., Zentbl. Bakt. ParasitKde, Abt. II 39: 630 (1914).

三Asteroma labecula Mont., Annls Sci. Nat., Bot., sér. 2 14: 328 (1840).

Index Fungorum number: IF 220570; Facesoffungi numbers: FoF 07912, Fig. 134

Epiphytic on leaves, appearing as "root-like" darkened areas. Thallus very thin, superficial, comprising neatly or irregularly arranged, angular or cylindrical to cuboid cells, with brown to dark brown walls. Sexual morph: Thyriothecia 65-78 $\mu \mathrm{m}$ diam. $\times 33-48 \mu \mathrm{m}$ high $(\bar{x}=74 \times 39 \mu \mathrm{m}, \mathrm{n}=$ 10), developing under thallus tissue, globose to subglobose, flattened, with a porate, central ostiole. Hamathecium comprising branched, aseptate pseudoparaphyses. Asci 20-29 $\times$ 14-17 $\mu \mathrm{m}(\bar{x}=26 \times 15 \mu \mathrm{m}, \mathrm{n}=10), 8$-spored, bitunicate, fissitunicate, clavate, short pedicellate or apedicellate, long pedicellate when immature, apically rounded, usually with a small ocular chamber. Ascospores $15-17 \times 3-4 \mu \mathrm{m}(\bar{x}$ $=16 \times 3 \mu \mathrm{m}, \mathrm{n}=10), 2-3$-seriate, long clavate, hyaline, 
sometimes pale brown in the lower cells, 1-2-septate, slightly constricted at each septum, upper cells wider and shorter than lower cells, smooth-walled. Asexual morph: Undetermied.

Material examined: France, Guiana, Gabaret River, on coriaceous leaf of Desfontainia, September 1835, Collec no. 664 (PC 0084645, syntype of Asterina labecula).

\section{Other genera included}

Acrogenotheca Cif. \& Bat., in Batista \& Ciferri, Saccardoa 2: 51 (1963).

Index Fungorum number: IF 49; Facesoffungi number: FoF 07913; - 3 morphological species (Species Fungorum 2020), molecular data unavailable.

Type species: Acrogenotheca pulcherrima Bat. \& Cif, Saccardoa 2: 52 (1963).

Notes: Acrogenotheca comprises three species, A. elegans, A. ornata and A. pulcherrima. Hongsanan et al. (2014a) examined the type material of A. pulcherrima and found that it has clavate asci, with clavate, 3-celled, greyish brown ascospores which differ from those of Trichopeltina.

Brefeldiella Speg., Boln Acad. nac. Cienc. Córdoba 11(4): 558 (1889).

Index Fungorum number: IF 648; Facesoffungi number: FoF 07914; - 4 morphological species (Species Fungorum 2020), molecular data unavailable.

Type species: Brefeldiella brasiliensis Speg., Boln Acad. nac. Cienc. Córdoba 11(4): 558 (1889).

Notes: The type collection of this genus was examined by Eriksson (1981), but specimens were considered immature (Hyde et al. 2013). Species of Brefeldiella are characterized by a superficial, irregularly arranged thin thallus, globose to subglobose flattened ostioles, thyriothecia, 8-spored, cylindric or clavate, fissitunicate asci with hyaline, oblong to ellipsoidal, 1-septate ascospores (Hongsanan et al. 2014a). Brefeldiella and Trichopeltella need molecular studies to investigate their separation (Hongsanan et al. 2014a).

Saccardinula Speg., Anal. Soc. cient. argent. 19(6): 257 (1885).

Index Fungorum number: IF 4809; Facesoffungi number: FoF 07915; - 12 morphological species (Species Fungorum 2020), molecular data unavailable.

Type Species: Saccardinula guaranitica Sacc., Anal. Soc. Cient. Argent. 19:257 (1885).

Notes: Saccardinula was introduced by Spegazzini (1885) and the type species (Saccardinula guaranitica) was illustrated in Li et al. (2011). Saccardinula guaranitica has a less well-developed thallus than Elsinoaceae species which covers the thyriothecia. Asci are saccate and typical of Trichopeltinaceae, while ascospores differ from Elsinoceae as they are muriform (Hyde et al. 2013; Li et al. 2011). Li et al. (2011) and Jayawardena et al. (2014) placed Saccardinula in Brefeldiellaceae and thus the genus should belong in Trichopeltinaceae (Hongsanan et al. 2014a).

Trichopeltella Höhn., Sber. Akad. Wiss. Wien, Math.naturw. Kl., Abt. 1 119: 458 (1910).

Index Fungorum number: IF 5564; Facesoffungi number: FoF 07916; - 1 morphological species (Species Fungorum 2020), molecular data unavailable.

Type species: Trichopeltella montana (Racib.) Höhn., Sber. Akad. Wiss. Wien, Math.-naturw. Kl., Abt. 1 119: 458 (1910).

$\equiv$ Trichopeltis montana Racib., Bull. int. Acad. Sci. Lett. Cracovie, Cl. sci. math. nat. Sér. B, sci. nat. 3: 378 (1909).

Notes: Wu et al. (2014) examined the holotype of T. montana, but the specimen only comprised the asexual morph. Thus, the comparison with Brefeldiella and Trichopeltella is unclear. Hyde et al. (2013) mentioned that Trichopeltella may be a synonym of Brefeldiella. Based on its distinct asexual morph, with a "root-like" thallus and aseptate hyaline conidia it is accommodated as a separate genus in Trichopeltinaceae (Hongsanan et al. 2014a).

Trichopeltheca Bat., C.A.A. Costa \& Cif., Atti Ist. bot. Univ. Lab. crittog. Pavia, Ser. 5 15: 44 (1958).

Index Fungorum number: IF 5565; Facesoffungi number: FoF 07917; - 2 morphological species (Species Fungorum 2020), molecular data unavailable.

Type species: Trichopeltheca asiatica Bat., C.A.A. Costa \& Cif., Publicações Inst. Micol. Recife 90: 13 (1958).

Notes: Trichopeltheca is similar to Saccardinula based on its muriform ascospores, but differs in ascus shape and thallus form. Saccardinula has globose to ovoid asci and the thallus is rounded (Spegazzini 1885), while Trichopeltheca has clavate to sub-cylindrical asci and the thallus appears "root-like" (Batista et al. 1958).

Trichothyrinula Petr. Sydowia 4(1-6): 171 (1950).

Index Fungorum number: IF 5595; Facesoffungi number: FoF 07918; - 2 morphological species (Species Fungorum 2020), molecular data unavailable.

Type species: Trichothyrinula sydowii Petr., Sydowia 4(1-6): 171 (1950).

Notes: Müller and von Arx (1962) introduced the second species, Trichothyrinula petrakii and assigned it to Trichothyriaceae. Lumbsch and Huhndorf (2010) placed Trichothyrinula in Microthyriaceae. However, Trichothyrinula is similar to Brefeldiella, but differs by its smaller globose to subglobose, apedicellate asci (Brefeldiella has cylindricclavate, short-pedicellate asci), and rough ornamented spore wall, with spores becoming brownish at maturity (Wu et al. 2014). 


\section{Economic and ecological significance}

Members of this family are epiphytic on living leaves. However, there is no record on penetration organs which can uptake nutrients from plants. The thallus covers host surface and can reduce respiration and photosynthesis of its plant host.

Trichothyriaceae Theiss., Beih. bot. Zbl., Abt. 2 32: 3 (1914).

Index Fungorum number: IF 81497; Facesoffungi numbers: FoF 06893; 75 species.

Parasitic on Diatrypaceae, Meliolaceae and lichens, or on their conidial morphs. Mycelium superficial, forming thalli on hyphae of parasitized fungus, membranous. Sexual morph: Thyriothecia superficial, solitary flattened, circular, brown, with a central ostiole. Upper wall comprising radial arranged cells in parallel rows of textura epidermoidea, anastomosing at the ostiole. Basal wall well-developed, with a single-cell thick layer. Asci 8 -spored, bitunicate, fissitunicate, obclavate, arranged at the periphery and converge towards the ostiole. Ascospores overlapping, hyaline or light brown, 1-septate, not constricted at the septum, sometimes with ciliate appendages. Asexual morph: Hyphomycetous. reported as Hansfordiella and Isthmospora (Hyde et al. 2011).

\section{Type: Trichothyrium Speg.}

Notes: Trichothyriaceae was introduced by Theissen (1914a) accommodating Loranthomyces, Trichothyriella, Trichothyriopsis and the type genus Trichothyrium, Hawksworth et al. (1983) included genera of Trichothyriaceae under Microthyriaceae, and this was followed by Lumbsch and Huhndorf (2010). Wu et al. (2011b) transferred them back to Trichothyriaceae based on its fungicolous life mode and a well-developed basal peridium, and included another parasitic genus Lichenopeltella in the family. This was followed by Hyde et al. (2013) and Wijayawardene et al. (2018). Trichothyriaceae differs from other thryriothecial families by a well-developed peridium, but there are too few morphological characters to delimit those similar genera. Sequence data is not available for this family.

Trichothyrium Speg., Boln Acad. nac. Cienc. Córdoba 11(4): 555 (1889).

Index Fungorum number: IF 5598; Facesoffungi number: FoF 06894; 25 morphological species (Species Fungorum 2020), molecular data unavailable.

Type species: Trichothyrium sarciniferum Speg.

Notes: Trichothyrium is characterized by flattened ascomata with an upper and lower, single-cell thick layer occurring on the surface of parallel hyphal bands. Another genus forming a similar cellular hypostroma with lobed thalli is Brefeldiella, which is characterized by ascomata dispersed beneath the band-like thallus and opening by a fissure of the upper covering cells. Hawksworth et al. (1983) included Trichothyrium under Microthyriaceae, Wu et al. (2011b) transferred Trichothyrium back to Trichothyriaceae based on its fungicolous life mode and a well-developed basal peridium. This was followed in subsequent studies (Hyde et al. 2013; Wijayawardene et al. 2018).

Trichothyrium sarciniferum Speg., Boln Acad. nac. Cienc. Córdoba 11(4): 556 (1889).

Index Fungorum number: IF 161963; Facesoffungi number: FoF 07919; Fig. 135

Description: see Hyde et al. (2013).

Material examined: Brazil, Apizhy, on Meliolaceae on unidentified leaves, 1881, C. Spegazzini (LPS1441, holotype).

\section{Other genera included:}

Lichenopeltella Höhn., Sber. Akad. Wiss. Wien, Math.naturw. Kl., Abt. 1 128: 553 (1919).

Index Fungorum number: IF 2850; Facesoffungi number: FoF 06895; 48 morphological species (Species Fungorum 2020), molecular data unavailable.

Type species: Lichenopeltella maculans (Zopf) Höhn. Sber. Akad Wiss. Wien, Math.-naturw.Kl., Abt.1128(7-8):553 (1919).

$\equiv$ Microthyrium maculans Zopf, Nova Acta Acad. Caes. Leop.-Carol. German. Nat. Cur. 70(4): 258 (1898).

Notes: Müller and von Arx (1962) and von Arx and Müller (1975) placed Lichenopeltella in Leptopeltidaceae, and this was followed in Kirk et al. (2008) who accept Leptopeltidaceae as one of three families in Microthyriales. However, this is not followed in the more recent classifications in Lumbsch and Huhndorf (2010), and Wu et al. (2011b) placed it in Trichothyriaceae based on its fungicolous life mode.

Macrographa Etayo, in Etayo \& Sancho, Biblthca Lichenol. 98: 116 (2008).

Index Fungorum number: IF 532867; Facesoffungi number: FoF 06896; 1 morphological species (Species Fungorum 2020), molecular data unavailable.

Type species: Macrographa antarctica Etayo, in Etayo \& Sancho, Biblthca Lichenol. 98: 116 (2008).

Notes: Macrographa was introduced as a monotypic genus occurring on lichens. This genus is characterised by multiloculate ascostromata, ellipsoidal-fusiform asci and 1-septate ascospores (Wu et al. 2011b). Lumbsch and Huhndorf (2010) accepted it as a member of Microthyriaceae. Wu et al. (2011b) placed it in Trichothyriaceae, along with Lichenopeltella, due to their fungicolous life mode.

Pachythyrium G. Arnaud ex Spooner \& P.M. Kirk, Mycol. Res. 94(2): 228 (1990). 
Index Fungorum number: IF 25378; Facesoffungi number: FoF 06897; 1 morphological species (Species Fungorum 2020), molecular data unavailable.

Type species: Pachythyrium parasiticum (Fabre) G. Arnaud ex Spooner \& P.M. Kirk, Mycol. Res. 94(2): 228 (1990).

三 Bertia parasitica Fabre, Annls Sci. Nat., Bot., sér. 69 : 95 (1879) [1878].

Notes: Pachythyrium was introduced as a monotypic genus, which is synonymised from Bertia parasitica occurring on Eutypa lata. Hawksworth et al. (1995) and Lumbsch and Huhndorf (2010) accepted it as a member of Microthyriaceae. Wu et al. (2011b) placed it in Trichothyriaceae, and noted that the placement of this genus in Trichothyriaceae may be warranted.

\section{Economic and ecological significance}

Trichothyriaceae is a poorly studied family parasitic on fungi.

Vizellaceae H.J. Swart, Trans. Br. mycol. Soc. 57: 456 (1971).

Index Fungorum number: IF 81519; Facesoffungi number: FoF 07920, 31 species.

Parasitic or saprophytic on leaves, tropical in distribution, developing in or beneath the cuticle, often forming an intracuticular mycelium, without superficial hyphae. Sexual morph: Ascostromata dimidiate, scutate or crustose, roundish or elongated in outline, with a thin wall composed of small, dark cells, opening by a fissure or dehiscence, central part of loculus may be sterile. Hamathecium comprising filamentous, pseudoparaphyses, often filling the central part of the loculus or may be sparse or absent. Asci 6-8-spored, bitunicate, probably evanescent, broadly clavate or nearly cylindrical. Ascospores 2-3-seriate, overlapping, hyaline to brown, 1-2-celled or with small appendage cell at the base, with a light transverse band. Asexual morph: linked to Chrysogloeum and Manginula. Pycnidia disc-shaped with upper wall of irregularly arranged cells, subglobose, dark brown to black, scutate or crustose. Conidiogenous cells hyaline, cylindrical, holoblastic. Conidia ovoid to ellipsoidal or rarely subglobose, brown to dark brown, with transverse hyaline band, formed on phialidic, hyaline cells lining the inner cavity of the upper wall (Hughes 1953a, b; Petrak 1953).

Type: Vizella Sacc.

Notes: Vizellaceae was introduced to include Blasdalea and Vizella (Swart 1971). Entopeltis was synonymized under Vizella (Swart 1971). Hughes (1953a) described the mycelium of the type species and confirmed mycelium composed of hyaline to light brown hyphae with thick, dark brown cross walls. Swart (1971) suggested that the mycelium might well be of diagnostic value, but several authors could not observe this because mycelium is entirely hyaline and thus difficult to see. In most species of Vizellaceae, the mycelium branches frequently at fairly wide angles, and so forms a network without radial orientation (Hyde et al. 2013). von Arx and Müller (1975) noted that Vizella and Entopeltis can be distinguished by the arrangement of the asci and ascospores characters. van Wyk et al. (1976) studied the type species and other Entopeltis and Vizella species and suggested that they could not be distinguished. Therefore, Entopeltis should be synonymised under Vizella.

The asexual morph of most species in this family are undetermined, except for three Vizella species and Blasdalea disciformis. Hughes (1953a) described a conidial form associated with Vizella hendrickxii. Swart (1971) introduced two new species to this genus from Australia with conidial morphs. The asexual morph of Blasdalea is Chrysogloeum (Petrak 1953). Wijayawardene et al. (2012) listed the asexual morphs as Chrysogloeum and Manginula. Chrysogloeum was established to accommodate the coelomycetous asexual morphs of Blasdalea (as Singeriella). Sivanesan (1984) considered that Vizella has Manginula or "Manginula"-like asexual morphs.

Vizella Sacc., Syll. Fung. (Abellini) 2: 662 (1883).

Index Fungorum number: IF 5747; Facesoffungi number: FoF 07921; 30 morphologocal species (Species Fungorum 2020), molecular data unavailable.

Type species: Vizella conferta (Cooke) Sacc.

三 Micropeltis conferta Cooke, Grevillea 6(no. 39): 118 (1878)

Notes: The confusion between Entopeltis and Vizella is discussed in the family notes and in Hyde et al. (2013). The ascomata of Vizella have thin walls as in Entopeltis (Fig. 136). This intermediate form between Vizella and Entopeltis further indicates they all two genera may be congeneric. Mycerema was introduced by Batista et al. (1963). It was considered to resemble Vizella in ascospores and pseudoparaphyses characters (Hyde et al. 2013). However, Phookamsak et al. (2016) indicated that the characters described in Hyde et al. (2013) is Vizella bingervilliana (see more detail in the note of Mycerema, Hongsanan et al. 2020).

\section{Other genera included}

Acarella Syd., Annls mycol. 25(1/2): 123 (1927). Index Fungorum number: IF 7005; Facesoffungi number: FoF 06207; - 3 morphological species (Species Fungorum 2020), molecular data unavailable.

Type species: Acarella costaricensis Syd., Annls mycol. 25(1/2): 123 (1927).

Notes: Acarella is characterized by scattered, small, completely superficial pycnidia, with a thin peridium, and ellipsoid to cylindrical conidia. The sexual morph of Acarella is 
undetermined. Perizomella was synonymised under Acarella based on the host relationship and morphological characters (Pem et al. 2019c). Acarella is placed in Vizellaceae due to the asexual species have ovoid to ellipsoidal or rarely subglobose, brown to dark brown, with transverse hyaline band, formed on phialidic, hyaline cells lining the inner cavity of the upper wall (Hyde et al. 2013; Pem et al. 2019c), pending fresh collections and molecular data.

Blasdalea Sacc. \& P. Syd., Syll. Fung. (Abelini) 16: 634 (1902).

Index Fungorum number: IF 592; Facesoffungi number: FoF 07922; - 1 morphological species (Species Fungorum 2020), molecular data unavailable.

Type species: Blasdalea disciformis (Rehm) Sacc. \& $\mathrm{P}$. Syd., Syll. Fung. (Abellini) 16: 634 (1902).

三Vizella disciformis Rehm, Hedwigia 39(4): 227 (1900).

Notes: von Arx and Müller (1954) illustrated the type species which has cylindrical asci and abundant pseudoparaphyses and ascomata opening by a large ostiole. Hyde et al. (2013) were unable to find the sexual morph in the holotype which was described in Rehm (1900). They found one-celled, brown conidia with a hyaline transverse band, some two-celled, hyaline to brown, with a medium lighter septum. Blasdalea may be related with Fasciatispora which has unitunicate asci, but the nature of the asci in the illustration provided in von Arx and Müller (1954) is not clear. In this study, Blasdalea is maintained as a distinct genus in Vizellaceae pending fresh collections and molecular studies.

\section{Economic and ecological significance}

Most species in Vizellaceae are parasitic on leaves which can uptake nutrients from plant issue.

Acknowledgements Sinang Honsanan would like to thank National Natural Science Foundation of China for supporting the project Biodiversity, Taxonomy, Phylogeny, Evolution and Phytogeography of phytopathogens in Dothideomycetes from Southern China (Grant No. 31950410548) for funding this research. Ning Xie would like to thank Project of DEGP (2019KTSCX150). Kevin D Hyde thanks the Thailand Research Fund for the grant RDG6130001 entitled "Impact of climate change on fungal diversity and biogeography in the Greater Mekong Subregion". Rungtiwa Phookamsak thanks CAS President's International Fellowship Initiative (PIFI) for young staff (Grant No. Y9215811Q1), the Yunnan Provincial Department of Human Resources and Social Security (Grant No. Y836181261), and National Science Foundation of China (NSFC) project code 31850410489 (Grant No. Y81I982211) for financial support. Dhanushka Wanasinghe would like to thank CAS President's International Fellowship Initiative (PIFI) for funding his postdoctoral research (number 2019PC0008) and the 64th batch of China Postdoctoral Science Foundation (Grant No. Y913083271). Vemuri V. Sarma would like to thank SERB, Department of Science and Technology, Government of India, for funding a project (SERB/SB/SO/PS/18/2014 dt.19.5.2015) and Ministry of Earth Sciences (MOES), Govt. of India for funding a project (Sanction order: MOES/36/OO1S/Extra/40/ 2014/PC-IV dt. 14.01.2015); the Department of Biotechnology, Pondicherry University for facilities; forest departments of Andaman and Nicobar Islands and Tamil Nadu, India are thanked for providing permission to collect samples. Saranyaphat Boonmee would like to thank the National Research Council of Thailand (projects no. 61215320013 and No. 61215320023), the Thailand Research Fund (project no. TRG6180001) and Plant Genetic Conservation Project under the Royal Initiation of Her Royal Highness Princess Maha Chakri Sirindhorn - Mae Fah Luang University. Alan JL Phillips acknowledges the support from UIDB/04046/2020 and UIDP/04046/2020 Centre grants from FCT, Portugal (to BioISI). Saowaluck Tibpromma would like to thank the International Postdoctoral Exchange Fellowship Program (number Y9180822S1), CAS President's International Fellowship Initiative (PIFI) (number 2020PC0009), China Postdoctoral Science Foundation, and the Yunnan Human Resources and Social Security Department Foundation for funding her postdoctoral research. Shu-Hua Jiang would like to thank the National Natural Science Foundation of China (Project Nos. 31800010 and 31750001 ) for financial support. Nalin N. Wijayawardene thanks the National Natural Science Foundation of China (No. NSFC 31950410558) and Guizhou Medical University (grant number FAMP201906K). Dong-Qin Dai would like to thank the National Natural Science Foundation of China (No. NSFC 31760013), the Scientific Research Foundation of Yunnan Provincial Department of Education (2017ZZX186) and the Thousand Talents Plan, Youth Project of Yunnan Provinces for finance support. R Jeewon would like to thank the University of Mauritius and Mae Fah Luang University for support. Mingkwan Doilom thanks the 5th batch of Postdoctoral Orientation Training Personnel in Yunnan Province (Grant No. Y934283261) and the 64th batch of China Postdoctoral Science Foundation (Grant No. Y913082271). M Niranjan thanks SERB, Govt. of India for a fellowship. Huang Zhang would like to thank Natural Science Foundation of China (NSF 31500017). Jadson DP Bezerra thanks the Conselho Nacional de Desenvolvimento Científico e Tecnológico (CNPq), the Coordenação de Aperfeiçoamento de Pessoal de Nível Superior (CAPES, Finance Code 001), and the Fundação de Amparo à Ciência e Tecnologia de Pernambuco (FACEPE) for fellowship. B. Devadatha thanks MOES, Govt. of India for a fellowship. Hai-Xia Wu would like to the Fundamental Research Funds for the Central Non-profit Research Institution of CAF (Grant No. CAFYBB2019QB005), and the Ten Thousand Talents Plan, Youth Top Project of Yunnan Provinces for finance support. Ausana Mapook thanks to Research and Researchers for Industries (RRI) under Thailand Research Fund for a personal grant (PHD57I0012). Putarak Chomnunti would like to thank Mae Fah Luang University (Grant No. DR256201012003) and DiversityBased Economy Development Office and National Research Council of Thailand Research (Grant No. T2561022) for the financial support. Satinee Suetrong thanks the collaborative project between BIOTEC and Department of Marine and Coastal Resources (DMCR), Ministry of Natural Resources and Environmentunder a project: Marine Microbes for National Reserves: Alternative Ways of State Property. N. Chaiwan would like to thank the Thailand Research Fund (PHD60K0147). Jianchu Xu thanks the Strategic Priority Research Program of Chinese Academy of Sciences. We would like to thank Huzefa Raja who provide the plate of Minutisphaera parafimbriatispora, Naruemon Huanraluek to provide plate of Pyrenidium actinellum, LiYan Mei to provide plate of Meliolina cladotricha, Wen-Jing Li to provide pictures of Pseudorobillarda phragmitis, Felix Schumm to provide ascospore images of Bogoriella isthmospora and Schummia angulate, Nick Turland for assistance in resolving the nomenclatural status of the name in Strigulaceae. We thank Supalak Yacharoen for providing part of the image plate of Trypetheliopsis boninensis.

Open Access This article is licensed under a Creative Commons Attribution 4.0 International License, which permits use, sharing, adaptation, distribution and reproduction in any medium or format, as long as you give appropriate credit to the original author(s) and the source, 
provide a link to the Creative Commons licence, and indicate if changes were made. The images or other third party material in this article are included in the article's Creative Commons licence, unless indicated otherwise in a credit line to the material. If material is not included in the article's Creative Commons licence and your intended use is not permitted by statutory regulation or exceeds the permitted use, you will need to obtain permission directly from the copyright holder. To view a copy of this licence, visit http://creativecommons.org/licenses/by/4.0/.

\section{References}

Abdollahzadeh J, Zare R, Phillips AJ (2013) Phylogeny and taxonomy of Botryosphaeria and Neofusicoccum species in Iran, with description of Botryosphaeria scharifii sp. nov. Mycologia 105:210-220

Aguirre-Hudson B (1991) A taxonomic study of the species referred to the ascomycete genus Leptorhaphis. Bull Br Mus Nat Hist (Bot) 21:85-192

Aguirre-Hudson B (2009) Celothelium, Cresporhaphis, Leptorhaphis, Rhaphidicyrtis. In: Smith CW et al (eds) The lichens of Great Britain and Ireland. The British Lichen Society, MPG Books Group, Bodmin

Aguirre-Hudson B, Fiol L (1993) A new species of Leptorhaphis (Arthopyreniaceae) on Opuntia from the Balearic Islands. Lichenologi 25:207-210

Aguirre-Hudson B, Hawksworth DL (1987) The circumscription, biology and relationships of the genus Leptorhaphis Körber. In: Peveling E (ed) Progress and problems in Lichenology in the eighties. Bibl Lichenol 25:249-255

Aguirre-Hudson B, Farkas E, Lokös L (2002) Pyrenolichens of the Hungarian lichen flora I: The genus Leptrorhaphis Körber. Bibl Lichenol 82:3-18

Ainsworth GC, Sparrow FK, Sussman AS (1973) The Fungi: An Advanced Treatise. IV (B):504

Akata I, Kaya A, Uzun Y (2016) Two new genus records for Turkish Helotiales. Kastamonu Uni, Orman Fakültesi Dergisi 16:131-134

Alves A, Correia A, Luque J, Phillips A (2004) Botryosphaeria corticola, sp. nov. on Quercus species, with notes and description of Botryosphaeria stevensii and its anamorph. Diplodia mutila. Mycologia 96:598-613

Ametrano CG, Knudsen K, Kocourková J, Grube M, Selbmann L, Muggia L (2019) Phylogenetic relationships of rock-inhabiting black fungi belonging to the widespread genera Lichenothelia and Saxomyces. Mycologia 111:127-160

Anahosur KH (1967) Shanoria indica sp. nov., from India. Nova Hedwig 14:404-405

Aptroot A (1991) A monograph of the Pyrenulaceae (excluding Anthracothecium and Pyrenula) and the Requienellaceae, with notes on the Pleomassariaceae, the Trypetheliaceae and Mycomicrothelia (lichenized and non-lichenized Ascomycetes). Biblioth Lichenol 44:1-178

Aptroot A (1995) Redisposition of some species excluded from Didymosphaeria (Ascomycotina). Nova Hedwig 60:325-379

Aptroot A (2002a) Julella. In: Nash TH III, Ryan BD, Gries C, Bungartz F (eds) Lichen Flora of the Greater Sonoran Desert Region. Arizona State University, Tempe, Arizona, I. Lichens Unlimited, pp 254-256

Aptroot A (2002b) Acrocordia. In: Nash TH III, Ryan BD, Gries C, Bungartz F (eds) Lichen flora of the Greater Sonoran Desert Region. Arizona State University, Tempe, Arizona, I. Lichens unlimited, $\mathrm{p} 89$

Aptroot A (2002c) Mycoporum. In: Nash TH III, Ryan BD, Gries C, Bungartz F (eds) Lichen Flora of the Greater Sonoran Desert
Region I. Arizona State University, Tempe, Arizona, Lichens unlimited, pp 287-288

Aptroot A (2012) A world key to the species of Anthracothecium and Pyrenula. Lichenologist 44:5-53

Aptroot A (2013) Ecology of the lichen family Trypetheliaceae in Brazil. Livro de Resumos do Sexto Encontro do Grupo Brasileiro de Liquenólogos 1:16

Aptroot A, Cáceres MES (2014) A refined species concept in the tropical lichen genus Polymeridium (Trypetheliaceae) doubles the number of known species, with a worldwide key to the species. Nova Hedwig 98:1-29

Aptroot A, Lücking R (2016) A revisionary synopsis of the Trypetheliaceae (Ascomycota: Trypetheliales). Lichenologi 48:763-982

Aptroot A, Moon KH (2014) 114 new reports of microlichens from Korea, including the description of five new species, show that the microlichen flora is predominantly Eurasian. Herzogia 27:347-366

Aptroot A, Nepi C (2017) (2492) Proposal to conserve the name Marcelaria against Buscalionia (Trypetheliaceae, lichenized Ascomycota). Taxon 66:200-201

Aptroot A, van den Boom PPG (1995) Strigula lateralis spec. nov. with notes on the genus Julella (Ascomycetes). Mycotaxon 56:1-8

Aptroot A, Weerakoon G (2018) Three new species and ten new records of Trypetheliaceae (Ascomycota) from Sri Lanka. Cryptogam Mycol 39:373-378

Aptroot A, Diederich P, Sérusiaux E, Sipman HJM (1997) Lichens and lichenicolous fungi from New Guinea. Biblioth Lichenol 64:1-220

Aptroot A, Lücking R, Sipman HJM, Umaña L, Chaves JL (2008) Pyrenocarpous lichens with bitunicate asci: a first assessment of the lichen biodiversity inventory in Costa Rica. Bibl Lichenologica 97:1-162

Aptroot A, Cáceres MES, Johnston MK, Lücking R (2016) How diverse is the lichenized fungal family Trypetheliaceae (Ascomycota: Dothideomycetes)? A quantitative prediction of global species richness. Lichenologi 48:983-994

Aptroot A, Sipman HJM, Barreto FMO, Nunes AD, Cáceres MES (2019) Ten new species and 34 new country records of Trypetheliaceae. Lichenologi 51:27-43

Ariyawansa HA, Jones EB, Suetrong S, Alias SA, Kang JC, Hyde KD (2013a) Halojulellaceae a new family of the order Pleosporales. Phytotaxa 130:14-24

Ariyawansa HA, Kang JC, Alias SA, Chukeatirote E, Hyde KD (2013b) Towards a natural classification of Dothideomycetes: The genera Dermatodothella, Dothideopsella, Grandigallia, Hysteropeltella and Gloeodiscus (Dothideomycetes incertae sedis). Phytotaxa 147:35-47

Ariyawansa HA, Thambugala KM, Kang JC, Alias SA, Chukeatirote E, Hyde KD (2014) Towards a natural classification of Dothideomycetes 2: The genera Cucurbidothis, Heterosphaeriopsis, Hyalosphaera, Navicella and Pleiostomellina (Dothideomycetes incertae sedis). Phytotaxa 176:7-17

Arnaud G (1918) Lés Asterinées. Ann Éc Natl Agric Montp 2(16): $1-288$

Arzanlou M, Groenewald JZ, Gams W, Braun U, Shin HD, Crous PW (2007) Phylogenetic and morphotaxonomic revision of Ramichloridium and allied genera. Stud Mycol 58:57-93

Asahina Y (1937) Lichenologische Notizen IX. J Jpn Bot 13:315-321

Atienza V, Calatayud V, Hawksworth DL (2003) Notes on the genus Polycoccum (Ascomycota, Dacampiaceae) in Spain, with a key to the species. Lichenologi 35:125-135

Aylward J, Steenkamp ET, Dreyer LL, Roets F, Wingfield BD, Wingfield MJ (2017) A plant pathology perspective of fungal genome sequencing. IMA Fungus 8:1-15 
Bagyanarayana G, Rao NK, Kunwar IK (2009) Manoharachariella, a new dematiaceous hyphomycetous genus from India. Mycotaxon 109:301-305

Bai YL, Li JY, Qiao M, Qian WY, Yang GZ, Yu ZF (2013) Setosynnema yunnanense sp. nov. from submerged decaying leaves. Mycotaxon 125:81-85

Bao DF, Luo ZL, Liu JK, Bhat DJ, Sarunya N, Li WL, Su HY, Hyde KD (2018) Lignicolous freshwater fungi in China III: New species and record of Kirschsteiniothelia from northwestern Yunnan Province. Mycosphere 9:755-768

Bao DF, Hyde KD, Luo ZL, Su HY, Nalumpang S (2019) Minutisphaera aquaticum sp. nov. increases the known diversity of Minutisphaeraceae. Asian Journal of Mycology 2:306-314

Barber PA, Burgess TJ, Hardy GEStJ, Slippers B, Keane PJ, Wingfield MJ (2005) Botryosphaeria species from Eucalyptus in Australia are pleoanamorphic, producing Dichomera synanamorphs in culture. Mycol Res 109:1347-1363

Barbosa FF, Gusmao LFP (2005) Two Speiropsis species (Anamorphic fungi-Hyphomycetes) from Bahia state, Brazil. Acta Bot Bras 19:515-518

Barbosa-Silva AM, Vasconcellos A (2019) Consumption rate of lichens by Constrictotermes cyphergaster (Isoptera): effects of $\mathrm{C}, \mathrm{N}$, and $\mathrm{P}$ contents and ratios. Insects 10:23

Barbosa-Silva AM, Silva AC, Pereira ECG, Buril MLL, Silva NH, Cáceres MES, Aptroot A, Bezerra-Gusmão MA (2019) Richness of lichens consumed by Constrictotermes cyphergaster in the semi-arid region of Brazil. Sociobiology 66:154-160

Barker NP, Weston PH, Rutschmann F, Sauquet H (2007) Molecular dating of the 'Gondwanan' plant family Proteaceae is only partially congruent with the timing of the break-up of Gondwana. $\mathrm{J}$ Biogeogr 34:2012-2027

Barr ME (1978) The Diaporthales in North America, with emphasis on Gnomonia and its segregates. Matsushima Mycological Memoirs 7:1-232

Barr ME (1979a) A classification of Loculoascomycetes. Mycologia 71:935-957

Barr ME (1979b) On the Massariaceae in North America. Mycotaxon 9:17-37

Barr ME (1980) On the family Tubeufiaceae (Pleosporales). Mycotaxon $12: 137-167$

Barr ME (1985) On Julella, Delacourea, and Decaisnella, three dictyosporous genera described by JH Fabre. Sydowia 38:11-19

Barr ME (1987a) New taxa and combinations in the Loculoascomycetes. Mycotaxon 29:501-505

Barr ME (1987b) Prodromus to class Loculoascomycetes. Massachusetts, University of Massachusetts, USA, Amherst

Barr ME (1990) Podromus to nonlichenized, pyrenomycetous members of class Hymenoascomycetes. Mycotaxon 39:43-184

Barr ME (1994) Note on Amphisphaeriaceae and related families. Mycotaxon 51:191-224

Barr ME (1996) Planistromellaceae, a new family in the Dothideales. Mycotaxon 60:433-442

Barr ME (1997) Notes on some 'dimeriaceous' fungi. Mycotaxon 64:149-171

Barr ME, Huhndorf SM (2001) Loculoascomycetes. In: McLaughlin DJ, McLaughlin EG, Lemke PA (eds) The mycota VII, part A. Springer Verlag, Berlin, Systematics and evolution, pp 283-305

Barrie FR, Buck WR, Demoulin V, Greuter W, Hawksworth DL, Herendeen PS, Knapp S, Marhold K, Prado J, Prud'homme Van Reine WF (2012) International Code of Nomenclature for Algae, Fungi and Plants (Melbourne Code). Koeltz Scientific Books, Königstein

Basnet BB, Liu L, Zhao W, Liu R, Ma K, Bao L, Ren J, Wei X, Yu H, Wei J, Liu H (2019) New 1, 2-naphthoquinone-derived pigments from the mycobiont of lichen Trypethelium eluteriae Sprengel. Nat Prod Res 33:2044-2050
Batista AC (1959) Monografia dos fungos Micropeltaceae. Publicações do Instituto de Micologia da Universidade do Recife 56:1-519

Batista AC, Bezerra JL (1964) Polystomellaceae: novas entidades Brasileiras. Portug Acta Biol 7:361-382

Batista AC, Vital AF (1960) A revision of some species of the genera Melanoplaca Syd, Mendogia Racib. and Palawania Syd. Atas do Instituto de Micologia da Universidade do Recife 112:79-92

Batista AC, Costa AA, Ciferri R (1958) Orgânogênese e sistemática dos fungos Trichopeltinaceae (Theiss.) emend. nobis. Atti Ist Bot Univ Lab Crittog Pavia sér 15:35-56

Batista AC, Bezerra JL, Cavalcante WA, da da Silva MH (1963) Mycerema e outros novos gêneros de Stomiopeltoideae, da familia Micropeltaceae. Publicações do Instituto de Micologia da Universidade do Recife. 392:1-40

Batista AC, Peres GEP, Torres SV (1966) Staibia - um nôvo gênero de Leptopeltaceae. Atas de Instituto de Micologie Univ. Recife 3:140-144

Bell NE, Newton AE (2004) Systematic studies of non-hypnanaean pleurocarps: establishing a phylogenetic framework for investigating origins of pleurocarpy. Monogr Syst Bot Mo Bot Gard 98:290-319

Berger F, Zimmermann E (2016) Ergänzungen zur Flechtenflora von Madeira mit besonderer Berücksichtigung lichenicoler Pilze. Herzogia 29:235-276

Berger SA, Stamatakis A, Lücking R (2011) Morphology-based phylogenetic binning of the lichen genera Allographa and Graphis via molecular site weight calibration. Taxon 60:1450-1457

Berger F, Braun U, Heuchert B (2015) Gonatophragmium lichenophilum sp. nov. - a new lichenicolous hyphomycete from Austria. Mycobiota. 5:7-13

Berkeley MJ, Broome CE (1851) Notices of British fungi (538-614). Ann Mag Nat Hist 7:176-189

Berlese AN (1893) Descrizione di alcuni nuovi generi di pirenomiceti, pp 567-576

Bessey EA (1952) Morphology and taxonomy of fungi. The Blakiston Co 295

Bezerra JD, Oliveira RJ, Paiva LM, Silva GA, Groenewald JZ, Crous PW, Souza-Motta CM (2017) Bezerromycetales and Wiesneriomycetales ord. nov. (class Dothideomycetes), with two novel genera to accommodate endophytic fungi from Brazilian cactus. Mycol Prog 16:297-309

Bianchinotti MV (1997) A new species of Pseudorobillarda from a leguminous tree in Argentina. Mycol Res 101:1233-1236

Bin S (2003) Goosia, a new genus of Englerulaceae. Mycotaxon 87:413-415

Boehm EW, Marson G, Mathiassen GH, Gardiennet A, Schoch CL (2015) An overview of the genus Glyphium and its phylogenetic placement in Patellariales. Mycologia 107:607-618

Boonmee S, Zhang Y, Chomnunti P, Chukeatirote E, Tsui CKM, Bahkali AH, Hyde KD (2011) Revision of lignicolous Tubeufiaceae based on morphological reexamination and phylogenetic analysis. Fungal Divers 51:63-102

Boonmee S, Ko-Ko TW, Chukeatirote E, Hyde KD, Chen H, Cai L, McKenzie EHC, Jones EBG, Kodsueb R, Hassan BA (2012) Two new Kirschsteiniothelia species with Dendryphiopsis anamorphs cluster in Kirschsteiniotheliaceae fam. nov. Mycologia 104:698-714

Boonmee S, Bhat DJ, Maharachchikumbura SS, Hyde KD (2014a) Clavatispora thailandica gen. et sp. nov., a novel taxon of Venturiales (Dothideomycetes) from Thailand. Phytotaxa. 176:92-101

Boonmee S, Rossman AY, Liu JK, Li WJ, Dai DQ, Bhat JD, Jones EBG, McKenzie EHC, Xu JC, Hyde KD (2014b) Tubeufiales, ord. nov., integrating sexual and asexual generic names. Fungal Divers 68:239-298

Boonmee S, Ekanayaka AH, Hyde KD, Hüseyin E, Ekici K, Selçuk F (2016) Phylogenetic placement of Neorhamphoria garethjonesii 
gen. et sp. nov (Tubeufiales, genus incertae sedis). Mycosphere 7:1447-1457

Boonmee S, Phookamsak R, Hongsanan S, Doilom M, Mapook A, McKenzie EHC, Bhat DJ, Hyde KD (2017) Mycosphere notes 51-101. Revision of genera in Perisporiopsidaceae and Pseudoperisporiaceae and other Ascomycota genera incertae sedis. Mycosphere 8:1695-1801

Bose SK (1961) Studies on Massarina Sacc. and related genera. J Phytopathol 41:151-213

Boudier JLÉ (1907) Histoire et Classification des Discomycètes d'Europe. Librairie des Sciences Naturelles Paul Klincksieck, Paris, pp 1-223

Brahamanage RS, Lu YZ, Bhat DJ, Wanasinghe DN, Yan JY, Hyde KD, Boonmee S (2017) Phylogenetic investigations on freshwater fungi in Tubeufiaceae (Tubeufiales) reveals the new genus Dictyospora and new species Chlamydotubeufia aquatica and Helicosporium flavum. Mycosphere 8:917-933

Braun U, Crous PW, Dugan F, Groenewald JZ, de Hoog GS (2003) Phylogeny and taxonomy of Cladosporium-like hyphomycetes, including Davidiella gen. nov., the teleomorph of Cladosporium s. str. Mycol Prog 2:3-18

Briquet J (1935) International rules of botanical nomenclature. Revised by the International Botanical Congress of Cambridge 1930, Fischer, Jena

Britton NL, Millspaugh CF (1920) The Bahama Flora. Published by the authors, New York Botanical Garden, New York

Bucher VVC, Hyde KD, Pointing SB, Reddy CA (2004) Production of wood decay enzymes, mass loss and lignin solubilization in wood by diverse freshwater fungi. Microb Ecol 48:331-337

Bunker SG (1985). Underdeveloping the Amazon. Extraction, unequal exchange, and the failure of the modern state.

Burgess T, Slippers B, Preisig O, Wingfield BD, Wingfield MJ (2003) Multiple gene genealogies and microsatellite markers reflect relationships between morphotypes of Sphaeropsis sapinea and distinguish a new species of Diplodia. Mycol Res 107:557-566

Bussaban B, Lumyong S, Lumyong P, Seelanan T, Park D, McKenzie E, Hyde K (2005) Molecular and morphological characterization of Pyricularia and allied genera. Mycologia 97:1002-1011

Butin H (1973) Beitrag zur Ascomyceten Flora von Chile. Sydowia 27:267-292

Butin H, Speer EO (1978) Über einige parasitische Ascomyceten auf Nadeln der Brasilianischen Araukarie. Sydowia 31:9-26

Cáceres MES, Aptroot A (2017) Lichens from the Brazilian Amazon, with special reference to the genus Astrothelium. Bryologist 120:165-181

Cáceres MES, Júnior NM, Santos LA, Pereira TA, Aptroot A (2017) New records to Brazil and Southern Hemisphere of corticolous and saxicolous lichens from the semiarid region in Ceará Stat. Iheringia 72:239-245

Cáceres MES, Lücking R, Schumm F, Aptroot A (2020) A lichenized family yields another renegade lineage: Papilionovela albothallina is the first non-lichenized, saprobic member of Graphidaceae subfam. Graphidoideae. Bryologist 123:144-154

Cain RF (1956) Studies on coprophilous ascomycetes. II. Phaeotrichum, a new cleistocarpous genus in a new family, and its relationships. Can J Bot 34:675-684

Cai L, Guo XY, Hyde KD (2008) Morphological and molecular characterization of a new anamorphic genus Cheirosporium, from freshwater in China. Persoonia 20:53-58

Campbell CK, Mulder JL (1977) Skin and nail infection by Scytalidium hyalinum sp. nov. Sabouraudia 15:161-166

Campbell R, Sutton BC (1977) Conidial ontogeny in Echinocatena arthrinioides gen. et sp. nov. (Deuteromycotina: Hyphomycetes). Trans Br mycol Soc 69:125-131

Campbell J, Ferrer A, Raja HA, Sivichai S, Shearer CA (2007) Phylogenetic relationships among taxa in the Jahnulales inferred from $18 \mathrm{~S}$ and $28 \mathrm{~S}$ nuclear ribosomal DNA sequences. Can $\mathrm{J}$ Bot 85:873-882

Cannon PF, Alcorn JL (1994) Omnidemptus affinis gen. et. sp. nov., teleomorph of Mycoleptodiscus affinis sp. nov. Mycotaxon $51: 483-487$

Cannon PF, Kirk PM (2007) Fungal Families of the World. CABI Bioscience, Wallingford, UK, pp 1-456

Carris LM, Poole AP (1993) A new species of Protoventuria on leaves of Vaccinium macrocarpon. Mycologia 85:93-99

Castañeda-Ruíz RF, Fabre DE, Parra M, Perez M, Guarro J (1996) Some airborne conidial fungi from Cuba. Mycotaxon. 60:283-290

Castañeda-Ruíz RF, Guarro J, Gené J (2000) Two new hyphomycetes from Arecaceae in La Gomera, Canary Islands. Mycotaxon 76:85-92

Castañeda-Ruíz RF, Hernández-Restrepo M, Gené J, Guarro J, Minter DW, Saikawa M (2013) Two new microfungi from Portugal: Magnohelicospora iberica gen. \& sp. nov. and Phaeodactylium stadleri sp. nov. Mycotaxon 121:171-179

Cavalcante JG, Cáceres MES (2014) Estudos liquênicos no Nordeste Brasileiro: registro de Strigula ziziphi (A. Massal.) Cl. Roux \& Sérus para a América do Sul. Sétimo Encontro do Grupo Brasileiro de Liquenólogos. 1. Grupo Brasileiro de Liquenólogos. Livro de Resumos: 69

Cejp K, Deighton FC (1969) New genera and species and redispositions of some hyphomycetes, mainly African. Mycol Pap 117:8-31

Cesati V, De Notaris G (1863) Schema di classificazione degle sferiacei italici aschigeri piu' o meno appartenenti al genere Sphaeria nell'antico significato attribuitoglide Persono. Comm Soc crittog Ital 1:177-420

Chaiwan N, Lu YZ, Tibpromma S, Bhat DJ, Hyde KD, Boonmee S (2017) Neotubeufia gen. nov. and Tubeufia guangxiensis sp. nov. (Tubeufiaceae) from freshwater habitats. Mycosphere 8:1443-1456

Chaverri P, Gazis RO (2010) Perisporiopsis lateritia, a new species on decaying leaves of Hevea spp. from the Amazon basin in Peru. Mycotaxon 113:163-169

Cheewangkoon R, Groenewald JZ, Summerell BA, Hyde KD, To-anun C, Crous PW (2009) Myrtaceae, a cache of fungal biodiversity. Persoonia 23:55-85

Chen JJ, Tzean SS (2015) One new species, Guedea lantania, and two new record of hyphomycetes from Taiwan. Taiwania 60:143-147

Chen SF, Morgan DP, Hasey JK, Anderson K, Michailides TJ (2014) Phylogeny, morphology, distribution, and pathogenicity of Botryosphaeriaceae and Diaporthaceae from English walnut in California. Plant Dis 98:636-652

Chethana KWT, Li XH, Wei ZH, Hyde KD, Yan J (2016) Trail of decryption of molecular research on Botryosphaeriaceae in woody plants. Phytopathol Mediterr 55:147-171

Christian W, Janice K, Hans-Peter G (2011) Aquatic fungi. In: Grillo $\mathrm{O}$ (ed) The dynamical processes of biodiversity, case studies of evolution and spatial distribution. Intech Press, Rijeka, Croatia, pp 227-258

Clements FE (1909) The genera of Fungi. Wilson, New York, pp 1-227

Clements FE, Shear CL (1931) Genera of fungi, edn 2. i-vii, 58 plates. H.W. Wilson Company, USA, New York, pp 496

Clendenin I (1896) Lasiodiplodia Ellis \& Everh. n. gen. Bot. gaz. crawfordsville. 21:92-93

Cooke MC (1885) Synopsis Pyrenomycetum (continued). Grevillea 13:100-109

Coppins BJ (2002) Checklist of lichens of Great Britain and Ireland. British Lichen Society, pp 87

Coppins BJ, James PW, Hawksworth DL (1992) New species and combinations in the lichen flora of Great Britain and Ireland. Lichenologi 24:351-369

Corda ACJ (1838) Icones fungorum hucusque cognitorum 2:1-43 
Crane JL, Shearer CA, Barr ME (1998) A revision of Boerlagiomyces with notes and a key to the saprobic genera of Tubeufiaceae. Can J Bot 76:602-612

Crivelli PG (1983) Ueber die heterogene Ascomycetengattung Pleospora Rabh. Vorschlag für eine Aufteilung. Zürich. Diss ETH $\mathrm{Nr} 7318: 1-215$

Crous PW, Denman S, Taylor JE, Swart L, Palm ME (2004) Cultivation and diseases of Proteaceae: Leucadendron, Leucospermum and Protea. CBS Biodiversity Series 2:1-228

Crous PW, Slippers B, Wingfield MJ, Rheeder J, Marasas WFO, Philips AJL, Alves A, Burgess T, Barber P, Groenewald JZ (2006a) Phylogenetic lineages in the Botryosphaeriaceae. Stud Mycol 55:235-253

Crous PW, Verkley GJM, Groenewald JZ (2006b) Eucalyptus microfungi known from culture. 1. Cladoriella and Fulvoflamma genera nova, with notes on some other poorly known taxa. Stud Mycol 55:53-64

Crous PW, Schubert K, Braun U, de Hoog GS, Hocking AD, Shin H-D, Groenewald JZ (2007b) Opportunistic, human-pathogenic species in the Herpotrichiellaceae are phenotypically similar to saprobic or phytopathogenic species in the Venturiaceae. Stud Mycol 58:185-217

Crous PW, Groenewald JZ, Wingfield MJ, Phillips AJL (2007a) Neofusicoccum mediterraneum. Fungal Planet 19. CBS-KNAW Fungal Biodiversity Centre, Utrecht, the Netherlands

Crous PW, Wood AR, Okada G, Groenewald JZ (2008) Foliicolous microfungi occurring on Encephalartos. Persoonia 21:135-146

Crous PW, Schoch CL, Hyde KD, Wood AR, Gueidan C, de Hoog GS, Groenewald JZ (2009) Phylogenetic lineages in the Capnodiales. Stud Mycol 64:17-47

Crous PW, Groenewald JZ, Shivas RG, Edwards J, Seifert KA, Alfenas AC, Alfenas RF, Burgess TI, Carnegie AJ, Hardy GEStJ, Hiscock N, Hüberli D, Jung T, Louis-Seize G, Okada G, Pereira OL, Stukely MJC, Wang W, White GP, Young AJ, McTaggart AR, Pascoe IG, Porter IJ, Quaedvlieg W (2011a) Fungal Planet description sheets: 69-91. Persoonia 26:108-156

Crous PW, Summerell BA, Swart L, Denman S, Taylor JE, Bezuidenhout CM, Palm ME, Marincowitz S, Groenewald JZ (2011b) Fungal pathogens of Proteaceae. Persoonia 27:20-45

Crous PW, Groenewald JZ, Lombard L, Wingfield MJ (2012a) Homortomyces gen. nov., a new dothidealean pycnidial fungus from the cradle of humankind. IMA Fungus 3:109-115

Crous PW, Summerell BA, Shivas RG, Burgess TI, Decock CA, Dreyer LL, Granke LL, Guest DI, Hardy GE, Hausbeck MK, Hüberli D, Jung T, Koukol O, Lennox CL, Liew EC, Lombard L, McTaggart AR, Pryke JS, Roets F, Saude C, Shuttleworth LA, Stukely MJ, Vánky K, Webster BJ, Windstam ST, Groenewald JZ (2012b) Fungal Planet description sheets: 107-127. Persoonia 28:138-182

Crous PW, Shivas RG, Quaedvlieg W, vander Ban KM, Zhang Y, Summerell BA, Guarro J, Wingfield MJ, Wood AR, Alfenas AC, Braun U, Cano-Lira JF, García D, Marin-Felix Y, Alvarado P, Andrade JP, Armengol J, Assefa A, den Breeÿen A, Camele I, Cheewangkoon R, DeSouza JT, Duong TA, Esteve-Raventós F, Fournier J, Frisullo S, García-Jiménez J, Gardiennet A, Gené J, Hernández-Restrepo M, Hirooka Y, Hospenthal DR, King A, Lechat C, Lombard L, Mang SM, Marbach PA, Marincowitz S, Marin-Felix Y, Montaño-Mata NJ, Moreno G, Perez CA, PérezSierra AM, Robertson JL, Roux J, Rubio E, Schumacher RK, Stchigel AM, Sutton DA, Tan YP,Thompson EH, vander Linde E, Walker AK, Walker DM, Wickes BL, Wong PT, Groenewald JZ (2013) Fungal Planet description sheets: 154-213. Persoonia 31:188-296

Crous PW, Wingfield MJ, Schumacher RK, Summerell BA, Giraldo A, Gené J, Guarro J, Wanasinghe DN, Hyde KD, Camporesi E, Jones EBG, Thambugala KM, Malysheva EF, Malysheva
VF, Acharya K, Álvarez J, Alvarado P, Assefa A, Barnes CW, Bartlett JS, Blanchette RA, Burgess TI, Carlavilla JR, Coetzee MPA, Damm U, Decock CA, den Breeÿen A, de Vries B, Dutta AK, Holdom DG, Rooney-Latham S, Manjón JL, Marincowitz S, Mirabolfathy M, Moreno G, Nakashima C, Papizadeh M, Shahzadeh Fazeli SA, Amoozegar MA, Romberg MK, Shivas RG, Stalpers JA, Stielow B, Stukely MJC, Swart WJ, Tan YP, van der Bank M, Wood AR, Zhang Y, Groenewald JZ (2014) Fungal Planet description sheets: 281-319. Persoonia 33:212-289

Crous PW, Müller MM, Sánchez RM, Giordano L, Bianchinotti MV, Anderson FE, Groenewald ZJ (2015a) Resolving Tiarosporella spp. allied to Botryosphaeriaceae and Phacidiaceae. Phytotaxa 202:73-93

Crous PW, Wingfield MJ, Guarro J, Hernández-Restrepo M, Sutton DA, Acharya K, Barber PA, Boekhout T, Dimitrov RA, Dueñas M, Dutta AK, Gené J, Gouliamova DE, Groenewald M, Lombard L, Morozova OV, Sarkar J, Smith MT, Stchigel AM, Wiederhold NP, Alexandrova AV, Antelmi I, Armengol J, Barnes I, CanoLira JF, Castañeda Ruiz RF, Contu M, Courtecuisse PR, da Silveira AL, Decock CA, de Goes A, Edathodu J, Ercole E, Firmino AC, Fourie A, Fournier J, Furtado EL, Geering AD, Gershenzon J, Giraldo A, Gramaje D, Hammerbacher A, He XL, Haryadi D, Khemmuk W, Kovalenko AE, Krawczynski R, Laich F, Lechat C, Lopes UP, Madrid H, Malysheva EF, Marín-Felix Y, Martín MP, Mostert L, Nigro F, Pereira OL, Picillo B, Pinho DB, Popov ES, Rodas Peláez CA, Rooney-Latham S, Sandoval-Denis M, Shivas RG, Silva V, Stoilova-Disheva MM, Telleria MT, Ullah C, Unsicker SB, van der Merwe NA, Vizzini A, Wagner HG, Wong PT, Wood AR, Groenewald JZ (2015b) Fungal Planet description sheets: 320-370. Persoonia 34:167-266

Crous PWWM, Burgess TI, Hardy GE, Crane C, Barrett S, Cano-Lira JF, Le Roux JJ, Thangavel R, Guarro J, Stchigel AM, Martín MP, Alfredo DS, Barber PA, Barreto RW, Baseia IG, Cano-Canals J, Cheewangkoon R, Ferreira RJ, Gené J, Lechat C, Moreno G, Roets F, Shivas RG, Sousa JO, Tan YP, Wiederhold NP, Abell SE, Accioly T, Albizu JL, Alves JL, Antoniolli ZI, Aplin N, Araújo J, Arzanlou M, Bezerra JD, Bouchara JP, Carlavilla JR, Castillo A, Castroagudín VL, Ceresini PC, Claridge GF, Coelho G, Coimbra VR, Costa LA, da Cunha KC, da Silva SS, Daniel R, de Beer ZW, Dueñas M, Edwards J, Enwistle P, Fiuza PO, Fournier J, García D, Gibertoni TB, Giraud S, GuevaraSuarez M, Gusmão LF, Haituk S, Heykoop M, Hirooka Y, Hofmann TA, Houbraken J, Hughes DP, Kautmanová I, Koppel O, Koukol O, Larsson E, Latha KP, Lee DH, Lisboa DO, Lisboa WS, López-Villalba Á, Maciel JL, Manimohan P, Manjón JL, Marincowitz S, Marney TS, Meijer M, Miller AN, Olariaga I, Paiva LM, Piepenbring M, Poveda-Molero JC, Raj KN, Raja HA, Rougeron A, Salcedo I, Samadi R, Santos TA, Scarlett K, Seifert KA, Shuttleworth LA, Silva GA, Silva M, Siqueira JP, SouzaMotta CM, Stephenson SL, Sutton DA, Tamakeaw N, Telleria MT, Valenzuela-Lopez N, Viljoen A, Visagie CM, Vizzini A, Wartchow F, Wingfield BD, Yurchenko E, Zamora JC, Groenewald JZ (2016a) Fungal Planet description sheets: 469-557. Persoonia 37:218-403

Crous PW, Wingfield MJ, Richardson DM, Le Roux JJ, Strasberg D, Edwards J, Roets F, Hubka V, Taylor PWJ, Heykoop M, Martín MP, Moreno G, Sutton DA, Wiederhold NP, Barnes CW, Carlavilla JR, Gené J, Giraldo A, Guarnaccia V, Guarro J, Hernández- Restrepo M, Kolařík M, Manjón JL, Pascoe IG, Popov ES, Sandoval-Denis M, Woudenberg JHC, Acharya K, Alexandrova AV, Alvarado P, Barbosa RN, Baseia IG, Blanchette RA, Boekhout T, Burgess TI, Cano-Lira JF, Čmoková A, Dimitrov RA, Dyakov MY, Dueñas M, Dutta AK, Esteve-Raventós F, Fedosova AG, Fournier J, Gamboa P, Gouliamova DE, Grebenc T, Groenewald M, Hanse B, Hardy GESJ, Held BW, Jurjević Ž, Kaewgrajang T, Latha KPD, Lombard L, Luangsa-ard JJ, Lysková 
P, Mallátová N, Manimohan P, Miller AN, Mirabolfathy M, Morozova OV, Obodai M, Oliveira NT, Ordóñez ME, Otto EC, Paloi S, Peterson SW, Phosri C, Roux J, Salazar WA, Sánchez A, Sarria GA, Shin HD, Silva BDB, Silva GA, Smith MT, SouzaMotta CM, Stchigel AM, Stoilova-Disheva MM, Sulzbacher MA, Telleria MT, Toapanta C, Traba JM, Valenzuela-Lopez N, Watling R, Groenewald JZ (2016b) Fungal Planet description sheets: 400-468. Persoonia 36:316-458

Crous PW, Wingfield MJ, Burgess TI, Carnegie AJ, StJ Hardy GE, Smith D, Summerell BA, Cano-Lira JF, Guarro J, Houbraken J, Lombard L, Martín MP, Sandoval-Denis M, Alexandrova AV, Barnes CW, Baseia IG, Bezerra JDP, Guarnaccia V, May TW, Hernández-Restrepo M, Stchigel AM, Miller AN, Ordoñez ME, Abreu VP, Accioly T, Agnello C, Agustincolmán A, Albuquerque CC, Alfredo DS, Alvarado P, Araújo-Magalhães GR, Arauzo S, Atkinson T, Barili A, Barreto RW, Bezerra JL, Cabral TS, Rodríguez F Camello, Cruz RHSF, Daniëls PP, da silva BDB, de Almeida DAC, de Carvalhojúnior AA, Decock CA, Delgat L, Denman S, Dimitrov RA, Edwards J, Fedosova AG, Ferreira RJ, Firmino AL, Flores JA, García D, Gené J, Giraldo A, Góis JS, Gomes AAM, Gonçalves CM, Gouliamova DE, Groenewald M, Guéorguiev BV, Guevara-Suarez M, Gusmão LFP, Hosaka K, Hubka V, Huhndorf SM, Jadan M, Jurjevi, Kraak B, Kuera V, Kumar TKA, Kušan I, Lacerda SR, Lamlertthon S, Lisboa WS, Loizides M, Luangsa-Ard JJ, Lysková P, Maccormack WP, Macedo DM, Machado AR, Malysheva EF, Marinho P, Matoec N, Meijer M, Meši A, Mongkolsamrit S, Moreira KA, Morozova OV, Nair KU, Nakamura N, Noisripoom W, Olariaga I, Oliveira RJV, Paiva LM, Pawar P, Pereira OL, Peterson SW, Prieto M, Rodríguez-Andrade E, Rojodeblas C, Roy M, Santos ES, Sharma R, Silva GA, Souza-Motta CM, Takeuchi-Kaneko Y, Tanaka C, Thakur A, Smith MTH, Tkalec Z, Valenzuela-Lopez N, Vanderkleij P, Verbeken A, Viana MG, Wang XW, Groenewald JZ (2017) Fungal Planet description sheets: 625-715. Persoonia 39:270-467

Crous PW, Luangsa-Ard JJ, Wingfield MJ, Carnegie AJ, HernándezRestrepo M, Lombard L, Roux J, Barreto RW, Baseia IG, CanoLira JF, Martín MP, Morozova OV, Stchigel AM, Summerell BA, Brandrud TE, Dima B, García D, Giraldo A, Guarro J, Gusmão LFP, Khamsuntorn P, Noordeloos ME, Nuankaew S, Pinruan U, Rodríguez-Andrade E, Souza-Motta CM, Thangavel R, van Iperen AL, Abreu VP, Accioly T, Alves JL, Andrade JP, Bahram M, Baral HO, Barbier E, Barnes CW, Bendiksen E, Bernard E, Bezerra JDP, Bezerra JL, Bizio E, Blair JE, Bulyonkova TM, Cabral TS, Caiafa MV, Cantillo T, Colmán AA, Conceição LB, Cruz S, Cunha AOB, Darveaux BA, da Silva AL, da Silva GA, da Silva GM, da Silva RMF, de Oliveira RJV, Oliveira RL, De Souza JT, Dueñas M, Evans HC, Epifani F, Felipe MTC, Fernández-López J, Ferreira BW, Figueiredo CN, Filippova NV, Flores JA, Gené J, Ghorbani G, Gibertoni TB, Glushakova AM, Healy R, Huhndorf SM, Iturrieta-González I, Javan-Nikkhah M, Juciano RF, Jurjević Ž, Kachalkin AV, Keochanpheng K, Krisai-Greilhuber I, Li YC, Lima AA, Machado AR, Madrid H, Magalhães OMC, Marbach PAS, Melanda GCS, Miller AN, Mongkolsamrit S, Nascimento RP, Oliveira TGL, Ordoñez ME, Orzes R, Palma MA, Pearce CJ, Pereira OL, Perrone G, Peterson SW, Pham THG, Piontelli E, Pordel A, Quijada L, Raja HA, Rosas de Paz E, Ryvarden L, Saitta A, Salcedo SS, SandovalDenis M, Santos TAB, Seifert KA, Silva BDB, Smith ME, Soares AM, Sommai S, Sousa JO, Suetrong S, Susca A, Tedersoo L, Telleria MT, Thanakitpipattana D, Valenzuela-Lopez N, Visagie CM, Zapata M, Groenewald JZ (2018a) Fungal Planet description sheets: 785-867. Persoonia 41:238-417

Crous PW, Schumacher RK, Wingfield MJ, Akulov A, Denman S, Roux J, Braun U, Burgess TI, Carnegie AJ, Váczy KZ, Guatimosim E, Schwartsburd PB, Barreto RW, Hernández-Restrepo M,
Lombard L, Groenewald JZ (2018b) New and Interesting Fungi 1. FUSE 1:169-215

Crous PW, Schumacher RK, Akulov A, Thangavel R, HernándezRestrepo M, Carnegie AJ, Cheewangkoon R, Wingfield MJ, Summerell BA, Quaedvlieg W, Coutinho TA, Roux J, Wood AR, Giraldo A, Groenewald JZ (2019a) New and Interesting Fungi 2. FUSE 3:57-134

Crous PW, Schumacher RK, Wood AR, Groenewald JZ (2019b) The Genera of Fungi - G5: Arthrinium, Ceratosphaeria, Dimerosporiopsis, Hormodochis, Lecanostictopsis, Lembosina, Neomelanconium, Phragmotrichum, Pseudomelanconium, Rutola, and Trullula. FUSE 5:77-98

Crous PW, Wingfield MJ, Cheewangkoon R, Carnegie AJ, Burgess TI, Summerell BA, Edwards J, Taylor PWJ, Groenewald JZ (2019c) Foliar pathogens of eucalypts. Stud Mycol 94:125-298

Dai DQ, Bahkali AH, Bhat DJ, Xiao YP, Chukeatirote E, Zhao RL, Mckenzie EHC, Jianchu Xu, Hyde KD (2014a) Towards a natural classification of Dothideomycetes 3: The genera Muellerites, Trematosphaeriopsis, Vizellopsis and Yoshinagella (Dothideomycetes incertae sedis). Phytotaxa 176:18-27

Dai DQ, Boonmee S, Tian Q, Xiao YP, Bhat DJ, Chukeatirote E, Alias SA, Wang Y, Hyde KD (2014b) Englerulaceae (Dothideomycetes). Phytotaxa 176:139-155

Dai DQ, Phookamsak R, Wijayawardene NN, Li WJ, Bhat DJ, Xu JC, Taylor JE, Hyde KD, Chukeatirote E (2017) Bambusicolous fungi. Fungal Divers 82:1-105

Dai DQ, Tang LZ, Liu C, Wang HB, Hyde KD (2018) Studies on Parmulariaceae I. A phylogeny based on available sequence data; introducing Parmulariales ord. nov., and Hemigraphaceae. Melaspileellaceae and Stictographaceae fam. nov. Phytotaxa 369:063-079

Daly DC, Millozza A (2007) "Lost" plant collections from the Amazon 1: the 1899 expedition of Dr. Luigi Buscalioni. Taxon 56:185-199

Damm U, Crous PW, Fourie PH (2007) Botryosphaeriaceae as potential pathogens of Prunus species in South Africa, with descriptions of Diplodia africana and Lasiodiplodia plurivora sp. nov. Mycologia 99:664-680

Del Prado R, Schmitt I, Kautz S, Palice Z, Lücking R, Lumbsch HT (2006) Molecular data place Trypetheliaceae in Dothideomycetes. Mycol Res 110:511-520

Denman S, Crous PW, Taylor JE, Kang JC, Pascoe I, Wingfield MJ (2000) An overview of the taxonomic history of Botryosphaeria, and a re-evaluation of its anamorphs based on morphology and ITS rDNA phylogeny. Stud Mycol 45:129-140

De Notaris G (1846) Frammenti Lichenografici di un lavorno inedito. Giorn Bot Ital 1:174-224

De Notaris G (1849) Abrothallus novum lichenum genus. Mem Reale Accad Sci Torino 10:351-355

Diederich P, Wedin M (2000) The species of Hemigrapha (lichenicolous Ascomycetes, Dothideales) on Peltigerales. Nord J Bot 20:203-214

Diederich P, Lücking R, Aptroot A, Sipman HJM, Braun U, Ahti T, Ertz D (2017) New species and new records of lichens and lichenicolous fungi from the Seychelles. Herzogia 30:182-236

Diederich P, Lawrey JD, Ertz D (2018) The 2018 classification and checklist of lichenicolous fungi, with 2000 non-lichenized, obligately lichenicolous taxa. Bryologist 121:340-425

Diehl WW (1950) Balansia and the Balansiae in America. Agriculture Monograph No. 4

Dilcher DL (1965) Epiphyllous fungi from Eocene deposits in western Tennessee, U.S.A. Palaeontogr Abt B 116:1-54

Dingley JM (1972) Some foliicolous ascomycetes on Ferns in Australia and New Zealand. The Genera Rhagadolobium P. Henn. \& Lind. and Lauterobachiella Theiss. \& Syd. NZ J Botany 10:74-86 
Dissanayake AJ, Jayawardena RS, Boonmee S, Thambugala KM, Tian Q, Mapook A, Senanayake IC, Yan JY, Li YM, Li XH, Chukeatirote E, Hyde KD (2014) The status of Myriangiaceae (Dothideomycetes). Phytotaxa 176:219-237

Dissanayake AJ, Phillips AJL, Li XH, Hyde KD (2016) Botryosphaeriaceae: Current status of genera and species. Mycosphere 7:1001-1073

Dix NJ, Webster J (1995) Fungal Ecology. Chapman \& Hall, Cambridge, Great Britain

Döbbeler P (1978) Moosbewohnende Ascomyceten I. Die pyrenocarpen, den Gametophyten besiedelnden Arten. Mitt Bot Staatssamml Münch 14:1-360

Döbbeler P (1979) Moosbewohnende Ascomyceten III. Einige neue Arten der Gattungen Nectria, Epibryon und Punctillum. Mitt Bot Staatssamml Münch 15:193-221

Döbbeler P, Poelt J (1981) Arthopyrenia endobrya, spec. nov., eine hepaticole Flechte mit intrazellulärem Thallus aus Brasilien. Plant Syst Evol 138:275-281

Doidge EM (1942) A revision of South African Microthyriaceae. Bothalia 4:273-420

Doilom M, Dissanayake AJ, Phillips AJL, Boonmee S, Liu JK, Bhat DJ, Taylor JE, Bahkali AH, McKenzie EHC, Hyde KD (2017) Microfungi on Tectona grandis (teak) in Northern Thailand. Fungal Divers 82:107-182

Doilom M, Hyde KD, Phookamsak R, Dai DQ, Tang LZ, Hongsanan S, Chomnunti P, Boonmee S, Dayarathne MC, Li WJ, Thambugala KM, Perera RH, Daranagama DA, Norphanphoun C, Konta S, Dong W, Ertz D, Phillips AJL, McKenzie EHC, Kumar V, Ariyawansa HA, Jones EBG, Mortimer PE, Xu JC, Promputtha I (2018) Mycosphere Notes 225-274: types and other specimens of some genera of Ascomycota. Mycosphere 9:647-754

Dong JY, Zhao ZX, Cai L, Liu SQ, Zhang HR, Duan M, Zhang KQ (2004) Nematicidal effect of freshwater fungal cultures against the pine-wood nematode, Bursaphelenchus xylophilus. Fungal Divers 15:125-135

Dong W, Wang B, Hyde KD, McKenzie EHC, Raja HA, Tanaka K, Abdel-Wahab MA, Abdel-Aziz FA, Doilom M, Phookamsak $\mathrm{R}$, Hongsanan S, Wanasinghe DN, Yu XD, Wang GN, Yang H, Yang J,Thambugala KM, Tian Q, Luo ZL, Yang JB, Miller AN, Fournier J, Boonmee S, Hu DM, Nalumpang S, Zhang H (2020) Freshwater Dothideomycetes. Fungal Divers (accepted)

Du Z, Fan XL, Yang Q, Hyde KD, Tian CM (2017) Aplosporella ginkgonis (Aplosporellaceae, Botryosphaeriales), a new species isolated from Ginkgo biloba in China. Mycosphere 8:1246-1252

Duby JE (1862) Mémoire sur la tribu des Hystérinées de la famille des Hypoxylées (Pyrénomycètes). Mem Soc Phys Hist Nat Geneve 16:15-70

Durand EJ (1922) The genus Catinella. Bull Torrey Bot Club 49:15-21

Ebersohn C, Eicker A (1992) Trichodelitschia microspora, a new coprophilous species from South Africa. South African Journal of Botany 58:145-146

Ekanayaka AH, Dissanayake AJ, Jayasiri SC, To-anun C, Jones EBG, Zhao Q, Hyde KD (2016) Aplosporella thailandica; a novel species revealing the sexual-asexual connection in Aplosporellaceae (Botryosphaeriales). Mycosphere 7:440-447

Ellis MB (1960) Dematiaceous hyphomycetes 1. Mycol Pap 76:1-36

Ellis MB (1971) Dematiaceous hyphomycetes. X. Mycol Pap 125:10

Ellis MB (1972) Dematiaceous Hyphomycetes. XI. Mycol Pap $131: 1-25$

Ellis JP (1980) The genus Morenoina in Britain. Trans Br Mycol Soc 74:297-307

Ellis JB, Everhart BM (1892) The North American pyrenomycetes. Newfield, NJ

Ellis JB, Everhart BM (1894) New species of fungi from various localities. Proc. Acad. Nat. Sci. Philadelphia. 46:322-386
Elsebai MF, Saleem M, Tejesvi MV, Kajula M, Mattila S, Mehiri M, Turpeinen A, Pirttilä AM (2014) Fungal phenalenones: chemistry, biology, biosynthesis and phylogeny. Nat Prod Rep $31: 628-645$

Eriksson OE (1981) The families of bitunicate ascomycetes. Opera Botanica 60:1-220

Eriksson OE (1982) Notes on ascomycetes and coelomycetes from NW Europe. Mycotaxon. 15:189-202

Eriksson OE, Hawksworth DL (1993) Outline of the ascomycetes 1993. Syst Ascomycetum 12:51-257

Eriksson OE, Baral HO, Currah RS, Hansen K, Kurtzman CP, Rambold G, Laessøe T (eds) (2001) Outline of Ascomycota - 2001. Myconet 7:1-88

Ertz D, Diederich P (2015) Dismantling Melaspileaceae: a first phylogenetic study of Buelliella, Hemigrapha, Karschia, Labrocarpon and Melaspilea. Fungal Divers 71:141-164

Ertz D, Lawrey JD, Common RS, Diederich P (2014) Molecular data resolve a new order of Arthoniomycetes sister to the primarily lichenized Arthoniales and composed of black yeasts, lichenicolous and rock-inhabiting species. Fungal Divers 66:113-137

Ertz D, Diederich P, Lawrey JD, Berger F, Freebury CE, Coppins B, Gardiennet A, Hafellner J (2015) Phylogenetic insights resolve Dacampiaceae (Pleosporales) as polyphyetic: Didymocyrtis (Pleosporales, Phaeosphaeriaceae) with phoma-like anamorphs resurrected and segregated form Polycoccum (Trypetheliales, Polycoccaceae fam. nov.). Fungal Divers 74:53-89

Ertz D, Heuchert B, Braun U, Freebury CE, Common RS, Diederich P (2016) Contribution to the phylogeny and taxonomy of the genus Taeniolella, with a focus on lichenicolous taxa. Fungal Biol 120:1416-1447

Espoz C, Guzman G, Castilla JC (1995) The lichen Thelidium litorale on shells of intertidal limpets: a case of lichen-mediated cryptic mimicry. Mar Ecol Prog Ser 119:191-197

Etayo J (1993) Strigula mediterranea, a new name for the forgotten lichen Porina schizospora. Lichenologi 25:257-260

Etayo J (2002) Aportación al conocimiento de los hongos liquenícolas de Colombia. Biblioth Lichenol 84:1-154

Etayo J (2010) Líquenes y hongos liquenícolas de Aragón. Guineana 16 Leioa: Universidad del Pais Vasco

Fan C, Lu YZ, Kang JC, Wang L, Lei BX, Chen LZ (2019) Bioactivity evaluation of secondary metabolites produced by species of Tubeufiaceae. Mycosystema 38:560-574

Farr ML (1965) Dimeriella, Wentiomyces, Episphaerella, and Epipolaeum (Fungi: Pyrenomycetes). Taxon 14:18-21

Farr ML (1968) The nomenclatural status and synonymy of Phyllachora bambusina, Lateropeltis bambusarum, and their conidial stages. Mycologia 60:924-931

Farr DF, Rossman AY (2020) Fungal Databases, Systematic Mycology and Microbiology Laboratory, ARS, USDA. from http://nt.arsgrin.gov/fungaldatabases/

Fernández-Brime S, Gaya E, Llimona X, Wedin M, Navarro-Rosinés P (2020) Rhagadodidymellopsis endocarpi gen. et sp. nov. and Arthopyrenia symbiotica (Dothideomyceta), two lichenicolous fungi growing on Endocarpon species. Plant and Fungal Systematics 65:176-184

Ferrer A, Sivichai S, Shearer CA (2007) Megalohypha anewgenus in the Jahnulales from aquatic habitats in the tropics. Mycologia 99:456-460

Ferrer A, Miller AN, Shearer CA (2011) Minutisphaera and Natipusilla: two new genera of freshwater Dothideomycetes. Mycologia 103:11-423

Fink B (1935) The Lichen Flora of the United States. Completed for Publication by Joyce Hedrick. University of Michigan Press, Ann Arbor

Firmino AL, Inácio CA, Pereira OL, Dianese JC (2016) Additions to the genera Asterolibertia and Cirsosia (Asterinaceae, 
Asterinales), with particular reference to species from the Brazilian Cerrado. IMA Fungus 7:9-28

Ford M, Blanchon DJ, Veale A, Doyle EJ, Rolfe JR, de Lange PJ (2019) Hidden in plain sight - a new Strigula species segregated from Strigula novae-zelandiae (Lichenized Ascomycota: Strigulaceae). Phytotaxa 424:267-281

Fries EM (1822) Systema Mycologicum 2:1-275

Fries EM (1823) Systema Mycologicum II. Officina Berlingiana, Lund Fries EM (1825) Systema Orbis Vegetabilis. Pars I. Plantae Homonemeae, Typografia Academica, Lund

Fries EM (1849) Summa Vegetabilium Scandinaveae. Sectio posterior. Typographia Academica, Leipzig, pp 259-572

Frisch A, Thor G, Ertz D, Grube M (2014) The Arthonialean challenge: restructuring Arthoniaceae. Taxon 63:727-744

Fuckel L (1870) Beiträge zur Kenntniss der Rheinischen Pilze. Jahrb Nassau Verh Naturk 23-24:1-459

Index Fungorum (2020) http://www.indexfungorum.org/Names/Names .asp

Gamundí IJ (1981) On Lagerheima Sacc. and Bulgariella Karst. Sydowia 34:82-93

Gardiennet A (2012) Découverte de Polycoccum slaptoniense D. Hawksw. en France. Bull Info Assoc Fr Lichénol 37:107-111

Gäumann EA (1964) ie Pilze. Grundzüge ihrer Entwicklungsgeschichte und Morphologie, 2nd edn. Birkhäuser, Basel

Gerdemann JW (1953) An undescribed fungus causing a root rot of red clover and other Leguminosae. Mycologia 45:548-554

Gibbs LS (1914) A contribution to the flora and plant formations of Mount Kinabalu and the highlands of British North Borneo. J Linn Soc Bot 42:1-240

Giraldo A, Sutton DA, Samerpitak K, De Hoog GS, Wiederhold NP, Guarro J, Gené J (2014) Occurrence of Ochroconis and Verruconis species in clinical specimens from the United States. Journal of clinical microbiology 52:4189-4201

Giraldo A, Crous PW, Schumacher RK, Cheewangkoon R, GhobadNejhad M, Langer E (2017) The Genera of Fungi - G3: Aleurocystis, Blastacervulus, Clypeophysalospora, Licrostroma, Neohendersonia and Spumatoria. Mycol Prog 16:325-348

Glawe DA (1985) The pleomorphic asexual state of Valsaria insitiva in artificial culture. Mycologia 77:62-71

Goebel F, Kunze G (1827) Pharmazeutische Waarenkunde. Eisenach

Goh TK, Hyde KD, Ho WH (1998a) Aquaphila albicans gen. et sp. nov., a hyphomycete from submerged wood in the tropics. Mycol Res 102:587-592

Goh TK, Hyde KD, Tsui KM (1998b) The hyphomycete genus Acrogenospora, with two new species and two new combinations. Mycol Res 102:1309-1315

González-Fragoso R, Ciferri R (1925) Hongos parasitos y saprofitos de la Republica Dominicana. 1a Serie. Bol R Soc Esp Hist Nat Sec Biol 25:356-368

Goos RD (1985) A review of the anamorph genus Helicomyces. Mycologia 77:606-618

Goos RD (1986) A review of the anamorph genus Helicoma. Mycologia 78:744-761

Goos RD (1989) On the anamorph genera Helicosporium and Drepanospora. Mycologia 81:356-374

Granmo A, Mathiassen G (2013) A new species of Dothiopeltis from Norway. Sydowia. 65(2):343-348

Greif M, Gibas CFC, Tsuneda A, Currah R (2007) Ascoma development and phylogeny of an apothecioid dothideomycete, Catinella olivacea. Am J Bot 94:1890-1899

Greville RK (1825) Scottish Cryptogamic Flora, or coloured figures and descriptions of cryptogamic plants, belonging chiefly to the order Fungi. Vol IV. Edinburgh: MacLachlan \& Stewart; London: Baldwin, Cradock \& Joy

Griffon E, Maublanc A (1909) Sur une maladie du cacaoyer. Bull Trimest Soc Mycol Fr. 25:51-58
Grube M (2005) Frigidopyrenia-a new genus for a peculiar subarctic lichen, with notes on similar taxa. Phyton 45:305-318

Grube M, Hafellner J (1990) Studien an flechtenbewohnenden pilzen der sammelgattung Didymella (Ascomycetes, Dothideales). Nova Hedwig 51:283-360

Grube M, Ryan BD (2002) Collemopsidium. In: Nash TH, Ryan BD, Gries C, Bungartz F (eds) Lichen flora of the Greater Sonoran Desert Region. Lichens Unlimited, Tempe, pp 1162-1164

Guatimosim E, Pinto HJ, Barreto RW, Prado J (2014) Rhagadolobiopsis, a new genus of Parmulariaceae from Brazil with a description of the ontogeny of its ascomata. Mycologia 106:276-281

Guatimosim E, Firmino A, Bezerra J, Pereira O, Barreto R, Crous P (2015) Towards a phylogenetic reappraisal of Parmulariaceae and Asterinaceae (Dothideomycetes). Persoonia 35:230-241

Guerrero Y, Hofmann TA, Williams C, Thines M, Piepenbring M (2011) Asterotexis cucurbitacearum, a poorly known pathogen of Cucurbitaceae new to Costa Rica, Grenada and Panama. Mycology 2:87-90

Guo JS, Zhang Z, Qiao M, Yu ZF (2019) Phalangispora sinensis sp. nov. from Yunnan, China and two new members of Wiesneriomycetaceae. Int J Syst Evol Microbiol 69:3217-3223

Hafellner J (1979) Karschia. Revision einer Sammelgattung an der Grenze von lichenisierten und nichlichenisierten Ascomyceten. Beih Nova Hedwig 62:1-248

Hafellner J (2002) Zur Diversität lichenisierter Pilze und ihrer Parasiten in den Seckauer Tauern (Ostalpen, Niedere Tauern, Steiermark). Mitt Naturwiss Ver Steiermark 132:83-137

Hafellner J (2019) A reinvestigation of Microthelia umbilicariae results in a contribution to the species diversity in Endococcus.

Hafellner J, Herzog G, Mayrhofer H (2008) Zur Diversität von lichenisierten und lichenicolen Pilzen in den Ennstaler Alpen (Österreich: Steiermark, Oberösterreich). Mitt Naturwiss Ver Steiermark 137:131-204

Halıcı MG, Kocourková J, Diederich P, Aksoy A (2007) Endococcus variabilis, a new species on Staurothele areolata. Mycotaxon 100:337-342

Hall T (2004) BioEdit v. 7.0.1. Department of Microbiology, North Carolina State University. Available at www.mbio.ncsu.edu/ BioEdit/bioedit.htm

Hametner C, Stocker-Wörgötter E, Rindi F, Grube M (2014) Phylogenetic position and morphology of lichenized Trentepohliales (Ulvophyceae, Chlorophyta) from selected species of Graphidaceae. Phycol Res 62:170-186

Hanada T, Sato T, Arioka M, Uramoto M, Yamasaki M (1996) Purification and characterization of a $15 \mathrm{kDa}$ Protein (p15) produced by Helicosporium that exhibits distinct effects on neurite outgrowth from cortical neurons and PC12 Cells. Biochem Biophys Res Commun 228:209-215

Hansford CG (1946) The foliicolous Ascomycetes, their parasites and associated fungi. Mycol Pap 15:1-240

Hansford CG (1961) The Meliolineae: a monograph. Sydowia. Ser. II, Beihefte 2:1-806

Hao L, Chen C, Zhang R, Zhu M, Sun G, Gleason ML (2013) A new species of Scolecobasidium associated with the sooty blotch and flyspeck complex on banana from China. Mycol prog 12:489-495

Harada H (2017) Taxonomic notes on pyrenocarpous lichens in Japan (8). Trypetheliopsis yoshimurae (lichenized Ascomycota, Monoblastiaceae) sp. nov. Lichenology 16:15-21

Harada H (2018) Taxonomic notes on pyrenocarpous lichens in Japan (10). Monoblastia chibaensis (lichenized Ascomycota, Monoblastiaceae), a new corticolous species with spinulose ascospores. Lichenology 17:51-58

Harada H (2019) Taxonomic notes on pyrenocarpous lichens in Japan (11). Anisomeridium yoshimurae sp. nov. (Monoblastiaceae). Lichenology 18:9-13

Haridas S, Albert R, Binder M, Bloem J, LaButti K, Salamov A, Andreopoulos B, Baker SE, Barry K, Bills G, Bluhm BH, 
Cannon C, Castanera R, Culley DE, Daum C, Ezra D, González JB, Henrissat B, Kuo A, Liang C, Lipzen A, Lutzoni F, Magnuson J, Mondo SJ, Nolan M, Ohm RA, Pangilinan J, Park HJ, Ramírez L, Alfaro M, Sun H, Tritt A, Yoshinaga Y, Zwiers LH, Turgeon BG, Goodwin SB, Spatafora JW, Crous PW, Grigoriev IV (2020) 101 Dothideomycetes genomes: A test case for predicting lifestyles and emergence of pathogens. Stud Mycol 96:141-153

Harris RC (1973) The corticoloios pyrenolichens of the Great Lakes region. Mich Bot 12:3-68

Harris RC (1986) The family Trypetheliaceae (Loculoascomycetes: lichenized Melanommatales) in Amazonian Brazil. Acta Amaz 14:55-80

Harris RC (1990) Some Florida lichens. Publ. by the Author,Bronx, N.Y.

Harris RC (1995) More Florida lichens. Including the 10c tour of the pyrenolichens. The New York Botanical Garden, Bronx

Hawksworth DL (1979) Studies in the genus Endococcus (Ascomycotina, Dothideales). Botaniska Notiser 132:283-290

Hawksworth DL (1981a) Lichenothelia, a new genus for the Microthelia aterrima group. Lichenologi 13:141-153

Hawksworth DL (1981b) The lichenicolous coelomycetes. Bull Br Mus Nat Hist Bot 9:1-98

Hawksworth DL (1982) Secondary fungi in lichen symbioses, parasites, saprophytes and parasymbionts. J Hattori Bot Lab 52:357-366

Hawksworth DL (1985) A redisposition of the species referred to the ascomycete genus Microthelia. Bull Br Mus Nat Hist Bot 14:43-181

Hawksworth DL (1989) Jarxia, a new genus of Didymosphaeria-like fungi from the West Indies. Stud Mycol 31:93-97

Hawksworth DL (ed) (1995) Biodiversity: measurement and estimation, vol 345. Springer, Dordrecht

Hawksworth DL, David JC (1989) Family names: index of fungi supplement. CAB International, Wallingford

Hawksworth DL, Diederich P (1988) A synopsis of the genus Polycoccum (Dothideales), with a key to accepted species. Trans $\mathrm{Br}$ Mycol Soc 90:293-312

Hawksworth DL, Eriksson OE (1986) The names of accepted orders of ascomycetes. Syst Ascomycetum 5:175-184

Hawksworth DL, Kirk PM, Sutton BC, Pegler DN (1983) Ainsworth \& Bisby's dictionary of the fungi. Commonwealth Mycological Institute, Kew

Hawksworth DL, Kirk PM, Sutton BC, Pegler DN (1995) Ainsworth $\&$ Bisby's dictionary of the fungi, 8th edn. CAB International, Wallingford

Hennings PC (1900) Fungi japonica. Bot Jahrb Syst Pflanzengesch Pflanzengeogr 28:259-280

Hennings PC (1902) Fungi S. Paulenses I. a cl. Puttemans collecti. Hedwigia 41:104-118

Hennings P (1904a) Fungi Africae orientalis III. Bot Jahrb Syst, Pflanzengesch Pflanzengeogr 34:39-57

Hennings P (1904b) Fungi Amazonici a cl. Ernesto Ule collecti III. Hedwigia 43:351-400

Henssen H (1987) Lichenothelia, a genus of microfungi on rocks. In: Peveling E, ed. Progress and problems in lichenology in the eighties. Bibliotheca Lichenologica 25:257-293

Henssen A, Jahns HM (1974) [1973] Lichenes. Thieme, Stuttgart

Hernández-Restrepo M, Bezerra JDP, Tan YP, Wiederhold N, Crous PW, Guarro J, Gené J (2019) Re-evaluation of Mycoleptodiscus species and morphologically similar fungi. Persoonia 42:205-227

Heuchert B, Braun U, Diederich P, Ertz D (2018) Taxonomic monograph of the genus Taeniolella s. lat. (Ascomycota). FUSE 2:69-261

Hofmann TA (2009) Plant parasitic Asterinaceae and Microthyriaceae from the Neotropics (Panama). Johann Wolfgang Goethe-University, Frankfurt
Hofmann TA, Piepenbring M (2006) New records and host plants of fly-speck fungi from Panama. Fungal Divers 22:55-70

Holm L, Holm K (1977) A study of Leptopeltidaceae. Bot Notiser 130:215-229

Hongsanan S, Hyde KD (2017) Phylogenetic placement of Micropeltidaceae. Mycosphere 8:1930-1942

Hongsanan S, Bahkali AH, McKenzie EHC, Chukeatirote E, Hyde KD (2014a) Trichopeltinaceae (Dothideomycetes), an earlier name for Brefeldiellaceae, with a new species of Trichopeltina. Phytotaxa 176:270-282

Hongsanan S, Li YM, Liu JK, Hofmann T, Piepenbring M, Bhat JD, Boonmee S, Doilom M, Singtripop C, Tian Q, Mapook A, Zeng XY, Bahkali AH, Xu JC, Mortimer PE, Wu HX, Yang JB, Hyde KD (2014b) Revision of genera in Asterinales. Fungal Divers 68:1-68

Hongsanan S, Hyde KD, Bahkali AH, Camporesi E, Chomnunti P, Ekanayaka AH, Gomes A, Valerie H, Jones EBG, Pinho DB, Pereira OL, Tian Q, Wanasinghe DN, Xu JC, Buyck B (2015a) Fungal biodiversity profiles 11-20. Cryptogam Mycol 36:355-380

Hongsanan S, Tian Q, Bahkali AH, Yang JB, McKenzie EHC, Chomunti P, Hyde KD (2015b) Zeloasperisporiales ord. nov., and two new species of Zeloasperisporium. Cryptogam Mycol 36:301-317

Hongsanan S, Tian Q, Hyde KD, Chomnunti P (2015c) Two new species of sooty moulds, Capnodium coffeicola and Conidiocarpus plumeriae in Capnodiaceae. Mycosphere 6:814-824

Hongsanan S, Tian Q, Peršoh D, Zeng XY, Hyde KD, Chomnunti P, Boonmee S, Bahkali AH, Wen TC (2015d) Meliolales. Fungal Divers 74:91-141

Hongsanan S, Hyde KD, Phookamsak R, Wanasinghe DN, McKenzie EHC, Sarma VV, Boonmee S, Lücking R, Pem D, Bhat JD, Liu N, Tennakoon DS, Karunarathna A, Jiang SH, Jones EBG, Phillips AJL, Manawasinghe I, Tibpromma S, Jayasiri SC, Sandamali D, Jayawardena RS, Wijayawardene NN, Ekanayaka AH, Jeewon R, Lu YZ, Dissanayake AJ, Zeng XY, Luo ZL, Tian Q, Phukhamsakda C, Thambugala KM, Dai DQ, Chethana TKW, Ertz D, Doilom M, Liu JK, Pérez-Ortega S, Suija A, Senwanna C, Wijesinghe SN, Konta S, Niranjan M, Zhang SN, Ariyawansa HA, Jiang HB, Zhang JF, de Silva NI, Thiyagaraja V, Zhang H, Bezerra JDP, Miranda-Gonzáles R, Aptroot A, Kashiwadani H, Harishchandra D, Aluthmuhandiram JVS, Abeywickrama PD, Bao DF, Devadatha B, Wu HX, Moon KH, Gueidan C, Schumm F, Bundhun D, Mapook A, Monkai J, Chomnunti P, Samarakoon MC, Suetrong S, Chaiwan N, Dayarathne MC, Jing Y, Rathnayaka AR, Bhunjun CS, Xu JC, Zheng JS, Liu G, Feng Y, Xie N (2020) Refined families of Dothideomycetes: Dothideomycetidae and Pleosporomycetidae. Mycosphere 11:1553-2107

Horré R, de Hoog GS, Kluczny C, Marklein G, Schaal KP (1999) rDNA diversity and physiology of Ochroconis and Scolecobasidium species reported from humans and other vertebrates. Stud Mycol 43:194-205

Hosagoudar VB (1991) Ascospore germination in meliolaceous fungi. Nova Hedwig 52:81-87

Hosagoudar VB (2011) The genus Schiffnerula in India. Plant Pathol Quar J 1:131-204

Hosagoudar VB, Abraham TK, Biju CK (2001) Re-evaluation of the family Asterinaceae. Mycopathol Res 39:61-63

Hosagoudar VB, Thimmaiah C, Jayashankara M (2011) Schiffnerulaceous fungi of Kodagu, Karnataka. India. Journal of Threatened Taxa 3(12):2268-2271

Huang SK, Maharachchikumbura SSN, Jeewon R, Bhat DJ, Chomnunti P, Hyde KD, Lumyong S (2018) Morphological and molecular taxonomy of Jahnula dianchia sp. nov. (Jahnulales) from submerged wood in Dianchi Lake, Yunnan. China. Mycol Prog $17: 547-555$ 
Huanraluek N, Ertz D, Phukhamsakda C, Hongsanan S, Jayawardena RS, Hyde KD (2019a) The family Pyrenidiaceae resurrected. Mycosphere 10:634-654

Huanraluek N, Phukhamsakda C, Senwanna C, Hongsanan S, Jayawardena RS, Bhat DJ, Hyde KD (2019b) Verruconis heveae, a novel species from Hevea brasiliensis in Thailand. Phytotaxa 403:47-54

Hudson O, Buchholz M, Doyle V, Sundue MA (2019) Multilocus phylogeny of Acrospermaceae: New epibiotic species and placement of Gonatophragmium, Pseudovirgaria, and Phaeodactylium anamorphs. Mycologia 111(6):1041-1055

Huelsenbeck JP, Ronquist F (2001) MRBAYES: Bayesian inference of phylogenetic trees. Bioinformatics 17:754-755

Hughes SJ (1953a) Conidiophores, conidia and classification. Can J Bot 31:577-659

Hughes SJ (1953b) Fungi from the Gold Coast. II. Mycol Pap 50:1-104

Hughes SJ (1981) Mucronate hyphopodia of Meliolaceae are phialides. Can J Bot 59:1514-1517

Hughes SJ (1984) Digitosarcinella caseariae n.gen., n. p. and Questieriella synanamorphs of the so-called Amazonia caseariae. Can J Bot 62:2208-2212

Hughes SJ (1993) Meliolina and its excluded species. Mycol Pap 166:1-255

Huhndorf SM (1992) Neotropical ascomycetes 1. Valsonectria cinnamomi in artificial culture. Mycologia 84:642-649

Huhndorf SM (1994) Neotropical Ascomycetes 5. Hypsostromataceae, a new family of Loculoascomycetes and Manglicola samuelsii, a new species from Guyana. Mycologia 86:266-269

Huhndorf SM, Harris RC (1996) Oletheriostrigula, a new genus for Massarina papulosa (Fungi, Ascomycetes). Brittonia 48:551-555

Hu H, Guo H, Li E, Liu X, Zhou Y, Che Y (2006) Decaspirones F-I, bioactive secondary metabolites from the saprophytic fungus Helicoma viridis. J Nat Prod 69:1672-1675

Hyde KD (1993) Tropical Australian freshwater fungi. V. Bombardia sp., Jahnula australiensis sp. nov., Savoryella aquatica sp. nov. and S. lignicola sp. nov. Aust Syst Bot 6:161-167

Hyde KD (1996) Fungi from palms. XXIV. The genus Bondiella. Mycotaxon 57:347-352

Hyde KD, Wong SW (1999) Tropical Australian freshwater fungi XV. The ascomycetes genus Jahnula, with five new species and one new combination. Nova Hedwig 68:489-509

Hyde KD, McKenzie EHC, KoKo TW (2011) Towards incorporating anamorphic fungi in a natural classification - checklist and notes for 2010. Mycosphere 2:1-88

Hyde KD, Jones EBG, Liu JK, Ariyawansa H, Boehm E, Boonmee S, Braun U, Chomnunti P, Crous PW, Dai DQ, Diederich P, Dissanayake A, Doilom M, Doveri F, Hongsanan S, Jayawardena R, Lawrey JD, Li YM, Liu YX, Lücking R, Monkai J, Muggia L, Nelsen MP, Pang KL, Phookamsak R, Senanayake IC, Shearer CA, Suetrong S, Tanaka K, Thambugala KM, Wijayawardene NN, Wikee S, Wu HX, Zhang Y, Aguirre-Hudson B, Alias SA, Aptroot A, Bahkali AH, Bezerra JL, Bhat DJ, Camporesi E, Chukeatirote E, Gueidan C, Hawksworth DL, Hirayama K, de Hoog GS, Liu JC, Knudsen K, Li WJ, Li XH, Liu ZY, Mapook A, McKenzie EHC, Miller AN, Mortimer PE, Phillips AJL, Raja HA, Scheuer C, Schumm F, Taylor JE, Tian Q, Tibpromma S, Wanasinghe DN, Wang Y, Xu JC, Yacharoen S, Yan JY, Zhang M (2013) Families of Dothideomycetes. Fungal Divers 63:1-313

Hyde KD, Nilsson RH, Alias SA, Ariyawansa HA, Blair JE, Cai L, de Cock AWAM, Dissanayake AJ, Glockling SL, Goonasekara ID, Gorczak M, Hahn M, Jayawardena RS, van Kan JAL, Laurence MH, Lévesque CA, Li XH, Liu JK, Maharachchikumbura SSN, Manamgoda DS, Martin FN, McKenzie EHC, McTaggart AR, Mortimer PE, Nair PVR, Pawłowska J, Rintoul TL, Shivas RG, Spies CFJ, Summerell BA, Taylor PWJ, Terhem RB, Udayanga
D, Vaghefi N, Walther G, Wilk M, Wrzosek M, Xu JC, Yan JY, Zhou N (2014) One stop shop: backbones trees for important phytopathogenic genera: I. Fungal Divers 67:21-125

Hyde KD, Fryar S, Tian Q, Bahkali AH, Xu JC (2016a) Lignicolous freshwater fungi along a northsouth latitudinal gradient in the Asian/Australian region; can we predict the affects of global warming on biodiversity and function? Fungal Ecol 19:190-200

Hyde KD, Hongsanan S, Jeewon R, Bhat DJ, McKenzie EHC, Jones EBG, Phookamsak R, Ariyawansa HA, Boonmee S, Zhao Q, Abdel-Aziz FA, Abdel-Wahab MA, Banmai S, Chomnunti P, Cui BK, Daranagama DA, Das K, Dayarathne MC, de Silva NI, Dissanayake AJ, Doilom M, Ekanayaka AH, Gibertoni TB, GóesNeto A, Huang SK, Jayasiri SC, Jayawardena RS, Konta S, Lee HB, Li WJ, Lin CG, Liu JK, Lu YZ, Luo ZL, Manawasinghe IS, Manimohan P, Mapook A, Niskanen T, Norphanphoun C, Papizadeh M, Perera RH, Phukhamsakda C, Richter C, de Santiago ALCMA, Drechsler-Santos ER, Senanayake IC, Tanaka K, Tennakoon TMDS, Thambugala KM, Tian Q, Tibpromma S, Thongbai B, Vizzini A, Wanasinghe DN, Wijayawardene NN, Wu HX, Yang J, Zeng XY, Zhang H, Zhang JF, Bulgakov TS, Camporesi E, Bahkali AH, Amoozegar AM, Araujo-Neta LS, Ammirati JF, Baghela A, Bhatt RP, Bojantchev S, Buyck B, da Silva GA, de Lima CLF, de Oliveira RJV, de Souza CAF, Dai YC, Dima B, Duong TT, Ercole E, Mafalda-Freire F, Ghosh A, Hashimoto A, Kamolhan S, Kang JC, Karunarathna SC, Kirk PM, Kytövuori I, Lantieri A, Liimatainen K, Liu ZY, Liu XZ, Lücking R, Medardi G, Mortimer PE, Nguyen TTT, Promputtha I, Raj KNA, Reck MA, Lumyong S, Shahzadeh-Fazeli SA, Stadler M, Soudi MR, Su HY, Takahashi T, Tangthirasunun N, Uniyal P, Wang Y, Wen TC, Xu JC, Zhang ZK, Zhao YC, Zhou JZ, Zhu L (2016b) Fungal diversity notes 367-490: taxonomic and phylogenetic contributions to fungal taxa. Fungal Divers 80:1-270

Hyde KD, Norphanphoun C, Abreu VP, Bazzicalupo A, Chethana KWT, Clericuzio M, Dayarathne MC, Dissanayake AJ, Ekanayaka AH, He MQ, Hongsanan S, Huang SK, Jayasiri SC, Jayawardena RS, Karunarathna A, Konta S, Kušan I, Lee H, Li J, Lin CG, Liu NG, Lu YZ, Luo ZL, Manawasinghe IS, Mapook A, Perera RH, Phookamsak R, Phukhamsakda C, Siedlecki I, Soares AM, Tennakoon DS, Tian Q, Tibpromma S, Wanasinghe DN, Xiao YP, Yang J, Zeng XY, Abdel-Aziz FA, Li WJ, Senanayake IC, Shang QJ, Daranagama DA, De Silva NI, Thambugala KM, Abdel-Wahab MA, Bahkali AH, Berbee ML, Boonmee S, Bhat DJ, Bulgakov TS, Buyck B, Camporesi E, Castañeda-Ruiz RF, Chomnunti P, Doilom M, Dovana F, Gibertoni TB, Jadan M, Jeewon R, Jones EBG, Kang JC, Karunarathna SC, Lim YW, Liu JK, Liu ZY, Plautz HL Jr, Lumyong S, Maharachchikumbura SSN, Matočec N, Mckenzie EHC, Mešić A, Miller D, Pawłowska J, Pereira OL, Promputtha I, Romero AI, Ryvarden L, Su HY, Suetrong S, Tkalčec Z, Vizzini A, Wen TC, Wisitrassameewong K, Wrzosek M, Xu JC, Zhao Q, Zhao RL, Mortimer PE (2017) Fungal diversity notes 603-708: Taxonomic and phylogenetic notes on genera and species. Fungal Divers 87:1-235

Hyde KD, Chaiwan N, Norphanphoun C, Boonmee S, Camporesi E, Chethana KWT, Dayarathne MC, de Silva NI, Dissanayake AJ, Ekanayaka AH, Hongsanan S, Huang SK, Jayasiri SC, Jayawardena RS, Jiang HB, Karunarathna A, Lin CG, Liu JK, Liu NG, Lu YZ, Luo ZL, Maharachchimbura SSN, Manawasinghe IS, Pem D, Perera RH, Phukhamsakda C, Samarakoon MC, Senwanna C, Shang Q, Tennakoon DS, Thambugala KM, Tibpromma S, Wanasinghe DN, Xiao YP, Yang J, Zeng XY, Zhang JF, Zhang SN, Bulgakov TS, Bhat DJ, Cheewangkoon R, Goh TK, Jones EBG, Kang JC, Jeewon R, Liu ZY, Lumyong S, Kuo CH, McKenzie EHC, Wen TC, Yan JY, Zhao Q (2018) Mycosphere notes 169-224. Mycosphere 9:271-430

Hyde KD, Tennakoon DS, Jeewon R, Bhat DJ, Maharachchikumbura SSN, Rossi W, Leonardi M, Lee HB, Mun HY, Houbraken J, 
Nguyen TTT, Jeon SJ, Frisvad JC, Wanasinghe DN, Lücking R, Aptroot A, Cáceres MES, Karunarathna SC, Hongsanan S, Phookamsak R, Silva NI, Thambugala KM, Jayawardena RS, Senanayake IC, Boonmee S, Chen J, Luo ZL, Phukhamsakda C, Pereira OL, Abreu VP, Rosado AWC, Bart B, Randrianjohany E, Hofstetter V, Gibertoni TB, Soares AMS, Plautz HL Jr, Sotão HMP, Xavier WKS, Bezerra JDP, Oliveira TGL, Souza-Motta CM, Magalhães OMC, Bundhun D, Harishchandra D, Manawasinghe IS, Dong W, Zhang SN, Bao DF, Samarakoon MC, Pem D, Karunarathna A, Lin CG, Yang J, Perera RH, Kumar V, Huang SK, Dayarathne MC, Ekanayaka AH, Jayasiri SC, Xiao Y, Konta S, Niskanen T, Liimatainen K, Dai YC, Ji XH, Tian XM, Mešić A, Singh SK, Phutthacharoen K, Cai L, Sorvongxay T, Thiyagaraja V, Norphanphoun C, Chaiwan N, Lu YZ, Jiang HB, Zhang JF, Abeywickrama PD, Aluthmuhandiram JVS, Brahmanage RS, Zeng M, Chethana T, Wei D, Réblová M, Fournier J, Nekvindová J, Barbosa RN, Santos JEF, Oliveira NT, Li GJ, Ertz D, Shang QJ, Phillips AJL, Kuo CH, Camporesi E, Bulgakov TS, Lumyong S, Jones EBG, Chomnunti P, Gentekaki E, Bungartz F, Zeng XY, Fryar S, Tkalčec Z, Liang J, Li G, Wen TC, Singh PN, Gafforov Y, Promputtha I, Yasanthika E, Goonasekara ID, Zhao RL, Zhao Q, Kirk PM, Liu JK, Yan JY, Mortimer PE, Xu J, Doilom M (2019) Fungal diversity notes 1036-1150: taxonomic and phylogenetic contributions on genera and species of fungal taxa. Fungal Divers 96:1-242

Hyde KD, de Silva NI, Jeewon R, Bhat DJ, Phookamsak R, Doilom M, Boonmee S, Jayawardena RS, Maharachchikumbura SSN, Senanayake IC, Manawasinghe IS, Liu NG, Abeywickrama PD, Chaiwan N, Karunarathna A, Pem D, Lin CG, Sysouphanthong P, Luo ZL, Wei DP, Wanasinghe DN, Norphanphoun C, Tennakoon DS, Samarakoon MC, Jayasiri SC, Jiang HB, Zeng XY, Li JF, Wijesinghe SN, Devadatha B, Goonasekara ID, Brahmanage RS, Yang EF, Aluthmuhandiram JVS, Dayarathne MC, Marasinghe DS, Li WJ, Dissanayake LS, Dong W, Huanraluek N, Lumyong S, Liu JK, Karunarathna SC, Jones EBG, Al-Sadi AM, Xu JC, Harishchandra D, Sarma VV (2020a) AJOM new records and collections of fungi: 1-100. Asian Journal of Mycology 3:22-294

Hyde KD, Dong Y, Phookamsak R, Jeewon R, Bhat DJ, Jones EBG, Liu NG, Abeywickrama PD, Mapook A, Wei DP, Perera RH, Manawasinghe IS, Pem D, Bundhun D, Karunarathna A, Ekanayaka AH, Bao DF, Li JF, Samarakoon MC, Chaiwan N, Lin CG, Phutthacharoen K, Zhang SN, Senanayake IC, Goonasekara ID, Thambugala KM, Phukhamsakda C, Tennakoon DS, Jiang HB, Yang J, Zeng M, Huanraluek N, Liu JK, Wijesinghe SN, Tian Q, Tibpromma S, Brahmanage RS, Boonmee S, Huang SK, Thiyagaraja V, Lu YZ, Jayawardena RS, Dong W, Yang EF, Singh SK, Singh SM, Rana S, Lad SS, Anand G, Devadatha B, Niranjan M, Sarma VV, Liimatainen K, Aguirre-Hudson B, Niskanen T, Overall A, Alvarenga RLM, Gibertoni TB, Pfliegler WP, Horváth E, Imre A, Alves AL, Santos ACS, Tiago PV, Bulgakov TS, Wanasinghe DN, Bahkali AH, Doilom M, Elgorban AM, Maharachchikumbura SSN, Rajeshkumar KC, Haelewaters D, Mortimer PE, Zhao Q, Lumyong S, Xu JC, Sheng J (2020b) Fungal diversity notes 1151-1276: taxonomic and phylogenetic contributions on genera and species of fungal taxa. Fungal Divers 100:5-277

Ihlen PG, Wedin M (2008) An annotated key to the lichenicolous Ascomycota (including mitosporic morphs) of Sweden. Nova Hedwig $86: 275-365$

Inácio CA, Cannon PF (2003) Viegasella and Mintera, two new genera of Parmulariaceae (Ascomycota), with notes on the species referred to Schneepia. Mycol Res 107:82-92

Inácio CA, Cannon PF (2008) The genera of the Parmulariaceae. CBS biodiversity series vol 8 . CBS Fungal Biodiversity Centre, Utrecht
Inácio CA, Cannon PF, Ferry BF (2005) Revision of the genus Placostromella and inclusion of Palawaniella castanopsis as a third species. Mycol Prog 4:133-137

Inácio CA, Pereira-Carvalho RC, Souza ESC, Dianese JC (2011) A new Dothidasteroma species on leaves of Psidium laruotteanum from the Brazilian Cerrado. Mycotaxon. 116:27-32

Inácio CA, Araúz K, Piepenbring M (2012) A new genus of Parmulariaceae from Panama. Mycol Prog 11:1-6

Inderbitzin P, Landvik S, Abdel-Wahab MA, Berbee ML (2001) Aliquandostipitaceae, a new family for two new tropical ascomycetes with unusually wide hyphae and dimorphic ascomata. Am J Bot 88:52-61

Jaklitsch WM, Scheuer Ch, Voglmayr H (2002) Notes on the genus Immotthia (Pleosporales, Ascomycetes), including some type studies. Österr Z Pilzk 11:93-106

Jaklitsch WM, Fournier J, Dai DQ, Hyde KD, Voglmayr H (2015) Valsaria and the Valsariales. Fungal Divers 73:159-202

Jaklitsch WM, Baral HO, Lücking R, Lumbsch HT (2016) Ascomycota. In: Frey W (ed) Syllabus of Plant Families - Adolf Engler's Syllabus der Pflanzenfamilien. Part $1 / 2,13^{\text {th }}$ edn, Borntraeger Science Publishers, Stuttgart

Jami F, Slippers B, Wingfield MJ, Gryzenhout M (2014) Botryosphaeriaceae species overlap on four unrelated, native South African hosts. Fungal Biol 118:168-179

Jami F, Marincowitz S, Slippers B, Wingfield MJ (2018) New Botryosphaeriales on native red milkwood (Mimusops caffra). Australas Plant Path 47:475-484

Janex-Favre MC (1971) Recherches sur l'ontogenie, l'organisation et les asques de quelques pyrenolichens. Rev Bryol Lichénol $37: 421-469$

Jayasiri SC, Hyde KD, Ariyawansa HA, Bhat J, Buyck B, Cai L, Dai YC, Abd-Elsalam KA, Ertz D, Hidayat I, Jeewon R, Jones EBG, Bahkali AH, Karunarathna SC, Liu JK, Luangsa-ard JJ, Lumbsch HT, Maharachchikumbura SSN, McKenzie EHC, Moncalvo JM, Ghobad-Nejhad M, Nilsson H, Pang KA, Pereira OL, Phillips AJL, Raspé O, Rollins AW, Romero AI, Etayo J, Selçuk F, Stephenson SL, Suetrong S, Taylor JE, Tsui CKM, Vizzini A, Abdel-Wahab MA, Wen TC, Boonmee S, Dai DQ, Daranagama DA, Dissanayake AJ, Ekanayaka AH, Fryar SC, Hongsanan S, Jayawardena RS, Li WJ, Perera RH, Phookamsak R, de Silva NI, Thambugala KM, Tian Q, Wijayawardene NN, Zhao RL, Zhao Q, Kang JC, Promputtha I (2015) The Faces of Fungi database: fungal names linked with morphology, phylogeny and human impacts. Fungal Divers 74:3-18

Jayasiri SC, Ariyawansa HA, Jones EBG, Kang JC, Promputtha I, Bahkali AH, Hyde KD (2016) Towards a natural classification of Dothideomycetes: 8. The genera Cocconia, Dianesea. Endococcus and Lineostroma. Phytotaxa 255:066-074

Jayasiri SC, Hyde KD, Jones EBG, Peršoh D, Camporesi E, Kang JC (2018) Taxonomic novelties of hysteriform Dothideomycetes. Mycosphere 9:803-837

Jayasiri SC, Hyde KD, Jones EBG, McKenzie EHC, Jeewon R, Phillips AJL, Bhat DJ, Wanasinghe DN, Liu JK, Lu YZ, Kang JC, Xu J, Karunarathna SC (2019) Diversity, morphology and molecular phylogeny of Dothideomycetes on decaying wild seed pods and fruits. Mycosphere 10:1-186

Jayawardena RS, Ariyawansa HA, Singtripop C, Li YM, Yan J, Li X, Nilthong S, Hyde KD (2014) A re-assessment of Elsinoaceae (Myriangiales, Dothideomycetes). Phytotaxa 176:120-138

Jayawardena RS, Hyde KD, Chethana KWT, Daranagama DA, Dissanayake AJ, Goonasekara ID, Manawasinghe IS, Mapook A, Jayasiri SC, Karunarathna A, Li CG, Phukhamsakda C, Senanayake IC, Wanasinghe DN, Camporesi E, Bulgakov TS, Li XH, Liu M, Zhang W, Yan JY (2018) Mycosphere Notes 102-168: Saprotrophic fungi on Vitis in China, Italy, Russia and Thailand. Mycosphere 9:1-114 
Jayawardena RS, Hyde KD, Jeewon R, Ghobad-Nejhad M, Wanasinghe DN, Liu N, Phillips AJ, Oliveira-Filho JRC, da Silva GA, Gibertoni TB, Abeywikrama P (2019a) One stop shop II: taxonomic update with molecular phylogeny for important phytopathogenic genera: 26-50. Fungal divers 94:41-129

Jayawardena RS, Hyde KD, McKenzie EHC, Jeewon R, Phillips AJL, Perera RH, de Silva NI, Maharachchikumburua SSN, Samarakoon MC, Ekanayake AH, Tennakoon DS, Dissanayake AJ, Norphanphoun C, Lin C, Manawasinghe IS, Tian Q, Brahmanage R, Chomnunti P, Hongsanan S, Jayasiri SC, Halleen F, Bhunjun CS, Karunarathna A, Wang Y (2019b) One stop shop III: taxonomic update with molecular phylogeny for important phytopathogenic genera: 51-75 (2019). Fungal Divers 97:1-84

Jayawardena RS, McKenzie EHC, Chen YJ, Phillips AJL, Hongsanan S, Norphanphoun C, Abeywikrama PD, Maharachchikumbura SSN, Manawasinghe IS, McTaggart AR, Shivas RG, Gentekaki E, Hyde KD (2019c) https://onestopshopfungi.org/, a database to enhance identification of phytopathogenic genera. Asian Journal of Mycology 2:281-286

Jiang N, Li J, Piao CG, Guo MW, Tian CM (2018a) Identification and characterization of chestnut branch-inhabiting melanocratic fungi in China. Mycosphere 9:1268-1289

Jiang N, Phillips AJL, Zhang ZX, Tian CM (2018b) Morphological and molecular identification of two novel species of Melanops in China. Mycosphere 9:1187-1196

Jiang SH, Hawksworth DL, Lücking R, Wei JC (2020a) A new genus and species of foliicolous lichen in a new family of Strigulales (Ascomycota: Dothideomycetes) reveals remarkable class-level homoplasy. IMA Fungus 11:1

Jiang SH, Lücking R, Xavier-Leite AB, Cáceres MES, Aptroot A, Portilla CV, Wei JC (2020b) Reallocation of foliicolous species of the genus Strigula into six genera (lichenized Ascomycota, Dothideomycetes, Strigulaceae). Fungal Divers 102:257-291

Jiang SH, Wei XL, Wei JC (2016) Strigula sinoaustralis sp. nov. and three Strigula spp. new to China. Mycotaxon 131:795-803

Jiang SH, Wei XL, Wei JC (2017a) Two new species of Strigula (lichenised Dothideomycetes, Ascomycota) from China, with a key to the Chinese foliicolous species. MycoKeys 19:31-42

Jiang SH, Wei XL, Wei JC (2017b) A new species and two new records of Strigula (lichenized Ascomycota) from China. Mycoscience 58:391-397

Jiao P, Gloer JB, Campbell J, Shearer CA (2006) Altenuene derivatives from an unidentified freshwater fungus in the family Tubeufiaceae. J Nat Prod 69:612-615

Johnston PR, Park D (2016) Neocoleroa metrosideri sp. nov. (Sympoventuriaceae, Venturiales). Phytotaxa 253:214-218

Jones EBG, Suetrong S, Sakayaroj J, Bahkali AH, Abdel-Wahab MA, Boekhout T, Pang KL (2015) Classification of marine Ascomycota, Basidiomycota, Blastocladiomycota and Chytridiomycota. Fungal Divers 73:1-72

Jones EBG, Pang KL, Abdel-Wahab MA, Scholz B, Hyde KD, Boekhout T, Ebel R, Rateb ME, Henderson L, Sakayaroj J, Suetrong S, Dayarathne MC, Kumar V, Raghukumar S, Sridhar KR, Bahkali AHA, Gleason FH, Norphanphoun C (2019) An online resource for marine fungi. Fungal Diversity 96:347-433

Jung CH, Lee SM, Kim SH, Kim DW, Choi YW, Joo WH (2012) A novel Helicosporium isolate and its antimicrobial and cytotoxic pigment. J Microbiol Biotechn 22:1214-1217

Ju YM, Rogers JD, Huhndorf SM (1996) Valsaria and notes on Endoxylina, Pseudothyridaria, Pseudovalsaria, and Roussoella. Mycotaxon 58:419-481

Kadowaki K, Sato H, Yamamoto S, Tanabe AS, Hidaka A, Toju H (2014) Detection of the horizontal spatial structure of soil fungal communities in a natural forest. Popul. Ecol 56(2):301-310
Kalb K, Hafellner J, Staiger B (1995) Haematomma - Studien II. Lichenicole Pilze auf Arten der Flechtengattung Haematomma. Bibl Lichenol 59:199-222

Kashiwadani H, Aptroot A, Moon KH (2009) New pyrenocarpous lichens in Japan, with the resurrection of the genus Trypetheliopsis for Musaespora. Bibl Lichenol 99:247-258

Katoh K, Rozewicki J, Yamada KD (2019) MAFFT online service: multiple sequence alignment, interactive sequence choice and visualization. Briefings in Bioinformatics 20:1160-1166

Kendrick WB (1958) Sympodiella, a new hyphomycete genus. Trans Br mycol Soc 41:519-521

Kirk PM (1984) Volutellaria laurinus Tassi, an earlier name for Wiesneriomyces javanicus Koorders. Trans Br Mycol Soc 82:748-749

Kirk PM, Cannon PF, David JC, Stalpers JA (2001) Ainsworth \& Bisby's dictionary of the fungi, 9th edn. CABI, Wallingford

Kirk PM, Cannon PF, Minter DW, Stalpers JA (2008) Ainsworth \& Bisby's dictionary of the fungi, 10th edn. CABI, Wallingford

Kirk PM, Stalpers JA, Braun U, Crous PW, Hansen K, Hawksworth DL, Hyde KD, Lücking R, Lumbsch TH, Rossman AY, Seifert KA, Stadler M (2013) A without-prejudice list of generic names of fungi for protection under the International Code of Nomenclature for algae, fungi, and plants. IMA Fungus 4:381-443

Knudsen K (2008) Endococcus janae, a new species from Peru on Acarospora rhabarbarina. Opuscula Philolichenum 5:25-28

Kohlmeyer J, Volkmann-Kohlmeyer B, Eriksson OE (1996) Fungi on Juncus roemerianus. 8. New bitunicate ascomycetes. Can J Bot 74:1830-1840

Komposch H, Hafellner J (2000) Diversity and vertical distribution of lichens in a Venezuelan tropical lowland rain forest. Selbyana 21:11-24

Komposch H, Hafellner J (2003) Species composition of lichen dominated corticolous communities: a lowland rain forest canopy compared to an adjacent shrubland in Venezuela. Bibl Lichenol 86:351-367

Kraichak E, Huang JP, Nelsen MP, Lumbsch T (2018) A revised classification of orders and families in the two major subclasses of Lecanoromycetes (Ascomycota) based on a temporal approach. Botanical Journal of the Linnean Society 188:233-249

Krauss GJ, Solé M, Krauss G, Schlosser D, Wesenberg D, Bärlocher F (2011) Fungi in freshwaters: ecology, physiology and biochemical potential. FEMS Microbiol Rev 35:620-651

Krishnamurthy YL, Subramanya SK (2016) Phenotype and genotype based cladistic analysis of the genus Strigula (foliicolous lichens) present in the Western Ghats region of Karnataka, India. SGEM $3: 317-324$

Kutorga E, Hawksworth DL (1997) A re-assessment of the genera referred to the family Patellariaceae (Ascomycota). Syst Ascomycetum 15:1-110

Lanjouw J, Baehni C, Robyns W, Ross R, Rousseau J, Schopf JM, Schulze GM, Smith AC, Vilmorin R, Stafleu EA (1961) International Code of Botanical Nomenclature (Montreal Code) Adopted by the Ninth International Botanical Congress, Montreal, August 1959 [Regnum Vegetabile 23]. International Bureau for Plant Taxonomy and Nomenclature, Utrecht

Lanjouw J, Mamay SH, McVaugh R, Robyns W, Rollins RC, Ross R, Rousseau J, Schulze GM, Vilmorin R, Stafleu FA (1966) International Code of Botanical Nomenclature Adopted by the Tenth International Botanical Congress Edinburgh, August 1964 [Regnum Vegetabile 46]. International Bureau for Plant Taxonomy and Nomenclature, Utrecht

Lawrey JD, Diederich P (2015) Lichenicolous fungi-worldwide checklist, including isolated cultures and sequences available. http://www.lichenicolous.net. Accessed 22 Feb 2015

Lawrey JD, Diederich P, Nelsen MP, Sikaroodi M, Gillevet PM, Brand AM, van den Boom PPG (2011) The obligately lichenicolous 
genus Lichenoconium represents a novel lineage in the Dothideomycetes. Fungal Biol 115:176-187

Lee SM, Kim DS, Lee KS, Lee CK, Lee DW (2013) Antibiotic properties of Helicosporium sp. KCTC 0635BP to Rhizoctonia solani AG2-2 IV. Weed Turfgrass Sci 2:202-206

Lendemer JC (2017) Recent literature on lichens-245. Bryologist 120:236-256

Letrouit-Galinou MA, Parguey-Leduc A, Janex-Favre MC (1994) Ascoma structure and ontogenesis in ascomycete systematics. In: Hawksworth DL (ed) Ascomycete systematics. Problems and perspectives in the nineties. NATO ASI, vol 269. Plenum Press, New York, pp 23-36

Léveillé JH (1846) Descriptions des champignons de l'herbier du Muséum de Paris. Ann Sci Nat Bot 5:249-305

Libert MA (1834) Plantae Cryptogamae, quas in Arduenna collegit. Fasc 3:272

Liew EC, Aptroot A, Hyde KD (2000) Phylogenetic significance of the pseudoparaphyses in Loculoascomycete taxonomy. Mol Phylogenet Evol 16:392-402

Linaldeddu BT, Deidda A, Scanu B, Franceschini A, Serra S, BerrafTebbal A, Zouaoui Boutiti M, Ben Jamâa ML, Phillips AJL (2015) Diversity of Botryosphaeriaceae species associated with grapevine and other woody hosts in Italy, Algeria and Tunisia, with descriptions of Lasiodiplodia exigua and Lasiodiplodia mediterranea sp. nov. Fungal Divers 71:201-214

Linder DH (1929) A monograph of the helicosporous fungi imperfecti. Ann Mo Bot Gard 16:227-388

Lindsay WL (1857) Monograph of the genus Abrothallus (De Notaris and Tulasne emend.). Quart J Microscop Sci 5:27-63

Link HF (1809) Observationes in ordines plantarum naturales. Dissertatio I Mag Ges naturf Fr Berl 3:3-42

Liu YJ, Hall DB (2004) Body plan evolution of ascomycetes, as inferred from an RNA polymerase II Phylogeny. Proc Natl Acad Sci USA 101:4507-4512

Liu JK, Phookamsak R, Doilom M, Wikee S, Li YM, Ariyawansha HA, Boonmee S, Chomnunti P, Dai DQ, Bhat DJ, Romero AI, Zhuang WY, Monkai J, Jones EBG, Chukeatirote E, Ko TWK, Zhao YC, Wang Y, Hyde KD (2012) Towards a natural classification of Botryosphaeriales. Fungal Divers 57:149-210

Liu JK, Hyde KD, Jones EBG, Ariyawansa HA, Bhat DJ, Boonmee S, Maharachchikumbura SSN, McKenzie EHC, Phookamsak R, Phukhamsakda C, Shenoy BD, Abdel-Wahab MA, Buyck B, Chen J, Chethana KWT, Singtripop C, Dai DQ, Dai YC, Daranagama DA, Dissanayake AJ, Doilom M, Dsouza MJ, Fan XL, Goonasekara ID, Hirayama K, Hongsanan S, Jayasiri SC, Jayawardena RS, Karunarathna SC, Li WJ, Mapook A, Norphanphoun C, Pang KL, Perera RH, Peršoh D, Pinruan U, Senanayake IC, Somrithipol S, Suetrong S, Tanaka K, Thambugala KM, Tian Q, Tibpromma S, Udayanga D, Wijayawardene NN, Wanasinghe DN, Wisitrassameewong K, Zeng XY, Abdel-Aziz FA, Adamčík S, Bahkali AH, Boonyuen N, Bulgakov T, Callac P, Chomnunti $\mathrm{P}$, Greiner K, Hashimoto A, Hofstetter V, Kang JC, Lewis D, Li XH, Liu XZ, Liu ZY, Matsumura M, Mortimer PE, Rambold G, Randrianjohany E, Sato G, Sri-Indrasutdhi V, Tian CM, Verbeken A, von Brackel W, Wang Y, Wen TC, Xu JC, Yan JY, Zhao RL, Camporesi E (2015) Fungal diversity notes 1-110: taxonomic and phylogenetic contributions to fungal species. Fungal Divers 72:1-197

Liu JK, Hyde KD, Jeewon R, Phillips AJ, Maharachchikumbura SS, Ryberg M, Liu ZY, Zhao Q (2017) Ranking higher taxa using divergence times: a case study in Dothideomycetes. Fungal Divers 84:75-99

Liu JK, Lu YZ, Cheewangkoon R, To-Anun C (2018) Phylogeny and morphology of Helicotubeufia gen. nov., with three new species in Tubeufiaceae from aquatic habitats. Mycosphere 9:495-509
Liu NG, Lu YZ, Bhat DJ, McKenzie EHC, Saisamorn L, Jumpathong J, Liu JK (2019) Kevinhydea brevistipitata gen. et sp. nov., and Helicoma hydei sp. nov. (Tubeufiaceae) from decaying wood habitats. Mycol Prog 18:671-682

Li YM, Wu H, Cheng H, Hyde KD (2011) Morphological studies in Doithideomycetes: Elsinoë (Elsinoaceae), Butleria and three excluded genera. Mycotaxon 115:507-520

Li WJ, Bhat JD, Hyde KD, Wang Y (2014) Towards a natural classification of Dothideomycetes 4: The genera Bryopelta, Bryorella, Bryosphaeria, Lophiosphaerella and Maireella (Dothideomycetes incertae sedis). Phytotaxa 176:28-41

Li WJ, McKenzie EHC, Liu JK, Bhat DJ, Dai DQ, Camporesi E, Tian Q, Maharachchikumbura SSN, Luo ZL, Shang QJ, Zhang JF, Tangthirasunun N, Karunarathna SC, Xu JC, Hyde KD (2020) Taxonomy and phylogeny of hyaline-spored coelomycetes. Fungal Divers 100:279-801

Lopes RDS, Pires M, Lima R, Periard F (2019) Monitoring air pollution with living organisms. case study use of lichens as bioindicators in the Miguel Pereira City, Rio De Janeiro. Brazil. Chem Eng Trans 74:253-258

Lopez-Bautista JM, Rindi F, Guiry MD (2006) Molecular systematics of the subaerial green algal order Trentepohliales: an assessment based on morphological and molecular data. Int J Syst Evol Microbiol 56:1709-1715

Luangsuphabool T, Lumbsch HT, Piapukiew J, Sangvichien E (2018) Architrypethelium murisporum (Ascomycota, Trypetheliaceae), a remarkable new lichen species from Thailand challenging ascospore septation as an indicator of phylogenetic relationships. MycoKeys 34:25-34

Lucheta F, Koch NM, Käffer MI, Riegel RP, Martins SMA, Schmitt JL (2019) Lichens as indicators of environmental quality in southern Brazil: An integrative approach based on community composition and functional parameters. Ecol Indicat 107:105587

Lücking R (1997) The use of foliicolous lichens as bioindicators in the tropics, with special reference to the microclimate. Abstr Bot 21:99-116

Lücking R (2008) Foliicolous lichenized fungi. Fl Neotrop. Monogr 103:1-867

Lücking R (2019) Stop the Abuse of Time! Strict Temporal Banding is not the Future of Rank-Based Classifications in Fungi (Including Lichens) and Other Organisms. Critical Reviews in Plant Sciences 38(3): 199-253

Lücking R, Kalb K (2018) Formal instatement of Allographa (Graphidaceae): how to deal with a hyperdiverse genus complex with cryptic differentiation and paucity of molecular data. Herzogia 31:525-561

Lücking R, Sérusiaux E (2013) Phyllobathelium nudum Zahlbr. is a second species in the genus Phyllocratera (lichenized Ascomycota: Strigulaceae). Lichenologi 45:691-693

Lücking R, Aptroot A, Thor G (1997) New species or interesting records of foliicolous lichens. II. Flavobathelium epiphyllum (Lichenized Ascomycetes: Melanommatales). Lichenologi 29:221-228

Lücking R, Sérusiaux E, Maia LC, Pereira ECG (1998) A revision of the names of foliicolous lichenized fungi published by Batista and co-workers between 1960 and 1975. Lichenologi 30:121-191

Lücking R, Sipman HJM, Umaña L, Chaves JL, Lumbsch HT (2007) Aptrootia (Dothideomycetes: Trypetheliaceae), a new genus of pyrenocarpous lichens for Thelenella terricola. Lichenologi 39:187-193

Lücking R, Lumbsch HT, Di Stefano JF, Lizano D, Carranza J, Bernecker A, Chaves JL, Umana L (2008) Eremithallus costaricensis (Ascomycota: Lichinomycetes: Eremothallales), a new fungal lineage with a novel lichen symbiotic lifestyle discovered in an urban relict forest in Costa Rica. Symbiosis 46:161-170 
Lücking R, Nelsen MP, Aptroot A, Barillas de Klee R, Bawingan PA, Benatti MN, Binh NQ, Bungartz F, Cáceres MES, Canêz LS, Chaves JL, Ertz D, Esquivel RE, Ferraro LI, Grijalva A, Gueidan C, Hernández M JE, Knight A, Lumbsch HT, Marcelli MP, Mercado-Díaz JA, Moncada B, Morales EA, Naksuwankul K, Orozco T, Parnmen S, Rivas Plata E, Salazar-Allen N, Spielmann AA, Ventura N (2016) A phylogenetic framework for reassessing generic concepts and species delimitation in the lichenized family Trypetheliaceae (Ascomycota: Dothideomycetes). Lichenologi 48:739-762

Lücking R, Hodkinson BP, Leavitt SD (2017) The 2016 classification of lichenized fungi in the Ascomycota and Basidiomycotaapproaching one thousand genera. Bryologist 119:361-416

Lumbsch HT, Huhndorf SM (2007) Outline of ascomycota-2007. Myconet 13:1-58

Lumbsch HT, Huhndorf SM (2010) Outline of Ascomycota 2009. Myconet 14:1-64

Lundqvist N (1964) The genus Trichodelitschia in Sweden. Sven Bot Tidskr 58:267-272

Luo ZL, Bhat DJ, Jeewon R, Boonmee S, Bao DF, Zhao YC, Chai HM, Su HY, Su XJ, Hyde KD (2017) Molecular phylogeny and morphological characterization of asexual fungi (Tubeufiaceae) from freshwater habitats in Yunnan, China. Cryptogam Mycol $38: 27-53$

Luttrell ES (1951) Taxonomy of Pyrenomycetes. University of Missouri Studies 24:1-120

Luttrell ES (1955) The ascostromatic Ascomycetes. Mycologia 47:511-532

Luttrell ES (1973) Loculoascomycetes. In: Ainsworth GC, Sparrow FK, Sussman AS (eds), The fungi. An advanced treatise, a taxonomic review with keys: ascomycetes and fungi imperfecti. Academic Press, New York, pp 135-219

Luttrell ES, Barr ME (1978) Additional species of Pododimeria (Loculoascomycetes). Am J Bot 65:251-257

Lu YZ, Boonmee S, Bhat DJ, Hyde KD, Kang JC (2017a) Helicosporium luteosporum sp. nov. and Acanthohelicospora aurea (Tubeufiaceae, Tubeufiales) from terrestrial habitats. Phytotaxa 319:241-253

Lu YZ, Boonmee S, Dai DQ, Liu JK, Hyde KD, Bhat DJ, Kang JC (2017b) Four new species of Tubeufia (Tubeufiaceae, Tubeufiales) from Thailand. Mycol Prog 16(4):403-417

Lu YZ, Boonmee S, Liu JK, Hyde KD, Bhat DJ, Eungwanichayapant PD, Kang JC (2017c) Novel Neoacanthostigma species from aquatic habitats. Cryptogam Mycol 38:169-190

Lu YZ, Boonmee S, Liu JK, Hyde KD, McKenzie EH, Eungwanichayapant PD, Kang JC (2018a) Multi-gene phylogenetic analyses reveals Neohelicosporium gen. nov. and five new species of helicosporous hyphomycetes from aquatic habitats. Mycol Prog 17:631-646

Lu YZ, Liu JKJ, Hyde KD, Jeewon R, Kang JC, Fan C, Boonmee S, Bhat DJ, Luo ZL, Lin CG, Eungwanichayapant PD (2018b) A taxonomic reassessment of Tubeufiales based on multi-locus phylogeny and morphology. Fungal Divers 92:131-344

Lu YZ, Liu JK, Hyde KD (2020) Proposal to conserve Pseudohelicomyces Y.Z. Lu \& al. (Tubeufiaceae) against Pseudohelicomyces Garnica \& E. Valenz. (Hymenogastraceae). Taxon (Accepted).

Machouart M, Samerpitak K, De Hoog GS, Gueidan C (2014) A multigene phylogeny reveals that Ochroconis belongs to the family Sympoventuriaceae (Venturiales, Dothideomycetes). Fungal divers 65:77-88

Madrida H, Ruíz-Cendoyaa M, Canoa J, Stchigel A, Orofinob R, Guarroa J (2009) Genotyping and in vitro antifungal susceptibility of Neoscytalidium dimidiatum isolates from different origins. Int $\mathbf{J}$ Ant A 34:351-354

Madrid H, Gene J, Cano J (2012) A new species of Leptodiscella from Spanish soil. Mycol Prog 11:535-541
Maharachchikumbura SSN, Hyde KD, Jones EBG, McKenzie EHC, Huang SK, Abdel-Wahab MA, Daranagama DA, Dayarathne M, D'souza MJ, Goonasekara ID, Hongsanan S, Jayawardena RS, Kirk PM, Konta S, Liu JK, Liu ZY, Norphanphoun C, Pang KL, Perera RH, Senanayake IC, Shang Q, Shenoy BD, Xiao YP, Bahkali AH, Kang JC, Somrothipol S, Suetrong S, Wen TC, Xu JC (2015) Towards a natural classification and backbone tree for Sordariomycetes. Fungal Divers 72:199-301

Maharachchikumbura SSN, Hyde KD, Jones EBG, McKenzie EHC, Bhat DJ, Dayarathne MC, Huang SK, Norphanphoun C, Senanayake IC, Perera RH, Shang QJ, Xiao YP, D'souza MJ, Hongsanan S, Jayawardena RS, Daranagama DA, Konta S, Goonasekara ID, Zhuang WY, Jeewon R, Phillips AJL, AbdelWahab MA, Al-Sadi AM, Bahkali AH, Boonmee S, Boonyuen N, Cheewangkoon R, Dissanayake AJ, Kang JC, Li QR, Liu JK, Liu XZ, Liu ZY, Luangsa-ard JJ, Pang KL, Phookamsak R, Promputtha I, Suetrong S, Stadler M, Wen TC, Wijayawardene NN (2016) Families of Sordariomycetes. Fungal Divers 79:1-317

Makhija U, Patwardhan PG (1990) On the lichen genus Pleurotrema Müll. Arg Biovigyanam 16:10-37

Malloch D, Cain RF (1971) Four new genera of cleistothecial Ascomycetes with hyaline ascospores. Can J Botan 49:847-854

Malloch D, Sigler L (1988) The Eremomycetaceae (Ascomycotina). Can J Botan 66:1929-1932

Manawasinghe IS, Phillips AJL, Hyde KD, Chethana KWT, Zhang W, Zhao WS, Yan JY, Li XH (2016) Mycosphere Essays 14: Assessing the aggressiveness of plant pathogenic Botryosphaeriaceae. Mycosphere 7:883-892

Manojlovic NT, Vasiljevic PJ, Gritsanapan W, Supabphol R, Manojlovic I (2010) Phytochemical and antioxidant studies of Laurera benguelensis growing in Thailand. Biol Res 43:169-176

Mapook A, Boonmee S, Liu JK, Jones EBG, Bahkali AHA, Hyde KD (2016a) Taxonomic and phylogenetic placement of Phaeodimeriella (Pseudoperisporiaceae, Pleosporales). Cryptogam Mycol 37:157-176

Mapook A, Hyde KD, Dai DQ, Li J, Jones EBG, Bahkali AH, Boonmee S (2016b) Muyocopronales, ord. nov., (Dothideomycetes, Ascomycota) and a reappraisal of Muyocopron species from northern Thailand. Phytotaxa 265:225-237

Mapook A, Hyde KD, Hongsanan S, Phukhamsakda C, Li JF, Boonmee S (2016c) Palawaniaceae fam. nov., a new family (Dothideomycetes, Ascomycota) to accommodate Palawania species and their evolutionary time estimates. Mycosphere 7:1732-1745

Mapook A, Hyde KD, McKenzie EHC, Gareth Jones EBG, Bhat DJ, Jeewon R, Stadler M, Samarakoon MC, Malaithong M, Tanunchai B, Buscot F, Wubet T, Purahong W (2020) Taxonomic and phylogenetic contributions to fungi associated with the invasive weed Chromolaena odorata (Siam weed). Fungal Divers 101:1-175

Marincowitz S, Groenewald JZ, Wingfield MJ, Crous PW (2008) Species of Botryosphaeriaceae occurring on Proteaceae. Persoonia 21:111-118

Mason EW (1941) Annotated account of fungi received at the Imperial Bureau of Mycology. Mycol Pap 5:1-144

Massalongo AB (1856) Miscellanea Lichenologica. Civelli, Verona, Milano

Mathey A (1979) Contribution a l'etude de la familie des Trypetheliacees (Lichens pyrenomycetes). Nova Hedwig 31:917-935

Mathey A, Steffan B, Steglich W (1980) 1, 2-Naphthochinon-derivate aus Kulturen des Mycosymbionten der Flechte Trypethelium eluteriae (Trypetheliaceae). Leibigs Ann Chem 1980:779-785

Matsushima T (1995) Matsushima Mycological Memoirs 8. Matsushima Mycological Memoirs. 8:1-44

Matzer M (1996) Lichenicolous ascomycetes with fissitunicate asci on foliicolous lichens. Mycol Pap 171:1-202 
Mayrhofer H (1987) Monographie der Flechtengattung Thelenella. Bibl. Lichenol 26:1-106

McCarthy PM (1993) New records of pyrenocarpous lichens from Australia. Muelleria 8:31-36

McCarthy PM (2000) The lichens of Rarotonga, Cook Islands, South Pacific Ocean I: pyrenocarpous taxa. Lichenologi 32:15-47

McCarthy PM (2001) The lichen genus Strigula in Christmas Island, Indian Ocean. Biblioth Lichenol 78:275-288

McCarthy PM (2009) Strigulaceae. Fl Australia 57 (Lichens 5):570-601

McCarthy PM, Kantvilas G (1999) Pyrenocollema montanum, a new species from Tasmania. Lichenologi 31:227-230

McCarthy PM, Malcolm WM (1996) Strigula occulta, a new saxicolous lichen from New Zealand. Mycotaxon 60:323-326

McNeill J, Barrie FR, Burdet HM, Demoulin V, Hawksworth DL, Marhold K, Nicolson DH, Prado J, Silva PC, Skog JE, Wiersema JH, Turland NJ (2006) International Code of Botanical Nomenclature (Vienna Code) Adopted by the Seventeenth International Botanical Congress Vienna, Austria, July 2005 [Regnum Vegetabile 146]. Gantner, Königstein, Germany

Mehl JWM, Slippers B, Roux J, Wingfield MJ (2011) Botryosphaeriaceae associated with Pterocarpus angolensis (kiaat) in South Africa. Mycologia 103:534-553

Menezes AA, Cáceres MES, Bastos CJP, Lücking R (2018) The latitudinal diversity gradient of epiphytic lichens in the Brazilian Atlantic Forest: does Rapoport's rule apply? Bryologist 121:480-497

Minnis AM, Kennedy AH, Grenier DB, Palm ME, Rossman AY (2012) Phylogeny and taxonomic revision of the Planistromellaceae including its coelomycetous anamorphs: contributions towards a monograph of the genus Kellermania. Persoonia 29:11-28

Minter DW, Peredo HL, Watson A (2007) Acrospermum chilense sp. nov. from Chile and the Acrospermales ord. nov. B Soc Argent Bot 42:107-112

Miranda-González R, Aptroot A, Lücking R, Flakus A, Barcenas-Peña A, Herrera-Campos MA (2020) The identity, ecology and distribution of Polypyrenula (Ascomycota: Dothideomycetes): a new member of Trypetheliaceae revealed by molecular and anatomical data. Lichenologist 52:27-35

Mohr F, Ekman S, Heegaard E (2004) Evolution and taxonomy of the marine Collemopsidium species (lichenized Ascomycota) in northwest Europe. Mycol Res 108:515-532

Monkai J, Liu JK, Boonmee S, Chomnunti P, Chukeatirote E, Jones EBG, Wang Y, Hyde KD (2013) Planistromellaceae (Botryosphaeriales) Cryptogam Mycol 34:45-77

Monkai J, McKenzie EHC, Phillips AJL, Hongsanan S, Pem D, Liu JK, Chethana KWT, Tian Q, Ekanayaka AH, Lestari AS, Zeng M, Zhao Q, Norphanphoun C, Abeywikrama PD, Maharachchikumbura SSN, Jayawardena RS, Chen YJ, Zhao R-L, He M-Q, Raspé O, Kirk PM, Gentekaki E, Hyde KD (2019) https://fungalgene ra.org/: a comprehensive database providing webbased information for all fungal genera. Asian J Mycol 2:298-305

Montagne C (1834) Notice sur les plantes cryptogames récemment découvertes en France, contenant aussi l'indication précise des localités de quelques espèces les plus rares de la flore française. Ann Sci Nat Bot 1:295-307

Monteiro JS, Gusmão LFP, Castañeda-Ruiz RF (2014) Helicodochium, a new microfungus from submerged wood in Brazil. Mycotaxon 127:5-9

Moon KH, Aptroot A (2009) Pyrenocarpous lichens in Korea. Bibl. Lichenol 99:297-314

Moore RT (1955) Index to the Helicosporae. Mycologia 47:90-103

Morgan AP (1895) New North American fungi. J Cincinnati Soc Nat Hist 18:36-45
Mueller WC, Goos RD, Quainoo J, Morgham AT (1991) The structure of the phialides (mucronate hyphopodia) of the Meliolaceae. Can J Bot 69:803-807

Muggia L, Gueidan C, Knudsen K, Perlmutter G, Grube M (2013) The lichen connections of black fungi. Mycopatho 175:523-535

Muggia L, Kocourková J, Knudsen K (2015) Disentangling the complex of Lichenothelia species from rock communities in the desert. Mycologia 107:1233-1253

Müller J (1882) Lichenologische Beiträge 15 (Schluss). Flora 65:397-402

Müller J (1883) Lichenologische Beiträge XVIII (Fortsetzung). Flora 66:286-290

Müller J (1884) Revisio lichenum Eschweilerianorum, Ser I. Flora 67:662-672

Müller J (1885) Pyrenocarpeae Cubenses a cl. C. Wright lectae. Bot Jahrb Syst, Pflanzengesch Pflanzengeogr 6:375-421

Müller J (1887) Lichenologische Beiträge XXVI (Schluss). Flora 70:423-429

Müller J (1888) Lichenologische Beiträge 29. Flora 71:195-208

Müller E (1956) Über die neue Ascomycetengattung Dothiopeltis. Sydowia. 10(1-6):197-200

Müller E, von Arx JA (1962) Beitr Kryptogamenfl Schweiz 11:1-922

Müller E, Patil BV (1973) The genus Aldona Raciborski (Ascomycetes). Trans Br Mycol Soc 60:117-121

Munk A (1953) The system of the pyrenomycetes. A contribution to a natural classification of the group Sphaeriales sensu Lindau. Dansk Bot Ark 15:1-163

Munk A (1957) Danish pyrenomycetes. A preliminary flora. Dansk Bot Ark 17:1-491

Muscavitch ZM, Lendemer JC, Harris RC (2017) A synopsis of the lichenicolous fungi occurring on Phlyctis including description of a new Monodictys widespread on $P$. speirea. Bryologist 120:418-426

Nag-Raj TR (1993) Coelomycetous anamorphs with appendage-bearing conidia. Mycologue Publications, Waterloo, p 1101

Nannfeldt JA (1932) Studien uber die Morphologie und Systematik der nicht-lichenisierten, inoperkulaten Discomyceten. Nova Acta Regiae Soc Sci Upsal IV 8:1-368

Nawawi A, Webster J (1982) Phalangispora constricta gen. et sp. nov., a Sporodochial hyphomycete with branched conidia. Trans $\mathrm{Br}$ Mycol Soc 79:65-68

Nelsen MP, Lücking R, Grube M, Mbatchou JS, Muggia L, Plata ER, Lumbsch HT (2009) Unravelling the phylogenetic relationships of lichenised fungi in Dothideomyceta. Stud Mycol 64:135-144

Nelsen MP, Lücking R, Mbatchou JS, Andrew CJ, Spielmann AA, Lumbsch HT (2011a) New insights into relationships of lichenforming Dothideomycetes. Fungal Divers 51:155-162

Nelsen MP, Rivas-Plata E, Andrew CJ, Lücking R, Lumbsch HT (2011b) Phylogenetic diversity of trentepohlialean algae associated with lichen-forming fungi. J Phycol 47:282-290

Nelsen MP, Lücking R, Aptroot A, Andrew CJ, Cáceres MES, Rivas Plata E, Gueidan C, Canêz LS, Knight A, Ludwig LR, MercadoDíaz JA, Parnmen S, Lumbsch HT (2014) Elucidating phylogenetic relationships and genus-level classification within the fungal family Trypetheliaceae (Dothideomycetes: Ascomycota). Taxon 63:974-992

Nelson PE, Wilhelm S (1956) An undescribed fungus causing a root rot of strawberry. Mycologia 48:547-551

Netto MSB, Assuncao IP, Lima GSA, Marques MW, Lima WG, Monteiro JHA, Balbino VQ, Michereff SJ, Phillips AJL, Câmara MPS (2014) Species of Lasiodiplodia associated with papaya stem-end rot in Brazil. Fungal Divers 67:127-141

Nordin A (2002) Collemopsidium angermannicum, a widespread but rarely collected aquatic lichen. Graphis Scripta 13:39-41

Norphanphoun C, Jeewon R, Mckenzie EHC, Wen TC, Camporesi E, Hyde KD (2017) Taxonomic position of Melomastia italica sp. 
nov. and phylogenetic reappraised of Dyfrolomycetales. Cryptogam Mycol 384:507-525

Norvell LL (2011) Report of the Nomenclature Committee for Fungi: 16. Taxon 60:223-226

Nylander W (1858) Expositio synoptica Pyrenocarpeorum. Mém Soc Acad Maine et Loire 4:5-88

Nylander W (1891) Sertum Lichenaeae Tropicae e Labuan et Singapore. Schmidt, Paris

Nylander W, Crombie JM (1884) On a collection of exotic Lichens made in Eastern Asia by the late Dr A. C. Maingay. J Linn Soc Bot 20:48-69

Nylander JAA, Wilgenbusch JC, Warren DL, Swofford DL (2008) AWTY (are we there yet?): a system for graphical exploration of MCMC convergence in Bayesian phylogenetics. Bioinformatics 24:581-583

Oh SY, Woo JJ, Hur JS (2019) Distribution of foliicolous lichen Strigula and genetic structure of S. multiformis on Jeju Island, South Korea. Microorganisms 7:430

Ohtsu Y, Sasamura H, Shibata T, Nakajima H, Hino M, Fujii T (2003) The novel gluconeogenesis inhibitors FR225659 and related compounds that originate from Helicomyces sp. No. 19353 II. Biological profiles. J Antibiot 56:689-693

Palmer MA, Covich A, Finlay BJ, Gilbert J, Hyde KD, Johnson AH, Kairesalo T, Lake S, Lovell CR, Naiman RJ, Ricci C, Sabater F, Strayer D (1997) Biodiversity and ecosystem processes in freshwater sediments. Ambio 26:571-577

Pang KL, Abdel-Wahab MA, Sivichai S, El-Sharouney HM, Jones EBG (2002) Jahnulales (Dothideomycetes, Ascomycota): a new order of lignicolous freshwater ascomycetes. Mycol Res 106:1031-1042

Pang KL, Hyde KD, Alias SA, Suetrong S, Jones EBG (2013) Dyfrolomycetaceae, a new family in the Dothideomycetes, Ascomycota. Cryptogam Mycol 34:223-232

Papendorf MC (1967) Two new genera of soil fungi from South Africa. Trans Br Mycol Soc 50:69-75

Papendorf MC (1969) Leptodiscella africana gen. et comb.nov. Trans Br Mycol Soc 53:145-147

Parnmen S, Lücking R, Lumbsch HT (2012) Phylogenetic classification at generic level in the absence of distinct phylogenetic patterns of phenotypical variation: a case study in Graphidaceae (Ascomycota). PLoS ONE 7:e51392

Pattengale ND, Alipour M, Bininda-Emonds OR, Moret BM, Stamatakis A (2009) How many bootstrap replicates are necessary? In: Annual international conference on research in computational molecular biology. Springer, Berlin, pp 184-200

Paulus BC, Gadek PA, Hyde KD (2003) Cylindrosympodium cryptocaryae sp. nov. (anamorphic fungi), with keys to the described species and to similar genera. Aust Syst Bot 16:577-580

Pavlic D, Wingfield MJ, Barber P, Slippers B, Hardy GESJ, BurgessTI Treena I (2008) Seven new species of the Botryosphaeriaceae from baobab and other native trees in Western Australia. Mycologia 100:851-866

Pem D, Gafforov Y, Jeewon R, Hongsanan S, Promputtha I, Doilom M, Hyde KD (2018) Multigene phylogeny coupled with morphological characterization reveal two new species of Holmiella and taxonomic insights within Patellariaceae. Cryptogam Mycol 39: $193-210$

Pem D, Hongsanan S, Doilom M, Tibpromma S, Wanasinghe DN, Dong W, Ningguo L, Phookamsak R, Phillips AJL, Jeewon R, Hyde KD (2019a) https://www.dothideomycetes.org: an online taxonomic resource for the classification, identification, and nomenclature of Dothideomycetes. Asian J Mycol 2: 287-297

Pem D, Hyde KD, Doilom M, Camporesi E, Hongsanan S, Rampadarath S, Bhoyroo V, Jeewon R (2019b) Multigene phylogenetic analyses to establish new Valsaria species and taxonomic significance of spore ornamentation. PLoS ONE 14:e0217982
Pem D, Jeewon R, Bhat DJ, Doilom M, Boonmee S, Hongsanan S, Promputtha I, Xu JC, Hyde KD (2019c) c) Mycosphere Notes 275-324: A morphotaxonomic revision and typification of obscure Dothideomycetes genera (incertae sedis). Mycosphere 10:1115-1246

Penzig AJO, Saccardo PA (1897) Diagnoses fungorum novorum in insula Java collectorum. Ser. I. Malpighia 11:387-409

Pérez-Ortega S, Etayo J (2010) Labrocarpon gen. nov. for Melaspilea canariensis, with the description of Buelliella protoparmeliopsis sp. nov. from South America. Lichenologi 42:271-276

Pérez-Ortega S, Suija A, de los Ríos A (2011) The connection between Abrothallus and its anamorph state Vouauxiomyces established by Denaturing Gradient Gel Electrophoresis (DGGE). Lichenologi 43:277-279

Pérez-Ortega S, Suija A, Crespo A, de los Ríos A (2014) Lichenicolous fungi of the genus Abrothallus (Dothideomycetes: Abrothallales ordo nov.) are sister to the predominantly aquatic Janhulales. Fungal Divers 64:295-304

Pérez-Ortega S, Garrido-Benavent I, Grube M, Olmo R, de los Ríos A (2016) Hidden diversity of marine borderline lichens and a new order of fungi: Collemopsidiales (Dothideomyceta). Fungal Divers 80:285-300

Petch T (1921) Studies in entomogenous fungi. 1. The nectriae parasitic on scale insects. Trans Br Mycol Soc 7:89-167

Petrak F (1947a) Nannfeldtia n. gen., eine neue Gattung der Diskomyzeten. Sydowia 1(1-3): 18-20

Petrak F (1947b) Ronnigeria, n. gen., eine neue Gattung der Leptopeltineen. Sydowia 1(4-6):309-312

Petrak F (1947c) Über die Gattungen Pycnoderma Syd. und Pycnodermella n.gen. Sydowia 1:108-113

Petrak F (1947d) Über Placostromella n.gen. und die Gattung Placostroma Theiss. et Syd. Sydowia 1:9-11

Petrak F (1953) Die Gattung Blasdalea Sacc. et Syd. Sydowia 7:343

Petrak F, Sydow H (1927) Die Gattungen der Pyrenomyzeten, Sphaeropsideen und Melanconieen. 1. Die phaeosporen Sphaeropsideen und die Gattung Macrophoma. Repert Spec Nov Regni Veg Beih 42:1-551

Petrini O (1986) Taxonomy of endophytic fungi of aerial plant tissues. In: Fokkema, N.J. \& van den Heuvel, J. (eds) Microbiology of the phyllosphere. Cambridge University Press,

Phillips AJL (2000) Excoriose, cane blight and related diseases of grapevines: a taxonomic review of the pathogens. Phytopathol Mediterr 39:341-356

Phillips AJL, Alves A (2009) Taxonomy, phylogeny, and epitypification of Melanops tulasnei, the type species of Melanops. Fungal Divers 38:155-166

Phillips AJL, Alves A, Correia A, Luque J (2005) Two new species of Botryosphaeria with brown, 1-septate ascospores and Dothiorella anamorphs. Mycologia 97:13-529

Phillips AJL, Crous PW, Alves A (2007) Diplodia seriata, the anamorph of "Botryosphaeria" obtusa. Fungal Divers 25:141-155

Phillips AJL, Alves A, Pennycook SR, Johnston PR, Ramaley A, Akulov A, Crous PW (2008) Resolving the phylogenetic and taxonomic status of dark-spored teleomorph genera in the Botryosphaeriaceae. Persoonia 21:29-55

Phillips AJL, Alves A, Abdollahzadeh J, Slippers B, Wingfield MJ, Groenewald JZ, Crous PW (2013) The Botryosphaeriaceae: genera and species known from culture. Stud Mycol 76:51-167

Phillips AJL, Hyde KD, Alves A, Liu JK (2019) Families in Botryosphaeriales: a phylogenetic, morphological and evolutionary perspective. Fungal Divers 94:1-22

Phookamsak R, Boonmee S, Norphanphoun C, Wanasinghe DN, de Silva NI, Dayarathne MC, Hongsanan S, Bhat DJ, Hyde KD (2016) Schizothyriaceae. Mycosphere 7:154-189

Phookamsak R, Lu YZ, Hyde KD, Jeewon R, Li JF, Doilom M, Boonmee S, Promputtha I (2018) Phylogenetic characterization of 
two novel Kamalomyces species in Tubeufiaceae (Tubeufiales). Mycol prog 17:647-660

Phookamsak R, Hyde KD, Jeewon R, Bhat DJ, Jones EBG, Maharachchikumbura SSN, Raspé O, Karunarathna SC, Wanasinghe DN, Hongsanan S, Doilom M, Tennakoon DS, Machado AR, Firmino AL, Ghosh A, Karunarathna A, Mešić A, Dutta AK, Thongbai B, Devadatha B, Norphanphoun C, Senwanna C, Wei DP, Pem D, Kwekucher Ackah F, Wang GN, Jiang HB, Madrid H, Lee HB, Goonasekara ID, Manawasinghe IS, Kušan I, Cano J, Gené J, Li JF, Das K, Acharya K, Raj KNA, Latha KPD, Chethana KWT, He MQ, Dueñas M, Jadan M, Martín MP, Samarakoon MC, Dayarathne MC, Raza M, Park MS, Telleria MT, Chaiwan N, Matočec N, de Silva NI, Pereira OL, Singh PN, Manimohan P, Uniyal P, Shang QJ, Bhatt RP, Perera RH, Alvarenga RLM, Nogal-Prata S, Singh SK, Vadthanarat S, Oh SY, Huang SK, Rana S, Konta S, Paloi S, Jayasiri SC, Jeon SJ, Mehmood T, Gibertoni TB, Nguyen TTT, Singh U, Thiyagaraja V, Sarma VV, Dong W, Yu XD, Lu YZ, Lim YW, Chen Y, Tkalčec Z, Zhang ZF, Luo ZL, Daranagama DA, Thambugala KM, Tibpromma S, Camporesi E, Bulgakov TS, Dissanayake AJ, Senanayake IC, Dai DQ, Tang LZ, Khan S, Zhang H, Promputtha I, Cai L, Chomnunti P, Zhao RL, Lumyong S, Boonmee S, Wen TC, Mortimer PE, Xu JC (2019) Fungal diversity notes 929-1035: taxonomic and phylogenetic contributions on genera and species of fungi. Fungal Divers 95:1-273

Pirogov M (2014) Ascomata micromorphology of Pyrenidium actinellum s.l. (Dacampiaceae, Ascomycota). Mod Phytomorphol 5:275-278

Pirozynski KA (1972) Microfungi of Tanzania. I. Miscellaneous fungi on oil palm. II. New hyphomycetes. Mycol Pap 12:1-64

Pirozynski KA, Shoemaker RA (1970) Some Asterinaceae and Meliolaceae on conifers in Canada. Can J Bot 48:1321-1328

Plaingam N, Somrithipol S, Jones EBG (2005) Pseudorobillarda siamensis sp. nov. and notes on P. sojae and P. texana from Thailand. Nova Hedwigia 80:335-348

Poch GK, Gloer JB, Shearer CA (1992) New bioactive metabolites from a freshwater isolate of the fungus Kirschsteiniothelia sp. J Nat Prod 55:1093-1099

Polizzi G, Aiello D, Vitale A, Giuffrida F, Groenewald JZ, Crous PW (2009) First report of shoot blight, canker, and gummosis caused by Neoscytalidium dimidiatum on citrus in Italy. Plant Dis 93:1215

Polizzi G, Aiello D, Castello I, Vitale A, Groenewald JZ, Crous PW (2011) Occurrence, molecular characterisation, and pathogenicity of Neoscytalidium dimidiatum on citrus in Italy. ISHS Acta Hortic 892:237-243

Prance GT (1972) An ethnobotanical comparison of four tribes of Amazonian Indians. Acta Amaz 2:7-27

Prasad N, Singh RD, Bhatnagar GC (1961) Some interesting fungi on Salvadora persica Linn. Proc Nat Inst Sci India 27:281-286

Pratibha J, Prabhugaonkar A (2016) Distribution and phylogeny of Mycosisymbrium cirrhosum. Mycosphere 7:44-50

Pratibha J, Nguyen HD, Mel'nik VA, Bhat DJ, White GP, Seifert KA (2015) Lectotypification, epitypification, and molecular phylogeny of the synnematous hyphomycete Pseudogliophragma indicum, the second genus in the Wiesneriomycetaceae. Mycoscience $56: 387-395$

Pratibha J, Bhat DJ, Prabhugaonkar A (2016) Molecular phylogeny of Speiropsis pedatospora. Mycosphere 7:679-686

Prihatini R, Boonyuen N, Sivichai S (2008) Phylogenetic evidence that two submerged-habitat fungal species, Speiropsis pedatospora and Xylomyces chlamydosporus, belong to the order, Jahnulales insertae sedis Dothideomycetes. Microbiol Indones 2:136-140

Promputtha I, Miller AN (2010) Three new species of Acanthostigma (Tubeufiaceae, Dothideomycetes) from Great Smoky Mountains National Park. Mycologia 102:574-587
Quaedvlieg W, Verkley GJM, Shin HD, Barreto RW, Alfenas AC, Swart WJ, Groenewald JZ, Crous PW (2013) Sizing up Septoria. Stud Mycol 75:307-390

Raciborski M (1900) Batavia, Indonesia, Staatsdruckerei. Parasitische Algen und Pilze Javas 1:1-39

Raciborski M (1909) Parasitische und epiphytische Pilze Javas. Bull Acad Sci Cracovie Classe Sci Math Nat 3:346-394

Raj TN (1981) Genera coelomycetum. XIX. Discosiella, a lichenized mycobiont. Can J Bot 59:2519-2533

Raja HA, Shearer CA (2008) Freshwater ascomycetes: new and noteworthy species from aquatic habitats in Florida. Mycologia 100:467-489

Raja HA, Miller AN, Shearer CA (2012) Freshwater ascomycetes: Natipusillaceae, a new family of tropical fungi, including Natipusilla bellaspora sp. nov. from the Peruvian Amazon. Mycologia 104:569-573

Raja HA, Oberlies NH, Figueroa M, Tanaka K, Hirayama K, Hashimoto A, Miller AN, Zelski SE, Shearer CA (2013) Freshwater ascomycetes: Minutisphaera (Dothideomycetes) revisited, including one new species from Japan. Mycologia 105:959-976

Raja HA, El-Elimat T, Oberlies NH, Shearer CA, Miller AN, Tanaka K, Hashimoto A, Fournier J (2015) Minutisphaerales (Dothideomycetes, Ascomycota): a new order of freshwater ascomycetes including a new family, Minutisphaeraceae, and two new species from North Carolina, USA. Mycologia 107:845-862

Rajeshkumar KC (2014) A reappraisal of the fungus genus Phalangispora with the rediscovery of $P$. bharathensis on leaf litter of Mangifera indica from the northern Western Ghats. India. Journal of Threatened Taxa 6:6278-6281

Rajeshkumar KC, Sharma R (2013) Tamhinispora a new genus belongs to family Tubeufiaceae from the Western Ghats, India based on morphology and phylogenetic analysis. Mycosphere 4:165-174

Rajeshkumar KC, Singh SK (2012) Manoharachariella indica sp. nov. from the Western Ghats. India. Mycotaxon 120:43-48

Rajeshkumar KC, Bhat DJ, Lad SS, Wijayawardene NW, Singh SK, Pandkar MR, Maurya DK, Ashtekar ND, Hyde KD (2018) Morphology and phylogeny of Tamhinispora srinivasanii sp. nov. (Tubeufiaceae) from northern Western Ghats. India. Phytotaxa 346:113-120

Ramaley AW (1991) Fungi of Yucca baccata 1. Piptarthron pluriloculare and its teleomorph. Planistroma yuccigena. Mycotaxon 42:63-75

Ramaley AW (1993) New fungi from Yucca: Planistromella yuccifoliorum, gen. et sp. nov., and its anamorph Kellermania yиccifoliorum, sp. nov., and Planistromella uniseptata, sp. nov., the teleomorph of Kellermania yuccigena. Mycotaxon 47:259-274

Ramaley AW (1995) New species of Kellermania, Piptarthron, Planistroma, Planistromella from members of the Agavaceae. Mycotaxon 50:255-268

Ramaley AW (1998) New teleomorphs of the anamorphic genus Kellermania. Mycotaxon 66:509-514

Rambaut A (2014) FigTree v1.4: Tree figure drawing tool. http://treebio.ed.ac.uk/software/figtree/

Réblová M, Barr M (2000) The genus Acanthostigma (Tubeufiaceae, Pleosporales). Sydowia 52:258-285

Redinger K (1938) Familie Graphidaceae. In: Rabenhorst's Kryptogamen-Flora von Deutschland, Österreich und der Schweiz. 9 (2/1/2). Leipzig, Akad. Verlagsges. M.B.H., pp 181-404

Rehm H (1887) Rabenhorst's Kryptogamen-Flora. Pilze - Ascomyceten. 1:1-64

Rehm H (1900) Beiträge zur Pilzflora von Südamerika VIII. Discomycetes (Nachtrag). IX. Hypocreaceae. X. Dothideaceae. Hedwigia 39:209-234

Renobales G, Aguirre B (1990) The nomenclature and systematic position of the genus Encephalographa. Syst Ascomycetum 8:87-92 
Reynolds DR (1971) The sooty mold ascomycetes genus Limacinula. Mycologia 63:1173-1209

Reynolds DR (1989) Briania gen. nov. and Briania fruticetum sp. nov. Pac Sci 43:161-165

Reynolds DR, Gilbert GS (2005) Epifoliar fungi from Queensland, Australia. Aust Syst Bot 18:265-289

Rickett HW (1963) Report of the Committee for Spermatophyta: conservation of generic names V. Taxon 12:235-238

Riddle LW (1920) Observations on the genus Acrospermum. Mycologia 12:175-181

Riddle LW (1923) The lichens of the Isle of Pines. Mycologia 15:68-88

Riedl H (1963) Vorstudien zu einer Revision der Gattung Arthopyrenia Mass. sensu amplo. I. Sydowia 16:263-274

Riedl H (1971) Zur Kenntnis von Polyblastiopsis A. Zahlbr. und Mycoglaena v. Höhnel (= Winteria Rehm). Österr Bot Z 119:41-67

Rindi F, Lam DW, López-Bautista JM (2009) Phylogenetic relationships and species circumscription in Trentepohlia and Printzina (Trentepohliales, Chlorophyta). Mol Phyl Evol 52:329-339

Rivas Plata E, Lücking R, Lumbsch HT (2008) When family matters: an analysis of Thelotremataceae (lichenized Ascomycota: Ostropales) as bioindicators of ecological continuity in tropical forests. Biodiv Cons 17:1319-1351

Rodas CA, Slippers B, Gryzenhout M, Wingfield MJ (2009) Botryosphaeriaceae associated with Eucalyptus canker diseases in Colombia. For Pathol 39:110-123

Rojas EI, Herre EA, Mejía LC, Arnold AE, Chaverri P, Samuels GJ (2008) Endomelanconiopsis, a new anamorph genus in the Botryosphaericeae. Mycologia 100:760-775

Rossman AY (1978) Podonectria, a genus in the Pleosporales on scale insects. Mycotaxon 7:163-182

Rossman AY (1987) The Tubeufiaceae and similar Loculoascomycetes. Mycol Pap 157:1-71

Rossman AY, Crous PW, Hyde KD, Hawksworth DL, Aptroot A, Bezerra JL, Bhat JD, Boehm E, Braun U, Boonmee S, Camporesi E, Chomnunti P, Dai DQ, D'Souza MJ, Dissanayake A, Gareth Jones EBG, Groenewald JZ, Hernández-Restrepo M, Hongsanan S, Jaklitsch WM, Jayawardena R, Jing LW, Kirk PM, Lawrey JD, Mapook A, McKenzie EHC, Monkai J, Phillips AJL, Phookamsak R, Raja HA, Seifert KA, Senanayake I, Slippers B, Suetrong S, Taylor JE, Thambugala KM, Tian Q, Tibpromma $\mathrm{S}$, Wanasinghe DN, Wijayawardene NN, Wikee S, Woudenberg JHC, Wu H-X, Yan JY, Yang T, Zhang Y (2015) Recommended names for pleomorphic genera in Dothideomycetes. IMA Fungus 6:507-523

Roux C (2009) Naetrocymbe saxicola, likeno kun Trentepohlia. Bull Soc Linnéenne Provence 60:127-142

Roux C, Sérusiaux E (2004) Le genre Strigula (lichens) en Europe et en Macaronésie. Biblioth Lichenol 90:1-96

Saccardo PA (1875) Conspectus generum pyrenomycetum italicorum additis speciebus fungorum Venetorum novis vel criticis, systemate carpologico dispositorum. Atti Soc Veneto-Trent Sci Nat, Padova sér 44:77-100

Saccardo PA (1878) Fungi Veneti novi vel critici vel mycologiae Venetae addendi. Ser. IX. Michelia 1:407

Saccardo PA (1880) Fungi Gallici lecti a cl. viris P. Brunaud, Abb. Letendre, A. Malbranche, J. Therry vel editi in Mycotheca Gallica C. Roumeguèri. Series II. Michelia 2:39-135

Saccardo PA (1883) Sylloge Pyrenomycetum, vol II. Sylloge Fungorum 2:1-815

Saccardo PA (1891) Supplementum Universale, Pars I. AgaricaceaeLaboulbeniaceae. Syll Fung 9:1-1141

Saccardo PA (1904) De Diagnostica et nomenclatura mycologica, Admonita quaedam. Ann Mycol 2:195-198

Saccardo PA (1913) Sylloge Fungorum XXIV: 234 (1925-1928), p 41
Saccardo PA (1928) Sylloge fungorum XXIV, sect. II. Syll Fung (Abellini) 24(2):705-1438

Saenz GS, Taylor JW (1999) Phylogenetic relationships of Meliola and Meliolina inferred from nuclear small subunit rRNA sequences. Mycol Res 103:1049-1056

Sambo MC (1940) Licheni del Brasile. Ann Bot 22:19-41

Samerpitak K, Van der Linde E, Choi HJ, van den Ende AG, Machouart M, Gueidan C, De Hoog GS (2014) Taxonomy of Ochroconis, genus including opportunistic pathogens on humans and animals. Fungal Divers 65:89-126

Samuels GJ, Romero AI (1991) Ascoporia (Fungi, Loculoascomycetes), a new genus from Para. Bol Museu Paraense Emilio Goeldi Ser Bot 7:263-268

Sanderson NA, Coppins BJ (2009a) Mycoporum. In: Smith CW, Aptroot A, Coppins BJ, Fletcher A, Gilbert OL, James PW, Wolseley PA (eds) The lichens of Great Britain and Ireland. British Lichen Society, London, pp 620-622

Sanderson NA, Coppins BJ (2009b) Tomasellia. In: Smith CW, Aptroot A, Coppins BJ, Fletcher A, Gilbert OL, James PW, Wolseley PA (eds) The lichens of Great Britain and Ireland. British Lichen Society, London, pp 894-895

Sanderson NA, Hawksworth DL, Aptroot A (2009) Melaspilea Nyl. (1857). In: Smith CW, Aptroot A, Coppins BJ, Fletcher A, Gilbert OL, James PW, Wolseley PA (eds) The lichens of Great Britain and Ireland. The British Lichen Society, the Natural History Museum, London, pp 576-579

Santesson R (1952) Foliicolous lichens I. A revision of the taxonomy of the obligately foliicolous, lichenized fungi. Symb Bot Upsal $12: 1-590$

Santesson J (1970) Chemical studies on lichens. 30. Anthraquinonoid pigments of Trypetheliopsis boninensis and Ocellularia domingensis. Acta Chem Scand 24:3334

Santesson R (1992) Pyrenocollema elegans, a new marine lichen. Lichenologi 24:7-11

Santos TAB (2015) Relações filogenéticas dos complexos Stachybotrys Memnoniella e Phalangispora-Speiropsis-Wiesneriomyces. Dissertation, Universidade Federal de Pernambuco

Schaumann K, Priebe K (1994) Ochroconis humicola causing muscular black spot disease of Atlantic salmon (Salmo salar). Can J Bot 72:1629-1634

Schoch CL, Shoemaker RA, Seifert KA, Hambleton S, Spatafora JW, Crous PW (2006) A multigene phylogeny of the Dothideomycetes using four nuclear loci. Mycologia 98:1041-1052

Schoch CL, Crous PW, Groenewald JZ, Boehm EWA, Burgess TI, De Gruyter J, De Hoog GS, Dixon LJ, Grube M, Gueidan C, Harada Y, Hatakeyama S, Hirayama K, Hosoya T, Huhndorf SM, Hyde KD, Jones EBG, Kohlmeyer J, Kruys A, Li YM, Lücking R, Lumbsch HT, Marvanova L, Mbatchou JS, McVay AH, Miller AN, Mugambi GK, Muggia L, Nelsen MP, Nelson P, Owensby CA, Phillips AJL, Phongpaichit S, Pointing SB, Pujade-Renaud V, Raja HA, Rivas Plata E, Robbertse B, Ruibal C, Sakayaroj J, Sano T, Selbmann L, Shearer CA, Shirouzu T, Slippers Bernard Suetrong S, Tanaka K, Volkmann-Kohlmeyer B, Wingfield Michael J, Wood AR, Woudenberg JHC, Yonezawa H, Zhang Y, Spatafora JW (2009a) A class-wide phylogenetic assessment of Dothideomycetes. Stud Mycol 64:1-15

Schoch CL, Sung GH, López-Giráldez F, Townsend JP, Miadlikowska J, Hofstetter V, Robbertse B, Matheny PB, Kauff K, Wang Z, Gueidan C, Andrie RM, Trippe K, Ciufetti LM, Wynns A, Fraker E, Hodkinson BP, Bonito G, Yahr R, Groenewald JZ, Arzanlou M, de Hoog GS, Crous PW, Hewitt D, Pfister DH, Peterson K, Gryzenhout M, Wingfield MJ, Aptroot A, Suh SO, Blackwell M, Hillis DM, Griffith GW, Castlebury LA, Rossman AY, Lumbsch HT, Lücking R, Büdel B, Rauhut A, Diederich P, Ertz D, Geiser DM, Hosaka K, Inderbitzin P, Kohlmeyer J, VolkmannKohlmeyer B, Mostert L, O’Donnell K, Sipman HJM, Rogers 
JD, Shoemaker RA, Sugiyama J, Summerbell RC, Untereiner W, Johnston P, Stenroos S, Zuccaro A, Dyer P, Crittenden P, Cole MS, Hansen K, Trappe JM, Lutzoni F, Spatafora JW (2009b) The Ascomycota Tree of Life: A phylum wide phylogeny clarifies the origin and evolution of fundamental reproductive and ecological traits. Syst Biol 58:224-239

Schoeneweiss DF (1981) The role of environmental stress in diseases of woody plants. Plant Dis 65:308-314

Schröter J (1894) [1835-1894] Die Pilze Schlesiens. Breslau: J. U. Kern (M. Müller) 2:1889-1908

Schubert K, Rischel A, Braun U (2003) A monograph of Fusicladium s. lat. (hyphomycetes). Schlechtendalia 9:1-132

Schumm F (2008) Flechten Madeiras. der Kanaren und Azoren, Wangen, Germany

Schumm F (2011) Kalkflechten der Schwäbischen Alb - ein mikroskopisch-anatomischer Atlas. Published by the author, Wangen, Germany. Books on Demand (BOD). https://www.bod.de/buchshop/ kalkflechten-der-schwaebischen-alb-ein-mikroskopisch-anato mischer-atlas-felix-schumm-9783844873658

Schumm F, Aptroot A (2013) Flechten Madeiras, der Kanaren und Azoren. Band 2. Published by the authors, Wangen, Germany. Books on Demand (BOD). https://www.bod.de/buchshop/flech ten-madeiras-der-kanaren-und-azoren-band-2-ergaenzungsband -felix-schumm-9783732274802

Schweinitz LD (1832) Synopsis fungorum in America Boreali media degentium. Secundum observationes Ludovici Davidis de Schweinitz. Communicated to the American Philosophical Society, Philadelphia, 15 April 1831. Trans Am Philos Soc II 4:141-316

Seaver FJ (1922) Phyllostictaceae. North Am. Flora 6:3-84

Seaver FJ (1951) The North American Cup-fungi (Inoperculates) 3:1-428

Seaward MR, Aptroot A (2005) Hong Kong lichens collected on the United States North Pacific exploring expedition, 1853-1856. Bryologist 108:282-287

Seifert K, Morgan-Jones G, Gams W, Kendrick B (2011) The genera of hyphomycetes. CBS Biodiversity Series no. 9: 1-997. CBSKNAW Fungal Biodiversity Centre, Utrecht

Selcuk F, Ekici K (2014) A new species of Manoharachariella (hyphomycetes) from Central Anatolia. Turkey. Mycosphere 5(3):419-423

Senanayake IC, Crous PW, Groenewald JZ, Maharachchikumbura SSN, Jeewon R, Phillips AJL, Bhat JD, Perera RH, Li QR, Li WJ, Tangthirasunun N, Norphanphoun C, Karunarathna SC, Camporesi E, Manawasighe IS, Al-Sadi AM, Hyde KD (2017) Families of Diaporthales based on morphological and phylogenetic evidence. Stud Mycol 86:217-296

Senwanna C, Wanasinghe DN, Bulgakov TS, Wang Y, Bhat DJ, Tang AMC, Mortimer PE, Xu J, Hyde KD, Phookamsak R (2019) Towards a natural classification of Dothidotthia and Thyrostroma in Dothidotthiaceae (Pleosporineae, Pleosporales). Mycosphere 10:701-738

Sérusiaux E, Aptroot A (1998) Mycomicrothelia striguloides sp. nov. from New Zealand. Bryologist 101:144-146

Sérusiaux E, Lücking R (2003) The lichen genus Caprettia Bat. \& H. Maia (Monoblastiaceae). Biblioth Lichenol 86:161-176

Shamsi S, Hosen S, Begum M (2017) New record of Gonatophragmium mori (Sawada) deighton on Ficus hispida L. from Bangladesh. Bangladesh J Plant Taxon 24:125-127

Sharma R, Kulkarni G, Sonawane MS (2017) Alanomyces, a new genus of Aplosporellaceae based on four loci phylogeny. Phytotaxa 297:168-178

Shaw DE, Sutton BC (1985) A new aero-aquatic hyphomycete from Papua New Guinea and Australia. Bot J Linn Soc 91:25-36

Shearer CA, Crane JL (1980) Taxonomy of two cleistothecial ascomycetes with papilionaceous ascospores. Trans Br Mycol Soc 75:193-200
Shearer CA, Raja HA, Miller AN, Nelson P, Tanaka K, Hirayama K, Marvanova L, Hyde KD, Zhang Y (2009) The molecular phylogeny of freshwater Dothideomycetes. Stud Mycol 64:145-153

Shen M, Zang JQ, Zhao LL, Groenewald JZ, Crous PW, Zang Y (2020) Venturiales. Stud Mycol 96:185-308

Sherwood MA (1979) Helochora, a new genus of Polystigmataceae. Mycologia 71:648-651

Shoemaker RA (1964) Conidia states of some Botryosphaeria species on Vitis and Quercus. Can J Bot 42:1297-1301

Tangthirasunun N Silar, P, Bhat DJ, Chukeatirote E, Wijayawardene NN, Maharachchikumbura SNN, Hyde KD (2014). Morphology and phylogeny of Pseudorobillarda eucalypti sp. nov., from Thailand. Phytotaxa 176: 251-259

Silvestro D, Michalak I (2012) raxmlGUI: a graphical front-end for RAxML. Organisms Diversity \& Evolution 12:335-337

Sivanesan A (1975) Redisposition and description of some Amphisphaeria species and a note on Macrovalsaria. Trans Br Mycol Soc 65:395-402

Sivanesan A (1981) Balladynopsis, Balladynocallia and Alina. Mycol Pap 146:1-38

Sivanesan A (1984) The bitunicate ascomycetes and their anamorphs. J. Cramer, Vaduz, p 701

Sivanesan A, Sinha ARP (1989) Aldonata, a new ascomycete genus in the Parmulariaceae. Mycol Res 92:246-249

Slippers B, Crous PW, Denman S, Coutinho TA, Wingfield BD, Wingfield MJ (2004a) Combined multiple gene genealogies and phenotypic characters differentiate several species previously identified as Botryosphaeria dothidea. Mycologia 96:83-101

Slippers B, Fourie G, Crous PW, Coutinho TA, Wingfield BD, Carnegie A, Wingfield MJ (2004b) Speciation and distribution of Botryosphaeria sp. on native and introduced Eucalyptus trees in Australia and South Africa. Stud Mycol 50:343-358

Slippers B, Boissin E, Phillips AJL, Groenewald JZ, Lombard L, Wingfield MJ, Postma A, Burgess T, Crous PW (2013) Phylogenetic lineages in the Botryosphaeriales; A systematic and evolutionary framework. Stud Mycol 76:31-49

Snover KL, Arneson PA (2002) Black knot. The Plant Health Instructor Sommai S, Nuankaew S, Khamsuntorn P, Suetrong S, Pinruan U (2019) Tamhinispora saraburiensis sp. nov. (Tubeufiaceae, Dothideomycetes) on bamboo in Thailand based on morphology \& phylogenetic analysis. Phytotaxa 402:1-12

Species Fungorum (2020) http://www.speciesfungorum.org/Index.htm

Spegazzini C (1880) Fungi argentini.Pugillus tertius (Continuacion). Anales Soc Ci Argent 10:145-168

Spegazzini C (1881) Nova addenda ad mycologiam venetam. Atti Soc Crittogam Ital 3:42-71

Spegazzini C (1885) Fungi Guaranitici. Pugillus 1 (cont.). Anales Soc Ci Argent 19:241-265

Spegazzini C (1888) Fungi Guarinitici. Pugillus II. Anales Soc Ci Argent 26:5-74

Spegazzini C (1912) Mycetes argentinenses (Series VI). An Mus Nac Hist Nat Buenos Aires 23:1-146

Spegazzini C (1919) Reliquiae mycologicae tropicae. Bol Acad Nac Cienc (Cordoba) 23:365-541

Srinivasan M, Shanmugam K, Kedike B, Narayanan S, Shanmugam S, Neelakantan HG (2019) Trypethelone and phenalenone derivatives isolated from the mycobiont culture of Trypethelium eluteriae Spreng. and their anti-mycobacterial properties. Nat Prod Res 23:1-8

Stevens FL (1917) Porto Rican fungi, old and new. Trans Ill State Acad Sci 10:162-218

Stevens FL (1923) Parasitic fungi from British Guiana and Trinidad. Illinois Biol Monogr 8:1-76

Stevens FL (1925) Hawaiian fungi. Bernice P Bishop Mus Bull 19:1-189

Stevens FL (1927) The Meliolineae. I. Ann Mycol 25:405-469 
Stevens FL (1928) The Meliolineae. II. Ann Mycol 26:165-384

Stevens NE (1933) Two apple black rot fungi in the United States. Mycologia 25:536-548

Stevens NE (1936) Two species of Physalospora in England. Mycologia 28:330-336

Stizenberger E (1891) Lichenaea africana. Ber Thätigk St Gallisch Naturw Ges 1889 90:133-268

Subramanian CV (1994) Hyphomycetes from South East Asia - novelties from Singapore and Malaysia. Kavaka 22(23):52-76

Subramanian CV, Ramakrishnan K (1956) Ciliochorella Sydow, Plagionema Subram. \& Ramakr. and Shanoria gen.nov. Trans Brit Mycol Soc 39:314-318

Su Y, Cai L (2012) Polyphasic characterisation of three new Phyllosticta spp. Persoonia 28:76-84

Suetrong S, Sakayaroj J, Phongpaichit S, Jones EBG (2010) Morphological and molecular characteristics of a poorly known marine ascomcycete, Manglicola guatamalensis (Jahnulales: Pezizomycotina; Dothideomycetes, Incertae sedis): new lineage of marine ascomycetes. Mycologia 102:83-92

Suetrong S, Boonyue N, Pang KL, Ueapattanakit J, Klaysuban A, Sri-Inddrasutdhi V, Sivichai S, Jones EBG (2011) A taxonomic revision and phylogenetic reconstruction of the Jahnulales (Dothideomycetes), and the new family Manglicolaceae. Fungal Divers 51:163-188

Suetrong S, Rungjindamai N, Sommai S, Rung-Areerate P, Sommrithipol S, Jones EBG (2014) Wiesneriomyces a new lineage of Dothideomycetes (Ascomycota) basal to Tubeufiales. Phytotaxa 176:283-297

Suija A, Perez-Ortega S, Hawksworth DL (2011) Abrothallus halei (Ascomycota, incertae sedis), a new lichenicolous fungus on Lobaria species in Europe and North America. Lichenologi 43:51-55

Suija A, de los Ríos A, Perez-Ortega S (2015) A molecular reappraisal of Abrothallus species growing on lichens of the order Peltigerales. Phytotaxa 195:201-226

Suija A, Hawksworth DL, Pérez-Ortega S (2018) The generic name Abrothallus (Abrothallales, Dothideomycetes), and names proposed in the genus by Giuseppe De Notaris, Søren Christian Sommerfelt, and Ignaz Kotte. Taxon 67:1169-1179

Summerell BA, Groenewald JZ, Carnegie AJ, Summerbell RC, Crous PW (2006) Eucalyptus microfungi known from culture. 2. Alysidiella, Fusculina and Phlogicylindrium genera nova, with notes on some other poorly known taxa. Fungal Divers 23:323-350

Sun LY, Liu ZL, Zhang T, Niu SB, Zhao ZT (2010) Three antibacterial naphthoquinone analogues from cultured mycobiont of lichen Astrothelium sp. Chin Chem Lett 21:842-845

Suto Y (2000) Septoria pini-thunbergii: a fungus produced on dead needles of Pinus thunbergii and P. ponderosa. Appl For Sci 9:163-164 (Japanese)

Sutton BC (1977) Nomenclature and taxonomy of Shanoria, Placonema, and Neoplaconema (Sphaeropsidales). Kew Bull $31: 461-464$

Sutton BC (1980) The Coelomycetes. Fungi imperfecti with pycnidia, acervuli and stromata. Commonwealth Mycological Institute, Kew, pp 1-696

Sutton BC (1984) Notes on Titaea (Hyphomycetes). Trans Br Mycol Soc 83:399-413

Sutton BC, Marasas WFO (1976) Observations on Neottiosporina and Tiarosporella. Trans Br Mycol Soc 67:69-76

Su HY, Hyde KD, Maharachchikumbura SSN, Ariyawansa HA, Luo ZL, Promputtha I, Tian Q, Lin CG, Shang QJ, Zhao YC, Chai HM, Liu XY, Bahkali AH, Bhat JD, McKenzie EHC, Zhou DQ (2016) The families Distoseptisporaceae fam. nov., Kirschsteiniotheliaceae, Sporormiaceae and Torulaceae, with new species from freshwater in Yunnan Province, China. Fungal Divers 80:375-409
Swart HJ (1971) Australian leaf-inhabiting fungi I. Two species of Vizella. Trans Br Mycol Soc 57:455-464

Swart HJ (1987) Australian leaf-inhabiting fungi. XXV. Dothidella inaequalis and Montagnella eucalypti. Trans Br Mycol Soc 89:483-488

Swart L, Crous PW, Petrini O, Taylor JE (2000) Fungal endophytes of Proteaceae, with particular emphasis on Botryosphaeria proteae. Mycoscience 41:123-127

Sweetwood G, Lücking R, Nelsen MP, Aptroot A (2012) Ascospore ontogeny and discharge in megalosporous Trypetheliaceae and Graphidaceae (Ascomycota: Dothideomycetes and Lecanoromycetes) suggest phylogenetic relationships and ecological constraints. Lichenologi 44:277-296

Swinscow TDV (1965a) Pyrenocarpous lichens: 9. Notes on various species. Lichenologi 3:72-83

Swinscow TDV (1965b) The marine species of Arthopyrenia in the British Isles: Pyrenocarpous Lichens: 8. Lichenologi 3:55-64

Sydow H (1924) Beiträge zur Kenntnis der Pilzflora Neu-Seelands. Ann Mycol 22:303

Sydow H, Sydow P (1914a) Diagnosen neuer philippinischer Pilze. Ann Mycol 12:545-576

Sydow H, Sydow P (1914b) Fungi from northern Palawan. Philipp J Sci (Bot) 9:157-189

Tai FL (1979) Sylloge Fungorum Sinicorum 1-1527

Takahashi K, Teramine T (1986) Zonate leaf spot of Mulberry, with special reference to the life-cycle and taxonomy of causal fungus Gonatophragmium mori. Ann Phytopathol Soc Japan 52:404-412

Takenaka Y, Naito Y, Le DH (2013) Naphthoquinones and phenalenone derivatives from the cultured lichen mycobionts of Trypethelium sp. Heterocycles 87:1897-1902

Talbot PHB (1971) Principles of fungal taxonomy. St. Martin's, New York

Tanney J, Miller AN (2017) Asexual-sexual morph connection in the type species of Berkleasmium. IMA Fungus 8:99-105

Taylor JE, Crous PW, Palm ME (2001) Foliar and stem fungal pathogens of Proteaceae in Hawaii. Mycotaxon 78:449-490

Tedersoo L, Sánchez-Ramírez S, Koljalg U, Bahram M, Döring M, Schigel D, May T, Ryberg M, Abarenkov K (2018) High-level classification of the Fungi and a tool for evolutionary ecological analyses. Fungal Divers 90:135-159

Tehler A (1990) A new approach to the phylogeny of Euascomycetes with a cladistic outline of Arthoniales focussing on Roccellaceae. Can J of Bot 68:2458-2492

Tehler A (1995) Morphological data, molecular data, and total evidence in phylogenetic analysis. Can J of Bot 73:S667-S676

Thambugala KM, Ariyawansa HA, Li YM, Boonmee S, Hongsanan S, Tian Q, Singtripop C, Bhat JD, Camporesi E, Jayawardena R, Liu ZY, Xu JC, Chukeatirote E, Hyde KD (2014a) Dothideales. Fungal Divers 68:105-158

Thambugala KM, Ariyawansa HA, Liu ZY, Chukeatirote E, Hyde KD (2014b) Towards a natural classification of Dothideomycetes 6: The genera Dolabra, Placostromella, Pleosphaerellula, Polysporidiella and Pseudotrichia (Dothideomycetes incertae sedis). Phytotaxa 176:55-67

Thambugala KM, Daranagama DA, Phillips AJL, Bulgakov TS, Bhat DJ, Camporesi E, Bahkali AH, Eungwanichayapant PD, Liu ZY, Hyde KD (2017) Microfungi on Tamarix. Fungal Divers 82:239-306

Theissen F (1912) Fragmenta brasilica IV nebst Bemerkungen über einige andere Asterina-Arten. Ann Mycol 10:1-32

Theissen F (1913) Lembosia - Studien. Ann Mycol 11:424-467

Theissen F (1914a) Die Trichothyriaceen. Beih Bot Centralbl 32:1-16

Theissen F (1914b) Trichopeltaceae $\mathrm{n}$. fam. Hemisphaerialium. Zentralbl Bakteriol Parasitenk, Abt 2 39:625-640 
Theissen F (1916) Mykologische Abhandlungen. Verh. der KaiserlichKoniglichen Zoologisch-Botanischen Gesell. Wien 66:296-400

Theissen F, Sydow H (1915) Die Dothideales. Kritisch-systematische riginaluntersuchungen. Ann Mycol 13:147-746

Theissen F, Sydow H (1918) Vorentwurfe zu den Pseudosphaeriales. Ann Mycol 16:1-34

Thongkantha S, Jeewon R, Vijaykrishna D, Lumyong S, McKenzie EHC, Hyde KD (2009) Molecular phylogeny of Magnaporthaceae (Sordariomycetes) with a new species Ophioceras chiangdaoense from Dracaena loureiroi in Thailand. Fungal Divers 34:157-173

Thüs H, Schultz M (2009) Süßwasserflora von Mitteleuropa, Bd. 21/1: Fungi, 1. Teil: Lichens. Spektrum Akademischer Verlag, Heidelberg

Tian Q, Chomnunti P, Bhat JD, Alias SA, Mortimer PE, Hyde KD (2014) Towards a natural classification of Dothideomycetes 5: The genera Ascostratum, Chaetoscutula, Ceratocarpia, Cystocoleus, and Colensoniella (Dothideomycetes incertae sedis). Phytotaxa 176:42-54

Tian Q, Hongsanan S, Dai DQ, Alias SA, Hyde KD, Chomnunti P (2015) Towards a natural classification of Dothideomycetes: Clarification of Aldona, Aldonata and Viegasella (Parmulariaceae). Mycosphere 7:511-524

Tibpromma S, Hyde KD, Jeewon R, Maharachchikumbura SSN, Liu JK, Bhat DJ, Jones EBG, McKenzie EHC, Camporesi E, Bulgakov TS, Doilom M, de Azevedo Santiago ALCM, Das K, Manimohan P, Gibertoni TB, Lim YW, Ekanayaka AH, Thongbai B, Lee HB, Yang JB, Kirk PM, Sysouphanthong P, Singh SK, Boonmee S, Dong W, Raj KNA, Latha KPD, Phookamsak R, Phukhamsakda C, Konta S, Jayasiri SC, Norphanphoun C, Tennakoon DS, Li JF, Dayarathne MC, Perera RH, Xiao Y, Wanasinghe DN, Senanayake IC, Goonasekara ID, de Silva NI, Mapook A, Jayawardena RS, Dissanayake AJ, Manawasinghe IS, Chethana KWT, Luo ZL, Hapuarachchi KK, Baghela A, Soares AM, Vizzini A, Meiras-Ottoni A, Mešić A, Dutta AK, de Souza CAF, Richter C, Lin CG, Chakrabarty D, Daranagama DA, Lima DX, Chakraborty D, Ercole E, Wu F, Simonini G, Vasquez G, da Silva GA, Plautz HL Jr, Ariyawansa HA, Lee H, Kušan I, Song J, Sun J, Karmakar J, Hu K, Semwal KC, Thambugala KM, Voigt K, Acharya K, Rajeshkumar KC, Ryvarden L, Jadan M, Hosen MI, Mikšík M, Samarakoon MC, Wijayawardene NN, Kim NK, Matočec N, Singh PN, Tian Q, Bhatt RP, de Oliveira RJV, Tulloss RE, Aamir S, Kaewchai S, Svetasheva STY, Nguyen TTT, Antonín V, Li WJ, Wang Y, Indoliya Y, Tkalčec Z, Elgorban AM, Bahkali AH, Tang AMC, Su HY, Zhang H, Promputtha I, Luangsa-ard J, Xu JC, Yan J, Chuan KJ, Stadler M, Mortimer PE, Chomnunti P, Zhao Q, Phillips AJL, Nontachaiyapoom S, Wen TC, Karunarathna SC (2017) Fungal diversity notes 491-602: taxonomic and phylogenetic contributions to fungal taxa. Fungal Divers 83:1-261

Tibpromma S, Hyde KD, Bhat JD, Mortimer PE, Xu JC, Promputtha I, Doilom M, Yang JB, Tang AMC, Karunarathna SC (2018a) Identification of endophytic fungi from leaves of Pandanaceae based on their morphotypes and DNA sequence data from southern Thailand. Mycokeys 33:25-67

Tibpromma S, Hyde KD, McKenzie EHC, Bhat DJ, Phillips AJL, Wanasinghe DN, Samarakoon MC, Jayawardena RS, Dissanayake AJ, Tennakoon DS, Doilom M, Phookamsak R, Tang AMC, Xu J, Mortimer PE, Promputtha I, Maharachchikumbura SSN, Khan S, Karunarathna SC (2018b) Fungal diversity notes 840-928: micro-fungi associated with Pandanaceae. Fungal Divers 93:1-160

Tilak ST, Rao R (1964) The genus Haplosporella in India. Mycopathol Mycol Appl 24:362-368

Tode HJ (1790) Fungi Mecklenburgenses Selecti. Fasc. 1. Nova Fungorum Genera Complectens. i-viii, 1-50, plates 1-7
Toro RA (1926) Mycological notes. I. Journal of the Department of Agriculture of Porto Rico 10:11-23

Trakunyingcharoen T, Lombard L, Groenewald JZ, Cheewangkoon R, To-Anun C, Crous PW (2015) Caulicolous Botryosphaeriales from Thailand. Persoonia 34:87-99

Tretiach MR (2006) Critical notes on the calcicolous endolithic lichen Strigula endolithea (Strigulaceae, Ascomycota). Nova Hedwig 83:451-458

Tsui CKM, Sivichai S, Rossman AY, Berbee ML (2007) Tubeufia asiana, the teleomorph of Aquaphila albicans in the Tubeufiaceae, Pleosporales, based on cultural and molecular data. Mycologia 99:884-894

Tucker SC, Harris RC (1980) New or noteworthy pyrenocarpous lichens from Louisiana and Florida. Bryologist 83:1-20

Tulasne LR (1852) Mémoire pour servir à l'historie et physiologique des lichens. Ann Sci Nat Bot 17(5-128):153-349

Turland NJ, Wiersema JH, Barrie FR, Greuter W, Hawksworth DL, Herendeen PS, Knapp S, Kusber WH, Li DZ, Marhold K, May TW (2018) International Code of Nomenclature for Algae, Fungi, and Plants (Shenzhen Code) adopted by the Nineteenth International Botanical Congress Shenzhen, China, July 2017 [Regnum Vegetabile 159]. Koeltz Botanical Books, Oberreifenberg

Udagawa S, Toyazaki N (1985) A new species of Leptodiscella. Mycotaxon 22:407-413

Untereiner WA, Straus NA, Malloch D (1995) A molecular-morphotaxonomic approach to the systematics of the Herpotrichiellaceae and allied black yeasts. Mycol Res 99:897-913

Vainio EA (1899) Lichenes e Caucaso et in peninsula Taurica annis 1884-1885 ab H. Lojka et M. a Déchy collecti. Természetr Füz 22:269-343

Vainio EA (1921a) Lichenes ab A. Yasuda in Japonia collecti. Continuatio I Bot Mag (Tokyo) 25:45-79

Vainio EA (1921b) Lichenes insularum Philippinarum III. Ann Acad Sci Fenn 15:1-368

Vainio EA (1923) Lichenes in insula Trinidad a professore R. Thaxter collecti. Proc Am Acad Arts Sci 58:131-147

Valadbeigi T, Schultz M, Von Brackel W (2016) Two new species of Lichenothelia (Lichenotheliaceae) from Iran. Lichenologi 48:191-199

van den Boom P, Etayo J (2014) New records of lichenicolous fungi and lichenicolous lichens from the Iberian Peninsula, with the description of four new species and one new genus. Opuscula Philolichenum 13:44-79

Van den Brink RB, Geesteranus RM, van Steenis CGGJ (1961) (84) Proposal to conserve the generic name Phyllocharis Diels (Lobeliaceae. Taxon 10:244-246

Van den Broeck D, Frisch A, Razafindrahaja T, Van de Vijver B, Ertz D (2018) Phylogenetic position of Synarthonia (lichenized Ascomycota, Arthoniaceae), with the description of six new species. Plant Ecol Evol 151:327-351

van Nieuwenhuijzen EJ, Miadlikowska JM, Houbraken JAMP, Adan OCG, Lutzoni FM, Samson RA (2016) Wood staining fungi revealed taxonomic novelties in Pezizomycotina: new order Superstratomycetales and new species Cyanodermella oleoligni. Stud Mycol 85:107-124

van Wyk PS, Marasas WFO, Hattingh MJ (1976) Morphology and taxonomy of Vizella interrupta (Ascomycetes: Vizellaceae). Trans Br Mycol Soc 66:489-494

Verma RK, Sharma N, Soni KK, Jamaluddin (2008) Forest fungi of Central India, pp 1-418

Vězda A (1984) Foliikole Flechten der Insel Kuba. Folia Geobot Phytotax 19:177-210

Viégas AP (1944) Alguns fungos do Brazil. II. Ascomicetos. Bragantia 4:1-392

Voglmayr H, Amengual AP (2018) Three new species of Stigmatodiscus from Mallorca (Spain). Mycol Prog 17:1-13 
Voglmayr H, Gardiennet A, Jaklitsch WM (2016) Asterodiscus and Stigmatodiscus, two new apothecial dothideomycete genera and the new order Stigmatodiscales. Fungal Divers 80:271-284

Voglmayr H, Fournier J, Jaklitsch WM (2017) Stigmatodiscus pruni, a new dothideomycete with hysteriform ascomata. Sydowia 69:29-35

von Arx JA, Müller E (1954) Die Gattungen der amerosporen Pyrenomyceten. Beitr Kryptogamenfl Schweiz 11:1-434

von Arx JA, Müller E (1975) A re-evaluation of the bitunicate Ascomycetes with keys to families and genera. Stud Mycol 9:1-159

von Höhnel F (1907) Fragmente zur Mykologie: IV. Mitteilung (Nr. 156 bis 168). Sitzungsber Kaiserl Akad Wiss, Wien, Math-Naturwiss $\mathrm{Cl}$, Abt 1 116:615-647

von Höhnel F (1909a) Fragmente zur Mykologie: IX. Mitteilung (Nr. 407 bis 467). Sitzb Akad Wiss Wien Kl 118:1461-1552

von Höhnel F (1909b) Fragmente zur Mykologie: VII. Mitteilung (Nr. 289 bis 353). Sitzungsber Kaiserl Akad Wiss, Wien, Math-Naturwiss $\mathrm{Cl}$, Abt 1 118:813-904

von Höhnel F (1909c) Fragmente der Mykologie (VIII. Mitteilung, No. 354 bis 406), gleichzeitig Vierte Mitteilung über die Ergebnisse der mit Unterstützung der kaiserl. Akademie 1907-1908 von ihm ausgeführten Forschungsreise nach Java. Sitzungsber Kaiserl Akad Wiss, Wien, Math-Naturwiss Cl, Abt 1 118:1175-1176

von Höhnel F (1910) Fragmente zur Mykologie: X. Mitteilung (Nr. 468 bis 526). Sber Akad Wiss Wien Math Naturw K1 119:393-473

von Höhnel F (1917) System der Phacidiales. Berichte der Deutschen Botanischen Gesellschaft 35:416-422

Vujanovic V, St-Arnaud M (2003) A new species of Pseudorobillarda, an endophyte from Thuja occidentalis in Canada, and a key to the species. Mycologia 95:955-958

Wakefield EM (1940) Nomina generica conservanda. Contributions from the Nomenclature Committee of the British Mycological Society. III. Trans Br Mycol Soc 24:282-293

Wei JC (1979) Identification of fungus handbook. Shanghai, China

Wijayawardene DNN, McKenzie EHC, Hyde KD (2012) Towards incorporating anamorphic fungi in a natural classification-checklist and notes for 2011. Mycosphere 3:157-228

Wijayawardene NN, Hyde KD, Camporesi E, Bhat DJ, Song Y, Chukeatirote E, Wang Y, Zhang JH (2014b) Homortomyces tamaricis sp. nov. and convergent evolution of Homortomyces and Stilbospora. Phytotaxa 176:156-163

Wijayawardene NN, Crous PW, Kirk PM, Hawksworth DL, Boonmee S, Braun U, Dai DQ, Dsouza MJ, Diederich P, Dissanayake A, Doilom M, Hongsanan S, Jones EBG, Groenewald JZ, Jayawardena R, Lawrey JD, Liu JK, Lücking R, Madrid H, Manamgoda DS, Muggia L, Nelsen MP, Phookamsak R, Suetrong S, Tanaka K, Thambugala KM, Wanasinghe DN, Wikee S, Zhang Y, Aptroot A, Ariyawansa HA, Bahkali AH, Bhat DJ, Gueidan C, Chomnunti P, De Hoog GS, Knudsen K, Li WJ, McKenzie EHC, Miller AN, Phillips AJL, Piątek M, Raja HA, Shivas RS, Slippers B, Taylor JE, Tian Q, Wang Y, Woudenberg JHC, Cai L, Jaklitsch WM, Hyde KD (2014a) Naming and outline of Dothideomycetes-2014 including proposals for the protection or suppression of generic names. Fungal Divers 69:1-55

Wijayawardene NN, Hyde KD, Wanasinghe DN, Papizadeh M, Goonasekara ID, Camporesi E, Bhat DJ, McKenzie EHC, Phillips AJL, Diederich P, Tanaka K, Li WJ, Tangthirasunun N, Phookamsak R, Dai DQ, Dissanayake AJ, Weerakoon G, Maharachchikumbura SSN, Hashimoto A, Matsumura M, Bahkali AH, Wang Y (2016) Taxonomy and phylogeny of dematiaceous coelomycetes. Fungal Diversity 77:1-316

Wijayawardene NN, Hyde KD, Rajeshkumar KC, Hawksworth DL, Madrid H, Kirk PM, Braun U, Singh RV, Crous PW, Kukwa M, Lucking R, Kurtzman CP, Yurkov A, Haelewaters D, Aptroot A, Lumbsch HT, Timdal E, Ertz D, Etayo J, Phillips AJL, Groenewald JZ, Papizadeh M, Selbmann L, Dayarathne MC,
Weerakoon G, Jones EBG, Suetrong S, Tian Q, Castanéda-Ruiz RF, Bahkali AH, Pang KL, Tanaka K, Dai DQ, Sakayaroj J, Hujslová M, Lombard L, Shenoy BD, Suija A, Maharachchikumbura SSN, Thambugala KM, Wanasinghe DN, Sharma BO, Gaikwad S, Pandit G, Zucconi L, Onofri S, Egidi E, Raja HA, Kodsueb R, Caceres MES, Perez-Ortega S, Fiuza PO, Monteiro JS, Vasilyeva LN, Shivas RG, Prieto M, Wedin M, Olariaga I, Lateef AA, Agrawal Y, Fazeli SAS, Amoozegar MA, Zhao GZ, Pfliegler WP, Sharma G, Oset M, Abdel MA, Takamatsu S, Bensch K, Silva NI, De Kesel A, Karunarathna A, Boonmee S, Pfister DH, Lu YZ, Luo ZL, Boonyuen N, Daranagama DA, Senanayake IC, Jayasiri SC, Samarakoon MC, Zeng XY, Doilom M, Quijada L, Rampadarath S, Heredia G, Dissanayake AJ, Jayawardena RS, Perera PH, Tang LZ, Phukhamsakda C, HernándezRestrepo M, Ma XY, Tibpromma S, Gusmao LFP, Weerahewa D, Karunarathna SC (2017a) Notes for genera: Ascomycota. Fungal Divers 86:1-594

Wijayawardene NN, Hyde KD, Tibpromma S, Wanasinghe DN, Thambugala KM, Tian Q, Wang Y (2017b) Towards incorporating asexual fungi in a natural classification: checklist and notes 2012-2016. Mycosphere 8:1457-1554

Wijayawardene NN, Hyde KD, Lumbsch HT, Liu JK, Maharachchikumbura SSN, Ekanayaka AH, Tian Q, Phookamsak R (2018) Outline of Ascomycota: 2017. Fungal Divers 88:167-263

Wijayawardene NN, Hyde KD, Al-Ani LKT, Tedersoo L, Haelewaters D, Rajeshkumar KC, Zhao RL, Aptroot A, Leontyev DV, Saxena RK, Tokarev YS, Dai DQ, Letcher PM, Stephenson SL, Ertz D, Lumbsch HT, Kukwa M, Issi IV, Madrid H, Phillips AJL, Selbmann L, Pfliegler WP, Horváth E, Bensch K, Kirk PM, Kolař́ková K, Raja HA, Radek R, Papp V, Dima B, Ma J, Malosso E, Takamatsu S, Rambold G, Gannibal PB, Triebel D, Gautam AK, Avasthi S, Suetrong S, Timdal E, Fryar SC, Delgado G, Réblová M, Doilom M, Dolatabadi S, Pawłowska J, Humber RA, Kodsueb R, Sánchez-Castro I, Goto BT, Silva DKA, de Souza FA, Oehl F, da Silva GA, Silva IR, Błaszkowski J, Jobim K, Maia LC, Barbosa FR, Fiuza PO, Divakar PK, Shenoy BD, Castañeda-Ruiz RF, Somrithipol S, Lateef AA, Karunarathna SC, Tibpromma S, Mortimer PE, Wanasinghe DN, Phookamsak R, Xu J, Wang Y, Tian F, Alvarado P, Li DW, Kušan I, Matočec N, Maharachchikumbura SSN, Papizadeh M, Heredia G, Wartchow F, Bakhshi M, Boehm E, Youssef N, Hustad VP, Lawrey JD, Santiago ALCMA, Bezerra JDP, Souza-Motta CM, Firmino AL, Tian Q, Houbraken J, Hongsanan S, Tanaka K, Dissanayake AJ, Monteiro JS, Grossart HP, Suija A, Weerakoon G, Etayo J, Tsurykau A, Vázquez V, Mungai P, Damm U, Li QR, Zhang H, Boonmee S, Lu YZ, Becerra AG, Kendrick B, Brearley FQ, Motiejūnaite J, Sharma B, Khare R, Gaikwad S, Wijesundara DSA, Tang LZ, He MQ, Flakus A, Rodriguez-Flakus P, Zhurbenko MP, McKenzie EHC, Stadler M, Bhat DJ, Liu JK, Raza M, Jeewon R, Nassonova ES, Prieto M, Jayalal RGU, Erdoğdu M, Yurkov A, Schnittler M, Shchepin ON, Novozhilov YK, SilvaFilho AGS, Liu P, Cavender JC, Kang Y, Mohammad S, Zhang LF, Xu RF, Li YM, Dayarathne MC, Ekanayaka AH, Wen TC, Deng CY, Pereira OL, Navathe S, Hawksworth DL, Fan XL, Dissanayake LS, Kuhnert E, Grossart HP, Thines M (2020) Outline of Fungi and fungus-like taxa. Mycosphere 11:1060-1456

Wikee S, Lombard L, Crous PW, Nakashima C, Motohashi K, Chukeatirote E, Alias SA, McKenzie EHC, Hyde KD (2013a) Phyllosticta capitalensis, a widespread endophyte of plants. Fungal Divers 60:91-105

Wikee S, Lombard L, Nakashima C, Motohashi K, Chukeatirote E, Cheewangkoon R, McKenzie EH, Hyde KD, Crous PW (2013b) A phylogenetic re-evaluation of Phyllosticta (Botryosphaeriales) Stud Mycol 76:1-29 
Winton LM, Stone JK, Hansen EM, Shoemaker RA (2007) The systematic position of Phaeocryptopus gaeumannii. Mycologia 99:240-252

Wirth V, Hauck M, Schultz M (2013) Die Flechten Deutschlands, vol 1. Ulmer, Stuttgart

Wong KMK, Goh TK, Hodgkiss IJ, Hyde KD, Ranghoo VM, Tsui CKM, Ho WH, Wong WSW, Yuen TK (1998) Role of fungi in freshwater ecosystems. Biodivers Conserv 7:1187-1206

Woo JJ, Lücking R, Oh SY, Jeun YC, Hur JS (2020) Two new foliicolous species of Strigula (Strigulaceae, Strigulales) in Korea offer insight in phorophyte-dependent variation of thallus morphology. Phytotaxa 443:001-012

Wulandari NF, ToAnun C, McKenzie EHC, Hyde KD (2011) Guignardia bispora and G. ellipsoidea spp. nov. and other Guignardia species from palms (Arecaceae). Mycosphere 2:115-128

Wulandari NF, Bhat DJ, To-anun C (2013) A modern account of the genus Phyllosticta. Plant Pathol Quar J 3:145-159

Wunderlich N, Ash GJ, Steel CC, Raman H, Savocchia S (2011) Association of Botryosphaeriaceae grapevine trunk disease fungi with the reproductive structures of Vitis vinifera. Vitis 50:89-96

Wu W, Sutton BC, Gange AC (1997) Notes on three fungicolous fungi: Anastomyces microsporus gen. et sp. nov., Idriella rhododendri sp. nov. and Infundibura adhaerens. Mycol Res 101(11):1318-1322

Wu HX, Li YM, Chen H, Hyde KD (2010) Studies on Microthyriaceae: some excluded genera. Mycotaxon 113:147-156

Wu HX, Hyde KD, Chen H (2011a) Studies on Microthyriaceae: placement of Actinomyxa, Asteritea, Cirsosina, Polystomellina and Stegothyrium. Cryptogam Mycol 32:3-12

Wu HX, Schoch CL, Boonmee S, Bahkali AH, Chomnunti P, Hyde KD (2011b) A reappraisal of Microthyriaceae. Fungal Divers $51: 189-248$

Wu HX, Tian Q, Li WJ, Hyde KD (2014) A reappraisal of Microthyriaceae. Phytotaxa 176:201-212

Wyka SA, Broders KD (2016) The new family Septorioideaceae, within the Botryosphaeriales and Septorioides strobi as a new species associated with needle defoliation of Pinus strobus in the United States. Fungal Biol 120:1030-1040

Yacharoen S, Tian Q, Chomnunti P, Boonmee S, Chukeatirote E, Bhat JD, Hyde KD (2015) Patellariaceae revisited. Mycosphere 6:290-326

Yamaguchi K, Tsurumi Y, Van Hop D, Ando K (2018) Hamatispora, a new genus of aquatic fungi in Microthyriales isolated from fallen leaves in Vietnam. Mycoscience 59:467-472

Yang T, Groenewald JZ, Cheewangkoon R, Jami F, Abdollahzadeh J, Lombard L, Crous PW (2017) Families, genera, and species of Botryosphaeriales. Fungal Biol 121:322-346

Yang J, Liu JK, Hyde KD, Jones EBG, Luo ZL, Liu ZY (2019) Aquimonospora tratensis gen. et sp. nov. (Diaporthomycetidae, Sordariomycetes), a new lineage from a freshwater habitat in Thailand. Phytotaxa 397:146-158

Yan WX, Shi YX, Chai AL, Xie XW, Guo MY, Li BJ (2018) Verticillium wilt of okra caused by Verticillium dahliae Kleb. in China. Mycobiology 46:254-259

Yazici K, Etayo J (2013) Buelliella, Codonmyces, and Polycoccum species new to Turkey. Mycotaxon 126:45-50

Yeshitela K, Fischer E, Killmann D, Sérusiaux E (2009) Aspidothelium hirsutum (Thelenellaceae) and Caprettia goderei
(Monoblastiaceae), two new species of foliicolous lichens from Ethiopia and Kenya. Bryologist 112:850-855

Yoo JJ, Eom AH (2012) Molecular identification of endophytic fungi isolated from needle leaves of conifers in Bohyeon Mountain, Korea. Mycobiology 40:231-235

Yoshimura S, Zenkoh T, Ohtsu Y, Kanasaki R, Shigematsu N, Takase S, Neya M (2003) Isolation, structure determination and biological study of novel gluconeogenesis inhibitors, FR225659 family. Symposium on the Chemistry of Natural Products 45:281-286

Yuen TK, Hyde KD, Hodgkiss IJ (1998) Physiological growth parameters and enzyme production in tropical freshwater fungi. Mater Org 32:2-16

Zahlbruckner A (1907) Specieller Teil. In: Engler A, Prantl K (eds) Die Natürlichen Planzenfamilien. Teil 1(1*). Engelmann, Leipzig, pp 49-249

Zahlbruckner A (1935) Florida-Flechten, gesammelt von S. Rapp. Ann Mycol 33:33-45

Zeller L, Tóth S (1960) Banhegyia, eine neue Gattung der Lecanorales. Sydowia 14:326-329

Zeng XY, Wu HX, Hongsanan S, Jeewon R, Wen TC, Maharachchikumbura SSN, Chomnunti P, Hyde KD (2019) Taxonomy and the evolutionary history of Micropeltidaceae. Fungal Divers 97:393-436

Zenkoh T, Ohtu Y, Yoshimura S, Shigematsu N, Takase S, Hino M (2003) The Novel Gluconeogenesis Inhibitors FR225659 and FR225656 from Helicomyces sp. No. 19353 III. Structure determination. J Antibiot 56:694-699

Žežlina I, Rot M, Kač M, Trdan S (2016) Causal agents of stone fruit diseases in Slovenia and the potential for diminishing their economic impact - a review. Plant Protect Sci 52:149-157

Zhang Y, Crous PW, Schoch CL, Bahkar AH, Guo LD, Hyde KD (2011) A molecular, morphological and ecological re-appraisal of Venturiales - a new order of Dothideomycetes. Fungal Divers 51:249-277

Zhang Y, Crous PW, Schoch CL, Hyde KD (2012) Pleosporales. Fungal Divers 53:1-221

Zhang JF, Liu JK, Hyde KD, Chen YY, Liu YX, Liu ZY (2017a) Two new species of Dyfrolomyces (Dyfrolomycetaceae, Dothideomycetes) from karst landforms. Phytotaxa 28:85-116

Zhang SN, Hyde KD, Jones EBG, Cheewangkoon R, Boonmee S, Doilom M, Mapook A, Liu JK (2017b) Novomicrothelia pandanicola sp. nov., a non-lichenized Trypetheliaceae species from Pandanus. Phytotaxa 321:254-264

Zhao GZ, Liu X, Wu W (2007) Helicosporous hyphomycetes from China. Fungal Divers 26:313-524

Zhaxybayeva O, Gogarten JP (2002) Bootstrap, Bayesian probability and maximum likelihood mapping: exploring new tools for comparative genome analyses. BMC genomics 3:4

Zhou S, Stanosz GR (2001) Relationships among Botryosphaeria species and associated anamorphic fungi inferred from the analysis of ITS and 5.8S rDNA sequences. Mycologia 93:516-527

Zhu H, Hu Z, Liu G (2017) Morphology and molecular phylogeny of Trentepohliales (Chlorophyta) from China. Eur J Phycol 52:330-341

Zhurbenko MP, Etayo J, Fedrowitz K, Thor G (2015) Miscellaneous reports of lichenicolous fungi from Argentina including the new species Didymellopsis nephromatis. Opusc Philolichenum $14: 82-89$ 


\section{Affiliations}

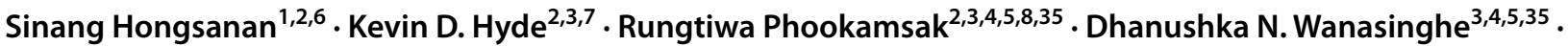
Eric H. C. McKenzie ${ }^{9} \cdot$ V. Venkateswara Sarma ${ }^{10} \cdot$ Robert Lücking $^{12}$ - Saranyaphat Boonmee ${ }^{2,11}$. Jayarama D. Bhat ${ }^{13} \cdot$ Ning-Guo Liu, 2,14,15 Danushka S. Tennakoon ${ }^{2,11}$. Dhandevi Pem ${ }^{2,11}$. Anuruddha Karunarathna ${ }^{2,3,4,6,50} \cdot$ Shu-Hua Jiang ${ }^{17} \cdot$ Gareth E. B. Jones ${ }^{18,19} \cdot$ Alan J. L. Phillips ${ }^{20}$. Ishara S. Manawasinghe ${ }^{2,7,21}$ - Saowaluck Tibpromma ${ }^{3,4,5,35}$. Subashini C. Jayasiri' ${ }^{2}$ Diana Sandamali ${ }^{2,11,50}$. Ruvishika S. Jayawardena ${ }^{2,11}$ • Nalin N. Wijayawardene ${ }^{22}$ - Anusha H. Ekanayaka ${ }^{2} \cdot$ Rajesh Jeewon $^{23}$. Yong-Zhong Lu ${ }^{24}$. Chayanard Phukhamsakda ${ }^{2}$ Asha J. Dissanayake ${ }^{16} \cdot$ Xiang-Yu Zeng $^{2,25,26} \cdot$ Zong-Long Luo $^{27}$. Qing $\operatorname{Tian}^{2} \cdot$ Kasun M. Thambugala ${ }^{28} \cdot$ Dongqin Dai $^{22} \cdot$ Milan C. Samarakoon ${ }^{2,48} \cdot \mathrm{K}$. W. Thilini Chethana ${ }^{2,11}$. Damien Ertz ${ }^{29,30}$ - Mingkwan Doilom ${ }^{3,4,5,35}$. Jian-Kui (Jack) Liu ${ }^{16}$. Sergio Pérez-Ortega ${ }^{31}$. Ave Suija ${ }^{32}$. Chanokned Senwanna ${ }^{2,6}$. Subodini N. Wijesinghe ${ }^{2,11,33}$. Mekala Niranjan ${ }^{10,36}$. Sheng-Nan Zhang ${ }^{2,6}$. Hiran A. Ariyawansa ${ }^{34} \cdot$ Hong-Bo Jiang 2,3,4,11 . Jin-Feng Zhang ${ }^{2,37}$. Chada Norphanphoun ${ }^{2}$. Nimali I. de Silva ${ }^{3,48}$. Vinodhini Thiyagaraja ${ }^{2,3,4,6} \cdot$ Huang Zhang ${ }^{38}$. Jadson D. P. Bezerra ${ }^{39} \cdot$ Ricardo Miranda-González $^{40}$. André Aptroot ${ }^{41}$. Hiroyuki Kashiwadani ${ }^{42}$. Dulanjalee Harishchandra ${ }^{2,11,21} \cdot$ Emmanuël Sérusiaux $^{43}$. Pranami D. Abeywickrama ${ }^{2,11,21}$. Dan-Feng Bao ${ }^{2,6,27} \cdot$ Bandarupalli Devadatha ${ }^{2,10} \cdot \mathrm{Hai}-\mathrm{Xia} \mathrm{Wu}^{44}$. Kwang Hee Moon ${ }^{45}$. Cecile Gueidan ${ }^{46}$. Felix Schumm ${ }^{47}$. Digvijayini Bundhun ${ }^{2,6}$. Ausana Mapook ${ }^{2}$. Jutamart Monkai ${ }^{2}$. Chitrabhanu S. Bhunjun ${ }^{2,11}$ - Putarak Chomnunti ${ }^{11}$. Satinee Suetrong ${ }^{49} \cdot$ Napalai Chaiwan $^{2,3}$. Monika C. Dayarathne ${ }^{33}$. Jing Yang ${ }^{2,15}$. Achala R. Rathnayaka ${ }^{2,11,50}$. Jian-Chu Xu ${ }^{3,4,5,35}$. Jiesheng Zheng ${ }^{1}$. Gang Liu ${ }^{1}$ Y Yao Feng ${ }^{51} \cdot$ Ning Xie $^{1}$

Ning Xie

ning.xie@szu.edu.cn

1 Guangdong Provincial Key Laboratory for Plant Epigenetics, Shenzhen Key Laboratory of Microbial Genetic Engineering, College of Life Science and Oceanography, Shenzhen University, Shenzhen 518060, People's Republic of China

2 Center of Excellence in Fungal Research, Mae Fah Luang University, Chiang Rai 57100, Thailand

3 CAS Key Laboratory for Plant Diversity and Biogeography of East Asia (KLPB), Kunming Institute of Botany, Chinese Academy of Science, Kunming 650201, Yunnan, People's Republic of China

4 East and Central Asia Regional Office, World Agroforestry Centre (ICRAF), Kunming 650201, Yunnan, People's Republic of China

5 Centre for Mountain Futures (CMF), Kunming Institute of Botany, Kunming 650201, Yunnan, People's Republic of China

6 Department of Entomology and Plant Pathology, Faculty of Agriculture, Chiang Mai University, Chiang Mai 50002, Thailand

7 Institute of Plant Health, Zhongkai University of Agriculture and Engineering, Haizhu District, Guangzhou 510225, People's Republic of China

8 World Agroforestry Centre, East and Central Asia, 132 Lanhei Road, Kunming 650201, Yunnan, People's Republic of China

9 Manaaki Whenua-Landcare Research, Private Mail Bag 92170, Auckland, New Zealand

10 Fungal Biotechnology Lab, Department of Biotechnology, School of Life Sciences, Pondicherry University, Kalapet, Pondicherry 605014, India
11 School of Science, Mae Fah Luang University, Chiang Rai 57100, Thailand

12 Botanischer Garten und Botanisches Museum, Freie Universität Berlin, Königin-Luise-Straße 6-8, 14195 Berlin, Germany

13 128/1-J, Azad Co-Op Housing Society, Curca, P.O. Goa Velha 403108, India

14 Faculty of Agriculture, Natural Resources and Environment, Naresuan University, Phitsanulok 65000, Thailand

15 Guizhou Key Laboratory of Agricultural Biotechnology, Guizhou Academy of Agricultural Sciences, Guiyang 550006, People's Republic of China

16 School of Life Science and Technology, University of Electronic Science and Technology of China, Chengdu 611731, People's Republic of China

17 State Key Laboratory of Mycology, Institute of Microbiology, Chinese Academy of Sciences, Beijing 100101, People's Republic of China

18 Department of Botany and Microbiology, College of Science, King Saud University, P.O Box 2455, Riyadh 11451, Kingdom of Saudi Arabia

19 Nantgaredig, 33B St Edwards Road, Southsea, Hants PO5 3DH, UK

20 Faculdade de Ciências, Biosystems and Integrative Sciences Institute (BioISI), Universidade de Lisboa, Lisbon, Portugal

21 Beijing Key Laboratory of Environment Friendly Management on Fruit Diseases and Pests in North China, Institute of Plant and Environment Protection, Beijing Academy of Agriculture and Forestry Sciences, Beijing, China

22 Center for Yunnan Plateau Biological Resources Protection and Utilization, College of Biological Resource and Food Engineering, Qujing Normal University, Qujing 655011, Yunnan, People's Republic of China 
23 Dept of Health Sciences, Faculty of Medicine and Health Sciences, University of Mauritius, Reduit, Mauritius

24 School of Food and Pharmaceutical Engineering, Guizhou Institute of Technology, Guiyang 550003, People's Republic of China

25 State Key Laboratory Breeding Base of Green Pesticide and Agricultural Bioengineering, Key Laboratory of Green Pesticide and Agricultural Bioengineering, Ministry of Education, Guizhou University, Guiyang 550025, People's Republic of China

26 The Engineering Research Center of Southwest Bio-Pharmaceutical Resource, Ministry of Education, Guizhou University, Guiyang 550025, People's Republic of China

27 College of Agriculture and Biological Sciences, Dali University, Dali 671003, Yunnan, People's Republic of China

28 Genetics and Molecular Biology Unit, Faculty of Applied Sciences, University of Sri Jayewardenepura, Gangodawila, Nugegoda, Sri Lanka

29 Department Research, Meise Botanic Garden, Nieuwelaan 38, 1860 Meise, Belgium

30 Fédération Wallonie-Bruxelles, Service Général de l'Enseignement Supérieur et de la Recherche Scientifique, Rue A. Lavallée 1, 1080 Bruxelles, Belgium

31 Dept. Micología, Real Jardín Botánico (CSIC), Plaza Murillo 2, 28014 Madrid, Spain

32 Institute of Ecology and Earth Sciences, University of Tartu, Lai 40, Tartu 51005, Estonia

33 Department of Plant Pathology, Agriculture College, Guizhou University, Guiyang 550025, Guizhou Province, People's Republic of China

34 Department of Plant Pathology and Microbiology, College of Bio-Resources and Agriculture, National Taiwan University, No.1, Sec. 4, Roosevelt Road, Taipei 106, Taiwan

35 Honghe Center for Mountain Futures, Kunming Institute of Botany, Chinese Academy of Sciences, Honghe County 654400, Yunnan, People's Republic of China

36 Department of Botany, Rajiv Gandhi University, Rono Hills, Doimukh, Itanagar, Arunachal Pradesh 791112, India

37 Guizhou Tea Research Institute, Guizhou Academy of Agricultural Sciences, Guiyang 550006, People's Republic of China
38 Faculty of Agriculture and Food, Kunming University of Science \& Technology, Kunming 650500, People's Republic of China

39 Setor de Micologia, Departamento de Biociências e Tecnologia, Instituto de Patologia Tropical e Saúde Pública, Universidade Federal de Goiás, Rua 235 - s/n - Setor Universitário, CEP: 74605-050 Goiânia, GO, Brazil

40 Department of Botany and Plant Pathology, Oregon State University, 2082 Cordley Hall, Corvallis, OR 97331-2902, USA

41 Instituto de Biociências, Universidade Federal de Mato Grosso do Sul, Avenida Costa e Silva, s/n Bairro Universitário, CEP 79070-900 Campo Grande, Mato Grosso do Sul, Brazil

42 Department of Botany, National Museum of Nature and Science, 4-1-1 Amakubo, Tsukuba 305-0005, Ibaraki, Japan

43 Evolution and Conservation Biology, InBios Research Center, University of Liège, Sart Tilman B22, Quartier Vallée 1, Chemin de la Vallée 4, 4000 Liège, Belgium

44 International Fungal Research and Development Centre, The Research Institute of Resource Insects, Chinese Academy of Forestry, Kunming 650224, People's Republic of China

45 Biological Resources Research Department, National Institute of Biological Resources, Gyoungser-dong, Seo-gu, Incheon 404-170, Korea

46 Australian National Herbarium, National Research Collections Australia, CSIRO-NCMI, Canberra, ACT 2601, Australia

47 Mozartstraße 9, 73117 Wangen, Germany

48 Department of Biology, Faculty of Science, Chiang Mai University, Chiang Mai 50200, Thailand

49 National Biobank of Thailand (NBT), National Science and Technology Development Agency (NSTDA), Thailand Science Park, Thanon Phahonyothin, Tambon Khlong Nueng, Amphoe Khlong Luang, Pathum Thani 12120, Thailand

50 Department of Plant Medicine, National Chiayi University, 300 Syuefu Road, Chiayi City 60004, Taiwan

51 College of Agriculture, Guizhou University, Guiyang 550025, Guizhou, People's Republic of China 